\title{
Doorwerking van de beginselen van behoorlijke rechtspleging in de bestuurlijke voorprocedures
}

Citation for published version (APA):

Wenders, D. W. M. (2010). Doorwerking van de beginselen van behoorlijke rechtspleging in de bestuurlijke voorprocedures. [Doctoral Thesis, Maastricht University]. Datawyse / Universitaire Pers Maastricht. https://doi.org/10.26481/dis.20101112dw

Document status and date:

Published: 01/01/2010

DOI:

10.26481/dis.20101112dw

Document Version:

Publisher's PDF, also known as Version of record

\section{Please check the document version of this publication:}

- A submitted manuscript is the version of the article upon submission and before peer-review. There can be important differences between the submitted version and the official published version of record.

People interested in the research are advised to contact the author for the final version of the publication, or visit the DOI to the publisher's website.

- The final author version and the galley proof are versions of the publication after peer review.

- The final published version features the final layout of the paper including the volume, issue and page numbers.

Link to publication

\footnotetext{
General rights rights.

- You may freely distribute the URL identifying the publication in the public portal. please follow below link for the End User Agreement:

www.umlib.nl/taverne-license

Take down policy

If you believe that this document breaches copyright please contact us at:

repository@maastrichtuniversity.nl

providing details and we will investigate your claim.
}

Copyright and moral rights for the publications made accessible in the public portal are retained by the authors and/or other copyright owners and it is a condition of accessing publications that users recognise and abide by the legal requirements associated with these

- Users may download and print one copy of any publication from the public portal for the purpose of private study or research.

- You may not further distribute the material or use it for any profit-making activity or commercial gain

If the publication is distributed under the terms of Article $25 \mathrm{fa}$ of the Dutch Copyright Act, indicated by the "Taverne" license above, 
Doorwerking van de beginselen van behoorlijke rechtspleging in de bestuurlijke voorprocedures 
Ontwerp omslag: [Grafisch Bureau Signia]

Grafische productie: Datawyse bv / Universitaire Pers Maastricht

ISBN 9789013078985

NUR 823-301

\section{(C) 2010 D.W.M. Wenders}

Alle rechten voorbehouden. Niets uit deze uitgave mag worden verveelvoudigd, opgeslagen in een geautomatiseerd gegevensbestand, of openbaar gemaakt, in enige vorm of op enige wijze, hetzij elektronisch, mechanisch, door fotokopieën, opnamen of enige andere manier, zonder voorafgaande schriftelijke toestemming van de uitgever.

Voor zover het maken van kopieën uit deze uitgave is toegestaan op grond van art. 16h $\mathrm{t} / \mathrm{m} 16 \mathrm{~m}$ Auteurswet jo. het Besluit van 27 november 2002, Stb. 2002, 575, dient men de daarvoor wettelijk verschuldigde vergoedingen te voldoen aan de Stichting Reprorecht (Postbus 3051, 2130 KB Hoofddorp).

Hoewel aan de totstandkoming van deze uitgave de uiterste zorg is besteed, aanvaarden de auteur(s), redacteur(en) en uitgever(s) geen aansprakelijkheid voor eventuele fouten en onvolkomenheden, noch voor de gevolgen hiervan.

Kluwer BV legt de gegevens van abonnees vast voor de uitvoering van de (abonnements)overeenkomst. De gegevens kunnen door Kluwer, of zorgvuldig geselecteerde derden, worden gebruikt om $\mathrm{u}$ te informeren over relevante producten en diensten. Indien $\mathrm{u}$ hier bezwaar tegen heeft, kunt $\mathrm{u}$ contact met ons opnemen.

Op al onze aanbiedingen en overeenkomsten zijn van toepassing de Algemene Voorwaarden van Kluwer bv, gedeponeerd ter griffie van de Rechtbank te Amsterdam op 8 augustus 2007 onder depotnummer 127/2007. Deze vindt u op www.kluwer.nl of kunt u opvragen bij onze klantenservice. 


\title{
Doorwerking van de beginselen van behoorlijke rechtspleging in de bestuurlijke voorprocedures
}

\author{
PROEFSCHRIFT
}

ter verkrijging van de graad van doctor aan de Universiteit Maastricht, op gezag van de Rector Magnificus, Prof. mr. G.P.M.F. Mols volgens het besluit van het College van Decanen, in het openbaar te verdedigen op vrijdag 12 november 2010 om 14.00 uur

door

DANIËLLE WILHELMINA MARIA WENDERS 


\section{Promotor}

Prof. mr. F.A.M. Stroink

\section{Copromotor}

Mr. dr. A.M.L. Jansen

\section{Beoordelingscommissie}

Prof. mr. Ch.W. Backes (voorzitter)

Prof. mr. A.W. Heringa

Prof. mr. N. Verheij

Prof. mr. B.W.N. de Waard (Universiteit Tilburg)

Prof. mr. R.J.G.M. Widdershoven (Universiteit Utrecht) 


\section{Voorwoord}

Toen ik eind 2004 als junior-onderzoeker begon aan dit proefschrift leek de afronding en de verdediging ervan oneindig ver weg. $\mathrm{Nu}$ is het dan (eindelijk) zo ver. De periode waarin ik aan dit proefschrift gewerkt heb, is, ondanks de soms eenzame en moeilijke momenten, vooral een leerzame en aangename periode geweest. Aan dat laatste hebben met name mijn familie, vrienden en alle collega's met wie ik prettig heb samengewerkt bijgedragen. Daarom maak ik in dit voorwoord graag gebruik van de gelegenheid om iedereen die op een of andere wijze betrokken is geweest bij de totstandkoming van dit proefschrift en enkele personen in het bijzonder te bedanken.

Om bij het begin te beginnen: ik ben Eveline van der Linden zeer dankbaar dat zij mij op het spoor van het schrijven van een proefschrift heeft gezet. Daarnaast wil ik mijn promotor, Frits Stroink, bedanken voor zijn vertrouwen in mij en dit proefschrift en zijn altijd plezierige en waardevolle begeleiding. Aan mijn copromotor, Sander Jansen, ben ik zo mogelijk nog meer dank verschuldigd. Het voorstel voor dit onderzoek kwam van zijn hand en zijn dagelijkse begeleiding is op allerlei vlakken zeer waardevol en leerzaam geweest. Een betere begeleider en meer betrokkenheid kan een junior-onderzoeker zich niet wensen.

Prof. mr. Ch.W. Backes, prof. mr. A.W. Heringa, prof. mr. N. Verheij, prof. mr. B.W.N. de Waard, prof. mr. R.J.G.M. Widdershoven, ben ik zeer dankbaar voor hun bereidheid om plaats te nemen in de beoordelingscommissie en hun waardevolle commentaar op het manuscript. Verder wil ik nog noemen, Elly van den Berg, die ik zeer erkentelijk ben voor het doornemen van en haar taalkundige opmerkingen bij een deel van het manuscript. Dat geldt ook voor Christian, Mira en Sascha voor hun hulp bij het opstellen van de Engelstalige samenvatting van het onderzoek.

Alle collega's van de capgroep Publiekrecht hebben ervoor gezorgd dat ik al die tijd in een zeer prettige werkomgeving heb mogen werken. In het bijzonder hebben de collega's met wie ik de laatste jaren met regelmaat plezierige momenten buiten de faculteit heb mogen delen en de twee kamergenoten die ik gehad heb gedurende het schrijven van dit proefschrift aan het werkplezier bijgedragen.

Verder mogen natuurlijk mijn ouders, mijn broer, mijn zusje en hun partners niet ontbreken, omdat zij mij altijd onvoorwaardelijk steunen en vertrouwen geven. Last but not least wil ik Irene, Elvier, Murat en Simone bedanken voor hun vriendschap en voor het feit dat zij hebben gezorgd voor vele leuke momenten buiten het proefschrift en de vaak broodnodige afleiding.

De tekst van dit boek is tot slot afgesloten op 1 maart 2010. Met ontwikkelingen van na die datum kon derhalve slechts in beperkte mate rekening worden gehouden.

Maastricht, augustus 2010 



\section{Inhoudsopgave}

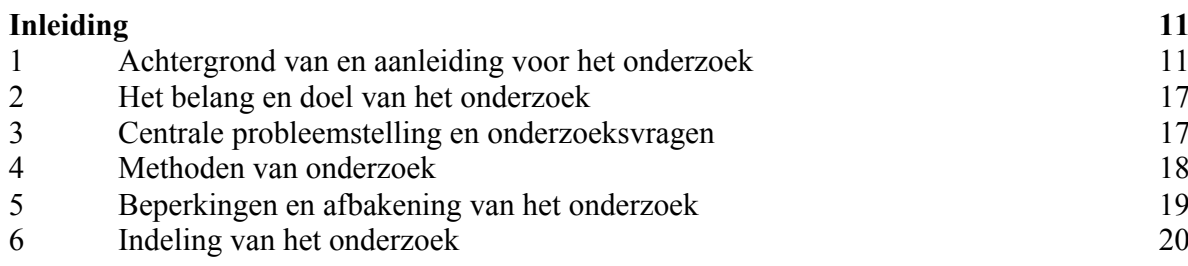

DEEL I Beginselen van behoorlijke rechtspleging 23

$1 \quad$ Inleiding 23

1.1 Doel van het onderzoek en de verhouding tot de probleemstelling 23

1.2 Beginselen voor rechtspraak 24

1.3 Op het begrip rechtspraak gerichte benaderingen 27

1.4 De keuze voor een variabele benadering 28

$2 \quad$ Rechtspraak 31

Invulling van het begrip rechtspraak: de formele en materiële benadering
nader bezien

2.2 De in dit onderzoek gekozen invulling van het begrip rechtspraak 34

2.3 Verschillen en overeenkomsten met de bestuurlijke werkzaamheid 36

2.3.1 De verschillen tussen bestuur en rechtspraak 36

$\begin{array}{ll}\text { 2.3.2 De gemeenschappelijkheden } & 40\end{array}$

2.3.3 Verschillende eisen gesteld door de bestuursrechter 42

2.4 Conclusies 45

$3 \quad$ Concretisering van de beginselen van behoorlijke rechtspleging 47

3.1 Noodzaak tot concretisering van beginselen 47

3.2 Beginselen, inrichtingseisen en concrete uitwerkingen van beginselen 48

3.2.1 Het onderscheid tussen beginselen, inrichtingseisen en concrete uitwerkingen 48

3.2.2 De samenhang tussen beginselen en concretere eisen 51

3.3 Relevantie voor dit onderzoek 56

$4 \quad$ De beginselen van behoorlijke rechtspleging $\quad 59$

4.1 De grondslagen van de beginselen van behoorlijke rechtspleging 59

4.2 De samenhang tussen en categorisering van de beginselen $\quad 65$

4.2.1 De gemeenschappelijke ratio van de beginselen van behoorlijke

$\begin{array}{ll}\text { 4.2.2 Categorisering van de beginselen } & 69\end{array}$

$\begin{array}{lll}4.3 & \text { De beginselen en hun inhoud } & 72\end{array}$

$\begin{array}{lll}4.3 .1 & \text { Inleiding } & 72\end{array}$

4.3.2 Het recht op toegang tot de rechter 74

$\begin{array}{ll}\text { 4.3.3 Onafhankelijkheid van de rechter } & 79\end{array}$

4.3.4 Het onpartijdigheidsbeginsel 85

4.3.5 Het beginsel van hoor en wederhoor $\quad 90$

$\begin{array}{llr}\text { 4.3.6 Het openbaarheidsbeginsel } & 96\end{array}$

4.3.7 Het motiveringsbeginsel 105

4.3.8 Het beginsel van de redelijke termijn 111

4.3.9 Effectieve rechtsbescherming: een nieuw beginsel? 117

$5 \quad$ De beginselen van behoorlijke rechtspleging in EU-perspectief 131

5.1 Inleiding 131

(11

(11

8

9

(

6

6

2

.

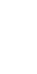

56

.


5.2 Verschillende Unierechtelijke eisen van behoorlijke rechtspleging nader bezien

5.2.1 Het verdedigingsbeginsel 134

5.2.2 Het motiveringsbeginsel 142

5.2.3 De overige beginselen in Unierechtelijke context 145

5.3 De positie van de beginselen van behoorlijke rechtspleging in het Unierecht $\quad 150$

$6 \quad$ Samenvatting en conclusies $\quad 153$

6.1 De beginselen van behoorlijke rechtspleging 153

6.2 De positie van de beginselen van behoorlijke rechtspleging in het
Nederlandse bestuursrecht

DEEL II Bestuurlijke voorprocedures $\quad 159$

$1 \quad$ De bestuurlijke voorprocedures onder de Awb $\quad 159$

1.1 Inleiding 159

$\begin{array}{ll}1.2 \text { De voorprocedures in de Awb } & 160\end{array}$

$\begin{array}{ll}\text { 1.2.1 Onderlinge verschillen } & 161\end{array}$

$\begin{array}{lll}1.3 & \text { Definitie van een voorprocedure } & 162\end{array}$

$\begin{array}{lll}1.4 & \text { Status quo? } & 164\end{array}$

1.4.1 Kritiek op de oorspronkelijke opzet 164

$\begin{array}{ll}\text { 1.4.2 Invoering van het rechtstreeks beroep } & 165\end{array}$

1.5 Recente en toekomstige wijzigingen in de Awb 168

$2 \quad$ Onderzoeksvragen $\quad 173$

3 Opbouw 175

$4 \quad$ De bezwaarschriftprocedure en het administratief beroep 177

4.1 Inleiding 177

$\begin{array}{lll}\text { 4.1.1 De klassieke voorprocedures } & 177\end{array}$

$\begin{array}{lll}4.1 .2 & \text { Voorvragen } & 178\end{array}$

$\begin{array}{lll}4.1 .3 & \text { Opbouw } & 178\end{array}$

$\begin{array}{llr}4.2 & \text { Functies van de bezwaarschriftprocedure } & 179\end{array}$

4.2.1 Inleiding 179

$\begin{array}{lr}4.2 .2 \text { De rechtsbeschermingsfunctie } & 180\end{array}$

4.2.2.1 Inleiding 180

4.2.2.2 De invulling van het begrip rechtsbescherming 182

$\begin{array}{lll}\text { 4.2.2.3 Verlengde besluitvorming } & 187\end{array}$

4.2.2.4 De aard van de bevoegdheid 189

$\begin{array}{lll}4.2 .3 & \text { Filterfunctie } & 193\end{array}$

$\begin{array}{lll}4.2 .4 & \text { Verduidelijkingsfunctie } & 195\end{array}$

$\begin{array}{llr}4.2 .5 & \text { Leerfunctie } & 198\end{array}$

4.2.6 Functies van het administratief beroep 199

$\begin{array}{lll}4.2 .7 & \text { Conclusies } & 203\end{array}$

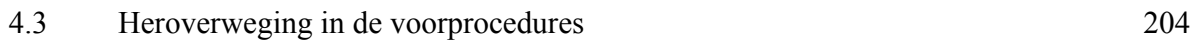

4.3.1 De omvang van de heroverweging 205

$\begin{array}{ll}\text { 4.3.1.1 Volledige heroverweging in de voorprocedures } & 205\end{array}$

4.3.1.2 Heroverweging op grondslag van het bezwaar 212

$\begin{array}{lll}\text { 4.3.1.3 De bestuurlijke heroverweging en de toetsing door de bestuursrechter } & \\ \text { vergeleken } & 218\end{array}$

$\begin{array}{ll}\text { 4.3.2 Heroverweging ex-nunc } & 218\end{array}$

4.3.2.1 Ex nunc-heroverweging in bezwaar als algemeen uitgangspunt $\quad 219$

4.3.2.2 Betrekkelijkheid van de hoofdregel 221

4.3.2.3 Relativering van het onderscheid tussen bestuurlijke en rechterlijke
werkzaamheid

$\begin{array}{lll}\text { 4.3.2.4 Conclusies } & 228\end{array}$ 
4.4 De bezwaarschriftprocedure en het administratief beroep: besluitvorming en/of rechtsbescherming?

5 De inrichting van de bezwaarschriftprocedure en het administratief beroep

$5.1 \quad$ Inleiding

Plan van aanpak

5.3 Hoor en wederhoor in de bestuurlijke voorprocedures

5.3.1 Inleiding

5.3.2 Het recht om mondeling informatie te verschaffen in de bezwaarfase

5.3.2.1 De verschillende mogelijkheden om mondeling informatie te verschaffen

5.3.2.2 Het horen in de bestuurlijke voorprocedures

5.3.2.3 De hernieuwde hoorplicht in het perspectief van hoor en wederhoor

5.3.2.4 Verschillende ongeschreven hoorplichten en reactiemogelijkheden gedurende de procedure

5.3.2.5 Andere mogelijkheden om informatie te verschaffen

5.3.2.6 De gevolgen van schendingen van het recht om mondeling informatie te verschaffen

5.3.3 Het recht om schriftelijk informatie te verschaffen

5.3.3.1 Inleiding 268

5.3.3.2 Het indienen van stukken in de bestuurlijke voorprocedures 268

$\begin{array}{ll}\text { 5.3.3.3 Begrenzing door de goede procesorde } & 269\end{array}$

5.3.3.4 Het recht om te reageren op adviezen 276

5.3.3.5 De gevolgen van schendingen van het recht om schriftelijk informatie te
verschaffen

$\begin{array}{lll}\text { 5.3.4 Het recht om informatie te ontvangen } & 278\end{array}$

$\begin{array}{lll}\text { 5.3.4.1 Het recht op inzage in de stukken } & 279\end{array}$

5.3.4.2 Het recht om informatie te ontvangen over procedure en incidenten in de
procedure

5.3.4.3 De gevolgen van schendingen van het recht om informatie te ontvangen 291

$\begin{array}{ll}\text { 5.3.5 Equality of arms in de bestuurlijke voorprocedures } & 293\end{array}$

5.3.5.1 De gelding van equality of arms 293

5.3.5.2 Gevolgen van schendingen van equality of arms in de bestuurlijke $\begin{array}{ll}\text { voorprocedures } & 303\end{array}$

5.3.6 Doorwerking van het beginsel van hoor en wederhoor 304

5.4 Onafhankelijkheid en onpartijdigheid van het bestuur in de bestuurlijke voorprocedures

5.4.1 Rechterlijke onpartijdigheid en onafhankelijkheid 309

$\begin{array}{ll}\text { 5.4.2 Onafhankelijk bestuur: een contradictio in terminis? } & 310\end{array}$

$\begin{array}{ll}\text { 5.4.3 Onpartijdigheid in de bestuurlijke voorprocedures } & 320\end{array}$

$\begin{array}{ll}\text { 5.4.3.1 Inleiding } & 320\end{array}$

5.4.3.2 Het onpartijdigheidsbeginsel voor het bestuur: een zelfstandig beginsel of

5.4.3.3 Inherente grenzen van de onpartijdigheid van het bestuur $\quad 330$

5.4.3.4 Categorieën van mogelijke partijdigheid van het bestuur 338

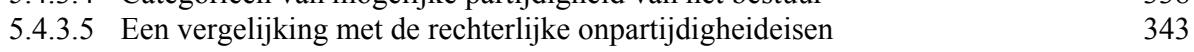

5.4.3.6 De gevolgen van schendingen van het verbod van vooringenomenheid 347

$\begin{array}{lll}\text { 5.4.4 Doorwerking van de onafhankelijkheids- en onpartijdigheidseisen in de } & \\ \text { bestuurlijke voorprocedures } & 349\end{array}$

$\begin{array}{lll}5.5 & \text { Openbaarheid in de bestuurlijke voorprocedures } & 351\end{array}$

$\begin{array}{ll}\text { 5.5.1 Openbaarheid als eis voor een behoorlijke voorprocedure } & 351\end{array}$

5.5.2 Het doel van de openbaarheidseisen in de bestuurlijke voorprocedure 356

5.5.3 Een openbare behandeling in de bezwaarschriftprocedure en het administratief beroep

5.5.4 Openbaarmaking van de beslissing in de bezwaarschriftprocedure en het administratief beroep

$\begin{array}{lll}\text { 5.5.5 De gevolgen van schendingen van de openbaarheideisen } & 365\end{array}$ 
$\begin{array}{lll}\text { 5.5.6 Doorwerking van de openbaarheidseisen } & 367\end{array}$

5.6 Motivering van besluiten in de bestuurlijke voorprocedures 369

5.6.1 De verschillende verschijningsvormen van het motiveringsbeginsel $\quad 369$

5.6.2 Waartoe dient de motiveringsplicht in de bestuurlijke voorprocedure(s)? 373

5.6.3 Invulling van de motiveringsplicht voor het bestuur in bezwaar en
administratief beroep

5.6.4 Specifieke motiveringseisen in de bestuurlijke voorprocedures 381

$\begin{array}{lll}\text { 5.6.4.1 Wettelijk voorgeschreven aanvullende motiveringseisen } & 381\end{array}$

5.6.4.2 Aanvullende ongeschreven motiveringseisen 384

$\begin{array}{lll}\text { 5.6.5 Gevolgen van schending van de motiveringseisen } & 389\end{array}$

5.6.6 Doorwerking van het motiveringsbeginsel in de bestuurlijke voorprocedures 390

5.7 Tijdigheid in de bestuurlijke voorprocedures 391

5.7.1 Groeiend belang van voortvarende besluitvorming in bezwaar en

5.7.2 De grondslagen voor de verplichting tot tijdige besluitvorming 396

5.7.3 Besluitvorming binnen een redelijke termijn als een afzonderlijk beginsel 403

5.7.5 Consequenties van stilzittend en traag bestuur 412

5.7.5.1 Gevolgen verbonden aan schendingen van beslistermijnen en de redelijke
termijn

$\begin{array}{lll}\text { 5.7.5.2 Effectieve rechtsbescherming tegen traag bestuur } & 412\end{array}$

5.7.6 Doorwerking van de redelijke termijn-eis 421

$\begin{array}{lll}5.8 & \text { Conclusies } & 422\end{array}$

$\begin{array}{lr}\text { DEEL III Slotbeschouwing } & \mathbf{4 2 5}\end{array}$

1 Inleiding 425

2 De doorwerking van de beginselen van behoorlijke rechtspleging 426

$\begin{array}{lll}2.1 & \text { De verschillende vormen van doorwerking } & 426\end{array}$

\begin{tabular}{ll}
2.1 .1 & Rechtstreekse toepasselijkheid \\
\hline
\end{tabular}

2.1.2 De tussenvormen van doorwerking $\quad 430$

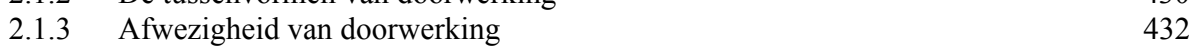

2.1.4 De gevolgen van de indeling in verschillende categorieën 433

2.2 Factoren die de mate van doorwerking kunnen beïnvloeden 434

2.2.1 De interne of externe werking van de beginselen van behoorlijke
rechtspleging

2.2.2 Equivalente beginselen van behoorlijk bestuur 437

De gevolgen van schendingen van de beginselen van behoorlijke
rechtspleging

3 Het bestuursrechtelijke systeem van rechtsbescherming, de bestuurlijke

$3.1 \quad$ Inleiding 444

3.2 De typering van de bestuurlijke voorprocedures in het Nederlandse
bestuursrechtelijke systeem van rechtsbescherming

3.3 De bestuursrechter en de beginselen van behoorlijke rechtspleging 449

$4 \quad \begin{aligned} & \text { De verhouding van de beginselen van behoorlijke rechtspleging tot de } \\ & \text { algemene beginselen van behoorlijk bestuur }\end{aligned}$

4.1 De overlap tussen de beginselen van behoorlijk bestuur en behoorlijke rechtspleging

4.2 Overkoepelende beginselen van een behoorlijke procedure of behoorlijk procesrecht

$5 \quad$ Slotopmerkingen 458

$\begin{array}{ll}\text { Summary } & \mathbf{4 6 1}\end{array}$

$\begin{array}{ll}\text { Literatuurlijst } & \mathbf{4 6 7}\end{array}$

$\begin{array}{ll}\text { Jurisprudentielijst } & 477\end{array}$

$\begin{array}{ll}\text { Curriculum vitae } & 489\end{array}$ 


\section{Inleiding}

\section{Achtergrond van en aanleiding voor het onderzoek}

De bestuurlijke voorprocedures: zowel besluitvorming als rechtspraak

In het Nederlandse bestuursrechtelijke systeem van rechtsbescherming is het gebruikelijk dat een belanghebbende, alvorens de toegang tot de bestuursrechter openstaat, een bestuurlijke voorprocedure doorloopt. Daarbij moet eerst en vooral gedacht worden aan de bezwaarschriftprocedure. Dat is de meest voorkomende en meest bekende (of wellicht beruchte $^{1}$ ) bestuurlijke voorprocedure, aangezien deze in de artikelen 7:1 juncto 8:1 Awb algemeen verplicht is gesteld voorafgaand aan het beroep op de bestuursrechter. ${ }^{2}$ Deze procedure heeft sinds de inwerkingtreding van de Awb in toenemende mate in de aandacht van de doctrine gestaan en zij vormt een veelbesproken onderdeel van het Nederlandse bestuursrechtelijke systeem van rechtsbescherming. ${ }^{3}$ Daarnaast komt het administratief beroep als bestuurlijke voorprocedure, hoewel deze procedure niet vaak meer wordt voorgeschreven (in elk geval niet als eindstation ${ }^{4}$ ), een belangrijke plaats toe in de ontwikkeling van het Nederlandse bestuursrechtelijke systeem van rechtsbescherming. Het administratief beroep is een bestuurlijke (voor)procedure die jarenlang dé bestuursrechtelijke voorziening van rechtsbescherming vormde en die de discussies over de inrichting van het systeem van rechtsbescherming heeft gedomineerd. ${ }^{5}$ De bezwaarschriftprocedure en het administratief beroep vormen de klassieke bestuurlijke voorprocedures, waarvan algemeen aanvaard is dat zij onderdeel uitmaken van het bestuursrechtelijke

\footnotetext{
${ }^{1 .}$ Naast positieve geluiden zijn er ook meer kritische geluiden te horen geweest over de werking van de bezwaarschriftprocedure in het Nederlandse bestuursrecht. Het meest bekend is wellicht de door Biesheuvel aangezwengelde discussie: M. Biesheuvel, 'Weg met de bezwaarschriftprocedure', NJB 1996, p. 390. De reacties daarop van: P. Vanderheyden, 'Weg met de advocatuur', NJB 1996, p. 1111-1112; E. Alders, 'Deregulering ook voor de Awb', NJB 1996, p. 1113; J.J.A. Bosch, 'De bezwaarschriftprocedure moet blijven', NJB 1996, p. 1214-1215; C.J.A.M. Kortmann, 'Weg met de bezwaarschriftprocedure?', $N J B$ 1996, p. 1113; M. Biesheuvel, 'Naschrift', NJB 1996, p. 1113-1114; B.E.M. Hendrickx, 'Weg met de bezwaarschriftprocedure?', NJB 1996, p. 1371.

${ }^{2}$ Hoewel onder voorwaarden het doorlopen van de bezwaarschriftprocedure kan worden overgeslagen, ingevolge art. 7:1a Awb, vormt deze procedure thans nog steeds een algemeen verplicht gestelde voorprocedure die gevolgd moet worden alvorens beroep op de bestuursrechter openstaat. Op de hoofdregel dat, alvorens beroep kan worden ingesteld bij de bestuursrechter, eerst bezwaar moet worden gemaakt, bestaan wel uitzonderingen. Zo is in art. 7:1 lid $1 \mathrm{sub}$ a $\mathrm{t} / \mathrm{m}$ e neergelegd dat geen bezwaar hoeft te worden gemaakt tegen een besluit dat op bezwaar of in administratief beroep is genomen, een besluit dat aan goedkeuring is onderworpen, een besluit da de goedkeuring van een ander besluit of de weigering van die goedkeuring inhoudt, een besluit dat is voorbereid met toepassing van de uniforme voorbereidingsprocedure of het beroep zich richt tegen het niet tijdig nemen van een besluit.

3. Getuige de vele publicaties die aan deze procedure zijn gewijd sedertdien. Een kleine greep daaruit: K.H. Sanders, De heroverweging getoetst. Een onderzoek naar het functioneren van bezwaarschriftprocedures, Deventer: Kluwer 1998; J.H.W. Notten, De Algemene wet bestuursrecht en het maken van bezwaar, Den Haag: Sdu 1998; H. Bolt, 'De bezwaarschriftenprocedure als voorprocedure: heroverweging en voorbehandeling', NTB 1988, p. 6-11. Zie verder Deel II van dit onderzoek, par. 1 tot en met 4.

4. Dit is zoals bekend het gevolg van een uitspraak van het EHRM waarin het Kroonberoep in strijd met de onafhankelijkheids- en onpartijdigheidseisen van art. 6 EVRM werd geacht, EHRM 23 oktober 1985, Benthem $\mathrm{t}$. Nederland, $A B$ 1986/1 m.nt. E.M.H. Hirsch Ballin; NJ 1986/102 m.nt. E.A. Alkema. Zie ook hierover: N. Verheij, 'De toegang tot de rechter in het bestuursrecht', in: 50 jaar Europees verdrag voor de rechten van de mens, NJCM-Bulletin 2000, nr. 1, p. 183-201.

5. Zie over de historische ontwikkeling van het systeem van rechtsbescherming en de plaats daarin van het administratief beroep: L.J.A. Damen, H.E. Bröring, K.J. de Graaf, A.T. Marseille, A.J.G.M. van Montfort, P. Nicolaï, B.J. Schueler, H.B. Winter, Bestuursrecht. Rechtsbescherming tegen de overheid. Bestuursprocesrecht (Deel II), Den Haag: BJu 2009, p. 32- 44; H.D. Van Wijk, bewerkt door W. Konijnenbelt \& R.M. Van Male, Hoofdstukken van bestuursrecht, Den Haag: Elsevier Juridisch 2008, p. 16-24; Verheij 2000, p. 188 e.v.
} 


\section{Doorwerking van de beginselen van behoorlijke rechtspleging}

systeem van rechtsbescherming. ${ }^{6}$ Er zijn ook nog andere procedures bij het bestuur die, afhankelijk van hetgeen onder het begrip 'voorprocedure' wordt verstaan, tot de bestuurlijke voorprocedures gerekend kunnen worden. Te denken valt aan de goedkeuringsprocedure en de uniforme voorbereidingsprocedure. ${ }^{?}$

In dit onderzoek staat de betekenis van de algemene beginselen van behoorlijke rechtspraak voor de inrichting van de bestuurlijke voorprocedures centraal. De vraag naar de betekenis van juist die beginselen voor die procedures lijkt op het eerste gezicht niet voor de hand te liggen. De beginselen van behoorlijke rechtspraak zijn immers beginselen die primair geassocieerd worden met procedures bij rechterlijke instanties en niet met procedures bij het bestuur. Beide soorten procedures vinden plaats bij geheel verschillende organen waaraan, vanuit de eigen aard van de werkzaamheid van die organen en hun onderscheiden posities in ons staatsbestel, specifieke 'eigen' eisen gesteld worden. ${ }^{8}$ Voor rechterlijke instanties vormen de beginselen van behoorlijke rechtspraak, zoals mede gepositiveerd in artikel 6 EVRM, de in acht te nemen behoorlijkheidsnormen, terwijl dat voor bestuursorganen de algemene beginselen van behoorlijk bestuur zijn. ${ }^{9}$

Desalniettemin bestaat er om drie redenen aanleiding om onderzoek te doen naar de betekenis van de beginselen van behoorlijke rechtspraak voor de bestuurlijke voorprocedures. Allereerst is dat de verwantschap tussen de bestuurlijke voorprocedures en (bestuurs)rechtspraak. Voorts zijn de bestuurlijke voorprocedures onderdeel van het bestuursrechtelijke systeem van rechtsbescherming. Ten slotte zijn al verschillende voor rechtspraak geldende eisen van toepassing op de bestuurlijke voorprocedures. Deze drie redenen worden hierna kort toegelicht.

Verwantschap tussen de bestuurlijke voorprocedures en rechtspraak

De bestuurlijke voorprocedures nemen in het Nederlandse bestuursrechtelijke systeem in zekere zin een merkwaardige positie in. ${ }^{10}$ Enerzijds zijn het besluitvormingsprocedures bij het bestuur en anderzijds vormen zij met waarborgen omklede voorzieningen voor burgers om een eerder genomen besluit van het bestuur aan te tasten. In de bestuurlijke voorprocedures wordt na volledige heroverweging een besluit genomen door het bestuur, maar dat geschiedt in een met waarborgen omklede procedure op initiatief van en naar aanleiding van bezwaren (of beroepsgronden dan wel zienswijzen) van belanghebbenden die het niet eens zijn met het in primo genomen besluit. Op het moment dat de bestuurlijke voorprocedure aanhangig wordt gemaakt, ontstaat er een geschil tussen de desbe-

\footnotetext{
6. VAR Commissie Rechtsbescherming, De toekomst van de rechtsbescherming tegen de overheid. Van toetsing naar geschilbeslechting (Rapport Commissie Rechtsbescherming), Den Haag: BJu 2004, p. 15. Zie ook: Damen e.a. 2009, Deel II, p. 22-33 en p. 173 e.v.; Van Wijk/Konijnenbelt \& Van Male 2008, p. 517, 521 en 543.

${ }^{7}$ Op de vraag of deze procedures als voorprocedure kunnen worden beschouwd, wordt teruggekomen in par. 1.3 van Deel II van dit onderzoek.

8. Zie bijvoorbeeld: M. Schreuder-Vlasblom, Rechtsbescherming en bestuurlijke voorprocedure, Deventer: Kluwer 2008, p. 55-56.

${ }^{9 .}$ In dit onderzoek wordt met de term behoorlijkheidsnormen gedoeld op rechtsnormen, waarvan schending een rechtmatigheidsgebrek met zich brengt. Meer specifiek zien de behoorlijkheidsnormen in dit onderzoek op de beginselen van behoorlijke rechtspleging, die als rechtsbeginselen en derhalve rechtsnormen worden beschouwd. De behoorlijkheidsnormen die de Nationale Ombudsman hanteert worden buiten beschouwing gelaten. Zie over het onderscheid tussen de behoorlijkheidsnormen die de Nationale ombudsman hanteert en de normen waaraan de bestuursrechter toetst alsmede de discussie daarover de recente bijdragen in het NTB: A.F.M. Brenninkmeijer en W.J. van Hoogstraten, 'De architectuur van behoorlijk bestuur. De bijdrag van de Nationale ombudsman aan behoorlijk bestuur in 25 jaar', NTB 2008/2, p. 33-39; L.J.A. Damen, 'Behoorlijk, en ook rechtmatig, of juist eerlijk?', NTB 2008/2, p. 40-51

${ }^{10}$. $\mathrm{Zij}$ worden ook weleens gekenschetst als hybride procedures die zich tussen bestuur en rechtspraak in bevinden. Wiarda heeft met name het administratief beroep als hybride aangemerkt, G.J. Wiarda, 'Het administratief beroep (openingsrede voor de algemene vergadering van de VAR op 7 oktober 1966), in: Verspreide geschriften van Wiarda, Den Haag: VUGA p. 124. Zij zijn ook al eens procedures met een Januskop genoemd, M.A. van der Ham, 'De gemeente als rechter in eigen zaak: (on)behoorlijke rechtspraak of (on)behoorlijk bestuur, in: H.A. Brasz en J.G. Steenbeek (red.), Klachten en bezwaren tegen de gemeente, Den Haag: VUGA 1988, p. 78.
} 


\section{Inleiding}

treffende belanghebbenden en het beslissende bestuursorgaan. ${ }^{11}$ In de bestuurlijke voorprocedures vindt derhalve tot op zekere hoogte naast bestuurlijke besluitvorming evenals in de rechterlijke procedure - geschilbeslechting plaats. ${ }^{12}$ De bestuurlijke voorprocedures, in het bijzonder de bezwaarschriftprocedure, behelzen aldus elementen van twee werelden: tegelijkertijd zijn zij (verlengde) besluitvormingsprocedures bij het bestuur die door middel van een volledige heroverweging moeten leiden tot een (nieuw) besluit én een vorm van rechtsbescherming die sterke gelijkenis kan vertonen met rechtspraak in functionele zin. ${ }^{13}$ Dat tweeledige karakter van verlengde besluitvorming en rechtsbescherming is onlosmakelijk verbonden met de klassieke voorprocedures. Over de mate waarin het (verlengde) besluitvormingskarakter, dan wel het rechtsbeschermingskarakter domineert (of zou moeten domineren), bestaat nog wel eens verschil van mening. ${ }^{14}$ Vaststaat echter dat beide functies in enigerlei mate aan in elk geval de bezwaarschriftprocedure toekomen. Dat geldt ook voor het administratief beroep, hoewel daaraan in plaats van een verlengde besluitvormingsfunctie veeleer een toezichtfunctie wordt toegekend. ${ }^{15}$

De verwantschap van bestuurlijke voorprocedures met rechtspraak is de belangrijkste aanleiding om te onderzoeken of er dientengevolge niet ook met rechtspraak gemeenschappelijke of vergelijkbare eisen bestaan voor de bestuurlijke voorprocedures. Onderzoek naar de waarborgen die gelden voor de inrichting van de bestuurlijke voorprocedures en de vraag waartoe deze processuele waarborgen te herleiden zijn, is bovendien nog niet uitvoerig verricht onder het regime van de Awb. Hoewel aan het tweeledige karakter van de bestuurlijke voorprocedures (bestuurlijke besluitvorming en een vorm van rechtsbescherming) veel aandacht is besteed, zijn de voorschriften voor de inrichting van de bestuurlijke voorprocedure alsmede de eisen uit de jurisprudentie van de bestuursrechter in de doctrine onderbelicht gebleven. De omstandigheid dat de bestuurlijke voorprocedures kenmerken van zowel besluitvorming als rechtspraak vertonen, doet immers de vraag rijzen naar de toepasselijke normen en eisen voor de inrichting van die procedures. Zijn dat de eisen die voor rechtspraak gelden óf zijn dat de eisen die voor bestuurlijke besluitvorming gelden? En is er materieel gezien sprake van vergelijkbare of juist verschillende eisen?

Omdat de bestuurlijke voorprocedures zich tussen besluitvorming en rechtspraak in bevinden, is het van belang te onderzoeken in hoeverre die positie van invloed is op de voor de bestuurlijke voorprocedures toepasselijke normen en eisen. Traditioneel worden in de doctrine en de rechtspraak (vooral) de algemene beginselen van behoorlijk bestuur als behoorlijkheidskader voor de bestuurlijke voorprocedures gehanteerd, omdat er nu eenmaal sprake is van besluitvorming en procedures bij het bestuur. Zo bezien, bestaat er ook geen verschil tussen de primaire besluitvormingsfase en de bestuurlijke voorprocedure, hoewel uitsluitend aan de laatste een rechtsbeschermingsfunctie wordt toegekend. Voor beide procedures gelden de algemene beginselen van behoorlijk bestuur en daaruit

\footnotetext{
11. Zie in het kader van de redelijke termijn, als neegelegd in art. 6 EVRM: EHRM 28 juni 1978, König t. Duitsland, NJ 1980/54 en EHRM 9 december 1994, Schouten en Meldrum t. Nederland, JB 1995/49 m.nt. AWH; AB 1995/599 m.nt. ICvdV. De nationale bestuursrechter legt de start van het geschil ook op dat moment door de redelijke termijn bij het indienen van een bezwaarschrift te laten lopen, zie bijv.: CRvB 3 januari 2008, $A B$ 2008/211 m.nt. AMLJ; AbRvS 12 december 2007, AB 2008/34 m.nt. Alfred van Hall; AbRvS 29 juni 2005, $A B$ 2006/43 m.nt. AMLJ. Zie over het redelijke termijn-vereiste nader par. 4.3.8 van Deel I en 5.7 van Deel II van dit onderzoek.

12. De bestuurlijke voorprocedures worden dan ook angemerkt als contentieuze procedures, zie bijvoorbeeld: Van Wijk/Konijnenbelt \& Van Male 2008, p. 30; C.P.J. Goorden, 'Rechtsbescherming tegen en door gemeentelijke bestuursorganen' NTB 1990, p. 130.

13. Vgl. C.J.N. Versteden, 'De plaats van bezwaar en administratief beroep in het stelstel van rechtsbescherming', NTB 1995/9-10, p. 290. Over het begrip rechtspraak in functionele zin kom ik nader te spreken in hfst. 2 van Deel I van dit onderzoek. Voor nu volstaat het te vermelden dat hiermee kort gezegd bedoeld wordt de beslechting van een rechtsgeschil.

14. Hierop wordt nader ingegaan in Deel II van dit onderzoek, par. 4.2

15. Van Wijk/Konijnenbelt \& Van Male 2008, p. 545-46. Zie over de functies van het administratief beroep nader Deel II, par. 4.2.6.
} 


\section{Doorwerking van de beginselen van behoorlijke rechtspleging}

voortvloeiende eisen. In de regeling van de Awb nemen de waarborgen voor de burger in iedere fase van de procedure inzake een besluit echter toe. ${ }^{16}$ Dat betekent dat het uitgangspunt wat betreft de inrichting van de procedure is dat de waarborgen ten opzichte van de primaire besluitvormingsfase in de bestuurlijke voorprocedure toenemen, terwijl de waarborgen nog niet gelijk zijn aan de waarborgen die gelden in de procedure bij de bestuursrechter. $^{17}$

De toename van procedurele waarborgen in de bestuurlijke voorprocedures hangt samen met de rechtsbeschermingsfunctie die deze procedures hebben (in tegenstelling tot de primaire besluitvormingsfase). ${ }^{18}$ De eisen in de Awb en ook de aanvullende eisen die soms in de jurisprudentie in samenhang met die rechtsbeschermingsfunctie worden gesteld, worden echter vaak herleid tot de algemene beginselen van behoorlijk bestuur en niet tot beginselen van behoorlijke rechtspraak. ${ }^{19}$ De rechtsbeschermingscomponent en de gelijkenis met rechtspraak lijkt daarmee in de toepasselijke normen lang niet altijd tot uitdrukking te komen. ${ }^{20}$ Het ligt echter in de rede dat het tweeledige karakter van de bestuurlijke voorprocedures ook tot uitdrukking komt in de behoorlijkheidsnormen en eisen die gesteld worden aan de inrichting van die procedures. Dat zou betekenen dat niet alleen de bestuurlijke behoorlijkheidsnormen, maar ook de voor rechtspraak geldende normen of eisen van invloed kunnen zijn. In dit onderzoek staat de specifieke betekenis van die beginselen en de gevolgen daarvan voor de inrichting van de bestuurlijke voorprocedures centraal. Daartoe worden de voor de inrichting van de bestuurlijke voorprocedures geldende eisen en voorschriften vergeleken met de voor rechtspraak geldende normen.

Onderdeel van het stelsel van bestuursrechtelijke rechtsbescherming

Niet alleen de verwantschap tussen de voorprocedures en de procedures bij de bestuursrechter geeft aanleiding tot het onderzoek. De omstandigheid dat, los van de verwantschap met rechtspraak, met name de bezwaarschriftprocedure en het administratief beroep onderdeel uitmaken van het stelsel van rechtsbescherming vormt een andere belangrijke reden voor het onderzoek. Bovendien dienen de voorprocedures, zodra voorgeschreven, verplicht doorlopen te worden alvorens de toegang tot de bestuursrechter openstaat, en beperken zij derhalve voor de burger in een geschil met het bestuur de toegang tot de bestuursrechter. ${ }^{21}$ Daar komt nog bij dat onder invloed van de Awb, en de

16. PG Awb I, p. 107. Zie ook: Notten 1998, p. 8; M. Scheltema, 'De rechter en de bezwaarschriftprocedure: meer aandacht voor snelheid en minder voor aansprakelijkheid', in: T. Hoogenboom en L.J.A. Damen (red.), In de sfeer van administratief recht (opstellen aangeboden aan Willem Konijnenbelt), Utrecht: Lemma 1994, p. 380381 .

17. Notten noemt dit de drie-fasen-filosofie van de Awb, Notten 1998, p. 8. Zie ook: Scheltema 1994, p. 380-381; PG Awb I, p. 107. Die bedoeling blijkt ook uit de omstandigheid dat hoofdstuk 3 van de Awb - dat ziet op de algemene bepalingen ten aanzien van besluiten - ook van toepassing is in bezwaar, voor zover deze bepalingen niet zijn uitgezonderd in artikel 7:14 Awb, én dat hoofdstuk 6 en 7 Awb nog aanvullende andere voorschriften voor die procedure (en de procedure bij de rechter) bevat die niet gelden voor de primaire besluitvormingsfase. Hoofdstuk 8 bevat vervolgens weer voorschriften uitsluitend voor de rechterlijke procedure.

${ }^{18 .}$ Damen e.a. 2009, Deel II, p. 174-175; Van Wijk/Konijnenbelt \& Van Male 2008, p. 544-545. Meer uitgebreid wordt op de rechtsbeschermingsfunctie ingegaan in par. 4.2 van Deel II van dit onderzoek.

19. Zie in het kader van het horen in bezwaar bijvoorbeeld: L.M. Koenraad en K.H. Sanders, Besluiten op bezwaar, Deventer: Kluwer 2006, p. 61-63.

${ }^{20 .}$ Het is niet altijd zo dat de toepasselijke eisen of voorschriften uitsluitend tot de algemene beginselen van behoorlijk bestuur herleid worden. Zo wordt de hernieuwde hoorplicht ex art. 7:9 Awb bijvoorbeeld herleid to het beginsel van hoor en wederhoor, zie bijvoorbeeld: AbRvS 26 april 2006, JB 2006/184 m.nt. D. Wenders. Hierop wordt in Deel II, hfst. 5, par. 5.3.2.3 nader ingegaan.

21. Vgl: Rapport VAR-Commissie Rechtsbescherming 2004, p. 50-51; H.J. Simon, 'Signalen uit Straatsburg', in: R.M. van Male, H. Bolt e.a. (red.), Centrale Raad van Beroep 1903-2003, Den Haag: Sdu 2003 (hierna: Simon 2003b), p. 381-283; R.J.N. Schlössels, 'Tussen finaliteit en fuik? Over de omvang van het bestuursrechtelijke geding in eerste aanleg en appèl', in: M.A. Heldeweg, E.C.H.J. van der Linden \& R.J.N. Schlössels (red.), Uit de school geklapt? Opstellen uit Maastricht, Den Haag: Sdu 1999, p. 184. De problematiek inzake de voorprocedures als beperking op de toegang tot de rechter wordt veelal (onder meer) in de sleutel van artikel 6 EVRM en de daaruit voortvloeiende vereisten geplaatst. 


\section{Inleiding}

daarin vooropgestelde partij-autonomie en rechtsbeschermingsfunctie van het bestuursprocesrecht, een ontwikkeling in gang is gezet waardoor de bestuurlijke voorprocedures, in het bijzonder de bezwaarschriftprocedure, in aanzienlijke mate bepalend kunnen zijn voor de daaropvolgende procedure bij de bestuursrechter. ${ }^{22}$ Gedoeld wordt op de vormgeving van een 'trechter of fuik' tussen bezwaar en beroep bij de bestuursrechter in eerste aanleg, waaruit volgde dat in bezwaar niet aangevoerde gronden tegen een besluit niet voor het eerst in beroep mochten worden aangevoerd. ${ }^{23}$ Hoewel deze trechter al aanzienlijk versoepeld was de laatste jaren ${ }^{24}$ en thans niet meer in deze vorm geldt, werpen de keuzes gemaakt door belanghebbenden in de bestuurlijke voorprocedures, gelet op artikel 6:13 Awb, nog steeds hun schaduw vooruit naar de procedure bij de bestuursrechter. Op grond van het huidige artikel 6:13 Awb wordt namelijk een onderdelentrechter aangenomen. ${ }^{25}$ Die trechter houdt in dat afzonderlijke besluitonderdelen die in de bestuurlijke voorprocedures niet zijn aangevochten door een belanghebbende, in de procedure bij de bestuursrechter niet meer door diezelfde belanghebbende ter discussie kunnen worden gesteld. ${ }^{26}$

Hoewel de discussie over trechters of fuiken tussen de bezwaarschriftprocedure en het beroep bij de bestuursrechter aan belang heeft ingeboet, is daardoor - nog daargelaten de vraag of een beperking van de toegang tot de rechter in de vorm van verschillende trechters (voor zover daar nog sprake van is), met het oog op artikel 6 EVRM, geoorloofd is ${ }^{27}$ - het belang van de voorfase in de gehele procedure toegenomen. Dat toegenomen belang rechtvaardigt de vraag of bepaalde waarborgen die gelden voor de rechterlijke procedure niet ook reeds in de voorprocedures gelden.

22. A.M.L. Jansen, Constitutionalisering van het bestuursprocesrecht, Deventer: Kluwer 2004, p. 45-46 en 51.

23. De trechter tussen bezwaar en beroep bij de bestuursrechter is vooral in de jurisprudentie van de verschillende bestuursrechtelijke colleges, met name de Afdeling bestuursrechtspraak van de Raad van State (hierna: de Afdeling) tot ontwikkeling gebracht. Zie hierover: P.A. Willemsen, De grenzen van de rechtsstrijd in het bestuursrechtelijk beroep en hoger beroep in rechtsvergelijkend perspectief (diss. Utrecht), Deventer: Kluwer 2005, p. 95-99; R. Ortlep, 'De fuikendynastie: van afbraak tot verbouwing', NTB 2005/1, p. 1-5; Rapport VARCommissie Rechtsbescherming 2004, p. 108-114; Schlössels 1999, p. 182-183. Uit deze jurisprudentie volgde dat een burger in bepaalde gevallen onderdelen van een besluit, gronden, feiten of bewijs niet meer (succesvol) in beroep bij de rechter aan de orde kon stellen, indien deze niet al in de voorprocedure aan de orde gesteld waren. Op het onderscheid tussen de verschillende trechters of fuiken ga ik hier niet in. Zie daarvoor de hiervoor genoemde bronnen of de bronnen genoemd in de volgende noot.

24. Zie: Van Wijk/Konijnenbelt \& Van Male 2008, p. 655-656; Ortlep 2005, p. 3. Vgl. ook: C.L.G.F.H. Albers \& R.J.N. Schlössels, 'De omvang van het bestuursrechtelijk geding: het Europese recht als het paard van Troje? Over de (on)toelaatbaarheid van procestechnische trechters en ambtshalve rechtstoepassing', Gst. (2005) 7224 p. 84-85. Voor een overzicht van de jurisprudentie verwijs ik naar: Willemsen 2005, p. 96-99. Verder over de trechter tussen bezwaar en beroep in eerste aanleg: Rapport VAR-Commissie Rechtsbescherming 2004, p. 108 114.

25. Art. 6:13 Awb is in zijn huidige vorm op 1 juli 2005 inwerking getreden, Kamerstukken II 2004/05, 29 421, nr. 3, p. 7 en nr. 11 .

26. Zie over het huidig art. 6:13 Awb ook: L.J.A. Damen, H.E. Bröring, K.J. de Graaf, A.T. Marseille, A.J.G.M. van Montfort, P. Nicolaï, B.J. Schueler, H.B. Winter, Bestuursrecht. Deel II Rechtsbescherming tegen de overheid. Bestuursprocesrecht, Den Haag: BJu 2009, p. 240-245; Van Wijk/Konijnenbelt \& Van Male 2008, p. 621622; H.J.M. Besselink, 'Art. 6:13 Awb; een tussenstand', JBplus 2008, p. 197-207; S.M.I. van Loon, 'Art. 6:13 Awb en de onderdelenfuik, NTB 2008, p. 333-338; B.J. van de Griend, Trechters in het bestuursprocesrecht, Den Haag: BJu 2007, par. 3.4, p. 165-189; M. Schreuder-Vlasblom, 'Art. 6:13 Awb: van berustingsbepaling tot koekoeksjong, JBplus 2007, p. 134-153; M. Schreuder-Vlasblom, 'Het gewijzigde artikel 6:13 Awb, een trechter tussen bestuur en rechter', JBplus Verklaard 2006, p. 3-15. Het huidige art. 6:13 Awb is ook al vaker in de jurisprudentie aan de orde gekomen: AbRvS 27 augustus 2008, AB 2008/328 m.nt. A.B. Blomberg; AbRvS 1 november 2006, $A B$ 2007/95 m.nt. G.M. van den Broek en A.T. Marseille.

27. Willemsen 2005 , p. 15. Zij merkt op dat het hanteren van een grondentrechter en/of bewijstrechter tussen de bestuurlijke fase en beroep in eerste aanleg risicovol is gelet op het recht op toegang tot de rechter. Zie ook: $\mathrm{T}$. Barkhuysen \& M.L. Emmerik, 'Het EVRM en het Nederlandse milieurecht', JB-plus 2004, p. 237; deze auteurs werpen de vraag op of de fuik-jurisprudentie van de Afdeling in overeenstemming is met het recht op behandeling van een zaak door een instantie met 'full jurisdiction'. In dezelfde zin: Willemsen 2005, p. 22-23; Albers \& Schlössels 2005, p. 91; Rapport VAR-Commissie Rechtsbescherming 2004, p. 61; Jansen 2004 p. 46; Schlössels 1999, p. 183-185; Widdershoven in zijn noot bij AbRvS 28 april 2004, AB 2004/276 m.nt. RW. 


\section{Doorwerking van de beginselen van behoorlijke rechtspleging}

Bepaalde voor rechtspraak geldende vereisten zijn al van toepassing

Ten slotte gelden thans al bepaalde vereisten die gesteld worden aan rechterlijke procedures ook voor de bestuurlijke voorfasen. Te denken valt daarbij aan het redelijke termijn-vereiste, zoals neergelegd in artikel 6, eerste lid van het EVRM. ${ }^{28}$ Voor de beoordeling of afdoening van een rechtsgeschil binnen een redelijke termijn heeft plaatsgevonden, beziet het EHRM immers de duur van de procedure in zijn geheel. Daarin is ook de duur van een bestuurlijke voorprocedure inbegrepen. ${ }^{29}$ Dat geldt niet alleen voor de bezwaarschriftprocedure en het administratief beroep, maar soms ook al voor andere 'voorprocedures' zoals de uniforme voorbereidingsprocedure, voor zover in dat stadium reeds sprake is van een geschil. ${ }^{30}$ Dat betekent dat de bestuurlijke voorprocedure tijdig afgerond dient te worden en tijdig tot een besluit dient te leiden. Overigens is besluitvorming (als eis voor een behoorlijke bestuurlijke voorprocedure) binnen een redelijke termijn een uitgangspunt dat eveneens naar nationaal (bestuurs)recht geldingskracht lijkt te hebben verkregen. ${ }^{31}$ De regelingen in de Awb aangaande de voorprocedures bevatten ook specifieke bepalingen waarin is neergelegd dat de besluitvorming binnen een bepaalde termijn dient plaats te vinden. ${ }^{32}$ Duidelijk is dat de redelijke termijn en de voortvarendheidseisen als eisen voor een behoorlijke procedure, evenzeer voor het bestuur als voor de rechter gelden. ${ }^{33} \mathrm{Nu}$ de procedures bij beide organen deze tijdigheidseisen gemeenschappelijk hebben, bestaat er ook daarom, naast de hiervoor genoemde redenen, aanleiding om te onderzoeken of en in hoeverre dat eveneens het geval is voor de overige eisen voor behoorlijke rechtspraak.

\footnotetext{
28. In deze zin Jansen die dit standpunt inneemt ten aanzien van bezwaarschriftachtige procedures, A.M.L. Jansen, 'Sloom bestuur onder vuur', JB-plus 2003, p. 166. Reeds in 1994 wijst Alkema overigens op die ontwikkeling: E.A. Alkema, 'Telt de 'voorfase' mee voor de redelijke termijn?', NJB 1994, p. 601-604. Zie hierover verder par. 4.3.8 van Deel I alsmede par. 5.7 van Deel II.

29. EHRM 29 juni 2006, Bozic t. Kroatië, nr. 22457/02; EHRM 29 juni 2006, Pocuca t. Kroatië, EHRC 2006/106. Al eerder in: EHRM 28 juni 1978, König t. Duitsland, NJ 1980/54; EHRM 9 december 1994, Schouten en Meldrum t. Nederland, AB 1995/599 m.nt. ICvdV; JB 1995/49 m.nt AWH; Willemsen 2005, p. 17-18; Jansen 2004, p. 71; J.H. Gerards, A.W. Heringa, H.L. Janssen, J. van der Velde, EVRM R\&C. Art. 6 Eerlijk proces, Den Haag: Sdu 2004, par. 3.6.6., p. 3; F.A.M. Stroink, Kern van de bestuursrechtspraak, Den Haag: Elsevier 2004 (hierna: Stroink 2004a), p. 71; T. Barkhuysen \& A.M.L. Jansen, 'Actuele ontwikkelingen in de redelijke termijnjurisprudentie: over Nederlandse termijnoverschrijdingen en ontbrekende nationale rechtsmiddelen', NJCMBulletin 2003/5, p. 588

30. T. Barkhuysen \& B.J. van Ettekoven, 'De compensatie voor schending van de redelijke termijn van art. 6 EVRM door de bestuursrechter', NTB 2009, p. 132; Rapport VAR-Commissie Rechtsbescherming 2004, p. 63 A.M.L. Jansen, 'De redelijke termijn, kaders voor de bestuursrechter', JB-plus 2001, p. 51-52; A.M.L. Jansen, De redelijke termijn. Met name in het bestuursrecht (diss. Tilburg), Den Haag: BJu 2000, p. 25-29. Van belang is ook dat het doorlopen van de voorprocedure verplicht is alvorens toegang tot de rechter te kunnen krijgen, Gerards, Heringa, Janssen \& Van der Velde 2004, par. 3.6.6, p. 3.

31. Kamerstukken II 2001/01, 27 461, nr. 1, p. 2. In deze nota 'Termijnen voor bestuur en rechter' wordt aangegeven dat de besluitvorming binnen een redelijke termijn onderdeel uitmaakt van het rechtszekerheidsbeginsel. In dezelfde zin: M. Scheltema, 'Het tijdigheidsbeginsel', in: De Awb-mens; boeman of underdog? (Opstellen aangeboden aan Leo Damen), Nijmegen: Ars Aequi libri 1996, p. 246. Zie hierover nader par. 5.7 van Deel II.

32. Zie bijvoorbeeld: art. 7:10 lid 1 Awb en art. 7:24 lid 1 en 2 Awb. Overigens staat tijdigheid van besluitvorming hoog op de politieke agenda, getuige ook de nota vermeld in de vorige noot en een tweetal recente wijzigingen van de Awb als gevolg van de Wet Dwangsom en rechtstreeks beroep bij niet tijdig beslissen, Wet van 28 augustus 2009, Stb. 2009, 383. Onderzoek heeft ook uitgewezen dat de termijnen die gelden voor de besluitvorming bijvoorbeeld veelvuldig door de rijksoverheid overschreden worden; Rapport Algemene Rekenkamer, Beslistermijnen. Waar blijft de tijd?, Kamerstukken 2003/04, 29 495, nrs. 1-2.

${ }^{33}$. Dat geldt in elk geval voor de geschillen die binnen de reikwijdte van art. 6 EVRM vallen en de vaststelling van een civil right or obligation dan wel criminal charge betreffen. De redelijke termijn-eis geldt tevens in vreemdelingenzaken op grond van het algemene rechtszekerheidsbeginsel, zo oordeelde de Afdeling in een uitspraak van 3 december 2008, AB 2009/70 m.nt. Barkhuysen en Van Emmerik. Blijkens een uitspraak van de CRvB geldt de redelijke termijn-eis uit art. 6 EVRM echter uitsluitend voor de bezwaarfase, indien ook die fase opgevolgd wordt door een procedure bij de bestuursrechter, CRvB 28 april 2009, JB 2009/152 m.nt. redactie. De Afdeling is de CRvB daarin gevolgd, zie: AbRvS 17 juni 2009, LJN BI8475. Het is de vraag in hoeverre deze uitspraken kunnen worden gehandhaafd, nu zij in strijd lijken te zijn met de eerder genoemde uitspraken waarin het rechtszekerheidsbeginsel als rechtsgrondslag wordt aangewezen. Zie hierover ook par. 5.7.3 van Deel II.
} 
Inleiding

\section{$2 \quad$ Het belang en doel van het onderzoek}

Het belang en het doel van dit onderzoek is eveneens drieledig. Uitvoerig onderzoek naar de op de inrichting van de bestuurlijke voorprocedures toepasselijke normen en eisen onder de werking van de Awb is nog niet verricht, in het bijzonder niet naar de met rechtspraak bestaande overeenkomsten of gelijkenissen.

Doel van het onderzoek is allereerst het inzichtelijk maken van de voor de inrichting van de bestuurlijke voorprocedures geldende normen en vereisten, waarmee tegelijkertijd gepoogd wordt de positie van deze voorprocedures in het Nederlandse bestuursrecht te verduidelijken. Het onderzoek kan de rechtspraktijk handvatten bieden voor de wijze waarop de doorlopen bestuurlijke voorprocedure in een concreet geval beoordeeld moet worden en in welk perspectief deze bezien moet worden. Dat is van belang omdat het verloop van de bestuurlijke voorprocedures belangrijk, en in sommige gevallen zelfs bepalend, kan zijn voor het verloop c.q. de uitkomst van de procedure bij de bestuursrechter.

Ten tweede wordt met dit onderzoek getracht een bijdrage te leveren aan de nationale rechtsontwikkeling op het gebied van de eisen van behoorlijke rechtspraak. Hoewel de beginselen van behoorlijke rechtspraak reeds geruime tijd worden erkend in het nationale recht, is de aandacht voor deze beginselen en de ontwikkeling ervan, in vergelijking tot de algemene beginselen van behoorlijk bestuur, beperkt. ${ }^{34}$ In dit onderzoek vervullen de reikwijdte en de uitwerking van de beginselen van behoorlijke rechtspraak een belangrijke rol.

Met het voorgaande doel hangt het derde, en laatste, doel samen. Het bestuurlijk optreden, in welke fase van de procedure dan ook, wordt genormeerd door de beginselen van behoorlijk bestuur. Deze beginselen vormen soortgenoten ${ }^{35}$ van de beginselen van behoorlijke rechtspraak, maar hebben in beginsel een andere adressaat, namelijk niet de rechter, maar het bestuur. Omdat de bestuurlijke voorprocedures trekken van zowel bestuur als rechtspraak vertonen, kunnen de beide categorieën beginselen en de daaruit voortvloeiende eisen elkaar voor de bestuurlijke voorprocedures overlappen. Vanwege de mogelijke verschillen in inhoud en rechtsgevolgen die verbonden worden aan schendingen van de onderscheiden beginselen en de daaruit voortvloeiende eisen is het voor de rechtspraktijk van belang dat inzichtelijk wordt welke eisen van toepassing zijn op de bestuurlijke voorprocedures en in hoeverre er verschillen bestaan tussen beide categorieen beginselen en de daaruit voortvloeiende eisen. Verduidelijking van de verhouding tussen deze twee categorieën beginselen, in het bijzonder van de verhouding tussen de formele beginselen van behoorlijk bestuur en de beginselen van behoorlijke rechtspraak is daarom geboden.

\section{Centrale probleemstelling en onderzoeksvragen}

In aansluiting op hetgeen hiervoor aan de orde kwam, luidt de centrale probleemstelling van het onderzoek: in hoeverre werken de beginselen van behoorlijke rechtspraak door in de inrichting van de bestuurlijke voorprocedures? De probleemstelling valt uiteen in twee deelvragen die in het onderzoek achtereenvolgens in twee delen aan bod komen.

Allereerst moet, om de probleemstelling te kunnen beantwoorden, vastgesteld worden welke beginselen van behoorlijke rechtspraak onderscheiden kunnen worden en welke eisen uit die verschillende beginselen voortvloeien. Deze beginselen en eisen vormen het referentiekader waarmee vervolgens de inrichting van de bestuurlijke voorprocedures vergeleken moet worden. De eerste deelvraag, welke (geldende) beginselen

\footnotetext{
34. P.P.T. Bovend'Eert, m.m.v. C.A.J.M. Kortmann, Rechterlijke organisatie, rechters en rechtspraak, Alphen aan den Rijn: Kluwer 2008, p. 256; De Waard 1987, p. 120-121 en 129-130.

${ }^{35}$ De Waard ziet ze als stamgenoten en spreekt zelfs over een verstrengeling tussen beide soorten beginselen in de praktijk van toetsing van bestuursbesluiten, De Waard 1987, p. 120-121 en 129.
} 


\section{Doorwerking van de beginselen van behoorlijke rechtspleging}

van behoorlijke rechtspraak en daaruit voortvloeiende eisen kunnen worden onderscheiden in het Nederlandse (bestuurs)recht, wordt in Deel I behandeld.

Vervolgens, nadat vastgesteld is welke beginselen van behoorlijke rechtspraak gelden voor de procedure bij de (bestuurs)rechter, moet de betekenis van deze beginselen voor de bestuurlijke voorprocedures onderzocht worden. Dat gebeurt in Deel II van dit onderzoek. Onderzocht wordt welke beginselen en eisen de inrichting van de bestuurlijke voorprocedures normeren en in hoeverre ten aanzien daarvan doorwerking merkbaar is van de onderscheiden beginselen van behoorlijke rechtspraak.

\section{Methoden van onderzoek}

\section{Methode ter vaststelling van doorwerking}

Om de doorwerking van de beginselen van behoorlijke rechtspraak voor de onderscheiden bestuurlijke voorprocedures te kunnen vaststellen, is allereerst de wijze waarop het begrip 'doorwerking' gedefinieerd wordt van belang. Met dat begrip wordt in dit onderzoek bedoeld: de betekenis of invloed van de beginselen van behoorlijke rechtspraak op de inrichting van de bestuurlijke voorprocedures. Van invloed zijn op, of van betekenis zijn voor, is ruimer dan het rechtstreeks van toepassing zijn op de bestuurlijke voorprocedures. Het is gelet op het bovenstaande ook niet vanzelfsprekend dat (alle) beginselen van behoorlijke rechtspraak rechtstreeks van toepassing zijn op die procedures. In de doctrine wordt zulks in elk geval niet algemeen aanvaard. ${ }^{36}$ De beginselen van behoorlijke rechtspraak kunnen wellicht ook op een meer indirecte wijze van betekenis zijn (geweest) voor de inrichting van de bestuurlijke voorprocedures. Zij kunnen bijvoorbeeld door de bestuursrechter 'slechts' als inspiratiebron gehanteerd worden of de toepassing dan wel uitwerking van bepaalde eisen voor de bestuurlijke voorprocedures kan geënt zijn op de wijze van toepassen van de eisen van behoorlijke rechtspraak. Het begrip doorwerking wordt met het oog daarop ruim uitgelegd. Daaronder kan elke vorm van invloed of betekenis op de inrichting van de bestuurlijke procedures vallen.

Het begrip invloed of betekenis wordt op voorhand niet nader gedefinieerd of ingevuld. Voor zover mogelijk wordt achteraf, na het verrichten van het onderzoek, die invloed in verschillende gradaties gevat en wordt duidelijk waaruit de invloed exact bestaat. Het op voorhand definiëren van het begrip invloed of betekenis is niet zinvol, omdat het tot gevolg zou kunnen hebben dat bepaalde vormen van invloed die niet voorzien waren bij de definitie buiten dat begrip en dit onderzoek vallen. Om dat probleem te ondervangen zou het begrip uitsluitend dermate ruim gedefinieerd kunnen worden dat alle vormen van invloed die denkbaar zijn eronder zouden kunnen vallen. Dan is het echter de vraag wat een definitie nog zou toevoegen. Bij aanvang van het onderzoek is eenvoudigweg niet te voorzien welke vormen van invloed geconstateerd zullen worden.

Een belangrijker vraag die zich dan als vanzelfsprekend aandient, is op welke wijze die invloed van de beginselen van behoorlijke rechtspraak op de bestuurlijke voorprocedures gemeten kan worden. De methode die gehanteerd wordt om vast te stellen of en in hoeverre sprake is van doorwerking is als volgt. Voorop staat in dit onderzoek dat het invloed of betekenis in juridische, positiefrechtelijke zin betreft. Dat wil zeggen dat onderzocht wordt in hoeverre de beginselen van behoorlijke rechtspraak (rechts)gevolgen hebben voor die procedures, die zich vertalen in concrete eisen die gesteld worden aan de inrichting van de voorprocedures. Om die gevolgen te kunnen achterhalen, worden aanknopingspunten of aanwijzingen gezocht in het positieve recht. Dat houdt in de eerste plaats in dat in dat perspectief de wettelijke regeling van de (inrichting van de) bestuurlijke voorprocedures in de Awb aan een onderzoek onderworpen wordt. Bezien wordt in hoeverre deze regeling concrete eisen of uitwerkingen van de verschillende beginselen van behoorlijke rechtspraak bevat. De ratio en functie van de

\footnotetext{
36. Zie bijv. als het gaat om de eisen die art. 6 lid 1 EVRM stelt: Schreuder-Vlasblom 2008, p. 55-56.
} 


\section{Inleiding}

aan de inrichting van de voorprocedure gestelde eisen wordt daarbij eveneens betrokken, omdat daaruit kan blijken of en in hoeverre de betreffende eis daadwerkelijk als een uitwerking van een beginsel van behoorlijke rechtspraak kan worden gezien. Indien de ratio of functie van de desbetreffende eisen overeenstemt met die van de eisen die gelden voor behoorlijke rechtspraak kan aanleiding bestaan om aan te nemen dat de eisen van behoorlijke rechtspraak ook van betekenis zijn voor de bestuurlijke voorprocedures. Naast de wettelijke regeling en bedoeling van de wetgever worden uiteraard door de verschillende bestuursrechters ook (in aanvulling daarop of in afwijking daarvan) eisen geformuleerd ten aanzien van de inrichting van de voorprocedures. Door middel van jurisprudentie-onderzoek worden deze eisen in kaart gebracht. Ook hierbij worden de ratio of functie die de bestuursrechter toekent aan de eisen in beschouwing genomen en wordt deze vergeleken met de ratio of functie voor vergelijkbare eisen van behoorlijke rechtspraak. Tot slot wordt bezien in hoeverre aan schending van de gevonden behoorlijkheideisen daadwerkelijk rechtsgevolgen verbonden worden. In de rechtsgevolgen van schendingen van de behoorlijkheidseisen schuilt immers uiteindelijk de betekenis van die eisen voor een procedure.

\section{Onderzoeksmethoden}

De bronnen die in het kader van de beschreven methode onderzocht worden zijn: het wettelijk kader en de parlementaire geschiedenis, de literatuur en de jurisprudentie inzake de inrichting van de bestuurlijke voorprocedures. De nadruk ligt op de literatuurstudie en het jurisprudentie-onderzoek. Daarbij wordt, vanwege de invloed daarvan op het nationale (bestuursproces)recht als geldende rechtsnormen, ook aandacht besteed aan artikel 6 EVRM en het Unierecht.

Wat betreft het jurisprudentie-onderzoek kan nog het volgende worden opgemerkt. In dit onderzoek zijn voornamelijk uitspraken die na de invoering van de Awb zijn gedaan onderzocht. Daarbij is de aandacht vooral uitgegaan naar de uitspraken van de hoogste bestuursrechtelijke rechtscolleges, te weten de Afdeling bestuursrechtspraak van de Raad van State, de Centrale Raad van Beroep, het College van Beroep voor het bedrijfsleven en de Hoge Raad. Indien relevant of illustratief zijn ook uitspraken van de 'lagere' bestuursrechters bij het onderzoek betrokken. Om de door de bestuursrechter gestelde eisen of interpretatie van die eisen te achterhalen, is bij het opsporen van de jurisprudentie gebruik gemaakt van vele verschillende zoektermen. Vanwege het tweeledige karakter van de bestuurlijke voorprocedures is daarbij gezocht op zowel eisen van behoorlijke rechtspraak ${ }^{37}$ als eisen van behoorlijk bestuur. De nadruk heeft daarbij, vanwege het grote aantal uitspraken dat ten aanzien van deze onderwerpen gedaan is, gelegen op gepubliceerde uitspraken in jurisprudentietijdschriften. Er zijn echter ook, indien illustratief, uitspraken meegenomen die uitsluitend via internet gepubliceerd zijn. ${ }^{38}$

\section{Beperkingen en afbakening van het onderzoek}

Uit de formulering dat het onderzoek betrekking heeft op de betekenis van de algemene beginselen van behoorlijke rechtspraak in bestuurlijke voorprocedures kunnen reeds enkele beperkingen van het onderzoek worden afgeleid. De algemene beginselen van behoorlijke rechtspraak zijn mede gepositiveerd in artikel 6, eerste lid, van het EVRM. Het zijn rechtsbeginselen die als uitgangspunt gelden voor alle rechtsgeschillen, ongeacht de aard van die rechtsgeschillen. In dit onderzoek wordt uitsluitend de betekenis van die algemene rechtsbeginselen voor de bestuurlijke voorprocedures onderzocht. Dat betekent dat specifieke beginselen die 'slechts' gelden voor geschillen van strafrechtelij-

\footnotetext{
37. In dat kader moet nog worden opgemerkt dat ter aanduiding van de eisen of beginselen van behoorlijke rechtspleging vele verschillende termen in omloop zijn. Te denken valt aan de goede procesorde, eerlijk proces of behoorlijke rechtspraak. Al deze verschillende termen zijn betrokken bij het jurisprudentie-onderzoek.

${ }^{38}$. Daarbij is www.rechtspraak.nl en www.raadvanstate.nl door middel van dezelfde zoektermen geraadpleegd.
} 


\section{Doorwerking van de beginselen van behoorlijke rechtspleging}

ke aard of geschillen inzake bestuurlijke punitieve sancties, zoals de beginselen die tot uitdrukking komen in artikel 6 tweede en derde lid van het EVRM, in beginsel niet bij het onderzoek worden betrokken. Juist vanwege de aard van de geschillen waarvoor deze beginselen gelden, ligt het in de rede dat deze beginselen al van toepassing zijn in de bestuurlijke fasen en doorwerken, indien daarin besluiten met een punitief karakter centraal staan. ${ }^{39}$

Een verdere afbakening is uiteraard gelegen in het aantal bestuurlijke voorprocedures, waarvan de inrichting en de daarop toepasselijke normen voorwerp zijn van onderzoek. Het onderzoek heeft zich allereerst beperkt tot de meest gangbare bestuurlijke voorprocedures, waarvan algemene regeling ook heeft plaatsgevonden in de Awb. Bovendien zijn uitsluitend bestuurlijke voorprocedures bij het onderzoek betrokken waarin een rechtsbeschermingscomponent besloten ligt. De gelijkenis met of verwantschap met rechtspraak is in die procedures (nog) sterker aanwezig dan in andere besluitvormingsprocedures bij het bestuur. In Deel II van dit onderzoek wordt een definitie gegeven van een bestuurlijke voorprocedure waarin de rechtsbeschermingsfunctie een belangrijk element vormt. Daar wordt ook aangegeven tot welke voorprocedures het onderzoek zich exact beperkt. $^{40}$

Voorts is geen onderzoek verricht naar het functioneren van de verschillende bestuurlijke voorprocedures in de praktijk en de wijze waarop bestuursorganen en (bezwaar)adviescommissies omgaan met, of aankijken tegen, procedurele waarborgen in het kader van die procedures. Vanwege de positiefrechtelijke insteek van dit onderzoek is dat perspectief, hoewel niet minder interessant, minder van belang. Het is de wetgever en uiteindelijk de bestuursrechter die (in een concreet geval) bepaalt welke eisen gelden voor de inrichting van de bestuurlijke voorprocedures en hoe deze geïnterpreteerd moeten worden. In dit onderzoek wordt aan de hand van de aanknopingspunten in het positieve recht de betekenis of invloed van de beginselen van behoorlijke rechtspraak vastgesteld.

\section{Indeling van het onderzoek}

Het onderzoek is opgedeeld in drie delen. In Deel I staan de beginselen van behoorlijke rechtspraak centraal. Dit deel valt uiteen in enkele inleidende hoofdstukken (1 tot en met 3 ), en in hoofdstuk 4 worden vervolgens de afzonderlijke beginselen van behoorlijke rechtspraak behandeld. Hoofdstuk 5 beziet de rol en de betekenis van de beginselen van behoorlijke rechtspraak in het Unierecht. Ten slotte bevat hoofdstuk 6 de belangrijkste bevindingen uit Deel I en enkele tussenconclusies.

Deel II van het onderzoek heeft betrekking op (de inrichting van) de bestuurlijke voorprocedures. In dat deel wordt de betekenis van de beginselen van behoorlijke rechtspraak voor die procedures in kaart gebracht. Na enkele algemene hoofdstukken (hoofdstuk 1 tot en met 4), waarin een inleiding wordt gegeven en de functies en de omvang van de werkzaamheid van het bestuur in de bestuurlijke voorprocedures uiteen wordt gezet, komt in hoofdstuk 5 de inrichting van de bezwaarschriftprocedure en het administratief beroep aan bod. Binnen hoofdstuk 5 is aan ieder afzonderlijk te onderzoeken beginsel van behoorlijke rechtspraak een paragraaf gewijd, waarin de betekenis van dat specifieke beginsel voor de inrichting van de bestuurlijke voorprocedures in kaart wordt

\footnotetext{
39. Dat blijkt ook uit de op 1 juli 2009 in werking getreden vierde tranche Awb waarin een deel van de strafprocesrechtelijke waarborgen uit artikel 6 en 7 EVRM voor bestuurlijke punitieve sancties zijn uitgewerkt, zie bijvoorbeeld het ne bis in idem- beginsel (art. 5:43 Awb), het zwijgrecht en de cautie (art. 5:10a Awb). Over de vraag in welke mate deze waarborgen gelden en of het nationale bestuursrecht daaraan voldoet: C.L.G.F.H. Albers, Rechtsbescherming bij bestuurlijke boeten. Balanceren op een magische lijn? (diss. Maastricht), Den Haag: Sdu 2002.

40. Zie par. 1.3 van Deel II. Zoals daar naar wordt toegelicht, blijven de goedkeuringsprocedure en de uniforme voorbereidingsprocedure buiten beschouwing in dit onderzoek.
} 


\section{Inleiding}

gebracht. Aan het einde van iedere paragraaf worden reeds tussenconclusies inzake de doorwerking van het desbetreffende beginsel getrokken.

Deel III ten slotte bevat de conclusies en enkele slotbeschouwingen. In Deel III wordt tevens in meer algemene zin ingegaan op de betekenis van de beginselen van behoorlijke rechtspraak voor die bestuurlijke voorprocedures en de positie van die beginselen in het bestuursrechtelijke systeem van rechtsbescherming. 



\title{
DEEL I Beginselen van behoorlijke rechtspleging
}

\author{
$1 \quad$ Inleiding
}

\subsection{Doel van het onderzoek en de verhouding tot de probleemstelling}

Het voornaamste doel van het onderzoek dat in Deel I verricht wordt, is het in kaart brengen van de verschillende beginselen van behoorlijke rechtspraak en de daaruit voortvloeiende eisen voor de inrichting van een procedure. De onderscheiden beginselen van behoorlijke rechtspraak en de daaruit voortvloeiende eisen vormen het referentiekader, waartegen in het vervolg van dit onderzoek de bestuurlijke voorprocedures en de daarvoor geldende normen en eisen afgezet moeten worden. In dat kader moet ook de verhouding tussen de beginselen van behoorlijke rechtspraak en de daaruit voortvloeiende eisen, dat wil zeggen de concretisering van de beginselen, een plaats krijgen in het onderzoek. Daarnaast vindt in de navolgende hoofdstukken onderzoek plaats naar de grondslag en functie van de onderscheiden beginselen van behoorlijke rechtspraak, omdat het toepassingsbereik van die beginselen daardoor mede bepaald wordt.

Deel I is in de volgende hoofdstukken opgedeeld. In het onderhavige inleidende hoofdstuk wordt kort stilgestaan bij de ontwikkeling van de beginselen van behoorlijke rechtspraak in de doctrine en de verhouding van deze behoorlijkheidsbeginselen tot rechtspraak. In hoofdstuk 2 wordt nader ingegaan op de verschillende benaderingen van het begrip rechtspraak in de doctrine en de met die verschillende benaderingen gepaard gaande knelpunten (voor dit onderzoek). Ook komt daarin aan bod welke benadering van het begrip rechtspraak in dit onderzoek gehanteerd wordt. Verder worden de verschillen en overeenkomsten tussen bestuur en rechtspraak bezien. In hoofdstuk 3 worden de beginselen van behoorlijke rechtspraak vervolgens onderscheiden van inrichtingseisen en concrete uitwerkingen van die beginselen. In hoofdstuk 4 staan de beginselen van behoorlijke rechtspraak zélf centraal. In dat hoofdstuk worden vragen beantwoord als welke beginselen van behoorlijke rechtspraak kunnen onderscheiden worden, op welke grondslagen berusten deze beginselen, welke inhoud hebben de specifieke beginselen en welke concrete eisen vloeien daaruit voort. Hoofdstuk 5 belicht de rol van de beginselen van behoorlijke rechtspraak in het Unierecht, in het bijzonder in de jurisprudentie van het Hof van Justitie van de Europese Unie (hierna: Hof van Justitie). ${ }^{41}$ Daarbij wordt ook aandacht besteed aan de invloed van de Unierechtelijke rechtsbeginselen op het nationale (bestuursrechtelijke) procesrecht. Hoofdstuk 6 ten slotte bevat enkele conclusies en het referentiekader waarop in Deel II van dit onderzoek wordt voortgebouwd.

\footnotetext{
41. Gemakshalve worden in dit onderzoek het Hof van Justitie, HvJ EG, het Gerecht van Eerste Aanleg en het Gerecht voor ambtenarenzaken in de hoofdtekst steeds aangeduid met Hof van Justitie, tenzij anders aangegeven. Sinds de inwerkingtreding van het Verdrag van Lissabon wordt het Hof van Justitie als instelling aangeduid als het Hof van Justitie van de Europese Unie. Het Hof van Justitie van de Europese Unie omvat ingevolge art. 19 VEU vervolgens verschillende gerechten die uitspraken wijzen: het Hof van Justitie, het Gerecht en de gespecialiseerde rechtbanken. In dit onderzoek is bovendien gebruik gemaakt van jurisprudentie die gewezen is door het HvJ EG of de andere gerechten voor de inwerkingtreding van het verdrag van Lissabon op 1 december 2009. Ten behoeve van de leesbaarheid en overzichtelijkheid wordt daarom in de hoofdtekst steeds de term Hof van Justitie gehanteerd, maar in de noten wordt, daar waar wordt verwezen naar uitspraken gewezen voor 1 december 2009, de oude terminologie gebruikt.
} 
Deel I Beginselen van behoorlijke rechtspleging

\subsection{Beginselen voor rechtspraak}

De beginselen van behoorlijke rechtspraak vormen een onderwerp dat met name sinds halverwege de jaren ' 60 van de vorige eeuw in de belangstelling staat van de doctrine. ${ }^{42}$ J.M. Polak heeft in 1968 de eerste aanzet gegeven tot het formuleren en opsporen van deze beginselen. ${ }^{43}$ Sindsdien hebben verschillende auteurs zich over het onderwerp gebogen, ook specifiek met het oog op de betekenis van die beginselen in het bestuursrecht. ${ }^{44}$ De laatste jaren is aan eisen van behoorlijke rechtspraak, vooral vanwege de invloed van artikel 6 EVRM, in het bestuursrecht meer aandacht besteed. ${ }^{45}$ Deze eisen komen ook regelmatig aan de orde in de jurisprudentie van de bestuursrechter, met name in het kader van een beroep op artikel 6 EVRM. ${ }^{46}$

De reeds verrichte onderzoeken hebben zich voornamelijk gericht op het opsporen van de beginselen van behoorlijke rechtspraak alsmede op het bepalen van de inhoud van de onderscheiden beginselen. ${ }^{47}$ Daarover lijkt thans in de doctrine nagenoeg overeenstemming te bestaan. In het bestuursrecht zijn de volgende beginselen van behoorlijke rechtspraak algemeen aanvaard ${ }^{48}$ : toegang tot de rechter en geschilbeslechting binnen een redelijke termijn (ook wel samen aangeduid als het decisiebeginsel), het onafhankelijkheid- en het onpartijdigheidsbeginsel, het verdedigingsbeginsel (waaronder onder meer hoor en wederhoor en equality of arms vallen), het openbaarheidsbeginsel (dit beginsel omvat twee deelvereisten: openbaarheid van behandeling van de zaak en een openbare uitspraak) en het motiveringsbeginsel. ${ }^{49}$ Over de beginselstatus van enkele van deze eisen bestaat nog wel enige discussie. ${ }^{50}$

42. Zie: J.M. Polak, ‘Algemene beginselen van behoorlijke rechtspraak', NJB 1968, p. 417-422. Daarna: R.J.G.M Widdershoven, Gespecialiseerde rechtsgangen in het administratieve recht, Zwolle: W.E.J. Tjeenk Willink 1989; B.W.N. de Waard, Beginselen van behoorlijke rechtspleging, met name in het administratief procesrecht, Zwolle: W.E.J. Tjeenk Willink 1987; P.F. van der Heijden, Een eerlijk proces in het sociaal recht?, Deventer: Kluwer 1984, p. 17-30 (hfst. 2); E.M.H. Hirsch Ballin, Het grondrecht op behoorlijke rechtspraak in het Nederlandse Administratieve recht (Handelingen NJV, 1983 deel I tweede stuk); P. van Dijk, De op Nederland rustende internationale verplichtingen ter zake van behoorlijke rechtspraak (Handelingen NJV, 1983 deel I eerste stuk); A.G. van Galen \& H.Th.J.F. van Maarseveen, Beginselen van administratief procesrecht (preadvies VAR), Alphen aan den Rijn: H.D. Tjeenk Willink 1978; H. Th.J.F. van Maarseveen \& H. Stout, 'Algemene beginselen van behoorlijke rechtspraak', NJB 1979, p. 193-200; J.M. Polak, Vormen en beginselen van rechtspraak in het algemeen (preadvies Vereniging voor Bouwrecht), Deventer: Kluwer 1976.

${ }^{43}$ Polak 1968, p. 421 e.v. Hij gaf destijds aan dat het mogelijk was de beginselen te formuleren, maar dat de ontwikkeling van die beginselen zich nog maar in de aanvangsfase bevond.

44. Zie bijvoorbeeld: A.M.L. Jansen, Constitutionalisering van het bestuursprocesrecht (preadvies NVR), Deventer: Kluwer 2004; Widdershoven 1989; De Waard 1987; Hirsch Ballin 1983.

45. Zie bijvoorbeeld de preadviezen voor de NJV in 1983 van Hirsch Ballin en Van Dijk genoemd in de noot hiervoor. En een kleine greep uit recentere bijdragen: Jansen 2004; H.J. Simon, 'Het EVRM en de bestuurlijke besluitvorming (deel II)', JB-plus 2004, p. 2-14; H.J. Simon, 'Het EVRM en de bestuurlijke besluitvorming (deel I)', JB-plus 2003 (hierna: Simon 2003a), p. 170-181; A.F.M. Brenninkmeijer, 'Algemene beginselen van behoorlijke geschillenbeslechting', in: M.V. Polak (red.), Geschillenbeslechting naar behoren. Algemene beginselen van behoorlijke geschillenbeslechting in traditionele en alternatieve procesvormen, Kluwer: Deventer 1998 , p. 13; E.A. Alkema, 'Bestuursrecht en EVRM- Awb en artikel 6', NTB 1996.

46. Op de redelijke termijn-eis uit artikel 6 EVRM wordt in de procedure voor de bestuursrechter in elk geval veelvuldig een beroep gedaan. Zie recent bijvoorbeeld: AbRvS 4 maart 2009, $J B$ 2009/82 m.nt. red; $A B$ 2009/236 m.nt. Barkhuysen \& Den Ouden; CRvB 26 januari 2009, JB 2009/66 m.nt. Barkhuysen \& Van Emmerik; $A B$ 2009/241 m.nt A.M.L. Jansen; AbRvS 4 juni 2008, $A B$ 2008/229 m.nt. Widdershoven; $J B$ 2008/146 m.nt. Jansen; USZ 2008/211 m.nt. Barkhuysen en Van Emmerik; CRvB 11 juli 2008, JB 2008/172 m.nt. AMLJ; $A B$ 2008/241 m.nt. R.J.G.M. Widdershoven; USZ 2008/238 m.nt. Barkhuysen en Van Emmerik. Voor meer voorbeelden zie: A.M.L. Jansen \& D.W.M. Wenders, 'Unificerende werking via de redelijke termijn of een kroniek van de redelijke termijn', NJCM-Bulletin 2006, p. 1091 e.v. De andere vereisten uit artikel 6 EVRM komen echter ook regelmatig aan bod, zie voor voorbeelden par. 4.3.3 t/m 4.3.9.

47. Zie: De Waard 1987; Van Maarseveen \& Stout 1979; Van Galen en Van Maarseveen 1978; Polak 1976.

${ }^{48 .}$ In hfst. 4 wordt nog nader ingegaan op de te onderscheiden beginselen van behoorlijke rechtspraak.

49. Van Wijk/Konijnenbelt \& Van Male 2008, p. 576-577; Stroink 2004a, p. 26-27; F.A.M. Stroink, Rechterlijke organisatie enrechtspraak in beweging, Zwolle: W.E.J. Tjeenk Willink 1993, p. 66; Widdershoven 1989, p. 113 114; De Waard 1987, p. 127-128.

50. Op de afzonderlijke beginselen en eisen en de vraag in hoeverre sprake is van een beginsel van behoorlijke rechtspleging wordt in paragraaf 4.3 van hoofdstuk 4 nader ingegaan. 


\section{Inleiding}

Omdat de beginselen van behoorlijke rechtspraak behoorlijkheidsnormen ${ }^{51}$ zijn die gelden voor rechtspraak, is - naast het achterhalen van deze behoorlijkheidsnormen zelf en hun inhoud - een belangrijke vraag wanneer sprake is van rechtspraak. Het antwoord op die vraag is immers in beginsel bepalend voor het toepassingsbereik van de onderscheiden beginselen. In verschillende onderzoeken naar de beginselen van behoorlijke rechtspraak is dan ook een plaats ingeruimd voor de beantwoording van die vraag. De werkwijze is dan veelal als volgt: eerst wordt bepaald wat onder rechtspraak moet worden verstaan en vervolgens wordt bepaald welke beginselen, waaraan de procedures die tot rechtspraak gerekend worden moeten voldoen, onderscheiden kunnen worden. ${ }^{52}$ Daarna vindt toepassing van die beginselen op procedures die tot rechtspraak behoren plaats en worden de procedures tegen die meetlat van behoorlijkheid gehouden om te bezien of deze ook daadwerkelijk daaraan voldoen. Op deze wijze gaat Widdershoven bijvoorbeeld te werk bij de toetsing van de speciale administratieve rechtsgangen aan de beginselen van behoorlijke rechtspraak. Eerst wordt het begrip (administratieve) rechtspraak geduid. Vervolgens worden de beginselen van behoorlijke rechtspraak vastgesteld als beoordelingskader. Daarna worden de geselecteerde procedures (die als administratieve rechtspraak kunnen worden aangemerkt) tegen deze behoorlijkheidsbeginselen afgezet. $^{53}$

Startpunt in verschillende onderzoeken naar de beginselen van behoorlijke rechtspraak of naar de behoorlijkheid van bepaalde (bestuursrechtelijke) rechtsgangen is derhalve het begrip rechtspraak. In de Nederlandse (bestuursrechtelijke) doctrine overheerst een meer formele benadering van dit begrip, waarbij met name de onafhankelijkheid van het orgaan dat de activiteit verricht doorslaggevend is. ${ }^{54}$ Uitsluitend handelingen van een onafhankelijke rechter worden aangemerkt als ('echte') rechtspraak en in beginsel worden ook alle activiteiten van die onafhankelijke rechter, ongeacht de aard ervan, beschouwd als rechtspraak. ${ }^{55}$ Beslissingen die niet gekarakteriseerd kunnen worden als het beslechten van een rechtsgeschil in een concreet geval, zoals het benoemen van een curator of voogd ${ }^{56}$, vallen strikt genomen binnen dit begrip rechtspraak, zodra het beslissende orgaan een onafhankelijke rechterlijke instantie is. ${ }^{57}$ Deze vormen van taakuitoefening door de rechter met een meer bestuurlijk karakter worden ook wel oneigenlijke rechtspraak of voluntaire jurisdictie genoemd ter onderscheiding van eigenlijke of contentieuze rechtspraak. ${ }^{58}$ In een uitsluitend formele benadering van het begrip rechtspraak, waarbij als enige voorwaarde geldt de onafhankelijkheid van de beoordelende instantie, vallen deze activiteiten van de rechter ook binnen het begrip rechtspraak. In het verlengde daarvan is het toepassingsbereik van de beginselen van behoorlijke rechtspraak in beginsel beperkt tot de procedures bij die organen wier activiteiten tot recht-

\footnotetext{
${ }^{51 .}$ In dit onderzoek worden de termen beginselen van behoorlijke rechtspraak, behoorlijkheidsnormen en behoorlijkheidsbeginselen als uitwisselbaar beschouwd en aan het gebruik van de ene of andere term liggen uitsluitend terminologische overwegingen ten grondslag. Voor zover deze termen worden gebruikt, worden daarmee uitsluitend rechtsnormen bedoeld die bij schending leiden tot een rechtmatigheidsgebrek. De behoorlijkheidsnormen zoals die door de Nationale ombudsman worden gehanteerd vallen - voor zover deze uiteenlopen - daarmee buiten het bestek van dit onderzoek.

52. Widdershoven 1989, p. 13-35; De Waard 1987, 11-55 (hfst. 1). Zie bijvoorbeeld ook: R.M.P.G. NiessenCobben, Behoorlijk fiscaal procesrecht, Arnhem: Gouda Quint BV 1995, p. 62-72; Van der Heijden 1984, p. $17-$ 30 (hfst. 2).

${ }^{53}$ Widdershoven 1989, p. 6-7 en hfst. A1, A3 en Deel B.

54. Van Wijk/Konijnenbelt \& Van Male 2008, p. 537; Brenninkmeijer 1987, p. 4. Zie hierover nader par. 2.1.

${ }^{55 .}$ Vgl. Widdershoven 1989, p. 15; De Waard 1987, p. 11.

56. Van der Pot-Donner, Handboek van het Nederlandse staatsrecht, $15^{\mathrm{e}}$ druk bewerkt door D.J. Elzinga en R. de Lange, Deventer: Kluwer 2006, p. 600; Van Wijk/Konijnenbelt \&Van Male 2008, p. 537; Widdershoven 1989, p. 19; De Waard 1987, p. 11; Polak 1976, p. 6.

57. Wel is het zo dat, hierop kom ik in par. 2.1 nog terug, er in de doctrine duidelijk aangegeven wordt dat het hier gaat om randverschijnselen en geen echte rechtspraak. De doctrine worstelt, zoals Polak opmerkt, met dit soort handelingen van de rechter in verhouding tot het rechtspraakbegrip, Polak 1976, p. 6.

58. Polak 1976, p. 6; H.J. Snijders, C.J.M. Klaassen, G.J. Meijer, Nederlands burgerlijk procesrecht, Zwolle: Kluwer 2007, p. 6.
} 


\section{Deel I Beginselen van behoorlijke rechtspleging}

spraak gerekend worden: onafhankelijke rechterlijke instanties. ${ }^{59}$ Dat betekent dat bepaalde activiteiten van andere organen die sterke materiële gelijkenis vertonen met rechterlijke activiteiten, denk bijvoorbeeld aan het administratief beroep bij een bestuursorgaan, in beginsel niet - althans niet rechtstreeks - door de beginselen van behoorlijke rechtspraak beheerst worden. Voor die activiteiten en procedures bij andere organen dan onafhankelijke rechterlijke instanties gelden andere behoorlijkheidsnormen. Voor procedures bij het bestuur moet dan met name gedacht worden aan de algemene beginselen van behoorlijk bestuur.

Er zijn echter ook auteurs die een meer materiële benadering van rechtspraak voorstaan. Beantwoording van de vraag wanneer sprake is van rechtspraak en de materiële invulling van het begrip vindt bijvoorbeeld plaats in de dissertatie van De Waard over de beginselen van behoorlijke rechtspraak in het bestuursrecht. ${ }^{60}$ De Waard beoogt in zijn onderzoek behoorlijkheidsnormen te vinden die aan alle procedures van rechtspraak gemeenschappelijk zijn, waarbij hij tevens de betekenis van die normen voor andere rechtspraakachtige procedures in het bestuursrecht heeft willen achterhalen. ${ }^{61}$ Mede daarom gaat De Waard uit van een materiële benadering van het begrip rechtspraak. Formele criteria zijn in zijn benadering niet doorslaggevend. De invulling van het begrip rechtspraak is niet afhankelijk van (de status van) het orgaan dat de werkzaamheid verricht, maar veeleer van de aard van de werkzaamheid zelf. ${ }^{62}$ Doordat De Waard een materieel begrip van rechtspraak hanteert waarbij de functie rechtspraak centraal staat, is het toepassingsbereik van de beginselen ruimer en niet alleen beperkt tot procedures bij een onafhankelijke rechterlijke instantie oftewel 'echte' rechtspraak. ${ }^{63}$ Hoewel er naast De Waard nog andere auteurs uitgaan van een materieel begrip van rechtspraak ${ }^{64}$, is deze opvatting - zoals aangegeven - geen gemeengoed in het Nederlandse bestuursrecht.

Het belangrijkste verschil tussen de formele en materiële benadering is gelegen in de rol die de onafhankelijkheid van de oordelende instantie daarin toekomt. ${ }^{65}$ In de formele benadering vormt onafhankelijkheid een voorwaarde om te kunnen spreken van rechtspraak, terwijl het in de materiële benadering uitsluitend een behoorlijkheidseis voor rechtspraak is. ${ }^{66}$ Gemeenschappelijk aan beide benaderingen is dat het begrip rechtspraak een belangrijke rol vervult bij het bepalen van de betekenis van de behoorlijkheidsnormen voor de procedures die ter beoordeling voorliggen. Het toepassingsbereik en de betekenis van de behoorlijkheidsnormen worden immers aan het begrip rechtspraak gekoppeld en blijven in beginsel beperkt tot de procedures die als rechtspraak beschouwd worden. Afhankelijk van de gekozen benadering kunnen de procedures die daaronder gerangschikt worden vanzelfsprekend aanzienlijk uiteenlopen. Daarmee kan ook de betekenis van de beginselen van behoorlijke rechtspraak voor bepaalde procedures (afhankelijk van het gehanteerde begrip rechtspraak) aanzienlijk verschillen.

\footnotetext{
59. Vgl. Polak: 1976, p. 6. Polak wijst er juist op dat we voor een dergelijke dogmatische benadering moeten oppassen.

60. Zie hoofdstuk 1 van zijn dissertatie, De Waard 1987, p. 11-55.

${ }^{61 .}$ Widdershoven 1989, p. 111. Zie De Waard 1987, p. 8-9.

62. De Waard 1897, p. 9

63. Echter ook in De Waards visie voldoen het administratief beroep en procedures bij het bestuur niet aan alle elementen van het begrip rechtspraak. Wel gaat hij ervan uit dat vanwege de gelijkenissen met rechtspraak (in aantal beperkte) gemeenschappelijke behoorlijkheidsnormen gelden, De Waard 1987, p. 55.

64. Bijvoorbeeld: Van der Heijden 1984, p. 23. Duynstee 1974, p. 48-50; Polak 1976, p. 5-6.

${ }^{65 .}$ Widdershoven 1989, p. 20.

66. Vgl. Widdershoven 1989, p. 20. Widdershoven wijst er terecht op dat in de formele benadering onafhankelijkheid het doorslaggevende criterium om van rechtspraak te kunnen spreken vormt, maar daarnaast ook als behoorlijkheidseis geldt. Het onderscheid tussen de materiële en formele benadering schuilt echter in de omstandigheid dat in de materiële benadering onafhankelijkheid juist geen criterium voor rechtspraak vormt. Op de omstandigheid dat de formele benadering aan de onafhankelijkheidseis min of meer een dubbele rol toekent, kom ik in par. 2.2 nader terug.
} 
Inleiding

\subsection{Op het begrip rechtspraak gerichte benaderingen}

Afhankelijk van de reikwijdte van het begrip rechtspraak kunnen de beginselen van behoorlijke rechtspleging al dan niet rechtstreeks van toepassing worden geacht op een procedure. Een middenweg of tussenvorm lijkt daarbij niet goed mogelijk, omdat men dan onvermijdelijk in de knoop raakt met het gehanteerde begrip rechtspraak ofwel de te onderscheiden beginselen.

Bij een uitsluitend formeel begrip vallen immers bepaalde geschillen gevoerd bij en activiteiten verricht door andere organen dan onafhankelijke rechterlijke instanties buiten dat begrip. Hoewel deze activiteiten sterke gelijkenis kunnen vertonen met 'echte' rechtspraak door rechterlijke instanties, vallen zij daarmee in beginsel ook buiten de werking van de behoorlijkheidsnormen die gelden voor rechtspraak. ${ }^{67}$ Het tegenovergestelde kan echter ook optreden bij een uitsluitend formele benadering. Bepaalde handelingen van onafhankelijke rechterlijke instanties die in een verder verwijderd verband staan van rechtspreken als werkzaamheid worden strikt genomen ook genormeerd door die beginselen. De vraag is gerechtvaardigd of dat wenselijk is. Verschillende auteurs zijn zich van dit probleem bewust geweest en hebben dan ook aangegeven dat dit soort activiteiten materieel gezien niet als echte rechtspraak kan worden aangemerkt. ${ }^{68}$ Van volledige toepasselijkheid van de behoorlijkheidseisen die aan 'echte' rechtspraak gesteld worden, lijken zij in die gevallen dan ook niet altijd uit te gaan. ${ }^{69}$

Daar tegenover staat de materiële benadering die uitgaat van de activiteiten van het betreffende orgaan. Zodra een activiteit als rechtspraak - meestal in de zin van beslechting van een rechtsgeschil aan de hand van rechtsvragen (hierop kom ik in paragraaf 2.1 nog terug) - gekwalificeerd kan worden, gelden daarvoor in beginsel ook de voor rechtspraak geldende behoorlijkheidsnormen. ${ }^{70}$ Activiteiten die niet typisch rechterlijk zijn vallen op grond van de aard van die werkzaamheden buiten het begrip. Wordt echter uitgegaan van een uitsluitend materieel begrip van rechtspraak waaronder ook procedures kunnen vallen die niet bij een onafhankelijke rechterlijke instantie plaatsvinden, dan kan in het verlengde daarvan het vereiste van onafhankelijkheid onmogelijk tot de behoorlijkheidseisen behoren. ${ }^{71}$ Een deel van de - op grond van de aard van de activiteiten die het orgaan verricht - tot rechtspraak gerekende procedures zou aan dat behoorlijkheidsvereiste immers bij voorbaat nimmer kunnen voldoen. Te denken valt bijvoorbeeld aan de bezwaarschriftprocedure of het administratief beroep.

Deze problemen met ofwel de afbakening van het begrip rechtspraak ofwel de te onderscheiden behoorlijkheidseisen, vormen belangrijke nadelen die zich voordoen bij op het begrip rechtspraak gerichte benaderingen. In hun meest dogmatische vorm bieden de formele en materiële benadering van (de beginselen van behoorlijke) rechtspraak nauwelijks ruimte om te differentiëren in de betekenis van de onderscheiden beginselen voor de verschillende procedures in het bestuursrecht. Daardoor ontbreekt de mogelijkheid bij de mate van toepasselijkheid van de beginselen rekening te houden met de eigen specifieke

\footnotetext{
67. Dat geldt ook voor een gemengd rechtspraakbegrip, nu het formele criterium daar ook onderdeel van is. Vgl. Widdershoven die, uitgaande van een gemengd rechtspraakbegrip, eerst vaststelt wanneer sprake is van administratieve rechtspraak en de administratieve rechtsgangen die hij wil onderzoeken waarna hij de beginselen van behoorlijke rechtspraak als toetsingskader vaststelt en die rechtsgangen daaraan toetst, Widdershoven 1989, p. 6, 35 en 109.

68. Zie bijvoorbeeld: Van der Pot/Donner 2006, p. 806; Polak 1976, p. 6.

69. Polak 1976, p. 6 . Hij merkt op dat er tussen het orgaan rechterlijke macht en de functie rechtspraak een begripsmatige samenhang bestaat waardoor onvoldoende aandacht uitgaat naar randverschijnselen, bijvoorbeeld werkzaamheden van de gewone rechterlijke macht die eerder bestuurlijk van aard dan rechterlijk lijken. Tegelijkertijd merkt hij op dat vermeden moet worden dat 'rechtspraakachtige verschijnselen die zich buiten de gewone rechterlijke macht en de met administratieve rechtspraak belaste bijzondere colleges afspelen, buiten onze op rechtspraak gerichte belangstelling te houden, met de redenering dat we dan met bestuur te maken hebben'.

70. Zie: De Waard 1987, p. 125.

71. Dat is ook het geval bij De Waard die uitgaat van een materieel rechtspraakbegrip en onafhankelijkheid niet rekent tot de beginselen van behoorlijke rechtspleging, De Waard 1987, p. 45, 111 en 127-128.
} 


\section{Deel I Beginselen van behoorlijke rechtspleging}

kenmerken en karakteristieken van de verschillende procedures. Hetzelfde geldt voor een combinatie van beide begrippen: een gemengd rechtspraakbegrip waarbij zowel formele als materiële criteria bepalen of er sprake is van rechtspraak. Gevolg van een gemengde benadering is immers dat een nóg geringer aantal op rechtspraak gelijkende procedures (dan het geval is bij de formele of materiële benadering) als zodanig tot rechtspraak gerekend worden. Daarmee komen ook meer procedures strikt genomen buiten het toepassingsbereik van de beginselen van behoorlijke rechtspraak te staan. Het etiket rechtspraak wordt in die benadering immers gereserveerd voor die activiteiten van de onafhankelijke rechter die in materieel opzicht als rechtspraak gekarakteriseerd kunnen worden. Een illustratie hiervan vormt de benadering van Widdershoven die in zijn dissertatie, uitgaande van een gemengd rechtspraakbegrip, de bezwaarschriftprocedure en de administratief beroepsprocedure buiten zijn onderzoek naar de behoorlijkheid van de speciale administratieve rechtsgangen heeft gelaten. Hoewel deze grotendeels voldeden aan de materiële elementen van rechtspraak in zijn ogen, is er in die procedures geen sprake van onafhankelijke colleges die een beslissing nemen. ${ }^{72}$ Ofschoon dergelijke procedures in belangrijke mate (vooral in materieel opzicht) verwantschap vertonen met rechtspraak door een rechterlijke instantie vallen deze in beginsel buiten de werking van de daarvoor geldende behoorlijkheidsnormen.

\subsection{De keuze voor een variabele benadering}

Gelet op de problemen met de afbakening of de te onderscheiden behoorlijkheidsnormen die verbonden zijn aan op rechtspraak gerichte benaderingen wordt in dit onderzoek gekozen voor andere benadering. Daarin staat de invulling van het begrip rechtspraak minder centraal en wordt uitgegaan van een variabele toepasselijkheid van de beginselen van behoorlijke rechtspraak. De invulling van het begrip rechtspraak is daarmee niet (exclusief) bepalend voor de betekenis van de beginselen van behoorlijke rechtspraak voor procedures die daar al dan niet onder vallen. In dit onderzoek staat immers centraal of en zo ja, in hoeverre die beginselen van betekenis zijn voor bestuurlijke voorprocedures die in elk geval niet tot rechtspraak gerekend worden. ${ }^{73}$ Rechtstreekse toepasselijkheid van deze behoorlijkheidsnormen is echter wel verbonden aan de invulling van het begrip rechtspraak. Als er sprake is van rechtspraak, dan zijn de behoorlijkheidsbeginselen ook rechtstreeks van toepassing. Maar daarmee is nog niet alles gezegd. De toepasselijkheid van die beginselen wordt op voorhand niet als absoluut beschouwd. De betekenis van de beginselen voor procedures die buiten het begrip rechtspraak vallen, kan variëren afhankelijk van het beginsel en de procedure die het betreft. Ook als er geen sprake is van rechtspraak in enge zin - dat wil zeggen door een onafhankelijke rechter - wordt toepasselijkheid in enigerlei mate (hoewel wellicht beperkter dan voor echte rechtspraak) derhalve niet uitgesloten. Zoals J.M. Polak in 1968 reeds opmerkte:

"Het gaat trouwens niet alleen om het opsporen, formuleren en vastleggen van de grondslagen. Onderzocht zal ook moeten worden of, en in hoeverre, onderscheid moet worden gemaakt tussen de verschillende vormen van rechtspraak. Het is immers zeker niet uitgesloten dat bepaalde beginselen slechts een beperkte toepassing mogen vinden., 74

\footnotetext{
72. Widdershoven 1989, p. 43-44. Hierbij moet wel aangetekend worden dat voor Widdershoven, naast het gebrek aan onafhankelijkheid, ook van belang is dat in die procedures een beleidstoetsing plaatsvindt waarbij eigen institutionele belangen een rol mogen spelen. Daaruit volgt dat ook niet aan de materiële criteria voor rechtspraak is voldaan, p. 24 .

${ }^{73}$. Waarom dat zo is, komt nader aan bod in par. 2.1 en 2.2.

74. Polak 1968, p. 421. Polak maakt niet geheel duidelijk op welke vormen van rechtspraak hij doelt maar verwijst verderop wel naar tuchtrechtspraakgedingen. In zijn preadvies uit 1976 noemt hij het administratief beroep een rechtspraakachtig verschijnsel (later ook pseudo-rechtspraak) waarvan het verantwoord en geboden is ook bepaalde rechtspraakeisen daaraan te stellen, p. 6. In een overzicht van bestaande pseudo-rechtspraak komt later ook de bezwaarschriftprocedure terug, p. 8 .
} 


\section{Inleiding}

In zijn preadvies voor de Vereniging van Bouwrecht bouwt hij hierop voort en stelt hij dat de voor echte rechtspraak geldende beginselen op de verschillende categorieën van wat hij noemt semi-rechtspraak (of pseudo-rechtspraak) steeds in telkens andere dosering zullen moeten worden toegepast. In zijn ogen is het van belang te weten welke beginselen dat zijn, in welke omvang dat moet gebeuren en voor welke categorie. ${ }^{75}$ Overigens benoemt Polak het administratief beroep en de bezwaarschriftprocedure in die context expliciet als semi-rechtspraak. ${ }^{76}$

Beginselen van behoorlijke rechtspraak vormen derhalve beginselen waarvan de mate van toepasselijkheid kan variëren, afhankelijk van de procedure waar zij betrekking op hebben. De hiervoor aangehaalde vragen die Polak onderscheidt, staan dan ook in dit onderzoek ten aanzien van de bestuurlijke voorprocedures centraal. Juist omdat deze vragen centraal staan, is de invulling van het begrip rechtspraak ook minder van belang. De hier gevolgde benadering biedt voorts ruimte voor differentiatie per procedure en per afzonderlijk beginsel. Door gedeeltelijke ontkoppeling van de betekenis van de beginselen van behoorlijke rechtspraak van de invulling van het begrip rechtspraak, kan per beginsel onderzocht worden of en in hoeverre dat beginsel, rekening houdend met de specifieke kenmerken van de betreffende voorprocedure, van betekenis is. Voor alle duidelijkheid: de inhoud van de onderscheiden beginselen staat vast. Het gaat erom dat de mate van toepasselijkheid kan verschillen van de mate van toepasselijkheid voor eigenlijke of echte rechtspraak. ${ }^{77}$ Dat betekent dat de concrete eisen die voortvloeien uit de afzonderlijke beginselen uiteen kunnen lopen. Ook ligt de mogelijkheid open dat bepaalde toepassingen van de beginselen niet of in mindere mate gelden voor de bestuurlijke voorprocedures. Het voorbeeld bij uitstek vormt de onafhankelijkheidseis waarvan verwacht mag worden dat deze voor de bestuurlijke voorprocedures geen of nauwelijks ${ }^{78}$ betekenis heeft, gelet op de omstandigheid dat het een procedure bij het bestuur betreft. Voor andere beginselen, zoals het beginsel van hoor en wederhoor, lijkt de mate van doorwerking op voorhand minder vast te staan.

Het EHRM heeft in zijn jurisprudentie ten aanzien van de waarborgen van artikel 6 EVRM voor geschillen waarin een 'criminal charge' centraal staat een soortgelijke benadering gehanteerd. ${ }^{79}$ In dat kader kan een onderscheid gemaakt worden tussen 'traditional criminal charges', zoals strafrechtelijke procedures, en 'criminal charges' die daar niet toe behoren, zoals bestuurlijke sancties of belastingverhogingen. Op beide soorten 'criminal charges' is artikel 6 EVRM van toepassing, maar wat betreft niveau van rechtsbescherming of de mate van toepasselijkheid van de waarborgen vindt differentiatie plaats. Voor de 'hardcore criminal law'- zaken gelden de waarborgen ten volle, terwijl voor de overige 'criminal charges' een lager niveau van rechtsbescherming volstaat en de waarborgen minder strikt kunnen worden toegepast. Voor de beginselen van behoorlijke rechtspraak behoort een vergelijkbare benadering naar de aard van de procedure, rechterlijk of bestuurlijk, en afhankelijk van de mate van verwantschap met de rechtspraak eveneens tot de mogelijkheden. ${ }^{80}$ De differentiatie bestaat in de mate van toepasselijkheid van de beginselen van behoorlijke rechtspraak: volledig van toepassing op rechtspraak, terwijl de mate van toepasselijkheid op andere, daarmee verwante procedures, uiteen kan lopen.

\footnotetext{
${ }^{75 .}$ Polak 1976 , p. 8.

76. Polak 1976, p. 6 en p. 8.

77. Zie ook Van Maarseveen \& Stout die opmerken dat de beginselen niet alleen betrekking hebben op rechtspraak in enge zin, maar ook op pseudo- en semi-rechtspraak zoals het administratief beroep alsmede dat daarin verdisconteerd ligt dat in de verschillende rechtspraakvormen nuanceverschillen kunnen optreden, Van Maarseveen \& Stout 1979, p. 197.

${ }^{78 .}$ Ik gebruik hier bewust de term nauwelijks omdat enige betekenis van die eis in de bestuurlijke voorprocedures niet uitgesloten is, indien er een adviescommissie is ingesteld. Zie hierover nader par. 5.4 van Deel II.

79. EHRM 23 november 2006, Jussila t. Finland, AB 2007/51 m.nt. Barkhuysen en Van Emmerik; EHRC 2007/31 m.nt. Albers

${ }^{80}$ Vgl. ook Jansen in zijn noot bij AbRvS 12 juli 2006, AB 2008/144 m.nt. A.M.L. Jansen.
} 


\section{Deel I Beginselen van behoorlijke rechtspleging}

Onderzoek naar de mate van toepasselijkheid is voor de meest gangbare bestuurlijke voorprocedure, de bezwaarschriftprocedure, ook nog niet (uitvoerig) verricht. Het onderzoek van De Waard beoogt weliswaar beginselen van behoorlijke rechtspraak op te sporen die een algemene gelding hebben, dat wil zeggen voor alle op dat moment 'in het recht voorkomende procedures waarin na een "klacht" wordt beslist over aanspraken rechtens van derden (waaronder bestuurlijke voorprocedures)' ${ }^{81}$ Die gelding is echter nog niet daadwerkelijk voor alle procedures, ook niet voor de bestuurlijke voorprocedures, als zodanig onderzocht. ${ }^{82}$ De Waard gaat er desondanks vanuit dat de beginselen van behoorlijke rechtspraak wel voor de voorprocedures gelden, maar slechts in beperkte mate. Per procedure zal dat echter nog nader moeten worden onderzocht. ${ }^{83}$ Daarin beoogt dit onderzoek te voorzien voor de bestuurlijke voorprocedures onder het regime van de Awb.

Hoewel de invulling van het begrip rechtspraak in dit onderzoek vanwege de hiervoor gekozen benadering minder van belang is (in vergelijking tot eerder verrichte onderzoeken), blijft invulling van het begrip onontbeerlijk om te kunnen bepalen op welke procedures de beginselen van behoorlijke rechtspraak in elk geval rechtstreeks toepasselijk zijn. De invulling van het begrip is ook van belang om vast te kunnen stellen om welke reden bestuurlijke voorprocedures niet tot rechtspraak gerekend kunnen worden. Vervolgens kan (na vergelijking met de bestuurlijke werkzaamheid) bepaald worden waar de overeenkomsten en verschillen liggen met de bestuurlijke voorprocedures. De mate van verwantschap met rechtspraak kan van invloed zijn op de doorwerking van bepaalde beginselen voor de bestuurlijke voorprocedures. Daarom wordt in het onderstaande toch kort nader stil gestaan bij de invulling van het begrip rechtspraak.

Tot slot geef ik er, in navolging van De Waard, ook de voorkeur aan de term beginselen van behoorlijke rechtspleging in plaats van beginselen van behoorlijke rechtspraak. De Waard kiest onder meer voor die term, omdat de beginselen een ruimer geldingsbereik hebben dan eigenlijke rechtspraak. ${ }^{84}$ Die term heeft mijn voorkeur, aangezien daardoor duidelijk wordt dat de geldingskracht van de beginselen niet beperkt hoeft te blijven tot (echte) rechtspraak. In het navolgende wordt in beginsel dan ook de term beginselen van behoorlijke rechtspleging gebruikt.

\footnotetext{
${ }^{81 .}$ De Waard 1987, p. 123.

82. De Waard 1987, p. 124.

${ }^{83 .}$ De Waard 1987, p. 125

84. Hij kiest daarnaast voor die term, omdat daarmee meer naar voren komt dat de behoorlijkheidsnormen op een activiteit betrekking hebben in plaats van de statische structuur van het proces, De Waard 1987, p. 9.
} 


\section{Rechtspraak}

\subsection{Invulling van het begrip rechtspraak: de formele en materiële benadering nader bezien}

Omdat het begrip rechtspraak in dit onderzoek een minder centrale plek heeft, beperkt het onderstaande zich grotendeels tot een beschrijving van de bestaande opvattingen in de doctrine. Zoals al elders werd aangestipt, kan er voor de invulling van het begrip rechtspraak grofweg een onderscheid gemaakt worden tussen twee benaderingen: een materiële en formele benadering. ${ }^{1}$ Daarnaast bestaat nog een gemengd rechtspraakbegrip, dat een combinatie van de materiële en formele benadering vormt. ${ }^{2}$

\section{De formele benadering}

De formele benadering is de heersende benadering in het Nederlandse bestuursrecht. ${ }^{3}$ In die benadering zijn - zoals eerder aangegeven - formele criteria bepalend voor de vraag of er sprake is van rechtspraak en wordt uitgegaan van een orgaangebonden invulling van het begrip rechtspraak. ${ }^{4}$ De hoedanigheid of status van de instantie die de werkzaamheid verricht is doorslaggevend voor de vraag of er sprake is van rechtspraak. Daarbij wordt ervan uitgegaan dat een dergelijke instantie een onafhankelijke rechterlijke instantie behoort te zijn. Onafhankelijkheid van het bestuur en van de wetgever vormt derhalve het belangrijkste criterium dat gesteld wordt ter vaststelling of er sprake is van 'echte' rechtspraak. Brenninkmeijer verwoordt dit uitgangspunt door op te merken:

"De rechter is per definitie onafhankelijk. Een overheidsorgaan dat niet in onafhankelijkheid geschillen kan beslechten is geen rechter. Aan de hand van de functie van de rechter in onze rechtsorde valt het begrip rechter niet exclusief te definiëren. Ook andere overheidsorganen kunnen zijn belast - en zijn ook belast met het beslechten van geschillen. Naar zijn functie onderscheidt de rechter zich dus niet van andere overheidsorganen; wel echter naar zijn positie in onze constitutionele rechtsorde als onafhankelijk overheidsorgaan."

Ook de Awb-wetgever lijkt een dergelijke formele benadering te hanteren in artikel 1:1 tweede lid van de Awb, waarin een omschrijving wordt gegeven van organen die niet als bestuursorgaan kunnen aangemerkt, waaronder onafhankelijke bij de wet ingestelde organen die met rechtspraak zijn belast. ${ }^{6}$ Het belangrijkste nadeel dat schuilt in een uitsluitend formele benadering is, zoals aangegeven, de omstandigheid dat alle activiteiten van een onafhankelijke rechterlijke instantie in die benadering als 'echte' rechtspraak zouden moeten worden beschouwd, ongeacht de aard van de betreffende activiteit. ${ }^{7}$ Problematisch daarbij is dat onafhankelijke rechterlijke instanties ook handelingen verrichten die in een ver verwijderd verband staan met rechtspreken (in functionele of materiële zin) in een concreet geschil. De vraag rijst dan ook hoe deze activiteiten passen in een dergelijk rechtspraakbegrip en vooral ook of de behoorlijkheidsnormen die gelden voor 'echte' rechtspraak daarop van toepassing zijn. Algemene voorbeelden van dergelijke activiteiten zijn benoemingen van een voogd of curator ${ }^{8}$, het uitspreken van een

${ }^{1 .}$ Van Wijk/ Konijnenbelt \& Van Male 2008, p. 522; Stroink 1993, p. 3-4

2. Widdershoven kiest daarvoor, Widdershoven 1989 , p. 18 e.v.

${ }^{3 .}$ Van Wijk/Konijnenbelt \& Van Male 2008, p. 522 en 537; Widdershoven 1989, p. 14-17.

4. Van Wijk/Konijnenbelt \& Van Male 2008, p. 522 en 537; Widdershoven 1989, p. 14

5. Brenninkmeijer 1987, p. 4.

6. Zie Widdershoven die daarop reeds wijst voor het Voorontwerp Algemene wet bestuursrecht, Widdershoven 1989, p. 16. Verder: Van Wijk/Konijnenbelt \& Van Male 2008, p. 537.

7. Van Wijk/Konijnenbelt 2008, p. 537; Widdershoven 1989, p. 18-19; De Waard 1987, p. 11-12.

${ }^{8}$ Zie noot 56 en 58 van hfst. 1 . 


\section{Deel I Beginselen van behoorlijke rechtspleging}

faillissement of beslissingen van de (civiele) rechter in kort geding. ${ }^{9}$ In bestuursrechtelijke context kan bijvoorbeeld gedacht worden aan het treffen van een voorlopige voorziening door de voorzieningenrechter (waarbij geen kortsluiting met de bodemzaak plaatsvindt). ${ }^{10}$

\section{De materiële benadering}

De dogmatische tegenhanger van deze benadering is een uitsluitend materiële invulling van het begrip. De Waard vormt de belangrijkste pleitbezorger van deze benadering in het bestuursrecht. De Waard kiest voor een materiële invulling van het begrip, juist omdat activiteiten die door een rechterlijke instantie verricht worden niet altijd eenvoudig van bestuur of bestuurlijke activiteiten zijn te onderscheiden - waarmee hij doelt op de hierboven gegeven voorbeelden. Ook speelt een belangrijke rol dat bepaalde activiteiten van andere organen dan rechterlijke instanties als 'twee druppels water op rechtspraak lijken', terwijl die activiteiten niet binnen een formele begripsomschrijving van rechtspraak passen. ${ }^{11}$ Als voorbeeld kunnen de vormen van pseudo- of semi-rechtspraak die Polak onderscheidt dienen, zoals het administratief beroep of tuchtrechtspraak. ${ }^{12}$ De Waards materiële begrip rechtspraak bevat een drietal elementen: het betreft een juridisch proces waarin sprake moet zijn van een gestelde rechtsschending, er moet sprake zijn van beantwoording van een rechtsvraag en van een beslissing die bindend is voor partijen. ${ }^{13}$ Een aanvullend formeel criterium, zoals onafhankelijkheid van de beoordelende instantie, vormt geen element van rechtspraak, maar een behoorlijkheidseis. ${ }^{14}$ Ook Van der Heijden besteedt in zijn onderzoek naar de vraag of er sprake is van een eerlijk proces in het sociaal recht aandacht aan de invulling van het begrip rechtspraak en geeft een definitie van een functioneel rechtspraakbegrip. ${ }^{15}$ Rechtspraak in functionele zin bevat in zijn optiek een viertal elementen: het beslechten van geschillen, op grondslag van rechtsregels, welke beslechting geschiedt door een derde, terwijl partijen aan de uitspraak inzake het geschil gebonden zijn. ${ }^{16}$ De materiële invullingen van het begrip rechtspraak in de doctrine lijken in het algemeen een drietal elementen gemeenschappelijk te hebben ${ }^{17}:$ 1) het beslechten van geschillen, 2) door beantwoording van rechtsvragen aan de hand van rechtsnormen, 3) waarbij een bindende uitspraak gegeven wordt voor partijen. ${ }^{18}$ Deze elementen worden gezien als het typische rechterlijke in de rechterlijke functie. Hierbij verdient opmerking dat ook gesteld kan worden dat de vaststelling van de feiten, een element dat in de omschrijvingen van rechtspraak nauwelijks afzon-

\footnotetext{
9. Van Wijk/Konijnenbelt \& Van Male 2008, p. 537; De Waard 1987, p. 11-12.

${ }^{10 .}$ In de toelichting op art. 8:81 Awb merkt de wetgever op dat de voorzieningenrechter een belangenafweging moet verrichten tussen het belang van betrokkenen en het belang van onmiddellijke uitvoering van het besluit waarbij mede acht kan worden geslagen op de rechtmatigheid van het besluit, PG Awb II, p. 506. Zie ook Marseille die, gelet op de MvT, de voorlopige voorziening die de voorzieningenrechter kan treffen beschouwt als een ordemaatregel waarbij de toetsing van de rechter zich niet richt op de rechtmatigheid van het besluit en de rechter meer als beslisser dan als toetser optreedt, A.T. Marseille, 'Voorlopige oordelen, verstrekkende beslissingen', in: De voorlopige voorziening in het bestuursrecht. Preadviezen VAR 2006, Den Haag: BJu 2006, p. 89-90. Marseille wijst er echter op dat een andere interpretatie van de MvT ook mogelijk is en verwijst naar: Th. G.M. Simons, 'De beoordeling van een verzoek om voorlopige voorziening', JB-plus 2005, p. 56-72.

${ }^{11 .}$ De Waard 1987, p. 12.

12. Zie noot 74 van hfst. 1

13. De Waard 1987, p. 16-40. Overigens zijn administratief beroep en andere bestuurlijke procedures met name vanwege het tweede en derde element in zijn optiek ook niet te beschouwen als rechtspraak, De Waard 1987, p. 25 en 31-32.

14. De Waard 1987, p. 44-45. Later blijkt dat hij de onafhankelijkheidseis niet als beginsel van behoorlijke rechtspleging beschouwt, maar als inrichtingseis, p. 111.

${ }^{15 .}$ Van der Heijden 1984, p. 17-30 (hfst. 2).

16. Van der Heijden 1984, p. 23.

${ }^{17}$ Bij de volgende auteurs komen een of meer van deze elementen terug: Niessen- Cobben 1995, p. 64-65; Polak 1976, p. 5-6; Duynstee 1974, p. 49-50.

18. Dit laatste element, een bindende uitspraak voor partijen, moet voor het bestuursrecht genuanceerd worden omdat de uitspraak van de rechter erga omnes-werking heeft. Dat betekent dat de uitspraak niet alleen bindend is voor partijen, maar in beginsel ook bindend is jegens een ieder.
} 


\section{Rechtspraak}

derlijk terugkomt, een belangrijk onderdeel vormt van de rechterlijke werkzaamheid. ${ }^{19}$ Die feitenvaststelling gaat vooraf aan de toepassing van rechtsnormen op die feiten. De vaststelling van feiten kan derhalve geacht worden in het tweede element van de functie rechtspraak besloten te liggen. ${ }^{20}$

Het voornaamste nadeel van een uitsluitend materieel begrip van rechtspraak (in welke vorm dan ook) is dat het lastig is om de rechterlijke activiteiten of werkzaamheid die tot rechtspraak gerekend moeten worden eenduidig af te bakenen. ${ }^{21}$ Met name de afbakening met bestuurlijke activiteiten is soms lastig te maken. ${ }^{22}$ Ook in bestuurlijke procedures, met name de bezwaarschriftprocedure en het administratief beroep, kan immers in bepaalde gevallen beslechting van een rechtsgeschil plaatsvinden op een voor de betrokken burger bindende wijze. ${ }^{23}$ Het materiële begrip is noodzakelijkerwijs erg ruim. Omdat een formeel criterium ontbreekt, omvat het eveneens activiteiten van organen die geen rechterlijke instanties zijn. Zoals in Van Wijk/Konijnenbelt \& Van Male wordt opgemerkt, heeft een uitsluitend materieel begrip van rechtspraak (te) weinig onderscheidend vermogen. ${ }^{24}$ Tevens rijst de vraag of de voor rechtspraak geldende behoorlijkheidsnormen ook rechtstreeks op die activiteiten van andere organen van toepassing (moeten) zijn, omdat zij binnen dat begrip vallen.

\section{Een gemengd begrip}

Er zijn auteurs die de hiervoor genoemde nadelen van beide benaderingen trachten te ondervangen door uit te gaan van een gemengd rechtspraakbegrip. ${ }^{25}$ Widdershoven doet dat bijvoorbeeld en stelt dat zowel materiële als formele criteria een rol moeten spelen bij de vraag of een bepaalde werkzaamheid van een orgaan tot rechtspraak gerekend moet worden. In zijn optiek is er sprake van rechtspraak, indien voldaan is aan vier elementen: 1) er is een geschil (gestelde rechtsschending), 2) in dat kader vindt beantwoording van een rechtsvraag plaats: toepassing van rechtsnormen, 3) door een onafhankelijke derde en 4) er moet een rechtens bindende beslissing gegeven worden. ${ }^{26}$ Hij acht de onafhankelijkheidseis (die slechts aan de rechterlijke instanties gesteld wordt) onmisbaar in de definitie en onderkent tegelijkertijd dat onafhankelijke rechterlijke instanties niet altijd belast zijn met het beslechten van rechtsgeschillen aan de hand van rechtsnormen. ${ }^{27}$ De activiteiten die niet beschouwd kunnen worden als het beslechten van rechtsgeschillen, zoals bestuurlijke taken, vallen daarmee ook buiten zijn rechtspraakbegrip. Ook Stroink stelt zich op het standpunt dat een gemengd rechtspraakbegrip de meest bevredigende omschrijving geeft van rechtspraak. Beide andere benaderingen leggen in zijn optiek te eenzijdig de nadruk op materiële of formele aspecten. ${ }^{28}$

\footnotetext{
19. P.P.T. Bovend'Eert m.m.v. C.A.J.M. Kortmann, Rechterlijke organisatie, rechters en rechtspraak, Alphen aan den Rijn: Kluwer 2008, p. 2-3.

20. De vraag in hoeverre de bestuursrechter, gelet op zijn functie, zelf de feiten moet vaststellen of uitsluitend moet onderzoeken of het bestuursorgaan dat zorgvuldig heeft gedaan, laat ik hier buiten beschouwing. Zie hierover o.m.: T. Barkhuysen, L.J.A. Damen, K.J. de Graaf, A.T. Marseille, W. den Ouden, Y.E. Schuurmans, A. Tollenaar, Feitenvaststelling in beroep (Derde evaluatie van de Awb), Den Haag: Bju 2007. Hoe het ook zij, de taak die de bestuursrechter heeft bij de feitenvaststelling moet begrepen worden onder het tweede element van het begrip rechtspraak.

${ }^{21 .}$ Widdershoven 1989, p. 19. Zie ook: Van Wijk/Konijnenbelt \& Van Male 2008, p. 522 en 537; Polak 1976, p. 6.

22. Widdershoven 1989, p. 19. Zie ook: Van Wijk/Konijnenbelt \& Van Male 2008, p. 522 en 537.

${ }^{23 .}$ De gelijkenis met rechtspraak in materiële zin bestaat met name als het bestuur beschikt over een gebonden bevoegdheid. Hierop ga ik nog nader in in Deel II par. 4.3.

24. Van Wijk/Konijnenbelt \& Van Male 2008 p. 537. Vgl.: Widdershoven 1989, p. 19

25. Widdershoven 1989 , p. $18-20$

26. Widdershoven 1989 , p. 23

27. Widdershoven 1989, p. 22.

28. Stroink 1993, p. 4.
} 
Deel I Beginselen van behoorlijke rechtspleging

\subsection{De in dit onderzoek gekozen invulling van het begrip rechtspraak}

\section{Formele én materiële aspecten}

Voor de keuze van een rechtspraakbegrip waarvan het formele criterium onafhankelijkheid onderdeel uitmaakt in dit onderzoek pleit dat de rechtstreekse en volledige toepasselijkheid van de behoorlijkheidsbeginselen als uitgangspunt beperkt blijft tot de procedures die in het algemeen beschouwd worden als 'echte' rechtspraak, dat wil zeggen procedures bij onafhankelijke rechterlijke instanties. Meer principieel kan ook gesteld worden dat onafhankelijkheid een wezenskenmerk is van elke vorm van rechtspraak in een democratische rechtsstaat en om die reden onderdeel behoort uit te maken van het begrip rechtspraak. ${ }^{29}$ Daarnaast is het echter van belang het begrip rechtspraak en de daarop rechtstreeks en volledig van toepassing zijnde eisen te beperken tot de werkzaamheden van de rechter die behoren tot de essentie of het kenmerkende van zijn activiteiten. Om die reden kunnen ook materiële elementen in het rechtspraakbegrip niet ontbreken. Gelet hierop wordt in beginsel aangesloten bij het gemengde rechtspraakbegrip dat Widdershoven hanteert. Dat betekent echter dat slechts een beperkte groep bestuursrechtelijke procedures binnen dit begrip vallen en alle bestuurlijke voorprocedures of andere procedures bij het bestuur daarbuiten vallen. Dan resteert echter de vraag of en zoja, in hoeverre de beginselen van behoorlijke rechtspleging niettemin betekenis kunnen hebben voor de procedures bij andere instanties die (op punten) gelijkenis vertonen met rechtspraak in materiële zin, maar daar niet toe gerekend worden. ${ }^{30}$

\section{De dubbele rol van onafhankelijkheid}

Een aspect van de benadering van Widdershoven verdient mijns inziens geen navolging. Hij beschouwt onafhankelijkheid als voorwaarde voor het begrip rechtspraak en tegelijkertijd als behoorlijkheidseis die aan rechtspraak gesteld moet worden. ${ }^{31}$ Daarin schuilt echter een zekere tegenstrijdigheid. Indien onafhankelijkheid als voorwaarde voor rechtspraak wordt gezien, zoals in de formele benadering geschiedt, behoeft een dergelijke behoorlijkheidseis strikt genomen niet meer gesteld te worden aan alle procedures die als rechtspraak worden beschouwd. De vraag of de vereiste onafhankelijkheid in acht is genomen, is dan immers een voorvraag die reeds beantwoord is bij de toetsing aan het begrip. Is niet voldaan aan de onafhankelijkheidseis, moet de conclusie getrokken worden dat geen sprake is van rechtspraak. Niet valt in te zien wat vervolgens toetsing aan de onafhankelijkheidseis als behoorlijkheidsnorm - terwijl al vaststaat of daarvan sprake is (dit vormt immers een element van het begrip) - nog kan toevoegen. Onafhankelijkheid is ofwel een voorwaarde om te kunnen spreken van rechtspraak (als formeel criterium onderdeel van het begrip) ofwel een behoorlijkheidsnorm waaraan alle vormen van rechtspraak in materiële zin behoren te voldoen. De onafhankelijkheidseis stellen als behoorlijkheidseis aan alle vormen van rechtspraak zou bij een materieel begrip van rechtspraak betekenen dat bepaalde procedures die als rechtspraak gekarakteriseerd kunnen worden op dat punt als onbehoorlijk gekwalificeerd moeten worden. ${ }^{32}$ De bezwaarschriftprocedure of het administratief beroep zou bijvoorbeeld (in bepaalde gevallen) als een vorm van materiële rechtspraak kunnen worden aangemerkt, terwijl deze

\footnotetext{
29. Vgl. Widdershoven 1989, p. 21-22. Zie ook: Bovend'Eert 2008, p. 3-4 en 13; de VAR-Commissie Rechtsbescherming die bestuursrechtspraak in elk geval lijkt te beperken tot een onafhankelijke rechterlijke instantie, Rapport VAR-Commissie Rechtsbescherming 2004, p. 31; Hirsch Ballin 1983, p. 16-17; G.J. Wiarda, 'Rechtsregels als houvast voor rechtspraak, NJB 1977, in: Verspreide geschriften van G.J. Wiarda, Den Haag: VUGA 1986, p. 196.

30. In hoeverre er gelijkenis bestaat tussen bestuurlijke voorprocedures en 'echte' (bestuurs)rechtspraak komt hierna aan bod in par. 2.3 en nog in hfst. 4 van Deel II.

${ }^{31 .}$ Widdershoven 1989 , p. 20-21.

32. In de visie van De Waard vormt onafhankelijkheid een inrichtingseis waardoor de procedures die in materieel opzicht als rechtspraak moeten worden beschouwd zelfs behoorlijk kunnen zijn zonder dat de instantie onafhankelijk moet zijn, De Waard 1987, p. 330.
} 


\section{Rechtspraak}

vorm van rechtspraak nimmer als behoorlijk zou kunnen worden aangemerkt wegens gebrek aan onafhankelijkheid. Het verschil schuilt in de omstandigheid dat in de formele benadering strikt genomen in het geheel geen sprake kan zijn van rechtspraak (bij ontbreken van onafhankelijkheid) en de behoorlijkheidsnormen die voor rechtspraak gelden om die reden niet onverkort of rechtstreeks gelden voor die procedures. In de materiële benadering zou daarentegen sprake zijn van rechtspraak, maar zou de betreffende procedure, bij gebrek aan onafhankelijkheid, hoogstens als onbehoorlijk kunnen worden gekwalificeerd. ${ }^{33}$ Ofschoon onafhankelijkheid in mijn ogen beschouwd worden als een voorwaarde voor rechtspraak en geen behoorlijkheidseis, betekent dat vanzelfsprekend niet dat in een concreet geval niet getoetst moet worden of de vereiste onafhankelijkheid in acht is genomen. Het EHRM lijkt in zijn jurisprudentie onder artikel 6 EVRM eveneens ervan uit te gaan dat onafhankelijkheid een voorwaarde is om te kunnen spreken van een 'tribunal' in de zin van die bepaling, en tegelijkertijd een behoorlijkheidseis vormt waaraan de betreffende gerechten behoren te voldoen. Het EHRM interpreteert het begrip 'tribunal established by law' autonoom ${ }^{34}$ en hanteert verschillende criteria om te bepalen of er sprake is van een 'tribunal'. ${ }^{35}$ Daartoe behoren onder meer onafhankelijkheid, in het bijzonder ten opzichte van het bestuur, en onpartijdigheid. ${ }^{36}$ Het lijkt erop dat deze behoorlijkheidseisen (of eisen voor een eerlijk proces) tevens constitutieve elementen vormen van het begrip gerecht in de benadering van het EHRM. ${ }^{37}$ Zoals Kuijer opmerkt, heeft deze benadering van het EHRM het 'slightly bizarre' gevolg dat deze eisen ook al een rol spelen bij het bepalen of een nationale instantie als een gerecht kan worden aangemerkt in de zin van artikel 6 EVRM. ${ }^{38}$ Hoewel Kuijer niet expliciteert waarom deze benadering zo opmerkelijk is, moet de reden daarvoor in mijn optiek gezocht worden in de min of meer dubbele toets die dan ontstaat. De vraag of sprake is van een gerecht gaat vooraf aan de vraag of de bij dat gerecht gevoerde procedure voldoet aan de daarvoor geldende behoorlijkheidseisen. Door beantwoording van de eerste vraag, wordt de tweede vraag in feite overbodig.

Onafhankelijkheid als onderdeel van het begrip rechtspraak

Voor de beantwoording van de vraag welke doorwerking de onafhankelijkheidseis kan hebben in de bestuurlijke voorprocedures doet het overigens niet ter zake of deze eis gekwalificeerd wordt als voorwaarde dan wel als behoorlijkheidseis. In beide gevallen moeten de bestuurlijke voorprocedures aan die eis getoetst worden en in beide gevallen luidt het antwoord negatief. Alleen het stadium waarin zulks geschiedt is verschillend. Voor de uitkomst is dat niet van belang. Strikt genomen moet echter de conclusie zijn dat de bestuurlijke voorprocedures niet voldoen aan deze eis en derhalve niet als rechtspraak aangemerkt kunnen worden. Aan de vraag of deze eis rechtstreeks van toepassing is op de bestuurlijke voorprocedure als behoorlijkheidsbeginsel (en of deze daaraan voldoet) wordt dan niet meer toegekomen. ${ }^{39}$

\footnotetext{
33. Vgl. De Waard 1987, p. 44-45. De Waard beschouwt onafhankelijkheid, zoals hiervoor aangegeven, als inrichtingseis en niet als beginsel van behoorlijke rechtspleging. Dat betekent dat het ontbreken van onafhankelijkheidswaarborgen op zichzelf, dus los van eventuele bijzondere wettelijke eisen, rechtens geen consequenties kan hebben. Zie over het onderscheid hfst. 3, par. 3.1

34. Dat wil zeggen los van de nationale kwalificatie van het orgaan, zie: Kuijer 2004, p. 174-175; A.W. Heringa, in: J.H. Gerards, A.W. Heringa, H.L. Janssen en J. van der Velde, EVRM Rechtspraak en Commentaar, katern. Art. 6 Eerlijk proces, Haag: Sdu 1-1-2004, par. 3.6, par. 3.6.5, p. 15-17.

35. Zie bijvoorbeeld: EHRM 23 oktober 1985, Benthem t. Nederland, NJ 1986/102 m.nt. EAA; AB 1986/1 m.nt Hirsch Ballin, par. 40 en 43. Zie verder: Kuijer 2004, p. 175-181; Heringa 2004, p. 14-17.

36. Bijvoorbeeld: Benthem, par. 43; EHRM 23 juni 1981, Le Compte, Van Leuven en De Meyere t. België, NJ 1982/602, par. 55. Zie verder met verwijzingen naar jurisprudentie: Heringa 2004, p. 14-17.

37. Zie ook: Kuijer 2004, p. 178.

38. Kuijer 2004, p. 177.

39. Dat betekent dat in Deel II in beginsel niet onderzocht wordt of de onafhankelijkheidseis doorwerkt in de bestuurlijke voorprocedures, omdat ik deze eis niet beschouw als beginsel van behoorlijke rechtspleging en de
} 
Deel I Beginselen van behoorlijke rechtspleging

\subsection{Verschillen en overeenkomsten met de bestuurlijke werkzaamheid}

De bestuurlijke voorprocedures voldoen niet aan het formele criterium van het begrip rechtspraak. Om die reden kan er reeds geen sprake zijn van rechtspraak. Zoals uit de voorgaande paragrafen bleek, is het echter vaak lastig om bepaalde activiteiten van het bestuur te onderscheiden van die van de rechter bij een materiële invulling van het begrip rechtspraak. De werkzaamheid van het bestuur in de bestuurlijke voorprocedures kan tot op zekere hoogte aangemerkt worden als rechtspraak in functionele zin. De bestuurlijke voorprocedures vertonen ook op andere punten trekken van zowel bestuurlijke besluitvorming als van rechtspraak. In deze paragraaf komen de verschillen en overeenkomsten met rechtspraak en de relevantie ervan voor dit onderzoek nader aan bod.

\subsubsection{De verschillen tussen bestuur en rechtspraak}

\section{De staatsrechtelijke context}

Om de verschillen en overeenkomsten tussen het bestuur en de (bestuurs)rechter in het juiste perspectief te kunnen plaatsen, is het van belang een helder beeld te hebben van de verhouding tussen deze organen in ons staatsbestel. De heersende overtuiging in de doctrine is dat de taakuitoefening door het bestuur verschilt van de taakuitoefening door de (bestuurs)rechter. ${ }^{40}$ Het in die opvatting vooropgestelde onderscheid tussen de rechterlijke en bestuurlijke werkzaamheid (in de voorprocedure) valt te herleiden tot de opvattingen omtrent de verhouding tussen de rechter en het bestuur in het algemeen. In het bijzonder speelt daarbij de staatsrechtelijke leer omtrent de scheiding van staatsmachten, de Trias Politica, een rol. ${ }^{41}$ Hoewel een strikte scheiding van staatsmachten in Nederland niet heeft plaatsgevonden en veeleer sprake is van verdeling van machten ${ }^{42}$, neemt de rechter, als rechtsprekende macht, de meest van de beide andere machten functioneel gescheiden en onafhankelijke positie in. ${ }^{43}$ De wetgevende en uitvoerende functie zijn in Nederland immers niet geheel van elkaar gescheiden; parlement en regering stellen krachtens artikel 81 Grondwet bijvoorbeeld gezamenlijk de wetgeving vast. ${ }^{44}$ De positie van de wetgevende en uitvoerende macht ten opzichte van elkaar wordt veeleer geken-

bestuurlijke voorprocedures niet als rechtspraak. Onafhankelijkheid komt uitsluitend terug in Deel II van het onderzoek voor zover het een waarborg vormt voor onpartijdigheid, zie hierover nader par. 5.4.

${ }^{40}$ Zie o.m.: Bovend'Eert 2008, p. 2-3; Van Wijk/Konijnenbelt \& Van Male 2008, p. 545; S. Pront-van Bommel, Bestuursrechtspraak. Voorstellen voor modernisering van de bestuursrechtspraak, Den Haag: Bju 2002, p. 17; J.H.W. Notten, De Algemene wet bestuursrecht en het maken van bezwaar. Zwaartepunten van een bestuurlijke voorprocedure, Den Haag: Sdu 1998, p. 114; J.M.H.F. Teunissen, 'Toetsing ex tunc of ex nunc?', in: J.B.J.M. ten Berge e.a. (red.), Nieuw bestuursprocesrecht, Deventer: Kluwer 1992, p. 113.

${ }^{41 .}$ Zie voor een beschrijving van de leer van de machtenscheiding of beter gezegd verdeling van machten zoals voorgestaan door Montesquieu, alsmede een beschrijving van de uitwerking van die leer in Nederland o.m.: A.F.M. Brenninkmeijer, De toegang tot de rechter. Een onderzoek naar de betekenis van onafhankelijke rechtspraak in een democratische rechtstaat, Zwolle: W.E.J. Tjeenk Willink 1987, p. 125-161.

${ }^{42 .}$ Bovend'Eert 2008, p. 7-12; R.M.M. Kleijkers, 'Over coöptatie en legitimatie: de benoeming van rechters anno 2006', in: A.W. Heringa, A.M.L. Jansen, E.C.H.J. van der Linden, L.F.M. Verhey (red.), Het bestuursrecht beschermd (liber amicorum F.A.M. Stroink), Den Haag: Sdu 2006, p. 33; K.F. Bolt, Het rechterlijk toetsingsmoment in het bestuursprocesrecht (diss. Groningen), Den Haag: Bju 2005, p. 18; P.P.T. Bovend'Eert, 'Het rechtsbeginsel van de machtenscheiding. Ontwikkelingen rond een taai constitutioneel beginsel', in: R.J.N. Schlössels e.a. (red.), In beginsel: over aard, inhoud en samenhang van rechtsbeginselen in het bestuursrecht, Deventer: Kluwer 2004, p. 248-249; P.P.T Bovend'Eert, 'De modernisering van de rechterlijke organisatie: integraal management als staatsrechtelijke probleem', in: Publicaties Staatstrechtkring, Organisatie van de rechtspraak, Deventer: W.E.J. Tjeenk Willink 1999, p. 6.

43. Bovend'Eert 2008, p. 9 en 229; Van der Pot-Donner, Handboek van het Nederlandse staatsrecht, $15^{\mathrm{e}}$ druk bewerkt door D.J. Elzinga en R. de Lange, Deventer: Kluwer 2006, p. 631; Bovend'Eert 2004, p. 248-249; L.F.M. Verhey, De onafhankelijkheid van de rechter naar Nederlands recht (preadvies Vereniging voor de vergelijkende studie van het recht van België en Nederland), Zwolle: W.E.J. Tjeenk Willink 2001, p. 20; Bovend'Eert 1999, p. 6; R.J.G.M. Widdershoven, Gespecialiseerde rechtsgangen in het administratieve recht (diss. Utrecht), Zwolle: W.E.J. Tjeenk Willink 1989, p. 21; Brenninkmeijer 1987, p. 10-11.

44. Bovend'Eert 2008, p. 9; Van der Pot/Donner 2006, p. 631. Zo ook Widdershoven die wijst op de verwevenheid tussen de wetgevende macht en het bestuur, Widdershoven 1989, p. 21. 


\section{Rechtspraak}

merkt door een systeem van 'checks and balances' waardoor beide machten in de uitoefening van bevoegdheden met elkaar zijn verbonden. ${ }^{45}$ De positie van de rechtsprekende macht ten opzichte van de beide andere staatsmachten wordt daarentegen in mindere mate gekenmerkt door die mate van verbondenheid, hoewel ook hier geen sprake is van absolute onafhankelijkheid. ${ }^{46}$ De rechtsprekende macht wordt uitsluitend uitgeoefend door de rechterlijke macht of rechterlijke instanties ${ }^{47}$ en dient functioneel onafhankelijk te zijn, dat wil zeggen dat de taakuitoefening buiten de invloedssfeer of inmenging van (in het bijzonder) de beide andere staatsmachten dient te blijven. ${ }^{48}$ Zoals aangegeven, is naar algemeen wordt aangenomen onafhankelijkheid van de wetgever en het bestuur, als uitvoerende macht, een vereiste om te kunnen spreken van rechtspraak. ${ }^{49}$

De opvattingen omtrent staatsrechtelijke verhouding tussen in het bijzonder het bestuur, als uitvoerende macht en de rechter, als rechtsprekende macht, hebben geruime tijd tot gevolg gehad dat het bestuur in beginsel verantwoording diende af te leggen aan democratisch gelegitimeerde organen en niet aan de (onafhankelijke) rechter. ${ }^{50}$ Thans is het echter vanzelfsprekend, vanuit rechtsstatelijk oogpunt, dat het bestuurshandelen onderworpen is aan controle door de onafhankelijke bestuursrechter. ${ }^{51}$

\section{Gescheiden functies}

Hoewel de toetsing door de rechter van het bestuurlijk handelen door onder meer de ontwikkeling van de algemene beginselen van behoorlijk bestuur is uitgebreid, blijft echter, gelet op de staatsrechtelijke verhouding tussen rechter en bestuur, ook thans het algemeen onderschreven uitgangspunt dat de rechter de beleidsruimte die het bestuur toekomt respecteert. ${ }^{52}$ In die benadering staat voorop dat de rechter niet 'op de stoel van het bestuur' dient te gaan zitten en de taakuitoefening door het bestuur niet behoort over

\footnotetext{
45. Bovend'Eert 2008, p. 9-10; Van der Pot/Donner 2006, p. 631; Bovend'Eert 2004, p. 249-250.

${ }^{46 .}$ Bovend'Eert 2008, p. 9-10; Kleijkers 2006, p. 33; Verhey 2001, p. 20; M.R. Wijnholt, 'Selectie en benoeming van onafhankelijke rechters in het Koninkrijk', in: Publikaties van de Staatsrechtkring, Organisatie van de rechtspraak, Deventer: W.E.J. Tjeenk Willink 1999, p. 73-74; Bovend'Eert 1999, p. 7; Brenninkmeijer 1987, p. 17. Zoals o.m. Verhey aangeeft is echter ook de rechterlijke macht onderworpen aan een zekere controle door de andere staatsmachten en gelden ook ten aanzien van de rechterlijke macht bepaalde 'checks and balances'. Er bestaat bijvoorbeeld indirect door middel van de begroting en het ministeriële toezicht controle door de regering of minister via de Raad voor de Rechtspraak op de bedrijfsvoering en (voor een deel) ook de organisatie en de werkwijze van de gerechten, zie hierover: Bovend'Eert 2008, p. 219 en 229; Bovend'Eert 2004, p. 257; Verhey 2001, p. 51-52; P.P.T Bovend'Eert, 'De modernisering van de rechterlijke organisatie als staatsrechtelijke probleem', in: A.K. Koekkoek e.a. (red.), Organisatie van de rechtspraak, Deventer: W.E.J. Tjeek Willink 1999, p. 20-21. Zie over de organisatie van de rechtspraak en de recente wijzigingen, Bovend'Eert 2008, hfst. 10, p. 205 e.v; Verhey 2001, p. 28 e.v.

47. Voor administratieve rechtspraak geldt, in tegenstelling tot burgerlijke rechtspraak en strafrechtspraak, dat deze krachtens artikel 112 lid 2 Grondwet ook kan worden opgedragen aan andere rechterlijke instanties dan de rechterlijke macht, zie hierover: Van der Pot/Donner 2006, p. 598-600; Stroink 1993, p. 7.

48. C.J.A.M. Kortmann, Constitutioneel recht, Deventer: Kluwer 2008, p. 363-366; Bovend'Eert 2004, p. 257.

49. Widdershoven kwalificeert bijvoorbeeld het administratief beroep en bezwaar o.m. vanwege het ontbreken van onafhankelijkheid expliciet niet als rechtspraak, Widdershoven 1989, p. 44. Zie verder: Bovend'Eert 2008 , p. 4; Van Wijk/Konijnenbelt \& Van Male, Hoofdstukken van bestuursrecht, Den Haag: Elsevier 2008, p. 537; Brenninkmeijer 1987, p. 7. Voor ogen moet echter worden gehouden dat de grenzen tussen rechtspraak en bestuur niet altijd scherp zijn te trekken, zie: Van Wijk/Konijnenbelt \& Van Male 2008, p. 6; Van der Pot/Donner 2006, p. 632

${ }^{50}$ Zie voor een beschrijving vanuit historisch oogpunt: PG Awb II, p. 73-75. Verder: B.J. Schueler e.a., Definitieve geschilbeslechting door de bestuursrechter (Derde evaluatie van de Awb), Den Haag: BJu 2007, p. 24-30; Verhey 2001, p. 24; N. Verheij, 'De toegang tot de rechter in het bestuursrecht', in: R.A. Lawson \& E. Myjer (red.), 50 jaar EVRM, NJCM-Bulletin 2000/1, p. 191; P. Nicolaï, B.K. Olivier, I.C. van der Vlies, L.J.A. Damen, B.J. Schueler, Bestuursrecht, Amsterdam: Factotum 1997, p. 581-583.

${ }^{51 .}$ Schueler e.a. 2007, p. 28-30; Kleijkers 2006, p. 33; VAR-Commissie Rechtsbescherming, De toekomst van de rechtsbescherming tegen de overheid. Van toetsing naar geschilbeslechting, Den Haag: BJu 2004, p. 139 Verheij 2000, p. 188-189; Stroink 1993, p. 61.

52. Rapport VAR-Commissie Rechtsbescherming 2004, p. 32; L.M. Koenraad \& F.F.W. Brouwer, 'De bezwaarschriftprocedure heroverwogen (I). Het karakter van de beslissing op bezwaar', Gst. (2001) 7151, p. 506; Bren-
} ninkmeijer 1987, p. 38. Vgl. ook: Schueler e.a. 2007, p. 28. 


\section{Deel I Beginselen van behoorlijke rechtspleging}

te nemen. ${ }^{53}$ De (bestuurs)rechter dient zich te beperken tot toetsing van besluiten op rechtmatigheid. ${ }^{54}$ Er bestaat derhalve ook een scheiding in werkzaamheid tussen de verschillende organen. Illustratief voor dit onderscheid tussen bestuur (in het algemeen) en (bestuurs)rechtspraak is hetgeen Verheij, zij het in een iets andere context, opmerkt:

"Toetsen is wat bestuursrechters doen. Toetsen is nagaan of iets - in dit geval een besluit - aan een maatstaf voldoet. (...) Het bestuur, daarentegen, moet niet nagaan of genomen besluiten aan maatstaven voldoen, maar besluiten nemen. Het bestuur toetst niet, maar beslist." 55

Dat uitgangspunt geldt ook voor de bestuurlijke voorprocedures. De voorprocedures maken onderdeel uit van de bestuurlijke takuitoefening en worden als zodanig ook beschouwd als een onderdeel, nl. het sluitstuk, van de besluitvormingsfase. ${ }^{56} \mathrm{Bij}$ de bestuurlijke voorprocedures wordt doorgaans ook de nadruk gelegd op de bestuurlijke elementen daarin. De wetgever stelt zich op die grond eveneens op het standpunt dat er een onderscheid bestaat tussen de procedures bij de rechter en de bestuurlijke voorprocedures. In het kader van de tweede tranche van de Awb wordt het volgende opgemerkt:

"Heroverwegingsprocedures en de uitgebreide en zware voorbereidingsprocedure van afdeling 3.4A zijn en blijven op bestuurlijke besluitvorming gerichte procedures en om die reden principieel [curs. DW] te onderscheiden van op rechtmatigheidstoetsing van bestuursbesluiten gerichte procedures bij de onafhankelijke rechter." 57

Elders is eenzelfde overweging, toegespitst op de bezwaarschriftprocedure als voorprocedure, terug te vinden. Daar wordt benadrukt dat de bezwaarschriftprocedure en de rechterlijke procedure geen uitwisselbare grootheden zijn. ${ }^{58}$

\section{Klassieke verschillen}

In eerste instantie lijkt de werkzaamheid van het bestuur in een voorprocedure ook typisch bestuurlijk te zijn. Een bestuurlijke voorprocedure is immers een procedure die gevolgd wordt bij het bestuur voorafgaand aan een procedure bij de bestuursrechter. De uitkomst van die procedure bij het bestuur is een besluit. Daarin schuilt een op het eerste gezicht essentieel verschil ten opzichte van (bestuurs)rechtspraak en de procedure bij de (bestuurs)rechter. Het bestuur neemt besluiten en bestuurt (ook in de bestuurlijke voorprocedure) mede op grond van beleidsoverwegingen, terwijl de bestuursrechter deze besluiten aan het recht toetst en zo doende rechtspreekt. ${ }^{59}$ Zoals aangegeven, is dit een uitgangspunt dat te herleiden valt tot de staatsrechtelijke verhouding tussen bestuur en

\footnotetext{
${ }^{53 .}$ Er zijn echter in de doctrine ook andere geluiden te horen. Zie bijvoorbeeld Brenninkmeijer die de beeldspraak 'de rechter mag niet op de stoel van het bestuur gaan zitten' een cliché noemt dat niet langer leerstellige betekenis moet hebben. Uit een oogpunt van o.m. finale geschilbeslechting zou de rechter de keuzevrijheid die het bestuur soms heeft moeten (kunnen) invullen, A.F.M. Brenninkmeijer, 'Een leerstellig cliché', in: T. Hoogenboom \& L.J.A. Damen, In de sfeer van administratief recht, Utrecht: Lemma 1994, p. 31. Vgl. ook: Rapport VAR-Commissie Rechtsbescherming 2004, p. 68-69.

54. B.J. Schueler e.a., Definitieve geschilbeslechting door de bestuursrechter (Evaluatieonderzoek Awb III), Den Haag: Bju 2007, p. 1; Van Wijk/Konijnenbelt \& Van Male 2008, p. 570.

${ }^{55}$ N. Verheij, 'Tussen toen en nu. Het relevante tijdstip voor besluitvorming in bezwaar en toetsing in beroep', JB-plus 2003, p. 28-29; Bolt 2005, p. 9.

56. Op dat standpunt stelt ook de wetgever zich in het kader van vergoeding van de kosten gemaakt in de bezwaarfase, Kamerstukken II 1999/00, 27 024, nr. 3, p. 4. Gesteld wordt in de toelichting dat de bezwaarschriftprocedure de mogelijkheid biedt gemaakte fouten snel en eenvoudig te herstellen. Vervolgens wordt opgemerkt dat als dat gebeurt eigenlijk niet gesproken kan worden van een achteraf onjuist gebleken besluit omdat de bezwaarschriftprocedure deel uitmaakt van de bestuurlijke besluitvorming en het bestuur dus uiteindelijk geen onjuist besluit heeft genomen.

57. PG Awb II, p. 196. Deze overwegingen van de wetgever werden gedaan in het kader van de vraag of twee feitelijke instanties in het bestuursrecht nodig zijn.

58. PG Awb II, p. 67. De wetgever plaatst deze opmerking in het nader rapport wederom in het kader van de vraag naar de noodzaak voor rechtspraak in twee feitelijke instanties. Zie in vergelijkbare zin: Van Wijk/Konijnenbelt \& Van Male 2008, p. 545

59. Verheij 2003, p. 28-29.
} 


\section{Rechtspraak}

rechter en de daarmee samenhangende afbakening van de takuitoefening van het bestuur en de taakuitoefening van de rechter.

Dit uitgangspunt vormt de basis voor een aantal andere traditioneel aangewezen verschillen tussen of kenmerken van beide procedures. Te denken valt dan in eerste instantie aan de ex nunc-beoordeling door het bestuur versus de ex tunc-toetsing door de bestuursrechter. ${ }^{60}$ Of aan een ander (met het voorgaande samenhangend) uitgangspunt: het feit dat de bestuursrechter (thans op grond van artikel 8:72, vierde lid van de Awb) slechts zelf in de zaak mag voorzien, indien maar één rechtens juiste beslissing overblijft en daarbij derhalve het primaat van het bestuur respecteert. ${ }^{61}$ Dit laatste uitgangspunt is de laatste tijd in de rechtspraak wel aan enige versoepeling onderhevig vanwege het belang van finale geschilbeslechting. Daarop kom ik in par. 4.3.9 van dit deel nog nader terug. Met name het gegeven dat het bestuur, voor zover de wet daartoe ruimte biedt, in het kader van de besluitvorming (ook in de voorprocedure) beleidsaspecten dient mee te nemen, weegt zwaar in de benadering waarin het onderscheid tussen besturen en rechtspraak benadrukt wordt. Op basis van deze verschillen lijkt de aanname dat er fundamentele verschillen bestaan tussen bestuur en rechtspraak ook gerechtvaardigd.

Verschil in werkzaamheid, verschil in eisen

Indien aangenomen wordt dat bestuur en rechtspraak wezenlijk verschillen en indien de bestuurlijke elementen in de voorprocedures vooropgesteld worden, ligt het in het verlengde van die opvatting in de rede dat daarop - alleen of vooral - vereisten die gelden voor het bestuur van toepassing (kunnen) zijn. Voor de bestuurlijke taakuitoefening gelden specifiek op de (eigen) aard ervan toegespitste vereisten. ${ }^{62}$ Illustratief voor deze benadering is de volgende passage van Schreuder-Vlasblom: "Bij de aanwending van bestuursbevoegdheden rijzen steeds nieuwe vragen waarvan het belang de indivi-
duele zaak overstijgt en die een nadere uitwerking van de normatieve grondslag voor beschikkingen ver-
gen. Normstelling los van de conrete zaak, ligt niet op de weg van de rechter (art. 12 Wet AB) en evenmin
rechtsvorming die politiek-maatschappelijke afwegingen en beleidskeuzen vergt. De rechter kan deze be-
leids- en besluitvorming wel aan een geobjectiveerde toetsing onderwerpen, maar gebreken er aan kan hij
niet herstellen (par. 1.2). Het recht dat die besluitvorming beheerst en waaraan hij zijn maatstaven ontleent,
is van andere aard en strekking dan het regime voor de rechtspleging, neergelegd en uitgewerkt in (de
rechtspraak op) art. 6 EVRM, al direct de onpartijdigheid en onafhankelijkheid. Bestuurlijke beleids- en
besluitvorming is geen rechtspraak en kan niet voldoen aan de daaraan gestelde eisen. Juist daarom kan de
rechter haar ook niet verrichten." 63

Schreuder-Vlasblom legt een verband met de eisen die de taakuitoefening door het bestuur en de rechter beheersen. Naar haar mening gelden de normen van artikel 6 EVRM slechts de rechterlijke toetsing en niet de besluitvorming zelf. ${ }^{64}$ Sommige andere auteurs

${ }^{60 .}$ Bolt 2005, p. 18; Rapport VAR-Commissie Rechtsbescherming 2004, p. 122-123; Verheij 2003, p. 26; Teunissen 1992, p. 113. In par. 4.3.2 wordt nader ingegaan op de ex nunc-beoordeling door het bestuur en de ex tunc-toetsing door de rechter alsmede op het onderscheid daartussen.

${ }^{61}$ Schueler e.a. 2007, p. 50; Rapport VAR-Commissie Rechtsbescherming 2004, p. 32; Koenraad \& Brouwer 2001, p. 506.

62. Zie bijvoorbeeld Notten in verband met de vraag naar de noodzaak voor een verbod van vooringenomenheid voor het bestuur in artikel 2:4 van de Awb. Hij plaatst vanuit de eigen aard van het bestuur vraagtekens daarbij; Notten 1998, p. 114.

${ }^{63 .}$ Schreuder-Vlasblom 2008, p. 55-56

64. Schreuder-Vlasblom 2008, p. 56. Overigens wordt uit de hierboven aangehaalde passage van SchreuderVlasblom niet meteen duidelijk of deze ook betrekking heeft op de bestuurlijke voorprocedures. Die veronderstelling is echter waarschijnlijk nu zij het niet eens lijkt te zijn met een uitspraak van de Centrale Raad van Beroep van 21 juli 2001, NJB 2001/22, p. 1625; ook gepubliceerd in $J B$ 2001/256; $A B$ 2001/252 m.nt. FP onder $A B$ 2001/253; RSV 2001/205; USV 2001/199. In die uitspraak overweegt de Centrale Raad dat in het midden kan worden gelaten of de in die zaak aan de orde zijnde elementen van artikel 6 EVRM ook in de bezwaarfase rechtstreeks van toepassing zijn. Er is in casu geen sprake van een schending van art. 6 EVRM omdat de procedure bij de rechtbank voldoet aan de uit dit artikel voortvloeiende vereisten. Schreuder-Vlasblom acht de aan de rechtspraak van het EHRM ontleende gedachte dat de besluitvorming gebrekkig mag zijn, mits die gebreken 


\section{Deel I Beginselen van behoorlijke rechtspleging}

menen eveneens dat voor de bezwaarschriftprocedure procedurele waarborgen dienen te gelden, maar dat deze dienen aan te sluiten bij het bestuurlijke karakter (en tweeledige karakter) van een bestuurlijke voorprocedure. Daarmee worden dan - al dan niet terecht - minder vergaande procedurele eisen bedoeld dan die gelden voor de rechterlijke procedures. Helder meent bijvoorbeeld dat, teneinde het bestuurlijke karakter van de procedure te verzekeren of te bewaken, de procedurele waarborgen in de bezwaarschriftprocedure minimaal moeten zijn. ${ }^{65}$

\subsubsection{De gemeenschappelijkheden}

Niettegenstaande de verschillen tussen bestuur en rechtspaak zijn er bij nadere beschouwing, zeker voor zover het de bestuurlijke voorprocedures betreft, ook overeenkomsten aan te wijzen. Het betreft in beide gevallen een procedure bij een overheidsorgaan, waarbij de taakuitoefening door dit orgaan leidt tot het eenzijdig vaststellen van de rechtspositie van de burger(s). ${ }^{66}$ Zowel het bestuur als de rechter zijn met enig openbaar gezag bekleed, aldus de Awb-wetgever. ${ }^{67}$ Met openbaar gezag bekleed houdt in dat een publiekrechtelijke bevoegdheid bestaat tot het bepalen van de rechtspositie van andere rechtssubjecten. ${ }^{68}$ Dat geldt voor zowel de werkzaamheid van het bestuur als van de (bestuurs)rechter.

In de literatuur is eveneens aandacht besteed aan de overeenkomsten tussen bestuur en rechtspraak in het algemeen, en tussen de voorprocedures en de procedure bij de rechter in het bijzonder. De Waard noemt als globaal punt van overeenkomst tussen de activiteiten van het bestuur en de rechter dat beide organen bevoegd zijn tot het nemen van bindende "besluiten" waarvan de naleving door de overheid in naam van het recht kan worden afgedwongen. ${ }^{69}$ Ook wordt wel gesteld dat in het geval van uitoefening van een strikt gebonden bestuursbevoegdheid door het bestuur in principe geen verschil bestaat met de taakuitoefening door de rechter. In beide gevallen bestaat de taakuitoefening door het betreffende orgaan uit wetstoepassing. ${ }^{70}$ In het verlengde daarvan wordt ook de werkzaamheid van het bestuur in de voorprocedure, indien sprake is van een (zuiver) gebonden bestuursbevoegdheid, gelijkgesteld met de werkzaamheid van de bestuursrechter. In beide gevallen bestaat die werkzaamheid, op initiatief van een belanghebbende burger, uit een rechtmatigheidstoetsing achteraf van een reeds genomen besluit. $^{71}$

Bovendien maken (bepaal)de voorprocedures, naar algemeen wordt aangenomen, onderdeel uit van het Nederlandse stelsel van bestuursrechtelijke rechtsbescherming en

geheeld worden doordat de procedure voor de rechter voldoet aan alle vereisten voortvloeiend uit art. 6 EVRM, onjuist. Zij stelt dat de besluitvorming niet gebrekkig is, maar zich volgens andere normen voltrekt.

${ }^{65 .}$ E. Helder, 'Rechtsbescherming door gemeente: zijn er klachten of bezwaren?, in: H.A. Brasz en J.G. Steenbeek, Klachten en bezwaren tegen de gemeente, Den Haag: VUGA 1988, p. 26.

${ }^{66 .}$ Vergelijk ook het rapport van de VAR-Commissie voor rechtsbescherming waarin dit als een van de kenmerken van het bestuur genoemd wordt, Rapport VAR-Commissie Rechtsbescherming 2004, p. 24

67. PG Awb I, p. 134. Rechterlijke organen zijn echter geen bestuursorganen, benadrukt de wetgever vervolgens. Daarmee wordt de nadruk gelegd op het (formele) onderscheid tussen bestuur en rechtspraak. Widdershoven signaleert en beschrijft die formele benadering van de wetgever, die reeds in het Voorontwerp Awb doorklonk, Widdershoven 1989, p. 16-17. De in dit stuk aangehaalde overwegingen van de wetgever worden gegeven in de toelichting op artikel 1:1 Awb. In het tweede lid van die bepaling zijn de organen opgesomd die niet dienen te worden beschouwd als bestuursorgaan in de zin van de Awb. Ook bij de wet ingestelde organen die met rechtspraak belast zijn en onafhankelijk zijn, worden in het tweede lid uitgezonderd.

68. PG Awb I, p. 133

69. De Waard 1987, p. 13. Een punt van verschil is overigens wel dat de rechter besluiten van het bestuur kan aantasten, terwijl de verbindendheid van uitspraken van de rechter niet door een ander orgaan (althans een orgaan dat geen rechterlijke instantie is) kan worden aangetast, zie ook: Bovend'Eert 2008, p. 3.

${ }^{70 .}$ Rapport VAR-Commissie rechtsbescherming 2004, p. 27.

71. Vgl: C.P.J. Goorden, 'Bezwaarschriftprocedures in de gemeentelijke praktijk', NTB 1995/9-10, p. 298. 


\section{Rechtspraak}

wordt daaraan (mede) een rechtsbeschermingscomponent toegedicht. ${ }^{72}$ Dit is ook onder de Awb het geval. ${ }^{73}$ Voorts wordt de rechtsbeschermingsfunctie van het bestuursprocesrecht $^{74}$ en de bestuursrechtspraak (recours subjectif) onder de Awb voorop gesteld en is handhaving van het objectieve recht (recours objectif) als primaire doelstelling verlaten. ${ }^{75}$ Ook vanuit die optiek lijkt er tussen de functies van (bepaal)de voorprocedures en de procedure bij de bestuursrechter enige mate van verwantschap te bestaan. In beide gevallen kan bindende beslechting van een geschil tussen burger en bestuur plaatsvinden in een met (bepaalde) waarborgen omklede procedure. Widdershoven meent dat administratief beroep en bezwaar kunnen worden getypeerd als vormen van geschilbeslechting die niet als rechtspraak beschouwd kunnen worden. Het element geschilbeslechting hebben deze procedures derhalve gemeen met rechtspraak. ${ }^{76}$ Ook de Raad van State merkt in zijn advies bij de tweede tranche van de Awb op dat de bezwaarschriftprocedure, als procedure voorafgaand aan het beroep op de bestuursrechter, elementen in zich draagt die vergelijkbaar zijn met de behandeling van het geschil door diezelfde bestuursrechter. $^{77}$

Verwantschap betekent verwante eisen

Wordt de verwantschap tussen de bestuurlijke voorprocedures meer benadrukt, dan worden over het algemeen ook meer overeenkomstige of vergelijkbare procedurele behoorlijkheidseisen aangenomen. Zo worden de bestuurlijke voorprocedures en de procedure bij de rechter door Nicolaï en Olivier e.a. gerekend tot de bestuursrechtelijke voorzieningen, die een aantal gemeenschappelijke kenmerken hebben. ${ }^{78}$ Een van die kenmerken is dat het orgaan waaraan de beslissing in een bestuursrechtelijke voorziening (dat kan dus zowel een bestuursorgaan als een rechterlijke instantie zijn) is opgedragen de beginselen

\footnotetext{
72. Van Wijk/Konijnenbelt \& Van Male 2008, p. 523 en 544. De mate waarin deze rechtsbeschermingscomponent aanwezig is, kan echter, per voorprocedure verschillen en binnen een voorprocedure per beleidsterrein of per bevoegdheid verschillen. In elk geval worden het administratief beroep en de bezwaarschriftprocedure vrij algemeen en reeds geruime tijd tot (onder meer) vormen van rechtsbescherming bestempeld. Ten Berge en Tak merken reeds op dat de gangbare opvatting inhoudt dat zowel administratief beroep als bezwaar plegen te worden gezien als onderdelen van rechtsbescherming, J.B.J.M. Ten Berge \& A.Q.C. Tak, Hoofdlijnen van het Nederlands administratief procesrecht, Zwolle: W.E.J. Tjeenk Willink 1990, p. 7. Op de vraag wat exact onder rechtsbescherming dient te worden verstaan en welke definitie daarvan in dit onderzoek gehanteerd wordt, wordt nader ingegaan in par. 4.2.2 van Deel II.

${ }^{73 .}$ C.J.N. Versteden, 'De plaats van bezwaar en administratief beroep in het stelstel van rechtsbescherming', NTB 1995/9-10, p. 286-287; Rapport VAR- Commissie rechtsbescherming 2004, p. 14-15. In dit rapport worden zowel het beroep bij de bestuursrechter als de bezwaarschriftprocedure en het administratief beroep beschouwd als klassieke vormen van rechtsbescherming.

74. Onder de Awb wordt het begrip bestuursprocesrecht ruim opgevat en worden daartoe de processuele voorschriften uit hfst. 6, 7 en 8 van de Awb, die zowel betrekking hebben op de procedure bij de rechter als op de bezwaarschriftprocedure en het administratief beroep, gerekend. Het bestuursprocesrecht ziet derhalve op de contentieuze fase waaronder ook bezwaar en administratief beroep vallen, Van Wijk/Konijnenbelt \& Van Male 2008, p. 567. In enge zin omvat het bestuursprocesrecht slechts procedurele voorschriften die betrekking hebben op de procedure bij de bestuursrechter.

75. PG Awb II, p. 174

76. Widdershoven 1989 , p. 44. De mogelijkheid om beleidsaspecten bij de beoordeling een rol te laten spelen en de omstandigheid dat de beslissende colleges niet onafhankelijk zijn de belangrijkste redenen om deze procedures niet als rechtspraak aan te merken.

77. PG Awb II, p. 60. De Raad van State legt in het advies over de aanpassing van de Awb wat betreft de kosten bestuurlijke voorprocedures weer de nadruk op het onderscheid tussen rechtspraak en bestuurlijke voorprocedures. Daar wordt benadrukt dat de voorprocedure een ander karakter heeft dan een rechtsgeding voor de bestuursrechter, Kamerstukken II 1999/00, 27 024, nr. A, p. 3.

78. Onder bestuursrechtelijke voorziening moet worden verstaan een niet in het burgerlijke recht geregelde bij wet opengestelde aparte voorziening die voor de burger de mogelijkheid biedt om de juistheid van een overheidsgedraging te laten beoordelen en die ertoe kan leiden dat een bestreden besluit ongedaan wordt gemaakt, P. Nicolaï, B.K. Olivier, I.C. van der Vlies, L.J.A. Damen \& B.J. Schueler, Bestuursrecht (zesde druk), Amsterdam: Factotum 1997, p. 568. Iets verderop blijkt dat het orgaan dat de overheidsgedraging moet beoordelen in een bestuursrechtelijke voorziening een rechterlijke instantie of een bestuursorgaan kan zijn.
} 


\section{Deel I Beginselen van behoorlijke rechtspleging}

van behoorlijk bestuursprocesrecht in acht heeft te nemen. ${ }^{79} \mathrm{Zij}$ menen derhalve dat op de bestuursrechtelijke voorzieningen bij het bestuur, zoals bezwaar en administratief beroep, beginselen van behoorlijk bestuursprocesrecht van toepassing zijn evenals op de procedure bij de rechter. Hoewel beide soorten voorzieningen verschillen, liggen de verschillen juist op het punt van de in acht te nemen behoorlijkheidseisen minder voor de hand. ${ }^{80}$ Versteden typeert de bezwaarschriftprocedure en administratief beroep als een overgangsgebied in het totale proces rond bestuursbesluiten. Deze voorprocedures liggen tussen het zuivere besluitvormingsproces en bestuursrechtspraak in en bestaan uit componenten die uit beide werelden afkomstig zijn. ${ }^{81}$ Daarop sluiten de toepasselijke procedurele eisen aan. In de Awb zijn enerzijds judiciële elementen, zoals procedurele voorschriften die een behoorlijke rechtsgang moeten waarborgen en die gelijkenis vertonen met regels die rechtspraak eigen zijn, opgenomen. Anderzijds bevat de Awb ook voorschriften die het bestuurlijke element in de voorprocedures veilig stellen. ${ }^{82}$ Anderen gaan daarin nog iets verder. Smit stelt bijvoorbeeld dat juist het geschilbeslechtende karakter van de bezwaarschriftprocedure bepalend dient te zijn voor de organisatie en inrichting van die voorprocedure. Dat betekent dat de eisen die aan behoorlijke rechtspraak worden gesteld eveneens gesteld moeten worden aan de bezwaarfase. ${ }^{83}$ Ook De Waard geeft aan dat bestuursorganen soms daden verrichten die sterk lijken op rechtspraak. Daarbij noemt hij het administratief beroep als voorbeeld. ${ }^{84}$ De Waard meent dat administratief beroep in het algemeen (naast bestuurlijke kenmerken) ook rechtspraakachtige aspecten bevat en voldoende verwant is met rechtspraak om te veronderstellen dat veel van de behoorlijkheidsnormen die voor rechtspraak gelden (in zekere mate) ook voor administratief beroep gelden. ${ }^{85}$ Hoewel de meningen uiteenlopen over de gewenste mate van toepasselijkheid, is er bij alle opvattingen, vanwege de aangenomen verwantschap met rechtspraak, plaats voor enige betekenis van de eisen van behoorlijke rechtspraak.

\subsubsection{Verschillende eisen gesteld door de bestuursrechter}

In de praktijk worden de voor rechterlijke procedures geldende procedurele vereisten veelal direct of indirect gegrond op artikel 6 EVRM, dat ook primair en vooral betrekking heeft op de procedure bij een rechterlijke instantie. De vraag of en in hoeverre de vereisten van artikel 6 EVRM en de daaruit voortvloeiende procedurele waarborgen van toepassing zijn op de bestuurlijke fase, in het bijzonder de bestuurlijke voorprocedures,

\footnotetext{
79. Zij lijken de beginselen van behoorlijk bestuursprocesrecht op te vatten als ruime behoorlijkheidsnormen die op contentieuze procedures van toepassing zijn. Zij stellen nl. dat voor beroep op de rechter eventuele behoorlijkheidseisen opgehangen kunnen worden aan de beginselen van behoorlijke rechtspraak terwijl de behoorlijkheidseisen voor administratief beroep of bezwaar als ongeschreven rechtseisen aan de beginselen van behoorlijk bestuur kunnen worden vastgeknoopt. Erkenning van aparte beginselen van bestuursprocesrecht achten zij wenselijk om twee redenen: 1) zo komt het bijzondere karakter van de beslissingen in deze voorprocedures to uitdrukking en 2) wordt de eenheid van bezwaar en administratief beroep en het beroep op de rechter benadrukt, zie Nicolaï en Olivier e.a. 1997, p. 570.

${ }^{80 .}$ Nicolaï en Olivier e.a. 1997 , p. 570.

81. Versteden 1995, p. 290.

82. Versteden is van oordeel dat bij deze voorprocedures een zwaar accent ligt op de bestuurlijke mogelijkheden, maar dat de meerwaarde van deze procedures slechts wordt gerealiseerd door een zorgvuldige combinatie van bestuurlijke en judiciële elementen, Versteden 1995, p. 291.

83. J.A. Smit, 'De administratieve voorprocedures', in: J.B.J.M. Ten Berge e.a. (red.), Nieuw bestuursprocesrecht, Deventer: Kluwer 1992, p. 52. Deze stelling nuanceert hij vervolgens enigszins door erop te wijzen dat het in de bezwaarschriftprocedure zijns inziens gaat om materiële bestuursrechtspraak en derhalve van onafhankelijkheid geen sprake is. Onduidelijk blijft echter of onafhankelijkheid daarmee een voorwaarde voor rechtspraak vormt of een behoorlijkheidseis.

84. De Waard 1987, p. 13. Hij geeft aan dat zelfs de procedure van het nemen van een originaire beslissing trekken kan vertonen van rechtspraak. Als voorbeeld haalt hij aan de rechtspraak-achtige procedures voor intrekking van een vergunning die door de jurisprudentie soms worden geëist alvorens het besluit mag worden genomen of in wetten vastgelegde procedures van preventieve rechtsbescherming.

${ }^{85 .}$ De Waard 1987, p. 55. Zie ook: G.J. Wiarda, 'Het administratief beroep', in: Verspreide geschriften van G.J. Wiarda, Den Haag: VUGA 1986, p. 124-125; Polak 1976, p. 6.
} 


\title{
Rechtspraak
}

is evenwel een aantal malen aan bod gekomen in de jurisprudentie. Allereerst is een aantal uitspraken van de Centrale Raad omtrent artikel 6 EVRM en de bezwaarfase van belang. ${ }^{86}$ De Centrale Raad neemt in die uitspraken geen geheel eenduidig standpunt in omtrent de toepasselijkheid van de vereisten voortvloeiend uit artikel 6 EVRM in de bezwaarfase. In een uitspraak overweegt hij bijvoorbeeld:

\begin{abstract}
"De Raad kan zich grotendeels verenigen met hetgeen door appellant in hoger beroep is aangevoerd met betrekking tot de toepassing van de in dit geding aan de orde zijnde elementen van artikel 6 van het EVRM in de bezwaarschriftprocedure. Daarbij acht de Raad van belang dat in de door appellant genoemde arresten van het Europees Hof voor de Rechten van de Mens en in het arrest van dat Hof van 3 mei 2001 in de zaak van de Vereniging Landelijk Overleg Betuweroute tegen Nederland (nr. 46664/99) steun kan worden gevonden voor de conclusie dat deze bepaling - in ieder geval voor wat betreft de in dit geding aan de orde zijn elementen ervan [curs. DW] - uitsluitend ziet op procedures van rechterlijke aard"
\end{abstract}

Hoewel de Centrale Raad voorop stelt dat artikel 6 EVRM betrekking heeft op de procedure bij de rechter wordt toch de mogelijkheid opengelaten voor toepassing van de vereisten uit dit artikel op de bezwaarschriftprocedure door de gecursiveerde zinsnede. ${ }^{88} \mathrm{Op}$ basis van die overweging lijkt voor het antwoord op de vraag of en in hoeverre artikel 6 EVRM van toepassing is op de bestuurlijke voorfase bepalend te zijn om welk vereiste van dat artikel het gaat. ${ }^{89}$ Dat zou betekenen dat een algemeen standpunt inzake de toepasselijkheid van artikel 6 EVRM op de bestuurlijke voorprocedure - volgens de Centrale Raad - niet te geven is en dat met inachtneming van de omstandigheden van het geval en per vereiste bezien dient te worden of en in hoeverre dit vereiste betekenis heeft voor de bestuurlijke voorprocedures. Mogelijk laat de Centrale Raad echter een kleine opening, omdat het redelijke termijn-vereiste uit artikel 6 EVRM in elk geval van toepassing is op de bezwaarfase..$^{90}$ Eerder overwoog de Centrale Raad al in een andere uitspraak dat in het midden kon worden gelaten of de in de desbetreffende zaak aan de orde zijnde elementen van artikel 6 EVRM rechtstreeks van toepassing waren op de bezwaarfase. ${ }^{91}$ Het uitgangspunt lijkt - voor de Centrale Raad - echter te zijn dat artikel 6 EVRM ziet op de rechterlijke procedure. De Centrale Raad stelt immers steeds voorop dat de in het geding zijn elementen van artikel 6 EVRM uitsluitend zien op de rechterlijke procedure en een bestuursorgaan niet gehouden kan worden, anders dan de rechter, om op grond van artikel 6 EVRM om af te wijken van de medische besluitenregeling. ${ }^{92}$ Welke opvatting de Centrale Raad exact is toegedaan, komt echter niet eenduidig in deze uitspraken naar voren en voor zover ik heb kunnen nagaan is deze kwestie daarna ook niet meer (zo expliciet) aan bod gekomen in de jurisprudentie (van de Centrale Raad). ${ }^{93}$

\footnotetext{
86. CRvB 13 februari 2002, USZ 2002/98 m.nt. red.; CRvB 13 februari 2002, USZ 2002/100 m.nt. red; CRvB 13 februari 2002, USZ 2002/101 m.nt. Driessen; $A B$ 2002/96 m.nt. FP.

87. CRvB 13 februari 2002, USZ 2002/101 m.nt. Driessen; $A B$ 2002/96 m.nt. FP. Appellant, het Lisv, had kort gezegd aangevoerd dat de bestuurlijke voorprocedure gelet op jurisprudentie van het EHRM niet aan de eisen van art. 6 EVRM hoeft te voldoen als er een vervolgfase is die wel volledig recht doet aan de eisen van dit artikel.

${ }^{88 .}$ Beide annotatoren genoemd in de vorige noot stellen zich - in mijn ogen ten onrechte - in hun noot bij de uitspraak op het standpunt dat de Raad in deze uitspraak uitdrukkelijk kiest voor de opvatting dat artikel 6 EVRM slechts van toepassing is op de rechterlijke toetsing en niet op de bestuurlijke voorprocedure.

${ }^{89}$. In de aangehaalde zaak geeft de Raad overigens niet expliciet aan om welk vereiste van artikel 6 EVRM het gaat. Uit een andere uitspraak over dezelfde materie, nl. art. 88c WAO (oud), van de Centrale Raad van Beroep van 21 juli 2001, $N J B$ 2001/22, p. 1625; ook gepubliceerd in $J B$ 2001/256; $A B$ 2001/252 m.nt. FP onder $A B$ 2001/253; RSV 2001/205; USV 2001/199 blijkt echter dat het o.m. gaat om het vereiste van ' equality of arms' oftewel de gelijke procespositie van partijen.

90. Zie hierover nader par. 5.7 van Deel II.

91. Zie noot 89 hiervoor.

92. De Raad overweegt in de aangehaalde uitspraak ook dat, gelet op artikel 6 EVRM, in de bezwaarschriftprocedure minder vergaande waarborgen gelden dan in de rechterlijke procedure.

93. Wel is de jurisprudentie van de Raad inzake de medische besluitenregeling en artikel 6 EVRM nog aan bod gekomen in onder meer een uitspraak in 2003, CRvB 7 januari 2003, USZ 2003/139. De Raad overweegt echter ook in deze uitspraak onder verwijzing naar zijn uitspraak van 13 februari 2002, USZ 2002/101 slechts dat "een bestuursorgaan, anders dan de rechter, niet gehouden kan worden geacht om op grond van artikel 6 van het EVRM af te wijken van de medische besluitenregeling en met name van art. $88 \mathrm{c}$ van de WAO, in het kader van
} 


\section{Deel I Beginselen van behoorlijke rechtspleging}

De Afdeling daarentegen geeft in stelliger bewoordingen haar benadering aan. In een uitspraak van 12 juli 2006 stelt de Afdeling, zonder nadere motivering, dat het beginsel van equality of arms niet van toepassing is op bestuurlijke besluitvorming en dat derhalve het betoog van de appellant dat de beslissing op bezwaar in strijd met dat beginsel genomen was faalt. ${ }^{94}$ De Afdeling lijkt het bestuurlijke karakter van de bezwaarfase voorop te stellen. In het verlengde daarvan lijkt zij de werking van het beginsel van equality of arms dat primair betrekking heeft op de rechterlijke fase, in de bezwaarfase geheel uit te sluiten. Omdat de motivering ontbreekt, staat echter niet onomstotelijk vast waarop de Afdeling haar overwegingen baseert dat het beginsel van equality of arms niet van toepassing is op bestuurlijke besluitvorming. Een mogelijke verklaring zou kunnen zijn dat de Afdeling het vereiste van equality of arms vooral in verband brengt met artikel 6 EVRM, dat primair gericht is op de rechterlijke procedure. Uit de uitspraak blijkt echter niet of de appellant een beroep op artikel 6 EVRM had gedaan dan wel zich beriep op het ongeschreven nationale beginsel van behoorlijke rechtspleging van hoor en wederhoor, waarvan equality of arms onderdeel uitmaakt. ${ }^{95}$

Een andere uitspraak van 22 november 2006 biedt meer duidelijkheid. Het bestuur had in die zaak een besluit genomen onder verwijzing naar een negatief advies van een adviescommissie. Het besluit hield een afwijzing van een subsidieaanvraag in. In bezwaar werd het besluit gehandhaafd na uitbrenging van een nader advies van de adviescommissie. De rechtbank vernietigde het besluit onder verwijzing naar het Mantovanelliarrest van het $\mathrm{EHRM}^{96}$, omdat het beginsel van hoor en wederhoor en het recht op tegenspraak zou zijn geschonden doordat de aanvrager niet in de gelegenheid was gesteld zijn standpunten toe te lichten bij de adviescommissie voordat het advies werd uitgebracht. Dat leverde strijd op met artikel 3:9 Awb, volgens de rechtbank. Het bestuur gaat met succes in hoger beroep bij de Afdeling. De Afdeling overweegt over de toepasselijkheid van het Mantovanelli-arrest:

\footnotetext{
"In het Mantovanelli-arrest is geoordeeld dat indien een rechter een vraag die betrekking heeft op een (technische) kwestie ter zake waarvan hij niet deskundig is, ter beantwoording voorlegt aan een deskundige in een geschil waarin de betrokken vraag identiek is aan de vraag waarover de rechter heeft te beslissen, het beginsel van hoor en wederhoor, zoals dat geldt voor de rechterlijke procedures, is geschonden indien partijen hun standpunt over het deskundigen rapport niet kenbaar hebben kunnen maken, voordat de deskundige zijn rapport bij de rechter indient. Hiermee wordt ten behoeve van een eerlijk proces beoogd te waarborgen dat de rechter het standpunt van partijen op adequate wijze in zijn oordeel betrekt. Bij de aanwending van de hem toegekende bevoegdheden beschikt het bestuur veelal, zoals ook in dit geval, over eigen materie-deskundigheid en voor de fase van de bestuurlijke besluitvorming gelden andere normen dan voor de procedure bij de rechter. In die fase staat centraal, de gehoudenheid van het bestuur actief de nodige kennis over de relevante feiten en de af te wegen belangen te vergaren."97
}

de heroverweging in bezwaar van een eerder genomen besluit." Hoewel de Raad hier niet expliciet ingaat op de toepasselijkheid van artikel 6 op de bezwaarfase, kan uit deze op de omstandigheden van het geval toegespitste overweging wellicht toch worden afgeleid dat de Raad van oordeel is dat de vereisten uit dit artikel geen betekenis hebben voor de bezwaarfase.

94. AbRvS 12 juli 2006, AB 2008/144 m.nt. A.M.L. Jansen; JB 2006/268 m.nt. Wenders, r.o. 2.4. De Afdeling heeft eerder al overwogen dat de in art. 6 EVRM neergelegde normen niet rechtstreeks van toepassing zijn op de bestuurlijke besluitvorming (zie: AbRvS 8 mei 2002, AB 2002/299 m.nt. Sew). In een uitspraak van 18 november 2009 overweegt de Afdeling nogmaals dat het fair trial beginsel van artikel 6 EVRM niet geldt voor de bezwaarschriftprocedure, omdat sprake is van verlengde besluitvorming, AbRvS 18 november 2009, nr. 200903566/1/H2. Zie anders: De Waard die het vereiste van equality of arms als onderdeel van het verdedigingsbeginsel beschouwt (De Waard 1987, p. 127 en hfst. 7). Op dat vereiste wordt in par. 4.3.5 van Deel I nader ingegaan.

95. Zie mijn noot bij $J B$ 2006/268 en A.M.L Jansen in zijn noot bij $A B$ 2008/144 en in zijn bijdrage 'De deskundige en een fair trial', $M \& R 2008$, p. 223-226. Zie ook De Waard die het vereiste van equality of arms als onderdeel van het verdedigingsbeginsel beschouwt (De Waard 1987, p. 127 en hfst. 7). Op het vereiste van equality of arms wordt in par. 4.3.5 van Deel I nader ingegaan.

96. EHRM 18 maart 1997, Mantovanelli t. Italië, JB 1997/112 m.nt. Heringa; NJ 1998/278 m.nt. Snijders.

97. AbRvS 22 november 2006, JB 2007/12 m.nt. AB; $A B$ 2008/62 m.nt. N. Verheij. 


\section{Rechtspraak}

De Afdeling stelt zich onomwonden op het standpunt dat op de bestuurlijke besluitvorming andere normen (dan die voortvloeien uit of samenhangen met artikel 6 EVRM) van toepassing zijn dan op de procedure bij de rechter. Daarbij lijken de typisch bestuurlijke elementen aan de werkzaamheid van het bestuur de doorslag te geven, ongeacht de fase waarin de besluitvorming zich bevindt. ${ }^{98}$

In de hiervoor aangehaalde uitspraken staat de toepasselijkheid van het equality of arms-vereiste uit artikel 6 EVRM op de bestuurlijke besluitvormingsprocedures centraal. Mogelijk zijn de bestuursrechters, vanwege de omstandigheid dat deze bepaling in beginsel ziet op rechtspraak, terughoudend met de aanname van toepasselijkheid van dat vereiste op de bestuurlijke procedures. In hoeverre dezelfde aarzeling te bespeuren is bij de beginselen van behoorlijke rechtspleging of goede procesorde ${ }^{99}$ dan wel andere vereisten uit artikel 6 EVRM zal het onderzoek in Deel II moeten uitwijzen. Vooralsnog kan worden volstaan met de constatering dat de verschillen tussen bestuur en rechter er voor de bestuursrechter toe lijken te leiden dat andere vereisten gelden voor de procedures bij deze organen.

\subsection{Conclusies}

Kort samengevat volgt uit de voorgaande paragrafen dat in dit onderzoek uitgegaan wordt van een gemengd rechtspraakbegrip waarbij zowel aan het formele criterium onafhankelijkheid moet worden voldaan als aan materiële criteria. Dat betekent dat er aan een viertal criteria voldaan moet zijn: 1) er is sprake van een geschil 2) in het kader waarvan beantwoording van een rechtsvraag plaatsvindt door toepassing van rechtsnormen 3 ) waarbij een rechtens bindende beslissing wordt gegeven 4) door een onafhankelijke (rechterlijke) instantie. Procedures bij het bestuur vallen op voorhand buiten dit rechtspraakbegrip vanwege het feit dat aan de onafhankelijkheidseis niet wordt voldaan. Ook aan de materiële elementen van dit begrip voldoet de werkzaamheid van het bestuur niet altijd in alle opzichten en verschilt deze van de werkzaamheid van de bestuursrechter. Het bestuur betrekt bij zijn beoordeling in de bestuurlijke voorprocedures immers ook, voor zover mogelijk, beleidsaspecten. Bovendien geschiedt de bestuurlijke werkzaamheid ex nunc, terwijl de rechterlijke werkzaamheid bestaat uit het ex tunc toetsen van besluiten. Wel bestaan er op belangrijke punten overeenkomsten. Zo is er in beide gevallen sprake van geschilbeslechting en wordt de rechtspositie van de betrokken burger door een overheidsorgaan eenzijdig bindend vastgesteld. De procedures bij bestuur en rechter worden beide gezien als onderdeel van het bestuursrechtelijke systeem van rechtsbescherming. Ook in de bestuurlijke voorprocedures vindt in veel gevallen op initiatief van een belanghebbende een rechtmatigheidstoetsing achteraf plaats van een reeds genomen besluit.

Veelal wordt in de doctrine of jurisprudentie de nadruk gelegd op de verschillen in de werkzaamheid en die leiden er, in het bijzonder in de rechtspraak van de bestuursrechter, toe dat er ook verschil bestaat in de toepasselijk geachte behoorlijkheidseisen. Naarmate er meer oog bestaat voor de verwantschap met rechtspraak, is er, in elk geval in de doctrine, ook meer plaats voor toepasselijkheid van de voor rechtspraak geldende behoorlijkheidseisen of daarmee vergelijkbare eisen. De vraag rijst in hoeverre de traditionele verschillen met rechtspraak de toepasselijkheid van andere behoorlijkheidseisen rechtvaardigen of daartoe nopen. Zelfs als de verschillen tussen bestuur en rechtspraak wezenlijk zijn, kan de vraag gesteld worden of en in hoeverre deze verschillen in de weg

98. Uitspraken van het College van Beroep voor het bedrijfsleven waarin deze expliciet overwegingen wijdt aan de toepasselijkheid van artikel 6 EVRM op de bestuurlijke voorprocedures of de besluitvormingsfase, afgezien van de redelijke termijn-eis ben ik overigens niet tegengekomen.

99. Deze begrippen worden soms met elkaar vereenzelvigd en met de goede procesorde wordt in bepaalde gevallen ook de eisen voor een eerlijk proces of beginselen behoorlijke rechtspraak bedoeld, zie hierover: B.W.N. de Waard, 'De goede procesorde', JB-plus 2001, p. 149-153. 
Deel I Beginselen van behoorlijke rechtspleging

moeten staan aan toepasselijkheid van dezelfde of vergelijkbare procedurele eisen. Daarop wordt in Deel II in paragraaf 4.4 nader ingegaan. 


\section{Concretisering van de beginselen van behoorlijke rechtspleging}

\subsection{Noodzaak tot concretisering van beginselen}

De gelding van een beginsel van behoorlijke rechtspleging voor een bepaalde procedure impliceert dat die procedure zo moet zijn vormgegeven dat aan dat beginsel wordt voldaan. Uit die vaststelling kan echter nog niet concreet worden afgeleid op welke wijze de procedure ingericht moet zijn, teneinde in overeenstemming te zijn met het desbetreffende beginsel. Inachtneming van een beginsel van behoorlijke rechtspleging kan op verschillende wijzen geschieden en de daartoe benodigde waarborgen behoeven niet op voorhand vast te liggen. Beginselen zijn immers open abstracte rechtsnormen, die nader geconcretiseerd of uitgewerkt moeten worden in concrete eisen. ${ }^{1}$ Zolang de desbetreffende procedure is ingericht op een wijze die recht doet aan de beginselen van behoorlijke rechtspleging, is de wijze waarop de inrichting heeft plaatsgevonden of plaats moet vinden (binnen dat kader) in beginsel vrij. Het is aan de wetgever of andere instantie die het desbetreffende procesrecht of de desbetreffende procesregeling ${ }^{2}$ vormgeeft op welke wijze de beginselen van behoorlijke rechtspleging daarin tot uitdrukking worden gebracht. Is er geen procesrecht dat de inrichting van de procedure normeert of geen procesregeling waarin eisen zijn vervat, zal de rechter eisen moeten formuleren die gelden in het concrete voorliggende geval (maar ook daarbuiten voor andere gevallen geldingskracht kunnen hebben). In alle gevallen is het de rechter die uiteindelijk het oordeel moet geven over de vraag of de desbetreffende procedure voldoet aan de beginselen van behoorlijke rechtspleging.

Het karakter van de beginselen van behoorlijke rechtspleging impliceert kortom dat deze beginselen uitgewerkt moeten worden in concretere eisen waaraan een procedure moet voldoen. Daaruit volgt voorts dat concrete toepassingen of uitwerkingen van een beginsel onderscheiden kunnen worden van het beginsel zelf. Uitwerkingen of toepassingen van een beginsel zijn derhalve eisen met een andersoortig karakter. In de doctrine wordt ook wel eens de term inrichtingseisen gebezigd in verband met de beginselen van behoorlijke rechtspleging. ${ }^{3}$ Deze inrichtingseisen wordt in de meeste gevallen eveneens een ander karakter toegedicht dan de beginselen van behoorlijke rechtspleging. ${ }^{4}$ De verhouding van deze verschillende eisen tot elkaar is niet altijd even helder. Om het referentiekader, dat wil zeggen de geldende behoorlijkheidsbeginselen voor rechtspleging, vast te kunnen stellen is het van belang het onderscheid - voor zover dat gehandhaafd moet worden - tussen deze verschillende soorten eisen in kaart te brengen. In het onderstaande wordt daaraan dan ook eerst aandacht besteed, alvorens in het volgende hoofdstuk aan de geldende behoorlijkheidsbeginselen en eisen wordt toegekomen.

\footnotetext{
${ }^{1 .}$ De Waard 1987, p. 94-95; Van der Heijden 1984, p. 49-50.

2. Dat kan derhalve ook een rechterlijke instantie zijn. De procesregelingen voor de rechtbanken worden conform de Landelijke procesregeling bestuursrecht 2008, een modelregeling, door ieder gerechtsbestuur voor het eigen gerecht vastgesteld, zie Stcrt. 2008, 114. Voor de Afdeling bestuursrechtspraak van de Raad van State, Centrale Raad van Beroep en het College van Beroep voor het bedrijfsleven is door deze colleges de Procesregeling bestuursrechterlijke colleges 2006 vastgesteld, Stcrt. 2005, 250 .

3. De Waard 1987, p. 107-112; Widdershoven 1989, p. 110-111.

${ }^{4 .}$ De Waard 1987, p. 107-112.
} 
Deel I Beginselen van behoorlijke rechtspleging

\subsection{Beginselen, inrichtingseisen en concrete uitwerkingen van beginselen}

\subsubsection{Het onderscheid tussen beginselen, inrichtingseisen en concrete uitwerkingen}

\section{Beginselen en inrichtingseisen}

De onderscheiding tussen inrichtingseisen en de (rechts)beginselen van behoorlijke rechtspleging in het bestuursrecht is afkomstig van De Waard en wordt door verschillende auteurs onderschreven. ${ }^{5}$ Het onderscheid houdt op hoofdlijnen in dat een beginsel van behoorlijke rechtspleging een procedurele rechtsnorm is waarvan schending rechtens consequenties met zich brengt, terwijl dat bij inrichtingseisen niet (noodzakelijkerwijs) het geval is. ${ }^{6}$ De beginselen van behoorlijke rechtspleging zijn derhalve rechtsnormen waaraan de betreffende procedure behoort te voldoen. ${ }^{7}$ Inrichtingseisen daarentegen zijn in de optiek van De Waard regels die hetzelfde doel nastreven als beginselen van behoorlijke rechtspleging of erop gericht zijn om tot realisering van die beginselen te komen, maar die niet, zoals de beginselen, worden toegepast indien de wetgever ze niet in een bepaalde procesregeling heeft ingebouwd. ${ }^{8}$ Hij verwoordt het in zijn dissertatie als volgt:

"Inrichtingseisen zijn eisen die aan een procedure worden gesteld ter bevordering van de kwaliteit van de procedure, dat wil zeggen gericht op het verkrijgen van een deugdelijk overwogen en zo objectief mogelijke beslissing, maar die niet het karakter van rechtsbeginsel (opgevat als rechtsnorm) hebben."

Deze op de inrichting van de procedure betrokken normen zijn derhalve géén rechtsnormen in de visie van De Waard en gelden uitsluitend, indien de wetgever ze gepositiveerd heeft. Dat betekent ook dat, als een inrichtingseis niet gesteld wordt in de betreffende (wettelijke) procesregeling of daarbuiten, in een andere toepasselijke regeling, daaraan rechtens geen consequenties worden verbonden. ${ }^{10}$ Is een inrichtingseis daarentegen gepositiveerd, dan vormt deze een geschreven rechtsnorm waarvan schending tot rechtsgevolgen behoort te leiden. ${ }^{11}$ Voorbeelden van inrichtingseisen zijn volgens De Waard openbaarheid van behandeling van de zaak, openbaarheid van de uitspraak, rechtspraak in twee instanties en de onafhankelijkheidseis. ${ }^{12}$ Wat betreft de eis van rechtspraak in twee instanties kan er in elk geval mee worden ingestemd dat deze eis geen beginsel van behoorlijke rechtspleging vormt, maar met betrekking tot de overige drie eisen is dat wat mij betreft de vraag. Hierop kom ik nader terug in hoofstuk 4 en de paragrafen waarin deze drie eisen centraal staan, te weten paragraaf 4.3.3 en 4.3.6. Thans is vooral het onderscheid in algemene zin van belang. In de omstandigheid dat aan het ontbreken van een inrichtingseis in de regelgeving rechtens geen consequenties verbonden zijn en in het

\footnotetext{
5. Zie: Widdershoven 1989, p. 111; K. Wiersma, 'Administratieve en burgerlijke procesgangen, beginselen en organisatie', in: W.H. Heemskerk, Th.B. ten Kate en B.C. Punt (red.), Een goede procesorde (Haardt-bundel), Deventer: Kluwer 1983, p. 143. Overigens lijkt niet iedere auteur exact hetzelfde als De Waard op het oog te hebben met de onderscheiding en vooral het begrip inrichtingseisen soms anders op te vatten dan mijns inziens is bedoeld. Widdershoven lijkt bijvoorbeeld iets af te wijken van De Waards opvatting zoals in de volgende paragraaf nog zal blijken. Er zijn ook auteurs die kritiek hebben op de onderscheiding die De Waard aanbrengt, zie Van der Heijden 1984, p. 42-44. Van der Heijden reageert overigens in zijn dissertatie op een artikel dat De Waard enkele jaren voor het verschijnen van zijn dissertatie geschreven heeft, B.W.N. de Waard, 'Een eerlijk proces (I en II), TvO 1983, p. 143-147 en 175-179. Zijn kritiek is derhalve niet gericht op overwegingen uit de dissertatie van De Waard. In het artikel wordt reeds een onderscheid gemaakt tussen beginselen en inrichtingseisen. Ook Wiersma, hiervoor aangehaald, refereert aan het artikel van De Waard en niet zijn dissertatie.

${ }^{6}$ De Waard 1987, p. 107-112. Zie ook: Widdershoven 1989, p. 110-111.

7. De Waard 1987 p. 92 en p. 107.

${ }^{8 .}$ De Waard 1987, p. 107. Zie ook: Widdershoven 1989, p. 111

9. De Waard 1987, p. 109. De Waard onderscheidt ook nog karakteristieken die hij beschouwt als kenmerken of grondtrekken van het bestuursprocesrecht die geen rechtsnormen (behoeven te) zijn, De Waard 1987, p. 103 104. Karakteristieken of grondbeginselen zijn in zijn ogen zuiver beschrijvend. Schending ervan heeft rechtens geen gevolgen.

${ }^{10}$ De Waard 1987, p. 109. Zie ook: Widdershoven 1989, p. 111.

11. De Waard 1987, p. 397.

12. De Waard 1987, p. 107-108 en 110-111.
} 


\section{Concretisering van beginselen}

ontbreken van het rechtsnormkarakter, schuilt derhalve het doorslaggevende verschil met de beginselen van behoorlijke rechtspleging. ${ }^{13}$ In zoverre zijn de onderscheidingen duidelijk.

Het onderscheid tussen inrichtingseisen en concrete uitwerkingen van beginselen

De door De Waard gehanteerde onderscheiding in inrichtingseisen en beginselen, roept de vraag op of er een verschil bestaat tussen concrete uitwerkingen van de beginselen en inrichtingseisen. Op basis van het voorgaande zou de indruk kunnen ontstaan dat inrichtingseisen concrete uitwerkingen zijn van de beginselen en dat er geen onderscheid te maken valt tussen beide soorten eisen. Een inrichtingseis beoogt immers als regel van procesrecht hetzelfde doel als de beginselen van behoorlijke rechtspleging of realisatie van die beginselen te bewerkstelligen. ${ }^{14}$ Een concrete uitwerking van een beginsel is een concrete eis waarmee eveneens realisatie van een (een aspect van) behoorlijke procedure beoogd wordt. In beide gevallen betreft het derhalve eisen, die geen beginsel zijn, maar waarmee wel realisatie van een behoorlijke procedure beoogd wordt.

De onduidelijkheid wordt versterkt, indien in ogenschouw wordt genomen dat de wetgever tegenwoordig in procesrechtelijke voorschriften uitwerkt op welke wijze concreet aan de beginselen tegemoet kan worden gekomen. Inrichtingseisen gelden uitsluitend, indien de wetgever ze gepositiveerd heeft. Omdat de wetgever thans echter gedetailleerde procesrechtelijke voorschriften heeft geschapen voor procedures bij rechterlijke instanties, zijn de concrete uitwerkingen van de beginselen ook veelal wettelijk geregeld. Ontbreekt een regeling, is het aan de rechterlijke instantie om in zijn jurisprudentie de beginselen uit te werken en concrete eisen te formuleren waaraan moet worden voldaan. In het geval de wetgever (of een andere regelgever) eisen die een behoorlijke procedure beogen te realiseren heeft uitgewerkt, kunnen concrete toepassingen van beginselen of inrichtingseisen in dit opzicht samenvallen. Niet duidelijk is wat in dat geval het onderscheidende criterium is.

Het verschil tussen beide soorten eisen lijkt in De Waards benadering met name te schuilen in de omstandigheid dat concrete uitwerkingen van beginselen van behoorlijke rechtspleging ook kunnen gelden, indien zij niet gepositiveerd zijn door de wetgever. Die gelding valt immers te herleiden naar de gelding van de beginselen. In dat geval zou de toepassing van het beginsel door de rechter als in acht te nemen ongeschreven eis in de jurisprudentie gesteld moeten zijn. Het gevolg van niet naleving van een concrete uitwerking van een beginsel is dan ook gelegen in de schending van het desbetreffende beginsel. Het rechtsnormkarakter van de eis is daarmee een afgeleide van het rechtsnormkarakter van het beginsel - afgezien van het feit dat het een wettelijk voorschrift en daarmee al een rechtsnorm kan betreffen. Uiteindelijk moet de conclusie immers luiden dat het desbetreffende beginsel, al dan niet naast het wettelijke voorschrift, dat aan de concrete uitwerking ten grondslag ligt geschonden is. Daarmee is echter nog steeds niet duidelijk waaraan een inrichtingseis en een concrete uitwerking herkend kunnen worden, indien zij beide wél door de wetgever gepositiveerd zijn. De omstandigheid dat een concrete toepassing van een beginsel ook kan gelden zonder vastlegging door de wetgever, lijkt welbeschouwd in de benadering van De Waard niet de doorslaggevende factor te vormen.

De Waard geeft zelf aan dat het verschil tussen beginselen, inrichtingseisen en concrete uitwerkingen van beginselen niet altijd scherp te maken is en dat de grens daartussen een vloeiende is. ${ }^{15}$ Het onderscheid lijkt te liggen in de mate van abstractheid van de eis. Inrichtingseisen zijn naar hun aard abstracter dan uitwerkingen van beginselen, en naderen de beginselen in dat opzicht meer. Inrichtingseisen zijn rechtsregels (in tegenstelling tot beginselen), maar ook zij dienen nog steeds nader uitgewerkt worden in con-

\footnotetext{
13. Vgl. Widdershoven 1989, p. 111.

14. De Waard 1987, p. 107 en 109-111.

15. De Waard 1987, p. 397.
} 


\section{Deel I Beginselen van behoorlijke rechtspleging}

crete eisen. Dat volgt uit de eisen die De Waard als inrichtingseis bestempelt: de eis van rechtspraak in twee instanties, de eis van onafhankelijkheid en de openbaarheidseisen. ${ }^{16}$ Concretere eisen, zoals een hoorplicht of de plicht tot het ingaan op de belangrijkste stellingen van partijen in de uitspraak, moeten worden beschouwd als uitwerkingen van beginselen, respectievelijk het beginsel van hoor en wederhoor en het motiveringsbeginsel. ${ }^{17}$ Dergelijke eisen beogen uitsluitend een beginsel te operationaliseren en schending van deze eisen kan - naast mogelijkerwijs schending van de wet - schending van een beginsel van behoorlijke rechtspleging opleveren.

\section{Relativering van het onderscheid}

De onduidelijkheid over het onderscheid tussen concrete toepassingen van beginselen en inrichtingseisen, doet twijfel rijzen aan de houdbaarheid ervan. De oorzaak van de onduidelijkheid is dat De Waard bepaalde eisen, mede vanwege een wenselijk geachte reductie $^{18}$, niet beschouwt als beginselen, terwijl deze eisen naar algemene opvatting (in elk geval thans) juist wel als beginselen van behoorlijke rechtspleging te beschouwen zijn. Het betreft de onafhankelijkheid ${ }^{19}$ en openbaarheidseisen. ${ }^{20} \mathrm{Nu}$ deze eisen geen beginselen zijn en ook geen toepassingen vormen van andere beginselen, ontstond de noodzaak om een derde categorie te onderscheiden. Bovendien bestonden er destijds nog niet dermate uitgewerkte voorschriften en eisen van bestuursprocesrecht, zoals thans in de Awb het geval is. Voorts ontstond die noodzaak, omdat er ten tijde van zijn onderzoek eisen, zoals rechtspraak in twee instanties en de openbaarheidseisen, bestonden die niet voor alle procedures die binnen zijn begrip rechtspraak vielen of rechtsgebieden als rechtsnorm golden en geen onderdeel vormden van het positieve recht. ${ }^{21}$ Overigens geldt dat voor de eis van rechtspraak in twee instanties nog steeds en kan deze derhalve niet als beginsel van behoorlijke rechtspleging worden beschouwd. ${ }^{22}$ Een procedure kan behoorlijk zijn, zonder dat deze in twee instanties is gevoerd. Thans worden de onafhankelijkheid van de rechter en de openbaarheidseisen echter wel als geldende normen voor rechtspraak beschouwd en de laatste eisen kunnen dan ook als beginselen van behoorlijke rechtspleging worden bestempeld. ${ }^{23}$ Bovendien zijn de eisen voor de procedures bij de bestuursrechtelijke rechterlijke instanties behoorlijk uitgewerkt. De noodzaak tot onderscheiding van beginselen, inrichtingseisen én concrete uitwerkingen van beginselen, zoals De Waard hanteert, is daarmee weggevallen. De eisen die De Waard bestempelt als inrichtingseisen vormen in dit onderzoek dan ook ofwel beginselen van behoorlijke rechtspleging ofwel andersoortige (rechts)normen, zoals het recht op toegang tot de rechter of onafhankelijkheid van de rechter, als gevolg waarvan uitsluitend een indeling in beginselen en concrete toepassingen van de beginselen resteert.

\footnotetext{
16. De Waard 1987, p. 107-111.

17. De Waard 1987, p. 303 e.v. en p. 393.

18. De Waard 1987, p. 123-124 en 395. De Waard is immers op zoek naar beginselen die een universele gelding hebben en voor alle procedures die als materiële rechtspraak kunnen worden aangemerkt gelden. Daaruit volgt noodzakelijkerwijs dat het aantal onderscheiden beginselen beperkt moet zijn, vgl. Widdershoven 1989, p. 111.

19. Overigens vormt onafhankelijkheid in mijn opinie, zie hierover par. 2.2, ook geen beginsel van behoorlijke rechtspleging, maar eerder een element van het begrip rechtspraak.

${ }^{20 .}$ Damen e.a. 2009, Deel II, p. 64-66; Van Wijk/Konijnenbelt \& Van Male 2008, p. 578; Schreuder-Vlasblom 2008, p. 58-66; Barkhuysen e.a. 2007, p. 71 en 90.

${ }^{21 .}$ De Waard 1987, p. 108.

22. Het EHRM schrijft deze eis in elk geval op grond van art. 6 EVRM niet voor: EHRM 17 januari 1970, Delcourt t. België, nr. 2689/65. Zie hierover ook: P. van Dijk, F. van Hoof, A. van Rijn en L. Zwaak (red.), Theory and Practice of the European Convention on Human Rights, Antwerpen-Oxford: Intersentia 2006, p. 564-567; Heringa 2004, par. 3.6.1, p. 2

${ }^{23}$. Zie hierover par. 4.3.6. Voor onafhankelijkheid van de rechter geldt, zoals eerder aangegeven, dat deze eis een geldende rechtsnorm vormt, maar van andere aard is dan een beginsel van behoorlijke rechtspleging.
} 


\section{Concretisering van beginselen}

\subsubsection{De samenhang tussen beginselen en concretere eisen}

Tweedeling binnen concrete uitwerkingen

In dit onderzoek wordt een tweedeling in beginselen en concretere eisen gehandhaafd in verband met de te hanteren methode ter vaststelling van de betekenis van de beginselen voor de onderscheiden bestuurlijke voorprocedures. Dat heeft vooral, zoals in het navolgende nog zal blijken, te maken met de samenhang die bestaat tussen de beginselen van behoorlijke rechtspleging en concrete toepassingen van die beginselen. In dat verband is het zinvol om stil te staan bij de overwegingen van Widdershoven inzake de samenhang die tussen de beginselen van behoorlijke rechtspleging en inrichtingseisen.

Widdershoven vestigt - na zich te hebben aangesloten bij de tweedeling van De Waard in enerzijds beginselen waarvan schending rechtens consequenties meebrengt en anderzijds inrichtingseisen waarbij dat niet het geval is -, de aandacht op de samenhang die bestaat tussen die eisen. In beide gevallen betreft het normen die gericht zijn op de realisatie van een behoorlijke procedure. Inrichtingseisen kunnen in zijn optiek ten dienste staan van de verwezenlijking van de beginselen, omdat bepaalde minimumeisen aan de procedure gesteld moeten worden teneinde schending van de beginselen te voorkomen. ${ }^{24}$ Het ontbreken van inrichtingseisen voor een procedure betekent dan niet per definitie dat de betreffende procedure in strijd is met een beginsel van behoorlijke rechtspleging, maar bij het ontbreken van bepaalde inrichtingseisen kan dat wel het geval zijn. In gevallen waarin bepaalde inrichtingseisen ontbreken kan sprake zijn van een onbehoorlijke procedure, aangezien een bepaald minimumniveau aan inrichtingseisen vereist is. Bepaalde inrichtingseisen zijn derhalve essentieel voor de realisatie van een beginsel van behoorlijke rechtspleging. Als voorbeeld geeft hij een procedure waarin de mogelijkheid voor partijen ontbreekt om het eigen standpunt naar voren te brengen. ${ }^{25}$ Dat betekent ook dat aan het ontbreken van essentiële inrichtingseisen consequenties verbonden zouden moeten worden.

Daarmee verschilt de benadering van Widdershoven - al dan niet bedoeld - van die van De Waard. ${ }^{26}$ Hij lijkt het onderscheid tussen inrichtingseisen en concrete uitwerkingen, zoals ook in de vorige paragraaf werd bepleit, los te laten. Het lijkt erop dat Widdershoven als inrichtingseisen eisen beschouwt die in De Waards optiek als uitwerkingen van de beginselen moeten worden gekwalificeerd, getuige het hiervoor aangehaalde voorbeeld inzake de mogelijkheid voor partijen om het eigen standpunt naar voren te brengen. Door de nadruk te leggen op de samenhang tussen inrichtingseisen (lees: concrete uitwerkingen of toepassingen van de beginselen) en de beginselen, en in dat kader essentiële concrete toepassingen te onderscheiden waarvan het ontbreken rechtens consequenties moeten hebben, wordt een relativering aangebracht op de verschillende door De Waard gehanteerde onderscheidingen. Op die wijze bestaat er een tweedeling tussen beginselen en concretere eisen die deze beginselen moeten realiseren, maar ook een tweedeling binnen die concretere eisen. Binnen die concretere eisen kan namelijk een onderscheid worden gemaakt tussen, voor de realisatie van de beginselen, meer en minder essentiële eisen. Uitsluitend schending of het ontbreken van de essentiële eisen leidt tot schending van het desbetreffende beginsel van behoorlijke rechtspleging, terwijl schending of het ontbreken van de overige eisen dat niet tot gevolg heeft. Zo blijft de tweedeling tussen normen waarvan schending rechtens consequenties heeft en normen waarvan schending rechtens geen consequenties heeft overeind. De tweedeling verschuift alleen naar de categorie uitwerkingen van de beginselen. Vanwege de nadruk op de samenhang tussen de beginselen en de concretere daaruit voortvloeiende eisen, en

\footnotetext{
24. Widdershoven 1989, p. 112.

25. Widdershoven 1989, p. 112.

${ }^{26 .}$ Dat is overigens ook op andere punten het geval. Zo onderscheidt hij meer beginselen dan De Waard en merkt hij bepaalde door De Waard als inrichtingseis bestempelde eisen, zoals onafhankelijkheid en openbaarheid, aan als beginselen, Widdershoven 1989, p. 111-112.
} 


\section{Deel I Beginselen van behoorlijke rechtspleging}

vanwege de in de voorgaande paragraaf al genoemde redenen, spreekt deze benadering meer aan dan de door De Waard gehanteerde indeling in inrichtingseisen en beginselen. Dat betekent dat er in dit onderzoek uitsluitend van het bestaan van beginselen en concretere uitwerkingen of toepassingen van die beginselen wordt uitgegaan. Schending van beginselen moet leiden tot consequenties en in beginsel vernietiging van de desbetreffende uitspraak. Realisatie van de beginselen kan op verschillende wijze plaatsvinden in een (wettelijke) regeling, waarbij er concrete toepassingen kunnen bestaan die dermate essentieel zijn voor de waarborging van een beginsel dat het ontbreken of de schending daarvan ook rechtens consequenties moet hebben. Tegenwoordig bevat de Awb voor de rechterlijke procedure en de bestuurlijke (voor)procedures echter eisen en ook bijzondere regelingen stellen eisen aan de inrichting van procedures. Daarom is het minder goed voor te stellen dat een situatie waarin essentiële inrichtingseisen ontbreken aan de orde van de dag zal zijn. ${ }^{27}$

\section{De adressaat van de beginselen}

Het voorgaande doet de vraag naar de adressaat van de beginselen rijzen. Welk orgaan moet zorgdragen dat deze in acht worden genomen? De beginselen van behoorlijke rechtspleging richten zich allereerst tot de rechterlijke instantie of de instantie die het geschil moet beslechten. ${ }^{28}$ De rechter zal ervoor moeten waken dat deze beginselen in een concreet geval in acht worden genomen. Miskent de rechter in eerste aanleg de beginselen van behoorlijke rechtspleging, dan zal vernietiging in hoger beroep moeten volgen. Omdat een schriftelijke procedureregeling echter gewenst is vanuit een oogpunt van rechtszekerheid en rechtsgelijkheid voor de betrokken actoren bij de procedure, rust daarnaast ook op het orgaan dat de regeling opstelt een taak in dat kader: de regeling zal zo moeten zijn ingericht, dat de beginselen van behoorlijke rechtspleging in acht kunnen worden genomen. In het bestuursrecht is dat de wetgever in formele zin, die het bestuursprocesrecht heeft neergelegd in de Awb, alsook de verschillende rechterlijke instanties die een nadere uitwerking daarvan gegeven hebben in de betreffende procesregelingen. ${ }^{29}$ De wetgever heeft, nu procedures bij de rechter en het procesrecht tegenwoordig wettelijk geregeld plegen te worden, derhalve ook een belangrijke rol of taak bij het waarborgen van inachtneming van de beginselen van behoorlijke rechtspleging. Gesteld zou zelfs kunnen worden dat er in het kader van het waarborgen van de beginselen van behoorlijke rechtspleging in eerste instantie een taak voor de wetgever ligt en pas in tweede instantie - namelijk wanneer de wetgever niets geregeld heeft of door toetsing van de naleving van de beginselen in het concrete geval - voor de rechter. Indien noodzakelijk op grond van de omstandigheden van het geval, zal de rechter om inachtneming van de beginselen van behoorlijke rechtspleging te verzekeren de regeling derhalve opzij moeten kunnen zetten of moeten kunnen aanvullen. De rechter zal in hoger beroep de uitspraak moeten vernietigen en (daarmee) 'de opdracht' moeten kunnen geven (aan de

\footnotetext{
27. Aangenomen mag worden dat strijd met de beginselen op het niveau van de regeling zich ook niet gauw zal voordoen en die strijdigheid zich vooral in concrete gevallen zal voordoen, vgl. De Waard 1987, p. 395.

${ }^{28 .}$ Bovend'Eert 2008, p. 256; R.J.N. Schlössels, 'Dimensies van rechtsbeginselen. Enige observaties vanuit het bestuursrecht', in: R.J.N. Schlössels, A.J. Bok, H.J.A.M. van Geest, S. Hillegers (red.), In beginsel. Over aard, inhoud en samenhang van rechtsbeginselen in het bestuursrecht, Deventer: Kluwer 2004, p. 24.

29. Landelijke procesregeling bestuursrecht 2008, Stcrt. 2008, 114, p. 119; Procesregeling bestuursrechterlijke colleges 2006, Stcrt. 2005, 250; Procesregeling belastingkamers gerechtshoven 2005, Stcrt. 2005, 198. Ten aanzien van de verschillende procesregelingen dient wel voor ogen te worden gehouden dat niet naleving daarvan door de desbetreffende instantie in een concreet geval veelal geen gevolgen zal hebben. De binding van de bestuursrechter aan dergelijk rechterlijke regelingen of beleid lijkt niet zo eenduidig te zijn als de binding van bestuursorganen aan beleidsregels of algemeen verbindende voorschriften, zie: Damen e.a. 2009, Deel II, p. 216; Van Wijk/Konijnenbelt \& Van Male 2008, p. 572. Er zullen wel gevolgen aan de niet-naleving van procesregelingen worden verbonden, indien tegelijkertijd sprake is van schending van een beginsel van behoorlijke rechtspleging. Voor het wettelijke procesrecht geldt dat een schending daarvan wel rechtens consequenties heeft. Zie ook: Damen e.a. 2009, Deel II, p. 216-217; Schreuder-Vlasblom 2008, p. 371; Van Wijk/Konijnenbelt \& Van Male 2008, p. 572.
} 


\section{Concretisering van beginselen}

rechterlijke instantie waarnaar de zaak mogelijkerwijs wordt teruggewezen) om van de regeling af te wijken (indien in hoger beroep geklaagd wordt hierover). Of de rechter zal zelf van de procedureregeling in een voorliggende zaak moeten afwijken, indien hij meent dat daardoor een beginsel van behoorlijke rechtspleging geschonden wordt. Dat geldt zelfs, indien de regeling waarin de inrichting van een procedure is neergelegd een wet in formele zin is, zoals de Awb. Dat lijkt wellicht op het eerste gezicht een verstrekkend standpunt te zijn, gelet op de verhouding rechter en wetgever in ons staatsbestel ${ }^{30}$, maar bij nadere beschouwing is dat niet het geval. Allereerst kan de rechter een dergelijke regeling uiteraard uitsluitend in het concrete geval niet toepassen en oordelen dat in het concrete geval sprake is van schending van de beginselen van behoorlijke rechtspleging. Formeel spreekt hij daarmee geen oordeel uit over de verbindendheid van de wet in formele zin. Dat oordeel, indien het een (structureel) gebrek in de regeling betreft, komt daar wel op neer, aangezien de rechter in vergelijkbare gevallen tot een vergelijkbaar oordeel zal komen. In dat geval is het echter aan de wetgever om in te grijpen. ${ }^{31}$ De taak van de rechter houdt (behoudens het geven van aansporing daartoe) hier op. ${ }^{32}$

Het recht op een eerlijk proces of fundamentele rechtsbeginselen die een eerlijk proces moeten waarborgen fungeren bovendien wel vaker als grondslag voor afwijking van een wet in formele zin of het niet toepassen van een wet in formele zin. Zo heeft de Centrale Raad overwogen dat artikel $88 \mathrm{~h}$ WAO in strijd was met de openbaarheidvereisten, zoals neergelegd in artikel 6 EVRM, en aangegeven dat die bepaling anders geïnterpreteerd moest worden om inachtneming van die vereisten te verzekeren. ${ }^{33}$ Een tekenend voorbeeld vormen ook de uitspraken waarin de bestuursrechter appèlverboden doorbreekt (en de wet naast zich neerlegt) vanwege het feit dat in eerste aanleg door de rechterlijke instantie dermate in strijd is gehandeld met fundamentele rechtsbeginselen, dat van een eerlijk proces geen sprake is geweest. ${ }^{34}$ De hoger beroepsrechter is uitermate terughoudend met het doorbreken van appèlverboden, maar acht zich daartoe gehouden bij strijd met de beginselen van behoorlijke rechtspleging in eerste aanleg. ${ }^{35}$ Overigens gelden de beginselen van behoorlijke rechtspleging als ongeschreven beginselen, ook indien een schriftelijke procedureregeling ontbreekt of zou ontbreken (hetgeen tegenwoordig slecht voorstelbaar is). Ook dan zou de rechterlijke instantie in het concrete geval die beginselen in acht moeten nemen.

De gevolgen van schending van beginselen en concrete uitwerkingen

Naast de vraag naar de adressaat van de beginselen komt in het voorgaande een ander belangrijk aspect naar voren: de gevolgen die verbonden moeten worden aan een schen-

\footnotetext{
${ }^{30 .}$ De HR leidt immers uit art. $120 \mathrm{GW}$ af dat de rechter de wet in formele zin niet aan de Grondwet én algemene rechtsbeginselen mag toetsen. De rechter kan echter wel de wet in een concreet geval buiten toepassing laten, indien toepassing daarvan in strijd komt met een of meer algemene rechtsbeginselen én het niet door de wetgever verdisconteerde omstandigheden betreft, zie o.m: HR 14 april 1989, AB 1989/207 m.nt. FVvdB (Harmonisatiewetarrest); HR 12 april 1978, $A B$ 1979/262 m.nt. FHvdB (Doorbraakarrest). Strikt genomen is er dan echter geen sprake van toetsing van de wet aan algemene rechtsbeginselen. Zie over dit onderwerp ook: W. Voermans, 'De bestuursrechter en artikel 120 Grondwet', JB-plus 2003, p. 142 e.v.

${ }^{31}$ Deze problematiek betreft de verhouding wetgever en rechter en de rechtsvormende taak van de laatste. Zie hierover ook: De Waard 1987, p. 413-414. De Waard meent dat bij strijd met de beginselen op het niveau van de regeling de wetgever de procedurevoorschriften moet aanpassen.

32. Zie over de rechtsvormende taak van de rechter: Van der Pot/Donner 2006, p. 821-832; S.K. Martens, 'De grenzen van de rechtsvormende taak van de rechter, NJB 2000, p. 747-758.

33. CRvB 28 januari 1998, AB 1998/168 m.nt. FP; JB 1998/ 61 m.nt. Heringa; RSV 1998/106 m.nt. Van der Kris; USZ 1998/69 m.nt. Driessen. Zie hierover par. 4.3.6. Verschil is uiteraard wel dat het hier een vereiste uit art. 6 EVRM betrof en in dat kader het toetsingsverbod van art. $120 \mathrm{GW}$ niet geldt.

34. Zie hierover: B.W.N. De Waard, 'Doorbreking van appelverboden', JB-plus 2005, p. 98-114.

35. Daarvan is volgens de rechter dan ook niet snel sprake. Doorbreking vond bijv. (omdat de rechterlijke onpartijdigheid in het geding was) wel plaats in: CRvB 25 november 2008, $J B$ 2008/24; $A B$ 2009/50; CRvB 22 november 2006, $A B$ 2007/180 m.nt. K.F. Bolt en in AbRvS 11 februari 2005, $A B$ 2005/181 m.nt. BdeW in een zaak waarin het bestuursorgaan (!) hoger beroep instelde tegen een uitspraak van de voorzieningenrechter. Zie voor andere voorbeelden waarin dat wel het geval was: De Waard 2001, p. 98-114.
} 


\section{Deel I Beginselen van behoorlijke rechtspleging}

ding van de onderscheiden eisen. Zoals hiervoor al werd aangegeven, moet schending van een beginsel van behoorlijke rechtspleging of een essentiële uitwerking van een beginsel, rechtens tot consequenties leiden. Voor de hand ligt dat een dergelijke schending in beginsel leidt tot vernietiging van de uitspraak van de rechter. ${ }^{36}$ Als voorbeeld kan dienen het ten onrechte achterwege laten van een mondelinge zitting, omdat niet alle partijen daarvoor toestemming hebben gegeven als bedoeld in artikel 8:57 Awb. Als hoofdregel leidt dat tot vernietiging. ${ }^{37}$ Een ander voorbeeld is het ten onrechte niet in het openbaar uitspreken van de uitspraak ex artikel 8:78 Awb. ${ }^{38}$

Soms worden er echter gevolgen aan de schending van een inrichtingseis gekoppeld, maar gaat het (in eerste instantie) niet om vernietiging van de uitspraak. Artikel 8:58 Awb bevat bijvoorbeeld in het eerste lid het voorschrift dat partijen tot tien dagen voor de zitting nadere stukken kunnen indienen. Die bepaling staat in het teken van hoor en wederhoor en voldoende gelegenheid voor partijen om te kunnen reageren op deze stukken. ${ }^{39}$ Worden de stukken te laat ingediend, kan de bestuursrechter deze met het oog op de goede procesorde buiten beschouwing laten en niet in zijn beoordeling betrekken. ${ }^{40}$ De bestuursrechter kan ze er echter ook bij betrekken, indien de goede procesorde zich er niet tegen verzet omdat de stukken niets nieuws bevatten en hoor en wederhoor verzekerd is. ${ }^{41}$ Het onderzoek ter zitting kan om hoor en wederhoor te verzekeren worden geschorst op grond van artikel 8:64 Awb of worden heropend op grond van artikel 8:68 Awb. ${ }^{42}$ De goede procesorde of hoor en wederhoor kan er zelfs toe nopen dat tijdig ingediende stukken niet meegenomen worden of dat de zitting uitgesteld moet worden om de wederpartij meer tijd te geven. ${ }^{43}$ De toepassing van het in artikel 8:58 Awb neergelegde voorschrift wordt derhalve beoordeeld in het licht van hoor en wederhoor, de goede procesorde en de procesbelangen van partijen. Is er sprake van een schending van het beginsel van hoor en wederhoor op welke wijze dan ook, leidt dat uiteindelijk tot vernietiging van de uitspraak. ${ }^{44}$ Overschrijding van de in de bepaling gegeven indieningstermijn brengt echter in eerste instantie andere gevolgen met zich, zoals het gunnen van een termijn ter voorbereiding aan de wederpartij of het niet betrekken van de stukken bij het oordeel.

In sommige gevallen wordt bij schending van een beginsel of een uitwerking ervan de uitspraak van de rechtbank vernietigd, maar wordt door de appèlrechter vervolgens het beroep bij de rechtbank (wederom) ongegrond verklaard. ${ }^{45}$ Ook komt het voor dat de bestuursrechter, gelet op de omstandigheden van het geval, een schending van een beginsel of essentiële inrichtingseis passeert, omdat deze in hoger beroep voldoende hersteld

\footnotetext{
36. CRvB 13 mei 2009, JB 2009/184 (vernietiging wegens schending van het beginsel van hoor en wederhoor); AbRvS 21 februari 2007, JB 2007/74 m.nt. LJMT (vernietiging wegens schending van verdedigingsbeginsel); AbRvS 27 mei 2007, $A B$ 2007/194 m.nt. Sewandono (vernietiging wegens schending van motiveringsbeginsel bij achterwege laten horen getuigen). AbRvS 25 juli 2001, $A B$ 2001/286 (vernietiging wegens schending van het beginsel van hoor en wederhoor); CRvB 5 april 2001, TAR 2001/88 (vernietiging wegens schending van de goede procesorde).

37. AbRvS 11 december 2003, JB 2004/55 m.nt. EvdL; CRvB 13 februari 1996, AB 1996/170 m.nt. F.J.L. Pennings. Daarop zijn ook weer uitzonderingen mogelijk, zie: CRvB 29 mei 1997, $A B$ 1997/308 m.nt. HH.

${ }^{38 .}$ CRvB 23 juni 2009, AB 2009/267; JB 2009/205 m.nt. Red.; AbRvS 17 oktober 2007, JB 2007/225.

39. Zie hierover par. 4.3.5.

40. AbRvS 27 mei 2004, $A B$ 2007/295 m.nt. O.J.D.M.L. Jansen onder $A B$ 2007/294; AbRvS 24 december 2002, $A B$ 2003/158.

${ }^{41}$ Zie bijvoorbeeld: CBb 16 april 2008, AB 2008/324 m.nt. I. Sewandono; JB 2008/136; AbRvS 15 juni 2005, JB 2005/231; CRvB 9 juni 2005, JB 2005/261.

42. CRvB 4 april 2003, JB 2003/156; CRvB 4 oktober 2000, JB 2000/334. Gebeurt dit niet, leidt dat overigens wel tot vernietiging van de uitspraak in hoger beroep. CRvB 11 januari 2008, $A B$ 2008/78 m.nt. Tollenaar. De CRvB overweegt overigens nog dat de stukken in hoger beroep wél bij de beoordeling kunnen worden betrokken.

43. AbRvS 15 augustus 2007, JB 2007/183 m.nt. RJNS.

44. CRvB 11 januari 2008, $A B$ 2008/78 m.nt. Tollenaar. Zie ook: CRvB 4 februari 2009, AB 2009/161 m.nt.

Tollenaar, waarin de uitspraak mede om die reden werd vernietigd.

${ }^{45}$. Bröring noemt dit een analoge toepassing van art. 8:72 lid 3 in zijn noot bij CRvB 6 mei 2008, AB 2008/243.
} 


\section{Concretisering van beginselen}

is $^{46}$ of de zich erop beroepende partij daardoor niet in haar belangen is geschaad. ${ }^{47}$ Schendingen van vormvoorschriften ${ }^{48}$ behoeven immers niet tot vernietiging te leiden, maar kunnen met toepassing van artikel 6:22 Awb worden gepasseerd, mits belanghebbenden daardoor niet zijn benadeeld. ${ }^{49}$ Andere (aanvullende) gevolgen bij schending van een beginsel of een uitwerking daarvan door de bestuursrechter, kunnen een proceskostenveroordeling of vergoeding van het griffierecht zijn (ook indien er niet tot vernietiging van de uitspraak wordt overgegaan). ${ }^{50}$

Schending van een minder essentiële eis behoeft in het geheel niet tot consequenties te leiden. Te denken valt aan artikel 8:66 Awb waarin de termijn voor het doen van schriftelijke uitspraak is vastgelegd op zes weken na sluiting van het onderzoek. Die eis dient het beginsel van de redelijke termijn ${ }^{51}$, maar de overschrijding van de daarin neergelegde termijn leidt op zichzelf niet tot vernietiging omdat de termijn van orde is. ${ }^{52}$ Talmt de bestuursrechter echter te lang, dan kan er sprake zijn van schending van het beginsel van de redelijke termijn, waaraan wel rechtens consequenties worden verbonden. $^{53}$

Uit het voorgaande blijkt dat, hoewel het uitgangspunt is dat schending van een beginsel of een essentiële inrichtingseis rechtens consequenties behoort te hebben, de wijze waarop die consequenties vorm krijgen gevarieerd is. De hoofdregel is vernietiging van de uitspraak, maar een vernietiging vindt lang niet altijd plaats. Er zijn nog verschillende andere mogelijkheden om aan dat uitgangspunt tegemoet te komen. Schending van minder essentiële eisen leidt doorgaans niet tot vernietiging of andere consequenties.

\footnotetext{
46. AbRvS 15 maart 2006, 200504091/1 waar Schreuder-Vlasblom op wijst, Schreuder-Vlasblom 2008, p. 577. Soms wordt dan de uitspraak wel vernietigd en vindt geen terugwijzing naar de rechtbank plaats die het geschil opnieuw zou moeten behandelen, omdat het gebrek in hoger beroep voldoende is hersteld of hernieuwde behandeling, om redenen verbandhoudend met de finale beslechting van het geschil, achterwege kan blijven, CRvB 2 oktober 2007, $A B$ 2008/5 m.nt. A. Tollenaar; CRvB 31 oktober 2006, AB 2007/74 m.nt. H.E. Bröring; CRvB 5 juli 2007, TAR 2007/193.

${ }^{47}$ Zie bijv.: AbRvS 22 augustus 2007, AB 2008/72 m.nt. O.D.M.L. Jansen.

48. Een vormvoorschrift is een voorschrift dat geen eisen stelt aan de inhoud van een besluit (lees: in dit geval uitspraak) en maar ziet op de procedure van totstandkoming of de wijze waarop het besluit moet worden genomen of vastgelegd, PG Awb I, p. 314. Zie over art. 6:22 Awb en de toepassing in de praktijk: SchreuderVlasblom 2008, p. 420-424; B.W.N. de Waard, 'Commentaar art. 6:22', in: M. Scheltema, R.M. van Male, B.W.N. de Waard, A.T. Marseille, A.J.C. de Moor-van Vugt (red.), Losbladig commentaar Algemene wet bestuursrecht, Amsterdam: Reed Elsvevier (voorheen Den Haag: VUGA), losbladige uitgave, p. E 6.2.14-1/12; N.M. Van Waterschoot, 'Het door de vingers zien van gebreken die de materiële inhoud niet raken', JB-plus 2002, p. 181-194; A.R. Neerhof, 'Van effectieve bestuursrechters en geschillen die voorbijgaan...? De bevoegdheden van de bestuursrechter om geschillen definitief op te lossen, JB-plus 1999 (hierna: Neerhof 1999b), p. 73 e.v. In de toekomst zullen ook schendingen van materiële voorschriften gepasseerd kunnen worden op grond van art. 6:22 Awb. De Awb zal daartoe gewijzigd worden, zie het wetsvoorstel 'Aanpassing bestuursprocesrecht', Kamerstukken II 2009/10, 32 450, nrs. 1-3.

49. Art. 6:24 Awb verklaart o.m. art. 6:22 Awb van overeenkomstige toepassing in hoger beroep.

50. Zie bijv.: AbRvS 14 augustus 2002, nr. 200104239/1. Art. 43 WRvS, art. 25 Beroepswet, art. 27 Wbbo bieden de grondslag in hoger beroep voor vergoeding van het griffierecht als er geen vernietiging van de uitspraak heeft plaatsgevonden. In het wetsvoorstel aanpassing bestuursprocesrecht is overigens in hfst. 8 van de Awb een afzonderlijke afdeling over hoger beroep, afdeling 8.4 , voorzien waarin de bepalingen uit afd. 8.1-8.3, die zien op het beroep in eerste aanleg bij de rechtbank, voor het grootste deel van toepassing worden verklaard. Dat geldt echter niet voor art. 8:74 Awb. De hiervoor genoemde bepalingen in de WRvS, Beroepswet en Wbbo komen echter te vervallen en worden vervangen door een nieuw art. 8:114 Awb, Kamerstukken II 2009/11, 32 450, nrs. 3 , p. 67 . De toelichting merkt op dat beoogd is de praktijk van de bestuursrechter te codificeren dat bij vernietiging van de uitspraak van de rechtbank, door een fout van de rechtbank, griffierecht door de griffier en niet door het bestuursorgaan kan worden vergoed.

${ }^{51 .}$ Zie hierover par. 4.3.8.

52. PG Awb II, p. 460; CRvB 22 april 2005, AB 2006/44 m.nt. A.M.L. Jansen; AbRvS 18 juli 2003, AB 2004/3 m.nt. A.M.L. Jansen.

53. Sinds kort bestaat de mogelijkheid om via een verdragsconforme toepassing van art. 8:73 Awb in samenhang met art. 39 lid 1 WRvS schadevergoeding toe te kennen voor rechterlijke traagheid, zie: AbRvS 4 juni 2008, $A B$ 2008/229 m.nt. Widdershoven; $J B$ 2008/146 m.nt. Jansen; USZ 2008/211 m.nt. Barkhuysen en Van Emmerik. Zie ook: CRvB 11 juli 2008, $J B$ 2008/172 m.nt. AMLJ; $A B$ 2008/241 m.nt. R.J.G.M. Widdershoven; USZ 2008/238 m.nt. Barkhuysen en Van Emmerik.
} 
Deel I Beginselen van behoorlijke rechtspleging

\subsection{Relevantie voor dit onderzoek}

Het vaststellen van de betekenis van beginselen voor een procedure

De uiteenzetting hierboven over concretere (inrichtings)eisen en de beginselen is van belang in het kader van de in dit onderzoek, in het bijzonder in Deel II, gehanteerde methode. Vanwege de geconstateerde samenhang is de tweedeling in beginselen en concretere eisen, die realisatie van een behoorlijke procedure beogen, bruikbaar voor dit onderzoek. Doel van het onderzoek is het opsporen van de invloed van de beginselen op bepaalde bestuurlijke voorprocedures. Die invloed zal zich uiten in concrete uitwerkingen of toepassingen voor de bestuurlijke voorprocedures die te herleiden zijn tot de beginselen van behoorlijke rechtspleging of dezelfde ratio hebben als de beginselen van behoorlijke rechtspleging. Aan de hand van het bestaan van en de vormgeving van concrete uitwerkingen van de beginselen van behoorlijke rechtspleging wordt bepaald in hoeverre die beginselen van invloed zijn op de inrichting van de bestuurlijke voorprocedures.

Aanknopingspunten in het positieve recht

Die concrete uitwerkingen van de beginselen worden gezocht in het positieve recht, aangezien de beginselen van behoorlijke rechtspleging rechtsnormen zijn en schending daarvan rechtens gevolgen moet hebben. Om doorwerking in de bestuurlijke voorprocedures te kunnen vaststellen, wordt derhalve naar aanknopingspunten daarvoor gezocht in met name de Awb en de jurisprudentie van de bestuursrechter neergelegde concrete toepassingen van de beginselen. Zowel wetgeving als jurisprudentie kunnen dienen als bron voor (het vaststellen van de betekenis van) de beginselen van behoorlijke rechtspleging. $\mathrm{Nu}$ de beginselen als rechtsnormen primair gericht zijn tot de rechter, ligt het in de eerste plaats voor de hand om de jurisprudentie te raadplegen en daaruit te destilleren of en welke betekenis de beginselen van behoorlijke rechtspleging hebben. Het is de (bestuurs)rechter die de beginselen, in het geval dat zij van belang worden geacht voor de bestuurlijke voorprocedures, moet toepassen en ervoor moet waken dat de beginselen in acht worden genomen in de desbetreffende voorprocedure. Daarnaast is er thans, nu er voor bestuursrechtelijke procedures veelal een wettelijke regeling bestaat, voor de wetgever een belangrijke taak weggelegd in het kader van het waarborgen van de behoorlijkheid van de inrichting van een procedure. Indien de beginselen van behoorlijke rechtspleging (tot op zekere hoogte) van toepassing zijn op de bestuurlijke voorprocedures, zouden de aanwijzingen daarvoor mede gevonden moeten worden in de wettelijke eisen die gesteld worden. Om echter te kunnen bepalen in hoeverre de beginselen van behoorlijke rechtspleging daarop van invloed zijn of zijn geweest, is het van belang om te achterhalen welke ratio volgens de wetgever en ook de bestuursrechter, schuilt in de wettelijke inrichtingseisen en welke beginselen ten grondslag gelegd worden aan invulling of afwijking van de wettelijke regeling. Aanwijzingen voor enige mate van doorwerking kunnen bestaan als de ratio van de gevonden concrete eisen hetzelfde is als voor de beginselen van behoorlijke rechtspleging of de realisatie van die beginselen vormt.

Concrete eisen in wetgeving of jurisprudentie met betrekking tot de bestuurlijke voorprocedures die rechtstreeks en expliciet te herleiden vallen tot de beginselen van behoorlijke rechtspleging laten over de betekenis van die beginselen voor de desbetreffende procedures geen twijfel bestaan. In veel gevallen zal het echter lastiger zijn om de betekenis van de beginselen voor de bestuurlijke voorprocedures te kunnen duiden. De wetgever kan daaraan geen aandacht hebben besteed of de kwestie is in de jurisprudentie van de bestuursrechter niet aan de orde geweest. Ook bestaat de mogelijkheid dat aan bepaalde eisen impliciet de beginselen van behoorlijke rechtspleging ten grondslag hebben gelegen en dat de wetgever of de bestuursrechter er niet uitdrukkelijk aan hebben gerefereerd. Vooral voor meer impliciete doorwerking van de beginselen kan de vaststelling van eenzelfde doel als de beginselen van behoorlijke rechtspleging een aanknopingspunt vormen voor toepasselijkheid of invloed op die procedures. 


\section{Concretisering van beginselen}

Verhouding tot de algemene beginselen van behoorlijk bestuur

Wat het vaststellen van de betekenis van de beginselen voor de bestuurlijke voorprocedures nog verder bemoeilijkt, is dat er van sommige van de beginselen van behoorlijke rechtspleging equivalenten in de vorm van algemene beginselen van behoorlijk bestuur, die de behoorlijkheid van procedures bij het bestuur normeren, bestaan. Evidente voorbeelden zijn het formele zorgvuldigheidsbeginsel en het motiveringsbeginsel. Evenals de beginselen van behoorlijke rechtspleging dienen deze beginselen nader geconcretiseerd te worden. Die uitwerking in concrete eisen heeft ook plaatsgevonden in de Awb. Veel van de voorschriften die de inrichting van de bestuurlijke voorprocedures normeren, zullen herleid moeten of kunnen worden tot de algemene beginselen van behoorlijk bestuur. Dat betekent echter niet dat daarmee betekenis of invloed van de beginselen van behoorlijke rechtspleging uitgesloten moet worden geacht of dat de vraag daarnaar geen toegevoegde waarde meer kan hebben (hierop kom ik nog nader terug in Deel III, paragraaf 4). Er kan sprake zijn van een zekere overlap tussen de beginselen van behoorlijke rechtspleging en de algemene beginselen van behoorlijk bestuur en uit die beginselen kunnen vergelijkbare inrichtingseisen voortvloeien. Ook dat zou echter een betekenisvolle bevinding vormen. De conclusie zou in dat geval immers zijn dat de behoorlijkheidseisen die gelden voor de inrichting van rechtspraak en bestuurlijke voorprocedures niet zozeer uiteenlopen als wellicht vaak wordt aangenomen of verondersteld. Vastgesteld moet worden of de betreffende eisen te herleiden zijn tot de algemene beginselen van behoorlijk bestuur, als norm voor bestuurlijke besluitvorming en/of equivalent van de beginselen van behoorlijke rechtspleging dan wel tot de beginselen van behoorlijke rechtspleging. Ook daarbij is het van belang te bezien welke ratio de (equivalente) beginselen van behoorlijk bestuur en de daarmee samenhangende (wettelijke of jurisprudentiële) eisen hebben. 



\section{De beginselen van behoorlijke rechtspleging}

\subsection{De grondslagen van de beginselen van behoorlijke rechtspleging}

\section{Een grondrecht op behoorlijke rechtspraak}

Voordat nader wordt ingegaan op de verschillende te onderscheiden beginselen van behoorlijke rechtspleging, worden enkele algemene opmerkingen gewijd aan de ongeschreven en geschreven grondslagen voor deze beginselen en de algemene vraag waarop het recht op een eerlijk proces of behoorlijke rechtspraak in het Nederlandse bestuursrecht is gebaseerd.

In onze nationale Grondwet is een grondrecht op een eerlijk proces of behoorlijke rechtspraak niet neergelegd. ${ }^{1}$ De Grondwet bevat slechts in artikel 121 enkele eisen met betrekking tot behoorlijke rechtspleging, zoals de openbaarheid van de behandeling van de zaak en de uitspraak alsmede het motiveringsbeginsel. Ook zijn er waarborgen voor de onafhankelijkheid van rechtspraak in artikel 117 van de Grondwet neergelegd. Voor de bestuursrechterlijke instanties die niet tot de rechterlijke macht behoren, gelden die eisen grotendeels niet. ${ }^{2}$ In verschillende andere wetten zijn echter voorschriften en eisen te vinden die een behoorlijke procesgang bij de bestuursrechter beogen te waarborgen. Voor de bestuursrechter kan gewezen worden op met name hoofdstuk 8 van de Awb, waarin de procedure bij de rechtbank geregeld is. ${ }^{3}$ Daarnaast bevat artikel 6 EVRM als ieder verbindende verdragsbepaling rechtsnormen voor een behoorlijk proces, die ook voor de meeste geschillen in het bestuursrecht gelden. ${ }^{4}$

Ofschoon een behoorlijke procesgang bij de bestuursrechter daarmee verzekerd lijkt, is het een gemis dat de Grondwet niets bepaalt over een recht op een eerlijk proces (en/of recht op toegang tot een rechter). Er is in de literatuur reeds verscheidene malen op gewezen dat het de voorkeur verdient een met artikel 6 EVRM vergelijkbaar grondrecht in de Grondwet vast te leggen. ${ }^{5}$ Daarvoor zijn verschillende redenen aan te voeren, maar hierna worden slechts die redenen aangestipt die van belang kunnen zijn in het kader van

\footnotetext{
${ }^{1 .}$ Barkhuysen \& Van Emmerik geven een aantal mogelijke verklaringen voor het niet opnemen van een dergelijk recht in de Grondwet, zie: T. Barkhuysen \& M.L. van Emmerik, 'Het recht op toegang tot de rechter en een eerlijk proces in de Nederlandse Grondwet?', in: T. Barkhuysen, M.L. van Emmerik \& J.P. Loof, Geschakeld recht. Verdere studies over Europese grondrechten ter gelegenheid van de $70^{\text {ste }}$ verjaardag van prof.mr. E.A. Alkema, Deventer: Kluwer 2009, p. 15 e.v. Zie verder nog: T. Barkhuysen, M.L. van Emmerik, J.H. Gerards, De toegang tot de rechter en een eerlijk proces in de Grondwet? Behoeft de Nederlandse Grondwet aanvulling met een recht op toegang tot de rechter en een eerlijk proces?, Deventer: Kluwer 2009, p. 9-22; Jansen 2004, o.m. p. 5 en 9; B.W.N. de Waard, 'De grote ogen van de grondwetgever', in: De Grondwet als voorwerp van aanhoudende zorg (Burkens-bundel), J.B.J.M. ten Berge, P.J.J. van Buuren, H.R.B.M. Kummeling, B.P. Vermeulen (red.), Zwolle, W.E.J. Tjeenk Willink 1995, p. 435 e.v.

2. Barkhuysen, Van Emmerik \& Gerards 2009, p. 17-21; L.F.M. Verhey, De onafhankelijkheid van de rechter naar Nederlands recht (preadvies Vereniging voor de vergelijkende studie van het recht van België en Nederland), Deventer: W.E.J. Tjeenk Willink 2001, p. 24; De Waard 1995, p. 446-450. Zie verder de par. 4.3.3, 4.3.6 en 4.3.7 waarin deze eisen behandeld worden.

${ }^{3 .}$ Dat hoofdstuk is ook grotendeels van overeenkomstige toepassing verklaard op de procedures bij de andere bestuursrechtelijke rechtscolleges in eerste aanleg en in hoger beroep. Zie: art. 36 en 39 Wet RvS, art. 17 en 21 Beroepswet, art. 19 en 22 Wbbo. In het wetsvoorstel aanpassing bestuursprocesrecht is overigens in hfst. 8 van de Awb een afzonderlijke afdeling over hoger beroep, afdeling 8.4, voorzien waarin de bepalingen uit afd. 8.18.3 , die zien op het beroep in eerste aanleg bij de rechtbank, voor het grootste deel van toepassing worden verklaard, Kamerstukken II 2009/10, 32 450, nrs. 1-3.

4. Zoals bekend zijn reguliere belastinggeschillen en geschillen inzake toelating, verblijf en uitzetting van vreemdelingen, uitgezonderd van de werking van art. 6 EVRM. Dat gold ook voor ambtenarengeschillen maar het EHRM heeft dienaangaande recent zijn jurisprudentie aangepast. Zie hierna noten 28 en 29 voor de betreffende jurisprudentie.

5. Barkhuysen, Van Emmerik \& Gerards 2009, p. 40-41; Barkhuysen \& Van Emmerik 2009, p. 38; Jansen 2004, p. 103-108; De Waard 1995, p. 443-444.
} 


\section{Deel I Beginselen van behoorlijke rechtspleging}

dit onderzoek. ${ }^{6}$ De Waard wijst er onder meer op dat het opnemen van een grondrecht op toegang tot een eerlijk proces een uitdrukkelijke erkenning van dat recht zou inhouden. Tevens zou daardoor de reikwijdte van dat grondrecht in bestuursrechtelijke geschillen niet meer beperkt zijn, omdat we niet meer aangewezen zouden zijn op artikel 6 EVRM. ${ }^{7}$ Voor de gelding van die eisen voor de procedures die buiten het toepassingsbereik van die verdragsbepaling vallen, zijn wij thans inderdaad - voor zover al sprake is van erkenning van die ongeschreven eisen - aangewezen op ongeschreven recht. ${ }^{8}$ Opname van een grondrecht op behoorlijke rechtspraak in de Grondwet zou daaraan een einde kunnen maken. Ook wijst De Waard erop dat vastlegging van een recht op toegang tot de rechter in de Grondwet zou kunnen leiden tot een concretere uitwerking van het grondrecht, zolang de minimumeisen die artikel 6 EVRM stelt maar in acht worden genomen. Voorts kunnen in de Grondwet waar nodig verdergaande eisen gesteld worden dan het geval is in artikel 6 EVRM. ${ }^{9}$ In elk geval biedt opname van een recht op een behoorlijk proces in de Grondwet en nationale codificatie van dat recht meer mogelijkheden tot rechtsvorming door de nationale rechter op het gebied van de eisen voor behoorlijke rechtspleging $^{10}$ en tot verdere ontwikkeling van een nationale visie, waarbij beperkingen die voortvloeien uit artikel 6 EVRM geen hindernis meer behoeven te vormen.

Opname van een grondrecht op een behoorlijk proces staat in hernieuwde belangstelling, omdat het kabinet een staatscommissie Herziening Grondwet heeft ingesteld ${ }^{11}$ die zich ook bezig gaat houden met de verhouding van de grondrechten genoemd in de Grondwet en de uit internationale verdragen voortvloeiende rechten, zoals het recht op een eerlijk proces in artikel 6 EVRM. ${ }^{12}$ Van de opdracht van de regering aan de staatscommissie makt tevens de mogelijke opname van een recht op een eerlijk proces en toegang tot de rechter uit. ${ }^{13}$ Wellicht dat het advies van de staatscommissie aanleiding gaat vormen om de Grondwet op dit punt aan te passen. Vooralsnog ziet het er echter naar uit dat we voor de geschreven grondslag van het recht op een eerlijk proces of op behoorlijke rechtspraak nog enige tijd aangewezen blijven op met name artikel 6 EVRM. Het advies van staatscommissie moet voor 1 oktober 2010 worden uitgebracht. ${ }^{14} \mathrm{Na}$ het uitbrengen van het advies moet nog de herziening van de Grondwet plaatsvinden. De behandeling van een grondwetsherziening neemt nogal wat tijd in beslag alvorens zij in werking kan treden en de uitkomst is onzeker, gelet op het feit dat er in tweede lezing een tweederde meerderheid dient te bestaan voor het voorstel. ${ }^{15}$

De invloed van artikel 6 EVRM

De nationale ongeschreven beginselen van behoorlijke rechtspleging zijn, zoals hierboven al werd aangegeven, mede of vooral tot ontwikkeling gekomen onder invloed van datzelfde artikel 6 EVRM. In de Nederlandse doctrine is relatief weinig aandacht ge-

6. Zie uitvoeriger over de voor- en nadelen van codificatie van een recht op toegang tot de rechter of een eerlijk proces: Barkhuysen, Van Emmerik \& Gerards 2009, p. 33-41; Barkhuysen \& Van Emmerik 2009, p. 33-39.

De Waard 1995, p. 443-444. In vergelijkbare zin: Barkhuysen, Van Emmerik \& Gerards 2009, p. 34-36; Barkhuysen \& Van Emmerik 2009, p. 35-36; Jansen 2004, p. 10.

${ }^{8}$ Zie ook Van der Pot/Donner waarin gesteld wordt dat er alle aanleiding bestaat naast de bepalingen in de Grondwet en het EVRM een ongeschreven recht op behoorlijke rechtspraak aan te nemen, Van der Pot/Donner 2006 , p. 605.

9. Barkhuysen, Van Emmerik \& Gerards 2009, p. 37; Barkhuysen \& Van Emmerik 2009, p. 35.

${ }^{10 .}$ Barkhuysen, Van Emmerik \& Gerards 2009, p. 35-36.

11. Persbericht 9 juli 2009 te raadplegen op de website van het ministerie van Binnenlandse Zaken en Koninksrijksrelaties; Instellingsbesluit staatscommissie Grondwet van 8 juli 2009, gepubliceerd in Stcrt. 2009, nr. 10354 Voor de leden van de commissie, zie: Regeling benoeming leden staatscommissie Grondwet van 6 juli 2009, gepubliceerd in Stcrt. 2009, nr. 10355.

2. Zie art. 2 onder c, van het Instellingsbesluit staatscommissie Grondwet van 8 juli 2009, gepubliceerd in Stcrt. 2009, nr. 10354.

13. Zie: Kamerstukken II 2007/08, 31 570, nrs. 1-6. Zie ook: Barkhuysen, Van Emmerik \& Gerards 2009, p. 7; Barkhuysen \& Van Emmerik 2009, p. 13.

14. Art. 4 van het Instellingsbesluit staatscommissie Grondwet.

15. Art. $137 \mathrm{GW}$. 


\section{De beginselen}

weest voor dit onderwerp voordat artikel 6 EVRM een belangrijke plaats in onze rechtsorde had verworven. ${ }^{16}$ Om die reden hanteert ook De Waard artikel 6 EVRM voor het opsporen van de beginselen van behoorlijke rechtspleging als leidraad. ${ }^{17}$ In de jurisprudentie van de nationale rechter zijn de eisen van behoorlijke rechtspleging eveneens pas de afgelopen decennia een belangrijke rol gaan spelen vanwege het veelvuldige beroep dat op artikel 6 EVRM wordt gedaan. ${ }^{18}$

Hoewel aansluiting bij artikel 6 EVRM in bepaald opzicht noodzakelijk is - namelijk om te waarborgen dat in elk geval aan de daarin gestelde eisen wordt voldaan en om schending van die verdragsbepaling te voorkomen - kleven daaraan ook belangrijke nadelen waar in het kader van dit onderzoek op gewezen moet worden. Het risico bestaat dat deze bepaling en de daarin neergelegde eisen bij uitsluiting als de geldende normen voor behoorlijke rechtspraak worden beschouwd en verdergaande eisen of andere eisen die daarop niet rechtstreeks zijn terug te voeren niet of onvoldoende erkend worden (en schendingen daarvan niet gesanctioneerd worden). Dat is niet wenselijk omdat, zoals bekend, de in deze bepaling (en ook de overige rechten neergelegd in het EVRM) vervatte eisen slechts minimumeisen betreffen waaraan rechtspraak behoort te voldoen. ${ }^{19}$ Het risico bestaat voorts dat men zich uitsluitend richt op deze bepaling waardoor de ontwikkeling van nationale beginselen van behoorlijke rechtspraak niet van de grond komt en een eigen benadering of visie daarop ontbreekt. Zo wordt een beroep op een (mede) uit artikel 6 EVRM voortvloeiende eis door de bestuursrechter voor geschillen waar die bepaling niet op ziet of niet primair betrekking op heeft, vaak betrekkelijk eenvoudig van de hand gewezen. ${ }^{20}$ Een nader onderzoek of een norm van ongeschreven nationaal recht in die geschillen geschonden is, vindt veelal niet meer plaats. De bestuursrechter past zijn bevoegdheden op grond van artikel 8:69 Awb eveneens terughoudend toe als het gaat om de beginselen van behoorlijke rechtspleging. Tot ambtshalve toetsing aan de beginselen van behoorlijke rechtspleging - of artikel 6 EVRM - lijkt de bestuursrechter bijvoorbeeld niet (expliciet) genegen. Naar algemeen aanvaard is, kan ambtshalve toetsing slechts plaatsvinden aan bepalingen van openbare orde. ${ }^{21}$ De bestuursrechter heeft vooralsnog niet eenduidig aangegeven dat daaronder de beginselen van behoorlijke rechtspleging vallen. ${ }^{22}$ In de literatuur wordt daar voor gepleit. ${ }^{23}$ De Afdeling heeft onlangs wel overwogen dat de bevoegdheid tot aanvulling van de rechtsgronden zoals

\footnotetext{
16. Vgl.: M.F.J.M. de Werd, 'De wetgever en artikel 6 EVRM, in: in: J.P. Loof (red.), Onafhankelijkheid en onpartijdigheid. De randvoorwaarden voor het bestuur en beheer van de rechterlijke macht', Leiden: Stichting NJCM-Boekerij 36 1999, p. 31; Widdershoven 1989, p. 113.

17. De Waard 1987, p. 7

${ }^{18 .}$ De Waard wijst erop dat de beginselen van behoorlijke rechtspleging nog geen gemeengoed in de jurisprudentie zijn geworden, hoewel er uitspraken aan te wijzen zijn waarbij de rechter door die beginselen lijkt te zijn geïnspireerd. Anderzijds wijst hij ook op uitspraken waarbij de beginselen lijken te worden genegeerd of ontkend, De Waard 1987, p. 100.

19. Widdershoven 1989, p. 113; Van Dijk 1983, p. 31-32. Zie recent over de vraag of het EVRM minimumnormen bevat: R.A. Lawson, 'Boven het maaiveld. Over de 'ruimhartige' toepassing van het EVRM door nationale rechters', in: T. Barkhuysen, M.L. van Emmerik \& J.P. Loof, Geschakeld recht. Verdere studies over Europese grondrechten ter gelegenheid van de $70^{\text {ste }}$ verjaardag van prof.mr. E.A. Alkema, Deventer: Kluwer 2009, p. 307 e.v.

20. Zie bijvoorbeeld: Rb. Den Haag, zittingsplaats Haarlem, 10 januari 2008, JV 2008/217; AbRvS 25 maart 2003, JV 2003/191 m.nt. PB onder verwijzing naar de uitspraak van het EHRM waarin het bepaalde dat geschillen inzake de toelating, verblijf en uitzetting van vreemdelingen buiten de reikwijdte van art. 6 EVRM vallen, zie noot 28.

21. Van Wijk/Konijnenbelt \& Van Male 2008, p. 648; Jansen \& Wenders 2006, p. 1123; D. Brugman, 'Ambtshalve toetsing afgebakend. De plaats van ambtshalve toetsing in het bestuursprocesrecht in nationaal- en Europeesrechtelijk perspectief', NTB 2005, p. 266.

${ }^{22}$ In enkele gevallen ziet de bestuursrechter aanleiding om ambtshalve na te gaan of de goede procesorde of beginselen van behoorlijke rechtspleging in acht zijn genomen: CRvB 17 juli 2007, JB 2007/175. Ook lijkt in sommige gevallen ambtshalve doorbreking van een appelverbod wegens schending van fundamentele rechtsbeginselen, zoals het beginsel van hoor en wederhoor, plaats te kunnen vinden: AbRvS 15 augustus 2001, $A B$ 2001/328 m.nt. P.A. Willemsen.

23. Jansen \& Wenders 2006, p. 1123-1124; Brugman 2005, p. 272.
} 


\section{Deel I Beginselen van behoorlijke rechtspleging}

neergelegd in artikel 8:69 tweede lid Awb, als het gaat om de redelijke termijn-eis, ruimhartig moet worden toegepast. ${ }^{24}$ Tevens heeft de Afdeling aangegeven dat er uitzonderingen bestaan op het uitgangspunt dat de bestuursrechter niet ambtshalve mag toetsen of de redelijke termijn is overschreden. ${ }^{25}$ Voor de overige eisen van behoorlijke rechtspleging zijn deze kwesties nog niet zo expliciet in de jurisprudentie aan de orde geweest. ${ }^{26}$ Het zou echter, gelet op het gewicht van die eisen, in de rede liggen dat de bestuursrechter ook ten aanzien van deze eisen zijn bevoegdheid tot aanvullen van de rechtsgronden ruimhartig hanteert.

De focus op artikel 6 EVRM leidt, vanwege de beperkte reikwijdte van die bepa$\operatorname{ling}^{27}$, tot een onderscheid inzake de toepasselijke behoorlijkheidsnormen binnen nationale (bestuursrechtelijke) geschillen: procedures inzake reguliere belastinggeschillen en geschillen inzake de toelating, verblijf en uitzetting van vreemdelingen vallen immers buiten het toepassingsbereik van de in artikel 6 EVRM neergelegde eisen. ${ }^{28}$ Daar komt nog bij dat die bepaling sinds kort volgens het EHRM wel van betekenis is in ambtenarengeschillen, maar uitsluitend voor zover op nationaal niveau toegang tot de rechter is voorzien. Indien dat niet het geval is, moeten er objectieve gronden bestaan die een blokkade van die toegang op nationaal niveau rechtvaardigen. ${ }^{29}$ Die jurisprudentie heeft voor het Nederlandse bestuursrecht tot gevolg dat 1) er bestuursrechtelijke geschillen bestaan waarop artikel 6 EVRM van toepassing is, 2) er bestuursrechtelijke geschillen bestaan waarop artikel 6 EVRM in het geheel niet van toepassing is en 3) er bestuursrechtelijke geschillen bestaan waarop artikel 6 EVRM uitsluitend van toepassing is, omdat er in het nationale recht in toegang tot de bestuursrechter is voorzien. Het valt te bezien of een dergelijk onderscheid in toepasselijke behoorlijkheidsnormen vanuit het perspectief van rechtseenheid en rechtsgelijkheid gerechtvaardigd is. ${ }^{30}$ In de toelichting op de Awb is in elk geval aangegeven dat ook in geschillen die niet onder de werking van artikel 6 EVRM vallen toegang tot de rechter gewaarborgd moet worden. De regering acht dat een rechtsstatelijk uitgangspunt. ${ }^{31}$ Dat kan echter niet alleen voor de eis van toegang tot de rechter onderschreven worden, maar eveneens voor de eisen die gesteld worden in het kader van de behoorlijkheid van de behandeling in die bepaling. Omdat de beginselen van behoorlijke rechtspraak mede een uiting zijn van de rechtsstaatgedachte en bepalend zijn voor het vertrouwen van burgers in de nationale rechtspraak mag een eigen nationale visie daarop ook niet ontbreken. ${ }^{32}$ De neiging bestaat echter, vooral in de rechtspraak, tot aansluiting bij of zelfs beperking tot de eisen neergelegd in artikel 6 EVRM. ${ }^{33}$

In het kader van de redelijke termijn-eis is daarentegen sinds kort ook een andere benadering in de jurisprudentie van de bestuursrechter te bespeuren. Volgens de Afde-

\footnotetext{
24. AbRvS 1 juli 2009, LJN BJ1126 (zaaknr. 200805262/1/M2).

25. AbRvS 10 februari 2010, LJN BL3354.

26. Zie nader de paragrafen waarin deze eisen aan bod komen, par. 4.3.4 tot en met 4.3.7.

27. Zie over het toepassingsbereik van artikel 6 EVRM: M. Viering, Het toepassingsgebied van artikel 6 EVRM (diss. Nijmegen, Zwolle: W.E.J. Tjeenk Willink 1994.

${ }^{28 .}$ Voor reguliere belastinggeschillen: EHRM 21 juli 2001, Ferrazzini t. Italië, EHRC 2001/57 m.nt. Heringa; $A B$ 2004/400 m.nt. Barkhuysen; NJ 2004/435 m.nt. Alkema. Voor vreemdelingrechtelijke geschillen: EHRM 5 oktober 2000, Maaouia t. Frankrijk, EHRC 2000/84 m.nt. Heringa; AB 2001/80 m.nt. Battjes.

29. EHRM 19 april 2007, Vilho Eskelinen e.a. t. Finland, EHRC 2007/82 m.nt. Geurink; AB 2007/317 m.nt. Barkhuysen en Van Emmerik; JB 2007/98; NJ 2007/375 m.nt. Alkema; NJCM-Bulletin 2007 p. 697 e.v. m.nt. Van Dijk.

30. Vgl. ook: Barkhuysen, Van Emmerik \& Gerards 2009, p. 25; Barkhuysen \& Van Emmerik 2009, p. 28; T. Barkhuysen, Eenheid en coherentie van rechtsbescherming in de veellagige Europese rechtsorde (oratie Leiden), Deventer: Kluwer 2006, p. 23; P. van Dijk, 'De toegang tot de rechter - een Straatsburgse springprocessie', NJCM-Bulletin 2003, p. 960; Verhey 2001, p. 23.

${ }^{31 .}$ PG Awb II, p. 77.

32. Vgl.: Jansen 2004, p. 8; Widdershoven 1989, p. 112-113; Hirsch Ballin 1983, p. 16 e.v.; Van Dijk 1983, p. 31.

33. De Afdeling heeft bijvoorbeeld in vreemdelingrechtelijke geschillen beroepen op art. 6 EVRM of daarin neergelegde eisen afgewezen vanwege het enkele feit dat art. 6 EVRM niet van toepassing is op dat soort geschillen, zie: AbRvS 27 januari 2003, AB 2003/286 m.nt. BPV.
} 


\section{De beginselen}

ling behoeft artikel 6 EVRM niet bepalend te zijn voor de geldingskracht van bepaalde daarin neergelegde eisen. De redelijke termijn-eis wordt voortaan ook toegepast op geschillen die buiten de reikwijdte van die bepaling vallen. Rechtsbasis daarvoor is het rechtszekerheidsbeginsel ${ }^{34}$ Hoewel deze ontwikkeling in de jurisprudentie moet worden toegejuicht, is de invloed ervan op de ontwikkeling van de (overige) beginselen van behoorlijke rechtspleging en daaruit voortvloeiende eisen waarschijnlijk beperkt. Allereerst omdat de rechtsbasis voor toepasselijkheid van de redelijke termijn-eis het rechtszekerheidsbeginsel is en niet het decisiebeginsel als beginsel van behoorlijke rechtspleging. De rechtszekerheid ligt weliswaar ook ten grondslag aan het beginsel van de redelijke termijn (als onderdeel van het decisiebeginsel) ${ }^{35}$, maar de Afdeling refereert in het geheel niet aan eisen of beginselen van behoorlijke rechtspleging. Bovendien wordt voor het bepalen van de immateriële schadevergoeding ook weer sterk aangesloten bij de jurisprudentie van het EHRM in het kader van de redelijke termijn-eis in artikel 6 EVRM. Al met al is de rechtspraak vooralsnog toch vooral gericht op (de jurisprudentie van het EHRM in het kader van) artikel 6 EVRM.

Het is om voornoemde redenen niet wenselijk blind te varen op artikel 6 EVRM en de door het EHRM gestelde eisen op grond van die bepaling. Daartegen pleit ook de omstandigheid dat de interpretatie van het EHRM van de verschillende waarborgen als neergelegd in artikel 6 EVRM niet altijd eenduidig en helder is, waardoor een eigen benadering te meer gemist wordt. ${ }^{36}$ Desondanks staat niet ter discussie dat de uit artikel 6 EVRM gedestilleerde eisen een aanzienlijke positieve bijdrage hebben geleverd (en leveren) aan de ontwikkeling van de nationale eisen die aan behoorlijke rechtspleging gesteld worden. Vanwege die invloed worden deze eisen ook in dit onderzoek betrokken bij de invulling van de beginselen van behoorlijke rechtspleging. Op de punten waar een eigen benadering nodig zou zijn in afwijking van of in aanvulling op deze eisen wordt in de betreffende paragrafen gewezen.

\section{Een nationale ongeschreven grondslag}

Hoewel artikel 6 EVRM bepalend lijkt te zijn geweest voor de ontwikkeling van beginselen van behoorlijke rechtspleging in de doctrine, zijn er ook aanknopingspunten voor de geldingskracht van die beginselen te vinden in literatuur en jurisprudentie die dateren van vóór de prominente invloed van artikel 6 EVRM. In het al eerder aangehaalde preadvies van J.M. Polak van 1976 worden reeds beginselen van behoorlijke rechtspraak onderscheiden: een schriftelijke procesregeling ${ }^{37}$, hoor en wederhoor, toegankelijkheid van de stukken, openbaarheid van de behandeling en tijdige, gemotiveerde en openbare uitspraken. ${ }^{38}$ Polak wijst in 1968 in zijn bijdrage in het NJB zelfs op een wettelijke regeling waarin algemene beginselen van behoorlijke rechtspraak als toetsingsgrond terugkomen: artikel 17 Wet tuchtrechtspraak bedrijfsorganisatie. ${ }^{39}$ Ook Van Maarseveen en Stout zoeken de grondslag voor de beginselen niet in artikel 6 EVRM en brengen alle te

34. Deze ontwikkeling begon min of meer impliciet in: AbRvS 20 juni 2007, JV 2007/348; Rb. Den Haag, nevenzittingsplaats A'dam, 10 september 2008, $A B$ 2008/337 m.nt. AMLJ. Daarna: AbRvS 20 mei 2009, JB 2009/167 m.nt. red; AbRvS 4 maart 2009, JB 2009/82 m.nt. red; AbRvS 28 januari 2009, LJN BH1101; AbRvS 3 december 2008, JB 2009/13; AB 2009/70 m.nt. Barkhuysen \& Van Emmerik.

35. Zie hierover nog nader par. 4.3.8

36. De Werd merkt zulks bijvoorbeeld op ten aanzien van de concepten onafhankelijkheid en onpartijdigheid in de jurisprudentie van het EHRM, De Werd 1999, p. 42. Overigens ligt de oplossing daarvoor zijns inziens niet zozeer in een eigen benadering of nationale ontwikkeling van die eisen maar in maatregelen om de effectiviteit van het EVRM voor de (nationale) rechtspleging te vergroten.

37. Hiermee doelt Polak niet per definitie op de procesregelingen zoals wij die tegenwoordig kennen van de verschillende bestuursrechterlijke instanties, zoals de Landelijke procesregeling bestuursrecht 2008, Stcrt. 2008, 114, en de Procesregeling bestuursrechterlijke colleges 2006, Stcrt. 2005, 250. Polak bedoelt met die eis vooral aan te geven dat de te volgen procedure schriftelijk dient te worden vastgelegd. Hij gaat niet in op de vraag in wat voor soort regeling die procedure dan moet worden vastgelegd.

38. Polak 1976, p. 14-17

39. Polak 1968, p. 417. 


\section{Deel I Beginselen van behoorlijke rechtspleging}

onderscheiden eisen van behoorlijke rechtspraak terug tot twee beginselen, het zorgvuldigheidsbeginsel en het motiveringsbeginsel. ${ }^{40}$ De eisen die daaronder vallen zijn: de zorg voor hoor en wederhoor, voor de rechten van de verdediging, het waken tegen misbruik van procesrecht, de zorg voor een tijdige beslissing, voor niet-vooringenomenheid en onpartijdigheid en de zorg voor een met redenen omklede beslissing. ${ }^{41}$ Voorts heeft de rechter in de periode voorafgaand aan de (aanwijsbare) invloed van artikel 6 EVRM verscheidene malen beginselen van behoorlijke rechtspleging (of daarmee vergelijkbare eisen maar onder een andere aanduiding) erkend of daaraan gerefereerd naast of los van artikel 6 EVRM. $^{42}$

Uit het bovenstaande blijkt dat voor de beginselen ook een grondslag gevonden kan worden in het nationale (ongeschreven) recht. De ontwikkeling daarvan in het nationale recht lijkt echter doorkruist te zijn door de almaar groeiende betekenis van artikel 6 EVRM voor onze rechtsorde. In literatuur en jurisprudentie van latere datum lijkt artikel 6 EVRM als voornaamste bron te worden beschouwd waaruit de eisen voor behoorlijke rechtspraak kunnen worden afgeleid of is de concrete invulling van die beginselen, zoals De Waard stelt, sterk beïnvloed door die bepaling. ${ }^{43}$ Dat komt niet alleen doordat een vergelijkbare bepaling in onze Grondwet ontbreekt, zoals hierboven is aangegeven. Ook aan de eisen die wel in de Grondwet zijn neergelegd, zoals de openbaarheidseisen en motiveringsplicht, lijkt minder betekenis toe te komen dan aan de equivalenten daarvan in artikel 6 EVRM. ${ }^{44}$ Het is met name de onduidelijkheid over de status en het bereik van de beginselen die volgens De Waard heeft bijgedragen aan de beperkte aandacht voor het onderwerp en waardoor de beginselen weinig ingang hebben gevonden. ${ }^{45}$ De Waard komt dan ook tot een eigen catalogus van beginselen die wel geïnspireerd is door artikel 6 EVRM, maar die ook uitdrukkelijk te herleiden valt tot nationale regelgeving en jurisprudentie. ${ }^{46}$ Voorts wijst hij er nadrukkelijk op dat de beginselen van behoorlijke rechtspleging voor hun bestaan niet afhankelijk zijn van artikel 6 EVRM alsmede dat zij buiten de werkingssfeer van die bepaling kunnen worden teruggevonden. ${ }^{47}$ Sinds zijn onderzoek lijkt de status van de beginselen van behoorlijke rechtspleging als (nationale) rechtsnormen waarvan schending rechtens tot gevolgen moet leiden onomstreden. ${ }^{48}$ Desalniettemin spelen de beginselen in hun ongeschreven variant, los van artikel 6 EVRM derhalve, nog steeds een betrekkelijk marginale rol in de jurisprudentie en doctrine. ${ }^{49}$ Dat is, zoals aangegeven, ook te zien in de hiervoor aangehaalde jurisprudentie van de Afdeling waarin de rechtsbasis voor de redelijke termijn-eis gevonden wordt in het algemene rechtszekerheidsbeginsel. Gelet op de gemeenschappelijke ratio is het jammer dat deze jurisprudentie niet nadrukkelijker in het perspectief van de beginselen van behoorlijke rechtspleging staat. Zeker in vergelijking tot de algemene beginselen van behoorlijk bestuur valt op dat de beginselen van behoorlijke rechtspleging in de rechtspraak nauwelijks of slechts in geringe mate ingang hebben gevonden. ${ }^{50}$ Daarom is het wenselijk dat de nationale wetgever en (bestuurs)rechter sterker de (verdere) ontwikkeling van de beginselen

\footnotetext{
40. Van Maarseveen \& Stout, p. 199.

41. Van Maarseveen \& Stout, p. 199.

42. Zie bijvoorbeeld: HR 29 maart 1985, NJ 1986/242 m.nt. WHH en LWH; HR 20 januari 1984, NJ 1984/388; HR 26 juni 1981, NJ 1982/450. Zie verder de verwijzingen naar jurisprudentie in: Van Maarseveen \& Stout 1979, p. 198.

43. De Waard 1987, p. 124

44. Ten dele is dit wellicht verklaarbaar door het rechterlijke toetsingsverbod als neergelegd art. $120 \mathrm{GW}$ en de omstandigheid dat de rechter bij toetsing aan artikel 6 EVRM wellicht meer houvast heeft vanwege de jurisprudentie van het EHRM.

${ }^{45 .}$ De Waard 1987, p. 99-101.

46. De Waard 1987, p. 6-7.

${ }^{47}$ De Waard 1987, p. 124

48. Zie par. 1.2 van dit deel.

49. Vgl. ook: Bovend'Eert 2008, p. 256. Enkele spaarzame voorbeelden waarin beoordeeld werd of sprake was van schending van een beginsel van behoorlijke rechtspleging (zonder dat art. 6 EVRM daarbij betrokken werd) CRvB 21 oktober 2003, $A B$ 2004/126 m.nt. BdeW; Hof Leeuwarden 20 maart 2002, AB 2002/316 m.nt. AMLJ.

${ }^{50}$ Bovend'Eert 2008, p. 256.
} 


\section{De beginselen}

van behoorlijke rechtspleging in onze rechtsorde ter hand nemen. ${ }^{51}$ Dit onderzoek zou ook aan die ontwikkeling kunnen bijdragen omdat de betekenis van de beginselen van behoorlijke rechtspleging niet op voorhand beperkt wordt tot rechtspraak. Voorwerp van onderzoek is juist of die beginselen niet een ruimere betekenis hebben in ons bestuursprocesrecht.

\subsection{De samenhang tussen en categorisering van de beginselen}

Voordat de beginselen en hun inhoud als zodanig aan bod komen, verdient de ratio van de verschillende beginselen van behoorlijke rechtspleging, gelet op de in dit onderzoek gehanteerde methode ${ }^{52}$, nog afzonderlijke aandacht. De samenhang tussen de verschillende beginselen van behoorlijke rechtspleging vloeit voort uit hun gemeenschappelijke ratio. Tevens worden enkele categoriseringen binnen deze beginselen aangebracht.

\subsubsection{De gemeenschappelijke ratio van de beginselen van behoorlijke rechtspleging}

De eisen van behoorlijke rechtspleging in grond-of mensenrechtelijk perspectief Zoals hiervoor al veelvuldig aan de orde is gekomen, vormen de beginselen van behoorlijke rechtspleging ongeschreven nationaalrechtelijke normen die door de (bestuurs)rechter in acht moeten worden genomen. Deze normen zijn voor het Nederlandse bestuursrecht gepositiveerd in onder meer artikel $6 \mathrm{EVRM}^{53}$ en gelden uit dien hoofde ook voor de nationale bestuursrechter in een geschil waarop die bepaling van toepassing is. Het karakter van de normen neergelegd in die bepaling en het karakter van de beginselen van behoorlijke rechtspleging is echter niet geheel hetzelfde. In het ene geval betreft het immers een grond- of mensenrecht ${ }^{54}$ en in het andere geval ongeschreven rechtsbeginselen. Het grond- of mensenrecht fungeert (mede) als de bron voor de beginselen van behoorlijke rechtspleging. ${ }^{55}$ De beginselen van behoorlijke rechtspleging dienen dan ook deels in een ander perspectief bezien te worden dan artikel 6 EVRM en de daaruit voortvloeiende eisen.

Artikel 6 EVRM vormt een mensenrecht waarvoor specifieke beperkingsclausules gelden. Dat betekent dat de daaruit voortvloeiende rechten voor burgers uitsluitend onder bepaalde voorwaarden door de overheid mogen worden beperkt. De eisen neergelegd in artikel 6 EVRM staan vanzelfsprekend, gelet op het mensrechtelijk karakter van die bepaling, sterk in het teken van bescherming van het individu tegen de overheid. Zo kan de overheid, in de vorm van een publiekrechtelijke rechtspersoon of andere overheidsorganen, geen beroep toekomen op de in het EVRM neergelegde rechten in een geschil met een burger. ${ }^{56}$ In een geschil met een ander bestuursorgaan kan dat, indien het geadresseerde bestuursorgaan zich in een met de positie van een burger vergelijkbare positie bevindt, anders liggen. ${ }^{57}$ Het EVRM biedt immers natuurlijke personen of rechtsperso-

\footnotetext{
${ }^{51 .}$ Vgl. ook: Brenninkmeijer 1998, p. 20.

52. Zie hierover nader par. 3.3

${ }^{53 .}$ Widdershoven 1989 , p. 113

54. De begrippen grondrechten en mensenrechten worden als synoniemen gebruikt in dit onderzoek. Het onderscheid tussen beide begrippen, voor zover daarvan al sprake is, wordt hier buiten beschouwing gelaten. Zie daarover met verwijzingen: Van der Pot/Donner 2006, p. 256.

55. Widdershoven 1989, p. 112

56. Vgl. art. 1 en art. 34 EVRM, zoals ook het EHRM heeft bepaald in een ontvankelijkheidsbeslissing van 1 februari 2001, Ayuntamiento de Mula t. Spanje, nr. 55346/00. Verder hierover: Barkhuysen \& Van Emmerik 2009, p. 30-31; Van Dijk \& Van Hoof e.a. 2006, p. 53-54; T. Barkhuysen, Het EVRM als integraal onderdeel van het Nederlandse materiële bestuursrecht, preadvies, VAR-reeks 132, Den Haag 2004, p. 35. Zie ook: HR 6 februari 1986, ARAL-arrest, AB 1987/272 m.nt. FHvdB waarin de HR dat overwoog. Zie hierover verder nog: A.G. Maris, Grondrechten tegen, jegens en voor de overheid, Deventer: Kluwer 2008.

${ }^{57 .}$ In een uitspraak van 8 juli 2005 overwoog de Hoge Raad dat het vereiste van een redelijke termijn neergelegd in art. 6 EVRM ook geldt voor publiekrechtelijke lichamen, HR 8 juli 2005, $A B$ 2006/17 m.nt. A.M.L. Jansen.
} 


\section{Deel I Beginselen van behoorlijke rechtspleging}

nen bescherming tegen ongeoorloofde inmenging van (organen of instanties van) de verdragsstaten in de aan hen toekomende rechten. ${ }^{58}$

De beginselen van behoorlijke rechtspleging hebben daarentegen een ander karakter dan de waarborgen die voortvloeien uit artikel 6 EVRM. Hoewel er een overlap bestaat tussen de uit artikel 6 EVRM voortvloeiende eisen en de beginselen van behoorlijke rechtspleging, bestaat een belangrijk verschil daarin dat de laatste ook kunnen gelden in geschillen tussen overheidsorganen onderling en in beginsel ook ten voordele kunnen strekken voor een overheidsorgaan in geschil met een burger. ${ }^{59}$ De beginselen van behoorlijke rechtspleging beogen een behoorlijk proces voor de daaraan deelnemende procespartijen te bewerkstelligen. De hoedanigheid van de procespartijen lijkt daarbij minder van belang.

Naast deze verschillen kan ook nog gewezen worden op het al meermalen aangehaalde verschil in toepassingsbereik van het recht op een eerlijk proces en de beginselen van behoorlijke rechtspleging. De reikwijdte van de beginselen is niet beperkt tot procedures waarin een 'civil right or obligation' dan wel een 'criminal charge' centraal staat en strekt zich in beginsel uit tot iedere procedure die tot rechtspleging of rechtspraak gerekend kan worden. ${ }^{60}$

\section{Gemeenschappelijke functies}

Wat de beginselen van behoorlijke rechtspleging en het recht op een eerlijk proces echter gemeen hebben, is de ratio achter deze normen. Die ratio valt te herleiden tot de rechtsstaatgedachte $^{61}$ en is tweeërlei van aard. Enerzijds wordt de ratio gevormd door de bescherming van de belangen van het individu of de partijen die in een procedure bij een rechterlijke instantie verwikkeld zijn die op enigerlei wijze gevolgen heeft voor de rechtspositie van de betrokkenen. ${ }^{62}$ Aan deze personen komt immers het recht op een behoorlijke procedure toe ter bescherming van hun belangen. Anderzijds hebben deze normen ook een meer algemene functie: het waarborgen van het vertrouwen in de rechtspraak van het publiek en het belang van een 'proper administration of justice' in een democratische rechtsstaat. ${ }^{63}$ De eerste functie is meer gericht op de bescherming van de betrokken individuele belangen binnen een procedure, terwijl de tweede functie meer gericht is op een algemeen belang dat uitstijgt boven het concrete geschil. Dat belang ligt buiten de desbetreffende procedure. In de eerste functie werken de beginselen derhalve intern en zijn zij gericht op bescherming van de belangen van de procesdeelnemers. Het waarborgen van het vertrouwen in rechtspraak daarentegen vormt de externe werking

\footnotetext{
58. Daargelaten de mogelijkheid voor een verdragsstaat om een andere verdragsstaat voor schending van het EVRM aan te spreken op grond van art. 33 EVRM.

59. Een voorbeeld daarvan vormt de toepassing door de Afdeling van haar bevoegdheid tot doorbreking van een appelverbod wegens een zodanige schending van fundamentele rechtsbeginselen, in het bijzonder het beginsel van hoor en wederhoor, dat geen sprake meer is van een eerlijk proces ten gunste van het bestuursorgaan, zie: AbRvS 11 februari 2005, $A B$ 2005/181 m.nt. BdeW. Ook worden weleens gelet op de goede procesorde stukken die te laat zijn ingediend door de burger ten faveure van de procesbelangen van het bestuursorgaan buiten beschouwing gelaten door de bestuursrechter, zie bijv.: AbRvS 27 mei 2004, AB 2007/295 m.nt. O.J.D.M.L. Jansen bij $A B$ 2007/294.

60. Zoals is aangegeven in par. $1.1 \mathrm{kan}$ het aantal procedures dat daaronder valt erg verschillen afhankelijk van de gekozen invulling van dit begrip. In dit onderzoek wordt ervan uitgegaan dat de rechtstreekse toepasselijkheid en de reikwijdte van de beginselen zich uitstrekt tot de procedures bij rechterlijke instanties.

${ }^{61 .}$ Widderhoven 1989, p. 112-113; Hirsch Ballin 1983, p. 12 en 16.

62. Zie bijvoorbeeld het EHRM in de zaak Pretto voor het vereiste van openbaarmaking van de uitspraak: "The public character of proceedings before the judicial bodies referred to in Article $6 \S 1$ (art. 6-1) protects litigants against the administration of justice in secret with no public scrutiny; it is also one of the means whereby confidence in the courts, superior and inferior, can be maintained", EHRM 8 december 1983, Pretto e.a. t. Italië, nr. $7984 / 77$.

63. Zie bijv. Van Lent die beide functies onderscheidt ten aanzien van de eis van een openbare zitting zoals neergelegd in art. 6 EVRM, Van Lent 2008, p. 55. Zie ook de noot hiervoor wat betreft openbaarmaking van de uitspraak.
} 


\section{De beginselen}

van die normen en ziet vooral op vertrouwen van het publiek buiten het proces en de procesdeelnemers om.

Dat het recht op een eerlijk proces en de daaruit voortvloeiende eisen eveneens die functies toekomen, blijkt bijvoorbeeld uit een arrest van het EHRM in de zaak NideröstHuber. Daarin overweegt het:

"(...) No doubt the filing of observations like those in issue in the present case is calculated to save time and expedite the proceedings. As its case-law bears out, the Court attaches great importance to that objective, which does not, however, justify disregarding such a fundamental principle as the right to adversial proceedings. In fact, Article 6 para. 1 (art. 6-1) is intended above all to secure the interests of the parties and those of the proper administration of justice (see, mutatis mutandis, the Acquaviva v. France judgment of 21 November 1995, Series A no. 333-A, p. 17, para 66)." ${ }^{, 64}$

Gelet op de grondrechtelijke context van de in artikel 6 EVRM vervatte eisen, worden deze eisen veelal geïnterpreteerd vanuit het perspectief van bescherming van de belangen van burgers. ${ }^{65}$ Dat perspectief geldt te meer, indien het een procedure betreft waarin een burger tegenover de overheid komt te staan, zoals in het bestuursrecht meestal het geval is. De overheid kan zich immers, zoals hiervoor al werd aangegeven, niet beroepen op de waarborgen uit artikel 6 EVRM. Dat geldt echter niet voor de beginselen van behoorlijke rechtspleging. ${ }^{66}$ De twee onderscheiden functies, interne of externe werking, komen aan alle beginselen toe en verbinden de verschillende beginselen met elkaar. Sommige beginselen zijn echter sterker gericht op de bescherming van de belangen van de betrokken procesdeelnemers en andere beginselen juist weer meer op het waarborgen van het vertrouwen in rechtspraak in meer algemene zin. Hieronder wordt nog nader ingegaan op beide functies en ook aangegeven aan welke beginselen de desbetreffende functie primair of in eerste instantie toekomt.

\section{Intern werkende beginselen}

De bescherming van de belangen van partijen in de procedure vormt een belangrijke component of ratio van de beginselen van behoorlijke rechtspleging. Die interne werking van de beginselen van behoorlijke rechtspleging komt het sterkst tot uitdrukking in het beginsel van hoor en wederhoor. In de doctrine wordt dit beginsel beschouwd als de kern van de normen voor behoorlijke rechtspleging. De belangrijkste functie van dit beginsel is, zoals in paragraaf 4.3.5 nog nader zal worden toegelicht, ook gelegen in die bescherming van de belangen van partijen. Doel van het beginsel is immers te waarborgen dat partijen voldoende gelegenheid hebben gehad hun eigen standpunt naar voren te brengen en te reageren op de standpunten van andere partijen. Daarnaast hebben het onpartijdigheidsbeginsel, het motiveringsbeginsel en het beginsel van de redelijke termijn ook vooral deze functie (zie nader hierover respectievelijk paragraaf 4.3.4, 4.3.7 en 4.3.8). Deze beginselen beogen in eerste instantie veilig te stellen dat de betrokken procesdeelnemers respectievelijk objectief bejegend worden, dat de redenen voor de beslissing die de procesdeelnemers aangaat aan hen bekend is en dat het geschil waarbij de procesdeelnemers betrokken zijn voortvarend wordt behandeld.

Verscheidene beginselen van behoorlijke rechtspleging hebben voorts een functie die ten dienste staat van het beginsel van hoor en wederhoor en (daarmee) de bescherming van de belangen van partijen. Te denken valt aan het vereiste van een openbare behandeling van de zaak, het vereiste van openbaarmaking van de uitspraak en het motiveringsbeginsel. Zo kan de motivering van de uitspraak bijdragen aan de indruk van partijen, dat hun stellingen gehoord zijn. ${ }^{67}$ Dit vereiste zorgt er immers voor dat de rede-

64. EHRM 27 januari 1997, Nideröst-Huber t. Zwitserland, nr. 18990/91, par. 30

65. Verhey 2001, p. 23.

66. Zie noot 57. Jansen pleit ervoor dat de HR de grondslag voor voortvarendheid in geschillen waarin de overheid is betrokken te construeren via de beginselen van behoorlijke rechtspleging (en niét via art. 6 EVRM gelet op de grondrechtelijke context). Zie zijn noot bij HR 8 juli 2005, $A B$ 2006/17 m.nt. Jansen.

67. Van der Heijden 1984, p. 49. Zie ook par. 4.3.7 van dit deel. 


\section{Deel I Beginselen van behoorlijke rechtspleging}

nering van de rechter en zijn oordeel omtrent de door de partijen aangedragen argumenten en bewijsmiddelen inzichtelijk wordt gemaakt. Bij het motiveringsbeginsel is de band met de bescherming van de belangen van partijen in de procedure dan ook behoorlijk sterk, aangezien de primaire functie van het motiveringsbeginsel ook in de bescherming van die belangen ligt. Bij de openbaarheidseisen, die eveneens het beginsel van hoor en wederhoor bevorderen, is die band minder sterk. Openbaarheid van behandeling en openbaarmaking van de uitspraak hebben vooral als doel het vertrouwen van het publiek in de rechtspraak te waarborgen. Deze eisen beogen echter ook willekeur van de kant van de rechter jegens de partijen in het concrete geschil te voorkomen. ${ }^{68}$ In dat opzicht dienen deze eisen tevens de belangen van partijen in de procedure, al is het verband daarmee minder rechtstreeks dan bij het motiveringsbeginsel.

\section{Het algemene belang: vertrouwen in rechtspraak}

De andere ratio vloeit voort uit het algemeen belang dat gemoeid is met rechtspraak in een democratische rechtsstaat. Vanwege de belangrijke positie die de onafhankelijke rechter in een rechtsstaat inneemt, ook ten opzichte van bestuur en wetgever, dient inachtneming van de beginselen van behoorlijke rechtspleging in concrete rechtsgeschillen het vertrouwen van het publiek in diezelfde rechter te waarborgen. ${ }^{69}$ Dat vertrouwen in de rechtspraak vormt mede de democratische legitimatie van de rechter. Die legitimatie ontbreekt anderszins grotendeels, aangezien de rechter geen verantwoording schuldig is aan andere organen (die een rechtstreekse of indirecte democratische legitimatie hebben) en zelf niet democratisch gekozen is. ${ }^{70}$ Het recht op een eerlijk proces en de beginselen van behoorlijke rechtspleging hebben derhalve een bredere betekenis dan het waarborgen van de belangen van partijen in een concreet geschil. Bij enkele beginselen lijkt dit algemeen belang zelfs boven de bescherming van de belangen van partijen in de procedure te gaan en de primaire functie van die beginselen te vormen. Dit geldt vooral voor de onafhankelijkheidseis en de twee aspecten van het openbaarheidsbeginsel. ${ }^{71}$ Aan deze eisen komt een duidelijke functie toe in het kader van de bevordering van het vertrouwen van de samenleving in de rechtspraak. De onafhankelijkheid van de rechter en de openbaarheid van rechtspraak bewerkstelligen immers vooral indirect effecten op de behandeling van het concrete geschil.

Ook bij de andere beginselen of vereisten speelt deze functie, zij het ondergeschikt aan de bescherming van partijen in het concrete rechtsgeschil, een rol. Zo draagt inachtneming van het beginsel van hoor en wederhoor, het beginsel van de redelijke termijn, het onpartijdigheidsbeginsel bij aan het algemene vertrouwen in de rechtspraak. Indien er iets schort aan de procedure of de rechterlijke instantie ten aanzien van deze aspecten, zeker indien het een structureel of systematisch gebrek betreft, doet dat afbreuk aan het gezag van de uitspraken van de rechter en zijn positie in onze samenleving. Ook het motiveringsbeginsel staat ten dienste van de bevordering van het vertrouwen in rechtspraak, maar dan vooral in combinatie met de eis van een openbare uitspraak. Het beginsel van een openbare uitspraak en de functie daarvan wordt immers uitsluitend verwezenlijkt, indien die uitspraak de redengeving van de rechter bevat voor zijn beslissing. Via de motivering en door openbaarmaking daarvan legt de rechter verantwoording af aan het publiek en de samenleving voor zijn beslissing. Hoe dat ook zij, voor het beginsel van hoor en wederhoor, het onpartijdigheidsbeginsel, het motiveringsbeginsel en het

68. Zie ook de overweging van het EHRM in de zaak Pretto e.a. aangehaald in noot 62. Zie over de functies van deze eisen nader par. 4.3.6 van dit deel.

${ }^{69 .}$ Zie hierover ook par. 4.3.3.

70. Zie de Conclusie van A-G Machielse bij HR 2 juli 2002, NJ 2003/2, par. 3.9-3.10. Vgl. S.K. Martens in zijn toespraak bij de opening van www.rechtspraak.nl (te raadplegen via http://www.rechtspraak.nl/Gerechten/HogeRaad/Actualiteiten/Archief/1999/12/). Vgl. ook: Bovend'Eert 2008, p. 163. De laatste wijst erop dat de rechter wel een beperkte afgeleide democratische legitimatie heeft omdat de grondwetgever de inrichting, samenstelling, werkwijze en bevoegdheden van de rechtspraak in de Grondwet geregeld heeft.

71. Zie par. 4.3.3 en 4.3.6 over de functies van deze beginselen. 


\section{De beginselen}

beginsel van de redelijke termijn ligt de primaire functie niettemin in de bescherming van de belangen van de betrokken partijen in de procedure en de interne werking van die beginselen.

\subsubsection{Categorisering van de beginselen}

De beginselen van behoorlijke rechtspleging vormen gezamenlijk één kader van rechtsnormen voor de beoordeling of vormen van rechtspraak als behoorlijk kunnen worden bestempeld en vertonen onderlinge samenhang vanwege de gemeenschappelijke functies die deze beginselen hebben. Binnen dat kader is echter een nadere categorisering mogelijk. Dergelijke onderscheidingen of indelingen binnen het geheel van rechtsnormen kunnen zinvol zijn, onder meer omdat de doorwerking van de beginselen per categorie verschillend zou kunnen uitpakken of wellicht beperkt moet blijven tot een bepaalde categorie van beginselen, afhankelijk van de grondslag voor de categorisering. Een indeling van de beginselen in verschillende categorieën kan op verschillende wijzen plaatsvinden. Verschillende mogelijkheden zijn denkbaar: een indeling in rangorde of een indeling naar de ratio van de beginselen, een chronologische indeling die de gang van de procedure volgt, een indeling die samenhangt met de gevolgen van de schending van beginselen of een indeling naar aard van de beginselen (institutioneel of materieel). Zonder uitputtend te willen zijn, worden in het onderstaande enkele indelingen in kaart gebracht. Daarbij vindt grotendeels een beperking plaats tot indelingen van beginselen van behoorlijke rechtspleging die reeds gehanteerd worden in de doctrine of die bij andere behoorlijkheidsbeginselen bestaan. In het bijzonder wordt aandacht besteed aan enkele indelingen die gebruikelijk zijn voor de algemene beginselen van behoorlijk bestuur en de vraag of een analoge categorisering voor de beginselen van behoorlijke rechtspleging zinvol kan zijn.

\section{Naar primaire functie of ratio}

In de vorige paragraaf is de samenhang tussen de verschillende beginselen van behoorlijke rechtspleging in kaart gebracht en aangegeven dat die samenhang te herleiden valt tot de functies van die beginselen. Die functies kunnen teruggebracht worden tot twee hoofdfuncties of primaire functies: de interne werking, die inhoudt bescherming van de belangen van partijen in de procedure en de externe werking, die ziet op bescherming van het algemene belang van vertrouwen van de samenleving in de rechtspraak. Bij elk afzonderlijk beginsel overheerst in mijn optiek een van deze functies (naast eventueel nog de andere functie als secundaire functie of nog andere daaraan ondergeschikte functies). Enerzijds bestaat er een groep beginselen binnen die categorie die vooral gericht is op individuele rechtsbescherming en de bescherming van de belangen van partijen in een concreet rechtsgeschil. Anderzijds is er een groep beginselen die primair het vertrouwen in rechtspraak van het publiek beoogt te waarborgen. Die laatste groep beginselen komt derhalve primair een functie toe die samenhangt met de positie van de onafhankelijke rechter in onze rechtsstaat en die een bredere betekenis heeft dan de context van individuele rechtsbescherming van artikel 6 EVRM of de beginselen van behoorlijke rechtspleging. Beide functies vertonen echter samenhang en kunnen daardoor, zeker in de praktijk, niet strikt van elkaar worden gescheiden.

Een categorisering naar primaire functie spreekt in het kader van dit onderzoek aan, omdat verwacht mag worden dat doorwerking van beginselen van behoorlijke rechtspleging sterker aanwezig is bij de beginselen waarvan de primaire functie samenhangt met de bescherming van de belangen van partijen in de procedure. Gelet op de plaats van de bestuurlijke voorprocedures in het bestuursrechtelijke systeem van rechtsbescherming, lijkt doorwerking van die beginselen die de belangen van partijen in het concrete geschil beogen te waarborgen op voorhand goed mogelijk of zelfs verdedigbaar. Een belangrijke functie van de voorprocedures is immers de rechtsbeschermingsfunctie en in dat opzicht bestaat ook, zoals eerder aangegeven, nauwe verwantschap met de procedure bij de 


\section{Deel I Beginselen van behoorlijke rechtspleging}

rechter. $^{72}$ Voor de tweede soort beginselen die in het teken staan van waarborging van de positie van de rechter in ons staatsbestel lijkt een vergelijkbare betekenis of beperkte toepasselijkheid voor de bestuurlijke voorprocedures minder aannemelijk. Geredeneerd vanuit deze categorisering zou derhalve de invloed van het beginsel van hoor en wederhoor, het onpartijdigheidsbeginsel, het motiveringsbeginsel, het beginsel van de redelijke termijn het sterkst voelbaar moeten zijn in de bestuurlijke voorprocedures. De beginselen van behoorlijke rechtspleging die primair beogen het vertrouwen in rechtspraak in het algemeen en niet zozeer in het concrete geschil te waarborgen, zoals de openbaarheidsbeginselen of de onafhankelijkheidseisen, zullen wellicht in mindere mate van betekenis zijn voor de bestuurlijke voorprocedures. In die voorprocedure staat immers niet zozeer dát belang op het spel. Het onderzoek in Deel II zal echter moeten aantonen of deze veronderstelling juist is en of doorwerking sterker aanwezig is naarmate het betreffende beginsel meer de bescherming van partijen in het concrete geschil waarborgt.

Categorisering aan de hand van de fasen van de procedure

Een andere indeling van de beginselen van behoorlijke rechtspleging, die ook gangbaar is bij de algemene beginselen van behoorlijk bestuur, vormt een indeling die aansluit bij de verschillende fasen in de procedure. ${ }^{73}$ Een dergelijke categorisering aan de hand van de onderdelen of fasen die te onderscheiden vallen in een procedure waarin de uitspraak van de rechterlijke instantie tot stand komt, naar analogie van de indeling van de beginselen van behoorlijk bestuur, is voor de beginselen van behoorlijke rechtspleging ook goed denkbaar. Widdershoven maakt een dergelijke indeling en onderscheidt de volgende onderdelen: toegang tot de rechtsgang, oordelende instantie, totstandkoming van de uitspraak en de uitspraak zelf. ${ }^{74}$ Daarnaast zijn er beginselen die door de gehele procedure een rol spelen. Omdat in dit onderzoek het recht op toegang tot de rechter niet tot de beginselen van behoorlijke rechtspleging wordt gerekend, aangezien dit geen eis vormt die betrekking heeft op een lopende procedure ${ }^{75}$, valt het eerste onderdeel weg. De onderdelen die resteren zien op het verloop van de procedure: de oordelende instantie, de totstandkoming van de uitspraak en de uitspraak. Er zijn beginselen die uitsluitend betrekking hebben op de samenstelling en inrichting van het orgaan dat de werkzaamheid moet verrichten, zoals het onafhankelijkheidsbeginsel en het onpartijdigheidsbeginsel. Ook vallen er beginselen te onderscheiden die uitsluitend betrekking hebben op de wijze waarop de procedure ingericht moet zijn, zoals het beginsel van hoor en wederhoor en de openbaarheid van behandeling. Er is voorts een aantal beginselen dat uitsluitend eisen stelt aan de uitkomst van de procedure zoals het motiveringsbeginsel en het beginsel van de openbare uitspraak. Sommige beginselen spelen echter een rol gedurende de gehele procedures, zoals de redelijke termijn. ${ }^{76}$ Een dergelijke indeling aan de hand van te onderscheiden onderdelen in een procedure, is echter niet relevant voor de mate van doorwerking van de beginselen. Er is geen reden om aan te nemen dat de mate van invloed van de beginselen afhankelijk is van de fase waarin de desbetreffende procedure zich bevindt. Daarom wordt deze indeling verder ook buiten beschouwing gelaten.

Categorisering naar analogie van de abbb en rangorde

Ten aanzien van de algemene beginselen van behoorlijk bestuur is een gangbare onderscheiding de indeling in formele en materiële beginselen van behoorlijk bestuur. ${ }^{77}$ Deze

\footnotetext{
72. Zie hierover nog nader par. 4.2.2 van Deel II.

73. Vgl. Widdershoven 1989, p. 113-114. Zie voor de abbb: G.H. Addink, Algemene beginselen van behoorlijk bestuur, Deventer: Kluwer 1999, p. 13; Nicolaï 1990, p. 288-289; De Waard 1987, p. 135-138.

74. Widdershoven 1989, 113-114.

75. Zie hierover nader par. 4.3.2 hierna.

${ }^{76 .}$ Widdershoven 1989, p. 114. Zie nader par. 4.3.8.

77. Van Wijk/Konijnenbelt \& Van Male 2008, p. 281-282; Addink 1999, p. 13; Nicolaï 1990, p. 283-288; J. in 't Veld \& N.S.J. Koeman, Beginselen van behoorlijk bestuur, Zwolle: W.E.J. Tjeenk Willink 1985, p. 33-34; De Waard 1987, p. 136 en 138-149.
} 


\section{De beginselen}

indeling kan mogelijk voor analyse van de betekenis van de beginselen van behoorlijke rechtspleging voor de bestuurlijke voorprocedures relevant zijn. Deze indeling houdt met name verband met de toetsing door de rechter en het onderscheid in rechtsgevolgen van de vernietiging van een besluit wegens een schending van een formeel of materieel beginsel. Aangenomen wordt dat schending van een formeel beginsel van behoorlijk bestuur na vernietiging door de rechter niet per definitie tot een inhoudelijk ander besluit behoeft te leiden, terwijl dat bij schending van materiële beginselen van behoorlijk bestuur wél het geval is. ${ }^{78}$ Een dergelijke onderscheiding tussen formele en materiële beginselen van behoorlijke rechtspleging in de betekenis die daaraan wordt toegekend bij de algemene beginselen van behoorlijk bestuur lijkt echter niet goed voorstelbaar. Zoals Van der Heijden stelt, zijn alle beginselen van behoorlijke rechtspleging formeel van aard in de zin dat bij schending van een beginsel en vernietiging van de uitspraak vervolgens in beginsel een nieuwe uitspraak gedaan kan worden (waarbij het betreffende beginsel in acht wordt genomen) met dezelfde inhoudelijke uitkomst. ${ }^{79}$ Bovendien is er geen reden om aan te nemen dat er een verband bestaat tussen de mate van doorwerking van de beginselen in andere procedures dan rechtspraak en deze indeling, waardoor deze indeling voor dit onderzoek niet nuttig is.

Een categorisering naar rangorde is evenmin aangewezen, omdat de status van de onderscheiden beginselen gelijk is. ${ }^{80}$ Ofschoon vaak het beginsel van hoor en wederhoor wordt aangemerkt als het meest fundamentele of essentiële beginsel van de beginselen van behoorlijke rechtspraak ${ }^{81}$, komt ook daaraan ten opzichte van de andere beginselen geen hogere status toe. Wel is het uiteraard zo dat sommige beginselen van behoorlijke rechtspleging in bepaalde omstandigheden kunnen conflicteren met andere beginselen van behoorlijke rechtspleging. Vooral het beginsel van de redelijke termijn kan tegenover andere beginselen, zoals hoor en wederhoor, de openbaarheid van de zittng en de motivering van de uitspraak, geplaatst worden. ${ }^{82}$ Aan welk beginsel 'voorrang' gegeven moet worden, zal uiteraard afhangen van de omstandigheden van het geval. In elk concreet geval moet een evenwicht tussen de verschillende beginselen gevonden worden.

\section{Materiële en institutionele beginselen}

Naar analogie van de tweedeling in de algemene beginselen van behoorlijk bestuur in formele en materiële beginselen, zou een indeling in institutionele beginselen en materiële beginselen wel degelijk zinvol kunnen zijn. Die indeling brengt echter geen onderscheid in rechtsgevolgen bij schending van de ene of andere soort beginselen mee. Brenninkmeijer makkt deze tweedeling en geeft aan dat de institutionele beginselen betrekking hebben op de rechter als onafhankelijke onpartijdige rechter (de oordelende instantie), terwijl de materiële beginselen zien op de (inrichting van) de procedure. ${ }^{83}$ Onder de institutionele beginselen schaart hij derhalve onafhankelijkheid en onpartijdigheid en onder de materiële beginselen hoor en wederhoor, motivering en redelijke termijn (waar-

\footnotetext{
78. Van Wijk/Konijnenbelt \& Van Male 2008, p. 282; Nicolaï 1990, p. 283; De Waard 1987, p. 138-149. Zie overigens de nuanceringen of kanttekeningen die De Waard maakt op dit onderscheid, De Waard 1987, p. 138147.

79. Van der Heijden 1984, p. 51. Kanttekening hierbij is echter dat erkend is dat het motiveringsbeginsel, als algemeen beginsel van behoorlijk bestuur, ook een meer materieel aspect omvat in de eis van een deugdelijke motivering. Soms zal er, vanwege de aard van de geconstateerde gebreken in de motivering, wel degelijk een andere beslissing genomen moeten worden. Dat is het geval wanneer duidelijk is dat besluit alleen maar een bepaalde inhoud kan hebben, waardoor iedere motivering die de andere kant opgaat ondeugdelijk zal blijken te zijn. Datzelfde zal gelden voor dergelijke schendingen van het rechterlijke motiveringsbeginsel, zie De Waard 1987, p. 1138 en 143-147.

${ }^{80 .}$ Vgl. ook Van der Heijden 1984, p. 50.

${ }^{81}$ Jansen 2004, p. 49; De Waard 1995, p. 443; De Waard, 1987, p. 245.

82. A.M.L. Jansen, De redelijke termijn. Met name in het bestuursrecht (diss. Tilburg), Den Haag: BJu 2000, p. $14-15$

${ }^{83 .}$ Brenninkmeijer 1998, p. 13.
} 
Deel I Beginselen van behoorlijke rechtspleging

aan in mijn ogen openbaarheid moet worden toegevoegd). ${ }^{84}$ In zijn optiek kunnen er bij rechtspleging drie kernvragen worden onderscheiden: wanneer bestaat er een recht op toegang tot de rechter, vervolgens welke institutionele vereisten gelden er voor behoorlijke rechtspleging en tot slot gelden er voor de procedure voor de rechter materiële behoorlijkheidseisen of beginselen. Een dergelijke categorisering spreekt in het kader van dit onderzoek ook erg aan, omdat mag worden aangenomen dat de doorwerking van de institutionele beginselen in de bestuurlijke voorprocedures geringer zal zijn dan de doorwerking van de materiële beginselen van behoorlijke rechtspleging. ${ }^{85}$ Naar aanleiding van de bevindingen in Deel II zal bezien moeten worden of een dergelijke indeling parallel loopt aan de mate van doorwerking of betekenis van de betreffende beginselen in de bestuurlijke voorprocedures. Opmerking verdient nog dat deze categorisering niet parallel loopt aan de eerder genoemde indeling in intern werkende en extern werkende beginselen. Het onpartijdigheidsbeginsel is bijvoorbeeld een institutioneel beginsel dat primair ziet op de bescherming van de belangen van partijen in het concrete geschil, terwijl onafhankelijkheid een institutionele eis vormt die primair extern werkt.

\subsection{De beginselen en hun inhoud}

\subsubsection{Inleiding}

De algemeen aanvaarde beginselen

In het Nederlandse bestuursrecht wordt thans een zevental beginselen van behoorlijke rechtspleging onderscheiden die algemeen erkend zijn en waarvan schendingen in beginsel leiden tot vernietiging van de uitspraak van de rechter. Het gaat om de volgende beginselen: het recht op toegang tot de rechter (als onderdeel van het decisiebeginsel), onafhankelijkheid van de rechter ${ }^{86}$, het onpartijdigheidsbeginsel, het beginsel van hoor en wederhoor of het verdedigingsbeginsel, het openbaarheidsbeginsel (met twee deelvereisten), het motiveringsbeginsel en het beginsel van de redelijke termijn (als onderdeel van het decisiebeginsel). Bij deze catalogus van beginselen die in de doctrine onderscheiden wordt ${ }^{87}$, wordt in beginsel aangesloten. Aangezien aan het opsporen en in kaart brengen van de beginselen van behoorlijke rechtspleging ook uitvoerig aandacht is besteed door onder meer De Waard, bestaat er in het kader van dit onderzoek geen aanleiding om dat geheel opnieuw te doen. De omstandigheid dat de door De Waard onderscheiden beginselen met enkele aanvullingen breed aanvaard $\mathrm{zijn}^{88}$, rechtvaardigt een dergelijke benadering te meer. Bovendien erkent ook het EHRM dat het recht op een eerlijk proces deze eisen omvat. Volgens het Hof wordt het recht op een eerlijk proces gevormd door verschillende aspecten: het recht op toegang tot de rechter, de waarborgen inzake de samenstelling en organisatie van het gerecht als genoemd in artikel 6 lid 1 EVRM (zoals onafhankelijkheid en onpartijdigheid) alsmede waarborgen ten aanzien van het verloop van de procedure als neergelegd in die bepaling (het betreft hoor en

\footnotetext{
84. Brenninkmeijer 1998, p. 16-17.

85. Bovendien wordt de eerste vraag die Brenninkmeijer onderscheidt en buiten zijn indeling lijkt te vallen, de vraag naar de toegang tot de rechter, ook buiten dit onderzoek naar de doorwerking in de bestuurlijke voorprocedures gelaten, zie hierover par. 4.3.2. Ook in dit onderzoek wordt het recht op toegang beschouwd als een recht dat geen betrekking heeft op het behoorlijkheidsgehalte van een lopende procedure.

${ }^{86 .}$ Zoals eerder aangegeven beschouw ik dit beginsel niet als een beginsel voor behoorlijke rechtspraak maar als een element van het begrip rechtspraak. Omwille van de overzichtelijkheid wordt de eis echter in deze paragraaf nader in kaart gebracht, zie hierover nader par. 4.3.3.

${ }^{87 .}$ Damen e.a. 2009, Deel II, p. 59-67; Schreuder-Vlasblom 2008, p. 58-66; Van Wijk/Konijnenbelt \& Van Male 2008 , p. 576.

88. Zie bijv.: F.A.M. Stroink, 'Iets over rechtsbeginselen en wat daarop lijkt in het bestuursprocesrecht', in: R.J.N. Schlössels, A.J. Bok, H.J.A.M. van Geest, S. Hillegers, In beginsel. Over aard, inhoud en samenhang van rechtsbeginselen in het bestuursrecht, Deventer: Kluwer 2004 (hierna: Stroink 2004b), p. 130; Stroink 1993, p. 68-71; Widdershoven 1989, p. 112-114.
} 


\section{De beginselen}

wederhoor, openbaarheidseisen en de redelijke termijn). ${ }^{89}$ Het geheel van die eisen vormt het recht op een eerlijk proces. Aan verschillende onderdelen van artikel 6 EVRM zijn ook reeds afzonderlijke dissertaties gewijd. ${ }^{90}$ Dat vormt nog een aanvullende reden voor de keuze grotendeels aan te sluiten bij de reeds verrichte onderzoeken en in het onderstaande slechts een beschrijving op hoofdlijnen van de verschillende beginselen te geven. Wel wordt, zonder de geldingskracht van de hiervoor genoemde eisen te willen betwisten, de vraag gesteld of in alle gevallen sprake is van een beginsel van behoorlijke rechtspleging en niet van een andersoortige eis.

In de onderstaande paragrafen wordt beschreven welke inhoud aan deze beginselen wordt toegekend alsmede wat de ratio en functie van deze beginselen zijn. Daarbij wordt in eerste instantie bezien op welke wijze deze beginselen invulling hebben gekregen in de nationale wetgeving, literatuur en jurisprudentie. Omdat echter artikel 6 EVRM grotendeels bepalend is geweest voor de ontwikkeling van en de invulling van deze beginselen op nationaal niveau wordt daarbij ook steeds deze bepaling en de jurisprudentie van het EHRM betrokken. De beginselen komen in de hiervoor genoemde volgorde komen aan bod. Het gehanteerde stramien in deze paragrafen is voor elk beginsel grotendeels hetzelfde: eerst wordt de inhoud van het desbetreffende beginsel bepaald, waarna de functie(s) en ratio van het beginsel worden bezien. Vervolgens komen de ter waarborging van het beginsel gestelde inrichtingseisen (in de Awb) kort aan orde.

Effectieve rechtsbescherming: een nieuw beginsel?

Op één punt wordt afgeweken van de hiervoor genoemde en in de doctrine aanvaarde beginselcatalogus. Een uitgangspunt dat vooral in het bestuursrecht veel aandacht heeft gekregen, verdient in mijn optiek namelijk nader onderzoek met het oog op de vaststelling of er sprake is van een beginsel van behoorlijke rechtspleging of niet. De laatste jaren staat, wat betreft het bestuursrechtelijke systeem van rechtsbescherming, namelijk de vraag of er sprake is van effectieve rechtsbescherming prominent in de aandacht van de doctrine. ${ }^{91}$ Vooral de omstandigheid dat de bestuursrechter in (te) veel gevallen niet tot een finale beslechting van het voorliggende geschil kan komen, roept in dat opzicht vraagtekens op. In het bijzonder staan de uitspraakmogelijkheden en bevoegdheden die de bestuursrechter heeft of zou moeten hebben centraal. ${ }^{92}$ Toegang tot rechtsbescherming en een behoorlijke procedure zijn zinledig, indien de rechtsbescherming die geboden kan worden niet effectief is en niet kan leiden tot een finale beslechting van het geschil. Enkele auteurs hebben een beginsel van effectieve rechtsbescherming dan ook onderscheiden als onderdeel van behoorlijkheidsnormen waaraan rechtspraak moet voldoen, maar dit beginsel lijkt als afzonderlijk beginsel van behoorlijke rechtspleging nog geen algemene ingang gevonden te hebben in de doctrine. ${ }^{93}$ Hoewel een brede erkenning als

\footnotetext{
${ }^{89 .}$ EHRM 21 februari 1975, Golder t. Verenigd Koninkrijk, NJ 1975/462 m.nt. Alkema.

${ }^{90 .}$ Zie bijvoorbeeld: M. Kuijer, The blindfold of Lady Justice. Judicial Independence and Impartiality in Light of the Requirements of Article 6 ECHR (diss. Leiden), Leiden 2004; M. Viering, Het toepassingsgebied van artikel 6 EVRM (diss. Nijmegen), Zwolle: W.E.J. Tjeenk Willink 1994; A.F.M. Brenninkmeijer, De toegang tot de rechter. Een onderzoek naar de betekenis van onafhankelijke rechtspraak in een democratische rechtsstaat. (diss. Tilburg), Zwolle: W.E.J. Tjeenk Willink 1987.

91. Zie bijvoorbeeld: F.F.W. Brouwer \& L.M. Koenraad, 'Slagvaardig bestuursprocesrecht. Over bestuurlijke lus, finale geschilbeslechting en conflictoplossing', NJB 2006, p. 1678-1684; Rapport VAR-Commissie rechtsbescherming 2004, p. 19-21 en 44-45; J.E.M. Polak, 'Effectieve bestuursrechtspraak: enkele beschouwingen over het vermogen van de bestuursrechtspraak om geschillen materieel te beslechten', Deventer: Kluwer 2000.

92. Overigens doen zich vooral problemen inzake finale geschilbeslechting voor in de gevallen waarin de bestuursrechter komt tot gegrondverklaring van het beroep en vernietiging van het besluit. In gevallen waarin de bestuursrechter een beroep ongegrond verklaart (of zijn onbevoegdheid of niet-ontvankelijkheid van het beroep uitspreekt) kan het geschil als beëindigd worden beschouwd. In zoverre gaat de kritiek op de effectiviteit van de bestuursrechtspraak niet helemaal op en moet deze ook gerelativeerd worden. Zie hierover: Schueler 2007 e.a., p. 5-12.

p. $5-12$.
93. Widdershoven onderscheidt de eis van effectieve rechtsbescherming als beginsel dat door de gehele procedure een rol speelt maar besteedt in het bijzonder aandacht aan dat beginsel bij de toegang tot de rechter, Widdersho-
} 


\section{Deel I Beginselen van behoorlijke rechtspleging}

beginsel van behoorlijke rechtspleging wellicht (nog) niet heeft plaatsgevonden, is het uitgangspunt dat er een effectief bestuursrechtelijke systeem van rechtsbescherming behoort te bestaan niet omstreden. Daar komt nog bij dat Europese ontwikkelingen ook steeds meer nopen tot effectieve rechtsbescherming op nationaal niveau. Daarbij moet gedacht worden aan het toegenomen belang van artikel 13 EVRM (in het bijzonder, maar niet alleen, in combinatie met het redelijke termijn- vereiste uit artikel 6 EVRM) ${ }^{94}$ alsmede de effectiviteiteisen die het Hof van Justitie stelt aan de nationale procedures ter uitvoering van Unierecht. ${ }^{95}$

De prominente aandacht voor deze problematiek en het feit dat in de doctrine brede overeenstemming bestaat over het feit dat de bestuursrechtelijke rechtsgang effectieve rechtsbescherming behoort te bieden, rechtvaardigen in mijn ogen de vraag of niet langzaamaan (volledige) erkenning van een nieuw rechtsbeginsel, een beginsel van effectieve rechtsbescherming, heeft plaatsgevonden of plaats moet vinden anders dan of naast de reeds bestaande beginselen. Bovendien bestaat er, zoals hiervoor al werd aangegeven, een duidelijk verband tussen effectieve rechtsbescherming en de toegang tot een behoorlijke procedure bij de een rechterlijke instantie: effectieve rechtsbescherming vormt het sluitstuk voor een burger om zijn rechten te gelde te maken, zonder welke waarborg de beginselen van behoorlijke rechtspleging aan kracht verliezen. Om die reden is ook een paragraaf gewijd aan de effectiviteit van de rechtsbescherming in het bestuursrecht en in het bijzonder de vraag of de ontwikkelingen en opvattingen dienaangaande moeten leiden tot de conclusie dat er sprake is van een rechtsbeginsel waaraan de bestuursrechtelijke procedures behoren te voldoen. Onder effectieve rechtsbescherming wordt derhalve in paragraaf 4.3.9 wordt nog teruggekomen op wat er onder effectieve rechtsbescherming moet worden verstaan - nadrukkelijk iets anders verstaan dan het voldoen aan de waarborgen voor een eerlijk proces of de beginselen van behoorlijke rechtspleging.

\section{Plan van aanpak}

In paragraaf 4.3.2 tot en met 4.3.8 komen de bestaande en erkende beginselen van behoorlijke rechtspleging in de hiervoor genoemde volgorde aan bod, te beginnen met het recht op toegang en eindigend met het beginsel van de redelijke termijn. Paragraaf 4.3.9 is gewijd aan de effectieve rechtsbescherming en de vraag of er sprake is van een nieuw beginsel van behoorlijke rechtspleging.

\subsubsection{Het recht op toegang tot de rechter}

Het recht op toegang tot de rechter ${ }^{96}$ vormt de toegangspoort tot de beginselen van behoorlijke rechtspleging, omdat dit recht een eerste vereiste is zonder welke de overige

ven 1989, p. 114. Volgens Brenninkmeijer omvat het recht op toegang tot de rechter ook de aanspraak op effectieve rechtsbescherming, Brenninkmeijer 1987, p. 49. Hierover nader par. 4.3.9.

94. Zie Schokkenbroek die wijst op de ontwikkeling dat art. 13 EVRM meer nadruk krijgt in de jurisprudentie in combinatie met materiële rechten, J.G.C. Schokkenbroek, 'Effectief rechtsmiddel', in: J.H. Gerards, A.W Heringa, H.L. Janssen en J. van der Velde, EVRM Rechtspraak en Commentaar, Den Haag Sdu, par. 3.13, p. 1721.

95. Zoals eerder aangegeven worden in dit onderzoek het HvJ EG, het Gerecht van Eerste Aanleg en het Gerecht voor ambtenarenzaken in de hoofdtekst kortheidshalve steeds aangeduid met Hof van Justitie, tenzij anders aangegeven. Sinds de inwerkingtreding van het Verdrag van Lissabon wordt het Hof van Justitie als instelling aangeduid als het Hof van Justitie van de Europese Unie. Het Hof van Justitie van de Europese Unie omvat volgens art. 19 VEU verschillende gerechten: het Hof van Justitie, het Gerecht en de gespecialiseerde rechtbanken.

96. Zie hierover recent nog: T. Barkhuysen \& M.L. van Emmerik, 'Het recht op toegang tot de rechter en een eerlijk proces in de Nederlandse Grondwet?', in: T.Barkhuysen, M.L. van Emmerik \& J.P. Loof, Geschakeld recht. Verdere studies over Europese grondrechten ter gelegenheid van de $70^{\text {ste }}$ verjaardag van prof.mr. E.A. Alkema, Deventer: Kluwer 2009, p. 13-39; T. Barkhuysen, M.L. van Emmerik, J.H. Gerards, De toegang tot de rechter en een eerlijk proces in de Grondwet? Behoeft de Nederlandse Grondwet aanvulling met een recht op toegang tot de rechter en een eerlijk proces?, Deventer: Kluwer 2009. 


\section{De beginselen}

eisen van behoorlijke rechtspleging hun betekenis verliezen. Een burger heeft immers niets aan een procedure die voldoet aan deze eisen, indien de toegang tot die procedure niet (voldoende) gewaarborgd is. ${ }^{97}$ Dat is ook de reden waarom het EHRM in zijn jurisprudentie heeft bepaald dat dit recht volgt uit artikel 6 EVRM, ook al is dit recht niet expliciet neergelegd in die bepaling. ${ }^{98}$ Het EHRM drukt het in Golder als volgt uit:

"It would be inconceivable, in the opinion of the Court, that Article 6 para. 1 (art. 6-1) should describe in detail the procedural guarantees afforded to parties in a pending lawsuit and should not first protect that which alone makes it in fact possible to benefit from such guarantees, that is, access to a court. The fair, public and expeditious characteristics of judicial proceedings are of no value at all if there are no judicial proceedings." 99

Deze uitspraak is in latere jurisprudentie vele malen bevestigd. Volgens het EHRM houdt artikel 6 EVRM in het recht op toegang tot de rechter voor een burger in een geschil omtrent burgerlijke rechten of verplichtingen alsmede in gevallen waarin een strafvervolging wordt ingesteld. ${ }^{100}$ Het recht op toegang tot de rechter is echter niet absoluut en beperkingen op dit recht op toegang tot de rechter zijn volgens het EHRM toegestaan $^{101}$, mits daarmee de essentie van het recht niet wordt aangetast. ${ }^{102}$ Het komt erop neer dat het voor een burger, gelet op de omstandigheden van het geval, niet onmogelijk moet zijn om het recht op toegang tot de rechter te effectueren. De beperking van het recht moet voorts een legitiem doel dienen en proportioneel zijn in dat geval. ${ }^{103}$

Nationaalrechtelijk is het beginsel evenmin expliciet gecodificeerd, ook niet in de Grondwet. ${ }^{104}$ De grondslag voor het recht op toegang tot een rechter ligt in de rechtsstaatgedachte. ${ }^{105}$ Het vormt een breed erkende en aanvaarde eis in de doctrine. ${ }^{106}$ De Waard beschouwt dit recht op toegang tot de rechter als onderdeel van het decisiebeginsel, dat daarnaast ook het beginsel van de redelijke termijn omvat. ${ }^{107}$ Zoals De Waard voorts aangeeft, bestaat er zodra toegang tot de rechter is opengesteld en daar gebruik van is gemaakt, ook een recht op een beslissing. Dit decisiebeginsel geldt volgens hem

97. Jansen 2004, p. 13; Kuijer 2004, p. 156.

98. Zoals in Van Dijk \& Van Hoof wordt opgemerkt wordt door de erkenning van het recht op toegang tot de rechter voorkomen dat verdragsstaten de procedurele waarborgen uit art. 6 EVRM uithollen door de toegang tot de procedure te beperken of zelfs af te schaffen, Van Dijk \& Van Hoof e.a. 2006, p. 558

99. EHRM 21 februari 1975, Golder t. Verenigd Koninkrijk, NJ 1975/462 m.nt. Alkema, par. 35.

${ }^{100}$ Zie bijvoorbeeld voor geschillen inzake civil rights and obligations, Golder, en voor geschillen betreffende een criminal charge bijvoorbeeld: EHRM 27 februari 1980, Deweer t. België, nr. 6903/75, par. 48-50. Zie verder hierover: A.W. Heringa, 'Art. 6 Eerlijk proces. Toegang tot de rechter', in: J.H. Gerards, A.W. Heringa, H.L. Janssen en J. van der Velde, EVRM Rechtspraak en Commentaar, katern. Art. 6 Eerlijk proces, Haag: Sdu 1-12004, par. 3.6.1, p. 1; Brenninkmeijer 1987, p. 120-124; De Waard 1987, p. 176

101. Zie Golder, par. 38-39; EHRM 28 mei 1985, Ashingdane t. Verenigd Koninkrijk, NJ 1991/623 m.nt. EAA, par. 57; EHRM 22 oktober 1996, Stubbings e.a. t. Verenigd Koninkrijk, NJ 1997/449 m.nt. JdB, par. 50.

102. Zie bijvoorbeeld: EHRM 24 oktober 1979, Winterwerp t. Nederland, nr. 6301/73, par. 60 en 75; Ashingdane, par. 57; Stubbings e.a., par. 50. Voor meer jurisprudentie: Van Dijk \& Van Hoof e.a. 2006, p. 557 e.v.; Jansen 2004, p. 24-26; A.W. Heringa, ‘Art. 6 Eerlijk proces. Toegang tot de rechter', in: J.H. Gerards, A.W. Heringa, H.L. Janssen en J. van der Velde, EVRM Rechtspraak en Commentaar, katern. Art. 6 Eerlijk proces, Haag: Sdu 1-1-2004, par. 3.6.1, p. 4-7.

${ }^{103 .}$ Bijvoorbeeld: Ashingdane, par. 57; Stubbings e.a., par. 50. Voor meer jurisprudentie: Jansen 2004, p. 23-30; A.W. Heringa, 'Art. 6 Eerlijk proces. Toegang tot de rechter', in: J.H. Gerards, A.W. Heringa, H.L. Janssen en J. van der Velde, EVRM Rechtspraak en Commentaar, katern. Art. 6 Eerlijk proces, Haag: Sdu 1-1-2004, par. 3.6.1, p. 8-12.

${ }^{104 .}$ De Waard wijst erop dat de Grondwet in art. 17 wel de garantie bevat dat niemand tegen zijn wil kan worden afgehouden van de rechter die de wet hem toekent (het ius de non evocando), maar een recht op toegang tot een rechter vormt deze garantie niet, De Waard 1987, p. 117. Brenninkmeijer meent echter dat sprake is van een negatief geformuleerde garantie van het recht op toegang tot de rechter: indien men ervan uitgaat dat een recht op toegang tot de rechter bestaat, geldt dat het betreffende rechtssubject daar niet van afgehouden mag worden, Brenninkmeijer 1987, p. 71. Zo ook: Hirsch Ballin 1983, p. 18.

${ }^{105 .}$ Widdershoven 1989, p. 109; Hirsch Ballin 1983, p. 15-16; Brenninkmeijer 1987, p. 108. Zo ook het EHRM in Golder, par. 34-35.

106. Zie o.m.: Rapport VAR-Commissie Rechtsbescherming 2004, p. 50-53; Stroink 1993, p. 66; Widdershoven 1989, p. 109; De Waard 1987, p. 176 e.v.; Van Dijk 1983, p. 88 e.v.; Hirsch Ballin 1983, p. 15 e.v.

107. De Waard 1987, p. 176 e.v. 


\section{Deel I Beginselen van behoorlijke rechtspleging}

ook als artikel 6 EVRM niet van toepassing is. ${ }^{108}$ Het recht op toegang tot de rechter is, zoals Brenninkmeijer stelt, ondanks gebrekkige codificatie van het beginsel in onze rechtsorde stevig verankerd en in belangrijke mate gerealiseerd. ${ }^{109}$ In het bestuursrecht bestaat er in het algemeen een mogelijkheid beroep in te stellen bij de bestuursrechter tegen besluiten en voor zover dat niet mogelijk is, bestaat er toegang tot de burgerlijke rechter. Daaruit kan worden afgeleid dat een recht op toegang tot de rechter erkend wordt, ook al heeft uitdrukkelijke codificatie van dat recht niet plaatsgevonden. ${ }^{110}$

Een recht op toegang tot een bevoegde rechter is echter niet voldoende. De toegang tot een procedure als zodanig zou eveneens niets waard zijn, indien in die procedure vervolgens allerlei obstakels bestaan voor de burger waardoor hij zijn rechten niet daadwerkelijk geldend kan maken. ${ }^{111}$ Een recht op toegang tot de rechter houdt volgens sommige auteurs dan ook een aanspraak op effectieve rechtsbescherming in. Zo onderscheidt Brenninkmeijer een formeel aspect aan de toegang tot de rechter, te weten dat er een bevoegde rechter moet zijn die kennis neemt van het geschil, en een materieel aspect, namelijk de aanspraak op effectieve rechtsbescherming. ${ }^{12}$ Het beginsel van toegang tot de rechter omschrijft hij als volgt:

"Rechtssubjecten behoren een aanspraak te hebben op toegang tot de rechter teneinde ter bescherming van hun (vermeende) rechten van een onafhankelijke rechter effectieve rechtsbescherming te verkrijgen door een rechtens bindende en zo nodig executoriale uitspraak over de rechtsbetrekking in geschil."113

Ook Widdershoven erkent een beginsel van effectieve toegang tot de rechter, maar hij ziet dit vooral als een verbijzondering van het beginsel van effectieve rechtsbescherming. ${ }^{114}$ Ik zou mij daarbij willen aansluiten in zoverre dat het recht op toegang tot de rechter, toegespitst op het bestuursrecht, inhoudt dat er een bevoegde rechter behoort te zijn in bestuursrechtelijke kwesties waaraan de burger zijn geschil kan voorleggen én dat diezelfde rechter ook een beslissing behoort te geven. Het beginsel van effectieve rechtsbescherming, waarover meer in paragraaf 4.3.9, is van belang voor de gehele procedure en brengt onder meer met zich dat die toegang tot de rechter daadwerkelijk geldend moet kunnen worden gemaakt. ${ }^{115}$ Het materiële aspect dat Brenninkmeijer onderscheidt, moet dan ook onder het beginsel van effectieve rechtsbescherming geschaard worden. Tot slot wordt ook nog, gelet op de jurisprudentie van het EHRM, de eis dat de rechter 'full jurisdiction' moet hebben en het geschil ten volle mag beoordelen onder het recht op toegang geschaard ${ }^{116}$

Hoewel duidelijk is dat er nationaalrechtelijk een recht op toegang tot de rechter wordt aangenomen, is een vraag die zich aandient of dit recht op toegang moet worden beschouwd als een beginsel van behoorlijke rechtspleging. In wezen heeft het recht op toegang tot een rechter betrekking op een vraag die in mijn ogen voorafgaat aan de beoordeling van de behoorlijkheid van de procedure. ${ }^{117}$ De beginselen van behoorlijke

\footnotetext{
108. De Waard 1987, p. 177-178.

109. Brenninkmeijer 1987, p. 113 en 124. Ten tijde van zijn dissertatie meende hij dat in het bestuursrecht het beginsel nog het minst gerealiseerd was, maar thans is dat door inwerkingtreding van de Awb en de omstandigheid dat tegen besluiten beroep openstaat bij de rechtbank niet meer het geval, lijkt mij.

${ }^{110 .}$ Brenninkmeijer 1987, p. 49

111. Widdershoven 1989, p. 114. Zie ook Van Dijk \& Van Hoof e.a. 2006, p. 560. Zij geven aan dat het EHRM ook bepaald heeft dat het recht op toegang tot de rechter 'must not be theoretical or illusory, but practical and effective'.

112. Brenninkmeijer 1987, p. 49. Zo ook: Barkhuysen, Van Emmerik \& Gerards 2009, p. 23.

${ }^{113 .}$ Brenninkmeijer 1987, p. 109

114. Widdershoven 1989, p. 121.

115. Widdershoven 1989, p. 121.

116. Barkhuysen \& Van Emmerik 2009, p. 27; Barkhuysen, Van Emmerik \& Gerards 2009, p. 24; Van Dijk \& Van Hoof e.a. 2006, p. 561

${ }^{117 .}$ Vgl. Brenninkmeijer die een onderscheid maakt tussen institutionele behoorlijkheidseisen en materiële eisen van behoorlijke rechtspraak en de vraag naar het recht op toegang tot de rechter van beide categorieën onderscheidt en daaraan voorafgaand stelt, Brenninkmeijer 1998, p. 13
} 


\section{De beginselen}

rechtspleging hebben immers betrekking op de inrichting van de voor een burger reeds openstaande procedure en de wijze waarop deze moet plaatsvinden alsmede op het orgaan waarbij deze procedure gevolgd wordt. Indien er toegang tot de rechtsgang bestaat, behoort deze vervolgens aan de eisen van behoorlijk rechtspleging te voldoen. ${ }^{118}$ Daarmee is niet in tegenspraak dat het recht op een eerlijk proces, neergelegd in artikel 6 EVRM, dit recht omsluit. Zou het recht op een eerlijk proces beperkt zijn opgevat door het EHRM, dan zouden de waarborgen voor een behoorlijk proces op nationaal niveau omzeild kunnen worden door geen toegang tot een rechter open te stellen. ${ }^{119}$ Zoals het EHRM echter zelf stelt in de hiervoor aangehaalde overweging, moet er eerst een recht op toegang tot een procedure bestaan, alvorens de behoorlijkheid van die procedure getoetst kan worden. Strikt genomen vormt het recht op toegang tot de rechter derhalve geen rechtsnorm (of toetsingsnorm) voor het behoorlijkheidgehalte van een lopende procedure, maar een rechtsnorm met een andersoortige grondslag. ${ }^{120}$ Het betreft, in de benadering van het EHRM $^{121}$ maar ook in de nationale doctrine ${ }^{122}$, veeleer een algemeen rechtsstatelijk beginsel.

De omstandigheid dat het recht op toegang tot de rechter geen beginsel van behoorlijke rechtspleging is, brengt ook met zich dat het - afgezien van de omstandigheid dat dit recht noodzakelijk is om de overige waarborgen te kunnen effectueren en daaraan voorafgaat - niet of nauwelijks samenhang vertoont met de beginselen voor een behoorlijke procedure. Als er al een duidelijk verband geconstateerd kan worden met een specifiek beginsel van behoorlijke rechtspleging, dan is dat het beginsel van hoor en wederhoor of het verdedigingsbeginsel. Ten behoeve van het effectueren van het recht op toegang tot de rechter is immers vereist dat de belanghebbende wordt ingelicht over de rechtsgang die openstaat en over de termijn waarbinnen hij daarvan gebruik moet maken. Dezelfde eis kan voorts in verband worden gebracht met de mogelijkheid van de belanghebbende tegen het besluit (of de uitspraak) actie te ondernemen, indien hij het daar niet mee eens is. Op dit punt raken het recht op toegang tot de rechter en het beginsel van hoor en wederhoor en de bescherming van de belangen van de betrokkenen bij de procedure elkaar.

Mogelijke beperkingen van en eisen ter waarborging van het recht op toegang

Zoals aangegeven, geldt het recht op toegang tot de rechter niet absoluut. Vele beperkingen zijn mogelijk van verschillende aard volgens het EHRM, zo lang die beperkingen maar een legitiem doel dienen en proportioneel zijn en de essentie van het recht op toegang niet aantasten. ${ }^{123} \mathrm{Zo}$ is het gebruikelijk en geoorloofd om griffierechten te heffen alvorens een rechterlijk oordeel verkregen kan worden. ${ }^{124}$ Ook mogen vormvereisten gesteld worden aan het stuk dat de procedure inleidt, op straffe van nietontvankelijkheid. ${ }^{125}$ Hetzelfde geldt voor het stellen van termijnen voor het indienen van het inleidend geschrift. ${ }^{126}$ Voorts is ook het stellen van voorwaarden aan de hoedanigheid

118. Zie ook: Brenninkmeijer die aangeeft dat het gaat om twee verschillende kwesties die ook in art. 6 EVRM door elkaar lopen, Brenninkmeijer 1987, p. 55 en p. 60.

119. Zo ook het EHRM in Golder, par. 35 .

${ }^{120 .}$ Om die reden wordt ook de doorwerking van het recht op toegang tot de rechter in de bestuurlijke voorprocedures in Deel II niet nader onderzocht. Het betreft immers geen behoorlijkheidsnorm en dit onderzoek beoogt te achterhalen of de normen voor een behoorlijke rechtsgang doorwerken in de bestuurlijke voorprocedures.

${ }^{121 .}$ Het EHRM herleidt het recht op toegang tot de rechter tot de 'rule of law', Golder, par. 34

122. Brenninkmeijer 1987, p. 108 en 110; Hirsch Ballin 1983, p. 15-16.

123. Zie voor een meer uitvoerig overzicht van mogelijke beperkingen: Jansen 2004, p. 23-47; A.W. Heringa, 'Art. 6 Eerlijk proces. Toegang tot de rechter', in: J.H. Gerards, A.W. Heringa, H.L. Janssen en J. van der Velde, EVRM Rechtspraak en Commentaar, katern. Art. 6 Eerlijk proces, Haag: Sdu 1-1-2004, par. 3.6.1, p. 6 e.v.

124. EHRM 19 juni 2001, Kreuz t. Polen, EHRC 2002/54 m.nt. AWH, par. 54 en 58-60. Zie ook: Van Dijk 2003, p. 957; Widdershoven 1989, p. 121 en p. 124

125. Zie met verwijzingen naar jurisprudentie: Van Dijk 2003, p. 957; Widdershoven 1989, p. 121 en 123-124.

${ }^{126 .}$ EHRM 22 oktober 1996, Stubbings t. Verenigd Koninkrijk, NJ 1997/449 m.nt. De Boer. Zie verder nog: Van Dijk 2003, p. 957; Widdershoven 1989, p. 121 en 123. 


\section{Deel I Beginselen van behoorlijke rechtspleging}

van de burger, zoals belanghebbendheid, toegestaan. ${ }^{127}$ Dit soort toegangsbeperkingen en inrichtingseisen bestaan, zoals bekend, ook thans onder de Awb voor de procedure bij de bestuursrechter. Er geldt bijvoorbeeld, op grond van artikel 6:7 Awb, een beroepstermijn van zes weken na bekendmaking van het (te bestrijden) besluit. Daarin ligt ook al de eerste voorwaarde voor toegang tot de bestuursrechter besloten: er moet sprake zijn van een besluit. ${ }^{128}$ Artikel 6:13 Awb beperkt voorts de toegang tot de bestuursrechter nog verder: geen beroep kan worden ingesteld door een belanghebbende aan wie redelijkerwijs verweten kan worden dat hij geen zienswijzen als bedoeld in artikel 3:15 Awb heeft ingediend, geen bezwaar heeft gemaakt of geen administratief beroep heeft ingesteld. Op grond van artikel 8:1 Awb kan vervolgens alleen een belanghebbende, in de zin van artikel 1:2 Awb, beroep instellen. ${ }^{129}$ Het beroepschrift dient, op straffe van nietontvankelijkheid ${ }^{130}$, te voldoen aan een aantal vormeisen welke zijn neergelegd in artikel 6:5 van de Awb. Tegelijkertijd behoren er inrichtingseisen te bestaan die waarborgen dat deze beperkingen het recht op toegang in het concrete geval niet te zeer inperken. Artikel 6:6 Awb, waarin is geregeld dat een bezwaar- of beroepschrift pas niet-ontvankelijk kan worden verklaard, indien een belanghebbende de gelegenheid heeft gehad om een verzuim ten aanzien van een wettelijke eis binnen een redelijke termijn te herstellen, vormt een belangrijke inrichtingseis in dat kader. ${ }^{131}$ Hetzelfde geldt voor artikel 6:11 Awb, waarin is geregeld dat overschrijding van de termijn niet tot niet-ontvankelijkheid mag leiden, indien de overschrijding verschoonbaar was. ${ }^{132}$ De rechter dient zich bij de interpretatie van deze bepalingen niet te formalistisch op te stellen. Het EHRM heeft regelmatig laten merken dat het niet gediend is van 'formalisme excessif' van de kant van de nationale rechters waardoor een burger de toegang tot een rechter die over het voorgelegde geschil moet oordelen, ontnomen wordt. ${ }^{13}$

Een in het bestuursrecht veel voorkomende beperking van de toegang tot de rechter is daarnaast uiteraard de verplichting om een bestuurlijke voorprocedure te doorlopen alvorens de rechter kan worden geadieerd. ${ }^{134}$ In het Nederlandse bestuursrecht is de bezwaarschriftprocedure de meest voorkomende voorprocedure. ${ }^{135}$ Voor de bestuurlijke voorprocedures is het recht op toegang tot de rechter in zoverre al relevant, omdat de vormgeving van de procedures en de daarbij te stellen eisen niet dermate stringent mo-

127. EHRM 27 juli 2006, Coorplan Jenni GmbH en Hascic t. Oostenrijk, EHRC 2006/122 en JB 2006/287 m.nt. Schlössels. Zie ook: Widdershoven 1989, p. 121.

128. Voorts staat niet tegen ieder besluit in de zin van art. 1:3 Awb beroep open op de bestuursrechter. Uitzonderingen zijn te vinden in art. 8:2 tot en met 8:6 Awb.

${ }^{129}$. Daarmee is de invulling van het begrip belanghebbende bepalend voor de rechtsbescherming in het bestuursrecht. Het EHRM hanteert soms een ruimer begrip in het kader van de vraag voor wie toegang tot een rechter moet openstaan dan de Nederlandse bestuursrechter. De Afdeling is onlangs, naar aanleiding van de uitspraak van het EHRM in de zaak Coorplan Jenni GmbH (EHRM 27 juli 2006, Coorplan Jenni GmbH en Hascic t. Oostenrijk, EHRC 2006/122 en JB 2006/287 m.nt. Schlössels), omgegaan en merkt de vreemdeling, die een van de werkgever (als aanvrager) afgeleid belang heeft bij de beslissing, aan als belanghebbende bij een tewerkstellingsvergunning op grond van de WAV, zie AbRvS 5 september 2007, AB 2008/4 m.nt. De Waard; JB 2007/194 m.nt. Red.

130. Op grond van art. 6:6 Awb dient echter wel eerst een gelegenheid tot herstel van het verzuim te moeten worden geboden, alvorens niet-ontvankelijkheid mag volgen.

131. Zie ook: Widdershoven 1989, p. 123. In de Crisis- en herstelwet die op 31 maart 2010 in werking is getreden is op die bepaling een uitzondering gemaakt. In art. 1.6 lid 2 is neergelegd dat het beroep niet ontvankelijk is (zonder herstelmogelijkheid) als de gronden van het beroep niet in het beroepschrift zijn opgenomen, zoals vereist in art. 6:5 lid 1 sub d Awb.

132. Zie ook: Widdershoven 1989, p. 123.

133. EHRM 24 april 2008, Kemp e.a. t. Luxemburg, EHRC 2008/78 m.nt. Fernhout. Zie voor meer uitspraken hierover de noot van Fernhout. Ook hierover de noot van Barkhuysen en Van Emmerik bij EHRM 24 mei 2006 , Liakopoulou t. Griekenland, AB 2006/257 met verwijzingen naar jurisprudentie.

${ }^{134}$ Vgl. ook Jansen die aangeeft dat meer Europese landen een verplichting tot het volgen van een voorprocedure kennen alvorens de toegang tot de rechter openstaat, Jansen 2004, p. 22.

135. Op grond van art. 7:1 jo. 8:1 Awb is de bezwaarschriftprocedure de algemene voorprocedure die doorlopen moet worden. Deze kan overgeslagen worden indien aan de voorwaarden genoemd in art. 7:1a Awb is voldaan. Daarnaast bestaan er uitzonderingen op de hoofdregel dat eerst bezwaar moet worden gemaakt in art. 7:1 lid 1 sub a $\mathrm{t} / \mathrm{m}$ e Awb. 


\section{De beginselen}

gen zijn (of worden geïnterpreteerd) dat het recht op toegang tot de rechter daardoor te vergaand beperkt wordt. ${ }^{136}$

In het kader van dit onderzoek zou echter ook de vraag gesteld kunnen worden of er zoiets geldt als een recht op toegang tot de bestuurlijke voorprocedures. De Waard besteedt in zijn dissertatie uitdrukkelijk aandacht aan die vraag voor de beslissing in primo. Uit de toepasselijke voorschriften blijkt vaak of een burger het recht heeft om een bepaald verzoek om een beslissing te doen. De Waard geeft ook aan dat, indien een burger een formele aanvraag voor een besluit doet - hetzelfde geldt voor het indienen van een bezwaarschrift of beroepschrift - hij recht heeft op een beslissing op zijn verzoek. Er moet dan in elk geval een bevoegdheid voor het bestuur bestaan om een beslissing te nemen, die in beginsel in een wettelijke regeling gegeven is. In deze zin geldt ook voor de besluitvormingsprocedures van het bestuur een decisiebeginsel. ${ }^{137}$ Eveneens onder Awb geldt dat, indien een bezwaarschriftprocedure aanhangig is gemaakt, het bestuursorgaan op grond van artikel 7:11 eerste lid van de Awb de plicht heeft om een besluit op bezwaar te nemen. ${ }^{138}$ Daaruit kan mijns inziens echter slechts worden afgeleid dat indien bezwaar kan worden gemaakt, er ook een beslissing van het bestuur dient te volgen. De wetgever is niet verplicht de toegang tot een bestuurlijke voorprocedure open te stellen. Een recht op toegang tot een voorprocedure - nog afgezien van de vraag of zulks in alle gevallen ook zinvol is ${ }^{139}$ - kan daaruit niet worden afgeleid. Om die reden heb ik ervoor gekozen de zelfstandige betekenis van dit vereiste voor de bestuurlijke voorprocedures niet verder te onderzoeken. Die keuze is daarenboven ook ingegeven door de omstandigheid dat het recht op toegang tot de rechter, hoewel het een geldende eis in het Nederlandse bestuursrecht betreft, geen rechtsnorm voor de behoorlijkheid van een lopende procedure vormt.

\subsubsection{Onafhankelijkheid van de rechter}

Plaats en betekenis van de onafhankelijkheid van de rechter

Hoewel onafhankelijkheid in dit onderzoek een element van het begrip rechtspraak vormt - en niet zozeer een beginsel van behoorlijke rechtspleging of behoorlijkheidsnorm waaraan rechtspraak moet voldoen - worden de onafhankelijkheidseisen toch op deze plaats (naast of tussen de behoorlijkheidsbeginselen) behandeld. Reden daarvoor is dat het, zoals eerder aangegeven, voor de toetsing van een procedure aan deze eisen niet terzake doet of dat uit hoofde van toetsing aan het begrip rechtspraak of uit hoofde van toetsing aan het toepasselijke behoorlijkheidskader geschiedt. Er dient toetsing plaats te vinden en de oordelende instantie moet aan de onafhankelijkheidseisen voldoen. Daar komt bij dat onafhankelijkheid van de rechter, zoals hierna nog zal blijken, ook een voorwaarde voor onpartijdigheid van de rechter - dat wel een beginsel van behoorlijke rechtspeging vormt - is. In het belang van de overzichtelijkheid worden de onafhankelijkheidseisen te midden van de overige behoorlijkheidseisen behandeld.

Vaststaat in elk geval dat het vereiste van onafhankelijkheid onlosmakelijk verbonden is met rechtspraak. ${ }^{140}$ Desondanks is een expliciete verwijzing naar de (vereiste)

${ }^{136 .}$ H.J. Simon, 'Bestuursrecht en mensenrechten. Top down of bottom up?', NJB 1999 (hierna: Simon 1999a), p. 1190.

137. De Waard 1987, p. 178-180. Zie ook: L.J.A. Damen, H.E. Bröring e.a., Deel II Bestuursrecht. Rechtsbescherming tegen de overheid. Bestuursprocesrecht, Den Haag: BJu 2009, p. 26.

${ }^{138}$ Damen e.a. 2009, p. 26. Zie ook art. 6:20 lid 1 Awb waaruit de plicht tot het nemen van een (primair) besluit kan worden afgeleid.

${ }^{139}$ In sommige gevallen vormt het doorlopen van een voorprocedure immers te zeer een herhaling van zetten en kan de toegevoegde waarde betwijfeld worden. Zie hierover Deel II par. 1.4.

140. Alkema noemt onafhankelijkheid (en onpartijdigheid) het wezenskenmerk van de rechterlijke macht, E.A. Alkema, 'De rechterlijke macht - enige opmerkingen vooraf', in: J.P. Loof (red.), Onafhankelijkheid en onpartijdigheid. De randvoorwaarden voor het bestuur en beheer van de rechterlijke macht', Leiden: Stichting NJCM-Boekerij 36 1999, p. 3. 


\section{Deel I Beginselen van behoorlijke rechtspleging}

onafhankelijkheid van de rechter in de Grondwet niet te vinden. ${ }^{141}$ De Grondwet bevat uitsluitend enkele garanties die de onafhankelijkheid beogen te waarborgen in artikel $117 .^{142}$ Het is echter een gegeven dat de rechter of rechtspraak onafhankelijk van de wetgever en het bestuur behoort te functioneren. ${ }^{143}$ Reeds geruime tijd wordt vanuit het beginsel van machtenscheiding en de rechtsstaatgedachte alsmede onder invloed van artikel 6 EVRM aan rechterlijke instanties de eis van onafhankelijkheid gesteld. ${ }^{144}$ In het bestuursrecht krijgt deze eis nog meer betekenis, omdat de overheid in de meeste gevallen partij is in het geschil dat de bestuursrechter moet beslechten. Zoals Brenninkmeijer opmerkt, staat de onafhankelijkheid van de rechter in het bestuursrecht met name voor de onafhankelijkheid ten opzichte van het bestuur. ${ }^{145}$ De afgelopen jaren is er veel te doen geweest over de onafhankelijkheid en de onpartijdigheid van de hoogste algemene bestuursrechter, de Afdeling. ${ }^{146}$ De problematiek vloeit voort uit het feit dat sommige staatsraden zowel bij de wetgevingsadvisering over een wetsvoorstel betrokken kunnen zijn als bij de beslechting van geschillen op grond van dezelfde wet. Die combinatie van functies werd door het EHRM in de zaak Procola ongeoorloofd geacht. ${ }^{147}$ Gebleken is echter uit de uitspraak Kleyn e.a. dat de situatie bij de Nederlandse Raad van State niet per definitie in strijd is met artikel 6 EVRM. ${ }^{148}$ Op 1 september 2010 is de wet tot herstructurering van de Raad van State ${ }^{149}$, waaruit volgt dat de Raad van State in twee afdelingen wordt opgedeeld, in werking getreden. ${ }^{150}$ Er komt een Afdeling advisering naast de Afdeling bestuursrechtspraak. Er bestaat echter, indien het wetsvoorstel kracht van wet krijgt, nog steeds een (theoretische) mogelijkheid dat bepaalde staatsraden betrokken zijn bij zowel wetgevingsadvisering als bestuursrechtspraak. ${ }^{151}$ Dat lijkt echter vooral

141. Zie ook: Van der Pot/Donner waarin ook wordt aangegeven dat rechterlijke onafhankelijkheid desondanks als een kernwaarde van de rechtsstaat wordt gezien, Van der Pot/Donner 2006, p. 603.

142. Het betreft enkele rechtspositionele waarborgen. Over het onderscheid tussen verschillende vormen van onafhankelijkheid kom ik hierna nog te spreken. Deze grondwettelijke waarborgen gelden overigens alleen voor de rechterlijke macht. Daarvan maken de hoogste bestuursrechters, met uitzondering van de belastingkamer van de HR, geen onderdeel uit.

143. Cliteur merkt nog op dat de rechter ook onafhankelijk van de rechterlijke macht, dat wil zeggen van andere rechters en het OM, behoort te functioneren, P.B. Cliteur, 'De onafhankelijkheid van de rechterlijke macht: acht vormen', in: J.P. Loof (red.), Onafhankelijkheid en onpartijdigheid. De randvoorwaarden voor het bestuur en beheer van de rechterlijke macht', Leiden: Stichting NJCM-Boekerij 36 1999, p. 13 en 15-20. Hoe ver deze onafhankelijkheid ten opzichte van andere rechters reikt, is echter niet geheel duidelijk. De rechter houdt immers rekening met uitspraken van andere rechters, er is overleg tussen verschillende rechterlijke instanties e.d.

${ }^{144 .}$ Bovend'Eert 2008, p. 17; M. Kuijer, The blindfold of Lady Justice. Judicial independence and impartiality in light of the requirements of article 6 ECHR, Nijmegen: Wolf Legal Publishers 2004, p. 203-210; L.F.M. Verhey, 'De onafhankelijkheid van de rechter naar Nederlands recht', Deventer: W.E.J. Tjeenk Willink 2001, p. 20; Widdershoven 1989, p. 21-22; Brenninkmeijer 1987, p. 8-12.

145. Brenninkmeijer 1987, p. 14.

146. Zie hierover: L.F.M. Verhey, 'De toekomst van de Raad van State: het einde van de Procola-kramp?, in: A.W. Heringa, A.M.L. Jansen, E. van der Linden en L.F.M. Verhey, Het bestuursrecht beschermd (liber amicorum F.A.M. Stroink), Den Haag: Sdu 2006, p. 17 e.v.; Rapport VAR-Commissie Rechtsbescherming, De toe komst van de rechtsbescherming tegen de overheid. Van toetsing naar geschilbeslechting, Den Haag: Bju 2004, p. 53-56; A.J. Bok, 'Het EHRM-arrest Kleyn e.a.: Raad van State grotendeels gesauveerd, maar nog niet uit de gevarenzone', Gst. (2003) 7186, p. 296-300; Th.G. Drupsteen, 'De Raad van State na Kleyn and others versus the Netherlands, NTB 2003/10, p. 317-323; R.A. Lawson, 'Procola in de polder. Een kleyne uitspraak over grote vragen', NJB 2003, p. 1114 e.v.; P. van Dijk, Artikel 6 EVRM en de Afdeling bestuursrechtspraak van de Raad van State, Lezing ter gelegenheid van de $19^{\mathrm{e}}$ verjaardag van het SIM op 26 oktober 2000, Utrecht: SIM 2001; N.S.J. Koeman, 'De gevolgen van de Procola-uitspraak voor Nederland', NTB 1996, p. 197 e.v.

${ }^{147 .}$ EHRM 28 september 1995, Procola t. Zwitserland, AB 1995/588 m.nt. ICvdV.

148. EHRM 6 mei 2003, Kleyn e.a. t. Nederland, $A B$ 2003/211, m.nt. L.V en BdeW; JB 2003/119 m.nt. AWH; EHRC 2003/54 m.nt. J.H. Gerards.

${ }^{149}$ Zie voor het wetsvoorstel en toelichting: Kamerstukken II, 2005/06, 30 585, nr. 1 e.v.

${ }^{150 .}$ Wet van 22 april 2010, Stb. 2010, 175; Besluit van 8 juni 2010 tot vaststelling van het tijdstip van inwerkingtreding van de wet van 22 april 2010 tot wijziging van de Wet op de Raad van State in verband met de herstructurering van de Raad van State (Stb.175), Stb. 2010, 236.

${ }^{151}$ Zij kunnen lid blijven van beide Afdelingen, zie hierover: A.J. Bok, 'De Raad van State gereorganiseerd, $N J B$ 2007, p. 266 e.v.; T. Barkhuysen, 'Het vereiste van rechterlijke onpartijdigheid en de voorgestelde nieuwe Wet op de Raad van State: mag het een onsje meer zijn?, Regelmaat 2007/3, p. 119 e.v. Zie ook de noten bij EHRM 9 november 2006, Sacilor-Lormines t. Frankrijk, AB 2007/281 m.nt. De Waard; EHRC 2007/15 m.nt. Verhey. 


\section{De beginselen}

vanuit het oogpunt van de vereiste onpartijdigheid problematisch te zijn en niet zozeer vanuit de vereiste onafhankelijkheid.

\section{Onafhankelijkheid in verschillende opzichten}

Onafhankelijkheid dient te bestaan in verschillende opzichten. In het algemeen wordt er een onderscheid gemaakt tussen functionele of zakelijke onafhankelijkheid en persoonlijke of rechtspositionele onafhankelijkheid. ${ }^{152}$ Onder functionele onafhankelijkheid wordt dan in het bijzonder onafhankelijkheid in de uitoefening van de rechterlijke werkzaamheid ten opzichte van de beide andere staatsmachten verstaan, hetgeen betekent dat de andere staatsmachten zich verre van de rechterlijke oordeelsvorming moeten houden. ${ }^{153}$ Dit aspect van functionele onafhankelijkheid wordt ook wel constitutionele onafhankelijkheid genoemd en valt terug te voeren op de theorie van de machtenscheiding. ${ }^{154}$ Daarmee hangt samen de sub judice-regel, waaruit volgt dat leden van de Tweede Kamer of ministers geen kritiek mogen geven op een zaak die onder de rechter is. ${ }^{155}$ Kuijer geeft verder aan dat soms onder functionele onafhankelijkheid ook feitelijke onafhankelijkheid wordt begrepen: onafhankelijke oordeelsvorming zonder druk van andere (externe, buiten de overheid liggende) actoren, zoals belangengroeperingen of de publieke opinie. ${ }^{156}$ Hij wijst er echter ook op dat deze feitelijke onafhankelijkheid niet geheel onomstreden is en door sommigen onder de onpartijdigheidseisen gebracht wordt. ${ }^{157}$ Kuijer schaart verder onder deze feitelijke onafhankelijkheid de interne onafhankelijkheid van de rechter, dat wil zeggen vrijwaring van druk binnen de rechterlijke macht of rechterlijke organisatie door bijvoorbeeld hierarchische relaties, doelmatigheid van de organisatie, interne richtlijnen of professionele ambities. ${ }^{158}$ In zijn optiek betekent onafhankelijkheid in enge zin onafhankelijkheid van de andere staatsmachten (zoals het begrip traditioneel wordt uitgelegd), terwijl het in ruime zin (zoals het tegenwoordig ook wel wordt opgevat) betekent dat de rechter zijn beslissing kan nemen gebaseerd op zijn eigen 'free conscience' onafhankelijk van druk van welke autoriteit dan ook, zoals andere staatsorganen (waaronder rechters), partijen en belangengroeperingen. ${ }^{159}$ De functionele onafhankelijkheid vereist in elk geval dat de uitoefening van de rechterlijke functie gevrijwaard blijft van invloeden of aanwijzingen van andere (overheids)organen waardoor een zelfstandige oordeelsvorming door de rechter gewaarborgd is. ${ }^{160}$

De eisen in het kader van de rechtspositionele of persoonlijke onafhankelijkheid van rechterlijke instanties hebben niet zozeer betrekking op de rechterlijke werkzaamheid, maar op de rechtspositie van de rechter en de vraag of er voldoende waarborgen bestaan ter bescherming ervan. ${ }^{161}$ Het betreft eisen inzake de benoeming, de benoemingstermijn

152. F.J.F.M. Duynstee, 'Rechterlijke onafhankelijkheid', in: G.C.J.J. van den Bergh e.a. (red.), Rechtspleging. Opstellen rond het thema rechterlijke organisatie, Deventer: Kluwer 1974, p. 43-54. De indeling is afkomstig van Duynstee en gangbaar in de doctrine, zie: Bovend'Eert 2008, p. 18; Kuijer 2004, p. 207-209; Verhey 2001,

p. 20-21; Stroink 1999, p. 8-9; Stroink 1993, p. 13-14; Brenninkmeijer 1987, p. 18 e.v.

${ }^{153 .}$ Bovend'Eert 2008, p. 21; Verhey 2001, p. 21.

154. Kuijer 2004, p. 207. Zie ook: Stroink 1999, p. 9.

${ }^{155 .}$ Barkhuysen, Van Emmerik \& Gerards 2009, p. 19; Bovend'Eert 2008, p. 23.

${ }^{156 .}$ Kuijer 2004, p. 207-208.

157. Zie bijvoorbeeld Stroink 1999, p. 9 en Verhey 2001, p. 22, die deze mening zijn toegedaan. Volgens Kuijer brengt feitelijke afhankelijkheid echter de onafhankelijkheid van de rechter in gevaar zodra de externe druk een structureel en systematisch karakter heeft, Kuijer 2004, p. 208.

${ }^{158 .}$ Kuijer 2004, p. 208. Ook in die zin: Duynstee 1974, p. 43. Geheel onomstreden is ook deze interne onafhankelijkheid niet zoals Kuijer zelf aangeeft. Zie ook: Verhey 2001,p. 21; Stroink 1999, p. 8 en 9 en Stroink 1993,

p. 13. Zoals aangegeven, zie noot 143, is nog niet geheel duidelijk in hoeverre onafhankelijkheid ten opzichte van andere rechters geldt.

${ }^{159 .}$ Kuijer 2004, p. 207.

${ }^{160 .}$ Bovend'Eert 2008, p. 21; Kortmann 2008, p. 364; Kuijer 2004, p. 207-208; Stroink 2004a, p. 67; Verhey 2001, p. 20-22; Stroink 1999, p. 8; Stroink 1993, p. 13; Brenninkmeijer 1987, p. 33; Duynstee 1974, p. 43.

${ }^{161 .}$ Kuijer 2004, p. 209; Verhey 2001, p. 21. 


\section{Deel I Beginselen van behoorlijke rechtspleging}

en ontslag. ${ }^{162}$ Deze waarborgen beogen de onafhankelijkheid van de rechter te bevorderen.

De onafhankelijkheid van rechterlijke instanties vormt, gelet op het bovenstaande, een waarborg tegen te vergaande inmenging in de rechterlijke taakuitoefening van in het bijzonder de beide andere staatsmachten, wetgever en bestuur. Daarnaast is volgens sommigen een waarborg tegen inmenging van andere externe en interne actoren. Ook het vereiste van een onafhankelijk gerecht, neergelegd in artikel 6 EVRM, omvat onafhankelijkheid in de hiervoor bedoelde betekenissen. ${ }^{163}$ Het EHRM overweegt echter daarnaast in zijn uitspraken tevens dat onafhankelijkheid wil zeggen onafhankelijkheid van de bij de procedure betrokken partijen. ${ }^{164}$ Primair zou ik het vereiste van onafhankelijkheid willen reserveren voor de verhouding van de rechterlijke instantie tot de andere staatsmachten (of andere overheidsorganen) en het vereiste van onpartijdigheid voor de verhouding (of zo men wil de onafhankelijkheid) van de rechterlijke instantie tot partijen in de concrete procedure (of andere actoren zoals belangengroeperingen of de publieke opinie) en het concrete geschil. ${ }^{165}$ Het voorgaande maakt echter wel duidelijk dat onafhankelijkheid en onpartijdigheid niet altijd duidelijk te scheiden (en soms te onderscheiden) zijn - het EHRM maakt in elk geval ook niet altijd een scherp onderscheid. ${ }^{166}$ Bovendien kunnen onpartijdigheid en onafhankelijkheid opgevat in genoemde zin door elkaar lopen, indien een overheidsorgaan of overheidsfunctionaris partij is bij een procedure. $^{167}$

Secundair: onafhankelijkheid als waarborg voor onpartijdigheid

In dat kader zijn we aanbeland bij de secundaire betekenis of functie van onafhankelijkheid (naast de primaire betekenis in het kader van de scheiding der machten). De onafhankelijkheid van het beslissende orgaan heeft namelijk een functie ten dienste van de onpartijdigheid van het beslissende orgaan. Onafhankelijkheid vormt een waarborg voor onpartijdigheid. ${ }^{168}$ Hoewel hierover overeenstemming bestaat in de doctrine, verschillen de meningen over de vraag of dat de enige en/of primaire functie is van de onafhankelijkheidseisen alsmede over het onderscheidend vermogen van de onafhankelijkheidseisen ten opzichte van de onpartijdigheidseisen. De Werd stelt hieromtrent:

"Rechterlijke onpartijdigheid staat tot rechterlijke onafhankelijkheid in een doel/middelen-verhouding. De staatsrechtelijke onafhankelijkheid van de rechterlijke macht schept de voorwaarden waarbinnen de onpartijdige rechterlijke mentaliteit tot haar recht kan komen." 169

Ook De Waard meent dat de onafhankelijkheidseis een voorwaardescheppende factor is en een species vormt van onpartijdigheid. ${ }^{170} \mathrm{Om}$ die reden moet deze eis als inrichtingseis worden beschouwd en niet als beginsel van behoorlijke rechtspraak. ${ }^{171}$ Voor zover de onafhankelijkheidseisen ten dienste staan aan de onpartijdigheid van het geschilbeslech-

\footnotetext{
162. Stroink 1999, p. 9; Stroink 1993, p. 13; Brenninkmeijer 1987, p. 18 e.v.

163. Zie hierover: Kuijer 2004, p. 216 en 300.

164. Zie bijvoorbeeld: EHRM 22 oktober 1984, Sramek t. Oostenrijk, nr. 8790/79, par. 42; EHRM 16 juli 1971, Ringeisen t. Oostenrijk, nr. 2614/65, par. 95. Zie hierover ook: Van Dijk \& Van Hoof e.a. 2006, p. 613.

165. Zo ook: Bovend'Eert 2008, p. 17; Van Dijk \& Van Hoof e.a. 2006, p. 613; Stroink 1999, p. 8-9; Stroink 1993, p. 4.

166. Bovend'Eert 2008, p. 21-22; Van Dijk \& Van Hoof e.a. 2006, p. 613; Stroink 1999, p. 9-10 en 20-21; De Werd 1999, p. 37; P.B. Cliteur, 'De onafhankelijkheid van de rechterlijke macht: acht vormen', in: J.P. Loof (red.), Onafhankelijkheid en onpartijdigheid. De randvoorwaarden voor het bestuur en beheer van de rechterlijke macht, Leiden: Stichting NJCM-Boekerij 36 1999, p. 9.

167. Van Dijk geeft aan dat indien er een formele of feitelijke band bestaat met een overheidsorgaan dat tevens deelnemer is in de procedure, de onafhankelijkheid en onpartijdigheid samenvallen, Van Dijk 1983, p. 1214

168. Van Dijk 1997, p. 1214; Widdershoven 1989, p. 125.

${ }^{169 .}$ De Werd 1999, p. 32.

${ }^{170 .}$ De Waard 1987, p. 111 en 330-339. De Waard meent dat een beslissing van een rechterlijke instantie behoor-

lijk kan zijn, ook al is de onafhankelijkheidseis niet in acht genomen, p. 330.

${ }^{171 .}$ De Waard 1987, p. 111.
} 


\section{De beginselen}

tende orgaan, hebben zij wellicht niet of nauwelijks onderscheidend vermogen ten opzichte van die eisen. Zij staan echter niet uitsluitend ten dienste van de onpartijdigheid, zoals uit het bovenstaande blijkt. Bovendien is dat ook niet de enige of primaire functie die onafhankelijkheid heeft. De eis komt ook een zelfstandige functie toe in het kader van de scheiding der machten en heeft een rechtsstatelijke betekenis. ${ }^{172}$ Zoals Widdershoven opmerkt, kan het onafhankelijkheidsbeginsel worden opgevat als één van de garanties voor onpartijdigheid, maar vereist het beginsel allerlei organisatorische waarborgen die niet in direct verband staan met onpartijdigheid (zoals bij voorkeur benoeming voor het leven, rechtsmachttoedeling bij wet). ${ }^{173}$ Illustratief in dat kader is ook hetgeen Brenninkmeijer stelt omtrent de onverenigbaarheid van het rechterlijke ambt met de vervulling van verschillende andere functies in de samenleving. In zijn optiek kunnen incompatibiliteiten tweeërlei achtergrond hebben: de machtenscheiding (denk aan onverenigbaarheid van het ambt van minister of kamerlid met dat van rechter) en het vergroten van de onpartijdigheid (afhankelijk van de plaats van het gerecht in het maatschappelijk leven wordt bepaald welke functies voor leden van dat gerecht onverenigbaar zijn). ${ }^{174} \mathrm{Er}$ kan derhalve een duidelijk onderscheid tussen deze twee functies van de onafhankelijkheidseisen gemaakt worden. Onpartijdigheid heeft primair betrekking op de verhouding tussen rechter en partijen of procesdeelnemers (hetgeen in het bestuursrecht ook uiteraard de uitvoerend macht kan zijn) en de houding van de rechter jegens de specifieke zaak die ter beoordeling voorligt. ${ }^{175}$ Onafhankelijkheid ziet niet op die verhouding (tot het concrete geval en de betrokken partijen), maar kan wel een inrichtingseis zijn die onpartijdigheid in die verhouding bevordert. Onafhankelijkheid ten opzichte van partijen en andere actoren levert meer distantie op bij de beoordeling en op die manier een zo objectieve mogelijke beslissing. De omstandigheid dat voldaan is aan de onafhankelijkheidseisen betekent echter niet automatisch dat ook de vereiste onpartijdigheid in acht is genomen. Onafhankelijkheid vormt, zoals De Waard stelt, een van de geobjectiveerde criteria voor het ontbreken van schijn van partijdigheid, maar zeker niet het enige criterium. ${ }^{176}$ Andersom hoeft gebrek aan onafhankelijkheid ook niet per definitie te betekenen dat er sprake is van (de schijn van) partijdigheid. Al zal vaak om die reden geoordeeld kunnen worden dat een burger objectief gerechtvaardigde twijfels heeft omtrent de onpartijdigheid van het orgaan; de structurele of objectieve onpartijdigheid van het orgaan is dan in het geding. ${ }^{177}$

Deze secundaire functie van onafhankelijkheid, als waarborg voor onpartijdigheid, kan wellicht nog van betekenis zijn voor procedures die niet bij een rechterlijke instantie gevoerd worden, zoals de bestuurlijke voorprocedures. Te denken valt bijvoorbeeld aan advisering door de bezwaarschriftcommissie of andere deskundigen. De mate waarin onafhankelijkheid als eis een zekere betekenis heeft of kan hebben in de bestuurlijke voorprocedures komt echter nog nader aan bod in Deel II, paragraaf 5.4.

Samenhang met het onpartijdigheidsbeginsel en de andere beginselen

Uit het bovenstaande is reeds gebleken dat de onafhankelijkheidseisen een belangrijke functie hebben in het licht van de triasgedachte. De rechter dient onafhankelijk ten opzichte van bestuur en wetgever recht te spreken. Met deze functie van de onafhankelijkheid van de rechter hangt ook voor een belangrijk deel het vertrouwen van partijen en het publiek in de rechter of rechtspraak samen. Onafhankelijkheid dient derhalve ook dit

\footnotetext{
172. Vgl. Verhey 2001, p. 23. Verhey wijst op de grondrechtelijke context van art. 6 EVRM en de interpretatie van die bepaling vanuit de invalshoek van de bescherming van het individu terwijl rechterlijke onafhankelijkheid rechtsstatelijk gezien een bredere betekenis heeft.

${ }^{173 .}$ Widdershoven 1989, p. 125.

174. Brenninkmeijer 1987, p. 23.

${ }^{175 .}$ Het begrip onpartijdigheid komt in de volgende paragraaf nader aan de orde.

176. De Waard 1987, p. 331. Vgl. ook: Van Dijk 1997, p. 1214.

177. Vgl. De Waard 1987, p. 33. Stroink meent dat indien er iets schort aan de onafhankelijkheid, er per definitie ook iets schort aan de structurele of objectieve onpartijdigheid. Stroink 1999, p. 19.
} 


\section{Deel I Beginselen van behoorlijke rechtspleging}

algemene belang en, zoals hiervoor aangegeven, in mijn optiek primair dit belang. De secundaire betekenis van de onafhankelijkheidseisen, namelijk als waarborg voor onpartijdigheid, dient meer de belangen van partijen bij de procedure en de rechtsbescherming van die partijen. Dat is ook de voornaamste ratio van de onpartijdigheidseisen (hoewel toegegeven moet worden dat ook hiervan, vooral in combinatie met het vereiste van een openbare behandeling van de zaak, het vertrouwen van het publiek in de rechter afhankelijk is). ${ }^{178}$ De samenhang van de onafhankelijkheidseisen met andere beginselen van behoorlijke rechtspleging is minder duidelijk aanwezig. Wellicht hangt dat ook samen met de omstandigheid dat de onafhankelijkheidseisen, in vergelijking tot de meeste andere beginselen, nadrukkelijker (of primair) in het perspectief van de trias politica geplaatst moeten worden.

Criteria en eisen om de onafhankelijkheid te waarborgen

De eisen die gelden om onafhankelijkheid te waarborgen worden doorgaans, vooral op grond van de jurisprudentie van het EHRM, in verschillende categorieën, ondergebracht: benoemingstermijn, wijze van benoeming, garanties tegen invloed of druk van buitenaf en schijn van afhankelijkheid. ${ }^{179}$ Het betreft waarborgen ten dienste aan zowel de persoonlijke als functionele onafhankelijkheid. Deze eisen worden hieronder kort toegelicht. A) de benoemingstermijn: hoe langer de benoemingstermijn, hoe meer de onafhankelijkheid daarmee gewaarborgd wordt. Bij voorkeur dienen rechterlijke instanties voor het leven benoemd te worden. Op grond van de jurisprudentie van het EHRM in het kader van artikel 6 EVRM is dit echter niet noodzakelijk. Het EHRM neemt genoegen met relatief korte termijnen; termijnen van drie jaar, vier jaar en zes jaar zijn termijnen die het Hof gebillijkt heeft. ${ }^{180}$ De eisen die het EHRM stelt in dit kader zijn derhalve niet erg stringent. In Nederland worden de leden van de rechterlijke macht voor het leven benoemd op grond van artikel 117, eerste lid, Grondwet. Voor bestuursrechterlijke instanties die niet tot de rechterlijke macht behoren geldt deze bepaling niet, maar geldt wél dat de leden ervan voor het leven worden benoemd. ${ }^{181}$

B) de wijze van benoeming: bij voorkeur zou benoeming van de rechter niet plaats moeten vinden door de uitvoerende macht, maar het is geoorloofd in de ogen van het EHRM als zulks het geval is. ${ }^{182}$ Wel geldt dat er in dat geval andere factoren moeten zijn die de onafhankelijkheid voldoende waarborgen. ${ }^{183}$ Ook inzake dit criterium zijn de eisen derhalve niet erg streng. ${ }^{184}$ In Nederland wordt de rechterlijke macht bij koninklijk besluit door de regering benoemd, volgens eerder genoemd artikel 117, eerste lid, Grondwet. Voor de overige bestuursrechters geldt dat benoeming eveneens plaatsvindt bij koninklijk besluit. ${ }^{185}$

\footnotetext{
${ }^{178 .}$ Hierop wordt in de volgende paragraaf nog nader ingegaan.

179. Bijvoorbeeld: EHRM 28 juni 1984, Campbell en Fell t. Verenigd Koninkrijk, nrs. 7819/77, 7878/77, par. 78. Zie verder hierover: Van Dijk \& Van Hoof e.a. 2006, p. 613-614; Heringa in: J.H. Gerards, A.W. Heringa, H.L. Janssen en J. van der Velde, EVRM Rechtspraak en Commentaar, katern. Art. 6 Eerlijk proces, Haag: Sdu 1-12004, par. 3.6.5, p. 2-6; Widdershoven 125-126.

180. Campbell and Fell, par. 80; EHRM 29 april 1988, Belilos t. Zwitserland, nr. 10328/83, par. 66; EHRM 23 juni 1981, Le Compte, Van Leuven en De Meyere t. België, NJ 1982/602, par. 57.

${ }^{181 .}$ Tot de rechterlijke macht behoren de kantongerechten, rechtbanken, gerechtshoven en de Hoge Raad volgens art. 2 RO. Op de CRvB en CBb is ingevolge art. 4 Beroepswet en art. 5 WBBO de Wet op de rechtspositie rechterlijke ambtenaren deels van toepassing, waaronder art. 1a lid 1 waarin is geregeld dat benoeming voor het leven geschiedt. De vice-president en de staatsraden van de Raad van State worden eveneens voor het leven benoemd op grond van art. 74 lid $2 \mathrm{GW}$ en art. 3, 3a WRvS. Voor staatsraden in buitengewone dienst gelden deze bepalingen eveneens, krachtens art. $4 \mathrm{WRvS}$.

182. Campbell en Fell, par. 79; Belilos, par. 66

${ }^{183 .}$ Heringa 2004, p. 3.

184. Zie Kuijer met verwijzingen naar jurisprudentie, Kuijer 2004, p. 216-231 en 301

185. Op de CRvB en CBb zijn ingevolge art. 4 Beroepswet en art. 5 WBBO is de Wet op de rechtspositie rechterlijke ambtenaren grotendeels van toepassing, waaronder art. 1a lid 1 waarin is geregeld dat benoeming bij koninklijk besluit plaatsvindt. De leden van de Raad van State worden op grond van art. 74 lid 2 GW en art. 3
} 


\section{De beginselen}

C) garanties tegen invloed of druk van buitenaf: deze garanties betreffen onder meer de aanwezigheid van ontslagbescherming voor rechters. Als die formele (wettelijke) bescherming tegen ontslag ontbreekt, kan volgens het EHRM de omstandigheid dat er de facto sprake is van ontslagbescherming, door bijvoorbeeld een praktijk dat rechters niet ontslagen worden, ook voldoen. ${ }^{186}$ In Nederland is in artikel 117, tweede lid en derde lid, van de Grondwet neergelegd in welke gevallen leden van de rechterlijke macht ontslagen kunnen worden: vanwege het bereiken van een bij de wet te bepalen leeftijd (thans 70 jaar ${ }^{187}$ ), op eigen verzoek of vanwege andere redenen bij de wet bepaald. Bovendien geldt dat, indien het gaat om ontslag (of schorsing) wegens andere redenen dan leeftijd of eigen verzoek, uitsluitend een gerecht behorend tot de rechterlijke macht daartoe kan overgaan. ${ }^{188}$ Dezelfde regeling geldt voor de overige bestuursrechters. ${ }^{189}$

D) schijn van afhankelijkheid of de indruk naar buiten: met deze eis wordt bedoeld dat de indruk naar buiten (oftewel de 'appearances') niet zodanig mag zijn dat er bij de burger objectief gerechtvaardigde twijfel kan ontstaan over de onafhankelijkheid. ${ }^{190}$ Het enkele feit dat de burger twijfels heeft - en dat is een subjectief gevoelen - is echter niet voldoende. ${ }^{191}$ Deze eis ligt in de jurisprudentie van het Hof dicht tegen de objectieve onpartijdigheidtoets aan (zoals ook in de volgende paragraaf zal blijken). ${ }^{192}$ Kuijer meent dat dit criterium eigenlijk niet te beschouwen is als een afzonderlijk criterium, omdat het een rol speelt bij alle voorgaande criteria. Bij al deze criteria kan immers schijn van afhankelijkheid bestaan. ${ }^{193}$

\subsubsection{Het onpartijdigheidsbeginsel}

Onpartijdigheid in de rechterlijke procedure

Zoals in de vorige paragraaf al naar voren kwam, hangen de concepten onafhankelijkheid en onpartijdigheid sterk samen. Onpartijdigheid van de rechter wordt, evenals of samen met onafhankelijkheid, beschouwd als een van de fundamentele principes in een democratische rechtsstaat en van het recht op een eerlijk proces. ${ }^{194}$

De kern van het onpartijdigheidsbeginsel houdt in dat de rechter of rechterlijke instantie onpartijdig, dat wil zeggen zonder vooringenomenheid en op objectieve wijze, tot zijn beslissing behoort te zijn gekomen, waarbij slechts de rechtens relevante belangen bij die beslissing een rol mogen spelen. Dat betekent dat de rechter neutraal moet staan ten opzichte van het onderwerp van het geschil en de bij het geschil betrokken partijen. ${ }^{195}$ De Waard stelt dat de beslissing zo objectief mogelijk moet zijn en dat de geschilbeslechtende instantie zich niet mag laten leiden door persoonlijke voorkeuren of belangen (van haar leden) of andere onzakelijke motieven. ${ }^{196}$ Onpartijdigheid heeft betrekking op de verhouding tussen de beslissende rechter (of rechters) en de partijen of deelnemers in de procedure. ${ }^{197}$

WRvS eveneens bij koninklijk besluit benoemd. Dat geldt, zoals aangegeven, ook voor staatsraden in buitengewone dienst op grond van art. 4 jo. $3 \mathrm{WRvS}$.

186. Campbell en Fell, par. 80.

187. Zie art. $46 \mathrm{~h}$ Wet op de rechterlijke organisatie.

188. Zie art. 117 lid 3 GW.

189. Op de CRvB en CBb zijn ingevolge art. 4 Beroepswet en art. 5 WBBO is de Wet op de rechtspositie rechterlijke ambtenaren grotendeels van toepassing, waaronder art. 46h-46n waarin deze kwesties geregeld zijn. Hetzelfde geldt voor de leden van de Raad van State op grond van art. 74 lid 3 en 4 GW en art. 3a WRvS. Voor staatsraden in buitengewone dienst is dat weer vastgelegd in art. 3a jo. $4 \mathrm{WRvS}$

${ }^{190 .}$ Campbell en Fell, par. 78 en 81; Belilos, par. 67.

${ }^{191 .}$ Kuijer 2004, p. 290.

192. Heringa 2004, p. 6; Stroink 1999, p. 19-20; De Werd 1999, p. 37.

${ }^{193 .}$ Kuijer 2004, p. 289.

194. Vgl.: Van Wijk/Konijnenbelt \& Van Male 2008, p. 629; Alkema 1999, p. 3; Van Dijk 1997, p. 1213.

${ }^{195 .}$ Van Dijk \& Van Hoof e.a. 2006, p. 613; Kuijer 2004, p. 303.

196. De Waard 1987, p. 127-128

197. Van Dijk \& Van Hoof e.a. 2006, p. 613; Van Dijk 1983, p. 1213. De onpartijdigheidseisen zien derhalve niet op de instantie als zodanig, maar uitsluitend op de beslissende rechter of lid dan wel leden van de meervoudig 
Deel I Beginselen van behoorlijke rechtspleging

In het algemeen wordt, in navolging van de jurisprudentie van het EHRM in het kader van artikel $6 \mathrm{EVRM}^{198}$, een onderscheid gemaakt tussen een subjectieve en objectieve toets in het kader van de vereiste onpartijdigheid. De subjectieve toets houdt in dat de rechter persoonlijk niet vooringenomen mag zijn en geen blijk mag geven persoonlijke opvattingen, belangen of overwegingen die daadwerkelijk op oneigenlijke wijze de uitkomst van de procedure beïnvloeden. ${ }^{199}$ De houding en het gedrag van de rechter ten opzichte van de zaak en de partijen wordt bezien. ${ }^{200}$ De persoonlijke onpartijdigheid van de rechter wordt door het EHRM verondersteld en het tegendeel moet bewezen worden. ${ }^{201}$ Persoonlijke partijdigheid is derhalve lastig te bewijzen en in de jurisprudentie van het EHRM wordt dan ook niet snel aangenomen dat er sprake was van subjectieve partijdigheid. Enkele voorbeelden daarvan zijn er echter wel in de jurisprudentie geweest. ${ }^{202}$ Het EHRM erkent ook de moeilijke bewijsbaarheid van subjectieve onpartijdigheid, maar ziet de objectieve onpartijdigheid als een belangrijke aanvullende waarborg en geeft ook aan dat om die reden de meeste gevallen in de jurisprudentie zich concentreren rond de objectieve onpartijdigheid. ${ }^{203}$

De objectieve toets ziet op de organisatorische en structurele onpartijdigheid van de rechterlijke instantie en houdt in dat er geen objectieve omstandigheden of feiten mogen bestaan waardoor een klager redelijkerwijs gerechtvaardigde twijfel kan hebben omtrent de onpartijdigheid van de rechterlijke instantie. ${ }^{204}$ Van daadwerkelijke partijdigheid behoeft derhalve geen sprake te zijn. Ook de schijn van partijdigheid moet in dit kader vermeden worden. ${ }^{205}$ Hier raakt de onpartijdigheid in de jurisprudentie van het EHRM de vereiste onafhankelijkheid. In het bijzonder betreft het de factor indruk naar buiten of schijn van afhankelijkheid die een rol speelt bij de vraag of het betreffende orgaan als onafhankelijk kan worden aangemerkt. ${ }^{206}$ Strijd met de objectieve onpartijdigheid is eenvoudiger te bewijzen, omdat 'slechts' aangetoond moet worden dat er redelijkerwijs gerechtvaardigde twijfel bestond aan de onpartijdigheid van de rechterlijke instantie. ${ }^{207}$ De opvatting van de betrokken partij is daarbij van belang maar niet doorslaggevend. Volgens het EHRM geeft de vraag of de vrees van de betrokken partij objectief gerechtvaardigd de doorslag. ${ }^{208}$ De objectieve toets houdt, zoals Van Dijk stelt, in dat een subjectief element (de vrees van de betrokken partij) geobjectiveerd wordt, althans naar objectieve maatstaven gemeten gerechtvaardigd moet zijn. ${ }^{209}$ Het is niet altijd duidelijk

beslissende kamer van de desbetreffende instantie. Uitsluitend waar de onafhankelijkheid en objectieve onpartijdigheid door elkaar lopen of elkaar raken, kan de instantie zelf in het geding zijn en niet zozeer de oordelende rechter(s).

${ }^{198 .}$ Het Hof introduceerde beide toetsen in de uitspraak Piersack t. België, EHRM 1 oktober 1982, nr. 8692/79, par. 30.

199. Van Dijk \& Van Hoof e.a. 2006, p. 616; Kuijer 2004, p 304; Jansen 2004, p. 76; A.W. Heringa, 'Wraking in het bestuursrecht', JB-plus 2001, p. 5; De Werd 1999, p. 35-36; Widdershoven 1989, p. 127.

${ }^{200}$. Van Dijk \& Van Hoof e.a.2006, p. 616; Kuijer 2004, p. 304; A.W. Heringa, 'Art. 6 Eerlijk proces. Onafhankelijk en onpartijdig gerecht dat bij de wet is ingesteld', in: J.H. Gerards, A.W. Heringa, H.L. Janssen en J. van der Velde, EVRM Rechtspraak en Commentaar, katern. Art. 6 Eerlijk proces, Haag: Sdu 1-1-2004, par. 3.6.5, p. 6.

201. EHRM 15 december 2005, Kyprianou t. Cyprus, EHRC 2006/21 m.nt. Jansen, par. 119 (Grote Kameruitspraak). Zie verder met verwijzingen naar jurisprudentie: Kuijer 2004, p. 305; Heringa 2004, p. 7; Heringa 2001, p. 5; Van Dijk 1997, p. 1214.

202. Zonder uitputtend te willen zijn, noem ik er een paar: EHRM 5 februari 2009, Olujić t. Kroatië, EHRC 2009/57 m.nt. De Werd; EHRM 15 december 2005, Kyprianou t. Cyprus, EHRC 2006/21 m.nt. Jansen; EHRM 9 november 2004, Svetlana Naumenko t. Oekraïne, nr. 41984/98; Lavents t. Letland, 28 november 2002, EHRC 2003/15 m.nt. Redactie.

203. Olujić, par. 58; Kyprianou, par. 119.

204. Zie bijvoorbeeld: Kyprianou, par. 118. Ook in die zin: Van Dijk \& Van Hoof e.a. 2006, p. 616; Kuijer 2004,

p. 304; Jansen 2004, p. 76; Heringa 2001, p. 5; Stroink 1999, p. 19-20; Widdershoven 1989, p. 127.

205. Eveneens overwogen in: Kyprianou, p. 118. Zie ook: Kuijer 2004, p. 304-305; Van Dijk 1997, p. 1215.

206. Kuijer 2004, p. 305; De Werd 1999, p. 37.

${ }^{207 .}$ Kuijer 2004, p. 305.

208. Zie bijvoorbeeld: EHRM 24 mei 1989, Hauschildt t. Denemarken, nr. 10486/83, par. 4. Hierover ook: Van

Dijk \& Van Hoof e.a. 2006, p. 616; Kuijer 2004, p. 305; Van Dijk 1997, p. 1215.

209. Van Dijk 1997, p. 1215. 


\section{De beginselen}

waarin bij de concrete toepassing op het voorliggende geval het onderscheid gelegen is tussen de objectieve toets in het kader van de onpartijdigheid en de toetsing van 'appearances' of de indruk naar buiten in het kader van de onafhankelijkheid. ${ }^{210}$ Onduidelijkheid bestaat ook inzake de toepassing van de objectieve onpartijdigheidtoets als zodanig en de door het EHRM gehanteerde criteria in dat kader. ${ }^{211}$ Op deze punten is de jurisprudentie van het EHRM dan ook aan kritiek onderhevig. ${ }^{212}$ Voorbeelden van gevallen (zonder uitputtend te willen zijn) 213 $^{213}$ waarin volgens het EHRM sprake kan zijn van een schending van de vereiste objectieve onpartijdigheid vormen: eerdere betrokkenheid van de rechter bij de rechterlijke procedure in hetzelfde geschil in een andere hoedanigheid $^{214}$, cumulatie van functies ${ }^{215}$ of behandeling van de zaak door de rechter in hoger beroep die ook in eerste aanleg een oordeel over de zaak heeft gegeven. ${ }^{216}$ Nevenfuncties kunnen problematisch zijn, maar zijn dat niet per definitie. ${ }^{217}$ Een strikte scheiding tussen de subjectieve en objectieve onpartijdigheid valt er volgens het EHRM echter niet altijd te maken. ${ }^{218}$ Het EHRM overweegt in Kyprianou dat zich twee situaties kunnen voordoen, waarin gebrek aan onpartijdigheid in het geding kan zijn: situaties die functioneel van aard zijn en die persoonlijk van aard zijn. Op de eerste situatie, waarin niet het persoonlijk gedrag van de rechter centraal staat maar de uitoefening van verschillende functies of de aanwezigheid van hiërarchische dan wel andere banden met een procesdeelnemer, wordt de objectieve toets toegepast. De tweede situatie heeft betrekking op het gedrag van de desbetreffende rechter in de voorliggende zaak. Afhankelijk van de specifieke feiten van het bestreden gedrag, wordt hierop de subjectieve of de objectieve toets dan wel worden beide toetsen toegepast. ${ }^{219}$ Het persoonlijke gedrag van de desbetreffende rechter kan aanleiding geven tot partijdigheid onder de objectieve toets, maar kan ook van dien aard zijn dat zelfs onder de subjectieve toets persoonlijke vooringenomenheid moet worden aangenomen.

De onpartijdigheidseisen blijven voorts niet altijd beperkt tot de rechterlijke instanties, maar kunnen zich ook uitstrekken naar andere actoren in de procedure. Voor dit onderzoek zijn in het bijzonder de eisen voor door de rechter ingeschakelde deskundigen van belang. De invloed van dergelijke deskundigen op de uiteindelijke uitkomst van de

\footnotetext{
${ }^{210 .}$ De Werd 1999, p. 37.

211. Van Dijk 1997, p. 1215-1217.

212. Kuijer 2004, p. 291-292; Stroink 1999, p. 30; De Werd 1999, p. 37. Zowel Kuijer als De Werd wijzen erop dat die kritiek ook afkomstig is van de rechters binnen het hof, zoals van de Nederlandse rechter Van Dijk in zijn dissenting opinion bij EHRM 26 augustus 1997, De Haan t. Nederland, JB 1997/186 m.nt. AWH.

213. Zie voor meer voorbeelden: Van Dijk \& Van Hoof e.a. 2006, p. 614-623; Van der Velde 2004, p. 8-13; Kuijer 2004, o.m. p. 334 e.v; Jansen 2004, p. 74-81.

214. Bv. als hoofd van een afdeling van het OM die verantwoordelijk was voor de vervolging, EHRM 1 oktober 1982, Piersack t. België, nr. 8692/79. Bv. als (familie van de) advocaat van de wederpartij, EHRM 15 juli 2005 Mežnarič t. Kroatië, EHRC 2005/100 m.nt. Jansen.

${ }^{215 .}$ EHRM 12 september 1995, Procola t. Luxemburg, AB 1995/588 m.nt. ICdV; JB 1995/383 m.nt. FAMS. De Procola-problematiek en de combinatie van rechtspraak en wetgevingsadvisering vallen onder deze categorie. Die combinatie kan strijd met de objectieve onpartijdigheid opleveren indien in beide gevallen geoordeeld moet worden over 'the same decision', zoals het EHRM in de zaak Kleyn e.a. tegen Nederland aangaf, EHRM 6 me 2003, AB 2003/211 m.nt. LV en BdeW; JB 2003/119 m.nt. AWH. Zie ook: EHRM 9 november 2006, SacilorLormines t. Frankrijk, AB 2007/281 m.nt. De Waard; EHRC 2007/15 m.nt. Verhey.

216. Strijd met art. 6 EVRM bestond bijvoorbeeld in EHRM 26 augustus 1997, De Haan t. Nederland, JB 1997/186 m.nt. AWH.

217. Zie bijv.: EHRM 22 juni 2004, Pabla Ky t. Finland, nr. 47221/99. Zie over het onderwerp nevenfuncties en rechterlijke onpartijdigheid: M. Kuijer, 'De blinddoek van Vrouwe Justitia of de luiken van de rechtspraak open? Over enkele recente ontwikkelingen op het terrein van de rechterlijke onafhankelijkheid en onpartijdigheid', in: T. Barkhuysen, M.L. van Emmerik en J.P. Loof (red.), Geschakeld recht. Verdere studies over Europese grondrechten ter gelegenheid van de $70^{\text {ste }}$ verjaardag van prof. mr. E.A. Alkema, Deventer: Kluwer 2009, p. 280-284.

218. Zie bijv.: EHRM 5 februari 2009, Olujić t. Kroatië, EHRC 2009/57 m.nt. De Werd, par. 58; EHRM 15 januari 2008, Micaleff t. Malta, EHRC 2008/42 m.nt. Jansen, par. 73 (overigens is deze zaak verwezen naar de Grote Kamer, die uitspraak heeft gedaan op 15 oktober 2009, $A B$ 2010/75 m.nt. Barkhuysen \& Van Emmerik; EHRC 2009/125 m.nt. A.M.L. Jansen); EHRM 15 december 2005, Kyprianou t. Griekenland, EHRC 2006/21 m.nt. Jansen, par. 119 (Grote Kamer-uitspraak)

${ }^{219 .}$ Kyprianou, par. 121.
} 


\section{Deel I Beginselen van behoorlijke rechtspleging}

zaak en het oordeel van de rechter kan immers groot zijn en derhalve moet ook een advies of rapport objectief zijn. Een door de rechter ingeschakelde deskundige behoeft uiteraard niet noodzakelijkerwijs aan dezelfde onpartijdigheidseisen (of andere waarborgen van artikel 6 EVRM) te voldoen als de rechterlijke instanties. ${ }^{220}$ Omdat echter de mening van de deskundige inzake de kwestie waarvoor hij is ingeschakeld naar alle waarschijnlijkheid van significant belang is voor de beoordeling van de rechter van die kwesties, kan in sommige gevallen volgens het EHRM neutraliteit van die deskundige vereist zijn. ${ }^{221}$ Het EHRM betrekt het gebrek aan onpartijdigheid van de deskundige veelal in het kader van de vraag of voldaan is aan het equality of arms-vereiste (hierop kom ik nog uitvoeriger terug in paragraaf 4.3.5). ${ }^{222}$ Daarbij is van belang wat de procedurele positie en de rol van de deskundige was in de procedure. ${ }^{223}$ In Sara Lind Eggertsdóttir oordeelt het Hof echter dat het gebrek aan onpartijdigheid van de deskundige gelet op diens procedurele positie en rol in de procedure, naast het vereiste van equality of arms, óók de onpartijdigheid van de rechter gecompromitteerd had. ${ }^{224}$ Dat de onpartijdigheidseisen in verband staan met het beginsel van hoor en wederhoor, meer in het bijzonder equality of arms, blijkt ook uit de algemeen aanvaarde plicht van de rechter om geen onderhands contact met een van de partijen in de procedure te hebben. ${ }^{225}$ Daarmee wordt de schijn van partijdigheid vermeden. Bovendien wordt vermeden dat een partij in een ongelijke positie ten opzichte van de andere partij wordt gesteld. Hetzelfde kan gesteld worden voor onderhands contact tussen een door de rechter ingeschakelde deskundige en (een van de) partijen. In een recente uitspraak achtte ook de Centrale Raad het benaderen van de medisch deskundige die door de rechter was ingeschakeld door (een van) de partijen, zonder dat de Centrale Raad of de wederpartij daarvan op de hoogte was, conform vaste rechtspraak, in strijd met de goede procesorde. ${ }^{226}$

\section{Ratio en functie van onpartijdigheid in het proces}

Het onpartijdigheidsbeginsel moet waarborgen dat een zo objectief mogelijke beslissing genomen wordt en oneigenlijke (dat wil zeggen rechtens niet relevante) belangen en motieven geen rol in de beoordeling van de rechterlijke instantie hebben gespeeld. Aangezien het beginsel ziet op de verhouding tussen de rechter en partijen, heeft het in eerste instantie ook een functie ter bescherming van de belangen van partijen in het concrete geschil. Gewaarborgd wordt dat de rechter niet vooringenomen is naar partijen of het onderwerp van geschil en dat partijen op gelijke wijze behandeld worden. Daarnaast heeft het beginsel ook een functie in het kader van het vertrouwen in rechtspraak van partijen en het publiek. Indien de onafhankelijke rechter blijk geeft van vooringenomenheid of anderszins oneigenlijke belangen laat meewegen in zijn beslissing, wordt immers het gezag en de geloofwaardigheid van de rechter aangetast. Het vertrouwen van partijen en het publiek in de rechtspraak loopt, zeker indien zulks vaker het geval is, een deuk op.

\footnotetext{
${ }^{220 .}$ EHRM 5 juli 2007, Sara Lind Eggertsdóttir t. IJsland, EHRC 2007/115 m.nt. De Werd, par. 47; EHRM 18 maart 1997, Mantovanelli t. Frankrijk, NJ 1998/278 m.nt. HJS; JB 1997/112 m.nt. AWH.

221. Sara Lind Eggertsdóttir t. IJsland, par. 47. Hoe groter het gewicht dat toekomt aan de mening van de deskundige (het gewicht is bijvoorbeeld groot indien de deskundige een wettelijk bepaalde adviserende rol heeft, zoals in Sara Lind Eggertsdóttir), hoe eerder neutraliteit vereist is. Zie voor een vergelijkbare redenering in het kader van het verdedigingsbeginsel, Koenraad 2007, p. 218.

${ }^{222 .}$ EHRM 6 mei 1985, Bönisch t. Oostenrijk, nr. 8658/79, par. 30-35; EHRM 28 augustus 1991, Brandstetter t. Oostenrijk, nrs. 11170/84, 12876/87 en 13468/87, par. 44-46.

223. Sara Lind Eggertsdóttir, par. 47; Bönisch, par. 31-35.

224. Zie par. 47, 53 en 54 van de uitspraak in Sara Lind Eggertsdóttir waarin het Hof voor het eerst, naast een schending van equality of arms, lijkt aan te nemen dat ook de rechterlijke onpartijdigheid onvoldoende gewaarborgd was. Zie over de toetsing van het EHRM alsmede langs welke wegen deze verloopt de noot van De Werd onder punt 5-8.

${ }^{225 .}$ De Waard 1987, p. 247, 339 en 342.

226. CRvB 30 december 2009, LJN BK8458. Zie ook CRvB 12 juni 2009, LJN BI9072 waarnaar de Centrale Raad zelf verwijst. De Centrale Raad acht zulk onderhands contact onwenselijk gelet op de onafhankelijke positie van de deskundige.
} 


\section{De beginselen}

Ook het EHRM benadrukt dat de onpartijdigheidseisen primair het vertrouwen van partijen in de rechter beogen te waarborgen. In strafrechtelijke context overwoog het in de zaak Kyprianou:

"(...) that it is of fundamental importance in a democratic society that the courts inspire confidence in the public and above all, as far as criminal proceedings are concerned, in the accused (see the Padovani v. Italy judgment of 26 February 1993, Series A no. 257-B, p. 20, § 27). To that end Article 6 requires a tribunal falling within its scope to be impartial."227

Vergelijkbare overwegingen uit het EHRM in geschillen waarin de vaststelling van een civil right or obligation in het geding is. ${ }^{228}$ Kortom, onpartijdigheid staat in het teken van het publieke vertrouwen in rechtspraak, maar bovenal van dat van partijen. Terwijl de primaire functie van onafhankelijkheid gelegen is in bescherming van het algemene belang, ligt de primaire functie van de onpartijdigheid derhalve in de bescherming van de belangen van partijen in het concrete geschil. Het onpartijdigheidsbeginsel heeft derhalve vooral interne werking, terwijl de onafhankelijkheids vooral externe werking heeft. Beide categorieën eisen hebben echter secundair ook een functie die ten dienste staat van dit concrete respectievelijk het algemene belang. ${ }^{229}$

Samenhang met andere beginselen

Het onpartijdigheidsbeginsel vertoont, zoals in de vorige paragraaf al is aangegeven, nauwe samenhang met het onafhankelijkheidseis. Onafhankelijkheid van de geschilbeslechtende instantie vormt een waarborg voor de vereiste onpartijdigheid van die instantie. De onpartijdigheidseisen staan echter niet alleen in nauw verband met de onafhankelijkheidseis, maar ook met het vereiste van een openbare behandeling van de zaak. De openbaarheid van de zitting bevordert de onpartijdigheid van de rechter, doordat de zitting openstaat voor publiek en de behandeling van de zaak controleerbaar wordt voor het publiek. ${ }^{230}$ Die controle vormt een extra waarborg tegen willekeur of partijdigheid. ${ }^{231}$ Hetzelfde geldt voor het vereiste van een openbare uitspraak in combinatie met de motiveringseis. De motivering en openbaarmaking daarvan maakt de beslissing van de rechter controleerbaar voor het publiek en hogere instanties. De rechter moet zich voor zijn beslissing verantwoorden en op die manier vormen deze eisen ook een waarborg voor objectiviteit aan de kant van de rechter. Voorts is in het bovenstaande gebleken dat onpartijdigheid samenhangt met het vereiste van equality of arms en vice versa. Beide vereisten beogen een gelijk(waardig)e of neutrale behandeling te bewerkstelligen van partijen.

Procesrechtelijke eisen ter waarborging van de onpartijdigheid

In hoofdstuk 8 van de Awb zijn verscheidene inrichtingseisen opgenomen om de onpartijdigheid van de behandelende rechter(s) te waarborgen. Om partijdigheid of twijfel aan onpartijdigheid te voorkomen is in artikel 8:15 Awb neergelegd dat op verzoek van een partij elk van de rechters die de zaak behandelen, kan worden gewraakt indien daartoe op grond van de feiten of omstandigheden aanleiding bestaat. ${ }^{232}$ Daarnaast kan een rechter op grond van dezelfde feiten of omstandigheden zelf verzoeken om verschoning inge-

227. EHRM 15 december 2005, EHRC 2006/21 m.nt. Jansen, par. 118 (Grote Kamer-uitspraak). Zie ook: Hauschildt, par. 48 .

${ }^{228}$ Zie bijvoorbeeld: EHRM 6 mei 2003, Kleyn e.a. t. Nederland, AB 2003/211 m.nt. LV en BdeW; JB 2003/119 m.nt. AWH.

229. Zie hierover ook de vorige par. 4.3.3.

230. In de paragraaf waarin het openbaarheidsbeginsel centraal staat wordt nader ingegaan op de doelen die openbaarheid dient en komt tevens het verband met het onpartijdigheidsbeginsel aan bod.

${ }^{231}$. De wetgever meent dat de ratio van het instituut wraking gelegen is in de rechterlijke onpartijdigheid, zie: PG Awb II, p. 410.

${ }^{232}$ Heringa 2001, p. 4. Heringa verwijst naar de MvT bij deze bepaling, PG Awb II, p. 410. Zie ook: De Waard 1987 , p. 367 


\section{Deel I Beginselen van behoorlijke rechtspleging}

volge artikel 8:19, eerste lid, van de Awb. In beide gevallen doet een meervoudige kamer van de rechtbank, waarin de betreffende rechter(s) geen zitting heeft (hebben), uitspraak op het verzoek. ${ }^{233}$ Heringa wijst erop dat wrakingsverzoeken veelal gericht zijn op het betwisten van objectieve onpartijdigheid, terwijl een verzoek om verschoning tevens kan samenhangen met subjectieve onpartijdigheid. ${ }^{234}$

In het Nederlandse bestuursprocesrecht is voorts bepaald dat de rechter op grond van artikel 8:47 eerste lid en artikel 8:60, eerste lid, Awb een deskundige kan benoemen en tevens in artikel 8:34, eerste lid, Awb dat die deskundige zijn taak onpartijdig dient te vervullen. ${ }^{235}$ Dezelfde eis wordt gesteld aan door de rechter ingeschakelde tolken op grond van artikel 8:35, eerste lid, van de Awb. Opvallend is dat in de Awb geen expliciet verbod is opgenomen voor de rechter om onderhands contact te hebben met een van de partijen. Dat was voorheen wel gebruikelijk in de procesregelingen van verschillende bestuursrechters $^{236}$ en is in elk geval een eis die de bestuursrechter in acht moet nemen op grond van het onpartijdigheidsbeginsel, zoals hierboven al werd aangegeven. Stroink leidt dit verbod af uit artikel 8:69, eerste lid, van de Awb, waarin is neergelegd dat de rechter uitspraak doet op de grondslag van het beroepschrift, de overgelegde stukken, het verhandelde tijdens het vooronderzoek en het onderzoek ter zitting. ${ }^{23}$

\subsubsection{Het beginsel van hoor en wederhoor}

\section{Inhoud en grondslag van het beginsel van hoor en wederhoor}

Het beginsel van hoor en wederhoor of het verdedigingsbeginsel is als beginsel van behoorlijke rechtspraak algemeen aanvaard en onomstreden. ${ }^{238}$ In het Nederlandse bestuursrecht vormt het echter een ongeschreven beginsel, dat als zodanig nergens is gecodificeerd. De Grondwet zwijgt ook in dit opzicht over een eerlijke of behoorlijke procedure bij de rechter. ${ }^{239}$ Desondanks is het belang van dit beginsel reeds van oudsher onderkend in de doctrine. ${ }^{240}$ Met recht wordt dit beginsel als de kern van de normen die gelden voor een behoorlijke procedure beschouwd of zoals De Waard stelt als 'het hart van de normen voor een behoorlijke procedure'. ${ }^{241}$ Het beginsel vormt in de procedure bij de bestuursrechter dan ook een belangrijk uitgangspunt. Inrichtingseisen in dat kader zijn op verschillende plaatsen in hoofdstuk 8 van de Awb terug te vinden (hierop kom ik in het onderstaande nog terug). Het belang van dit beginsel vloeit tevens voort uit het recht op een 'fair trial' zoals neergelegd in artikel 6, eerste lid EVRM en de jurispruden-

\footnotetext{
233. Art. 8:18 en 8:20 Awb. In het geval van wraking zal de meervoudige kamer zich over het verzoek buigen indien de rechter niet berust heeft in de wraking. Ingevolge art. 8:17 Awb bestaat die mogelijkheid ook. Zie uitgebreider over de wrakings- en verschoningsregeling in de Awb, Heringa 2001, p. 2-18.

${ }^{234 .}$ Heringa 2001, p. 3. Reden daarvoor lijkt te zijn dat in het geval van verschoning het initiatief van de rechter zelf komt, waardoor deze er blijk van geeft persoonlijk vooringenomen te zijn of daarover in elk geval zelf twijfelt.

235. Zie nader over de rol van deskundigen in het bestuursprocesrecht: L.M. Koenraad, 'Deskundig rechtspreken: Beschouwingen over de plaats van deskundigen in het Nederlands bestuursprocesrecht', JB-plus 2007, p. 202 223. Koenraad geeft ook aan dat de deskundige de beginselen van behoorlijke rechtspleging moet respecteren, waaronder de onpartijdigheidseisen, p. 217-218.

${ }^{236}$ Widdershoven 1989, p. 133 en De Waard 1987, p. 339 en 342 met verwijzingen naar de betreffende regelingen In de huidige procesregelingen is het verbod niet expliciet geregeld, zie de Landelijke procesregeling bestuursrecht 2008, Stcrt. 2008, 114, p. 119; Procesregeling bestuursrechterlijke colleges 2006, Stcrt. 2005, 250; Procesregeling belastingkamers gerechtshoven 2005, Stcrt. 2005, 198. Ook in de Leidraad onpartijdigheid van de rechter, opgesteld in opdracht van de Nederlandse vereniging voor rechtspraak en de presidentenvergadering van de rechtbanken en appelcolleges, gepubliceerd op www.rechtspraak.nl, wordt niets vermeld over een verbod van onderhands contact met partijen.

237. Stroink 2004b, p. 130. De grondslag voor dit verbod zoekt hij overigens in het verdedigingsbeginsel.

238. Stroink 2004a, p. 23-27; Stroink 2004b, p. 130; Stroink 1993, p. 66 en 68; Widdershoven 1989, o.m. p. 114; De Waard 1987, p. 127.

239. De Waard pleit voor opname van een grondrecht in de Grondwet dat dit beginsel insluit, De Waard 1995, p. $443-444$.

240. Zie bijvoorbeeld al: Polak 1976, p. 14.

${ }^{241 .}$ De Waard 1987, p. 245. Zie ook: Jansen 2004, p. 49.
} 


\section{De beginselen}

tie van het EHRM in dat kader alsook uit de jurisprudentie van het Hof van Justitie waarin het beginsel erkend is als algemeen beginsel van Unierecht. ${ }^{242}$

Het beginsel van hoor en wederhoor houdt primair in dat een partij in een procedure de gelegenheid moet hebben zijn standpunt deugdelijk naar voren te brengen en ook gelegenheid moet hebben om te reageren op andermans standpunten. Er dient derhalve sprake te zijn van een procedure op tegenspraak. De Waard omschrijft het beginsel als volgt:

"het recht om stellingen en eventuele bewijsmiddelen naar voren te brengen en voldoende in de gelegenheid gesteld te worden op door de wederpartij aangedragen stellingen en bewijsmiddelen te reageren: partijen dienen in de gelegenheid gesteld te worden in beginsel alle stukken waarop de geschilbeslechtende instantie haar oordeel zal baseren in te zien. Met andere woorden, het beginsel verbiedt dat recht wordt gedaan op onbekende stukken, en dat een partij met relevante informatie 'overvallen' wordt op een moment dat een adequate reactie in redelijkheid niet meer verlangd kan worden." 243

Als belangrijk element van dit beginsel beschouwt hij tevens het vereiste van evenwicht in de kansen van partijen, welke kansen bovendien goed en voldoende dienen te zijn, om hun standpunt te verdedigen. Daarmee doelt hij op de bekende eis dat sprake moet zijn van 'equality of arms of gelijkheid der wapenen' alsmede op de eis dat sprake moet zijn van 'quality' en 'quantity of arms'. ${ }^{244}$ Meer concreet omvat het beginsel van hoor en wederhoor in zijn optiek derhalve vier deeleisen: het recht om informatie te ontvangen, het recht om informatie te verschaffen (en mondeling gehoord te worden), voldoende gelegenheid voor de voorbereiding van het eigen standpunt en gelijke processuele mogelijkheden voor partijen. ${ }^{245}$ Het recht om informatie te verschaffen betekent in beginsel dat partijen recht hebben op een mondelinge behandeling van de zaak en om mondeling gehoord te worden (naast mogelijkheden om schriftelijk hun standpunt uiteen te zetten). ${ }^{246}$ Het recht om informatie te ontvangen betekent toegang tot en inzage in alle relevante stukken voor de beoordeling van de zaak door de rechter, zoals stukken ingediend door de wederpartij en verklaringen van getuigen en deskundigen. ${ }^{247}$ Uit de eis dat er voldoende gelegenheid voor de voorbereiding van het eigen standpunt moet zijn, vloeit voort dat de rechten om informatie te verschaffen en te ontvangen ook daadwerkelijk uitgeoefend kunnen worden en partijen daarvoor voldoende tijd ter beschikking behoren te krijgen in een procedure. Zoals De Waard aangeeft, vormt het bieden van voldoende gelegenheid voor de voorbereiding van het verweer of het eigen standpunt de verbindingsschakel tussen informatie ontvangen en verschaffen. ${ }^{248}$ Equality of arms vereist voorts dat bij partijen in de procedure bij de uitoefening van hun rechten om informatie te verschaffen en te ontvangen gelijke kansen en mogelijkheden hebben zodat een partij niet wordt achtergesteld ten opzichte van een andere partij. Dat betekent ook een verbod voor de rechter om contact met een van de partijen te hebben buiten medeweten om van de andere partij. ${ }^{249}$

Al deze onderscheiden elementen van het beginsel van hoor en wederhoor worden in de doctrine uitdrukkelijk erkend. ${ }^{250}$ Ook het EHRM stelt deze eisen in zijn jurisprudentie

\footnotetext{
242. In de jurisprudentie van het HvJ EU wordt het echter het verdedigingsbeginsel genoemd. De inhoud en betekenis van dat beginsel voor de bestuurlijke voorprocedures komt aan bod in hoofdstuk 5 .

243. De Waard 1987, p. 127

244. De Waard 1987, p. 127

245. De Waard 1987, p. 247.

246. Widdershoven 1989, p. 141 en 148; De Waard 1987, p. 303 e.v.

247. Widdershoven 1989, p. 142. Zie ook: CRvB 13 mei 2009, JB 2009/184 waarin een schending van het beginsel van hoor en wederhoor werd geconstateerd omdat de rechtbank bij haar oordeelsvorming stukken heeft laten meewegen die niet aan appellant ter kennis waren gebracht.

${ }^{248 .}$ De Waard 1987, p. 246

249. De Waard 1987, p. 247. Zie hierover ook par. 4.3.4 inzake het onpartijdigheidsbeginsel.

${ }^{250 .}$ Stroink 1993, p. 68; Van der Heijden 1984, p. 46-47; Widdershoven 1989, p. 141-142.
} 
Deel I Beginselen van behoorlijke rechtspleging

in het kader van artikel 6 EVRM. ${ }^{251}$ In de uitspraak Mantovanelli t. Frankrijk formuleert het EHRM een van deze eisen, het recht op tegenspraak, als volgt:

"The Court notes that one of the elements of a fair hearing within the meaning of Article $6 \$ 1$ is the right to adversial proceedings; each party must in principle have an opportunity not only to make known any evidence needed for his claims to succeed, but also to have knowledge of and comment on all evidence adduced or observations filed with a view to influencing the court's decision (...).,"252

Uit die overweging volgt dat partijen het recht hebben om informatie, zoals bewijs, ter ondersteuning van het eigen standpunt te verschaffen, alsmede het recht hebben op kennis van respectievelijk een reactiemogelijkheid op standpunten en bewijs van de wederpartij (en andere actoren in de procedure). Het recht op een procedure op tegenspraak geldt in zowel procedures ter vaststelling van een burgerlijk recht of verplichting als procedures die een ingestelde strafvervolging betreffen. ${ }^{253}$ Ook het vereiste van equality of arms geldt voor beide soorten procedures en wordt door het EHRM als een belangrijk onderdeel van het recht op een eerlijk proces gezien. ${ }^{254}$ Hetzelfde geldt voor de eis dat partijen voldoende gelegenheid moeten hebben om het eigen standpunt voor te bereiden en te verdedigen. ${ }^{255}$ Wel heeft het EHRM regelmatig overwogen dat de vereisten in civiele procedures en strafrechtelijke procedures niet noodzakelijkerwijs identiek zijn en dat de verdragsstaten meer ruimte toekomt in het geval van civiele procedures. ${ }^{256}$ De eisen voor een fair trial, die het EHRM afleidt uit artikel 6 EVRM, kunnen ook relevant zijn voor bij de procedure betrokken deskundigen. Uit de Mantovanelli-uitspraak blijkt immers dat uit het beginsel van hoor en wederhoor, meer in het bijzonder het vereiste van equality of arms, niet alleen voortvloeit dat partijen achteraf moeten kunnen reageren op het door de deskundige uitgebrachte advies, maar ook dat zij soms vooraf, dat wil zeggen vóór de definitieve totstandkoming ervan, daartoe in de gelegenheid worden gesteld. ${ }^{257}$

Het recht op een mondelinge behandeling komt opmerkelijk genoeg niet altijd terug in de jurisprudentie van het EHRM in het kader van de vereisten van hoor en wederhoor. Dat vereiste brengt het EHRM soms onder het recht op een openbare behandeling van de zaak. ${ }^{258}$ In beginsel is een 'oral hearing' verplicht, tenzij er bijzondere omstandigheden zijn die rechtvaardigen dat daarvan wordt afgezien. ${ }^{259}$ Te denken valt dan aan procedures die zeer technische kwesties betreffen of zuivere rechtsvragen aldus het EHRM. ${ }^{260}$ Ook

251. Zie bijvoorbeeld: EHRM 28 augustus 1991, Brandstetter t. Oostenrijk, nrs. 11170/84, 12876/87 en 13468/87, par. 66-67; EHRM 22 januari 1996, Vermeulen t. België, nr. 19075/91, par. 33. Zie verder met verwijzingen: Van Dijk \& Van Hoof e.a. 2006, p. 578 e.v.; Jansen, p. 49-60; J. van der Velde, 'Art. 6 Eerlijk proces. Eerlijke en openbare behandeling', in: J.H. Gerards, A.W. Heringa, H.L. Janssen en J. van der Velde, EVRM Rechtspraak en Commentaar, katern. Art. 6 Eerlijk proces, Haag: Sdu 1-1-2004, katern 3.6, par. 3.6.4, p. 1-41.

252. EHRM 18 maart 1997, JB 1997/112 m.nt. AWH, par. 33.

253. Zie hierover met verwijzingen naar jurisprudentie: Van Dijk \& Van Hoof e.a. 2006, p. 584-589; Van der Velde 2004, p. 2 e.v.

254. Zie bijvoorbeeld: EHRM 27 januari 1997, Nideröst-Huber t. Zwitserland, nr. 18990/91, par. 23; EHRM 27 oktober 1993, Dombo Beheer B.V. t. Nederland, nr. 14448/88, par. 33. Hierover nader: Van Dijk \& Van Hoof e.a. 2006, p. 580-584; Van der Velde 2004, p. 5-6; Jansen 2004, p. $49-50$ met verwijzingen naar jurisprudentie.

255. Van der Velde 2004, p. 17-18. Voor procedures betreffende een criminal charge is in art. 6 lid 3 aanhef en sub $b$ deze eis afzonderlijk neergelegd.

${ }^{256 .}$ EHRM 27 oktober 1993, Dombo beheer t. Nederland, nr. 14448/88, NJ 1994/534 m.nt. HJS en EJD. In deze zaak gaf het EHRM overigens wel aan dat equality of arms-vereiste in beide gevallen geldt. De grotere ruimte lijkt vooral te gelden bij vereisten die terugkomen in art. 6 lid 2 en 3 EVRM aangezien deze bepalingen zien op geschillen waarbij het gaat om de vaststelling van een 'criminal charge'. Zie verder nog: EHRM 10 februari 1983, Albert en Le Compte t. België, NJ 1987/315. Zie ook: Van Dijk \& Van Hoof e.a. 2006, p. 579.

${ }^{257}$ Mantovanelli, par. 36. Zie hierover ook: A.M.L. Jansen, 'De deskundige en een fair trial', $M \& R 2008$, p. 225; Koenraad 2007, p. 217-218; M.A. Heldeweg, 'Confidence in the working of justice', NTB 1994, p. 81-88.

258. Zie: EHRM 21 september 2006, Moser t. Oostenrijk, EHRC 2006/129, par. 91. Zie hierover ook: Van Dijk \& Van Hoof e.a. 2006, p. 599. Nader hierover par. 4.3.6 inzake het openbaarheidsbeginsel.

${ }^{259}$ Moser, par. 91

260. Jussila, par. 42; Moser, par. 91-92; EHRM 24 juni 1993, Schuler-Zgraggen t. Zwitserland, nr. 14518/89, par. 58. 


\section{De beginselen}

overwegingen van efficiency of proceseconomie kunnen een rol spelen. ${ }^{261}$ Dogmatisch acht ik echter het zuiverder en logischer om het recht op een mondelinge behandeling, dat wil zeggen het recht om in persoon gehoord te worden, onder te brengen bij het beginsel van hoor en wederhoor. Gelet op het verschil in ratio van het recht om gehoord te worden en het openbaarheidsbeginsel - waarop ik in het onderstaande nader terug kom ligt het ook veeleer in rede die eis bij het beginsel van hoor en wederhoor onder te brengen. Openbaarheid ziet eerder op de toegang van het publiek tot de zitting, terwijl het beginsel van hoor en wederhoor de toegang van partijen tot de zitting normeert.

In dit onderzoek wordt aangesloten bij de omschrijving van De Waard van het beginsel van hoor en wederhoor alsook bij de vier deeleisen die hij in dat kader onderscheidt. Op één punt is dat echter niet het geval: De Waard prefereert de term verdedigingsbeginsel boven het beginsel van hoor en wederhoor. Hij beschouwt de begrippen weliswaar als onderling uitwisselbaar, maar meent dat hoor en wederhoor het risico in zich bergt te beperkt te kunnen worden opgevat, bijvoorbeeld als het recht om mondeling gehoord te worden. ${ }^{262}$ Het beginsel moet inderdaad in ruime zin worden opgevat. Het begrip hoor en wederhoor heeft echter mijn voorkeur, omdat de kernelementen van het beginsel, het recht om informatie te verschaffen en te ontvangen, er beter door op de voorgrond worden gebracht. De kern van het beginsel wordt gevormd door de mogelijkheid om het eigen standpunt naar behoren naar voren te brengen (het recht om informatie te verschaffen), alsmede om op de hoogte te zijn van de standpunten van de andere partijen (het recht om informatie te ontvangen) en daarop te kunnen reageren. De twee andere eisen - equality of arms en voldoende voorbereidingstijd voor het eigen standpunt die uit het beginsel afgeleid worden, zijn vooral dienstbaar aan deze twee voorgaande eisen. Uit de benaming van het beginsel zouden bij voorkeur de kerneisen moeten blijken. Hoor en wederhoor lijkt mij in dat kader meer geschikt als term dan het verdedigingsbeginsel. Hoor en wederhoor is bovendien een uitgangspunt dat in verband kan worden gebracht met procedures van allerlei aard en niet uitsluitend met strafrechtelijke procedures of rechten van de verdediging in die procedures, welke connotatie zoals De Waard ook zelf aangeeft enigszins aan het verdedigingsbeginsel verbonden is. ${ }^{263}$

\section{Ratio en functie van het beginsel}

Voor de ratio en functie van het beginsel van hoor en wederhoor volstaat het om kort te zijn: het doel van het beginsel van hoor en wederhoor is gelegen in de bescherming van de bij de procedure betrokken belangen van partijen. In een procedure waarin de rechtspositie van een burger wordt bepaald of diens rechten anderszins in het geding zijn, moet die burger de gelegenheid krijgen om zijn standpunt daarover naar voren te kunnen brengen. Daarnaast is het van belang dat er gelegenheid bestaat om zich te verweren tegen of te reageren op het standpunt van de wederpartij. Het EHRM heeft de ratio achter hoor en wederhoor en een eerlijke behandeling van de zaak weleens als volgt verwoord:

"In fact, Article 6 para. 1 (art. 6-1) is intended above all to secure the interests of the parties and those of the proper administration of justice (see, mutatis mutandis, the Acquaviva v. France judgment of 21 November 1995, Series A no. 333-A, p. 17, para. 66). ${ }^{.264}$

Naast de bescherming van de belangen van partijen bestaat de ratio van het beginsel van hoor en wederhoor als onderdeel van het recht op een eerlijk proces derhalve ook, zo blijkt uit de aangehaalde overweging, uit "the proper administration of justice" als alge-

\footnotetext{
261. Schuler-Zgraggen, par. 58.

262. De Waard 1987, p. 246

${ }^{263 .}$ De Waard 1987, p. 245. Het EHRM hanteert bijvoorbeeld de term rechten van de verdediging in procedures die onder de werking van art. 6 EVRM vallen uit hoofde van de vaststelling van een criminal charge terwijl het daarmee het algemene concept fair trial zoals ook gehanteerd in civiele procedures op het oog lijkt te hebben, zie Van Dijk \& Van Hoof e.a. 2006, p. 580.

264. Zie bijvoorbeeld: EHRM 27 januari 1997, Nideröst-Huber t. Zwitserland, nr. 18990/91, par. 29.
} 


\section{Deel I Beginselen van behoorlijke rechtspleging}

meen belang. Maar het lijkt het EHRM vooral te gaan om het vertrouwen dat 'the parties' hebben in rechtspraak en de bescherming van hun belangen. De functie van het beginsel ligt derhalve primair in de rechtsbescherming van partijen, maar daarnaast ook in 'een goede of behoorlijke rechtsbedeling' in het algemeen. Uiteraard zou een structureel gebrek aan hoor en wederhoor in rechterlijke procedures ook afbreuk kunnen doen aan het vertrouwen van het publiek in rechtspraak en de goede rechtsbedeling in het algemeen. Meer indirect beogen die eisen dan ook dat belang te waarborgen.

Hoor en wederhoor en de andere beginselen van behoorlijke rechtspleging

Het beginsel van hoor en wederhoor waarborgt dat partijen hun belangen in de procedure voldoende voor het voetlicht kunnen brengen, opdat de rechter hiermee rekening kan (en moet) houden bij de beoordeling van het geschil. Hoor en wederhoor houdt niet alleen een recht van partijen in, maar ook een plicht van de rechter (als adressaat van het beginsel) om partijen daadwerkelijk te horen en met hun argumenten en stellingen, voor zover rechtens mogelijk, rekening te houden in zijn uitspraak. Het feit dat de rechter dat gedaan heeft en de wijze waarop dat is geschied, komt tot uitdrukking in de motivering van de uitspraak. Het motiveringsbeginsel staat derhalve ook ten dienste aan het beginsel van hoor en wederhoor. ${ }^{265}$ Eenzelfde functie wordt in de literatuur ook wel toegekend aan het openbaarheidsbeginsel, althans het deelvereiste van een openbare behandeling van de zaak. Stroink meent bijvoorbeeld dat dit openbaarheidsbeginsel het verdedigingsbeginsel bevordert en dat het recht op inzage in de stukken en het verbod aan de rechter tot onderhands contact met een van de partijen ook daarop valt te baseren. ${ }^{266}$ Het recht op een openbare behandeling van de zaak vormt in elk geval een waarborg tegen willekeur van de rechter, omdat er publieke controle bestaat van de mondelinge behandeling van de zaak. Toch zou ik het recht op inzage in de stukken van partijen en het verbod van onderhands contact vooral willen baseren op het recht om informatie te ontvangen en equality of arms (en bij dat laatste verbod ook het onpartijdigheidsbeginsel). Het betreft eisen die veeleer uit het beginsel van hoor en wederhoor voortvloeien. Openbaarheid van behandeling dient in eerste instantie de controle door het publiek (en, enigszins vooruitlopend op hetgeen in paragraaf 4.3.6 nog nader aan bod komt, het vertrouwen in rechtspraak van het publiek) en die controle door het publiek kan vervolgens ook bijdragen aan een eerlijke en gelijke behandeling van partijen en de zaak. Dat lijkt mij echter niet primair het doel van de eis van een openbare behandeling, maar eerder een neveneffect. Om dezelfde reden moet ook, in tegenstelling tot de jurisprudentie van het EHRM, het recht op een mondelinge behandeling onder het beginsel van hoor en wederhoor geschaard worden en niet zozeer onder dit aspect van het openbaarheidsbeginsel. Voor het vereiste van een openbare uitspraak geldt mijns inziens nog sterker dat daaraan een andere ratio toekomt dan aan het beginsel van hoor en wederhoor. Een duidelijker verband bestaat mijns inziens tussen het onpartijdigheidsbeginsel en equality of arms: beide vereisten beogen een gelijk(waardig)e behandeling van de partijen in de procedure. Een gebrek aan equality of arms in de procedure kan in sommige gevallen duiden op (schijn van) partijdigheid aan de kant van de rechter. Dat is bijvoorbeeld terug te zien in het verbod van onderhands contact met partijen. Dat kan in mijn optiek zowel onder equality of arms gebracht worden als onder het onpartijdigheidsbeginsel. ${ }^{267}$

\footnotetext{
265. Zie uitgebreider over de functies van het motiveringsbeginsel par. 4.3.7 waarin dit beginsel centraal staat. 266. Stroink 1993, p. 69.

267. Zie bijv.: CRvB 13 mei 2009, JB 2009/184 waarin de uitspraak van de rechtbank werd vernietigd wegens schending van het beginsel van hoor en wederhoor, maar ook geoordeeld had kunnen worden dat de rechtbank in strijd had gehandeld met het verbod van onderhands contact met partijen. De rechtbank had telefonisch vragen gesteld aan een partij zonder de andere partij daarover te informeren en had stukken die ontvangen waren van een partij niet doorgezonden aan de andere partij.
} 


\section{De beginselen}

Procesrechtelijke eisen die samenhangen met hoor en wederhoor

Inrichtingseisen die uit het beginsel van hoor en wederhoor kunnen voortvloeien, zijn bepalingen waarin geregeld is hoe en wanneer partijen welke informatie dienen te ontvangen, hoe en wanneer partijen mondeling en/of schriftelijk hun respectieve standpunten naar voren kunnen brengen en op welke wijze zij deze met bewijsmiddelen kunnen ondersteunen. Meer concreet kan gedacht worden aan het recht om op zitting aanwezig te zijn en zich te doen horen, het recht op het meebrengen en horen van getuigen en deskundigen, het recht om verklaringen van getuigen en deskundigen over te leggen of andere bewijsmiddelen of het recht om te reageren op stukken van welke aard ook die de wederpartij heeft ingediend.

Enkele van deze eisen zijn ook terug te vinden in de processuele voorschriften van hoofdstuk 8 van de Awb. ${ }^{268}$ Het uitgangspunt is dat in eerste aanleg bij de rechtbank een terechtzitting plaatsvindt en dat partijen mondeling hun standpunt kunnen toelichten, ingevolge artikel 8:56 en 8:57 Awb. ${ }^{269}$ In de Awb is verder in artikel 8:58 neergelegd dat partijen tot tien dagen voor de zitting stukken kunnen indienen waarmee enerzijds het recht op het indienen van stukken wordt erkend, maar anderzijds ook wordt gewaarborgd dat partijen niet door stukken van de wederpartij worden overvallen. Voorts volgt uit artikel 8:63 Awb dat partijen het recht hebben om zelf getuigen en deskundigen mee te nemen naar de zitting. De rechter kan echter afzien van het horen van die getuigen of deskundigen, indien dat redelijkerwijs niet kan bijdragen aan de beoordeling van de zaak. ${ }^{270}$ Indien de rechter zelf besluit tot het inschakelen van een deskundige op grond van artikel 8:47 eerste lid Awb, dient daarbij het verdedigingsbeginsel en meer in het bijzonder het deelaspect equality of arms in acht te worden genomen. Koenraad meent zelfs dat de deskundige de beginselen van behoorlijke rechtspleging in acht moet nemen bij de vervulling van zijn taak, zoals bij het opstellen van het advies, en dat daarbij in het bijzonder het verdedigingsbeginsel van belang is. ${ }^{271}$ In de inrichtingseisen of bij de toepassing ervan door de rechter moeten de andere twee deeleisen, voldoende gelegenheid voor de voorbereiding van het eigen standpunt en equality of arms, tot uitdrukking komen. Deze twee deelaspecten van hoor en wederhoor kunnen als zodanig lastiger worden neergelegd in inrichtingseisen in een regeling omdat de werking ervan minder concreet is en pas aan de orde komt in de toepassing van het recht om informatie te ontvangen of te verschaffen of wanneer die aspecten geëffectueerd worden. Bij de regeling van of de toepassing van die inrichtingseisen of bevoegdheden van de rechter in dat kader moeten de deeleisen voldoende voorbereidingsmogelijkheid voor partijen en gelijkheid in de procesmogelijkheden in acht genomen worden. Dat betekent bijvoorbeeld dat de gestelde termijnen voor het ontvangen en verschaffen van informatie niet dermate kort mogen zijn dat daaraan geen recht meer wordt gedaan of dat partijen niet overvallen mogen worden met bepaalde informatie. Het betekent ook dat de betreffende mogelijkheden in beginsel voor alle partijen op gelijke wijze dienen te gelden.

\footnotetext{
${ }^{268 .}$ Ik volsta ter illustratie in deze paragraaf met de weergave van enkele van die bepalingen. Voor een uitvoeriger of uitputtend overzicht van deze bepalingen, verwijs ik naar bestuurs(proces)rechtelijke handboeken: Van Wijk/Konijnenbelt \& Van Male 2008, p. 567 e.v.; Schreuder-Vlasblom 2008, p. 273 e.v.; Damen e.a., Deel II, p. 209 e.v.

269. In bepaalde gevallen kan een zitting achterwege blijven. Zoals bij vereenvoudigde behandeling van de zaak op grond van art. 8:54 Awb of indien partijen daarvoor toestemming geven op grond van art. 8:57 Awb. Daarbuiten mag niet worden afgezien van het houden van een mondelinge behandeling, zie bv.: AbRvS 11 december 2003, JB 2004/55 m.nt. EvdL.

270. Zie bijvoorbeeld: CRvB 6 mei 2008, AB 2008/243 m.nt. Hbr; AbRvS 22 augustus 2007, AB 2008/72 m.nt. O.J.D.M.L. Jansen. Indien de rechter besluit tot het niet horen van door partijen meegebrachte getuigen of deskundigen behoort hij deze beslissing wel te motiveren. Zie hierover par. 4.3.7 inzake het motiveringsbeginsel. ${ }^{271 .}$ Koenraad 2007, p. 217. Of dat werkelijk een geldende regel is, is mijns inziens nog maar de vraag. In elk geval kan een gebrek aan onpartijdigheid of anderszins een schending van de beginselen van behoorlijke rechtspleging wel doorwerken in de procedure bij de rechter en de vraag of die procedure voldoet aan de beginselen lijkt mij.
} 


\section{Deel I Beginselen van behoorlijke rechtspleging}

\subsubsection{Het openbaarheidsbeginsel}

Verbondenheid openbaarheidsvereisten met rechtspraak

Openbaarheid van rechtspraak is een vereiste dat van oudsher onderdeel uitmaakt van het samenstel van eisen dat aan behoorlijke (bestuurs)rechtspraak gesteld wordt. ${ }^{272}$ Het vormt een van de vereisten van behoorlijke rechtspraak die gecodificeerd zijn, zelfs in de Grondwet. Het vereiste is immers in artikel 121 Grondwet en voor de verschillende vormen van rechtspraak in verschillende desbetreffende wetten vastgelegd. De in de Grondwet neergelegde eisen gelden echter - merkwaardigerwijs - strikt genomen niet voor de bestuursrechterlijke instanties die niet tot de gewone rechterlijke macht behoren. ${ }^{273}$ De openbare behandeling wordt uitsluitend ten aanzien van terechtzittingen van de gewone rechterlijke macht voorgeschreven. ${ }^{274}$ De openbaarmaking van de uitspraak ${ }^{275}$ is daarentegen ook voor de uitspraken van de bestuursrechter voorgeschreven, aldus de toelichting op die bepaling. ${ }^{276}$ Aangenomen wordt ook dat artikel 121 Grondwet (of in elk geval de daarin neergelegde eisen) voor alle bestuursrechterlijke instanties geldt. ${ }^{277}$ Specifiek voor de bestuursrechter zijn ook voorschriften inzake openbaarheid te vinden in de artikelen 8:62, 8:78 en 8:79 Awb. ${ }^{278}$ Daarnaast stelt artikel 6 EVRM buiten twijfel dat, wil er sprake zijn van eerlijk proces, voldaan moet zijn aan de uit die bepaling voortvloeiende openbaarheidvereisten.

De eisen van openbaarheid die gesteld worden aan rechtspraak kunnen worden ingedeeld in twee categorieën. Enerzijds betreft het eisen die betrekking hebben op de openbaarheid van de behandeling van de zaak of de zitting en anderzijds gaat het om eisen die betrekking hebben op het openbaar maken van de uitspraak. ${ }^{279}$ Ondanks het feit dat deze openbaarheidvereisten al geruime tijd stevig verankerd zijn in het nationale recht door opname in de Grondwet en de Awb alsook vanwege de doorwerking van artikel 6 EVRM, vormen deze eisen geen rustig bezit. De vereisten en de naleving daarvan in de praktijk hebben de afgelopen jaren ter discussie gestaan. ${ }^{280}$

272. De studiecommissie van de Vereniging voor Media- en communicatierecht (hierna: VMC-studiecommissie) Openbaarheid van rechtspraak wijst er in haar rapport op dat de geschiedenis van art. 121 Grondwet reeds teruggaat tot de Staatsregeling van 1798, Rapport Toegang tot rechterlijke uitspraken, Mediaforum 2006/4, p. 3. Ook worden openbaarheidvereisten reeds geruime tijd in de literatuur gesteld. Zie bijvoorbeeld: K. Wiersma, Administratieve en burgerlijke procesgangen, beginselen en organisatie, in: Een goede procesorde (Haardtbundel), Deventer: Kluwer 1983, p. 132 en 140-143; A.G. van Galen \& H.Th.J.F. van Maarseveen, Beginselen van administratief procesrecht (preadvies VAR), Alphen aan den Rijn: Tjeenk Willink 1978, p. 60 e.v.; J.M. Polak, Vormen en beginselen van rechtspraak (preadvies Vereniging voor Bouwrecht), Deventer: Kluwer 1976, p. 1516. Meer recent ook: Rapport VAR-Commissie Rechtsbescherming 2004, p. 56-57; A.M.L. Jansen, Constitutionalisering van het bestuursprocesrecht, Deventer: Kluwer 2004, p. 60-65; M.F.J.M. de Werd, De openbare uitspraak. Reconstructie van een verwaarloosd leerstuk, NJB 2001/2, p. 67 e.v.

273. Zie: Rapport VMC-studiecommissie Openbaarheid van rechtspraak 2006, p. 3-4; Jansen 2004, p. 65; B.W.N. de Waard, 'De grote ogen van de grondwetgever, in: J.B.J.M. ten Berge e.a. (red.), De Grondwet als voorwerp van aanhoudende zorg (Burkens-bundel), Zwolle: W.E.J. Tjeenk Willink 1995, p. 449-450. Zie ook de toelichting op art. $121 \mathrm{GW}$ in: A.W. Koekkoek (red.), De Grondwet. Een systematisch en artikelsgewijs commentaar, Deventer: W.E.J. Tjeenk Willink 2000, p. 549-550.

274. Zie de toelichting van de grondwetgever op art. $121 \mathrm{GW}$, Kamerstukken II 1979/80, 16 162, nr. 3, p. 21-23.

275. Bedoeld lijkt te zijn vonnissen. Volgens de toelichting vallen echter onder de term vonnissen ook de beslissingen van de administratieve rechter, zie: Kamerstukken II 1979/80, 16 162, nr. 3, p. 22.

276. Zie vorige noot. Merkwaardigerwijs wordt in art. $121 \mathrm{GW}$ gesproken van terechtzittingen, vonnissen en uitspraken in het kader van respectievelijk de drie daar genoemde eisen van openbare behandeling, motivering en openbaarmaking. In de literatuur is dan ook kritiek geuit op de onduidelijkheid van de tekst van de bepaling en de reikwijdte daarvan, zie: De Waard 1995, p. 448-450.

277. Rapport VMC-studiecommissie Openbaarheid van rechtspraak 2006, p. 4.

278. Deze bepalingen zijn van overeenkomstige toepassing in procedures in eerste aanleg en in hoger beroep bij de Afdeling, de CRvB en het CBb, zie art. 36 lid 1 en 39 lid 1 WRvS, art. 17 lid 1 en 21 lid 1 Beroepswet, art. 19 lid 1 en 22 lid 1 Wbbo.

279. Zie art. $121 \mathrm{Gw}$ dat dat onderscheid maakt, evenals de Awb door eisen ten aanzien van beide aspecten in artt. 8:62, 8:78 en 8:79 Awb neer te leggen. Zie over de eisen verder: Jansen 2004, p. 60-65

280. Zie bijvoorbeeld: De Werd 2001, p. 67 e.v.; De Waard 1995, p. 449-450. Hoewel de laatste jaren meer aandacht bestaat voor de openbaarheidseisen, wijst Widdershoven erop dat de aandacht, in vergelijking tot andere eisen die gesteld worden aan behoorlijke rechtspraak, gering is, Widdershoven 1989, p. 142. 


\section{De beginselen}

Voor dit onderzoek is allereerst van belang dat er verschil van mening bestaat over de vraag of openbaarheid van rechtspraak moet worden gezien als een beginsel van behoorlijke rechtspraak dan wel als een aan rechtspraak te stellen inrichtingseis. De Waard stelt zich uitdrukkelijk op het standpunt dat openbaarheid van de behandeling en van de uitspraak moeten worden gezien als inrichtingseisen en niet als beginselen van behoorlijke rechtspraak. ${ }^{281}$ Met name het feit dat categoriale uitzonderingen op de openbaarheidseisen mogelijk zijn (op grond van artikel 6 EVRM) en dat deze eisen voor bepaalde categorieën van rechtspraak niet van toepassing zijn, brengt De Waard ertoe deze eisen aan te merken als inrichtingseis. ${ }^{282}$ Widdershoven daarentegen meent dat er wel degelijk sprake is van een beginsel van behoorlijke rechtspraak. ${ }^{283}$ In het algemeen wordt openbaarheid in de literatuur, mede onder invloed van artikel 6 EVRM, ook gezien als een beginsel van behoorlijke rechtspleging. ${ }^{284}$ Ik zou mij bij die heersende opvatting willen aansluiten omdat zowel vanuit een oogpunt van het nationale recht als van artikel 6 EVRM schending van de openbaarheidseisen tot vernietiging van de uitspraak leidt en rechtens derhalve consequenties heeft. ${ }^{285}$

In de literatuur is voorts aandacht gevraagd voor het feit dat de (bestuurs)rechterlijke praktijk niet in overeenstemming zou zijn met het vereiste van een mondelinge openbare uitspraak. ${ }^{286}$ De bestuursrechter pleegt in de praktijk, in tegenspraak met hetgeen artikel 8:62 Awb en artikel 121 Grondwet voorschrijven, het dictum van de uitspraak niet (altijd) meer in het openbaar op een zitting uit te spreken. Op deze kwestie wordt hieronder nog nader ingegaan.

Het eerste deelaspect: een openbare behandeling van de zaak

Zoals aangegeven, heeft het openbaarheidsbeginsel betrekking op twee aspecten: de behandeling van de zaak en de uitspraak. Het eerste aspect staat in dit onderdeel centraal. Een openbare behandeling van de zaak ter zitting waarbij de zitting openstaat voor publiek is het uitgangspunt, maar uitzonderingen daarop zijn geoorloofd. In artikel 121 Grondwet is neergelegd dat, behoudens de gevallen bij de wet bepaald, terechtzittingen in het openbaar plaatsvinden. Hoewel, zoals hiervoor aangegeven werd, niet geheel duidelijk is of deze bepaling uitsluitend ziet op zittingen van de gewone rechterlijke macht - strikt genomen volgt uit de tekst van de bepaling dat dit het geval is - wordt er in het algemeen van uitgegaan dat deze eisen ook gelden voor de bestuursrechterlijke instanties die daartoe niet behoren ${ }^{287}$; de openbaarheidseisen gelden in elk geval op grond van het ongeschreven openbaarheidsbeginsel of op grond van artikel 6 EVRM. ${ }^{288}$ Op grond van welke belangen afgezien mag worden van een openbare behandeling, wordt in de Grondwet niet geregeld. Artikel 6 EVRM regelt dat wel. Ook in deze bepaling is neergelegd dat een openbare behandeling het uitgangspunt is maar tevens is geregeld dat op grond van de daar genoemde belangen uitzonderingen mogelijk zijn daarop. De zitting mag met gesloten deuren plaatsvinden indien dat in het belang is van de goede zeden, de openbare orde of nationale veiligheid, de belangen van minderjarigen of de privacy van procespartijen of een behoorlijke rechtspleging. In de Awb heeft in artikel

\footnotetext{
${ }^{281 .}$ De Waard 1987, p. 110.

282. Dat heeft in zijn ogen te maken met het onderscheid rechtsbeginsel en regel en de omstandigheid dat inrichtingseisen evenals regels, in tegenstelling tot de beginselen van behoorlijke rechtspleging, gelden of niet gelden waardoor ook duidelijker is of zij in een concreet geval geschonden zijn en wat de consequenties daarvan moeten zijn, De Waard 1987, p. 111.

283. Widdershoven 1989, p. 111-114 en p. 142-143.

284. Van Wijk/Konijnenbelt \& Van Male 2008, p. 576; Stroink 2004a, p. 23-30; Stroink 1993, p. 66-69; Van der Heijden 1984, p. 48; Polak 1976, p. 15-16.

285. Zie hieronder de jurisprudentie bij de behandeling van de verschillende deelaspecten van het openbaarheidsbeginsel.

${ }^{286 .}$ De Werd 2001, p. 67 e.v.

${ }^{287 .}$ Het betreft dan in het bijzonder de Afdeling, de Centrale Raad en het $\mathrm{CBb}$ die geen onderdeel vormen van de gewone rechterlijke macht. Zie art. 2 Wet op de Rechterlijke organisatie.

288. Jansen 2004, p. 60-65; Rapport VAR-Commissie Rechtsbescherming 2004, p. 56; De Waard 1995, p. 449.
} 


\section{Deel I Beginselen van behoorlijke rechtspleging}

8:62 aansluiting plaatsgevonden bij de in artikel 6 EVRM genoemde doelcriteria. ${ }^{289}$ Het Nederlandse algemene bestuursrecht lijkt wat dat betreft derhalve met deze bepaling (en artikel 121 Grondwet) in overeenstemming te zijn. Dat betekent niet dat de bestuursrechtelijke procedures zich nimmer in de gevarenzone kunnen bevinden. Soms wordt immers in een bijzondere wet afgeweken van de regeling in de Awb op een wijze die niet verenigbaar is met artikel 6 EVRM. Een bekend voorbeeld in dat kader betreft artikel $88 \mathrm{~h}$ WAO waarin werd bepaald dat de zitting, voor zover betrekking hebbend op medische gegevens, met gesloten deuren moest plaatsvinden. De Centrale Raad heeft deze regeling in strijd geacht met artikel 6 EVRM, omdat deze een categorische uitsluiting van de openbare behandeling met zich bracht. ${ }^{290}$ Interessant aan deze uitspraak is 1) dat de Centrale Raad zich ambtshalve over deze kwestie uitspreekt en 2) dat volgens de Centrale Raad dit wettelijk voorschrift zo moet worden toegepast dat de behandeling in beginsel met gesloten deuren plaatsvindt maar dat de rechter ambtshalve of op verzoek van partijen kan beslissen dat de zitting in het openbaar behoort te geschieden. De bestuursrechter heeft immers nog nooit expliciet aangegeven dat aan de openbaarheid van de zitting of andere eisen van behoorlijke rechtspleging ambtshalve moet worden getoetst. ${ }^{291}$ Bovendien wordt uit de uitspraak duidelijk dat het de bestuursrechter zelf is die beoordeelt of de beginselen van behoorlijke rechtspleging in het concrete geval in acht zijn genomen, waarbij hij de daarmee in strijd zijnde wettelijke voorschriften anders kan uitleggen of buiten toepassing kan laten. ${ }^{292}$

Zoals de Centrale Raad terecht aangeeft in de hiervoor aangehaalde uitspraak zijn categoriale uitzonderingen op het vereiste van een openbare behandeling in geschillen waarop artikel 6 EVRM van toepassing is in beginsel niet toegestaan. De noodzaak voor behandeling met gesloten deuren moet volgens het EHRM gelegen zijn in de omstandigheden van het geval. ${ }^{293}$ Beperking van het recht op een openbare behandeling is mogelijk, mits daarmee een van de in artikel 6 genoemde belangen gediend wordt. Ook erkent het EHRM dat een partij afstand kan doen van het recht op een openbare behandeling, maar indien een zwaarwegend publiek belang dat vereist vindt desondanks een openbare behandeling plaats. ${ }^{294}$ Het EHRM heeft wel aangegeven voor de openbare behandeling dat niet in alle stadia van het geschil, afhankelijk van de bijzondere kenmerken van de betreffende procedure, een openbare behandeling van de zaak behoeft plaats te vinden. In beginsel moet in elk geval in één instantie een openbare behandeling plaatsvinden zowel in gevallen waarin burgerlijke rechten of verplichtingen in het geding zijn als gevallen waarin het een ingestelde strafvervolging betreft; dat geldt ook, indien er uitsluitend één instantie geadieerd kan worden. ${ }^{295}$ Als in eerste aanleg echter een openbare zitting heeft plaatsgevonden, mag daarvan in appèl worden afgezien, indien er slechts rechtsvragen beantwoord hoeven worden. ${ }^{296}$ Heeft in eerste aanleg geen openbare zitting plaatsgevonden, dan kan dat in (hoger) beroep hersteld worden, mits het appél devolutief is en de rechter zowel rechtsvragen als feitelijke kwesties mag beoordelen. ${ }^{297}$ Openbaar-

\footnotetext{
${ }^{289 .}$ PG Awb II, p. 458; Van Wijk/Konijnenbelt \& Van Male 2008, p. 638.

${ }^{290 .}$ CRvB 25 januari 1998, $A B$ 1998/168 m.nt. FP; JB 1998/61 m.nt. Heringa; $R S V$ 1998/106 m.nt. Van der Kris; USZ 1998/69 m.nt. Driessen.

291. De beginselen van behoorlijke rechtspleging of inrichtingseisen in de Awb in dat kader worden door de bestuursrechter niet gerekend tot de bepalingen van openbare orde waaraan de bestuursrechter ambtshalve mag en moet toetsen, zie hierover: Brugman 2005, p. 266 e.v. Zie ook par. 4.1 van dit deel.

292. Zie daarover ook par. 3.2.2 van dit deel.

${ }^{293 .}$ Er moet een mogelijkheid bestaan voor de rechter om al dan niet op verzoek van partijen van de regel dat de zitting met gesloten deuren plaatsvindt af te wijken, aldus het EHRM in: EHRM 24 april 2001, B. en P. t. Verenigd Koninkrijk, EHRC 2001/43 par. 38-40.

294. Zie bijvoorbeeld: EHRM 24 juni 1993, Schuler-Zgraggen t. Zwitserland, nr. 14518/89, par. 58; EHRM 21 februari 1990, Hakansson en Sturesson t. Zweden, nr. 11855/85, par. 66.

${ }^{295}$ Van der Velde 2004, p. 30-31, en, Jansen 2004, p. 61 met verwijzingen naar jurisprudentie.

296. Zie bijvoorbeeld: EHRM 29 november 2007, Hummatov t. Azerbeidzjan, EHRC 2008/12 m.nt. Van der

Velde, par. 141; EHRM 8 december 1983, Axen t. Duitsland, nr. 8273/78, par. 28.

297. Hummatov, par. 151; EHRM 26 september 1995, Diennet t. Frankrijk, nr. 18160/91, par. 34.
} 


\section{De beginselen}

heid moet niet alleen de jure gewaarborgd zijn, maar ook de facto. Soms betekent dat dat een staat maatregelen moet treffen om de toegang voor het publiek en aanwezigheid van publiek mogelijk te maken, zoals een vervoersvoorziening indien de zitting in een afgelegen gebied plaatsvindt. ${ }^{298}$ De eis van een openbare behandeling van de zaak bevindt zich in de Nederlandse doctrine verder in redelijk rustig vaarwater en lijkt niet vaak onderwerp van geschil in de jurisprudentie te vormen.

Een punt dat echter nog nadere toelichting verdient, vormt de omstandigheid dat, zoals al werd aangegeven in paragraaf 4.3.5, soms naar aanleiding van of in de jurisprudentie van het EHRM het recht op een openbare behandeling in verband wordt gebracht met het recht op een mondelinge behandeling van de zaak, dat wil zeggen het recht van de belanghebbende om bij de behandeling aanwezig te zijn. ${ }^{299}$ Dat lijken mij twee verschillende kwesties. Openbaarheid ziet op controle en toegang door het publiek, terwijl het beginsel van hoor en wederhoor en equality of arms de aanwezigheid van alle partijen/belanghebbenden bij de zitting eisen. ${ }^{300}$ Het lijkt mij onzuiver om onder openbaarheid (naast het openbare karakter van de zitting) ook een recht om bij de zitting aanwezig te zijn te begrijpen. ${ }^{301}$ Een zitting kan heel goed niet in het openbaar gehouden worden, terwijl belanghebbenden wel het recht hebben om deze bij te wonen. De vraag of alle belanghebbenden in elkaars aanwezigheid gehoord moeten worden, is ook een vraag die door het beginsel van hoor en wederhoor en equality of arms beheerst wordt en niet zo zeer verband houdt met de openbaarheid van de zitting. ${ }^{302}$ In theorie kan het immers zo zijn dat belanghebbenden afzonderlijk worden gehoord maar (bei)de zitting(en) toch openbaar is (of zijn) voor het publiek. Wel is mogelijk dat een zitting in het geheel achterwege blijft, waarmee het recht op de openbare behandeling en het recht op een mondelinge behandeling van de belanghebbende samenvallen, maar dan gaat het in mijn optiek nog steeds om twee te onderscheiden kwesties die ook op een verschillende grondslag berusten. In het bovenstaande stond dan ook uitsluitend het recht op een openbare behandeling en uitspraak centraal. De vraag of een belanghebbende recht heeft op een mondelinge behandeling en daarbij aanwezig moet kunnen zijn, is reeds aan de orde geweest in het kader van paragraaf 4.3.5. ${ }^{303}$ Deze interne openbaarheid kan beter bij het beginsel van hoor en wederhoor worden ondergebracht.

Het openbaar maken van de uitspraak

Van de twee deelvereisten van het openbaarheidsbeginsel staat het vereiste van een openbare uitspraak in de Nederlandse doctrine het meest ter discussie. Daarbij draait het vooral om de vraag in hoeverre het in het openbaar mondeling uitspreken van de beslis-

\footnotetext{
298. Zie Hummatov, par. 149.

299. In de volgende uitspraken lijkt het recht op een mondelinge behandeling (en aanwezigheid van partijen) samen te vallen met of niet duidelijk onderscheiden te worden van het recht op een openbare behandeling, EHRM 20 mei 2008, Gülmez t. Turkije, EHRC 2008/89 m.nt. Jansen, par. 35-39; EHRM 18 maart 2008, Piroğlu en Karakaya t. Turkije, nrs. 36370/02 en 37581/02, par. 38-40; EHRM 23 november 2006, Jussila t. Finland, EHRC 2007/31 m.nt. Albers. Zie verder: Van der Velde 2004, EVRM R\&C (katern 3.6.0 art. 6 Eerlijk proces), p. 29-30. Zie hierover ook: P. van Dijk, F. van Hoof, A. van Rijn en L. Zwaak (red.), Theory and Practice of the European Convention on Human Rights, Antwerpen: Intersentia 2006, p. 599.

${ }^{300 .}$ In sommige uitspraken scheidt het EHRM beide kwesties wel duidelijk van elkaar. Zie bijvoorbeeld: Moser, par. 89-98 waarin het EHRM eerst beziet of klaagster recht had op een 'oral hearing' en de toepasselijke principes en daarna of er een recht op een 'public hearing' bestond. Zo ook: EHRM 7 juni 2007, Zagorodnikov t. Rusland, nr. 66941/01, par. 18-27 (openbare behandeling van de zaak) en par. 28-35 (recht om aanwezig te zijn bij de zitting). Het EHRM constateert een schending van art. 6 lid 1 vanwege gebrek aan een openbare zitting, maar géén schending het recht om aanwezig te zijn bij de zitting. Vgl. ook: De Waard 1987, p. 111.

301. Zie bijvoorbeeld Van den Hoogen in navolging van de jurisprudentie van het EHRM, R.H. van de Hoogen, Beginselen van behoorlijke elektronische rechtspraak (diss Utrecht), Den Haag: Sdu 2007, p. 33; Jansen 2004, p. 61 e.v.; Van der Velde 2004, p. 29.

302. Zie anders: Van der Velde 2004, p. 30 met verwijzing naar EHRM 25 maart 1998, Belziuk t. Polen, nr. 23103/93, par. 38-39.

${ }^{303}$ De eis dat een belanghebbende aanwezig moet zijn bij de behandeling van de zaak is een interne openbaarheidseis die in mijn ogen evengoed op het beginsel van hoor en wederhoor, zie par. 4.3.5, gegrond kan worden.
} 


\section{Deel I Beginselen van behoorlijke rechtspleging}

sing zinvol is alsmede in hoeverre dat vereist is en of de praktijk daarmee in overeenstemming is.

Zoals hierboven al is aangegeven, bepaalt de Grondwet dat de uitspraak te allen tijde in het openbaar geschiedt. Uitzonderingen daarop lijken gelet op de tekst van de bepaling niet mogelijk. ${ }^{304}$ De vraag is echter of de grondwetgever met de term 'geschiedt' bedoeld heeft dat (het dictum van) de uitspraak mondeling in het openbaar gewezen moet worden. ${ }^{305}$ In artikel 8:78 Awb is in elk geval ondubbelzinnig neergelegd dat het dictum van de uitspraak in het openbaar moet worden uitgesproken. ${ }^{306}$ In de praktijk heeft de bestuursrechter (in eerste aanleg) zich daaraan echter niet altijd gehouden en het dictum van de uitspraak wer veelal niet in het openbaar uitgesproken. ${ }^{307}$ Die (alom bekende) praktijk kwam echter nooit in de uitspraak zelf tot uitdrukking. Daarin werd steevast de zinsnede 'in het openbaar uitgesproken' opgenomen. ${ }^{308}$ De rechtbank Amsterdam heeft een einde aan deze fictie gemaakt. In verschillende uitspraken is duidelijk aangegeven dat (het dictum van) de uitspraak niet mondeling openbaar is gemaakt, maar 'is gedaan' op een bepaalde datum. ${ }^{309}$ Dat heeft vervolgens geleid tot vernietiging van de uitspraken door de Afdeling wegens strijd met artikel 8:78 Awb. ${ }^{310}$ Overigens heeft de commissie Verbetervoorstellen bestuursrecht aan de rechtbanken het advies gegeven om in elk geval een einde te maken aan de handhaving van de fictie in de uitspraken zelf dat de dicta mondeling worden uitsproken. ${ }^{311}$ Voor dat advies valt iets te zeggen, omdat vermelding in de uitspraak dat mondelinge openbaarmaking heeft plaatsgevonden, terwijl dat in werkelijkheid niet het geval is geweest, in elk geval geen praktijk is die moet blijven voortbestaan. De fictie kan opgeheven worden, door het in het openbaar uitspreken van de (dicta van) de uitspraken door de rechtbanken (de dicta) totdat de wetgever aan zet is geweest. Zo lang dat niet is geschied, is de handelwijze van de rechtbank Amsterdam naar de letter in strijd met de Awb en daarmee evenmin te billijken. Daarvan lijkt deze rechtbank (en ook andere rechtbanken) zich bewust, omdat inmiddels wordt overgaan tot het mondeling in het openbaar uitspraken van alle uitspraken. ${ }^{312}$ In het wetsvoorstel aanpassing bestuursprocesrecht is een wijziging op dit punt van de Awb vooralsnog evenmin voorgenomen ${ }^{313}$, hetgeen betekent dat ook in de toekomst in bestuursrechtelijke

\footnotetext{
${ }^{304 .}$ De Werd 2001, p. 70.

305. De toelichting op art. $121 \mathrm{GW}$ lijkt daar wel op te duiden, zie hierover: De Werd, p. 70. De VMC-Commissie lijkt te menen dat openbaarmaking ook op andere wijze kan omdat de essentie volgens de grondwetgever het voorkomen van geheime vonnissen was, p. 4-5.

306. Zie hierover ook: De Werd 2001, p. 71.

${ }^{307}$ Rapport VMC-studiecommissie Openbaarheid van rechtspraak 2006, p. 4-5; De Werd, p. 67.

${ }^{308 .}$ Rapport Commissie verbetervoorstellen bestuursrecht, p. 16.

309. Rb. Den Haag, nevenzittingsplaats A'dam, 8 oktober 2007, zaaknr. AWB 06/57653 en Rb. Den Haag, nevenzittingsplaats A'dam, 11 december 2006, AWB 06/46447. In beide gevallen blijkt uit de uitspraak slechts dat op welke datum deze is gedaan en verzonden aan partijen. In beide gevallen blijkt ook niet uit het proces-verbaal dat (het dictum van) de uitspraak mondeling openbaar is gemaakt en heeft de rechtbank eveneens aangegeven in een brief dat zulks niet is geschied, zie de uitspraken van de Afdeling genoemd in de noot hierna. Overigens zijn er via www.rechtspraak.nl nog meer gevallen te vinden waarin de rb. A'dam (en ook andere rechtbanken) deze praktijk lijkt te hanteren.

${ }^{310}$. AbRvS 21 januari 2008, $A B$ 2008/115 m.nt. De Waard; AbRvS 9 februari 2007, JB 2007/68 m.nt. DWMW; $A B$ 2007/90 m.nt. Sew. Ook de CRvB heeft deze praktijk inmiddels in strijd bevonden met art. 8:78 Awb, zie: CRvB 23 juni 2009, LJN BJ0880, AB 2009/267.

311. Rapport Commissie verbetervoorstellen bestuursrecht, p. 16. De commissie doet daarnaast de aanbeveling aan de wetgever om art. 8:78 Awb aan te passen en daarin te bepalen dat het uitspreken van de beslissing in het openbaar ook kan geschieden door publicatie op de website van de rechtbank. Zie verder het advies van de Raad voor de Rechtspraak over het conceptvoorstel aanpassing bestuursprocesrecht, waarin de aanbevelingen van de commissie verbetervoorstellen bestuursrecht overgenomen worden, waaronder de aanbeveling inzake het openbaar uitspreken van de uitspraak, Raad voor de Rechtspraak, 19 oktober 2006, p. 16.

312 Op de website www.rechtspraak.nl wordt bij de verschillende rechtbanken aangegeven dat de uitspraken op grond van de Awb in het openbaar moeten worden uitgesproken. Dat gebeurt op een dagelijkse of wekelijkse zitting.

313. Kamerstukken II 2009/10, 32 450, nr. 1-3. Dit wetsvoorstel is op 24 juli 2010 ingediend bij de Tweede Kamer. In dit proefschrift konden eventuele wijzingen ten opzichte van het concept-voorstel echter niet meer
} 


\section{De beginselen}

geschillen openbaarmaking van het dictum van de uitspraak nog steeds mondeling dient plaats te vinden. Duidelijk is echter dat hier een punt van aandacht ligt voor zowel de grondwetgever als de Awb-wetgever.

Vanuit het perspectief van de openbaarheidseisen, zoals neergelegd in artikel 6 EVRM, vormt de praktijk om uitspraken niet in het openbaar uit te spreken geen probleem. Het EHRM laat de geoorloofdheid van de vorm van publiciteit die aan de uitspraak gegeven wordt door een verdragsstaat vooral afhangen van de bijzondere kenmerken van de procedure waar het in het betreffende geval om gaat. ${ }^{314}$ Een algemene eis dat (het dictum van) een uitspraak te allen tijde in het openbaar mondeling uitgesproken moet worden, stelt het EHRM niet. ${ }^{315}$ Afhankelijk van de aard van de desbetreffende procedure, kan openbaarmaking ook geschieden op andere wijze, zoals door toezending aan partijen en/of ter inzagelegging bij de griffie en/of publicatie in een officiële collectie of tijdschriften. ${ }^{316}$ Het EHRM lijkt vooral waarde te hechten aan de vraag of de toegang voor het publiek tot de uitspraak oftewel 'public scrutiny' voldoende gewaarborgd is. ${ }^{317}$ Wel bestaat er soms een samenhang met de openbare behandeling van de zaak. Is dat vereiste geschonden, dan lijken er ook hogere eisen gesteld te worden aan de openbaarmaking van de uitspraak. ${ }^{318}$ In het geval dat er een openbare zitting is geweest in eerste aanleg, kan openbaarmaking aan partijen en belanghebbenden en in vaktijdschriften voldoende zijn. ${ }^{319}$ Daarentegen kan juist de omstandigheid dat een zitting in camera mocht worden gehouden in sommige gevallen ook betekenen dat openbaarmaking van de uitspraak, vanwege de in het geding zijnde belangen, op andere wijze dan in het publiek uitspreken daarvan geoorloofd is. ${ }^{320}$

Openbaarheidseisen en controle door het publiek

De eisen dat de zitting in de procedure bij de (bestuurs)rechter openbaar moet zijn en ook de uitspraak openbaar gemaakt moet worden of (althans naar Nederlands recht in elk geval het dictum) in het openbaar moet worden uitgesproken, worden gesteld ten behoeve van de inzichtelijkheid en controleerbaarheid van de werkzaamheid van de rechter voor de betrokken partijen en het publiek. ${ }^{321}$ Openbaarheid van rechtspraak is van fundamenteel belang, omdat de rechter onafhankelijk behoort te zijn en vanwege zijn onafhankelijkheid geen verantwoording over zijn uitspraken schuldig is aan andere staatsmachten. Het vertrouwen in rechtspraak wordt door de openbaarheid bevorderd. Martens noemt deze functie de democratische functie van de openbaarheidseisen. ${ }^{322}$ Daarnaast wordt de kwaliteit van rechtspraak gediend door openbaarheid van rechtspraak, in het bijzonder door de combinatie van de openbare uitspraak en motivering van de uitspraak. Het afleggen van verantwoording naar buiten en de controle van het publiek werkt kwaliteitsverhogend. ${ }^{323}$ Met openbaarheid van de rechtspraak wordt naast het algemene belang

worden meegenomen. Waarin de hoofdstekst op dit wetsvoorstel wordt ingegaan, betreft het derhalve de voorstellen zoals gedaan in het concept-voorstel.

314. Zie EHRM 8 december 1983, Pretto t. Italië, nr. 7984/77, par. 21-26; Moser, par. 101; EHRM 22 februari 1984, Sutter t. Zwitserland, nr. 8209/78, par. 32-33; EHRM 8 december 1983, Axen t. Duitsland, nr. 8273/78, par. 30 .

315. Moser, par. 101; Sutter, par. 32-33; Axen, par. 30; Pretto, par. 21-26. Zie hierover ook: De Werd 2001, p. 6869.

316. Sutter, par. 34; Pretto, par. 26-28

317. EHRM 17 januari 2008, Ryakib Biryukov t. Rusland, EHRC 2008/43 m.nt. Van der Velde, par. 43-45; Pretto, par. 27.

par. 27.

319. Zie Moser, par. 102 waarin het EHRM verwijst naar Sutter, par. 33-34.

${ }^{320 .}$ B. en P., par. 46-48.

321. PG Awb II, p. 458; De Werd 2001, p. 68; Widdershoven 1989, p. 142; De Waard 1987, p. 110; U. Van de Pol, Openbaar terecht (diss. Amsterdam VU), Arnhem: Gouda Quint 1986, p. 16; Van Galen \& Maarseveen 1978, p. 60.

322. S.K. Martens in zijn openingsrede bij de opening van www.rechtspraak.nl (te raadplegen via http://www.rechtspraak.nl/Gerechten/HogeRaad/Actualiteiten/Archief/1999/12/).

323. Zie over de kwaliteitsbevorderende functie van het motiveringsbeginsel par. 3.2.2.7. 


\section{Deel I Beginselen van behoorlijke rechtspleging}

ook het belang van partijen gediend. ${ }^{324}$ Openbaarheid van de behandeling door en de beslissing van de rechter vormt immers een waarborg voor partijen tegen willekeur en heeft een functie ten behoeve van het vertrouwen van het publiek in de onafhankelijke rechtspraak. ${ }^{325}$

Ook het EHRM wijst er in zijn jurisprudentie standaard op dat deze belangen gediend worden met de openbaarheid van de rechtspraak alsmede dat openbaarheid van procedures en uitspraken bijdraagt aan de realisatie van een eerlijk proces. ${ }^{326}$ In een vrij recente uitspraak verwoordde het EHRM het als volgt:

“(...) that the public character of proceedings protects litigants against the administration of justice in secret with no public scrutiny; it is also one of the means whereby confidence in the courts, superior and inferior, can be maintained. By rendering the administration of justice visible, publicity contributes to the achievement of the aim of Article $6 \S 1$, namely a fair trial, the guarantee of which is one of the fundamental principles of any democratic society, within the meaning of the Convention (...). ${ }^{327}$

Een onderscheid tussen de openbare behandeling en de openbare uitspraak maakt het EHRM in dat kader niet. ${ }^{328}$ Ook in de Nederlandse doctrine wordt een onderscheid in functies niet expliciet gemaakt tussen het vereiste van de openbare behandeling en de openbare uitspraak. In het licht van de functies van de openbaarheidseisen wordt soms wel aangenomen dat aan de openbaarheid van de uitspraak minder gewicht toekomt dan de openbaarheid van behandeling. ${ }^{329}$ De scepsis richt zich echter vooral tegen de (nationale) eis dat een uitspraak mondeling in het openbaar moet worden uitgesproken en betreft niet zozeer de eis dat een uitspraak openbaar moet worden gemaakt. ${ }^{330}$ Dat bleek ook uit de (inmiddel verlaten) praktijk van de Nederlandse bestuursrechter waarin een openbaar mondeling uitgesproken (dictum van de) uitspraak nauwelijks meer voorkwam. ${ }^{331}$ Publieke controle kan ook, zoals hierboven is gebleken, plaatsvinden (naast de openbaarheid van de zitting) op andere wijze of door het gebruik van andere middelen dan het mondeling in het openbaar uitspreken van de beslissing.

In de hiervoor genoemde functies van de openbaarheidseisen is er wederom een duidelijke tweedeling te herkennen: bescherming van de belangen van partijen bij de procedure alsmede bescherming van het algemene belang bevordering van het vertrouwen in rechtspraak door middel van controle door het publiek. Die tweedeling wordt ook wel treffend geilllustreerd door het onderscheid tussen inwendige en uitwendige (of interne en externe) openbaarheid dat met name in het strafprocesrecht en strafrechtelijke procedures onderkend wordt. ${ }^{332}$ Inwendige openbaarheidseisen beogen de betrokken partijen te beschermen tegen willekeur, terwijl uitwendige openbaarheidseisen de controle door het publiek beogen te waarborgen. ${ }^{333}$ Aan de interne openbaarheid wordt voldaan, indien partijen of procesdeelnemers toegang tot de zitting hebben en de beschikking krijgen over de betreffende uitspraak, terwijl de externe of uitwendige openbaarheid vereist dat

\footnotetext{
324. Widdershoven 1989, p. 142. Zie ook: Van Dijk \& Van Hoof e.a. 2006, p. 597; Van Dijk 1983, p. 109.

325. Van Dijk \& Van Hoof e.a. 2006, p. 597; Widdershoven 1989, p. 142; Van Dijk 1983, p. 109.

326. Zie bijvoorbeeld: Gülmez, par. 34; Hummatov, par. 140. Zie ook: Jansen 2004, p. 61.

327. Ryakib Biryukov, par. 30.

328. Zie bijvoorbeeld: Pretto, par. 21 (openbaar maken uitspraak); Moser, par. 93 (openbare behandeling), par. 93.

329. Stroink beschouwt de eis van een openbare uitspraak bijvoorbeeld als een afgeleide van de eis dat een openbare behandeling moet plaatsvinden en acht de eerste ook van ondergeschikt belang daaraan, Stroink 1993, p. 68 . Zie ook: De Waard 1995, p. 449.

330. Zie bijvoorbeeld De Waard die zich afvraagt welke waarde het in het openbaar uitspreken van vonnissen nog heeft, De Waard 1995, p. 449.

${ }^{331 .}$ Zie over die praktijk van de bestuursrechter: De Werd 2001, p. 67 e.v.

332. L. van Lent, Externe openbaarheid in het strafproces (diss. Utrecht), Den Haag: BJu 2008, p. 1. Zie ook conclusie A-G Machielse bij HR 2 juli 2002, NJ 2003/2 m.nt. Kn, par. 3.7; J. C. Somer, 'Openbaarheid en de rechtsbescherming van het individu’, in: B. de Goede, H.Th.J.F. van Maarseveen (red.), Hoe openbaar wordt ons bestuur, Den Haag: VUGA 1969, 243-244.

${ }^{333 .}$ Van Lent 2008, p. 1.
} 


\section{De beginselen}

de zitting en de uitspraak toegankelijk zijn voor het publiek. ${ }^{334}$ In mijn opinie moet openbaarheid van rechtspraak met name met die uitwendige openbaarheidseisen in verband worden gebracht en dienen de openbaarheidseisen ook met name dat algemene belang. De bescherming van partijen tegen willekeur vormt daaraan een ondergeschikt belang, aangezien dit belang bijvoorbeeld ook (of zelfs primair) door de mondelinge behandeling in elkaars aanwezigheid of de motiveringsplicht voor de rechter gewaarborgd wordt. De mogelijke controle door het publiek versterkt dat alleen maar. De VMCstudiecommissie Openbaarheid van rechtspraak wijst erop dat de omstandigheid dat de grondwetgever destijds een openbare uitspraak wenselijk vond ten behoeve van het voorkomen van geheime vonnissen, erop duidt dat het vereiste in eerste instantie gericht is op bescherming van individuen die voor de rechter moeten verschijnen. ${ }^{335}$ Tevens geeft zij echter aan dat tegenwoordig ook gewezen wordt op de controle door het publiek als een belangrijke ratio van dat vereiste alsmede een functie in het kader van de rechtseenheid en rechtsontwikkeling. Dat de controle door het publiek echter de doorslag geeft als ratio blijkt mijns inziens uit het feit dat het EHRM op de mogelijke toegang van het publiek tot de uitspraken de nadruk lijkt te leggen bij de beoordeling of aan de openbaarheidseisen op grond van artikel 6 EVRM is voldaan. ${ }^{336}$ Het EHRM overwoog ook in Pretto dat het doel van artikel 6 EVRM in de context van de openbaarheidseisen is:

"to ensure scrutiny of the judiciary by the public with a view to safeguarding the right to a fair trial.",337

Voorts blijkt ook uit de jurisprudentie van het EHRM inzake het afstand doen van het recht op een openbare behandeling dat de bescherming van de belangen van partijen in het concrete geschil niet altijd voorop staat. Indien immers een zwaarwegend algemeen of publiek belang daartoe noopt, behoort, hoewel de betrokken partij daartoe de noodzaak blijkbaar niet zag, toch een openbare zitting plaats te vinden. ${ }^{338}$ Het Hof overweegt dienaangaande dat:

"However, a waiver must be made in an unequivocal manner and must not run counter to any important public interest." 339

De primaire functie van de openbaarheidseisen schuilt derhalve in de bescherming van het vertrouwen in rechtspraak door controle van het publiek. ${ }^{340}$ Secundair staan de openbaarheidseisen ten dienste van de bescherming van de belangen van partijen tegen willekeur. In dat licht wordt hier een enigszins andere benadering voorgestaan dan die van Stroink inzake het vereiste van een openbare behandeling van de zaak. Stroink meent dat het vereiste van een openbare behandeling van de zaak ten dienste staat aan het verdedigingsbeginsel en derhalve de bescherming van de belangen van partijen. ${ }^{341}$ In zijn optiek bevordert het een gelijke positie van partijen, doordat partijen kennis hebben van alle relevante informatie en elkaars standpunten. Ook legt hij een verband tussen het recht op inzage van stukken en het verbod van de rechter om onderhandse contacten met partijen te hebben (als onderdeel van het verdedigingsbeginsel) en het vereiste van openbare behandeling van de zaak. ${ }^{342}$ In mijn ogen geldt hier echter hetzelfde als ik reeds heb

334. Conclusie A-G Machielse bij HR 2 juli 2002, NJ 2003/2 m.nt. Kn, par. 3.8. A-G Machielse legt in par. 3.10 ook een uitdrukkelijk verband tussen het openbaarheidsbeginsel (als uitwendige eis) en de grondslagen van onze democratische rechtsstaat alsmede de (democratische) legitimatie van de rechter die schuilt in het vertrouwen in rechtspraak van het publiek. Zie ook: Van Lent 2008, p. 1

335. Rapport VMC-studiecommissie Openbaarheid van rechtspraak 2006, p. 5.

336. Zie noot 318 .

337. Pretto, par. 27

338. Vgl.: Van Dijk \& Van Hoof e.a. 2006, p. 597; Van Dijk 1983, p. 109-110.

339. Schuler-Zgraggen t. Zwitserland, par. 58; Hakansson en Sturesson t. Zweden, par. 66

340. Vgl. ook De Werd die aangeeft dat het doel van openbaarmaking van rechterlijke uitspraken de publieke controle van de rechtspleging is, De Werd 2001, p. 68

341. Stroink 1993, p. 69.

342. Stroink 1993, p. 69. 


\section{Deel I Beginselen van behoorlijke rechtspleging}

betoogd ten aanzien van het recht van partijen op een mondelinge behandeling van de zaak en daarbij aanwezig te mogen zijn. Die eisen worden reeds volledig door het beginsel van hoor en wederhoor gedekt (zie hierover paragraaf 4.3.5). Het recht op inzage in stukken moet dan ook eerder in verband worden gebracht met dat beginsel (en de deelaspecten het recht om informatie te ontvangen en equality of arms) dan met het openbaarheidsbeginsel. Het beginsel van hoor en wederhoor heeft als primaire functie ook de bescherming van belangen van partijen in het concrete geschil. Voor het openbaarheidsbeginsel vormt dit 'slechts' een secundaire functie of neveneffect. De openbaarheidseisen hebben in mijn ogen op hoor en wederhoor en de genoemde eisen een gering - doch versterkend - effect.

\section{Openbaarheid in samenhang met andere beginselen}

Het voorgaande laat zien dat het openbaarheidsbeginsel samenhangt met enkele andere beginselen van behoorlijke rechtspleging. Allereerst bestaat er een (zij het in mijn ogen niet al te sterk) verband tussen het vereiste van een openbare behandeling van de zaak en het beginsel van hoor en wederhoor. Het openbaarheidsbeginsel staat in zeker opzicht ten dienste van of heeft als neveneffect de realisatie van het beginsel van hoor en wederhoor en de belangen van partijen in de procedure.

De openbare behandeling van de zaak kan ook in verband worden gebracht met de onpartijdigheidseisen. Hier is er een verband tussen de externe werking in de vorm de publieke controle van de werkzaamheid van de rechter en de wijze waarop hij deze verricht van het openbaarheidsbeginsel en de interne werking van het onpartijdigheidsbeginsel. Doordat de behandeling in het openbaar geschiedt, is de kans op willekeur of partijdigheid van de rechter door de publieke controle geringer. Evenals bij het verdedigingsbeginsel versterkt het openbaarheidsbeginsel de onpartijdigheid van de rechter. Op deze wijze verkrijgt het beginsel, dat primaire externe werking heeft, ook een interne dimensie.

Er bestaat niet alleen een samenhang tussen het openbaarheidsbeginsel en deze beginselen, maar ook tussen het motiveringsbeginsel en het vereiste van een openbare uitspraak bestaat deze. ${ }^{343}$ Zo kan publieke controle van de uitspraak slechts plaatsvinden indien die uitspraak openbaar wordt gemaakt, maar tevens de motivering bevat waardoor de rechter publiekelijk verantwoording aflegt voor de uitspraak. Een openbare uitspraak zonder motivering zou zinloos zijn en kan het doel ervan - publieke controle ten behoeve van het vertrouwen in de rechtspraak - maar zeer ten dele bewerkstelligen. Een gegeven motivering is echter evenzeer zinloos in het kader van dát doel indien de uitspraak niet openbaar is; de groep personen die kennis kan nemen van de uitspraak en de motivering is dan zo beperkt dat ook in dat geval die functie van de motiveringsplicht niet tot zijn recht komt. Van belang is voor ogen te houden dat de openbaarmaking niet mondeling behoeft plaats te vinden; voldoende om de functies te realiseren is dat de uitspraak en de gegeven motivering in elk geval voor het publiek voldoende toegankelijk zijn op welke wijze dan ook.

Procesrechtelijke eisen voor de procedure bij en uitspraak van de bestuursrechter De inrichtingseisen voor een procedure om aan de beide deelvereisten van het openbaarheidsbeginsel te voldoen, kunnen van verschillende aard zijn. Voor een openbare behandeling van de zaak moet gedacht worden aan het uitgangspunt dat in de procedure voor de rechter een terechtzitting behoort plaats te vinden die in beginsel ook open is voor publiek. Uitzonderingen daarop kunnen in bepaalde nauwkeurig omschreven gevallen mogelijk zijn. Aangesloten kan worden bij de mogelijkheden tot beperking die in artikel

\footnotetext{
343. Zie ook S.K. Martens die het verband tussen beide beginselen legt in zijn toespraak bij de opening van www.rechtspraak.nl (te raadplegen via http://www.rechtspraak.nl/Gerechten/HogeRaad/Actualiteiten/Archief/1999/12/). Zie nader par. 4.3.7 inzake het motiveringsbeginsel.
} 


\section{De beginselen}

6 EVRM genoemd worden, zoals ook is geschied in artikel 8:62 van de Awb voor de procedure bij de bestuursrechter. Die bepaling legt een openbare behandeling van de zaak als uitgangspunt vast in het eerste lid, terwijl in het tweede lid is vastgelegd dat dit uitgangspunt uitzondering lijdt in het belang van de openbare orde en goede zeden, in het belang van de veiligheid van de Staat, indien de belangen van minderjarigen of de eerbiediging van de persoonlijke levenssfeer van de partijen dit eisen of indien openbaarheid het belang van een goede rechtspleging ernstig zou schenden.

Voor de openbaarmaking van de uitspraak zien de inrichtingseisen op de wijze waarop de uitspraak bekend wordt gemaakt aan partijen, maar ook op de wijze van bekendmaking voor het publiek. De Awb bevat verschillende voorschriften daarover. Allereerst het al eerder aangehaalde voorschrift in artikel 8:78 dat het dictum van de uitspraak in het openbaar wordt uitgesproken. Voorts bepaalt artikel 8:79 Awb dat een afschrift van de uitspraak (of van het proces-verbaal van de mondelinge uitspraak) door de griffier binnen twee weken kosteloos aan partijen wordt verstrekt. Aan anderen kan eveneens op verzoek een afschrift of uittreksel van de uitspraak (of het proces-verbaal van de mondelinge uitspraak) verstrekt worden. Geheel kosteloos is dit echter niet. ${ }^{344}$ Daarnaast worden verschillende uitspraken geselecteerd voor publicatie op internet ${ }^{345}$ en vaktijdschriften en bestaat op die wijze (beperkte) toegang voor het publiek tot uitspraken van de rechterlijke instanties.

\subsubsection{Het motiveringsbeginsel}

Het motiveringsbeginsel voor de rechter

Het motiveringsbeginsel is, evenals de openbaarheidseisen, in de Grondwet neergelegd. In artikel 121 Grondwet is bepaald dat vonnissen de gronden behoren te bevatten waarop zij rusten. Door verschillende auteurs is erop gewezen dat de term vonnissen problematisch is, omdat uitspraken van verschillende rechterlijke colleges, zoals de Hoge Raad of verschillende bestuursrechters, doorgaans niet als vonnissen worden aangemerkt. ${ }^{346}$ Daardoor kan onduidelijkheid bestaan omtrent de reikwijdte van de grondwettelijke motiveringsplicht en in het bijzonder de vraag of de bestuursrechterlijke uitspraken door die eis bestreken worden. Strikt genomen is dat niet zo. ${ }^{347}$ Aangenomen wordt echter dat de grondwettelijke motiveringsplicht zich ook uitstrekt tot de uitspraken van de bestuursrechterlijke instanties. ${ }^{348}$ Zoals Jansen opmerkt, komt een beroep op de Grondwetsbepaling bij de (bestuurs)rechter nauwelijks voor. ${ }^{349}$ De bepaling lijkt een sluimerend bestaan te leiden. In de Awb is daarnaast ook een motiveringsplicht voor de bestuursrechter tot uitdrukking gebracht in artikel 8:77 sub b Awb. Daarin is bepaald dat de uitspraak de gronden van de beslissing behoort te vermelden en daarnaast is in het tweede lid van die bepaling neergelegd dat de rechter bij gegrondverklaring van het beroep verplicht is aan

\footnotetext{
344. Zoals lid 2 van art. 8:79 Awb bepaalt is het bij of krachtens de Wet tarieven in strafzaken bepaalde van overeenkomstige toepassing. Het betreft dan art. 17 van die wet en art. 12 lid 3 Besluit tarieven in strafzaken 2003.

345. Zie hierover en over de selectiecriteria die gehanteerd worden: R.H. van den Hoogen,

E-justice: beginselen van behoorlijke elektronische rechtspraak (diss. Utrecht), Den Haag: Sdu 2007, p. 77-80 (hfst. 5).

346. A.M.L Jansen, 'Op goede gronden. De motivering van uitspraken door de bestuursrechter', in: A.W. Heringa, A.M.L. Jansen, E.C.H.J. van der Linden, L.F.M. Verhey (red.), Het bestuursrecht beschermd (liber amicorum F.A.M. Stroink), Den Haag: Sdu 2006, p. 173; Jansen 2004, p. 70; Rapport VAR-Commissie Rechtsbescherming 2004, p. 64; De Waard 1995, p. 448. Zie ook de toelichting op art. $121 \mathrm{GW}$ in: Koekkoek 2000, p. 551.

${ }^{347}$ De tekst van de bepaling suggereert dat in elk geval, door het gebruik van de term vonnissen, niet. De bedoeling van de grondwetgever was echter wel dat ook de uitspraken van de bestuursrechter onder de werking van deze eis vielen, Kamerstukken II 1979/80, 16 162, nr. 3, p. 21-23.

348. Jansen 2006, p. 173; Jansen 2004, p. 70; Koekkoek 2000, p. 551; De Waard 1995, p. 448-449. Zowel Jansen als De Waard pleiten mijns inziens terecht voor aanpassing van de tekst van de bepaling door vervanging van de term vonnissen door rechterlijke uitspraken, Jansen 2004, p. 70; De Waard 1995, p. 448-449.

349. Jansen 2006, p. 173. Jansen wijst op CRvB 27 september 2002, AB 2003/83 m.nt. FP, als een van de weinige uitspraken waarin art. $121 \mathrm{GW}$ een rol speelt en ook nog strijdigheid met die bepaling wordt aangenomen.
} 


\section{Deel I Beginselen van behoorlijke rechtspleging}

te geven welk rechtsregel of rechtsbeginsel hij geschonden acht. Een beroep op deze bepaling komt vaker voor in de jurisprudentie. ${ }^{350}$ Ook ben ik een enkele uitspraak tegengekomen waarin de bestuursrechter, indien er geen beroep op deze bepaling wordt gedaan, ambtshalve nagaat of wel voldaan is aan artikel 8:77. ${ }^{351}$ Dat zou betekenen dat deze bepaling moet worden aangemerkt als een bepaling van openbare orde waaraan ambtshalve moet worden getoetst. ${ }^{352}$ Geheel eenduidig is de rechtspraak van de bestuursrechter op dit punt echter niet, maar ambtshalve toetsing of de motiveringsplicht door de rechter is nageleefd, zou het fundamentele karakter van de motiveringsplicht en het belang daarvan onderstrepen. ${ }^{353}$

Naast de nationale grondslagen voor het motiveringsbeginsel als beginsel voor behoorlijke rechtspleging volgt uiteraard ook uit artikel 6 EVRM en het recht op een eerlijke behandeling van de zaak dat de nationale rechter zijn uitspraken dient te motiveren. ${ }^{354}$ Hoewel een dergelijke verplichting niet genoemd wordt in de tekst van die bepaling zelf, heeft het EHRM die verplichting afgeleid uit het recht op een eerlijke behandeling van de zaak, zoals ook blijkt in de uitspraak Hirvisaari t. Finland:

"The Court reiterates that, according to its established case-law reflecting a principle linked to the proper administration of justice, judgments of courts and tribunals should adequately state the reasons on which they are based. The extent to which this duty to give reasons applies may vary according to the nature of the decision and must be determined in the light of the circumstances of the case. Although Article $6 \S 1$ obliges courts to give reasons for their decisions, it cannot be understood as requiring a detailed answer to every argument." 35

Het motiveringsbeginsel als beginsel van behoorlijke rechtspleging is niet omstreden in de doctrine. ${ }^{356}$ Er wordt een onderscheid gemaakt tussen het formele en materiële motiveringsbeginsel. Het formele beginsel houdt in dat een motivering gegeven moet worden voor de beslissing van de rechter (kenbaarheid van de motivering). Het materiële beginsel heeft betrekking op de kwaliteit van de motivering, de deugdelijkheid ervan derhalve. De Grondwet en de Awb geven slechts aan dat de gronden waarop de uitspraak berust gegeven moeten worden, maar algemeen aanvaard is dat de motivering van de rechter

${ }^{350 .}$ Zie bijvoorbeeld: AbRvS 16 mei 2002, $A B$ 2002/267 m.nt. Sew (strijd met art. 8:77 lid 2 Awb); AbRvS 28 december 2001, $A B$ 2002/146 m.nt. Sew (strijd met art. 8:77 lid 2). Zie voor meer voorbeelden: Jansen 2006, p. 174.

351. AbRvS 16 april 2008, LJN BC9614, r.o. 2.1. In die uitspraak overweegt de Afdeling dat zij ambtshalve constateert dat de beslissing van de rechtbank niet in de bestreden uitspraak is opgenomen en dat de uitspraak, wegens strijd met art. 8:77 sub c Awb, moet worden vernietigd.

352. Zie over ambtshalve toetsing: D. Brugman, 'Ambtshalve toetsing afgebakend. De plaats van ambtshalve toetsing in het bestuursprocesrecht in nationaal- en Europeesrechtelijk perspectief', NTB 2005, 34, p. 265-266. Het is geen gemeengoed dat aan beginselen van behoorlijke rechtspleging of wettelijke bepalingen waaraan deze ten grondslag liggen, ambtshalve moet worden getoetst. In de literatuur wordt daarvoor door sommigen gepleit. Bijvoorbeeld Verheij in zijn noot bij AbRvS 24 december 2003, AB 2004/383 waarin hij zich op het standpunt stelt dat fundamentele beginselen van behoorlijke rechtspleging behoren tot bepalingen waaraan de rechter ambtshalve dient te toetsen. Zie hierover: A.M.L. Jansen \& D.W.M. Wenders, 'De unificerende werking van de redelijke termijn. Een kroniek van de redelijke termijn', NJCM-Bulletin 2006, p. 1122-1125. De hoogste bestuursrechters hebben zulks echter nog nimmer expliciet overwogen.

353. Zie de vorige noot.

354. Jansen 2004, p. 65-70; Rapport VAR-Commissie Rechtsbescherming 2004, p. 64.

355. EHRM 27 september 2001, Hirvisaari t. Finland, NJCM-Bulletin 2001 m.nt. R.J.N. Schlössels, par. 30. Zie ook: EHRM 4 oktober 2007, Sanchez Cardenas t. Spanje, EHRC 2007/141; EHRM 27 september 2007, Estate of Nitschke t. Zweden, nr. 6301/05; EHRM 22 februari 2007, Tatashvili t. Rusland, ERHC 2007/59; AB 2007/324 m.nt. Barkhuysen en Schuurmans. Zie voor meer jurisprudentie: Jansen 2006, p. 176-178; Kuijer 2004, p. $167-$ 170; J. van der Velde, 'Eerlijke en openbare behandeling', in: A.W. Heringa, J.G.C. Schokkenbroek, J. van der Velde, EVRM Rechtspraak \& Commentaar. Art. 6 Eerlijk proces, Den Haag: Sdu 2004, katern par. 3.6, par. 3.6.4.7, p. 21-24; Jansen 2004, p. 65-70.

356. Jansen 2006, p. 171; Van Wijk/Konijnenbelt \& Van Male 2008, p. 657-658; Jansen 2004, p. 65-70; Stroink 2004b, p. 130; De Waard 1995, p. 448-449; Stroink 1993, p. 66 en 68-69; Widdershoven 1989, p.152; De Waard 1987, p. 371 e.v.; Van der Heijden 1984, p. 49. 


\section{De beginselen}

deugdelijk moet zijn. ${ }^{357}$ Ook het EHRM eist een deugdelijke, draagkrachtige motivering, zoals blijkt uit de hiervoor aangehaalde passage waarin het overweegt dat:

'judgments of courts and tribunals should adequately [curs. DW] state the reasons on which they are based. ${ }^{358}$

Wat onder een deugdelijke motivering verstaan moet worden, kan van geval tot geval verschillen. Het EHRM heeft aangegeven dat de motiveringseisen die gesteld worden aan de rechterlijke uitspraak kunnen variëren afhankelijk van de aard van de beslissing. ${ }^{359}$ Enkele algemene eisen kunnen echter wel uit de rechtspraak gedestilleerd worden. In elk geval vloeit uit het beginsel noch uit artikel 6 EVRM voort, zoals ook blijkt uit de hiervoor aangehaalde passage in de uitspraak Hirvisaari, dat de rechter op elke stelling van een partij behoort te reageren in de uitspraak. ${ }^{360}$ De belangrijkste stellingen en bewijsmiddelen van partijen en het oordeel van de rechter daaromtrent alsmede omtrent de essentiële rechtsvragen behoren echter in de uitspraak tot uitdrukking te komen. ${ }^{361}$ De motivering van de rechter in eerste aanleg moet zodanig zijn dat partijen op effectieve wijze gebruik kunnen maken van hun recht om hoger beroep in te stellen en behoort derhalve aanknopingspunten voor hoger beroep te bieden. ${ }^{362}$ In hoger beroep daarentegen mag het appèlcollege volstaan met verwijzing naar en overneming van de gronden van de uitspraak in eerste aanleg. ${ }^{363}$ Is de motivering door de eerdere instantie echter innerlijk tegenstrijdig of anderszins gebrekkig, dan volstaat overname van die motivering, zeker indien geklaagd is over de gebrekkige motivering, niet. ${ }^{364}$ Indien de rechter een uitspraak moet doen met toepassing van vage begrippen of vage normen, waarbij een waardering van de feiten of feitelijke kwesties moet plaatsvinden, behoort de motivering gedetailleerd te zijn. ${ }^{365} \mathrm{Al}$ met al houdt de motiveringsplicht voor de rechter op grond van de jurisprudentie van EHRM in dat de uitspraak uitdrukking moet geven aan de essentiële argumenten en bewijsmiddelen van partijen, de beoordeling daarvan door de rechter én de redenen voor zijn beslissing; dat geldt in elk geval voor één instantie in de procedure, of dat nu in eerste aanleg of in hoger beroep is, aangezien het EHRM de eerlijkheid van de procedure in zijn geheel beoordeelt. De doctrine en bestuursrechters sluiten hierbij, ook bij de interpretatie van de nationale (wettelijke) motiveringseisen, grotendeels aan. ${ }^{366}$ De bestuursrechter heeft aangegeven dat niet op ieder argument van partijen afzonderlijk behoeft te worden ingegaan in de uitspraak ${ }^{367}$, maar tevens dat het ingaan op geen enkele beroepsgrond in strijd is met de op de rechter (ingevolge artikel 8:77 Awb) rustende motiveringsplicht. ${ }^{368}$ Kritiek is er in de literatuur vooral op de soms

357. Jansen 2006, p. 176; Van Wijk/Konijnenbelt \& Van Male 2008, p. 657-658.

358. Zie ook: Jansen 2006, p. 176; Jansen 2004, p. 66.

359. Zie o.m.: EHRM Hiro Balani t. Spanje, 9 december 1994, nr. 18064/91; EHRM 29 mei 1997, Georgiadis t. Griekenland, nr. 21522/93; EHRM 19 december 1997, Helle t. Finland, nr. 20772/92.

360. Zie ook: EHRM 19 april 1994, Van de Hurk t. Nederland, NJ 1995/462 m.nt. EAA, par. 61. Jansen 2004, p 67; Widdershoven 1989, p. 153; De Waard 1987, p. 387.

${ }^{361 .}$ EHRM Hiro Balani t. Spanje, 9 december 1994, nr. 18064/91. Zie ook: Jansen 2004, p. 67 en Schlössels in zijn noot bij Hirvisaari, p. 294. Zie over motiveringseisen inzake bewijsmiddelen de noot van Barkhuysen en Schuurmans bij Tatashvili.

362. Zie de hiervoor genoemde uitspraak Hirvisaari. Ook in: EHRM 27 september 2007, Estate of Nitschke t. Zweden, nr. 6301/05.

363. Zie de hiervoor genoemde uitspraak Hirvisaari, par. 30. Verder: EHRM 27 september 2007, Estate of Nitschke t. Zweden, nr. 6301/05; EHRM 21 januari 1999, Garcia Ruiz t. Spanje, nr. 30544/96; EHRM 19 december 1997, Helle t. Finland, nr. 20772/92

364. Hirvisaari, par. 31 en 33; Tatashvili, par. 61-62. Zie hierover de noot van Schlössels bij Hirvisaari, punt 2.

365. EHRM 29 mei 1997, Georgiadis t. Griekenland, nr. 21522/93, par. 43; in het nationale geschil stond het begrip 'gross negligence' en de vraag of daarvan sprake was centraal. Zie hierover: Jansen 2004, p. 66; Rapport VAR-Commissie Rechtsbescherming 2004, p. 64.

366. Zie hierover: Jansen 2006, p. 174-176.

367. CRvB 11 december 2003, JB 2004/88 m.nt. AMLJ; AbRvS 22 mei 2002, AB 2002/247 m.nt. Sew; AbRvS 17

oktober 2001, $A B$ 2002/108 m.nt. Sew.

368. AbRvS 4 mei 2005, LJN AT5101, r.o. 2.3. 


\section{Deel I Beginselen van behoorlijke rechtspleging}

in hoger beroep wel erg bondige motiveringen waarbij verwijzing naar het oordeel van de rechtbank plaatsvindt. ${ }^{369}$ Zoals Damen ook terecht doet, kan de vraag gesteld worden of door de bestuursrechter, gelet op de functies van het motiveringsbeginsel, in hoger beroep niet een hogere maatstaf dan die van het EHRM moet worden aangelegd, aangezien de uit artikel 6 EVRM voortvloeiende eisen minimumnormen betreffen. ${ }^{370}$

Tot slot zijn er niet alleen gevallen waarin een ontbreken van of een gebrekkige motivering zich voordoet, soms kan er ook sprake zijn van een overdaad aan motivering. In de zaak Sanchez Cardenas t. Noorwegen komt het EHRM weliswaar niet tot een schending van artikel 6 eerste lid EVRM, maar overweegt het:

"50. The Court sees no reason to doubt that the High Court's judgment provided reasons that must be deemed sufficiently detailed for its conclusion that the deprivation of access was on balance justified by the children's interest.

51. However, the problem in the present instance is rather one of excess of reasoning [curs. DW] on a matter that was of a particularly sensitive nature and of paramount importance for all the persons concerned." 371

De nationale rechter had in zijn bestreden uitspraak inzake de omgangsrechten van de klager met zijn zoon gerefereerd aan beschuldigingen van seksueel misbruik door klager van zijn zoon (waarvoor klager niet strafrechtelijk veroordeeld was) maar had uiteindelijk geen oordeel hierover gegeven of het bewijs in dat kader gewaardeerd of onderzocht. Klager werd wél de omgang met zijn zoon ontzegd. De passage in de uitspraak inzake het seksueel misbruik betrof echter een obiter dictum. Klager meende derhalve dat deze passage hem geschaad had en dat de rechter ofwel er zelf onderzoek naar had moeten doen ofwel er niet naar had moeten verwijzen. Omdat het EHRM de klacht niet nader heeft onderzocht, is niet duidelijk of overwegingen ten overvloede of overwegingen die niet direct doorslaggevend zijn voor de uitkomst in sommige gevallen inderdaad 'too much' kunnen zijn en daarmee de deugdelijkheid van de motivering kunnen aantasten. ${ }^{372}$

Ratio en functie van het motiveringsbeginsel

De motiveringsplicht voor rechters dient verschillende doelen en heeft derhalve verschillende functies. In het algemeen worden de volgende functies onderscheiden: kwaliteitsbevordering, een legitimatiefunctie, een controlefunctie en een functie in het kader van de rechtsvorming. ${ }^{373}$ Met kwaliteitsbevordering wordt bedoeld dat de motiveringsplicht het geschilbeslechtende orgaan ertoe dwingt om op grond van deugdelijke argumenten en een deugdelijke redenering tot zijn beslissing te komen; de kwaliteit van de oordeelsvorming wordt erdoor verhoogd. ${ }^{374}$ Daarnaast heeft de motivering een legitimatiefunctie. De motivering verschaft de betrokkenen inzicht in de redenen voor de beslissing en deze beslissing kan daardoor eerder geaccepteerd worden. ${ }^{375}$ Voorts vormt de motivering het aanknopingspunt voor het verweer tegen die uitspraak bij het instellen van rechtsmiddelen. ${ }^{376}$ De controlefunctie is van belang, omdat de rechter door middel van zijn motivering verantwoording aflegt over de uitspraak. Omdat de rechter onafhankelijk behoort te zijn en geen verantwoording over zijn uitspraken aan de beide andere staatsmachten behoort af te leggen, is het stellen van motiveringsplichten van belang om inzicht te

369. Zie hierover: Jansen 2006, p. 179-182 en de noten bij: CRvB 31 mei 2007, AB 2007/285 m.nt. Y.E. Schuurmans; AbRvS 15 mei 2002, $A B$ 2003/196 m.nt. LD; CRvB 21 januari 1999, $A B$ 1999/169 m.nt. HBr.

370. Zie de noot bij AbRvS 15 mei 2002, $A B$ 2003/196 m.nt. LD.

371. EHRM 4 oktober 2007, Sanchez Cardenas t. Noorwegen, EHRC 2007/141.

372. Een geval waarin het EHRM tot een schending komt van art. 6 lid 1 EVRM vanwege een overdaad aan motivering ben ik niet tegengekomen.

373. Van Wijk/Konijnenbelt \& Van Male 2008, p. 657-658; Jansen 2004, p. 65-66; Stroink 1993, p. 70; Widdershoven 1989, p. 152; De Waard 1987, p. 371-374.

374. Stroink 1993, p. 70; De Waard 1987, p. 371.

375. Kuijer 2004, p. 167; Stroink 1993, p. 70.

376. Jansen 2006, p. 172; Kuijer 2004, p. 167; Stroink 1993, p. 70; Widdershoven 1989, p. 152; De Waard 1987, p. 372. Zie ook Schlössels in zijn noot bij Hirvisaari. 


\section{De beginselen}

geven in de redenen voor de uitspraak aan partijen, publiek en hogere instanties. ${ }^{377} \mathrm{Al}-$ leen door middel van de motivering kan de uitspraak immers daadwerkelijk gecontroleerd worden. De functie in het kader van de rechtsvorming houdt in dat de motivering en het daarin besloten liggende oordeel van belang kan zijn voor andere gevallen en daarmee bijdraagt aan de rechtsontwikkeling. ${ }^{378}$

Evenals bij de hiervoor behandelde beginselen van behoorlijke rechtspleging, kunnen de functies van het motiveringsbeginsel herleid worden tot twee hoofdfuncties: bescherming van de belangen van partijen in de procedure alsmede waarborging van algemene belangen, zoals het vertrouwen in rechtspraak of de rechtsontwikkeling en rechtsvorming. ${ }^{379}$ Die algemene belangen zijn echter ook in het kader van het motiveringsbeginsel mijns inziens (zeker in eerste aanleg) ondergeschikt aan het belang van partijen in het concrete rechtsgeschil en hun verdedigingsrechten. In gevallen waarin bijvoorbeeld geen rechtsmiddel openstaat of wordt ingesteld en zonder de ondersteuning van de openbaarmaking van de (motivering van de) uitspraak, blijven toch primair de functies die zien op de bescherming van belangen van partijen over. Voor het EHRM lijkt eveneens vooral centraal te staan dat de motivering aanknopingspunten biedt voor partijen om in hoger beroep te gaan en dat daarmee tot uitdrukking wordt gebracht dat zij ook daadwerkelijk gehoord zijn. Het EHRM benoemt die functie in elk geval expliciet als functie van een gemotiveerde uitspraak in Estate of Nitschke t. Zweden. Daarin overweegt het:

"The Court wishes to emphasise that the function of a reasoned judgment is to afford the parties the possibility of an effective appeal and to show to the parties that they have been heard (see, Suominen v. Finland, no. 37801/97, § 37, 1 July 2003)., 380

De andere functies van het motiveringsbeginsel legt het EHRM niet altijd zo expliciet ten grondslag aan de motiveringseisen die voortvloeien uit artikel 6 EVRM. $^{381}$ In de uitspraak Tatashvili t. Rusland worden de hiervoor genoemde functies wel weer uitdrukkelijk genoemd. ${ }^{382}$

Samenhang met enkele andere beginselen van behoorlijke rechtspleging

$\mathrm{Er}$ is, gelet op deze functies van het motiveringsbeginsel, ook een duidelijke samenhang met de eis van een openbare uitspraak, het verdedigingsbeginsel en zelfs met het onpartijdigheidsbeginsel. Zonder de (externe) openbaarheid van de uitspraak is immers de motivering van het rechterlijk oordeel niet bij het publiek kenbaar, en daarmee ook niet controleerbaar (zie hierover paragraaf 4.3.6). ${ }^{383}$ Daarnaast blijkt uit de motivering van de uitspraak of partijen ook daadwerkelijk gehoord zijn en hoe de rechter de stellingen en argumenten van partijen heeft gewogen. ${ }^{384}$ Daarmee is het ook een waarborg tegen willekeur en tegelijkertijd een waarborg voor de vereiste onpartijdigheid van de rechter. ${ }^{385}$ Uit de motivering kan blijken dat de rechter recht heeft gedaan aan het beginsel van hoor en wederhoor alsmede aan het onpartijdigheidsbeginsel. De band met het verdedigingsbeginsel bestaat er voorts uit dat de motivering van de uitspraak het aanknopingspunt vormt voor het instellen van hoger beroep en het voeren van een verdediging tegen die

\footnotetext{
${ }^{377 .}$ Vgl. Jansen 2006, p. 183; Jansen 2004, p. 70. Soms wordt daaraan nog toegevoegd dat motivering vanuit het algemeen belang gewenst is omdat het publiek in een democratische samenleving behoort te weten om welke reden een uitspraak namens die samenleving gedaan is, Kuijer 2004, p. 167. De Waard noemt dit de legitimatiefunctie naar de gemeenschap van rechtsgenoten, De Waard 1987, p. 372.

${ }^{378 .}$ Stroink 1993, p. 70; De Waard 1987, p. 372.

379. Jansen 2006, p. 173; Jansen 2004, p. 70

380. Estate of Nitschke t. Zweden, 27 september 2007, nr. 6301/05, par. 45. Vgl. ook: De Waard 1987, p. 373-375.

381. Zie ook in deze zin de noot van Schlössels bij Hirvisaari, onder punt 3. Schlössels wijst er ook op de informatie- en legitimatiefunctie voorop lijkt te staan voor het EHRM.

382. Tatashvili, par. 58.

383. De Waard legt tussen deze legitimatiefunctie naar de gemeenschap van rechtsgenoten en het openbaarheidsbeginsel ook een uitdrukkelijk verband, De Waard 1987, p. 372.

384. Van der Heijden 1984, p. 49

385. Kuijer 2004, p. 167.
} 


\section{Deel I Beginselen van behoorlijke rechtspleging}

uitspraak $^{386}$; die samenhang strekt zich derhalve uit naar de fase die volgt op de rechterlijke uitspraak in eerste aanleg. Het is van belang dat de desbetreffende rechterlijke instantie die de uitspraak doet, zich daarvan bewust is.

\section{Procesrechtelijke eisen voor de uitspraak van de bestuursrechter}

Omdat de motivering van een uitspraak per definitie toegesneden moet zijn op de omstandigheden van het geval en derhalve bestaat uit maatwerk, is het lastig algemene inrichtingseisen in de wet op te nemen waaruit blijkt wanneer sprake is van een deugdelijke motivering. Wel zijn in de Awb een algemene motiveringsplicht en eisen inzake onderdelen die hoe dan ook in de uitspraak behoren terug te komen opgenomen. De uitspraak van de bestuursrechter dient bijvoorbeeld de gronden van de beslissing en de beslissing zelf te bevatten op grond van artikel 8:77, eerste lid, onder b en c Awb. Tevens dient de uitspraak te vermelden welke geschreven of ongeschreven rechtsregel of welk algemeen rechtsbeginsel geschonden wordt geacht bij gegrondverklaring van het beroep. Indien de uitspraak mondeling wordt uitgesproken, behoort de rechter eveneens het dictum en de gronden voor de beslissing te vermelden, zo volgt uit artikel 8:67, tweede lid, Awb. Voor het overige bevat de Awb geen concrete motiveringseisen voor de rechter. De bestuursrechter heeft, zoals eerder aangegeven, conform de jurisprudentie van het EHRM bepaald dat uit artikel 8:69 noch uit artikel 8:77, eerste lid, van de Awb voortvloeit dat de rechter in zijn uitspraak op alle door een belanghebbende aangevoerde argumenten afzonderlijk behoort in te gaan. ${ }^{387}$ In de jurisprudentie is verder nog uitgemaakt dat bepaalde processuele beslissingen van de rechter, waarbij deze gebruik maakt van hem toegekende bevoegdheden in de Awb, gemotiveerd dienen te worden. Als grondslag daarvoor lijkt het ongeschreven motiveringsbeginsel te fungeren. Zo behoort de rechter te motiveren in de uitspraak waarom bepaalde door (een der) partijen meegebrachte of opgeroepen getuigen of deskundigen niet zijn gehoord. ${ }^{388}$ Mij lijkt, in het verlengde daarvan, dat voor alle processuele beslissingen van de rechter, waarbij hij een discretionaire bevoegdheid hanteert die van belang kan zijn voor de uitkomst van de procedure, een dergelijke motiveringsplicht geldt. Te denken valt aan de beslissing om op grond van artikel 8:47 Awb al dan niet een deskundige in te schakelen. ${ }^{389}$ Tot slot wijst Jansen er nog op dat voor bijzondere (neven-)dicta, zoals het in stand laten van de rechtsgevolgen ex artikel 8:72, derde lid, Awb of het zelf in de zaak voorzien ex artikel 8:72, vierde lid, Awb, eveneens een motiveringsverplichting geldt. ${ }^{390}$ De rechter moet aangeven waarom van de bevoegdheid daartoe gebruik wordt gemaakt.

\footnotetext{
${ }^{386 .}$ De Waard 1987, p. 372. Zie ook de uitspraak van het EHRM in de zaak Estate of Nitschke.

387. Zie bijvoorbeeld: CRvB 11 december 2003, JB 2004/88 m.nt. AMLJ; AbRvS 22 mei 2002, AB 2002/247 m.nt. Sew; AbRvS 17 oktober 2001, $A B$ 2002/108 m.nt. Sew.

388. CRvB 8 januari 2009, LJN BH1537; CRvB 6 mei 2008, $A B$ 2008/243 m.nt. H.E. Bröring; AbRvS 22 mei 2007, $A B$ 2008/72 m.nt. O.J.D.M.L. Janssen; AbRvS 21 mei 2007, AB 2007/194 m.nt. Sew; JB 2007/134 m.nt. DWMW. Eerder oordeelde de Afdeling nog dat een motivering voor het afzien van het horen niet in de uitspraak behoefde te worden vermeld: AbRvS 26 januari 2005, AB 2005/374 m.nt. R.H. de Bock. Die motivering behoort de beslissing van de rechtbank ook te kunnen dragen. In CRvB 8 november 2000, $A B$ 2001/41 m.nt. HBr was dat niet het geval. Indien in het proces-verbaal van de zitting is vermeld waarom van het horen van de getuigen is afgezien en partijen de gelegenheid hebben gekregen om, na toezending ervan, op het proces-verbaal te reageren, wordt de schending van het motiveringsbeginsel overigens voldoende hersteld geacht, zie: AbRvS 2 augustus 2006, $A B$ 2008/65 m.nt. N. Verheij.

389. Zie over deze bevoegdheid in het algemeen en de rol van deskundigen in het bestuursprocesrecht: L.M. Koenraad, 'Deskundig rechtspreken: Beschouwingen over de plaats van deskundigen in het bestuursprocesrecht', JB-plus 2007, p. 202-223.
}

${ }^{390}$ Jansen 2006, p. 175 . 


\section{De beginselen}

\subsubsection{Het beginsel van de redelijke termijn}

Het beginsel van de redelijke termijn en artikel 6 EVRM

Het beginsel van de redelijke termijn houdt (voor het bestuursrecht) in dat een geschil tussen burger en overheid inzake bestuursrechtelijke aanspraken, verplichtingen of sancties binnen een redelijke termijn beslecht moet worden. De herkomst en het belang van dit beginsel van behoorlijke rechtspleging lijken, meer nog dan bij de overige beginselen het geval is, voornamelijk te herleiden tot artikel 6 EVRM. Daarin is neergelegd dat geschillen die leiden tot de vaststelling van burgerlijke rechten en verplichtingen of geschillen inzake de gegrondheid van een ingestelde strafvervolging, binnen een redelijke termijn beslecht behoren te worden. Het beginsel bestrijkt, volgens het EHRM, niet slechts de procedure bij de rechter, maar werkt ook door in fasen voorafgaand aan die procedure, zoals de bestuurlijke voorprocedures, en fasen ter executie van uitspraken van de rechterlijke instanties. ${ }^{391}$ Beslechting van geschillen binnen een redelijke termijn, voor zover er sprake is van de vaststelling van burgerlijke rechten en plichten in de zin van artikel 6 EVRM, wil zeggen dat vanaf aanvang van het geschil tot de definitieve beslechting van het geschil een redelijke termijn in acht moeten worden genomen. De aanvang van de relevante periode wordt in deze gevallen gelegd bij de aanvang van het geschil, dat wil in beginsel zeggen het aanhangig maken van de procedure bij de rechter. ${ }^{392}$ Voor bestuursrechtelijke geschillen begint de termijn in het algemeen te lopen vanaf de start van de bestuurlijke voorprocedures. ${ }^{393}$ Bij bestuursrechtelijke procedures inzake een 'criminal charge', zoals het opleggen van een bestuurlijke boete of een andere punitieve sanctie, kan dat moment eerder liggen, namelijk op het moment dat een daad van vervolging wordt gepleegd jegens de klager of soms nog eerder, indien de situatie van de verdachte wordt geraakt ('substantially affected') door een andere handeling. ${ }^{394}$ De periode die beoordeeld moet worden in het licht van de redelijke termijn eindigt pas zodra het geschil definitief is beëindigd en de rechtspositie van de burger is bepaald dan wel de straf definitief is vastgesteld. ${ }^{395}$ Voor bestuursrechtelijke geschillen betekent dit dat de periode gedurende welke het bestuursorgaan, na vernietiging van een besluit door de bestuursrechter, een nieuw besluit neemt, meetelt bij de beoordeling of een redelijke termijn in acht is genomen (alsmede alle daartegen gerichte vervolgprocedures). ${ }^{396}$ Het EHRM hanteert voorts al geruime tijd verschillende factoren om te bepalen of in een concreet geval de redelijke termijn is overschreden. In Frydlender zette het deze nog eens op een rij: de ingewikkeldheid van de zaak, het processuele gedrag van de klager, de wijze waarop de zaak door het bestuur en de rechter (c.q. de justitiële autoriteiten) behandeld wordt en de belangen die voor de klager op het spel staan. ${ }^{397}$

Onder invloed van artikel 6 EVRM heeft het beginsel van de redelijke termijn een stevig verankerde grondslag gekregen in de Nederlandse rechtspraak en literatuur. ${ }^{398}$ Een

\footnotetext{
391. EHRM 28 juni 1978, König t. Duitsland, Series A, vol. 27 en EHRM 9 december 1994, Schouten en Meldrum t. Nederland, $A B$ 1995/599, m.nt. ICvdV; JB 1995/49 m.nt. AWH. Zie ook: Jansen 2000, p. 27-28; R.J.G.M. Widdershoven, 'Tijdigheid in het bestuursprocesrecht', in: G.R. Rutgers en H.E. Bröring (red.), Rechtspraak op tijd, Den Haag: BJu 1999, p. 77-79.

393. König, par. 98. Zie over de betekenis van de redelijke termijn-eis voor de bestuurlijke voorprocedures nader par. 5.7 van Deel II.

394. Zie bijvoorbeeld: EHRM 15 juli 1982, Eckle t. Duitsland, Series A, vol. 51 en EHRM 27 februari 1980, Deweer t. België, Series A, vol. 35; EHRM 24 mei 2005, Intiba t. Turkije, EHRC 2005/70 m.nt. Jansen. Zie ook: Jansen 2000, o.m. p. 40-41.

395. Jansen \& Wenders 2006, p. 1098; Jansen 2000, p. 43 e.v. en 56 e.v.; Widdershoven 1999, p. 78.

396. EHRM 22 mei 2003, Kyrtatos t. Griekenland, EHRC 2003/57 m.nt. Janssen; AB 2004/172, m.nt. TB; EHRM

19 maart 1997, Hornsby t. Griekenland, JB 1997/98 m.nt. AWH; NJ 1998/434. Zie ook: Barkhuysen \& Van Ettekoven 2009, p. 132; Jansen 2000, p. 42 e.v.; Widdershoven 1999, p. 78.

397. EHRM 27 juni 2000, EHRC 2000/67 m.nt. Heringa. Zie voor een nadere uitwerking: Schreuder-Vlasblom 2009, p. 457-460; Jansen \& Wenders 2006, p. 1099-1104; Jansen 2000, p. 129-172.

398. Zie recent over de redelijke termijn o.m.: Barkhyusen \& Van Ettekoven 2009, p. 129-141; M. SchreuderVlasblom, 'Dertig jaar later; de redelijke termijn als nationale uitdaging', in: T. Barkhuysen, M.L. van Emmerik
} 


\section{Deel I Beginselen van behoorlijke rechtspleging}

nationale geschreven grondslag valt echter, in elk geval voor het bestuursrecht, niet aan te wijzen. Ook in onze Grondwet is een dergelijk vereiste voor rechtspraak niet gepositiveerd. Toch meende J.M. Polak in 1976 al dat de eis dat uitspraken tijdig moeten worden gegeven, moest worden beschouwd als een beginsel van behoorlijke rechtspraak. ${ }^{399}$ Ook Van Maarseveen lijkt de eis van een tijdige uitspraak te beschouwen als een eis voor behoorlijke rechtspraak, maar geeft er de voorkeur aan (vanwege gewenste reductie van het beginselenaantal) deze eis onder te brengen onder een zorgvuldigheidsbeginsel. ${ }^{400}$ Beide auteurs refereren niet (expliciet) aan artikel 6 EVRM. Verschillende auteurs pleiten er thans ook voor of erkennen, gelet op het toenemende belang van voortvarendheid in het bestuursprocesrecht en de beperkte reikwijdte van artikel 6 EVRM, een ongeschreven grondslag van de redelijke termijn-eis in de vorm van een tijdigheidbeginsel, (al dan niet) als onderdeel van het rechtszekerheidbeginsel. ${ }^{401}$ Opvallend is daarbij dat zij niet verwijzen naar het decisiebeginsel (of beginsel van de redelijke termijn), dat als ongeschreven beginsel van behoorlijke rechtspleging reeds door De Waard onderscheiden werd en ook erkend is. ${ }^{402}$

Er zijn derhalve aanknopingspunten dat het beginsel van de redelijke termijn reeds onderdeel uitmaakte van het nationale (ongeschreven) recht, als beginsel van behoorlijke rechtspleging, nog voordat de invloed van artikel 6 EVRM daarop in sterke mate aanwijsbaar was. Door de sterke doorwerking van artikel 6 EVRM in onze rechtsorde is echter buiten kijf komen te staan dat geschilbeslechting binnen een redelijke termijn ook moet worden beschouwd als een beginsel van behoorlijke rechtspleging dat in iedere procedure of geheel van procedures in acht moet worden genomen. ${ }^{403}$ De invulling en toepassing van het beginsel geschiedt in de Nederlandse literatuur en jurisprudentie echter grotendeels overeenkomstig de benadering van het EHRM, zoals neergelegd in diens jurisprudentie. ${ }^{404}$ Wat betreft aanvang en einde van de relevante periode en de van belang zijnde factoren - de complexiteit van de zaak, het gedrag van de klager, het gedrag van de autoriteiten en het belang dat voor klager op het spel staat ${ }^{405}-$ om te bepalen of een redelijke termijn in acht is genomen, volgen de bestuursrechters in beginsel de jurisprudentie van het EHRM. ${ }^{406}$ Op een enkel punt wordt door de bestuursrechter afgeweken van de door het EHRM gehanteerde benadering. De belastingkamer van de Hoge Raad hanteert voor fiscale boetes (ergo: criminal charges) vaste, gefixeerde termijnen als uitgangspunt ter bepaling of de redelijke termijn geschonden is. ${ }^{407}$ De Hoge Raad legt in zijn benadering iets meer nadruk op de deelfasen dan op de totale duur van de procedure

\& J.P. Loof (red.), Geschakeld recht. Verdere studies over Europese grondrechten ter gelegenheid van de 70ste verjaardag van prof.mr. E.A. Alkema, Deventer: Kluwer 2009, p. 453-474; A.M.L. Jansen, 'Overheidsaansprakelijkheid voor overschrijding van de redelijke termijn', $O \& A$ 2009, p. 60-68; Jansen \& Wenders 2006, p. 10911127.

399. Polak 1976, p. 16

${ }^{400 .}$ Van Maarseveen \& Stout 1979, p. 199.

${ }^{401 .}$ B.M.J. van der Meulen, 'Vooruit te branden bestuur. Over rechtsbescherming tegen uitblijven van besluiten en een requiem voor de fictieve weigering', JB-plus 1999, p. 16; Widdershoven 1999, p. 76-77; M. Scheltema, 'Het tijdigheidbeginsel', in: R.L. Vucsán (red.), De Awb-mens: boeman of underdog? (Opstellen aangeboden aan Leo Damen), Nijmegen: Ars Aequi Libri 1996, p. 241-253.

402. Jansen 2000, p. 5; Widdershoven 1989, p. 114 en 116-117; De Waard 1987, p. 225 e.v.

403. Van belang is wel dat de reikwijdte van art. 6 EVRM beperkt is tot geschillen inzake de vaststelling van een civil right or obligation dan wel criminal charge.

404. Zie hierover: Jansen \& Wenders 2006, p. 1096-1098, 1099 en 1104- 1107. De Hoge Raad wijkt op enkele punten af van de benadering van het EHRM, zoals in het navolgende zal blijken.

405. EHRM 27 juni 2000, Frydlender t. Frankrijk, EHRC 2000/67 m.nt. Heringa.

406. Zie met verwijzingen: Jansen \& Wenders 2006, p. 1104-1107.

${ }^{407 .}$ HR 22 april 2005, JB 2005/166 m.nt. Wenders; $A B$ 2006/11 m.nt. A.M.L. Jansen. De strafkamer van de Hoge Raad had al eerder vuistregels geformuleerd voor de beoordeling of de redelijke termijn is geschonden, samengevat in HR 3 oktober 2000, NJ 2000/721 m.nt. JdH; Rawb 2001/21 m.nt. A.M.L. Jansen en onlangs aangepast in HR 17 juni 2008, NJ 2008/358 m.nt. P.A.M. Mevis; AB 2009/231 m.nt. AMLJ. Die laatste uitspraak heeft de belastingkamer van HR weer gevolgd in HR 19 december 2008, $A B$ 2009/230 m.nt. Jansen. 


\section{De beginselen}

en de factoren zoals het EHRM doet. ${ }^{408}$ De uitspraak van de Hoge Raad en de daarin geformuleerde vuistregels hebben in de jurisprudentie van de overige bestuursrechters navolging gevonden in de zin dat ernaar verwezen werd. ${ }^{409}$ Inmiddels hanteren de hoogste bestuursrechtelijke colleges zelf ook gefixeerde termijnen. In geschillen waarin een bestuurlijke boete centraal staat, hanteren de bestuursrechters conform de uitspraken van de Hoge Raad een termijn van vier jaar, waarbij de eerste aanleg inclusief de bezwaarfase twee jaar mag duren en de fase in hoger beroep ook twee jaar. ${ }^{410}$ Voor geschillen waarin het de vaststelling van 'civil rights or obligations' betreft, lopen de door de bestuursrechters gehanteerde termijnen uiteen. De Afdeling gaat uit van een periode van vijf jaar over drie instanties waarbij voor bezwaar een jaar staat, voor beroep twee jaar en voor hoger beroep twee jaar. ${ }^{411}$ De termijnen die de Centrale Raad hanteert in uitkeringszaken wijken daar weer enigszins vanaf: een half jaar voor bezwaar, anderhalf jaar voor beroep en twee jaar voor hoger beroep. ${ }^{412}$ De totale duur van de procedure mag derhalve niet meer dan vier jaar beslaan. Het $\mathrm{CBb}$ lijkt weer enigszins daarvan afwijkende termijnen te hanteren. ${ }^{413}$ Bovendien hanteren de hoogste bestuursrechters ook vaste tarieven voor immateriële schadevergoeding. ${ }^{414}$ Dat doet het EHRM (voor zichzelf) ook, maar het hanteert een andere berekeningsmethode. ${ }^{415}$

Voorts past de bestuursrechter zijn bevoegdheid tot aanvullen van de rechtsgronden ruimhartig toe als het gaat om de redelijke termijn. Als er geklaagd wordt over de lange duur van de procedure dient de bestuursrechter dat op te vatten als een klacht over schending van de redelijke termijn en daarbij dienen alle fases in de procedure beoordeeld te worden. ${ }^{416}$ Dat leek al eerder in de jurisprudentie het geval te zijn. ${ }^{417}$ De Afdeling oordeelde ook dat in de klacht over de duur van de procedure bij de rechtbank een verzoek om schadevergoeding begrepen ligt, waardoor een belanghebbende daar niet zelf expliciet meer om hoeft te verzoeken. ${ }^{418}$ Voor boetezaken lijkt te gelden dat de bestuursrechter, blijkens een uitspraak van de Hoge Raad, ambtshalve moet beoordelen of de redelijke termijn overschreden is. Daarbij is echter nog niet geheel duidelijk of het gaat om ambtshalve toetsing aan een bepaling van openbare orde (de redelijke termijn-eis) of

\footnotetext{
408. Zie hierover: Jansen \& Wenders 2006, p. 1105-1107; A.M.L. Jansen, 'Tijdige rechtspraak en de rol van de Hoge Raad', WFR 2005/183, p. 1584-1588.

409. Zie: CRvB 28 augustus 2008, AB 2010/17 m.nt. A.M.L. Jansen; AbRvS 14 maart 2007, AB 2007/213 m.nt A.M.L. Jansen; Rb. Rotterdam, 22 mei 2006, LJN AX8428.

410. Zie: Barkhuysen \& Van Ettekoven 2009, p. 132. Zij verwijzen naar AbRvS 24 december 2008, LJN BG8313; CRvB 28 augustus 2008, $A B$ 2010/17 m.nt. A.M.L. Jansen.

411. AbRvS 4 maart 2009, AB 2009/236 m.nt. Barkhuysen \& Den Ouden; JB 2009/82; AbRvS 24 december 2008, $J B$ 2009/42 m.nt. C.L.G.F.H. A.; USZ 2009/75 m.nt. Barkhuysen \& Van Emmerik; $A B$ 2009/213 m.nt. Van Ravels \& Jansen.

412. CRvB 26 januari 2009, JB 2009/66 m.nt. Barkhuysen en Van Emmerik; $A B$ 2009/241 m.nt. Jansen.

413. CBb 3 maart 2009, LJN BH6281, JB 2009/139; $A B$ 2009/304 m.nt. Sew. Zie hierover de noot van Jansen bij $A B$ 2009/213.

414. CRvB 26 januari 2009, JB 2009/66 m.nt. Barkhuysen en Van Emmerik; $A B$ 2009/241 m.nt. Jansen; AbRvS 24 december 2008, JB 2009/42 m.nt. C.L.G.F.H. A.; USZ 2009/75 m.nt. Barkhuysen \& Van Emmerik; $A B$ 2009/213 m.nt. Van Ravels \& Jansen.

415. Zie hierover: Barkhuysen \& Van Ettekoven 2009, p. 135.

416. AbRvS 1 juli 2009, LJN BJ1126; AbRvS 24 december 2008, JB 2009/42 m.nt Albers; $A B$ 2009/213 m.nt. Ravels \& Jansen. In boetezaken toetst in elk geval de HR ambtshalve of de redelijke termijn is geschonden, HR 22 april 2005, $A B$ 2006/11 m.nt. A.M.L. Jansen; $J B$ 2005/166 m.nt. DWMW.

417. Zie o.m.: AbRvS 24 december 2008, JB 2009/42 m.nt Albers; AB 2009/213 m.nt. Ravels \& Jansen; CRvB 26 januari 2009, JB 2009/66 m.nt. Barkhuysen \& Van Emmerik; AbRvS 19 november 2003, AB 2004/27 m.nt. AMLJ.

418. AbRvS 24 december 2008, JB 2009/42 m.nt Albers; $A B$ 2009/213 m.nt. Ravels \& Jansen; AbRvS 4 maart 2009, $A B$ 2009/236 m.nt. Barkhuysen \& Den Ouden; $J B$ 2009/82 m.nt. red.; AbRvS 4 juni 2008, $A B$ 2008/229 m.nt. Widdershoven; $J B$ 2008/146 m.nt. Jansen; USZ 2008/211 m.nt. Barkhuysen \& Van Emmerik. De CRvB lijkt overigens nog te eisen dat om schadevergoeding verzocht moet worden wil er een vergoeding kunnen worden toegekend op grond van art. 8:73 Awb, CRvB 3 januari 2008, AB 2008/211 m.nt Jansen. In die zaak ging het wel om vergoeding van schade door de lange duur van de procedure bij het bestuursorgaan.
} 


\section{Deel I Beginselen van behoorlijke rechtspleging}

om ambtshalve aanvulling van de rechtsgronden. ${ }^{419}$ De Afdeling daarentegen heeft in een recente uitspraak in een zaak waarin een boete op grond van de Wet arbeid Vreemdelingen was opgelegd overwogen dat de redelijke termijn-eis in beginsel geen bepaling van openbare orde vormt waaraan ambtshalve door de bestuursrechter moet worden getoetst. In uitzonderingsgevallen kan het zo zijn dat de bestuursrechter ambtshalve moet nagaan of de redelijke termijn is geschonden. Daarvan is sprake in de gevallen waarin een vertraging, die leidt tot overschrijding van de redelijke termijn, zich voordoet nádat het onderzoek ter zitting is gesloten maar vóórdat uitspraak wordt gedaan. ${ }^{420}$ In de desbetreffende zaak werd, in strijd met artikel 8:66 Awb, twee en een halve maand na sluiting van het onderzoek pas uitspraak gedaan. Omdat het onderzoek al gesloten was en de voorgenomen datum waarop uitspraak zou worden gedaan nog binnen de redelijke termijn viel, was de vertraging niet te voorzien en was er geen reden om daarover te klagen. In dergelijke gevallen ligt het in de rede dat de bestuursrechter ambtshalve nagaat of met de opgelopen vertraging na sluiting van het onderzoek de redelijke termijn wordt overschreden.

Rechtszekerheid voor burgers als belangrijkste ratio voor het beginsel

Het primaire belang van het beginsel van de redelijke termijn is gelegen in bescherming van de belangen van de bij de procedure betrokken partijen. ${ }^{421}$ Geschillen die bepalend kunnen zijn voor de rechtspositie van burgers dienen binnen een redelijke termijn definitief beslecht te worden, opdat de betreffende burgers niet langer dan nodig in onzekerheid omtrent hun rechtspositie verkeren. ${ }^{422}$ De ratio van het beginsel is de rechtszekerheid van de betrokken partijen. ${ }^{423}$ Voor procedures waarin strafrechtelijke vervolging plaatsvindt of anderszins een punitieve sanctie wordt opgelegd, geldt dat de ratio van het beginsel eveneens gelegen is in de rechtszekerheid voor de 'vervolgde' persoon, aangezien er zo spoedig mogelijk duidelijkheid moet bestaan inzake strafvervolging en de eventuele gevolgen daarvan voor die burger. ${ }^{424}$

Jansen wijst erop dat het redelijke termijn-vereiste, naast dit belang, ook nog een aantal accessoire belangen dient. Daarbij valt te denken aan het feit dat geschilbeslechting binnen een redelijke termijn ook van belang kan zijn voor derden die niet bij de betreffende procedure zijn betrokken, voor bestuursorganen die uiteraard zo spoedig als mogelijk tot uitvoering van besluitvorming willen overgaan, voor de bestuursrechter zelf en meer in het algemeen voor de doelmatigheid en rechtszekerheid. ${ }^{425}$ Ook andere auteurs wijzen erop dat het beginsel van de redelijke termijn zowel de belangen van betrokkenen beschermt als de rechtszekerheid. ${ }^{426}$ In feite heeft het beginsel dus ook een functie in het kader van de rechtszekerheid voor alle betrokken actoren bij de procedure, maar ook een functie in het algemeen belang. Dat algemeen belang is gediend met spoedige uitvoering van door het bestuur genomen besluiten alsmede (voor procedures met een strafrechtelijke karakter) spoedige vervolging van verdachten en uitvoering van eventueel opgelegde straffen en sancties. Ter aanvulling moet nog opgemerkt worden dat inachtneming van dit beginsel een belangrijke algemene functie heeft in het kader van het vertrouwen in rechtspraak van de samenleving. Procedures die teveel tijd in beslag

419. HR 22 april 2005, $A B$ 2006/11 m.nt. Jansen; JB 2005/166 m.nt. D.W.M. Wenders. Zie ook: Barkhuysen \& Van Ettekoven 2009, p. 134.

420. AbRvS 10 februari 2010, LJN BL3354. Zie hierover ook nog par. 3.3 van Deel III van dit onderzoek.

${ }^{421 .}$ Vgl. Jansen 2000 , p. 13.

422. Jansen 2000, p. $23-24$ en 97; Van Dijk 1983, p. 114.

423. Zoals ook door de Afdeling is aangegeven in: AbRvS 3 december 2008, AB 2009/70 m.nt. Barkhuysen en Van Emmerik; $J B$ 2009/13; AbRvS 4 maart 2009, $J B$ 2009/82 m.nt. red.; $A B$ 2009/236 m.nt. Barkhuysen \& Den Ouden; AbRvS 17 april 2009, nr. 200806348/1. In die uitspraken werd overwogen dat aan het vereiste van de redelijke termijn, zoals neergelegd in artikel 6 EVRM, het rechtszekerheidsbeginsel ten grondslag ligt. Om die reden geldt die eis ook in geschillen die buiten de reikwijdte vallen van artikel 6 EVRM.

424. Jansen 2000, p. 55-56 en 97; Van Dijk 1983, p. 114.

425. Jansen 2000, p. 13.

426. Widdershoven 1989, p. 116; Van Dijk 1983, p. 115. 


\section{De beginselen}

nemen tasten het gezag voor en het vertrouwen in rechtspraak dat burgers hebben aan; is er sprake van een structureel gebrek in dit opzicht, dan wordt meer algemeen ook het vertrouwen in rechtspraak (van de samenleving derhalve) aangetast. Uit het voorgaande blijkt dat het beginsel ook belangen dient die de procedure en de belangen van de bij de procedure betrokken actoren overstijgen.

Voor het beginsel van de redelijke termijn, als ongeschreven nationaal beginsel van behoorlijke rechtspleging, lijkt de ratio met name gezocht te worden in de belangen van de betrokken partijen en hun rechtszekerheid. Er zijn auteurs die menen dat sprake is van afzonderlijke erkenning in het nationale (ongeschreven) recht van een beginsel van de redelijke termijn. ${ }^{427} \mathrm{Zij}$ stellen zich zonder uitzondering ook op het standpunt dat dit beginsel onderdeel uitmaakt van het rechtszekerheidsbeginsel dan wel dat de ratio voor het beginsel gezocht moet worden in het rechtszekerheidsbeginsel. ${ }^{428}$ Niet altijd duidelijk is of zij daarmee het oog hebben op de rechtszekerheid van de betrokken burgers als zodanig dan wel de rechtszekerheid meer in het algemeen of beide. Primair moet aangenomen worden dat het beginsel de belangen van de bij het geschil betrokken partijen dient.

De verhouding tot andere beginselen van behoorlijke rechtspleging

Er bestaat nauwelijks samenhang tussen het beginsel van de redelijke termijn en de overige beginselen van behoorlijke rechtspleging, althans niet zodanig dat dit beginsel ten dienste staat van andere beginselen en vice versa. Het tegendeel lijkt bij sommige beginselen eerder het geval. ${ }^{429}$ Naleving van het beginsel van de redelijke termijn kan in sommige gevallen immers op gespannen voet staan of conflicteren met het beginsel van hoor en wederhoor, het onpartijdigheidsbeginsel, een openbare behandeling van de zaak of het motiveringsbeginsel. ${ }^{430}$ Hoe voortvarender de procedure, hoe minder tijd en mogelijkheden er bestaan om op behoorlijke wijze het geschil te behandelen en de uiteindelijke beslissing vorm te geven. Omgekeerd geldt dat hoe meer waarborgen in een procedure zijn ingebouwd, hoe meer tijd een procedure in beslag kan nemen. Er dient een balans te bestaan tussen de voortvarendheid en de overige eisen van behoorlijkheid die de rechterlijke instanties dienen te betrachten, afhankelijk van de omstandigheden van het geval. De noodzaak van evenwicht tussen die belangen is deels ook te herkennen in de factoren die het EHRM en de nationale rechters hanteren ter bepaling of de redelijke termijn in acht is genomen. De factor complexiteit van de zaak, als onderdeel van die afweging, vormt daarvan een duidelijk voorbeeld. De bestuursrechter hanteert ook in dit verband een iets andere werkwijze. De Centrale Raad heeft aangegeven dat de standaardtermijnen en de behandelingsduur voor een procedure bij de rechtbank in het algemeen voldoende ruimte bieden voor het normale verloop van een proces. De inschakeling van een deskundige wordt daaronder inbegrepen geacht en kan derhalve geen rechtvaardiging voor vertraging opleveren. ${ }^{431}$ Daarvan kan slechts in bijzondere omstandigheden sprake zijn, waarbij de door het EHRM gehanteerde factoren een rol spelen.

Een conflictsituatie lijkt zich gezien het bovenstaande met name voor te kunnen doen tussen het beginsel van de redelijke termijn en de overige beginselen van behoorlijke rechtspleging die primair de belangen van partijen in de procedure beogen te beschermen.

${ }^{427}$ De Waard schaart het beginsel van de redelijke termijn onder het decisiebeginsel, De Waard 1987, p. 127 en 225 e.v.

428. Zie: R.G.J.M. Widdershoven, 'Tijdigheid in het bestuursprocesrecht', in: G.R. Rutgers \& H.E. Bröring, Rechtspraak op tijd, Den Haag: Bju 1999, p. 77; B.J.M van der Meulen, 'Vooruit te branden bestuur', JB-Plus 1999, p. 16.

429. Vgl. Jansen 2000, p. 14-15

430. Jansen 2000, p. 15, noot 51. Vgl. Jussila, par. 42 waarin ook het EHRM aangeeft dat het houden van openbare zittingen vanwege inachtneming van het redelijke termijn-vereiste soms achterwege kan blijven. Zie ook: Van der Velde 2004, p. 41.

${ }^{431 .}$ CRvB 30 juni 2009, LJN BJ2125. 
Deel I Beginselen van behoorlijke rechtspleging

Procesrechtelijke eisen in de procedure bij de bestuursrechter

Een (wettelijke) garantie voor geschilbeslechting binnen een redelijke termijn lijkt het wettelijk vastleggen van termijnstellingen voor de procedure bij de bestuursrechter te zijn. In de Awb is dat onder meer in hoofdstuk 8 op verschillende plaatsen ook gebeurd. Te denken valt daarbij aan de termijn van zes weken voor het indienen van het beroepschrift in artikel 6:7 Awb of de termijn van vier weken voor indiening van het verweerschrift na verzending van het beroepschrift door de rechtbank (met mogelijkheid tot verlenging van die termijn) in artikel 8:42 Awb. Voorts bevat artikel 8:47, derde lid, respectievelijk vierde lid van de Awb de bevoegdheid voor de rechter om een ingeschakelde deskundige een termijn te stellen waarbinnen deze deskundige verslag dient uit te brengen, alsmede een termijn van vier weken voor partijen om na verzending van dat verslag te reageren. Ook kan gedacht worden aan de termijn die bepaalt binnen hoeveel weken uitspraak moet worden gedaan na afloop van de zitting: binnen zes weken na sluiting van het onderzoek behoort de rechtbank uitspraak te doen op grond van artikel 8:66, eerste lid, Awb. ${ }^{432}$ Daarnaast biedt de Landelijke procesregeling bestuursrecht 2008 voor de rechtbanken en de Procesregeling bestuursrechterlijke colleges 2006 voor de bijzondere bestuursrechters op verschillende plaatsen termijnstellingen of uitwerkingen van bepalingen in de Awb. ${ }^{433} \mathrm{Zo}$ is in artikel 4 van de procesregeling bepaald dat uitstel van door de rechtbank gestelde termijnen slechts in uitzonderlijke omstandigheden wordt verleend en kan de rechtbank bij inwilliging van een dergelijk verzoek slechts een nadere termijn van vier weken gunnen aan de indiener van het verzoek. ${ }^{434}$ Een ander voorbeeld is de termijn die bepaald is voor het repliceren en dupliceren op grond van artikel 8:43 Awb: indien de rechtbank van die bevoegdheid gebruik makt, krijgt de indiener van het beroepschrift vier weken de tijd om te repliceren en het bestuursorgaan vervolgens vier weken om te dupliceren na ontvangst van de repliek. ${ }^{435}$ Ook zijn termijnstellingen in verband met deskundigenonderzoek opgenomen in de procesregeling: partijen krijgen twee weken de tijd om hun wensen omtrent het deskundigenonderzoek kenbaar te maken en de deskundige in kwestie krijgt dertien weken de tijd om zijn onderzoek af te ronden. $^{436}$

Hoewel dergelijke inrichtingseisen kunnen waarborgen dat de procedure voldoende voortvarend verloopt, verdient daarbij aantekening dat partijen in het bestuursrecht weinig tot niets kunnen ondernemen tegen overschrijdingen van de rechter van deze termijnen. ${ }^{437}$ Uitsluitend indien in de rechterlijke procedure de redelijke termijn wordt overschreden, kan zulks in hoger beroep aangekaart worden én staat daar een sanctie tegenover. Het is echter niet de rechter zelf die door de sanctie geraakt wordt, maar de Staat die de compensatie voor de schending moet voldoen. ${ }^{438}$ Bovendien wordt hiermee niet

\footnotetext{
432. Zie hierover ook de noot bij AbRvS 18 juli 2003, $A B$ 2004/3 en J.M. Polak, "Termijnen voor rechterlijke uitspraken", $N J B$ 1996, p. 248-249.

433. Landelijke procesregeling bestuursrecht 2008, Stcrt. 2008, 114; Procesregeling bestuursrechterlijke colleges 2006, Stcrt. 2005, 250. Datzelfde geldt ook voor de Procesregeling belastingkamers gerechtshoven 2005, Stcrt. $2005,198$.

434. Zie art. 4 lid 1 en lid 3. Een volgend verzoek om uitstel wordt blijkens lid 4 in beginsel afgewezen.

435. Art. 14 lid 1 en lid 2.

436. Art. 15 lid 1 en 2 . Zie lid 3 en 4 voor verdere termijnstellingen in het kader van het deskundigenonderzoek.

437. De bestuursrechter heeft meermalen aangegeven dat het termijnen van orde betreft en geen fatale termijnen waardoor overschrijding van de termijnen niet kan leiden tot vernietiging van de uitspraak van de rechter, zie bijvoorbeeld: CRvB 22 april 2005, JB 2005/198 (overschrijding termijn art. 8:79 Awb); CRvB 11 december 2003, $J B$ 2004/88 m.nt. AMLJ (overschrijding termijnen art. 8:66 en 8:79 Awb); AbRvS 18 juli 2003, $A B$ 2004/3 m.nt. AMLJ; $J B$ 2003/242 (overschrijding termijn art. 8:66 Awb). De jurisprudentie van de bestuursrechter is in overeenstemming met de bedoeling van de wetgever, zie PG Awb II, p. 460-461.

${ }^{438}$ Zie AbRvS 4 juni 2008, AB 2008/229 m.nt. Widdershoven; JB 2008/146 m.nt. AMLJ; USZ 2008/211 m.nt. Barkhuysen en Van Emmerik in USZ 2008/212 waarin de Afdeling daartoe het onderzoek heropent en de Staat als partij bij het geding op grond van art. 8:26 Awb oproept. Zie verder: CRvB 11 juli 2008, JB 2008/172 m.nt. AMLJ; $A B$ 2008/241 m.nt. R.J.G.M. Widdershoven; USZ 2008/238 m.nt. Barkhuysen en Van Emmerik waarin de CRvB vanwege zijn eigen overschrijding van de redelijke termijn het onderzoek heropent en de Staat oproept als partij bij de procedure.
} 


\section{De beginselen}

bewerkstelligd dat een lopende procedure versneld kan worden, maar vindt uitsluitend repressief compensatie voor een te lange duur van de procedure plaats. Om de voortvarendheid van de procedure preventief te bevorderen kunnen verschillende inrichtingseisen opgenomen worden in de wet. Widdershoven stelt bijvoorbeeld dat het van belang is om de voorzitter van een rechterlijk college de bevoegdheid te geven om termijnen te stellen, teneinde de voortgang van de procedure te bewaken. ${ }^{439}$ De discussie over een mogelijke wettelijke voorziening en de vormgeving ervan is, naar aanleiding van de recente uitspraken van de hoogste bestuursrechters waarin een artikel 13 EVRM- conforme interpretatie van artikel 8:73 Awb plaatsvindt bij schendingen van de redelijke termijn $^{440}$ en de recente uitspraken waarin deze bestuursrechters gefixeerde termijnen hanteren $^{441}$, op gang gekomen. ${ }^{442}$ Barkhuysen en Van Emmerik doen het voorstel tot instelling van een kamer die moet oordelen over dergelijke schendingen naar analogie van de wrakingskamer. ${ }^{443}$ Die kamer zou dan ook preventief moeten kunnen optreden, teneinde dergelijke schendingen te voorkomen. De bevoegdheid tot het stellen van termijnen aan de rechter(s) die de zaak behandelt zou bijvoorbeeld een optie kunnen zijn in dat kader. Het scheppen van een wettelijke voorziening, teneinde een effectief rechtsmiddel te bewerkstelligen, stond al enige tijd hoog op de agenda van de minister van Justitie. $^{444}$ Inmiddels is er een wetsvoorstel opgesteld dat voor advies onder meer is voorgelegd aan de Raad voor de Rechtspraak en de Nederlandse orde van advocaten. ${ }^{445}$ Het voorstel voorziet in de invoering van een snelle en eenvoudige verzoekschriftprocedure tot vergoeding van immateriële schade, die aanhangig kan worden gemaakt na het einde van de procedure bij de bestuursrechter of reeds gedurende de procedure bij de bestuursrechter. Het verzoek wordt ingediend bij de bestuursrechter bij wie het beroep of het hoger beroep aanhangig is, indien dat wordt ingediend gedurende het beroep of het hoger beroep tegen het besluit ten gronde, dan wel bij de bestuursrechter die als laatste een beslissing heeft genomen in de hoofdzaak, indien de procedure reeds is beëindigd. Er komt voorts een $\mathrm{AMvB}$ waarin een uniforme regeling plaatsvindt van de termijnen en vaste bedragen voor de berekening van het bedrag dat wordt uitgekeerd.

\subsubsection{Effectieve rechtsbescherming: een nieuw beginsel?}

Effectieve rechtsbescherming als speerpunt in het bestuursrecht

De afgelopen jaren heeft de vraag naar de effectiviteit van de geschilbeslechting een steeds dominantere plaats gekregen in de discussies over de inrichting van het bestuursrechtelijke systeem van rechtsbescherming. ${ }^{446}$ Vanuit verschillende hoeken is daarbij

\footnotetext{
439. Widdershoven 1989, p. 119.

${ }^{440 .} \mathrm{Zie}$ de uitspraken in noot 439.

441. Zie de uitspraken in noot $411,412,413$ en 414.

442. Zie hierover ook: A.M.L. Jansen, 'Overheidsaansprakelijkheid voor overschrijding van de redelijke termijn', $O \& A$ 2009, p. 60-68; Barkhyusen \& Van Ettekoven 2009, p. 129-141.

443. T. Barkhuysen en M. Van Emmerik, 'Schadevergoeding bij schending van de redelijke termijn: op weg naar een effectief rechtsmiddel', $N J B$ 2008, 26, p. 1579-1582. De noodzaak van een dergelijk rechtsmiddel vloeit overigens voort uit de eis van effectieve rechtsbescherming in combinatie met de redelijke termijn- eis.

444. Zie Barkhuysen \& Van Ettekoven 2009, p. 129, noot 8, die wijzen op een ontvankelijkheidsbeslissing van het EHRM (EHRM 3 maart 2009, Voorhuis t. Nederland, nr. 28692/06) waarin de minister heeft aangekondigd een wettelijke voorziening te zullen treffen.

445. Persbericht Ministerie van Justitie, 23 april 2010. Het persbericht en het wetsvoorstel zijn te raadplegen via de website http://www.justitie.nl/actueel/persberichten/archief-2010/100413minister-schadevergoeding-alsrechtszaken-veel-te-lang-duren.aspx? $\mathrm{cp}=34 \& \mathrm{cs}=579$

446. J.A.M. van Angeren, 'Zelf voorzien in stroomversnelling', JB-plus 2009, p. 257 e.v.; Verslag Evaluatie Awb III, p. 37; J.A.M. van Angeren, 'De rechter als bestuurder-plaatsvervanger. Een pleidooi voor meer zelf voorzien door de bestuursrechter', JB-plus 2007, p. 16-23; F.F.W. Brouwer \& L.M. Koenraad, 'Slagvaardig bestuursprocesrecht. Over bestuurlijke lus, finale geschilbeslechting en conflictoplossing', $N J B$ 2006, p. 1678-1684; C.E. Drion, 'Het geringe probleemoplossend vermogen van het bestuurs(proces)recht', $N J B$ 2006, p. 1089; Rapport VAR-Commissie Rechtsbescherming 2004, o.m. 19-21; B.J. van Ettekoven, 'Alternatieven van de bestuursrechter (observaties vanuit de eerste lijn) in: B.J. van Ettekoven, M.A. Pach, I.C. van der Vlies, Alternatieven van en
} 


\section{Deel I Beginselen van behoorlijke rechtspleging}

kritiek geuit op de huidige regeling in de Awb van de procedure bij de bestuursrechter en in het bijzonder diens uitspraakbevoegdheden. Als belangrijkste probleem wordt gezien het gebrek aan mogelijkheden en/of het onvoldoende gebruik maken van bestaande mogelijkheden door de rechter om het geschil definitief te beslechten. ${ }^{447}$ De bestuursrechter heeft immers als uitgangspunt de bevoegdheid om een beroep gegrond te verklaren en een besluit te vernietigen, waarna het bestuur weer aan zet is om een nieuw besluit te nemen. ${ }^{448}$ In sommige gevallen kan de bestuursrechter ook op grond van artikel 8:72, vierde lid, van de Awb zelf in de zaak voorzien, maar met die bevoegdheid wordt veelal terughoudend omgesprongen. ${ }^{449}$ De klassieke opvatting is dat zelf voorzien mogelijk is, indien er rechtens nog maar één besluit genomen kan worden (omdat sprake is van een gebonden bevoegdheid). ${ }^{450}$ In andere gevallen moet terughoudendheid worden betracht. ${ }^{451}$ Datzelfde geldt in beginsel voor de bevoegdheid om de rechtsgevolgen van een besluit in stand te laten op grond van artikel 8:72, derde lid, van de Awb, met dien verstande dat het te nemen besluit dezelfde rechtsgevolgen moet hebben als het vernietigde besluit. ${ }^{452}$ Op dit punt is echter de rechtspraak van de bestuursrechter sterk in beweging, waarbij recent versoepelingen hebben plaatsgevonden ten aanzien van de voorwaarden waaronder de bestuursrechter van deze bevoegdheden gebruik kan maken. ${ }^{453}$ Op deze rechtspraak wordt hieronder nog nader ingegaan. Na vernietiging van het besluit staan vervolgens tegen het nieuwe door het bestuur genomen besluit wederom de reguliere rechtsgangen open, waardoor een geschil zich jarenlang kan voortslepen alvorens het definitief beslecht wordt. ${ }^{454}$ Het is met name de takverdeling tussen bestuur en bestuursrechter, gelet op staatsrechtelijke uitgangspunten, die aan de basis staat van het huidige stelsel en die tevens mede de oorzaak vormt van de niet definitieve beslechting van geschillen. ${ }^{455}$

De actualiteit en het belang van deze problematiek in het bestuursrecht wordt nog eens onderstreept door het feit dat het onderwerp finale geschilbeslechting voorwerp van onderzoek is geweest in het kader van de derde evaluatie van de Awb. ${ }^{456}$ Uit dit onderzoek zijn negen factoren naar voren gekomen die een definitieve geschilbeslechting in het bestuursrecht in de weg (kunnen) staan: de beslissingsruimte van het bestuur, de benodigde inhoudelijke deskundigheid, het verschil in toetsingsmoment in de bestuurlijke en rechterlijke procedure, mandaat van de vertegenwoordigers van het bestuursorgaan, procedurele en formele belemmeringen, betrokkenheid van derden, doorlooptijden, werklastverdeling tussen bestuur en rechter en tot slot het zittingsgericht werken. ${ }^{457}$

voor de bestuursrechter (preadviezen VAR-reeks 126), Den Haag: BJu 2001, m.nt. hfst. 3, p. 53. e.v; J.E.M. Polak, 'Effectieve bestuursrechtspraak: enkele beschouwingen over het vermogen van de bestuursrechtspraak om geschillen materieel te beslechten, Deventer: Kluwer 2000; A.R. Neerhof, 'Van effectieve bestuursrechters en geschillen die voorbijgaan...?, JB-plus 1999 (hierna: Neerhof 1999b), p. 71-87.

447. Zie hierover bijvoorbeeld: E.J. Daalder, 'Kroniek van het algemeen bestuursrecht. Over de omvang van rechtsbescherming, rechtseenheid en verschillen in benadering', NJB 2008, p. 2128-2136; A.T. Marseille \& R.R. van der Heide, 'De onderbenutting van de mogelijkheden tot finale beslechting door de bestuursrechter', JB-plus 2008, p. 78-92; Verslag Evaluatie Awb III, p. 37.

448. Art. 8:72 lid $1 \mathrm{Awb}$

449. Zie hierover: Marseille \& Van der Heide 2008, p. 78 e.v.; Schueler e.a. 2007, p. 50-59, 101-104 en 105-145.

450. Marseille \& Van der Heide 2008, p. 80; Verslag Evaluatie Awb III, p. 38; Schueler e.a. 2007, p. 50-59; Neerhof 1999b, p. 80-83; PG Awb II, p. 460. Zie ook: CRvB 3 januari 2003, AB 2003/99 m.nt. FP. Nader over de achtergrond hiervan: Van Angeren 2007, p. 16-19. Zie ook de noot van Ortlep bij AbRvS 11 februari 2009, $A B$ 2009/224 m.nt. Ortlep, met verdere verwijzingen, die erop wijst dat ook onder de klassieke benadering in de jurisprudentie meer ruimte bestaat voor zelf voorzien dan weleens wordt aangenomen.

451. Vgl.: Schueler e.a. 2007, p. 50-59.

452. Marseille \& Van der Heide 2008, p. 80; Schueler e.a. 2007, p. 60-62.

453. Zie over deze ontwikkeling: J.A.M. van Angeren, 'Zelf voorzien in stroomversnelling', JB-plus 2009, p. 257 e.v.; Verslag Evaluatie Awb III, p. 37; J.A.M. van Angeren, 'De rechter als bestuurder-plaatsvervanger. Een pleidooi voor meer zelf voorzien door de bestuursrechter', JB-plus 2007, p. 16-23.

454. Verslag Evaluatie Awb III, p. 37.

455. Verslag Evaluatie Awb III, p. 37; Schueler e.a. 2007, p. 1-2; Brouwer \& Koenraad 2006, p. 1678-1679.

456. Schueler e.a. 2007.

457. Schueler e.a. 2007, p. 139-142; Verslag Evaluatie Awb III, p. 43-44. 


\section{De beginselen}

Zoals aangegeven, vloeit een deel van deze factoren onmiskenbaar voort uit de staatsrechtelijke verhouding tussen bestuur en rechter en de taakverdeling tussen deze organen.

De discussie over de effectiviteit van de bestuursrechtelijke rechtsbescherming heeft daarnaast een belangrijke impuls gekregen door Europese ontwikkelingen. Zowel het Hof van Justitie als het EHRM eisen immers dat er effectieve rechtsbescherming voor een burger op nationaal niveau dient te bestaan wanneer diens rechten op grond van het Unierecht of op grond van het EVRM in het geding zijn. ${ }^{458}$

Gelet op deze ontwikkelingen dient zich de vraag aan of effectieve rechtsbescherming, en als onderdeel daarvan finale geschilbeslechting, aangemerkt kan worden als een beginsel van behoorlijke rechtspleging. Dat betekent dat effectieve rechtsbescherming een open, abstracte rechtsnorm moet vormen, waarvan de schending rechtens gevolgen met zich zou moeten brengen. Vastgesteld moet worden of deze eis onderdeel is van het positieve recht. In het onderstaande worden eerst de Europese eisen - daaronder worden in dit verband mede uit het EVRM voortvloeiende verplichtingen verstaan - en vervolgens de nationale eisen die gelden in het kader van effectieve rechtsbescherming in kaart gebracht.

Effectiviteit als voorwaarde gesteld door het EHRM

In artikel 13 EVRM is neergelegd dat er op nationaal niveau effectieve rechtsbeschermingsmogelijkheden behoren te bestaan voor een burger tegen beweerdelijke schendingen van rechten neergelegd in het EVRM. Deze eis houdt in het bestuursrecht de gemoederen vooral bezig wat betreft beweerdelijke schendingen van de redelijke termijn- eis uit artikel 6 EVRM. ${ }^{459}$ Het EHRM eist immers in dat kader dat er op nationaal niveau een effectief compensatoir rechtsmiddel of een effectief preventief rechtsmiddel moet bestaan dan wel een combinatie daarvan. ${ }^{460}$ In de jurisprudentie van de bestuursrechter zijn verschillende ontwikkelingen waarneembaar om daaraan tegemoet te komen. ${ }^{461}$ Op de vraag of de thans bestaande bestuursrechtelijke voorzieningen aan de door het EHRM gestelde voorwaarden voldoen ${ }^{462}$, wordt, voor zover van belang voor dit onderzoek, nader ingegaan in paragraaf 5.7 van Deel II.

Artikel 13 EVRM eist effectieve rechtsbescherming in alle gevallen waarin er een 'arguable claim' van schending van een in het EVRM neergelegd materieel recht bestaat. ${ }^{463}$ Dat betekent voor het bestuursrecht dat er ook effectieve rechtsbescherming in

458. Zie hierover bijvoorbeeld: Rapport VAR-Commissie Rechtsbescherming 2004, p. 48-49.

459. Zie bijvoorbeeld: P. van Dijk, 'Een effective remedy in de zin van artikel 13 EVRM bij overschrijding van de redelijke termijn in de zin van artikel 6 EVRM - bestuursrechtelijke procedures', in: T. Barkhuysen, M.L. van Emmerik \& J.P. Loof (red.), Geschakeld recht. Verdere studies over Europese grondrechten ter gelegenheid van de 70ste verjaardag van prof.mr. E.A. Alkema, Deventer: Kluwer 2009, p. 116-133; Schreuder-Vlasblom 2009, p. 453-474; T. Barkhuysen \& A.M.L. Jansen, 'Actuele ontwikkelingen in de redelijke termijn-jurisprudentie: over de Nederlandse termijnoverschrijdingen en ontbrekende nationale rechtsmiddelen', NJCM-Bulletin 2003, p. 586-600; T. Barkhuysen \& A.M.L. Jansen, 'Rechtsmiddelen tegen bestuurlijke en rechterlijke traagheid: het EVRM noopt tot aanpassing van het Nederlandse recht', NJB 2002, p. 845.

460. Zie onder meer verschillende Grote Kamer-uitspraken in 2006: EHRM 8 juni 2006, Sürmeli t. Duitsland, EHRC 2006/100 m.nt. Jansen; EHRM 29 maart 2006, Scordino (nr. 1) t. Italië, EHRC 2006/61 m.nt. Van der Velde. In 2005 oordeelde de Grote Kamer ook al over deze kwestie in een zaak tegen Slovenië, EHRM 6 oktobe 2005, Lukenda t. Slovenië, EHRC 2005/114 m.nt. Van der Velde. En voor het eerst in: EHRM 26 oktober 2000, Kudla t. Polen, NJCM-Bulletin 2001, nr. 1 m.nt. T. Barkhuysen; EHRC 2000/89 m.nt Van der Velde; AB 2001, 275 m.nt. LV.

${ }^{461}$ Z Zie bijv. de uitspraken van de hoogste bestuursrechters terzake compensatie voor schendingen van de redelijke termijn wegens rechterlijke traagheid: CRvB 11 juli 2008, $A B$ 2008/241 m.nt. Widdershoven; JB 2008/172 m.nt. AMLJ; AbRvS 4 juni 2008, AB 2008/229 m.nt. Widdershoven; JB 2008/146 m.nt. Jansen; USZ 2008/211 m.nt. Barkhuysen en Van Emmerik.

462. Zie hierover recent: Van Dijk 2009, p. 128 e.v.; T. Barkhuysen en M. Van Emmerik, 'Schadevergoeding bij schending van de redelijke termijn: op weg naar een effectief rechtsmiddel', $N J B$ 2008, p. 1579-1582.

463. Zie bijv. EHRM 13 november 2008, Frijns t. Nederland, AB 2009/7 m.nt. Barkhuysen en Tjepkema. Hierover ook: Van Dijk 2009, p. 115; T. Barkhuysen, Artikel 13 EVRM: effectieve nationale rechtsbescherming bij schending van mensenrechten (diss. Leiden), Leiden: Koninklijke Vermande 1998, p. 55 e.v. 


\section{Deel I Beginselen van behoorlijke rechtspleging}

de zin van die bepaling moet bestaan tegen besluiten of handelingen van het bestuur die een inbreuk maken op andere in het EVRM neergelegde rechten dan beslechting van het geschil binnen een redelijke termijn. ${ }^{464}$ Te denken valt bijvoorbeeld aan artikel 8 EVRM $^{465}$ en artikel 1 Eerste Protocol ${ }^{466}$, maar in het bijzonder voor vreemdelingrechtelijke geschillen ook aan artikel 3 EVRM. ${ }^{467}$ Dat betekent dat veel bestuursrechtelijke geschillen binnen het bereik van de in het EVRM neergelegde rechten vallen en daarmee ook binnen het bereik van artikel 13 EVRM.

Barkhuysen heeft in zijn dissertatie aan de hand van de jurisprudentie van het EHRM onderzocht aan welke voorwaarden een rechtsmiddel moet voldoen om als effectief in de zin van artikel 13 EVRM te kunnen worden aangemerkt. Hieronder komen enkele eisen aan bod. ${ }^{468}$ Het middel moet daadwerkelijk bestaan. Bovendien moet het rechtsmiddel voor de klager voldoende toegankelijk zijn. Voorts moet het doelmatig en voldoende doeltreffend zijn. ${ }^{469}$ Het EHRM eist ook dat de toetsing van het handelen van het nationale orgaan dat de vermeende schending van een in het EVRM neergelegd recht op zijn geweten heeft niet te beperkt is. Er moet inhoudelijk getoetst kunnen worden aan de in het EVRM neergelegde bepaling of vergelijkbare normen in het nationale recht. ${ }^{470}$ De uitspraak of beslissing van de oordelende instantie moet bindend zijn, maar specifieke eisen aan de aard van de beslissing, zoals een vernietiging of toekenning van schadevergoeding stelt het EHRM nauwelijks, aldus Barkhuysen. ${ }^{471}$ Waar het om draait is dat in het betreffende geval de voorziening geschikt redres moet kunnen bieden voor de beweerdelijke schending. ${ }^{472}$ Zoals de VAR-Commissie rechtsbescherming opmerkt, betekent het kunnen bieden van daadwerkelijk rechtsherstel ook dat de uitspraakbevoegdheden van de (rechterlijke) instantie toereikend moeten zijn en dat onder omstandigheden de enkele vernietigingsbevoegdheid onvoldoende kan zijn. ${ }^{473}$ De eisen gelden in abstracto voor het rechtsmiddel waarbij niet van belang is of in concreto daadwerkelijk rechtsherstel kan worden geboden. Een positieve uitkomst voor de klager doet evenmin terzake in het kader van de beoordeling van de effectiviteit. Dat wil zeggen dat een rechtsmiddel

\footnotetext{
464. Barkhuysen 1998, p. 87-89.

465. Vgl. R.J.G.M. Widdershoven, 'De invloed van EG-recht en EVRM op de Nederlandse bestuursrechtspraak', JB-plus 2006, p. 30; T. Barkhuysen, Het EVRM als integraal onderdeel van het Nederlandse materiële bestuursrecht (preadvies VAR 2004), Den Haag: BJu 2004, p. 65 e.v. Zie voor voorbeelden waarin bestuursrechtelijke procedures binnen het bereik van art. 8 EVRM vallen: EHRM 26 februari 2008 (ontv.besl.), Fägerskiöld t. Zweden, EHRC 2008/85 m.nt. Backes; $A B$ 2008/225 m.nt. Barkhuysen \& Van Emmerik. EHRM 2 november 2006, Giacomelli t. Italië, EHRC 2007/7 m.nt Peeters; $A B$ 2008/23 m.nt. Barkhuysen \& Van Emmerik; $J B$ $2007 / 1$.

${ }^{466 .}$ Vgl. Widdershoven 2006, p. 30; Barkhuysen 2004, p. 73 e.v. Een voorbeeld van een geval waarin een bestuursrechtelijke procedure binnen het bereik van art. 1 EP kwam: EHRM 8 april 2008, Megadat.com SRL t. Moldavië, EHRC 2008/75 m.nt. Backes; AB 2008/224 m.nt. Barkhuysen \& Van Emmerik.

${ }^{467}$ Vgl.: Widdershoven 2006, p. 30; Barkhuysen 2004, p. 58 e.v. EHRM 26 april 2007, Gebremedhin t. Frankrijk, EHRC 2007/75 m.nt. Woltjer; AB 2007/227 m.nt. Battjes; EHRM 11 januari 2007, Salah Sheekh t. Nederland, EHRC 2007/36 m.nt. Woltjer; AB 2007/76 m.nt. B.P. Vermeulen; JB 2007/52 m.nt. DWMW.

468. Voor een uitvoerige bespreking van deze eisen en de overige eisen verwijs ik naar de dissertatie van Barkhuysen, zie noot 703 PM. De eisen zijn recent op hoofdlijnen op een rij gezet door het EHRM in: EHRM 8 juni 2006, Sürmeli t. Duitsland, EHRC 2006/100 m.nt. A.M.L. Jansen.

469. Barkhuysen 1998, p. 118 e.v. Zie verder: Rapport VAR-Commissie Rechtsbescherming 2004, p. 49.

470. Sürmeli, par. 98. Vgl.: Barkhuysen 1998, p. 126-134. Zie ook met verwijzingen naar jurisprudentie: J.G.C. Schokkenbroek, 'Effectief rechtsmiddel', in: J.H. Gerards, A.W. Heringa, H.L. Janssen en J. van der Velde, EVRM Rechtspraak en Commentaar, katern. Art. 6 Eerlijk proces, Haag: Sdu 1-1-2004, par. 3.13, p. 8.

${ }^{471 .}$ Barkhuysen 1998, p. 138-140.

472. Sürmeli, par. 98. Zie ook: Barkhuysen 1998, p. 139-140; Schokkenbroek 2002, p. 8.

473. Rapport VAR-Commissie Rechtsbescherming 2004, p. 49 en p. 130. De VAR-Commissie wijst ter onderbouwing daarvan naar de uitspraak EHRM 7 november 2000, Kingsley t. Verenigd Koninkrijk, AB 2002/25 m.nt. LV. In die uitspraak werd echter een schending van de uit art. 6 lid 1 EVRM voortvloeiende eis van 'full jurisdiction' vastgesteld omdat de Engelse rechter na gegrond verklaring van het beroep tegen een besluit van een bestuursorgaan (the Gaming Board) de zaak voor hernieuwde beslissing niet kon terug verwijzen naar een ander (bestuurs)orgaan.
} 


\section{De beginselen}

effectief kan zijn, ook al wordt de klager wat betreft de schending van een in het EVRM neergelegd recht niet in het gelijk gesteld. ${ }^{474}$

Het EHRM stelt niet uitsluitend effectiviteitseisen aan rechtsmiddelen in het kader van artikel 13 EVRM. Ook in het kader van het uit artikel 6 EVRM voortvloeiende recht op toegang tot de rechter heeft het EHRM bijvoorbeeld overwogen dat het niet alleen in theorie moet bestaan, maar ook dat er een 'practical and effective right to access' moet bestaan. ${ }^{475}$ Volgens het EHRM vereist artikel 13 EVRM overigens niet dat er een effectief rechtsmiddel op nationaal niveau moet bestaan tegen schendingen van het recht op toegang. ${ }^{476}$ Voor schendingen van de redelijke termijn geldt op grond van artikel 13 EVRM wel dat er op nationaal niveau voorzien moet zijn in een effectief rechtsmiddel waarin deze beweerdelijke schending aan de kaak kan worden gesteld, zoals hiervoor aangegeven. ${ }^{477}$

\section{Effectieve rechtsbescherming in Unierechtelijk perspectief}

Het Hof van Justitie stelt in zijn jurisprudentie eveneens de eis dat op nationaal niveau effectieve bescherming van de rechten van burgers op grond van het Unierecht behoort te bestaan. In het kader van de uitvoering van Unierecht op nationaal niveau gaat het Hof van Justitie uit van het principe van nationale procesautonomie. ${ }^{478}$ Dat betekent dat de lidstaten in principe vrij zijn om hun procedures op een wijze in te richten die zij wenselijk achten en dat het nationale procesrecht van toepassing is. ${ }^{479}$ Daarbij moeten echter bepaalde randvoorwaarden in acht worden genomen. Het betreft de voorwaarden die in de literatuur bekend staan als de Rewe-riedel ${ }^{480}$, te weten het beginsel van gelijkwaardigheid en het beginsel van effectiviteit. ${ }^{481}$ Uit het eerste beginsel volgt dat in een procedure voor de nationale rechter waar rechten van een burger op grond van het Unierecht in het geding zijn of de uitvoering van Unierecht een rol speelt, de nationale procesrechtelijke regels in dat geval niet ongunstiger mogen zijn dan de regels die gelden voor een vergelijkbare louter nationale kwestie waarbij het Unierecht geen rol speelt. ${ }^{482}$ Uit het effectiviteitsbeginsel volgt dat de nationale procesrechtelijke regels de uitoefening van de rechten op grond van het Unierecht niet onmogelijk of nagenoeg onmogelijk mogen maken. ${ }^{483}$ Daarnaast geldt op grond van het door het Hof van Justitie erkende algemene rechtsbeginsel van effectieve rechtsbescherming dat een burger zijn rechten op grond van het Unierecht voor de nationale rechter ook daadwerkelijk moet kunnen effectueren. ${ }^{484}$

474. Sürmeli, par. 98. Hierover nader: Schokkenbroek 2002, p. 7; Barkhuysen 1998, p. 134-138.

475. Van Dijk \& Van Hoof e.a. 2006, p. 560. Zie ook: Widdershoven die wijst op EHRM 9 oktober 1979, Airey t. Ierland, NJ 1980/376 m.nt. E.A. Alkema, Widdershoven 1989, p. 115.

${ }^{476 .}$ Kudla, par. 151. Zie verder: Schokkenbroek 2002, p. 16.

477. In Kudla overweegt het Hof verder dat het niet uit de tekst of de totstandkomingsgeschiedenis van art. 13 EVRM kan afleiden dat die bepaling niet van toepassing kan zijn in relatie tot 'any aspects of the "right to a court", als neergelegd in art. 6 lid 1, par. 151. De betekenis van art. 13 lijkt, buiten het recht op toegang tot de rechter, derhalve ook niet uitgesloten te zijn in gevallen waarin sprake zou zijn van schendingen van de overige eisen uit art. 6 lid 1, vgl. Widdershoven 2006, p. 30.

478. Widdershoven e.a. 2007, p. 29; Jans e.a. 2007, p. 40; Widdershoven 2006, p. 27; E.M. Vermeulen, Nederlandse rechtsbescherming in communautaire context (diss. Tilburg), Den Haag: BJu 2001, p. 83.

${ }^{479}$ Widdershoven e.a. 2007, p. 29; Jans e.a. 2007, p. 40 en 42; Widdershoven 2006, p. 27; Vermeulen 2001, p. 83.

${ }^{480 .}$ Deze term is geïntroduceerd door S. Prechal, zie: R.J.G.M. Widdershoven, R.J.N. Schlössels, F.A.M. Stroink, J.B.J.M. ten Berge, A.J. Bok, W.J.M. Voermans, B.W.N. de Waard, P.A. Willemsen, Algemeen bestuursrecht 2001. Hoger beroep, Den Haag: BJu 2001, p. 30.

481. Naar de uitspraken waarin het HvJ-EG voor het eerst deze voorwaarden formuleerde, HvJ EG 16 december 1976, nr. 33/76, Rewe, en HvJ EG 16 december 1976, nr. 45/76, Comet. Zie verder: Jans e.a. 2007, p. 42; Widdershoven e.a. 2007, p. 29 en 30-31; Vermeulen 2001, p. 90-92.

482. Widdershoven e.a. 2007, p. 29; Jans e.a. 2007, p. 42; Widdershoven 2006, p. 27; Vermeulen 2001, p. $90-92$ en 174.

483. HvJ EG 9 november 1983, nr. 199/82, San Giorgio. Zie verder: Widdershoven e.a. 2007, p. 29 en 32-35; Jans e.a. 2007, p. 42; Widdershoven 2006, p. 28; Vermeulen 2001, p. 91 en 174.

484. HvJ EG 15 mei 1986, Johnston, nr. 222/84; HvJ EG 15 oktober 1987, Union nationale des entraîneurs et cadres techniques professionnels du football (Unectef) t. Heylens e.a., nr. 222/86..Zie verder hierover: A. Ger- 
Deel I Beginselen van behoorlijke rechtspleging

Dit beginsel van effectieve rechtsbescherming beschouwt het Hof van Justitie als een algemeen rechtsbeginsel. ${ }^{485}$ Het beginsel van effectieve rechtsbescherming wordt in de literatuur soms beschouwd als een uitwerking van het effectiviteitsbeginsel, terwijl tegelijkertijd wordt aangegeven dat dit beginsel een (nog) grotere invloed heeft op het nationale (bestuurs)procesrecht. ${ }^{486}$ De verhouding tussen beide beginselen is echter nog onduidelijk en de jurisprudentie van het Hof van Justitie lijkt op dit punt nog in ontwikkeling te zijn. ${ }^{487}$ Er lijkt sprake te zijn van verschillende beginselen, waarbij het gelijkwaardigheidsbeginsel en het effectiviteitsbeginsel uitdrukking geven aan het beginsel van effectieve rechtsbescherming. ${ }^{488}$ Niet duidelijk is echter hoe de verhouding tussen de beginselen is. Soms blijft afzonderlijke toetsing aan het beginsel van effectieve rechtsbescherming achterwege en lijkt deze op te gaan in de toetsing van het effectiveitsbegin$\mathrm{sel}^{489}$, maar in andere gevallen wordt aangegeven dat hoewel voldaan is aan het effectiviteitsbeginsel desondanks strijd kan bestaan met het beginsel van effectieve rechtsbescherming en vindt nog een afzonderlijke toets plaats. ${ }^{490}$ In het evaluatierapport van de Awb inzake de Europese agenda van de Awb komt naar voren dat twee aspecten van het beginsel onderscheiden kunnen worden: een formeel en materieel aspect. Het formele aspect ziet op de eis van effectieve toegang tot een rechterlijke instantie, terwijl het materiële aspect de eis behelst dat een procedure op zodanige wijze ingericht wordt dat de rechten op grond van het Unierecht ook daadwerkelijk geëffectueerd kunnen worden. ${ }^{491}$ Met name de laatste eis heeft betrekking op de effectiviteit van de nationale rechtsmiddelen. ${ }^{492}$ Ter ondersteuning van het beginsel van effectieve rechtsbescherming wijst het Hof van Justitie ook regelmatig mede op de artikelen 6 en 13 EVRM en vindt in zijn jurisprudentie afstemming met de jurisprudentie van het EHRM plaats. ${ }^{493}$ Daarnaast is het recht op een doeltreffende voorziening in rechte neergelegd en volgens het Hof van Justitie opniew bevestigd in artikel 47 van het Handvest van de grondrechten van de EU. ${ }^{494}$ Hoewel het Handvest lange tijd niet bindend is geweest en pas sinds de inwerkingtreding van het Verdrag van Lissabon bindend is, onderstreept de opname ervan in het Handvest in elk geval het belang dat in Unierechtelijke context gehecht wordt aan effectieve rechtsbescherming. ${ }^{495}$

Uit het beginsel van effectieve rechtsbescherming kunnen eisen voortvloeien ten aanzien van verschillende procesrechtelijke kwesties, zo is uit de jurisprudentie van het Hof van Justitie gebleken. Naast eisen in het kader van toegang tot de rechter in meer algemene zin, zoals beroepstermijnen en het belanghebbendebegrip ${ }^{496}$ en toegang tot voorlopige rechtsbescherming ${ }^{497}$ (formeel aspect), zijn er ook materiële eisen gesteld aan

brandy, Convergentie in het mededingingsrecht. De invloed van het EG-recht op materiële toepassing, toegang, bewijs en toetsing bij de Nederlandse mededingingsbestuursrechter, bezien in het licht van effectieve rechtsbescherming (diss. Utrecht), Den Haag: BJu 2009, p. 19 e.v; Widdershoven e.a. 2007, p. 29 en 35-37; Jans e.a. 2007, p. 49-54; Vermeulen 2001, p. 119 e.v. en 175.

485. Zie de jurisprudentie genoemd in de noot hiervoor. Zie ook: Widdershoven e.a. 2007, p. 35-37; Jans e.a. 2007, p. 49; Vermeulen 2001, p. 119.

486. Widdershoven e.a. 2007, p. 35; Jans e.a. 2007, p. 51; Vermeulen 2001, p. 176. Zie echter in iets andere zin een recente uitspraak van het HvJ EG van 29 oktober 2009 in de zaak Pontin t. T-Comalux SA, AB 2010/1 m.nt. R.J.G.M. Widdershoven en de noot van Widdershoven daarbij.

${ }^{487}$ Zie hierover: Gerbrandy 2009 , p. 25 e.v.

${ }^{488}$ HvJ EU 18 maart 2010, Alassini, nr. C-317-220/08, r.o. 49; HvJ EG 29 oktober 2009, Pontin t. T-Comalux

$S A, A B$ 2010/1 m.nt. R.J.G.M. Widdershoven, r.o. 44.

${ }^{489}$ Pontin, r.o. 60-68.

${ }^{490}$ Alassini, r.o. 60 e.v

491. Widdershoven e.a. 2007, p. 36. Zie ook: Widdershoven 2006, p. 28; Vermeulen 2001, p. 175.

492. Zie: Widdershoven e.a. 2007, p. 36.

${ }^{493 .}$ HvJ EG 15 mei 1986, Johnston, nr. 222/84; HvJ EG 10 april 2003, Steffensen, nr. C-276/01, AB 2003/310

m.nt. AdMvV. Zie hierover wederom: Jans e.a. 2007, p. 120-121; Widdershoven e.a. 2007, p. 36-37.

${ }^{494}$ HvJ EU 18 maart 2010, Alassini, nr. C-317-220/08; HvJ EG 13 maart 2007, Unibet (London) Ltd, Unibet (International) Ltd t. Justiekanslern, nr. C-432/05.

${ }^{495}$ Zie over het Handvest nader hfst. 5.

496. Heylens, par. 14. Zie voor meer voorbeelden: Widdershoven e.a. 2007, p. 36; Vermeulen 2001, p. 120-128.

497. Hierover o.m.: Vermeulen 2001, p. 123-124. 


\section{De beginselen}

de nationale rechtsbescherming. Volgens Widdershoven e.a. gaat het dan om eisen in het kader van voorlopige rechtsbescherming, regels op het gebied van aansprakelijkheid of vernietiging van besluiten betreffen. ${ }^{498}$ Ook brengt het Hof van Justitie de motiveringsplicht voor nationale instanties van hun beslissingen ten behoeve van de doeltreffendheid van de controle door een rechterlijke instantie nadrukkelijk in verband met het beginsel van effectieve rechtsbescherming. ${ }^{499}$ Tot slot kunnen er op grond van dat beginsel eisen voortvloeien voor de bevoegde rechterlijke instantie, zoals de wettelijke grondslag, het permanente karakter, de verplichting om zich ertoe te wenden, het feit dat uitspraak wordt gedaan na een procedure op tegenspraak, en de toepassing van rechtsregels alsmede de onafhankelijkheid en onpartijdigheid. ${ }^{500}$

\section{Een nationaal beginsel van effectieve rechtsbescherming}

Een beginsel van effectieve rechtsbescherming kennen we in het Nederlandse (bestuurs)recht niet als zodanig. ${ }^{501}$ De Grondwet of bijzondere wetten zwijgen in dat opzicht. In de doctrine daarentegen wordt steeds vaker aandacht gevraagd voor (voldoende) erkenning en onderkenning van dit beginsel en daarmee gepaard gaand ook voor opname in de Grondwet. De VAR-Commissie Rechtsbescherming pleit er bijvoorbeeld voor om, gelet op het fundamentele karakter van dit recht dat thans slechts ontleend kan worden aan Europese normen, een recht op effectieve rechtsbescherming in onze Grondwet op te nemen. ${ }^{502}$ Eerder al heeft onder meer Widdershoven het beginsel aangemerkt als een beginsel van behoorlijke rechtspraak. ${ }^{503}$ In zijn optiek speelt het beginsel een rol speelt gedurende de gehele procedure, maar hij besteedt vooral aandacht aan het beginsel in het kader van de toegang tot de rechter. ${ }^{504}$ Ik voel er meer voor het beginsel te beschouwen als een beginsel dat ziet op de kwaliteit en behoorlijkheid van de gehele procedure. ${ }^{505}$ Toegang tot de rechter wordt reeds verondersteld en vereist op grond van een ander beginsel in dit onderzoek, waarbij ook geldt dat die toegang effectief moet zijn. ${ }^{506} \mathrm{Het}$ materiële aspect ziet dan op het 'eigenlijke' beginsel van effectieve rechtsbescherming, dat wil zeggen op de gehele procedure en alle facetten daarvan. Aangesloten kan worden bij de jurisprudentie van het Hof van Justitie over het formele aspect (effectieve toegang tot de rechtsgang) en materiële aspect (effectief rechtsmiddel) van het beginsel van effectieve rechtsbescherming.

Als beginsel van behoorlijke rechtspleging heeft effectieve rechtsbescherming, ondanks de hiervoor vermelde ontwikkelingen, echter nog geen vaste voet aan de grond gekregen in louter nationale geschillen. De regering lijkt zich weliswaar steeds meer bewust van het belang van de effectiviteit van de rechtsbescherming en de noodzaak om de procedures in het bestuursrecht daarmee in overeenstemming te brengen. Zoals hiervoor al is aangegeven, maakte de finale geschilbeslechting (als onderdeel van effectieve rechtsbescherming) in het bestuursrecht niet voor niets onderdeel uit van de laatste evaluatie van de Awb. Ook in het wetsvoorstel Aanpassing bestuursprocesrecht zijn reeds enkele voorstellen opgenomen om de effectiviteit en finaliteit van de procedure bij de bestuursrechter in dat opzicht te vergroten. Zo wordt artikel 6:22 Awb aangepast waardoor de mogelijkheid ontstaat voor de bestuursrechter om niet alleen schendingen van

\footnotetext{
498. Widdershoven e.a. 2007, p. 36. Zie voor meer voorbeelden: Vermeulen 2001, p. 129-168.

499. HvJ EG 15 oktober 1987, Union nationale des entraîneurs et cadres techniques professionnels du football (Unectef) t. Heylens e.a., nr. 222/86.

${ }^{500}$ HvJ EG 19 september 2006, Wilson, nr. C-506/04. Zie over enkele van deze eisen ook nog hfst. 5 van dit deel.

${ }^{501}$ Zie over dit beginsel in nationale context ook: Gerbrandy 2009, p. 40 e.v. Zij geeft ook aan dat het beginsel in die context nog geen onderdeel is van het positieve recht, Gerbrandy 2009, p. 51 en 54

502. Rapport VAR-Commissie Rechtsbescherming 2004, p. 48.

${ }^{503 .}$ Widdershoven 1989 , p. 111 en 114. In dezelfde zin: Gebrandy 2009, p. 45 e.v.

${ }^{504 .}$ Widdershoven 1989, p. 114-119 en p. 121. Zie ook: Brenninkmeijer 1987, p. 49; Hirsch Ballin 1983, p. 145

505. Vgl. ook: Rapport VAR-Commissie Rechtsbescherming 2004, p. 48.

506. Zie par. 4.3.2.
} 


\section{Deel I Beginselen van behoorlijke rechtspleging}

vormvoorschriften te passeren, maar ook schendingen van materiële voorschriften indien blijkt dat de belanghebbenden daardoor niet zijn benadeeld. ${ }^{507}$ Een bepaling met dezelfde strekking is thans al neergelegd in artikel 1.5 van de Crisis- en herstelwet die al in werking is getreden. ${ }^{508}$ Ook bevat het conceptvoorstel de mogelijkheid van een bestuurlijke lus, die inmiddels door een initiatief van enkele kamerleden in de Awb achterhaald is en ingevoerd is in artikel 8:51a. ${ }^{509}$ Tot brede erkenning van een national beginsel van effectieve rechtsbescherming, als geldende rechtsnorm, hebben de ontwikkelingen nog niet geleid. ${ }^{510}$ Hoewel de effectiviteit van de bestuursrechtelijke rechtsbescherming nadrukkelijk op nationaal niveau in de belangstelling staat en de wenselijkheid ervan onomstreden is, betekent dat immers nog niet dat ook daadwerkelijk sprake is van een nationaal beginsel van behoorlijke rechtspleging. Daarvoor moet sprake zijn van een rechtsnorm, waarvan schending rechtens leidt tot gevolgen. Duidelijk is dat wanneer een burger zich beroept op in het EVRM neergelegde rechten of Unierechtelijke rechten (voor zover ontleend aan rechtstreeks werkende bepalingen), er op nationaal niveau voorzien moet worden in effectieve rechtsbescherming en dat een nalaten in dat opzicht rechtens consequenties kan hebben. ${ }^{511}$ Zoals de VAR-Commissie Rechtsbescherming opmerkt, wordt dit recht vooralsnog ontleend aan de Europese normen en vormt het nationaalrechtelijk hoewel sprake is van een belangrijk uitgangspunt dat ook erkend wordt in de doctrine en te herkennen is in bepaalde inrichtingseisen die in de Awb zijn opgenomen ${ }^{512}$ - als zodanig geen rechtsnorm. Effectieve rechtsbescherming, in de zin van finale beslechting van een geschil, maakt in zuiver nationaalrechtelijke geschillen nog niet eenduidig onderdeel uit van het positieve recht.

Finale geschilbeslechting in de jurisprudentie van de bestuursrechter

Desalniettemin is effectieve rechtsbescherming in de nationale jurisprudentie langzamerhand een leidend principe geworden, dat van invloed is op de positie van de bestuursrechter en zijn gebruik van de uitspraakbevoegdheden op grond van de Awb. In verschillende recente uitspraken heeft de Afdeling overwogen dat de bestuursrechter verplicht is om de mogelijkheden tot effectieve en finale geschilbeslechting te onderzoeken. ${ }^{513}$ Hoewel daaruit geen plicht volgt tot bijvoorbeeld het zelf voorzien in de zaak of het gebruik maken van andere uitspraakbevoegdheden, vormt deze onderzoeksplicht wel een duidelijke aansporing tot het gebruik maken van deze uitspraakbevoegdheden waar mogelijk. De bestuursrechter zal in elk voorliggend geschil moeten nagaan in hoeverre en op welke wijze dat geschil finaal beslecht kan worden. Bovendien zal hij van zijn onderzoek in dit

\footnotetext{
507. Niet iedereen is overigens ervan overtuigd dat de voorstellen zullen leiden tot het beoogde resultaat, zie bijvoorbeeld: Verslag Evaluatie Awb III, p. 46; Brouwers \& Koenraad 2006, p. 1681-1684.

508. Wet van 18 maart 2010, Stb. 2010, 135 (Crisis- en herstelwet) in werking getreden op 31 maart 2010, Stb. 2010, 137; Kamerstukken II 2009/10, 32 127, nr. 1-3; Kamerstukken I 2009/10, 32 127, nr. A.

${ }^{509 .}$ Initiatiefvoorstel van de Kamerleden Vermeij/Koopmans/Nepperus, Kamerstukken II 2008/09, 31 352, nr. 13; Kamerstukken I 2008/09, 31 352, nr. A. Wet van 14 december 2009, Stb. 2009, 570. Op 1 januari 2010 is deze initiatiefwet inwerkinggetreden, KB 21 december 2009, Stb. 2009, 597.

${ }^{510 .}$ Er zijn wel auteurs die spreken over een finaliteitsbeginsel in verband met de finale geschilbeslechting door de rechter, zie bijvoorbeeld: Neerhof 1999b, p. 72. In Van Wijk/Konijnenbelt \& Van Male wordt gesproken over een effectiviteitsbeginsel dat ziet op het effectief en finaal beslissen van een geschil, Van Wijk/Konijnenbelt \& Van Male 2008, p. 570.

511. Om die reden hebben de hoogste bestuursrechters ook hun jurisprudentie wat betreft compensatie voor schendingen van de redelijke termijn wegens rechterlijke traagheid onlangs ook aangepast, CRvB 11 juli 2008 , $A B$ 2008/241 m.nt. Widdershoven; $J B$ 2008/172 m.nt. Jansen; AbRvS 4 juni 2008, $A B$ 2008/229 m.nt. Widdershoven; $J B$ 2008/146 m.nt. Jansen; USZ 2008/211 m.nt. Barkhuysen en Van Emmerik.

512. Te denken valt aan de mogelijkheid tot het verzoeken om een voorlopige voorziening en de verschillende uitspraakbevoegdheden van de bestuursrechter die de wetgever in hfst. 8 van de Awb heeft opgenomen teneinde effectieve rechtsbescherming mogelijk te maken, waarover hieronder meer.

513. AbRvS 12 augustus 2009, AB 2009/368 m.nt. B.W.N. de Waard; AbRvS 10 juni 2009, AB 2009/369 m.nt. Nijhuis en Den Ouden; AbRvS 10 december 2008, nr. 200802431/1;JB 2009/39. In het eerste geval had de rechtbank volgens de Afdeling overigens ten onrechte gebruik gemaakt van de bevoegdheid om de rechtsgevolgen na vernietiging van een besluit in stand te laten. Inmiddels is het $\mathrm{CBb}$ de Afdeling daarin gevolgd, $\mathrm{CBb} 11$ november 2009, $A B$ 2009/402 m.nt. Sew.
} 


\section{De beginselen}

opzicht blijk moeten geven in de uitspraak. Vervolgens kunnen partijen zich in hoger beroep tegen het al dan niet gebruik van uitspraakbevoegdheden om het geschil finaal te beslechten keren. Bovendien zal ook in hoger beroep de bestuursrechter de mogelijkheden tot finale geschilbeslechting dienen te onderzoeken. ${ }^{514}$

In de jurisprudentie zijn er de afgelopen jaren voorts voorbeelden te zien van gevallen waarin de bestuursrechter ten behoeve van de finale of effectieve geschilbeslechting overgaat tot het zelf voorzien in de zaak, terwijl daar naar gangbare opvattingen geen ruimte voor zou bestaan. ${ }^{515}$ Een mooi voorbeeld vormt een uitspraak van de Afdeling van 11 februari $2009 .{ }^{516}$ Het betrof een zaak waarin het college van B en W van de gemeente Haarlem geweigerd had een kapvergunning te verlenen. Het besluit op bezwaar liet die weigering in stand. De rechtbank vernietigde echter dat besluit op bezwaar en herriep de primaire weigering om de kapvergunning te verlenen. Tegelijkertijd voorzag zij zelf in de zaak door de kapvergunning alsnog te verlenen. Daartegen stelde het college van B en W bij de Afdeling hoger beroep in, waarbij het onder meer aanvoerde dat de rechtbank ten onrechte zelf in de zaak had voorzien omdat er rechtens niet nog maar een beslissing mogelijk was. Uit de uitspraak van de Afdeling volgt dat er voor het zelf voorzien in de zaak door de bestuursrechter in elk geval niet altijd vereist is dat slechts één beslissingsmogelijkheid resteert na vernietiging van het besluit. Voorheen was dat het uitgangspunt, hetgeen betekende dat zelf voorzien niet mogelijk was in geval van een beleidsvrije of beoordelingsvrije bevoegdheid van het bestuur. ${ }^{517}$ Daaronder vielen meer gevallen dan op het eerste gezicht het geval lijkt te zijn. ${ }^{518} \mathrm{Er}$ werden al op ruimere basis gevallen aangenomen waarin rechtens nog maar een besluit mogelijk is dan waar de wetgever wellicht oorspronkelijk het oog op had. ${ }^{519}$ Daaraan kan ook nog de situatie toegevoegd worden dat zelf voorzien vanuit een oogpunt van finale geschilbeslechting opportuun is. In enkele uitspraken lijkt de bevoegdheid tot zelf in de zaak voorzien door de bestuursrechter ruimhartiger gehanteerd te worden, omdat de finale geschilbeslechting of duur van de procedure daarmee gediend is. ${ }^{520}$ Eerder heeft de Afdeling nog wel eens overwogen dat de effectieve geschilbeslechting of de redelijke termijn geen reden kan vormen voor zelf in de zaak voorzien ${ }^{521}$ noch dat daaruit een plicht voor de bestuursrechter kan voortvloeien om dat te doen. ${ }^{522}$ Die tendens naar een ruimhartig(er) gebruik van de reeds bestaande uitspraakbevoegdheden ten behoeve van een finale geschilbeslechting valt ook te bespeuren bij het gebruik van de bevoegdheid om de rechtsgevolgen, na vernietiging

\footnotetext{
514. Zie bijvoorbeeld AbRvS 2 december 2009, AB 2010/34 m.nt. B. de Waard waarin de Afdeling dat zelf ook doet.

515. Zie hierover ook: J.A.M. van Angeren, 'Zelf voorzien in een stroomversnelling', JB-plus 2009, p. 257 e.v.; L.J. Gerritsen, "Finale geschilbeslechting; art. 8:72, leden 3 en 4 Awb", JBactueel 2009, p. 66 e.v.; Van Angeren 2007, p. 20-21. Zie bijvoorbeeld: CBb 26 mei 2009, AB 2009/303 m.nt. D.W.M. Wenders; AbRvS 20 februari 2008, JB 2008/76 m.nt. C.L.G.F.H. A; AbRvS 30 januari 2008, JB 2008/59 m.nt. C.L.G.F.H. A.

516. AbRvS 11 februari 2009, $A B$ 2009/224 m.nt. Ortlep; $J B$ 2009/80.

517. AbRvS 6 oktober 2004, $A B$ 2004/390 m.nt. TN; JB 2004/370 m.nt. AMLJ; AbRvS 8 juli 1996, $A B$ 1996/344 m.nt. Van Buuren. Hierover ook: Schueler e.a. 2007, p. 50-60; de noot bij AbRvS 20 februari 2008, JB 2008/76 m.nt. C.L.G.F.H. A met verwijzingen naar jurisprudentie.

${ }_{518 .}$ Voor een overzicht: Schueler 2007 e.a., p. 52-55. Zie ook: de noten van Albers bij JB 2008/76 en JB 2008/59.

519. PG Awb II, p. 460.

520. Zie: CBb 26 mei 2009, AB 2009/303 m.nt. D.W.M. Wenders; AbRvS 20 februari 2008, JB 2008/76 m.nt. C.L.G.F.H. A.

521. In 2004 overwoog de Afdeling bijvoorbeeld dat de duur van een geschil of de omstandigheid dat het bestuursorgaan reeds tweemaal door de rechter in de gelegenheid was gesteld het motiveringsgebrek te herstellen, geen reden vormde voor ruimere toepassing van de bevoegdheid om zelf in de zaak te voorzien, AbRvS 6 oktober 2004, $A B$ 2004/390 m.nt. TN; JB 2004/370 m.nt. AMLJ. Zie hierover ook: Schueler e.a. 2007, p. 56. De Afdeling heeft overigens ook wel eens geoordeeld dat de lange duur van de procedure noopte tot zelf in de zaak voorzien vanuit een oogpunt van finale geschilbeslechting, AbRvS 19 juni 2002, AB 2002/282 m.nt. AMLJ.

522. In een uitspraak overwoog de Afdeling dat art. 6 EVRM geen plicht tot zelf voorzien met zich brengt, AbRvS 12 augustus 1999, $A B$ 1999/392 m.nt. MSV.
} 
Deel I Beginselen van behoorlijke rechtspleging

van een besluit, in stand te laten op grond van artikel 8:72, derde lid, Awb. ${ }^{523}$ Voorheen werd aangenomen dat vereist was dat rechtens nog een beslissing met dezelfde rechtsgevolgen mogelijk zou zijn ${ }^{524}$, maar thans kan ook de finale geschilbeslechting of proceseconomie ertoe nopen in gevallen waarin beleidsvrijheid bestaat te volstaan met vernietiging van het besluit en instandlating van de rechtsgevallen. ${ }^{525}$ Als het bestuursorgaan voornemens is de inhoud van het bestreden besluit niet te wijzigen na een hernieuwde belangenafweging én die belangenafweging kan de rechterlijke toets doorstaan, kan er aanleiding bestaan de rechtsgevolgen in stand te laten mits de andere partijen zich over het besluit hebben kunnen uitlaten. Voor instandlating van de rechtsgevolgen is derhalve niet vereist dat nog slechts één beslissing mogelijk is. ${ }^{56}$

Er valt ook een voorbeeld te noemen dat ziet op de bevoegdheid c.q. verplichting van de bestuursrechter om te beslissen op een verzoek om schadevergoeding op grond van artikel 8:73 Awb. In een zaak waar het ging om immateriële schadevergoeding wegens overschrijding van de redelijke termijn is een uitspraak van de rechtbank vernietigd, omdat de rechtbank nagelaten had zelf de schadevergoeding te bepalen. Zij had de zaak had terugverwezen naar het bestuursorgaan, terwijl geen nadere besluitvorming nodig was voor het bepalen van de omvang van de schade. De rechtbank diende volgens de Afdeling een besluit te nemen op het verzoek om schadevergoeding en de uitspraak werd vernietigd. ${ }^{527}$ Hoewel de Afdeling niet refereert aan effectieve geschilbeslechting, lijkt dit wel de achtergrond te vormen voor deze overwegingen. De terugverwijzing was onnodig, omdat (de omvang van) de schadevergoeding al vastgesteld kon worden en de terugverwijzing uitsluitend vertraging opleverde.

Ofschoon tegen de hiervoor geschetste ontwikkeling vanuit een oogpunt van de verhouding tussen bestuur en rechter in ons staatsbestel ook bezwaren kunnen worden aangevoerd, valt de ontwikkeling vanuit een oogpunt van effectieve en finale geschilbeslechting alleen maar toe te juichen. ${ }^{528}$ Zeker in gevallen waarin het bestuursorgaan bij herhaling in gebreke blijft of blijft volharden in zijn besluit, valt er wat voor te zeggen dat de bestuursrechter ingrijpt en een einde maakt aan het geschil. ${ }^{529}$

Niettegenstaande het feit dat effectieve rechtsbescherming in het bestuursprocesrecht, voor zover het de finale geschilbeslechting en de uitspraakbevoegdheden van de bestuursrechter betreft, een steeds belangrijkere plaats krijgt, vormt het thans primair een Europese rechtsnorm. Een duidelijk afgebakende rechtsplicht - waarvan de schending rechtens consequenties heeft - om bijvoorbeeld in het kader van finale geschilbeslechting in bepaalde gevallen zelf in de zaak te voorzien (of de rechtsgevolgen van een besluit in stand te laten) wordt in het algemeen niet aangenomen. ${ }^{530}$ Er rust vooralsnog 'slechts' een verplichting op de bestuursrechter om de mogelijkheden tot finale geschilbeslechting te onderzoeken in een concreet geval. Het nalaten van een dergelijk onderzoek of een onjuist gebruik van de uitspraakbevoegdheden in een concreet geschil leiden uiteraard wel tot vernietiging van de uitspraak van de bestuursrechter. Nog niet geheel duidelijk is echter wanneer en onder welke voorwaarden overgegaan moet worden tot finale geschilbeslechting en tot het gebruik van de voor de bestuursrechter beschikbare

\footnotetext{
523. AbRvS 21 oktober 2009, $A B$ 2010/29 m.nt. R. Ortlep; AbRvS 12 augustus 2009, $A B$ 2009/368 m.nt. B. de Waard; AbRvS 10 december 2008, $J B$ 2009/39. Zie hierover ook de noot van Ortlep bij AbRvS 11 februari 2009, $A B$ 2009/224 met verdere verwijzingen.

524. Zie hierover: Schueler e.a. 2007, p. 60-62

525. AbRvS 10 december 2008, JB 2009/39.

526. AbRvS 12 augustus 2009, LJN BJ5099, AB 2009/368 m.nt. BdeW; AbRvS 10 juni 2009, AB 2009/369 m.nt. Nijhuis en Den Ouden.

AbRvS 3 juni 2009, AB 2009/249 m.nt. D.W.M. Wenders. Overigens heeft de Afdeling vervolgens gedaan wat de rechtbank behoorde te doen en een beslissing genomen op het verzoek.

${ }^{528}$ Zie hierover o.m.: Schueler e.a. 2007, p. 77-79; de noten van Albers bij JB 2008/76 en JB 2008/59 en Jansen bij $A B 2002 / 282$.

${ }_{529}$ Zoals het geval was in: CBb 26 mei 2009, $A B$ 2009/303 m.nt. D.W.M. Wenders.

530. Schueler e.a. 2007, p. 59. Een uitzondering vormt art. 8:72a Awb waaruit volgt dat de bestuursrechter na vernietiging van een boetebesluit zelf in de zaak moet voorzien.
} 


\section{De beginselen}

uitspraakbevoegdheden. Tot erkenning van een beginsel van effectieve rechtsbescherming als rechtsbasis daarvoor is de bestuursrechter ook nog niet gekomen. De ontwikkelingen in de jurisprudentie zijn op dit punt zijn nog gaande. ${ }^{531}$

Het fundamentele karakter van de eis van effectieve rechtsbescherming en de ontwikkelingen de afgelopen jaren in de doctrine, vormen goede redenen dit beginsel te rekenen tot de nationale (ongeschreven) beginselen van behoorlijke rechtspleging of zelfs om dat beginsel, zoals de VAR-Commissie rechtsbescherming voorstelt, op te nemen in de Grondwet. Het beginsel van effectieve rechtsbescherming zou dan ook in zuiver nationale geschillen in acht moeten worden genomen en aan schending ervan dienen dan rechtens gevolgen te worden verbonden. ${ }^{532}$ Gelet op de ontwikkelingen die gaande zijn op dit vlak, is verdedigbaar dat sprake is van positief recht in ontwikkeling of in wording. Er zijn voldoende aanknopingspunten voor de aanname dat het eindpunt van de ontwikkelingen nog niet in zicht is. Afgewacht moet ook worden of en in hoeverre de wetgever de plicht tot onderzoek van de mogelijkheden tot finale geschilbeslechting die de bestuursrechter in de jurisprudentie van de Afdeling heeft gekregen wettelijk vast zal leggen. Daarop vooruitlopend beoogt het wetsvoorstel aanpassing bestuursprocesrecht artikel 8:72 eerste lid Awb al zodanig te wijzigen dat daarin een aanscherping van de uitspraakbevoegdheden van de bestuursrechter plaatsvindt. ${ }^{533}$

\section{Effectieve rechtsbescherming als derde aspect van het decisiebeginsel}

Er valt, gelet op het bovenstaande, veel voor te zeggen dat een burger niet alleen recht heeft op toegang tot een rechter die binnen een redelijke termijn uitspraak behoort te doen, maar ook dat er sprake moet zijn van een effectieve behandeling van het geschil en een effectieve procedure. Dat recht bestaat reeds in geschillen met een Unierechtelijke dimensie of een EVRM- dimensie, maar zou ook dienen te gelden in geschillen met een louter nationaal karakter. Effectiviteit speelt een rol gedurende de gehele procedure, maar is thans in het bijzonder van belang voor de uitspraakbevoegdheden van de bestuursrechter en de mogelijkheden van de bestuursrechter om het geschil materieel (en finaal) te beslechten. 534

Het doel van dit beginsel is het waarborgen dat aan de burger toekomende rechten ook daadwerkelijk geëffectueerd kunnen worden voor de nationale rechter en dat deze ook de mogelijkheid heeft om daadwerkelijk en adequaat rechtsherstel te bieden. Het beginsel hangt sterk samen met het recht op toegang tot de rechter en het beginsel van de redelijke termijn (de twee onderdelen van het decisiebeginsel). ${ }^{535}$ Het eerste recht waarborgt dat er een bevoegde rechter geadieerd kan worden, terwijl het tweede beoogt te verzekeren dat de betrokken partijen vervolgens niet te lang in onzekerheid verkeren omtrent hun rechtspositie. Het beginsel van effectieve rechtsbescherming waarborgt ten slotte dat partijen gedurende de rechtsgang hun rechten op effectieve wijze te gelde kunnen maken en dat de rechtsgang uiteindelijk leidt tot vaststelling van de rechtspositie en eventueel rechtsherstel. Het beginsel van effectieve rechtsbescherming zou, aldus opgevat, het derde aspect en het sluitstuk van het decisiebeginsel kunnen vormen. De ratio van dit derde aspect van het decisiebeginsel wordt primair ook gevormd door de rechtsbescherming van de betrokken partijen in het concrete geschil. ${ }^{536}$ De procedure dient

\footnotetext{
531. Zie de bijdrage van Van Angeren over de ontwikkelingen in de jurisprudentie op specifieke deelterreinen van het bestuursrecht, Van Angeren 2009, p. 257-266.

${ }^{532} \mathrm{Zie}$ ook Gebrandy die ervoor pleit dat het beginsel van effectieve rechtsbescherming onderdeel zou moeten uitmaken van het positieve recht, Gerbrandy 2009, p. 52

533. Zie de MvT bij het voorstel, p. 36-.37

${ }^{534}$ Vgl. Gerbrandy 2009, p. 46.

${ }^{535}$ De Waard 1987, p. 127,176 e.v. en 225 e.v.

536. Vgl. over het beginsel van effectieve rechtsbescherming in de jurisprudentie van het Hof van Justitie: R.J.G.M. Widdershoven, 'De Europese rol van de nationale rechter: rechtsbeschermer of controleur?', in: A.W. Heringa, A.M.L. Jansen, E.C.H.J. van der Linden, L.F.M. Verhey (red.), Het bestuursrecht beschermd (liber amicorum F.A.M. Stroink), Den Haag: Sdu 2006, p. 61; R.J.G.M. Widdershoven,'Rechtsbeginselen in het
} 


\section{Deel I Beginselen van behoorlijke rechtspleging}

zodanig ingericht en vormgegeven te zijn dat de toegang tot de procedure de betrokken partijen ook daadwerkelijk de mogelijkheid biedt om hun rechten te kunnen effectueren en dat de procedure kan opleveren wat deze ermee beoogden te bewerkstelligen. Het heeft echter ook een secundaire functie die ten dienste staat aan de effectieve inrichting van het stelsel van rechtsbescherming in zijn geheel en daarmee het vertrouwen in rechtspraak.

Omdat het beginsel van effectieve rechtsbescherming als zodanig nog niet eenduidig onderdeel is van het positieve recht in geschillen zonder een Europese dimensie en nog in ontwikkeling is, wordt de betekenis van het beginsel voor de bestuurlijke voorprocedures in Deel II van dit onderzoek niet onderzocht. Bovendien kan het beginsel van effectieve rechtsbescherming, als eis met betrekking tot de uitspraakbevoegdheden van de bestuursrechter en bevoegdheden om het geschil finaal te beslechten, niet eenzelfde betekenis hebben voor de bestuurlijke voorprocedures en het bestuur. Die procedure eindigt immers altijd in een besluit afkomstig van het bestuursorgaan, waarmee totdat beroep wordt ingesteld het geschil in beginsel wordt beëindigd. De betekenis van de eis van effectieve rechtsbescherming komt in dat deel uitsluitend aan de orde in verband met overschrijdingen van de redelijke termijn door het bestuur en de vraag naar effectieve rechtsmiddelen daartegen.

\section{Procesrechtelijke eisen en operationalisering van het beginsel van effectieve rechtsbescherming}

Zoals Widdershoven ook opmerkt, kunnen de eisen die met het oog op de effectiviteit van de rechtsbescherming aan een procedure gesteld worden varia zijn. Hij geeft enkele voorbeelden waar de inrichtingseisen betrekking op zouden kunnen hebben: voorlopige maatregelen moeten mogelijk zijn teneinde onomkeerbare gevolgen te voorkomen, geen onnodige stringente beperkingen op de toegang tot de procedure zoals hoge griffierechten, een regeling ter voorkoming excessief hoge kosten voor de bewijsvorming en regelingen ter executie van een uitspraak. ${ }^{537}$ De mogelijke uitspraakbevoegdheden worden nog niet genoemd. Verschillende bepalingen die beogen te waarborgen dat de burger zijn rechten daadwerkelijk te gelde kan maken of dat diens rechten effectief beschermd worden, zijn ook terug te vinden in hoofdstuk 8 van de Awb. Te denken valt aan de mogelijkheid tot het doen van een verzoek om een voorlopige voorziening in artikel 8:81 Awb e.v. Ook heeft de bestuursrechter verschillende uitspraakbevoegdheden op grond van artikel 8:72 eerste, derde, vierde en vijfde lid: vernietiging van het besluit, vernietiging van het besluit en in stand laten van de rechtsgevolgen, opdracht geven tot het nemen van een nieuw besluit of zelf in de zaak voorzien en het stellen van een termijn voor het nemen van een nieuw besluit alsmede het treffen van een voorlopige voorziening. Ten slotte heeft de rechter de mogelijkheid om bij een gegrond beroep en vernietiging van het besluit schadevergoeding toe te kennen op grond van artikel 8:73 Awb. ${ }^{538}$

De nationale discussies en hiervoor vermelde jurisprudentie over de effectiviteit van de bestuursrechtelijke rechtsbescherming hebben zich, zoals aangegeven, voornamelijk geconcentreerd op een belangrijk aspect daarvan: finale geschilbeslechting. Het beginsel van effectieve rechtsbescherming, zoals tot uitdrukking komend in artikel 13 EVRM en met name de jurisprudentie van het Hof van Justitie, heeft echter een ruimere strekking en zien op de gehele procedure. De concrete uitwerkingen van het beginsel van effectieve rechtsbescherming zien dus ook op meer aspecten dan uitsluitend de uitspraakbevoegdheden van de bestuursrechter. Die overige aspecten, zoals voorlopige rechtsbe-

Europese recht', in: R.J.N. Schlössels, A.J. Bok, H.J.A.M. van Geest, S. Hillegers (red.), In beginsel. Over aard, inhoud en samenhang van rechtsbeginselen in het bestuursrecht, Deventer: Kluwer 2004, p. 316-317. ${ }^{537 .}$ Widdershoven 1989 , p. 115 en 117-119.

538. Ook bij intrekking van een beroep omdat het bestuur aan de indiener ervan geheel of gedeeltelijk tegemoet is gekomen, kan de rechtbank schadevergoeding toekennen op grond van art. 8:73a Awb. Zie voor de inrichtingseisen in het kader van het recht op (effectieve) toegang tot de rechter, par. 4.3.2. 


\section{De beginselen}

scherming, zijn echter al geruime tijd gerealiseerd in het bestuursrecht en leveren over het algemeen geen of nauwelijks problemen op. Daaraan wordt bijgevolg minder aandacht besteed. 



\section{De beginselen van behoorlijke rechtspleging in EU-perspectief}

\subsection{Inleiding}

Grondrechten in Unierechtelijke context

Als het gaat om bescherming van grondrechten op Europees niveau en zeker als het gaat om het recht op een eerlijk proces, wordt meestal in eerste instantie gedacht aan het EVRM en het EHRM als belangrijkste hoeders. De eisen van behoorlijke rechtspraak hebben in onze nationale rechtsorde ook vooral aan betekenis gewonnen door de invloed van artikel 6 EVRM en de jurisprudentie van het EHRM. Een vergelijkbaar geschreven grondrecht dat een ieder verbindende kracht heeft in het Unierecht lange tijd niet bestaan. In het Handvest voor de grondrechten van de EU (hierna: het Handvest) is in artikel 47 een recht op een doeltreffende voorziening in rechte en op een onpartijdig gerecht neergelegd. ${ }^{1}$ Het Handvest ${ }^{2}$ is echter pas, in de aangepaste versie van 7 december 2000 , bindend sinds inwerkingtreding van het Verdrag van Lissabon. ${ }^{3}$ Artikel 6 EU bepaalt sindsdien in het eerste lid dat de Unie de in het Handvest neergelegde rechten en vrijheden erkent alsmede dat het Handvest dezelfde juridische waarde heeft als de Verdragen. Artikel 6, derde lid, EU bepaalt vervolgens (in plaats van het oude tweede lid) dat de grondrechten, zoals gewaarborgd door het EVRM, als algemene beginselen onderdeel uitmaken van het recht van de Unie. ${ }^{4}$ Dat betekent echter niet dat dit Handvest daarvoor geheel zonder betekenis is geweest ${ }^{5}$ of dat de grondrechten, meer specifiek het recht op een eerlijk proces, eerder geen bescherming genoten in het Unierecht of bij de uitvoering van het Unierecht op nationaal niveau. In het oude artikel 6 EU-verdrag was in het eerste lid neergelegd dat de Europese Unie gegrondvest is op de beginselen van vrijheid, democratie, eerbiediging van de rechten van de mens en de fundamentele vrijheden, en van de rechtsstaat, welke beginselen de lidstaten gemeen hebben. Voorts bepaalde het tweede lid dat de Europese Unie de grondrechten, zoals die worden gewaarborgd door het EVRM en zoals uit de gemeenschappelijke constitutionele tradities van de lidstaten voortvloeien, als algemene rechtsbeginselen eerbiedigt. Deze bepalingen vormden een codificatie van de vaste rechtspraak van het Hof van Justitie waarin het heeft aangegeven dat de rechten, zoals neergelegd in het EVRM, onderdeel uitmaken van de rechtsorde van de Europese Unie als algemene rechtsbeginselen waarvan de eerbiediging verzekerd moet worden. ${ }^{6}$ Het voorgaande heeft tot gevolg dat de grondrechten of mensenrechten

\footnotetext{
${ }^{1 .}$ Hfst. VI, art. 47 van het Handvest.

2. Zie over het Handvest van de grondrechten van de EU en de status ervan, met nadere verwijzingen: K. Mortelmans, 'het Handvest van grondrechten van de EU in de Europese en Nederlandse rechtspraak', in: T. Barkhuysen, M.L. van Emmerik \& J.P. Loof (red.), Geschakeld recht. Verdere studies over Europese grondrechten ter gelegenheid van de $70^{\text {ste }}$ verjaardag van prof.mr. E.A. Alkema, Deventer: Kluwer 2009, p. 378 e.v.; T. Trimidas, The General Principles of EU Law, Oxford University Press 2006, p. 356 e.v.

3. Verdrag van Lissabon tot wijziging van het Verdrag betreffende de Europese Unie en het Verdrag tot oprichting van de Europese Gemeenschap, zie artikel 1 van de Wijzigingen van het verdrag betreffende de Europese Unie en het Verdrag tot oprichting van de Europese Gemeenschap, C 306-10.

Z. Zie hierover: Mortelmans 2009, p. 379-380.

${ }^{5 .}$ Verschillende auteurs wijzen erop dat het Handvest (desondanks) als inspiratiebron gehanteerd werd (en kon worden) door zowel de advocaten-generaal bij het HvJ EG als het Gerecht van Eerste Aanleg en het HvJ EG zelf, zie: Barkhuysen, Van Emmerik \& Gerards 2009, p. 29; Mortelmans 2009, p. 380-390; R.J.G.M. Widdershoven, M.J.M. Verhoeven, S. Prechal, A.P.W. Duijkersloot, J.W. van de Gronden, B. Hessel en R. Ortlep, De Europese agenda van de Awb, Den Haag: BJu 2007, p. 37; J.H. Jans, R. de Lange, S. Prechal, R.J.G.M. Widdershoven, Europeanisation of Public Law, Groningen: Europa Law Publishing 2007, p. 120; Trimidas 2006, p. 359-362.

${ }^{6 .}$ Het HvJ EG hanteerde in dit verband de term algemene beginselen van gemeenschapsrecht voor het eerst in HvJ EG 12 november 1969, Stauder t. City of Ulm, 29/69, aldus Jans e.a. 2007, p. 119. Daarna heeft het dat herhaald in zijn jurisprudentie, zie recent: HvJ EG 19 februari 2009, Gorostiaga Atxalandabaso t. Europees
} 


\section{Deel I Beginselen van behoorlijke rechtspleging}

niet rechtstreeks golden, maar als algemene rechtsbeginselen deel uitmaakten van die rechtsorde. ${ }^{7}$ Een van die algemene rechtsbeginselen was het recht op een eerlijk proces, dat het Hof van Justitie reeds geruime tijd erkende in zijn jurisprudentie. ${ }^{8}$ Gelet op de inwerkingtreding van het Verdrag van Lissabon op 1 december 2009 en de afsluiting van dit onderzoek op 1 oktober 2009 komen in het navolgende uitsluitend uitspraken van het Hof van Justitie aan de orde over het recht op een eerlijk proces en de daaruit voortvloeiende eisen van voor de inwerkingtreding van het Verdrag van Lissabon. Afgewacht moet worden in hoeverre de interpretatie van de inhoud van de eisen die voortvloeien uit het recht op een eerlijk proces door het Hof van Justitie door de inwerkingtreding wijzigingen zal ondergaan. Dat ligt echter niet in de rede.

Hoewel het Hof van Justitie wat betreft de bescherming van grondrechten en het recht op een eerlijk proces op Europees niveau een minder belangrijke rol heeft gespeeld dan het EHRM, hebben de eisen van behoorlijke rechtspraak de afgelopen jaren een prominentere plaats gekregen in het Unierecht en de rechtspraak van die instantie. ${ }^{9}$ Het Hof van Justitie laat zich daarbij leiden door de interpretatie van het EHRM van de uit artikel 6 EVRM voortvloeiende rechten en verwijst regelmatig naar de jurisprudentie van het EHRM. ${ }^{10}$ Deze afstemming betekent niet dat het risico op discrepanties tussen de Unierechtelijke interpretatie en die van het EHRM louter denkbeeldig is. ${ }^{11}$ Wel is er in toenemende mate sprake van overleg en samenwerking tussen het Hof van Justitie en het EHRM. $^{12}$

De relevantie van de Unierechtelijke eisen van behoorlijke rechtspleging

Vanwege de steeds groter wordende invloed van het Unierecht op de nationale rechtsorde in het algemeen, en daarbij het toenemend belang van het recht op een eerlijk proces in de jurisprudentie van het Hof van Justitie, is het zinvol het Unierecht bij dit onderzoek te betrekken. In die jurisprudentie worden als algemene rechtsbeginselen, beginselen of eisen erkend die in ons nationale recht onder de beginselen van behoorlijke rechtspleging geschaard worden. Deze beginselen zijn door het Hof van Justitie primair ontwikkeld voor de instellingen van de EU. ${ }^{13}$ De door het Hof van Justitie erkende algemene rechtsbeginselen zijn echter voor de (organen van de) lidstaten ook van belang in gevallen waarin het de nationale uitvoering van Unierecht betreft of handelingen van nationale organen binnen het bereik van het Unierecht komen. ${ }^{14}$ De geldingskracht van de Unierechtelijke beginselen wordt tegelijkertijd begrensd door de omstandigheid dat ze uitsluitend gelden, indien (organen van) de lidstaten in de werkingssfeer van het Unierecht geraken. ${ }^{15}$ Het Hof van Justitie maakt daarbij in beginsel geen onderscheid tussen de

parlement, EHRC 2009/46. Het Verdrag van Maastricht heeft de codificatie van deze jurisprudentie in art. 6 EUverdrag bewerkstelligd. Zie ook: Jans e.a. 2007, p. 119; Trimidas 2006, p. 298-299.

7. Barkhuysen, Van Emmerik \& Gerards 2009, p. 29; Jans e.a. 2007, p. 120.

${ }^{8}$ Jans e.a. 2007, p. 119-121; A.J.C. de Moor-van Vugt m.m.v. E.M. Vermeulen, Europees bestuursrecht, Deventer: W.E.J. Tjeenk Willink 1998, p. 72-78.

9. Trimidas 2006, p. 298-299 en 343.

10. Zie bijvoorbeeld: HvJ EU 18 maart 2010, Alassini, nr. C-317-220/08; HvJ EG 26 juni 2007, Orde van Franstalige en Duitstalige balies, Franse Orde van advocaten bij de balie te Brussel, Orde van Vlaamse balies, Nederlandse orde van Advocaten bij de balie te Brussel t. Ministerraad, EHRC 2007/10 m.nt. Fermon; HvJ EG 10 april 2003, Steffensen, $A B$ 2003/310 m.nt. AdMvV. Zie over deze ontwikkeling: Widdershoven e.a. 2007, p. 38; Jans e.a. 2007, p. 120; Trimidas 2006, p. 343.

${ }^{11}$ Zie voor voorbeelden: Trimidas 2006, p. 342-343.

12. Jans e.a. 2007, p. 121; Widdershoven e.a. 2007, p. 36-37; Trimidas 2006, p. 299

13. Jans e.a. 2007, p. 122 en 187; Trimidas 2006, p. 370 e.v.

14. Jans e.a. 2007, p. 123; Trimidas 2006, p. 6, 36 e.v en 320 e.v. Niet altijd duidelijk is wanneer er sprake is van een geval dat binnen de reikwijdte van het gemeenschapsrecht valt, waardoor ook het bereik of werking van de algemene beginselen van gemeenschapsrecht in de nationale rechtsordes niet altijd duidelijk is, zie hierover: Jans e.a. 2007, p. 123; Trimidas 2006, p. 36 e.v. Zie hierover ook de noot bij: HvJEG 23 september 2008, C-427/06, Bartsch t. Bosch und Siemens Hausgeräte (BSH) Altersfürsorge GmbH, AB 2008/356, m.nt. Verhoeven en Ortlep.

${ }^{15 .}$ HvJ EG 30 september 1987, Meryem Demirel t. Ville de Swäbisch Gmündt, nr. 12/86; HvJ EG 11 juli 1985, Cinéthèque $S A$ t. Fédération nationale des cinémas français, nr. 60/84. Zie ook de noot hiervoor. 


\section{De beginselen in EU-perspectief}

verschillende (bestuurs)organen van de desbetreffende (lid)staat. ${ }^{16}$ Dat betekent dat ook het bestuur in de nationale besluitvormingsprocedures die binnen het bereik van het Unierecht komen die beginselen en derhalve, voor zover het Hof van Justitie dat eist in zijn jurisprudentie, de eisen van behoorlijke rechtspraak in acht behoort te nemen. ${ }^{17}$ Het handelen van de nationale organen, als uitvoerders van het Unierecht, kan derhalve aan deze beginselen getoetst worden. Kanttekening daarbij is wel dat de toetsing aan de beginselen slechts in het kader van toetsing aan andere Unierechtelijke bepalingen kan plaatsvinden. Een zelfstandige grondslag voor een vordering bij de nationale rechter kunnen zij vooralsnog niet vormen, aldus Widdershoven e.a. ${ }^{18}$

In dit hoofdstuk wordt vastgesteld welke beginselen van behoorlijke rechtspleging het Hof van Justitie onderscheidt, alsmede welke inhoud die beginselen hebben en welke eisen daaruit voortvloeien. In het onderzoek naar de jurisprudentie van het Hof van Justitie en de relevante beginselen van Unierecht ligt de nadruk primair op de betekenis van de beginselen van behoorlijke rechtspleging voor de bestuurlijke besluitvormingsprocedures, meer in het bijzonder de bezwaarschriftprocedure en het administratief beroep. Doel is immers om de eisen die op grond van de door het Hof van Justitie erkende beginselen gesteld worden aan de bestuurlijke (voor)procedures te achterhalen en de invloed daarvan op de nationale bestuurlijke (voor)procedures vast te stellen. Omdat het Hof van Justitie heeft bepaald dat sommige beginselen, zoals het verdedigingsbeginsel, ook reeds in bestuurlijke besluitvormingsprocedures van betekenis zijn en niet alleen in de rechterlijke fase ${ }^{19}$, kan onderzoek in dat kader interessante inzichten opleveren.

Daarnaast wordt aan sommige rechtsbeginselen die door het Hof van Justitie zijn erkend uitvoeriger aandacht besteed dan aan andere beginselen. Er zijn namelijk Unierechtelijke beginselen waarvan de invloed op de nationale (bestuurlijke) procedures gering lijkt te zijn. Het verdedigingsbeginsel is een voorbeeld van een beginsel waarvan de invloed aanzienlijk kan zijn. ${ }^{20}$ Het onpartijdigheidsbeginsel of onafhankelijkheidsbeginsel zijn daarentegen voorbeelden van beginselen die in de jurisprudentie van het Hof van Justitie als zodanig, dat wil zeggen voor de instellingen van de EU, al nauwelijks een rol lijken te spelen. ${ }^{21}$ Dat geldt te meer ten aanzien van de in dat verband aan de nationale procedures te stellen eisen ten behoeve van de effectieve doorwerking van het Unierecht. ${ }^{22}$ Eerder onderzoek, zoals het onderzoek verricht in het kader van de derde evaluatie van de Awb, wijst ook uit dat met name het verdedigingsbeginsel en het motiveringsbeginsel van belang kunnen zijn. ${ }^{23}$ Dat onderzoek alsook enkele andere recente bijdragen op dit terrein worden in het onderstaande als leidraad gehanteerd. Aan het beginsel van effectieve rechtsbescherming wordt in dit hoofdstuk geen afzonderlijke aandacht meer besteed, omdat in paragraaf 4.3.9 van hoofdstuk 4 reeds is ingegaan op het beginsel van effectieve rechtsbescherming in Unierechtelijke context.

16. Trimidas 2006, p. 44-45. Zie ook art. 51 lid 1 van het Handvest waaruit blijkt dat de bepalingen van het Handvest zich richten tot de lidstaten voor zover zij gemeenschapsrecht ten uitvoer leggen.

17. Ten aanzien van bijvoorbeeld het verdedigingsbeginsel heeft het HvJ EG zulks ook uitdrukkelijk overwogen in de uitspraak Dokter e.a. t. Minister van LNV, C-28/05, AB 2006/390 m.nt. R.J.G.M. Widdershoven, zie par. 74 e.v.

18. Widdershoven e.a. 2007 , p. 39.

19. Zie vorige noot.

20. Zie over dat beginsel en de wisselwerking met de Awb: Widdershoven e.a. 2007, p. 78 e.v. Zie ook: Jans e.a 2007, p. 119 die de beginselen behandelen die van normatieve betekenis zijn voor o.m. de nationale autoriteiten. Daaronder ook het verdedigingsbeginsel.

${ }^{21 .}$ In de jurisprudentie van het HvJ EG komen deze eisen niet regelmatig aan de orde, zie hierover nader par. 5.2 .3 .

${ }^{22}$. In de literatuur en het onderzoeken naar de betekenis van de beginselen voor het Nederlandse bestuursrecht in het kader van de derde evaluatie van de Awb, komen het onpartijdigheidsbeginsel en onafhankelijkheidsbeginsel ook niet nadrukkelijk terug, zie: Widdershoven e.a. 2007, p. 37-40 en 67 e.v.; Jans e.a. 2007, p. 115 e.v.

${ }^{23 .}$ Widdershoven e.a. 2007 , p. $78-85$; Jans e.a. 2007 , p. 187. In de eerdere druk van de laatste komt het motiveringsbeginsel wel nog aan bod, zie Jans e.a. 2002, p. 249. Overigens is ook de invloed van het verdedigingsbeginsel en het motiveringsbeginsel nog beperkt in vergelijking tot het evenredigheidsbeginsel of gelijkheidsbeginsel, zie: Jans e.a. 2007, p. 116. 
Deel I Beginselen van behoorlijke rechtspleging

Plan van aanpak

Paragraaf 5.2 heeft betrekking op de uit het Unierecht te destilleren eisen van behoorlijke rechtspleging die van invloed kunnen zijn op de nationale (besluitvormings)procedures. In paragraaf 5.2.1 komt allereerst het verdedigingsbeginsel aan bod. Het motiveringsbeginsel wordt behandeld in paragraaf 5.2.2. Vervolgens wordt in paragraaf 5.2.3 kort aandacht besteed aan enkele andere beginselen van behoorlijke rechtspleging. Paragraaf 5.3 bevat tot slot een conclusie over de mogelijke invloed en reikwijdte van de door het Unierecht gestelde vereisten van behoorlijke rechtspleging voor de nationale bestuursrechtelijke procedures.

\subsection{Verschillende Unierechtelijke eisen van behoorlijke rechtspleging nader bezien}

\subsubsection{Het verdedigingsbeginsel}

Het verdedigingsbeginsel lijkt van alle beginselen van behoorlijke rechtspraak het meest aanwezig in de jurisprudentie van het Hof van Justitie - ook in het kader van de bestuurlijke besluitvormingsprocedures. ${ }^{24}$ Het Hof van Justitie omschreef het beginsel in eerste instantie als het recht van belanghebbenden, die aanmerkelijk in hun belangen worden getroffen, bij een overheidsbeslissing om hun standpunt kenbaar te maken. ${ }^{25}$ Het betroft derhalve een recht om gehoord te worden. Dat recht heeft zich, aldus Jans e.a., verder ontwikkeld tot de rechten van de verdediging, die thans meer omvatten dan uitsluitend het recht om gehoord te worden. ${ }^{26}$ Daarnaast betrof het in eerste instantie procedures waarin een (punitieve) sanctie werd opgelegd. ${ }^{27}$ Later heeft het Hof van Justitie bepaald dat het verdedigingsbeginsel geëerbiedigd moet worden in iedere procedure die leidt tot een bezwarende handeling voor een belanghebbende, dat wil zeggen een persoon die aanmerkelijk in zijn belang wordt getroffen. ${ }^{28}$ Dat betekent dat het verdedigingsbeginsel - waaronder het recht om gehoord te worden en andere rechten die hierna aan de orde komen - in beginsel ${ }^{29}$ geldt voor alle besluitvormingsprocedures die leiden tot een bezwarende handeling.

Het Hof van Justitie beperkt de werking van het verdedigingsbeginsel niet tot rechterlijke procedures, maar heeft aangegeven dat dit beginsel ook in de bestuurlijke besluitvormingsfase(n) in acht moet worden genomen. ${ }^{30}$ Het verdedigingsbeginsel, waaronder het beginsel van hoor en wederhoor valt, is een beginsel dat door alle gemeenschapsinstellingen dient te worden geëerbiedigd. ${ }^{31}$ In de uitspraak Hoffmann-La Roche overwoog het Hof van Justitie dat:

"Eerbiediging van de rechten der verdediging in iedere procedure die tot de oplegging van sancties, met name geldboeten of dwangsommen, kan leiden, is te beschouwen als een grondbeginsel van het gemeen-

24. Jans e.a. 2007, p. 187.

25. HvJ EG 23 oktober 1974, Transocean Marine Paint Association t. Commissie van de Europese Gemeenschappen, nr. 17/74. Zie ook: Widdershoven e.a. 2007, p. 78; Jans e.a. 2007, p. 187.

26. Jans e.a. 2007, p. 187.

27. HvJ EG 13 februari 1979, Hoffmann - La Roche en CO. AG t. Commissie van de Europese Gemeenschappen, C-85/76. Zie ook: Trimidas 2006, p. 378-381.

${ }^{28 .}$ HvJ EG 24 oktober 1996, Commissie van de Europese Gemeenschappen t. Lisrestal e.a., nr. C-32/95 P. Zie ook: Jans e.a. 2007, p. 187; Trimidas 2006, p. 378-379.

29. Er zijn beperkingen mogelijk op het recht om gehoord te worden en dit recht is niet absoluut, zie Jans e.e. 2007, p. 190 die verwijzen naar HvJ EG 15 juni 2006, Dokter e.a. t. Minister van Landbouw, Natuur en Voedselkwaliteit, C-28/05, AB 2006/390 m.nt. R.J.G.M. Widdershoven.

30. HvJ EG 18 december 2008, nr. C-349/07, Sopropé- Organizaçoes de Calçado Lda t. Fazenda Pública en Ministério Público, AB 2009/29 m.nt. Widdershoven; HvJ EG 15 juni 2006, Dokter e.a. t. Minister van Landbouw, Natuur en Voedselkwaliteit, C-28/05, AB 2006/390 m.nt. R.J.G.M. Widdershoven; Widdershoven e.a. 2007, p. 78; Jans e.a. 2007, p. 187.

31. HvJ EU 2 december 2009, Commissie t. Ierland e.a., nr. C-89/08 P. In deze zaak betrof het de vraag of het GEA het beginsel van hoor en wederhoor had geschonden bij de ambtshalve beoordeling van de motivering van de bestreden beslissing van de Commissie. 


\section{De beginselen in EU-perspectief}

schapsrecht, dat zelfs in een administratieve procedure moet worden inachtgenomen. (...) Zowel krachtens voormelde bepalingen als krachtens het algemeen beginsel dat erin wordt toegepast, brengt de eerbiediging van de rechten de verdediging derhalve mede dat de betrokken onderneming tijdens de administratieve procedure behoorlijk in staat moet zijn geweest haar standpunt kenbaar te maken met betrekking tot de juistheid en relevantie der gestelde feiten en omstandigheden, alsook met betrekking tot de stukken waarmee de commissie de door haar gestelde inbreuk op artikel 86 van het verdrag heeft gestaafd." 32

Het verdedigingsbeginsel, althans het recht op een hoorzitting, is als onderdeel van het recht op behoorlijk bestuur, tevens neergelegd in artikel 41 tweede lid van het Handvest.

Voorts is het inmiddels vaste rechtspraak dat het verdedigingsbeginsel als ongeschreven beginsel in acht moet worden genomen, ook als een wettelijke regeling of procedure ontbreekt. ${ }^{33}$ Bovendien dienen de gemeenschapsinstellingen er zelf op toe te zien dat het beginsel geëerbiedigd wordt in een procedure voor hen of door henzelf. ${ }^{34}$ De gemeenschapsinstellingen kunnen ook zelf een beroep doen op dat beginsel. Het geldt voor elke partij in een procedure ongeacht de juridische hoedanigheid van die partij. ${ }^{35}$ Bovendien dienen aan de schending van het verdedigingsbeginsel rechtsgevolgen te worden verbonden. ${ }^{36}$ Nietigverklaring van een beschikking of verordening is pas mogelijk, indien vaststaat dat als gevolg van de schending van het verdedigingsbeginsel of elementen ervan een andere uitkomst van het geding mogelijk was geweest en daadwerkelijk afbreuk is gedaan aan de verdedigingsrechten van de betrokkene. ${ }^{37}$ Pas als dat het geval is, is sprake van een schending van het verdedigingsbeginsel. Het Hof van Justitie stelt het als volgt:

"De rechten van de verdediging zijn geschonden indien zonder de door de Commissie begane onregelmatigheid de door haar gevoerde administratieve procedure tot een ander resultaat had kunnen leiden (arrest van 10 juli 1980, Distillers Company/Commissie, 30/78, Jurispr. blz. 2229, punt 26). Om een dergelijke schending te bewijzen, moet een verzoekende onderneming genoegzaam aantonen, niet dat de beschikking van de Commissie anders zou hebben geluid, maar wel dat zij zich zonder de onregelmatigheid beter had kunnen verdedigen, bijvoorbeeld omdat zij voor haar verweer stukken had kunnen gebruiken waartoe haar tijdens de administratieve procedure geen toegang was verleend (zie in die zin arrest van 8 juli 1999, Hercules Chemicals/Commissie, C51/92 P, blz. I-4235, punt 81, en arrest Limburgse Vinyl Maatschappij e.a./Commissie, reeds aangehaald, punt 318).",38

Hoewel het Hof van Justitie het verdedigingsbeginsel met name ontwikkeld heeft met het oog op procedures van de gemeenschapsinstellingen, is het beginsel ook van betekenis voor de nationale autoriteiten in het kader van procedures ter uitvoering of implementatie

32. HvJ EG 13 februari 1979, Hoffmann - La Roche en CO. AG t. Commissie van de Europese Gemeenschappen, C-85/76, r.o. 9 en 11. Zie ook nog: HvJ EG 2 oktober 2003, Thyssen Stahl AG t. Commissie van de Europese Gemeenschappen, nr. C-194/99 P. Zoals hiervoor werd aangegeven, lijkt het HvJ EG het recht om gehoord te worden in deze uitspraken te beperken tot procedures waarin een opgelegde sanctie in het geding is. Later is duidelijk geworden dat de rechten van de verdediging in acht moeten worden genomen in alle procedures waarin een persoon aanmerkelijk getroffen wordt in zijn belangen door een bezwarende handeling.

33. Zie bijvoorbeeld: HvJ EG 18 december 2008, nr. C-349/07, Sopropé- Organizaçoes de Calçado Lda t. Fazenda Pública en Ministério Público, AB 2009/29 m.nt. Widdershoven; HvJ EG 15 juni 2006, Dokter e.a. t. Minister van Landbouw, Natuur en Voedselkwaliteit, C-28/05, AB 2006/390 m.nt. R.J.G.M. Widdershoven; HvJ EG 29 juni 1994, Fiskano AB t. Commissie van de Europese Gemeenschappen, nr. C-135/92.

34. HvJ EU 2 december 2009, Commissie t. Ierland e.a., nr. C-89/08 P. Het HvJ EU lijkt te impliceren dat de gemeenschapsinstellingen ambtshalve erop dienen toe te zien dat het beginsel wordt nageleefd.

35. Zie de noot hiervoor.

${ }^{36}$ Het HvJ EG acht het in elk geval onjuist dat het Gerecht, indien het tot de conclusie komt dat de Commissie het verdedigingsbeginsel geschonden heeft, geen rechtsgevolgen aan die conclusie verbindt en de litigieuze beschikking van de Commissie bevestigt. Vervolgens vernietigt het de uitspraak van het Gerecht, doet het de zaak zelf af en verklaart de litigieuze beschikking nietig, zie: HvJ EG 3 september 2009, Papierfabrik August Koehler AG (C-322/07 P), Bolloré SA (C-327/07 P) en Distribuidora Vizcaína de Papeles SL (C-338/07 P) t. Commissie van de Europese Gemeenschappen, nrs. C-322/07 P, C-327/07 P en C-338/07 P.

${ }^{37}$ Het Hof van Justitie spreekt van een onregelmatigheid in de procedure, die enkel en alleen tot nietigverklaring van de litigieuze verordening kan leiden indien daadwerkelijk afbreuk is gedaan aan de verdedigingsrechten van rekwirante, zie bijv.: HvJ EG 1 oktober 2009, Foshan Shunde Yongjian Housewares \& Hardware Co. Ltd t. De Raad van de Europese Unie, C-141/08 P, par. 81.

${ }^{38 .}$ HvJ EG 2 oktober 2003, Thyssen Stahl AG t. Commissie van de Europese Gemeenschappen, nr. C-194/99 P. 


\title{
Deel I Beginselen van behoorlijke rechtspleging
}

van Unierecht. ${ }^{39}$ In een uitspraak in 2006 in de zaak Dokter e.a. bevestigt het Hof van Justitie zulks expliciet. Widdershoven geeft in zijn noot bij die uitspraak aan dat het belang van de uitspraak er mede in gelegen is dat het Hof van Justitie voor de eerste maal expliciet aangeeft dat het verdedigingsbeginsel ook geldt en in acht genomen moet worden door de nationale autoriteiten als zij binnen de werkingssfeer van het Unierecht handelen. ${ }^{40}$

Vaststaat dat de nationale bestuurlijke voorprocedures door het verdedigingsbeginsel als algemeen beginsel van Unierecht - in geschreven of ongeschreven vorm - genormeerd worden, indien daarin een bezwarende handeling centraal staat van het bestuur in het kader van de tenuitvoerlegging van Unierecht of die anderszins binnen het raakvlak van het Unierecht vallen. ${ }^{41}$

Functies van het verdedigingsbeginsel

Het Hof van Justitie lijkt bij het recht op een hoorzitting geen scherp onderscheid te maken tussen de bestuurlijke fase of rechtsbeschermingsfase. Als beginsel dat vooral als norm van behoorlijk bestuur gericht tot de instellingen van de EU ontwikkeld is ${ }^{42}$, heeft het een tweeledige functie. Trimidas wijst op die duale functie die het Hof van Justitie toekent aan het recht om gehoord te worden: een functie vanuit een oogpunt van behoorlijk bestuur en zorgvuldige besluitvorming en een functie in het kader van 'formal justice' die verband houdt met het mensenrechtelijk karakter en de rechtsstaatgedachte. ${ }^{43}$ Deze twee functies worden wel de instrumentele en non-instrumentele ratio van het recht om gehoord te worden en procedurele rechten in het algemeen genoemd. ${ }^{44}$ In een recente uitspraak overwoog het Hof van Justitie bijvoorbeeld over het doel van het recht om gehoord te worden (de kern van het verdedigingsbeginsel):

\begin{abstract}
"De regel dat aan de adressaat van een bezwarend besluit de gelegenheid moet worden gegeven om zijn opmerkingen kenbaar te maken voordat dit besluit wordt genomen, heeft tot doel de bevoegde autoriteit in staat te stellen naar behoren rekening te houden met alle relevante elementen. Hij beoogt met name, ter verzekering van de effectieve bescherming van de betrokken persoon of onderneming, deze laatsten in staat te stellen om een vergissing te corrigeren of individuele omstandigheden aan te voeren die ervoor pleiten dat het besluit wordt genomen, niet wordt genomen of dat in een bepaalde zin wordt besloten.

50 De eerbiediging van de rechten van de verdediging impliceert bijgevolg dat de administratie met de nodige aandacht kennis neemt van de opmerkingen van de betrokken persoon of onderneming. Slechts dan kan de houder van deze rechten worden geacht de gelegenheid te hebben gekregen om zijn standpunt naar behoren kenbaar te maken." 45
\end{abstract}

Hierin komt de tweeledige ratio van de waarborgen tot uitdrukking: zorgvuldige besluitvorming en effectieve rechtsbescherming. De nadruk lijkt zelfs te liggen op de effectieve rechtsbescherming van betrokkenen, doordat het Hof van Justitie stelt het doel van het recht om gehoord te worden met name is de verzekering van effectieve rechtsbescherming. Als eis die zich uitstrekt tot het bestuur dient het verdedigingsbeginsel in het Unierecht derhalve niet alleen de kwaliteit of zorgvuldigheid van de besluitvorming, maar in elk geval ook de rechtsbescherming van de betrokken partijen. Het Hof van Justitie legt in zijn rechtspraak ook weleens een verband tussen de verdedigingsrechten en het begin-

\footnotetext{
39. Widdershoven e.a. 2007, p. 79; Jans e.a. 2007, p. 187; Trimidas 2006, p. 415-416.

${ }^{40 .}$ Noot bij HvJ EG 15 juni 2006, Dokter e.a. t. Minister van Landbouw, Natuur en Voedselkwaliteit, C-28/05, $A B$ 2006/390 m.nt. R.J.G.M. Widdershoven.

${ }^{41 .}$ Trimidas 2006, p. 415.

42. Widdershoven e.a. 2007, p. 79.

43. Trimidas 2006, p. 370-371

44. Trimidas 2006, p. 371. Trimidas wijst er overigens op dat het recht op een hoorzitting een terrein is waarop het gemeenschapsrecht meer gemeen heeft met common law stelsels (en de principals of natural justice) dan de continentale stelsels.

45. Zie ook: HvJ EG 18 december 2008, Sopropé-Organizaçoes de Calçado Lda t. Fazenda Pública en Ministério Público, AB 2009/29 m.nt. R.G.J.M. Widdershoven.
} 


\section{De beginselen in EU-perspectief}

sel van hoor en wederhoor en artikel 6 EVRM. In elk geval voor zover het gaat om de procedure bij de rechterlijke instanties van de EU. ${ }^{46}$

\section{Deelaspecten van het verdedigingsbeginsel}

Jans e.a. onderscheiden, naast het (kern)recht om gehoord te worden, verschillende deelaspecten van het verdedigingsbeginsel in de rechtspraak van het Hof van Justitie: het recht om informatie te ontvangen, het recht op geheimhouding van zakengeheimen en andere vertrouwelijke stukken van betrokkenen, het verbod van zelfincriminatie (nemo tenetur-beginsel), vertrouwelijkheid van communicatie tussen advocaat en cliënt (legal privilege), het recht op rechtsbijstand en ten slotte voldoende tijd voor de voorbereiding van de verdediging. ${ }^{47}$

Enkele aspecten die zij noemen vormen geen algemeen beginsel van behoorlijke rechtspleging noch onderdeel van het algemene beginsel van hoor en wederhoor. Bovendien lijken enkele aspecten tot op heden uitsluitend toegepast te zijn in het mededingingsrecht of op andere specifiek afgebakende terreinen dan wel hebben deze vooralsnog geen algemene gelding maar uitsluitend voor bestraffende sancties. ${ }^{48} \mathrm{Om}$ die redenen worden deze aspecten in het onderstaande verder niet uitvoerig behandeld. Het gaat om de volgende aspecten: het recht op geheimhouding van zakengeheimen, het recht op geheimhouding van verschafte informatie buiten of na de procedure, het verbod van zelfincriminatie (nemo tenetur-beginsel) en het legal professional privilege. ${ }^{49}$

Uit de hiervoor gegeven opsomming van algemene deelaspecten van het verdedigingsbeginsel blijkt al dat deze deelaspecten voor een groot deel overeenstemmen met de elementen van het beginsel van hoor en wederhoor, dat in paragraaf 4.3.5 van hoofdstuk 4 beschreven is. Ook het Unierechtelijke verdedigingsbeginsel omvat het recht om informatie te verschaffen, het recht om informatie te ontvangen en voldoende tijd voor de voorbereiding van de verdediging. Een deel van de Unierechtelijke eisen complementeren of ondersteunen de kernrechten, het recht om op informatie te ontvangen of te verschaffen, die in het verdedigingsbeginsel besloten liggen. Hieronder wordt allereerst ingegaan op het recht om gehoord te worden, waarna enkele andere (ondersteunende) aspecten aan bod komen.

\section{Het recht om gehoord te worden}

Het recht om gehoord te worden oftewel 'the right to a fair hearing' omvat het recht van de belanghebbende om zijn eigen standpunt kenbaar te maken en zijn eigen belangen te verdedigen. ${ }^{50}$ Het Hof van Justitie stelt de eis dat belanghebbenden (adressaten van besluiten die hun belangen aanmerkelijk raken) op effectieve wijze hun standpunt kenbaar moeten kunnen maken. ${ }^{51}$ Niet vereist is dat zulks mondeling moet plaatsvinden. Schriftelijk kenbaar maken van het eigen standpunt volstaat ook. ${ }^{52}$

Het recht om gehoord te worden bestaat, blijkens de jurisprudentie van het Hof van Justitie, uit verschillende elementen. Daaronder valt het recht om het eigen standpunt kenbaar te maken over de elementen of de grond waarop het bestuur zijn beslissing of

46. HvJ EU 2 december 2009, Commissie t. Ierland e.a., nr. C-98/08 P.

47. Jans e.a. 2007, p. 190-192. Zie ook: Widdershoven e.a. 2007, p. 79-81.

48. Widdershoven e.a. 2007 , p. $79-80$. Zij wijzen erop dat het nemo tenetur-beginsel vooralsnog alleen in het mededingingsrecht toegepast wordt.

49. Zie over de doorwerking van die aspecten in het nationale bestuursrecht: Widdershoven e.a. 2007, p. 80 e.v.; Jans e.a. 2007, p. 191-196.

${ }^{50 .}$ Trimidas 2006, p. 385-386.

51. Zie o.m.: HvJ EG 18 december 2008, nr. C-349/07, Sopropé- Organizaçoes de Calçado Lda t. Fazenda Pública en Ministério Público, AB 2009/29 m.nt. Widdershoven; HvJ EG 15 juni 2006, Dokter e.a. t. Minister van Landbouw, Natuur en Voedselkwaliteit, C-28/05, AB 2006/390 m.nt. R.J.G.M. Widdershoven; HvJ EG 24 oktober 1996, Commissie van de Europese Gemeenschappen t. Lisrestal e.a., nr. C-32/95 P. Soms gebruikt het ook de term 'naar behoren moet kunnen worden uitgeoefend', maar aangenomen kan worden dat dit op hetzelfde neerkomt, zie: Trimidas 2006, p. 385-386.

52. Widdershoven e.a. 2007 , p. 80. 
Deel I Beginselen van behoorlijke rechtspleging

maatregel wil baseren. ${ }^{53}$ Het recht om gehoord te worden is niet absoluut en mag beperkt worden. De beperkingen dienen echter werkelijk te beantwoorden aan de doeleinden van algemeen belang die met de betrokken maatregel worden nagestreefd en zij mogen, het nagestreefde doel in aanmerking genomen, niet te beschouwen zijn als een onevenredige en onduldbare ingreep waardoor de gewaarborgde rechten in hun kern worden aangetast. $^{54}$ In een zaak waarin maatregelen ter bestrijding van mond- en klauwzeer centraal stonden, was er volgens het Hof van Justitie pas sprake van een onevenredige en onduldbare ingreep waardoor de rechten van de verdediging in hun kern worden aangetast, indien de belanghebbende(n) nadat de maatregelen genomen zijn, zonder hen vooraf in de gelegenheid te stellen hun standpunt kenbaar te maken, niet in een procedure tegen die maatregelen zouden kunnen opkomen en niet in dat kader naar behoren hun standpunt kenbaar zouden kunnen maken. ${ }^{55}$

Naar nationaal recht zou het recht om gehoord te worden onder het deelaspect 'het recht om informatie te verschaffen' van het beginsel van hoor en wederhoor vallen. Dat deelaspect is in verschillende bepalingen in de Awb - in sommige gevallen als uitwerking van het zorgvuldigheidsbeginsel - voor zowel de primaire besluitvormingsfase als voor de bestuurlijke voorprocedures uitgewerkt. Het komt onder meer tot uitdrukking in de geldende hoorplichten neergelegd in artikelen 4;7, 4:8, 7:2 en 7:9 Awb. Die hoorplichten zijn eveneens niet absoluut en uitzonderingen daarop zijn mogelijk. De hoorplichten en de uitzonderingen hebben echter niet het grondrechtelijk karakter van het verdedigingsbeginsel en de bijbehorende beperkingssystematiek. Zij worden veeleer herleid tot het formele zorgvuldigheidsbeginsel als algemeen beginsel van behoorlijk bestuur. Voor de bestuurlijke voorprocedures wordt op het recht om gehoord te worden nader ingegaan in Deel II, paragraaf 5.3.

\section{Het recht om informatie te ontvangen}

Het verdedigingsbeginsel omvat ook het recht om geinformeerd te worden over feiten of elementen waarop de bestreden handeling of beslissing gebaseerd is. ${ }^{56} \mathrm{Om}$ het eigen standpunt te bepalen en kenbaar te maken, is immers noodzakelijk dat alle voor de handeling of beslissing relevante informatie ter beschikking staat aan de betrokken partij. Daarnaast omvat dit recht ook het recht op toegang tot de stukken van het dossier of mededeling van de processtukken. ${ }^{57}$

De grens van het recht op informatie ligt in algemene zin in het recht op professionele geheimhouding. ${ }^{58}$ Dat komt ook tot uitdrukking in artikel 41 tweede lid van het Handvest waarin is vastgelegd dat een ieder het recht heeft om toegang te krijgen tot het dossier hem betreffende, met inachtneming van het gerechtvaardigde belang van de vertrouwelijkheid en het beroeps- en het zakengeheim. Een mooie illustratie daarvan is ook te vinden in een uitspraak in een prejudiciële procedure betreffende een aanbestedingszaak waarin het Hof van Justitie overwogen heeft dat het beginsel van hoor en wederhoor en het recht op tegenspraak geen onvoorwaardelijk en onbeperkt recht tot toegang tot informatie inzake de aanbestedingsprocedure impliceren. Het recht op toegang tot informatie moet in een evenwichtige verhouding staan tot de rechten van anderen op bescherming van vertrouwelijke gegevens en zakengeheimen. Is er sprake van een procedure bij een beroepsinstantie of rechterlijke instantie over een toekenning van publiek contract, waarin geoordeeld moet worden over de vraag of toegang tot de informatie

${ }^{53 .}$ HvJ EG 14 februari 2008, Varec SA t. Belgische Staat, EHRC 2008/64; HvJ EG 15 juni 2006, Dokter e.a. t. Minister van $L N V, A B 2006 / 390$ m.nt. Widdershoven.

54. Dokter e.a., par. 75. Zie ook dezelfde overweging voor het beginsel van effectieve rechtsbescherming: HvJ EU 18 maart 2010, Alassini, nr. C-317-220/08.

55. Dokter e.a., par. 76.

56. Af te leiden ook uit Dokter e.a., par. 76

57. Zie bijvoorbeeld: HvJ EG 2 mei 2006, Insloventieprocedure met betrekking tot Eurofood IFSC Ltd., EHRC

2006/67. Zie hierover nader: Trimidas 2006, p. 386 en 397 e.v.

58 Zie hierover: Trimidas 2006, p. 388 e.v. 


\section{De beginselen in EU-perspectief}

gegeven wordt dan wel geheimhouding op zijn plaats is, dan dient de beroepsinstantie in elk geval zelf toegang tot alle informatie, ook de vertrouwelijke gegevens, te hebben opdat deze in staat is met kennis van alle feiten een beslissing te nemen. ${ }^{59}$ Het is aan de nationale beroepsinstantie om de vertrouwelijkheid en het zakengeheim te waarborgen ten aanzien van de informatie in het dossier dat door partijen, in het bijzonder door de contracterende overheid, aan die instantie is toegezonden. De instantie mag kennis nemen van de informatie en de informatie in beschouwing nemen. Vervolgens moet de instantie zelf beslissen in welke mate en door welke procedure de vertrouwelijkheid voldoende wordt gewaarborgd, daarbij rekening houdend met de vereisten van effectieve rechtsbescherming en de rechten van de verdediging.

Het deelaspect 'recht om informatie te ontvangen' wordt ook in het nationale recht onderscheiden en onder het beginsel van hoor en wederhoor geschaard. Het omvat tevens het recht om informatie te ontvangen over de feiten waarop de beslissing gebaseerd wordt. Het recht op toegang tot de stukken en de informatie waarover de wederpartij beschikt, valt naar nationaal recht eveneens onder het algemenere deelaspect 'het recht om informatie te ontvangen'. Voor de bestuurlijke voorprocedures is dit deelaspect uitgwerkt in artikel 7:4 en 7:18 Awb. Een verplichting tot terinzagelegging van alle op de zaak betrekking hebbende stukken is voor de bezwaarschriftprocedure en het administratief beroep neergelegd in artikel 7:4 tweede lid en 7:18 tweede lid. Ook hier ligt de grens in noodzakelijk geachte geheimhouding wegens gewichtige redenen, zo volgt uit de leden zes tot en met acht van beide bepalingen. In Deel II, paragraaf 5.3.4 komt dit aspect voor de bestuurlijke voorprocedures nader aan de orde.

Dat het Europeesrechtelijke verdedigingsbeginsel, in het bijzonder het recht op toegang tot informatie, desondanks in weerwil van of bij toepassing van de nationaalrechtelijke bepalingen of eisen niet altijd gewaarborgd wordt, blijkt bijvoorbeeld uit een uitspraak van het $\mathrm{CBb}$ van 9 september 2008. Het $\mathrm{CBb}$ overweegt dat appellanten in de bezwaarfase ten onrechte niet in de gelegenheid waren gesteld kennis te nemen van de labaratoriumgegevens waarop de maatregelen ter bestrijding van mond- en klauwzeer waren gebaseerd en ten onrechte niet in de gelegenheid waren gesteld daarop te reageren. Onder meer daarom worden de bestreden besluiten wegens strijd met artikel 3:2 Awb vernietigd. Het $\mathrm{CBb}$ overweegt voorts dat verweerder onvoldoende kennis vergaard heeft over de relevante feiten en de af te wegen belangen. ${ }^{60}$ Wat opvalt in deze uitspraak, is dat de Unierechtelijke verplichting tot toegang tot informatie en de verplichting tot het bieden van een mogelijkheid voor belanghebbenden om hun standpunt kenbaar te maken in de bestuurlijke voorprocedures nationaalrechtelijk onder de algemene noemer van het zorgvuldigheidsbeginsel wordt gebracht. Op deze wijze kunnen de eisen die voortvloeien uit het Unierechtelijke verdedigingsbeginsel doorwerken in de nationale besluitvormingsprocedure via dit algemene beginsel van behoorlijk bestuur.

Voldoende tijd ter verdediging van het eigen standpunt

Een andere waarborg van het verdedigingsbeginsel, die ten dienste staat aan het recht om informatie te verschaffen of te ontvangen, is het recht op voldoende tijd ter voorbereiding van het eigen standpunt. Dat recht houdt in dat er een voldoende ruime termijn moet zijn om ontvangen informatie te bestuderen en om daarover een standpunt te vormen alsmede voldoende tijd moet worden gegeven om dat standpunt kenbaar te maken. ${ }^{61}$ In algemene zin kan gesteld worden dat rekening gehouden moet worden met verschillende

\footnotetext{
${ }^{59 .}$ HvJ EG 14 februari 2008, Varec SA t. Belgische Staat, EHRC 2008/64.

${ }^{60 .}$ CBb 9 september 2008, $A B$ 2009/300 m.nt. Sewandono; JB 2008/245 m.nt. M.O.-V. Het gaat om het nationale vervolg op de uitspraak van het HvJ EG in de zaak Dokter e.a. gewezen naar aanleiding van prejudiciële vragen van het $\mathrm{CBb}$.

${ }^{61 .}$ Widdershoven e.a. 2007, p. 80; Jans e.a. 2007, p. 191.
} 


\section{Deel I Beginselen van behoorlijke rechtspleging}

factoren, zoals complexiteit van de zaak, het aantal betrokken partijen en de omvang van het dossier. ${ }^{62}$

Een recente uitspraak waarin dit deelaspect van het verdedigingsbeginsel centraal stond, is de uitspraak van het Hof van Justitie van 18 december 2008 in de zaak SopropéOrganizaçoes de Calçado Lda t. Fazenda Pública en Ministério Público. ${ }^{63}$ Daarin overwoog het Hof van Justitie dat het verdedigingsbeginsel vereist dat de adressaten van besluiten die hun belangen aanmerkelijk raken, in staat worden gesteld naar behoren hun standpunt kenbaar te maken over de elementen waarop het bestuur haar besluit wil baseren. Daartoe behoort een toereikende termijn gesteld te worden. De verplichting daartoe rust op de bestuursorganen van de lidstaten wanneer zij besluiten nemen die binnen de werkingssfeer van het Unierecht vallen, ook al voorziet de toepasselijke Europese wetgeving niet uitdrukkelijk in een dergelijke formaliteit. Bepaalt het Unierecht niets, dan wordt de termijn door het nationale recht bepaald, met dien verstande dat zij even lang moeten zijn als die waarover particulieren of ondernemingen in vergelijkbare nationaalrechtelijke situaties beschikken en de uitoefening van de door het Unierecht verleende rechten van de verdediging in de praktijk niet onmogelijk of uiterst moeilijk mogen maken. ${ }^{64}$ Het Hof van Justitie overweegt vervolgens:

"Het staat aan de lidstaten om voor de nationale regelingen die binnen de werkingssfeer van het gemeenschapsrecht vallen, termijnen vast te stellen die met name in verhouding staan tot het belang van de te nemen besluiten voor de belanghebbenden, de complexiteit van de toe te passen procedures en wetgeving, het aantal personen dat door het besluit kan worden geraakt en de overige in aanmerking te nemen publieke of particuliere belangen."

Afhankelijk van de genoemde belangen kan de termijn die in acht genomen moet worden derhalve verschillen. Het Hof van Justitie geeft wel aan dat vanuit een oogpunt van gelijkheid algemene termijnen gesteld moeten worden. Bij het opstellen van die algemene termijnen kan vervolgens rekening gehouden worden met de genoemde belangen. In de onderhavige zaak gold een minimum- en maximumtermijn. In dat kader oordeelde het Hof van Justitie dat de nationale rechter zich ervan dient te vergewissen of de termijn die de administratie dienovereenkomstig in een concreet geval heeft toegekend, beantwoordt aan de specifieke situatie van de betrokken persoon of onderneming en hen, met inachtneming van het doeltreffendheidsbeginsel, de mogelijkheid heeft geboden om hun rechten van verdediging uit te oefenen. De nationale rechter dient in dat geval naar behoren rekening te houden met de specifieke gegevens van de zaak. ${ }^{65}$

Voorts overwoog het Hof van Justitie ook nog dat de eerbiediging van de rechten van de verdediging impliceert dat:

“(...) de administratie met de nodige aandacht kennis neemt van de opmerkingen van de betrokken persoon of onderneming. Slechts dan kan de houder van deze rechten worden geacht de gelegenheid te hebben gekregen om zijn standpunt naar behoren kenbaar te maken.

51 Het staat uitsluitend aan de nationale rechter om na te gaan of al dan niet kan worden aangenomen dat de betrokken administratie naar behoren rekening heeft gehouden met de bij haar ingediende opmerkingen, gelet op de tijd die is verstreken tussen het tijdstip waarop zij deze opmerkingen heeft ontvangen en het tijdstip waarop zij haar besluit heeft vastgesteld."

De duur van de termijn waarbinnen het bestuur een besluit neemt nadat de betrokkene zijn standpunt heeft kenbaar gemaakt, moet derhalve ook worden bezien in het perspectief van het verdedigingsbeginsel. Van belang is dat de autoriteiten naar behoren rekening hebben kunnen houden met het standpunt van de betrokkene.

62. Widdershoven e.a. 2007, p. 80; Jans e.a. 2007, p. 191

${ }^{63 .}$ HvJ 18 december 2008, Sopropé-Organizaçoes de Calçado Lda t. Fazenda Pública en Ministério Público, AB 2009/29 m.nt. R.G.J.M. Widdershoven.

${ }^{64 .}$ Het betreft het gelijkwaardigheidsbeginsel en het effectiviteitsbeginsel dat daarbij in acht moet worden genomen, zie hierover par. 4.3.9.

${ }^{65}$ Zie hierover verder de noot van Widdershoven bij $A B$ 2009/29. 


\section{De beginselen in EU-perspectief}

In het nationale recht vormt het aspect voldoende tijd ter voorbereiding van het eigen standpunt ook onderdeel van het beginsel van hoor en wederhoor. Het komt voor de procedure bij de bestuursrechter en de bestuurlijke voorprocedures onder meer tot uitdrukking in artikel 8:58 Awb en artikel 7:4 Awb. In Deel II, paragraaf 5.3 wordt nader ingegaan op dit aspect voor zover het de bestuurlijke voorprocedures betreft.

\section{Doorwerking van het Unierechtelijke verdedigingsbeginsel}

Wat betreft de invloed van het Unierechtelijke verdedigingsbeginsel valt een aantal punten op. Allereerst beperkt het Hof van Justitie de geldingskracht van het verdedigingsbeginsel voor de nationale rechtsorde in geschillen waarin de uitvoering van Unierecht speelt niet tot procedures bij rechterlijke instanties. Het Unierechtelijke verdedigingsbeginsel werkt uitdrukkelijk door in de fasen waarin het bestuur nog een besluit moet nemen of een genomen besluit moet heroverwegen. Het Hof van Justitie heeft immers bepaald dat het verdedigingsbeginsel geldt in alle procedures ${ }^{66}$ die leiden tot een bezwarende handeling voor de betrokkenen met een aanmerkelijk belang. ${ }^{67}$

Wat verder opvalt is dat het verdedigingsbeginsel als norm van behoorlijk bestuur ten aanzien van de Europese instellingen sterk in de jurisprudentie van het Hof van Justitie is ontwikkeld. In Nederland kennen we het verdedigingsbeginsel als beginsel van behoorlijk bestuur niet. ${ }^{68}$ De rechten die voortvloeien uit het Unierechtelijke verdedigingsbeginsel vloeien in Nederland voort uit of kunnen gebaseerd worden op het zorgvuldigheidsbeginsel en/of de Awb. ${ }^{69}$ In de primaire besluitvormingsfase staan deze waarborgen, zo wordt aangenomen, meer in het teken van de bestuurlijke functie. ${ }^{70}$ Voor de bestuurlijke voorprocedures kan dat anders liggen, maar daarover meer in Deel II, hfst. 4 en 5. Inmiddels laat de nationale bestuursrechter het Unierechtelijke beginsel ook doorwerken in de nationale besluitvormingsprocedures door middel van het zorgvuldigheidsbeginsel, als norm voor het bestuurlijk handelen. De functie van (de deelaspecten van) het Unierechtelijke verdedigingsbeginsel is bovendien tweeledig, naast de bestuurlijke functie komt daaraan ook uitdrukkelijk een rechtsbeschermingsfunctie toe. Beide functies dicht het Hof van Justitie aan het beginsel voor de besluitvorming van de gemeenschapsinstellingen toe. Aan de kernrechten, het recht om informatie te ontvangen en te verschaffen, zijn ook accessoire rechten verbonden die meer in verband staan met de rechtsbeschermingsfunctie. ${ }^{71}$ Voor zover het verdedigingsbeginsel doorwerkt in de nationale bestuurlijke procedures heeft het ook in die procedures een tweeledige functie en moet de rechtsbeschermingsfunctie in het kader van het (ongeschreven) zorgvuldigheidsbeginsel en/of de voorschriften uit de Awb gewaarborgd worden. ${ }^{72}$ De bestuursrechter zou het zorgvuldigheidsbeginsel dan zo moeten uitleggen dat daarmee ook het rechtsbeschermingsperspectief gewaarborgd is. ${ }^{73}$

66. Waarbij het begrip procedures door het HvJ EG niet eng wordt uitgelegd en wordt beperkt tot procedures bij rechterlijke instanties.

67. Zie noot 28 .

68. Overigens schijnt Nederland daarin vrijwel alleen te staan, aldus Widdershoven e.a. 2007, p. 78. Zie ook: Trimidas 2006, p. 372, waaruit blijkt dat het HvJ EG het beginsel uit de gemeenschappelijke tradities van de lidstaten gedestilleerd heeft. In beide gevallen wordt verwezen naar de conclusie van AG Warner in de zaak Transocean Marine Paint t. Commissie, 17/74 waarin deze een rechtsvergelijkend onderzoek naar de betekenis van het beginsel in de lidstaten heeft verricht.

69. Widdershoven e.a. 2007, p. 82-85. Dat vormt voor de Commissie evaluatie Awb III (Cie Evaluatie Awb III) overigens ook de aanleiding om de opname van het verdedigingsbeginsel in de Awb af te wijzen, Eindrapport Toepassing en effecten van de Algemene wet bestuursrecht 2000-2006 (Rapport Cie Evaluatie Awb III), Den Haag: BJu 2007, p. 53. Vaak worden de eisen overigens ook op artikel 6 EVRM gebaseerd, Rapport Cie Evaluatie Awb III, p. 53.

70. Widdershoven e.a. 2007, p. 82-83. Onder meer om die reden menen de onderzoekers dan ook dat het verdedigingsbeginsel in de Awb opgenomen moet worden, p. 82-85.

${ }^{71}$ Widdershoven 2007 e.a., p. 81-84; Rapport Cie Evaluatie Awb III, p. 53.

72. Daar zit volgens Widdershoven e.a. dan ook juist het probleem, omdat de Awb in de rechtsbeschermingsfunc-

tie onvoldoende voorziet, Widdershoven e.a. 2007, p. 82-83.

${ }^{73}$ Zie hierover ook de noot van Verheij bij AbRvS 1 november 2006, AB 2008/55 m.nt. N. Verheij. 


\section{Deel I Beginselen van behoorlijke rechtspleging}

Het Unierechtelijke verdedigingsbeginsel verschilt voor het overige op belangrijke punten niet van het beginsel van hoor en wederhoor dat in het nationale bestuursrecht als beginsel van behoorlijke rechtspleging wordt erkend. ${ }^{74}$ Deelaspecten zoals het recht om informatie te ontvangen en te verschaffen en voldoende tijd ter voorbereiding van het eigen standpunt kent ook het Unierechtelijke verdedigingsbeginsel. Daarmee staat vast dat de deelaspecten, die ook deel uitmaken van het Unierechtelijke beginsel, gelden voor de bestuurlijke voorprocedures voor zover daarin een bezwarende handeling van het bestuur die in de werkingssfeer van het Unierecht valt centraal staat. Wel kan pas sprake zijn van een schending van het verdedigingsbeginsel volgens het Hof van Justitie en van rechtsgevolgen - in de zin van nietigverklaring - voor de litigieuze beschikking of verordening, indien daadwerkelijk afbreuk is gedaan aan de verdedigingsrechten doordat bij inachtneming ervan een andere uitkomst van het geding mogelijk zou zijn. ${ }^{75}$ Als het Hof van Justitie eenzelfde benadering hanteert bij de vraag of de nationale autoriteiten in het kader van de tenuitvoerlegging van het Unierecht het verdedigingsbeginsel in acht hebben genomen, betekent dat dat vernietiging van een besluit van het bestuur ook niet altijd vereist is. Dat is alleen het geval indien daadwerkelijk afbreuk is gedaan aan de verdedigingsrechten van een belanghebbende.

\subsubsection{Het motiveringsbeginsel}

De motiveringseisen die het Hof van Justitie de afgelopen jaren in zijn jurisprudentie heeft geformuleerd, zijn evenals de verdedigingsrechten, primair tot stand gekomen in relatie tot handelingen van de andere gemeenschapsinstellingen. ${ }^{76}$ Motiveringseisen stelt het Hof van Justitie aan de beslissingen van de Commissie en de Raad (al dan niet samen met het Europees Parlement). Voor de beslissingen van deze instellingen is de motiveringsplicht ook neergelegd in artikel 253 EG-verdrag. Als ongeschreven eis van behoorlijk bestuur of voor behoorlijke besluitvorming bestaat de motiveringseis echter ook al geruime tijd voor beslissingen die niet in artikel 253 EG-verdrag genoemd worden. ${ }^{77}$ In artikel 41 eerste en tweede lid onder c van het Handvest is thans ook, als eis van behoorlijk bestuur, neergelegd dat de gemeenschapsinstellingen hun beslissingen met redenen dienen te omkleden.

Ook voor de rechterlijke instanties van de EU gelden motiveringseisen. Die rechterlijke (ongeschreven) motiveringseisen worden niet of nauwelijks in verband gebracht met het recht op een eerlijk proces, zoals neergelegd in artikel 6 EVRM, aan de orde in de jurisprudentie van het Hof van Justitie. ${ }^{78}$ Voorts is in artikel 47 van het Handvest ook geen motiveringsplicht is neergelegd als onderdeel van het recht op een eerlijke proces-

\footnotetext{
74. Zie par. 4.3.5 van hfst. 4

${ }^{75}$ Zie bijv.: HvJ EG 2 oktober 2003, Thyssen Stahl AG, nr. C-194/99 P.

76. Zie hierover ook: A.J.C. de Moor-van Vugt, Algemene beginselen van behoorlijk bestuur en buitenlandse equivalenten, Zwolle: W.E.J. Tjeenk Willink 1987, p. 152-154.

77. HvJ EG 15 oktober 1987, Union nationale des entraîneurs et cadres techniques professionnels du football (Unectef) t. Heylens e.a., nr. 222/86. Zie ook de voorlaatste druk van het boek van J.H. Jans, R. de Lane, S Prechal, R.J.G.M. Widdershoven, Inleiding tot het Europees bestuursrecht, Ars Aequi: Nijmegen 2002, p. 246249 , waarin nog wordt ingegaan op de communautaire motiveringseisen. In de nieuwe Engelstalige druk van 2007 is dat niet meer het geval.

78. Zie enkele willekeurige uitspraken van het HvJ EG waarin het verwijst naar de relevante artikelen van het Statuut: HvJ EG 3 september 2009, Papierfabrik August Koehler AG (C-322/07 P), Bolloré SA (C-327/07 P) en Distribuidora Vizcaina de Papeles SL $(C-338 / 07$ P) t. Commissie van de Europese Gemeenschappen, nrs. C322/07 P, C-327/07 P en C-338/07 P; HvJ EG 2 april 2009, Bouygues en Bouygues Télécom t. Commissie van de Europese gemeenschappen, C-431/07 P. In de nationale literatuur wordt aan die eis alsmede aan de gevolgen daarvan voor de uitspraken van nationale rechterlijke instanties ook geen aandacht besteed, zie: Jans e.a. 2007, p 115; Widdershoven e.a. 2007 , p. 37 e.v.
} 


\title{
De beginselen in EU-perspectief
}

gang. Wel is in artikel 36 van het Statuut van het Hof van Justitie opgenomen dat de arresten met redenen omkleed zijn. ${ }^{79}$

De motiveringseisen strekken zich eveneens uit tot de nationale autoriteiten en nationale procedures wanneer rechten op grond van het Unierecht in het geding zijn. In het kader van het beginsel van effectieve rechtsbescherming wordt door het Hof van Justitie namelijk een plicht tot motivering of het geven van redenen voor inbreuken op de aan het Unierecht ontleende rechten van burgers onderscheiden, die geldt voor alle nationale autoriteiten. Dat blijkt uit de uitspraak van het Hof van Justitie in de zaak Heylens waarin het overweegt:

\begin{abstract}
"Voor een doeltreffende rechterlijke controle, die zich moet kunnen uitstrekken tot de wettigheid van de motivering van de bestreden beslissing, is het in het algemeen noodzakelijk dat de rechter bij wie de zaak aanhangig is gemaakt, van de bevoegde instantie de overlegging van die motivering kan verlangen. Wanneer echter, zoals in casu, meer in het bijzonder de doeltreffende bescherming moet worden gewaarborgd van een fundamenteel recht dat het verdrag de werknemers van de gemeenschap toekent, moeten deze laatsten dit recht bovendien onder zo goed mogelijke omstandigheden kunnen verdedigen en moeten zij de mogelijkheid hebben om met volledige kennis van zaken te beslissen, of zij er baat bij hebben om zich tot de rechter te wenden. Bijgevolg is de bevoegde nationale instantie in een dergelijk geval gehouden, hen in kennis te stellen van de beweegredenen van haar weigering, hetzij in de beslissing zelf, hetzij in een latere, op hun verzoek verstrekte mededeling." 80
\end{abstract}

Het beginsel van effectieve rechtsbescherming richt zich vooral tot de nationale rechter, maar de verplichting tot opgave van redenen van beslissingen strekt zich, in verband met de verweermogelijkheden van de belanghebbenden in de procedure voor die rechter en de doeltreffendheid van de rechterlijke controle van de beslissing, ook uit tot andere nationale organen. ${ }^{81}$ De motivering van de beslissingen van bestuursorganen is immers essentieel voor de controle door de rechter, de verweermogelijkheden en de effectieve rechtsbescherming van de betrokkenen, zo blijkt ook uit de hiervoor aangehaalde overweging uit uitspraak in de zaak Heylens.

Tot slot verdient nog vermelding dat het vaste rechtspraak is dat een ontbrekende of ontoereikende motivering, hetgeen betrekking heeft op de motiveringsplicht, schending van wezenlijke vormvoorschriften in de zin van artikel 230 EG (thans: artikel 263 eerste lid VWEU) oplevert en een middel van openbare orde vormt dat door de gerechten van de EU ambtshalve kan en zelfs moet worden onderzocht. ${ }^{82}$ Ook een gebrek in de motivering vormt een onregelmatigheid in de procedure die slechts tot nietigverklaring van een beschikking kan leiden, indien komt vast te staan dat de beschikking zonder deze onregelmatigheid een andere inhoud zou kunnen hebben. ${ }^{83}$

Aspecten van de motiveringsplicht

Van de motiveringsplicht maken verschillende elementen onderdeel uit. Allereerst moet uit het besluit blijken op welke rechtsbasis het is gebaseerd. ${ }^{84}$ Uit de motiveringsplicht volgt verder dat de beslissing de rechtselementen en feitelijke elementen dient te vermel-

\footnotetext{
79. Statuut van het Hof van Justitie, maart 2008, te raadplegen via de website www.curia.europa.eu. Zie ook art. 63 Reglement voor de procesvoering van het HvJ EU. Zoals blijkt naar de uitspraken genoemd in de noot hiervoor verwijst het HvJ EU ook naar het Statuut als grondslag voor de motiveringplicht.

${ }^{80}$ HvJ EG 15 oktober 1987, Union nationale des entraîneurs et cadres techniques professionnels du football (Unectef) t. Heylens e.a., nr. 222/86. Zie ook: Trimidas 2006, p. 445.

${ }^{81 .}$ Trimidas 2006, p. 445.

82. Zie bijv.: HvJ 2 december 2009, Commissie t. Ierland e.a, C-89/08 P; HvJ EG 20 februari 1997, Commissie t. Daffix, C-166/95 P; HvJ EG 2 april 1998, Commissie t. Sytraval en Brink's France, C-367/95 P; HvJ EG 30 maart 2000, VBA t. Florimex e.a., C-265/97 P; HvJ EG 10 juli 2008, Bertelsmann en Sony Corporation of America t. Impala, C-413/06 P.

${ }^{83}$ Zie o.m.: R. Barents \& L.J. Brinkhorst, Grondlijnen van Europees recht, Deventer: Kluwer 2006, p. 231. Zie over ambtshalve toetsing door het HvJ EU: D.J.M. de Grave, 'Ambtshalve toetsing door de Europese rechter: een ander perspectief', SEW 2009, 3, p. 12-20.

84. HvJ EG 16 juni 1993, Frankrijk t. Commissie van de Europese Gemeenschappen, nr. C-325/91. Zie over het rechtsbasisvereiste, Barents \& Brinkhorst 2006, p. 146-147.
} 


\section{Deel I Beginselen van behoorlijke rechtspleging}

den op grond waarvan deze genomen is. ${ }^{85}$ Er volgt voorts uit dat dat de overwegingen of de redenering die tot de beslissing geleid hebben duidelijk zijn. ${ }^{86}$ Op een beslissing die bestaat uit toepassing van een vaste praktijk, rust een minder vergaande motiveringsplicht. Wanneer van die vaste besluitvormingspraktijk wordt afgeweken, behoort gemotiveerd aangegeven worden waarom dit gerechtvaardigd is. ${ }^{87}$ Er bestaat geen verplichting voor de instellingen van de EU om alle stellingen of argumenten van partijen te weerleggen of daarop in te gaan of om alle relevante gegevens, feitelijk of rechtens, te specificeren. ${ }^{88}$ In het algemeen is de omvang van de motiveringsplicht afhankelijk van de aard en context van de maatregel of beslissing waar het om gaat. ${ }^{89}$ Dat betekent onder meer dat uiteraard voor de eisen die de motiveringsplicht stelt relevant is of het gaat om een beschikking van de Commissie of een verordening van de Raad.

De motiveringsplicht heeft vergelijkbare functies als het motiveringsbeginsel op nationaal niveau en op grond van artikel 6 EVRM heeft. ${ }^{90}$ Het Hof van Justitie onderscheidt er drie: een rechtsbeschermingsfunctie die verband houdt met de verweermogelijkheden van belanghebbenden tegen een beslissing, controle van de besluiten door het Hof van Justitie en kenbaarheid van de toepassing van Unierecht voor lidstaten en andere derde-belanghebbenden. ${ }^{91}$ In de functies die het Hof van Justitie onderscheidt lijkt iets meer dan in de functies die in het Nederlandse bestuursrecht onderscheiden worden het algemeen belang naar voren te komen. Dat houdt wellicht verband met de specifieke aard van de Europese rechtsorde en de effectieve doorwerking van het Unierecht. Voor het Hof van Justitie is de uniforme toepassing van het Unierecht binnen de lidstaten zeer van belang. Een goede motivering van de beslissingen van de gemeenschapsinstellingen kan daaraan bijdragen. Trimidas wijst erop dat het Hof van Justitie wellicht om die reden ook geneigd is om meer ambtshalve na te gaan of de gemeenschapsinstellingen wel aan de motiveringsplicht hebben voldaan. ${ }^{92}$ Tegelijkertijd bestaat er echter een verband met het beginsel van effectieve rechtsbescherming en is er een duidelijk verband met de verweermogelijkheden van de belanghebbenden.

Doorwerking van de motiveringsplicht in de nationale procedures

Het motiveringsbeginsel is in het Unierecht vooral als eis van behoorlijk bestuur van belang. De elementen die er onderdeel vanuit maken, worden ook in het nationale bestuursrecht door het motiveringsbeginsel, als beginsel van behoorlijk bestuur, bestreken. ${ }^{93}$ Dezelfde elementen worden begrepen onder het motiveringsbeginsel als beginselen van behoorlijke rechtspleging, zoals uiteengezet in paragraaf 4.3.7. Het motiveringsbeginsel heeft voorts dezelfde functies in het Unierecht als het beginsel van behoorlijke rechtspleging in het nationale recht. Er ligt wellicht iets meer nadruk op het algemene

\footnotetext{
${ }^{85 .}$ HvJ EU 26 maart 1987, Commissie van de Europese Gemeenschappen t. Raad van de Europese Gemeenschappen, nr. 45/86. Zie ook: Jans e.a. 2002, p. 247.

86. Zie bijv.: GEA 3 maart 2010, Freistaat Sachsen (Duitsland) (T-102/07), MB Immobilien Verwaltungs GmbH en MB System GmbH \& Co. KG (T-120/07) t. Europese Commissie, nrs. T-102/07 en T-120/07.

${ }^{87 .}$ Zie: Jans 2002, p. 247

88. Zie voor enkele willekeurige uitspraken van het GEA: GEA 15 juni 2005, Corsica Ferries France t. Commissie, T-349/03; GEA 3 maart 2010, Freistaat Sachsen (Duitsland) (T-102/07), MB Immobilien Verwaltungs GmbH en MB System GmbH \& Co. KG (T-120/07) t. Europese Commissie, nrs. T-102/07 en T-120/07; GEA van 6 maart 2003, Westdeutsche Landesbank Girozentrale en Land Nordrhein-Westfalen t. Commissie, nrs. T-228/99 en T-233/99. Zie ook: HvJ EG 1 juli 2008, Chronopost SA en La Poste e.a., EHRC 2008/94. Zie hierover ook: Trimidas 2006, p. 409-410. Trimidas wijst erop dat er een kentering in de jurisprudentie van het GEA lijkt plaats te vinden waarbij in sommige gevallen geeist wordt er een uitwisseling van standpunten en dialoog met de betrokkenen plaatsvindt.

89. Zie bijvoorbeeld een uitspraak met verwijzingen van het GEA waarin deze aangeeft dat dit uit vaste rechtspraak volgt: GEA 3 maart 2010, Freistaat Sachsen (Duitsland) (T-102/07), MB Immobilien Verwaltungs GmbH en MB System GmbH \& Co. KG (T-120/07) t. Europese Commissie, nrs. T-102/07 en T-120/07.

90. Zie hierover par. 4.3.7.

91. Trimidas 2006, p. 409; Jans e.a. 2002, p. 246-247.

92. Trimidas 2006, p. 409

93. Zie hierover nader Deel II, par. 5.6
} 


\section{De beginselen in EU-perspectief}

belang van uniforme toepassing van het Unierecht. In het nationale recht staat het beginsel meer in teken van bescherming van de belangen van partijen in de procedure. Het Hof van Justitie legt echter ook duidelijk een verband met de verdedigingsrechten en het beginsel van effectieve rechtsbescherming, ook als het gaat om de motiveringseisen die gelden voor bestuurlijke beslissingen van de gemeenschapsinstellingen.

Voor zover de beslissingen van de nationale bestuurlijke autoriteiten binnen de werkingssfeer vallen van het Unierecht, dienen zij aan de elementen van het motiveringsbeginsel te voldoen. Dat betekent ook dat zij het perspectief van effectieve rechtsbescherming en de verweermogelijkheden van belanghebbenden in dat verband niet uit het oog mogen verliezen. De Unierechtelijke motiveringseisen als zodanig lijken echter niet verder dan de nationale motiveringseisen.

\subsubsection{De overige beginselen in Unierechtelijke context}

De overige beginselen van behoorlijke rechtspleging lijken niet allemaal even regelmatig aan de orde te komen in de jurisprudentie van het Hof van Justitie als het verdedigingsbeginsel of het motiveringsbeginsel. Om desondanks de betekenis van deze eisen voor de nationale (bestuurlijke) procedures te kunnen bepalen is de volgende werkwijze gehanteerd. In eerste instantie is gezocht naar uitspraken of voorschriften waarin deze eisen zoals onpartijdigheid, onafhankelijkheid, openbaarheid en de redelijke termijn-eis aan de orde zijn ten aanzien van de EU- instellingen. Het verdedigingsbeginsel en het motiveringsbeginsel zijn immers in het Unierecht ook eerst voor de instellingen tot ontwikkeling gekomen, waarna de gelding van die waarborgen is uitgebreid naar nationale procedures met een Unierechtelijke dimensie. Het kan echter ook zo zijn dat het Hof van Justitie sommige beginselen, zoals het onpartijdigheidsbeginsel, in werking beperkt tot procedures bij (nationale) rechterlijke instanties. Indien blijkt dat een beginsel van behoorlijke rechtspleging door het Hof van Justitie niet doorgetrokken wordt naar de nationale bestuurlijke procedures, maar alleen naar de nationale rechterlijke procedures, wordt ook nog gezocht naar (de betekenis van) equivalente beginselen van behoorlijk bestuur. Zoals ook het geval was bij het motiveringsbeginsel, kunnen er zelfstandig en los van de eisen van behoorlijke rechtspleging vergelijkbare eisen voor het bestuur (op Europees en nationaal niveau) door het Hof van Justitie gesteld worden.

\section{Het onpartijdigheidsbeginsel}

Om de betekenis van het onpartijdigheidsbeginsel te kunnen bepalen, behoeft in elk geval minder ver terug in de tijd gegaan te worden dan voor het verdedigingsbeginsel het geval is. Het onpartijdigheidsbeginsel als eis voor behoorlijke rechtspraak komt veel minder aan de orde in de jurisprudentie van het Hof van Justitie. ${ }^{94}$ Het lijkt geen rol van betekenis te spelen bij de handelingen of beslissingen van de Commissie en de Raad ${ }^{95}$, hoewel in artikel 41 van het Handveest is neergelegd dat een ieder recht heeft op een onpartijdige behandeling van zijn zaken door de instellingen en organen van de EU. De beslissingen van deze instelling zijn onderworpen aan de rechterlijke controle van het Hof van Justitie, voor welk orgaan de onpartijdigheidseisen in elk geval ook gelden. Die vereiste onpartijdigheid is ook terug te zien in artikel 47 van het Handvest en uitgewerkt het Statuut van het Hof van Justitie in bijvoorbeeld artikel 2 en $4 .{ }^{96}$

94. Zeker in vergelijking tot het verdedigingsbeginsel, zie: Trimidas 2006, p. 373. Zie ook: De Moor-van Vugt 1987, p. 148-147.

95. Zie literatuur waarin een behandeling ontbreekt van die eisen: Jans e.a. 2007, hfst. 5; Trimidas 2006, p. 373; De Moor-van Vugt 1987, p. 147-148. Invoering van die zoekterm op de zoekmachine op de website van het HvJ EU (www.curia.europa.eu) leidt tot aanzienlijk minder uitspraken dan het geval is bij het verdedigingsbeginsel of het motiveringsbeginsel.

96. Statuut van het Hof van Justitie, maart 2008, te raadplegen via de website www.curia.europa.eu. Zie verder nog de reglementen van procesvoering van het Hof van Justitie, het Gerecht van eerste aanleg en het Gerecht voor ambtenarenzaken, via diezelfde website te raadplegen. 
Deel I Beginselen van behoorlijke rechtspleging

Recent is het vereiste van rechterlijke onpartijdigheid wel aan bod gekomen in enkele uitspraken van het Hof van Justitie, waarbij het de vermeende partijdigheid van die instantie zelf of het GEA betrof. Zo stond in een uitspraak van 19 februari 2009 de klacht van een voormalig lid van het Europees parlement dat het GEA niet onpartijdig geoordeeld zou hebben in ambtenaarrechtelijk geschil centraal. ${ }^{97}$ In die zaak doet klager voor het Hof van Justitie rechtstreeks een beroep op de objectieve rechterlijke onpartijdigheid die vereist is ingevolge artikel 6 eerste lid EVRM. Het Hof van Justitie sluit aan bij de criteria die het EHRM heeft ontwikkeld en refereert aan de subjectieve en objectieve toets. Het oordeelt uiteindelijk dat de vereiste onpartijdigheid in acht is genomen.

In een andere uitspraak van 1 juli 2008 in de zaak Chronopost SA en La Poste e.a. draaide het wederom om de vermeende partijdigheid van het GEA. ${ }^{98}$ Het GEA had uitspaak gedaan op het ingesteld beroep tot nietigverklaring ex artikel 230 EG van een beschikking van de Commissie van de Europese Gemeenschappen (hierna: de Commissie). De hogere voorziening die daartegen was ingesteld bij het Hof van Justitie had succes en het Hof van Justitie vernietigde de uitspraak van het GEA en verwees de zaak terug. Van de nieuwe kamer van het GEA, dat opnieuw over de zaak moest oordelen, maakte dezelfde rechter-rapporteur deel uit. Ook in deze uitspraak richt het Hof van Justitie zich sterk op de interpretatie van het EHRM van de onpartijdigheidseisen, zoals voortvloeiend uit artikel 6 EVRM. Het verwijst zelfs naar artikel 27 derde lid EVRM, waaruit volgt dat in de Grote Kamer van het EHRM ook, onder bepaalde voorwaarden, dezelfde rechters als onderdeel van een andere formatie mogen plaatsnemen als in de Kamer die eerder over de zaak geoordeeld heeft. Naar analogie geldt, aldus het Hof van Justitie, dat ook rechters in een andere formatie in het GEA nogmaals - en zonder dat zulks in strijd is met de vereisten van een eerlijk proces - kunnen kennisnemen van dezelfde zaak.

De onpartijdigheidseisen, zoals voortvloeiend uit artikel 6 EVRM, koppelt het Hof van Justitie nadrukkelijk aan de gerechten van de EU. Voor de overige instellingen gelden zoals aangegeven ook onpartijdigheidseisen, maar deze worden niet zo zeer gerelateerd aan die bepaling. De onpartijdigheidseisen als eisen van behoorlijk bestuur komen verder echter, zoals hiervoor al werd aangegeven, niet regelmatig aan de orde in de jurisprudentie. Uit jurisprudentie van het Hof van Justitie blijkt dat de Commissie niet kan worden beschouwd als een gerecht, waardoor de onpartijdigheidseisen als bedoeld in artikel 6 EVRM en onderdeel van het algemene beginsel van Unierecht 'recht op een eerlijk proces', niet van toepassing zijn op die instelling. ${ }^{99}$ Wel rust er op de Commissie een verplichting om zorgvuldig en op onpartijdige wijze onderzoek te verrichten naar alle relevante gegevens en het dossier. ${ }^{100}$ Die verplichting lijkt echter niet zozeer te herleiden tot een specifiek algemeen rechtsbeginsel of beginsel van behoorlijk bestuur, zoals het onpartijdigheidsbeginsel. Het vormt een procedurele waarborg die vanuit zorgvuldigheidsoogpunt gesteld wordt. Onpartijdigheid als zelfstandige behoorlijkheidsnorm of onderdeel van zorgvuldige bejegening als bestuurlijke eis, zoals wij dat in het Nederlandse bestuursrecht kennen, komt in de jurisprudentie echter niet naar voren. Onpartijdigheidseisen voor de nationale autoriteiten, komen als zodanig ook niet naar voren in de jurisprudentie van het Hof van Justitie. ${ }^{101}$

\footnotetext{
${ }^{97 .}$ HvJ EG 19 februari 2009, Gorostiaga Atxalandabaso t. Europees parlement, EHRC 2009/46.

98. HvJ EG 1 juli 2008, Chronopost SA en La Poste e.a., EHRC 2008/94.

99. Zie bijv.: HvJ EG 29 oktober 1980, Van Landewyck t. Commissie, nrs. 209-215 en 218/78.

${ }^{100 .}$ HvJ EG 21 november 1991, Technische universität München t. Hauptzollamt München-Mitte, C-269/90. Zie ook: HvJ EG 2 april 1998, Commissie van de Europese Gemeenschappen t. Chambre syndicale nationale des entreprises de transport de fonds et valeurs (Sytraval) en Brink's France SARL, nr. C-367/95 P. In deze zaak ging het om het al dan niet verstrekken van steunmaatregelen door de Franse staat.

101. Door invoering van de zoektermen onpartijdigheid, onpartijdig of onpartijdigheidsbeginsel in de zoekmachine van de website van het HvJ EU www.curia.europa.eu ben ik in elk geval geen uitspraken tegengekomen. Ook in de nationale literatuur wordt aan deze eisen geen aandacht besteed.
} 


\section{De beginselen in EU-perspectief}

Het beginsel van de redelijke termijn

De redelijke termijn-eis is van alle vereisten van behoorlijke rechtspleging op nationaal niveau het sterkst in ontwikkeling. De ontwikkelingen in de jurisprudentie van de nationale bestuursrechter volgen elkaar in hoog tempo op en ook in de doctrine brengt dit beginsel veel pennen in beweging. ${ }^{102}$ Dezelfde eis op Europees niveau lijkt minder in de aandacht te staan. Het beginsel van de redelijke termijn is een van de beginselen dat echter naast het verdedigingsbeginsel en het motiveringsbeginsel regelmatig aan de orde geweest in de jurisprudentie van het Hof van Justitie. Bovendien is in artikel 41 eerste lid van het Handvest, als beginsel van behoorlijk bestuur, opgenomen dat een ieder recht heeft op een behandeling van zijn zaak door de gemeenschapsinstellingen binnen een redelijke termijn. Voorts is het recht op een behandeling van de zaak binnen een redelijke termijn door een onafhankelijk en onpartijdig gerecht neergelegd in artikel 47 van het Handvest. In dat artikel is volgens het Hof van Justitie het beginsel van effectieve rechtsbescherming bevestigd. ${ }^{103}$ Desondanks is er weinig aandacht voor deze eis en de jurisprudentie van het Hof van Justitie in dat kader noch voor de gevolgen ervan voor het nationale bestuursprocesrecht in de nationale doctrine. ${ }^{104}$ De verklaring daarvoor is wellicht gelegen in de dominante invloed die de redelijke termijn-eis uit artikel 6, eerste lid EVRM heeft op het nationale bestuursprocesrecht in dit opzicht. Toch kan afzonderlijke aandacht voor het Unierechtelijke beginsel van de redelijke termijn zinvol zijn, omdat, zoals Widdershoven aangeeft, de reikwijdte van het beginsel ruimer lijkt te zijn dan de reikwijdte van artikel 6, eerste lid EVRM. ${ }^{105}$ Hij wijst erop dat de lidstaten, wanneer zij het Unierecht ten uitvoer leggen, ook aan die ruimere reikwijdte zijn gebonden.

Het Hof van Justitie beschouwt het beginsel van de redelijke termijn als een algemeen rechtsbeginsel van Unierecht. ${ }^{106}$ Volgens vaste rechtspraak op het gebied van het mededingingsrecht wordt het nemen van een beslissing door de Commissie in administratieve procedures door dat beginsel bestreken. ${ }^{107}$ De gelding van het beginsel is echter niet beperkt tot het mededingingsrecht en de reikwijdte van het beginsel van de redelijke termijn lijkt ruim te zijn. ${ }^{108}$ Het beginsel moet als onderdeel van het recht op behoorlijk bestuur, zoals neergelegd in artikel 41 van het Handvest, in acht worden genomen in elke Unierechtelijke administratieve procedure. ${ }^{109}$ Tegelijkertijd wordt er soms door het GEA een verband gelegd met de rechten van de verdediging in die zin dat een nietigverklaring van een beslissing wegens de lange duur en overschrijding van een redelijke termijn pas

\footnotetext{
102. Zie hoofdstuk 4, par. 4.3.9 van Deel I en par. 5.7 van Deel II.

103. HvJ EG 16 juli 2009, Der Grüne Punkt - Duales System Deutschland GmbH t. Commissie van de Europese Gemeenschappen, nr. C-385/07 P, EHRC 2010/20 m.nt. R.J.G.M. Widdershoven, par. 178; HvJ EG 13 maart 2007, Unibet (London) Ltd en Unibet (International) Ltd t. Justitiekanslern, nr. C-432/05, par. 37.

104. Aan dit beginsel wordt bijvoorbeeld geen aandacht besteed in Widdershoven e.a. 2007, p. en Jans e.a. 2007, hfst. 5 .

105. Zie de noot van Widdershoven bij HvJ EG 16 juli 2009, Der Grüne Punkt - Duales System Deutschland GmbH t. Commissie van de Europese Gemeenschappen, nr. C-385/07 P, EHRC 2010/20 m.nt. R.J.G.M. Widdershoven.

106. Zie bijvoorbeeld: HvJ EG 21 september 2006, Nederlandse Federatieve Vereniging voor de Groothandel op Elektrotechnisch Gebied t. Commissie, nr. C-105/04 P (hogere voorziening arrest GEA).

107. Zie onder meer: HvJ EG 21 september 2006, Nederlandse Federatieve Vereniging voor de Groothandel op Elektrotechnisch Gebied t. Commissie, nr. C-105/04 P (hogere voorziening arrest GEA); HvJ EG 17 december 1998, Baustahlgewebe t. Commissie, nr. C-185/95; HvJ EG 15 oktober 2002, Limburgse Vinyl Maaschappij NV (LVM) e.a. t. Commissie, nrs. C-239/99 P, C-244/99 P, C-245/99 P, C-247/99 P, C-250/99 P, tot en met C252/99 P en C-254/99 P; GEA 22 oktober 1997, Stichting Certificatie Kraanverhuurbedrijf (SCK) en Federatie van Nederlandse Kraanverhuuurbedrijven (FNK) t. Commissie, nrs. T-213/95 en T-18/96. Zonder uitputtend te willen zijn, komen deze uitspraken ter illustratie van de betekenis van het beginsel van de redelijke termijn aan de orde. Het strekt te ver om in het kader van dit onderzoek alle uitspraken van de communautaire rechters ten aanzien van het beginsel van de redelijke termijn in kaart te brengen. Voor meer uitspraken verwijs ik naar de website http://curia.europa.eu/jcms/jcms/j_6/.

${ }^{108 .}$ HvJ EG 16 juli 2009, Der Grüne Punkt - Duales System Deutschland GmbH t. Commissie van de Europese Gemeenschappen, EHRC 2010/20 m.nt. Widdershoven.

109. Zie bijvoorbeeld: GEA 1 juli 2008, nr. T-276/04, Compagnie maritime belge SA t. Commissie. In deze uitspraak werd overigens het beginsel van de redelijke termijn niet toegepast.
} 


\section{Deel I Beginselen van behoorlijke rechtspleging}

in de rede ligt, indien daarmee ook een schending van de rechten van de verdediging heeft plaatsgevonden. ${ }^{110}$ De ratio van het beginsel vormt de rechtszekerheid en de behoorlijke rechtsbescherming, aldus het GEA. ${ }^{111}$ Het beginsel van de redelijke termijn strekt zich op Europees niveau vanzelfsprekend ook uit tot de gerechtelijke procedures. Ter bepaling van de vraag of de redelijke termijn geschonden is, verwijst het Hof van Justitie regelmatig naar de jurisprudentie van het EHRM en de door die instantie gehanteerde factoren dezelfde factoren om te bepalen of gelet op de specifieke omstandigheden van het geval met de duur van de procedure de redelijke termijn is overschreden. ${ }^{12}$

Wat betreft het rechtsherstel dat dient plaats te vinden voor schendingen van de redelijke termijn door gemeenschapsinstellingen moet erop worden gewezen dat het Hof van Justitie in zaken waarin een mededingingsboete was opgelegd bepaald heeft dat een opgelegde boete met het bedrag aan schadevergoeding voor schending van de redelijke termijn verminderd moet worden. De overschrijding van de redelijke termijn kan slechts leiden tot nietigverklaring van het arrest van het Gerecht, als de uitkomst van het geding erdoor is beïnvloed. ${ }^{113}$ Dat is later ook bevestigd voor niet-mededingingszaken in Der Grüne Punkt. ${ }^{114}$ In die uitspraak gaf het Hof van Justitie aan dat de overschrijding van de redelijke termijn aanleiding kan geven tot een vordering tot schadevergoeding op grond van artikel 235 juncto 288, tweede alinea, EG (thans artikel 268 junctio artikel 340, tweede alinea VWEU). ${ }^{115}$ Hetzelfde had het Hof van Justitie al eerder overwogen ten aanzien van overschrijdingen van de redelijke termijn door de Commissie. Alleen indien zonder de schending van de redelijke termijn een andere beslissing mogelijk was geweest leidt dat tot nietigverklaring van de litigieuze beslissing. Daarbij legt het ook een verband met het verdedigingsbeginsel. ${ }^{116}$ Als dat geschonden is als gevolg van de lange duur van de procedure, is er noodzakelijkerwijs sprake van invloed op de uitkomst van de procedure, aldus het Hof van Justitie.

Uitspraken waarin het Hof van Justitie bepaald heeft dat in nationale procedures die binnen het toepassingsgebied van het Unierecht vallen het Europese beginsel van de redelijke termijn in acht moet worden genomen zijn er bij mijn weten niet. In de procedures ten overstaan van de nationale rechter lijkt de Unierechtelijke redelijke termijn-eis eveneens geen grote rol van betekenis te spelen in geschillen waarin de uitvoering van Unierecht centraal staat. In de nationale procedures wordt, ongeacht de nationale of

\footnotetext{
110. GEA 4 februari 2009, Omya AG t. Commissie, nr. T-145/06. Zie ook de uitspraak van het GEA (20 april 1999, Limburgse Vinyl Maatschappij e.a. t. Commissie, nrs. C-239/99 P, C-244/99 P, C-245/99 P, C-247/99 P, $\mathrm{C}-250 / 99 \mathrm{P}$, tot en met C-252/99 P en C-254/99 P) dat voorafging aan de uitspraak van het HvJ EG in de hogere voorziening Limburgse Vinyl Maaschappij NV (LVM) e.a. t. Commissie, nrs. C-239/99 P, C-244/99 P, C-245/99 P, C-247/99 P, C-250/99 P, tot en met C-252/99 P en C-254/99 P. Helaas gaat het HvJ EG niet nader in op deze overweging van het GEA in zijn uitspraak in de hogere voorziening.

111. GEA 22 oktober 1997, Stichting Certificatie Kraanverhuurbedrijf (SCK) en Federatie van Nederlandse Kraanverhuuurbedrijven (FNK) t. Commissie, nrs. T-213/95 en T-18/96.

112. Zie: HvJ EG 27 november 2001, Z. t. Europees Parlement (hogere voorziening tegen arrest GEA), nr. C270/99 P; HvJ EG 17 december 1998, Baustahlgewebe t. Commissie (hogere voorziening tegen arrest GEA), nr. C-185/95. Dat laatste werd voor het eerst bevestigd voor niet-mededingingszaken in het hiervoor vermelde arrest Der Grüne Punkt.

${ }^{113}$ Zie: Baustahlgewebe, zoals in de noot hiervoor aangehaald. De uitspraak van het GEA werd vernietigd voor zover het de vaststelling van de opgelegde boete van 3.000.000 euro betrof. Vervolgens stelde het Hof een bedrag van 50.000 euro vast als schadevergoeding en stelde de boete opnieuw vast op een bedrag van 2.950.000. Als de uitkomst van het geschil niet beinvloed wordt door de duur van de procedure, is het gevolg van schending van de redelijke termijn dus een schadevergoedingsplicht of vermindering van de boete.

${ }^{114 .}$ HvJ EG 16 juli 2009, Der Grüne Punkt-Duales System Deutschland GmbH t. Commissie van de Europese Gemeenschappen, nr. C-385/07 P, EHRC 2010/20 m.nt. R.J.G.M. Widdershoven. In deze zaak werden alle andere middelen tegen de uitspraak van het Gerecht ongegrond bevonden en was de schending van de redelijke termijn niet van invloed geweest op de uitkomst van het geding, waardoor volgens het HvJ EU de schending niet kon leiden tot nietigverklaring van de uitspraak van het Gerecht.

115. VWEU staat voor het Verdrag betreffende de Werking van de Europese Unie en vormt hetgeen voor het Verdrag van Lissabon het EG-verdrag was.

116. HvJ EG 21 september 2006, Technische Unie BV t. Commissie van de Europese Gemeenschappen, nr. C$113 / 04 \mathrm{P}$.
} 


\section{De beginselen in EU-perspectief}

Unierechtelijke dimensie van het geschil, eerder een beroep gedaan op artikel 6, eerste lid EVRM. In de procedures ten overstaan van de rechterlijke instanties van de EU wordt ook wel een beroep gedaan op artikel 6 EVRM, maar het Hof van Justitie grijpt rechtstreeks terug op het equivalente Unierechtelijke algemene rechtsbeginsel. ${ }^{117}$ Op nationaal niveau heeft de Centrale Raad zich onlangs uitgelaten over de vraag of de door het stellen van prejudiciële vragen veroorzaakte verlenging van de procedure meegerekend moet worden bij de duur van de gehele procedure. ${ }^{118}$ In dit geval betroffen de prejudiciële vragen de uitleg van artikel 18 eerste lid EG. Het ging om een geschil inzake een weigering een uitkering te verlenen op grond van de Wet uitkeringen burger-oorlogsslachtoffers (hierna: WUBO). Die uitkering werd geweigerd aan een belanghebbende met de Nederlandse nationaliteit uitsluitend vanwege het feit dat deze bij de indiening van de aanvraag niet woonachtig was op het grondgebied van deze lidstaat, maar op het grondgebied van een andere lidstaat, te weten Spanje. Het Hof van Justitie oordeelde onder meer dat het geschil binnen de werkingssfeer van het Unierecht valt en beheerst wordt door het recht van de burgers van de Unie om in de lidstaten vrij te reizen en te verblijven, zoals volgt uit artikel 18 eerste lid EG. ${ }^{119}$ In de daaropvolgende uitspraak van de Centrale Raad komt de vraag in hoeverre het Unierecht eist dat geschillen binnen een redelijke termijn beslecht worden op nationaal niveau komt echter niet aan de orde. De Centrale Raad gaat uit van de toepasselijkheid van artikel 6, eerste lid, EVRM in dit geval en beoordeelt de klacht over de lange duur van de procedure in dat verband. Het wachten op de uitspraak van het Hof van Justitie op de prejudiciële vragen rechtvaardigt een langere behandelingsduur, maar desondanks acht de Centrale Raad de duur van de procedure in hoger beroep te lang. Er wordt een schending van artikel 6, eerste lid EVRM geconstateerd.

Als het gaat om tijdigheid van besluitvorming of rechtspraak lijkt artikel 6 EVRM derhalve de voornaamste rechtsbasis te vormen die in de praktijk wordt ingeroepen voor de nationale rechter. De functies van het Unierechtelijke beginsel van de redelijke termijn verschillen niet van die van het nationale beginsel en de in artikel 6 EVRM neergelegde eis. Rechtszekerheid voor de betrokkenen lijkt de belangrijkste ratio van het beginsel. ${ }^{120}$ Ook wat betreft de relevante factoren om te beoordelen of er sprake is van een schending van de redelijke termijn lijkt er geen verschil te bestaan.

\section{Openbaarheid}

Het vereiste van openbaarheid van de zitting en de uitspraak is terug te vinden in het Statuut van het Hof van Justitie. ${ }^{121}$ Artikel 37 bepaalt dat de arresten in een openbare zitting worden uitgesproken. In artikel 31 is neergelegd dat de zittingen bij het Hof van Justitie openbaar zijn, tenzij het Hof van Justitie ambtshalve of op verzoek van partijen vanwege gewichtige redenen anders beslist. Deze twee eisen, openbaarheid van de zitting en de uitspraak, maken onderdeel uit van de uit artikel 6 EVRM voortvloeiende eisen. Daarmee vormen zij ook algemene Unierechtelijke rechtsbeginselen die geëerbiedigd moeten worden. Er wordt echter in het Unierecht niet of nauwelijks een beroep op deze eisen gedaan. Er zijn, voor zover ik weet, geen uitspraken waarin de twee deelaspecten van het openbaarheidsbeginsel centraal staan. Dat geldt voor uitspraken van het Hof van Justitie waarin het moet oordelen over de openbaarheid van de zitting bij of de

\footnotetext{
117. Zie bijvoorbeeld: Der Grüne Punkt, zoals eerder aangehaald.

118. CRvB 9 april 2009, LJN BI2179, JB 2009/150 m.nt. Redactie.

119. HvJ EG 26 oktober 2006, K. Tas-Hagen en R.A. Tas t. Raadskamer WUBO van de Pensioen-en Uitkeringsraad, nr. C-192/05.

${ }^{120 .}$ Vgl. par. 180 van Der Grüne Punkt.

121. Dat Statuut van het Hof van Justitie geldt ook voor het GEA en het Gerecht voor ambtenarenzaken met dien verstande dat zij een eigen reglement voor de procesvoering hebben waarin nog nadere uitwerkingen hebben plaatsgevonden, Reglement voor de procesvoering van het Gerecht van eerste aanleg; Reglement voor de procesvoering van het Gerecht voor ambtenarenzaken. In art. 57 respectievelijk art. 51 wordt gerefereerd aan de openbaarheid van de zitting.
} 
Deel I Beginselen van behoorlijke rechtspleging

uitspraak van het GEA of zittingen bij en beslissingen van de andere gemeenschapsinstellingen, maar ook voor uitspraken in prejudiciële procedures. Daarom is het lastig de doorwerking van de Unierechtelijke openbaarheidseisen in de nationale rechterlijke én bestuurlijke procedures vast te stellen. Vooralsnog lijkt de betekenis van deze eisen derhalve beperkt te zijn. Gelet op de uitwerkingen in het Statuut van het Hof van Justitie wordt er bovendien aangesloten bij de interpretatie van het EHRM in het kader van artikel 6 EVRM en wijken de bepalingen evenmin af van hetgeen in het nationale bestuursrecht geldt. ${ }^{122}$

Doorwerking van de overige eisen in de nationale bestuurlijke procedures

De betekenis van de vereisten van de rechterlijke onpartijdigheidseisen en de openbaarheidseisen lijkt in het Unierecht vooralsnog beperkt te zijn. Zij vormen ook algemene Unierechtelijke rechtsbeginselen, maar spelen geen grote rol. De statuten van het Hof van Justitie bevatten uitwerkingen van deze eisen. De vereisten worden echter voor het Hof van Justitie niet regelmatig ingeroepen en zij spelen eveneens een geringe rol in de prejudiciële procedures voor het Hof van Justitie. Ook als norm voor het bestuurlijk handelen van de Europese instellingen of de nationale autoriteiten die binnen de werkingssfeer van het Unierecht besluiten nemen, lijkt er nauwelijks invloed uit te gaan van deze eisen op de procedures voor deze organen. Het Hof van Justitie is in elk geval nauwelijks aangezocht in verband met veronachtzaming van deze eisen door de instellingen of de te stellen eisen in dat kader aan de nationale autoriteiten. Wellicht vormt artikel 6 EVRM het belangrijkste Europese referentiekader op nationaal niveau. De Unierechtelijke eisen lijken ook met die bepaling en de interpretatie ervan door het EHRM overeen te stemmen. Wel lijken het onpartijdigheidsbeginsel en openbaarheidsbeginsel zich op Europees niveau (en waarschijnlijk dan ook wat betreft hun invloed op nationale geschillen die binnen het bereik van het Unierecht vallen) zich te beperken tot procedures bij de rechterlijke instanties.

Het beginsel van de redelijke termijn is daarentegen in vaste rechtspraak door het Hof van Justitie erkend als een beginsel dat door de Commissie in bestuurlijke procedures in acht moet worden genomen. Die betekenis heeft het Hof van Justitie er nog niet expliciet aan gegeven voor de nationale bestuurlijke voorprocedures. De equivalente eis uit artikel 6 EVRM en de interpretatie van het EHRM daarvan lijken echter ook bii deze eis bepalend te zijn. De betekenis het Unierechtelijke beginsel voor nationale procedures met een communataire dimensie lijkt vooralsnog gering te zijn.

\subsection{De positie van de beginselen van behoorlijke rechtspleging in het Unierecht}

Uit de voorgaande paragrafen blijkt dat de beginselen of eisen van behoorlijke rechtspleging in het Unierecht en de jurisprudentie van het Hof van Justitie een steeds belangrijkere rol gaan spelen. Toch blijft bij de interpretatie van deze eisen artikel 6 EVRM en de benadering van het EHRM een grote rol spelen. Regelmatig wordt nog, zowel in de Europese procedures als in de nationale procedures met een Unierechtelijke dimensie, een beroep gedaan op die bepaling en de daaruit voortvloeiende rechten in plaats van op daaraan Unierechtelijke equivalente algemene rechtsbeginselen. Daarnaast kan geconstateerd worden dat de betekenis van de beginselen van behoorlijke rechtspleging lijkt te verschillen per beginsel. Van bepaalde beginselen van behoorlijke rechtspleging, zoals het verdedigingsbeginsel, lijkt de betekenis aanzienlijker te zijn dan van andere beginselen, zoals het openbaarheidsbeginsel. Van die laatste soort beginselen lijkt daarmee ook de invloed via de band van het Unierecht op de nationale procedures gering. Wat betreft die eisen lijkt de betekenis van artikel 6 EVRM op de nationale procedures directer en omvangrijker te zijn.. Daarnaast is het zo dat het Hof van Justitie enkele van de eisen van

122. Zie hierover par. 4.3.6. 


\section{De beginselen in EU-perspectief}

behoorlijke rechtspleging afleidt uit of schaart onder het beginsel van effectieve rechtsbescherming en de verweermogelijkheden van de belanghebbende.

Van belang is verder dat het Hof van Justitie zich niet sterk lijkt te bekommeren om de scheiding tussen bestuurlijke besluitvormingsprocedures en procedures bij rechterlijke instanties wat betreft de toepasselijkheid van de eisen, zoals in het Nederlandse bestuursrecht traditioneel wel het geval is. Wellicht speelt daarbij een rol dat het Hof van Justitie niet gehinderd wordt door de problematiek of spanning inzake verhouding tussen bestuur en rechter die kan bestaan in het staatsbestel van een lidstaat. Voor het Hof van Justitie is bepalend dat in geschillen waarin het Unierecht ten uitvoer wordt gelegd of die anderszins binnen het bereik van het Unierecht vallen de algemene rechtsbeginselen in acht worden genomen. Vanuit Unierechtelijk perspectief is het evenwicht in de verhouding tussen bestuur en rechter op nationaal niveau wellicht minder van belang. Die verhouding lijkt niet op voorhand een obstakel te vormen voor het toepasselijk achten van dezelfde procedurele waarborgen in beide fasen van een geschil. Dat is in elk geval bij de toepassing van het verdedigingsbeginsel te zien in de jurisprudentie. Van belang is dat de verdedigingsrechten gewaarborgd worden in geschillen met een Unierechtelijke dimensie, hetgeen kan betekenen dat deze zich ook kunnen uitstrekken naar de fases bij het bestuur die voorafgaan aan een geschil bij een rechterlijke instantie. Ook de motiveringsplicht die het Hof van Justitie afleidt uit het beginsel van effectieve rechtsbescherming strekt zich, hoewel dit laatste beginsel zich primair richt tot de nationale rechterlijke instanties, echter uit tot de nationale bestuursorganen. Reden daarvoor is de samenhang tussen de motivering van beslissingen, de verweermogelijkheden van belanghebbenden en hun recht op effectieve rechtsbescherming. Het beginselen van de redelijke termijn strekt zich in de jurisprudentie van het Hof van Justitie eveneens niet uitsluitend uit tot de duur bij de rechterlijke instanties van de EU, maar ook tot fases in de procedure die daaraan voorafgaan. Aangenomen kan worden dat hetzelfde zal gelden voor de fases in een procedure op nationaal niveau waarin het Unierecht ten uitvoer wordt gelegd. Het onpartijdigheidsbeginsel, zoals mede neergelegd in artikel 6 EVRM, lijkt het enige beginsel te zijn waarvan het Hof van Justitie expliciet heeft bepaald dat het in geldingskracht beperkt is tot rechterlijke instanties (op Europees niveau).

Van sommige beginselen bestaan er derhalve voor de Europese instellingen equivalente beginselen, die wij op nationaal niveau als algemene beginselen van behoorlijk bestuur zouden bestempelen, zoals het verdedigingsbeginsel, de redelijke termijn en het motiveringsbeginsel. Van enkele beginselen bestaan echter op gemeenschapsniveau als zodanig geen equivalenten voor de Europese instellingen. Het gaat dan om het onpartijdigheidsbeginsel en het openbaarheidsbeginsel. Denkbaar is echter dat het beginsel van effectieve rechtsbescherming ook als kapstok kan dienen voor deze of andere procedurele waarborgen, aangezien al deze waarborgen ook daarmee in verband kunnen worden gebracht.

Het verdedigingsbeginsel, het motiveringsbeginsel en het beginsel van de redelijke termijn worden dezelfde ratio toegedicht in Unierechtelijke context als in nationale of EVRM-context. Aan deze beginselen komen de functies bescherming van de belangen van belanghebbenden in de procedure en bescherming van het algemene belang 'administration of justice' toe. Ook in dit verband lijkt het Hof van Justitie geen scheiding aan te brengen tussen de bestuurlijke fase(n) en de rechterlijke fase. Dat zou kunnen betekenen dat voor de nationale bestuurlijke (voor)procedures soms ten dele een ander perspectief gehanteerd zal moeten worden, aangezien deze vooral in teken lijken te staan van zorgvuldige besluitvorming en niet zozeer rechtsbescherming.

Wat betreft de rechtsgevolgen die volgens het Hof van Justitie verbonden moeten worden aan schendingen van de communaire beginselen van behoorlijke rechtspleging lijkt het erop dat het uitgangspunt is dat deze uitsluitend tot nietigheid of vernietiging van de litigieuze beschikking van de Commissie of de uitspraak van het Gerecht kunnen leiden, indien zonder de procedurele onregelmatigheid een andere inhoud van het besluit of uitkomst van het geschil mogelijk was geweest. Als dat niet geval is, is, in elk 
Deel I Beginselen van behoorlijke rechtspleging

geval bij schendingen van het beginsel van de redelijke termijn, schadevergoeding mogelijk. In dat opzicht lijkt de mogelijke betekenis van de jurisprudentie voor het nationale bestuursrecht - voor zover deze benadering door het Hof van Justitie ook gehanteerd zou worden bij schendingen van het beginsel van de redelijke termijn in nationale procedures met een Unierechtelijke dimensie - beperkt te zijn. De mogelijkheid tot schadevergoeding in het nationale bestuursrecht wordt door de bestuursrechter in zijn jurisprudentie zonder meer erkend. ${ }^{123}$

\footnotetext{
123. Zie daarover nader par. 4.3.9 van Deel I en par. 5.7 van Deel II.
} 


\section{Samenvatting en conclusies}

In dit laatste hoofdstuk van Deel I wordt een samenvatting gegeven van de belangrijkste bevindingen uit de voorgaande hoofdstukken. Het onderzoek in Deel I staat ten dienste aan het onderzoek dat in Deel II verricht wordt en diende vooral ter vaststelling van het referentiekader waarmee de inrichting van de bestuurlijke voorprocedures vergeleken moet worden. In het onderhavige hoofdstuk vindt dan ook op hoofdlijnen de uiteenzetting van dat referentiekader, zoals afgeleid kan worden uit de voorgaande hoofdstukken, plaats. Dat gebeurt in paragraaf 6.1. Daarnaast wordt, naar aanleiding van de bevindingen in de voorgaande hoofdstukken, in paragraaf 6.2 meer in algemene zin nog aandacht besteed aan de positie van de beginselen in het Nederlandse bestuurs(proces)recht.

\subsection{De beginselen van behoorlijke rechtspleging}

Rechtsnormen die gelden voor rechtspraak

Beginselen van behoorlijke rechtspleging zijn behoorlijkheidsnormen die primair gelden voor rechtspraak. In dit onderzoek wordt uitgegaan van een gecombineerd rechtspraakbegrip, waarvan formele en materiële elementen deel uitmaken. Onafhankelijkheid is derhalve een voorwaarde voor rechtspraak en maakt onderdeel uit van het begrip rechtspraak. Dat betekent dat het vereiste van onafhankelijkheid van de rechter niet tevens kan worden beschouwd als een beginsel van behoorlijke rechtspleging. Daarnaast moet rechtspraak in materiële zin worden opgevat als het beslechten van geschillen aan de hand van rechtsvragen en toepasselijke rechtsnormen waarbij een voor partijen bindende beslissing wordt genomen.

Op procedures die tot rechtspraak gerekend kunnen worden zijn de beginselen van behoorlijke rechtspleging rechtstreeks van toepassing. Voor procedures die buiten het begrip rechtspraak vallen, uitgaande van dit gemengde rechtspraakbegrip, wordt een bepaalde mate van toepasselijkheid of gelding van de beginselen van behoorlijke rechtspleging niet uitgesloten. Die benadering biedt ruimte voor differentiatie. Voor procedures die buiten het gemengde rechtspraakbegrip vallen moet per procedure en per beginsel bepaald worden of het betreffende beginsel van betekenis is als behoorlijkheidsnorm. Dat geldt ook voor de bestuurlijke voorprocedures. Deze procedures voldoen in elk geval niet aan het formele element van het begrip rechtspraak: onafhankelijkheid.

\section{Beginselen en inrichtingseisen}

De beginselen van behoorlijke rechtspleging vormen rechtsnormen waaraan het rechterlijk optreden en de uitspraak getoetst kunnen worden. Schending van de beginselen leidt tot een rechtmatigheidsgebrek op grond waarvan in beginsel vernietiging van de uitspraak dient plaats te vinden. De rechter zal (in hoger beroep) moeten toetsen of de beginselen in het concrete geval in acht zijn genomen. Beginselen vormen echter vage en abstracte rechtsnormen, die nader uitgewerkt moeten worden in concrete eisen of toepassingen van de beginselen. Ten aanzien van die concrete uitwerkingen bestaat een zekere vrijheid voor de rechterlijke instantie of de opsteller van het procesrecht dan wel de procesregeling. De beginselen schrijven immers niet een specifieke wijze van handelen voor en verschillende uitwerkingen kunnen in overeenstemming zijn met het desbetreffende beginsel. Binnen de concretere uitwerkingen van de beginselen kan echter een onderscheid gemaakt worden tussen essentiële eisen, waarvan schending of het ontbreken ervan leidt tot schending van het daaraan ten grondslag liggende beginsel en in beginsel gevolgen heeft, en minder essentiële eisen, waarvan schending geen gevolgen heeft. 


\section{Deel I Beginselen van behoorlijke rechtspleging}

Concrete geschreven of ongeschreven eisen die te herleiden vallen tot de beginselen van behoorlijke rechtspleging of dezelfde ratio hebben als deze beginselen, vormen een aanknopingspunt voor invloed van die beginselen op de inrichting van de procedure bij een geschilbeslechtende instantie. Om die reden wordt een onderscheid tussen de beginselen en concrete toepassingen van die beginselen in dit onderzoek gehanteerd. Andere categorieën eisen of andere onderscheidingen die voor dit onderzoek niet interessant zijn worden buiten beschouwing gelaten. Om te kunnen bepalen of een concrete procedurele eis te herleiden valt tot een beginsel van behoorlijke rechtspleging moet ook de ratio van die eis in ogenschouw worden genomen en vergeleken worden met de ratio van het beginsel.

De onderscheiden beginselen en de categorisering van die beginselen

Er kan een vijftal algemeen erkende beginselen van behoorlijke rechtspleging worden onderscheiden: het onpartijdigheidsbeginsel, het beginsel van hoor en wederhoor, het openbaarheidsbeginsel, het motiveringsbeginsel en het beginsel van de redelijke termijn. Het recht op toegang tot de rechter en de onafhankelijkheid van de rechter zijn tevens geldende rechtsnormen voor rechtspraak, maar zij zijn van andere aard. Beide eisen vormen geen eis die in het kader van het behoorlijkheidsgehalte aan een lopende procedure bij de rechter gesteld worden en daarmee geen beginsel van behoorlijke rechtspleging. Het recht op toegang tot de rechter is een eis die voorafgaat aan de behoorlijkheidseisen die aan een lopende procedure gesteld worden en de onafhankelijkheidseis vormt een voorwaarde voor rechtspraak.

Naast de vijf algemeen erkende beginselen kan ook het beginsel van effectieve rechtsbescherming in geschillen met een Europeesrechtelijke dimensie tot de geldende rechtsnormen worden beschouwd. Zuiver nationaalrechtelijk beschouwd, vormt effectieve rechtsbescherming echter nog niet eenduidig onderdeel van het positieve recht en is deze eis nog in ontwikkeling. Finale geschilbeslechting en de uitspraakbevoegdheden van de rechter als onderdeel van effectieve rechtsbescherming staan desalniettemin erg in de aandacht. De bevindingen pleiten voor de erkenning van effectieve rechtsbescherming in zuiver nationaalrechtelijke geschillen als beginsel en pleiten ervoor om dit uitgangspunt te rekenen tot het positieve recht. Het zou dan het derde aspect van het decisiebeginsel kunnen vormen. Effectieve rechtsbescherming speelt thans in het kader van behoorlijke rechtspleging vooral een rol bij de vraag naar effectieve rechtsmiddelen tegen overschrijdingen van de redelijke termijn in artikel 6 EVRM. Daarom komt effectieve rechtsbescherming in Deel II uitsluitend in dat verband aan de orde als eis waaraan de bestuurlijke voorprocedures eventueel zouden moeten voldoen.

De vijf beginselen van behoorlijke rechtspleging, waarvan de betekenis voor de bestuurlijke voorprocedures in Deel II wordt onderzocht, kunnen worden opgedeeld in twee categorieën die interessant zijn voor dit onderzoek: materiële versus institutionele beginselen en intern werkende of extern werkende beginselen. Materiële beginselen hebben betrekking op de inrichting van de procedure en de wijze waarop de uitspraak tot stand komt. De institutionele beginselen zien op de organisatie of inrichting van de rechterlijke instantie, het orgaan zelf. Intern werkend houdt in dat het beginsel primair de belangen van de procesdeelnemers beogen te waarborgen, terwijl een extern werkend beginsel primair het algemene belang van vertrouwen in rechtspraak beoogt te verzekeren. Deze twee indelingen vallen niet samen, maar de indeling in intern en extern werkende beginselen loopt dwars door de indeling materiële en institutionele beginselen heen. Zo is onafhankelijkheid van de rechter een institutionele eis (voor zover sprake is van een beginsel van behoorlijke rechtspleging) die hoofdzakelijk extern werkt, terwijl het onpartijdigheidsbeginsel een institutionele eis is die vooral intern werkt.

Deze categoriseringen zijn interessant, omdat de verwachting gerechtvaardigd is dat de materiële beginselen dan wel de intern werkende beginselen (of de beginselen die zowel materieel als intern werkend zijn) van meer betekenis kunnen zijn voor de bestuurlijke voorprocedures. Deze beginselen staan immers geheel los van en houden geen 


\section{Samenvatting en conclusies}

verband met de aard of organisatie van de oordelende of beslissende instantie. Voor de geldingskracht of werking van die beginselen en de daaruit voortvloeiende eisen lijkt minder van belang te zijn of die oordelende instantie onderdeel uitmaakt van de rechtspraak of het bestuur.

\section{De Unierechtelijke context}

De beginselen van behoorlijke rechtspleging vormen in het Unierecht algemene rechtsbeginselen die geëerbiedigd moeten worden via de band van artikel 6 EVRM. De rechten die voortvloeien uit deze bepaling vormen algemene Unierechtelijke beginselen die volgens het Hof van Justitie en het EU-verdrag in acht moeten worden genomen. Het Hof van Justitie beperkt de gelding van sommige van deze beginselen in elk geval niet tot procedures bij een rechterlijke instantie, maar acht ze ook van toepassing op bestuurlijke besluitvormingsfasen. Van sommige van die beginselen gaat ook invloed uit op de besluitvormingsprocedures in de nationale rechtsordes. Dat geldt vooralsnog vooral voor het verdedigingsbeginsel en het motiveringsbeginsel. Deze beginselen hebben of zouden de meeste invloed op de nationale procedures bij het bestuur kunnen hebben. Vooralsnog lijkt de doorwerking van die beginselen vooral plaats te hebben in het kader van Nederlandse equivalente beginselen van behoorlijk bestuur of toepassingen daarvan in de Awb. De invulling van deze beginselen op EU-niveau wijkt echter nauwelijks af van de invulling van de beginselen van behoorlijke rechtspleging op nationaal niveau (via artikel 6 EVRM) of de beginselen van behoorlijk bestuur. Soms is er een ander perspectief vereist dan op nationaal niveau gebruikelijk is. Andere beginselen, zoals het onpartijdigheidsbeginsel, het openbaarheidsbeginsel en het beginsel van de redelijke termijn, lijken vanuit het Unierecht bezien vooralsnog nauwelijks tot geen gevolgen voor de nationale procedures bij het bestuur en de rechter te hebben.

\section{Toetsingskader}

In Deel II wordt de betekenis van het onpartijdigheidsbeginsel, het beginsel van hoor en wederhoor, het openbaarheidsbeginsel, het motiveringsbeginsel en het beginsel van de redelijke termijn bezien. Meer concreet wordt in Deel II voor de bestuurlijke voorprocedures bezien of er op grond van wetgeving dan wel jurisprudentie deze of vergelijkbare normen in acht moeten worden genomen. Nagegaan wordt of er concrete uitwerkingen of toepassingen van de beginselen van behoorlijke rechtspleging gelden in die procedures. Tevens wordt daarbij de ratio en grondslag van de voor het bestuur geldende eisen betrokken. Dat betekent bijvoorbeeld dat voor het beginsel van hoor en wederhoor bezien wordt in hoeverre in de voorprocedures de verschillende deelaspecten, zoals equality of arms, gewaarborgd worden. Daarbij moet ook aan de orde komen of de ratio van de geldende eisen voor de inrichting, expliciet dan wel impliciet, de gelijkwaardige procespositie is van de betrokken partijen. Hetzelfde geschiedt voor de andere deelaspecten van het beginsel van hoor en wederhoor en gaat op voor de andere beginselen. Het voorgaande betekent dat het referentiekader er, vertaald naar de bestuurlijke voorprocedures, als volgt uitziet:

Beginsel van hoor en wederhoor. Onder dit beginsel vallen het recht om informatie te ontvangen (met als onderdeel de toegang tot stukken, de aanwezigheid bij of toegang tot verklaringen van de wederpartij en getuigen en deskundigen), het recht om informatie te verschaffen (zowel mondeling als schriftelijk, het horen van getuigen en deskundigen), voldoende tijd voor de voorbereiding van het eigen standpunt en het vereiste van equality of arms.

Onpartijdigheidsbeginsel. Onderdeel van dit beginsel vormen de objectieve en subjectieve toets zoals door het EHRM ontwikkeld, de onafhankelijkheidseisen voor zover zij ten dienste staan aan de onpartijdigheid, wrakings- en verschoningsregelingen, de 
Deel I Beginselen van behoorlijke rechtspleging

rechtspositionele waarborgen voor personen die betrokken zijn bij de besluitvorming, het verbod van onderhands contact met partijen voor het bestuursorgaan.

Openbaarheidsbeginsel. Dit beginsel omvat de toegankelijkheid van de hoorzitting voor het publiek, de criteria voor het houden van de zitting met gesloten deuren, de toegankelijkheid van de beslissing voor het publiek en de bekendmakingseisen voor de besluiten van het bestuur.

Motiveringsbeginsel. Van dit beginsel maken onderdeel uit de motiveringseisen aan de vaststelling en kwalificatie van de feiten, de interpretatie van de wet en de afweging van belangen. Ook omvat dit beginsel een reactieplicht op aangevoerde bezwaren en tot slot een motiveringsplicht bij het gebruik van processuele bevoegdheden.

Beginsel van de redelijke termijn. Onder dit beginsel vallen tot slot de besluitvorming binnen wettelijke termijnen en een redelijke termijn, de criteria om te bepalen wanneer de redelijke termijn is overschreden en de effectieve rechtsmiddelen tegen overschrijdingen van de redelijke termijn.

Het hiervoor vermelde toetsingskader zal als uitgangspunt worden gehanteerd. Aan de verschillende hierboven genoemde aspecten bij de onderscheiden beginselen, zal - voor zover van belang - in Deel II aandacht worden besteed. Daarbij is echter de kanttekening op zijn plaats dat het een kader op hoofdlijnen betreft, aangezien het onderzoek ook andere - afwijkende of aanvullende - eisen voor de bestuurlijke voorprocedures aan het licht kan brengen.

\subsection{De positie van de beginselen van behoorlijke rechtspleging in het Nederlandse bestuursrecht}

Ondergeschikte rol in het Nederlandse bestuursrecht

Uit het onderzoek in de voorgaande hoofdstukken komt naar voren dat, ondanks erkenning in de bestuursrechtelijke doctrine, de nationale ongeschreven beginselen van behoorlijke rechtspleging, een betrekkelijk marginale rol spelen in het Nederlandse bestuursrecht(spraak). Dat is vooral toe te schrijven aan de dominante positie van artikel 6 EVRM. De ontwikkeling van de beginselen van behoorlijke rechtspleging is, in vergelijking tot de beginselen van behoorlijk bestuur, minder sterk op gang gekomen. Een eigen invulling van de rechtsnormen voor een behoorlijke rechterlijke procedure is, gelet op het fundamentele karakter van de beginselen en de ratio van de beginselen, nodig en wenselijk. Opname van een grondrecht op een eerlijk proces of behoorlijke rechtspraak in de Grondwet zou voorts aan de nationale ontwikkeling of rechtsvorming, voor zover het toetsingsverbod uit artikel 120 Grondwet daaraan niet in de weg staat ${ }^{1}$, kunnen bijdragen.

\section{De rol van de bestuursrechter}

Verdere ontwikkeling van de beginselen van behoorlijke rechtspleging moet geschieden door de nationale wetgever, maar ook of vooral door de nationale rechter. De bestuursrechter zou meer en explicieter aandacht aan deze normen kunnen besteden in zijn uitspraken. In gevallen waarin een beroep op artikel 6 EVRM wordt gedaan, zou daarin bijvoorbeeld (tevens) een beroep op een ongeschreven beginsel van behoorlijke rechtspleging gelezen kunnen worden. De bestuursrechter zou het betreffende nationale begin-

\footnotetext{
${ }^{1 .}$ Er ligt een initiatiefvoorstel van F. Halsema tot invoering van een constitutioneel toetsingsrecht, Kamerstukken II 2001/02, 28 333, dat in eerste lezing door de Tweede Kamer en Eerste Kamer is aanvaard. Een tweede lezing moet nog plaatsvinden, gelet op de benodigde wijziging van de Grondwet (zie art. $137 \mathrm{GW}$ ).
} 


\section{Samenvatting en conclusies}

sel, gelet op de beperkte reikwijdte van artikel 6 EVRM, als primaire aanknopingspunt kunnen nemen bij de beoordeling van de voorliggende uitspraak of procedure. Zelfs indien geen beroep wordt gedaan op artikel 6 EVRM zou de bestuursrechter in elk geschil kunnen nagaan of de beginselen van behoorlijke rechtspraak in acht zijn genomen. Dat zou echter ambtshalve toetsing aan die normen betekenen. Hoewel ambtshalve toetsing in het Nederlandse bestuursrecht uitsluitend kan plaatsvinden aan bepalingen van openbare orde en de bestuursrechter vooralsnog terughoudend is met ambtshalve toetsing aan eisen van behoorlijke rechtspleging, bestaat er - zoals hierna nog zal worden uiteengezet - aanleiding die terughoudendheid te laten varen bij de beginselen van behoorlijke rechtspleging. Wel is het zo dat de bestuursrechter zijn bevoegdheid tot ambtshalve aanvulling van de rechtsgronden in geschillen waarin op een of andere wijze geklaagd wordt over de lange duur van de procedure ruimhartig toepast en dan tevens beoordeelt of een overschrijding van de redelijke termijn heeft plaatsgevonden. Aan de overige eisen van behoorlijke rechtspleging wordt soms impliciet ambtshalve getoetst en wordt de bevoegdheid tot ambtshalve aanvulling van de rechtsgronden wellicht ook ruimhartig toegepast. Expliciet is in de jurisprudentie door de bestuursrechter wat betreft de overige eisen echter nog nimmer duidelijk gemaakt in hoeverre deze normen zich lenen voor ambtshalve toepassing of aanvulling van de rechtsgronden. Zoals aangegeven, noopt het fundamentele karakter van deze normen en het belang van naleving ervan in ons stelsel van rechtsbescherming tot een ambtshalve toetsing van die eisen of in elk geval een ruimhartige toepassing van de bevoegdheid tot ambtshalve aanvulling in dat kader. De bestuursrechter zou er ambtshalve op moeten toezien dat iedere procedure bij de rechter voldoet aan de eisen van behoorlijke rechtspleging. Verwacht mag worden dat procesrechtelijke voorschriften of procesregelingen als uitgangspunt daarmee ook in overeenstemming zullen zijn, maar in concrete gevallen kan de toepassing van die voorschriften leiden tot strijd met de beginselen van behoorlijke rechtspleging. In die gevallen rust op de bestuursrechter een taak om te waarborgen dat de beginselen in acht worden genomen en schending ervan wordt voorkomen.

De eerste stap is gezet

Een eerste aanzet tot een 'eigen' nationale invulling is tot op zekere hoogte bij enkele eisen te bespeuren in de jurisprudentie. De bestuursrechter laat zich in elk geval bij overschrijdingen van de redelijke termijn niet meer leiden door het toepassingsbereik van artikel 6 EVRM. De bescherming van die waarborg is thans niet meer beperkt tot geschillen die binnen die reikwijdte vallen, maar lijkt zich uit te strekken tot alle bestuursrechtelijke geschillen. Voor de geldingskracht van de redelijke termijn-eis is uitdrukkelijk gezocht naar een nationale rechtsbasis. Kanttekening hierbij is dat de bestuursrechter een aan artikel 6 EVRM en de nationale eis gemeenschappelijke rechtsbasis heeft vastgesteld. Verder hanteert de bestuursrechter ook nog vaste standaardtermijnen, in tegenstelling tot het EHRM, om te bepalen of de redelijke termijn in een concreet geval is overschreden. Voor de toepassing van de eis en de schadevergoedingscriteria wordt daarentegen nog sterk aangesloten bij artikel 6 EVRM. Deze jurisprudentie is wellicht de eerste stap naar uitbreiding van toepasselijkheid van de overige in artikel 6 EVRM neergelegde waarborgen voor alle bestuursrechtelijke geschillen. De uitspraak waar het om gaat, lijkt ook te impliceren dat het vereiste van een onafhankelijke en onpartijdige rechter uit artikel 6 EVRM van toepassing is in vreemdelingrechtelijke geschillen. Aan deze ontwikkeling zou een verder vervolg gegeven kunnen worden voor de overige vereisten van artikel 6 EVRM die immers, zoals ook uit het onderzoek naar voren is gekomen, een nationale rechtsbasis hebben in de beginselen van behoorlijke rechtspleging. Daarmee zouden de gevolgen van het beperkte toepassingsgebied van artikel 6 EVRM voor het Nederlandse bestuursrecht voor alle vereisten worden weggenomen. De reikwijdte van de ongeschreven beginselen van behoorlijke rechtspleging is niet beperkt tot bepaalde geschillen. Er bestaat geen rechtvaardiging om, een door artikel 6 EVRM ingegeven, onderscheid naar toepasselijke behoorlijkheidsnormen binnen de nationale bestuursrech- 


\section{Deel I Beginselen van behoorlijke rechtspleging}

telijke geschillen te handhaven. Vanuit een oogpunt van rechtseenheid en rechtsgelijkheid behoren in alle geschillen ten overstaan van de bestuursrechter dezelfde behoorlijkheidseisen te gelden. Ook om die reden zou meer aandacht voor deze beginselen in de bestuursrechtelijke doctrine en rechtspraak niet misstaan. Dat betekent niet dat geen aansluiting gezocht kan of moet worden bij de invulling van die eisen door het EHRM in zijn jurisprudentie, zoals ook in het kader van hiervoor aangehaalde jurisprudentie van de nationale rechter geschiedt ten aanzien van de redelijke termijn-eis. Dat moet zeker het geval zijn, maar alleen voor zover nodig en artikel 6 EVRM niet in de weg staat aan verdergaande bescherming. De focus op artikel 6 EVRM moet echter niet zodanige vormen aannemen dat daardoor te geringe aandacht bestaat voor de nationale rechtsontwikkeling op dit vlak. 


\section{DEEL II Bestuurlijke voorprocedures}

\section{De bestuurlijke voorprocedures onder de Awb}

\subsection{Inleiding}

Doel en afbakening van het onderzoek

Het zwaartepunt van het onderzoek naar de doorwerking van de beginselen van behoorlijke rechtspleging in de bestuurlijke voorprocedures, in het bijzonder de bezwaarschriftprocedure en het administratief beroep, ligt in het onderhavige Deel II van dit boek. In Deel I is een aantal beginselen van behoorlijke rechtspleging en hun inhoud en reikwijdte vastgesteld: het beginsel van hoor en wederhoor, het onpartijdigheidsbeginsel, het openbaarheidbeginsel, het motiveringsbeginsel en het beginsel van de redelijke termijn. De vraag naar de doorwerking van die beginselen in de bestuurlijke voorprocedures ligt nog open. Onderzoek naar de inrichting van de bestuurlijke voorprocedures met het oog daarop vindt plaats in Deel II.

Alvorens de inrichting van de bestuurlijke voorprocedures wordt onderzocht, dienen de verschillende voorprocedures in het Nederlandse bestuursrecht in kaart te worden gebracht. Daarbij gaat het allereerst om de vraag welke voorprocedures thans kunnen worden onderscheiden en waaruit de onderlinge verschillen en overeenkomsten bestaan. De verschillen tussen de voorprocedures worden, voor zover relevant, in aanmerking genomen bij beantwoording van de vraag naar de doorwerking in de verschillende voorprocedures. In dit deel van het onderzoek staan voorts de te onderscheiden bestuurlijke voorprocedures in de periode vanaf inwerkingtreding van de Awb centraal. ${ }^{1}$ Een eerste beperking die daaruit volgt, is dat uitsluitend die bestuurlijke procedures waarvoor de Awb een algemene regeling bevat bij het onderzoek worden betrokken. Dat betekent dat het aantal in aanmerking komende procedures beperkt is tot vier: de bezwaarschriftprocedure, het administratief beroep, de uniforme voorbereidingsprocedure en de goedkeuringsprocedure. Een verdere afbakening volgt uit de omstandigheid dat de verschillende procedures zoals thans vormgegeven in de Awb tot uitgangspunt worden genomen in dit onderzoek. De vormgeving en inrichting van de procedures naar positief recht zijn derhalve voorwerp van onderzoek. De vormgeving van deze procedures in de periodes voorafgaand aan de Awb vervult in dit onderzoek slechts een ondergeschikte rol.

Zoals bekend is (ook) de regeling van de bestuurlijke voorprocedures in de Awb inmiddels, mede onder invloed van de resultaten van de twee evaluaties die hebben plaatsgevonden, wel op een aantal punten gewijzigd. ${ }^{3}$ In de navolgende paragraaf wordt ter inleiding kort stilgestaan bij de regeling ten tijde van de inwerkingtreding van de Awb. Reden daarvoor is dat, hoewel de oorspronkelijke regeling gewijzigd is, de wijzigingen

\footnotetext{
${ }^{1 .}$ De eerste en tweede tranche van de Awb zijn op 1 januari 1994 in werking getreden, de derde tranche op 1 januari 1998 en de vierde tranche op 1 juli 2009.

${ }^{2 .}$ Voor een beschrijving van deze voorgeschiedenis van de bezwaarschriftprocedure verwijs ik naar K.H. Sanders, De heroverweging getoetst. Een onderzoek naar het functioneren van bezwaarschriftprocedures (diss. Groningen), Deventer: Kluwer 1998, p. 2-15. Voor een overzicht van de ontwikkeling van de administratieve rechtspraak (waaronder administratief beroep) verwijs ik verder naar verschillende handboeken, zie bijvoorbeeld: Damen e.a. 2009, Deel II, p. 32-44; Van Wijk/Konijnenbelt \& Van Male 2008, p. 16-24.

3. Commissie-Polak, Toepassing en effecten van de Algemene wet bestuursrecht 1994-1996 (verslag van de Commissie Evaluatie Awb I); Commissie-Boukema, Toepassing en effecten van de Algemene wet bestuursrecht, 1997-2001 (verslag van de Commissie Evaluatie Awb II).
} 


\section{Deel II Bestuurlijke voorprocedures}

en de huidige regeling daarvan toch niet geheel los kunnen worden gezien. Het in die paragraaf geschetste beeld betreft slechts, ter inleiding, een korte schets in algemene zin. Aan de uitzonderingen of bijzonderheden wordt daar grotendeels voorbijgegaan, maar deze komen, voor zover van belang, aan bod in de paragrafen waarin de verschillende bestuurlijke voorprocedures afzonderlijk worden behandeld.

\subsection{De voorprocedures in de Awb}

Het uitgangspunt sinds de inwerkingtreding van de Awb is dat een burger, alvorens beroep bij de bestuursrechter in te kunnen stellen tegen een (ontwerp)besluit van een bestuursorgaan, een bestuurlijke voorprocedure dient te doorlopen. ${ }^{4}$ Ten tijde van de eerste en tweede tranche van de Awb in 1994 kunnen vijf bestuurlijke procedures worden onderscheiden die aan de procedure bij de bestuursrechter vooraf kunnen gaan: de bezwaarschriftprocedure, het administratief beroep, de goedkeuringsprocedure en de openbare voorbereidingsprocedures van afdeling 3.4 en afdeling 3.5. Thans zijn dat er nog maar vier omdat de beide openbare voorbereidingsprocedures zijn samengevoegd tot een procedure, de uniforme voorbereidingsprocedure in afdeling $3.4 \mathrm{Awb}^{5}$

Aan het beroep op de bestuursrechter dient derhalve een bestuurlijke herbeoordeling van de (ontwerp)besluitvorming vooraf te gaan. ${ }^{6}$ In de regel vindt die bestuurlijke herbeoordeling plaats in het kader van de bezwaarschriftprocedure. In artikel 7:1, eerste lid, onderdelen a tot en met $\mathrm{d}$ van de Awb is neergelegd dat geen bezwaar behoeft te worden gemaakt tegen op bezwaar genomen besluiten alsmede besluiten waarvoor administratief beroep, de goedkeuringsprocedure of de uniforme voorbereidingsprocedure is voorgeschreven. ${ }^{7}$ In beginsel behoeft slechts eenmaal een bestuurlijke voorprocedure te worden gevolgd alvorens tegen een besluit beroep kan worden ingesteld bij de bestuursrechter. De achterliggende gedachte is met name geweest dat het volgen van de bezwaarschriftprocedure tegen een in het kader van een van de verschillende andere procedures genomen besluit te zeer een herhaling van zetten zal opleveren, omdat reeds door een (ander) bestuursorgaan een herbeoordeling heeft plaatsgevonden in een van de (ontwerp)be-

4. Het onderzoek beperkt zich tot de bestuurlijke procedures in het kader van een rechtsverhouding tussen burger en bestuursorgaan. De rechtsverhouding tussen verschillende bestuursorganen (in de bestuurlijke voorfase), voor zover sprake is van een 'zuiver' bestuursgeschil, blijft buiten beschouwing omdat doorgaans wordt aangenomen dat de waarborgen neergelegd artikel 6 EVRM niet strekken tot bescherming van bestuursorganen of andere overheidsorganen. Organen van de, lokale en centrale, overheid kunnen ook op grond van artikel 34 EVRM geen klacht indienen bij het EHRM (zie o.m.: EHRM 1 februari 2001, Ayuntamiento de Mula t. Spanje, Reports of Judgements and Decisions 2001-I; KB 14 april 1995, $A B$ 1995/618 m.nt. RH; HR 6 februari 1986, AB 1987/272 m.nt. FHvdB) Zie ook in deze zin het standpunt van de regering in de nota 'Alternatieve afdoening van bestuursgeschillen', Kamerstukken II 1999/00, 27 286, nr. 1, p. 4. Dat standpunt wordt onderschreven in het rapport VAR-Commissie Rechtsbescherming, p. 29. Recent heeft de Hoge Raad ook een andere benadering gehanteerd. In een uitspraak van 8 juli 2005 overweegt de HR dat ook publiekrechtelijke lichamen een beroep op het redelijke termijn-vereiste in art. 6 EVRM toekomt, HR 8 juli 2005, $A B$ 2006/17 m.nt. A.M.L. Jansen; $B N B$ 2005/340 m.nt. Bijl. Daarmee wijkt de HR dus af van de heersende leer dat, gelet op de jurisprudentie van het EHRM, overheidsinstanties geen beroep op art. 6 EVRM kunnen doen.

5. De twee openbare voorbereidingsprocedures zijn sinds 1 juli 2005 samengevoegd tot een uniforme openbare voorbereidingsprocedure, Wet van 24 januari 2002, Stb. 2002, 54. De inwerkingtreding van deze wet was afhankelijk gesteld van de Aanpassingswet Uniforme openbare voorbereidingsprocedure, welke per 1 juli 2005 in werking is getreden; Wet van 26 mei 2005, Stb. 2005, 282; Besluit van 22 juni 2005, Stb. 2005, 320. In deze en de navolgende paragrafen wordt voor zover relevant ook de oude situatie nog weergegeven.

${ }^{6 .} \mathrm{Er}$ is voor gekozen om de meer neutrale term bestuurlijke herbeoordeling te hanteren daar waar de voorprocedures in het algemeen beschreven worden, zodat de term bestuurlijke heroverweging, gelet op de terminologie van artikel 7:11 Awb en analoog daaraan artikel 7:25 Awb, beperkt kan blijven tot de herbeoordeling in het kader van de bezwaarschriftprocedure of het administratief beroep. De term toetsing wordt in navolging van Verheij slechts gehanteerd voor de door de bestuursrechter te verrichten beoordeling van een besluit, zie: Verheij 2003, p. 28-29.

${ }^{7}$ Oorspronkelijk gold dat in de Awb slechts voor de uitgebreide openbare voorbereidingsprocedure in afd. 3.5 en niet voor de openbare voorbereidingsprocedure in afd. 3.4. Awb. Thans geldt ook dat indien de uniforme openbare voorbereidingsprocedure is doorlopen, geen bezwaar meer gmaakt behoeft te worden, zie het huidige art. 7:1 sub d Awb. 


\section{De bestuurlijke voorprocedures onder de Awb}

sluitvorming. ${ }^{8}$ Aan deze gedachtegang lijkt de vooronderstelling ten grondslag te liggen dat sprake is van enige mate van vergelijkbaarheid van de verschillende voorprocedures, zodat het daaropvolgend doorlopen van de bezwaarschriftprocedure geen of onvoldoende meerwaarde kan hebben. ${ }^{9}$ Aangenomen wordt dat sprake is van enige (mate van) overlap in de functies en het karakter van de verschillende bestuurlijke voorprocedures.

\subsubsection{Onderlinge verschillen}

Ofschoon de hiervoor genoemde voorprocedures gemeen hebben dat op enig moment in de besluitvormingsfase een bestuurlijke herbeoordeling plaatsvindt, valt, zoals bekend, reeds na oppervlakkige beschouwing een aantal verschillen, aan te wijzen. Het meest in het oog springende verschil tussen de verschillende voorprocedures in de oorspronkelijke opzet van de Awb betreft vanzelfsprekend het algemeen verplichte karakter van de bezwaarschriftprocedure ten opzichte van het uitzonderingskarakter van de overige procedures. De bezwaarschriftprocedure dient te worden gevolgd, tenzij van deze hoofdregel bij bijzonder wettelijk voorschrift of bij besluit van het bestuursorgaan wordt afgeweken.

Daarnaast kan het tijdstip waarop de bestuurlijke herbeoordeling plaatsvindt verschillen. In het kader van de bezwaarschriftprocedure, het administratief beroep en de goedkeuringsprocedure vindt de herbeoordeling achteraf, dat wil zeggen nádat het primaire besluit is genomen, plaats door ofwel het bestuursorgaan dat de primaire beslissing heeft genomen ofwel door een ander (hoger) bestuursorgaan. In de uniforme openbare voorbereidingsprocedure daarentegen is de herbeoordeling ingebed in de primaire besluitvormingsfase, derhalve vóórdat het primaire besluit tot stand is gekomen. ${ }^{10}$

Ook de aard en omvang van de herbeoordeling verschilt per voorprocedure. In de bezwaarschriftprocedure omvat de herbeoordeling, gelet op artikel 7:11 van de Awb, een volledige heroverweging door het betreffende bestuursorgaan. Hiermee wordt kort gezegd bedoeld dat deze beoordeling van het bestuursorgaan zich, naast rechtmatigheidsaspecten, ook (opnieuw) dient uit te strekken over beleidsmatige aspecten. Voor administratief beroep is in artikel 7:25 van Awb slechts neergelegd dat het beroepsorgaan het bestreden besluit vernietigt, voorzover het beroep ontvankelijk en gegrond acht. De bestuurlijke herbeoordeling in het kader van deze procedure kan in beginsel ook bestaan uit een volledige heroverweging door het beroepsorgaan. ${ }^{11}$ De heroverweging kan echter ook meer terughoudend van aard zijn afhankelijk van de positie die het beroepsorgaan (waarbij administratief beroep kan worden ingesteld) inneemt ten opzichte van het bestuursorgaan dat het besluit in primo heeft genomen. ${ }^{12}$ Ook de goedkeuringsprocedure

\footnotetext{
${ }^{8 .}$ Rapport VAR-Commissie Rechtsbescherming 2004, p. 152-153. Zie voor de (uniforme) openbare voorbereidingsprocedure: Van Wijk/Konijnenbelt \& Van Male 2008, p. 303; Kabinetsstandpunt Juridisering van het openbaar bestuur p. 21-22; Notten 1998, p. 344. Dat standpunt werd door de Awb-wetgever zoals aangegeven ten aanzien van de 'oude' openbare voorbereidingsprocedure in afd. 3.4 van de Awb niet ingenomen, PG Awb I, p. 318-319; PG Awb II, p. 43-45.

9. Vgl: Sanders 1998, p. 240. Deze veronderstelling kan ook min of meer afgeleid worden uit hetgeen in de MvA II wordt opgemerkt bij de tweede tranche van de Awb. De wetgever geeft (zij het in het kader van de vraag of rechtspraak in twee instanties gewenst is) aan dat aan beroep op de rechter een bezwaarschriftprocedure of een daarmee vergelijkbare op bestuurlijke heroverweging gerichte procedure vooraf dient te gaan. Voorts wordt aangegeven dat ook de uitgebreide openbare voorbereidingsprocedure in zekere zin inwisselbaar is met een op heroverweging gerichte voorprocedure, omdat in beide gevallen sprake is van een op bestuurlijke besluitvorming gerichte procedure, PG Awb II, p. 195-196.

0. Zowel in de oude openbare voorbereidingsprocedures als ook in de nieuwe uniforme openbare voorbereidingsprocedure is de hernieuwde beoordeling ingebed in de primaire besluitvormingsfase. Om die reden lijkt de term herbeoordeling in deze procedure minder op zijn plaats. Het resultaat van de procedure is immers een primair besluit.

${ }^{1 .}$ Van Wijk/Konijnenbelt \& Van Male 2008, p. 545-546; Rapport VAR-Commissie Rechtsbescherming 2004, p. 153; Notten 1998, p. 57; Versteden 1995, p. 287.

12. PG Awb I, p. 362. Vgl: Van Wijk/Konijnenbelt \& Van Male 2008, p. 545-546 en p. 563-564; SchreuderVlasblom 2003, p. 171-172; Notten 1998, p. 57; Stroink 1993, p. 167. Hierop wordt in par. 4.3.1.1 nader ingegaan.
} 


\section{Deel II Bestuurlijke voorprocedures}

leidt, soms naar aanleiding van door burgers ingediende bedenkingen, tot een herbeoordeling door een bestuursorgaan, maar deze is als uitgangspunt beperkt(er) van omvang. ${ }^{13}$ De beoordeling blijft, ingevolge artikel 10:27 van de Awb, beperkt tot het geschreven en ongeschreven recht alsmede de in bijzondere wetgeving opgenomen gronden. De openbare voorbereidingsprocedure - dat gold ook voor de 'oude' uitgebreide openbare voorbereidingsprocedure - kan worden gekarakteriseerd als een inspraakprocedure die, aan de hand van door belanghebbende(n) ingediende zienswijzen, de zorgvuldigheid van de primaire besluitvorming dienen te bevorderen. ${ }^{14}$ De wetgever kenschetste destijds de openbare voorbereidingsprocedure van afdeling 3.4, indien de zienswijzen gericht zijn tegen een ontwerp-besluit, als een uitgebreide hoorprocedure vooraf die bepaalde trekken van een bezwaarprocedure vooraf kan krijgen. ${ }^{15}$ Dit standpunt geldt te meer voor de later ingevoegde uitgebreide openbare voorbereidingsprocedure(s) van afdeling 3.5 van de Awb, aangezien de bedenkingen in die procedure(s), gelet op artikel 3:24, eerste lid Awb altijd gericht zullen zijn tegen een ontwerp-besluit. ${ }^{16}$ In de thans geldende uniforme openbare voorbereidingsprocedure, neergelegd in afdeling 3.4 van de Awb, zijn de zienswijzen altijd gericht tegen een ontwerpbesluit. Omdat deze procedure onderdeel uitmaakt van de primaire besluitvormingsfase kan de (her)beoordeling van het bestuursorgaan naar aanleiding van de ingediende zienswijzen zich uitstrekken tot zowel rechtmatigheids- als doelmatigheidsaspecten.

De verschillen die na een eerste verkenning naar voren komen tussen de voorprocedures onderling, doen de vraag rijzen naar de exacte verhouding tussen de verschillende voorprocedures. Op het eerste gezicht lijken de procedures niet zonder meer uitwisselbaar te zijn. De vraag is echter in hoeverre de functies en karakter van de verschillende procedures daadwerkelijk uiteenlopen. Bij beantwoording van de vraag naar de doorwerking van de beginselen van behoorlijke rechtspleging in de huidige bestuurlijke voorprocedures, dienen zoals eerder aangegeven, voor zover daarvan na nadere beschouwing sprake blijkt te zijn, de verschillen in aanmerking te worden genomen. Om die reden vindt in dit onderzoek differentiatie per voorprocedure plaats en worden de verschillende voorprocedures afzonderlijk behandeld.

\subsection{Definitie van een voorprocedure}

In de Awb kunnen thans derhalve vier procedures onderscheiden worden, waarvan er een bij het bestuur gevolgd moet worden alvorens de toegang tot de rechter voor een belanghebbende openstaat. In dit onderzoek worden echter niet al deze procedures gerekend tot de bestuurlijke voorprocedures. Er wordt een beperking aangebracht die samenhangt met de probleemstelling van dit onderzoek. Omdat gezocht wordt naar de betekenis van de beginselen van behoorlijke rechtspleging voor de bestuurlijke voorprocedures, is het van belang dat de verwantschap met rechtspraak in die voorprocedures voldoende tot uit-

\footnotetext{
${ }^{13 .}$ Rapport VAR-Commissie Rechtsbescherming 2004, p. 153. Uit de begripsomschrijving van een voorprocedure volgt dat de goedkeuringsprocedure in het navolgende slechts, als voorprocedure, bij het onderzoek wordt betrokken voor zover in het kader van die procedure de mogelijkheid bestaat voor belanghebbenden om bedenkingen in te dienen tegen het primaire besluit.

14. Het onderscheid tussen de oude openbare voorbereidingsprocedure en de uitgebreide openbare voorbereidingsprocedure, namelijk het wel of niet kunnen indienen van zienswijzen, verliest thans aan betekenis omdat sinds 1 juli 2005 er nog slechts één uniforme openbare voorbereidingsprocedure bestaat. In die uov bestaat, evenals het geval was in de uitgebreide openbare voorbereidingsprocedure, de mogelijkheid bestaat om zienswijzen in te dienen tegen een ontwerp-besluit, zie art. 3:15 Awb.

15. In eerste instantie was in de Awb slechts voorzien in de openbare voorbereidingsprocedure van afdeling 3.4 van de Awb. Voormeld standpunt van de wetgever is zoals aangegeven ingenomen ten aanzien van deze procedure, PG Awb I, p. 221. Bij wet van 14 oktober 1993, Stb. 581, is afdeling 3.5, inzake de uitgebreide openbare voorbereidingsprocedure, in de Awb opgenomen.

16. PG Awb II, p. 44-45. Om die reden is, zoals aangegeven, destijds in artikel 7:1 lid 1 sub d Awb van de verplichting tot het volgen van de bezwaarschriftprocedure de situatie uitgezonderd dat de uitgebreide voorbereidingsprocedure van deze afdeling reeds is doorlopen.
} 


\section{De bestuurlijke voorprocedures onder de Awb}

drukking komt. In dit onderzoek wordt onder een bestuurlijke voorprocedure ${ }^{17}$ verstaan: een procedure die verplicht voorafgaat aan een procedure bij een (bestuurs)rechterlijke instantie en waarin achteraf een (her)beoordeling door een bestuursorgaan van een primair besluit plaatsvindt naar aanleiding van zienswijzen, bedenkingen of bezwaren daartegen van een of meer belanghebbende burgers, die leidt tot een definitieve bestuurlijke vaststelling van de rechtspositie van de bij dat besluit betrokken belanghebbende burgers. ${ }^{18}$ Een procedure bij het bestuur wordt derhalve slechts betrokken bij het onderzoek als voorprocedure, voor zover daarin voor een of meer burgers de mogelijkheid bestaat standpunten omtrent een besluit of ontwerpbesluit kenbaar te maken en aantasting van het genomen besluit mogelijk is. In deze zin bieden de procedures voorafgaand aan het beroep op de rechter een met bepaalde rechtswaarborgen omklede mogelijkheid én verplichting voor de burger om tegen een concreet besluit bij het bestuur in het geweer te komen, indien hij of zij het daarmee oneens is. ${ }^{19}$ Een belangrijk element in die definitie is ook dat het initiatief voor de bestuurlijke voorprocedure/herbeoordeling afkomstig is van een of meer belanghebbenden. ${ }^{20}$ De belanghebbende leidt de voorprocedure in door (al dan niet) schriftelijk zijn of haar standpunt tegen een besluit kenbaar te maken en pas op dat moment ontstaat er een geschil tussen bestuur en burger of wellicht tussen bijvoorbeeld de geadresseerde en mogelijk betrokken derde-belanghebbenden. Door deze elementen toe te voegen in de begripsomschrijving wordt de nadruk gelegd op de aanwezigheid van een geschilachtig element in de verschillende voorprocedures. Bovendien brengt de definitie door daarin de verplichting om een procedure bij het bestuur te doorlopen op te nemen, de connexiteit tussen deze procedures en de toegang tot de rechter alsmede de plaats van deze procedures in het stelsel van rechtsbescherming tot uitdrukking. Daarnaast moet het gaan om een procedure waarmee repressief een besluit kan worden aangetast. ${ }^{21} \mathrm{Te}$ verwachten valt immers dat slechts indien een rechtsbeschermingscomponent aanwezig is in de procedure bij het bestuur de mogelijkheid bestaat dat vereisten die voor rechtspraak gelden ook betekenis kunnen hebben in het kader van deze procedures. De opname van de hiervoor genoemde elementen in de begripsomschrijving, waaraan de te onderzoeken procedures moeten voldoen, verzekert dat er enige verwantschap bestaat tussen rechtspraak en de te onderzoeken bestuurlijke voorprocedures. ${ }^{22}$

Uit het voorgaande volgt dat de bezwaarschriftprocedure en het administratief beroep bestuurlijke voorprocedures vormen in dit onderzoek. De uniforme voorbereidingsprocedure en de goedkeuringsprocedure worden daartoe in beginsel niet gerekend. In zowel de uniforme voorbereidingsprocedure als in bepaalde goedkeuringsprocedures bestaat de mogelijkheid tot het indienen van zienswijzen of bedenkingen. Desondanks vormen zij geen bestuurlijke voorprocedures met een voldoende rechtsbeschermingska-

\footnotetext{
${ }^{17 .}$ In dit onderzoek worden de termen 'voorprocedure' en 'voorfase' als inwisselbaar beschouwd. Soms wordt ter afwisseling derhalve de term voorfase gehanteerd, maar daarmee wordt niet beoogd een inhoudelijk verschil aan te geven

18. Met de term definitief wordt beoogd tot uitdrukking te brengen dat een in beginsel definitieve bestuurlijke vaststelling van de rechtspositie van de betrokken belanghebbenden heeft plaatsgevonden. Na het verstrijken van de beroepstermijn zonder rechterlijke tussenkomst wordt het besluit dat voortvloeit uit de voorprocedure in beginsel immers onaantastbaar. Hiermee is niet beoogd aan te geven dat een besluit niet erga omnes werkt. In beginsel is het besluit algemeen bindend jegens een ieder.

19. De burger dient immers op straffe van niet-ontvankelijkheid bij de bestuursrechter eerst de voorprocedure te hebben doorlopen.

20. Veelal wordt immers als kenmerkend verschil tussen bestuur en rechtspraak naar voren gebracht dat de rechter (in tegenstelling tot het bestuur) rechtspreekt op initiatief van een belanghebbende, dus als er al sprake is van een geschil. Zie bijvoorbeeld: S. Pront-Van Bommel, Bestuursrechtspraak. Voorstellen voor modernisering van de bestuursrechtspraak, Den Haag: Bju 2002, p. 17-18; Stroink 1993, p. 2. Dit kenmerkende verschil met bestuursrechtspraak gaat nu juist niet op voor de bestuurlijke voorprocedures (in de zin van dit onderzoek). Ook voor die procedures berust het initiatief bij de belanghebbende die meent een geschil te hebben met het bestuur omdat hij of zij het niet eens is met een (ontwerp)besluit.

21. Damen e.a. 2009, Deel II, p. 22.

22. Zie over deze verwantschap het inleidende hoofdstuk van dit onderzoek, par. 1 en par. 2.3 van Deel I van het onderzoek.
} 


\section{Deel II Bestuurlijke voorprocedures}

rakter in de zin van dit onderzoek. Voor de uniforme voorbereiding vormt het bepalende verschil met rechtspraak het feit dat er uitsluitend geageerd kan worden tegen een ontwerp-besluit in het kader van de primaire besluitvormingsfase en er daarom slechts sprake kan zijn van rechtsbescherming vooraf, dat wil zeggen voorafgaand aan het definitieve besluit. ${ }^{23}$ De goedkeuringsprocedure heeft uitsluitend een rechtsbeschermingscomponent, indien in het kader ervan bedenkingen kunnen worden ingediend door belanghebbenden. ${ }^{24}$ In lang niet alle goedkeuringsprocedures bestaat daartoe de mogelijkheid. Integendeel, het meest voorkomende geval en belangrijkste geval voor de praktijk was de goedkeuringsprocedure tegen bestemmingsplannen op grond van de WRO. ${ }^{25}$ Deze procedure is echter door een recente wijziging van de WRO komen te vervallen. Bovendien is in de goedkeuringsprocedure het toezichtelement, sterker dan het geval is voor administratief beroep, aanwezig. ${ }^{26}$ Om die redenen wordt de goedkeuringsprocedure in dit onderzoek niet meegenomen als bestuurlijke voorprocedure.

\subsection{Status quo?}

\subsubsection{Kritiek op de oorspronkelijke opzet}

De afgelopen jaren heeft het Nederlandse bestuursrecht ervaring kunnen opdoen met de hiervoor genoemde algemeen in de Awb geregelde bestuurlijke voorprocedures. ${ }^{27}$ Dat de regeling en inrichting van deze voorprocedures in de Awb gedurende deze korte periode aan veranderingen onderhevig is geweest, is bekend. ${ }^{28}$ Overigens hebben niet alleen wijzigingen plaatsgevonden in de regeling van de verschillende voorprocedures. In de jaren na de inwerkingtreding van de Awb is, onder meer naar aanleiding van het rapport van de werkgroep Van Kemenade ${ }^{29}$, vanuit de praktijk en de literatuur een discussie op gang gekomen over de Awb en de zogenaamde juridisering van het openbaar bestuur. ${ }^{30}$ De juridiseringsdiscussie heeft ten aanzien van het openbaar bestuur ook betrekking op de verhouding tussen de rechter en het bestuur in algemene zin. ${ }^{31}$ Zoals het kabinet opmerkt, worden ten aanzien van het openbaar bestuur 'niet alleen de toenemende regeldichtheid en proceduredichtheid onder de noemer juridisering gebracht, maar ook de toetsingsmogelijkheden van de rechter, ${ }^{32}$ De kritiek vanuit het bestuur luidt dat de rechter te vergaand het bestuurshandelen toetst en te ingrijpend optreedt tegen dit bestuurshandelen. Het aloude cliché dat de rechter te zeer op de stoel van het bestuur zou plaats-

\footnotetext{
23. Vgl.: Damen e.a. 2009, p. 22.

24. Van Wijk/Konijnenbelt \& Van Male 2008, p. 509; Rapport VAR-Commissie Rechtsbescherming 2004, p. 153. Van Wijk/Konijnenbelt \& Van Male merken op dat de goedkeuringsprocedure dan een mengvorm van administratief beroep en de reguliere goedkeuringsprocedures als vorm van bestuurlijk toezicht vormt.

${ }^{25}$ Zie art. 27 en 28 WRO oud.

26. Vgl. Koenraad \& Sanders 2006, p. 26-27.

27. De verschillende voorprocedures kennen een lange voorgeschiedenis in het Nederlandse bestuursrecht. Een algemene regeling van de bezwaarschriftprocedure heeft, hoewel slechts verplicht voor beschikkingen die niet afkomstig zijn van de centrale overheid, al plaatsgevonden in de Wet Arob, Sanders 1998, p. 5-11. Ook de Wet Bab kende bijvoorbeeld voor beschikkingen van de centrale overheid de mogelijkheid van een voorbehandeling door de betreffende minister alvorens op het beroep op de Kroon een beslissing werd gegeven, Sanders 1998, p. $3-5$

${ }^{28 .}$ Zie ook: K.H. Sanders, 'De flexibiliteit van een rituele dans', NTB 1999/7, p. 171. Sanders merkt in algemene zin op dat de snelheid waarmee in de Awb gemaakte keuzes opnieuw ter discussie gesteld worden fascinerend is. 29. Werkgroep Van Kemenade, 'Bestuur in geding', Provinciehuis Haarlem november 1997 (rapport Van Kemenade).

30. Onder juridisering van de rechtsverhouding tussen burger en bestuur wordt hier verstaan het in juridische regels vastleggen van relaties tussen burger en bestuur, zie hetgeen de commissie-Polak opmerkt in het Verslag evaluatie Awb I op p. 33; Kabinetsstandpunt Juridisering in het openbaar bestuur, Kamerstukken II 1998/99, 26 360 , nr. 1, p. 3-4.

31. Zie voor een beschrijving van de ontwikkeling van de juridiseringsdiscussie: Kabinetsstandpunt Juridisering in het Openbaar bestuur, Kamerstukken II 1998/99, 26 360, nr. 1.

32. Kabinetsstandpunt Juridisering in het openbaar bestuur, p. 5.
} 
De bestuurlijke voorprocedures onder de Awb

nemen, wordt vaak in stelling gebracht. ${ }^{33}$ Op deze kritiek ten aanzien van de actieve houding van de rechter is in de literatuur ook negatief gereageerd. Benadrukt wordt onder meer dat de toenemende juridisering en de rol van de rechter daarin positief te waarderen zijn en passen binnen de ontwikkeling van de rechtsbescherming van de burger in een democratische rechtsstaat. ${ }^{34}$ Dat laatste benadrukt ook het kabinet. ${ }^{35}$

Niet alleen is in algemene zin de verhouding tussen bestuur en rechter onder de Awb voorwerp van discussie geweest, ook op de inrichting en het functioneren van de verschillende voorprocedures onder het regime van de Awb is vanuit verschillende hoeken kritiek geuit. Hoewel de invoering van een algemeen geldende bezwaarschriftprocedure een weloverwogen keuze van de wetgever is geweest ${ }^{36}$, heeft deze keuze vrijwel direct na de inwerkingtreding van de Awb ter discussie gestaan. ${ }^{37}$ Een veelgehoord standpunt in dat kader is dat de wijze waarop de bezwaarschriftprocedure is ingericht in de praktijk, heeft bijgedragen aan de juridisering van de verhouding tussen bestuur en burger. ${ }^{38}$ De kritiek op de vormgeving van de voorprocedures in de Awb heeft zich vooral gericht tot de algemene verplichtstelling van de bezwaarschriftprocedure. ${ }^{39}$ In paragrafen 4.2 wordt voor zover van belang bij de omschrijving van de verscheidene functies van de bestuurlijke voorprocedures nader op de kritiek ingegaan. Thans wordt volstaan met de bovenstaande constatering en de hiernavolgende beschrijving van de daaropvolgende ontwikkelingen ten aanzien van de bezwaarschriftprocedure. ${ }^{40}$

\subsubsection{Invoering van het rechtstreeks beroep}

\section{Het rechtstreeks beroep}

Zoals eerder aangegeven, heeft in de Awb de invoering van een algemeen verplichte bezwaarschriftprocedure plaatsgevonden. In afwijking van het voorontwerp Algemene wet bestuursrecht is destijds gekozen voor de algemene verplichtstelling van deze voorprocedure en niet voor een dubbel facultatieve bezwaarschriftprocedure. In de memorie van antwoord wordt in dat kader nog opgemerkt:

"De mogelijkheid om een bezwaarschriftprocedure met wederzijds goedvinden van bestuur en belanghebbende over te slaan, gaat niet alleen voorbij aan het belang van eventuele derden bij een heroverweging

\footnotetext{
${ }^{33 .}$ Kabinetsstandpunt Juridisering in het openbaar bestuur, p. 7.

34. Zie hierover o.m.: J.E.M. Polak, 'Nationaal bestuursrecht in een internationale context. Over verwaarloosde aspecten bij de discussie over de juridisering van het openbaar bestuur.', NJB 2003, p. 266 e.v.; E.M.H. Hirsch Ballin, 'Controversieel bestuursrecht', NTB 1999, p. 53 e.v.; A.H. Korthals, 'Juridisering in het openbaar bestuur', NJB 2000, p. 209-214. Zie ook: Verslag Evaluatie Awb I, p. 33-34

${ }^{35}$ Kabinetsstandpunt Juridisering openbaar bestuur, p. 14-15.

${ }^{36}$ De wetgever heeft destijds nog uitdrukkelijk overwogen dat een algemeen verplichte bezwaarschriftprocedure de voorkeur verdient boven de dubbel facultatieve regeling zoals neergelegd in het Voorontwerp van de Algemene wet bestuursrecht, PG Awb I p. 318-320.

37. Sanders 1998, p. 239. Zie voor de kritiek en reacties daarop: M. Biesheuvel, 'Weg met de bezwaarschriftprocedure', NJB 1996, p. 390. De reacties daarop van: P. Vanderheyden, 'Weg met de advocatuur', NJB 1996, p. 1111-1112; E. Alders, 'Deregulering ook voor de Awb', NJB 1996, p. 1113; C.J.A.M. Kortmann, 'Weg met de bezwaarschriftprocedure?', NJB 1996, p. 1113; M. Biesheuvel, 'Naschrift', NJB 1996, p. 1113-1114; B.E.M. Hendrickx, 'Weg met de bezwaarschriftprocedure?', NJB 1996, p. 1371.

38. Kabinetsstandpunt Juridisering openbaar bestuur, p. 21-22; Notten 1998, p. 338. Door de commissie-Polak wordt overigens gewezen op het feit dat vooral de wijze waarop bestuursorganen de bezwaarschriftprocedure inrichten en toepassen leidt tot juridisering van de verhouding tussen bestuur en burger. De regeling van bezwaarschriftprocedure in de Awb biedt als zodanig voldoende mogelijkheden voor het bestuur om deze ontwikkeling tegen te gaan, Verslag evaluatie Awb I, p. 83. Ook in het kabinetsstandpunt ten aanzien van de juridisering van het openbaar bestuur wordt daaromtrent opgemerkt dat juist vanuit een oogpunt van tegengaan van juridisering de voordelen van de bezwaarschriftprocedure zwaar wegen. Niettemin wordt in beide stukken aangegeven dat een zekere versoepeling van de verplichting om bezwaar te maken wenselijk kan zijn. In deze zin ook: Verslag evaluatie Awb II, p. 16.

39. Sanders 1998, p. 243.

40. In het onderstaande passeren niet alle aanpassingen en wijzigingen de revue. Slechts enkele daarvan worden, voor zover relevant in het kader van dit onderzoek, weergegeven.
} 


\section{Deel II Bestuurlijke voorprocedures}

door het bestuur, maar ook aan het belang dat de administratieve rechter heeft bij een goed voorbereide zaak. Om die reden zien wij op dit moment geen reden de bedoelde mogelijkheid op te nemen.",

Deze argumenten blijken thans niet meer van doorslaggevend belang voor het standpunt van de wetgever over het nut en de functies van de bezwaarschriftprocedure. De geuite kritiek, zoals hierboven omschreven, is door de wetgever ter harte genomen. De wetgever is, amper tien jaar na de invoering ervan, van mening dat een versoepeling van de verplichting een bezwaarschriftprocedure te doorlopen in bepaalde gevallen zinvol kan zijn. ${ }^{42}$ Sinds 1 september 2004 is door de inwerkingtreding van de Wet rechtstreeks beroep een (mogelijke) versoepeling van het algemeen verplichte karakter van de bezwaarschriftprocedure gerealiseerd. ${ }^{43}$

In artikel 7:1a van de Awb is de mogelijkheid vastgelegd om, indien het bestuursorgaan en de betrokken belanghebbende(n) daarmee instemmen, onder bepaalde voorwaarden de bezwaarschriftprocedure over te slaan en rechtstreeks tegen het primaire besluit beroep in te stellen bij de bestuursrechter. ${ }^{44}$ De indiener van het bezwaarschrift dient op grond van het eerste lid van dit artikel daarin een verzoek aan het bestuursorgaan te doen om in te stemmen met rechtstreeks beroep op de rechter. Ingevolge het derde, vierde en vijfde lid, dient het bestuursorgaan indien het de zaak 'geschikt' bevindt voor rechtstreeks beroep, dat zo spoedig mogelijk in een beslissing vast te leggen en stuurt het onverwijld het bezwaarschrift door naar de bevoegde rechter. De rechter is vervolgens, op grond van artikel 8:54a van de Awb, bevoegd om het onderzoek te sluiten en het bezwaarschrift terug te zenden naar het bestuursorgaan, indien hij van mening is dat het bestuursorgaan kennelijk ten onrechte heeft ingestemd met het verzoek om rechtstreeks beroep in te stellen. Daarbij dient de rechter marginaal te toetsen of sprake is van een geval waarin kennelijk ten onrechte is ingestemd met het verzoek. ${ }^{45}$ Zelfs indien hij van mening is dat daarvan sprake is, is de rechter niet verplicht om de zaak terug te verwijzen. Artikel 8:54a kent een discretionaire bevoegdheid toe aan de rechter. ${ }^{46}$

Beoogd wordt om met de nieuwe regeling tegemoet te komen aan de bezwaren die in de literatuur en vanuit de praktijk geuit zijn tegen het algemeen verplichte karakter van de bezwaarschriftprocedure, en daarmee samenhangend ook de uniforme regeling van de bezwaarschriftprocedure. ${ }^{47}$ De mogelijkheid om de bezwaarfase over te slaan is vooral bedoeld voor gevallen waarin in de primaire fase reeds een zodanig uitputtende gedachtewisseling heeft plaatsgevonden tussen bestuur en belanghebbende dat de bezwaarschriftprocedure daaraan weinig of niets meer kan toevoegen, terwijl tevens vast-

\footnotetext{
${ }^{41 .}$ PG Awb I, p. 280.

42. Kamerstukken II 2000/01, 27 563, nr. 3, p. 1-3. In de literatuur zijn ook andere geluiden te horen. Sanders meent dat uiteindelijk de verplichte bezwaarschriftprocedure, na afweging van de voor- en nadelen, te verkiezen is boven prorogatie of een enkelvoudig facultatieve bezwaarschriftprocedure, K.H. Sanders, 'De flexibiliteit van een rituele dans', NTB 1999/7, p. 178.

${ }^{43 .}$ Wet van 13 mei 2004, Stb. 2004, nr. 220; KB van 7 juni 2004, Stb. 2004, 270. De regeling van het rechtstreeks beroep op de bestuursrechter is neergelegd in art. 7:1a en 8:54a Awb. Inmiddels is ook de invoeringsevaluatie afgerond en is het evaluatierapport verschenen: B.M.J. van der Meulen e.a., Prorogatie in de Awb. Invoeringesevaluatie rechtstreeks beroep, WODC 2005 (hierna: Rapport Prorogatie in de Awb).

44. Een integrale bespreking van de Wet rechtstreeks beroep en artikel 7:1a Awb wordt achterwege gelaten. Daarvoor verwijs ik onder meer naar de uitvoerige literatuur die naar aanleiding van het wetsvoorstel is verschenen: C.H. Bangma, 'Wet rechtstreeks beroep', Gst. (2004) 7215, p. 549 e.v.; I. Kolhoop, 'Wet rechtstreeks beroep en Wet elektronisch bestuurlijk verkeer', $A A$ 2004/9, p. 664-670; R. Ortlep, 'Rechtstreeks beroep in het bestuursrecht', $A A$ 2004/4, p. 259-263; M.H. Blokvoort, 'Rechtstreeks in beroep bij de administratieve rechter', Gst. (2001) 7139, p 193-198; G.J.M. Cartigny, 'Prorogatie in het bestuursprocesrecht: rechtstreeks beroep op de bestuursrechter', NTB 2001, p. 89-96; A. Weggeman, 'Wetsvoorstel rechtstreeks beroep, NTB 2001/3, p. 85-87; H.M. Breunese \& A. Weggeman, 'Voorontwerp rechtstreeks beroep', NTB 2000/4, p. 113-114.

K5. Kamerstukken I 2003/04, 27 653, nr. B, p. 5 .

46. Zie over het gebruik van de bevoegdheid: Rapport Prorogatie in de Awb, p. 58 e.v.; M.E.G. Litjens, B.M.J. van der Meulen, A.A. Freriks, 'De werking van een controversiële rechtsgang. Invoeringsevaluatie rechtstreeks beroep in de Awb, JB-plus 2006, p. 65-67.

47. Sanders 1999, p. 171. Zie voor kritiek die zich met name richt tot het uniforme karakter van de bezwaarschriftprocedure: Simon 1999b, p. 61.
} 


\section{De bestuurlijke voorprocedures onder de Awb}

staat dat het besluit nog altijd in geschil is. ${ }^{48}$ Het overslaan van de bezwaarfase levert in deze gevallen, aldus de wetgever, aanzienlijke tijdwinst op en voorkomt onnodige lasten voor burger en bestuur. ${ }^{49}$ De Raad van State wijst echter terecht in haar advies op onder meer het feit dat er slechts sprake is van tijdwinst, indien de rechter akkoord gaat met het instellen van rechtstreeks beroep. Indien de rechter van mening is dat het bestuursorgaan kennelijk ten onrechte heeft ingestemd met rechtstreeks beroep, levert de gehele gang van zaken door de terugverwijzing van het bezwaarschrift juist extra vertraging op. De wetgever gaat er echter vanuit dat terugverwijzing slechts incidenteel zal geschieden en het nadeel voor de concrete zaak op de koop toe dient te worden genomen. ${ }^{50}$

\section{De bezwaarschriftprocedure nog onverminderd van belang}

Het feit dat de bezwaarschriftprocedure niet meer zonder meer verplicht wordt voorgeschreven, betekent echter niet dat deze voorprocedure of de daaraan toegekende functies per definitie aan belang hebben ingeboet. De verwachtingen omtrent het gebruikmaken van de mogelijkheid om rechtstreeks beroep te maken liepen uiteen. ${ }^{51}$ Over de toepassing van artikel 7:1a van de Awb en het functioneren van de mogelijkheid om de bezwaarschriftfase over te slaan zijn niet veel gegevens bekend. ${ }^{52}$ Uit de beschikbare gegevens blijkt dat niet op grote schaal van de mogelijkheid om de bezwaarschriftprocedure over te slaan gebruik wordt gemaakt. De in 2005 afgeronde invoeringsevaluatie wijst uit dat slechts in ongeveer 50 zaken rechtstreeks beroep is ingesteld bij de bestuursrechter. ${ }^{53}$ Vooralsnog lijkt het derhalve een gering aantal zaken te betreffen. In het evaluatierapport wordt zelfs het gevaar genoemd dat de prorogatiemogelijkheid een dode letter zal blijken te zijn. ${ }^{54}$ Dat hangt volgens de onderzoekers mede samen met de positieve waardering van de bezwaarschriftprocedure door alle betrokkenen. Het lijkt erop dat het doorlopen van de bezwaarschriftprocedure nog steeds in veel gevallen zinvol wordt geacht. ${ }^{55}$ Dit gegeven is toch enigszins opvallend te noemen gelet op de kritiek naar aanleiding waarvan de invoering van de mogelijkheid om rechtstreeks beroep in te stellen heeft plaatsgevonden. ${ }^{56}$ Aangevoerd werd immers dat het verplicht doorlopen van deze voorprocedure in veel gevallen nu juist geen toegevoegde waarde had. Voorlopig lijkt ook in relatief veel gevallen terugverwijzing door de rechter plaats te vinden. ${ }^{57}$ De vraag rijst dan ook of de boogde tijdwinst wel gerealiseerd wordt in voldoende zaken.

48. Kamerstukken II 2000/01, 27 563, nr. 3, p. 3 .

49. Zie vorige noot. De Raad van State wijst overigens terecht in zijn advies op onder meer het feit dat slechts sprake is van tijdwinst indien de rechter akkoord gaat met het instellen van rechtstreeks beroep. Indien de rechter echter van mening is dat het bestuursorgaan kennelijk ten onrechte heeft ingestemd met rechtstreeks beroep, levert de gehele gang van zaken door de terugverwijzing van het bezwaarschrift juist extra vertraging op. De wetgever stelt zich echter op het standpunt dat terugverwijzing slechts incidenteel zal geschieden en het nadeel voor de concrete zaak op de koop toe dient te worden genomen; Kamerstukken II 2000/01, 27 563, nr. A, p. 2.

${ }^{50 .}$ Kamerstukken II 2000/01, 27563 , nr. A, p. 2-4.

51. Jansen voorspelde dat rechtstreeks beroep, mede gelet op het feit dat de kosten van rechtsbijstand in de bezwaarfase slechts bij uitzondering vergoed worden, een grote vlucht zou kunnen nemen, A.M.L. Jansen, 'Bezwaar, van hoofdregel naar uitzondering', NJB 2000, p. 1748-1749. Sanders daarentegen meende dat bij besluitvorming waar meerdere belanghebbenden zijn betrokken, de mogelijkheid om rechtstreeks beroep in te stellen geringe praktische betekenis zou hebben, K.H. Sanders, 'De flexibiliteit van een rituele dans', NTB 1999/7, p. 176-177.

52. De invoeringsevaluatie bestrijkt immers slechts een periode van een jaar na inwerkingtreding van de wet Aldus ook de onderzoekers die bij hun slotbeschouwing o.m. aantekenen dat het onderzoek in een zeer pril stadium is uitgevoerd, Rapport Prorogatie in de Awb, p. 76.

${ }^{53 .}$ Rapport Prorogatie in de Awb, p. 35 en 66.

54. Rapport Prorogatie in de Awb, p. 75.

55. Rapport Prorogatie in de Awb, p. 76. In het rapport wordt ook ingegaan op de mogelijke redenen die daaraan ten grondslag kunnen liggen.

56. Rapport Prorogatie in de Awb, p. 76. De onderzoekers merken ook op dat 'de mate waarin gebruikt word gemaakt kan worden gezien als de proef op de som wat betreft de kritiek die is geuit op de verplichte bezwaarschriftprocedure in de Awb', Rapport Prorogatie in de Awb, p. 76.

57. Uit de invoeringsevaluatie komt naar voren dat in ongeveer de helft van de gevallen (de voorlopige voorzieningen niet meegerekend) terugwijzing plaatsvindt, Rapport Prorogatie in de Awb, p. 76 en bijlage 5. 
Deel II Bestuurlijke voorprocedures

De onderzoekers waarschuwen ervoor dat de prorogatiemogelijkheid een dode letter zal worden gezien het geringe gebruik dat er tot nog toe van gemaakt wordt. ${ }^{58}$ Het geringe aantal gevallen waarin de prorogatiemogelijkheid vooralsnog is benut zou een indicatie kunnen vormen voor het nut van het bestaan van de bezwaarschriftprocedure. Belangrijker nog is dat de aan de bezwaarschriftprocedure toegekende functies onverminderd gelden in die gevallen waarin tegen een besluit in primo wél deze voorprocedure gevolgd wordt. De bezwaarschriftprocedure is nog steeds de voorprocedure die in de meeste gevallen gevolgd wordt en moet worden. Omdat het uitgangspunt is dat alle indieners van een bezwaarschrift, naast het betrokken bestuursorgaan, dienen in te stemmen met het overslaan van de bezwaarschriftprocedure, is ook de verwachting dat bij besluitvorming waarbij meer belanghebbenden zijn betrokken weinig gebruik kan worden gemaakt van het rechtstreeks instellen van beroep bij de bestuursrechter. ${ }^{59}$ Bij besluitvorming waarbij een groot aantal belanghebbenden is betrokken, wordt echter vaak de (uniforme) openbare voorbereidingsprocedure gehanteerd in de primaire besluitvormingsfase. Dit heeft automatisch, gelet op artikel 7:1, eerste lid, onderdeel d van de Awb, tot gevolg dat geen bezwaarschriftprocedure doorlopen hoeft te worden. ${ }^{60}$ Voor besluiten waarbij meer belanghebbenden betrokken zijn en die procedure niet gevolgd wordt in de primaire besluitvormingsfase, geldt nog steeds de bezwaarschriftprocedure en zal deze veelal ook doorlopen worden. Vooralsnog kan de conclusie zijn dat de bezwaarschriftprocedure niet wezenlijk aan belang lijkt te hebben ingeboet en als voorportaal voor de procedure bij de bestuursrechter nog steeds een belangrijke functie heeft. De vraag naar de voor die procedure geldende eisen en de betekenis in dat kader van de beginselen van behoorlijke rechtspleging blijft daarmee dan ook onverminderd van belang.

\subsection{Recente en toekomstige wijzigingen in de Awb}

In beginsel is het onderzoek in Deel II gericht op de thans in de Awb geregelde voorprocedures. Gebleken is echter uit het voorgaande dat de Awb een wet is die, daargelaten de aanvullingen omdat sprake is van aanbouwwetgeving, gedurende het afgelopen decennium aan tamelijk wat aanpassingen onderhevig is geweest. Die ontwikkeling is nog niet ten einde. Recent is de Awb op enkele, voor dit onderzoek, relevante punten gewijzigd. Er bestaan bovendien op dit moment nog plannen om een aantal wijzigingen in de regeling van de voorprocedures in de Awb door te voeren. In het onderstaande wordt, voor zover van belang voor dit onderzoek, kort ingegaan op de wijzigingen die recent hebben plaatsgevonden of op korte termijn te verwachten zijn.

Verdere versoepeling van de verplichte bezwaarschriftprocedure

Naast de mogelijkheid van rechtstreeks beroep heeft de Wet Uniforme openbare voorbereidingsprocedure ${ }^{61}$, als gevolg waarvan beide openbare voorbereidingsprocedures zijn samengevoegd tot een uniforme procedure die is neergelegd in afdeling 3.4 van de Awb, geleid tot een verdere versoepeling van de verplichte bezwaarschriftprocedure, aldus de wetgever. $^{62}$ Artikel 7:1, eerste lid, onderdeel d van de Awb is gewijzigd in die zin dat na het doorlopen van de uniforme openbare voorbereidingsprocedure geen bezwaarschriftprocedure behoeft te worden gevolgd. Deze wijzigingen in de Awb zijn onderdeel van een pakket van maatregelen dat bedoeld is om de juridisering van het openbaar bestuur tegen te gaan. ${ }^{63}$

\footnotetext{
58. Rapport Prorogatie in de Awb, p. 75.

${ }^{59 .}$ Kamerstukken II 2000/01, 27 563, nr. 3, p. 6; Sanders 1999, 176-177.

${ }^{60 .}$ Kamerstukken II 2000/01, 27 563, nr. 3, p. 6.

${ }^{61 .}$ Deze is, zoals eerder aangegeven, op 1 juli 2005 in werking getreden; Besluit van 22 juni 2005, Stb. 2005, 320.

62. Kamerstukken II 2000/01, 27 563, nr. 3, p. 1.

${ }^{63 .}$ Kamerstukken II 2000/01, 27 563, nr. 3, p. 1; Kamerstukken II 1999/00, 27023, nr. 3, p. 1.
} 
De bestuurlijke voorprocedures onder de Awb

Niet tijdig beslissen door bestuursorganen

Een recente wijziging die genoemd moet worden heeft betrekking op de tijdigheid van de besluitvorming. De tijdigheid van overheidsoptreden in het bestuursrecht is een onderwerp dat de afgelopen jaren volop in de belangstelling staat. ${ }^{64}$ Dat geldt niet alleen voor de termijnen waarbinnen een procedure bij de rechter leidt tot een definitieve beslechting van het rechtsgeschil tussen bestuur en burger, maar ook voor de termijnen waarbinnen besluitvorming plaatsvindt door het bestuur. ${ }^{65}$

In dat kader heeft de Commissie wetgeving algemene regels van het bestuursrecht (hierna: Commissie Scheltema) het voorontwerp direct beroep bij niet tijdig beslissen door bestuursorganen opgesteld. Het wetsvoorstel 'Wet beroep bij niet tijdig beslissen' dat is gebaseerd op het voorontwerp ${ }^{66}$ is op 23 januari 2006 bij de Tweede Kamer ingediend. ${ }^{67}$ Met de regeling wordt beoogd de bescherming van de burger tegen trage besluitvorming te verbeteren door de Awb aan te vullen met een doeltreffender rechtsmiddel tegen het niet tijdig beslissen door bestuursorganen. ${ }^{68}$ De regeling opent de mogelijkheid om tegen het niet tijdig nemen van een besluit door het bestuursorgaan rechtstreeks beroep bij de bestuursrechter in te stellen. De verplichting om in gevallen, waarin het bestuurorgaan niet binnen de voorgeschreven termijn een beslissing neemt, de bezwaarschriftfase te volgen, is gecompliceerd en inefficiënt. ${ }^{69}$ Ook hier blijkt dat het algemeen verplichte karakter van de bezwaarschriftprocedure niet in alle gevallen positief wordt beoordeeld.

Vanuit de Tweede Kamer zijn, met het wetsvoorstel 'Wet dwangsom bij niet tijdig beslissen', eveneens stappen ondernomen om burgers een effectiever rechtsmiddel te geven tegen te trage besluitvorming door het bestuur. ${ }^{70}$ Beide voorstellen beogen een oplossing te bieden voor het probleem van trage besluitvorming door het bestuur en een middel te scheppen om het bestuur aan te sporen tot voortvarende besluitvorming. De voorstellen zijn dan ook samengevoegd tot de Wet rechtstreeks beroep en dwangsom bij niet tijdig beslissen. ${ }^{71}$ Deze wet is op 1 oktober 2009 in werking getreden. ${ }^{72}$ De wet bevat - naast de mogelijkheid van rechtstreeks beroep - een uitbreiding van de Awb met een

\footnotetext{
64. Kamerstukken II 1997/98, 25600 VI, nr. 46, p. 20 (kabinetsstandpunt evaluatie Awb I); Kamerstukken II 1998/99, 26 360, nr. 1, p. 19-21 (kabinetsstandpunt juridisering openbaar bestuur); Kamerstukken II, 2000/01, 27 461, nr. 1 (Nota termijnen voor bestuur en rechter); Rapport Algemene Rekenkamer, 'Beslistermijnen. Waar blijft de tijd?, Kamerstukken II 2003/04, 29 495, nrs. 1-2. Scheltema wees overigens in 1994 al op het belang van tijdige besluitvorming door het bestuur, M. Scheltema, 'De rechter en de bezwaarschriftprocedure: meer aandacht voor snelheid en minder voor aansprakelijkheid', in: T. Hoogenboom \& L.J.A. Damen (red.), In de sfeer van administratief recht, Utrecht: Lemma p. 379-392. Zie verder over dit onderwerp par. 5.7.

65. Kamerstukken II 2001/01, 27 461, nr.1, p. 2. In deze nota 'Termijnen voor bestuur en rechter' wordt aangegeven dat de besluitvorming binnen een redelijke termijn onderdeel uitmakt van het rechtszekerheidbeginsel. In dezelfde zin: M. Scheltema, 'Het tijdigheidsbeginsel', in: De Awb-mens; boeman of underdog? (Opstellen aangeboden aan Leo Damen), Nijmegen: Ars Aequi libri 1996, p. 246. Scheltema geeft overigens aan dat er niet zo iets bestaat als een tijdigheidsbeginsel. Hij acht het wenselijk dat, in verband met de rechtzekerheid van de burger, aan regels over het tijdstip waarop beslissingen worden genomen een meer fundamentele betekenis wordt toegekend.

66. Voor een bespreking van het voorontwerp verwijs ik naar R.J. van Dam \& R.J.N. Schlössels, 'Het voorontwerp Wet beroep bij niet tijdig beslissen', $N J B$ 2002, p. 2137-2142.

${ }^{67 .}$ Kamerstukken II 2005/06, 30435 , nrs. 2, 3 en 4.

${ }^{68 .}$ Kamerstukken II 2005/06, 30 435, nr. 3, p. 1.

69. Kamerstukken II 2005/06, 30 435, nr. 3, p. 2 en 9. Zie ook: Verheij 2008, p. 229-230; Koenraad \& Sanders 2006, p. 146; Saris 2006, p. 63; Marseille 2005, p. 10; Van Dam \& Schlössels 2002, p. 2137-2138; Jansen 2003, p. 1756.

70. Enkele leden hebben een initiatiefwetsvoorstel opgesteld dat beoogt het bestuur met het opleggen van een dwangsom bij niet-naleving van de wettelijk voorgeschreven termijnen te sanctioneren: Kamerstukken II 2004/05, 29 934, nr. 6, p. 1. Voor een uitvoerigere bespreking van het wetsvoorstel verwijs ik naar: A.T. Marseille, 'Het niet op tijd beslissende bestuur', Openbaar Bestuur 2005, p. 9-12; R.J. van Dam \& R.J.N. Schlössels, 'Het wetsvoorstel Wet dwangsom bij niet tijdig beslissen. Enkele kritische kanttekeningen', Gst. (2005) afl. 7232, p. 359-363; J. Bootsma \& E.J. Daalder, 'Kroniek van het algemeen bestuursrecht. All the news that is fit to print', $N J B$ 2005/31, p. 1623.

71. Zie gewijzigd amendement- Fierens en Van Schijndel, Kamerstukken II, 2005/06, 29 934, nr. 16.

72. Wet van 28 augustus 2009, Stb. 2009, 383.
} 
Deel II Bestuurlijke voorprocedures

dwangsomregeling die opgenomen dient te worden in afdeling 4.1.3 van de Awb. Indien een bestuursorgaan niet tijdig op een aanvraag een beschikking neemt of niet tijdig een besluit op bezwaar neemt, dient de aanvrager/bezwaarmaker het bestuur dienaangaande schriftelijk in gebreke te stellen. ${ }^{73}$ Indien het bestuur vervolgens nalaat om binnen twee weken na ontvangst van de ingebrekestelling alsnog een besluit te nemen, verbeurt het per dag dat het daartoe ingebreke blijft een dwangsom. ${ }^{74}$ De regeling beoogt op deze wijze een financiële prikkel te scheppen voor het bestuur om tijdig dan wel zo spoedig mogelijk een besluit te nemen. ${ }^{75}$ Tot slot zijn enkele beslistermijnen in de Awb en bijzondere wetgeving opnieuw tegen het licht gehouden en aangepast. ${ }^{76}$ Op deze regeling wordt in hoofdstuk 5, paragraaf 5.7 nader ingegaan.

\section{Aanpassing bestuursprocesrecht}

Een andere relevante ontwikkeling op het terrein van het bestuursprocesrecht vormt het wetsvoorstel voor een Wet aanpassing bestuursprocesrecht. ${ }^{77}$ Het wetsvoorstel voorziet in een aanzienlijk aantal wijzigingen en aanvullingen van de Awb. De wijzigingen dienen in het bijzonder de effectieve geschilbeslechting te bevorderen en de toegankelijkheid van de wetgeving te verbeteren door het bestuursprocesrecht zo veel mogelijk te concentreren in de Awb. ${ }^{78}$ In het bijzonder drie beoogde wijzigingen zijn relevant voor dit onderzoek: de verruiming van de uitzonderingen op de hoorplicht in bezwaar, de bestuurlijke lus en de verruiming van de mogelijkheid om gebreken in de besluitvorming te passeren met toepassing van artikel 6:22 Awb.

Oorspronkelijk was een bestuurlijke lus voorzien die eruit zou bestaan dat de bestuursrechter bij een tussenuitspraak het bestuursorgaan in de gelegenheid kan stellen om de gebreken die aan het besluit kleven binnen een bepaalde termijn te herstellen. Ook dit voorstel is ingehaald door een initiatief van een aantal leden van de Tweede Kamer die een aanvulling van de Awb wensen met een regeling van een bestuurlijke lus. ${ }^{79}$ Die wet bestuurlijke lus Awb is op 1 januari 2010 inwerkinggetreden. ${ }^{80}$ Verder is een aanvullende grond waarop kan worden afgezien van het horen in de bezwaarschriftprocedure voorzien in artikel 7:3 Awb. Indien een belanghebbende niet binnen een redelijke termijn aangegeven heeft er prijs op te stellen gehoord te worden, kan het bestuursorgaan daarvan afzien. Tot slot wil het voorstel bewerkstelligen dat gebreken in de besluitvorming eerder gepasseerd kunnen worden met toepassing van artikel 6:22 Awb. Het artikel wordt zo gewijzigd dat ook materiële gebreken niet tot een vernietiging behoeven te leiden, indien belanghebbenden door de gebreken niet worden benadeeld. ${ }^{81}$ Uiteraard voorziet het concept-wetsvoorstel in nog meer belangrijke wijzigingen en aanvullingen, maar deze komen in dit onderzoek niet nader aan de orde. ${ }^{82}$ Omdat het wetsvoorstel aanpassing bestuursprocesrecht nog niet was ingediend bij de Tweede Kamer op het moment van schrijven en nog niet in werking is getreden, wordt aan de daarmee beoogde wijzigingen niet uitvoerig aandacht besteed in dit onderzoek. In de paragraaf over de hoorplicht in de bestuurlijke voorprocedures (paragraaf 5.3.2.2) en in de slotbeschou-

\footnotetext{
73. Zie hierover: Marseille 2005, p. 10.

74. Kamerstukken II 2004/05, 29 934, nr. 6, p. 7; Marseille 2005, p. 10.

${ }^{75 .}$ Kamerstukken II 2004/05, 29 934, nr. 6, p. 7.

76. Kamerstukken II, 2008/09, 31 751, nr. 1-4. De Eerste Kamer heeft dit wetsvoorstel aangenomen op 16 juni 2009 en de wet is in werking getreden op 1 oktober 2009, Wet van 18 juni 2009, Stb. 384.

77. Kamerstukken II 2009/10, 32 450, nr. 1-3. De Raad van State heeft op 31 oktober 2008 advies uitgebracht en het voorstel is op 24 juli 2010 ingediend bij de Tweede Kamer.

78. MvT bij het conceptvoorstel, p. 2.

79. Initiatiefvoorstel van de Kamerleden Vermeij/Koopmans/Nepperus, Kamerstukken II 2008/09, 31 352, nr. 1-3;

Kamerstukken I 2008/09, 31 352, nr. A. Wet van 14 december 2009, Stb. 2009, 570.

${ }^{80 .}$ KB 21 december 2009, Stb. 2009, 597.

81. De bevoegdheid voor de bestuursrechter om het besluit in stand te laten en de gebreken te passeren (die inhoudelijk overeenkomt met art. 6:22 Awb) wordt voorzien in art. 8:72 lid $5 \mathrm{Awb}$.

${ }^{82}$. Zie voor een bespreking van het concept-voorstel: W. Konijnenbelt, E.J. Daalder, S.E. Zijlstra, R.J.N. Schlössels, A. Weggeman, N.S.J. Koeman, 'Herziening bestuursprocesrecht ter tafel', NTB 2006, p. 259 e.v.
} 
wingen in Deel III wordt op het wetsvoorstel voor zover relevant voor dit onderzoek ingegaan.

\section{Crisis- en herstelwet}

Last but not least is vlak voor het afronden van dit proefschrift nog de Crisis- en herstelwet door de regering ingediend bij beide Kamers en uiteindelijk op 31 maart 2010 door de Eerste Kamer aangenomen. ${ }^{83}$ Ook die wet is de moeite waard om te noemen, vanwege allerlei wijzigingen in of afwijkingen ten opzichte van de toepasselijke procesrechtelijke bepalingen uit de Awb die worden aangebracht. Doel daarvan is een versnelling van besluitvormingsprocedures in grote infrastructrurele projecten en bouwprojecten te realiseren. ${ }^{84}$ Een deel van de wijzigingen en maatregelen bevindt zich echter in het spanningsveld tussen voortvarende en effeciënte geschilbeslechting en besluitvorming enerzijds en de zorgvuldigheid van de besluitvorming en behoorlijke rechtsbescherming anderzijds. Om die reden kunnen bepaalde wijzigingen interessant zijn voor dit onderzoek. Zo is voor dit onderzoek bijvoorbeeld de verruiming van de mogelijkheid tot het herstellen van gebreken in de besluitvorming die is neergelegd in artikel 1.5 Crisis- en herstelwet van belang. Die bepaling maakt het voor de bestuursrechter mogelijk om niet alleen schendingen van vormvoorschriften te passeren, zoals thans neergelegd in artikel 6:22 Awb, maar ook materiële gebreken te passeren. Voorts wordt in artikel 1.9 een relativiteitsvereiste geïntroduceerd, waaruit volgt dat een besluit uitsluitend vernietigd wordt wegens strijd met een geschreven of ongeschreven rechtsregel of algemeen rechtsbeginsel, indien deze regel of dit beginsel kennelijk niet strekt tot bescherming van de belangen van degene die zich daarop beroept. ${ }^{85}$ Voor de gevolgen die verbonden worden aan schendingen van de beginselen van behoorlijke rechtspleging of behoorlijk bestuur en uitwerkingen daarvan en daarmee voor de betekenis van deze eisen kunnen deze bepalingen van belang worden. Gelet op het tijdstip van inwerkingtreding van deze wet kon echter aan de wet en de implicaties ervan voor dit onderzoek niet uitvoerig meer aandacht worden besteed. De Crisis- en herstelwet en de daaruit voortvloeiende wijzigingen komen echter in Deel III in het kader van de slotbeschouwingen kort aan de orde.

\footnotetext{
${ }^{83}$ Wet van 18 maart 2010, Stb. 2010, 135 (Crisis- en herstelwet) in werking getreden op 31 maart 2010, Stb. 2010, 137; Kamerstukken II 2009/10, 32 127, nr. 1-3; Kamerstukken I 2009/10, 32 127, nr. A.

84. Kamerstukken II, 32 127, nr. 3, p. 2.

85. Zie de toelichting van de wetgever op deze bepalingen, Kamerstukken II 2009/10, 32 127, nr. 3, p. 45-51.
} 



\section{Onderzoeksvragen}

In dit deel van het onderzoek moet vastgesteld worden welke eisen gelden voor de inrichting van de bestuurlijke voorprocedures en in hoeverre daarop invloed van de onderscheiden beginselen van behoorlijke rechtspleging merkbaar is. Om dat vast te kunnen stellen worden voor iedere voorprocedure de geldende eisen in kaart gebracht gerelateerd aan de onderscheiden beginselen van behoorlijke rechtspleging. Dat betekent dat de gelding van het onpartijdigheidsbeginsel, het beginsel van hoor en wederhoor, het openbaarheidsbeginsel, het motiveringsbeginsel en het beginsel van de redelijke termijn in afzonderlijke hoofdstukken voor de bestuurlijke voorprocedures onderzocht worden. In het kader daarvan komen ook equivalente eisen van behoorlijk bestuur aan bod. Vervolgens wordt bezien in hoeverre de voor rechtspleging geldende beginselen van invloed zijn (geweest) op de voor de bestuurlijke voorprocedures. Daartoe worden de ratio van de voor het bestuur geldende eisen in kaart gebracht en vergeleken met de ratio van de voor de (bestuurs)rechter geldende eisen. Tevens worden met het oog daarop de concrete inrichtingseisen die voortvloeien uit de verschillende beginselen die gelden voor het bestuur aan een onderzoek onderworpen.

De onderzoeksvragen die in dit deel van het onderzoek onderzocht worden kunnen onderverdeeld worden in drie deelvragen. Om de verwantschap of verschillen met rechtspraak te kunnen bepalen en ook om te kunnen bepalen in hoeverre deze gevolgen moeten hebben voor de eisen ten aanzien van de inrichting van de bestuurlijke voorprocedures, wordt eerst onderzocht welke functies aan deze procedures toekomen. Vervolgens wordt onderzocht wat de aard en omvang is van de werkzaamheid van het bestuur in die procedures en in hoeverre deze verschilt van de werkzaamheid van de bestuursrechter. De derde deelvraag vormt vervolgens de kern van het onderzoek en ziet op de eisen die gesteld worden aan de inrichting van de procedure.

Op basis van het voorgaande kom ik tot de volgende onderzoeksvragen die in dit deel beantwoord moeten worden:

- Welke functies worden aan de bestuurlijke voorprocedures, in het bijzonder de bezwaarschriftprocedure toegeschreven? In hoeverre zijn de bestuurlijke voorprocedures een vorm van rechtsbescherming?

- Waaruit bestaat de herbeoordeling door het bestuur in het kader van de bestuurlijke voorprocedures, in het bijzonder de bezwaarschriftprocedure, en in hoeverre vertoont deze gelijkenis met de toetsing door de bestuursrechter in een rechterlijke procedure?

Doel van het onderzoek in het kader van deze eerste vragen is, zoals gezegd, vast te stellen in hoeverre de functies of aard van de desbetreffende procedures aanleiding vormen om aan te nemen dat er aan de desbetreffende procedures vergelijkbare of verschillende eisen als aan (bestuurs)rechtspraak gesteld moeten worden. $\mathrm{Na}$ een conclusie te hebben getrokken naar aanleiding van de bevindingen in dit verband, vindt beantwoording van de laatste deelvraag plaats:

- Welke vereisten gelden voor de inrichting van deze procedures en in hoeverre komt de invloed van de beginselen van behoorlijke rechtspleging tot uitdrukking in die eisen?

Doel van het onderzoek in het kader van de laatste vraag is een vergelijking te maken tussen de vereisten die gelden voor de inrichting van de bestuurlijke voorprocedures en de procedure bij de bestuursrechter. Daarmee kan de doorwerking van de beginselen van behoorlijke rechtspleging in de bestuurlijke voorprocedures vastgesteld worden. 



\section{Opbouw}

De opbouw van dit deel van het onderzoek loopt parallel aan de hierboven geformuleerde onderzoeksvragen. Dat betekent dat Deel II bestaat uit verschillende hoofdstukken die uiteenvallen in drie onderdelen die uiteraard met elkaar samenhangen. In de navolgende hoofdstukken worden de onderscheiden voorprocedures gekarakteriseerd aan de hand van de verschillende functies die daaraan worden toegekend, de aard een omvang van de bestuurlijke werkzaamheid in deze procedures en (een aantal aspecten van) de inrichting van de betreffende voorprocedure. Er is voor gekozen de functies van de bestuurlijke voorprocedures en de aard en omvang van de herbeoordeling door het bestuur gezamenlijk in hoofdstuk 4 te behandelen. Dat hoofdstuk valt derhalve uiteen in twee onderdelen. In hoofdstuk 5 komt vervolgens het laatste onderdeel de inrichting van de bestuurlijke voorprocedures aan de orde. De methode van onderzoek die gehanteerd wordt, is voor de drie onderdelen grotendeels hetzelfde en wordt hieronder toegelicht.

\section{Functies}

Teneinde de functies van de verschillende bestuurlijke voorprocedures in kaart te brengen vindt allereerst in hoofdstuk 4, paragraaf 4.2, een korte weergave van de relevante bepalingen uit de Awb en de parlementaire geschiedenis plaats alsmede de in dat kader reeds verschenen onderzoeken en literatuur. ${ }^{1}$ Er wordt, voor zover van belang, een onderscheid gemaakt tussen verschillende typen van bestuursbevoegdheden die ten grondslag liggen aan de primaire besluitvorming. De mate waarin een functie aanwezig is in een bestuurlijke voorprocedure kan verschillen al naar gelang sprake is van een meer gebonden dan wel een meer discretionaire (uitoefening van) bestuursbevoegdheid. ${ }^{2} \mathrm{Ju}-$ risprudentie-onderzoek vindt in dit onderdeel niet of nauwelijks plaats, aangezien in de uitspraken van de bestuursrechter de verschillende functies van de voorprocedures als zodanig niet regelmatig expliciet aan de orde komen. In een enkel geval wordt er ter adstructie of illustratie gewezen op uitspraken van de bestuursrechter(s).

\section{Aard en omvang van de bestuurlijke herbeoordeling}

De hierboven omschreven werkwijze voor het vaststellen van de functies van de bezwaarschriftprocedure en het administratief beroep wordt in paragraaf 4.3 van hoofdstuk 4 eveneens gehanteerd bij het onderzoek naar de omvang en aard van de herbeoordeling die plaatsvindt in de verschillende voorprocedures. Op deze wijze wordt aan de hand van de bepalingen in de Awb, de parlementaire geschiedenis en de literatuur getracht de werkzaamheid van het bestuur in de verschillende voorprocedures vast te stellen. Wel wordt bij het onderzoek naar de herbeoordeling, meer dan het geval is bij de functies van de voorprocedures, relevante jurisprudentie betrokken. De bestuursrechter heeft zich immers regelmatig uitgelaten over de omvang van de heroverweging en de strekking van de desbetreffende bepalingen in de Awb. Ook ten aanzien van deze onderwerpen vervult de jurisprudentie van de bestuursrechter in dit onderzoek slechts een adstruerende rol. In paragraaf 4.4 wordt tenslotte naar aanleiding van de bevindingen inzake de functies en aard van de herbeoordeling ingegaan op de vraag in hoeverre de bestuurlijke voorprocedures als rechtsbescherming of verlengde besluitvorming kunnen worden gekarakteriseerd.

\footnotetext{
1. $\mathrm{Nu}$ reeds een aantal onderzoeken heeft plaatsgevonden naar met name de bezwaarschriftprocedure en de functies van deze voorprocedure, wordt hier in belangrijke mate op deze onderzoeksresultaten voortgebouwd.

2. Zie onder meer: Verslag evaluatie Awb I, p. 28-29 en 44-45; Sanders 1998, p. 23-24.
} 
Deel II Bestuurlijke voorprocedures

Inrichting

Het derde onderdeel betreft de inrichting van de verschillende voorprocedures. De geldende eisen, op grond van de relevante nationale wettelijke voorschriften, literatuur en jurisprudentie, voor die inrichting worden in kaart gebracht in hoofdstuk 5. Daarbij vindt een beperking plaats tot de volgende eisen: het beginsel van hoor en wederhoor (paragraaf 5.3), de onafhankelijkheidseis en het onpartijdigheidsbeginsel (paragraaf 5.4), het openbaarheidsbeginsel (paragraaf 5.5), het motiveringsbeginsel (paragraaf 5.6) en tijdige besluitvorming (paragraaf 5.7). In de laatste paragraaf 5.8 worden enkele conclusies getrokken naar aanleiding van de uitkomsten van het onderzoek. De hiervoor genoemde elementen omvatten waarborgen die, ter bescherming van de burger, beogen de herbeoordeling in het kader van die procedures op behoorlijke en zorgvuldige wijze te laten geschieden. Het onderzoek is toegespitst op deze aspecten van de inrichting van de bezwaarschriftprocedure omdat deze of gelijksoortige aspecten, als vereisten voor behoorlijke rechtspleging, ook in het kader van rechtspraak gesteld worden en derhalve onderzocht werden in Deel I. Bovendien omvat het onderzoek op deze wijze de essentiële elementen in de inrichting van deze voorprocedures en de voorschriften in de Awb die sterke gelijkenis vertonen met de regels die gelden voor rechtspraak. ${ }^{3}$ Het doel is de vereisten die gesteld worden aan de inrichting van de verschillende voorprocedures eenduidig vast te stellen, zodat na vergelijking de verschillen of overeenkomsten en daardoor de effecten van de waarborgen voor de rechterlijke procedure op deze vereisten blootgelegd kunnen worden.

In tegenstelling tot de vorige twee onderdelen zal het onderzoek in het kader van de inrichting van de verschillende procedures veeleer bestaan uit jurisprudentie-onderzoek. Hoewel literatuuronderzoek zeker plaatsvindt, zal de jurisprudentie van de verschillende bestuursrechters in dit kader een belangrijke kenbron zijn om de geldende vereisten te achterhalen. Daarbij is niet alleen de nationaalrechtelijke jurisprudentie van belang, maar ook ten aanzien van bepaalde onderdelen de jurisprudentie van het EHRM. Zoals in de inleiding al naar voren is gekomen vallen de bestuurlijke voorprocedures binnen het bereik van bepaalde vereisten die het EHRM stelt aan procedures betreffende de vaststelling van een 'civil rights and obligations' dan wel een 'criminal charge' op grond van artikel 6 EVRM. Voor zover uit de jurisprudentie van het EHRM eisen kunnen worden afgeleid voor de inrichting van bestuurlijke voorprocedures worden deze bij de afzonderlijke onderdelen behandeld.

\footnotetext{
3. Zie ook: Versteden 1995 , p. 290. Versteden merkt op dat bezwaar ook bestaat uit judiciële componenten: procedurele voorschriften die een behoorlijke rechtsgang moeten waarborgen en gelijkenis vertonen met regels die rechtspraak eigen zijn. Daartoe rekent hij de bepalingen over het horen met het principe van hoor en wederhoor, beperkingen ten aanzien van het horen door personen die bij de primaire besluitvorming betrokken waren en het principe van openbaarheid van het horen, de regels ten aanzien van het meebrengen van getuigen en deskundigen, de contradictoire werkwijze van de adviescommissie en de beperking ten aanzien van het contrair gaan door het beslissend orgaan ten opzichte van een commissie-advies. In dit onderzoek worden grotendeels dezelfde bepalingen onderzocht, zie nader hfst. 5 van dit deel van het onderzoek.
} 


\section{De bezwaarschriftprocedure en het administratief beroep}

\subsection{Inleiding}

\subsubsection{De klassieke voorprocedures}

Zowel de bezwaarschriftprocedure als het administratief beroep wordt in de doctrine beschouwd als bestuurlijke voorprocedure. ${ }^{1}$ In beide gevallen is sprake van een procedure waarin een herbeoordeling van een besluit door een bestuursorgaan plaatsvindt, welke herbeoordeling verplicht is alvorens de toegang tot de (bestuurs)rechter openstaat. Deze procedures kunnen vanzelfsprekend ook gekwalificeerd worden als bestuurlijke voorprocedures in de zin van dit onderzoek op basis van de eerder gegeven begripsomschrijving. Eerder werd immers vastgesteld dat slechts sprake is van een bestuurlijke voorprocedure, indien het een procedure betreft: 1) die verplicht voorafgaat aan een procedure bij een (bestuurs)rechterlijke instantie, 2) waarin een (her)beoordeling door een bestuursorgaan van een primair besluit plaatsvindt, 3) naar aanleiding van zienswijzen, bedenkingen, beroepsgronden of bezwaren daartegen van een of meer belanghebbende burgers, en 4) die leidt tot een (in beginsel) definitieve bestuurlijke vaststelling van de rechtspositie van de bij dat besluit betrokken belanghebbende burgers. De kwalificatie van de bezwaarschriftprocedure en het administratief beroep als bestuurlijke voorprocedure ligt, gelet op de elementen in deze begripsomschrijving, voor de hand. Iedere bezwaarschriftprocedure en iedere procedure in administratief beroep zal, op grond van de bepalingen in de Awb, aan deze elementen voldoen. ${ }^{2}$

Niet alleen worden de bezwaarschriftprocedure en het administratief beroep aangemerkt als bestuurlijke voorprocedure, beide procedures maken ook onderdeel uit van het stelsel van rechtsbescherming tegen de overheid. ${ }^{3}$ De VAR-Commissie Rechtsbescherming rekent beide procedures tot de klassieke vormen van rechtsbescherming. ${ }^{4}$ Hoewel van oudsher het administratief beroep een belangrijkere positie heeft ingenomen in dit stelsel van rechtsbescherming en zelfs gezien werd als alternatief voor een beroep op de onafhankelijke rechter, is deze dominante positie langzaamaan veranderd. ${ }^{5}$ Thans vormt de bezwaarschriftprocedure het uitgangspunt en dient het administratief beroep bij uitzondering nog doorlopen te worden. Om die reden wordt aan het administratief beroep in beginsel slechts afzonderlijk aandacht besteed voor zover deze voorprocedure afwijkt van de bezwaarschriftprocedure. Daar waar in het navolgende de bezwaarschriftprocedure wordt beschreven, moet derhalve ook administratief beroep gelezen worden, tenzij anders wordt aangegeven. Het ligt ook in de rede het onderzoek naar beide voorprocedures te integreren, nu de regelingen inzake de bezwaarschriftprocedure en het administratief beroep in de Awb grotendeels overeenstemmen en onnodige herhaling daardoor kan worden voorkomen.

\footnotetext{
${ }^{1 .}$ In Van Wijk/Konijnenbelt \& Van Male wordt bijvoorbeeld aangegeven dat er slechts twee bestuurlijke voorprocedures bestaan, de bezwaarschriftprocedure en administratief beroep, Van Wijk/Konijnenbelt \& Van Male 2008, p. 543. Zie ook: Rapport Commissie Rechtsbescherming 2004, p. 15.

${ }^{2 .}$ De begripsomschrijving stelt overigens niet als voorwaarde dat mondeling op een hoorzitting de standpunten tegen een besluit naar voren worden gebracht, waardoor de gevallen waarin in de procedure is afgezien van het mondeling horen van belanghebbenden ook binnen het bereik van de omschrijving en dit onderzoek komen. Voor het administratief beroep geldt in principe hetzelfde. In de omschrijving of definitie zijn derhalve geen eisen aan de inrichting van de procedure opgenomen.

3. Van Wijk/Konijnenbelt \& Van Male 2008, p. 517 en 521.

4. Rapport VAR-Commissie Rechtsbescherming 2004, p. 15.

5. Rapport VAR-Commissie Rechtsbescherming 2004, p. 153; F.A.M. Stroink, Kern van de bestuursrechtspraak, Den Haag: Elsevier 2004 (hierna: Stroink 2004a), p. 99. Op die ontwikkeling wordt hier niet nader ingegaan.
} 
Deel II Bestuurlijke voorprocedures

\subsubsection{Voorvragen}

De verwantschap met (bestuurs)rechtspraak vormt, zoals aangegeven, een van de redenen waarom in dit onderzoek de betekenis van de beginselen van behoorlijke rechtspleging voor de bezwaarschriftprocedure en het administratief beroep wordt onderzocht. Alvorens de inrichting van die procedures en de voor die procedures geldende eisen in kaart worden gebracht, wordt in paragrafen 4.2 en 4.3 aandacht besteed aan de functies van die procedures en de aard en omvang van de heroverweging in die procedures. Doel daarvan is de omvang van de verschillen en overeenkomsten tussen de voorprocedures en de procedure bij de bestuursrechter vast te stellen. De verschillen en overeenkomsten bestaan op het vlak van de werkzaamheid van beide organen en de functies van de bij hen gevoerde procedures. In de doctrine en rechtspraak vormen de traditionele verschillen tussen bestuur en rechtspraak vaak een reden om toepasselijkheid van andersoortige eisen aan te nemen. ${ }^{6}$ Aangenomen wordt dat die traditionele verschillen bestaan en in het verlengde daarvan worden die verschillen vervolgens aangegrepen om andere vereisten te laten gelden voor bestuur en rechtspraak. Op die benadering als zodanig valt wel wat af te dingen, nu de bestuurlijke voorprocedures zich tussen de primaire besluitvormingsfase en de procedure bij de bestuursrechter bevinden. ${ }^{7}$ Die benadering gaat uit van de verschillen, terwijl het even gerechtvaardigd lijkt om uit te gaan van de overeenkomsten. Als echter, afgezien daarvan, blijkt dat de traditionele verschillen niet zo omvangrijk zijn als wordt aangenomen, is er ook in die benadering minder reden om toepasselijkheid van de beginselen van behoorlijke rechtspleging uit te sluiten. Bovendien zou uit het onderzoek kunnen blijken dat ten onrechte een verband gelegd wordt tussen die traditionele kenmerken van bestuur en rechtspraak en de respectieve toepasselijke behoorlijkheidseisen. Voordat de inrichting van de bezwaarschriftprocedure en het administratief beroep aan de orde komen, worden derhalve eerst enkele voorvragen inzake de verschillen en overeenkomsten tussen de bestuurlijke voorprocedures en bestuursrechtspraak beantwoord.

\subsubsection{Opbouw}

De opbouw van hoofdstuk 4 inzake de bezwaarschriftprocedure en administratief beroep is als volgt. In paragraaf 4.2, in het bijzonder 4.2.1 tot en met 4.2.5, worden de verschillende functies van de bezwaarschriftprocedure beknopt weergegeven. In paragraaf 4.2.6 wordt ingegaan op de functies van het administratief beroep, omdat deze op een enkel punt afwijken van de functies van de bezwaarschriftprocedure. In paragraaf 4.2.7 worden de conclusies inzake de functies van de bestuurlijke voorprocedures samengevat. Paragraaf 4.3 is vervolgens gewijd aan de heroverwegingsplicht, zoals neergelegd in artikel 7:11 en 7:28 van de Awb, en het ex nunc-karakter van die heroverweging. ${ }^{8}$ Voordat met

\footnotetext{
6. Zie hierover par. 2.3 van Deel I.

7. Vgl. Scheltema die aangeeft dat de voorprocedures zich wat betreft de geldende waarborgen tussen de primaire besluitvorming en rechtspraak in bevinden, Scheltema 1994, p. 380-381. Zo ook de wetgever, PG Awb I, p. 107. Zoals eerder aangegeven in hfst. 1 van Deel I, blijkt die bedoeling ook uit de omstandigheid dat hoofdstuk 3 van de Awb - dat ziet op de algemene bepalingen ten aanzien van besluiten - ook van toepassing is in bezwaar, voor zover deze bepalingen niet zijn uitgezonderd in artikel 7:14 Awb, én dat hoofdstuk 6 en 7 Awb nog aanvullende andere voorschriften voor die procedure (en de procedure bij de rechter) bevat die niet gelden voor de primaire besluitvormingsfase. Hoofdstuk 8 bevat vervolgens weer voorschriften uitsluitend voor de rechterlijke procedure.

${ }^{8}$. De feitenvaststelling door het bestuur komt in deze paragraaf niet nader aan de orde. Dit onderdeel van de werkzaamheid van het bestuur wordt buiten beschouwing gelaten, omdat er geen noodzaak bestaat een vergelijking in dat verband met de rechterlijke werkzaamheid te maken ten behoeve van de vraag naar doorwerking van de beginselen van behoorlijke rechtspleging. De verschillen in de bevoegdheden van het bestuur en de bestuursrechter tot het vaststellen van de feiten zijn ook niet dermate groot dat afzonderlijke bespreking daarvan gerechtvaardigd is. Zie over de feitenvaststelling door de bestuursrechter: T. Barkhuysen, L.J.A. Damen, K.J. de Graaf,
} 
De bezwaarschriftprocedure en het administratief beroep

de inrichting van de procedures wordt aangevangen in hoofdstuk 5, bevat paragraaf 4.4 tot slot nog conclusies en een korte samenvatting van de bevindingen uit de voorgaande paragrafen.

\subsection{Functies van de bezwaarschriftprocedure}

\subsubsection{Inleiding}

Aan de bezwaarschriftprocedure worden door de wetgever verschillende functies toegekend. Deze functies worden tevens algemeen erkend in de literatuur en komen naar voren in verschillende onderzoeken die verricht zijn naar het functioneren van de bezwaarschriftprocedure. ${ }^{9}$ In beginsel worden vier functies onderscheiden: de rechtsbeschermingsfunctie, de filterfunctie, de leerfunctie en de verduidelijkingsfunctie. ${ }^{10}$ Deze functies hebben de reden gevormd voor de algemene verplichtstelling van een bestuurlijke voorprocedure in de Awb, meer in het bijzonder de bezwaarschriftprocedure. ${ }^{11}$

De bezwaarschriftprocedure vormt, althans zo luidt thans het algemene standpunt, een combinatie van verlengde besluitvorming en rechtsbescherming. ${ }^{12}$ In de visie van de Awb-wetgever biedt de bezwaarschriftprocedure juist dóór verlengde besluitvorming rechtsbescherming aan de burger. ${ }^{13}$ Doordat de bezwaarschriftprocedure zowel bestuurlijke als judiciële ${ }^{14}$ elementen in zich draagt, heeft deze voorprocedure - naar algemeen wordt aangenomen - een tweeledig of zelfs tweeslachtig karakter. ${ }^{15}$ In de verschillende functies van de bezwaarschriftprocedure komt die tweeledigheid ook tot uitdrukking. Hoewel in algemene zin de bovenstaande vier functies kunnen worden onderscheiden, kan de mate waarin de bezwaarschriftprocedure in een specifiek geval gekenmerkt wordt door deze functies, afhankelijk van een aantal factoren, verschillen. Daarbij valt onder meer te denken aan het soort bestuursbevoegdheid waarvan de uitoefening in bezwaar in geschil is. Bovendien is uit verschillende onderzoeken gebleken dat niet elke functie die deze voorprocedure verondersteld wordt te hebben, in de praktijk optimaal gerealiseerd wordt. ${ }^{16}$ Niettemin wordt elk van deze functies, in meer of mindere mate, toegeschreven aan de bezwaarschriftprocedure. Hierna wordt afzonderlijk op elke functie van de bezwaarschriftprocedure ingegaan. In het onderstaande wordt grotendeels voortgebouwd op de resultaten van de onderzoeken die de afgelopen jaren hebben plaatsgevonden naar het functioneren van de Awb en de bezwaarschriftprocedure in het bijzonder. De bevin-

A.T. Marseille, W. den Ouden, Y.E. Schuurmans, A. Tollenaar, Feitenvaststelling in beroep (Evaluatie Awb III), Den Haag: BJu 2007.

9. PG Awb I, p. 279; Verslag evaluatie Awb I, p 44 e.v.; Van Wijk/Konijnenbelt \& Van Male 2008, p. 544-545; Notten 1998, p. 340; R.M. van Male, 'Bezwaar in de Algemene wet bestuursrecht. Van maakwerk tot maatwerk?', in: Capra jubileum-symposium, Awb en ambtenarenrecht; progressie of regressie?, Elsevier 1998, $\mathrm{p}$. 27-29; Scheltema 1994, p. 380.

${ }^{10 .}$ De omschrijving en typering van de verschillende functies zijn grotendeels ontleend aan: Sanders 1998, p. $71-$ 85. Zie verder voor min of meer vergelijkbare onderscheidingen: Van Wijk/Konijnenbelt 2008, p. 544-545; Notten 1998, p. 340; Verslag Evaluatie Awb I, p. 44; R.M. van Male, 'Een onsje minder stroperigheid kan!', NTB 1995/9-10, p.307.

${ }^{11 .}$ Daarbij is aan bezwaar de voorkeur gegeven boven administratief beroep, omdat het wenselijk werd bevonden hetzelfde bestuursorgaan het besluit te laten heroverwegen.

12. Damen e.a. 2009 Deel II, p. 174; Stroink 2004a, p. 99; Verslag evaluatie Awb I, p. 44; Smit 1992, p. 48. Vgl.:Versteden 1995, p. 290.

13. Dit standpunt van de wetgever komt het duidelijkst naar voren in het kader van de Wet kosten bestuurlijke voorprocedures. Kamerstukken II, 1999/00, 27 024, nr. 3, p. 4 (Wet kosten bestuurlijke voorprocedures). Zie ook: Verheij 2003, p. 32. Stroink merkt ook op dat naar zijn mening bij de bezwaarschriftprocedure geen sprake is van verlengde besluitvorming ofwel rechtsbescherming maar van én-én, Stroink 2004a, p. 99.

14. Met de term judicieel wordt in dit onderzoek rechterlijk of aan rechtspraak eigen bedoeld.

${ }^{15}$ Koenraad \& Sanders 2006, p. 11. Mijn voorkeur gaat uit naar de term tweeledig omdat daarmee mijns inziens minder een tegenstelling tussen verlengde besluitvorming en rechtsbescherming benadrukt wordt (op de vermeende tegenstelling kom ik later nog in de volgende paragraaf terug). De term tweeslachtig is echter gangbaar in de literatuur.

16. Zie onder meer: Sanders 1998, p. 115-182; Verslag evaluatie Awb II, p. 15-16. 
Deel II Bestuurlijke voorprocedures

dingen die daaruit naar voren zijn gekomen, zijn als uitgangspunt genomen bij de beschrijving van de functies en het karakter van de bezwaarschriftprocedure.

\subsubsection{De rechtsbeschermingsfunctie}

\subsubsection{Inleiding}

De eerste functie die de wetgever, in het kader van de eerste tranche van de Awb, toekent aan de bezwaarschriftprocedure is de rechtsbeschermingsfunctie. Benadrukt wordt dat de bezwaarschriftprocedure een vorm van rechtsbescherming is die in de jaren voorafgaand aan de inwerkingtreding van de Awb sterk aan betekenis heeft gewonnen. De procedure vervult onder meer in het kader van de rechtsbescherming inmiddels een zelfstandige functie, aldus de wetgever. ${ }^{17}$ Doordat de heroverweging in de bezwaarschriftprocedure bijdraagt aan een evenwichtige besluitvorming en de mogelijkheid bestaat om tot op zekere hoogte andere aspecten bij de besluitvorming te betrekken dan in de primaire fase is geschied, leidt de bezwaarschriftprocedure - aldus de wetgever - in veel gevallen tot een oplossing (of in elk geval beëindiging) van het gerezen geschil. ${ }^{18}$

De rechtsbeschermingsfunctie vindt, zoals bekend, ook zijn neerslag in artikel 7:11, eerste lid, van de Awb. Daarin is neergelegd dat op grondslag van het bezwaar een heroverweging dient plaats te vinden. Daarmee heeft de wetgever het uitgangspunt tot uitdrukking willen brengen dat het bestuursorgaan niet ultra petita mag gaan en de omvang van het geschil zoals vastgelegd door de burger dient te respecteren. Ook volgt uit die bepaling dat een belanghebbende door het instellen van bezwaar in beginsel niet in een slechtere positie terecht mag komen ten opzichte van het primaire besluit (verbod van reformatio in peius). ${ }^{19}$ Door de vastlegging van deze twee verboden, komt aan de bescherming van de rechten en belangen van de burger aanzienlijk gewicht toe. ${ }^{20}$ In het kader van de tweede tranche van de Awb wordt nog steeds opgemerkt dat de bezwaarschriftprocedure mede de rechtsbescherming dient, maar in de toelichting wordt ook overwogen dat de heroverwegingsprocedures, waaronder de bezwaarschriftprocedure, op bestuurlijke besluitvorming gerichte procedures zijn en blijven. ${ }^{21}$ Hoewel de rechtsbeschermingsfunctie hier weliswaar niet meer zo prominent op de voorgrond wordt geschoven, wordt zij nog altijd toegerekend aan de bezwaarschriftprocedure. ${ }^{22}$ In de toelichting klinkt echter iets meer door dat de bezwaarschriftprocedure ook of daarnaast een bestuurlijk karakter heeft.

Tegenstelling tussen rechtsbescherming en verlengde besluitvorming

Vaststaat dat de bezwaarschriftprocedure beide kenmerken, zowel bestuurlijk als rechtsbescherming, in zich draagt. De vraag kan gesteld worden of het rechtsbeschermingskarakter dan wel het bestuurlijke karakter domineert in de huidige regeling van de bezwaarschriftprocedure. Volgens sommige auteurs is onder de Awb het bieden van rechtsbescherming de primaire functie van de bezwaarschriftprocedure. ${ }^{23}$ Verheij meent

\footnotetext{
17. PG Awb I, p. 279.

${ }^{18 .}$ PG Awb I, p. 279.

19. PG Awb I, p. 347. Bepalend is derhalve hetgeen de burger als gronden voor zijn bezwaar aanvoert. Overigens zijn beide verboden niet absoluut, zie hierover nader par. 4.3.1.2.

20. Van Wijk/Konijnenbelt \& Van Male 2008, p. 561; Sanders 2005, p. 4; Sanders 2004, p. 43; Verheij 2003, p. 35. Zie hierover par. 4.3.1.2.

21. PG Awb II, p. 195-196.

22. Kamerstukken II 1997/98, 25600 VI, nr. 46, p. 23; Van Wijk/Konijnenbelt \& Van Male 2008, p. 544; Sanders 1998, p. 72-73; Verslag evaluatie Awb I, p. 44; Nicolaï \& Olivier e.a. 1997, p. 664. Sommige auteurs geven ook thans aan dat de primaire functie van de bezwaarschriftprocedure in de Awb nog steeds de rechtsbeschermingsfunctie is, Sanders 2005, p. 4; Verheij 2003, p. 35.

23. Zie de vorige noot. Die opvatting lijkt verband te houden met het feit dat in de Awb als functie van het bestuursprocesrecht de individuele rechtsbescherming van de burger centraal staat en niet meer of in mindere mate de objectieve handhaving van het recht, PG Awb II, p. 174. Onder de Awb wordt het begrip bestuursprocesrecht
} 


\section{De bezwaarschriftprocedure en het administratief beroep}

bijvoorbeeld dat uit artikel 7:11 Awb blijkt dat de rechtsbeschermingsfunctie voorrang heeft boven de functie van verlengde besluitvorming. ${ }^{24}$

Daarentegen wordt ook wel gesteld dat de rechtsbeschermingsfunctie als primaire functie voor (bestuurs)rechtspraak voor de hand ligt, maar dat zulks voor de bezwaarschriftprocedure minder voor zich spreekt. Deze procedure betreft uit de aard der zaak verlengde besluitvorming en is derhalve (vooral) bestuurlijk van karakter. ${ }^{25}$ Die opvatting keert zich dus tegen het feit dat de bezwaarschriftprocedure onder de Awb vooral een rechtsbeschermingsfunctie heeft of zou hebben. Voor het bestuursprocesrecht in enge zin - dat wil zeggen betrekking hebbend op de procedure bij de bestuursrechter - is algemeen aanvaard dat onder de Awb de primaire functie van het procesrecht het bieden van (individuele) rechtsbescherming is. ${ }^{26}$ Over de vraag of dat ook geldt of moet gelden voor het bestuursprocesrecht in ruime zin, zoals de wetgever voorstaat ${ }^{27}$, lopen de meningen echter uiteen.

In de vraag naar de rangorde tussen de rechtsbeschermingsfunctie en het verlengde besluitvormingskarakter schuilt de vooronderstelling dat beide aspecten elkaar uitsluiten of tegengesteld zijn aan elkaar. Het is echter de vraag of een dergelijke tegenstelling tussen beide karakteristieken gerechtvaardigd is. In het verleden is ook wel het standpunt verdedigd dat de volledige heroverweging, als kenmerk van de verlengde besluitvorming, juist méér rechtsbescherming biedt. Ook de bestuurlijke afwegingen worden immers nogmaals beoordeeld. ${ }^{28}$ Dat standpunt werd vooral ingenomen ter verdediging van het administratief beroep in vergelijking tot het beroep op de onafhankelijke bestuursrechter. Schueler geeft bijvoorbeeld aan dat het een verkeerde conclusie is dat de procedure bij de onafhankelijke rechter meer rechtsbescherming biedt dan de meer beleidgerichte toetsing in administratief (vol) beroep. ${ }^{29}$ De beoordeling door de bestuursrechter kan en mag zich immers slechts uitstrekken tot rechtsmatigheidsaspecten. ${ }^{30}$ Het al eerder gememoreerde standpunt van de wetgever, dat de bezwaarschriftprocedure juist door de verlengde besluitvorming rechtsbescherming biedt, stemt daarmee overeen. ${ }^{31}$ Het bestuurlijke element in de voorprocedures, dat gevormd wordt door de beleidsoverwegingen, conflicteert derhalve niet per definitie met de daarin geboden rechtsbescherming. Integendeel, vanuit het perspectief van de burger kan het juist de rechtsbescherming verruimen.

ruim opgevat en worden daartoe de processuele voorschriften uit hfst. 6, 7 en 8 van de Awb, die zowel betrekking hebben op de procedure bij de rechter als op de bezwaarschriftprocedure en het administratief beroep, gerekend. Het bestuursprocesrecht ziet derhalve op de contentieuze fase waarvan ook de klassieke bestuurlijke voorprocedures onderdeel uitmaken, Van Wijk/Konijnenbelt \& Van Male 2008 p. 567. In enge zin omvat het bestuursprocesrecht slechts procedurele voorschriften die betrekking hebben op de procedure bij de bestuursrechter neergelegd in hfst. 8 van de Awb. Zie ook: Verheij 2003, p. 32.

24. Verheij 2003, p. 35. Zo ook: M.A. van der Ham, 'De gemeente als rechter in eigen zaak: (on)behoorlijke rechtspraak of (on)behoorlijk bestuur', in: H.A. Brasz en J.G. Steenbeek (red.), Klachten en bezwaren tegen de gemeente, Den Haag: VUGA 1988, p. 79.

25. Sanders 2005, p. 4.

26. Damen e.a. 2009, Deel II, p. 54-58; Van Wijk/Konijnenbelt \& Van Male 2008, p. 568; Rapport VARCommissie Rechtsbescherming 2004, p. 30; Sanders 2005, p. 4.

27. Zie noot 23 .

28. Dat argument werd veelal door de voorstanders van het administratief beroep, in het bijzonder op de Kroon, naar voren gebracht in het kader van de keuze voor ofwel administratief beroep ofwel administratieve rechtspraak, Schueler e.a. 2007, p. 28-29; Stroink 2004a, p. 35; Nicolaï en Olivier e.a. 1997, p. 580-583; P.J.J. van Buuren, H. Bolt \& M. Scheltema, Kroonberoep en Arob-beroep, Deventer: Kluwer 1981, p. 4-5 en 301-302. Laatstgenoemde auteurs nuanceren dit standpunt overigens in die zin dat beroep op de bestuursrechter in sommige opzichten ook meer bescherming bood dan het Kroonberoep, zie p. 19 e.v. en 302.

29. Schueler 1994, p. 138. Zie ook: N. Verheij, 'De toegang tot de bestuursrechter in het bestuursrecht (Benthem, Van Marle, Oerlemans, Batco en Van de Hurk), in: R.A. Lawson \& E. Myjer (eindred.), 50 jaar Europees Verdrag voor de Rechten van de Mens, Leiden: Stichting NJCM-Boekerij 2000, p. 190-191.

${ }^{30 .}$ Schueler e.a. 2007, p. 1. Zie hierover nader nog par. 4.3.1.1.

31. Zie par. 4.2.1, noot 13 . 
Deel II Bestuurlijke voorprocedures

Het gekozen perspectief

Er is dan ook veeleer sprake van verschillende perspectieven op de bezwaarschriftprocedure in plaats van een tegenstelling tussen rechtsbescherming en verlengde besluitvorming. Vanuit het perspectief van het bestuur domineert de verlengde besluitvorming en gaat de aandacht uit naar de toename van de zorgvuldigheid van de besluitvorming, terwijl voor de belanghebbende burger in de procedure de nadruk ligt op de geboden rechtsbescherming. ${ }^{32}$ Zoals Verheij opmerkt, biedt de bezwaarschriftprocedure de burger een recht op herbeslissing door het bestuur en tegelijkertijd het bestuur een tweede kans. ${ }^{33}$

De kwaliteitsverbetering en toename van de zorgvuldigheid van de besluitvorming die gekoppeld wordt aan de verlengde besluitvormingsfunctie, komt tegelijkertijd de rechtsbescherming van de burger ten goede. Andersom dienen de waarborgen die de rechtsbescherming van de burger moeten realiseren eveneens de zorgvuldigheid van de besluitvorming. Beide karakteristieken staan ten dienste aan elkaar of complementeren elkaar. Zo kan de inbreng van belanghebbenden in het kader van de hun geboden rechtsbescherming, tot meer zorgvuldigheid in de besluitvorming leiden en kan een zorgvuldigere besluitvorming, door het vergaren van informatie en onderzoek naar de relevante feiten of belangen, ook de rechtsbescherming van belanghebbenden ten goede komen.

Uit het voorgaande blijkt dat de opvattingen omtrent de mate waarin de bezwaarschriftprocedure een rechtsbeschermingsfunctie heeft voor een groot deel samenhangen met de invulling die aan het rechtsbescherming wordt gegeven. Ook voor dit onderzoek is het van belang te achterhalen wat onder rechtsbescherming wordt verstaan, omdat het bieden van rechtsbescherming aan de burger (tegen bestuurlijk handelen) de primaire functie van de bestuursrechtspraak vormt en mede met het oog daarop de procedure bij de rechter aan bepaalde vereisten moet voldoen. Voor doorwerking of toepasselijkheid van de vereisten die gelden voor de procedure bij de (bestuurs)rechter in de bestuurlijke voorprocedure(s) bestaat eerder aanleiding, indien sprake is van in enige mate met de rechterlijke procedure vergelijkbare functies van deze voorprocedures dan wel werkzaamheid van het bestuur. Hetzelfde kan gesteld worden over het begrip verlengde besluitvorming. Ook daarover bestaat enige onduidelijkheid, nu dat begrip betrekking lijkt te hebben op zowel een toename van de zorgvuldigheid als op de mogelijkheid tot bestuurlijk beleidsmatig heroverwegen. Op beide begrippen wordt hieronder nader ingegaan.

\subsubsection{De invulling van het begrip rechtsbescherming}

Rechtsbescherming: bescherming van rechten en belangen burgers

In de term rechtsbescherming ligt vanzelfsprekend reeds de kern van het begrip besloten: een mogelijkheid tot bescherming van vermeende of bestaande rechten. Voor het bestuursrecht betekent dit bescherming van de rechten en belangen van belanghebbenden tegen of in het kader van een handeling (met rechtsgevolgen) van het bestuur. In het verslag van de eerste evaluatie van de Awb wordt over de rechtsbeschermingsfunctie van de bezwaarschriftprocedure opgemerkt dat deze procedure een met rechtswaarborgen omklede procedurele mogelijkheid is voor de burger om op te komen tegen een door de overheid genomen besluit. ${ }^{34}$ Ook in het rapport van de VAR-Commissie Rechtsbescherming inzake het bestuursrechtelijke stelsel van rechtsbescherming, wordt bij aanvang opgemerkt dat sprake is van rechtsbescherming (in eigenlijke zin), als een burger tegen een overheidshandeling een voorziening kan vragen die ook de overheid rechtens bindt. ${ }^{35}$ Onder deze ruime algemene omschrijving vallen volgens de commissie de klassieke

\footnotetext{
32. Koenraad \& Sanders 2006, p. 12.

33. Verheij 2003, p. 32.

34. Verslag evaluatie Awb I, p. 44.

35. Rapport VAR-Commissie rechtsbescherming 2004, p. 14.
} 


\section{De bezwaarschriftprocedure en het administratief beroep}

vormen van rechtsbescherming, bestaande uit beroep bij de bestuursrechter, vordering bij de civiele rechter en de bestuurlijke voorprocedures bezwaar en administratief beroep. ${ }^{36}$ Van belang is ook dat de handeling of het besluit van het bestuur aangetast kan worden. In Nicolaï \& Olivier e.a. wordt een bestuursrechtelijke voorziening bijvoorbeeld omschreven als:

"een (niet in het burgerlijk recht geregelde) bij de wet geopende aparte voorziening die voor de burger de mogelijkheid biedt om de juistheid van een overheidsgedraging laten beoordelen en die ertoe kan leiden dat een bestreden besluit ongedaan wordt gemaakt." 37

Rechtsbescherming opgevat in de hiervoor bedoelde ruime zin - dat wil zeggen als een procedure waarmee een besluit kan worden aangetast op rechtens bindende wijze - omvat ook de bestuurlijke voorprocedures.

De soort instantie die rechtsbescherming moet bieden

In het algemeen wordt ook niet als onderdeel van het begrip rechtsbescherming geëist dat sprake dient te zijn van een onafhankelijke rechter. In het Nederlandse bestuursrecht is het uitgangspunt wel dat de rechtsbescherming in laatste instantie in handen te liggen van een overheidsinstantie. ${ }^{38}$ Tegen de achtergrond van de trias politica in de Nederlandse rechtsstaat, vormt het bieden van rechtsbescherming primair een taak die (uiteindelijk) aan de rechter toebehoort. Deze taak komt echter de onafhankelijke rechter niet exclusief toe. Zoals aangegeven, kunnen ook de bezwaarschriftprocedure of het administratief beroep rechtsbescherming bieden. Het begrip rechtsbescherming lijkt derhalve niet strikt gekoppeld te worden aan een specifiek orgaan dat de rechtsbescherming dient te bieden. Centraal staat het vragen van een voorziening in het kader van een geschil tussen burger en bestuur omtrent de vaststelling van de rechtspositie van de burger door het bestuur (gezien als een rechtsverhouding tussen bestuur en burger).

Opgevat in enge zin, zou het begrip rechtsbescherming kunnen worden gedefinieerd als een voorziening tegen de vaststelling van de rechtspositie van een burger bij een (bestuurs)rechter. In dat geval zou het begrip rechtsbescherming en bestuursrechtspraak samenvallen. In de ruime benadering is dat niet het geval. ${ }^{39}$

\section{Rechtmatigheidstoetsing, geschilbeslechting en rechtsbescherming}

Hiervoor is vastgesteld dat in het Nederlandse bestuursrecht zowel de procedures bij rechter als bij het bestuur bescherming van de rechten en belangen van burgers tegen een besluit van het bestuur kunnen bewerkstelligen. Thans is het zo dat de bestuursrechter rechtsbescherming biedt door middel van een toetsing van het door het bestuur genomen besluit op rechtmatigheidsaspecten. Het bestuur beoordeelt daarentegen nogmaals zijn eigen (of andermans) besluit en betrekt daarbij tevens - voor zover de aard van de bevoegdheid dat toelaat - beleidsaspecten. In beide gevallen wordt echter rechtsbescherming geboden. Wellicht worden, zoals hiervoor al werd aangestipt, in het geval van de bestuurlijke voorprocedure de rechten en belangen van de burger zelfs meer beschermd, omdat de herbeoordeling vollediger is. ${ }^{40}$ Bovendien biedt de voorprocedure de mogelijk-

\footnotetext{
36. Rapport VAR-Commissie Rechtsbescherming 2004, p. 15.

37. P. Nicolaï, B.K. Olivier, I.C. van der Vlies, L.J.A. Damen, B.J. Schueler, Bestuursrecht, Amsterdam: Factotum 1997 , p. 568. Ook de procedure bij de civiele rechter kan worden gezien als een voorziening die bestuursrechtelijke rechtsbescherming kan bieden.

38. Van Wijk/Konijnenbelt \& Van Male 2008, p. 518. Sinds de uitspraak van het EHRM in de zaak Benthem $\mathrm{t}$ Nederland, 23 oktober 1985, $A B$ 1986/1 m.nt. E.M.H. Hirsch Ballin, is ook duidelijk geworden voor het Nederlandse bestuursrecht dat art. 6 EVRM dat vereist voor de binnen de reikwijdte van die bepaling vallende geschillen. Zie over die uitspraak: N. Verheij, 'De toegang tot de rechter in het bestuursrecht', in: 50 jaar Europees verdrag voor de rechten van de mens, NJCM-Bulletin 2000, nr. 1, p. 183-201.

39. Vgl. Damen e.a. 2009, Deel II, p. 23

40. Zoals ook altijd het standpunt is geweest van de voorstanders van administratief beroep in vergelijking tot beroep op de bestuursrechter, zie hierover Schueler e.a. 2007, p. 29-30; Verheij 2000, p. 190-191.
} 


\section{Deel II Bestuurlijke voorprocedures}

heid van beslechting van het geschil door het bestuur. Rechtmatigheidstoetsing, geschilbeslechting en rechtsbescherming vallen derhalve niet per definitie geheel samen. ${ }^{41}$

Hoewel de wetgever nergens aangeeft wat onder rechtsbescherming dient te worden verstaan, kan uit de parlemenaire geschiedenis van de Awb worden afgeleid dat het bindend beslechten van een rechtsgeschil daar onderdeel van uitmaakt. Opgemerkt wordt dat de primaire functie van het bestuursprocesrecht het bieden van rechtsbescherming is. Aansluitend daarop wordt gesteld dat het bestuursprocesrecht een adequaat kader dient te bieden voor het bindend beslechten van een rechtsgeschil in de verhouding tussen burger en bestuursorgaan. ${ }^{42}$

Ook in de literatuur krijgt de afgelopen jaren het element geschilbeslechting of beslechting van een rechtsgeschil bij de invulling van het begrip rechtsbescherming meer nadruk. Dat element wordt ofwel geacht deel uit te maken van het begrip rechtsbescherming ofwel wordt het daaraan toebedacht in de toekomst. Zo wordt in Van Wijk/Konijnenbelt \& Van Male rechtsbescherming als volgt gedefinieerd:

"Rechtsbescherming tegen het bestuur is gericht op het bindend beslechten van een geschil over de inhoud
van een bestuursrechtelijke rechtsbetrekking. Een bestuursrechtelijke rechtsbetrekking is daarbij te begrij-
pen als een door rechtsnormen beheerste verhouding tussen het bestuur (...) en een of meer burgers, dan
wel tussen bestuursorganen of tot het bestuur behorende rechtspersonen onderling.",

Vervolgens wordt opgemerkt dat het bij rechtsbescherming gaat om het bindend beslechten van een geschil over een wet, een besluit of een andere beslissing of handeling van de overheid binnen die rechtsbetrekking, waarbij onder overheid moet worden verstaan wetgever, bestuur of rechter. Pront-Van Bommel legt nog meer nadruk op het element geschilbeslechting. Zij is bijvoorbeeld van mening dat rechtsbescherming gericht is op het bindend vaststellen welke rechten en plichten een belanghebbende en een bestuursorgaan jegens elkaar hebben (het bindend vaststellen van hun rechtsbetrekking) alsmede op het naleven daarvan. ${ }^{44}$ Het betreft in haar ogen derhalve definitieve beslechting van een rechtsgeschil. ${ }^{45}$ Ook Schreuder-Vlasblom constateert dat 'rechtsbescherming' kennelijk, nu de wetgever aan het begrip geen nadere inhoud heeft gegeven, dient te worden opgevat als geschillenbeslechting.

Naast de vrij algemene omschrijving in de aanvang van het rapport gaat ook de VAR-Commissie Rechtsbescherming elders in het rapport uitgebreider in op het begrip rechtsbescherming. Zij stelt zich, in tegenstelling tot de hierboven genoemde auteurs, op het standpunt dat geschilbeslechting (nog) niet geheel samenvalt met rechtsbescherming. ${ }^{47}$ De reden daarvoor is allereerst dat de bestuursrechter het geschil niet altijd kan beëindigen. Ook speelt daarbij een rol dat de bestuursrechter slechts een deel van de geschillen met de overheid kan beslechten, namelijk voor zover het appellabele besluiten betreft (de uitbreidende of beperkende uitzonderingen daargelaten). ${ }^{48}$ Volgens de commissie is de bestuursrechtspraak bezig zich te ontwikkelen van toetsing naar geschilbeslechting, maar is dit proces nog niet voltooid. De commissie voegt daaraan toe dat bestuursrechtspraak op den duur wellicht kan worden gedefinieerd als geschilbeslechting. ${ }^{49}$ Ook in het derde evaluatieonderzoek naar de definitieve geschilbeslechting in het be-

41. Zie Schueler e.a. 2007, p. 32 e.v.

42. PG Awb II, p. 174. Zie ook: Schueler e.a. 2007, p. 49. Onder het bestuursprocesrecht valt in de visie van de wetgever, zoals eerder aangegeven, ook het procesrecht voor de voorprocedures.

43. Van Wijk/Konijnenbelt \& Van Male 2008, p. 518.

44. Pront-Van Bommel 2002, p. 8.

45. Pront-Van Bommel wijst erop dat definitieve beslechting van rechtsgeschillen (rechtsbescherming) door de wetgever en in de literatuur veelal in een adem worden genoemd met conflictbeslechting maar dat deze niet geheel samenvallen. Conflictbeslechting omvat volgens haar meer en het begrip 'conflict' heeft een ruimere betekenis dan 'rechtsgeschil'.

46. Schreuder-Vlasblom 2003, p. 25 en 184

${ }^{47}$ Rapport VAR-Commissie Rechtsbescherming 2004, p. 30. Zie ook: Damen e.a. 2009, Deel II, p. 58

48. Rapport VAR-Commissie Rechtsbescherming 2004, p. 30-31.

49. Rapport VAR-Commissie Rechtsbescherming 2004, p. 31 


\section{De bezwaarschriftprocedure en het administratief beroep}

stuursrecht wordt aangegeven dat de rechter onder de Awb, meer dan vroeger, de (primaire) taak heeft geschillen bindend te beslechten. ${ }^{50}$ In het rapport wordt echter ook opgemerkt dat rechtsbescherming (nog) niet hetzelfde is als geschilbeslechting. ${ }^{51}$

De opvattingen in de literatuur waarbij geschilbeslechting al dan niet erkend wordt als bepalend element van rechtsbescherming moeten vooral worden gezien tegen de achtergrond van het bekende onderscheid tussen 'individuele rechtsbescherming oftewel recours subjectif' en 'handhaving van het objectieve recht oftewel recours objectif'. Traditioneel wordt het 'recours subjectif' in verband gebracht met (individuele) rechtsbescherming van de burger, gericht op bescherming van de subjectieve rechten van de burger en het 'recours objectif' met de handhaving van het objectieve recht. ${ }^{53}$ Zoals eerder aangegeven is onder de Awb (althans in theorie en op instigatie van de wetgever) de nadruk op subjectieve of individuele rechtsbescherming komen te liggen. ${ }^{54}$ Van oudsher heeft in het bestuursrechtelijke stelsel van rechtsbescherming echter de toetsing op objectieve rechtmatigheid van besluit, de handhaving van het objectieve recht als doel centraal gestaan. ${ }^{55}$ Ook in een zodanige rechtsgang kan echter rechtsbescherming aan de burger geboden worden. Diens subjectieve rechten kunnen immers ook beschermd worden door aantasting van het besluit of de handeling van het bestuur vanwege strijd met het objectieve publiekrecht. Verschil is echter dat bescherming van de subjectieve rechten van de burger een secundaire plaats inneemt; handhaving van het objectieve recht vormt de primaire functie en daarop zijn de inrichting van de procedure, de bevoegdheden rechter en het procesrecht dan ook primair gericht. ${ }^{56}$ Ook de Awb bevat belangrijke elementen van het recours objectif. Ofschoon in theorie de individuele rechtsbescherming voorop is gesteld, vormt bijvoorbeeld nog steeds het besluit de ingang tot de rechter en is de belangrijkste vordering van de burger vernietiging van een besluit (met eventueel schadevergoeding als meer subjectief element) die verwijdering van het besluit uit de rechtsorde bewerkstelligt. ${ }^{57}$ Vanuit echter met name het oogpunt van effectieve en finale (materiële) geschilbeslechting wordt thans veelal gepleit voor een meer subjectieve benadering van het bestuursrechtelijke proces. ${ }^{58}$ Juist deze kenmerken van een op het recours objectif gericht proces in de Awb oogsten kritiek. Met name de uitspraakbevoegdheden van de bestuursrechter liggen onder vuur en geopperd wordt om het besluitbegrip los te laten als toegangspoort tot de rechter. ${ }^{59}$

Overigens komt het onderscheid tussen rechtsbescherming en geschilbeslechting dat gemaakt wordt voort uit de positie en taak van de bestuursrechter in het stelsel van bestuursrechtelijke rechtsbescherming. Betrekt men dit onderscheid op het bestuur, dan is het echter zo dat rechtsbescherming en geschilbeslechting wel samen kunnen vallen. Voor het bestuur werd het, gelet op zijn positie, nimmer problematisch geacht om geschillen te beslechten. ${ }^{60}$

Bestuursrechtelijke rechtsbescherming (in ruime zin, dus niet beperkt tot bestuursrechtspraak of de procedure bij de bestuursrechter) moet, gelet op het voorgaande, dan

\footnotetext{
50. Schueler e.a. 2007 , p. 23

${ }^{51 .}$ Schueler e.a. 2007, p. 32

52. Zie hierover: Rapport VAR-Commissie Rechtsbescherming 2004, p. 38-45.

53. P.A. Willemsen, Een meer definitieve geschilbeslechting in het bestuursrecht in rechtsvergelijkend perspectief (preadvies NVvR), Nijmegen: Wolf Legal Publishers 2008, p. 3-4; Van Wijk/Konijnenbelt \& Van Male 2008, p. 528 en 568; Schueler e.a. 2007, p. 33 e.v.; Rapport VAR-Commissie Rechtsbescherming 2004, p. 41-45.

54. Zie hierover o.m.: Schueler e.a. 2007, p. 48; D.A. Lubach, 'Convergerende tendensen in het Europees bestuursrecht', NTB 2004/7, p. 252 en 259; F.A.M. Stroink, Kern van de bestuursrechtspraak, Den Haag: Elsevier 2004, p. 17. De laatste auteur hanteert de termen 'contentieux subjectif' en 'contentieux objectif'.

55. Vgl. Schueler e.a. 2007, p. 31-43; Rapport VAR-Commissie Rechtsbescherming 2004, p. 40-45; Pront-Van Bommel 2002, p. 7-8.

${ }^{56 .}$ Vgl. Schueler e.a. 2007, p. 49; Rapport VAR-Commissie Rechtsbescherming 2004, p. 130.

57. Damen e.a. 2009 Deel II, p. 56-58; Van Wijk/Konijnenbelt \& Van Male 2008, p. 568; Rapport VARCommissie Rechtsbescherming 2004, p. 44-45.

58. Zie: Rapport VAR-Commissie Rechtsbescherming 2004, p. 41.

${ }^{59 .}$ Bijv.: VAR-Commissie Rechtsbescherming 2004, p. 129-132; Lubach 2004, p. 253 en 259

${ }^{60 .}$ Schueler e.a. 2007 , p. 23.
} 
Deel II Bestuurlijke voorprocedures

ook omschreven worden als het vragen van een voorziening tegen een door het bestuur genomen besluit waarbij de rechtspositie van de burger is vastgesteld (aldus rechten en belangen van de burger geraakt worden) op een wijze die in geschil is tussen burger en bestuur. Vervolgens hangt de wijze waarop het bestuursrechtelijke proces (waarbinnen rechtsbescherming plaatsvindt) vormgegeven wordt af van de keuze tussen een meer op het recours subjectif of recours objectif gerichte inrichting van de procedure (afhankelijk van de mate waarin het doel is de subjectieve rechten van de burger dan wel de objectieve geldigheid van het besluit centraal te stellen). Die keuze is bepalend voor de uitspraakbevoegdheden van de rechter en andere procesrechtelijke kwesties, zoals invulling van het belanghebbendebegrip. ${ }^{61}$

Eisen aan de behoorlijkheid en effectiviteit van de rechtsbescherming

Voor het daadwerkelijk bieden van rechtsbescherming is noodzakelijk dat de procedure die opengesteld wordt om een besluit aan te tasten met bepaalde waarborgen is omkleed. Het enkel openstellen van een voorziening of procedure is niet voldoende. Het geheel van procedures die de rechtsbescherming omvatten voor de burger dient ook te voldoen aan de vereisten van artikel 6 EVRM. Artikel 6 EVRM geldt volledig voor procedures bij onafhankelijke rechterlijke instanties, waarbij voor de verschillende fasen, eerste aanleg, hoger beroep of cassatie als zodanig bepaalde vereisten gelden. ${ }^{62}$ Zelfs voor de bestuurlijke voorprocedures gelden, voor zover zij de toegang tot de rechter blokkeren, bepaalde vereisten en moeten de procedures met bepaalde waarborgen zijn omkleed. ${ }^{63}$ Vanuit het nationale recht worden behoorlijkheidseisen aan alle rechtsbeschermingsvoorzieningen gesteld. In een definitie van rechtsbescherming kunnen deze vereisten ook tot uitdrukking komen. Rechtsbescherming betekent niet alleen dat een geschil tussen burger en overheid of burgers onderling materieel en finaal beslecht kan worden, maar ook dat zulks dient plaats te vinden in (een geheel van) procedures die voldoen aan de vereisten die gelden voor een behoorlijke procedure. ${ }^{64}$ Het begrip rechtsbescherming heeft in deze zin een procedurele dimensie: geschilbeslechting in behoorlijke met waarborgen omklede procedure. Rechtsbescherming kan dan worden opgevat als het beslechten van het rechtsgeschil in een daarvoor op behoorlijke wijze ingerichte procedure. Daarmee staat nog niet vast welke vereisten gelden voor iedere afzonderlijke procedure waarin geschillen kunnen worden beslecht. Voorts betekent het bovenstaande ook niet dat de vereisten voor een behoorlijke procedure voor de voorprocedures en de procedure voor de (bestuurs)rechter gelijk zijn.

Tot slot volgt uit artikel 13 EVRM dat de rechtsbescherming die geboden wordt ook effectief dient te zijn. ${ }^{65}$ Met de geboden voorziening moet een belanghebbende zijn vermeende rechten daadwerkelijk te gelde kunnen maken of moet een schending van zijn rechten geredresseerd kunnen worden. Een effectief rechtsmiddel op grond van artikel 13 EVRM impliceert niet een rechtsmiddel bij een onafhankelijke en onpartijdige rechterlijke instantie. Het EHRM eist wel een zekere mate van onafhankelijkheid in het kader van artikel 13 EVRM, maar van een (onafhankelijke) rechterlijke instantie behoeft geen sprake te zijn. ${ }^{66}$

\footnotetext{
${ }^{61 .}$ Zie voor meer voorbeelden: Rapport VAR-Commissie Rechtbescherming 2004, p. 41-45;

62. Die vereisten behoeven niet in elke fase gelijk te zijn. Artikel 6 EVRM geldt primair voor de rechterlijke procedure in eerste aanleg. Bovendien geeft art. 6 EVRM geen recht op hoger beroep. Indien hoger beroep mogelijk is gemaakt, dient het wel aan de daarvoor uit die bepaling voortvloeiende vereisten te voldoen, zie: Van der Velde 2004, p. 4-5.

63. In elk geval is daarop het vereiste van de redelijke termijn rechtstreeks van toepassing, zie hierover par. 5.7 van dit deel. Bovendien mogen de bestuurlijke voorprocedures en de vormgeving ervan niet de essentie van het recht op toegang beperken, zie daarover par. 4.3.2 van Deel I.

64. Vgl. Damen e.a. 2009, Deel II, p. 63-66

65. Zie hierover nader par. 4.3.9 van Deel I.

66. Van Dijk \& Van Hoof e.a. 2006, p. 1006 met verwijzingen naar jurisprudentie van het EHRM.
} 
De bezwaarschriftprocedure en het administratief beroep

Invulling van het begrip rechtsbescherming

De verschillende standpunten omtrent het begrip rechtsbescherming indachtig, wordt in het vervolg van dit onderzoek wat betreft het begrip rechtsbescherming aangesloten bij het (impliciete) standpunt van de wetgever en de geschetste ontwikkeling in het bestuursprocesrecht. In dit onderzoek wordt onder bestuursrechtelijke rechtsbescherming derhalve verstaan: het bindend beslechten van rechtsgeschillen tussen burger en bestuur over de uitoefening van een publiekrechtelijke bevoegdheid waardoor rechten of belangen van die burger geraakt worden. Deze definitie sluit aan bij het door de wetgever daaromtrent ingenomen standpunt omtrent de rechtsbeschermingsfunctie van het bestuursprocesrecht in de Awb en de ontwikkelingen in het bestuursrechtelijke stelsel van rechtsbescherming sinds de inwerkingtreding van de Awb. Dat de bezwaarschriftprocedure (ook) een vorm van geschilbeslechting is waarbij een rechtsgeschil tussen burger en bestuursorgaan definitief en bindend kan worden beslecht en derhalve ook een rechtsbeschermingsfunctie heeft, is niet omstreden. Rechtsbescherming wordt aldus opgevat in ruime zin.

Rechtsbescherming omvat meer dan alleen het bindend en materieel beslechten van rechtsgeschillen tussen burger en bestuur over de uitoefening van een publiekrechtelijke bevoegdheid waardoor rechten of belangen van die burger geraakt worden. Rechtsbescherming houdt tevens in dat dit bindend en materieel beslechten van rechtsgeschillen plaats behoort te vinden in een behoorlijke ingerichte procedure die tevens effectief is.

\subsubsection{Verlengde besluitvorming}

Twee vormen van verlengde besluitvorming

Om een goed beeld te krijgen van de verhouding tussen de rechtsbeschermingsfunctie en het verlengde besluitvormingskarakter van de bezwaarschriftprocedure, is tevens de invulling van het begrip verlengde besluitvorming van belang. Wat opvalt in de verschillende beschouwingen over de bezwaarschriftprocedure is dat de term verlengde besluitvorming in twee verschillende betekenissen gehanteerd lijkt te worden. Het aanmerken van de bezwaarschriftprocedure als verlengde besluitvorming betekent dat deze procedure wordt gezien als verlengstuk van de primaire besluitvormingsfase. In de literatuur en de verschillende onderzoeken die verricht zijn naar onder meer de bezwaarschriftprocedure wordt het begrip verlengde besluitvorming echter in dat verband niet alleen gehanteerd om aan te geven dat er herstel van gebreken in de primaire besluitvorming kan plaatsvinden, maar ook om aan te geven dat sprake is van een procedure waarin een bestuurlijke, beleidsmatige heroverweging kan plaatsvinden. ${ }^{67}$

\section{Herstel van fouten}

De mogelijkheid tot herstel van fouten wordt allereerst als kenmerk van de verlengde besluitvorming aangemerkt, bijvoorbeeld omdat een zorgvuldigere besluitvorming plaatsvindt in deze fase in vergelijking tot de besluitvorming in primo of anderszins in tweede instantie fouten hersteld worden. ${ }^{68}$ Door de informele en makkelijke manier voor het bestuur om fouten te herstellen, wordt de bezwaarschriftprocedure gezien als verlengstuk van de primaire besluitvorming. ${ }^{69}$ Het begrip verlengde besluitvorming en bestuurlijke heroverweging heeft in deze zin betrekking op de kwaliteitsbevordering en

\footnotetext{
67. Zie ook: Damen e.a. 2009, Deel II, p. 174-175.

68. Damen e.a., Deel II, p. 174-176; M. Herweijer en R.A. van de Peppel, 'Eerst bezwaar maken en daarna wellicht nog in beroep: het perspectief van de belanghebbende', in: F.A.M. Stroink, A.W. Heringa \& A.R. Neerhof (red.), Vijf jaar JB en Awb, Den Haag: Sdu 1999, p. 39; A.R. Neerhof, 'De bezwaarschriftprocedure: functioneel voor de rechtsbescherming en de kwaliteit van de besluitvorming', in: F.A.M. Stroink, A.W. Heringa \& A.R. Neerhof (red.), Vijf jaar JB en Awb, Den Haag: Sdu 1999 (hierna: Neerhof 1999a), p. 66-67; Verslag Evaluatie Awb I, p. 44.

69. Vgl.: Herweijer en Van de Peppel 1999, p. 39.
} 


\section{Deel II Bestuurlijke voorprocedures}

toename van zorgvuldigheid van de besluitvorming. ${ }^{70}$ Daaruit kan volgen dat het bestuur, doordat het besluit aan kwaliteit en zorgvuldigheid (in juridisch opzicht) heeft gewonnen, sterker staat in beroep bij de rechter. ${ }^{71}$ Hoewel op de hantering van het begrip verlengde besluitvorming in deze zin op zichzelf niets valt af te dingen, kan de vraag gesteld worden of foutenherstel niet mede of tevens kan worden gezien als een uitdrukking van de rechtsbeschermingsfunctie van de bezwaarschriftprocedure voor de belanghebbende. Foutenherstel kan immers ook betekenen dat tegemoet wordt gekomen aan de bezwaren en de belanghebbende gelijk krijgt. ${ }^{72}$ Daardoor worden de rechten en belangen van de belanghebbende beschermd en daarmee kan een einde komen aan het geschil. Zo bezien vormt de bezwaarschriftprocedure ook een betrekkelijk informele en makkelijke vorm van rechtsbescherming. ${ }^{73}$ Ook hier lijkt het perspectief (dat van het bestuur of dat van de belanghebbende) waarmee men naar de procedure kijkt bepalend te zijn voor de kwalificatie verlengde besluitvorming of rechtsbescheming. ${ }^{74}$ Hoe dit ook zij, van belang is om voor ogen te houden dat met verlengde besluitvorming in veel gevallen bedoeld wordt dat het bestuur op eenvoudige wijze fouten in de primaire besluitvorming kan herstellen en de bezwaarfase in dat opzicht als verlengstuk van die primaire besluitvormingsfase moet worden gezien. Deze vorm van verlengde besluitvorming doet zich vooral voor, indien het bestuur beschikt over een (overwegend) gebonden bevoegdheid, in beschikkingenfabrieken derhalve. ${ }^{75}$ Doordat in het primaire besluitvormingsproces grote aantallen besluiten genomen moeten worden en er eenvoudigweg minder gelegenheid en tijd is voor zorgvuldige besluitvorming, worden fouten en misverstanden in bezwaar hersteld. ${ }^{76}$ De bezwaarschriftprocedure vormt zo daadwerkelijk het verlengstuk van de primaire besluitvorming. Dit aspect van de verlengde besluitvorming is interessant voor dit onderzoek, omdat het laat zien dat er in de voorprocedures een toename van de zorgvuldigheid van de besluitvorming - en ook van waarborgen in dat kader - kan plaatsvinden. Die toename van processuele waarborgen, die in de inrichting van de procedure terug te zien (moeten) zijn, betekenen vanuit het perspectief van de belanghebbende burger echter vooral een toename van rechtsbescherming.

Ruimte voor bestuurlijke afwegingen

Naast deze invulling van het begrip verlengde besluitvorming, wordt dit begrip ook gehanteerd om aan te geven dat in de bezwaarschriftprocedure een bestuurlijke heroverweging moet plaatsvinden die (naast rechtmatigheidsaspecten) ook beleidsmatige afwegingen omvat. ${ }^{77}$ Verlengde besluitvorming ziet dan vooral op de omvang en de aard van de werkzaamheid van het bestuur in de bezwaarschriftprocedure. Met het begrip wordt tot uitdrukking gebracht dat de werkzaamheid van het bestuur principieel verschilt van de werkzaamheid van de bestuursrechter die zich beperkt tot rechtmatigheidsaspecten. De bezwaarschriftprocedure wordt beschouwd als verlengde besluitvorming, omdat de

\footnotetext{
70. Verslag Evaluatie Awb I, p. 44.

71. Uit de tweede evaluatie van de Awb blijkt ook dat bestuursorganen de bezwaarschriftprocedure vaak gebruiken om hun positie met het oog op beroep bij de rechter te versterken waardoor vaak geen volledige heroverweging plaatsvindt en de focus ligt op rechtmatigheidsaspecten, Verslag Evaluatie Awb II, p. 15.

72. Verslag Evaluatie Awb I, p. 44

73. Vgl.: M. Scheltema, 'De rechter en de bezwaarschriftprocedure: meer aandacht voor snelheid en minder voor aansprakelijkheid', in: T. Hoogenboom en L.J.A. Damen (red.), In de sfeer van administratief recht (opstellen aangeboden aan Willem Konijnenbelt), Utrecht: Lemma 1994, p. 380

74. Koenraad en Sanders wijzen er ook op dat de (veronderstelde) tweeslachtigheid van het karakter van de bezwaarschriftprocedure duidelijk wordt indien deze procedure door de ogen van de appellerende burger dan wel door de ogen van het bestuursorgaan bezien wordt, Koenraad \& Sanders 2006, p. 11-12.

${ }^{75 .}$ Neerhof 1999a, p. 66-67; H.J. Simon, 'Het nut van de Awb voor bezwaarmakers', in: F.A.M. Stroink, A.W. Heringa \& A.R. Neerhof (red.), Vijf jaar JB en Awb, Den Haag: Sdu 1999 (hierna: Simon 1999b), p. 53. Zie hierover nader par. 4.2.2.4.

76. Verslag Evaluatie Awb I, p. 44

77. Damen e.a. 2009, Deel II, p. 175; Versteden 1995, p. 291. Zie over de omvang van de heroverweging nader par. 4.3.1.1.
} 


\section{De bezwaarschriftprocedure en het administratief beroep}

heroverweging door het bestuur in die procedure 'typisch' bestuurlijke en politieke afwegingen omvat, welke van de rechterlijke toetsing uitgesloten zijn. Deze laatste invulling van het begrip verlengde besluitvorming en de vraag in hoeverre daarvan in dat opzicht daadwerkelijk sprake is zijn voor dit onderzoek interessant, omdat daaruit verschillen of overeenkomsten met de rechterlijke werkzaamheid voortvloeien. Deze vorm van verlengde besluitvorming doet zich met name voor bij de beschikkingenateliers, waarin het bestuur een meer discretionaire bevoegdheid uitoefent. ${ }^{78}$ In de praktijk blijkt dat de bezwaarschriftprocedures in beschikkingenateliers een meer contradictoir karakter hebben en dat de heroverweging vaak beperkt blijft tot rechtmatigheidsaspecten. ${ }^{79}$ Het bestuurlijke element en de verlengde besluitvorming in deze zin komen derhalve in de praktijk niet tot zijn recht. De rechtsbeschermingsfunctie en de gelijkenissen met de procedure bij de bestuursrechter lijkt de boventoon te voeren. De rechtsbeschermingsfunctie is meer aanwezig in dit soort gevallen, vanwege de toename van het contradictoire karakter van de procedure door bijvoorbeeld de inschakeling van adviescommissie. Bovendien blijkt de heroverweging veelal beperkt te blijven tot rechtmatigheidsaspecten. In zoverre worden de verschillen met de toetsing door de bestuursrechter dan ook kleiner. ${ }^{80}$ Daarbij past wel de kanttekening dat een rechtmatigheidstoetsing (zoals aangegeven in de vorige paragraaf inzake de rechtsbeschermingsfunctie) niet per definitie betekent meer rechtsbescherming voor de burger. Juist het typisch bestuurlijke kenmerk van de bezwaarschriftprocedure kan, zoals eerder al werd aangegeven, zelfs leiden tot 'meer' bescherming van de rechten en belangen van de belanghebbende, aangezien het bestuur meer kan dan de bestuursrechter. Ook leidt de bezwaarschriftprocedure in dit soort gevallen, volgens het eerste evaluatieonderzoek van de Awb, tot een verbetering van de motivering en wordt daarmee het bestuurlijk belang gediend. In dit opzicht is er, ondanks de beperkte bestuurlijke heroverweging, toch sprake van verlengde besluitvorming. ${ }^{81}$ In het navolgende wordt het begrip verlengde besluitvorming voor beide aspecten gehanteerd, maar zal indien nodig worden aangegeven welke van beide aspecten het in concreto betreft.

\subsubsection{De aard van de bevoegdheid}

Naar aanleiding van hetgeen hiervoor is opgemerkt, verdient de aard van de bevoegdheid die uitgeoefend wordt in primo door het bestuursorgaan nog nadere aandacht. De aanwezigheid van een rechtsbeschermingscomponent of van het verlengde besluitvormingskarakter kan variëren afhankelijk van de aard van de aan de besluitvorming ten grondslag liggende bevoegdheid. ${ }^{82} \mathrm{Er}$ dient in dat kader een onderscheid gemaakt te worden tussen meer gebonden bestuursbevoegdheden en meer discretionaire bestuursbevoegdheden. Bij dit onderscheid tussen gebonden en discretionaire bestuursbevoegdheden speelt ook het onderscheid tussen de 'beschikkingenfabrieken' en 'beschikkingateliers' een rol. ${ }^{83}$

\section{Gebonden bevoegdheid}

Het primaire besluitvormingsproces in beschikkingenfabrieken wordt, zoals aangegeven, in beginsel gekenmerkt door een meer fabrieksmatige totstandkoming van beschikkingen, waarbij sprake is van grote aantallen beschikkingen alsmede van hoge mate van

\footnotetext{
${ }^{78 .}$ Damen e.a. 2009, Deel II, p. 175; Verslag Evaluatie Awb I, p. 44-45. Zie hierover nader par. 4.2.2.4.

79. Verslag Evaluatie Awb I, p. 44-45.

${ }^{80 .}$ Rapport VAR-Commissie Rechtsbescherming 2004, p. 27; Verslag Evaluatie Awb I, p. 44-45.

${ }^{81 .}$ Verslag Evaluatie Awb I, p. 45.

82. Verslag Evaluatie Awb I, p. 44-45.

${ }^{83 .}$ Dijkstra laat dit onderscheid in de aard van (de uitoefening van) deze bestuursbevoegdheden tot uitdrukking komen door te spreken van 'geprogrammeerde of niet-geprogrammeerde beschikkingen', G.S.A. Dijkstra, 'Bestuurslasten van de Algemene wet bestuursrecht', in: J.L. Boxum e.a. (red.), Aantrekkelijke gedachten. Beschouwingen over de Algemene wet bestuursrecht, Deventer: Kluwer 1993, p. 166.
} 


\section{Deel II Bestuurlijke voorprocedures}

standaardisering en automatisering. ${ }^{84}$ In overwegende mate is sprake van besluitvorming op grond van een gebonden bestuursbevoegdheid waarbij slechts twee partijen, het bestuursorgaan en de betrokken burger, betrokken zijn. De werkzaamheid van het bestuur in primo beperkt zich in dit soort gevallen grotendeels tot toepassing van de wet. ${ }^{85}$ Uit de wet volgt immers in hoge mate welk concreet besluit in het voorliggende geval genomen dient te worden. De totstandkoming van de besluitvorming in het belastingrecht, het sociale zekerheidsrecht, in het overige financiële bestuursrecht en het vreemdelingenrecht ${ }^{86}$ wordt vaak door deze aspecten gekenmerkt.

Voor de rechtsbeschermingsfunctie van de bezwaarschriftprocedure en de overeenkomsten met de procedure bij de bestuursrechter heeft de gebondenheid van de bevoegdheid gevolgen. Is er sprake van een (meer) gebonden bestuursbevoegdheid in primo, dan is ook de herbeoordeling van het concrete besluit door het bestuur in de bezwaarfase beperkt. De herbeoordeling kan zich immers niet verder uitstrekken dan tot hetgeen waarvoor ook in primo een bevoegdheid bestaat. Dat betekent dat bij overwegend gebonden bevoegdheden de herbeoordeling zich veelal beperkt tot de vraag of het bestuursorgaan de wet op juiste wijze heeft toegepast en of het besluit conform het toepasselijke en relevante recht is genomen. In dat geval is min of meer sprake van een rechtmatigheidstoetsing achteraf door het bestuursorgaan naar aanleiding van door de burger ingebrachte bezwaren tegen het besluit die vergelijkbaar is met de toetsing die door de bestuursrechter plaatsvindt. ${ }^{87}$ Het bestuur beoordeelt als het ware als secundair orgaan op initiatief van de appellerende belanghebbende het voorliggende besluit naar aanleiding van de ingediende bezwaren. Daarbij treedt het bestuur in de bezwaarschriftfase op als secundaire rechtsvormer en is de 'rechtsvorming' tevens grotendeels beperkt (tot rechtmatigheidsaspecten). De rechtsvragen en de rechtmatigheidsaspecten overheersen in het geschil tussen de burger en het bestuursorgaan en daarmee lijkt de werkzaamheid van het bestuur in dit soort gevallen sterk op de werkzaamheid van de bestuursrechter. ${ }^{88}$

Kanttekening hierbij is dat, zoals hierboven ook al werd aangestipt, de bezwaarschriftprocedure bij beschikkingenfabrieken gezien de massaliteit van de besluiten, vooral en primair een mogelijkheid biedt om snel en eenvoudig fouten te herstellen. In dit opzicht dient de bezwaarschriftprocedure vooral ook als verlengde besluitvorming te worden gezien. ${ }^{89}$ In dat opzicht is ook een bestuurlijk element nadrukkelijk aanwezig (dat tevens de rechtsbescherming van de burger dient omdat deze in relatief veel gevallen zijn gelijk behaald). Hoewel de wet min of meer voorschrijft welk besluit genomen moet worden, is er een fout gemaakt of is de wet verkeerd toegepast hetgeen in bezwaar hersteld wordt. In het rapport evaluatie Awb I wordt in dat verband opgemerkt dat de bezwaarschriftprocedure bij beschikkingenfabrieken onmisbaar is en als noodzakelijk sluitstuk van de besluitvorming dient te worden gezien. ${ }^{90}$ De nadruk ligt meer op de bestuurlijke heroverweging, omdat het besluit intensiever en meer aandacht krijgt dan in de primaire fase (vanwege het aantal besluiten dat genomen moet worden) het geval is. ${ }^{91}$

\footnotetext{
84. Zie over het onderscheid beschikkingenfabrieken en beschikkingenateliers: Sanders 1998, p. 23-24; H. Bröring en H.B. Winter, 'Massale beschikkingverlening en het bestuursrechtelijke trechtermodel', in: R.L. Vucsán (red.), De Awb-mens: boeman of underdog? Opstellen aangeboden aan Leo Damen., Nijmegen: Ars Aequi Libri 1996, p. 13-14.

85. Rapport VAR-Commissie Rechtsbescherming 2004, p. 27 en 71. Daarnaast is een belangrijke taak van het bestuur ook dan natuurlijk de vaststelling van de feiten. Zoals eerder aangegeven, wordt op dit onderdeel van de bestuurlijke werkzaamheid niet afzonderlijk ingegaan.

${ }^{86 .}$ Voor het vreemdelingenrecht geldt het voorgaande maar in beperkte mate. In die geschillen betreft het ook twee partijen die tegenover elkaar staan, maar heeft het bestuur echter veel beleidsvrijheid. Die beleidsvrijheid is dan wel weer grotendeels ingevuld door beleidsregels in de vreemdelingencirculaire, waardoor per saldo het bestuur in concrete gevallen ook weer weinig vrijheid kan hebben.

87. Goorden 1995, p. 298.

88. Rapport VAR-Commissie Rechtsbescherming 2004, p. 27 en 71

89. Verslag evaluatie Awb I, p. 44

90. Verslag evaluatie Awb I, p. 44.

${ }^{91 .}$ Sanders 1998, p. 241; Verslag Evaluatie Awb I, p. 44
} 


\section{De bezwaarschriftprocedure en het administratief beroep}

Het voorgaande doet niet af aan het feit dat de beoordeling door het bestuur in hoge mate vergelijkbaar is met die van de rechter, aangezien deze beperkt moet blijven tot rechtmatigheidsaspecten. De bezwaarschriftprocedure is vanuit bestuurlijk oogpunt weliswaar een eenvoudige manier tot herstel van fouten en het sluitstuk van het besluitvormingsproces, maar vanuit het perspectief van de belanghebbende(n) een mogelijkheid tot herstel van de (onjuiste) aantasting van zijn rechten. ${ }^{92}$ Als er sprake is van een gebonden bevoegdheid van het bestuur, vallen in de bestuurlijke voorprocedures de begrippen rechtsbescherming en rechtmatigheidstoetsing in zekere zin samen. In die gevallen staat de bezwaarschriftprocedure ook in het teken van het bieden van rechtsbescherming, evenals als de procedure bij de bestuursrechter.

\section{Discretionaire bevoegdheden}

Tegenover de gebonden besluitvorming staat de besluitvorming op grond van (meer) discretionaire bestuursbevoegdheden die vaak plaatsvindt in de beschikkingenateliers waar op een meer 'ambachtelijke' wijze de besluitvorming totstandkomt. De aantallen besluiten die genomen worden zijn geringer en de belangen van derden spelen vaak een rol bij de besluitvorming. ${ }^{93}$ Gevolg daarvan is ook dat de besluitvorming complexer is en om die reden, in plaats van gestandaardiseerd, meer is toegespitst op het voorliggende geval. Met name in het ruimtelijk bestuursrecht en milieurecht vindt de besluitvorming op deze wijze plaats. ${ }^{94}$ Indien sprake is van een meer discretionaire (of vrije) bestuursbevoegdheid heeft het bestuur de ruimte om ofwel zelf een belangenafweging te maken ofwel zelf een waardering van de feiten te geven. ${ }^{95}$ Daaruit volgt dat het bestuursorgaan in bezwaar ook meer ruimte (dan in beschikkingenfabrieken het geval is) heeft om bestuurlijke en politieke aspecten mee te laten wegen bij de besluitvorming. Met name bij atelierachtige besluitvorming kan het bestuurlijke karakter van de procedure in dit opzicht tot uitdrukking worden gebracht. ${ }^{96}$ Indien echter de discretionaire bevoegdheid sterk door beleidsregels is ingevuld, is de vrijheid van het bestuur weer beperkt en staat de bezwaarschriftprocedure ook dan vooral in het teken van de rechtmatigheidsaspecten.

Zoals hiervoor al is opgemerkt, is in de praktijk voorts gebleken dat in de bezwaarschriftprocedure bij beschikkingenateliers de heroverweging in bezwaar vaak beperkt blijft tot rechtmatigheidsaspecten. Ook wordt gesignaleerd dat de procedure vaak contradictoire trekken vertoont waardoor een sterke gelijkenis met de procedure voor de bestuursrechter optreedt. ${ }^{97}$ Deze effecten worden mede veroorzaakt door het feit dat in deze gevallen vaak een adviescommissie wordt ingesteld (waarin veelal ook juristen plaatsnemen). ${ }^{98}$ Uit de eerste evaluatie van de Awb is ook gebleken dat het belangrijkste effect van de bezwaarschriftprocedure in deze gevallen een verbetering van de motivering door

\footnotetext{
92. Verslag Evaluatie Awb I, p. 44.

93. Zie o.m.: Sanders 1998, p. 23-24; Verslag Evaluatie Awb I, p. 44-45.

94. Verslag Evaluatie Awb I, p. 44-45.

95. Zie vrij recent over het verschil tussen beleidsvrijheid en beoordelingsvrijheid: A.P. Klap, 'Rechter en bestuur: coomunicerende vaten of concurrerende machten?, NTB 2007, p. 183-194. De termininologie is afkomstig van Duk, W. Duk, 'De zachte kern van het bestuursrecht', RM-Themis 1978, p. 564-587 en W. Duk, 'Beoordelingsvrijheid en beleidsvrijheid', RM-Themis 1988, p. 156-169. Sommige auteurs merken uitsluitend de bevoegdheid waarbij beleidsvrijheid bestaat aan als een discretionaire bevoegdheid. Voor dit onderzoek is vooral van belang dat zowel bij beleidsvrijheid als bij beoordelingsvrijheid het bestuur een taak toekomt die de bestuursrechter niet heeft en ten aanzien waarvan deze zich terughoudend moet opstellen.

96. Hierbij dient opgemerkt te worden dat vaak bij de uitoefening van discretionaire bevoegdheden, gelet op artikel 7:1 lid 1 sub d van de Awb, geen bezwaarschriftprocedure meer gevolgd hoeft te worden.

97. C.L.G.F.H. Albers, 'Commentaar artikel 7:13', in: M. Scheltema, R.M. van Male, B.W.N. de Waard, A.T Marseille, A.J.C. de Moor-van Vugt (red.), Commentaar Algemene wet bestuursrecht, Amsterdam: Reed Elsevier (voorheen Den Haag: VUGA), losbladige uitgave, E 7:13-3; Koenraad \& Sanders 2006, p. 57; Sanders 2004, p. 34; Verslag evaluatie Awb I, p. 44-45.

98. Zie vorige noot. Dat heeft te maken met het feit dat deze commissies niet democratisch gelegitimeerd zijn en zich zodoende genoodzaakt zien tot terughoudendheid ten aanzien van beleidsaspecten, zie hierover nog par. 4.3.1.1. Dat is echter in strijd met de bedoeling van de wetgever. Die heeft aangegeven dat in bezwaar een volledige heroverweging dient plaats te vinden.
} 


\section{Deel II Bestuurlijke voorprocedures}

het bestuur inhoudt. In dat opzicht komt het karakter van verlengde besluitvorming duidelijk naar voren. ${ }^{99}$ Sanders merkt nog op dat het bij bezwaarschriftprocedures in beschikkingenateliers met name aankomt op het geschiloplossend vermogen omdat er veelal sprake is van een echt meningsverschil tussen de burger en het bestuursorgaan. Dit in tegenstelling tot de beschikkingenfabrieken waarbij het corrigerende vermogen van de bezwaarschriftprocedure meer naar voren komt. ${ }^{100}$ De bezwaarschriftprocedure in beschikkingenateliers heeft in deze zin meer een geschilbeslechtend karakter dan die in beschikkingenfabrieken. Ook hier vertoont de bezwaarschriftprocedure en de in het kader daarvan verrichte heroverweging in de praktijk gelijkenissen met de procedure bij de bestuursrechter. Een heroverweging met beleidsmatige aspecten kan de belanghebbende zelfs meer rechtsbescherming bieden. Tegelijkertijd verschilt de werkzaamheid van het bestuur dan echter in grotere mate van de toetsing die de bestuursrechter verricht en heeft deze een sterk bestuurlijk element.

\section{Gradueel onderscheid}

Zoals de Commissie Polak stelt, dient in het gebruik van dit globale onderscheid tussen beschikkingenfabrieken en -ateliers enige terughoudendheid te worden betracht. In plaats van een eenvoudige tweedeling betreft het hier veeleer twee uitersten op een glijdende schaal - aldus de commissie - waarbij sprake kan zijn van vele tussenvormen afhankelijk van het type besluit dat genomen dient te worden. ${ }^{101}$ Per besluitvormingstraject zal moeten worden beoordeeld of deze gekenmerkt wordt door een meer 'fabrieksmatig'- dan wel 'atelierachtig'- karakter. ${ }^{102}$ Bovendien behoeft niet in alle beschikkingenfabrieken sprake te zijn van gebonden bestuursbevoegdheden of in alle beschikkingenateliers van discretionaire bestuursbevoegdheden. ${ }^{103}$ Ook in dat opzicht is nuancering van deze typeringen geboden. Verder dient ook voor ieder besluitvormingstraject afzonderlijk te worden bezien in hoeverre de rechtsbeschermingsfunctie of verlengde besluitvormingskarakter in de bezwaarschriftprocedure tot uitdrukking komt.

\section{Conclusie}

Uit de verschillende onderzoeken blijkt dat, zowel in het geval van een gebonden bevoegdheid als in het geval van een discretionaire bevoegdheid, gelijkenissen kunnen bestaan met de procedure bij of de werkzaamheid van de bestuursrechter. De rechtmatigheidstoetsing is in beginsel bij meer gebonden bestuursbevoegdheden nadrukkelijker aanwezig in de bezwaarschriftprocedure, terwijl de inrichting van de procedure minder een contradictoir karakter heeft. In het geval van discretionaire bevoegdheden worden veelal adviescommissie ingeschakeld die tot gevolg hebben dat er meer nadruk ligt op rechtmatigheidsaspecten in de heroverweging en de procedure een meer contradictoir karakter krijgt. In beide gevallen is er echter sprake van het bieden van rechtsbescherming. In het geval van discretionaire bevoegdheden soms nog meer, omdat het veelvuldig instellen van een adviescommissie leidt tot meer contradictoire procedures ofwel omdat het bestuur ook op beleidsmatige gronden kan heroverwegen. Op sommige punten ligt de besluitvorming(sprocedure) in de beschikkingenfabrieken dichter bij de rechter en op sommige punten de besluitvorming(sprocedure) in de beschikkingenateliers. Daarin schuilt wel een zekere paradox. In de beschikkingenateliers, waarvan wordt aangenomen dat de werkzaamheid van bestuur het meest typisch bestuurlijke elementen bevat, lijkt de

\footnotetext{
99. Verslag evaluatie Awb I, p. 45.

${ }^{100 .}$ Sanders 1998, p. 241-242; Sanders 2005, p. 173

101. Verslag evaluatie Awb I, p. 28. Zie ook in deze zin: Dijkstra 1993, p. 166; Sanders 1998, p. 23-25.

102. Illustratief in dit verband is ook het onderscheid dat naar voren komt tussen twee instellingen die beiden beschouwd worden als beschikkingenfabrieken, de Informatie Beheer Groep en de Immigratie- en Naturalisatiedienst, in het artikel van H. Bröring en H.B. Winter, 'Massale beschikkingverlening en het bestuursrechtelijke trechtermodel', in: R.L. Vucsán (red.), De Awb-mens: boeman of underdog? Opstellen aangeboden aan Leo Damen., Nijmegen: Ars Aequi Libri 1996, p. 11-29.

${ }^{103 .}$ Vgl. Verslag Evaluatie Awb I, p. 28.
} 
De bezwaarschriftprocedure en het administratief beroep

inrichting van de procedure vaak sterker op die van de rechter dan in de beschikkingenfabrieken. Dat terwijl van de werkzaamheid van het bestuur in die laatste juist wordt aangenomen dat zij meer de toetsing van de rechter nadert. In beide gevallen is ook sprake van verlengde besluitvorming, zij het wederom om verschillende redenen. In beschikkingenateliers is daarvan sprake vanwege de bestuurlijke elementen in de heroverweging, terwijl in beschikkingenfabrieken daarvan sprake is vanwege het herstel van fouten in de primaire besluitvorming. In hoeverre de aard van de bevoegdheid een rol speelt bij de drie andere onderscheiden functies van de bezwaarschriftprocedure komt hieronder, voor zover daarover gegevens bekend zijn, voor elke functie afzonderlijk nog aan de orde.

\subsubsection{Filterfunctie}

De bezwaarschriftprocedure heeft, naast het bieden van rechtsbescherming, van oudsher als doel om het beroep op de bestuursrechter te voorkomen en de werklast voor de bestuursrechter te verminderen. ${ }^{104}$ Deze filterwerking, ook wel zeefwerking genoemd, vormt een belangrijke functie van deze voorprocedure. ${ }^{105}$ Doordat in veel gevallen het geschil tussen de burger en het bestuursorgaan in de bezwaarschriftprocedure kan worden opgelost of beëindigd, kan beroep op de bestuursrechter worden voorkomen. ${ }^{106}$ Verschillende redenen kunnen daaraan ten grondslag liggen. Het geschil kan niet worden voortgezet, omdat bijvoorbeeld aan de bezwaren van de indiener tegemoet wordt gekomen. Een belanghebbende kan echter ook, hoewel met het besluit op bezwaar niet aan zijn bezwaren tegemoet wordt gekomen, berusten in dat besluit omdat gedurende de procedure de indruk is ontstaan dat het besluit (rechtens) juist is. ${ }^{107}$ De bezwaarschriftprocedure biedt bestuursorganen voorts, zoals reeds eerder aangegeven, de mogelijkheid om fouten die gemaakt zijn in de primaire besluitvormingsfase te herstellen. In die gevallen zal een belanghebbende ook (indien en voorzover aan zijn bezwaren tegemoet is gekomen) veelal afzien van de gang naar de rechter. ${ }^{108}$ In dit laatste opzicht hangt de filterfunctie van de bezwaarschriftprocedure (vanuit het perspectief van het bestuur) samen met het verlengde besluitvormingskarakter van deze procedure. Of het in de gevallen waarin het bestuur fouten heeft gecorrigeerd daadwerkelijk niet komt tot een procedure bij de rechter, hangt daarnaast nog af van de vraag of er nog andere belanghebbenden betrokken zijn in de procedure en in hoeverre deze hun gelijk hebben gekregen. Ook buiten de gevallen waarin (uitsluitend) foutenherstel plaatsvindt, is echter (zoals aangegeven) gebleken dat de bezwaarschriftprocedure filterwerking tot gevolg kan hebben. ${ }^{10}$

De filterfunctie van de bezwaarschriftprocedure ligt derhalve ook in het verlengde van of houdt nauw verband met de rechtsbeschermingsfunctie van die procedure. Omdat de bezwaarschriftprocedure een met bepaalde judiciële waarborgen omklede procedure is waarin de burger een besluit kan aanvechten, kan immers in veel gevallen het rechtsge-

\footnotetext{
104. Aldus de MvT bij de eerste tranche van de Awb, PG Awb I, p. 279; Koenraad \& Sanders 2006, p. 16; Sanders 1998, p. 81; Verslag Evaluatie Awb I, p. 50.

105. Van Wijk/Konijnenbelt \& Van Male 2008, p. 544; Herweijer en Van de Peppel 1999, p. 40; Neerhof 1999a, p. 68; Sanders 1998, p. 81; Notten 1998, p. 340-341; M.S. Beerten e.a., Aspecten van financiële beschikkingverlening (verslag in het kader van Evaluatie Awb I), Deventer: W.E.J. Tjeenk Willink 1996, p. 123-124; Verslag Evaluatie Awb I, p. 50-51.

${ }^{106 .}$ Verslag Evaluatie Awb I, p. 50

107. Sanders 1998 , p. 81. Sanders geeft nog een aantal andere mogelijke redenen waarom van het instellen van beroep bij de rechter wordt afgezien; Sanders 1998, p. 81-82. Zie ook: Koenraad \& Sanders 2006, p. 16.

${ }_{108}$ Met name bij fabrieksmatig totstandgekomen besluiten geldt dat in de bezwaarfase vaak herstel van fouten plaatsvindt en de belanghebbenden vaak gelijk krijgen, Verslag Evaluatie Awb I, p. 44.

109. Zie ook Helder die aangeeft dat de term filterwerking in neutrale zin begrepen moet worden aangezien het feit dat geen beroep wordt ingesteld, niet betekent dat de bezwaren daadwerkelijk opgelost zijn of daaraan tegemoet is gekomen; E. Helder, 'Rechtsbescherming door gemeente: zijn er klachten of bezwaren?, in: H.A. Brasz en J.G. Steenbeek, Klachten en bezwaren tegen de gemeente, Den Haag: VUGA 1988, p. 22.
} 


\section{Deel II Bestuurlijke voorprocedures}

schil tussen burger en bestuur definitief beslecht worden. ${ }^{110}$ In die gevallen bestaat geen noodzaak meer voor een oordeel van de bestuursrechter of rechtsbescherming door de bestuursrechter, omdat de rechten en belangen van de burger in de bezwaarschriftprocedure reeds voldoende tot hun recht zijn gekomen. Foutenherstel betekent vanuit het perspectief van de rechtsbescherming van de belanghebbende dat er geen noodzaak meer bestaat tot een gang naar de bestuursrechter. De daaruit voortvloeiende vermindering van de werklast voor de bestuursrechter, heeft een belangrijke rol gespeeld bij de algemeen verplichtstelling van deze procedure in de opzet van de Awb. ${ }^{11}$ De afname van de werklast voor de bestuursrechter in eerste aanleg (en in het verlengde daarvan ook uiteindelijk in hoger beroep) door de invoering van de bezwaarschriftprocedure blijft een belangrijk gevolg van deze voorprocedure. Uit verschillende onderzoeken is gebleken dat de filterwerking die de bezwaarschriftprocedure in de praktijk genereert in beginsel ook aanzienlijk is. ${ }^{112}$ Uit het onderzoek van Sanders komt wel naar voren dat de filterwerking van de bezwaarschriftprocedure vooral aanzienlijk is op terreinen waar geen belangen van derden in het geding zijn. ${ }^{113}$ Ook is zijn bevinding dat op terreinen van de financiële beschikkingverlening de filterwerking iets hoger is dan op terreinen van de niet-financiële beschikkingverlening. ${ }^{114}$ Voor de filterwerking blijkt het onderscheid tussen beschikkingenfabrieken en beschikkingenateliers verder minder van belang, aangezien bij zowel beschikkingenfabrieken als beschikkingenateliers sprake is van aanzienlijke filterwerking. ${ }^{115}$ De aard van de bevoegdheid die in het geding is, lijkt geen grote gevolgen te hebben voor deze functie van de bezwaarschriftprocedure. ${ }^{116}$ Sanders zoekt de verklaring daarvoor in het feit dat hoewel de belanghebbende in bezwaar bij beschikkingenateliers minder snel gelijk krijgt, deze veelal wel gehoord wordt. Van dat laatste gaat dan een (gematigd) positief effect uit. ${ }^{17}$

\section{Verband met de inrichting van de procedure}

Sanders constateert in zijn onderzoek derhalve een - zoals hijzelf stelt zwak - verband tussen de inrichting van de bezwaarschriftprocedure en de mate van filterwerking van die procedure. ${ }^{118}$ Het horen van belanghebbenden zoals vaak (en meer dan in beschikkingenfabrieken) in beschikkingenateliers plaatsvindt, kan bijdragen aan de filterwerking (ook al worden belanghebbenden uiteindelijk in bezwaar bij beschikkingenfabrieken veel vaker in het gelijk gesteld waardoor beroep op de rechter overbodig is). ${ }^{119}$

In het verslag van de eerste evaluatie van de Awb wordt eveneens voorzichtig een verband gelegd met de kwaliteit van de bezwaarschriftprocedure gelegd. De commissie heeft daarbij echter vooral het oog op de instelling van een adviescommissie. Dat lijkt de zeefwerking van de bezwaarschriftprocedure te bevorderen. ${ }^{120}$ Het voorgaande lijkt erop te duiden dat hoe meer processuele waarborgen in de procedure worden ingebouwd, hoe

110. Verslag Evaluatie Awb I, p. 50.

${ }^{111 .}$ PG Awb I, p. 279. Vgl: Neerhof 1999a, p. 68.

112. In het eerste evaluatieverslag merkt de commissie Polak nog op dat er sterke indicaties zijn dat de zeefwerking in sommige sectoren aanzienlijk is en de voorzichtige conclusie getrokken kan worden dat de bezwaarschriftprocedure in positieve zin heeft bijgedragen aan de zeefwerking op sommige terreinen, maar dat bij de volgende evaluatie meer gegevens wat dat betreft bekend zullen zijn, Verslag Evaluatie Awb I, p. 50-51. Uit de tweede evaluatie blijkt dat de zeefwerking niet altijd plaatsvindt omdat bestuursorganen te veel nadruk leggen op de rechtmatigheidsaspecten, Verslag Evaluatie Awb II, p. 15. Zie verder Sanders die bevestigt dat de filterwerking aanzienlijk is, Sanders 1998, p. 156-157.

113. Sanders 1998, p. 156-157.

114. Zie vorige noot.

${ }^{115 .}$ Sanders 1998, p. 148-149 en 157. Uit de eerste evaluatie van de Awb blijkt overigens dat de filterwerking in het ruimtelijk bestuursrecht (waar over het algemeen sprake is van beschikkingenateliers) minder sterk is, Verslag Evaluatie Awb I, p. 51

116. Zie ook: Verslag Evaluatie Awb I, p. 50-51

117. Sanders 1998, p. 157 en 195

118. Sanders 1998, p. 206-210.

119. Sanders 1998, p. 156-157 en 195

120. Verslag Evaluatie Awb I, p. 50. 
De bezwaarschriftprocedure en het administratief beroep

groter de filterwerking is. Er lijkt derhalve een verband tussen de gelijkenis met de procedure bij de rechter en de filterwerking te bestaan. De filterwerking is afhankelijk van de geneigdheid van belanghebbenden tot het instellen van beroep en daarmee ook van hun perspectief - het rechtsbeschermingsperspectief - op de procedure.

\section{De filterwerking in de voorprocedures}

De filterwerking van de bezwaarschriftprocedure ligt in het verlengde van zowel het verlengde besluitvormingskarakter als de rechtsbeschermingsfunctie van die procedure. De hoge mate van filterwerking bij vooral beschikkingenfabrieken vanwege het foutenherstel dat plaatsvindt, lijkt de rol van de bezwaarschriftprocedure als verlengde besluitvorming te bevestigen. Ook in andere gevallen is echter sprake van een aanzienlijke filterwerking, hetgeen ook de rol van de bezwaarschriftprocedure in het kader van de rechtsbescherming bevestigt. Bovendien betekent foutenherstel vanuit het perspectief van de belanghebbende burger dat sprake is van bescherming van zijn rechten en belangen. Naarmate de inrichting van de procedure meer gelijkenis vertoont met de rechterlijke procedure, lijkt de filterwerking toe te nemen. De mate waarin de procedure een rechtsbeschermingsfunctie heeft in de ogen van belanghebbenden lijkt derhalve van belang te zijn voor de mate van filterwerking. Hoe het ook zij, de filterwerking van de bezwaarschriftprocedure is in algemene zin sterk aanwezig.

\subsubsection{Verduidelijkingsfunctie}

In het verlengde van de filterwerking en de daaruit voortvloeiende vermindering van de werklast voor de bestuursrechter, ligt de verduidelijkingsfunctie, ook wel de dossiervormingsfunctie genoemd. ${ }^{121}$ Ook indien de bezwaarschriftprocedure niet leidt tot een definitief einde van het geschil tussen een burger en een bestuursorgaan, gaat er een positieve invloed uit van deze voorprocedure op het verdere verloop van het geschil. Omdat het geschil is voorbewerkt door de behandeling in de bezwaarfase, krijgt de rechter een beter afgebakend en duidelijker uitgewerkt geschil voor zich. ${ }^{122}$

De verduidelijking van het geschil bestaat - aldus Sanders - uit twee kanten. ${ }^{123}$ Ten eerste zorgt de behandeling in bezwaar ervoor dat het geschil verder afgebakend wordt. Daarmee wordt bedoeld dat de bezwaarschriftprocedure ertoe leidt dat eenduidiger komt vast te staan welke punten partijen verdeeld houden en over welke punten een geschil bestaat. ${ }^{124}$ Ook wordt aangenomen dat de geschilpunten beter omlijnd zijn na het doorlopen van de bezwaarschriftprocedure. ${ }^{125}$ Ten tweede wordt het bestaande geschil duidelijker uitgewerkt omdat er meer informatie beschikbaar komt over de standpunten van zowel de burger als het bestuur. Er wordt een dossier gevormd waarop de rechter bij de behandeling van de zaak kan voortbouwen. ${ }^{126}$ In het verslag van de eerste evaluatie van de Awb komt dit onderscheid tussen enerzijds een betere uitwerking van de zaak en anderzijds een nadere afbakening van het geschil overigens niet zo duidelijk naar voren. Daarin wordt slechts opgemerkt dat het geschil duidelijker en scherper omlijnd wordt. ${ }^{127}$ Daarmee lijkt de evaluatiecommissie slechts het oog te hebben op het effect dat bij Sanders de eerste kant van de verduidelijkingsfunctie vormt.

De door de bezwaarschriftprocedure bewerkstelligde verduidelijking van het geschil heeft ook een vermindering van de werklast voor de bestuursrechter tot gevolg; de ver-

\footnotetext{
121. Vgl. Damen e.a. 2009, Deel II, p. 176. Zij geven aan dat zowel de filterfunctie als de verduidelijkingsfunctie vooral zien op de relatie tussen de bestuurlijke fase en de rechterlijke fase.

122. Damen e.a. 2009, Deel II, p. 176; Van Wijk/Konijnenbelt \& Van Male 2008, p. 544-545; Verslag Evaluatie Awb I, p. 51; Helder 1988, p. 22.

123. Sanders 1998, p. 84 en 158.

124. Vgl: Sanders 1998, p. 84 en 158

125. Sanders 1998 , p. 84

126. Sanders 1998, p. 84 en 158-159.

127. Verslag Evaluatie Awb I, 51.
} 
Deel II Bestuurlijke voorprocedures

mindering van de werklast treedt niet op in aantallen zaken, maar in intensiviteit en duur van het (voor)onderzoek. ${ }^{128}$ Uit het eerste evaluatieonderzoek blijkt dat dit effect met name optreedt indien in bezwaar de rechtmatigheidsaspecten nogmaals bezien worden zodat tijdens het vooronderzoek minder tijd behoeft te worden besteed aan het samenstellen van het procesdossier; in het bijzonder lijkt daarvan sprake te zijn indien een adviescommissie in de zin van artikel 7:13 Awb is samengesteld. ${ }^{129}$ Het voorgaande komt ook tot uitdrukking in de bepalingen in hoofdstuk 8 van de Awb betreffende het beroep bij de rechtbank en de door de wetgever gegeven toelichting op die bepalingen. Smit noemt als voorbeeld artikel 8:43 van de Awb waarin de bevoegdheid van de rechtbank is neergelegd om de indiener van het beroepschrift en het bestuursorgaan in de gelegenheid te stellen nogmaals schriftelijk op elkaars standpunten te reageren. ${ }^{130}$ De wetgever merkt daaromtrent op dat na de wisseling van beroep- en verweerschrift de zaak in haar algemeenheid, mede gelet op de daaraan voorafgaande bezwaarschriftprocedure, wel zo duidelijk zal liggen dat aan een nadere schriftelijke ronde geen behoefte zal bestaan. ${ }^{131}$ De door de bezwaarschriftprocedure teweeg gebrachte verduidelijking van het geschil kan op deze wijze doorwerken in de manier waarop het vooronderzoek in de procedure bij de bestuursrechter plaatsvindt. De bevoegdheid in het voormelde artikel is dan ook aan de rechtbank gegeven met het oog op die gevallen waarin desondanks toch behoefte zal zijn aan een nadere schriftelijke ronde. ${ }^{132}$

Uit de diverse onderzoeken die verricht zijn naar de bezwaarschriftprocedure is voorts gebleken dat het doorlopen van deze procedure in het overgrote deel van de gevallen ook daadwerkelijk een betere uitwerking, de tweede kant van de verduidelijkingsfunctie, van de bestaande geschilpunten oplevert met als (te verwachten) gevolg een vermindering van de werklast voor de rechter. ${ }^{133}$ Ook uit het onderzoek dat Sanders heeft verricht komt naar voren dat de bezwaarschriftprocedure in alle gevallen leidt tot een betere uitwerking van de zaak. ${ }^{134}$ Er komt meer informatie beschikbaar door onder meer de verslagen van de hoorzitting waar de standpunten van partijen worden weergegeven. Ook draagt de motivering van de beslissing op bezwaar volgens Sanders bij aan een betere uitwerking van de zaak. Daarin wordt veelal specifieker op de omstandigheden van het geval ingegaan. ${ }^{135}$

De andere kant van de verduidelijkingsfunctie, de nadere afbakening van het geschil, komt daarentegen in de praktijk minder goed uit de verf. Van een nadere afbakening van het geschil blijkt lang niet altijd sprake te zijn. ${ }^{136}$ Sanders geeft aan dat uit de bevindingen van zijn onderzoek blijkt dat de geschilpunten regelmatig, in plaats van de verwachte beperking, worden uitgebreid. Ook vindt slechts in geringe mate een nadere omlijning van de geschilpunten plaats. ${ }^{137}$

\section{Adviescommissie}

Er kan voorts nog een onderscheid gemaakt te worden tussen de gevallen waarin een adviescommissie op grond van artikel 7:13 van de Awb is ingesteld en de gevallen waar-

\footnotetext{
128. Verslag Evaluatie Awb I, p. 51; A.R. Neerhof, 'De bezwaarschriftprocedure; functioneel voor de rechtsbescherming en de kwaliteit van de besluitvorming?', in: F.A.M. Stroink, A.W. Heringa \& A.R. Neerhof (red.), Vijf jaar JB en Awb, Den Haag: Sdu 1999 (hierna: Neerhof 1999a), p. 69.

129. Verslag Evaluatie Awb I, p. 51.

${ }^{130 .}$ Smit 1992, p. 49-50.

131. PG Awb II, p. 441.

132. PG Awb II, p. 441. Verder merkt de wetgever nog op dat een nadere uitwisseling van standpunten ook in sommige gevallen ook een goede bijdrage kan leveren aan oplossing van het geschil zodat een rechterlijk uitspraak niet meer nodig zal zijn. Daarmee wordt ook de mogelijkheid van dupliek en repliek in het perspectief van vermindering van de werklast voor de rechter geplaatst.

${ }^{133 .}$ Sanders 1998, p. 159-160; Verslag Evaluatie Awb I, p. 51.

134. Sanders 1998, p. 160.

135. Zie vorige noot

136. Sanders 1998, p. 158-159.

137. Sanders 1998, p. 159.
} 


\section{De bezwaarschriftprocedure en het administratief beroep}

in daarvan geen sprake is. Het eerste evaluatierapport van de Awb geeft aan dat vooral in die gevallen waarbij een adviescommissie betrokken is sprake is van een verduidelijking van het geschil. Mede omdat in een dergelijke adviescommissie vaak juristen en bovendien externe leden plaatsnemen wordt naast (of wellicht veeleer in plaats van) de beleidsmatige aspecten ook volop aandacht aan de rechtmatigheidsaspecten besteed. ${ }^{138}$ De deelname van externe leden leidt tot een focus op rechtmatigheidsaspecten nu deze zich terughoudend opstellen ten aanzien van beleidskwesties, omdat de (democratische) legitimatie ontbreekt om een oordeel te geven over politiek-bestuurlijke kwesties. In de literatuur wordt ook wel gesteld dat in die gevallen zelfs te veel aandacht aan de rechtmatigheidsaspecten besteed waardoor het bestuurlijke karakter van de bezwaarschriftprocedure verloren gaat. ${ }^{139}$ Door de aandacht voor rechtmatigheidsaspecten treedt volgens de evaluatiecommissie een betere omlijning van het geschil op. ${ }^{140}$ Uit het eerste evaluatie-onderzoek blijkt dat de mate waarin een verduidelijking van het geschil optreedt afhankelijk is van de kwaliteit van de voorafgaande bezwaarschriftprocedure en de mate waarin contentieuze elementen zijn ingebouwd (zoals de instelling van een adviescommissie in de zin van artikel 7:13 Awb). ${ }^{141}$

\section{Aard van de bevoegdheid}

Voor de verduidelijkingsfunctie van de bezwaarschriftprocedure lijkt de aard van de bevoegdheid die uitgeoefend wordt door het bestuur niet van noemenswaardige betekenis te zijn. Verduidelijking van het geschil treedt volgens Sanders in vrijwel alle door hem onderzochte gevallen op ongeacht het type bestuursbevoegdheid of beleidsterrein. ${ }^{142}$ Daarbij maakt hij echter een belangrijke nuancering. Van een nadere afbakening van het geschil (het eerste aspect van de verduidelijkingsfunctie volgens Sanders) lijkt in geen van de door hem onderzochte gevallen sprake te zijn. Een betere uitwerking van het geschil doordat meer informatie beschikbaar komt (de tweede kant van die functie) vindt veelal wel plaats. Wel kan nog worden opgemerkt dat in beschikkingenateliers, waarin de meer discretionaire besluitvorming plaatsvindt, veelal ook gebruik wordt gemaakt van een adviescommissie in bezwaar. ${ }^{143}$ De instelling van een dergelijke commissie leidt in het algemeen tot een betere uitwerking van het geschil zoals hiervoor aangegeven. ${ }^{144}$

\section{Conclusie}

Al met al lijkt de conclusie gerechtvaardigd dat de bezwaarschriftprocedure een zekere verduidelijking van het geschil oplevert, in elk geval wat betreft de nadere uitwerking van het geschil. In samenhang daarmee is de verwachting dat daardoor ook sprake is van een daadwerkelijke afname van de werklast van de rechter. Sanders geeft echter aan dat niet vaststaat dat rechters daardoor ook daadwerkelijk minder tijd besteden aan een zaak of het procesdossier maar uit interviews met diverse rechters lijkt dit wel naar voren te komen. ${ }^{145}$ De wetgever is daar wat betreft het te verrichten vooronderzoek door de rechter op grond van de Awb wel vanuit gegaan. De verduidelijkingsfunctie ligt in het verlengde van de rechtsbeschermingsfunctie van de bezwaarschriftprocedure en bevestigt de rol van de bezwaarschriftprocedure (ook in de praktijk) als voorportaal van de rechtsbe-

\footnotetext{
138. Verslag Evaluatie Awb I, p. 51

139. Koenraad \& Sanders 2006, p. 54; Verslag Evaluatie Awb II, p. 15-16; Verslag Evaluatie Awb I, p. 44-45. Zie hierover par. 4.3.1 van dit deel.

${ }^{140 .}$ Verslag Evaluatie Awb I, p. 51

${ }^{141 .}$ Verslag Evaluatie Awb I, p. 51

142. Sanders 1998, p. 160-161.

143. Vooral in het milieurecht en ruimtelijk bestuursrecht lijkt dat het geval te zijn, Verslag Evaluatie Awb I, p. 45.

44. Zoals nog wordt toegelicht in par. 4.3.1 leidt de instelling van dergelijke commissies tegelijkertijd ook tot meer aandacht voor de rechtmatigheidsaspecten in de heroverweging.

${ }^{145 .}$ Sanders 1998, p. 160.
} 
Deel II Bestuurlijke voorprocedures

scherming. Naarmate de procedure of de toetsing meer gelijkenissen vertoont met die van de bestuursrechter, lijkt de verduidelijking van het geschil toe te nemen.

\subsubsection{Leerfunctie}

De bezwaarschriftprocedure biedt niet alleen voor (de procedure bij) de bestuursrechter of de burger voordelen. ${ }^{146}$ Aangenomen wordt dat de bezwaarschriftprocedure ook een zuiver vanuit bestuurlijk oogpunt nuttige functie kan hebben. ${ }^{147}$ Door de heroverweging van de primaire besluitvorming door het bestuursorgaan kunnen gebreken in de organisatie naar voren komen waartegen vervolgens maatregelen getroffen kunnen worden. ${ }^{148}$ In deze zin heeft de bezwaarschriftprocedure aldus een signaalfunctie ofwel leerfunctie. ${ }^{149}$ Sanders omschrijft de leerfunctie als volgt:

"De bezwaarschriftprocedure signaleert gebreken in de primaire besluitvorming en stelt bestuursorganen en hun medewerkers in staat van de geconstateerde fouten te leren."150

De omschrijving die Sanders hanteert is echter ruimer dan de omschrijving van de wetgever. ${ }^{151}$ Naast het leereffect op 'managementniveau' waardoor organisatorische maatregelen getroffen kunnen worden tegen de gebleken gebreken, onderscheidt hij nog het leereffect op 'individueel niveau'. ${ }^{152}$ Daarmee doelt hij op het leereffect dat de bezwaarschriftprocedure op de individuele ambtenaar kan hebben indien deze op de hoogte worden gesteld van de beslissing op bezwaar. Op die wijze kan worden bewerkstelligd dat de individuele ambtenaar in vergelijkbare gevallen niet bij herhaling dezelfde fout maakt. ${ }^{153}$ Voorwaarde voor het aanwezig zijn van een leereffect in welke zin dan ook is echter wel dat organisatorische maatregelen getroffen worden waarbij informatie uit de bezwaarfase verzameld en geanalyseerd wordt, waarna vervolgens terugkoppeling naar de primaire beslissers dient plaats te vinden. ${ }^{154}$ Dat blijkt niet altijd het geval te zijn. De bevindingen van de verschillende onderzoeken verricht naar het functioneren van de bezwaarschriftprocedure lijken aan te tonen dat de leerfunctie van de bezwaarschriftprocedure nog niet optimaal uit de verf komt. ${ }^{155}$ Dit is met name te wijten aan het gebrek aan organisatorische maatregelen om dit leereffect optimaal te benutten. ${ }^{156}$ In dat opzicht is derhalve nog verbetering mogelijk. Dat de bezwaarschriftprocedure deze functie kan hebben en ook heeft indien bestuursorganen daartoe de juiste maatregelen treffen, wordt echter nog steeds onderschreven. ${ }^{157}$ De leerfunctie brengt vooral tot uitdrukking dat de bezwaarschriftprocedure een vanuit het perspectief van de kwaliteit van het bestuur een nuttige

146. Notten signaleert dat dat een van de kritiekpunten vormde: de bezwaarschriftprocedure zou slechts deze actoren voordelen bieden, terwijl het voordelig effect voor het bestuur niet bestond, Notten 1998, p. 340

147. PG Awb I, p. 279.

148. PG Awb I, p. 279; Neerhof 1999a, p. 68; Verslag Evaluatie Awb I, p. 44; Sanders 1998, p. 78-79.

149. Zie hierover o.m.: Koenraard \& Sanders 2006, p. 18; Neerhof 1999a, p. 68 e.v.; A.J.G.M. van Montfort en H.B. Winter, 'Kleine gebreken geen bezwaar?: een evaluatie van de bezwaarschriftprocedure uit de Awb', in: M. Herweijer, K.F. Schuiling en H.B. Winter (red.), In wederkerigheid (Scheltema-bundel), Deventer: Kluwer 1997, p. 188.

${ }^{150 .}$ Sanders 1998 , p. 79

151. Sanders 1998, p. 79

152. Sanders 1998 , p. $79-80$

153. Sanders 1998, p. 80

154. Van Wijk/Konijnenbelt \& Van Male 2008, p. 545; Sanders 1998, p. 79-80; Verslag Evaluatie Awb I, p. 50; Neerhof 1999a, p. 70-71; Van Montfort en Winter 1997, p. 192.

155. Sanders 1998, p. 145-146; Verslag Evaluatie Awb I, p. 50. De evaluatiecommissie merkt wel op dat er nog onvoldoende gegevens voorhanden zijn om definitieve conclusies trekken. Ook hierbij is van belang het onderscheid tussen beschikkingenfabrieken en -ateliers. Zie hierover par. 4.2.2.4.

${ }^{156 .}$ Zie vorige noot.

157. Zie bijvoorbeeld Sanders die echter de kanttekening plaatst dat de bezwaarschriften een vertekend beeld geven van de primaire fase en derhalve veel minder leermogelijkheden biedt dat de wetgever heeft verondersteld. Toch stelt hij zich op het standpunt dat de bezwaarschriftprocedure een (beperkte) leerfunctie kan hebben en dat het zaak is dat bestuursorganen de leerkansen die er zijn maximaal benutten, Sanders 1998, p. 146. 
De bezwaarschriftprocedure en het administratief beroep

functie kan hebben. ${ }^{158}$ De bezwaarschriftprocedure biedt het bestuur immers nogmaals de mogelijkheid naar het besluit te kijken en het besluitvormingsproces over te doen teneinde fouten te kunnen herstellen (voor de toekomst). In dit verlengde besluitvormingsproces zorgt de signalering van fouten en de terugkoppeling daarvan voor een leereffect. In beginsel heeft de bezwaarschriftprocedure vanuit deze functie bezien, mits deze functie in de praktijk gerealiseerd wordt, vooral voordelige effecten voor het bestuur. ${ }^{159}$

Opmerkelijk en vermeldenswaard is ten slotte dat, zoals uit het onderzoek van Sanders blijkt, het leereffect van de jurisprudentie van de rechter omvangrijker is dan het leereffect van de beslissing op bezwaar. De oorzaak, zo stelt Sanders, blijkt gelegen te zijn in het gezag van de oordelende instantie:

"Het oordeel van de bezwaarbehandelende instantie heeft niet het gezag van een rechterlijke uitspraak. Een gegrondverklaring van het bezwaarschrift heeft, naar het oordeel van de meeste ondervraagden, minder verstrekkende gevolgen dan de gegrondverklaring van een beroepschrift en dus weegt het oordeel van de bezwaarbehandelende instantie (...) minder zwaar." 160

Deze bevinding bevestigt het gezag dat aan uitspraken van de (bestuurs)rechter wordt toegekend, ook door het bestuur. Deze bevinding stemt ook overeen met hetgeen Herweijer opmerkt in de Scheltema-bundel. Hij stelt dat de Awb een toegenomen gezag voor de bestuursrechter heeft veroorzaakt en dat die toename het management van bestuursorganen ertoe doet nopen meer nadruk te leggen op de geschilbeslechtingsfunctie (of rechtsbeschermingsfunctie) van de bezwaarschriftprocedure in plaats van de functie van verlengde besluitvorming. ${ }^{161}$ Daarmee lijkt hij te doelen op het feit dat het bestuur zich meer op de rechtmatigheid van het besluit en het kunnen doorstaan van de toets door de bestuursrechter lijkt te richten.

Tot slot lijkt ook wat betreft de leerfunctie het onderscheid tussen de beide typen bevoegdheden of de verschillende beleidsterreinen geen rol van betekenis te spelen. In beide gevallen worden de leermogelijkheden nog niet optimaal benut en zijn de leereffecten dientengevolge gering, zo blijkt uit het onderzoek van Sanders. ${ }^{162}$

\section{Conclusie}

Kortom, de leerfunctie van de bezwaarschriftprocedure staat vooral in het teken van de verlengde besluitvorming en de verbetering van de kwaliteit van het bestuur. Als er in de praktijk meer lessen zouden worden getrokken uit de geconstateerde fouten in de primaire besluitvormingsfase en organisatorische maatregelen getroffen zouden worden, dan zou de procedure een nuttige functie voor het bestuur in dit opzicht kunnen vervullen. In de praktijk blijkt echter dat de ogen vooral gericht zijn op de bestuursrechter en het bestuur vooral bezig is met diens (rechtmatigheids)oordeel over het besluit.

\subsubsection{Functies van het administratief beroep}

Dezelfde functies als de bezwaarschriftprocedure

Evenals in de bezwaarschriftprocedure wordt door middel van het instellen van administratief beroep een voorziening bij een bestuursorgaan gevraagd tegen een reeds genomen besluit. Indien administratief beroep is voorgeschreven, gaat het altijd vooraf aan een procedure voor de rechter en behoeft geen andere voorprocedure meer te worden

\footnotetext{
158. Damen e.a. 2009, Deel II, p. 176.

159. Op termijn zullen uiteraard ook belanghebbende burgers daar profijt van hebben omdat in andere gevallen niet dezelfde fout gemaakt zal worden.

160. Sanders 1998, p. 144.

${ }^{161 .} \mathrm{M}$. Herweijer, 'Tussen het bezwaar en de beslissing op dat bezwaar: verlengde besluitvorming of geschilbeslechting?', in: M. Herweijer, K.F. Schuiling en H.B. Winter (red.), In wederkerigheid (Scheltema-bundel), Deventer: Kluwer 1997, p. 203.

162. Sanders 1998, p. 146.
} 


\section{Deel II Bestuurlijke voorprocedures}

doorlopen. Doordat voor administratief beroep deze met de bezwaarschriftprocedure gemeenschappelijke uitgangspunten gelden, stemmen de functies die aan het administratief beroep worden toegekend en de omvang van de heroverweging door het beroepsorgaan in die procedure, grosso modo overeen met de functies van de bezwaarschriftprocedure. ${ }^{163}$

Allereerst komt deze procedure eveneens een plaats toe in het stelsel van bestuursrechtelijke rechtsbescherming. De VAR-Commissie Rechtsbescherming schaart het administratief beroep, samen met de bezwaarschriftprocedure, onder de klassieke vormen van rechtsbescherming. ${ }^{164}$ Ook in Van Wijk/Konijnenbelt \& Van Male wordt aangegeven dat rechtsbescherming geboden kan worden door bestuursorganen in administratief beroep. ${ }^{165}$ Jarenlang was het administratief beroep in het bestuursrecht de belangrijkste (door velen geaccepteerde) vorm van rechtsbescherming voor burgers tegen overheidshandelingen. ${ }^{166}$ Het bekendste voorbeeld daarvan was het Kroonberoep. In deze voorprocedure kunnen ook rechtsbeschermingselementen worden onderscheiden. Evenals de bezwaarschriftprocedure biedt deze procedure de burger een mogelijkheid om tegen een reeds genomen besluit bezwaren aan te voeren waarbij het bestuursorgaan op grond van de herbeoordeling het bestreden besluit indien daar aanleiding toe bestaat vernietigt. Voorts zijn in de Awb voor administratief beroep vrijwel gelijke procedurele waarborgen neergelegd. ${ }^{167}$ Goorden merkt dan ook op:

"Uit het onderzoek is gebleken dat er uit het oogpunt van rechtsbescherming geen principiële verschillen tussen bezwaar en beroep bestaan. In beide gevallen kan er worden gesproken van een contentieuze procedure waarin een volledige heroverweging dient plaats te vinden."168

Het administratief beroep heeft echter niet uitsluitend een (met de bezwaarschriftprocedure overeenstemmende) rechtsbeschermingsfunctie. De drie andere functies van de bezwaarschriftprocedure worden in beginsel ook aan het administratief beroep toegeschreven. ${ }^{169}$ Omvangrijk onderzoek naar deze functies van administratief beroep, zoals bij de bezwaarschriftprocedure heeft plaatsgevonden, is bij mijn weten niet verricht. De filterfunctie, verduidelijkingsfunctie en leerfunctie krijgen minder nadruk dan bij de bezwaarschriftprocedure het geval is. ${ }^{170}$ In de literatuur wordt vooral gewezen op de rechtsbeschermingsfunctie en de toezichtfunctie van het administratief beroep. ${ }^{171}$ Het karakter van het administratief beroep is evenals dat van de bezwaarschriftprocedure derhalve tweeledig, maar in plaats van een vorm van verlengde besluitvorming wordt het aangemerkt als een vorm van toezicht. Dat volgt uit de omstandigheid dat het administratief beroepsorgaan een ander bestuursorgaan is dan het orgaan dat het primaire besluit genomen heeft. ${ }^{172}$ In Van Wijk/Konijnenbelt \& Van Male wordt het administratief beroep gekenschetst als een mengvorm van de bezwaarschriftprocedure en het bestuurlijk toezicht. ${ }^{173}$ Daarbij wordt echter opgemerkt dat de rechtsbeschermingsfunctie, de kwali-

163. Van Wijk/Konijnenbelt \& Van Male 2008, p. 545.

${ }^{164 .}$ Rapport VAR-Commissie Rechtsbescherming 2004, p. 15.

165. Van Wijk/Konijnenbelt \& Van Male 2008, p. 521

166. Zie hierover o.m.: Schueler e.a. 2007, p. 24 e.v.; N. Verheij, 'De toegang tot de rechter in het bestuursrecht', in: 50 jaar Europees verdrag voor de rechten van de mens, NJCM-Bulletin 2000, nr. 1, p. 188 e.v.

${ }^{167 .}$ PG Awb I, p. 356. Zie bijvoorbeeld: art. 7:16 en 7:17 Awb inzake het horen alsook art. 7:18 Awb inzake het indienen van stukken en ter inzage leggen van stukken.

168. C.P.J. Goorden, 'Rechtsbescherming tegen en door gemeentelijke bestuursorganen', NTB 1990, p. 137.

169. Van Wijk/Konijnenbelt \& Van Male 2008, p. 545-546.

170. Zie bijvoorbeeld: Helder 1988, p. 23. Overigens wordt in de hedendaagse literatuur over het algemeen weinig aandacht meer besteed aan het administratief beroep, gelet op de ondergeschikte positie die deze voorziening thans in ons stelsel van rechtsbescherming inneemt. Voor de specifieke kenmerken van het administratief beroep en zijn functies moet derhalve noodgedwongen teruggegrepen worden op wat oudere literatuur.

${ }^{171 .}$ Helder 1988 , p. 23.

172. Damen e.a. 2009, Deel II, p. 175

173. Van Wijk/Konijnenbelt \& Van Male 2008, p. 545-546. Voor het Kroonberoep: T. Barkhuysen, A. Hoeneveld en J.J. Nuijten, 'Het Kroonberoep leek dood, leve het Kroonberoep?', NTB 2000/4, p. 85. 


\section{De bezwaarschriftprocedure en het administratief beroep}

teitsbevordering en de filterwerking samenkomen met de elementen van toezicht en controle in die procedure. Hoewel de verduidelijkingsfunctie niet specifiek genoemd wordt, heeft het administratief beroep die functie in mijn optiek ook. Wat dat betreft zou er geen of nauwelijks verschil met de bezwaarschriftprocedure moeten bestaan, aangezien ook deze procedure verplicht voorafgaat aan het beroep op de bestuursrechter en de belanghebbenden in hun beroepschrift en eventueel tijdens de hoorzitting standpunten kunnen aanvoeren. Ook in deze procedure vindt een voorbehandeling van het geschil in de eerder besproken zin plaats waarop de bestuursrechter kan voortbouwen. Het administratief beroep nadert bovendien de procedure bij de rechter meer dan bezwaar, doordat een beroep wordt gedaan op een ander orgaan dan het orgaan dat het bestreden besluit genomen heeft. In dat opzicht kan aan administratief beroep een meer met rechtspraak vergelijkbaar karakter toegedicht worden. ${ }^{174}$ Voor de filterfunctie ligt het eveneens voor de hand om aan te nemen dat deze ongeveer even omvangrijk, zo niet omvangrijker is dan bij de bezwaarschriftprocedure. Die veronderstelling is gerechtvaardigd, omdat in administratief beroep een ander orgaan in de voorprocedure zich een oordeel vormt over het reeds genomen besluit. Goed voorstelbaar is dat de appellerende burger zich in een dergelijk geval doordat hij niet of minder het gevoel heeft (om maar weer eens een in dit verband veelgebruikte frase van stal te halen) 'bij de duivel te biecht te gaan' eerder bij de uitkomst van de procedure neerlegt. De door een adviescommissie in bezwaar bewerkstelligde afstandelijkheid en objectiviteit is in administratief beroep doordat een ander orgaan oordeelt immers al meer aanwezig. En zoals werd aangegeven in paragraaf 4.2.3, lijkt er een zeker verband te zijn tussen de toename van processuele waarborgen en de gelijkenis met de rechterlijke procedure en de filterwerking.

\section{Mengvorm van bestuurlijk toezicht en rechtsbescherming}

Het belangrijkste verschil met de bezwaarschriftprocedure is dat de voorziening gevraagd dient te worden bij een ander, in de regel, hoger bestuursorgaan. ${ }^{175}$ Vanwege dat verschil wordt aangenomen dat het administratief beroep een mengvorm van rechtsbescherming en bestuurlijk toezicht vormt. ${ }^{176}$ In de literatuur is echter ook gesignaleerd dat de typering van het administratief beroep als een mengvorm van rechtsbescherming en bestuurlijk toezicht geen duidelijkheid verschaft over de verhouding tussen deze beide functies. Hennekens e.a. merken hierover op:

"Soms is het dan ook onduidelijk of de rechtsbescherming met de regeling van het toezicht 'meelift' of dat het toezicht met de regeling van de rechtsbescherming 'meelift.",177

Elders wordt in Van Wijk/Konijnenbelt \& Van Male duidelijk de rechtsbeschermingsfunctie van het administratief beroep voorop gesteld:

“(...), terwijl het administratief beroep een vorm van rechtsbescherming is, zij het een vorm die ook enkele trekjes van bestuurlijk toezicht heeft.",178

\footnotetext{
174. Dat gold te meer voor het Kroonberoep, onder meer op grond van de Wet Bab, waarin judiciële elementen ingebouwd waren, zoals het advies van de Afdeling voor geschillen van bestuur van de Raad van State in een met waarborgen omklede procedure, zie over het karakter van het administratief beroep: G.J. Wiarda, 'Het administratief beroep in het ontwerp van de Wet BAB, in: Verspreide geschriften van Wiarda, Den Haag: VUGA 1986, p. 93 e.v. en G.J. Wiarda, 'Het administratief beroep', in: Verspreide geschriften van Wiarda,Den Haag: VUGA 1986, p. 121 e.v. Sommige auteurs menen echter dat administratief beroep vanwege de toezichtfunctie (waarover later meer) meer op bezwaar lijkt dan op beroep bij de rechter. In bezwaar kan er vanwege de mandaatverhoudingen ook intern toezicht bestaan, Damen e.a. 2009, Deel II, p. 25.

${ }^{175 .}$ De term hoger geeft echter geen uitdrukking aan een hiërarchische relatie tussen beide organen.

${ }^{176 .}$ Damen e.a. 2009, Deel II, p. 25 en 175; E. Helder, 'Rechtsbescherming door de gemeente: zijn er klachten of bezwaren?, in: H.A. Brasz en J.G. Steenbeek (red.), Klachten en bezwaren tegen de gemeente, Den Haag: VUGA 1988, p. 23; A.M. Donner, Algemeen bestuursrecht, Alphen aan den Rijn: Samson H.D. Tjeenk Willink 1987 , p. 330

${ }^{177}$ Hennekens e.a. 1998 , p. 148

178. Van Wijk/Konijnenbelt \& Van Male 2008, p. 515.
} 
Deel II Bestuurlijke voorprocedures

Dit in tegenstelling tot de spontane vernietiging die een vorm van bestuurlijk toezicht is met voorheen onder omstandigheden ook trekken van quasi rechtsbescherming. In hun benadering is de rechtsbeschermingsfunctie derhalve de functie die domineert (ten opzichte van de toezichtfunctie). ${ }^{179}$ Het vooropstellen van de rechtsbeschermingsfunctie lijkt dan ook de heersende benadering in de doctrine te zijn. ${ }^{180}$ Zo wordt het administratief beroep bijvoorbeeld in de verschillende handboeken behandeld als onderdeel van de beschrijving van ons stelsel van rechtsbescherming en niet zo zeer bij de onderdelen die betrekking hebben op het bestuurlijk toezicht in Nederland in samenhang met de decentralisatiegedachte. ${ }^{181}$ Illustratief is hetgeen A.M. Donner opmerkt over het Kroonberoep:

"Daarnaast zou kunnen worden genoemd [als vorm van toezicht door het hoger gezag DW] het Kroonberoep (en het beroep op g.s.), waardoor belanghebbenden in staat worden gesteld om tegen besluiten van lagere lichamen beroep in te stellen op hoger bestuursgezag: het zal hierna worden besproken als instituut van rechtsbescherming, maar het draagt nog altijd sporen van toezicht." 182

Dat de toezichtfunctie meer op de achtergrond staat bij het administratief beroep in vergelijking tot de rechtsbeschermingsfunctie kan ook uit de omstandigheid dat het initiatief in administratief beroep bij de belanghebbende(n) ligt, worden afgeleid. ${ }^{183}$ Slechts indien deze zich ten onrechte of op onbehoorlijke wijze voelt aangetast in zijn rechten of belangen kan hij of zij gebruik maken van deze voorziening om tegen die belangenaantasting op te komen (mits hij of zij rechtstreeks in zijn belangen is getroffen). Tegelijkertijd vindt daardoor controle door het beroepsorgaan van het beslissende bestuursorgaan plaats. Omdat de voorziening aanhangig gemaakt moet worden bij een ander (veelal hoger) bestuursorgaan vertoont administratief beroep, zoals aangegeven, meer dan de bezwaarschriftprocedure gelijkenis en verwantschap met de procedure voor de bestuursrechter.

Toezicht door orgaan van een ander of hetzelfde openbaar lichaam

Ook de toezichtfunctie die het administratief beroep in tegenstelling tot de bezwaarschriftprocedure heeft, hangt samen met de omstandigheid dat het een voorziening betreft bij een ander 'hoger' bestuursorgaan. Dat betekent dat een ander 'hoger' bestuursorgaan de beslissing van het primaire bestuursorgaan kan overdoen. De heroverweging in administratief beroep is in beginsel volledig, omdat ook beleidsafwegingen een rol mogen spelen. ${ }^{184}$ Daarin verschilt het administratief beroep, evenals de bezwaarschriftprocedure, van de procedure bij de bestuursrechter. De mate waarin de toezichtsfunctie zijn stempel drukt op de voorprocedure in een concreet geval, kan wel nog verschillen afhankelijk van de omstandigheid of het een voorziening betreft bij een bestuursorgaan dat behoort tot hetzelfde of een ander openbaar lichaam. Administratief beroep kan immers ofwel worden opengesteld op een ander bestuursorgaan behorend tot hetzelfde openbaar lichaam ofwel op een ander bestuursorgaan behorend tot eveneens een ander openbaar lichaam. ${ }^{185}$ Met name indien het administratief beroep ingesteld kan worden bij

\footnotetext{
179. Zie ook in die zin: Nicolaï en Olivier e.a. 1997, p. 521.

${ }^{180 .}$ Vgl. o.m.: H.Ph.J.A.M. Hennekens, H.J.A.M. van Geest, R. Fernhout, Decentralisatie, Nijmegen: Ars Aequi Libri 1998, p. 148. Veelal vindt ook in die volgorde de behandeling van beide functies plaats; eerst wordt aandacht besteed aan de rechtsbeschermingsfunctie en vervolgens aan de toezichtfunctie.

${ }^{181}$ Zie bijv.: Kortmann 2008, p. 282; Van Wijk/Konijnenbelt \& Van Male 2008, p. 521.

${ }^{182 .}$ Donner 1987, p. 168. Daarbij zij aangetekend dat Donner bij de behandeling van het administratief beroep als rechtsbeschermingsinstituut weer tekstueel toezicht voorop stelt. Hij stelt dat administratief beroep een element van toezicht verenigt met een element van rechtbescherming, p. 330. De vraag is derhalve in hoeverre door Donner maar ook andere auteurs welbewust aan de ene dan wel de andere functie het primaat lijkt te worden toegekend.

183. Nicolaï \& Olivier 1997, p. 521.

184. Damen e.a. 2009, Deel II, p. 207-208; Van Wijk/Konijnenbelt \& Van Male 2008, p. 521; Hennekens e.a. 1998 , p. 148

${ }^{185 .}$ Stroink 2004a, p. 98.
} 
De bezwaarschriftprocedure en het administratief beroep

een orgaan van een ander openbaar lichaam komt de toezichtfunctie het sterkst naar voren. ${ }^{186}$ Tegelijkertijd wordt er dan van het orgaan een meer terughoudende toetsing gevraagd. Als het primair beslissende orgaan beleidsvrijheid heeft, dient het beroepsorgaan, zeker indien dit behoort tot een ander openbaar lichaam, op afstand van de invulling daarvan te blijven. In het algemeen wordt ervan uitgegaan dat het beroepsorgaan terughoudendheid betracht ten aanzien van beleidsmatige afwegingen van het primair beslissende orgaan, vanwege de decentralisatiegedachte. ${ }^{187}$ Vanwege die terughoudendheid is de gelijkenis met de toetsing die de bestuursrechter verricht weer sterker en schuift de toezichtfunctie, die het meest gediend is met een volle toetsing, wat meer naar de achtergrond. ${ }^{188}$

\subsubsection{Conclusies}

De positie van de bestuurlijke voorprocedures in het bestuursrechtelijke systeem van rechtsbescherming

Ondanks de huidige mogelijkheid om rechtstreeks beroep in te stellen, blijft de bezwaarschriftprocedure onverminderd van belang als bestuursrechtelijke voorziening van rechtsbescherming en verlengde besluitvorming. Het ziet er immers niet naar uit dat van het rechtstreeks beroep in de toekomst dermate veel gebruik zal worden gemaakt dat de het doorlopen van de bezwaarschriftprocedure langzaamaan een uitzondering zal worden. De bezwaarschriftprocedure als bestuurlijke voorprocedure lijkt nog voldoende toegevoegde waarde te hebben en vormt nog steeds de belangrijkste bestuurlijke voorprocedure. De procedure heeft in algemene zin vier functies: de rechtsbeschermingsfunctie, filterfunctie, leerfunctie en verduidelijkingsfunctie. Uit de omstandigheid dat de bezwaarschriftprocedure nog steeds de belangrijkste voorprocedure is die in de meeste gevallen ook gevolgd wordt, kan afgeleid worden dat de vier functies die aan de bezwaarschriftprocedure worden toegekend nog steeds als waardevol worden ervaren door zowel de belanghebbende als het bestuursorgaan. De bestuursrechters zien eveneens een toegevoegde waarde, aangezien zij ervoor waken dat niet al te lichtvaardig gebruik wordt gemaakt van de prorogatiemogelijkheid. De vier functies van de bezwaarschriftprocedure vallen te herleiden tot het tweeledige karakter van die procedure, rechtsbescherming en verlengde besluitvorming. De verduidelijkingsfunctie en de filterfunctie kunnen worden afgeleid van de rechtsbeschermingsfunctie en maken duidelijk dat de bestuurlijke voorprocedures en de procedure bij de bestuursrechter in elkaars verlengde liggen. De leerfunctie valt vooral te herleiden tot het verlengde besluitvormingskarakter, in de zin dat er een mogelijkheid tot foutenherstel bestaat.

\section{Rechtsbescherming en verlengde besluitvorming}

Rechtsbescherming en verlengde besluitvorming zijn echter geen twee aan elkaar tegengestelde uitgangspunten. Er is veeleer sprake van twee verschillende perspectieven. Vanuit het perspectief van de belanghebbende burger is de bezwaarschriftprocedure een rechtsbeschermingsvoorziening waarmee een besluit aangetast kan worden. Vanuit het perspectief van het bestuur vormt de bezwaarschriftprocedure daarentegen een mogelijkheid om fouten in de besluitvorming te herstellen en een zorgvuldiger besluit te nemen.

De rechtsbeschermingsfunctie van de bezwaarschriftprocedure valt tot op zekere hoogte te vergelijken met de rechtsbeschermingsfunctie die aan bestuursrechtspraak wordt toegekend. In bezwaar vindt in een groot aantal gevallen een rechtmatigheidstoetsing en beslechting van een rechtsgeschil plaats, evenals het geval is bij bestuursrechtspraak. Rechtsbescherming en bestuursrechtspraak vallen niet samen. Rechtsbescher-

\footnotetext{
186. Van Wijk/Konijnenbelt \& Van Male 2008, p. 498.

187. PG Awb I, p. 362. Zie ook: Damen e.a. 2009 Deel II, p. 208; Van Wijk/Konijnenbelt \& Van Male 2008, p. 545-546.

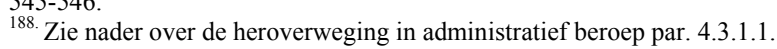




\section{Deel II Bestuurlijke voorprocedures}

ming kan ook geboden worden door andere organen dan de onafhankelijke rechter en kan meer omvatten dan een rechtmatigheidstoetsing. Rechtsbescherming in ruime zin omvat ook de heroverweging van beleidsaspecten. In de gevallen waarin het bestuur geen gebonden bevoegdheid uitoefent, maar een discretionaire bevoegdheid kan er derhalve door de volledige heroverweging sprake zijn van meer rechtsbescherming. Het begrip rechtsbescherming wordt in dit onderzoek ingevuld als het bindend beslechten van rechtsgeschillen tussen burger en bestuur over de uitoefening van een publiekrechtelijke bevoegdheid waardoor rechten of belangen van die burger geraakt worden in een behoorlijke en effectieve procedure.

Het verlengde besluitvormingskarakter komt tot uitdrukking in twee aspecten. Allereerst omdat er in de bezwaarschriftprocedure herstel van fouten plaatsvindt die in de primaire besluitvormingsfase door het bestuursorgaan gemaakt zijn. Het andere aspect waarin het verlengde besluitvormingskarakter naar voren komt, is de volledige heroverweging, met inbegrip van beleidsaspecten, die in de bezwaarschriftprocedure moet plaatsvinden. In hoeverre er sprake is van volledige heroverweging en waaruit de heroverweging bestaat, wordt in de volgende paragraaf onderzocht.

De aard van de bevoegdheid die in primo wordt uitgeoefend is van belang voor beide functies. In beschikkingenfabrieken, waar veelal meer gebonden besluitvorming plaatsvindt, vertoont de werkzaamheid van het bestuur gelijkenis met die van de bestuursrechter. Er vindt, ook in de bestuurlijke voorprocedures, een heroverweging plaats die lijkt op de rechtmatigheidstoetsing die de bestuursrechter verricht. De begrippen rechtmatigheidstoetsing en rechtsbescherming vallen hier samen. Er is sprake van verlengde besluitvorming die tot uitdrukking komt in het herstel van fouten en een meer zorgvuldige besluitvorming. In beschikkingenateliers, waar veelal meer discretionaire bevoegdheden worden uitgeoefend, kan het bestuur meer rechtsbescherming bieden door de beleidsmatige heroverweging. In de praktijk blijkt dat niet altijd te gebeuren, omdat er adviescommissies worden ingesteld die zich richten op rechtmatigheidsaspecten. Ook in die gevallen zijn er derhalve gelijkenissen met de werkzaamheid van de bestuursrechter en verkrijgt de procedure meer contradictoire trekken. Tegelijkertijd vormt het bestuurlijke element in de heroverweging, de beleidsmatige aspecten, in beschikkingenateliers vanuit het perspectief van het bestuur het verlengde besluitvormingskarakter.

\subsection{Heroverweging in de voorprocedures}

Zoals in de vorige paragraaf al een paar keer aan de orde kwam, komt het tweeledige karakter van de bezwaarschriftprocedure niet alleen tot uitdrukking in de functies van deze procedure, maar ook in de aard en omvang van de bestuurlijke werkzaamheid in de bezwaarfase. Om deze vast te kunnen stellen, wordt in het onderstaande het algemene kader op grond van de relevante wettelijke voorschriften, literatuur en jurisprudentie geschetst. Voor dit onderzoek zijn de omvang van de heroverwegingsplicht (paragraaf 4.3.1) en het ex-nunc-karakter van de heroverweging (paragraaf 4.3.2) in het bijzonder bepalend. Daarbij wordt vooral bezien in hoeverre er verschillen of overeenkomsten bestaan met de rechterlijke werkzaamheid in een bestuursrechtelijke procedure. Vervolgens is van belang of, als er grote verschillen of overeenkomsten geconstateerd kunnen worden, deze aanleiding vormen voor het al dan niet aannemen van toepasselijkheid of betekenis van de beginselen van behoorlijke rechtspleging voor de bestuurlijke voorprocedures. Daarop wordt in paragraaf 4.4 nader ingegaan. 
De bezwaarschriftprocedure en het administratief beroep

4.3.1 De omvang van de heroverweging

\subsubsection{Volledige heroverweging in de voorprocedures}

Volledige heroverweging in bezwaar

De omvang van de bestuurlijke herbeoordeling en de heroverwegingsplicht die in artikel 7:11 Awb is neergelegd, bepaalt in belangrijke mate het karakter van de bezwaarschriftprocedure. ${ }^{189}$ Ingevolge het eerste lid van dit artikel dient, voorzover het bezwaar ontvankelijk is, op grondslag daarvan een heroverweging van het bestreden besluit plaats te vinden. Heroverweging van de primaire besluitvorming vormt de kern van de werkzaamheid van het bestuursorgaan in deze (voor)procedure. ${ }^{190}$ Uit de tekst van voormelde bepaling als zodanig komt niet duidelijk naar voren wat de omvang is van de heroverweging en op welke aspecten van de besluitvorming de heroverweging kan zien. ${ }^{191}$ Uit de toelichting blijkt echter dat de wetgever met deze bepaling uitdrukkelijk in de wet heeft willen vastleggen dat de heroverweging niet beperkt mag blijven tot rechtmatigheidsaspecten en de vraag of het besluit de toetsing door de rechter kan doorstaan. Ook kwesties van beleid dienen onderdeel uit te maken van de heroverweging. ${ }^{192}$ De heroverweging (in het kader van deze voorprocedure) dient derhalve een volledige herbeoordeling van de primaire besluitvorming te zijn, in de zin dat deze zowel rechtmatigheidsaspecten als beleidsmatige aspecten dient te omvatten. ${ }^{193}$

De volledigheid van de heroverweging brengt, zoals eerder aangegeven, tot uitdrukking dat de bezwaarschriftprocedure in beginsel dient te worden gezien als een vorm van verlengde besluitvorming. ${ }^{194}$ Dit bestuurlijke aspect van de bezwaarschriftprocedure komt ook naar voren in de gevolgen die de heroverweging met zich kan brengen, ingevolge het tweede lid van artikel 7:11 Awb. Daarin is neergelegd dat voorzover de heroverweging daartoe aanleiding geeft, het bestreden besluit dient te worden herroepen en het bestuursorgaan voor zover nodig in plaats daarvan een nieuw besluit neemt. Stroink is van oordeel dat de integrale heroverweging (ex nunc) zoals die voortvloeit uit artikel 7:11 Awb met als resultaat een nieuw besluit, de belangrijkste karakteristiek van de bezwaarschriftprocedure (alsook van het administratief beroep) vormt. Daarin is zijns inziens ook het belangrijkste verschil met bestuursrechtspraak gelegen. ${ }^{195}$ In de doctrine geldt de volledige heroverweging, waarbij beleids- en rechtmatigheidsaspecten betrokken worden, als gangbaar uitgangspunt. Daarmee wordt met name het karakteristieke verschil met de werkzaamheid van de bestuursrechter, gelet op de positie en de verhouding tussen bestuur en rechter in ons staatsbestel, en het karakter van verlengde besluitvorming benadrukt. ${ }^{196}$ Ook in de jurisprudentie wordt uitgegaan van een plicht tot volledige heroverweging en wordt dit kenmerk gesteld tegenover de toetsing door de rechter op rechtmatigheidsaspecten. Dat uitgangspunt werd al vrij snel na inwerkingtreding van de Awb in de jurisprudentie bevestigd. Zo overweegt de Centrale Raad van Beroep in een uitspraak van 23 september 1996 dat:

(...) "de mondelinge behandeling van het beroep niet op een lijn kan worden gesteld met het horen in de bezwaarschriftprocedure, daar de rechterlijke toetsing van de rechtmatigheid van het besluit van andere

\footnotetext{
${ }^{189 .}$ Notten 1998, p. 13 e.v.; K.H. Sanders, 'Ruimte voor heroverweging', JB-plus 2005, p. 3.

${ }^{190 .}$ Koenraad \& Sanders 2006, p. 86-87; Sanders 2005, p. 3; Sanders 2004, p. 39; Notten 1998, p. 35.

191. Vgl: Sanders 2005, p. 3.

192. PG Awb I, p. 347.

${ }^{193 .}$ Damen e.a. 2009, Deel II, p. 193; Van Wijk/Konijnenbelt \& Van Male 2008, p. 560-561; Koenraad \& Sanders 2006, p. 86-87; Sanders 2004, p. 40; L.M. Koenraad \& F.F.W. Brouwer, 'De bezwaarschriftprocedure heroverwogen (I). Het karakter van de beslissing op bezwaar', Gst. (2001) 7151, p. 503; Van Male 1998, p. 44; Notten 1998, p. 20 en 36.

194. Zie par. 4.2.2.4.

195. Stroink 2004a, p. 101.

196. Zie bijvoorbeeld: Van Wijk/Konijnenbelt \& Van Male 2008, p. 525-526; Notten 1998, p. 36-37.
} 
Deel II Bestuurlijke voorprocedures

aard is dan de integrale bestuurlijke heroverweging door een bestuurorgaan naar aanleiding van een bezwaarschrift."

Hoewel in de uitspraak centraal staat dat het bestuur ten onrechte had nagelaten de belanghebbende te horen op grond van artikel 7:2 Awb en in hoeverre de schending van deze bepaling gepasseerd kon worden op grond van artikel 6:22 Awb, wordt daarbij nadrukkelijk het verschil in werkzaamheid in bezwaar en in beroep bij de rechter in algemene zin voorop gesteld. Van belang is ook de aard van de bevoegdheid in dit kader. Zoals in de noot bij voormelde uitspraak wordt opgemerkt, is de gedachte dat bij een discretionaire bevoegdheid (die niet volledig gestructureerd is door beleidsregels) een schending van artikel 7:2 Awb in beroep bij de rechter in elk geval niet hersteld kan worden, juist omdat dan de werkzaamheid van de rechter verschilt van die van het bestuur. ${ }^{198}$ De werkzaamheid van het bestuur is in zo'n geval typisch bestuurlijk vanwege de beleidsmatige afwegingen. Uitsluitend indien er een discretionaire bevoegdheid in primo is uitgeoefend, kan eveneens sprake zijn van een volledige heroverweging in bezwaar als hiervoor bedoeld.

\section{Rechtmatigheid en doelmatigheid}

In het verlengde van het voorgaande verdient een aantal nuanceringen van het onderscheid tussen een beoordeling van uitsluitend rechtmatigheidsaspecten en een beoordeling waarbij ook doelmatigheidsaspecten een rol mogen spelen, aandacht. Van oudsher werd het verschil hiertussen naar voren gebracht om met name de keuze voor een vol en onbeperkt (administratief) beroep op de Kroon of een beroep op de onafhankelijke rechter te rechtvaardigen. ${ }^{199}$ Het is een onderscheid dat vooropgesteld wordt, teneinde het verschil tussen het bestuur en daartoe behorende beroepsorganen en de administratieve rechtspraak, rechterlijke instanties te verduidelijken en te verscherpen. Hoewel dit onderscheid nog steeds opgeld doet in de doctrine wordt hierop al geruime tijd, mede gelet op de ontwikkeling van de algemene beginselen van behoorlijk bestuur, enige relativering aangebracht. ${ }^{200}$ De rechter heeft door middel van de ontwikkeling van de algemene beginselen van behoorlijk bestuur meer grip gekregen op de uitoefening van (onder meer) discretionaire bevoegdheden door het bestuur (ook in de bestuurlijke voorprocedure) en de strikte scheiding tussen de wijze van beoordelen door het bestuur en de bestuursrechter vervaagt ook daardoor. ${ }^{201}$ De rechter mag de bestuurlijke en beleidsmatige afweging die het bestuur maakt niet overdoen en dient deze terughoudend te beoordelen, maar kan deze voor het overige toetsen aan de algemene beginselen van behoorlijk bestuur. ${ }^{202}$

Schueler e.a. wijzen er in het kader van de derde evaluatie van de Awb wel op dat de rechter zich vaak moet beperken tot een terughoudende formele toetsing aan de algemene beginselen van behoorlijk bestuur waardoor er nog steeds belangrijke verschillen bestaan tussen de werkzaamheid van het bestuur en de rechter. ${ }^{203} \mathrm{Zij}$ geven aan dat bij de instelling van algemene bestuursrechtspraak deze aspecten, rechtmatigheid en doelmatigheid, uit elkaar getrokken zijn, terwijl deze voorheen (bij de toetsing in het administratief beroep) verenigd waren. Zij stellen:

"de rechtmatigheid wordt in eindeloos veel gevallen gescheiden van de inhoudelijke waardering van belangen". 204

197. CRvB 23 december 1996, AB 1997/239, m.nt. HBr; RSV 1997/119.

198. Over de vraag of dit wel mogelijk is bij gebonden bevoegdheden loopt de jurisprudentie van de verschillende bestuursrechters uiteen. Zie hierover nader: par. 5.3.2.6.

199. Schueler e.a. 2007, p. 28-30.

200. Zie bijvoorbeeld: Schueler e.a. 2007, p. 28; Schueler 1994, p. 137.

201. Vgl.: Van Wijk/Konijnenbelt \& Van Male 2008, p. 284-285; Schueler e.a. 2007, o. 28; P. de Haan, Th.G. Drupsteen, R. Fernhout, Bestuursrecht in de sociale rechtstaat, Deel I, Deventer: Kluwer 2001, p. 101-102.

202. Zie bijv.: De Haan e.a., p. 99-100.

203. Schueler e.a. 2007 , p. 39-40.

204. Schueler e.a. 2007, p. 39. 
De bezwaarschriftprocedure en het administratief beroep

Geheel zonder betekenis is het onderscheid derhalve niet voor het bepalen van de bestuurlijke en rechterlijke werkzaamheid onder de Awb en de daartussen bestaande verschillen; de betekenis ervan moet echter intussen ook niet worden overschat. Het onderscheid heeft enigszins aan scherpte ingeboet, juist omdat de rechter via de algemene beginselen van behoorlijk bestuur meer controlemogelijkheden van de beleidsmatige afwegingen die het bestuur maakt heeft gekregen.

\section{Aard van de bevoegdheid}

Daarnaast moet gewezen worden op de omstandigheid dat, ofschoon de volledige heroverweging het uitgangspunt is, de omvang van de heroverweging in een concreet geval toch met name afhankelijk is van het type bestuursbevoegdheid dat ten grondslag ligt aan de (primaire) besluitvorming. Hoe meer gebonden de bevoegdheid des te minder ruimte er voor het bestuur bestaat, ook in de bezwaarfase, om beleidsaspecten of bestuurlijke afwegingen een rol te laten spelen bij de besluitvorming. ${ }^{205}$ Slechts bij meer discretionaire bevoegdheden komt in dit opzicht het bestuurlijke karakter van de heroverweging tot zijn recht. Daarmee staat in elk geval vast dat het bestuur lang niet altijd beschikt over de vrijheid om bestuurlijke en beleidsmatige overwegingen een rol te laten spelen in het besluitvormingsproces. Dat betekent ook dat in die gevallen in bezwaar in overwegende mate sprake is van een rechtmatigheidsbeoordeling van de door het bestuur in primo gegeven toepassing en interpretatie van de wet. De heroverweging die het bestuur verricht, ligt dan zeer dicht aan tegen de toetsing van de bestuursrechter.

Algemeen bekend is dat het bestuur in veel gevallen op verschillende terreinen slechts beschikt over overwegend gebonden bevoegdheden. ${ }^{206}$ Volgens de VARCommissie Rechtsbescherming stelt het bestuur in die gevallen slechts de feiten vast, kwalificeert deze in het licht van de toepasselijke wettelijke voorschriften en past het bestuur die wettelijke voorschriften toe. Daarmee verschilt in die gevallen de taak van het bestuur niet wezenlijk van de taak van de rechter en vertoont daarmee juist sterke gelijkenissen. ${ }^{207}$ In de literatuur wordt daarbij geen onderscheid gemaakt tussen de bestuurlijke taak in de primaire besluitvormingsfase of de bestuurlijke voorfase. ${ }^{208} \mathrm{Kwanti}-$ tatief gezien neemt het bestuur vele besluiten op grond van meer gebonden bevoegdheden. ${ }^{209}$ In dit opzicht kan reeds vastgesteld worden dat daarmee ook in abstracto het doctrinaire uitgangspunt dat in de voorprocedures ook een beleidsmatige beoordeling plaatsvindt (of kan plaatsvinden), een karakteristiek verschil met de toetsing door de bestuursrechter, deels aan kracht verliest.

Daar komt nog bij dat zelfs indien het bestuur over een discretionaire bevoegdheid beschikt, het deze veelal invult met beleidsregels ten behoeve van de voorspelbaarheid van de besluitvorming en de rechtszekerheid. Het opstellen van beleidsregels heeft tot gevolg dat de vrijheid om op grond van bestuurlijke afwegingen in een concreet geval een besluit te nemen door het bestuur beperkt wordt. ${ }^{210}$ De beleidsregel dient immers, gelet op artikel 4:84 Awb, gevolgd te worden, tenzij de concrete omstandigheden van het geval nopen tot afwijking daarvan. ${ }^{211}$ Een bevoegdheid die gestructureerd is door middel

205. Verslag Evaluatie Awb I, p. 46; Van Male 1998, p. 44

206. Dat is in elk geval in kwantiteit het geval. De meeste besluiten zijn verhoudingsgewijs immers afkomstig van bestuursorganen die aangemerkt worden als beschikkingenfabrieken en enorme aantallen beslissingen moeten geven. Bijvoorbeeld op het terrein van het belastingrecht of sociale zekerheid.

${ }^{207}$ Rapport VAR-Commissie Rechtsbescherming 2004, p. 71.

208. Dat onderscheid wordt in elk geval niet expliciet benoemd, zie bv.: Rapport VAR-Commissie Rechtsbescherming 2004, p. 27.

${ }^{209}$ De grote aantallen besluiten die genomen worden is ook inherent aan de beschikkingenfabrieken.

${ }^{210 .} \mathrm{Vgl}$. A. Tollenaar, 'Het is maar wat je bijzonder noemt. Rechterlijke toetsing aan beleid en beleidsregels', $J B$ plus 2006, p. 176. Dat geldt voor beleidsregels in de Awb, maar ook voor overig beleid.

211. Over de binding van beleidsregels (en overig beleid) ook: Tollenaar 2006, p. 177 e.v. Zie ook: Van Wijk/Konijnenbelt \& Van Male 2008, p. 237. 


\section{Deel II Bestuurlijke voorprocedures}

van beleidsregels kan niet gelijk gesteld worden met een overwegend gebonden bevoegdheid. Het stellen van beleidsregels kan nimmer zo ver gaan dat de beslisruimte van het bestuur in het concrete geval geheel teniet wordt gedaan. ${ }^{212}$ Het stellen van beleidsregels leidt evenwel tot een beperking van de mogelijkheid belangen af te wegen in de 'normale' gevallen die bestreken worden door de beleidsregel. Afwijking is immers op grond van artikel 4:84 Awb slechts mogelijk in bijzondere gevallen. ${ }^{213}$ Dat heeft mijns inziens tot gevolg dat de voor de bestuurlijke werkzaamheid kenmerkende bestuurlijke vrijheid in zekere mate gereduceerd wordt en daarmee ook het onderscheid tussen de bestuurlijke en rechterlijke werkzaamheid vervaagt. De rechter mag bovendien nagaan of het bestuur in het concrete geval zijn eigen beleid heeft nageleefd en of er reden was om van dat beleid af te wijken. Voorts kan de rechter het beleid achter het ter toetsing voorliggende besluit toetsen op willekeur. ${ }^{214}$

Gelet op de ontwikkeling van de abbb en de verruiming van de toetsing door de rechter daardoor enerzijds en de omstandigheid dat de beleidsmatige heroverweging slechts kan plaatsvinden in gevallen waarin het bestuur over een discretionaire bevoegdheid beschikt, die ook veelal wordt ingevuld door beleidsregels anderzijds, is het de vraag in hoeverre de verschillen in takkuitoefening door bestuur en rechter andere waarborgen rechtvaardigen voor de inrichting van de procedures bij deze organen. Enige relativering van het traditionele verschil tussen de heroverweging door het bestuur en de toetsing door de bestuursrechter is op zijn plaats en daarmee ook het - in de inleiding en paragraaf 2.2.3 van Deel I toegelichte - daarop gebaseerde onderscheid in toepasselijke eisen.

\section{Adviescommissie in bezwaar}

Tot slot wordt algemeen aangenomen dat de instelling van een adviescommissie ex artikel 7:13 Awb tot gevolg heeft dat het verlengde besluitvormingsaspect (in de zin van typisch bestuurlijke beleidsmatige aspecten betrekken bij de heroverweging) van de bezwaarschriftprocedure meer naar de achtergrond wordt gedrukt. ${ }^{215}$ In de praktijk blijkt dat de toetsing die deze commissies verrichten (te zeer) beperkt blijft tot rechtmatigheidsaspecten. ${ }^{216}$ De oorzaak daarvan is veelal gelegen in de samenstelling van de commissie. Omdat de commissie voor een deel of geheel uit externe personen (veelal juristen) bestaat, hebben dergelijke commissies de neiging zich niet in te laten met beleidsmatige kwesties en deze als een gegeven te beschouwen. In het geval waarin binnen deze commissies in het geheel geen interne leden hebben plaatsgenomen, is zulks ook verdedigbaar aangezien de (democratische) legitimatie voor maken van politiek-bestuurlijke afwegingen ontbreekt. ${ }^{217}$ De beoordeling die een dergelijke commissie verricht en in het advies neerlegt, vertoont daardoor sterke gelijkenis met de toetsing die de bestuursrechter verricht. Ook de inrichting van de procedure krijgt in het geval van de instelling van een adviescommissie in de zin van artikel 7:13 Awb meer rechterlijke trekken en de procedure krijgt het karakter van een meer contentieuze contradictoire procedure. ${ }^{218}$

\footnotetext{
212. Vgl.: Damen e.a. 2009, Deel I, p. 234-235; F.A.M. Stroink, '(Stroink 2004c)', in: E.C.H.J. van der Linden en F.A.M. Stroink (red.), JB-Select, Den Haag: Sdu 2004, p. 261.

213. Tollenaar 2006, p. 177.

214. Tollenaar 2006, p. 180 e.v

215. C.P.J. Goorden, 'Bezwaarschriftprocedures in de gemeentelijke praktijk', NTB 1995/9-10, p. 298.

${ }^{216 .}$ Koenraad \& Sanders 2006, p. 54; Sanders 2004, p. 40-41; Verslag evaluatie Awb I, p. 44-45; Verslag evaluatie Awb II, p. 16. Dat druist overigens, zoals bleek in het bovenstaande, in tegen de uitdrukkelijke bedoeling van de wetgever.

217. Vgl. Verslag Evaluatie Awb II, p. 16.

218. Zie bijv.: L.M. Koenraad en G.A.L. van Schijndel, 'Raadsleden en bezwaar. Enige beschouwingen over de voor- en nadelen van de aanwezigheid van raadsleden in commissies die zijn belast met advisering over de afhandeling van bezwaren', Gst. 2005, 7226, p. 157 e.v.; C.L.G.F.H. Albers, 'Commentaar artikel 7:13', in: M. Scheltema, R.M. van Male, B.W.N. de Waard, A.T. Marseille, A.J.C. de Moor-van Vugt (red.), Commentaar Algemene wet bestuursrecht, Amsterdam: Reed Elsevier (voorheen Den Haag: VUGA), losbladige uitgave, E 7:13-3; Koenraad \& Sanders 2006, p. 57; Sanders 2004, p. 34; Verslag Evaluatie Awb I, p. 44-45.
} 
De bezwaarschriftprocedure en het administratief beroep

Bestuur en de belanghebbende burger staan immers voor de commissie tegenover elkaar als twee partijen die hun standpunt kunnen verdedigen en toelichten.

Uit onderzoek is gebleken dat veel bestuursorganen gebruik maken van een adviescommissie ten behoeve van de beslissing op bezwaar. ${ }^{219}$ Daarenboven wordt in veel gevallen het advies dat deze commissie geeft, waarbij een (te) sterke nadruk ligt op de rechtmatigheidsaspecten, door het betreffende bestuursorgaan veelal gevolgd. Dat maakt dat in de praktijk in deze gevallen de rechtmatigheidstoetsing en de rechtsbeschermingsfunctie het karakter van verlengde besluitvorming en de daarbij behorende doelmatigheidsoverwegingen is gaan overheersen. Goorden merkt daarover op dat:

“(...) door de inschakeling van een onafhankelijke commissie het zwaartepunt in de bezwaarschriftprocedure met name op het rechtsbeschermingselement komt te liggen en minder op de verlengde besluitvorming".220

Bij de wenselijkheid van deze ontwikkeling zijn vraagtekens geplaatst vanwege de beperking van de bestuurlijke karakteristieken van de bezwaarfase die daardoor teweeg gebracht wordt. ${ }^{221}$ Buiten kijf staat echter dat de rechtmatigheidsbeoordeling en rechtsbeschermingsfunctie hierdoor, ten koste van dit aspect van verlengde besluitvorming, meer nadruk krijgen in de bestuurlijke voorfase. In de gevallen waarin een adviescommissie wordt ingesteld, is derhalve sprake van een, bovenop de hiervoor al geschetste omstandigheden, omstandigheid die leidt tot een beperking van het typische bestuurlijke element in de beoordeling in bezwaar en daarmee ook tot een verdere vervaging van het onderscheid tussen de bestuurlijke en rechterlijke werkzaamheid. Daar komt nog bij dat in veel gevallen waarin het bestuur over een gebonden bevoegdheid beschikt, vanwege de massaliteit van het besluitvormingsproces en de daarmee gepaard gaande tijd, niet gewerkt wordt met bezwaaradviescommissies. Juist in die gevallen waarin het bestuur de vrijheid heeft om bestuurlijke afwegingen te maken in bezwaar en de bezwaarschriftprocedure meer bestuurlijke kenmerken zou kunnen vertonen, in de beschikkingenateliers derhalve, blijkt dat dit effect teniet wordt gedaan of verminderd doordat (veelal) gebruik wordt gemaakt van een adviescommissie. ${ }^{22}$

Dat betekent dat ook in de gevallen waarin het bestuurlijke aspect, vanwege de discretionaire bevoegdheid van het bestuur, meer aanwezig kan zijn in de bestuurlijke voorprocedures door de inschakeling van een adviescommissie de betekenis van de beginselen van behoorlijke rechtspleging en voor de rechter geldende eisen niet onaannemelijk is.

\section{Volledige heroverweging in administratief beroep}

Zoals eerder aangegeven is in artikel 7:25 van de Awb neergelegd dat het administratief beroepsorgaan het bestreden besluit vernietigt, voorzover het beroep ontvankelijk en gegrond wordt geacht. Hoewel dit artikel correspondeert met artikel 7:11 van de Awb voor de bezwaarschriftprocedure wat betreft de herbeoordeling, is daarin echter, in tegenstelling tot artikel 7:11 van de Awb, geen volledige heroverwegingsplicht voor het beroepsorgaan neergelegd. ${ }^{223}$ Omdat er over de omvang van de heroverweging geen consensus bestaat in de literatuur en jurisprudentie is er, aldus de wetgever, vanaf gezien om in dat verband een bepaling op te nemen in de Awb. ${ }^{224}$ Uit artikel 7:25 Awb volgt

\footnotetext{
219. Onder de werking van de voorloper van de Awb, de Wet Arob, was dit reeds het geval zo meldt Goorden. Hij suggereert tevens dat dit onder de Awb ook het geval zal zijn, zie Goorden 1995, p. 299-301. Zie ook: Koenraad \& Sanders 2006, p. 54.

${ }^{220 .}$ Goorden 1995, p. 302

${ }^{221 .}$ Bv.: Simon 1999b, p. 57; Verslag Evaluatie Awb I, p. 45-46.

222. Verslag Evaluatie Awb I, p. 45

223. PG Awb I, p. 362; C.P.J. Goorden, 'Rechtsbescherming tegen en door gemeentelijke bestuursorganen', NTB 1990/5, p. 136. Zoals Stroink opmerkt komt de term heroverweging in het geheel niet voor in die bepaling, Stroink 2004a, p. 107.

224. PG Awb I, p. 362. Zie ook: Goorden 1990, p. 136.
} 
Deel II Bestuurlijke voorprocedures

evenwel dat het beroepsorgaan na gedeeltelijke of gehele vernietiging van een bestreden besluit de mogelijkheid heeft om, voor zover nodig, daarvoor een nieuw besluit in de plaats te stellen. ${ }^{225}$ In beginsel kan in administratief beroep derhalve een volledige heroverwegingsmogelijkheid tot uitgangspunt worden genomen. De gangbare opvatting is dat de heroverweging, evenals in bezwaar, in beginsel zowel rechtmatigheidsaspecten als doelmatigheidsaspecten kan omvatten. ${ }^{226}$ De volle toetsing in administratief beroep werd van oudsher ook gezien als een belangrijk voordeel van ten opzichte van beroep bij de rechter. ${ }^{227}$ Hierbij gelden evenzeer de kanttekeningen die in het kader van de heroverweging in bezwaar werden gemaakt ten aanzien van het onderscheid tussen rechtmatigheids- en doelmatigheidsaspecten; een scherp onderscheid is niet altijd te maken.

Niettemin wordt in administratief beroep lang niet altijd een volledige heroverweging van het bestreden besluit verricht. Uit de parlementaire geschiedenis blijkt dat de wetgever bewust is afgeweken van de terminologie van artikel 7:11 Awb. De toetsing in administratief beroep, hoewel er volgens de wetgever geen sprake is van beperkte toetsingsgronden, verschilt in een aantal gevallen van de heroverweging in het kader van bezwaar. ${ }^{228}$ Aangenomen wordt wel dat het administratief beroepsorgaan zich terughoudend dient op te stellen ten aanzien van de wijze waarop het primair beslissende orgaan zijn beleidsvrijheid heeft uitgeoefend of ingevuld. ${ }^{22}$ Van belang is daarbij het onderscheid in de positie die het beroepsorgaan inneemt ten opzichte van het primair beslissende bestuursorgaan aangezien dat onderscheid van invloed is op de te verrichten omvang van de heroverweging. Terughoudendheid lijkt vooral geindiceerd in de gevallen waarin het in administratief beroep oordelende orgaan niet tot hetzelfde openbaar lichaam behoort als waartoe het bestuursorgaan in primo behoort. ${ }^{230}$ Indien de voorziening gevraagd wordt bij een 'hoger' bestuursorgaan dat niet tot hetzelfde openbaar lichaam behoort, pleegt deze zich, als administratief beroepsorgaan, terughoudender op te stellen zodat het primaat van de besluitvorming door het primaire bestuursorgaan niet op te vergaande wijze verstoord wordt. De beleidsvrijheid en de wijze waarop daarmee wordt omgegaan door het primaire bestuursorgaan moet, zoals aangegeven, tot op zekere hoogte gerespecteerd worden. De Afdeling bestuursrechtspraak heeft dit onderscheid tussen de heroverweging in bezwaar en administratief beroep recent nog bevestigd:

"De wetgever heeft in art. 7:25, anders dan in art. 7:11, Awb geen volledige heroverweging voorgeschreven, maar de omvang van de toetsing in administratief beroep in het midden gelaten. Gedeputeerde staten waren dan ook niet op grond van deze bepaling gehouden het besluit van het waterschap van 17 december 2003 indringend te toetsen. De rechtbank heeft, onder verwijzing naar de beleidsverantwoordelijkheid en de beleidsvrijheid die het waterschap te dezen heeft, terecht overwogen dat gedeputeerde staten zich in dit geval hebben kunnen beperken tot de toets zoals die is verricht.,231

Die terughoudende opstelling heeft vooral te maken met de decentralisatiegedachte en de omstandigheid dat anders een te vergaande inbreuk wordt gemaakt op het primaat van het betreffende orgaan om beleid uit te stippelen. ${ }^{232}$ De omvang van de heroverweging is derhalve beperkt(er), afhankelijk van de positie die het beroepsorgaan inneemt ten opzichte van het bestuursorgaan dat het primaire besluit neemt.

Op grond van het bovenstaande, en de omstandigheid dat een ander bestuursorgaan de herbeoordeling verricht, kan het administratief beroep in mindere mate dan de be-

\footnotetext{
225. Tenzij bijzondere wetgeving die mogelijkheid uitsluit.

${ }^{226 .}$ Damen e.a. 2009, Deel II, p. 207; Van Wijk/Konijnenbelt \& Van Male 2008, p. 546; Hennekens e.a. 1998, p. 148; Goorden 1990, p. 130; P.D.A. Claessen, Beleidsvrijheid in het medebewind, Den Haag: Vuga 1989, p. 156157. 


\section{De bezwaarschriftprocedure en het administratief beroep}

zwaarschriftprocedure als een vorm van verlengde besluitvorming worden gekwalificeerd. Deze voorprocedure ligt in dit opzicht dichter dan bezwaar tegen rechtspraak en de door de rechter gegeven beoordeling aan. Ook de wetgever lijkt dit, al dan niet bewust, te impliceren in de toelichting op artikel 7:25 Awb. Daar wordt de heroverweging door het beroepsorgaan als toetsing betiteld (zo ook de Afdeling in de hiervoor aangehaalde overwegingen). ${ }^{233}$ Deze door de wetgever gebruikte terminologie roept de vraag op of daarmee bewust (nogmaals) het verschil met de bezwaarschriftprocedure is beoogd tot uitdrukking te brengen. Datzelfde geldt ook voor de omstandigheid dat het administratief beroepsorgaan een besluit kan vernietigen, terwijl dat normaliter is voorbehouden aan de rechter en het bestuursorgaan in bezwaar bijvoorbeeld een besluit herroept. Ook hier wijkt de gehanteerde terminologie af van die in bezwaar en wordt meer aangesloten bij terminologie die past bij of geassocieerd kan worden met de werkzaamheid van de bestuursrechter. Daar kan echter tegen ingebracht worden dat ook in administratief beroep het bestuursorgaan in beginsel de mogelijkheid heeft om op grond van artikel 7:25 Awb een nieuw besluit te nemen. Die bevoegdheid betreft een typische bestuurlijke bevoegdheid die het bestuurlijke karakter van de procedure benadrukt. Daarmee is een aan het bestuur voorbehouden bevoegdheid toegekend die de bestuursrechter in beginsel niet toekomt (uitgezonderd de gevallen waarin hij zelf in de zaak kan voorzien op grond van artikel 8:72 vierde lid Awb). ${ }^{234}$

Er zijn derhalve duidelijke verschillen met de bezwaarschriftprocedure alsook met bestuursrechtspraak aan te wijzen. Er is onmiskenbaar sprake van bestuurlijke elementen, hoewel in mindere mate (als uitgangspunt) dan in de bezwaarschriftprocedure. De beoordeling die het beroepsorgaan verricht nadert de rechtmatigheidstoetsing die de bestuursrechter verricht meer dan het geval is in de bezwaarschriftprocedure. Het administratief beroep lijkt zich derhalve wat betreft de omvang van de herbeoordeling tussen de bezwaarschriftprocedure en de procedure bij de bestuursrechter te bevinden. De veronderstelling is dan ook gerechtvaardigd dat het administratief beroep en het beroep bij de bestuursrechter nog sterker overeenkomen in dit opzicht en bijgevolg is er ook eerder doorwerking van de beginselen van behoorlijke rechtspleging denkbaar.

\section{Conclusies}

De bevindingen in de voorgaande paragrafen overziend, kan daaruit worden afgeleid dat het uitgangspunt van verlengde besluitvorming in de bezwaarfase (en het administratief beroep), voor zover gekoppeld aan de volledigheid van de heroverweging, te absoluut gesteld wordt. De werkzaamheid van het bestuur en de bestuursrechter zijn, onder meer door de toetsing die de rechter kan verrichten aan de algemene beginselen van behoorlijk bestuur, naar elkaar toegegroeid (voor zover al gesproken kan worden van een strikt onderscheid tussen rechtmatigheidstoetsing en beleidsmatige toetsing). Daarenboven kan in zijn algemeenheid niet gesteld worden dat het bestuur in de bestuurlijke voorprocedure beleidsmatige afwegingen kan verrichten, omdat zulks vooral afhankelijk is van de aan het bestuur toegekende bevoegdheid. Deze bevoegdheid zal in veel gevallen een overwegend of gedeeltelijk gebonden karakter hebben waardoor het bestuur aan beleidsmatige afwegingen niet toekomt. Zelfs in gevallen waarin een beleidsvrije bevoegdheid bestaat, zal deze veelal zijn ingevuld door het bestuur opgestelde beleidsregels die deze vrijheid inperken en waaraan de rechter het besluit kan toetsen. Indien een adviescommissie wordt ingesteld, richt deze zich vooral op de rechtmatigheidsaspecten waardoor het in theorie bestaande bestuurlijke element in de heroverweging in de praktijk niet

\footnotetext{
233. Zoals eerder aangegeven is in dit onderzoek deze term voorbehouden aan de rechterlijke werkzaamheid in het kader van de bestuursrechtspraak. In het navolgende wordt dan ook, om die reden, indien gedoeld wordt op de herbeoordeling in het kader van deze voorprocedure, de term heroverweging gebruikt.

${ }^{234 .}$ Vgl. ook Schueler e.a. 2007, p. 29. Dat vormde wederom een van de voordelen van het administratief beroep waarop werd gewezen in de discussie over de vraag of bestuursrechtspraak wenselijk was.
} 
Deel II Bestuurlijke voorprocedures

maximaal benut wordt. In de praktijk wordt veel gebruik gemaakt van dergelijke adviescommissies.

Het uitgangspunt voor de heroverweging in de bezwaarfase is derhalve dat het bestuur, voor zover het over vrijheid beschikt op grond van de toegekende bevoegdheid, de vrijheid die resteert na de invulling daarvan door beleidsregels door middel van het verrichten van bestuurlijke afwegingen bij de besluitvorming kan benutten. De beoordeling en de vrijheid die vervolgens voor het bestuur resteert, moet volledig zijn en volledig benut worden door het meenemen van beleidsmatige en rechtmatigheidsaspecten. Het gaat echter om een betrekkelijk uitgangspunt, omdat in lang niet alle gevallen een volledige heroverweging kan plaatsvinden. Ook het verschil met de rechterlijke wijze van toetsen is minder omvangrijk dan weleens gesuggereerd wordt. Hetzelfde kan gesteld worden ten aanzien van de beoordeling in administratief beroep, zij het om (deels) andere redenen. Omdat in deze procedure de beoordeling plaatsvindt door een ander bestuursorgaan dan het bestuursorgaan dat het besluit heeft genomen is de beoordeling per definitie afstandelijker en ook terughoudender dan in bezwaar, ondanks het feit dat ook in administratief beroep een volledige heroverweging kan plaatsvinden. Die terughoudendheid ten aanzien van het beleid en de vrijheid van het primaire bestuursorgaan, wordt nog versterkt, indien het beroepsorgaan tot een ander openbaar lichaam behoort dan het primaire bestuursorgaan. Voorts kan de beoordeling in administratief beroep worden beperkt tot bepaalde toetsingsgronden en zelfs bepaalde rechtmatigheidsaspecten. De beoordeling in deze procedure ligt derhalve dicht(er) tegen de toetsing door de bestuursrechter aan.

$\mathrm{Nu}$ is vastgesteld dat het verschil in de omvang van de heroverweging door het bestuur in de bestuurlijke voorprocedures en de toetsing door de bestuursrechter in dit opzicht enige relativering behoeft, kan hetzelfde gesteld worden over de in het verlengde daarvan aangenomen verschillen in toepasselijke eisen voor de inrichting van de procedures bij de verschillende organen. Aangezien het onderscheid tussen de heroverweging door het bestuur en de toetsing door de bestuursrechter minder scherp is dan de klassieke tegenstelling suggereert, is er ook meer ruimte voor doorwerking van de beginselen van behoorlijke rechtspleging in de bestuurlijke voorprocedures.

\subsubsection{Heroverweging op grondslag van het bezwaar}

Rechtsbeschermingsfunctie en het verbod van ultra petita en reformatio in peius In de heroverwegingsplicht zoals neergelegd in artikel 7:11 van de Awb komt, naast het aspect van verlengde besluitvorming zoals hierboven uiteengezet, ook duidelijk de rechtsbeschermingsfunctie tot uitdrukking. Daaruit kan afgeleid worden dat het bestuursorgaan niet 'ultra petita' mag gaan en de heroverweging niet mag leiden tot 'reformatio in peius,. ${ }^{235}$ Het eerste lid bevat immers het voorschrift dat op grondslag van het bezwaar een heroverweging van het bestreden besluit plaats moet vinden. Dezelfde voorwaarden, het verbod van ultra petita gaan en reformatio in peius, gelden ingevolge artikel 8:69 Awb ook voor het beroep op de bestuursrechter, wiens taak primair gelegen is in het bieden van rechtsbescherming aan de burger. ${ }^{236}$ In de literatuur wordt ook uit de zinsnede 'op grondslag van' de rechtsbeschermingsfunctie van de bezwaarschriftprocedure afgeleid. ${ }^{237}$ Volgens sommigen volgt daar zelfs uit dat de rechtsbeschermingsfunctie domineert en voorrang krijgt boven de herbeslissingsfunctie van de bezwaarschriftprocedure. ${ }^{238}$ In Van Wijk/Konijnenbelt \& van Male wordt voorts gesteld dat het uitgangspunt

\footnotetext{
235. PG Awb I, p. 347; Sanders 2005, p. 4; Verheij 2003, p. 35; Goorden 1999, p. 232; Notten 1998, p. 55-56. 236. PG Awb II, p. 463.

237. Zie bijvoorbeeld Sanders die het rechtsbeschermingselement in het bijzonder gelegen acht in het verbod van reformatio in peius, Sanders 2004, p. 43.

${ }^{238 .}$ Verheij 2003, p. 35.
} 
De bezwaarschriftprocedure en het administratief beroep

van volledige heroverweging beperkt wordt, indien daartoe vanuit het oogpunt van individuele rechtsbescherming noodzaak bestaat. ${ }^{239}$

Beide verboden hangen samen met de wijziging van de primaire doelstelling van het bestuursprocesrecht van handhaving van het objectieve recht in het bieden van individuele rechtsbescherming. ${ }^{240} \mathrm{Bij}$ het feit dat de rechtsbeschermingsfunctie door middel van het verbod om ultra petita te gaan en het verbod van reformatio in peius ook bij de bezwaarschriftprocedure benadrukt wordt, plaatst Sanders (tegen de achtergrond van het verlengde besluitvormingsaspect dat inherent is aan de bezwaarprocedure) vraagtekens. ${ }^{241}$ Er worden voor de uitoefening van de heroverweging in artikel 7:11 Awb en de toetsing door de bestuursrechter in artikel 8:69 Awb dezelfde voorwaarden gesteld die in verband worden gebracht met de hoofdfunctie van het bestuursprocesrecht, het bieden van individuele rechtsbescherming, terwijl de vraag gesteld kan worden of dat laatste terecht is voor de bestuurlijke voorprocedures. Ook De Waard meent dat de parallellie met de bepalingen over rechtspraak in de Awb te ver is doorgeschoten. Dat geldt in het bijzonder voor de vergelijking tussen artikel 8:69 Awb voor de rechter en artikel 7:11 Awb voor het bestuur:

"Het idee, dat een verbod van reformatio in peius "in strikte zin" in art. 7:11 Awb besloten ligt is daar een exponent van." 242

Uit het bovenstaande blijkt dat het verbod om 'ultra petita' te gaan en het verbod van 'reformatio in peius' in zekere mate een uitdrukking zijn van de rechtsbeschermingsfunctie van de bezwaarschriftprocedure. Artikel 7:11 regelt de afbakening van het geschil in bezwaar en brengt tot uitdrukking dat de appellerende belanghebbende de grenzen van het geschil bepaalt. ${ }^{243}$ Vaststaat dat uit artikel 7:11 Awb en de hiervoor genoemde verboden voortvloeit dat de appellerende belanghebbende bepaalt welke onderdelen van het besluit heroverwogen moeten worden en dat de gevolgen van de heroverweging niet nadeliger mogen uitpakken voor de indiener van het bezwaarschrift (voor zover de bevoegdheid tot wijziging ten nadele van de belanghebbende niet reeds bestaat op andere gronden en geen derde-belanghebbende bezwaar heeft gemaakt). ${ }^{244}$ Sanders onderscheidt ten aanzien van de heroverweging twee regels: de eerste betreft het object van de heroverweging en houdt in dat de belanghebbende het object kan beperken (dat wil zeggen dat het bestuur niet 'ultra petita', buiten het gevorderde, mag gaan); de tweede betreft de resultaten van de heroverweging en daaruit vloeit voort dat een persoon door het indienen van bezwaar niet in een nadeliger positie mag komen te verkeren (verbod van 'reformatio in peius'). ${ }^{245}$ Deze twee aspecten worden in het onderstaande afzonderlijk nader bezien.

Object van geschil in bezwaar

De eerste regel heeft tot gevolg dat de appellerende belanghebbende de omvang van het geschil in bezwaar in bepaalde mate vaststelt. Onderdelen van het besluit waarop de bezwaren geen betrekking hebben worden zoals gezegd in beginsel buiten beschouwing

\footnotetext{
239. Van Wijk/Konijnenbelt \& Van Male 2008, p. 561.

240. Sanders 2005, p. 4.

${ }^{241 .}$ Sanders 2005, p. 4. Ook in Damen e.a. wordt dit aspect van de heroverweging van de bezwaarschriftprocedure gekoppeld aan de individuele rechtsbescherming die onder de Awb meer nadruk heeft gekregen, Damen e.a. 2009, Deel II, p. 194.

242. De Waard in een noot bij AbRvS 10 september 2003, AB 2004/2.

243. Damen e.a. 2009, Deel II, p. 193-194

244. PG Awb I, p. 347; Sanders 2005, p. 7-8; Verheij 2003, p. 35; Goorden 1999, p. 232; K.F. Bolt, 'Commentaar art. 7:11 Awb', in: M. Scheltema, R.M. van Male, B.W.N. de Waard, A.T. Marseille, A.J.C. de Moor-van Vugt (red.), Commentaar Algemene wet bestuursrecht, Amsterdam: Reed Elsevier (voorheen Den Haag: VUGA), losbladige uitgave, E 7:11-3/8.

${ }^{245 .}$ Sanders 2005, p. 3-4.
} 
Deel II Bestuurlijke voorprocedures

gelaten. ${ }^{246}$ Een en ander is afhankelijk van de vraag of sprake is van een deelbaar of ondeelbaar besluit. ${ }^{247}$ De wetgever heeft daarbij wel aangegeven dat de bezwaren voldoende ruim moeten worden geïnterpreteerd door het bestuur. Indien tijdens de procedure blijkt dat deze ruimer moeten worden opgevat dan op grond van het bezwaarschrift kan worden aangenomen, moet daarmee rekening worden gehouden. ${ }^{248}$

Uit de jurisprudentie en literatuur die dateert van voor de Awb vloeit volgens Sanders voort dat - hoewel ook toen een volledige heroverwegingsplicht werd aangenomen die zowel rechtmatigheidsaspecten als beleidsaspecten omvatte - geen sprake was van heroverweging van het volledige primaire besluit. ${ }^{249}$ Met de toevoeging 'volledig' werd, evenals thans het geval is, uitsluitend gedoeld op de mogelijkheid om ook beleidsoverwegingen een rol te laten spelen (naast de rechtsmatigheidskwesties). Of de belanghebbende het voorwerp van de heroverweging kon beperken is volgens Sanders echter niet duidelijk te achterhalen uit de jurisprudentie. Onder de Awb lijkt dat in elk geval wel mogelijk te zijn. Indien de belanghebbende een onderdeel van een besluit (voor zover een besluit op te delen valt in verschillende onderdelen) niet aanvecht in bezwaar wordt dat onderdeel in beginsel niet betrokken bij de heroverweging. ${ }^{250}$ Over de mate waarin belanghebbenden de heroverweging beperken tot een onderdeel van het besluit, zijn geen empirische gegevens voorhanden en tevens valt daarover nauwelijks iets te herleiden uit de jurisprudentie, aldus Sanders. ${ }^{251}$ Voorop staat vooralsnog dat een belanghebbende op grond van artikel 7:11 Awb het object van de heroverweging kan begrenzen tot bijvoorbeeld een of meer onderdelen van een besluit. Dat betekent dat de rechtsbeschermingsfunctie in dit opzicht voorrang krijgt boven de verlengde besluitvormingsfunctie. Indien het primaat bij de laatste functie had gelegen had het immers meer in de rede gelegen dat het bestuur ongeacht de aard van de bezwaren of de onderdelen waar deze betrekking op hebben een heroverweging van het volledige besluit kan verrichten. ${ }^{252}$ Het voorgaande betekent niet dat het bestuur bij de heroverweging in materiële zin beperkt is tot de bezwaren en argumenten van de belanghebbende. ${ }^{253}$ De wetgever verduidelijkt in het nader rapport dat de heroverweging niet gebonden is aan de argumenten of omstandigheden die in het bezwaarschrift aan de orde zijn gesteld. ${ }^{254}$ De appellerende belanghebbende kan uitsluitend bepalen welk onderdeel van het besluit wel en welk onderdeel van het besluit niet heroverwogen wordt. Zoals de wetgever in het nader rapport echter nogmaals benadrukt, betekent de omstandigheid dat de heroverweging dient te geschieden op grondslag van het bezwaar ook dat de onderdelen van het besluit die geheel los staan van de aangevoerde bezwaren, in beginsel buiten beschouwing blijven. ${ }^{255}$

De gelijkenis met artikel 8:69 Awb voor de bestuursrechter is aanzienlijk. Ook voor de bestuursrechter geldt dat deze in beginsel niet 'ultra petita' mag gaan en het bestreden besluit toetst op basis van de door de belanghebbende aangevoerde beroepsgronden. ${ }^{256}$

\footnotetext{
246. PG Awb I, p. 330; Damen e.a. 2009, Deel II, p. 193-194; Van Wijk/Konijnenbelt \& Van Male 2008, p. 561562; Sanders 2005, p. 3-4; Goorden 1999, p. 232; Van Male 1998, p. 44; Notten 1998, p. 38.

248. PG Awb I, p. 347. Zie ook: Bolt, E 7:11-3/6 met verwijzingen naar jurisprudentie. Dat betekent ook dat een toelichting die ter hoorzitting naar voren wordt gebracht, meegenomen moet worden, PG Awb I, p. 347.

249. Sanders 2005 , p. 5.

${ }^{250 .}$ Sanders 2005, p. 6. Hij wijst erop dat de Hoge Raad in belastingzaken ervan uitgaat dat een belastingaanslag niet meerledig is teneinde correctie van de belastinginspecteur van niet bestreden posten (interne compensatie) mogelijk te maken; zie bijvoorbeeld HR 24 januari 2003, AB 2003/139 m.nt. BdeW. Zie ook: Van Wijk/Konijnenbelt \& Van Male 2008, p. 562.

251. Sanders 2005 , p. 5.

252. Vgl. Damen e.a. 2009, Deel II, p. 194

253. PG Awb I, p. 347; Addink, p. E 6.3.16-1. Uitdrukkelijk bevestigd met verwijzing naar de wetsgeschiedenis in: AbRvS 15 december 2004, $A B$ 2005/431 m.nt. JSt.

254. PG Awb I, p. 347.

255. PG Awb I, p. 347.

${ }^{256 .}$ Vgl. Bolt, die aangeeft dat art. 7:11 Awb een vergelijkbare functie heeft als art. 8:69 Awb, Bolt, p. E 7:11-1. Zij voegt er overigens wel aan toe dat er desondanks grote verschillen zijn tussen de heroverweging in bezwaar en de toetsing in beroep.
} 


\section{De bezwaarschriftprocedure en het administratief beroep}

Onderdelen van het besluit die door de belanghebbende niet worden bestreden, blijven buiten de beoordeling van de bestuursrechter. ${ }^{257} \mathrm{Wel}$ toetst de bestuursrechter het besluit alleen aan die beroepsgronden die de belanghebbende heeft aangevoerd, behoudens de bepalingen van openbare orde waaraan hij ambtshalve moet toetsen. ${ }^{258}$ De aangevoerde beroepsgronden moeten ook door de bestuursrechter niet te beperkt worden opgevat ${ }^{259}$ en hij is verplicht om de rechtsgronden aan te vullen op grond van het tweede lid van artikel 8:69 Awb.

\section{Reformatio in peius}

Zoals aangegeven heeft de wetgever uitdrukkelijk willen vastleggen dat een belanghebbende niet in een slechtere positie komt te verkeren door het instellen van bezwaar. ${ }^{260}$ Het verbod van reformatio in peius geldt echter in de ogen van de wetgever niet onverkort, maar slechts voor zover de bevoegdheid tot wijziging door het bestuursorgaan ten nadele van de belanghebbende niet reeds bestaat op andere gronden en geen derdebelanghebbende bezwaar heeft gemaakt. ${ }^{261}$ In het laatste geval moet het verbod en de bescherming van de rechtspositie van de direct-belanghebbende (op grond van het primaire besluit) of bezwaarmaker wijken voor het recht van derde- of andere belanghebbenden om bezwaar te maken, met andere woorden de rechtsbescherming van derden. ${ }^{262}$ In het geval het bestuur ook zonder bezwaarschrift reeds over de bevoegdheid beschikt om op andere gronden het besluit te wijzigen ten nadele van de indiener, merkt de wetgever op dat het verbod zich er niet toe verzet dat de wijziging betrokken wordt bij de beslissing op het bezwaarschrift. ${ }^{263}$ Wel speelt daarbij een rol of de belanghebbende in zijn verweermogelijkheden wordt geschaad. ${ }^{264}$ Als dat het geval is zal de wijziging (door middel van een afzonderlijk besluit) buiten de bezwaarschriftprocedure om bewerkstelligd moeten worden, aldus de wetgever. ${ }^{265}$ In de jurisprudentie wordt in deze gevallen inderdaad aangenomen dat geen sprake is van (ongeoorloofde) reformatio in peius. ${ }^{266}$ De verweermogelijkheden van de belanghebbenden zijn zowel bij de Centrale Raad als bij de Afdeling vervolgens bepalend voor de vraag of de verslechtering toegestaan is. Lever merkt echter op dat de Centrale Raad reeds overgaat tot vernietiging op grond van het enkele feit dat de belanghebbende niet gehoord is over de nieuwe feiten die geleid hebben tot de verslechtering, terwijl de Afdeling een meer materiële benadering hanteert en

\footnotetext{
257. Zie hierover: Damen e.a. 2009, Deel II, p. 228-229; Van Wijk/Konijnenbelt \& Van Male 2008, p. 647. Ook hier geldt dat het besluit wel opgesplitst moet kunnen worden in verschillende onderdelen.

258. Damen e.a. 2009, Deel II, p. 231-234; Van Wijk/Konijnenbelt \& Van Male 2008, p. 648; D. Brugman, 'Ambtshalve toetsing afgebakend', NTB 2005, p. 265-277.

${ }^{259 .}$ Damen e.a. 2009, Deel II, p. 230. Zie ook: CRvB 22 oktober 2008, AB 2008/358 m.nt. Marseille.

260. PG Awb I, p. 347.

261. PG Awb I, p. 347; A.E.M. Lever, 'Het verbod van reformation in peius onder de Awb', JB-plus 2006, p. 6970; Sanders 2005, p. 7-8; Sanders 2004, p. 43. Lever wijst erop dat in de (hoger) beroepsfase reformatio in peius volgens de wetgever ook mogelijk is indien bepalingen van openbare orde in het geding zijn, Lever 2007, p. 70 met verwijzing naar de parlementaire geschiedenis bij art. 8:69 Awb.

262. Zie ook Verheij die opmerkt dat een verslechtering van positie door bezwaar van een andere (derde)belanghebbende geen reformatio in peius oplevert, omdat anders de rechten van een (derde)belanghebbende illusoir zouden worden, Verheij 2003, p. 35, noot 31. Zie verder: Lever 2006, p. 70; Sanders 2004, p. 43. Lever merkt ook op dat strikt genomen geen sprake is van reformatio in peius omdat de geadresseerde (directbelanghebbende) er door het bezwaar op achteruit gaat maar niet de indiener van het bezwaar.

${ }^{263 .}$ PG Awb I, p. 347. Zie meer uitgebreid hierover met voorbeelden uit de jurisprudentie: Lever 2006, p. 77-80.

264. Zie ook Lever 2006, p. 78-79. Zij wijst op een uitspraak van de CRvB waarin deze hoewel aan de voorwaarden voor reformatio in peius was voldaan het besluit op bezwaar vernietigt, omdat de belanghebbende niet adequaat gehoord was. Er was niet voldoende aangegeven waar de tweede hoorzitting (naar aanleiding van de nieuwe feiten die tot een verslechtering van de positie van de belanghebbenden zouden leiden) over zou gaan, CRvB 25 juni 2003, $J B$ 2003/247. Op deze wijze wordt hoor en wederhoor gewaarborgd over het gewijzigde standpunt van het bestuur, zie hierover ook: par. 5.3.2.4.

265. PG Awb I, p. 347-348. Zie ook: Lever 2006, p. 69-70.

266. Zie voor voorbeelden ten aanzien van een reeds bestaande bevoegdheid tot wijziging: CRvB 26 mei 2003, JB 2003/195; CBb 13 januari 1998, AB 1998/112 m.nt. JHvdV. Een voorbeeld ten aanzien van instellen van bezwaar door derde-belanghebbenden: AbRvS 15 december 2004, AB 2005/431 m.nt. JSt. Zie ook: Bolt, E 7:11$6 / 8$
} 


\section{Deel II Bestuurlijke voorprocedures}

beziet of de belanghebbenden door dat niet-horen ook daadwerkelijk in zijn belang is geschaad. ${ }^{267}$ Hoe dit ook zij, ook bij deze categorie gevallen waarin reformatio in peius in beginsel mogelijk is, vormt derhalve de rechtsbescherming van de belanghebbende en zijn verweermogelijkheden de grens van die mogelijkheid.

Van belang is voorts nog dat reformatio in peius zo wordt uitgelegd dat het om een materiële verslechtering in rechtspositie die bewerkstelligd wordt door het bezwaar moet gaan; het besluit moet derhalve een andere ongunstigere inhoud hebben gekregen. Lever laat zien dat de bestuursrechters bijvoorbeeld een andere motivering waarbij materieel gezien het besluit niet gewijzigd wordt niet als een verslechtering of een reformatio in peius beschouwen. ${ }^{268}$ De Afdeling lijkt naast de vraag of het besluit materieel gelijk is gebleven ook betekenis toe te kennen aan de verweermogelijkheden van de appellerende burger. ${ }^{269}$ Die mogen door de wijziging niet worden aangetast.

Aan het verbod van reformatio in peius komt derhalve, zoals Sanders opmerkt, in de praktijk maar beperkte betekenis toe. ${ }^{270}$ Dat heeft vooral te maken met de hiervoor ook door de wetgever genoemde omstandigheden. In gevallen waarin slechts sprake is van één belanghebbende (dat zal vooral het geval zijn in het financiële bestuursrecht) leidt schending van het verbod, zoals hij aangeeft, nog wel eens tot vernietiging door de rechter. ${ }^{271}$ In veel gevallen zal echter juist door derde-belanghebbenden bezwaar worden gemaakt ten nadele van de geadresseerde. Sanders meent om die reden dat het verbod slechts een relatief karakter draagt en als een soort basiswaarborg moet worden gezien om te voorkomen dat de bezwaarde voor onaangename verrassingen komt te staan. ${ }^{272}$

Niettegenstaande de relatieve betekenis van het verbod in de praktijk, kan mijns inziens uit de gelding daarvan in de bezwaarfase worden afgeleid dat de bescherming van de belangen van de appellerende burger en individuele rechtsbescherming voorop staat. Het is niet de bedoeling dat direct-belanghebbenden die beogen hun belangen te beschermen door bezwaar te maken juist materieel slechter af zijn daardoor. De enige uitzonderingen zijn de gevallen waarin strikte handhaving van het verbod moet wijken voor de rechtsbescherming van andere belanghebbenden of juist de door het verbod in bezwaar geboden bescherming zinloos zou zijn omdat het bestuur hetzelfde besluit anderszins zou kunnen nemen. In dat geval kan de wijziging in de beslissing op bezwaar meegenomen worden mits de appellerende belanghebbende maar de gelegenheid krijgt om zich ertegen te verweren. Ook dat laatste, het waarborgen van de verweermogelijkheden, staat derhalve nadrukkelijk in het teken van de rechtsbescherming van de appellerende belanghebbende. De conclusie moet dan ook zijn dat de grenzen van reformatio in peius in bezwaar bepaald worden door de individuele rechtsbescherming van de (appellerende) belanghebbende(n). Vanwege die rechtsbescherming is reformatio in peius immers in beginsel niet mogelijk en in die gevallen dat het toch is toegestaan, is het wederom de rechtsbescherming van de belanghebbenden die beperkingen daarop kan aanbrengen. In beroep bij de bestuursrechter geldt het verbod van 'reformatio in peius' zoals bekend eveneens, maar kan de ambtshalve toetsing aan bepalingen van openbare orde wel leiden tot een verslechtering in positie van de appellerende belanghebbende. ${ }^{273}$

Grenzen aan de volledige heroverweging

Uit het vereiste dat op grondslag van het bezwaar een heroverweging moet plaatsvinden volgt ook dat de heroverweging in een ander opzicht begrensd is. Van belang is dat zo lang de rechtsbetrekking tussen bestuur en burger niet wijzigt en de buitengrenzen van

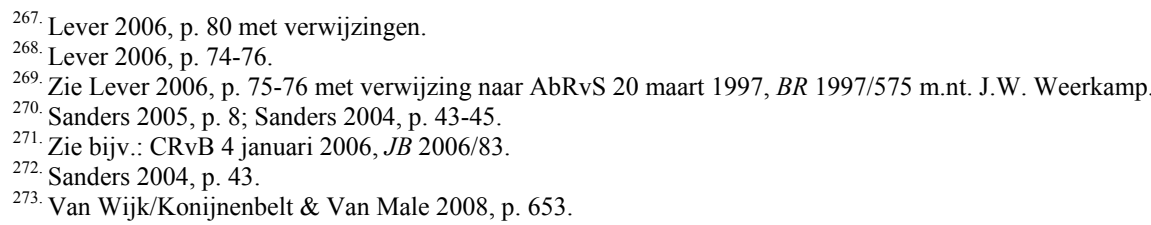




\section{De bezwaarschriftprocedure en het administratief beroep}

het besluit in primo gehandhaafd blijven, er ruimte bestaat voor het bestuur om de argumentatie en motivering van het besluit in bezwaar te wijzigen. Het bestuur is niet gebonden aan de argumenten die zijn aangevoerd in bezwaar en het kan besluit op verbeterde gronden handhaven, zo stelt Sanders. In het geval van een handhavingsbesluit kan zelfs de rechtsgrondslag gewijzigd worden: een besluit tot toepassing van bestuursdwang kan worden omgezet in een besluit tot oplegging van een last onder dwangsom. Bepalend is of het besluit naar aanleiding van de bezwaren nog wel valt aan te merken als het resultaat van de heroverweging. ${ }^{274}$ De heroverweging van een besluit in primo waarbij een boete op grond van overtreding van het Arbeidsomstandighedenbesluit werd opgelegd, mocht echter in bezwaar niet op overtreding van andere voorschriften van datzelfde Arbeidsomstandighedenbesluit worden gebaseerd. Door de wijziging van de rechtsgrond wordt volgens de Afdeling buiten de grondslag van het bezwaar getreden, zodat het besluit moet worden gezien als een nieuw primair besluit. ${ }^{275}$

Heroverweging op grondslag van het beroepschrift?

In tegenstelling tot de bezwaarschriftprocedure heeft de wetgever voor het administratief beroep niet expliciet aangegeven dat het beroepsorgaan niet ultra petita mag gaan of dat het administratief beroep niet tot reformatio in peius mag leiden. ${ }^{276}$ Ten aanzien van de heroverweging in het administratief beroep wordt slechts hetgeen inzake de volledigheid van de heroverweging in paragraaf 4.3.1.1 is aangehaald overwogen. Stroink merkt op dat niet duidelijk is of de wetgever bewust verwijzingen naar deze uitgangspunten (die wel gelden voor bezwaar) achterwege heeft gelaten of dat slechts sprake is van een omissie. ${ }^{277}$ Versteden lijkt er vanuit te gaan dat sprake is van een welbewuste keuze die gunstig voor het bestuur zou kunnen zijn (in vergelijking tot de bezwaarschriftprocedure). ${ }^{278}$ Lever merkt over het verbod van reformatio in peius op dat deze beperkt blijft tot de bezwaarschriftprocedure en de (hoger) beroepfase. Zij lijkt echter vooral het oog te hebben op uitsluiting van de gelding van het verbod in de zienswijzenfase en niet zozeer te willen suggereren dat het verbod in administratief beroep niet geldt. ${ }^{279}$ Rongen stelt zich onomwonden op het standpunt dat het verbod van reformatio in peius niet geldt in administratief beroep. ${ }^{280}$ In de literatuur wordt voor het overige uitsluitend doorgaans vrij algemeen aangegeven dat in administratief beroep een heroverweging plaatsvindt die vergelijkbaar is met de heroverweging in bezwaar, maar dan wordt met name gedoeld op de volledigheid van de heroverweging en het ex nunc-karakter daarvan. ${ }^{281}$

$\mathrm{Nu}$ het verbod om ultra petita te gaan en het verbod van reformatio in peius voor de bezwaarschriftprocedure met name de rechtsbeschermingsfunctie van die procedure tot uitdrukking brengen en ook het administratief beroep een erkende rechtsbeschermingsfunctie heeft, is er weinig aanleiding om aan te nemen dat deze verboden in administratief beroep niet op gelijke wijze zouden gelden. Voorts ligt het op grond van de omstandigheid dat beide verboden zowel in de bezwaarschriftfase als in de beroepsfase bij de bestuursrechter gelden meer voor de hand dat sprake is van een omissie en geen welbewuste keuze van de wetgever om deze verboden niet te laten gelden voor het administratief beroep. Een reden voor een dergelijk onderscheid tussen de bezwaarschriftfase en de procedure bij de bestuursrechter enerzijds en het administratief beroep anderzijds valt

\footnotetext{
274. Sanders 2005, p. 9-12, onder verwijzing naar jurisprudentie van de CRvB en de Afdeling.

275. AbRvS 10 september 2003, $A B$ 2004/1 en $A B$ 2004/2 m.nt. BdeW.

276. PG Awb I, p. 362. Zie ook: Stroink 2004a, p. 107.

277. Stroink 2004a, p. 107.

Versteden 1995, noot 4, p. 287

279. Lever 2006, p. 70

280. Rongen in zijn noot bij AbRvS 27 juni 2007, JB 2007/164 m.nt. Marc Rongen. Overigens lijkt dezelfde auteur minder stellig in een bijdrage in JB-plus van datzelfde jaar over het administratief beroep op gedeputeerde staten, M.P.T. Rongen, Heeft administratief beroep op gedeputeerde staten anno nu nog nut? Haal deze discussie in elk geval uit de vergeetput!, JB-plus 2007, p. 42.

${ }^{281 .}$ Van Wijk/Konijnenbelt \& Van Male 2008, p. 546 en 563; Goorden 1990, p. 130.
} 


\section{Deel II Bestuurlijke voorprocedures}

niet goed in te zien. Zeker omdat de drie procedures (bezwaar en administratief beroep te meer) vergelijkbare functies hebben. De enige functie die het administratief beroep heeft die beide andere procedures niet hebben, is een toezichtfunctie. Rongen zoekt daarin dan ook de verklaring voor de omstandigheid dat het verbod van reformatio in peius niet zou gelden in administratief beroep. ${ }^{282}$ Daargelaten dat de Awb-wetgever (voor zover ik heb kunnen nagaan) zich er in het geheel niet over heeft uitgelaten is deze verklaring om de hiervoor genoemde redenen ook niet overtuigend. Daaraan kan nog toegevoegd worden dat dit verbod in de procedure bij de bestuursrechter eveneens geldt, terwijl deze ook een taak heeft in de controle van de objectieve rechtmatigheid en geldigheid van besluiten; een taak die te vergelijken valt met de toezichtfunctie die aan het administratief beroep wordt toegekend. Wat betreft het verbod van ultra petita en het verbod van reformatio in peius moet het er mijns inziens derhalve op worden gehouden dat de herbeoordeling in administratief beroep niet verschilt van de heroverweging in bezwaar of de toetsing door de bestuursrechter. ${ }^{28}$

\section{Conclusies}

Wat betreft de heroverweging die op grondslag van het bezwaar (en het beroep) moet plaatsvinden, kan geconcludeerd worden dat dezelfde uitgangspunten gelden voor het bestuur als voor de bestuursrechter op grond van artikel 8:69 Awb. Voor beide organen gelden het verbod om ultra petita te gaan en het verbod van reformatio in peius. Beide verboden staan in beide procedures in het teken van het bieden van individuele rechtsbescherming. De gelijkenissen tussen de heroverweging in de bestuurlijke voorprocedures en de toetsing door de bestuursrechter ten aanzien van deze aspecten zijn aanzienlijk.

\subsubsection{De bestuurlijke heroverweging en de toetsing door de bestuursrechter vergeleken}

De volledigheid van de heroverweging

Het uitgangspunt is dat in de bezwaarschriftprocedure een volledige heroverweging plaatsvindt, die zich ook uitstrekt tot beleidsmatige aspecten. Dat uitgangspunt moet echter gerelativeerd worden. Het lijdt bijvoorbeeld uitzondering wanneer er een (overwegend) gebonden bevoegdheid bestaat, aangezien de heroverweging zich dan niet verder kan uitstrekken dan die bevoegdheid toelaat. In dat geval lijkt de herbeoordeling door het bestuur in de bezwaarschriftfase op de rechtmatigheidstoetsing achteraf die de bestuursrechter verricht. Ook als er wel een discretionaire bevoegdheid bestaat, dan wordt die discretionaire ruimte in de praktijk in bezwaar niet altijd benut. Bovendien worden veel discretionaire bevoegdheden ingevuld met beleidsregels die de vrijheid van het bestuur om in een concreet geval een besluit te nemen beperken. Voor het administratief beroep geldt voorts dat de toetsing die het beroepsorgaan verricht dichter aan ligt tegen de toetsing die de bestuursrechter verricht. Vanwege de decentralisatiegedachte wordt terughoudendheid gevraagd van het beroepsorgaan om het besluitvormingsprimaat en de beleidsvrijheid van het in primo beslissende bestuursorgaan te beschermen. Al met al kan gezegd worden dat de volledige heroverweging in bezwaar een betrekkelijk uitgangspunt is en dat de traditionele verschillen tussen de werkzaamheid van het bestuur in de bestuurlijke voorprocedures en de toetsing door de bestuursrechter te absoluut gepresenteerd worden. De verschillen en tegenstellingen die er zijn hangen samen met de positie van het bestuur en de bestuursrechter in ons staatsbestel. In concrete gevallen waarin het bestuur een besluit moet nemen en de bestuursrechter dat besluit moet beoordelen, zijn de verschillen minder omvangrijk dan op grond van de traditionele uitgangspunten aangenomen zou kunnen worden.

282. Rongen in zijn noot bij AbRvS 27 juni 2007, JB 2007/164 m.nt. Marc Rongen.

283. Vgl. Damen e.a. 2009, Deel II, p. 208. 
De bezwaarschriftprocedure en het administratief beroep

De grenzen aan de heroverweging

De grenzen van de heroverwegingsplicht van het bestuur in de bestuurlijke voorprocedures liggen in het verbod van ultra petita te gaan en het verbod van reformatio in peius. Daarmee wordt, evenals het geval is voor de toetsing door de bestuursrechter op grond van artikel 8:69 Awb, de grens van de heroverwegingsplicht in de bezwaarschrifprocedure gelegd bij de individuele rechtsbescherming. Als deze daartoe noopt, wordt de heroverwegingsplicht van het bestuur in de bezwaarschriftprocedure beperkt.

Voor het verbod van 'ultra petita' gaan geldt dat de appellerende belanghebbende kan bepalen welk onderdeel van het besluit wel en welk onderdeel van het besluit niet heroverwogen wordt. Het bestuurorgaan kan op andere gronden dan de aangevoerde bezwaren de bestreden onderdelen van het besluit heroverwegen en moet ook de bezwaren ruim opvatten. Artikel 7:11 vertoont in dit opzicht grote gelijkenis met artikel 8:69 Awb en de rechterlijke toetsing. Ook voor de bestuursrechter geldt dat niet aangevochtend onderdelen van een besluit buiten beschouwing blijven en dat de beroepsgronden ruim opgevat moeten worden. Daarbij behoren de rechtsgronden aangevuld te worden, maar moet de rechterlijke toetsing zich beperken tot de aangevoerde beroepsgronden.

Wat betreft het verbod van 'reformatio in peius' is van belang, dat dit verbod geen absoluut karakter heeft. Het geldt niet als de bevoegdheid tot wijziging door het bestuursorgaan ten nadele van de belanghebbende niet reeds bestaat op andere gronden en als een derde-belanghebbende bezwaar heeft gemaakt. In het laatste geval wijkt de rechtsbescherming van de bezwaarmaker voor de rechtsbescherming van de derdebelanghebbende. In het eerste geval is 'reformatio in peius' mogelijk, mits de belanghebbende niet in zijn verweermogelijkheden wordt geschaad. In zekere zin vormt de bescherming van de belangen van de belanghebbende hier dan ook de grens. Het verbod geldt op dezelfde wijze voor de bestuursrechter. Voor de bestuursrechter geldt echter nog een extra uitzonderingsgrond: de ambtshalve toetsing aan bepalingen van openbare orde. Deze toetsing mag leiden tot 'reformatio in peius'.

Doorwerking van de verschillen in de toepasselijke procedurele vereisten

Al met al lijken de verschillen tussen de omvang van de heroverweging en de omvang van de rechterlijke toetsing minder omvangrijk te zijn dan uit de klassieke tegenstelling kan worden afgeleid. Zowel de heroverweging door het bestuur als de rechterlijke toetsing staan (mede) in het teken van individuele rechtsbescherming. Aangenomen moet worden dat de herbeoordeling in administratief beroep op deze punten niet afwijkt van die in bezwaar. Nu de verschillen tussen de taak van het bestuur in de bestuurlijke voorprocedures en de taak van de bestuursrechter in de hiervoor besproken opzichten gering zijn en de gelijkenissen aanzienlijk, is ook eerder doorwerking van de beginselen van behoorlijke rechtspleging denkbaar in de bestuurlijke voorprocedures.

\subsubsection{Heroverweging ex-nunc}

\subsubsection{Ex nunc-heroverweging in bezwaar als algemeen uitgangspunt}

De heroverweging van het bestuursorgaan in de bezwaarschriftprocedure wordt niet alleen gekenmerkt door de kenmerken in de omvang daarvan in bovenbedoelde zin, maar ook doordat deze in beginsel ex nunc dient plaats te vinden. Het ex nunc-karakter van de heroverweging is niet neergelegd in de Awb, maar vormt de heersende leer in de doctrine. ${ }^{284}$ Ex nunc beoordelen in bezwaar houdt, kortheidshalve, in dat het bestuursorgaan de heroverweging in beginsel dient te laten plaatsvinden aan de hand van de ten tijde van de

\footnotetext{
284. Rapport VAR Commissie Rechtsbescherming 2004, p. 121; W. van Blommestein, 'Toetsing ex nunc; in het vreemdelingenrecht én in het bestuursrecht?', NTB 2000/5, p. 131; C.P.J. Goorden, 'Toetsing van sanctiebesluiten in bezwaar', NTB 1999, p. 232; Teunissen 1992, p. 111.
} 


\section{Deel II Bestuurlijke voorprocedures}

beslissing op bezwaar geldende recht, feiten en omstandigheden. ${ }^{285}$ Het bestuursorgaan dient als uitgangspunt in bezwaar rekening te houden met feiten en omstandigheden die zich tussen de primaire besluitvormingsfase en de beslissing op bezwaar hebben voorgedaan. ${ }^{286}$ Het kan derhalve uitgaan van de feitelijke en juridische toestand op het moment van de beslissing op bezwaar, aldus Nicolaï e.a. ${ }^{287}$ Overigens geldt ook in administratief beroep het uitgangspunt dat de heroverweging ex nunc dient plaats te vinden. ${ }^{288}$

Het ex nunc- karakter van de herbeoordeling brengt bij uitstek het bestuurlijke aspect in de werkzaamheid van het bestuur in de voorprocedure naar voren. ${ }^{289}$ Omdat sprake is van verlengde besluitvorming kan en moet het bestuur op het moment van het nemen van de beslissing op bezwaar de bestaande omstandigheden en het geldende recht bij de besluitvorming betrekken. ${ }^{290}$ Het ex nunc-aspect dat aan de heroverweging in bezwaar kleeft, geeft duidelijk weer dat de werkzaamheid van het bestuur in de bezwaarfase het verlengde vormt van de werkzaamheid van het bestuur in de primaire besluitvormingsfase. De ex nunc-beoordeling door het bestuur wordt in de literatuur dan ook veelal lijnrecht tegenover de ex tunc-toetsing door de bestuursrechter gesteld. ${ }^{291}$ Vóór de algemene erkenning van de wenselijkheid van toetsing van bestuursbesluiten door de administratieve rechter was dat juist het geval bij administratief beroep om het ex nunckarakter als een van de kenmerken voorop te stellen ter onderscheiding van deze voorziening met bestuursrechtspraak. Thans geschiedt dat vooral bij de bezwaarschriftprocedure. ${ }^{292}$ Door de tegenstelling tussen de beoordeling door het bestuur en de toetsing door de rechter in dit opzicht voorop te stellen, wordt wederom beoogd het verschil tussen bestuur en rechter en de daarmee samenhangende rechtsstatelijke en staatsrechtelijke verhouding van deze organen scherp naar voren te brengen. ${ }^{293}$ De beoordelingen door bestuur en rechter worden daardoor ook gepresenteerd als twee (in dit opzicht) aan elkaar tegengestelde activiteiten. Het bestuur heeft het recht op 'Erstentscheidung, ${ }^{294}$, terwijl de rechter dat zou dienen te respecteren en zich verre zou moeten houden van nieuwe feiten of omstandigheden waarover het bestuur (nog) niet heeft kunnen oordelen. ${ }^{295}$

Hoewel de ex nunc-beoordeling door het bestuur (in de bezwaarfase) een algemeen aanvaard uitgangspunt in het Nederlandse bestuursrecht vormt, bestaan daarop vele uitzonderingen. ${ }^{296}$ Goorden stelt bijvoorbeeld dat:

"in het algemeen geldt dat de toetsing van een besluit in de bezwaarschriftprocedure dient te geschieden aan het ten tijde van die toetsing geldende recht en naar de dan bestaande feiten, dus ex nunc."29

\footnotetext{
${ }^{285 .}$ Van Wijk/Konijnenbelt \& Van Male 2008, p. 560-561; K.F. Bolt, 'Dat verandert de zaak! De eerste ervaringen met de rechterlijke ex-nunc-toetsing', JB-plus 2002, p. 159; Goorden 1999, p. 232; Notten 1998, p. 40.

286. Verheij 2003, p. 32; Van Male 1998, p. 45. Vgl. Notten 1998, p. 40.

${ }^{287 .}$ Nicolaï en Olivier e.a. 1997, p. 575.

288. Goorden 1990, p. 130.

289. Vgl.: Verheij 2003, p. 32; Versteden 1995, p. 291. Zie ook: A.F.M. Brenninkmeijer, 'Een leerstellig cliché', in: T. Hoogenboom \& L.J.A. Damen, In de sfeer van administratief recht, Utrecht: Lemma 1994, p. 24; Teunissen 1992, p. 111.

${ }^{290 .}$ Koenraad \& Sanders 2006, p. 96; K.H. Sanders, De bezwaarschriftprocedure, Nijmegen: Ars Aequi Libri 2004, p. 45 Verheij 2003, p. 32

${ }^{291 .}$ Vgl.: Koenraad \& Sanders 2006, p. 96; Sanders 2004, p. 45-46; Stroink 2004a, p. 101 en 174; Bolt 2002, p. 159; Van Blommestein 2000, p. 128 en 132-133; T. Groenewegen, 'De toetsing ex nunc', $N A V$ 2000/4, p 245; Notten 1998, p. 39; Nicolaï en Olivier e.a. 1997, p. 575; Teunissen 1992, p. 111

292. Verheij 2003, p. 27; Teunissen 1992, p. 111.

293. Vgl.: Bolt 2007, p. 5-6; Koenraad \& Sanders 2006, p. 96-97; Bolt 2005, p. 18; Sanders 2004, p. 45-46; Notten 1998, p. 39; Teunissen 1992, p. 113

294. Deze term is ontleend aan het rapport van de VAR-Commissie Rechtsbescherming, Rapport VARCommissie Rechtsbescherming 2004, p. 122. Zie ook: Teunissen 1992, p. 113, noot 5.

${ }^{295 .}$ VAR-Commissie Rechtsbescherming 2004, p. 122-123; Sanders 2004, p. 45-46; Brenninkmeijer, 1994, p. 24; Teunissen 1992, p. 113.

${ }^{296 .}$ Bolt 2005, p. 4; Stroink 2004a, p. 101; Groenewegen 2000, p. 245. Zie ook Notten die de ex nunc toetsing door het bestuur o.m. een grondbeginsel van de heroverweging met relatieve trekken noemt, Notten 1998, p. 40 en p. 52-53.

297. Goorden 1999, p. 232.
} 


\section{De bezwaarschriftprocedure en het administratief beroep}

Even later geeft hij echter aan dat er nuanceringen op dat uitgangspunt kunnen worden aangebracht. ${ }^{298}$ Sommige auteurs gaan zelfs verder dan enkele nuanceringen. Verheij stelt zich in zijn veel gememoreerde bijdrage over het tijdstip van beoordelen in de drie fasen van de besluitvorming bijvoorbeeld op het standpunt dat de regel dat het bestuur ex nunc beslist onjuist is omdat deze regel veel te ongenuanceerd is. ${ }^{299}$ In verschillende annotaties herhaalt hij dat standpunt en stelt hij meermalen dat de ex nunc-regel een vangnetregel is, die van toepassing is voor zover uit de wettelijke voorschriften of de aard van het besluit niets anders voortvloeit. ${ }^{300}$ De ex nunc-regel is derhalve lang niet zo hard als wel wordt gesuggereerd en daarmee wordt ook in dit opzicht het - in de doctrine mede daarop gebaseerde - onderscheid tussen de werkzaamheid van het bestuur en de rechter minder scherp. De door Verheij naar voren gebrachte opvatting over de ex nuncbeoordeling in bezwaar wordt in de literatuur algemeen onderschreven. ${ }^{301}$ Tegelijkertijd wordt het ex nunc-karakter van de bestuurlijke werkzaamheid nog steeds naar voren geschoven als een essentieel verschil ten opzichte van de rechterlijke toetsing. ${ }^{302}$ Hieronder wordt allereerst bezien in hoeverre ex nunc-heroverweging moet worden gezien als een karakteristiek van de bestuurlijke werkzaamheid in de bestuurlijke voorprocedures.

\subsubsection{Betrekkelijkheid van de hoofdregel}

\section{Ex nunc-heroverweging}

Zoals hierboven reeds werd aangegeven, houdt ex nunc- heroverweging in dat het bestuursorgaan in bezwaar een besluit neemt met inachtneming van de op dat moment bestaande recht, feiten en omstandigheden. Verheij maakt daarbij de kanttekening dat de ex nunc-beoordeling de ten tijde van bezwaar de voor de besluitvorming relevante feiten, beleid en recht betreft. ${ }^{303}$ Daarmee wil hij aangeven dat bezien dient te worden welke feiten of omstandigheden van belang zijn voor de besluitvorming en dat deze vraag duidelijk onderscheiden dient te worden van de vraag tot welk tijdstip in de procedure daarop een beroep mag worden gedaan. Bezien moet worden welk tijdstip relevant is voor de beoordeling van de feiten, beleid en recht. ${ }^{304}$ Ook merkt hij op dat het uitgangspunt dat het bestuur rekening dient te houden met feiten en omstandigheden die zich na het besluit in primo hebben voorgedaan slechts geldt, indien voor het primaire besluit het tijdstip van de besluitvorming beslissend was; alleen in dat geval is ook voor het besluit op bezwaar het tijdstip van besluitvorming beslissend en kan het bestuur daadwerkelijk ex nunc beslissen. ${ }^{305}$ De hoofdregel om het relevante tijdstip in bezwaar te bepalen - aldus Verheij - is dat hetzelfde criterium geldt voor de bezwaarfase als voor het primaire besluit. ${ }^{306}$ Er kan in bezwaar in beginsel slechts ex nunc beslist worden, indien in primo ook het tijdstip van het nemen van het besluit bepalend is. De bevoegdheid van het bestuur om in bezwaar een besluit te nemen, vormt derhalve een soort van 'afgeleide' bevoegdheid. De bevoegdheid en de begrenzing van de werkzaamheid van het bestuur naar een bepaald tijdstip in primo is (meestal) bepalend voor de uitoefening van die bevoegdheid in bezwaar.

\footnotetext{
298. Zie ook Notten 1998, p. 43-44.

${ }^{299 .}$ Verheij 2003, p. 26 en 47. Zie ook zijn noten bij AbRvS 13 november 2002, AB 2003/135; AbRvS 15 augustus 2001, $A B$ 2001/334; AbRvS 25 juli 2001, $A B$ 2001/339. Zie ook: Sanders 2004, p. 47.

${ }^{300}$ Zie bijvoorbeeld: AbRvS 19 oktober 2005, JB 2006/4 en de in de vorige noot genoemde uitspraken. Zie ook: Verheij 2003, p. 47.

${ }^{301 .}$ Sanders 2004, p. 46-47; Rapport VAR-Commissie Rechtsbescherming 2004, p. 121 e.v.

302. Zie verschillende handboeken: Van Wijk/Konijnenbelt \& Van Male 2008, p. 525-526; R.J.N. Schlössels \& F.A.M. Stroink, Kern van het bestuursrecht, Den Haag: BJu 2006, p. 302.

303. Verheij 2003, p. 28.

304. Rapport VAR-Commissie Rechtsbescherming 2004, p. 121.

305. Verheij 2003, p. 32.

306. Verheij 2003, p. 32.
} 


\title{
Deel II Bestuurlijke voorprocedures
}

Om die reden stelt Verheij ook dat de ex nunc-regel (in bezwaar) een vangnetregel is, die van toepassing is voor zover uit de wettelijke voorschriften of de aard van het besluit niets anders voortvloeit. ${ }^{307}$ Daarmee lijkt (de afgelopen tijd) in de literatuur de benadering dat de ex nunc-regel in bezwaar vrij betrekkelijk is te overheersen. ${ }^{308}$ De bestuursrechter lijkt begrijpelijkerwijs, juist vanwege zijn staatsrechtelijke positie, daarbij enigszins achter te blijven en daarentegen de ex nunc-regel in algemene zin nog steeds voorop te stellen (met erkenning van het feit dat uitzonderingen mogelijk zijn). Zo overweegt de Afdeling in een uitspraak van 19 oktober 2005:

\begin{abstract}
"In het algemeen dient bij een beslissing op bezwaar een heroverweging plaats te vinden met inachtneming van de feiten en omstandigheden zoals die bestaan op het tijdstip van de heroverweging. In de door appellante aangevoerde stelling (...) behoefde het college (...) geen aanleiding te zien een uitzondering hierop te maken. De rechtbank heeft derhalve terecht geoordeeld dat voor het college ten tijde van de heroverweging geen aanleiding bestond om bij de beslissing op bezwaar in afwijking van de hoofdregel van artikel 7:11 van de Awb tevens te beslissen over de vraag of al eerder dan bij de beslissing op bezwaar een standplaatsvergunning aan appellante had moeten worden verleend." 309
\end{abstract}

Deze overwegingen zijn illustratief voor de door de bestuursrechters gehanteerde benadering waarin ex nunc-heroverweging als de hoofdregel vooropgesteld wordt. ${ }^{310}$ De uitspraken van de bestuursrechter bevestigen echter tevens het beeld dat Verheij, zoals hiervoor werd aangegeven schetst: het bestuur dient ex nunc in bezwaar te beslissen, voor zover de aard van het besluit of de toepasselijke wettelijke voorschriften daaraan niet in de weg staan. In de jurisprudentie wordt de ex nunc-heroverweging echter meer als hoofdregel neergezet waarop uitzonderingen bestaan, terwijl Verheij het ex nunckarakter van de heroverweging benadert als vangnetregel juist vanwege alle uitzonderingen die gelden. De bestuursrechter lijkt dit te doen mede om te benadrukken dat er onderscheid bestaat tussen de bestuurlijke heroverweging en rechterlijke toetsing in verband met de staatsrechtelijke verhouding tussen bestuur en rechter. Terwijl Verheij en Sanders zich meer lijken te laten leiden door de realiteit. Ook zij menen echter dat er een principieel onderscheid bestaat tussen de rechterlijke werkzaamheid, toetsen van besluiten, en de bestuurlijke werkzaamheid, het nemen van besluiten.

\subsubsection{Relativering van het onderscheid tussen bestuurlijke en rechterlijke werkzaamheid}

\section{Relativering van het onderscheid}

Het uitgangspunt dat in bezwaar opnieuw ex nunc beslist dient te worden brengt zoals eerder aangegeven tot uitdrukking dat de bezwaarfase een vorm van verlengde besluitvorming is. ${ }^{311}$ Daarmee wordt ook een in beginsel belangrijk verschil ten opzichte van de werkzaamheid van de bestuursrechter in de rechterlijke procedure tot uitdrukking gebracht. ${ }^{312}$ Het uitgangspunt voor de bestuursrechter is immers volgens de heersende leer dat deze ex tunc dient te toetsen of het besluit van het bestuur, ten tijde van het nemen van het besluit of naar het tijdstip dat voor het bestuur relevant was, in stand kan blij-

\footnotetext{
307. Zie ook: Verheij 2003, p. 27. Daar stelt hij dat de ex nunc-regel slechts aanvullend werkt.

${ }^{308 .}$ Koenraad en Sanders geven aan dat het er de schijn van heeft dat we zelfs op zoek moeten naar een nieuwe regel ten aanzien van de vraag in hoeverre nieuwe feiten of omstandigheden in de heroverweging betrokken moeten worden, Koenraad \& Sanders 2006, p. 97.

309. AbRvS 19 oktober 2005, JB 2006/4 m.nt. NV.

310. AbRvS 3 maart 2010, JB 2010/106; AbRvS 14 maart 2007, $J B$ 2007/86 m.nt. LJMT; AbRvS 2 juni 2006, JB 2004/262. De bestuursrechter lijkt vooral te benadrukken dat de bevoegdheid in bezwaar en de werkzaamheid van het bestuur het verlengde vormt van de bevoegdheid en werkzaamheid in primo.

${ }^{311 .}$ Vgl: Verheij 2003, p. 32

312. Vgl: Stroink 2004a, p. 101. Stroink geeft overigens ook aan dat er belangrijke uitzonderingen bestaan op de regel dat de heroverweging in de bezwaarschriftprocedure ex nunc plaatsvindt.
} 
De bezwaarschriftprocedure en het administratief beroep

ven. ${ }^{313}$ De rechter behoort in beginsel geen rekening te houden met feiten of ontwikkelingen die na het nemen van het bestreden besluit zijn opgekomen. ${ }^{314}$ De achtergrond van het uitgangspunt van ex tunc-toetsing door de bestuursrechter is het principe van de machtenscheiding. ${ }^{315}$ Toch moet het onderscheid tussen de rechterlijke werkzaamheid en de bestuurlijke werkzaamheid op dit punt niet overdreven worden en verdient het om de verschillende redenen relativering.

\section{De uitzonderingen}

Allereerst bestaan er verscheidene uitzonderingen op het ex nunc beslissen door het bestuur. Over die uitzonderingen als zodanig bestaat brede overeenstemming in literatuur en jurisprudentie. De besluiten waarbij geen ex nunc-heroverweging plaatsvindt zijn algemeen bekend en ook al eerder uitvoerig weergegeven. ${ }^{316}$

Het gaat om besluiten in het sociale zekerheidsrecht of het belastingrecht waarbij het gaat om het vaststellen van aanspraken van een belanghebbende over een bepaalde periode (in het verleden) of tijdvak. ${ }^{317}$ Voor deze categorie besluiten geldt voor de beoordeling van de feiten op grond van wettelijke voorschriften of beleid een ander moment of periode dan het moment van het nemen van het besluit in primo en bijgevolg ook in bezwaar. ${ }^{318}$ Voor deze besluiten geldt uiteraard dat ook in de bezwaarfase slechts nieuwe feiten en omstandigheden kunnen worden meegenomen, voor zover deze van belang zijn voor de aanspraken voor de betreffende periode en betrekking hebben op die periode. ${ }^{319}$

Op grond van bepaalde wettelijke regelingen of beleid kan het tijdstip waarop een beoordeling van de feiten plaats moet vinden ook gekoppeld worden aan een bepaalde peildatum. ${ }^{320}$ Dat heeft tot gevolg dat ook in bezwaar naar dat moment nagegaan moet worden of sprake is van een bepaalde feitelijke situatie aan welke beoordeling vervolgens al dan niet rechtsgevolgen verbonden kunnen worden. Deze besluiten vormen de tweede belangrijke uitzondering op de ex-nunc beoordeling in bezwaar of administratief beroep. ${ }^{321}$ Te denken valt aan belastingaanslagen of bepaalde uitkeringen. Beide uitzonderingen vormen tezamen een belangrijke en aanzienlijke categorie besluiten waarbij op grond van wettelijke regeling of beleid een ander tijdstip voor beoordeling van de feiten geldt dan het moment van het nemen van het besluit.

Een andere belangrijke categorie die in de literatuur en jurisprudentie naar voren komt, betreft de subsidiebesluiten. In het kader van dit soort besluiten kan een einddatum voor indiening van aanvragen bepaald zijn. ${ }^{322}$ Dat betekent dat met gewijzigde omstandigheden of feiten na deze einddatum geen rekening meer kan worden gehouden door het bestuur. Dat geldt ook voor feiten of omstandigheden die dateren van voor de einddatum

\footnotetext{
${ }^{313 .}$ Bolt 2005, p. 14; Rapport VAR Commissie Rechtsbescherming 2004, p. 121; Van Blommestein 2000, p. 128; Groenewegen 2000, p. 245; Teunissen 1992, p. 111-113; PG Awb II, p. 175. Dat uitgangspunt gold voor de rechter al voor de totstandkoming van de Awb in het Nederlands bestuurs(proces)recht maar is onder de Awb overgenomen. In de Awb zelf is ook het ex tunc- karakter van de toetsing door de rechter niet expliciet neergelegd. Zie voor een korte beschrijving: PG Awb II, p. 172-173; Bolt 2005, p. 14-17.

314. Bolt 2005, p. 3; Rapport VAR-Commissie Rechtsbescherming 2004, p. 121; Verheij 2003, p. 35-36.

315. Vgl: Bolt 2005, p. 18; Groenewegen 2000, p. 245; Van Blommestein 2000, p. 132; Teunissen 1992, p. 113.

316. Zie verder: Damen e.a. 2009, Deel II, p. 197-198; Van Wijk/Konijnenbelt \& Van Male 2008, p. 560-561; Koenraad \& Sanders 2006, p. 96-107; Verheij 2003, p. 26-47; Goorden 1999, p. 233 e.v. met verdere verwijzingen. Zie ook Timmermans in zijn noot bij CRvB 16 januari 2007, JB 2007/61.

317. Goorden 1999, p. 233. Zie ook: Timmermans in zijn noot bij CRvB 16 januari 2007, JB 2007/61; Koenraad \& Sanders 2006, p. 97-101; Verheij in zijn noot bij AbRvS 19 oktober 2005, JB 2006/4; Stroink 2004a, p. 101; Sanders 2004, p. 46.

318. Verheij 2003, p. 32;

319. Sanders 2004, p. 46

320. Zie: Bolt, E 7:11-11; Timmermans in zijn noot bij CRvB 16 januari 2007, JB 2007/61; Koenraad \& Sanders 2006, p. 97-101; Verheij 2003, p. 33

321. Verheij 2003, p. 32-33.

322. Sanders 2004, p. 47. Zie ook de noten van Verheij bij AbRvS 12 januari 2005, $A B$ 2005/239; AbRvS 13 november 2002, $A B$ 2003/135; AbRvS 25 juli 2001, $A B$ 2001/339.
} 
Deel II Bestuurlijke voorprocedures

maar daarna worden ingebracht. Aldus vindt in primo vanaf de einddatum geen ex nuncbeoordeling plaats en daarmee ook geen ex nunc-heroverweging in bezwaar. ${ }^{323}$

Een andere algemeen aanvaarde uitzondering wordt gevormd door sanctiebesluiten. ${ }^{324}$ Voor deze categorie besluiten geldt eveneens dat het voor de besluitvorming relevante tijdstip niet op grond van de ex nunc-hoofdregel bepaald wordt, aldus Verheij. ${ }^{325}$ Zo ook Goorden, die er wel op wijst dat in dat kader een onderscheid tussen punitieve sancties en situatieve oftewel herstelsancties gemaakt moet worden. ${ }^{326}$ Voor de punitieve sancties geldt naar algemeen wordt aangenomen in beginsel het volgende. Indien de overtreding naar aanleiding waarvan het sanctiebesluit is genomen na het besluit in primo maar voor de beslissing op bezwaar wordt beëindigd, zou ex nunc-heroverweging inhouden dat het besluit moet worden herroepen omdat de grondslag daarvoor is komen te ontvallen. Aangezien dit niet wenselijk is omdat de overtreder dan zijn straf zou ontlopen, geldt in het algemeen dat het besluit destijds (ex tunc dus) rechtmatig was. ${ }^{327} \mathrm{Na}-$ dien gewijzigde feiten of recht hoeven in dit opzicht niet betrokken te worden bij de beoordeling. ${ }^{328}$ Goorden en Timmermans wijzen op de sterke gelijkenis met besluiten die betrekking hebben op een bepaalde peildatum of tijdvak. ${ }^{329}$

Voor herstelsancties geldt, gelet op het reparatoire karakter van de sanctie, een iets andere benadering. Sanders wijst erop dat in het geval van een besluit tot toepassing van bestuursdwang en de last onder dwangsom, indien de overtreding tussen het besluit in primo en het besluit op bezwaar wordt beëindigd, aangenomen wordt dat het besluit wordt herroepen vanaf het moment waarop de overtreding is beëindigd. ${ }^{330} \mathrm{Op}$ die manier blijft de sanctie tot het moment van beëindiging van de overtreding rechtmatig gehandhaafd, maar valt de werking daarvan weg na beëindiging. Dat betekent dat geen volledige ex nunc-heroverweging plaatsvindt. ${ }^{331}$ Voor zover het een last onder dwangsom betreft betekent dit dat verbeurde dwangsommen moeten worden voldaan tot het moment van beëindiging van de overtreding en dat na beëindiging geen dwangsommen meer kunnen worden verbeurd. Indien voor de beëindiging van de overtreding het maximale aantal dwangsommen is verbeurd, bestaat er evenmin grond voor herroeping en is het genomen dwangsombesluit niet onrechtmatig. ${ }^{332}$

Uitzonderingen en kwantiteit

De vele uitzonderingen in kwantitatief opzicht op de ex nunc-regel voor de beoordeling door het bestuur vormen een eerste reden voor nuancering van het karakter van de bestuurlijke werkzaamheid en dientengevolge ook van het verschil tussen de werkzaamheid van het bestuur en de bestuursrechter. Op het eerste gezicht zijn de uitgangspunten voor de beoordeling door rechter en en bestuur (ex nunc versus ex tunc) tegengesteld, maar bij nader inzien blijkt die tegenstelling minder scherp te zijn nu ook het bestuur in veel gevallen ex tunc herbeoordeelt in de bezwaarfase.

\section{Rechterlijke toetsing ex nunc}

Een tweede relativering die op de tegenstelling tussen de rechterlijke en bestuurlijke beoordeling in dit kader kan worden aangebracht is de omstandigheid dat ook de bestuursrechter in een aantal gevallen ex-nunc kan toetsen - of wellicht zuiverder gezegd

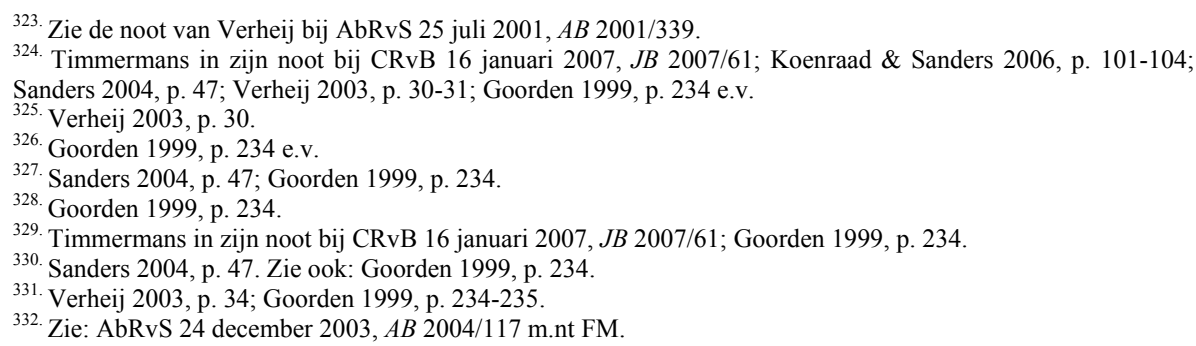




\section{De bezwaarschriftprocedure en het administratief beroep}

kan beslissen. Verheij merkt over de regel dat de bestuursrechter ex tunc toetst op dat deze regel ongeveer juist is, maar niet helemaal. ${ }^{333}$ De rechter toetst vrijwel steeds naar toen, hetgeen betekent dat hij de feiten moet beoordelen naar het tijdstip dat het bestuur bij het bestreden besluit in aanmerking moest nemen. ${ }^{334}$ Ook volgens de wetgever staat in de nieuwe opzet van de Awb de rechtmatigheidstoetsing ex tunc van een besluit centraal, maar heeft de rechter vanuit een oogpunt van doelmatige en doeltreffende geschilbeslechting wel de bevoegdheid gekregen om zelf in de zaak te voorzien als na vernietiging slechts één beslissing mogelijk is. Daarbij geldt dat de rechter rekening kan houden (voor zover het bestuur dat ook diende te doen) met na het instellen van het beroep opgekomen feiten en omstandigheden. ${ }^{335}$ De heersende benadering in de literatuur en rechtspraak leek lange tijd eveneens te zijn dat de rechter, gelet op zijn staatsrechtelijke positie, niet op de stoel van het bestuur mag plaatsnemen en (slechts) indien nog maar één beslissing mogelijk is en er derhalve sprake is van een gebonden bevoegdheid van het bestuur zelf in de zaak mag voorzien. ${ }^{336}$ Dat betekent dat de mogelijkheden voor de rechter om zelf te voorzien in de zaak zeer beperkt waren, maar dat de rechter in bepaalde gevallen wel degelijk ex nunc beslissingen neemt. De mogelijkheden om zelf in de zaak te voorzien zijn echter uitgebreid in de jurisprudentie gelet op het belang dat gehecht wordt aan finale geschilbeslechting. ${ }^{337}$ Voor de rechter gelden dan echter dezelfde beperkingen die voor het bestuur gelden op grond van de aard van het besluit of de wettelijke voorschriften. Kon het bestuur niet ex nunc beslissen dan kan de rechter ook niet ex nunc zelf voorzien. ${ }^{338}$ Het zelf voorzien is derhalve een algemene uitzondering op het uitgangspunt dat de rechter ex tunc toetst.

Verder bestaan er incidentele kwesties die de rechter ex nunc beoordeelt. Bolt wijst op een aantal aspecten die ex nunc worden getoetst, zoals de toetsing inzake de bevoegdheid en ontvankelijkheid. ${ }^{339}$ Ook beoordeelt de rechter, zoals ook Verheij, stelt op grond van de actuele omstandigheden of een appellant nog procesbelang heeft ten tijde van de uitspraak. ${ }^{340}$ In het kader van die beoordeling worden gewijzigde omstandigheden feiten of recht meegenomen. In de literatuur worden nog meer mogelijkheden voor de rechter om ex nunc te toetsen genoemd, die ik hier verder laat rusten. Voorts wordt in de literatuur door enkele auteurs ook aangegeven dat met het oog op finale geschilbeslechting de bestuursrechter meer mogelijkheden zou moeten krijgen om ex nunc te oordelen. ${ }^{341}$ Over wijze waarop een dergelijke toetsing moet worden vormgegeven bestaat echter nog geen overeenstemming. ${ }^{342}$ Indien gewaarborgd blijft dat de rechter zijn positie ten opzichte van het bestuur niet uit het oog verliest, door middel van bijvoorbeeld een bestuurlijke lus, lijken de meeste auteurs principieel niets tegen een vorm van ex nunc-toetsing te zien. $^{343}$

\footnotetext{
333. Verheij 2003, p. 26.

334. Verheij 2003, p. 36

335. PG Awb II, p. 175. De hoofdregel dat de rechter ex tunc dient te toetsen is overigens niet in de Awb zelf vastgelegd. Vgl: Groenewegen 2000, p. 245.

336. B.J. Schueler, Vernietigen en opnieuw voorzien. Over het vernietigen van besluiten en beslechten van geschillen, Zwolle: W.E.J. Tjeenk Willink 1994, p. 21. Zie nader hierover par. 4.3.9 van Deel I.

337. Zie par. 4.3.9 van Deel I daarover met verwijzingen naar jurisprudentie.

338. Zie Verheij 2003, p. 45-46. Verheij wijst ook nog op andere omstandigheden die ertoe kunnen leiden dat de rechter niet ex nunc zelf mag voorzien, zie p. 46.

339. Bolt 2005, p. 23 e.v.

${ }^{340 .}$ Verheij 2003, p. 36. Zie ook: Teunissen 1992, p. 111. Zie: AbRvS 6 november 2002, AB 2003/115 m.nt. NV; AbRvS 5 juni 2002, $A B$ 2002/349 m.nt BJS.

341. Zie o.m.: J.A.M. van Angeren, 'De rechter als bestuurder-plaatsvervanger. Een pleidooi voor meer zelf voorzien door de bestuursrechter', JB-plus 2007, p. 16-23; Bolt 2005, p. 23; VAR-Commissie Rechtsbescherming 2004, p. 122; Van Blommestein 2000, p. 136. Volgens Bolt heeft de ex tunc-toetsing door de rechter altijd al ter discussie gestaan, Bolt 2005, p. 20-23.

342. Rapport VAR-Commissie Rechtsbescherming 2004, p. 123-128.

343. Zie uitvoeriger over de bezwaren die kleven aan invoering van een ex nunc-toets door de bestuursrechter, Bolt 2005, p. 17 e.v en 258 e.v; Rapport VAR-Commissie Rechtsbescherming 2004, p. 126-128.
} 
Deel II Bestuurlijke voorprocedures

Vreemdelingenrecht

Tot slot heeft de wetgever ook op een specifiek bestuursrechtelijk terrein, het vreemdelingenrecht, de bestuursrechter de bevoegdheid toegekend om in het kader van verblijfsvergunningen asiel in beroep ex nunc te toetsen. ${ }^{344}$ Wel dient de rechter (om tegemoet te komen aan het recht op Erstentscheidung van het bestuur) ingevolge artikel 83 derde lid van de Vw 2000 het bestuur te vragen naar zijn oordeel omtrent de nieuwe feiten of omstandigheden. ${ }^{345}$ Naar aanleiding van deze ontwikkeling in het vreemdelingenrecht is op verschillende plaatsen in de literatuur (zij het soms met enige reserve) gepleit voor de invoering van een vergelijkbare ex nunc-toetsing in het overige bestuursrecht. ${ }^{346}$ Bolt geeft aan dat de wetgever in navolging van de ex nunc-toetsing in asielzaken ook in enkele andere gevallen een dergelijke toetsing door de rechter wilt laten plaatsvinden. ${ }^{347}$ Zelf stelt zij zich op een genuanceerd standpunt waarbij gelet op de daaraan klevende praktische bezwaren, die niet als zodanig zien op de staatsrechtelijke verhouding tussen bestuur en rechter, in een beperkt aantal gevallen invoering van een dergelijke toetsing wenselijk is. ${ }^{348}$ Voor invoering van ex nunc-toetsing in het gehele bestuursrecht zou, zoals hiervoor aangegeven, met name het uitgangspunt van finale geschilbeslechting in het bestuursrecht nopen.

Een ex nunc-toetsing door de bestuursrechter in het vreemdelingenrecht (maar ook daarbuiten) wordt derhalve niet problematisch geacht voor de rechtsstatelijke positie van de bestuursrechter, mits gewaarborgd is dat het bestuur het primaire orgaan is dat een oordeel geeft over de nova. Dat laat zien dat voor het onderscheid tussen de rechterlijke en bestuurlijke werkzaamheid toch vooral de rechtstatelijke positie van de rechter ten opzichte van het bestuur bepalend is. Zolang deze positie gehandhaafd blijft, lijken geen principiële argumenten zich er tegen te verzetten om de rechter ex nunc te laten oordelen en in feite in dat opzicht te doen wat het bestuur ook zou moeten doen. De VARCommissie Rechtsbescherming merkt hierover op dat aan het principiële bezwaar dat de rechter op de stoel van het bestuur zou plaatsnemen in het vreemdelingenrecht tegemoet gekomen wordt door de invoering een variant van een bestuurlijke lus in artikel 83 derde lid van de Vw 2000. Deze variant zou zelfs mogelijk zijn in het kader van beroepen waarbij de rechter zou moeten oordelen over een discretionaire bevoegdheidsuitoefening. ${ }^{349}$ Daaruit kan ook worden afgeleid dat ex tunc oordelen geen wezenlijk kenmerk vormt of behoeft te vormen van de rechterlijke werkzaamheid in het algemeen. Essentieel is dat de rechter terughoudendheid betracht daar waar dat vereist is vanuit de verschillende positie en taakuitoefening van de rechter en het bestuur. Terughoudendheid kan echter ook op andere wijze gerealiseerd worden of blijven dan door vast te blijven houden aan de tegenstelling ex nunc-heroverweging versus ex tunc-toetsing. Bij het voorgaande moet wel de kanttekening geplaatst worden dat asielzaken in zekere zin in dit opzicht niet representatief zijn omdat daarin geen bezwaar mogelijk is en derhalve geen tweede ex nunc-beoordeling door het bestuur mogelijk is alsmede omdat artikel 3 EVRM ook noopt tot een beoordeling naar de actuele stand van zaken. ${ }^{350}$

Relativering: aard van de bevoegdheid van het bestuur

Omdat het bestuur het recht op 'Erstentscheidung' heeft, is het niet aan de rechter om relevante (nieuwe) feiten of omstandigheden te beoordelen zonder dat het bestuur daar-

\footnotetext{
344. Art. 83 Vw 2000. Zie over die bevoegdheid o.m.: Rapport VAR-Commissie Rechtsbescherming 2004, p 123; Groenewegen 2000, p. 245-248; W. van Blommestein, 'Toetsing ex nunc; in het vreemdelingenrecht én in het bestuursrecht?', NTB 2000, p. 128-137. Voor een bespreking van de jurisprudentie in het kader van art. 83 Vw 2000 verwijs ik naar: Bolt 2005, p. 145-211; Bolt 2002, p. 160 e.v.; Verheij 2003, p. 37-39.

${ }^{345 .}$ Zie hierover: Rapport VAR-Commissie Rechtsbescherming 2004, p. 126; Verheij 2003, p. 37

346. Bv.: Blommestein 2000, p. 128-137; Teunissen 1992, p. 128.

${ }^{347 .}$ K.F. Bolt, 'Voor de verandering een rechterlijke ex nunc-toets?, JB-plus 2007, p. 2-3.

348. Bolt 2007, p. 6-13.

349. Rapport VAR-Commissie Rechtsbescherming 2004, p. 126.

350. Zie over de ex nunc-toetsing in het vreemdelingenrecht: Bolt 2007, p. 2-13.
} 


\section{De bezwaarschriftprocedure en het administratief beroep}

over eerst zijn licht heeft kunnen laten schijnen. ${ }^{351}$ Dat vormt de achtergrond van het traditionele onderscheid. Van belang is echter dat deze overwegingen vooral van betekenis zijn in de gevallen waarin het bestuur over beslisruimte beschikt en een belangenafweging dient te verrichten. In die gevallen komt het karakteristieke van de bestuurlijke werkzaamheid het duidelijkst naar voren en moet de rechter gelet op zijn positie en door het bestuur te verrichten belangenafweging terughoudendheid betrachten. In het verlengde daarvan ligt dat het bestuur ex nunc beslist en belangen afweegt terwijl de rechter ex tunc de beslissing van het bestuur beoordeelt. ${ }^{352}$ In de literatuur wordt aangenomen dat bij gebonden bevoegdheden de positie van de rechter ten opzichte van het bestuur niet of nauwelijks in het geding is bij een ex nunc-toetsing. ${ }^{353}$ Teunissen wijst er ook op dat in de literatuur reeds geopperd is dat ex nunc-toetsing door de rechter in het geval van sterk gebonden bevoegdheden bij het bestuur vanuit rechtsstatelijk oogpunt minder problematisch is. ${ }^{354}$ De staatsrechtelijke verhouding tussen bestuur en rechter lijkt met name in gevaar te kunnen komen indien het discretionaire bevoegdheden betreft waarvan de uitoefening door de rechter ex nunc zou kunnen worden getoetst. Zo merkt de VARcommissie Rechtsbescherming (weliswaar in het kader van de vraag of ex nunc-toetsing door de rechter wenselijk is) op dat de ex tunc-leer 'vooral functioneel is op terreinen van het bestuursrecht waar de besluitvorming een zuivere belangenafweging inhoudt'. ${ }^{555}$ Voorts kan opgemerkt worden dat het in de gevallen waar uit een gestelde peildatum of tijdvak volgt dat het bestuur niet ex nunc kan heroverwegen, veelal gebonden bestuursbevoegdheden betreft. Het gaat om rechtsgebieden, zoals het sociale zekerheidsrecht en het belastingrecht waarin het bestuur vaak over gebonden bevoegdheden beschikt die betrekking hebben op een bepaalde periode of peildatum. Daarmee lijkt de mate waarin ex nunc heroverwogen kan worden deels samen te vallen met de mate van gebondenheid dan wel vrijheid van de aan het bestuur toegekende bevoegdheid. De door het bestuur verrichte beoordeling is in hoge mate gelijk aan die van de rechter. Het principiële bezwaar dat de rechter op de stoel van het bestuur gaat zitten, bestaat in die gevallen in mindere mate aangezien de werkzaamheden van het bestuur en de rechter in die gevallen niet of nauwelijks verschillen en het bestuur nog maar een rechtens juist besluit kan nemen. ${ }^{356}$ Anderzijds is het in die gevallen zo dat het bestuur vaak niet ex nunc kan heroverwegen (en in het verlengde daarvan de rechter natuurlijk ook niet). Het creatieve element dat schuilt in de bestuurlijke taakuitoefening, althans daaraan traditioneel wordt toegekend, bestaat in dat geval niet of nauwelijks.

Uit het voorgaande volgt dat het onderscheid tussen de rechterlijke en bestuurlijke werkzaamheid teneinde de rechtsstatelijke positie van de (bestuurs)rechter ten opzichte van het bestuur te waarborgen bij gebonden bevoegdheden niet per definitie in gevaar komt door een ex nunc-toetsing van de besluitvorming van het bestuur. Voorts volgt daaruit dat bij een meer discretionaire bevoegdheidsuitoefening door het bestuur de rechter meer terughoudendheid past ten aanzien van nova waarbij het recht op 'Erstentscheidung' door het bestuur verzekerd moet blijven. In dat geval is het bij uitstek aan het bestuur om primair de nieuwe feiten of omstandigheden te beoordelen en daar gevolgtrekkingen aan te verbinden aangezien niet op voorhand vaststaat welk besluit genomen moet worden. In de overige gevallen kan het bestuur immers maar op een beperkte wijze omspringen met het nieuwe feit of omstandigheid en kan de rechter ook niet snel treden in de bestuurlijke ruimte. ${ }^{357}$

\footnotetext{
351. Rapport VAR-Commissie Rechtsbescherming 2004, p. 122-123; Van Blommestein 2000, p. 132; Teunissen 1992, p. 113

352. Rapport VAR-Commissie Rechtsbescherming 2004, p. 122-123 en p. 126-127; Blommestein 2000, p. 132; Teunissen 1992, p. 113-114

${ }^{353}$ Bolt 2007, p. 6; Rapport VAR-Commissie Rechtsbescherming 2004, p. 123-125; Teunissen 1992, p. 113-114.

354. Teunissen 1992, p. 113-114. Zie ook: Bolt 2007, p. 5-6

${ }^{355 .}$ Rapport VAR-Commissie Rechtsbescherming 2004, p. 122-123.

${ }^{356 .}$ Rapport VAR-Commissie Rechtsbescherming 2004, p. 126; Teunissen 1992 p. 113

357. Vgl. Bolt 2007, p. 5-6.
} 
Deel II Bestuurlijke voorprocedures

Dat betekent echter niet dat ex nunc-toetsing door de rechter volledig uitgesloten behoeft te zijn in de gevallen waarin een discretionaire bevoegdheid bestaat. Er bestaan immers andere mogelijkheden om die positie van het bestuur te waarborgen. Bolt wijst er bijvoorbeeld op dat het behoud van de machtenscheiding tussen de bestuurlijke en rechterlijke macht mogelijk is door de introductie van een bestuurlijke lus zoals in het vreemdelingenrecht het geval is. ${ }^{358}$ Ook de VAR-Commissie Rechtsbescherming geeft aan dat ex nunc-toetsing met behoud van de rechtstatelijke positie van de rechter ten opzichte van het bestuur mogelijk is in gevallen waarin het bestuur over discretionaire bevoegdheden beschikt mits een bestuurlijke lus het primaat van bestuur bij nova waarborgt. ${ }^{359} \mathrm{Bij}$ zowel gebonden als discretionaire bevoegdheidsuitoefeningen lijkt een ex nunc-toetsing door de rechter derhalve niet problematisch mits het bestuur zich als eerste mag buigen over de nieuwe feiten of omstandigheden.

\subsubsection{Conclusies}

\section{Geen tegengestelde uitgangspunten}

Alle relativeringen overziend behoeven de bestuurlijke werkzaamheid en de rechterlijke werkzaamheid wat betreft het tijdstip waarnaar beoordeeld of getoetst moet worden, niet te worden gezien als absoluut aan elkaar tegengestelde werkzaamheden, hoewel de doctrinaire uitgangspunten dit lijken te suggereren. De doctrinaire tegenstelling moet vooral geplaatst worden tegen de achtergrond van de staatsrechtelijke verhouding tussen bestuur en rechter. In de praktijk blijkt de tegenstelling, hoewel zeker aanwezig, minder scherp te zijn. Niet alleen beslist het bestuur lang niet altijd ex nunc, ook de rechter toetst niet uitsluitend ex tunc. Ex nunc-toetsing door de rechter lijkt zeer wel mogelijk zonder de positie van de rechter ten opzichte van het bestuur in gevaar te brengen, mits de rechter het bestuur maar eerst de gelegenheid biedt om zich over de nieuwe feiten en omstandigheden uit te laten. Daarmee is uiteraard niet gezegd dat een ex nunc-toetsing wenselijk is, omdat daaraan zoals Bolt aangeeft in het huidige stelsel van bestuursrechtelijke rechtsbescherming andersoortige bezwaren kunnen kleven. ${ }^{360}$ Voor dit onderzoek is echter slechts de vraag van belang in hoeverre het onderscheid naar de werkzaamheid van de bestuurlijke en rechterlijke organen wat betreft het moment van beoordeling bestaat en noopt tot het stellen van andere vereisten aan de procedures bij deze organen. Gelet op het voorgaande is het de vraag of het kenmerkende verschil tussen de werkzaamheid van het bestuur (in de voorprocedures) en de rechter gezocht moet worden in dit onderscheid tussen beide werkzaamheden, nu de grondslag daarvoor vooral gelegen is in de onderlinge rechtstatelijke verhouding tussen deze organen en deze ook op andere wijze gewaarborgd kan worden. Bovendien is in dat kader de aard van de aan het bestuur toekomende bevoegdheid nog een factor die de absolute tegenstelling tussen de werkzaamheid van beide organen afzwakt. Op de vraag in hoeverre de verschillen tussen de bestuurlijke heroverweging en de rechterlijke toetsing nopen tot het stellen van andere behoorlijkheidseisen wordt in de volgende paragraaf ingegaan. Hier kan echter alvast worden opgemerkt dat het onderscheid tussen de ex nunc- heroverweging door het bestuur en de ex tunc- toetsing door de bestuursrechter - evenals het geval was bij de omvang van de heroverweging door het bestuur en de omvang van de toetsing door de bestuursrechter zoals beschreven in paragraaf 4.3.1 - minder scherp is dan wel wordt aangenomen en derhalve ook minder nopen tot het op voorhand afwijzen of uitsluiten van doorwerking van de beginselen van behoorlijke rechtspleging in de bestuurlijke voorprocedures.

\footnotetext{
358. Bolt 2007, p. 6

${ }^{359 .}$ Rapport VAR-Commissie Rechtsbescherming 2004, p. 126

${ }^{360}$ Zie over deze bezwaren Bolt 2007, p. 2-13; Bolt 2005, p. 17 e.v. en p. 258 e.v.
} 
De bezwaarschriftprocedure en het administratief beroep

\subsection{De bezwaarschriftprocedure en het administratief beroep: besluitvorming en/of rechtsbescherming?}

\section{Besluitvorming en/of rechtsbescherming}

In de voorgaande paragrafen werd bezien waaruit de functies van de bestuurlijke voorprocedures en de omvang en aard van de heroverweging in de bestuurlijke voorprocedures bestaat. Het doel daarvan was allereerst een vergelijking mogelijk te maken tussen de bestuurlijke en rechterlijke werkzaamheid. De traditionele verschillen - zoals de rechtsbeschermingsfunctie versus verlengde besluitvorming, de rechtmatigheidstoetsing versus volledige heroverweging, de ex-tunc toetsing versus ex nunc heroverweging - die in de doctrine steeds worden aangewezen, vormen voor sommige auteurs en ook voor de bestuursrechter, een reden om uiteenlopende vereisten voor de behoorlijkheid van de procedure aan te nemen voor de bestuurlijke voorprocedures en de procedure bij de bestuursrechter. ${ }^{361}$ Het is derhalve van belang om vast te stellen in hoeverre er verschillen dan wel overeenkomsten bestaan tussen de werkzaamheid van het bestuur in deze opzichten en de werkzaamheid van de bestuursrechter. Vervolgens kan de vraag gesteld en beantwoord worden in hoeverre de bestaande verschillen daadwerkelijk in de weg staan aan invloed van de beginselen van behoorlijke rechtspleging op de procedure en de totstandkoming van de beslissingen in de bestuurlijke voorprocedures. Hoe groter de verwantschap en de overeenkomsten tussen beide procedures, hoe meer aanleiding er lijkt te bestaan voor toepasselijkheid van vergelijkbare eisen. Het onderzoek in de voorgaande paragrafen is dan ook vooral erop gericht geweest om de hiervoor bedoelde verschillen en overeenkomsten bloot te leggen en niet zozeer een uitputtende beschrijving te geven van wat al deze aspecten in de heroverweging door het bestuur of de toetsing door de bestuursrechter inhouden.

\section{Het tweeledige karakter van de bestuurlijke voorprocedures}

De bestuurlijke voorprocedures hebben onmiskenbaar een rechtsbeschermingsfunctie bezien vanuit het perspectief van de belanghebbende. Tegelijkertijd hebben zij bezien vanuit de belangen van het bestuur een verlengde besluitvormingsfunctie. Rechtsbescherming en verlengde besluitvorming vormen derhalve geen tegengestelde uitgangspunten, maar verschillende perspectieven op de bestuurlijke voorprocedures. Het tweeledige karakter van de bestuurlijke voorprocedures valt te herkennen in de vier functies die doorgaans aan die procedures worden toegekend: de rechtsbeschermingsfunctie, filterfunctie, leerfunctie en verduidelijkingsfunctie. Als er sprake van een gebonden bevoegdheid bij het bestuur dan valt het begrip rechtsbescherming samen met rechtmatigheidstoetsing en verschilt de toetsing en de rechtsbescherming die geboden kan worden niet van de procedure bij de bestuursrechter. Als er sprake is van een discretionaire bevoegdheid dan kan het bestuur in principe meer rechtsbescherming bieden dan de bestuursrechter.

\section{Te absolute uitgangspunten}

Het vertrekpunt in het onderzoek vormden de traditionele verschillen en tegenstellingen die aangenomen en benadrukt worden als het gaat om de positie en verhouding van bestuur en bestuursrechter in het bestuursrecht. Van alle dogmatische verschillen is geconstateerd dat zij te zeer als absolute uitgangspunten of tegenstelling gepresenteerd worden.

Zo kan het bestuur, gelet op de aard van de bevoegdheid die het uitoefent, lang niet altijd volledig heroverwegen. De aard en omvang van de bestuurlijke werkzaamheid (ook in de bestuurlijke voorprocedure) wordt namelijk in belangrijke mate bepaald door de aard van de uitgeoefende bevoegdheid. Indien de aan het bestuur toegekende bevoegdheid gebonden is, bestaat de (aard van de) bestuurlijke werkzaamheid naar alge-

\footnotetext{
${ }^{361 .}$ Zie hierover Deel I, par. 2.3.
} 


\section{Deel II Bestuurlijke voorprocedures}

meen wordt onderschreven uit wetstoepassing en rechtsvaststelling. Er bestaat immers geen (wettelijke) ruimte om beleidsaspecten mee te nemen bij de herbeoordeling van het primaire besluit, omdat die ruimte in primo ook ontbreekt. Indien de taak van het bestuur in die gevallen in de primaire fase nauwelijks verschilt van die van de rechter, geldt dat voor de werkzaamheid van het bestuur in de bestuurlijke voorfase mijns inziens des te meer. In dat geval dient het bestuur immers als tweede instantie nogmaals na te gaan of een juiste rechtsvaststelling heeft plaatsgevonden waarbij het initiatief voor het volgen van de voorprocedure, evenals het geval is bij de rechterlijke procedure, bij de belanghebbende burger ligt. Het bestuur is in de bestuurlijke voorfase dan ook veeleer een secundaire rechtsvormer dan in de primaire besluitvormingsfase.

Bij discretionaire bevoegdheden ligt de situatie aanzienlijk anders. In die gevallen blijft er voor het bestuur ruimte over om eigen afwegingen te maken bij de besluitvorming. In beginsel komt hier het onderscheid tussen de bestuurlijke en rechterlijke werkzaamheid het scherpst naar voren. Het bestuur kan politiek-bestuurlijke, beleidsmatige aspecten betrekken bij de (heroverweging van) besluitvorming terwijl de omvang van de toetsing door de rechter beperkt is tot rechtmatigheidsaspecten. Daarbij is het wel van belang te signaleren dat de beslisruimte van het bestuur in het geval van discretionaire bevoegdheden vaak beperkt wordt door opgestelde beleidsregels. In aanmerking dient te worden genomen dat de ruimte die het bestuur heeft en die zo kenmerkend is voor de bestuurlijke taakuitoefening (althans daar is het doctrinaire onderscheid tussen rechter en bestuur mede op gebaseerd) afneemt naar mate de discretionaire bevoegdheid meer gestructureerd is door beleidsregels. Ook dan wordt de beslisruimte ingeperkt en heeft reeds (in bepaalde mate) een afweging van belangen in abstracto (door het bevoegde bestuursorgaan) plaatsgevonden. Indien een beleidsvrije of beoordelingsvrije bevoegdheid vrijwel geheel gestructureerd is door beleidsregels, wordt in het overgrote deel van de gevallen waarin de bevoegdheid wordt uitgeoefend het rechtsvormende element in de besluitvorming gereduceerd. Het bestuur maakt in de praktijk, gelet op de voordelen voor het bestuur, vrij veel gebruik van de mogelijkheid beleidsregels (of ander beleid) op te stellen. $^{362}$

Daar komt nog bij dat de heroverweging onder de Awb voor een belangrijk deel in het teken van de individuele rechsbescherming. Voor het bestuur gelden in de bestuurlijke voorprocedures, evenals voor de bestuursrechter, het verbod van 'ultra petita' gaan en het verbod van 'reformatio in peius'. De gelijkenissen met de rechterlijke toetsing zijn op dit punt groot.

Ook bestaat, gelet op wettelijke voorschriften of de aard van de bevoegdheid, lang niet altijd de mogelijkheid voor het bestuur om ex nunc beslissingen te nemen en deze beslissingen ex nunc te heroverwegen. Er zijn vele uitzonderingen op deze hoofdregel. Bovendien heeft de bestuursrechter meer mogelijkheden om ex nunc te toetsen of te beslissen dan verondersteld kan worden op grond van de ex tunc-regel. Deze karakteristiek van de bezwaarschriftprocedure moet eveneens vooral in staatsrechtelijk perspectief worden geplaatst en brengt vooral de staatsrechtelijke gehoudenheid van de rechter tot het bewaren van afstand tot de bestuurlijke besluitvorming tot uitdrukking. Om die reden stelt Verheij ook dat de klassieke regel 'in bezwaar ex nunc, in beroep ex tunc' vervangen moet worden door het adagium 'het bestuur beslist, de rechter toetst'. Zoals hij zelf aangeeft zegt dit echter weinig over hetgeen het bestuur moet doen, maar komt daarin vooral tot uitdrukking dat de rechter meestal ex tunc toetst. ${ }^{363}$

De gevolgen voor de te stellen inrichtingseisen

De vraag kan gesteld worden of de verschillen in werkzaamheid tussen bestuur en rechter ook de toepasselijkheid van verschillende eisen op de inrichting van de procedure bij

\footnotetext{
362. Zie hierover: Van Wijk/Konijnenbelt \& Van Male 2008, p. 228 e.v.
}

${ }^{363}$. Verheij 2003, p. 47. 


\section{De bezwaarschriftprocedure en het administratief beroep}

beide organen rechtvaardigen. Mijns inziens is dat niet het geval. Zoals is gebleken, lijkt de inrichting van de voorprocedures bij beschikkingenateliers, waarin veelal bestuurlijke besluitvorming plaatsvindt op basis van een discretionaire bevoegdheid, juist vaak meer op de procedure bij de rechter dan de inrichting van de voorprocedures bij beschikkingenfabrieken. Daarin schuilt een paradox: in de beschikkingenfabrieken vindt immers doorgaans besluitvorming plaats op grond van overwegend gebonden bevoegdheden, waardoor de taak van het bestuur sterke gelijkenissen met de toetsing van de rechter. Daaruit blijkt in elk geval dat het enkele feit dat de bestuurlijke werkzaamheid verschilt van die van de rechter niet op voorhand behoeft te betekenen dat die verschillen ook moeten doorwerken in de inrichting van de bestuurlijke voorprocedures. Voor zover al gesteld kan worden dat op basis van de verschillen in werkzaamheid tussen het bestuur en de bestuursrechter er verschillende procedurele vereisten gesteld moeten worden aan de procedures waarin de beslissingen van beide organen tot stand komen, wijzen de relativeringen van de tegenstellingen bovendien in een andere richting. De werkzaamheid van het bestuur in de bestuurlijke voorprocedures groeit onder de Awb naar de werkzaamheid van de bestuursrechter toe. Dat zou derhalve eerder pleiten voor het stellen van vergelijkbare of dezelfde eisen aan de inrichting van de procedure en de totstandkoming van de beslissing, dan andersom. In de gevallen waarin de bestuurlijke kenmerken sterk aanwezig zijn en de verschillen met de rechterlijke werkzaamheid het grootst zijn, kunnen deze worden teruggevoerd op de staatsrechtelijke positie die het bestuur inneemt in ons staatsbestel de onderlinge verhouding tussen de bestuur en rechter in ons staatsbestel terug te voeren. Voor de conclusie dat geheel verschillende vereisten aan de inrichting van de procedures bij beide organen gesteld moeten worden zijn geen aanknopingspunten te vinden. De verschillen die bestaan en die terug te voeren zijn op de staatsrechtelijke verhouding tussen beide organen kunnen, voor zover al noodzakelijk, ook gewaarborgd blijven door bepaalde behoorlijkheidsvereisten die deze verhouding raken voor het bestuur anders te in te vullen dan voor de rechter. De bestaande verschillen vormen in mijn optiek onvoldoende rechtvaardiging voor het stellen van verschillende eisen aan de voorprocedures of voor het afhouden van geldingskracht van de beginselen van behoorlijke rechtspleging op die procedures.

De geconstateerde verschillen behoeven bovendien hoe dan ook niet de basis te vormen voor verschillende inrichtingseisen of in de weg te staan aan betekenis van de beginselen van behoorlijke rechtspleging voor de bestuurlijke voorprocedures. De waarborgen waarmee de inrichting van een procedure is omkleed, behoeven immers geen invloed op de aard of omvang van de heroverweging door het bestuursorgaan te hebben. Met de toepasselijkheid van de beginselen van behoorlijke rechtspleging verandert er niets aan de werkzaamheid van het bestuur in de bestuurlijke voorprocedures. In hoeverre komt bijvoorbeeld de positie van het bestuur en de te verrichten ex nuncheroverweging in het geding indien voor de bestuurlijke voorprocedures gelijksoortige of ten aanzien van sommige onderdelen van de inrichting van de procedure dezelfde procedurele vereisten zouden gelden als voor de procedure bij de rechter? Voor zover daarvan al sprake is, noopt ex nunc-heroverweging in mijn ogen vanuit het oogpunt van hoor en wederhoor eerder tot zwaardere eisen in de voorprocedure dan in de procedure voor de rechter. Indien het bestuur nieuwe feiten of omstandigheden mag meenemen, zelfs moet meenemen, moet het de belanghebbende ook de gelegenheid geven om daarover een standpunt in te nemen. Voor zover nodig zou aan de vrees dat de bestuurlijke werkzaamheid in het geding komt bovendien tegemoet kunnen worden gekomen door het geven van een verschillende invulling van de vereisten die voortvloeien uit de beginselen van behoorlijke rechtspleging voor de bestuurlijke voorprocedure.

Het voorgaande betekent geenszins dat de bestaande verschillen ontkend worden of de goede redenen die daarvoor bestaan niet onderkend worden. Het laat ook onverlet dat de onderscheiden posities die bestuur en rechter innemen in ons staatsbestel verschillen in de werkzaamheid van deze organen met zich brengen die ook kunnen doorwerken in de procedurele vereisten voor de inrichting van de desbetreffende procedures. Dat is 


\section{Deel II Bestuurlijke voorprocedures}

echter een aspect dat aan de orde dient te komen bij de vraag in welke mate de onderscheiden vereisten/beginselen van behoorlijke rechtspleging betekenis kunnen hebben voor de bestuurlijke voorprocedures. Indien van belang voor een behoorlijkheidseis dient vastgesteld te worden welke betekenis het verschil in positie en de onderlinge verhouding heeft of kan hebben. De verschillende posities en het daaruit voortvloeiende onderscheid in werkzaamheid van beide organen rechtvaardigen mijns inziens echter niet op voorhand een categorische uitsluiting van alle mogelijke betekenis van de beginselen van behoorlijke rechtspleging. Dat betekent dat voor ieder vereiste voor een behoorlijke procedure (bij de rechter) afzonderlijk onderzocht moet worden in hoeverre dit vereiste betekenis kan hebben voor de bestuurlijke voorprocedures. In die beoordeling kan en moet de staatsrechtelijke positie van het bestuur en in het verlengde daarvan ook de verhouding tussen bestuur en rechter een factor van belang zijn. Die factor kan dan uiteraard nog steeds tot de conclusie leiden dat bepaalde vereisten geen of slechts deels betekenis hebben of kunnen hebben in de bestuurlijke voorfasen. Ook zou de conclusie juist kunnen zijn dat bepaalde vereisten voor het bestuur van grotere betekenis zijn of dat aan de bestuurlijke procedure hogere eisen gesteld moeten worden. Voorts bestaat de mogelijkheid dat enkele overkoepelende vereisten voor contentieuze procedures (waartoe ook de bestuurlijke voorprocedures gerekend worden) onderscheiden kunnen worden. In de hiernavolgende paragrafen wordt onderzocht welke vereisten aan de inrichting van de voorprocedures bij het bestuur gesteld worden en ook, indien daar aanleiding toe bestaat, in hoeverre de specifieke positie en werkzaamheid van het bestuur daarbij een rol speelt. 


\section{De inrichting van de bezwaarschriftprocedure en het administratief beroep}

\section{$5.1 \quad$ Inleiding}

Omdat de bezwaarschriftprocedure en het administratief beroep onmiskenbaar (ook) een plaats innemen in het stelsel van bestuursrechtelijke rechtsbescherming is de inrichting van die procedures in de Awb met een aantal processuele waarborgen voor de burger omkleed. ${ }^{1}$ In principe nemen in iedere fase van de procedure met betrekking tot een besluit de waarborgen voor de burger toe. ${ }^{2}$ De bezwaarschriftprocedure (maar ook het administratief beroep) bevindt zich in de structuur van de Awb - primaire besluitvormingsproces, secundaire besluitvormingsproces en procedure bij de rechter - tussen de primaire besluitvormingsfase en de rechterlijke fase. Daaruit volgt dat het uitgangspunt is dat de zorgvuldigheidswaarborgen ten opzichte van de eerste fase toenemen, maar nog niet die van de rechterlijke fase genaderd zijn. ${ }^{3}$ Scheltema spreekt in dat verband over drie stadia die een geschil tussen burger en bestuur kan doorlopen, waarbij de waarborgen voor een goede rechtmatigheidsbeoordeling het grootst zijn in de procedure voor de rechter. De besluitvorming in de bezwaarschriftfase is echter weer met meer waarborgen omgeven dan in de primaire fase. ${ }^{4}$

In hoofdstuk 7 van de Awb zijn voor de bezwaarschriftprocedure verscheidene procedurele vereisten en waarborgen neergelegd waaraan de inrichting van die voorprocedure dient te voldoen. Zo is het uitgangspunt, ingevolge artikel 7:2 van de Awb, dat een belanghebbende die bezwaar heeft gemaakt, alvorens een beslissing op zijn bezwaar wordt genomen, wordt gehoord. Ook bevat de regeling van de bezwaarschriftprocedure een aantal voorschriften, zoals artikel 7:5 van de Awb, waarmee wordt beoogd een element van objectiviteit in de herbeoordeling door het bestuur te brengen. Als voorbeeld kan verder nog genoemd worden de in artikel 7:4 van de Awb opgenomen voorschriften waarin bepaald wordt tot welk tijdstip stukken kunnen worden ingediend voor de hoorzitting alsmede dat belanghebbenden een recht op inzage in alle relevante stukken hebben. De regeling voor het administratief beroep bevat grotendeels dezelfde waarborgen (op de verschillen met de bezwaarschriftprocedure wordt, voor zover relevant, in de desbetreffende paragrafen nader ingegaan).

In de literatuur is ook gewezen op de(ze) judiciële elementen in de inrichting van de bezwaarschriftprocedure die vergelijkbaar zijn met de vereisten die gelden voor de rechterlijke procedure. Versteden rekent daartoe bijvoorbeeld sommige bepalingen omtrent het horen met het principe van hoor en wederhoor, beperkingen ten aanzien van het horen door personen die bij de primaire besluitvorming betrokken waren en het principe

\footnotetext{
${ }^{1 .}$ Omdat de regeling inzake de inrichting van de bezwaarschriftprocedure en het administratief beroep in de Awb grotendeels overeenstemmen worden deze in het navolgende grotendeels gezamenlijk behandeld. Uitgangspun blijft de regeling van de bezwaarschriftprocedure en overal waar bezwaarschriftprocedure staat moet administratief beroep worden gelezen. Op de regeling inzake het administratief beroep wordt slechts ingegaan voor zover deze afwijkt van die van de bezwaarschriftprocedure.

2. PG Awb I, p. 107; Notten 1998, p. 8 en 31.

${ }^{3 .}$ PG Awb I, p. 107; Notten 1998, p. 8 en 31; M. Scheltema, 'De rechter en de bezwaarschriftprocedure: meer aandacht voor snelheid en minder voor aansprakelijkheid', in: T. Hoogenboom en L.J.A. Damen (red.), In de sfeer van administratief recht (opstellen aangeboden aan Willem Konijnenbelt), Utrecht: Lemma 1994, p. 381. Vgl: Versteden 1995, p. 290.

4. Scheltema 1994, p. 381-382. Zo ook de wetgever die aangeeft dat de waarborgen in de procedure voor de rechter het zwaarst zijn, PG Awb I, p. 107. Vgl. ook: Notten 1998, p. 8 en 31.
} 


\section{Deel II Bestuurlijke voorprocedures}

van openbaarheid van het horen. ${ }^{5}$ Er zijn echter ook auteurs die van mening zijn dat de judiciële of voor rechtspraak geldende elementen in de regeling van de bezwaarschriftprocedure in de Awb niet ver genoeg gaan of zelfs ver zijn te zoeken. ${ }^{6}$ Wat daarvan ook zij, de Awb bevat voorschriften voor de voorprocedures die onmiskenbaar onder die noemer 'judicieel' geschaard moeten worden. Deze eisen aangaande inrichting van de bezwaarschriftprocedure zijn echter betrekkelijk summier teneinde variatie daarin naar behoefte mogelijk te maken ${ }^{7}$ - in vergelijking tot de voor de Awb geldende regelingen zijn de voorschriften overigens aanzienlijk uitgebreid. In bijzondere wettelijke regelingen kunnen aanvullingen of afwijkingen neergelegd worden. Uit de jurisprudentie kunnen verder nadere eisen voortvloeien, waaraan voldaan dient te worden. De grondslag voor deze vereisten wordt veelal gezocht in de ongeschreven en geschreven beginselen van behoorlijk bestuur die, nu het om bestuurlijke besluitvorming gaat, ook op de bestuurlijke voorfasen van toepassing zijn. ${ }^{8}$ De inrichting en de vereisten die voor de bezwaarschriftprocedure gelden worden derhalve door een samenspel van ongeschreven normen, geschreven vereisten (in de Awb) en jurisprudentie bepaald. In de paragrafen die volgen wordt getracht dit geheel van regels waardoor de inrichting in deze voorprocedures genormeerd wordt in kaart te brengen.

De normering van de inrichting van deze procedures wordt echter niet uitsluitend nationaalrechtelijk bepaald. Omdat een groot deel van het bestuursrecht door artikel 6 EVRM bestreken wordt en in het bijzonder de redelijke termijn-eis voor de bestuurlijke voorprocedures van belang is, kunnen ook uit die bepaling en de jurisprudentie van het EHRM eisen voortvloeien voor de inrichting van de bestuurlijke voorprocedures. De redelijke termijn-eis uit artikel 6 EVRM is immers rechtstreeks van toepassing op de bestuurlijke voorprocedures ${ }^{9}$ en bij de overige vereisten die voortvloeien uit die bepaling kan sprake zijn van doorwerking (op andere wijze dan rechtstreekse toepasselijkheid) in die voorprocedures. Ook deze jurisprudentie dient derhalve - voor zover van belang aan bod te komen. Pas nadat een volledig beeld van de vereisten die gelden voor de inrichting bestaat, kan getracht worden te achterhalen in hoeverre dat samenspel van vereisten vergelijkbaar is met de vereisten die gelden voor rechtspraak en wat de betekenis is van 'de regels die rechtspraak eigen zijn" ${ }^{10}$ voor de inrichting van deze voorprocedures. Dat betekent echter dat voor de vaststelling van het geldende normen- en eisenkader voor de bestuurlijke voorprocedures zowel normen en eisen voor bestuurlijke besluitvorming (en dus ook de primaire besluitvormingsfase) in het algemeen bezien moeten worden als normen en eisen die zich in beginsel richten tot rechterlijke instanties en procedures bij rechterlijke instanties.

Tot slot kan ook bij de wijze waarop de bezwaarschriftprocedure is ingericht het onderscheid tussen beschikkingenfabrieken en beschikkingenateliers een rol spelen. In het verlengde van het meer gebonden dan wel discretionaire karakter van de primaire besluitvorming - zo is gebleken uit onderzoek - verschilt ook de inrichting van de bezwaarschriftprocedure. ${ }^{11}$ Sanders heeft aangegeven dat het onderscheid tussen verlengde besluitvorming en zelfstandige beroepsgang tot uitdrukking komt in de inrichting van deze procedure. Naar gelang meer sprake is van verlengde besluitvorming, veelal bij beschikkingenfabrieken dus, zullen in de inrichting van die fabrieksbezwaarschriftproce-

${ }^{5 .}$ Versteden 1995 , p. 290

6. Zie bijvoorbeeld Smit 1992, p. 53. Hij meent dat de waarborgen die voor rechtspraak gelden in de regeling van de Awb-bezwaarfase ver te zoeken zijn.

${ }^{7 .}$ PG Awb I, p. 329; Van Male 1998, p. 48.

8. Te denken valt aan het formele zorgvuldigheidsbeginsel of het motiveringsbeginsel.

9. Uit de jurisprudentie van het EHRM volgt dat de termijn voor de beoordeling of voldaan is aan de redelijke termijn-eis begint te lopen bij de start van een 'dispute', hetgeen in de bestuursrechtelijke geschillen veelal het moment van indiening van een bezwaarschrift zal zijn, zie bijvoorbeeld: EHRM 9 december 1994, Schouten en Meldrum t. Nederland, AB 1995/599 m.nt. ICvcV; JB 1995/49 m.nt AWH. Hierop wordt nader ingegaan in Deel

I, par. 4.3.8 en in par. 5.7 van dit deel van het onderzoek.

${ }^{10 .}$ Deze zinsnede is ontleend aan: Versteden 1995, p. 290.

11. Sanders 1998, p. 98-99. 


\section{De inrichting van de voorprocedures}

dures minder rechterlijke elementen te vinden zijn. ${ }^{12}$ Voor de atelierbezwaarschriftprocedures ligt dat, volgens hem, anders. Die procedures vertonen in meer of mindere mate trekken van een procedure voor de administratieve rechter. ${ }^{13}$ Opvallend daarbij is dat naarmate het bestuurlijke, discretionaire aspect in de werkzaamheid van het bestuur in bezwaar meer aanwezig is of zou kunnen zijn, tegelijkertijd eerder sprake lijkt te zijn van een procedure met rechterlijke elementen en een grotere gelijkenis met een procedure voor de bestuursrechter. De verwachting zou zijn - gelet op het traditionele onderscheid dat gemaakt wordt tussen bestuur en rechtspraak - dat juist omdat in die gevallen een karakteristiek verschil bestaat met de rechterlijke werkzaamheid ook de procedure en de inrichting daarvan sterk verschilt met de procedure bij de rechter. De inrichting van de procedure en de mate waarin gelijkenis bestaat met de inrichting van de procedure voor de rechter lijkt derhalve niet (althans niet op de wijze zoals verwacht) af te hangen van of samen te hangen met de mate waarin sprake is van een typische bestuurlijke taakuitoefening. Uit zijn onderzoek blijkt immers dat in fabrieksbezwaarschriftprocedures, die vooral een verlengde besluitvormingsfunctie hebben in de zin dat fouten gemakkelijk hersteld kunnen worden, vaak rechterlijke elementen ontbreken. ${ }^{14}$ Naarmate een bezwaarschriftprocedure meer is ingericht als zelfstandige beroepsgang en minder sprake is van herstel van fouten, wordt de gelijkenis met een procedure voor de rechter groter. Voor zover van belang zal het onderscheid tussen gebonden en discretionaire bevoegdheden nader aan bod komen in de verschillende onderdelen betreffende de inrichting.

\subsection{Plan van aanpak}

In hoofdstuk 5 wordt allereerst de inrichting van de bezwaarschriftprocedure op grond van de voorschriften in de Awb, de parlementaire geschiedenis en de in de doctrine bestaande opvattingen beschreven. Tevens wordt aandacht besteed aan de vereisten die in de jurisprudentie in aanvulling daarop of in afwijking daarvan aan de inrichting van de bezwaarschriftprocedure gesteld worden. Zoals eerder aangegeven wordt dit hoofdstuk opgesplitst in verschillende onderdelen: het beginsel van hoor en wederhoor (paragraaf 5.3), de onafhankelijkheid en onpartijdigheid van het bestuur (paragraaf 5.4), het openbaarheidsbeginsel (paragraaf 5.5), de motiveringsplicht (paragraaf 5.6) en de tijdigheid van de besluitvorming (paragraaf 5.7). Per onderdeel wordt de hiervoor beschreven aanpak gehanteerd. In elk onderdeel worden voorts verschillende aspecten onderzocht: 1) de uitwerkingen van de betreffende beginselen in de wettelijke regeling, 2) de grondslag voor de geldende eisen, 3) de ratio of functie van deze eisen. Het onderdeel betreffende de inrichting wordt tot besluit in paragraaf 5.8 afgesloten met een weergave van de voornaamste bevindingen en conclusies inzake de betekenis van de beginselen van behoorlijke rechtspleging voor de inrichting van de bestuurlijke voorprocedures.

\subsection{Hoor en wederhoor in de bestuurlijke voorprocedures}

\subsubsection{Inleiding}

Hoor en wederhoor vormt in het kader van een rechterlijke procedure een belangrijke in acht te nemen norm. Het belang van dit beginsel vloeit, zoals uiteen is gezet in paragraaf 4.3.5 in Deel I, mede voort uit artikel 6, eerste lid van het EVRM en de jurisprudentie van het EHRM in het kader van die bepaling. Ook het Hof van Justitie heeft de laatste jaren in zijn jurisprudentie steeds meer nadruk gelegd op inachtneming van dit beginsel als algemeen rechtsbeginsel van Unierecht, zelfs in bestuurlijke besluitvormingsprocedu-

\footnotetext{
12. Sanders 1998 , p. $97-98$

13. Sanders 1998, p. 98-99.

14. Zie hierover par. 4.2 van dit deel.
} 


\section{Deel II Bestuurlijke voorprocedures}

res. ${ }^{15}$ Het beginsel van hoor en wederhoor, ook wel genoemd het verdedigingsbeginsel, is voorts als (ongeschreven) nationaal beginsel van behoorlijke rechtspleging algemeen aanvaard en onomstreden. ${ }^{16}$ De Waard beschouwt dit beginsel als de kern van de normen die gelden voor een behoorlijke procedure. ${ }^{17}$ Ter herinnering geef ik nogmaals zijn omschrijving van het beginsel weer:

"het recht om stellingen en eventuele bewijsmiddelen naar voren te brengen en voldoende in de gelegenheid gesteld te worden op door de wederpartij aangedragen stellingen en bewijsmiddelen te reageren: partijen dienen in de gelegenheid gesteld te worden in beginsel alle stukken waarop de geschilbeslechtende instantie haar oordeel zal baseren in te zien. Met andere woorden, het beginsel verbiedt dat recht wordt gedaan op onbekende stukken, en dat een partij met relevante informatie 'overvallen' wordt op een moment dat een adequate reactie in redelijkheid niet meer verlangd kan worden." ${ }^{18}$

Belangrijke elementen van het beginsel van hoor en wederhoor zijn ook 'equality of arms' of gelijkheid der wapenen en 'quality en quantity of arms'. Dat betekent dat er voor partijen niet alleen een evenwicht in kansen moet zijn om hun standpunt te verdedigen, maar bovendien dat deze kansen goed en voldoende dienen te zijn. ${ }^{19}$ In dit onderzoek worden, in navolging van De Waard, vier deeleisen van het beginsel van hoor en wederhoor gehanteerd: het recht om informatie te ontvangen, het recht om informatie te verschaffen, voldoende gelegenheid voor de voorbereiding van het eigen standpunt en gelijke processuele mogelijkheden voor partijen. ${ }^{20}$ De functie van het beginsel van hoor en wederhoor en de vier deelaspecten is primair de bescherming van de processuele belangen van de deelnemers aan de procedure bij de rechter. Daaruit volgt dat aan het beginsel van hoor en wederhoor vooral interne werking toekomt. ${ }^{21}$

Hoor en wederhoor in de bestuursrechtelijke procedures

Het beginsel van hoor en wederhoor heeft in hoofdstuk 8 van de Awb in verschillende bepalingen zijn uitwerking gekregen voor de procedure bij de bestuursrechter. De mondelinge behandeling van het beroep neemt bijvoorbeeld een belangrijke plaats in de procedure in getuige artikel 8:56 e.v. van de Awb. In hoofdstuk 8 van de Awb, waarin de processuele voorschriften zijn neergelegd voor de rechterlijke procedure, zijn naast de mondelinge behandeling van het beroep echter ook nog diverse andere uitwerkingen van het beginsel van hoor en wederhoor (die daar overigens wel mee samenhangen) terug te vinden. Te denken valt dan aan artikel 8:58 waarin het recht is neergelegd voor partijen om nadere stukken in te dienen. Een ander voorbeeld van een uitwerking van het beginsel van hoor en wederhoor voor de procedure bij de bestuursrechter is het recht van partijen om deskundigen of getuigen mee te brengen of op te roepen als geregeld in artikel 8:63 tweede lid van de Awb. In paragraaf 4.3.5 van Deel I zijn deze inrichtingseisen reeds aangestipt.

De procedure bij de bestuursrechter is echter niet het eerste moment in het gehele proces met betrekking tot een bepaald besluit waarop hoor en wederhoor een rol kan spelen. In eerdere fases, zelfs non-contentieuze bestuurlijke fases, kan bijvoorbeeld het mondeling horen van belanghebbende(n) een belangrijke plaats innemen. Zo bestaat er immers een gelegenheid tot het geven van een zienswijze (schriftelijk al dan niet mondeling) in de primaire besluitvormingsfase voor beschikkingen op grond van artikel 4:7 en

\footnotetext{
${ }^{15 .}$ Het verdedigingsbeginsel in communautaire context is aan bod geweest in Deel I, hfst. 5, par. 5.2.1.

16. Zie bijvoorbeeld: Widdershoven 1989, o.m. p. 114; De Waard 1987, p. 127.

${ }^{17 .}$ De Waard 1987, p. 245. Het beginsel hoor en wederhoor en het verdedigingsbeginsel beschouwt hij als onderling uitwisselbare begrippen, alhoewel zijn voorkeur uitgaat naar de term verdedigingsbeginsel, p. 246. Zoals ik heb aangegeven wordt in dit onderzoek als uitgangspunt de term beginsel van hoor en wederhoor gehanteerd, zie par. 4.3.5 van Deel I.

${ }^{18 .}$ De Waard 1987, p. 127.

19. De Waard 1987, p. 127

${ }^{20 .}$ Dat geschiedt in navolging van De Waard, zie: De Waard 1987, p. 247 en par. 4.3 .5 van Deel I.

${ }^{21 .}$ Op de functies van het beginsel van hoor en wederhoor is nader ingegaan in par. 4.3.5 van Deel I.
} 


\section{De inrichting van de voorprocedures}

4:8 $\mathrm{Awb}^{22}$ De mogelijkheden tot hoor en wederhoor worden in de fase die daarop kan volgen, bezwaar of administratief beroep, van nog meer gewicht geacht. De wetgever merkt de hoorplicht in bezwaar op grond van artikel 7:2 Awb zelfs aan als essentieel element in die procedure. ${ }^{23}$ Voor de bezwaarfase bevat de Awb in hoofdstuk 7, artikel 7:2 tot en met 7:9, een regeling inzake het horen van belanghebbenden door het bestuursorgaan. De regeling inzake het administratief beroep in artikel 7:16 e.v. van de Awb bevat grotendeels dezelfde bepalingen. Deze bepalingen in de Awb bevatten slechts de minimumeisen waaraan de procedure dient te voldoen. ${ }^{24}$ Vrijwel alle in afdeling 7.2 en 7.3 van de Awb neergelegde voorschriften voor de inrichting van de bestuurlijke voorprocedures hebben betrekking op of hangen samen met het horen in het kader van die procedure. ${ }^{25}$ Dat onderstreept, zoals uiteraard het vastleggen van een verplichting daartoe ook doet, het belang dat de wetgever gehecht heeft aan het horen in het kader van de bezwaarschriftprocedure (en het administratief beroep). ${ }^{26}$

Hoewel het horen in de voorfase niet geheel gelijk kan worden gesteld met de mondelinge behandeling bij de bestuursrechter, neemt de mondelinge behandeling in beide fasen van de procedure een belangrijke plaats in. ${ }^{27}$ Ook is de achtergrond van de mondelinge behandeling (en de daarmee samenhangende bepalingen) in beide procedures deels hetzelfde: de belanghebbende(n) moet de mogelijkheid krijgen om zijn standpunt en zijn belangen toe te lichten en te verdedigen. Van de vier aspecten die De Waard onderscheidt in het kader van hoor en wederhoor zijn dan ook duidelijk sporen terug te vinden in de regeling van de bezwaarschriftprocedure en het administratief beroep in de Awb. Enkele bepalingen worden (zoals hierna zal blijken) ook beschouwd als een expliciete uitwerking van het beginsel van hoor en wederhoor in de bezwaarfase. ${ }^{28}$

Van een toepassing die geheel overeenstemt met die voor de rechterlijke procedure of expliciete erkenning van de geldingskracht van alle deeleisen van het beginsel van hoor en wederhoor voor de bestuurlijke voorprocedures is echter geen sprake. Dat is in elk geval niet de benadering van de bestuursrechter. Zo heeft onder meer de Afdeling het beginsel van equality of arms expliciet niet van toepassing geacht op de bezwaarschriftprocedure. ${ }^{29}$ Het beginsel van hoor en wederhoor wordt door de bestuursrechter, als ongeschreven beginsel van behoorlijke rechtspraak of vereiste op grond van artikel 6 EVRM, veelal niet expliciet van toepassing geacht op de voorprocedures, aangezien die

\footnotetext{
22. Aantekening verdient wel dat in het algemeen wordt aangenomen (in navolging van de wetgever) dat het horen in die fase een andere functie heeft dan het horen van belanghebbenden in de procedure voor de rechter en het horen vooral ten dienste van de zorgvuldige besluitvorming staat, PG Awb I, p. 247; P. van den Brekel, 'Horen', in: E.H.J.C. van der Linden \& F.A.M. Stroink (red.), JB-select, Den Haag: Sdu 2004, p. 150.

23. PG Awb I, p. 329.

24. PG Awb I, p. 329; Van den Brekel 2004, p. 143; J.M.H.F. Teunissen, 'Commentaar art. 7:2 Awb', in: M. Scheltema, R.M. van Male, B.W.N. de Waard, A.T. Marseille, A.J.C. de Moor-van Vugt (red.), Losbladig commentaar Algemene wet bestuursrecht, Amsterdam: Reed Elsvevier (voorheen Den Haag: VUGA), losbladige uitgave, p. E 6.3.7-5.

25. Vgl.: Stroink 2004a, p. 102.

26. Het belang dat gehecht wordt aan het horen van belanghebbenden in de bezwaarfase wordt, zoals uit het navolgende zal blijken, nadrukkelijk naar voren gebracht in de toelichting op art. 7:2 Awb, zie PG Awb I, p. 329-331. Van de Peppel en Sanders merken in dat kader ook op dat het belang dat de wetgever hecht aan het horen ook blijkt uit het feit dat in art. 7:3 Awb, waarover hierna meer, limitatief is aangegeven in welke gevallen van het horen kan worden afgezien, R.A. van de Peppel \& K.H. Sanders, 'Van 'heel eenzijdig' tot 'in één woord correct': meningen van burgers over de bezwaarschriftprocedure, in: M. Herweijer, K.F. Schuiling en H.B. Winter (red.), In wederkerigheid (Scheltema-bundel), Deventer: Kluwer 1997, p. 222.

27. Verschil met de rechterlijke procedure bestaat er hoe dan ook omdat in bezwaar in beginsel het bestuursorgaan de belanghebbende hoort en derhalve in mindere mate sprake is van een contradictoire mondelinge behandeling zoals het geval is bij de bestuursrechter, tenzij ten behoeve van de beslissing op bezwaar een adviescommissie is ingesteld.

28. Teunissen, p. E 6.3.7-1 e.v.; Notten 1998, p. 176.

29. AbRvS 12 juli 2006, $A B$ 2008/144 m.nt. A.M.L. Jansen; $J B$ 2006/268 m.nt. D.W.M. Wenders. Zie over het
} vereiste van equality of arms en de bestuurlijke besluitvormingsprocedures nader par. 5.3.5. 


\section{Deel II Bestuurlijke voorprocedures}

procedures niet worden gezien als rechtspraak (in formele zin). ${ }^{30}$ Daarnaast wordt het beginsel van hoor en wederhoor ook in het algemeen niet erkend als afzonderlijk beginsel van behoorlijk bestuur ${ }^{31}$ en worden eisen van die strekking (ook voor de bestuurlijke voorprocedures) - hierop wordt nog nader ingegaan in de verschillende paragrafen hieronder - vaak onder het zorgvuldigheidsbeginsel gebracht. ${ }^{32}$ Opvallend is in dat verband dat de Nationale ombudsman het vereiste van hoor en wederhoor wel expliciet onderscheidt als norm voor behoorlijk bestuur en van toepassing acht op zowel de primaire als secundaire besluitvormingsprocedures. ${ }^{33}$

Van verschillende onderdelen van het beginsel van hoor en wederhoor, zoals equality of arms, lijkt de betekenis voor de bestuurlijke voorprocedures derhalve bij eerste beschouwing gering te zijn of te worden ontkend. Daar staat tegenover dat andere bepalingen in afdeling 7.2 expliciet in verband worden gebracht met het beginsel van hoor en wederhoor, te denken valt dan aan artikel 7:9 waaruit de plicht tot opnieuw horen volgt bij na de hoorzitting bekend geworden feiten of omstandigheden van aanmerkelijk belang. Dat artikel 7:9 Awb het beginsel van hoor en wederhoor tot uitdrukking brengt is zelfs regelmatig bevestigd in jurisprudentie. ${ }^{34}$ Ook is er een aantal auteurs dat sommige (andere) bepalingen in afdeling 7.2 van de Awb expliciet herleidt tot het beginsel van hoor en wederhoor (als beginsel van behoorlijke rechtspraak). ${ }^{35}$ Toch lijkt die (expliciete) erkenning van de betekenis van het beginsel van hoor en wederhoor in de bezwaarschriftprocedure (en het administratief beroep) een incidenteel karakter te hebben en blijft deze vooral beperkt tot enkele specifieke voorschriften voor de inrichting van de bezwaarschriftprocedure. Een algemene visie op de toepasselijkheid of het bestaan van een beginsel van hoor en wederhoor en de daartoe behorende deeleisen op de inrichting van de bezwaarschriftprocedure en het administratief beroep ontbreekt vooralsnog. Gelet op het contentieuze karakter van de bezwaarschriftprocedure, de opzet van de regeling van die procedure in de Awb en de interne werking van het beginsel, ligt het echter in de rede dat het beginsel van hoor en wederhoor van betekenis kan zijn of is voor de inrichting van die procedure. In deze paragraaf wordt onderzocht in hoeverre de bepalingen in de Awb die betrekking hebben op het horen of daarmee samenhangen een uitwerking vormen van het beginsel van hoor en wederhoor. Daartoe wordt het onderzoek opgedeeld aan de hand van de hiervoor aangegeven vier deeleisen van het beginsel van hoor en wederhoor. Aan het deelaspect 'voldoende tijd voor de voorbereiding van het eigen standpunt' wordt echter geen afzonderlijke paragraaf besteed. Dit aspect komt in de paragrafen die betrekking hebben op de overige drie deelaspecten van het beginsel van hoor en wederhoor, indien van belang, aan de orde. Bezien wordt ook in hoeverre de schending van de desbetreffende eisen rechtens gevolgen heeft.

\footnotetext{
30. Zie bijv.: CRvB 13 februari 2002, JB 2002/126 m.nt. A. van Eijs; $A B$ 2002/96 m.nt. Pennings. Verder nog: A.M.L. Jansen, 'De deskundige en een 'fair trial', $M \& R$ 2008, p. 224.

31. Zie ook: Jansen 2008 , p. 224. Opmerking verdient wel dat Nicolaï in zijn dissertatie wijst op verschillende auteurs die het verdedigingsbeginsel onderscheiden als beginsel van behoorlijk bestuur alsmede enkele uitspraken van de bestuursrechter, Nicolaï 1990, p. 111 e.v. In meer recente literatuur en jurisprudentie heeft het beginsel echter geen ingang gevonden als nationaal beginsel van behoorlijk bestuur (op een enkele verwijzing na, zie bijvoorbeeld: Van Wijk/Konijnenbelt \& Van Male 2008, p. 283).

32. Een bekend voorbeeld vormt de hoorplicht, zie hierover par. 5.3.2. Verscheidene auteurs onderscheiden ook een beginsel van zorgvuldige bejegening waaruit vereisten voortvloeien die eenzelfde strekking hebben als het de eisen die uit het beginsel van hoor en wederhoor voortvloeien. Bijvoorbeeld: G.H. Addink, Algemene beginselen van behoorlijk bestuur, Deventer: Kluwer 1999, p. 191 en p. 195; Nicolai 1990, p. 290 e.v. en 327 e.v.

33. Nationale ombudsman, Burgerschap verzilverd, Jaarverslag 2007, Den Haag: Sdu 2007, p. 152 en 163. Wel heeft het vereiste een beperkte strekking en ziet het op het in de gelegenheid stellen van burgers om gehoord te worden.

34. Bijvoorbeeld: CBb 11 november 2005, JB 2006/46. Zie uitvoeriger hierover par. 5.3.2.3.

35. Teunissen herleidt art. 7:2 Awb bijvoorbeeld tot 'één van de meest fundamentele beginselen voor een behoorlijke procedure: het beginsel van hoor en wederhoor', Teunissen, p. E. 6.3.7-1. Doel van dit beginsel is overigens in zijn ogen het aan partijen verschaffen van een gelijkwaardige positie.
} 


\section{De inrichting van de voorprocedures}

Plan van aanpak

De volgorde van behandeling is als volgt. In paragraaf 5.3.2 wordt het recht om mondeling informatie te verschaffen in de voorprocedures onder de loep genomen. Vervolgens gaat in pararaaf 5.3.3 de aandacht uit naar het recht om schriftelijk informatie te verschaffen. Paragraaf 5.3.4 is gewijd aan het recht om informatie te ontvangen, waaronder het inzagerecht, en paragraaf 5.3.5 staat in het teken van het vereiste van equality of arms en de betekenis daarvan voor de bestuurlijke voorprocedures. De volgende paragraaf 5.3.6 heeft betrekking op de vraag of hoor en wederhoor als beginsel voor het bestuur kan worden erkend en de conclusies inzake de doorwerking van het beginsel van hoor en wederhoor in de bestuurlijke voorprocedures.

\subsubsection{Het recht om mondeling informatie te verschaffen in de bezwaarfase}

\subsubsection{De verschillende mogelijkheden om mondeling informatie te verschaffen}

Het onderzoek naar de betekenis van het beginsel van hoor en wederhoor in de bestuurlijke voorprocedures vangt aan met het recht om informatie te verschaffen aan het bestuur, in het bijzonder met de voor het bestuur in afdelingen 7.2 en 7.3 van de Awb neergelegde hoorplicht(en). Zoals De Waard opmerkt, vormt hoor en wederhoor een essentieel en onmisbaar element voor een behoorlijke procedure. Een belangrijk onderdeel van dat beginsel is weer de mogelijkheid om (mondeling) het eigen standpunt naar voren te brengen en informatie te verschaffen aan het bestuur. ${ }^{36}$ In de bezwaarschriftprocedure en het administratief beroep vormt, naast het ingediende bezwaar- of beroepschrift, de hoorzitting bij uitstek de gelegenheid om het eigen standpunt toe te lichten en te verdedigen. Zoals aangegeven, staan afdelingen 7.2 en 7.3 en de overige rechten van belanghebbenden in de bestuurlijke voorprocedures ook grotendeels in het teken van het horen. De reguliere hoorplicht, zoals vastgelegd voor het bestuur in artikelen 7:2 en 7:17 Awb, vormt weliswaar een belangrijke mogelijkheid om mondeling informatie te verschaffen in die procedures, maar is niet de enige mogelijkheid. Er bestaan daarnaast nog diverse andere mogelijkheden voor de burger om mondeling informatie aan te dragen. Indien nieuwe feiten of omstandigheden aan het bestuursorgaan bekend worden ná de hoorzitting, die van aanmerkelijk belang kunnen zijn voor het te nemen besluit, rust op het bestuursorgaan een hernieuwde hoorplicht, ingevolge de artikelen 7:9 en 7:23 Awb. Voorts hebben belanghebbenden op grond van artikelen 7:8 en 7:22 Awb het recht om getuigen of deskundigen mee te nemen naar de hoorzitting, die tijdens de hoorzitting gehoord kunnen worden. Tot slot kan er, indien het beroep tegen een besluit op bezwaar (of in administratief beroep) door de bestuursrechter gegrond wordt verklaard en het besluit wordt vernietigd, onder omstandigheden een plicht bestaan voor het bestuursorgaan om de belanghebbende opnieuw te horen. ${ }^{37}$ In de jurisprudentie zijn daarenboven nog in enkele andere gevallen ongeschreven hoorplichten of reactiemogelijkheden aangenomen. $^{38}$

Al met al bestaat er een scala aan mogelijkheden voor belanghebbenden om mondeling hun visie op het bestreden besluit te geven en hun belangen in de procedure te verdedigen. Van al deze verschillende mogelijkheden wordt in de onderhavige paragraaf onderzocht in hoeverre deze in het teken staan van hoor en wederhoor en derhalve als een uitwerking van dat beginsel kunnen worden beschouwd. Daarbij worden, voor zover

\footnotetext{
36. De Waard 1987, p. 303.

37. Zie bijvoorbeeld: AbRvS 22 september 2004, AB 2005/202 m.nt. BdeW. De bestuursrechter heeft echter bepaald dat uit art. 7:2 Awb niet de algemene verplichting volgt dat bestuursorganen na een vernietiging van het besluit om belanghebbenden opnieuw te horen (voor zover belanghebbenden in bezwaar eerder wel zijn gehoord), zie bijvoorbeeld: AbRvS 17 september 2003, $A B$ 2004/195 m.nt. N. Verheij; CRvB 8 januari 2002, $A B$ 2002/97 m.nt. HBr; AbRvS 15 mei 1997, AB 1997/263.

38. Te denken valt aan de hoorplicht na vernietiging van een besluit door de bestuursrechter. Op de verschillende ongeschreven reactiemogelijkheden wordt in de desbetreffende paragrafen in het navolgende nader ingegaan.
} 


\section{Deel II Bestuurlijke voorprocedures}

van belang, de vergelijkbare mogelijkheden die bestaan in het kader van de procedure bij de bestuursrechter in ogenschouw genomen. De opbouw van deze paragraaf is als volgt. In paragraaf 5.3.2.2 wordt de reguliere hoorplicht, op grond van artikelen 7:2 en 7:16 Awb geanalyseerd. De hoorplicht die bestaat na het bekend worden van nieuwe feiten of omstandigheden, zoals neergelegd in artikelen 7:9 en 7:23 Awb, komt aan bod in paragraaf 5.3.2.3. Op de verschillende (aanvullende) ongeschreven hoorplichten en reactiemogelijkheden wordt in paragraaf 5.3.2.4 ingegaan. Paragraaf 5.3.2.5 heeft betrekking op de verschillende andere mogelijkheden om informatie te verschaffen tijdens de hoorzitting. Ten slotte komen in paragraaf 5.3.2.6 de gevolgen van schendingen van het recht om mondeling informatie te verschaffen aan de orde.

\subsubsection{Het horen in de bestuurlijke voorprocedures}

\section{De functies van de algemene hoorplicht}

In artikel 7:2 van de Awb is als hoofdregel neergelegd dat een belanghebbende, voordat het bestuursorgaan op het ingediende bezwaarschrift beslist, in elk geval eenmaal in de gelegenheid moet worden gesteld om mondeling zijn standpunten en bezwaren toe te lichten. De hoorplicht in bezwaar wordt in het algemeen gezien als een essentieel onderdeel van de procedure. ${ }^{39}$ Dat hangt samen met de vier functies die door de wetgever aan het horen worden toegekend. ${ }^{40}$ In de eerste plaats vormt het horen in de bezwaarfase het belangrijkste moment waarop belanghebbenden mondeling hun standpunten kunnen toelichten. Ook biedt het horen de mogelijkheid om, indien nodig, nadere informatie te vergaren. Als derde functie van het horen onderscheidt de wetgever de mogelijkheid om meer in het algemeen te komen tot een oplossing van het gerezen geschil. Ten slotte kan het horen een legitimerende functie hebben. Door het horen kan de burger het gevoel krijgen dat, ongeacht de uitkomst, (voldoende) rekening is gehouden met zijn standpunten. In dat kader is mogelijk dat de belanghebbende tijdens of na het horen tot de conclusie komt dat het besluit in primo niet onjuist is en zich daarbij neerlegt. ${ }^{41}$

De wetgever gaat er aldus vanuit dat het horen in de bezwaarfase niet alleen waarborgen voor de burger tegen het bestuur biedt, maar ook vanuit zorgvuldigheidsoogpunt kan bijdragen aan de kwaliteit van de besluitvorming waardoor een procedure bij de bestuursrechter kan worden vermeden. ${ }^{42}$ Daarmee neemt het horen in de optiek van de wetgever zowel vanuit rechtsbeschermingsoogpunt (en hoor en wederhoor) als vanuit bestuurlijk oogpunt een belangrijke plaats in bij de inrichting van deze voorprocedure. Die tweeledige ratio van de hoorplicht, in de vorm van een waarborgfunctie voor de burger én het bestuur, wordt bevestigd in de doctrine. ${ }^{43}$ De erkenning van de combinatie van deze functies van de hoorplicht voor de bezwaarfase en het administratief beroep door de bestuursrechter vond reeds voor de werking van de Awb plaats. De Afdeling rechtspraak verwoordde het in een uitspraak in van 9 maart 1982 als volgt:

"Verweerders hebben vervolgens op het bezwaarschrift beslist zonder appellante te hebben uitgenodigd voor een hoorzitting. De Afd. overweegt naar aanleiding van het vorenstaande dat de in bovengenoemd artikellid [artikel 14 lid 1 Arob DW] neergelegde verplichting [om de indiener van het bezwaarschrift in de gelegenheid te stellen om gehoord te worden DW] niet slechts waarborgen schept voor de indiener van het

39. Zo ziet ook de wetgever het, PG Awb I, p. 329. Vgl.: L.M. Koenraad, 'Afzien van het horen. De betekenis van art. 7:3 Awb', Gst.2008, 7294, 45, p. 201-202. In de jurisprudentie van de bestuursrechter is dat ook meermalen aangegeven, zie bijv.: AbRvS 2 december 2009, $A B$ 2009/342 m.nt. B. de Waard; CRvB 7 februari 2001, $A B$ 2001/178 m.nt. HBr; CRvB 23 december 1996, AB 1997/239 m.nt. HBr.

40. PG Awb I, p. 329. Zie ook: Koenraad \& Sanders 2006, p. 61; Van den Brekel 2004, p. 142; Sanders 1998, p. 100; Van de Peppel \& Sanders 1997, p. 220; Notten 1998, p. 200. Ondanks het feit dat het horen in de bezwaarfase essentieel wordt geacht, betreft artikel 7:2 Awb volgens de jurisprudentie van de hoogste bestuursrechters geen bepaling van openbare orde waaraan de rechter ambtshalve dient te toetsen, zie bijvoorbeeld CRvB 7 februari 2001, $A B$ 2001/178 m.nt. HBr met verdere verwijzingen naar jurisprudentie in de noot.

${ }^{41 .}$ PG Awb I, p. 329. Teunissen noemt dit de therapeutische functie van het horen, Teunissen, p. E. 6.3.7-5.

42. PG Awb I, p. 329 en 331.

43. Vgl. bijvoorbeeld: Koenraad \& Sanders 2006, p. 61; Notten 1998, p. 199. 


\section{De inrichting van de voorprocedures}

bezwaarschrift doch ook voor het administratief orgaan, dat zich er aldus van kan vergewissen dat het over alle relevante gegevens beschikt alvorens tot een nadere overweging over te gaan en tot een nieuwe beslissing te komen, waarbij ook die feiten en omstandigheden die eerst ter hoorzitting zijn aangedragen of gebleken in ogenschouw moeten worden genomen." 44

De Afdeling rechtspraak geeft hier expliciet aan dat de hoorplicht tegelijkertijd twee aspecten dient: de zorgvuldigheid van de besluitvorming én de rechtsbescherming van de burger.

\section{Rechtsbescherming óf zorgvuldige besluitvorming}

In de doctrine worden beide functies - in het kader van de hoorplicht, maar ook in algemene zin ten aanzien van de bestuurlijke voorprocedures, zoals gebleken is in paragraaf 4.2 - echter ook weleens gepresenteerd als tegenstelling. Gekozen wordt dan als uitgangspunt voor een van beide functies van het horen. Sommige auteurs zien de voorschriften omtrent het horen met name als waarborgen voor de burger. Zo ziet Versteden sommige bepalingen over het horen in de bezwaarfase vooral als judiciële elementen, die gelijkenis vertonen met voor rechtspraak geldende regels. Hij noemt geen specifieke bepalingen, maar wijst onder meer op 'sommige bepalingen over het horen met het principe van hoor en wederhoor, beperkingen ten aanzien van het horen door personen die bij de primaire besluitvorming betrokken waren'. ${ }^{45}$ Teunissen wijst als grondslag voor de hoorplicht in bezwaar het beginsel van hoor en wederhoor aan. Dat beginsel is in zijn optiek een van de meest fundamentele beginselen voor een behoorlijke procedure. ${ }^{46}$ In die benadering lijkt de hoorplicht eveneens vooral een waarborgfunctie te hebben. Teunissen beschouwt de hoorplicht in bezwaar overigens als een inrichtingseis te stellen aan de procedure die volgt uit het gelijkwaardigheidsbeginsel. Met dat beginsel lijkt hij te doelen op het vereiste van equality of arms en/of ongelijkheidscompensatie. ${ }^{47}$ Zoals in hoofdstuk 3 van Deel I is uiteengezet, heeft De Waard met inrichtingseisen - als ik het goed zie - geen concrete uitwerkingen van beginselen op het oog, maar eisen van andere aard. De hoorplicht daarentegen vormt een concrete uitwerking van een beginsel. Welk beginsel dat is, het beginsel van hoor en wederhoor dan wel het zorgvuldigheidsbeginsel, komt later aan de orde. ${ }^{48}$

Hoe het ook zij, deze auteurs plaatsen het horen, door de referte aan hoor en wederhoor, vooral in het perspectief van de bescherming van de processuele belangen van de belanghebbenden in de procedure. Daarmee staat het horen primair in het teken van de rechtsbescherming van belanghebbenden. De informatieverschaffingsfunctie die het horen heeft voor het bestuur en de zorgvuldigheid van de besluitvorming, verdwijnt wat meer naar de achtergrond.

Anderen leggen de nadruk echter weer meer op deze functie(s) van het horen vanuit bestuurlijk oogpunt. ${ }^{49}$ Koenraad ziet de hoorplicht, als neergelegd in artikel 7:2 Awb, als een species van of lex specialis ten opzichte van het in artikel 3:2 Awb neergelegde

\footnotetext{
44. ArRvS 9 maart 1982, $A B$ 1982/302, m.nt. J.R.St. Zie ook Teunissen die verwijst naar deze uitspraak, Teunissen, p. E 6.3.7-2.

45. Versteden 1995, p. 290. Zie ook: Koenraad \& Sanders 2006, p. 61. Zij leiden uit het feit dat art. 7:2 Awb niet aan te merken valt als een bepaling van openbare orde waaraan volgens de bestuursrechter ambtshalve moet worden getoetst af dat het horen vooral als een middel ter rechtsbescherming van belanghebbenden moet worden

gezien.

47. Teunissen, p. E 6.3.7-1/2. Een invulling van het gelijkwaardigheidsbeginsel geeft hij niet. In dezelfde zin: Van der Ham 1988, p. 85. Ook Van der Ham geeft niet aan wat hij bedoelt met het gelijkwaardigheidsbeginsel en meent eveneens ten onrechte dat de hoorplicht een inrichtingseis is in de door De Waard bedoelde zin en geen uitwerking van hoor en wederhoor.

48. Daarnaast wijst Teunissen overigens ook op de vier functies die door de wetgever aan het horen in de bezwaarfase worden toegekend, Teunissen, p. E 6.3.7-2.

49. Zie bijvoorbeeld: H.J. Simon, 'Het EVRM en de bestuurlijke besluitvorming (Deel I)', JB-plus 2003 (hierna: Simon 2003a), p. 174.
} 


\section{Deel II Bestuurlijke voorprocedures}

zorgvuldigheidsbeginsel. ${ }^{50}$ Soms legt hij echter ook een verband tussen de hoorplicht als vorm van kennisvergaring en het beginsel van hoor en wederhoor. ${ }^{51}$ Simon stelt zich zelfs, onder verwijzing naar de wetsgeschiedenis, op het standpunt dat de hoorplichten in de Awb in de bestuurlijke fase geen uitdrukking geven van het beginsel van hoor en wederhoor, maar uitsluitend ten behoeve van de zorgvuldigheid van de besluitvorming dienen. ${ }^{52}$ Hoewel niet duidelijk is of hij daarmee ook het oog heeft op het horen in de bezwaar- en administratief beroepsfase, is dat laatste een te eenzijdig standpunt, gelet op onder meer de in het bovenstaande weergegeven opvatting van de wetgever omtrent de functies van het horen. Voor de primaire besluitvormingsfase kan dat inderdaad worden aangenomen ${ }^{53}$, maar voor de bestuurlijke voorprocedures valt dat nog niet zo eenduidig vast te stellen.

\section{Tegengestelde functies of twee verschillende perspectieven}

De vraag die rijst is of daadwerkelijk sprake is van een tegenstelling tussen rechtsbescherming voor belanghebbenden en zorgvuldige besluitvorming vanuit bestuurlijk oogpunt, zoals het bovenstaande lijkt te suggereren. Zoals eerder is betoogd in het kader van de functies van de bezwaarschriftprocedure (zie paragraaf 4.2), zijn de informatieverschaffingsfunctie van het horen en de rechtsbeschermingsfunctie van het horen niet scherp van elkaar te onderscheiden en daartoe bestaat ook geen noodzaak. De ene functie sluit de andere functie niet uit. Een mondelinge behandeling van de zaak kan beide functies tegelijkertijd dienen zonder afbreuk te doen aan de bestuurlijke elementen in of het bestuurlijke karakter van de bestuurlijke voorprocedures. Het betreft eerder twee kanten van een en dezelfde medaille. Bij de ene functie wordt het perspectief van de belanghebbende op het horen voorop gesteld, terwijl de andere functie vooral in het teken staat van het perspectief van het bestuur op de procedure en het horen. Van een tegenstelling is geen sprake. Wel kan het uiteraard zo zijn dat in bepaalde gevallen het ene perspectief zwaarder weegt dan het andere perspectief.

De Waard stelt zich ook min of meer op dat standpunt in het kader van de functies van de mondelinge behandeling voor bestuursrechtspraak. Het verschaffen van informatie kan gezien worden in het licht van de realisatie van de verdedigingsrechten, maar ook in het licht van de waarheidsvinding. ${ }^{54}$ Hij onderscheidt verschillende functies van de mondelinge behandeling van een zaak. Ten eerste moet deze wijze van informatieverschaffing in het perspectief van de realisatie van de verdedigingsrechten van de belanghebbende geplaatst worden. Voorts heeft het verschaffen van informatie een functie in het licht van de waarheidsvinding: de mondelinge behandeling als zodanig heeft een informatieverschaffingsfunctie voor het geschilbeslechtende orgaan. De derde functie bestaat uit de mogelijkheid van confrontatie van standpunten, zowel in het licht van de verdedigingsrechten als de waarheidsvinding. ${ }^{55}$ De Waard wijst er ook op dat de mondelinge behandeling in het administratieve proces, bestuursrechtspraak dus, soms inquisitoire trekjes heeft en niet alleen een rechtsbeschermingsfunctie voor de burger heeft. ${ }^{56}$ Hoewel dat tegenwoordig, door de verschuiving naar de individuele rechtsbescherming en een partijenproces onder de Awb, minder het geval is, geldt dat nog steeds in enige

\footnotetext{
${ }^{50 .}$ Koenraad 2008a, p. 202; L.M. Koenraad, 'Deskundig besturen. Beschouwingen over de plaats van deskundigen-advisering in het bestuursrecht', JB-plus 2006, p. 17-18. Zie ook: Koenraad \& Sanders 2006, p. 61-62.

${ }^{51 .}$ Koenraad 2008a, p. 202; Koenraad 2008b, p. 474

52. Simon 2003a (deel I), p. 174.

53. PG Awb I, p. 251-252. Zie hierover: Damen e.a. 2009, Deel I, p. 344-345; F.M.D. Aardema, 'De hoorplicht van de artikelen 4:7 en 4:8 Awb: een wettelijke inkleuring van de zorgvuldigheidsnorm in fletse tinten?', JB-plus 2003 , p. $50-59$

54. De Waard 1987, p. 303-304.

55. De Waard 1987, p. 303-304.

56. De Waard 1987, p. 306-307. Zie ook de jurisprudentie van het Hof van Justitie inzake het verdedigingsbeginsel en het recht om gehoord te worden. Het Hof van Justitie brengt ook de bestuurlijke fasen onder de geldingskracht van dat beginsel en kent daaraan ook een tweeledige functie toe, zie: Deel I, hfst. 5, par. 5.2.1.
} 


\section{De inrichting van de voorprocedures}

mate. ${ }^{57}$ Een voorbeeld is de ambtshalve toetsing aan bepalingen van openbare orde, die de bestuursrechter moet verrichten en die zelfs in het nadeel van de belanghebbende kan uitpakken.

Voor de mondelinge behandeling in administratief beroep of bezwaar geldt hetzelfde. In het geval van zowel rechtspraak als de bestuurlijke voorprocedures komt aan de procedure een functie in het kader van de rechtsbescherming van belanghebbende(n) toe, terwijl daarnaast ook een andere functie daaraan toekomt die specifiek samenhangt met de taak van de rechter of het bestuur. In de procedure bij het bestuur bestaat die functie uit het verzamelen van informatie ten behoeve van een zorgvuldige en kwalitatief goede besluitvorming (die in het geval van discretionaire bevoegdheden ook betrekking kan hebben op beleidsaspecten). Zo bezien bestaan er geen grote verschillen tussen de functies van het horen in de bezwaarfase of het administratief beroep en de mondelinge behandeling van de zaak in de procedure voor de rechter.

\section{Horen in bestuurlijke voorprocedure niet geheel gelijk aan horen tijdens procedure bestuursrechter}

Het recht op het (mondeling) verschaffen van informatie in de bezwaarfase staat, gelet op het bovenstaande, derhalve ten dienste van zowel de verweermogelijkheden van belanghebbenden als de zorgvuldige besluitvorming door het bestuur. Dat betekent uiteraard niet dat horen in bezwaar (of administratief beroep) geheel gelijk gesteld kan worden met de mondelinge behandeling in beroep bij de bestuursrechter. De bestuursrechter heeft dat in zijn jurisprudentie ook overwogen. In een al eerder aangehaalde uitspraak van 23 december 1996, waarin (schending van) de hoorplicht in bezwaar op grond van artikel 7:2 van de Awb centraal staat, overweegt de Centrale Raad van Beroep bijvoorbeeld dat de mondelinge behandeling van het beroep niet op een lijn kan worden gesteld met het horen in de bezwaarschriftprocedure, daar de rechterlijke toetsing van de rechtmatigheid van het besluit van andere aard is dan de integrale bestuurlijke heroverweging door een bestuurorgaan naar aanleiding van een bezwaarschrift. ${ }^{58}$ In de betreffende zaak heeft de rechtbank het door het bestuursorgaan genomen besluit op bezwaar, ondanks het feit dat ten onrechte het horen van de belanghebbende achterwege is gelaten in de bezwaarfase op grond van artikel 6:22 Awb in stand gelaten. De Centrale Raad kan zich daarin onder meer niet vinden vanwege het in casu bestaande onderscheid tussen de rechterlijke toetsing en de bestuurlijke heroverweging in de bezwaarfase. In de door de Centrale Raad gehuldigde opvatting werkt het traditionele onderscheid tussen bestuur en rechtspraak door in de vergelijking tussen het horen in de bezwaarfase en de mondelinge behandeling van het beroep bij de bestuursrechter. De aard van de bevoegdheid die het bestuursorgaan uitoefent, speelt daarbij een rol. Het verschil tussen rechterlijke toetsing en bestuurlijke heroverweging in de bezwaarfase is duidelijker aanwezig indien sprake is van een discretionaire bevoegdheid, omdat het bestuur in tegenstelling tot de rechter ook beleidsaspecten bij zijn heroverweging kan betrekken. Nu volledig herstel van het gebrek door de mondelinge hoorzitting in beroep vanwege de ruimere beoordeling in bezwaar niet mogelijk is, ligt het passeren van een schending van de hoorplicht in die gevallen volgens de Centrale Raad minder in de rede. ${ }^{59}$

Uit het voorgaande volgt dat er tussen het horen in bezwaar en de mondelinge behandeling van de rechter ook verschillen te constateren zijn. Het onderscheid is echter niet zo zeer in de functies van het horen gelegen, maar eerder in het onderwerp waarop

\footnotetext{
57. Damen e.a. 2009, Deel II, p. 54 e.v.; Van Wijk/Konijnenbelt \& Van Male 2008, p. 568; Rapport VARCommissie Rechtsbescherming 2004, p. 35-45; PG Awb II, p. 172-176.

58. CRvB 23 december 1996, AB 1997/239, m.nt. HBr.

59. Op de gevolgen van een schending van de hoorplicht en de jurisprudentie in dit kader wordt later in deze par. nader ingegaan. Wel wil ik hier reeds opmerken dat het de vraag is of een gebrek in het horen, gelet op de functies van het horen, niet te allen tijde (ongeacht de aard van de bevoegdheid die in het geding is) moet leiden tot vernietiging van het besluit en het passeren daarvan niet achterwege moet blijven.
} 


\section{Deel II Bestuurlijke voorprocedures}

het horen betrekking kan hebben. Het horen in bezwaar kan op meer en andere aspecten betrekking hebben, aangezien er ook beleidskwesties aan de orde kunnen komen en om die reden kan de mondelinge behandeling in bezwaar inderdaad niet gelijk worden gesteld met die in beroep bij de rechter. In beide gevallen staat het horen zowel in het perspectief van de zorgvuldigheid van de bestuurlijke besluitvorming of de waarheidsvinding, als van de rechtsbescherming van belanghebbenden. Ook bij beleidsaspecten waarborgt de hoorplicht echter dat belanghebbenden hierover hun standpunt naar voren kunnen brengen en voldaan wordt aan het beginsel van hoor en wederhoor. De omstandigheid dat de heroverweging ruimer is in de bestuurlijke voorprocedures dan de toetsing door de bestuursrechter doet derhalve niet(s) af aan de omstandigheid dat het horen vergelijkbare functies heeft in beide procedures.

De wijze van horen als spanningsveld tussen rechtsbescherming en bestuurlijke belangen Dat het horen in algemene zin in het teken van de informatiegaring door het bestuur én de rechtsbescherming van belanghebbende(n) staat, betekent niet dat er zich geen spanningen kunnen voordoen tussen deze twee hoofdfuncties. In bepaalde gevallen kan de ene functie de andere domineren. Een voorbeeld daarvan kan gevonden worden in de wijze waarop het horen plaatsvindt. Hoewel voorop staat dat het bestuursorgaan in beginsel een plicht heeft om belanghebbenden in de gelegenheid te stellen gehoord te worden, alvorens het een beslissing op bezwaar neemt, bevat de Awb geen uitvoerige regeling omtrent de wijze van horen. De wetgever heeft dat bewust achterwege gelaten, gelet op de sterke onderlinge verschillen tussen de onderscheiden gevallen waarin een bezwaarschriftprocedure gevolgd moet worden. ${ }^{60}$ De Awb schrijft derhalve niet voor dat een hoorzitting moet worden georganiseerd, maar dat lijkt wel het uitgangspunt te zijn. ${ }^{61}$ Dat is zeker zo, indien het horen plaatsvindt door een adviescommissie. Zou het horen uitsluitend in het teken staan van informatiegaring door het bestuur, dan zou een hoorzitting niet altijd of in minder gevallen noodzakelijk hoeven zijn. In dat geval zou bijvoorbeeld het telefonisch inwinnen van informatie bij de bezwaarmakers kunnen volstaan. In de toelichting op de in artikel 7:2 Awb neergelegde hoorplicht wordt echter opgemerkt dat telefonisch horen niet voldoet aan de minimum-eisen die gelden voor het horen in de bezwaarschriftprocedure. ${ }^{62}$ Wel kan het bestuursorgaan, voordat een uitnodiging voor een hoorzitting wordt verstuurd, telefonisch contact opnemen met de indiener van het bezwaarschrift waardoor deze eventueel, door het geven van nadere informatie en een verduidelijking, kan afzien van het horen. ${ }^{63}$ Vanuit een oogpunt van informatiegaring is immers een uitvoerige gedachtewisseling met belanghebbenden en het toelichten van standpunten over en weer niet nodig, maar uitsluitend het inwinnen van informatie. Dat is veelal ook mogelijk via telefonische vragen. Het organiseren van een hoorzitting komt daarentegen ook de verdedigingsrechten van de belanghebbenden ten goede en biedt de mogelijkheid van confrontatie van de verschillende standpunten in het licht van beide perspectieven. ${ }^{64}$ Wordt daaraan meer waarde gehecht, dan ligt een hoorzitting - waarbij alle belanghebbenden aanwezig zijn - weer meer in de rede. In de jurisprudentie van de

60. PG Awb I, p. 329; Teunissen, p. E. 6.3.7-5.

${ }^{61 .}$ Damen e.a. 2009, Deel II, p. 185; Verslag Evaluatie Awb I, p. 48.

62. PG Awb I, p. 330. Koenraad \& Sanders wijzen erop dat in de praktijk toch nog weleens telefonisch word gehoord. Zij raden aan dat in dat geval de belanghebbende daar mee moet instemmen en deze naderhand kan reageren op het verslag van de telefonische hoorzitting, Koenraad \& Sanders 2006, p. 81. In een recente uitspraak heeft de CRvB nog geoordeeld dat telefonisch horen in strijd is met art. 7:2 Awb, CRvB 27 augustus 2008, JB 2008/260 m.nt. C.L.G.F.H. A.. De schending werd overigens wel gepasseerd met toepassing van art. 6:22 Awb.

${ }^{63}$ PG Awb I, p. 330. Zie hierover ook bijvoorbeeld: Van Wijk/Konijnenbelt \& Van Male 2008, p. 552 en CRvB 27 mei 1998, $A B$ 1998/367; AbRvS 8 november 1993, $A B$ 1994/205 m.nt. NV. Het informeren of de bezwaarmaker gehoord wilt worden is toegestaan, zolang de mogelijkheid om gehoord te worden niet van een niet in de wet voorziene formaliteit afhankelijk wordt gemaakt of het (telefonisch) contact inhoudt dat het gebruik maken van die mogelijk ontraden wordt dan wel de suggestie wordt gewekt dat het horen zinloos is.

${ }^{64 .}$ De Waard 1987, p. 303-304. 


\section{De inrichting van de voorprocedures}

bestuursrechter komt nadrukkelijk naar voren dat de hoorzitting ook in het teken staat van de gedachtewisseling tussen alle betrokkenen over hetgeen aan de orde is gekomen. ${ }^{65}$

De wijze waarop de hoorzitting wordt vormgegeven en de opzet daarvan is tevens aan het bestuur overgelaten. Zo heeft de Centrale Raad gebillijkt dat het nader medisch onderzoek door een bezwaarverzekeringsarts in Ziektewetzaken tevens als hoorzitting functioneerde, mits geen afbreuk wordt gedaan aan de door de wetgever beoogde functie van de hoorplicht, de gang van zaken voor alle betrokkenen duidelijk is en ook voor het overige wordt voldaan aan de wettelijke bepalingen waaronder die over de verslaglegging van het horen. ${ }^{66}$ Dat was in de betreffende zaak echter in het geheel niet het geval. De Centrale Raad volgt het oordeel van de rechtbank dat artikel 7:2 Awb geschonden is. De rechtbank had daartoe overwogen dat door de belanghebbende slechts uit te nodigen voor een medisch onderzoek zonder aan te geven dat er tevens sprake was van een hoorzitting, er geen uitwisseling van informatie had kunnen plaatsvinden. Saillant detail is dat de rechtbank uitdrukkelijk refereert aan het beginsel van hoor en wederhoor en het horen tijdens het medisch onderzoek slechts geoorloofd acht, indien geen afbreuk wordt gedaan aan dat beginsel. In de overwegingen van de Centrale Raad komt evenwel een verwijzing naar dat beginsel niet terug, hoewel een verbetering van de overwegingen van de rechtbank ook niet plaatsvindt. Zolang het horen voorziet in de daarmee beoogde functies en alle overige daarmee samenhangende processuele waarborgen voor de belanghebbende(n) worden nageleefd, is de wijze waarop het horen plaatsvindt behoorlijk vrij. Dat lijkt in overeenstemming met de informele opzet van het horen die de wetgever voor ogen stond. ${ }^{67}$ Zoals Schreuder-Vlasblom ook opmerkt, is het echter de vraag in hoeverre aan alle waarborgen en wettelijke voorschriften kan worden voldaan. ${ }^{68}$ Het lijkt op zijn zachtst gezegd niet waarschijnlijk dat de functies van het horen, zeker als het gaat om hoor en wederhoor en een uitwisseling van standpunten, tot hun recht komen in het kader van een medisch onderzoek. Belangrijk is in elk geval dat een belanghebbende zich voldoende heeft kunnen voorbereiden op de hoorzitting, er een gedachtewisseling kan plaatsvinden en daadwerkelijk over en weer informatie en standpunten uitgewisseld worden. Er moet geen afbreuk worden gedaan aan de waarborgfunctie van het horen.

Horen op grond van artikel 7:2 en 7:3 Awb: wanneer wel en wanneer niet?

Zowel door de wetgever als in de literatuur wordt het belang van het horen, gelet op de functies daarvan, in de bezwaarfase in algemene zin onderkend. Desalniettemin behoeven belanghebbenden, zoals bekend is, niet steeds in de gelegenheid te worden gesteld om gehoord te worden en is in de regeling van de Awb de hoorplicht niet absoluut. In artikel 7:3 van de Awb (voor zover bijzondere wetgeving daar niet reeds in heeft voorzien) wordt immers op de hoorplicht een viertal uitzonderingen gemaakt. Het bestuursorgaan beschikt ingevolge die bepaling over de bevoegdheid om het horen van belanghebbenden achterwege te laten wanneer een van de situaties als genoemd in voormeld artikel zich voordoet. De uitzonderingen dienen zich, aldus de wetgever, te beperken tot de gevallen waarin het horen van belanghebbenden niet zinvol wordt geacht. ${ }^{69}$ In de uitzonderingen op de hoorplicht zijn de functies van het horen te herkennen, of misschien beter gezegd indien er geen toegevoegde waarde bestaat in het licht van die functies in het concrete geval kan van het horen worden afgezien.

65. Zie bv.: AbRvS 3 februari 2010, nr. 200903524/1/H2, LJN BL1825; Rb. Den Haag, 28 april 2000, $A B$ 2001/125 m.nt. H. Battjes.

66. CRvB 1 juli 2003, JB 2003/248 m.nt. Van Eijs

67. PG Awb I, p. 329.

68. Schreuder-Vlasblom 2008, p. 266.

69. PG Awb I, p. 332. Zie voor een overzicht van de jurisprudentie ten aanzien van die uitzonderingen o.m.: Koenraad 2008a, p. 202 e.v.; Koenraad \& Sanders 2006, p. 64 e.v.; J.M.H.F. Teunissen, 'Commentaar art. 7:3 Awb', in: M. Scheltema, R.M. van Male, B.W.N. de Waard, A.T. Marseile, A.J.C. de Moor-van Vugt (red.), Commentaar Algemene wet bestuursrecht, Amsterdam: Reed Elsevier (voorheen Den Haag: VUGA), losbladige uitgave, E 6.3.8-1 e.v. 


\section{Deel II Bestuurlijke voorprocedures}

Het bestuur kan allereerst afzien van het horen indien het bezwaar kennelijk ongegrond of kennelijk niet ontvankelijk is. Deze uitzonderingen dienen primair in het licht van de zorgvuldigheid van de besluitvorming te worden geplaatst: indien de zaak duidelijk ligt of de belanghebbende evident niet aan de vormvereisten heeft voldaan (na geboden herstelmogelijkheid van het verzuim), draagt het horen niets bij aan de zorgvuldigheid van de besluitvorming en kan daarom achterwege blijven. Dat gaat dan ten koste van de rechtsbescherming van de belanghebbende(n), aangezien hem of haar de mogelijkheid tot mondelinge toelichting ontnomen wordt. Dat is echter gerechtvaardigd, omdat de belanghebbende met die mogelijkheid niets zou opschieten en ook geen nieuwe relevante informatie zou kunnen aandragen. Gelet op het gewicht dat aan de hoorplicht toekomt, is daarbij echter de eis van kennelijkheid gesteld als waarborg tegen al te lichtvaardig afzien van het horen. ${ }^{70}$ De kennelijkheidseis komt derhalve vooral de processuele belangen van de belanghebbenden ten goede. In gevallen van twijfel wegen de informatiegaring en rechtsbescherming van de belanghebbende zwaarder zal het bestuur de belanghebbende(n) de gelegenheid moeten geven gehoord te worden. Er bestaat overigens in de gevallen waarin een bezwaarschrift kennelijk ongegrond is enige verwantschap met de gevallen waarin de bestuursrechter op grond van artikel 8:54 Awb het beroep ongegrond kan verklaren. ${ }^{71} \mathrm{Er}$ is echter ook een belangrijk verschil: omdat het bestuur een volledige heroverweging moet verrichten, waarvan beleidsoverwegingen onderdeel uitmaken, zullen bezwaren die niet tot een vernietiging door de rechter zouden leiden (omdat deze niet de rechtmatigheid van de beslissing betwisten) wel tot een andere bestuursbeslissing kunnen leiden.

Van de mogelijkheid om af te zien van het horen, indien aan het bezwaar volledig tegemoet wordt gekomen en andere belanghebbenden daardoor niet in hun belangen kunnen worden geschaad $^{72}$, zal in het algemeen slechts sprake kunnen zijn bij gebonden bevoegdheidsuitoefeningen waarbij geen derde-belanghebbenden betrokken zijn. Bij deze uitzonderingsgrond lijken beide functies samen te komen. Indien een belanghebbende het gelijk volledig aan zijn zijde heeft en op voorhand is duidelijk dat het bestuursorgaan volledig tegemoet komt aan diens bezwaren en verzoeken, bestaat zowel vanuit het oogpunt van zorgvuldigheid van de besluitvorming als vanuit rechtsbeschermingsoogpunt geen behoefte aan het horen. Wel is van belang dat derde-belanghebbenden niet in hun rechtsbeschermingsmogelijkheden beknot worden.

De vierde uitzondering staat primair in het teken van de rechtsbescherming en de verdedigingsrechten van belanghebbenden worden gezien. Indien immers de belanghebbende(n) heeft aangegeven geen prijs te stellen op het horen, mag dat achterwege blijven. Daarbij is uit jurisprudentie gebleken dat een belanghebbende dat expliciet aangegeven dient te hebben, alvorens het bestuur op die grond het horen achterwege kan laten. ${ }^{73} \mathrm{Er}$ mag niet te snel vanuit worden gegaan dat een belanghebbende zijn recht om een mondelinge toelichting te geven van zijn bezwaren heeft opgegeven. Een plicht voor het bestuur om er in die gevallen van af te zien, bestaat in elk geval niet. Acht het bestuur het uit oogpunt van verzamelen van informatie toch noodzakelijk om de belanghebbende te horen, kan het daartoe alsnog overgaan. Een plicht voor belanghebbenden om te verschijnen en gehoord te worden in dergelijke gevallen bestaat echter evenmin. Het niet verschijnen kan uiteraard gevolgen hebben voor de besluitvorming en nadelig zijn voor de betreffende belanghebbende die niet verschijnt. Was het verzamelen van informatie ten behoeve van een zorgvuldige besluitvorming het primaire doel geweest van de hoor-

\footnotetext{
70. Teunissen, p. E 6.3.8-3.

71. PG Awb I, p. 333.

72. Deze uitzonderingsgrond bestaat overigens niet in administratief beroep, zie art. 7:17 Awb. Reden daarvoor is dat het beroepsorgaan, naast de bezwaarmaker en eventueel andere belanghebbenden, ook te maken heeft met het bestuursorgaan, PG Awb I, p. 357.

73. Zie in deze zin: AbRvS 3 maart 2004, $A B$ 2004/252 m.nt. NV, r.o. 2.5. Zie ook: HR 15 mei 2009, $A B$ 2009/342 m.nt. B. de Waard.
} 


\section{De inrichting van de voorprocedures}

zitting had het echter wellicht meer in de rede gelegen om, evenals voor de procedure bij de rechter, een verschijningsplicht te scheppen voor de belanghebbende, indien het bestuur dat nodig acht. De rechter heeft een dergelijke bevoegdheid, omdat waarheidsvinding een belangrijk doel is in het administratieve proces. ${ }^{74}$ Of het achterwege laten van een verschijningsplicht erop duidt dat de rechtsbescherming van belanghebbenden ten grondslag ligt aan deze uitzonderingsgrond is lastig, omdat een verschijningsplicht ook niet zou passen bij de informele opzet van de bezwaarschriftprocedure. Een verschijningsplicht wil ook niet zeggen dat de toepassing ervan altijd in het nadeel zal zijn van een belanghebbende. De bestuursrechter kan de verschijningsplicht ook aangrijpen ten behoeve van de rechtsbescherming van een belanghebbende en als gevolg van het gestelde tijdens de zitting ten gunste van een belanghebbende uitspraak doen.

Ongeacht de uitzondering die in het geding is, is in alle vier ${ }^{75}$ gevallen slechts sprake van een bevoegdheid tot het afzien van de hoorplicht; het bestuur kan ervoor kiezen om toch over te gaan tot horen. ${ }^{76}$ Indien er enige twijfel bestaat over de toepasselijkheid van een van de vier uitzonderingsgronden, ligt het ook in de rede dat het bestuur dat doet. ${ }^{77}$ Inmiddels is immers duidelijk uit de jurisprudentie van de verschillende bestuursrechters gebleken dat de uitzonderingsgronden in voornoemd artikel, juist vanwege het belang dat gehecht wordt aan het horen in de bezwaarfase, strikt dienen te worden uitgelegd en er bij twijfel gehoord moet worden. ${ }^{78}$ Teunissen wijst er nog op dat een rol kan spelen of een belanghebbende in een eerdere fase de gelegenheid heeft gehad om zijn standpunt mondeling toe te lichten. Hij zou daartoe in elk geval eenmaal in de gelegenheid moeten worden gesteld; het bestuur kan om die reden besluiten toch te horen hoewel een van de uitzonderingen zich voordoet. ${ }^{79}$ Vanuit het oogpunt van hoor en wederhoor is ook gerechtvaardigd dat een belanghebbende in de bestuurlijke fase tenminste eenmaal zijn mondeling zijn standpunt uit een kan zetten.

Terzijde zij nogmaals opgemerkt, dat de gronden waarop kan worden afgezien van het in de gelegenheid stellen van een belanghebbende om gehoord te worden deels dezelfde zijn, als die waarop de bestuursrechter kan besluiten tot het achterwege laten van een mondelinge behandeling op grond van artikel 8:54 Awb: kennelijke onbevoegdheid, kennelijke niet-ontvankelijkheid, kennelijke ongegrondheid en kennelijke gegrondheid. Ook hier wordt de kennelijkheidseis strikt geïnterpreteerd, omdat belanghebbenden in hun rechtsbescherming worden beknot. ${ }^{80}$ Wel is er verzet mogelijk tegen de uitspraak gedaan met vereenvoudigde behandeling op grond van artikel 8:55 Awb en kan via doorbreking van een appelverbod (indien fundamentele rechtsbeginselen of de goede procesorde zijn geschonden) hoger beroep openstaan tegen de uitspraak op verzet. ${ }^{81}$ In beide procedures hoeft geen mondelinge behandeling plaats te vinden, indien dat geen toegevoegde waarde heeft. Zoals gezegd, zal daarvan echter niet snel sprake zijn en in

\footnotetext{
74. Zie De Waard die de verschijningsplicht in het administratieve proces (evenals in het strafproces) ook nadrukkelijk koppelt aan de functie van waarheidsvinding van het onderzoek ter zitting, De Waard 1987, p. 306-307. Hierbij moet echter wel de kanttekening worden geplaatst dat de waarheidsvinding als doel van het bestuursrechtelijke proces tegenwoordig ondergeschikt is aan de individuele rechtsbescherming.

75. In de toekomst worden dat er overigens vijf. In het wetsvoorstel Aanpassing bestuursprocesrecht wordt een vijfde geval toegevoegd aan art. 7:3. Hierop wordt later in deze par. nader ingegaan.

${ }^{76 .}$ Koenraad 2008a, p. 202; Teunissen, p. E 6.3.8-2.

77. CRvB 29 juni 1995, JB 1995/180 m.nt. Red.

78. Koenraad 2008a, p.202; Van den Brekel 2004, p. 141 en de daar genoemde jurisprudentie; Koenraad \& Brouwer 2001, p. 505; Teunissen, p. E 6.3.8-3-4. Zie verder o.m. de volgende uitspraken: AbRvS 3 maart 2004, $A B$ 2004/252 m.nt. NV; CRvB 17 oktober 2000, JB 2000/354; CRvB 29 juni 1995, JB 1995/180.

79. Teunissen, p. E 6.3.8-2-3 en 4.

${ }^{80 .}$ De wetgever heeft ook niet gewild dat er al te lichtvaardig van een mondelinge behandeling wordt afgezien, PG Awb II, p. 450. Zie ook: Schreuder-Vlasblom 2008, p. 411.

${ }^{81}$ Zie art. 37 lid 2 aanhef en onder c Wet RvS. Een voorbeeld van doorbreking van een appelverbod in geval van een verzetsuitspraak vormt: CRvB 22 november 2006, AB 2007/180 m.nt. K.F. Bolt. Zie verder over doorbreking van appelverboden: B.W.N. de Waard, "Doorbreking van appèlverboden", JBplus 2005, p. 98-114; R.J.N. Schlössels, "Hoe hard mag een appèlverbod zijn?", $J B$ 1997, 166, p. 743-750 en de noot van o.m Marseille bij AbRvS 5 apri 2006, $A B$ 2006/320 m.nt. A.T. Marseille.
} 


\section{Deel II Bestuurlijke voorprocedures}

bezwaar zal nog minder snel tot kennelijke ongegrondheid kunnen worden geconcludeerd.

Ten slotte moet, terugkomend op de uitzonderingen die bestaan op de hoorplicht, nog worden gewezen op de omstandigheid dat op een aantal beleidsterreinen horen in bezwaar niet gebruikelijk is of standaard is uitgezonderd. Zoals hierboven is aangegeven kan de bijzondere formele wetgever van de regeling in de Awb afwijken en is dat ook een enkele maal geschied. Dan gaat het met name om bezwaarschriftprocedures bij een beschikkingenfabriek. Voor het belastingrecht is bijvoorbeeld in de Algemene Wet Rijksbelastingen in artikel 25 eerste lid vastgelegd dat het horen van een belanghebbende slechts geschiedt op diens verzoek. ${ }^{82}$

\section{Een nieuwe grond om af te zien van het horen}

Volgens vaste jurisprudentie is het ongeoorloofd om, gelet op het belang dat daaraan gehecht wordt, het horen afhankelijk te stellen van een niet in de wet voorziene formaliteit. Volgens de Afdeling is:

"Niet geoorloofd [is DW] dat het bestuursorgaan een hoorzitting achterwege laat op de grond dat de be-
zwaarde daarom niet uitdrukkelijk heeft verzocht zoals - in dit geval - door middel van het tijdig terugzen-
den van een antwoordformulier. Slechts indien, overeenkomstig art. 7:3 aanhef en onder c Awb, de belang-
hebbende - al dan niet naar aanleiding van een daartoe strekkende vraag van het bestuursorgaan - uitdruk-
kelijk heeft verklaard geen gebruik te willen maken van zijn recht gehoord te worden, kan van het horen
worden afgezien" 83

Annotator Verheij stelt zich op het standpunt dat de wet slechts eist dat een belanghebbende in de gelegenheid wordt gesteld om gehoord te worden en dat uit de wet niet voortvloeit dat het recht om te worden gehoord niet afhankelijk mag worden gemaakt van enige handeling van de burger. Een redelijke wetsuitleg brengt volgens Verheij mee, gelet op de logistieke gevolgen en gevolgen voor de schaarse capaciteit bij beschikkingenfabrieken die de in de jurisprudentie voorgestane benadering veroorzaken, dat de burger dient aan te geven of hij een hoorzitting op prijs stelt. ${ }^{84}$ Hij krijgt daarin bijval van Schlössels die in zijn kroniek naar aanleiding van deze uitspraak opmerkt dat van de bezwaarde mag worden verwacht dat hij aangeeft of hij van zijn recht gebruik zou willen maken. ${ }^{85}$

Niet geheel verrassend wellicht wordt in de toekomst in de Awb, indien het wetsvoorstel 'Aanpassing bestuursprocesrecht ${ }^{86}$ ongewijzigd aangenomen wordt, tegemoet gekomen aan de geuite kritiek op deze door de rechter voorgestane benadering. In de Awb wordt in artikel 7:3 sub d uitdrukkelijk opgenomen dat van het horen mag worden afgezien, indien de indiener van het bezwaar- of beroepschrift niet binnen een daartoe gestelde redelijke termijn heeft aangegeven of hij of zij gehoord wil worden. ${ }^{87}$ Een antwoordkaartmethode dient mogelijk te zijn, omdat het zonder deze mogelijkheid vóórkomt dat het bestuursorgaan een hoorzitting moet organiseren vanwege het uitblijven van een reactie van belanghebbende via het antwoordformulier. Wanneer sprake is van een redelijke termijn wordt niet nader verduidelijkt. ${ }^{88} \mathrm{Mij}$ lijkt dat het bestuur - gelet op de functies van het horen - op de antwoordkaart, in de begeleidende brief of in de uitnodi-

82. Zie een recente uitspraak over de hoorplicht en de uitzonderingen daarop in een belastingzaak: HR 15 mei 2009, $A B$ 2009/342 m.nt. B. de Waard.

83. AbRvS 3 maart 2004, $A B$ 2004/252 m.nt. NV; $J B$ 2004/175. Zie ook: AbRvS 8 juni 2005, AB 2005/310 m.nt. NV; CRvB 27 mei 1998, $A B$ 1998/367.

84. Op dat standpunt stelt ook het kabinet zich, zie: Kabinetsstandpunt Evaluatie Awb I, Kamerstukken II 1997/98, 25600 VI, nr. 46, p. 28. Ook de Commissie Polak meent dat de wet zich tegen een dergelijke praktijk niet verzet, Rapport Evaluatie Awb I, p. 48.

${ }^{85 .}$ R.J.N. Schlössels, 'Beginselen van behoorlijk bestuur', NTB 2005/7, p. 258.

86. Zie ook: A. Weggeman, 'Afzien van horen in bezwaar' in: W. Konijnenbelt e.a., 'Herziening bestuursprocesrecht ter tafel', NTB 2006, 36, p. 267-269.

87. Kamerstukken II 2009/10, 32 450, nrs. 1-3.

88. Kamerstukken II 2009/10, 32 450, nrs. 1-3. 


\section{De inrichting van de voorprocedures}

ging voor de hoorzitting moet aangeven dat het nalaten om een reactie te geven binnen de gestelde termijn kan leiden tot de 'sanctie' dat niet gehoord zal worden. De rechtsbescherming van belanghebbenden of hoor en wederhoor worden op deze wijze niet tekort gedaan.

\section{De algemene hoorplicht: uitwerking van hoor en wederhoor of van het zorgvuldigheidsbeginsel}

Uit het bovenstaande blijkt dat de tweeledigheid van de bezwaarschriftprocedure in de algemene hoorplicht sterk tot uitdrukking komt. Evenals aan de bezwaarschriftprocedure zelf worden hieraan een functie vanuit zorgvuldige besluitvorming, namelijk informatiegaring, en een rechtsbeschermingsfunctie, te weten hoor en wederhoor, toegekend. Zoals aangegeven, zijn beide functies twee kanten van een en dezelfde medaille en gaat het om verschillende perspectieven op het horen. De hoorplicht in de bezwaarschriftprocedure (en het administratief beroep) wordt in de doctrine meestal herleid tot het formele zorgvuldigheidsbeginsel, zoals dat mede is neergelegd in artikel $3: 2 \mathrm{Awb}{ }^{89}$ Een enkeling legt aan de hoorplicht het beginsel van hoor en wederhoor ten grondslag. ${ }^{90}$ De bestuursrechter laat zich in zijn rechtspraak over artikel 7:2 Awb (en artikel 7:3 Awb) niet snel uit over de vraag of het zorgvuldigheidsbeginsel aan die bepaling ten grondslag ligt. Voor zover dat gebeurt, is dat in het kader van de vraag of na vernietiging van een besluit een nieuwe hoorplicht bestaat. Die rechtspraak komt in paragraaf 5.3.2.4 aan de orde, maar daarop vooruitlopend kan reeds opgemerkt worden dat de bestuursrechter daarin niet consistent kiest voor het zorgvuldigheidsbeginsel.

Deze hoorplicht voor het bestuur, gebaseerd op het zorgvuldigheidsbeginsel, beoogt echter dezelfde belangen te waarborgen als het recht om gehoord te worden door de rechter en heeft dezelfde functies (vanuit zowel nationaal als Europees perspectief overigens ${ }^{91}$ ). De hoorplicht heeft in beide gevallen ook een waarborgfunctie en daarnaast een andere functie, toegespitst op de taak van het orgaan. Voor het bestuur is dat de informatiegaringsfunctie die verband houdt met de zorgvuldigheid van de besluitvorming, terwijl het voor de bestuursrechter de waarheidsvinding is en controle van de besluiten van het bestuur. De hoorplicht voor het bestuur kan, doordat deze in het teken staat van uitwisseling en confrontatie van standpunten, ook gezien worden als een uitwerking van hoor en wederhoor. Hoewel de hoorplicht niet expliciet aangemerkt wordt als een uitwerking van het beginsel van hoor en wederhoor, maakt dat voor het karakter van de hoorplicht in mijn optiek geen verschil. Voor de inhoud van de hoorplicht van het bestuur en het recht van de belanghebbende om gehoord te worden, zoals thans onder de Awb vormgegeven, heeft dat immers geen gevolgen. Materieel gezien gaat het om vergelijkbare eisen en de uitzonderingsgronden in de Awb zijn voor de voorprocedure en procedure bij de bestuursrechter ook grotendeels hetzelfde.

\subsubsection{De hernieuwde hoorplicht in het perspectief van hoor en wederhoor}

\section{De hernieuwde hoorplicht}

Het onderzoek inzake het horen van belanghebbenden in de bezwaarschriftprocedure (en het administratief beroep) in het bovenstaande heeft zich gericht op de algemene hoorplicht, zoals neergelegd in artikel 7:2 (en 7:16) Awb. Van die algemene hoorplicht moet worden aangenomen dat deze een waarborgfunctie heeft voor zowel het bestuur als de belanghebbende(n). Bezien in dat laatste perspectief vormt de hoorplicht een uitwerking van het beginsel van hoor en wederhoor. In de bezwaarschriftprocedure en het administratief beroep geldt echter op grond van artikel 7:9 en 7:23 Awb nog een aanvullende

\footnotetext{
${ }^{89 .}$ Koenraad \& Sanders 2006, p. 61; Weggeman 2006, p. 268.

90. Teunissen, E 6.3.7-1; Van der Ham 1988, p. 85.

91. Zie: Deel I, par. 4.3.5 en par. 5.2.1.
} 


\section{Deel II Bestuurlijke voorprocedures}

hoorplicht voor het bestuur (of de adviescommissie ${ }^{92}$ ), indien na het horen aan het bestuursorgaan feiten of omstandigheden bekend worden die voor de te nemen beslissing van aanmerkelijk belang kunnen zijn. In dat geval behoren belanghebbenden van die feiten of omstandigheden op de hoogte te worden gesteld en de gelegenheid te krijgen daarover gehoord te worden. De vraag is of aan deze hoorplicht dezelfde ratio wordt toegekend als aan de algemene hoorplicht.

\section{De ratio van de hernieuwde hoorplicht}

Als reden voor deze - wat ik maar noem - hernieuwde hoorplicht voor het bestuur voert de wetgever aan dat het voorkomt dat naar aanleiding van het horen nader onderzoek nodig is. Na de eerste hoorzitting kunnen nieuwe feiten of omstandigheden bekend worden die voor de beslissing van aanmerkelijk belang kunnen zijn. Dan is het van belang dat belanghebbenden in staat worden gesteld daarop te reageren. ${ }^{93}$ De bepaling beoogt te bewerkstelligen dat een belanghebbende de gelegenheid krijgt om een reactie te geven op nieuwe feiten of omstandigheden, teneinde te voorkomen dat een daarop (mede) gebaseerd besluit wordt genomen waardoor deze wordt overvallen. ${ }^{94}$ In het licht daarvan moet er ook voldoende tijd bestaan om een reactie te kunnen voorbereiden en kan niet worden volstaan met de enkele mededeling van de informatie. De noodzaak tot het organiseren van een hoorzitting vervalt niet door die mededeling omdat er voldoende tijd dient te bestaan om de gevolgen van of de betekenis van de nieuwe informatie te kunnen overzien. ${ }^{95}$ De ratio is derhalve het voorkomen van overrompeling door de nieuwe feiten of omstandigheden (en vervolgens het besluit).

De hernieuwde hoorplicht staat daarmee in het teken van de verweermogelijkheden van belanghebbende(n) en hoor en wederhoor. Aan de andere kant hangt deze bepaling ook duidelijk samen met het verlengde besluitvormingskarakter van de bezwaarschriftprocedure en de vereiste zorgvuldigheid van de besluitvorming. Daaruit volgt immers dat het bestuur (voor zover uit de wet of de aard van het besluit niet anders voortvloeit) ${ }^{96}$ alle feiten of omstandigheden die relevant zijn tot het moment van de beslissing op bezwaar moet meenemen. Daarbij is ook van belang, vanuit een oogpunt van informatiegaring door het bestuur, dat de standpunten van belanghebbenden, voor zover van belang, ten aanzien van die nieuwe feiten meegenomen worden in de besluitvorming. In tegenstelling tot de algemene hoorplicht beperkt de informatiegaring van het bestuur in het kader van de hernieuwde hoorplicht zich echter hoofdzakelijk tot de visie van belanghebbenden op de nieuwe feiten of bevestiging van de nieuwe feiten. Het horen heeft niet primair als oogmerk dat het bestuur op de hoogte raakt van nieuwe feiten of gegevens. De hoorplicht ontstaat juist omdat het feiten of omstandigheden betreft die aan het bestuursorgaan bekend zijn geworden na de eerste hoorzitting. Dat impliceert dat het bestuur reeds kennis heeft gekregen van die feiten. Daarom kan worden gesteld dat de bepaling beoogt een gelijke positie te bewerkstelligen van (enkele) belanghebbenden die daarvan nog niet op de hoogte zijn én beoogt hen de gelegenheid te bieden daarop te reageren. Zo bezien staat de hernieuwde hoorplicht vooral in het teken van hoor en wederhoor. De bepaling lijkt hiermee zelfs 'equality of arms' of een gelijke procespositie voor belanghebbenden ten aanzien van die nieuwe feiten te waarborgen. ${ }^{97}$ Uiteraard wordt met de uitwisseling van standpunten over de nieuwe feiten tegelijkertijd eveneens de zorgvuldigheid van de

92. Art. 7:13 lid 5 Awb bepaalt overigens niet dat de adviescommissie kan beslissen tot het houden van een nieuwe hoorzitting op grond van art. 7:9 Awb. Aangenomen moet echter worden dat zulks wel het geval is Hetzelfde moet lijkt mij gelden voor de beslissing tot het horen van getuigen of deskundigen op grond van art. 7:8 Awb, vgl. Koenraad \& Sanders 2006, p. 76.

93. PG Awb I, p. 344.

94. Stroink 2004a, p. 103.

95. CRvB 17 mei 2005, LJN AT8156, Abkort 2005/495.

96. Zie over de ex nunc-heroverweging in de bestuurlijke voorprocedures par. 4.3.2 van dit deel.

97. Vgl. ook: Teunissen, ' Commentaar art. 7:9 Awb', E 6.3.14-2, die ervan uitgaat dat processuele benadeling door de bepaling voorkomen wordt. 


\section{De inrichting van de voorprocedures}

besluitvorming gediend. Toch lijkt dat laatste niet de voornaamste ratio van de hernieuwde hoorplicht te zijn.

In de doctrine wordt een wisselend standpunt ingenomen ten aanzien van de grondslag van de hoorplicht neergelegd in artikel 7:9 Awb. Soms wordt deze bepaling beschouwd als een judicieel of aan rechtspraak eigen element in de regeling inzake het horen in de bezwaarfase. ${ }^{98}$ Daarentegen wordt deze bepaling ook in het licht van het zorgvuldigheidsbeginsel geplaatst. ${ }^{99}$ Soms wordt ook op twee gedachten gehinkt. De bepaling wordt door Koenraad bijvoorbeeld gezien als een uitwerking van of een lex specialis van het in artikel 3:2 Awb neergelegde zorgvuldigheidsbeginsel. ${ }^{100}$ Tegelijkertijd neemt hij aan dat deze (uit het zorgvuldigheidsbeginsel voortvloeiende) vorm van informatievergaring samenhangt met het beginsel van hoor en wederhoor. ${ }^{101}$ Tevens plaatst hij de algemene hoorplicht neergelegd in artikel 7:2 Awb en de hernieuwde hoorplicht neergelegd in artikel 7:9 Awb in dat opzicht op een lijn. In mijn optiek staat de hoorplicht ten aanzien van nieuwe feiten van aanmerkelijk belang echter, meer nog dan de algemene hoorplicht, in het teken van hoor en wederhoor. Voornaamste doel is immers, zoals hiervoor uiteen is gezet, voorkoming van processuele benadeling van belanghebbenden. ${ }^{102}$

\section{De jurisprudentie van de bestuursrechter}

Het voorgaande verklaart wellicht ook waarom de bestuursrechter als grondslag voor de hernieuwde hoorplicht gekozen heeft voor het beginsel van hoor en wederhoor. De bestuursrechter heeft meer dan eens overwogen dat artikel 7:9 Awb een uitwerking vormt van dat beginsel. ${ }^{103}$ Zo overweegt het College van Beroep voor het bedrijfsleven in een uitspraak van 11 november 2005 dat het niet in de gelegenheid stellen van een belanghebbende om nader gehoord te worden, allereerst in tegenspraak is met het belang dat de wetgever heeft toegekend aan het horen in de bezwaarfase. Vervolgens wordt overwogen dat daarmee geen recht wordt gedaan aan het belang van hoor en wederhoor dat artikel 7:9 beoogt te beschermen. ${ }^{104}$ Ook de Afdeling neemt aan dat in artikel 7:9 Awb het beginsel van hoor en wederhoor tot uitdrukking komt. ${ }^{105}$

In de jurisprudentie die dateert van voor de Awb en voordat een dergelijk voorschrift wettelijk was vastgelegd, werd de regel, dat belanghebbenden in de gelegenheid dienen te worden gesteld om te reageren op nieuwe feiten of omstandigheden die bekend geworden zijn na het horen en die voor de beslissing op bezwaar van belang kunnen zijn, ook al erkend. Teunissen geeft aan dat deze plicht uit vaste jurisprudentie voortvloeide. ${ }^{106}$ De mogelijkheid om te reageren kon schriftelijk geboden worden dan wel in de vorm van een hoorzitting. De grondslag voor die verplichting werd soms gezocht in de

\footnotetext{
98. Stroink 2004a, p. 103; Versteden 1995, p. 290.

99. Vgl. Van Wijk/Konijnenbelt \& Van Male 2008, p. 557.

100. Zie ook Koenraad en Sanders die alle hoorplichten vooral in het teken van het zorgvuldigheidsbeginsel plaatsen, Koenraad \& Sanders 2006, p. 62-63.

${ }^{101 .}$ Zie bijv.: L.M. Koenraad, 'Van aanmerkelijk belang', Gst. 2008, 7302, 100, p. 473-474. Elders baseert hij de mededelingsplicht van het bestuur ten aanzien van de nieuwe feiten of omstandigheden enerzijds op het verdedigingsbeginsel en anderzijds geeft hij aan dat de invulling ervan niet door het beginsel van hoor en wederhoor wordt genormeerd maar door art. 3:2 Awb en de noodzaak tijdig een besluit te nemen, p. 476

102. Zie ook: Teunissen, E 6.3.14-2.

103. Zie bijvoorbeeld: AbRvS 26 april 2006, JB 2006/184 m.nt. D. Wenders; CBb 11 november 2005, JB 2005/46; AbRvS 16 februari 2005, JB 2005/102 m.nt. Hamer; AbRvS 19 december 2001, JB 2002/46.

${ }^{104 .} \mathrm{CBb} 11$ november 2005, JB 2006/46. Zie ook de noot bij CBb 3 juni 1999, AB 1999/364 m.nt. JHvdV waarin de annotator aangeeft dat bij schending van art. 7:9 Awb het beginsel van hoor en wederhoor, als beginsel van behoorlijke rechtspleging zoals door De Waard is omschreven, in het gedrang komt.

105. AbRvS 26 april 2006, JB 2006/184 m.nt. D. Wenders; AbRvS 16 februari 2005, JB 2005/102 m.nt. Hamer; AbRvS 19 december 2001, $J B$ 2002/46. In de uitspraken refereert de Afdeling overigens aan het beginsel van hoor en wederhoor zoals dat onder meer tot uitdrukking komt in artikel 7:9 Awb. Daarmee wekt de Afdeling de suggestie dat dit beginsel ook aan andere bepalingen in de Awb (voor de bezwaarschriftprocedure?) ten grondslag ligt.

${ }^{106 .}$ Teunissen, p. E 6.3.14-1.
} 


\section{Deel II Bestuurlijke voorprocedures}

goede procesorde. ${ }^{107}$ De Afdeling rechtspraak vernietigde echter in veel gevallen waarin een belanghebbende die gelegenheid om te reageren niet was geboden, hoewel de nadere informatie wel van belang was voor de beslissing op bezwaar, het besluit wegens strijd met het zorgvuldigheidsbeginsel. ${ }^{108}$ Het hernieuwd horen in de bestuurlijke voorprocedure vloeide derhalve soms voort uit de goede procesorde, maar soms ook uit de zorgvuldigheid van de besluitvorming.

Onder de Awb geldt de hernieuwde hoorplicht echter in de rechtspraak duidelijk(er) als een uitwerking van het beginsel van hoor en wederhoor. De bestuursrechter heeft in recente uitspraken de toepassing van artikel 7:9 Awb in het teken van het beginsel van hoor en wederhoor geplaatst. ${ }^{109}$ De verklaring voor deze verschuiving in de grondslag voor de plicht tot horen bij nieuwe feiten of omstandigheden in de rechtspraak, moet wellicht gezocht worden in de het tweeledige karakter van de bezwaarschriftprocedure onder de Awb. Indien wordt geredeneerd vanuit het besluitvormingskarakter van die procedure dan ligt het voor de hand de grondslag, zoals de Afdeling rechtspraak deed, te zoeken in het zorgvuldigheidsbeginsel als toepasselijke norm voor bestuurlijke besluitvorming. Vanuit het perspectief van de belanghebbende en het rechtsbeschermingskarakter ligt echter de goede procesorde of het beginsel van hoor en wederhoor als toepasselijke norm evenzeer of zelfs meer in de rede. Het is niet duidelijk of de bestuursrechter in zijn meer recente jurisprudentie het oog heeft op het beginsel van hoor en wederhoor als beginsel van behoorlijke rechtspleging dan wel als een (nieuw of niet algemeen aanvaard) beginsel van behoorlijk bestuur. De inhoud en ratio van de eisen blijven echter ongewijzigd, ongeacht de grondslag of het perspectief dat gekozen wordt. Voorstelbaar is dat het perspectief hoor en wederhoor voor belanghebbenden ertoe leidt dat belanghebbenden in twijfelgevallen, wanneer niet duidelijk is of het feiten van aanmerkelijk belang voor het te nemen besluit betreft, bijvoorbeeld eerder de gelegenheid krijgen om te reageren. Het perspectief vanuit het bestuursorgaan zal er wellicht uitsluitend toe nopen belanghebbenden te horen, indien het bestuursorgaan meent dat het van betekenis kan zijn voor de zorgvuldigheid van het te nemen besluit. ${ }^{110}$ De betekenis van het verschil in grondslag zal echter beperkt zijn en hoogstens in grens- of twijfelgevallen relevant zijn.

Reikwijdte van artikel 7:9 Awb

Zoals hiervoor al werd aangestipt, geldt de wettelijke verplichting om de belanghebbende(n) opnieuw te horen op grond van artikel 7:9 Awb alleen voor feiten of omstandigheden die na het horen in eerste instantie bekend zijn geworden en die van aanmerkelijk belang zijn voor de te nemen beslissing op bezwaar. Daarmee worden twee belangrijke beperkingen in de reikwijdte van artikel 7:9 Awb en derhalve ook op de gelding van het beginsel van hoor en wederhoor in deze fase van de bezwaarschriftprocedure aangebracht.

Ten eerste bestaat slechts een hoorplicht op grond van artikel 7:9 Awb, indien sprake is van feiten of omstandigheden die ná het horen bekend zijn geworden. Uit deze zinsnede kunnen twee deelvoorwaarden worden onderscheiden. Allereerst volgt hieruit dat in gevallen, waarin terecht toepassing is gegeven aan artikel 7:3 Awb, ook niet ge-

\footnotetext{
107. Zie bijvoorbeeld: ArRvS 14 mei 1985, $A B$ 1986/103 m.nt. JHvdV; CBb 19 april 1985, $A B$ 1985/443 m.nt. JHvK. In beide gevallen betrof het administratief beroep. Zie ook: Teunissen, p. E 6.3.14-1-2 .

108. Zie bijvoorbeeld: ArRvS 7 augustus 1989, AB 1990/191 m.nt. J.C.J. Dute; ArRvS 14 mei 1985, AB 1986/103 m.nt. JHvdV; ArRvS 8 juli 1983, $A B$ 1984/29 m.nt. JHvdV; ArRvS 8 april 1982, $A B$ 1982/553 m.nt. v.d.V. Zie ook: Pres. Rb. Rotterdam 29 maart 1994, JB 1994/100.

109. Er zijn ook uitspraken waarin de bestuursrechter slechts refereert aan art. 7:9 Awb en geen enkel beginsel noemt, zie bijv.: AbRvS 19 augustus 2009, JB 2009/217 (geen schending overigens).

${ }_{110}$ Artikel 7:9 Awb of andere bepalingen in de Awb regelen overigens niets omtrent de gang van zaken rondom de tweede hoorzitting. Er worden geen eisen gesteld met betrekking tot de inzage van stukken, de termijn waarbinnen stukken kunnen worden ingediend of de oproeping voor de hoorzitting. Mij lijkt echter in de rede te liggen dat de bepalingen uit afdeling 7.2 Awb analoog worden toegepast in dit soort situaties.
} 


\section{De inrichting van de voorprocedures}

hoord behoeft te worden op grond van artikel 7:9 Awb, indien nieuwe feiten of omstandigheden bekend worden gedurende de procedure. De bepaling mist toepassing, indien (terecht) geen eerste hoorzitting heeft plaatsgevonden. In de jurisprudentie is in elk geval bevestigd dat, indien het horen achterwege is gelaten omdat de belanghebbende(n) daarvan heeft afgezien, artikel 7:9 Awb niet noopt tot het horen van belanghebbenden. ${ }^{111}$ Of er in deze situatie onder omstandigheden desondanks op grond van een ongeschreven plicht gehoord moet worden, komt aan de orde in paragraaf 5.3.2.4 hierna.

Voorts volgt uit die zinsnede, dat slechts gehoord dient te worden indien het feiten of omstandigheden betreft die ná het horen aan het bestuursorgaan bekend zijn geworden. Het kan gaan om feiten of omstandigheden die ontstaan zijn na de hoorzitting, maar ook om feiten of omstandigheden waarvan het bestuur slechts voor het eerst op de hoogte raakte na de hoorzitting. Het doet er ook niet toe op welke wijze het bestuur met de feiten of omstandigheden bekend is geraakt. Deze kunnen verstrekt zijn door belanghebbenden of het kan gaan om feiten of omstandigheden die voortvloeien uit nader onderzoek door het bestuur naar aanleiding van de hoorzitting. De informatie kan mondeling of schriftelijk verstrekt zijn na de hoorzitting. Zelfs informatie die naar voren komt tijdens telefonische contacten na de hoorzitting kunnen binnen de reikwijdte van artikel 7:9 Awb vallen. ${ }^{12}$ Tot slot is van belang dat blijkens een uitspraak van de Afdeling zelfs gegevens die reeds voorhanden waren bij het bestuur, maar niet betrokken waren bij de primaire besluitvorming en op verzoek van de commissie na de hoorzitting verstrekt waren, toch kunnen worden gezien als feiten of omstandigheden die na het horen bekend zijn geworden. ${ }^{113}$ De voorwaarde, dat de feiten of omstandigheden aan het bestuursorgaan bekend moeten zijn geworden na de hoorzitting, lijkt derhalve niet al te strikt gehanteerd te worden. Van belang lijkt vooral dat het gegevens betreft die nog niet aan bod zijn gekomen in de procedure en waarmee belanghebbenden nog niet bekend waren. Omdat de beslissing op bezwaar daarop steunt, is het niet geoorloofd belanghebbenden de gelegenheid te onthouden om zich daarover uit te laten. Dat lijkt tenminste de algemene teneur te zijn in de uitspraken van de bestuursrechter. Het gaat er vooral om dat hoor en wederhoor in de desbetreffende procedure gewaarborgd is en belanghebbenden niet overvallen worden door een beslissing die steunt op dergelijke feiten of omstandigheden.

De tweede beperking die voortvloeit uit artikel 7:9 Awb is dat er geen verplichting bestaat om bij alle nieuwe feiten of omstandigheden opnieuw een gelegenheid te bieden gehoord te worden. Het moet feiten of omstandigheden betreffen die van aanmerkelijk belang zijn voor de beslissing op bezwaar. Voor de invulling van het begrip aanmerkelijk belang is met name de jurisprudentie omtrent artikel 7:9 Awb van belang. ${ }^{114}$ Veel zal afhangen van de omstandigheden van het geval. De vraag is wel of het moet gaan om feiten of omstandigheden die bepalend of doorslaggevend zijn voor de besluitvorming. Teunissen meent dat analoog aan de jurisprudentie van voor inwerkingtreding van de Awb de zinsnede 'van aanmerkelijk belang' moet worden gelezen als 'van belang'. Hij meent dat artikel 7:9 Awb deze ongeschreven regel, die gold voor de Awb, beoogt te codificeren, zonder dat sprake is van een versoepeling (voor het bestuur) ten opzichte van deze jurisprudentie. ${ }^{115}$ Hamer meent echter dat de jurisprudentie ten aanzien van het begrip 'feiten of omstandigheden van aanmerkelijk belang (voor de te nemen beslissing op bezwaar)' zo moet worden geïnterpreteerd dat het feiten of omstandigheden betreft die richtinggevend zijn voor de beslissing op bezwaar. ${ }^{116}$ Hamer wijst er terecht op dat

\footnotetext{
111. CRvB 6 september 2002, JB 2002/309.

112. AbRvS 5 juni 2002, JB 2002/222.

113. AbRvS 19 december 2001, JB 2002/46

114. Zie hierover ook: Koenraad 2008b, p. 473 e.v.

115. Teunissen, p. E. 6.3.14-2.

116. Zie de noot bij AbRvS 22 september 2004, JB 2005/5 m.nt. M.C.M. Hamer; AbRvS 16 februari 2005, JB 2005/102 m.nt. M.C.M. Hamer. Zie recent: AbRvS 19 augustus 2009, JB 2009/217.
} 


\section{Deel II Bestuurlijke voorprocedures}

ondersteuning of bevestiging van eerder ingenomen standpunten of ingewonnen adviezen door de bestuursrechter niet worden gezien als feiten of omstandigheden van aanmerkelijk belang. ${ }^{117}$ Uit de jurisprudentie blijkt in mijn optiek dat indien de beslissing op bezwaar is gebaseerd of gegrond op de nieuwe feiten of omstandigheden deze feiten of omstandigheden in elk geval van aanmerkelijk belang voor de beslissing worden geacht. Dat betekent dat in het geval van een college van $b$ en $w$ dat in de beslissing op bezwaar passages uit een advies, dat na de hoorzitting was ingewonnen, letterlijk had overgenomen en nagelaten had belanghebbenden te horen over het betreffende advies, een schending van artikel 7:9 Awb werd aangenomen. ${ }^{118}$ Een besluit mede baseren op een na de hoorzitting ingewonnen advies, dat ook nog de basis vormde om af te wijken van het advies van de adviescommissie bezwaarschriften, en nalaten belanghebbenden over dat advies te horen, kon evenmin door de beugel. ${ }^{119}$ In een andere uitspraak overwoog de Afdeling dat het bestuur zich bij het nemen van het besluit uitsluitend gebaseerd had op twee uitgevoerde akoestische onderzoeken, waarvan de resultaten waren neergelegd in twee rapporten die dateerden van na de hoorzitting (alsook het vernietigde besluit op bezwaar), en dat de rapporten aan te merken waren als na het horen bekend geworden feiten of omstandigheden die van aanmerkelijk belang kunnen zijn. ${ }^{120}$ Hoewel duidelijk is dat het zal afhangen van de omstandigheden van het geval welke feiten of omstandigheden als van aanmerkelijk belang moeten worden beschouwd, kan uit de jurisprudentie worden afgeleid dat het feiten of omstandigheden moet betreffen die de inhoudelijke beslissing kunnen beïnvloeden. Dat zij zelfstandig de beslissing moeten kunnen dragen of de beslissing uitsluitend daarop gebaseerd moet zijn, is mijns inziens niet per definitie nodig. ${ }^{121}$ Koenraad geeft ook aan dat het moet gaan om feiten die kunnen leiden tot een ander resultaat van de heroverweging, dat wil zeggen een ander dictum of een andere grondslag voor het dictum van het besluit op bezwaar. ${ }^{122}$ Het beginsel van hoor en wederhoor vereist ook niet dat belanghebbenden op feiten of omstandigheden van ondergeschikt belang opnieuw behoren te reageren. Als daarvan sprake is worden belanghebbenden immers ook niet benadeeld of in hun belangen geschaad. Wel kan het vanuit een oogpunt van hoor en wederhoor eerder in de rede liggen belanghebbenden te horen over nieuwe feiten dan vanuit een oogpunt van zorgvuldigheid van de besluitvorming. In het eerste geval staat immers voorop dat belanghebbenden hun standpunt hebben kunnen verdedigen en daarover van gedachte hebben kunnen wisselen (met het bestuur en andere belanghebbenden), terwijl in het laatste geval vooral van belang is in hoeverre de nieuwe feiten relevant zijn voor het te nemen besluit. ${ }^{123}$ In dat licht is het van belang voor ogen te houden dat deze hoorplicht, ook in de rechtspraak, wordt gezien als een uitwerking van hoor en wederhoor. De eis van aanmerkelijk belang zal derhalve niet te strikt moeten worden geïnterpreteerd.

\section{De heropening van het onderzoek door de rechter}

De plicht tot het opnieuw horen van belanghebbenden valt enigszins te vergelijken met de bevoegdheid van de bestuursrechter om het onderzoek te heropenen op grond van

\footnotetext{
117. Zie de noot bij AbRvS 22 september 2004, JB 2005/5 m.nt. M.C.M. Hamer. Hij verwijst naar verschillende uitspraken: AbRvS 30 november 1998, JB 1999/12; CRvB 10 december 2002, USZ 2003/70.

${ }_{118}$ AbRvS 26 april 2006, JB 2006/184 m.nt. DWMW.

119. AbRvS 16 februari 2005, JB 2005/102 m.nt. M.C.M. Hamer.

120. AbRvS 22 september 2004, JB 2005/5 m.nt. M.C.M. Hamer; $A B$ 2005/202 m.nt. BdeW. Deze uitspraak betrof een geval waarin vernietiging van het besluit op bezwaar had plaatsgevonden en daarna rapporten to stand gekomen waren waarover appellant niet was gehoord. Strikt genomen is het dan de vraag of art. 7:9 Awb daarop van toepassing is, zoals in de volgende par. aan bod komt, maar de Afdeling gaat daar in elk geval vanuit. Voor de invulling van de verplichting om te horen op grond van art. 7:9 Awb is deze uitspraak derhalve ook relevant.

121. Zie bijvoorbeeld: AbRvS 16 februari 2005, JB 2005/102 m.nt. Hamer (besluit mede gegrond op advies ingewonnen na hoorzitting).

${ }^{122 .}$ Koenraad 2008b, p. 474

${ }^{123 .}$ Zie ook de noot van Sewandono bij AbRvS 16 januari 2008, $A B$ 2008/308 m.nt. Sew.
} 


\section{De inrichting van de voorprocedures}

artikel 8:68 Awb, indien de rechter ambtshalve of op verzoek van partijen aanleiding toe ziet. Aan het einde van de zitting en mondelinge behandeling sluit de bestuursrechter immers het onderzoek, ingevolge artikel 8:65 Awb. Er kunnen echter omstandigheden rijzen die nopen tot heropening van het onderzoek. In sommige gevallen kan dan ook een hernieuwd onderzoek ter terechtzitting plaatsvinden; de rechtbank bepaalt op welke wijze het onderzoek wordt voortgezet. Met toestemming van partijen kan, na heropening van het vooronderzoek, op grond van artikel 8:57 Awb ook het onderzoek ter zitting achterwege worden gelaten.

Aanleiding voor heropening van het onderzoek kunnen tijdens of na de zitting overgelegde stukken zijn. Indien de rechtbank deze bij de uitspraak wilt betrekken, behoort zij (behoudens de mogelijkheid om het onderzoek te schorsen op grond van artikel 8:64 Awb) het onderzoek te heropenen, teneinde partijen in staat te stellen zich daarover uit te laten. ${ }^{124}$ De ratio is evenals voor de verplichting voor het bestuur neergelegd in artikel 7:9 Awb gelegen in het beginsel van hoor en wederhoor en de verweermogelijkheden van partijen, zo blijkt uit de jurisprudentie. ${ }^{125}$ Partijen moeten hun standpunt kunnen geven over de nog niet eerder bij de procedure betrokken stukken en een partij mag door de (inhoud van de) stukken en de uitspraak niet overvallen worden.

Een uitwerking van het beginsel van hoor en wederhoor

Artikel 7:9 van de Awb beoogt te waarborgen dat belanghebbenden de gelegenheid krijgen om te reageren op alle feiten en omstandigheden die voor de beslissing op bezwaar van belang (kunnen) zijn. Het stelt veilig dat feiten of omstandigheden die na het horen bekend zijn geworden door bestuur, voor zover de beslissing op bezwaar daarop mede steunt, aan belanghebbenden worden voorgelegd. Voorts stelt het veilig dat zij voldoende gelegenheid krijgen om daarop te reageren. Uit het bovenstaande blijkt onomstotelijk dat artikel 7:9 Awb een uitwerking vormt van het beginsel van hoor en wederhoor. De ratio of functie van die waarborg valt ook daartoe te herleiden. De bepaling beoogt processuele benadeling en overrompeling van belanghebbenden te voorkomen. Bovendien wordt dat beginsel in de doctrine én de rechtspraak als grondslag voor de hernieuwde hoorplicht aangewezen. Daarmee wordt toepasselijkheid van het beginsel van hoor en wederhoor in de bestuurlijke voorprocedures aangenomen. De vergelijkbare bepaling voor administratief beroep, artikel 7:23 Awb, is nauwelijks aan de orde gekomen in doctrine en rechtspraak, maar daarvan moet worden aangenomen dat de strekking dezelfde is. Ook deze bepaling vormt een uitwerking van hoor en wederhoor voor die procedure.

\subsubsection{Verschillende ongeschreven hoorplichten en reactiemogelijkheden gedurende de procedure}

Ongeschreven hoorplichten en reactiemogelijkheden gedurende een lopende procedure Naast de wettelijk vastgelegde gevallen waarin het bestuursorgaan de belanghebbenden de gelegenheid moet bieden om gehoord te worden, zijn er ook nog situaties denkbaar waarin een dergelijke verplichting of anderszins een verplichting tot het bieden van een reactiemogelijkheid bestaat voor het bestuur. Hieronder worden twee situaties besproken, waarin een dergelijke ongeschreven eis door de bestuursrechter wordt aangenomen. Een derde geval, de mogelijke verplichting tot horen indien het besluit op bezwaar is vernietigd, komt in een volgend onderdeel afzonderlijk aan de orde.

De eerste situatie die onderscheiden kan worden, ligt min of meer in het verlengde van artikel 7:9 Awb. Hoewel de reikwijdte van die bepaling beperkt is, volgt daaruit niet

124. AbRvS 15 juni 2005, $J B$ 2005/231; CRvB 4 april 2003, $J B$ 2003/156; AbRvS 25 juli 2001, $A B$ 2001/286; CRvB 3 maart 1998, $A B$ 1998/363. Vgl. in hoger beroep: AbRvS 2 augustus 2006, $A B$ 2008/65 m.nt. N. Verheij.

${ }^{125}$ Zie o.m. de in de noot hiervoor genoemde uitspraken. Zie ook par. 4.3.5 van Deel I. 


\section{Deel II Bestuurlijke voorprocedures}

noodzakelijkerwijs dat in alle gevallen waarop die bepaling niet van toepassing is geen plicht tot horen of het bieden van een reactiemogelijkheid voor het bestuur bestaat. Artikel 7:9 Awb vormt een wettelijke uitwerking van het beginsel van hoor en wederhoor in de bezwaarfase, maar dat beginsel kan ook betekenis hebben in die gevallen die niet binnen de reikwijdte van die bepaling vallen. In de jurisprudentie wordt in enkele gevallen ook een hoorplicht of de mogelijkheid tot reageren aangenomen. De basis voor een dergelijke hoorplicht vormt dan veelal het zorgvuldigheidsbeginsel. In een geval waarin artikel 7:9 Awb niet van toepassing was, omdat de belanghebbende af had gezien van het recht om gehoord te worden, overwoog de Centrale Raad dat desondanks vanwege het oogpunt van zorgvuldigheid een mogelijkheid om te reageren op bepaalde feiten of omstandigheden, in dit geval een medisch rapport dat was overgelegd en afweek van de door appellant overgelegde medische verklaringen, moest worden geboden. ${ }^{126}$ Daarbij laat de Centrale Raad in het midden of er door middel van een hoorzitting gelegenheid moet worden geboden om mondeling te reageren. ${ }^{127}$

Evenals voor de inwerkingtreding van de Awb veelal het geval was, zoekt de bestuursrechter de grondslag voor een dergelijke buitenwettelijke en ongeschreven plicht in het zorgvuldigheidsbeginsel. Het zou echter de voorkeur verdienen, indien de bestuursrechter ook in dit soort gevallen het beginsel van hoor en wederhoor expliciet als grondslag voor de verplichting om te horen aanwijst in plaats van het ruime en algemene zorgvuldigheidsbeginsel. In meer algemene zin kom ik daar nog op terug in paragraaf 5.3.6. Hier valt echter reeds een reden, die specifiek samenhangt met deze uitspraak en de hier aan de orde zijnde ongeschreven reactiemogelijkheid, aan te wijzen waarom het beginsel van hoor en wederhoor als grondslag meer geëigend is. Die is gelegen in de omstandigheid dat - zoals hierboven uiteengezet - naar gangbare opvatting aan de wettelijke plicht om te horen op grond van artikel 7:9 Awb juist wél het beginsel van hoor en wederhoor ten grondslag wordt gelegd. Het is consistenter om een buitenwettelijke hoorplicht van vergelijkbare strekking te baseren op hetzelfde beginsel. De Afdeling heeft zulks, in een geval waarin artikel 7:9 Awb niet van toepassing was, omdat het geen feiten of omstandigheden betrof die noopten tot een nieuwe hoorzitting, ook al eens gedaan. Op grond van het beginsel van hoor en wederhoor had in elk geval een reactiemogelijkheid moeten worden geboden ten aanzien van het desbetreffende aanvullende advies dat na de hoorzitting was gegeven. ${ }^{128}$ Ook hier geldt dat, ongeacht welk beginsel de grondslag vormt, de inhoud van de eis verandert niet, aangezien de ratio niet lijkt te verschillen. Materieel komt het op hetzelfde neer en gaat het erom dat belanghebbenden moeten kunnen reageren op nieuwe feiten of omstandigheden die de beslissing kunnen beïnvloeden.

De tweede situatie die onderscheiden kan worden is het geval waarin het besluit op bezwaar zodanig gewijzigd is ten opzichte van het primaire besluit, dat die wijzigingen aan de belanghebbenden kenbaar gemaakt moeten worden en hen een gelegenheid tot reageren geboden moet worden. Omdat de bezwaarschriftprocedure een vorm van verlengde besluitvorming is, kan het besluit op bezwaar onderhevig zijn aan aanzienlijke wijzigingen ten opzichte van het primaire besluit. Beoogd is immers een volledige heroverweging. Zolang het besluit op bezwaar kan worden beschouwd als het resultaat van de heroverweging (zie paragraaf 4.3), zijn die wijzigingen in beginsel toegestaan. Van belang is dat, hoewel wijzigingen toegestaan zijn, de bestuursrechter in sommige gevallen eist dat het bestuursorgaan vanuit een oogpunt van zorgvuldigheid de belanghebben-

\footnotetext{
${ }^{126 .}$ CRvB 6 september 2002, JB 2002/309; RSV 2002/285.

127. De Centrale Raad acht het nalaten van het bestuur om het betreffende rapport aan de belanghebbende te doen toekomen en de mogelijkheid te bieden om te reageren daarop geen grond voor vernietiging van het besluit, omdat deze laatste in de procedure bij de rechtbank en in hoger beroep voldoende gelegenheid heeft gehad om zich daarover uit te laten.

128. AbRvS 30 november 1998, JB 1999/12 m.nt. R.J.N.S. Ook hier leidde het gebrek overigens niet tot vernietiging van het besluit omdat het advies en standpunt van de commissie (een deskundigencommissie die moest oordelen nadeelcompensatie) niet doorslaggevend was in de besluitvorming en de belanghebbende niet in haar belangen was geschaad.
} 


\section{De inrichting van de voorprocedures}

den in de gelegenheid stelt om te reageren op de wijzigingen. ${ }^{129}$ Wordt een tweede hoorzitting georganiseerd dient duidelijk te zijn dat het een koerswijziging van het bestuursorgaan betreft, zodat de belanghebbende(n) daarover hun standpunt kunnen geven. De Centrale Raad geeft aan dat het verstrekken van een voorlopig standpunt van het bestuur of een concept-besluit zinvol kan zijn in dit soort gevallen. ${ }^{130}$ Een wijziging van het besluit op bezwaar kan ook plaatsvinden tijdens de procedure bij de rechter of gedurende die procedure kan door de rechter een gebrek worden geconstateerd waardoor het besluit wijziging behoeft. Voor zover artikel 7:2 en 7:9 Awb geen uitkomst bieden in dit soort gevallen, kan een ongeschreven hoorplicht of plicht tot het bieden van een reactiemogelijkheid worden aangenomen, die gebaseerd wordt op het zorgvuldigheidsbeginsel ${ }^{131}$ of het beginsel van hoor en wederhoor. Een vergelijkbare situatie doet zich voor als het bestuursorgaan, gelet op de volledige heroverweging die moet plaatsvinden in bezwaar, ambtshalve bepaalde aspecten bij de heroverweging wilt betrekken. Het betreft dan aspecten die niet door belanghebbenden zijn aangevoerd. Koenraad geeft aan dat in die gevallen een reactiemogelijkheid aan belanghebbenden moet worden geboden op grond van het beginsel van hoor en wederhoor. ${ }^{132}$ Deze gevallen bieden een goed voorbeeld van de wisselwerking tussen de verlengde besluitvormingsfunctie en de rechtsbeschermingsfunctie van de bezwaarschriftprocedure en laten tevens zien dat betekenis van het beginsel van hoor en wederhoor niet in de weg hoeft te staan aan deze verlengde besluitvorming. De wijze waarop de verlengde besluitvorming plaatsvindt, behoort immers 'slechts' recht te doen aan dat beginsel en binnen het kader van de daaruit voortvloeiende waarborgen plaats te vinden. Dat betekent concreet dat bij voor de belanghebbende nieuwe wijzigingen een gelegenheid tot reageren moet worden geboden waarbij voldoende tijd wordt gegeven een standpunt omtrent de wijziging voor te bereiden. ${ }^{133}$

\section{Horen na vernietiging van het besluit op bezwaar door de bestuursrechter}

Er kan onder omstandigheden nog een derde ongeschreven hoorplicht bestaan, die onderscheiden moet worden van de twee hiervoor genoemde gevallen. Deze situatie heeft geen betrekking op een lopende bezwaarschriftprocedure waarin nog een besluit op bezwaar moet volgen, maar ziet op het horen door het bestuursorgaan nadát de beslissing op bezwaar door de bestuursrechter is vernietigd. In de jurisprudentie van de bestuursrechter is verschillende malen de vraag aan de orde gekomen of op grond van artikel 7:2 Awb dan wel anderszins een hoorplicht bestaat voor het bestuursorgaan na een rechterlijke vernietiging van het bestreden besluit. In verschillende uitspraken heeft de Afdeling geoordeeld dat een algemene hoorplicht in elk geval niet voortvloeit uit artikel 7:2 Awb. ${ }^{134}$ Dat uitgangspunt hanteert ook de Centrale Raad. ${ }^{135}$ Een algemene verplichting tot horen bestaat derhalve niet bij het nemen van een nieuw besluit op bezwaar na vernietiging van het eerdere besluit op bezwaar door de bestuursrechter. De Afdeling en Centrale Raad oordelen dat het bestuursorgaan dan in bezwaar al voldaan heeft aan artikel 7:2 Awb. Er moet echter nog wel een beslissing op bezwaar worden genomen (met inachtneming van de uitspraak van de bestuursrechter). Wellicht ten overvloede merk ik op dat het voorgaande uitsluitend geldt, indien het bestuursorgaan in de bezwaarschriftprocedure de belanghebbende al gehoord had. Is in de bezwaarschriftprocedure ten onrechte niet gehoord en volgt om die reden vernietiging, ligt een plicht tot horen uiteraard op

\footnotetext{
129. CRvB 25 juni 2003, $A B$ 2003/395; JB 2003/247.

130. $\mathrm{Zie}$ vorige noot.

${ }^{131 .}$ Koenraad 2008b, p. 474 e.v.

132. Met verwijzingen naar jurisprudentie, Koenraad 2008a, p. 201 e.v.

133. Zie de noot van Bröring bij $A B$ 2003/395.

134. Zie onder meer: AbRvS 4 mei 2005, JB 2005/186; AbRvS 22 september 2004, AB 2005/202 m.nt. BdeW; JB 2004/5 m.nt. Hamer; AbRvS 17 september 2003, AB 2004/195; AbRvS 15 mei 1997, AB 1997/263. Zie hierover ook: Koenraad \& Sanders 2006, p. 63.

${ }^{135 .}$ CRvB 25 februari 2003, JB 2003/115 m.nt. C.L.G.F.H. A.; CRvB 8 januari 2002, AB 2002/97 m.nt. HBr.
} 
Deel II Bestuurlijke voorprocedures

grond van artikel 7:2 Awb in de rede. ${ }^{136}$ Tot slot heeft de Centrale Raad geoordeeld dat na vernietiging van een beslissing op administratief beroep evenmin een plicht tot horen bestaat. $^{137}$

Het voorgaande betekent echter niet dat belanghebbenden na vernietiging van het besluit op bezwaar in geen geval gehoord behoeven te worden. Er zijn verschillende uitzonderingen aangenomen op de door de bestuursrechter geformuleerde regel. De belangrijkste is dat er, bij nieuwe feiten of omstandigheden die van aanmerkelijk belang zijn voor de op het bezwaar te nemen beslissing, een plicht tot horen bestaat. Die plicht vloeit volgens de Afdeling voort uit artikel 7:9 Awb. ${ }^{138}$ De Waard merkt in zijn noot bij een uitspraak van 22 september 2004 op dat de Afdeling een verbinding legt met artikel 7:9 Awb en dat deze bepaling een bruikbaar kader kan vormen om te beoordelen of gehoord moet worden. ${ }^{139}$ Ik meen echter dat de Afdeling (in die uitspraak) nog verder gaat en dit artikel rechtstreeks van toepassing verklaart. Zij overweegt immers:

(...) 'moet de conclusie zijn dat het bestreden besluit in strijd met art. 7:9 Awb tot stand is gekomen en reeds hierom niet in stand kan blijven.'

Het besluit wordt in strijd met die bepaling geacht en deswege vernietigd. De conclusie moet dan zijn in mijn optiek dat deze bepaling rechtstreeks op dit geval is toegepast. De vraag is echter of dat juist is. Artikel 7:9 Awb ziet, zoals De Waard ook aangeeft in zijn noot, op gevallen waarin in de lopende bezwaarschriftprocedure opnieuw gehoord moet worden zonder dat een vernietiging door de rechter van het besluit op bezwaar heeft plaatsgevonden. Artikel 7:9 Awb is strikt genomen niet rechtstreeks van toepassing, althans dat is destijds niet de bedoeling van de wetgever geweest. Na de vernietiging van het besluit valt de procedure in de benadering van de Afdeling echter als het ware terug in de stand waarin deze zich bevond: vóórdat het besluit genomen wordt, maar nádat op grond van artikel 7:2 Awb gehoord is.

Er kan in dit soort gevallen twee kanten op geredeneerd worden: artikel 7:9 Awb is desondanks van toepassing, omdat de procedure terugvalt in de situatie waarin er nog geen beslissing op bezwaar bestaat en het gaat om nieuwe feiten van na de eerste hoorzitting $^{140}$ ofwel artikel 7:9 Awb is niet rechtstreeks van toepassing aangezien die bepaling voor dit soort situaties niet bedoeld is, maar kan analoog worden toegepast. Dat laatste betekent echter ook dat het besluit vernietigd zou moeten worden wegens een schending van het onderliggende of daaraan ten grondslag liggende beginsel in verbinding met artikel 7:9 Awb. Daarvan lijkt De Waard uit te gaan. Het resultaat is uiteraard hoe dan ook aanvaardbaar, maar het zou zuiverder zijn om (schending van) het beginsel van hoor en wederhoor als grondslag daarvoor aan te wijzen indien artikel 7:9 analoog wordt toegepast.

Dat nóg een andere benadering mogelijk is, heeft de Centrale Raad in een aantal uitspraken laten zien. Hij overwoog dat er geen algemene verplichting tot het horen in dit soort gevallen uit artikel 7:2 Awb kan worden afgeleid - tot zover is er dus geen verschil met de benadering van de Afdeling - én dat er ook buiten de gevallen van artikel 7:3 Awb van het horen kan worden afgezien. Dat zal het geval zijn indien het horen niet meer dan een herhaling van bezwaren zal opleveren. Is dat niet het geval omdat sprake is van nieuwe feiten of omstandigheden waarop het besluit steunt, bestaat er grond om te horen, waarbij die plicht volgens de Centrale Raad uit artikel 7:2 Awb lijkt voort te

\footnotetext{
136. CRvB 15 april 1999, Rawb 1999/147 m.nt. Klap.

137. CRvB 3 mei 2002, TAR 2002/139.

138. AbRvS 4 mei 2005, JB 2005/186; AbRvS 22 september 2004, $A B$ 2005/202 m.nt. BdeW; $J B$ 2004/5 m.nt. Hamer. Zie ook: CBb 10 september 2002, JB 2002/373; AB 2003/54 m.nt. JHvdV, het CBb verwijst daarin naar zowel art. 7:9 Awb als art. 7:2 Awb.

${ }^{139}$. Noot bij AbRvS 22 september 2004, $A B$ 2005/202 m.nt. BdeW; JB 2005/5 m.nt. M.C.M. Hamer. Min of meer dezelfde formulering wordt gehanteerd in: AbRvS 26 april 2006, nr. 200509238/1; AbRvS 4 mei 2005, JB 2005/186.

${ }^{140}$ Zie bijvoorbeeld: AbRvS 4 mei 2005, JB 2005/186.
} 


\section{De inrichting van de voorprocedures}

vloeien. ${ }^{141}$ In dat laatste opzicht verschilt de benadering van de Centrale Raad derhalve van die van de Afdeling. De Centrale Raad sluit aan bij de algemene hoorplicht, zoals neergelegd in artikel 7:2 Awb. ${ }^{142}$ Deze benadering lijkt mij echter niet juist, aangezien die bepaling uitsluitend voorschrijft dat eenmaal gehoord moet worden, hetgeen reeds is geschied, en de vernietiging van het besluit op bezwaar luidt geen geheel nieuwe bezwaarschriftprocedure in. ${ }^{143}$

De hiervoor geschetste benaderingen zorgen al voor behoorlijk wat onduidelijkheid, maar er is een derde factor die de onduidelijkheid verder versterkt. De bestuursrechter lijkt de plicht tot horen na vernietiging van het besluit in sommige gevallen ook te baseren op het zorgvuldigheidsbeginsel. ${ }^{144}$ Voor het horen kan een noodzaak vanuit zorgvuldigheidsoogpunt bestaan, indien als gevolg van de vernietiging bij de besluitvorming nieuwe omstandigheden of argumenten, waar niet tijdens de eerste hoorzitting een reactie op gegeven kon worden, bij de besluitvorming moeten worden betrokken, aldus de Afdeling. ${ }^{145}$ Ook de Centrale Raad heeft geoordeeld dat een plicht tot horen uit zorgvuldigheidsoogpunt niet bestaat, indien de belanghebbende reeds is gehoord met betrekking tot de feiten en omstandigheden die ook aan nieuwe besluit op bezwaar ten grondslag liggen. ${ }^{146}$ Daaruit zou a contrario afgeleid kunnen worden dat de zorgvuldigheid wel noopt tot het horen, indien er sprake is van nieuwe feiten of omstandigheden. In deze benadering weten de bestuursrechters zich gesteund door Koenraad \& Sanders, die de grondslag voor het horen na vernietiging door de bestuursrechter van het besluit op bezwaar baseren op artikel 3:2 Awb. Zij merken echter tevens op dat de jurisprudentie over de reikwijdte van artikel 7:9 Awb een bruikbaar handvat kan vormen hierbij. ${ }^{147}$ Omdat, al dan niet analoog aan artikel 7:9 Awb, de achtergrond van een hoorplicht in dergelijke gevallen ook gelegen zal zijn in het verdedigingsbeginsel of het beginsel van hoor en wederhoor, is het echter opmerkelijk dat de bestuursrechter in dit soort gevallen voor een ongeschreven hoorplicht steun zoekt bij het zorgvuldigheidsbeginsel.

De benadering van de bestuursrechter is op het punt van de grondslag voor de eis om in dit soort gevallen te horen op zijn minst inconsistent. Het komt de duidelijkheid niet ten goede, indien de bestuursrechter wel uitdrukkelijk erkent dat aan artikel 7:9 Awb het beginsel van hoor en wederhoor ten grondslag ligt en deze bepaling in dit soort gevallen soms rechtstreeks toepast of daarnaar verwijst, maar in andere gevallen of tegelijkertijd teruggrijpt op het zorgvuldigheidsbeginsel of zelfs artikel 7:2 Awb. Het ligt meer voor de hand en het is consistenter om in dit soort gevallen, gelet op de gemeenschappelijke ratio achter de diverse hoorplichten, het beginsel van hoor en wederhoor (al dan niet in combinatie met artikel 7:9 Awb) aan te wijzen als grondslag. Hoe dat ook zij, alle gehanteerde benaderingen komen erop neer dat er geen algemene plicht tot het opnieuw horen bestaat, tenzij er sprake is van bijzondere of nieuwe omstandigheden. De redeneringen en grondslagen daarvoor verschillen slechts. ${ }^{148}$ In de jurisprudentie van de bestuursrechter zijn twee sporen te zien en wordt op twee gedachten gehinkt. Een verklaring voor deze wisselende benadering en de inconsistentie van de bestuursrechter is wellicht het tweeledige karakter van de bezwaarschriftprocedure.

\footnotetext{
${ }^{141 . ~ C R v B ~} 27$ juni 2007, RSV 2007/303; CRvB 6 november 2002, JB 2003/25 m.nt. JHK; RSV 2003/38 m.nt. R Stijnen; CRvB 8 januari 2002, $A B$ 2002/97 m.nt. HBr.

${ }^{142 .}$ Het $\mathrm{CBb}$ gaat overigens weleens voor twee ankers liggen in dit soort gevallen, art. 7:2 en 7:9 Awb, CBb 10 september 2002, $A B$ 2003/54 m.nt. JHvdV.

${ }^{143 .}$ Vgl. AbRvS 4 mei 2005, JB 2005/186.

144. AbRvS 9 januari 2008, $J B$ 2008/41; AbRvS 15 maart 2006, $J B$ 2006/123; AbRvS 17 september 2003, $A B$ 2004/195 m.nt. NV; CRvB 25 februari 2003, JB 2003/115 m.nt. C.L.G.F.H. A.; AbRvS 15 mei 1997, $A B$ $1997 / 263$.

145. AbRvS 9 januari 2008, JB 2008/41; AbRvS 17 september 2003, AB 2004/195 m.nt. NV.

146. CRvB 25 februari 2003, JB 2003/115 m.nt. C.L.G.F.H. A.

${ }^{147 .}$ Koenraad \& Sanders 2006, p. 63.

148. Zie ook de noot van Keinemans bij CRvB 6 november 2002, JB 2003/25.
} 
Deel II Bestuurlijke voorprocedures

\subsubsection{Andere mogelijkheden om informatie te verschaffen}

Horen van getuigen en deskundigen als onderdeel van hoor en wederhoor

Het recht van belanghebbenden om mondeling informatie te verschaffen aan het bestuur in de bezwaarschriftprocedure en het administratief beroep bestaat uit meer dan alleen het recht van de belanghebbenden om dat zélf te doen. De informatie die belanghebbenden kenbaar willen maken aan het bestuur, kan ook afkomstig zijn van getuigen of deskundigen. Uit het beginsel van hoor en wederhoor vloeit voor de rechterlijke procedure voort dat de belanghebbende de mogelijkheid heeft om deze getuigen of deskundigen mondeling een verklaring te laten geven ten overstaan van de rechter (en de wederpartij). ${ }^{149}$ Onder het recht om informatie te verschaffen als onderdeel van hoor en wederhoor schaart De Waard dan ook de gelegenheid tot het doen horen van getuigen en/of deskundigen. ${ }^{150}$ De Awb-wetgever heeft in bezwaar en administratief beroep voorzien in een bepaling waaruit blijkt dat ook in die bestuurlijke fasen meegebrachte getuigen of deskundigen namens de belanghebbende kunnen worden gehoord door het bestuur, te weten artikel 7:8 en 7:22 Awb. Dat betekent dat belanghebbenden hun standpunten en bezwaren in de bestuurlijke voorfase kunnen onderbouwen of adstrueren dan wel bewijs daarvan kunnen leveren door middel van mondelinge verklaringen van getuigen en/of deskundigen.

Door het recht om getuigen of deskundigen te laten horen wordt voornamelijk de (mondelinge) verweermogelijkheden van belanghebbenden gewaarborgd, maar tegelijkertijd kunnen de verklaringen van deze getuigen ook de zorgvuldigheid van de besluitvorming dienen. In de parlementaire geschiedenis van deze bepaling wordt slechts opgemerkt dat deze regel aansluit bij de praktijk en dat het nuttig is om deze regel voor de bezwaarschriftprocedure uitdrukkelijk vast te leggen. ${ }^{151}$ Een verband met het beginsel van hoor en wederhoor wordt door de wetgever en de doctrine niet expliciet gelegd. In de rechtspraak is dit echter - hoewel de bepaling nauwelijks aan de orde is gekomen daarin - een enkele maal wel het geval. De president van de rechtbank Zutphen doet dat bijvoorbeeld door op te merken dat een goede procesorde vereist dat partijen en hun raadslieden het recht hebben om aanwezig te zijn bij het horen van getuigen door de bezwarencommissie. ${ }^{152}$

\section{Hoor en wederhoor en equality of arms}

Uit de tekst van de bepaling kan worden afgeleid dat het de wetgever voor ogen stond dat zowel de belanghebbenden als de getuigen en deskundigen op een en dezelfde hoorzitting gehoord worden. De bepaling rept immers van door de belanghebbende meegebrachte getuigen of deskundigen. De bepaling stelt dit door de gekozen formulering echter niet expliciet buiten twijfel. Wel geldt op grond van artikel 7:6 Awb dat belanghebbenden in beginsel gezamenlijk worden gehoord, hetgeen meebrengt dat meegebrachte getuigen ook in aanwezigheid van alle belanghebbenden zullen worden gehoord. Hier lijkt sprake van eis die vooral vanuit een oogpunt van hoor en wederhoor en equality of arms wordt gesteld. ${ }^{153}$ Iedere belanghebbende (of diens vertegenwoordiger) moet de gelegenheid krijgen te reageren op de verklaringen van de getuigen of deskundigen. Dat hoeft echter niet tijdens de hoorzitting waarin deze personen worden gehoord te zijn, aldus de bestuursrechter, mits het geschiedt voordat het advies van de adviescommissie of besluit op bezwaar tot stand is gekomen. ${ }^{154}$ Wel kan het zo zijn dat het horen van

\footnotetext{
149. Zie par. 4.3.6 van Deel I.

${ }^{150 .}$ De Waard 1987, p. 301 en 313 e.v.

151. PG Awb I, p. 344. Zie ook: Notten 1998, p. 223

152. Pres. Rb. Zutphen 11 november 1999, JB 2000/17.

${ }^{153 .}$ Op het vereiste van equality of arms en de implicaties ervan in de bezwaarschriftprocedure wordt in par. 5.3.5 nader ingegaan.

154. CRvB 4 december 1997, JB 1998/38.
} 


\section{De inrichting van de voorprocedures}

getuigen of deskundigen in afwezigheid van een of meer belanghebbenden ertoe kan leiden dat er een hernieuwde hoorplicht ontstaat ten aanzien van die belanghebbenden, ingevolge artikel 7:9 Awb, omdat daaruit nieuwe feiten of omstandigheden van aanmerkelijk belang naar voren zijn gekomen. Uit dien hoofde is dan een mogelijkheid tot reageren vereist. ${ }^{155}$

Indien een commissie is ingesteld die voldoet aan de vereisten neergelegd in artikel 7:13 eerste lid van de Awb, is deze commissie belast met het horen van belanghebbenden, ingevolge het derde lid van die bepaling. In het verlengde daarvan (nu deze bevoegdheid niet aan de commissie is toegekend in artikel 7:13 lid 4 Awb) moet worden aangenomen dat de commissie dan ook belast is met het horen van meegebrachte getuigen of deskundigen. ${ }^{156}$ Omdat een vertegenwoordiger van het bestuur voor het horen wordt uitgenodigd, betekent dit in de praktijk dat de getuigen in beginsel in het bijzijn van de belanghebbenden en de vertegenwoordiger van het bestuur zullen worden gehoord. ${ }^{157}$

Uit de tekst van de bepaling volgt overigens dat de belanghebbende niet per definitie vooraf de komst van de getuige of deskundige hoeft aan te kondigen. Het lijkt mij echter in verband met de verweermogelijkheden en de voorbereidingsmogelijkheden van de andere belanghebbenden wel gewenst. Indien de getuigen niet worden aangekondigd en wel worden gehoord tijdens de hoorzitting, bestaat er een kans dat andere belanghebbenden daardoor overvallen kunnen worden en niet voldoende gelegenheid hebben gehad om zich daarop voor te bereiden. Het recht om informatie te verschaffen van de ene belanghebbende, conflicteert in deze situatie met de verweermogelijkheden van de andere belanghebbenden. De Waard geeft aan dat voor het administratief beroep voor de inwerkingtreding van de Awb ook erkend werd dat er een mogelijkheid moest bestaan om getuigen of deskundigen te doen horen, maar dat deze dan wel tijdig aangezegd moesten worden. ${ }^{158}$ Hoewel een dergelijke begrenzing niet door artikel 7:8 Awb of de jurisprudentie voorgeschreven wordt, ligt het wel in de rede om deze aan te nemen. Op dat standpunt stellen ook Koenraad en Sanders zich. Zij menen dat het verdedigingsbeginsel eist dat alle belanghebbenden tijdig op de hoogte worden gesteld van het verzoek (van een belanghebbende) om getuigen of deskundigen te horen alsmede de beslissing daarop. ${ }^{159} \mathrm{Op}$ het recht om informatie te ontvangen over de procedure, waaronder dit aspect geschaard kan worden, wordt in paragraaf 5.3.4.2 nader ingegaan.

De weigering om getuigen te horen op grond van artikel 7:8 Awb

Artikel 7:8 Awb geeft geen duidelijkheid inzake de vraag wanneer het horen van meegebrachte getuigen of deskundigen geweigerd kan worden. Doordat de wetgever een discretionaire bevoegdheid toekent aan het bestuur, heeft het bestuur de mogelijkheid om van het horen van getuigen en deskundigen af te zien. Een wettelijk criterium of voorwaarden voor de toepassing van die bevoegdheid ontbreken echter. Over het al dan niet toepassen van de bevoegdheid om meegebrachte getuigen of deskundigen te horen is ook nauwelijks jurisprudentie voorhanden. Dat zou kunnen betekenen dat het horen van door belanghebbenden meegebrachte getuigen niet of nauwelijks voor problemen zorgt in de praktijk en dat het bestuursorgaan daartoe in de meeste gevallen zal overgaan. Aangenomen kan immers worden dat indien het bestuur dit achterwege laat, terwijl een belanghebbende daarom uitdrukkelijk verzocht heeft, deze in de beroepsprocedure dat oordeel

\footnotetext{
${ }^{155 .}$ Zie de uitspraak aangehaald in de noot hiervoor.

156. Zie ook Koenraad \& Sanders 2006, p. 76. Zij pleiten eveneens voor een redelijke wetsuitleg in dit kader.

157. Dit lijdt slechts uitzondering indien besloten wordt op grond van art. 7:6 Awb om belanghebbenden niet gezamenlijk te horen. In dat geval zullen ook de door hen meegebrachte getuigen en deskundigen niet in het bijzijn van alle betrokkenen worden gehoord (hierover meer in par. 5.3.5)

158. De Waard 1987 , p. 315

${ }^{159 .}$ Koenraad \& Sanders 2006, p. 77.
} 


\section{Deel II Bestuurlijke voorprocedures}

zal aanvechten. ${ }^{160}$ Een conclusie in dat kader valt echter moeilijk te trekken zonder empirisch onderzoek naar de toepassing van deze bepaling door bestuursorganen, zeker gelet op de filterwerking van de bezwaarschriftprocedure. Koenraad en Sanders merken op dat zij de indruk hebben dat nauwelijks gebruik wordt gemaakt van de bevoegdheid om tijdens de bezwaarfase getuigen of deskundigen te horen. ${ }^{161}$

Een belanghebbende doet er in elk geval verstandig aan om de getuige of deskundige mee te brengen of diens verklaring in bezwaar naar voren te brengen. Indien het bestuur daarmee ten onrechte geen rekening houdt, kan de bestuursrechter in beroep daarover desgevraagd een oordeel vellen. Bovendien kan het zo zijn dat de bestuursrechter in de beroepsfase weigert getuigen of deskundigen te horen, omdat zulks al in de bezwaarfase had moeten geschieden (althans door de bezwaarmaker aangeboden had moeten worden). ${ }^{162}$ Hier zou zich de trechter- of fuikbenadering die met name de Afdeling leek voor te staan tussen bezwaar en beroep ten aanzien van bewijs kunnen wreken, hoewel die de afgelopen tijd aanzienlijk gemitigeerd lijkt te zijn. ${ }^{163}$ In elk geval kan de bestuursrechter dan beoordelen of de verklaring van de getuige of deskundige relevant is en eventueel gevolgen verbinden aan de omstandigheid dat het horen achterwege is gelaten.

Uit de schaarse jurisprudentie die omtrent artikel 7:8 Awb voorhanden is, kan in elk geval het volgende worden afgeleid. Indien een getuigenverklaring niet relevant is of niets kan toevoegen aan hetgeen reeds bekend is of ingebracht is, behoeft het bestuur de getuige of deskundige niet te horen. De Afdeling stelt zich op het standpunt dat artikel 7:8 Awb niet verplicht tot het afleggen van getuigenverklaringen waaraan voor de beoordeling van de zaak geen behoefte bestaat. Volgens de Afdeling is er ook overigens geen rechtsregel die een dergelijke verplichting met zich mee zou brengen. ${ }^{164}$ Dat lijkt als zodanig een aanvaardbare benadering. Het is niet zinvol om getuigen te horen die niets kunnen toevoegen aan de behandeling van de zaak. Het beginsel van hoor en wederhoor (waaraan de Afdeling wellicht refereert indien zij spreekt over 'ook overigens is er geen rechtsregel') noopt daartoe ook niet. ${ }^{165}$

De Centrale Raad heeft de weigering van een bezwarencommissie op een verzoek om meegebrachte getuigen te horen vanwege de omstandigheden dat de komst van de getuigen niet tevoren was aangekondigd, dat de gemachtigde vooraf mededeelde niet op de hoogte te zijn wat en waarover de getuigen zouden gaan verklaren alsmede dat partijen en de moeder van de man wel waren gehoord, gebillijkt. ${ }^{166}$ De Centrale Raad weegt daarbij echter mee dat de getuigen in de procedure bij de rechtbank meegebracht hadden kunnen worden alsook dat in hoger beroep alsnog, na aankondiging van het tegendeel, uitdrukkelijk is afgezien van het meebrengen van de getuigen. Het lijkt erop dat de Centrale Raad uit de houding van de belanghebbende (althans de gemachtigde) in beroep en hoger beroep afleidt dat de verklaringen niet van groot belang zijn dan wel dat deze zijn recht om te klagen over het niet horen door die houding heeft verspeeld.

Ook in het kader van de procedure bij de bestuursrechter bestaat de mogelijkheid voor belanghebbenden om getuigen of deskundigen mee te brengen. De bestuursrechter heeft, ingevolge artikel 8:63 tweede lid Awb, eveneens de bevoegdheid om deze niet te

\footnotetext{
${ }^{160 .}$ Omdat het een procesbeslissing betreft, staat hiertegen geen zelfstandig beroep open bij de bestuursrechter en zal de belanghebbende in het kader van het beroep tegen het besluit op bezwaar daartegen moeten opkomen.

${ }^{161 .}$ Koenraad \& Sanders 2006, p. 76.

162. Zie bijv.: AbRvS 13 februari 2002, AB 2002/123; Vz. AbRvS 31 maart 1994, AB 1994/479 m.nt. P.J.J. van Buuren.

163. Zie daarover: Zie: Van Wijk/Konijnenbelt \& Van Male 2008, p. 655-656; Ortlep 2005, p. 3. Vgl. ook: C.L.G.F.H. Albers \& R.J.N. Schlössels, 'De omvang van het bestuursrechtelijk geding: het Europese recht als het paard van Troje? Over de (on)toelaatbaarheid van procestechnische trechters en ambtshalve rechtstoepassing', Gst. (2005) 7224, p. 84-85. Voor een overzicht van de jurisprudentie verwijs ik naar: Willemsen 2005, p. 96-99. Verder over de trechter tussen bezwaar en beroep in eerste aanleg: Rapport VAR-Commissie Rechtsbescherming 2004, p. 108-114.

164. AbRvS 11 mei 2005, JB 2005/188.

165. Vgl. De Waard 1987, p. 314-315.

166. CRvB 14 januari 2003, LJN AF6338.
} 


\section{De inrichting van de voorprocedures}

horen. Van die bevoegdheid mag hij gebruik maken als duidelijk is dat het horen niet zinvol is. ${ }^{167}$ In de jurisprudentie is bepaald dat het horen van getuigen of deskundigen achterwege kan worden gelaten, indien de verklaring niets toevoegt. ${ }^{168}$ Het ligt voor de hand om aan te nemen dat de bestuursrechter hetzelfde criterium hanteert voor de toepassing van artikel 7:8 Awb als voor 8:63 tweede lid Awb en in beide gevallen beoordeelt of de verklaring toegevoegde waarde heeft.

\subsubsection{De gevolgen van schendingen van het recht om mondeling informatie te verschaffen}

In de onderhavige paragraaf wordt, voor zover mogelijk, ingegaan op de gevolgen die verbonden worden aan schendingen van de verschillende rechten van belanghebbenden om mondeling informatie te verschaffen in de bestuurlijke voorprocedures.

\section{Gevolgen van schending van de hoorplicht: rechtsbescherming en verlengde besluitvorming}

De hoorplicht in de bezwaarschriftprocedure vormt een essentieel onderdeel in die procedure en moet mede worden gezien als een uitwerking van het beginsel van hoor en wederhoor in die fase. Wat nu als het bestuur ten onrechte een belanghebbende niet heeft gehoord? Welke gevolgen dienen daaraan, gelet op het belang dat aan het horen gehecht wordt, te worden verbonden?

In beginsel heeft de bestuursrechter twee mogelijkheden: ofwel de schending leidt per definitie tot vernietiging van de beslissing op bezwaar (eventueel met instandlating van de rechtsgevolgen op grond van artikel 8:72 derde lid van de Awb) ofwel onder omstandigheden kan de schending van vormvoorschriften door de bestuursrechter worden gepasseerd door toepassing van artikel 6:22 Awb. ${ }^{169}$ De wetgever zelf heeft in de toelichting op artikel 6:22 Awb uitdrukkelijk aangegeven dat de regels omtrent het horen behoren tot vormvoorschriften waarbij de bestuursrechter op grond van deze bepaling de bevoegdheid heeft om schending daarvan te passeren, mits belanghebbenden niet benadeeld worden daardoor. ${ }^{170}$ Dat laatste betekent dat schendingen van de hoorplicht gepasseerd kunnen worden voor zover ook indien de hoorplicht was nageleefd geen andere uitkomst van de besluitvorming mogelijk was geweest. ${ }^{171}$ Was een ander besluit mogelijk geweest, dient de schending te leiden tot vernietiging. De bestuursrechter heeft zich regelmatig uitgelaten over de vraag welke gevolgen verbonden moeten worden aan een schending van de hoorplicht als neergelegd in artikel 7:2 en 7:3 en volgt de benadering van de wetgever niet altijd. ${ }^{172}$ De Centrale Raad lijkt zich daarbij in beginsel wel aan de

\footnotetext{
167. Aldus de wetgever: Kamerstukken II 1997/98, 25 175, nr. 5, p. 18 (NnavV Herziening fiscaal procesrecht). ${ }^{168 .}$ CRvB 6 mei 2008, $A B$ 2008/243 m.nt. Hbr; AbRvS 22 augustus 2007, AB 2008/72 m.nt. O.J.D.M.L. Jansen. Vgl.: AbRvS 26 juni 2007, $A B$ 2008/88 m.nt. O.J.D.M.L. Jansen.

169. Een vormvoorschrift is een voorschrift dat geen eisen stelt aan de materiële inhoud van een besluit en maar ziet op de procedure van totstandkoming of de wijze waarop het besluit moet worden genomen of vastgelegd, PG Awb I, p. 314. Zie over art. 6:22 Awb en de toepassing in de praktijk: Schreuder-Vlasblom 2008, p. 420-424; B.W.N. de Waard, 'Commentaar art. 6:22', in: M. Scheltema, R.M. van Male, B.W.N. de Waard, A.T. Marseille, A.J.C. de Moor-van Vugt (red.), Losbladig commentaar Algemene wet bestuursrecht, Amsterdam: Reed Elsvevier (voorheen Den Haag: VUGA), losbladige uitgave, p. E 6.2.14-1/12; N.M. Van Waterschoot, 'Het door de vingers zien van gebreken die de materiële inhoud niet raken', JB-plus 2002, p. 181-194; A.R. Neerhof, 'Van effectieve bestuursrechters en geschillen die voorbijgaan...? De bevoegdheden van de bestuursrechter om geschillen definitief op te lossen, JB-plus 1999 (hierna: Neerhof 1999b), p. 73 e.v. In de toekomst zullen ook schendingen van materiële voorschriften gepasseerd kunnen worden op grond van art. 6:22 Awb. De Awb zal daartoe gewijzigd worden, zie het wetsvoorstel 'Aanpassing bestuursprocesrecht', Kamerstukken II 2009/10, 32 450 , nrs. 1-3.Eenzelfde bepaling is ook reeds opgenomen in artikel 1.5 van de Crisis- en herstelwet die op 31 maart 2010 in werking is getreden. Zie hierover par. 1.5 van Deel II en par. 3 van Deel III.

${ }^{170 .}$ PG Awb I, p. 314. Zie ook: Schueler e.a. 2007, p. 65-69; Van Waterschoot 2002, p. 187; Neerhof 1999b, p.

75. Koenraad is het daar overigens niet mee eens, Koenraad 2008a, p. 211.

171. PG Awb I, p. 313.

172. Zie ook Neerhof 1999 b, p. 75 met verwijzingen.
} 


\section{Deel II Bestuurlijke voorprocedures}

bedoeling van de wetgever te conformeren. Voor de Centrale Raad lijkt met name de aard van de bevoegdheid van het bestuur doorslaggevend voor het antwoord op de vraag of een schending van de hoorplicht gepasseerd kan worden. Is sprake van een bevoegdheid met discretionaire elementen ligt volgens de Centrale Raad het passeren van de schending niet in de rede. ${ }^{173}$ In die gevallen kan immers nog tot een ander besluit worden gekomen en is een belanghebbende wel degelijk benadeeld door de schending omdat het horen in bezwaar niet op dezelfde lijn kan worden gesteld als het horen in beroep bij de rechtbank aangezien in bezwaar ook beleidsaspecten een rol kunnen spelen bij de heroverweging. ${ }^{174} \mathrm{Bij}$ de uitoefening van gebonden bevoegdheden lijkt een schending in de meeste gevallen niet tot vernietiging te leiden omdat enerzijds geen ander besluit kan worden genomen en anderzijds de beoordeling van de rechter, nu daarbij slechts rechtmatigheidsaspecten een rol kunnen spelen, niet wezenlijk verschilt van die van het bestuur in de bezwaarfase. ${ }^{175}$ In de door de Centrale Raad gehuldigde opvatting werkt het traditionele onderscheid tussen bestuur en rechtspraak derhalve door in de vergelijking tussen het horen in de bezwaarfase en de mondelinge behandeling van het beroep bij de bestuursrechter en kan om die reden een schending van de hoorplicht in bezwaar niet hersteld worden in beroep. Ook onafhankelijk van de aard van de bevoegdheid neemt de Centrale Raad soms aan dat een belanghebbende niet is benadeeld. Die situatie deed zich voor in de ogen van de Raad toen een belanghebbende kort voor het besluit op bezwaar in een andere bezwaarschriftprocedure wel was gehoord en deze zich hierbij had kunnen uitspreken over het rapport dat ten grondslag lag aan het besluit op bezwaar. ${ }^{176}$ Feitelijk had appellante zich kunnen uitlaten over het rapport en was zij door het niet horen in bezwaar derhalve niet benadeeld, aldus de Centrale Raad in navolging van de rechtbank. De rechtbank had echter het besluit op bezwaar vernietigd en de rechtsgevolgen in stand gelaten en het bestuur in de proceskosten veroordeeld, terwijl de Centrale Raad om dezelfde reden toepassing van artikel 6:22 Awb aangewezen achtte. Het bestuursorgaan was het met name vanwege de proceskostenveroordeling niet eens met de uitspraak van de rechtbank en betoogde dat de rechtbank ten onrechte geen toepassing had gegeven aan artikel 6:22 Awb. De Centrale Raad onderschrijft dat oordeel en overweegt dat de rechtbank de proceskostenveroordeling niet had mogen uitspreken. Wellicht dat voor de Centrale Raad ook meer in het algemeen meespeelt dat een gegrond beroep en vernietiging in beginsel leiden tot een proceskostenveroordeling ${ }^{177}$, terwijl deze bij toepassing van artikel 6:22 Awb eerder achterwege blijft. ${ }^{178}$ Er zijn echter, zoals aangegeven, ook uitspraken van de Centrale Raad waaruit volgt dat een schending van de hoorplicht niet gepasseerd kan worden. ${ }^{179}$

De Afdeling lijkt in dit verband minder waarde te hechten aan de aard van de bevoegdheid waarvan de uitoefening in het geding is. De Afdeling hanteert als uitgangs-

\footnotetext{
173. Zie bijvoorbeeld: CRvB 4 januari 2000, $A B$ 2000/146 m.nt. HBr en CRvB 4 januari 2000, $A B$ 2000/147 m.nt. $\mathrm{HBr}$ bij de hiervoor genoemde uitspraak; CRvB 21 juli 1998, RSV 1998/306; CRvB 23 december 1996, $A B$ 1997/239 m.nt. HBr; JB 1997/28 m.nt. Red.

174. Zie in deze zin: CRvB 23 december 1996, AB 1997/239 m.nt. HBr. Uiteraard kan de Centrale Raad wel na vernietiging besluiten om de rechtsgevolgen van het besluit alsnog in stand te laten.

${ }^{175}$. Zie ook de noot van Bröring bij de in de vorige noot genoemde uitspraak.

176. CRvB 23 juli 1996, RSV 1996/241.

177. De bestuursrechter hanteert als uitgangspunt immers dat wanneer een belanghebbende deels of geheel in het gelijk gesteld wordt dat de proceskosten vergoed behoren te worden. Zie: HR 12 mei 2006, $A B$ 2006/303 m.nt. Knijff. Overigens is ook zonder vernietiging van het besluit een proceskostenvergoeding mogelijk, zie art. 8:75 Awb. Zie ook: CRvB 26 april 2005, JB 2005/217; CRvB 4 juli 2003, JB 2003/268; CRvB 23 december 1996, AB 1997/239 m.nt. HBr, JB 1997/28 m.nt. Red.

178. CRvB 27 augustus 2008, JB 2008/260 m.nt. C.L.G.F.H. A.; CRvB 21 december 2000, JB 2001/50 m.nt. ARN. In Rb. Maastricht 30 maart 1995, JB 1995/149 m.nt. R.J.G.H. S. wordt art. 6:22 Awb toegepast én een proceskostenvergoeding toegekend.

179. Er vindt dan vernietiging plaats en veelal instandlating van de rechtsgevolgen, zie bijv.: CRvB 26 april 2005 , $J B$ 2005/217; CRvB 4 juli 2003, $J B$ 2003/268; CRvB 20 mei 2003, $J B$ 2003/193; CRvB 6 november 2002, $J B$ 2003/25 m.nt. JHK; CRvB 23 december 1996, JB 1997/28 m.nt. Red; CRvB 13 juli 1995, JB 1995/222 m.nt. Red.
} 


\section{De inrichting van de voorprocedures}

punt dat een schending van de hoorplicht niet kan worden gepasseerd met toepassing van artikel 6:22 Awb en dat het besluit vernietigd dient te worden zonder daarbij een onderscheid te maken naar gelang het meer of minder discretionaire karakter van de bevoegdheid. ${ }^{180}$ Verheij merkt hierover op in een noot bij een uitspraak van 18 augustus 2004 van de Afdeling dat de reden voor het categorisch uitsluiten van toepassing van artikel 6:22 Awb waarschijnlijk gelegen is in het belang dat de Afdeling hecht aan het horen in bezwaar. ${ }^{181}$ In die uitspraak was overigens duidelijk dat het bestuursorgaan geen ander besluit had kunnen nemen en het horen van belanghebbenden dus ook niet tot een ander resultaat had kunnen leiden. De Afdeling vernietigt het besluit desondanks maar laat vervolgens, vanwege het feit dat geen andere uitkomst mogelijk is, de rechtsgevolgen van het besluit in stand. De Afdeling heeft ook in andere uitspraken expliciet laten blijken dat op een schending van de hoorplicht vernietiging dient te volgen, maar vervolgens de rechtsgevolgen van het besluit in stand kunnen worden gelaten. ${ }^{182}$ Ook ben ik een uitspraak tegengekomen waarin de Afdeling oordeelt dat de rechtbank terecht het besluit vernietigd heeft wegens schending van de hoorplicht alsmede terecht vervolgens zelf in de zaak heeft voorzien nu rechtens nog maar een besluit mogelijk was. ${ }^{183}$

De Afdeling lijkt derhalve een voorkeur te hebben voor het niet passeren van een schending van de hoorplicht en na vernietiging, indien slechts één besluit rechtens juist kan zijn te volstaan met ofwel instandlating van de rechtsgevolgen ofwel het zelf in de zaak voorzien. Voor de laatste twee opties, zo werd tot voor kort wel aangenomen, was slechts plaats, indien rechtens nog maar een besluit mogelijk is. Daarvoor lijkt evenwel thans meer ruimte te bestaan. ${ }^{184}$ In een andere uitspraak overwoog de Afdeling echter weer dat belanghebbenden niet benadeeld zijn door de schending van artikel 7:2 en vernietiging met toepassing van artikel 6:22 Awb achterwege wordt gelaten. ${ }^{185}$ Daarbij moet de kanttekening geplaatst worden dat het in dat geval belanghebbenden betrof die geen bezwaar hadden gemaakt, maar wel een zienswijze hadden uitgebracht tegen het voornemen en het besluit op bezwaar slechts gunstige gevolgen had voor hen. Deze uitspraak lijkt derhalve eerder een incident te zijn dan een wijziging in benadering.

De algemene benadering van de Afdeling spreekt mij - gelet op het belang dat gehecht moet worden aan het horen - meer aan dan die van de Centrale Raad. Hoewel ik mij kan voorstellen dat vernietiging slechts nuttig is indien het bestuur ook opnieuw een besluit op bezwaar moet nemen dat eventueel een andere inhoud kan krijgen, geeft een vernietiging duidelijk aan het bestuur aan dat het een rechtsplicht geschonden heeft. ${ }^{186}$ Het bestuur wordt zich op deze wijze terdege bewust van het belang van de hoorplicht en zal daar niet lichtvaardig mee omgaan. Anderzijds heeft de wetgever uitdrukkelijk beoogd de regels omtrent het horen onder de werking van artikel 6:22 Awb te brengen en is de benadering van de Centrale Raad daarmee in overeenstemming. Dezelfde uitkomst kan echter ook bereikt worden als de Centrale Raad net als de Afdeling er voor kiest om de rechtsgevolgen in stand te laten, indien een ander besluit niet tot de mogelijkheden behoort. Daaraan kleeft echter het gevolg dat vrijwel altijd een vergoeding van de pro-

\footnotetext{
${ }^{180 .}$ AbRvS 18 augustus 2004, $A B$ 2004/416 m.nt. NV; AbRvS 31 juli 2000, JB 2000/269 m.nt. Red.

181. AbRvS 18 augustus 2004, $A B$ 2004/416 m.nt. NV.

182. Zie: AbRvS 31 juli 2000, $J B$ 2000/269 m.nt. Red. Uit verschillende uitspraken waarin een schending van artikel 7:2 aan de orde werd gesteld en de rechtbank de schending niet onderkend had, valt ook impliciet op te maken dat de Afdeling daarvoor een voorkeur heeft, zie bv.: AbRvS 2 juli 2003, JB 2003/230. Dan vernietigt de Afdeling de uitspraak van de rechtbank en verklaart (doende hetgeen de rechtbank had moeten doen) de beroepen gegrond, vernietigt de besluiten maar laat de rechtsgevolgen in stand.

183. AbRvS 30 juni 2004, JB 2004/292.

${ }^{184 .}$ De afgelopen tijd is er in de jurisprudentie een ontwikkeling op gang gekomen waarin ten behoeve van finale geschilbeslechting eerder overgegaan wordt tot gebruikmaking van deze bevoegdheden door de bestuursrechter, zie hierover par. 4.3.9 van Deel I.

185. Zie bijvoorbeeld: AbRvS 8 oktober 2003, JB 2003/320.

186. Zie ook: Koenraad 2008a, p. 210 e.v. Koenraad wijst er wel op dat het instandlaten van de rechtsgevolgen merkwaardige gevolgen kan hebben als het besluit op bezwaar strekt tot herroeping en vervanging van een primair besluit. Die situatie wordt hier buiten beschouwing gelaten.
} 


\section{Deel II Bestuurlijke voorprocedures}

ceskosten behoort plaats te vinden. Als uitgangspunt geldt immers dat de bestuursrechter gebruik maakt van de hem toekomende bevoegdheid om dat te doen, indien een belanghebbende deels of geheel in het gelijk wordt gesteld en het besluit deels of geheel vernietigt. $^{187}$

Gevolgen schending artikel 7:9 Awb

Zoals Koenraad opmerkt, is ook niet geheel duidelijk uit de jurisprudentie van de bestuursrechter op te maken welke gevolgen een schending van artikel 7:9 Awb dient te hebben. ${ }^{188}$ Een schending van artikel 7:9 Awb lijkt in veel gevallen tot vernietiging van het bestreden besluit te leiden, waarna het bestuur een nieuw besluit dient te nemen. ${ }^{189}$ De rechtsgevolgen van het bestreden besluit worden na vernietiging op grond van artikel 8:72 derde lid van de Awb niet snel in stand gelaten. In een uitspraak overwoog het College van Beroep voor het bedrijfsleven dat daarvoor slechts plaats is, indien appellant alsnog in beroep in de gelegenheid was gesteld om te reageren op het feit van aanmerkelijk belang. ${ }^{190}$ Een enkele keer worden de rechtsgevolgen van het besluit wel in stand gelaten. ${ }^{191}$ Daarbij lijkt de aard van de bevoegdheid waarvan de uitoefening in het geding is - in afwijking van hetgeen in het kader van artikel 7:2 het geval lijkt te zijn - geen noemenswaardige rol te spelen. Soms wordt, hoewel vernietiging van het besluit uitgangspunt is, de schending van artikel 7:9 Awb geacht voldoende te zijn hersteld door de gelegenheid tot het geven van een mondelinge toelichting in beroep en/of hoger beroep, hetgeen aanleiding vormt om de rechtsgevolgen in stand te laten. ${ }^{192}$

In de literatuur is ook wel gesteld dat een schending van artikel 7:9 Awb gepasseerd kan worden met toepassing van artikel 6:22 Awb, omdat eveneens sprake is van een vormvoorschrift. ${ }^{193}$ Desalniettemin worden deze schendingen door de bestuursrechter niet snel gepasseerd met toepassing van artikel 6:22 Awb. ${ }^{194}$ Daarvoor is vereist dat belanghebbenden door het niet horen niet in hun processuele belangen zijn geschaad of benadeeld en volgens de bestuursrechter is daarvan slechts sprake, indien zij zich op andere wijze over de nieuwe feiten of omstandigheden van gedachte hebben kunnen wisselen met het bestuur. ${ }^{195}$ De meer recente rechtspraak lijkt er ook op te duiden dat de bestuursrechter een voorkeur heeft voor vernietiging van het besluit. ${ }^{196}$ Dat is toch wel opmerkelijk te noemen, omdat de Centrale Raad ten aanzien van artikel 7:2 Awb en de reguliere hoorplicht toepassing van artikel 6:22 Awb niet uitsluit. Een verschil in karakter, vormvoorschrift of niet, bestaat niet tussen artikel 7:2 Awb en artikel 7:9 Awb.

In een geval waarin artikel 7:9 Awb strikt genomen niet van toepassing was, maar wel vanuit zorgvuldigheidsoogpunt een bepaald rapport overgelegd had moeten worden

\footnotetext{
${ }^{187 .}$ Damen e.a. 2009, Deel II, p. 299-300. Zie bijvoorbeeld: HR 12 mei 2006, AB 2006/303 m.nt. Knijff; AbRvS 26 september 2000, $A B$ 2000/484 m.nt. Sewandono; AbRvS 28 november 1997, JB 1997/9; CRvB 13 maart 1997, JB 1997/104

${ }^{188 .}$ Koenraad 2008b, p. 479 e.v.

189. Zie bijvoorbeeld: AbRvS 26 april 2006, JB 2006/184 m.nt. DWMW; AbRvS 4 mei 2005, JB 2005/186; AbRvS 16 februari 2005, JB 2005/102 m.nt. Hamer; AbRvS 17 maart 2003, JB 2004/184; AbRvS 5 juni 2002, $J B$ 2002/222; AbRvS 19 december 2001, JB 2002/46; AbRvS 29 juni 2000, JB 2000/223.

${ }^{190}$ Zie CBb 11 november 2005, JB 2006/46. Het gebrek was derhalve niet in beroep geheeld en het $\mathrm{CBb}$ daarom oordeelde dat de rechtbank ten onrechte de rechtsgevolgen in stand had gelaten.

${ }^{191 .}$ CRvB 4 december 1997, JB 1998/38.

192. CRvB 17 mei 2005, LJN AT8156, ABkort 2005/495.

193. Zie: N.M. Van Waterschoot, 'Het door de vingers zien van gebreken die de materiële inhoud niet raken', $J B$ plus 2002, p. 187. Zij verwijst daartoe naar AbRvS 30 november 1998, JB 1999/12 m.nt. RJNS.

${ }^{194 .}$ Uit AbRvS 12 oktober 2005, JB 2005/327 lijkt impliciet te blijken dat het passeren van een schending van art. 7:9 Awb wel mogelijk is. Zie ook: Pr. Rb. Zutphen 1 februari 1995, JB 1995/71.

195. AbRvS 7 mei 2008, AB 2009/4 m.nt. B.W.N. de Waard. Zie ook: AbRvS 16 februari 2005, JB 2005/102 m.nt. M.C.M. Hamer, waarin de Afdeling de mogelijkheid om gebruik te maken van inspreekrecht in de vergadering van de Commissie van Advies en de stadsdeelraad niet met het horen in de zin van art. 7:9 Awb gelijk te

stellen acht.
196. AbRvS 26 april 2006, JB 2006/184 m.nt. DWMW; AbRvS 4 mei 2005, JB 2005/186; AbRvS 16 februari 2005, JB 2005/102 m.nt. Hamer.
} 


\section{De inrichting van de voorprocedures}

en de belanghebbende in dat kader ten onrechte niet de gelegenheid was geboden om te reageren, liet de Centrale Raad na te vernietigen. Omdat de belanghebbende in beroep en hoger beroep voldoende gelegenheid had gehad om te reageren op het rapport werd door de vernietiging geen redelijk belang van appellant gediend. ${ }^{197}$ Zoals al eerder aangegeven, zou het ook hier de voorkeur verdienen om in deze gevallen wel te vernietigen en de rechtsgevolgen in stand te laten. Daarmee staat duidelijk vast dat een rechtsplicht geschonden is door het bestuur en wordt meer recht gedaan aan het fundamentele karakter van het beginsel van hoor en wederhoor. ${ }^{198}$ Bovendien kan vernietiging zoals hiervoor al werd aangegeven in verband met een proceskostenveroordeling van belang zijn. Daartegen kan worden ingebracht dat vernietiging van het besluit wegens schending van artikel 7:9 niet nodig is, omdat het gaat om een tweede hoorzitting en belanghebbenden al een keer mondeling hun belangen hebben kunnen verdedigen. Ik meen echter dat juist omdat het gaat om nieuwe feiten die van aanmerkelijk belang zijn horen in bezwaar en dus ook vernietiging bij nalaten ervan aangewezen is. Indien vervolgens geconstateerd moet worden dat belanghebbende(n) niets opschiet met een vernietiging omdat geen andere uitkomst mogelijk is, kan gekozen worden voor instandlating van de rechtsgevolgen.

De andere mogelijkheden om mondeling informatie te verschaffen

Als het gaat om de ongeschreven hoorplichten of reactiemogelijkheden, die voortvloeien uit ofwel het zorgvuldigheidsbeginsel ofwel het beginsel van hoor en wederhoor (dan wel artikel 7:2 Awb of artikel 7:9 Awb) geldt dat het bestreden besluit in beginsel vernietigd wordt, indien ten onrechte nagelaten is te horen of een reactiemogelijkheid te bieden. Dat geldt in elk geval voor het ten onrechte niet horen na vernietiging van een besluit door de bestuursrechter. ${ }^{199}$ Soms wordt vernietiging achterwege gelaten, indien de belanghebbende door de schending niet in zijn belangen is geschaad. ${ }^{20}$

Een schending van artikel 7:8 Awb als ten onrechte is nagelaten een meegebrachte getuige of deskundige te horen, zal in beginsel ook leiden tot vernietiging van het besluit is mijn verwachting. Omdat er echter nauwelijks jurisprudentie voorhanden is, is het lastig te voorspellen welke gevolgen er aan een schending verbonden zullen worden. Indien de betreffende getuige of deskundige in beroep of hoger beroep kan worden gehoord, is het gebrek hersteld en kan wellicht ook vernietiging van het besluit achterwege blijven (indien er geen sprake is van een besluit met andere uitkomst daardoor). ${ }^{201}$ Aangenomen mag worden dat de bestuursrechter op dezelfde wijze met schendingen van artikel 7:8 Awb zal omgaan als met schendingen van artikel 7:2 Awb en artikel 7:9 Awb. Dat zou betekenen dat onder omstandigheden een schending gepasseerd kan worden met toepassing van artikel 6:22 Awb. In hoeverre de bestuursrechter daartoe echter bereid zal zijn, is nog niet duidelijk.

\section{Conclusies}

Al met al ontstaat er een wisselend beeld wat betreft de gevolgen die de bestuursrechter verbindt aan schendingen van uitwerkingen van het beginsel van hoor en wederhoor in de bestuurlijke voorprocedures. In veel gevallen lijkt vernietiging van het besluit het uitgangspunt te zijn, maar tegelijkertijd worden schendingen van hoorplichten of de plicht tot het bieden van een reactiemogelijkheid in sommige gevallen gepasseerd. Bovendien lijken de verschillende bestuursrechtelijke rechtscolleges ten aanzien van de verschillende vereisten niet consistent te werk te gaan. Zo volgt vernietiging in de regel bij schending van artikel 7:9 Awb, maar bij schending van artikel 7:2 Awb lijkt voor de

\footnotetext{
197. CRvB 6 september 2002, RSV 2002/285; JB 2002/309.

198. Zie ook in deze zin: De Waard 1987, p. 310.

199. AbRvS 22 september 2004, JB 2005/5 m.nt. Hamer; CBb 10 september 2002, JB 2002/373; AB 2003/54 m.nt. JHvdV.

200. AbRvS 30 november 1998, JB 1999/12

${ }^{201 .}$ Daarop lijkt de volgende uitspraak van de CRvB te duiden: CRvB 14 januari 2003, LJN AF6338.
} 
Deel II Bestuurlijke voorprocedures

Centrale Raad de aard van de uitgeoefende bevoegdheid die in het geding is bepalend voor de vraag of een schending gepasseerd kan worden dan wel onherroepelijk leidt tot vernietiging.

\subsubsection{Het recht om schriftelijk informatie te verschaffen}

\subsubsection{Inleiding}

Naast het in de vorige paragraaf belichte recht van belanghebbenden om mondeling informatie te verschaffen, bevat de regeling van de bezwaarschriftprocedure en het administratief beroep in de Awb nog een tweetal andere mogelijke uitwerkingen van het beginsel van hoor en wederhoor. Het betreft eisen of waarborgen die met name het horen beogen te faciliteren. De desbetreffende voorschriften beogen te waarborgen dat belanghebbenden (ten behoeve daarvan) de beschikking hebben over alle relevante informatie voor de besluitvorming en ook alle in hun ogen relevante informatie ter beschikking kunnen stellen aan het bestuur. Het horen van belanghebbenden en hen de gelegenheid bieden om hun standpunt naar voren te brengen en toe te lichten is slechts zinvol, indien zij over de relevante stukken beschikken en ook zelf ter adstructie van hun standpunt stukken aan het bestuur kunnen overleggen. ${ }^{202}$ Het beginsel van hoor en wederhoor vereist dat een belanghebbende de mogelijkheid moet krijgen om deugdelijk verweer te voeren, althans zijn standpunt moet kunnen verdedigen. In de Awb zijn in de artikelen 7:4 en 7:18 enkele eisen neergelegd om de informatieverschaffing door het bestuur aan de belanghebbenden en het recht van de belanghebbenden om informatie te verschaffen te waarborgen. Vergelijkbare eisen voor de procedure bij de rechter kunnen worden beschouwd als een uitwerking van het beginsel van hoor en wederhoor (in ruime zin). ${ }^{203}$ In de artikelen 7:4 en 7:18 Awb is enerzijds neergelegd dat tot tien dagen voor het horen door belanghebbenden nadere stukken kunnen worden ingediend en anderzijds dat belanghebbenden een recht op inzage van de relevante stukken hebben. Het laatstgenoemde recht vormt het onderwerp van paragraaf 5.3.4. In de onderhavige paragraaf wordt uitsluitend ingegaan op de mogelijkheid om stukken in te dienen voor de hoorzitting. Bezien wordt in hoeverre de in deze bepalingen neergelegde waarborgen moeten worden gezien als een uitwerking van het beginsel van hoor en wederhoor.

\subsubsection{Het indienen van stukken in de bestuurlijke voorprocedures}

In het eerste lid van de artikelen 7:4 en 7:18 van de Awb is, zoals hiervoor al werd aangegeven, neergelegd, dat belanghebbenden tot tien dagen voor het horen de mogelijkheid hebben om nadere stukken in te dienen. Op deze wijze kunnen het bestuursorgaan en belanghebbenden tijdig voor de hoorzitting kennis nemen van de nadere stukken. ${ }^{204}$ De stukken dienen ter inzage te worden gelegd, zodat iedere belanghebbende deze (tijdig) kan raadplegen of een afschrift daarvan tegen vergoeding van de kosten kan verkrijgen, ingevolge het tweede en vierde lid. Niet alleen bezwaarmakers (of indieners van een beroepschrift) beschikken op grond van deze bepalingen over het recht om nadere stukken in te dienen. Hetzelfde geldt voor andere belanghebbenden, zoals in sommige gevallen de aanvrager van een vergunning (bij een positief besluit op de aanvraag) of de geadresseerde van een besluit (die niet de aanvrager is).

De mogelijkheid voor belanghebbenden om nadere stukken in te dienen, betekent in feite dat zij de gelegenheid hebben om hun standpunt nader toe te lichten, te onderbou-

202. Zie ook: Teunissen in zijn commentaar op art. 7:4 Awb, J.M.H.F Teunissen, 'Commentaar art. 7:4 Awb', in: M. Scheltema, R.M. van Male, B.W.N. de Waard, A.T. Marseille, A.J.C. de Moor- van Vugt (red.), Commentaar Algemene wet bestuursrecht, Amsterdam: Reed Elsevier (voorheen Den Haag: VUGA), losbladige uitgave, p. E 6.3.9-2.

203. De Waard 1987, p. 246-247 en 301. Zie par. 4.3.5 van Deel I.

204. PG Awb I, p. 338. 


\section{De inrichting van de voorprocedures}

wen of aan te vullen. Ook de mogelijkheid om (nader) bewijs te geven van hun (in het bezwaar- of beroepschrift ingenomen) standpunt valt daaronder. Zo bezien vormen deze bepalingen materieel een uitwerking van het beginsel van hoor en wederhoor. In de doctrine en jurisprudentie worden deze bepalingen echter nauwelijks expliciet in verband gebracht met dat beginsel. Dat geldt zeker voor artikel 7:18 Awb, nu daaraan als zodanig geen of nauwelijks aandacht wordt besteed. Voor het administratief beroep moet echter aangenomen worden dat hetgeen voor de bezwaarschriftprocedure geldt in beginsel ook voor die procedure geldt. ${ }^{205}$ Teunissen geeft wel aan dat de mogelijkheid om nadere stukken in te dienen in de bezwaarschriftprocedure een codificatie vormt van een ongeschreven regel die vóór de Awb reeds in de jurisprudentie van de bestuursrechter tot uitdrukking kwam. ${ }^{206}$ Hij wijst op een uitspraak van de Afdeling rechtspraak van de Raad van State waarin deze de mogelijkheid tot het indienen van nadere stukken baseert op een 'goed beginsel van procesvoering'. ${ }^{207}$ Koenraad en Sanders menen ook dat artikel 7:4 Awb in zijn geheel, maar ook het daarin neergelegde recht om stukken in te dienen in het perspectief van het verdedigingsbeginsel moet worden geplaatst. Dat leiden zij af uit het verband dat wordt gelegd met de goede procesorde. ${ }^{208}$ Koenraad neemt echter in een recente bijdrage een ander standpunt in en meent dat het recht om tot tien dagen voor de hoorzitting stukken in te dienen, niet genormeerd wordt door het beginsel van hoor en wederhoor, maar door de zorgvuldigheid van de besluitvorming en de noodzaak tijdig een besluit te nemen. ${ }^{209}$ Het is vooral de vraag in hoeverre en tot welk tijdstip de mogelijkheid bestaat om stukken in te dienen - de begrenzing van het recht om stukken in te dienen en niet het recht om dat te doen als zodanig - die in het teken van het beginsel van hoor en wederhoor of de goede procesorde wordt geplaatst. Een verband met het zorgvuldigheidsbeginsel, zoals soms het geval is bij het recht om mondeling informatie te verschaffen, wordt maar incidenteel uitdrukkelijk gelegd. In het onderstaande wordt ingegaan op de rol die de goede procesorde speelt bij het recht om stukken in te dienen in de bestuurlijke voorprocedures.

\subsubsection{Begrenzing door de goede procesorde}

De goede procesorde als maatstaf

In de toelichting bij artikel 7:4 Awb gaat de wetgever met name in op de vraag wat dient te gebeuren met stukken die niet binnen de door het eerste lid van de Awb voorgeschreven termijn worden ingediend. In de bepaling is immers zelf niet neergelegd welke consequenties daaraan moeten worden verbonden. Volgens de wetgever zijn de gevolgen van het overschrijden van de termijn ook van belang in verband met de termijn die geldt voor de ter inzage legging van die stukken op grond van artikel 7:4, eerste lid, van de Awb. ${ }^{210}$ Die is tenminste een week en latere indiening van de stukken, reduceert ook de termijn waarbinnen de stukken ter inzage kunnen worden gelegd. Het is echter, vanwege de wens de bezwaarschriftprocedure niet te zeer te formaliseren, aan het bestuursorgaan overgelaten om te beoordelen of toezending van later ingekomen stukken aan belanghebbenden dient plaats te vinden. De goede procesorde is daarbij maatgevend. ${ }^{211}$ Afhankelijk van de omstandigheden kan met de nader ingekomen stukken rekening worden gehouden, maar belanghebbenden mogen daardoor niet in hun verweermogelijkheden

\footnotetext{
${ }^{205 .}$ In de onderhavige paragrafen komt het administratief beroep dan ook niet meer expliciet (afzonderlijk) aan de orde.

206. Teunissen, p. E 6.3.9-3.

207. Teunissen, p. E 6.3.9-3.

${ }^{208 .}$ Koenraad \& Sanders 2006, p. 77-78.

209. Koenraad 2008b, p. 477

210. PG Awb I, p. 338.

211. PG Awb I, p. 338.
} 


\section{Deel II Bestuurlijke voorprocedures}

worden geschaad. ${ }^{212}$ In de Memorie van Antwoord benadrukt de wetgever dat de tiendagen-termijn als hoofdregel moet worden gezien en dat het bestuur daar slechts van kan afwijken voor zover daardoor geen procesbelang wordt geschaad. ${ }^{213}$ Wel verwijst de wetgever nog naar artikel 7:9 van de Awb als eventuele mogelijkheid om nieuwe informatie toch mee te nemen en belanghebbenden daarover te horen. ${ }^{214}$

De mogelijkheid om nadere stukken in te dienen en te betrekken bij de besluitvorming is derhalve beperkt en het recht om informatie te verschaffen reikt niet zover dat er te allen tijde een plicht bestaat om niet tijdig ingediende stukken mee te nemen bij het horen en de daaropvolgende besluitvorming. De verweermogelijkheden van belanghebbenden (en het bestuur) die deze stukken niet hebben ingediend, bepalen de grenzen van het recht om stukken in te dienen. Voorkomen moet worden dat andere belanghebbenden en het bestuur onvoldoende gelegenheid hebben om zich deugdelijk voor te bereiden op de hoorzitting en te reageren op de stukken. Teunissen merkt in dit verband op dat het recht om zoveel mogelijk geïnformeerd te worden (de informatiefunctie van het horen) en de plicht om verrassing of overrompeling van belanghebbenden te voorkomen met elkaar kunnen conflicteren. ${ }^{215}$ Mij lijkt dat zich vooral een conflict voordoet tussen de verweer- of verdedigingsmogelijkheden van de indiener én de procesbelangen van de andere belanghebbenden. Afhankelijk van de omstandigheden van het geval, moet de balans soms doorslaan naar de belangen van de indiener en moeten soms de belangen van de andere belanghebbenden voorrang krijgen. Omdat het twee vereisten van het beginsel van hoor en wederhoor (ten behoeve van verschillende procesdeelnemers) betreft die met elkaar conflicteren, moet een oplossing gezocht worden die zoveel mogelijk recht doet aan beide vereisten. Indien het bestuur de betreffende stukken, ondanks te late indiening, bij de besluitvorming wil betrekken, zullen de overige belanghebbenden wellicht gelet op de goede procesorde of het beginsel van hoor en wederhoor, de mogelijkheid moeten krijgen om na de hoorzitting (nog nader) schriftelijk of mondeling op de stukken te reageren. ${ }^{216}$ De goede procesorde is maatgevend. ${ }^{217}$ Het bestuursorgaan kan er onder omstandigheden ook voor kiezen de hoorzitting uit te stellen en zo de termijn te verlengen waarbinnen de stukken kunnen worden ingediend en ter inzage liggen.

Een conflictsituatie tussen de verschillende procesbelangen en verweermogelijkheden van alle betrokkenen speelt vooral, indien er meer belanghebbenden bij procedure zijn betrokken. ${ }^{218}$ Zijn er echter geen andere belanghebbenden, die benadeeld kunnen worden door de te late indiening en het meenemen van de stukken, moet mijns inziens veel gewicht toekomen aan de procesbelangen van de indiener en niet te lichtvaardig besloten worden om de stukken niet te betrekken bij het horen en de besluitvorming. ${ }^{219}$ Uitsluitend indien het bestuursorgaan (beroepsorgaan) of de adviescommissie belemmerd worden in hun taak door de te late indiening, zou daartoe kunnen worden overgaan. ${ }^{220}$ In de toepassing van deze bepaling komt voorts ook duidelijk een ander, nog niet expliciet besproken, onderdeel van het beginsel van hoor en wederhoor tot uitdrukking: het voldoende gelegenheid krijgen voor de voorbereiding van het eigen standpunt. ${ }^{221}$ De

\footnotetext{
212. PG Awb I, p. 338. Wel verwijst de wetgever hier naar het huidige artikel 7:9 Awb waarin is neergelegd dat indien feiten of omstandigheden die voor de te nemen beslissing op bezwaar van belang zijn bekend worden na het horen de belanghebbenden opnieuw gehoord moet worden.

213. PG Awb I, p. 340

214. PG Awb I, p. 338

215. Teunissen, p. E 6.3.9-4.

${ }^{216 .}$ Koenraad \& Sanders 2006, p. 72

${ }^{217 .}$ PG Awb I, p. 338; Teunissen, p. E 6.3.9-4.

218. Teunissen, p. E 6.3.9-5.

${ }^{219 .}$ CRvB 28 mei 2002, $A B$ 2002/364 m.nt. HBr; $J B$ 2002/211 m.nt A. van Eijs.

220. Art. 7:13 lid $4 \mathrm{Awb}$, waarin bepaalde processuele bevoegdheden aan de commissie worden toegekend, rept overigens niet over de bevoegdheid om stukken niet mee te nemen bij de advisering wegens te late indiening. Mij lijkt dat ook hier, evenals bij de bevoegdheid neergelegd in art. 7:8 Awb, aangenomen moet worden dat de commissie, die belast is het met het horen, ook over die bevoegdheid beschikt.

${ }^{221 .}$ De Waard 1987, p. 246.
} 


\section{De inrichting van de voorprocedures}

achtergrond daarvan is immers het voorkomen van verrassingen voor of overrompeling van de betrokken procesdeelnemers. Zij behoren voldoende tijd te hebben om zich voor te bereiden op het in te nemen standpunt ten aanzien van de ingediende informatie. ${ }^{22}$

\section{Goede procesorde en/of hoor en wederhoor}

De bestuursrechter volgt hetgeen in de toelichting gemeld wordt over de mogelijkheid om stukken in te dienen, hoewel de termijn daarvoor wordt overschreden. Zo overweegt de Centrale Raad in een uitspraak van 28 mei 2002 - waarin het weliswaar ging om stukken die binnen een bepaalde termijn ná de hoorzitting moesten worden ingediend omtrent artikel 7:4 Awb het volgende:

"De Raad stelt voorts vast dat appellant niet duidelijk heeft kunnen maken dat enige belanghebbende, de commissie of het bestuursorgaan, door deze termijnoverschrijding is benadeeld. In dit verband verwijst de Raad naar art. 7:4 lid 1 Awb. In dit artikel is weliswaar bepaald dat belanghebbenden tot tien dagen voor het horen stukken kunnen indienen, maar dat ongeregeld is gebleven wat moet gebeuren met stukken die later worden ingediend. Uit de wetsgeschiedenis blijkt dat de wetgever voor ogen heeft gestaan niet met een te strak geformaliseerde regeling te komen en dat aan het bestuursorgaan ter beoordeling staat of in het kader van een goede procesorde toezending van nader ingekomen stukken aan de andere belanghebbenden gewenst moet worden geacht. Het kan, volgens de toelichting op dit artikellid, van de omstandigheden afhangen of met dergelijke stukken nog rekening kan worden gehouden. Er kan volgens die toelichting in redelijkheid geen rekening mee worden gehouden indien daardoor belanghebbenden in hun verweermogelijkheden worden geschaad."223

Bij de hiervoor weergegeven overwegingen is, zoals aangegeven, van belang dat het ging om een brief die belanghebbende na de hoorzitting buiten de daarvoor gestelde termijn door de adviescommissie had overgelegd. De brief werd twee dagen na afloop van die nadere termijn ontvangen en om die reden buiten beschouwing gelaten. Strikt genomen gaat het derhalve niet om een situatie waarop artikel 7:4 Awb betrekking heeft. De Centrale Raad verwijst dan ook slechts naar deze bepaling en de ratio daarachter. In lijn daarmee komt de Raad tot het oordeel dat het bestuurorgaan in kwestie een brief die na ommekomst van de gestelde (nadere) termijn in redelijkheid niet buiten beschouwing had mogen laten. De uitspraak maakt echter de hoofdregel op grond van artikel 7:4 Awb duidelijk en geeft tegelijkertijd ook treffend de ratio daarvan weer. Nadere stukken die niet tijdig zijn ingediend behoeven niet reeds om die enkele reden buiten beschouwing te worden gelaten; daarvoor bestaat aanleiding, indien belanghebbenden in hun verdedigingsmogelijkheden zijn geschaad. De vraag in hoeverre er een recht bestaat om stukken in te dienen en tot welk tijdstip, lijkt volledig te worden beheerst door de eisen die voortvloeien uit de goede procesorde. ${ }^{224}$ Daarmee lijkt gedoeld te worden op de goede procesorde in de zin van waarborgen van het beginsel van hoor en wederhoor en de verweermogelijkheden of procesbelangen van belanghebbenden. ${ }^{225}$ Ook de Afdeling heeft aangegeven dat uit artikel 7:4 eerste lid geen plicht volgt om te laat ingediende stukken, bijvoorbeeld na de hoorzitting ingediende stukken, wegens de goede procesorde buiten beschouwing te laten. ${ }^{226}$ Een dergelijke restrictieve interpretatie is volgens de Afdeling ook niet in overeenstemming met de ex nunc heroverweging op grond van artikel 7:11 Awb en de hernieuwde hoorplicht bij nieuwe feiten of omstandigheden in artikel 7:9 Awb.

Voor het indienen van nadere stukken voor de zitting bij de bestuursrechter geldt eenzelfde termijn, aldus artikel 8:58 Awb. Kennelijk is voor de wetgever voor de voorbereiding voor de zitting in beroep niet principieel en per definitie meer voorbereidingstijd nodig. De bestuursrechter heeft de bevoegdheid om stukken die buiten de termijn zijn

222. Teunissen, E 6.3.9-4.

${ }^{223 .}$ CRvB 28 mei 2002, $A B$ 2002/364 m.nt. HBr; $J B$ 2002/211 m.n.t A. van Eijs.

224. Zie ook Bröring in zijn noot bij CRvB 28 mei 2002, $A B$ 2002/364.

225. Zie over de verschillende betekenissen waarin het begrip de goede procesorde wordt gebruikt: B.W.N. de Waard, 'De goede procesorde', JB-plus 2001, p. 149 e.v.

226. AbRvS 3 september 2003, $A B$ 2003/389 m.nt. Sew. 


\section{Deel II Bestuurlijke voorprocedures}

ingediend al dan niet mee te nemen bij de beoordeling van het bestreden besluit. Zoals bekend, verwijst de bestuursrechter in het kader van de toepassing van die bevoegdheid ook regelmatig naar (beginselen van) de goede procesorde of een behoorlijk verloop van de procedure. ${ }^{227}$ Indien de bestuursrechter de te laat ingediende stukken in de procedure toelaat, moet in beginsel ofwel het onderzoek ter zitting geschorst worden op grond van artikel 8:64 Awb ofwel het onderzoek na de zitting heropend worden op grond van artikel 8:68 Awb, teneinde de overige procesdeelnemers in staat te stellen kennis te nemen van de stukken en daarop te reageren. ${ }^{228}$ De bestuursrechter lijkt met het begrip goede procesorde in dit kader ook vooral de verweermogelijkheden of procesbelangen van de andere procesdeelnemers op het oog te hebben. ${ }^{229}$ Een onderscheid tussen de bezwaarschriftprocedure en het (hoger) beroep bij de bestuursrechter wordt in de rechtspraak wat betreft het indienen van processtukken en de begrenzing door de goede procesorde niet expliciet gemaakt. ${ }^{230}$ Dat is op zich opmerkelijk, omdat de goede procesorde doorgaans in verband wordt gebracht met de procedure bij de bestuursrechter en deze soms huiverig is die term ook te gebruiken voor de bezwaarschriftprocedure. ${ }^{231}$ Wel is het zo dat de Afdeling in het kader van artikel 8:58 Awb ervan uit gaat dat in beginsel aan de tiendagentermijn strikt de hand wordt gehouden, maar het is de goede procesorde als zodanig die, los van de tiendagentermijn, bepalend is waardoor uitzonderingen op die termijn mogelijk zijn. ${ }^{232}$ De omvang van de stukken en de mate waarin daarin nieuwe informatie staat kunnen van belang zijn. ${ }^{233}$ Zoals aangegeven, gaat het erom dat hoor en wederhoor en voldoende voorbereidingstijd gegarandeerd zijn. ${ }^{234}$

In de toelichting op artikel 7:4 Awb wordt gerefereerd aan de goede procesorde zonder dat duidelijk wordt wat daarmee precies bedoeld wordt. Het lijkt er uiteindelijk om te gaan dat de verweermogelijkheden en voorbereidingstijd van (andere) belanghebbenden niet beperkt mogen worden. In de memorie van antwoord wordt een procesbelang genoemd als omstandigheid, die zich kan verzetten tegen het meenemen van later ingekomen stukken. Gelet ook op de benadering van de bestuursrechter ligt het in de rede dat de verwijzing naar de goede procesorde en een procesbelang doelt op het beginsel van hoor en wederhoor.

Het bestuurlijke karakter van de procedure: een beperking of juist niet?

Bij de afweging die het bestuur moet maken, kan ook de omstandigheid dat de bezwaarschriftprocedure een bestuurlijke voorprocedure is een rol spelen. Het bestuur zal vanuit het oogpunt van verlengde besluitvorming wellicht eerder geneigd zijn de stukken en informatie te willen meenemen. Uit de ex nunc- heroverweging volgt dat het bestuur alle relevante feiten, omstandigheden en recht tot het moment van het nemen van het besluit

\footnotetext{
227. Zie bijvoorbeeld: CBb 16 april 2008, $A B$ 2008/324 m.nt. Sew; CRvB 11 januari 2008, $A B$ 2008/78 m.nt. A. Tollenaar; AbRvS 27 mei 2004, AB 2007/295 m.nt. O.J.D.M.L. Jansen onder $A B$ 2007/294; CRvB 20 augustus 2003, $A B$ 2004/13 m.nt. HBr. Zie hierover ook: De Waard 2001, p. 148 e.v.

${ }^{228}$ CRvB 11 januari 2008, $A B$ 2008/78 m.nt. A. Tollenaar; CRvB 8 april 1998, AB 1998/430. Zie hierover ook: Damen e.a. 2009, Deel II, p. 220-222; Van Wijk/Konijnenbelt \& Van Male 2008, p. 632-633.

229. Zie de in de vorige noot weergegeven uitspraken en ook CBb 16 april 2008, AB 2008/324 m.nt. Sew; AbRvS 25 april 2007, $A B$ 2007/264 m.nt. Damen. De uitspraken van de CRvB en het CBb lijken het oog te hebben op de verweermogelijkheden van de andere procesdeelnemers, terwijl de Afdeling in de daar genoemde uitspraak ook de proceseconomie en de voorbereidingstijd van de rechter voor ogen lijkt te hebben, AbRvS 24 mei 2002, $A B$ 2003/158.

230. Zie ook: CRvB 20 augustus 2003, $A B$ 2004/13 m.nt. HBr, waarin de CRvB bezwaar en beroep op een lijn lijkt te stellen wat betreft de mogelijkheid om nadere bewijsstukken in te dienen en dezelfde eisen, beginselen van de goede procesorde, daarbij bepalend lijkt te achten.

231. Zie bijvoorbeeld: AbRvS 7 mei 2008, $A B$ 2009/4 m.nt. B.W.N. de Waard.

232. AbRvS 24 mei 2002, $A B$ 2003/158

233. AbRvS 25 april 2007, $A B$ 2007/264 m.nt. L.J.A. Damen. Die kunnen er zelfs toe leiden dat tijdig ingediende stukken niet mogen worden meegenomen of uitstel van de zitting moet plaatsvinden, AbRvS 15 augustus 2007 , $J B$ 2007/183; AbRvS 25 april 2007, AB 2007/264; AbRvS 4 juli 2005, $A B$ 2006/62; JB 2005/254. Zie ook: Damen e.a. 2009, Deel II, p. 221.

${ }^{234 .}$ CRvB 8 mei 2009, AB 2009/239 m.nt. Tollenaar; AbRvS 15 juni 2005, JB 2005/231.
} 


\section{De inrichting van de voorprocedures}

op bezwaar bij de heroverweging moet betrekken (voor zover uit de wet of de aard van het besluit niet anders volgt). Dit bestuurlijk element wordt tot op zekere hoogte echter, wat betreft het moment in de procedure waarop stukken en bewijs ingediend kunnen worden door belanghebbenden, beperkt door het beginsel van hoor en wederhoor. Tot welk tijdstip dergelijke stukken kunnen worden ingediend in de procedure, hangt immers af van de vraag in hoeverre de overige betrokkenen zich daartegen nog deugdelijk kunnen verweren. Het bestuursorgaan zal nadere stukken die te laat zijn ingediend om die reden niet behoeven te betrekken in de besluitvorming en in ieder concreet geval een afweging moeten maken tussen hetgeen vanuit het oogpunt van hoor en wederhoor geëigend is en hetgeen voor de (zorgvuldigheid van de) besluitvorming wenselijk is. De mogelijkheid bestaat immers dat er geen belanghebbenden zijn die in hun verweermogelijkheden worden geschaad of dat op andere wijze tegemoet kan worden gekomen aan de verweermogelijkheden van belanghebbenden. Vanuit een oogpunt van dejuridisering én de rechtsbescherming van de indiener van de stukken, maar ook het ex nunc-karakter van de heroverweging, zou mijn voorkeur in het algemeen uitgaan naar een soepele opstelling van het bestuursorgaan in deze gevallen. De indieningstermijn fataal te laten werken, zou in deze gevallen ook tegen het heroverwegingskarakter kunnen werken, omdat het bestuur daardoor wellicht ten onrechte feiten of omstandigheden niet meeneemt bij de besluitvorming. ${ }^{235}$ Het zou eerder voor de hand liggen dat het bestuursorgaan belanghebbenden een andere gelegenheid, eventueel na de hoorzitting, biedt om te reageren op de stukken. Uit het voorgaande blijkt dat procedurele waarborgen ook het bestuurlijke karakter van de heroverweging kunnen ondersteunen en dat deze niet zozeer altijd daarmee behoeven te conflicteren.

\section{Stukken ingediend door het bestuur}

In het bovenstaande is uitsluitend aandacht besteed aan het recht om stukken in te dienen vanuit het perspectief van de belanghebbende(n) en de begrenzing daarvan door het recht van andere belanghebbenden om daarop te kunnen reageren. In de praktijk kan het echter voorkomen dat, indien bijvoorbeeld een adviescommissie belast is het met het horen, ook het bestuur nog nadere stukken indient of ten grondslag legt aan hetgeen wordt ingebracht tijdens de hoorzitting. Gelet op het meer contradictoire karakter van de procedure moet het bestuur in dat soort gevallen veelal gezien worden als een 'echte' wederpartij, met een meer met de belanghebbenden vergelijkbare positie. Voor die situatie biedt artikel 7:4 van de Awb strikt genomen geen uitkomst. Het ligt echter voor de hand om analoog aan die bepaling aan te nemen dat het bestuur nadere stukken kan indienen voor de hoorzitting of ten grondslag kan leggen aan de stellingname tijdens de hoorzitting, mits belanghebbenden voldoende verweermogelijkheden hebben. Dat betekent in eerste instantie dat ook het bestuur tot tien dagen voor de hoorzitting stukken kan indienen en indiening van stukken na die termijn eveneens beheerst wordt door de goede procesorde. Hier lijkt eveneens in de rede te liggen dat de stukken niet buiten beschouwing worden gelaten. Onder omstandigheden kan dat wel betekenen dat bij niet tijdige indiening van stukken bij de commissie belanghebbenden nog na de hoorzitting de gelegenheid moeten krijgen om te reageren. In deze zin ook een uitspraak van de Afdeling van 25 juni 2003 in een zaak waarin het college van $b$ en $w$ tijdens de hoorzitting een pleitnota had overgelegd. Tijdens de hoorzitting was een mondelinge samenvatting van de pleitnota gegeven, maar was deze niet geheel voorgedragen. Op de mondelinge samenvatting had appellant kunnen reageren en er was zelfs de mogelijkheid geboden na de hoorzitting op de gehele pleitnota te reageren. Appellant stelde zich op het standpunt dat desondanks sprake was van strijd met het beginsel van hoor en wederhoor. De Afdeling volgt appellant daarin niet, maar overweegt:

\footnotetext{
235. Vgl. AbRvS 3 september 2003, AB 2003/389 m.nt. Sew.
} 
Deel II Bestuurlijke voorprocedures

"Appellant is ter hoorzitting in de gelegenheid gesteld om op de mondelinge samenvatting van de pleitnota te reageren. Voorts heeft de bezwarencommissie appellant een termijn gegeven waarbinnen hij nog schriftelijk heeft mogen reageren op de door verweerder overgelegde pleitnota. Bij brief van 10 februari 2002 heeft appellant van deze gelegenheid gebruik gemaakt. Gelet hierop ziet de Afdeling geen aanleiding voor het oordeel dat tijdens de voorbereiding van het bestreden besluit het beginsel van hoor en wederhoor niet in acht is genomen." 236

De Afdeling geeft in deze uitspraak aan dat het beginsel van hoor en wederhoor in dit geval de voorbereiding van het besluit op bezwaar normeert. Door te overwegen dat het beginsel van hoor en wederhoor in acht is genomen gelet op de geboden reactiemogelijkheden, wordt, hoewel niet uitdrukkelijk, toepasselijkheid van dat beginsel op de bezwaarschriftprocedure aangenomen. Kanttekening is wel dat appellant gesteld had dat het beginsel van hoor en wederhoor geschonden was en de mogelijkheid bestaat dat de Afdeling uitsluitend om die reden aan het beginsel refereert. Doordat de geboden reactiemogelijkheden bepalend lijken te zijn geweest voor het oordeel dat het beginsel van hoor en wederhoor niet is geschonden en de Afdeling daar uitdrukkelijk op ingaat, lijken dergelijke reactiemogelijkheden onder omstandigheden derhalve in de bezwaarschriftprocedure ook op het beginsel van hoor en wederhoor te kunnen worden gebaseerd. Ook lijkt de Afdeling hetzelfde op het oog te hebben als wanneer de goede procesorde wordt aangehaald in het kader van het recht om stukken in te dienen door belanghebbenden.

De verhouding tussen de artikelen 7:4 en 7:9 Awb

De hiervoor beschreven situaties moeten onderscheiden worden van de situatie waarin het bestuur nieuwe feiten of omstandigheden, die ná de hoorzitting bekend zijn geworden, aan het besluit ten grondslag wil leggen of mee wil nemen in de besluitvorming. Ook dat kunnen (feiten of omstandigheden zijn neergelegd in) schriftelijke stukken zijn, maar deze waren eerder nog niet bekend. Gelet op het ex nunc-karakter van de heroverweging dient het bestuur, voor zover uit de aard van de bevoegdheid of de wet niet anders voortvloeit, deze bij de besluitvorming te betrekken. Het beginsel van hoor en wederhoor staat daaraan niet in de weg. Dat zou ook te zeer afbreuk doen aan het bestuurlijke karakter van de procedure en de zorgvuldigheid van de besluitvorming. De Awb voorziet in artikel 7:9 Awb voor dit soort situaties in een regeling die het beginsel van hoor en wederhoor en de verweermogelijkheden van belanghebbenden beoogt te waarborgen. Artikel 7:9 van de Awb bepaalt immers dat, indien na het horen feiten of omstandigheden die van aanmerkelijk belang zijn voor de beslissing op bezwaar bekend zijn geworden, het bestuursorgaan een nieuwe hoorzitting behoort te beleggen. Deze bepaling vormt bij uitstek een uitdrukking van het tweeledige karakter van de bezwaarschriftprocedure. Op die bepaling werd in paragraaf 5.3.2.3 nader ingegaan.

De vraag is hoe artikel 7:9 Awb en artikel 7:4 Awb zich tot elkaar verhouden. Artikel 7:4, eerste lid, Awb ziet slechts op nadere stukken die vóór de hoorzitting worden ingediend. ${ }^{237}$ Artikel 7:9 Awb geeft een regeling inzake feiten of omstandigheden die ná de eerste hoorzitting bekend zijn geworden. In artikel 7:4 van de Awb is geregeld tot welk moment voor die eerste hoorzitting er in elk geval stukken kunnen worden ingediend, namelijk tien dagen. Of later ingediende stukken of tijdens de hoorzitting ingediende stukken kunnen worden meegenomen hangt af van de vraag in hoeverre de overige betrokkenen nog deugdelijk kunnen reageren op deze stukken. Indien het bestuur besluit deze mee te nemen, moeten zij daarop in elk geval hebben kunnen reageren. Zoals de bestuursrechter de mogelijkheid heeft tot schorsing van het onderzoek ter zitting of heropening van het onderzoek op grond van artikel 8:64 Awb of artikel 8:68 Awb, kan het bestuursorgaan de hoorzitting schorsen, uitstellen of een mogelijkheid bieden om na de hoorzitting schriftelijk nog te reageren. In deze gevallen gaat het strikt

\footnotetext{
236. AbRvS 25 juni 2003, nr. 200202706/1, r.o. 2.2.2 (te raadplegen via www.raadvanstate.nl).

237. Koenraad en Sanders lijken te suggereren dat beide verklaringen alle situaties dekken waarin nieuwe informatie en/of stukken ter beschikking komen, Koenraad \& Sanders 2006, p. 78.
} 


\section{De inrichting van de voorprocedures}

genomen niet om stukken die onder de werking van artikel 7:9 Awb vallen. De feiten of omstandigheden zijn immers bekend voor of tijdens de hoorzitting. ${ }^{238}$ Dat betekent dus dat te laat ingediende stukken (te laat in de zin van artikel 7:4, eerste lid Awb) strikt genomen niet via artikel 7:9 Awb bij de besluitvorming betrokken kunnen worden, omdat deze bepaling daarop niet ziet. Betreft het echter stukken die na de hoorzitting zijn ingediend en derhalve na de hoorzitting bekend zijn geworden aan het bestuur, komt artikel 7:9 Awb in beeld. In dat geval moeten belanghebbenden gehoord worden, indien aangenomen kan worden dat deze stukken van aanmerkelijk belang zijn voor de beslissing op bezwaar. Ik kan mij echter voorstellen dat artikel 7:9 Awb in de praktijk ook dienst doet voor stukken die buiten de termijn als bedoeld in artikel 7:4, eerste lid, van de Awb zijn ingediend en die het bestuur, met een reactiemogelijkheid van belanghebbenden, toch wil meenemen in de besluitvorming. De bestuursrechter gaat ook vrij soepel om met de reikwijdte van artikel 7:9 Awb, zo bleek in paragraaf 5.3.2.3. Dat is niet bezwaarlijk, aangezien de ratio van artikel 7:4, eerste lid, hoor en wederhoor, zo ook gewaarborgd wordt.

\section{Een uitwerking van het beginsel van hoor en wederhoor}

Uit het voorgaande kan worden afgeleid dat het recht om stukken in te dienen voor de hoorzitting, op grond van artikel 7:4, eerste lid, van de Awb, moet worden gezien als een judiciële waarborg, die beoogt de processuele belangen van belanghebbenden zeker te stellen. Het beginsel van hoor en wederhoor of de goede procesorde (zoals de wetgever en de bestuursrechter aangeven) bepaalt tot welk moment nadere informatie en stukken door belanghebbenden kunnen worden aangedragen en dientengevolge meegenomen kunnen worden bij de besluitvorming. De bepaling geeft belanghebbenden enerzijds het recht om nadere stukken in te dienen zodat zij hun standpunt adequaat naar voren kunnen brengen en nader kunnen onderbouwen of adstrueren met stukken. Anderzijds beoogt de bepaling door het stellen van een termijn voor het indienen van de stukken veilig te stellen dat (eventuele) andere belanghebbenden (en het bestuur) voldoende gelegenheid hebben om te reageren op nog onbekende stukken en daarmee de verweermogelijkheden te bewaken. Voor de procedure bij de bestuursrechter is eenzelfde bepaling en termijn opgenomen in artikel 8:58 Awb, waarbij de invulling of begrenzing door de goede procesorde op dezelfde wijze geschiedt.

Het voorgaande biedt derhalve duidelijke aanknopingspunten om het recht op indienen van stukken te zien als een eis die voortvloeit uit of een uitwerking vormt van het beginsel van hoor en wederhoor. Tegelijkertijd wordt dat recht vanuit het oogpunt van datzelfde beginsel (namelijk voor zover daardoor de verweermogelijkheden van andere belanghebbenden worden beperkt) begrensd. Het recht om nadere stukken in te dienen staat derhalve, ook in de bestuurlijke voorprocedures, in het teken van het beginsel van hoor en wederhoor en de rechtsbescherming van de betrokken deelnemers aan de procedure. Daarnaast dient het recht om stukken in te dienen ook het verlengde besluitvormingskarakter en de ex nunc-heroverweging, aangezien het bestuur op die grond verplicht nieuwe feiten en omstandigheden te betrekken in zijn besluitvorming indien deze relevant zijn. Vanuit beide perspectieven is een soepele benadering voordelig en beide perspectieven lijken, mits er voldoende voorbereidingstijd gegund wordt aan de belanghebbenden die niet met de stukken bekend zijn, samen te vallen voor zover het de mogelijkheid betreft om nadere stukken in te dienen.

\footnotetext{
238. Bröring meent overigens dat te laat ingediende stukken die niet worden meegenomen formeel moeten worden gezien als niet bekend geworden stukken en daarom aan toepassing van art. 7:9 Awb niet meer wordt toegekomen, zie zijn noot bij CRvB 28 mei 2002, $A B$ 2002/364 m.nt. HBr.
} 
Deel II Bestuurlijke voorprocedures

\subsubsection{Het recht om te reageren op adviezen}

Adviezen ingewonnen door het bestuur in de bezwaarfase en de mogelijkheid te reageren Niet alleen belanghebbenden kunnen van mening zijn dat een verklaring van een getuige of deskundige van belang kan zijn voor de uitkomst van de zaak. Het bestuursorgaan is in sommige gevallen voor zover nodig in het kader van zorgvuldige besluitvorming verplicht om advies in te winnen bij deskundigen. ${ }^{239}$ Indien het bestuursorgaan besluit om deskundigen te horen dan wel om schriftelijk een advies van hen te vragen, zou gesteld kunnen worden dat het beginsel van hoor en wederhoor vereist dat belanghebbenden ook de mogelijkheid krijgen om daarop te reageren. Teunissen noemt het een beginsel van behoorlijk procesrecht dat belanghebbenden op de hoogte worden gebracht van tijdens de bezwaarschriftprocedure ingewonnen adviezen die een rol spelen in de besluitvorming. $\mathrm{Zij}$ dienen tevens de gelegenheid te krijgen daarop te reageren. ${ }^{240}$ Ook Notten wijst er op dat het beginsel van hoor en wederhoor eist dat ingewonnen adviezen aan belanghebbenden moeten worden verschaft en zij de gelegenheid moeten krijgen om daarop te reageren. ${ }^{241}$ De advisering en daaromtrent te stellen eisen in de bestuurlijke fasen, waaronder de bezwaarfase, worden in de rechtspraak en doctrine thans vooral gebaseerd op het zorgvuldigheidsbeginsel. ${ }^{242}$ Voor advisering ingewonnen in de primaire besluitvormingsfase en de bestuurlijke voorprocedures geldt in dat verband dezelfde grondslag. Voor wettelijk verplichte advisering biedt afdeling 3.3 in de Awb uitwerkingen van het zorgvuldigheidsbeginsel ${ }^{243}$, welke bepalingen - met uizondering van artikel 3:6, tweede lid, van de Awb - op grond van artikelen 7:14 en 7:27 Awb ook van toepassing zijn in de bestuurlijke voorprocedures. Uit die bepalingen volgt echter niet dat belanghebbenden de gelegenheid moeten krijgen om te reageren op het advies. Soms zullen de adviezen in de bestuurlijke voorprocedures echter ook onder de werking van artikel 7:9 Awb kunnen vallen. In dat geval worden zij tevens genormeerd door het beginsel van hoor en wederhoor.

Hoor en wederhoor en equality of arms

In het algemeen is de bestuursrechter echter als het gaat om advisering huiverig om rechterlijke waarborgen daarop van toepassing te verklaren in de bestuurlijke fasen. Een plicht tot het bieden van gelegenheid tot reageren in de totstandkomingsfase van adviezen wordt door de Afdeling in een uitspraak van 22 november 2006 in elk geval niet aangenomen op grond van artikel 6 EVRM en het Mantovanelli-arrest van het EHRM. ${ }^{244}$ Voor de procedure bij de bestuursrechter volgt uit de bekende Mantovanelli-uitspraak van het EHRM dat er voldoende mogelijkheden voor belanghebbenden moeten bestaan om te reageren op een advies van een deskundige, zo nodig vooraf. ${ }^{245}$ Dat is vooral het geval waarin de vraag die de deskundige moet beantwoorden doorslaggevend is voor de uitkomst van het geschil en gelijk is aan de vraag die de rechter moet beantwoorden, waarbij de rechter zich op het oordeel van de deskundige zal baseren. Het beginsel van hoor en wederhoor stelt in dat kader ook eisen aan de totstandkoming van het deskundi-

\footnotetext{
239. Zie hierover: L.M. Koenraad, 'Deskundig besturen. Beschouwingen over de plaats van deskundigenadvisering', JB-plus 2006, p. 15-33; A.M.M.M. Bots, Het zorgvuldigheidsbeginsel en advisering', in: R.J.N. Schlössels (red.), In beginsel. Over aard, inhoud en samenhang van rechtsbeginselen in het bestuursrecht, Deventer: Kluwer 2004, p. 141-165; S.V. Hoogendijk-Deutsch, 'Advisering in het bestuursrecht (in het bijzonder aan de centrale overheid)', in: S.V. Hoogendijk-Deutsch en R. Samkalden, Advisering in het bestuursrecht (VARgeschrift LXXX), Deventer: H.D. Tjeenk Willink 1978, p. 11-65.

240. Teunissen, p. E 6.3.7-3.

${ }^{241 .}$ Notten 1998 , p. 231.

${ }^{242 .}$ Met name art. 3:9 Awb lijkt van belang, zie: AbRvS 25 februari 2009, $A B$ 2009/222 m.nt. Den Ouden en Van Rijn van Alkemade; AbRvS 22 november 2006, $A B$ 2008/62 m.nt. N. Verheij; JB 2007/12 m.nt. AB. Zie ook: Koenraad 2006, p. 18; Bots 2004, p. 143 e.v.

243. Koenraad 2006, p. 18.

244. AbRvS 22 november 2006, AB 2008/62 m.nt. N. Verheij; JB 2007/12 m.nt. AB.

245. EHRM 18 maart 1997, Mantovanelli t. Italië, JB 1997/112, m.nt. Heringa; NJ 1998/278 m.nt. Snijders
} 


\section{De inrichting van de voorprocedures}

genadvies in de rechterlijke procedures. ${ }^{246}$ Voor de besluitvormingsfasen gelden echter de zorgvuldigheidseisen en niet de uit het Mantovanelli-arrest voortvloeiende eisen, aldus de Afdeling. Als het bestuur in het kader van zijn informatiegaringsplicht op grond van het zorgvuldigheidsbeginsel overgaat tot het inwinnen van advies, dient het zich ervan te vergewissen dat het advies zorgvuldig tot stand is gekomen en of de resultaten van het onderzoek het advies kunnen dragen. In het kader daarvan ligt het in de rede belanghebbenden te laten reageren op het advies. In tegenstelling tot hetgeen uit Mantovanelli volgt, betreft het hier een reactiemogelijkheid achteraf.

\section{Advisering en zorgvuldig besturen}

Als het gaat om advisering brengt de bestuursrechter, in het bijzonder de Afdeling, een duidelijkere scheiding aan tussen de bestuurlijke fasen en de rechterlijke fase dan het geval is bij andere procedurele rechten in de bestuurlijke (voor)procedures. Het betreft in de hiervoor aangehaalde uitspraak echter vereisten die herleid kunnen worden tot artikel 6 EVRM, waardoor voorstelbaar is dat de bestuursrechter terughoudender is in het van toepassing verklaren van dergelijke eisen. Voor de fasen van besluitvorming gelden nu eenmaal andere eisen, zo overweegt de Afdeling in de hiervoor aangehaalde uitspraak. $\mathrm{Nu}$ artikel 6 EVRM ook vooral het oog heeft op procedures bij rechterlijke instanties is de benadering van de Afdeling verklaarbaar. Toch lijkt dat niet de enige reden te zijn voor terughoudendheid. De Afdeling doet in dat kader immers ook een beroep op de zorgvuldigheid die geldt als norm voor het bestuur en de specifieke deskundigheid die het bestuur bezit en de rechter ontbeert. Daarmee legt de Afdeling een verband met de werkzaamheid en taakopvatting van het bestuur en vooral ook het (traditionele) onderscheid met de bestuursrechter in dat opzicht. Daaruit volgt blijkbaar dat equality of arms of hoor en wederhoor in het kader van advisering geen normen zijn die voor het bestuur gelden. Gelet op het feit dat de Afdeling in het kader van andere eisen of rechten minder terughoudend is en het de vraag is of een onderscheid in behoorlijkheidseisen wel gerechtvaardigd wordt door het bestaande onderscheid in werkzaamheid of deskundigheid van beide organen ${ }^{247}$, kunnen bij deze overwegingen van algemene aard van de Afdeling vraagtekens worden geplaatst. ${ }^{24}$ Bovendien geeft ook de Afdeling aan dat de mogelijkheid tot reageren voor belanghebbenden achteraf wel moet bestaan, aldus de hiervoor aangehaalde uitspraak. In dit opzicht verschilt hetgeen equality of arms of het zorgvuldigheidsbeginsel vereist niet heel sterk, behoudens de mogelijkheid van vooraf betrokkenheid bij het advies. De eisen uit het zorgvuldigheidsbeginsel lijken iets minder verstrekkend te zijn en de bestuursrechter legt in dat verband meer nadruk op de eigen verantwoordelijkheid van het bestuur voor de totstandkoming van het advies en de eigen deskundigheid van het bestuur. Hoe het ook zij, de Afdeling plaatst de advisering en in dat verband geldende eisen voor het bestuur in het teken van het zorgvuldigheidsbeginsel. Op het vereiste van equality of arms in de bestuurlijke voorprocedures wordt in paragraaf 5.3.5 nader ingegaan.

\subsubsection{De gevolgen van schendingen van het recht om schriftelijk informatie te verschaffen}

Wat betreft de gevolgen van schendingen van het recht om schriftelijk informatie te verschaffen, moet allereerst gedacht worden aan de mogelijkheid voor het bestuur om de stukken die zijn ingediend niet in zijn beoordeling te betrekken. In principe heeft het die

\footnotetext{
${ }^{246 .}$ En ook het onpartijdigheidsbeginsel is in dat kader van belang, vgl. de noot van Barkhuysen en Van Emmerik bij EHRM 5 juli 2007, Sara Lind Eggertsdóttir t. IJsland, AB 2009/319. Zie hierover ook: par. 4.3.5 van Deel I. Zie over dit onderwerp verder: Jansen 2008, p. 223-226; Koenraad 2007, p. 202-223.

247. Zie ook de noot van N. Verheij bij AbRvS 22 november 2006, $A B$ 2008/62 m.nt. N. Verheij.

248. Vgl. ook Koenraad 2006, p. 26. Koenraad meent dat aan de procedure tot totstandkoming van het advies bij het bestuur ook zwaardere eisen, evenals het geval is bij de rechter op grond van Mantovanelli, moeten worden gesteld naarmate de invloed van het advies groter is op de besluitvorming.
} 
Deel II Bestuurlijke voorprocedures

bevoegdheid, indien het stukken betreft die binnen de termijn van tien dagen voor de hoorzitting zijn ingediend op grond van artikel 7:4, eerste lid, Awb. Als de goede procesorde dat vereist, kan het deze stukken buiten beschouwing laten. Het kan ze echter ook meenemen, maar dient de belanghebbenden dan een mogelijkheid te bieden om daarop te kunnen reageren. Worden de goede procesorde of verweermogelijkheden van belanghebbenden geschonden, leidt dat in beginsel tot vernietiging van het bestreden besluit. ${ }^{249}$ Omdat artikel 7:4, eerste lid, Awb echter een vormvoorschrift betreft, kan een dergelijke schending gepasseerd worden met toepassing van artikel 6:22 Awb indien belanghebbenden daar niet door worden benadeeld. Dat kan afgeleid worden uit het feit dat de bestuursrechter een schending van artikel 7:4, tweede lid, met toepassing van die bepaling weleens gepasseerd heeft. ${ }^{250}$ Ook hier bestaat de mogelijkheid om over te gaan tot vernietiging van het besluit, indien de goede procesorde geschonden is en de rechtsgevolgen in stand te laten. ${ }^{251}$

Als het bestuursorgaan advies inwint bij een of meer deskundigen, dan dient een belanghebbende de mogelijkheid te hebben daar achteraf op te reageren. Wordt die gelegenheid niet geboden dan constateert de bestuursrechter een schending van het zorgvuldigheidsbeginsel. Daarmee lijkt vernietiging geimpliceerd. ${ }^{252}$ Bij een schending van de plicht van het bestuursorgaan om zich ervan te vergewissen dat het advies zorgvuldig tot stand komt in strijd met artikel 3:9 Awb en/of het zorgvuldigheidsbeginsel wordt normaliter ook vernietigd. ${ }^{253}$ Er zal niet snel aanleiding bestaan een dergelijk gebrek met toepassing van artikel 6:22 Awb te passeren. Het is de vraag of uitwerkingen van artikel 3:2 Awb kunnen worden gezien als een vormvoorschrift waarvan schending gepasseerd kan worden. ${ }^{254}$ Desondanks worden schendingen van die bepaling soms zonder gevolgen gelaten $^{255}$ en worden schendingen van andere uitwerkingen van het zorgvuldigheidsbeginsel soms ook gepasseerd met toepassing van artikel 6:22 Awb. ${ }^{256}$

\subsubsection{Het recht om informatie te ontvangen}

Naast het recht om informatie te verschaffen vormt het recht om informatie te ontvangen een belangrijk onderdeel van hoor en wederhoor in een procedure. Beide rechten hangen nauw met elkaar samen en de (goede) uitoefening van het eerste recht door de procesdeelnemers is grotendeels afhankelijk van de vormgeving en inachtneming van het recht om informatie te ontvangen in de desbetreffende procedure. De beschikking hebben over alle relevante informatie is immers onontbeerlijk voor het naar voren brengen en onderbouwen van het eigen standpunt. Dat recht om informatie te ontvangen is ook uitgewerkt in de regeling van de bezwaarschriftprocedure en het administratief beroep in hoofdstuk 7 van de Awb. Het komt tot uitdrukking in verschillende bepalingen inzake de inrichting van deze procedures. Die bepalingen hebben, zoals de Afdeling overwogen heeft, een

\footnotetext{
249. AbRvS 3 september 2003, AB 2003/389 m.nt. Sew waarin de Afdeling een vernietiging en gegrondverklaring van het beroep door de rechtbank bevestigt. Hetzelfde gebeurt in: CRvB 28 mei 2002, AB 2002/364 m.nt. $\mathrm{HBr}$.

250. Van Waterschoot wijst erop dat art. 7:4 lid 2 Awb als zodanig wordt beschouwd, Van Waterschoot 2002, p. 187. Zie ook: AbRvS 8 januari 1998, AB 1998/194 m.nt. PvB waarin schending van die bepaling wordt gepasseerd. Datzelfde lijkt mij dan in de rede te liggen voor art. 7:4 lid 1 Awb.

${ }^{251 .}$ Voorbeelden daarvan heb ik echter niet gevonden. Zie echter ook bij schending van art. 7:4 lid 2 Awb: CRvB 26 april 2005, JB 2005/218

252. Vgl.: AbRvS 25 februari 2009, AB 2009/222 m.nt. Den Ouden en Van Rijn van Alkemade. Daarin vond vernietiging wegens strijd met het motiveringsbeginsel plaats.

${ }^{253 .}$ CBb 24 juni 1998, JB 1998/213; CRvB 12 december 1994, JB 1995/25 m.nt. ABJH/ELB.

254. Vgl.: Koenraad 2008a, p. 211; Van Waterschoot 2002, p. 187-188. De laatste meent van wel, maar wijst er wel op dat hoewel sprake is van een vormvoorschrift de vraag of een schending ervan gepasseerd moet worden een andere kwestie betreft.

${ }^{255}$. Zie bijvoorbeeld: CRvB 9 november 1995, $A B$ 1996/175.

256. $\mathrm{Zie}$ voor schendingen van de hoorplicht par. 5.3.2.6.
} 


\section{De inrichting van de voorprocedures}

processuele functie en regelen de partijtoegang tot informatie. ${ }^{257}$ In het onderstaande staan uitsluitend deze waarborgen in het kader van de partijtoegang tot informatie centraal en wordt het recht op informatie op grond van de Wet openbaar bestuur, die de publieke toegang tot informatie regelt, in beginsel buiten beschouwing gelaten. ${ }^{258}$ In de onderhavige paragraaf worden de verschillende uitwerkingen van het recht om informatie te ontvangen in de bestuurlijke voorprocedures nader onderzocht wat betreft inhoud en grondslag, ratio en functie en wordt de jurisprudentie die in dat kader gevormd is behandeld. Het recht om informatie te ontvangen is opgedeeld in verschillende deelaspecten: het recht op inzage in stukken, het recht om informatie te ontvangen over de procedure en enkele andere uitwerkingen die samenhangen met het horen in de bestuurlijke voorprocedures. Deze deelaspecten worden achtereenvolgens behandeld in de paragrafen 5.3.4.1, 5.3.4.2 en 5.3.4.3. Paragraaf 5.3.4.4 staat in het teken van de grondslag voor het recht om informatie te ontvangen. Tot slot worden in paragraaf 5.3.4.5 de gevolgen van schendingen van het recht om informatie te ontvangen in kaart gebracht.

\subsubsection{Het recht op inzage in de stukken}

Het inzagerecht en de samenhang met de rechterlijke procedure

Een belangrijk onderdeel van het recht om informatie te ontvangen, is het recht op inzage in de stukken die op de zaak betrekking hebben. Inzage daarin is een onmisbaar element voor de verweermogelijkheden van de belanghebbenden. Het inzagerecht is wettelijk vastgelegd voor de bezwaarschriftprocedure en het administratief beroep in artikel 7:4 tweede lid en 7:18 tweede lid van de Awb. In die bepalingen is vastgelegd dat het bestuursorgaan de plicht heeft om het bezwaarschrift (of beroepschrift) en alle verder op de zaak betrekking hebbende stukken voorafgaand aan het horen gedurende ten minste één week voor belanghebbenden ter inzage te leggen. Ten aanzien van dat inzagerecht merkt de wetgever op dat het als een van de fundamentele waarborgen voor een goed verlopende bezwaarschriftprocedure is te beschouwen. ${ }^{259}$ Teunissen noemt het inzagerecht de kern van artikel 7:4 Awb. ${ }^{260}$ In tegenstelling tot hetgeen bij vele andere (al besproken en nog te bespreken) procedurele eisen voor de bestuurlijke voorprocedures is geschied, wordt in de toelichting expliciet de vergelijking met de rechterlijke procedure gemaakt. Omdat beide procedures connexiteit vertonen en de rechterlijke procedure in het verlengde ligt van de bestuurlijke voorprocedure behoort het recht op inzage in stukken, aldus de wetgever, op dezelfde wijze ingevuld te worden in de bestuurlijke voorprocedure als in de rechterlijke fase. De wetgever merkt op dat, om te voorkomen dat onnodig een procedure voor de bestuursrechter gestart wordt, de bepaling een belanghebbende beoogt te laten kennisnemen van alle stukken die ook aan de beroepsinstantie plegen te worden toegezonden. Daaruit vloeit voort dat de bepaling - aldus de wetgever - niet meer eist "dan dat stukken die de belanghebbende in een eventuele procedure voor de rechter toch al zou kunnen inzien, reeds in de bezwaarschriftprocedure voor hem ter kennisneming beschikbaar zijn". ${ }^{261}$ Het inzagerecht kan derhalve worden gezien als een judiciële waarborg voor de inrichting van de bezwaarschriftprocedure, die de rechtsbeschermingsfunctie en in het verlengde daarvan de filterfunctie van die procedure beoogt

\footnotetext{
${ }^{257}$ Zie bijvoorbeeld: AbRvS 26 juli 1999, JB 1999/226. De Afdeling overwoog in die uitspraak ook dat het recht van een belanghebbende op kennisneming van gedingstukken minimaal gelijk is aan de aanpsraak op publieke openbaarheid die aan een ieder toekomt op grond van de Wob. De mate van publieke toegang vormt de ondergrens voor de partijtoegang en omgekeerd rechtvaardigt een weigering van publieke openbaarheid nog geen geheimhouding in de Awb-procedure.

258. Zie daarover o.m.: P.J. Stolk, Wet openbaarheid van bestuur, Deventer: Kluwer 2009; E.J. Daalder, Toegang tot overheidsinformatie. Het grensvlak tussen openbaarheid en vertrouwelijkheid (diss. Leiden), Den Haag: BJu 2005 en par. 5.5 van Deel I.

259. PG Awb I, p. 338

260. Teunissen, p. E 6.3.9-2.

261. PG Awb I, p. 338.
} 


\section{Deel II Bestuurlijke voorprocedures}

te verzekeren. Wat voor het recht op inzage expliciet gebeurt, lijkt voor het recht op indienen van stukken op grond van artikel 7:4 Awb impliciet te zijn gebeurd. Ook dat recht wordt op dezelfde wijze ingevuld en begrensd als in de rechterlijke procedure.

\section{Het verband met de hoorplicht en hoor en wederhoor}

In de memorie van antwoord wordt niet alleen een verband gelegd met de procedure bij de bestuursrechter, maar ook met het voor die procedure geldende beginsel van hoor en wederhoor. Overwogen wordt dat de ter inzage legging van stukken realisering van het beginsel van hoor en wederhoor mogelijk maakt en om die reden is gekoppeld aan de hoorzitting. Indien er niet wordt gehoord, is er derhalve ook geen sprake van een verplichte ter inzage legging. ${ }^{262}$ De wetgever legt zelf een uitdrukkelijk verband met hoor en wederhoor in de bestuurlijke voorprocedure en koppelt het inzagerecht om die reden aan de hoorzitting. Op zichzelf is dat opmerkelijk te noemen, omdat bij artikel 7:2 Awb zélf de verbinding met hoor en wederhoor veel minder expliciet is gelegd. ${ }^{263}$ In de literatuur wordt het inzagerecht eveneens vooral in verband gebracht met het beginsel van hoor en wederhoor (zoals dat tot uitdrukking is gebracht in de hoorplicht van artikel 7:2 Awb) en het rechtsbeschermingskarakter van de bezwaarschriftprocedure. ${ }^{264}$ Teunissen en Van der Ham beschouwen het recht op inzage in de stukken als inrichtingseis die voortvloeit uit het gelijkwaardigheidsbeginsel (met als onderdeel hoor en wederhoor), een algemeen beginsel van behoorlijk procesrecht. ${ }^{265}$ Het is mij niet geheel duidelijk welk beginsel zij hiermee op het oog hebben, maar het ligt in de rede dat zij doelen op equality of arms en/of ongelijkheidscompensatie. Wat daarvan ook zij, een verband met de rechterlijke procedure en de daarvoor geldende behoorlijkheidsnormen wordt ook door hen gelegd.

De ratio achter het recht op inzage in de stukken wordt in de doctrine derhalve gezocht in de verweermogelijkheden voor belanghebbenden (tijdens de hoorzitting). Dat ligt ook in de rede omdat zonder op de hoogte te zijn van alle relevante stukken, de belanghebbende immers niet in de positie zal zijn om deugdelijk verweer te voeren en zijn standpunt te onderbouwen tijdens de hoorzitting (en gedurende de procedure). Deze ratio is ook bevestigd in de jurisprudentie van de bestuursrechter. ${ }^{266}$ Illustratief is een uitspraak van de Centrale Raad van 29 november $2005 .{ }^{267}$ In dat geval had het bestuur ondanks uitdrukkelijk verzoek daartoe van appellant - tijdens de bezwaarschriftprocedure niet de stukken waarnaar in het rapport van de sociale recherche werd verwezen (en welk rapport ten grondslag lag aan het advies van de bezwarencommissie) ter inzage gelegd conform artikel 7:4 van de Awb. De Centrale Raad overweegt:

"Met appellant is de Raad voorts van oordeel dat gedaagde, in strijd met artikel 7:4, tweede lid, van de Awb, in bezwaar - ondanks uitdrukkelijk verzoek van appellant - niet ook de stukken ter inzage heeft gelegd waarnaar in het rapport van de sociale recherche wordt verwezen. Als gevolg daarvan is appellant onvoldoende in de gelegenheid geweest in het kader van de bezwarenprocedure zijn bezwaren tegen het primaire besluit van 10 februari 2003 naar voren te brengen en te onderbouwen. Dat appellant nadien de beschikking heeft gekregen over de betreffende stukken (... DW), kan daar niet aan afdoen." 268

De ratio van deze bepaling is echter niet alleen gelegen in het recht om het eigen standpunt te verdedigen. Uit het voorgaande kan ook worden afgeleid dat zij tevens of tegelijkertijd schuilt in een ander onderdeel van het beginselen van hoor en wederhoor: het voldoende gelegenheid krijgen om het eigen standpunt voor te bereiden. Zoals De Waard heeft aangegeven, vormt dit onderdeel de schakel tussen het recht om informatie te ver-

\footnotetext{
262. PG Awb I, p. 340. Dat is bevestigd in jurisprudentie, zie bijv.: HR 7 juni 2002, JB 2002/219.

263. Zie par. 5.3.2.2 van Deel I.

${ }^{264 .}$ Koenraad \& Sanders 2006, p. 73

265. Teunissen, p. E 6.3.9-2; Van der Ham 1988, p. 82.

266. Zie bijvoorbeeld: CRvB 26 april 2005, JB 2005/218; CRvB 6 november 2003, JB 2004/28; CRvB 4 april

2003, JB 2003/182; CBb 23 mei 1995, JB 1995/177.

267. CRvB 29 november 2005, JB 2006/40.

268. CRvB 29 november 2005, JB 2005/40.
} 


\section{De inrichting van de voorprocedures}

schaffen en het recht om informatie te ontvangen. Dit element van hoor en wederhoor komt derhalve tot uitdrukking in de vormgeving of operationalisering van deze twee kernelementen van het beginsel van hoor en wederhoor. De termijn voor het inzien van de stukken voor de hoorzitting biedt een mooie illustratie van die wisselwerking tussen de verschillende onderdelen van hoor en wederhoor in de bestuurlijke voorprocedures.

Op grond van het bovenstaande zou de indruk kunnen ontstaan dat het recht op inzage in stukken absoluut geldt. Dat is echter niet het geval. Toepassing van het tweede lid van de artikelen 7:4 en 7:18 Awb kan op twee gronden achterwege blijven: omdat belanghebbenden afzien van hun inzagerecht zoals neergelegd in het vijfde lid ofwel indien geheimhouding om gewichtige redenen is geboden volgens het zesde lid van dit artikel. ${ }^{269}$ De eerste uitzonderingsgrond brengt duidelijk naar voren dat de processuele belangen van belanghebbenden in het geding zijn, nu zij toestemming behoren te geven voor het achterwege laten van het ter inzage leggen. Aangenomen moet mijns inziens worden dat het bestuursorgaan zich ervan dient te vergewissen dat belanghebbenden daadwerkelijk afzien van hun recht op inzage in de stukken. Daarvan zal niet snel sprake zijn lijkt mij. Dat zal slechts het geval zijn, indien de belanghebbende(n) reeds over alle relevante informatie beschikt omdat deze al eerder is toegezonden of ingezien. De tweede uitzonderingsgrond staat minder in het teken van de processuele belangen van de deelnemers aan de procedure. De gewichtige redenen op grond waarvan kan worden afgezien van het ter inzage leggen, zijn afhankelijk van de omstandigheden van het geval. De wetgever noemt concurrentiegevoelige gegevens of medische gegevens als voorbeeld. Overgegaan kan ook worden tot gedeeltelijke geheimhouding. ${ }^{270}$ Het moet bovendien een grond van meer gewicht betreffen dan de redenen waarom op grond van de Wet openbaarheid van bestuur een verzoek om informatie kan worden geweigerd. ${ }^{271}$ Doet zich deze uitzonderingsgrond voor dan wegen andere belangen zwaarder dan de verdedigingsbelangen van de procesdeelnemers. Afzien van ter inzage legging op grond van gewichtige redenen kan zowel op initiatief van het bestuursorgaan als op initiatief van een belanghebbende plaatsvinden. ${ }^{272}$ In het laatste geval dient evenwel mededeling te worden gegeven dat van deze bevoegdheid gebruik wordt gemaakt. De beslissing tot geheimhouding kan in een procedure bij de rechter tegen het bestreden besluit aan de orde gesteld worden. Voor geheimhouding van stukken geldt in de rechterlijke procedure eenzelfde criterium op grond van artikel 8:29 Awb. ${ }^{273}$ Die bepaling doet volgens de wetgever recht aan verschillende belangen: de procesbelangen van partijen en hun recht op informatie, het belang van de rechter die over alle informatie moet beschikken ter beoordeling van de zaak en het belang dat bepaalde gegevens niet openbaar mogen worden. Voor de bestuurlijke voorprocedures speelt de bescherming van vergelijkbare belangen vanzelfsprekend een rol.

De beslissing tot geheimhouding vormt een beperking van hoor en wederhoor en equality of arms en dient dan ook alleen genomen te worden voor zover zij nodig is. Voor de bestuursrechterlijke procedure geldt ingevolge artikel 8:29 Awb eveneens dat geheimhouding of kennisname door uitsluitend de rechtbank wegens gewichtige redenen mogelijk is. Het is uiteindelijk de bestuursrechter die oordeelt of geheimhouding gerechtvaardigd is in beide procedures. Van artikel 8:29 Awb heeft de Afdeling overigens geoordeeld dat het een geoorloofde beperking vormt op artikel 6 EVRM en het vereiste van equality of arms. ${ }^{274}$ Aangenomen kan worden dat, voor zover deze vereisten toepas-

\footnotetext{
269. In leden 7 en 8 van die bepaling is de uitzonderingsgrond 'geheimhouding wegens gewichtige redenen', nader uitgewerkt, onder meer in verhouding tot WOB. Zie hierover nader: Daalder 2005, p. 270 e.v.

270. PG Awb I, p. 339.

271. De Wob-criteria gelden als ondergrens, PG Awb I, p. 339. Zie ook: Rb. Arnhem, 23 juni 2009, JB 2009/190 m.nt. R.J.N.S.

272. PG Awb I, p. 338-339.

273. PG Awb II, p. 417.

274. AbRvS 8 april 2009, $A B$ 2009/375 m.nt. C.M. Bitter; AbRvS 13 juni 2001, $A B$ 2001/267 m.nt. Sew. De Afdeling overweegt overigens ook dat artikel 8:29 Awb een beperking oplevert van de processuele openbaar-
} 
Deel II Bestuurlijke voorprocedures

selijk zijn op de bestuurlijke voorprocedures, van artikel 7:4 Awb hetzelfde gesteld kan worden.

Op de zaak betrekking hebbende stukken

Inmiddels is er redelijk wat jurisprudentie gevormd inzake de vraag welke stukken ter inzage moeten worden gelegd en wat verstaan moet worden onder 'op de zaak betrekking hebbende stukken' - of wellicht kan ik beter zeggen wat daar niet onder verstaan moet worden. Het begrip wordt in het kader van de bestuurlijke voorprocedures en de rechterlijke procedure, gelet op artikel 7:4 en artikel 8:29 Awb, op dezelfde wijze ingevuld. Het gaat om de stukken die tot het dossier behoren op grond van artikel 8:42 Awb. ${ }^{275}$

In beginsel behoren belanghebbenden alle stukken die van invloed zijn op of betrokken zijn bij de voorbereiding van de besluitvorming van het bestuursorgaan te kunnen inzien. Duidelijk is inmiddels echter dat een ambtelijk advies van een (interne) adviseur inzake de aan de orde zijnde rechtsvragen in de betreffende zaak met het oog op de positiebepaling van het bestuursorgaan (eventueel gelet op mogelijke beroepsprocedures) door de bestuursrechter niet wordt beschouwd als een op de zaak betrekking hebbend stuk. ${ }^{276}$ Dat geldt ook voor een advies of correspondentie tussen het bestuursorgaan en de landsadvocaat of andere externe adviseurs, die van belang zijn voor de positiebepaling van het bestuursorgaan. ${ }^{277}$ Zowel de Centrale Raad als de Afdeling zitten op deze lijn. De Afdeling had eerder in een uitspraak van 24 april 1998 al overwogen dat het een dergelijk advies niet behoorde tot de op de zaak betrekking hebbende stukken. Volgens de Afdeling staat deze problematiek echter in het teken van het waarborgen van de gelijkwaardigheid van het bestuur in de procedure. $\mathrm{Zij}$ overweegt immers:

"Indien de overheid niet, zoals andere rechtszoekenden, de mogelijkheid zou hebben om haar interne en externe adviseurs te raadplegen over de aan de orde zijnde rechtsvragen alvorens haar positie te bepalen, zou de gelijkwaardigheid tussen behartigers van het algemene en van het individuele belang in het gedrang kunnen komen. De schriftelijke neerslag van die raadpleging levert niet een op de zaak betrekking hebbend stuk als bedoeld in artikel 7:4, tweede lid, van de Awb op."278

Nog afgezien van het feit dat de Afdeling hier lijkt te verwijzen naar gelijkwaardigheid van procespartijen of ongelijkheidscompensatie ten voordele van het bestuur - daarop kom ik in paragraaf 5.3.5 nader terug -, geeft deze overweging en de thans vaste jurisprudentielijn van de Afdeling en de Centrale Raad aanleiding tot het maken van enkele opmerkingen. Zoals Schlössels reeds opmerkte in zijn noot bij de hiervoor aangehaalde uitspraak, wordt door de bestuursrechter een onderscheid gemaakt tussen (interne) ambtelijke adviezen die wel worden beschouwd als een op de zaak betrekking hebbend stuk en (interne) ambtelijke adviezen die dat niet zijn, maar wel van invloed zijn op de besluitvorming van het bestuursorgaan. Beslissend criterium lijkt te zijn in hoeverre het advies betrekking heeft op de aan de orde zijnde rechtsvragen en de procespositie van het bestuursorgaan. ${ }^{279}$ Of dat geheel conform de bedoeling van de wetgever is, is twijfelachtig. De wetgever zelf heeft aangegeven dat opname van een plicht tot ter inzage legging van interne adviezen niet nodig was in artikel 7:4 Awb, omdat uitdrukkelijk is bepaald dat alle voor de zaak relevante stukken ter inzage dienen te liggen, behalve wanneer het vierde, vijfde of zesde lid van die bepaling van toepassing is. ${ }^{280}$ De Afdeling en de Cen-

heid. Zoals meermalen aangegeven acht ik het zuiverder om de eis van openbaarheid van de stukken niet onder het openbaarheidsbeginsel maar onder het beginsel van hoor en wederhoor te scharen.

275. CRvB 16 januari 2008, $A B$ 2008/161 m.nt. Tollenaar.

276. Vzr. CRvB 25 februari 2008, $A B$ 2008/254 m.nt. A. Tollenaar.

277. AbRvS 5 november 2003, $A B$ 2004/176 m. nt. BdeW.

278. AbRvS 24 april 1998, JB 1998/145 m.nt. R.J.N.S.

279. Zie hierover ook de noot van Tollenaar en De Waard bij Vzr. CRvB 25 februari 2008, AB 2008/254 m.nt. A.

Tollenaar en AbRvS 5 november 2003, $A B$ 2004/176 m. nt. BdeW.

${ }^{280}$. PG Awb I, p. 340. 


\section{De inrichting van de voorprocedures}

trale Raad lijken desondanks een beperkt begrip van 'een op de zaak betrekking hebbend stuk' te hanteren, terwijl de Hoge Raad (belastingkamer) en het College van Beroep voor het bedrijfsleven een ruimere invulling lijken te geven aan dat begrip (in het kader van artikel 8:42 Awb). ${ }^{281}$ Tollenaar wijst erop dat de Hoge Raad een ruimere invulling aan het begrip lijkt te geven (in het kader van artikel 8:42 Awb). ${ }^{282}$ In een uitspraak van 25 april 2008 overweegt de Hoge Raad dat artikel 8:42 Awb zo dient te worden uitgelegd dat, behoudens gevallen van gerechtvaardigde weigering op grond van artikel 8:29 Awb en uitzonderingsgevallen als misbruik van procesrecht, een verzoek van een belanghebbende om stukken moet worden ingewilligd, indien deze voldoende gemotiveerd heeft gesteld dat het stuk van enig belang kan zijn (geweest) voor de besluitvorming in zijn zaak. ${ }^{283}$ Ook dan kunnen de stukken uit het dossier blijven, maar alleen als het bestuursorgaan een beroep doet op gewichtige redenen. Met Tollenaar kan gesteld worden dat de benadering van de Hoge Raad de voorkeur moet krijgen, omdat op grond daarvan in beginsel alle stukken en adviezen die van invloed zijn op de besluitvorming tot het dossier behoren en het bestuursorgaan of een andere partij vervolgens een beroep kan doen op gewichtige redenen die tot geheimhouding nopen. Pas dan behoeft bestuursrechter het stuk inhoudelijk te beoordelen. ${ }^{284}$ Deze lijn doet ook meer recht aan het beginsel van hoor en wederhoor en het recht op informatie van partijen. Andersoortige adviezen, die niet zozeer betrekking hebben op de in te nemen procespositie en het procedeergedrag van het bestuursorgaan, dienen wel aangemerkt te worden als op de zaak betrekking hebbende stukken. ${ }^{285}$ Ook in dit verband geldt dat de bestuursrechter uiteindelijk bepaalt of sprake is van een op de zaak betrekking hebbend stuk dat al dan niet ter inzage (had) moet(en) worden gelegd.

\section{Een zelfstandig recht op inzage?}

Het recht op inzage in alle relevante stukken wordt, zoals uit het voorgaande blijkt, gekoppeld aan het recht om gehoord te worden. In dat verband wordt het gezien als een noodzakelijke voorwaarde om de verdediging of hoor en wederhoor tijdens de hoorzitting optimaal te realiseren en als een fundamentele waarborg voor een behoorlijke procedure. Daarmee blijft echter de vraag onbeantwoord of ook onder omstandigheden een zelfstandig inzagerecht kan bestaan, dat wil zeggen een recht op inzage hoewel het bestuursorgaan in bezwaar terecht toepassing heeft gegeven aan artikel 7:3 van de Awb. Te denken valt vooral aan de situatie waarin een belanghebbende heeft afgezien van het horen, hetgeen als grond voor het afzien van het horen is neergelegd in artikel 7:3 sub c van de Awb. Ofschoon de belanghebbende niet gehoord wenst te worden, kan hij er immers baat bij hebben kennis te nemen van relevante (nieuwe) stukken. Van deze situatie moet onderscheiden worden het geval waarin het bestuur de belanghebbende niet heeft gehoord, maar ten onrechte toepassing heeft gegeven aan artikel 7:3 Awb. Is dat het geval, zal de rechter het besluit op bezwaar in beginsel vernietigen ${ }^{286}$ en in voorkomende gevallen zal het bestuur de belanghebbende moeten horen. In dat geval geldt artikel 7:4 Awb onverminderd. Indien de rechter de schending van artikel 7:2 Awb passeert of de rechtsgevolgen van het besluit in stand laat na vernietiging, kan de schending van het inzagerecht geacht te zijn hersteld in beroep, aangenomen dat de belanghebbende dan wel alle relevante stukken heeft mogen inzien. Weer een andere situatie betreft het geval waarin het besluit omwille van andere redenen door de bestuursrechter wordt vernietigd en het bestuur opnieuw een besluit moet nemen. In dat geval rijst allereerst de vraag of het bestuur opnieuw moet horen (zie hierover paragraaf 5.3.2.4) en in het ver-

${ }^{281 .}$ Zie hierover ook: Damen e.a. 2009, Deel II, p. 188-189.

282. Zie ook de noot van Tollenaar bij Vzr. CRvB 25 februari 2008, AB 2008/254.

${ }^{283 .}$ HR 25 april 2008, JB 2008/123.

284. Zie de noot van Tollenaar bij Vzr. CRvB 25 februari 2008, $A B$ 2008/254.

${ }^{285 .}$ Nogmaals de noot van Tollenaar bij Vzr. CRvB 25 februari 2008, $A B$ 2008/254.

286. Zie over de gevolgen van een schending van de hoorplicht, par. 5.3.2.6. 


\title{
Deel II Bestuurlijke voorprocedures
}

lengde daarvan ook of het bestuur (opnieuw) stukken ter inzage moet leggen. Als op grond van artikel 7:9 Awb dan wel 7:2 Awb of analoog daaraan een plicht tot horen bestaat na vernietiging door de bestuursrechter ook analoog een recht op inzage bestaat, voor zover het dossier nog niet bekend is of sprake is van nieuwe informatie. Mij lijkt verdedigbaar dat indien de hoorplicht van het bestuur niet zozeer voortvloeit uit artikel 7:2 Awb (omdat een van de uitzonderingen uit artikel 7:3 Awb van toepassing is en bestuur van het horen mocht afzien), maar desondanks uit het zorgvuldigheidsbeginsel (of een andere ongeschreven rechtsnorm) wordt afgeleid, daarmee ook een inzagerecht in alle relevante stukken geïndiceerd is. Ook in dit geval gaat het echter strikt genomen om een inzagerecht dat gekoppeld wordt aan een hoorplicht - maar dan ongeschreven - en niet zo zeer om een zelfstandig inzagerecht.

Een algemeen recht op inzage, dat ontkoppeld is van de hoorplicht, is in elk geval niet algemeen aanvaard op grond van de Awb. Een dergelijk recht werd in een uitspraak van de President van de rechtbank Amsterdam wel aangenomen. Daarin wordt overwogen dat het beginsel van een eerlijk proces met zich brengt dat een belanghebbende of zijn gemachtigde het recht heeft om voor het indienen van de gronden van het bezwaar de relevante stukken in te zien. Dit recht kan, gelet op het bovengemeld beginsel, volgens de President niet beperkt blijven tot het ter inzage leggen van de stukken gedurende tenminste een week voorafgaand aan het horen zoals bepaald in artikel 7:4 tweede lid van de Awb. ${ }^{287}$ Uit een uitspraak van de Hoge Raad kan echter worden afgeleid dat een zelfstandig inzagerecht in beginsel niet wordt erkend. ${ }^{288}$ De Centrale Raad heeft in een uitspraak van 25 januari 2002 bijvoorbeeld in dat verband, in een geval waarin de belanghebbende had afgezien van een hoorzitting, overwogen dat:

\begin{abstract}
“(... DW) gedaagde in dit geval van de bevoegdheid op grond van art. 7:3 van de Awb geen gebruik had behoren te maken vanwege het feit dat kort na die brief [waarin de gemachtigde had verklaard dat afgezien werd van het recht te worden gehoord DW] de bezwaarverzekeringsarts het rapport van 8 maart 1999 uitbracht. Noch de specifieke, op het horen in de bezwaarfase en het toezenden van stukken na dat horen toegespitste bepalingen in afdeling 7.2 van de Awb, noch de overige bepalingen in deze afdeling regelen voor het geval dat van het horen wordt afgezien - strikt genomen - de verplichting voor gedaagde het als een intern aan te merken rapport ter reactie ter kennis van de betrokkene te brengen. Een dergelijke verplichting valt naar het oordeel van de Raad ook niet te onlenen aan het in art. 3:2 van de Awb vervatte zorgvuldigheidsbeginsel dan wel aan hetgeen de beginselen van de goede procesorde, voor zover al van toepassing in de bezwaarprocedure van die beginselen sprake kan zijn, medebrengen. Met gedaagde is de Raad immers van oordeel dat dit rapport ten opzichte van de appellant eerder toegezonden stukken geen nieuwe feiten en/of omstandigheden bevat, welke tot een nadere of aanvullende standpuntbepaling van de zijde van appellant noopt." 289
\end{abstract}

In de literatuur zijn de meningen enigszins verdeeld over deze kwestie. Koenraad en Sanders bepleiten een dergelijk zelfstandig inzagerecht voor belanghebbenden, die in de bestuurlijke voorprocedure niet in de gelegenheid zijn gesteld om (mondeling) hun belangen te verdedigen. ${ }^{290}$ De Waard daarentegen acht een (algemeen) inzagerecht in stukken voor personen die niet gehoord zullen worden minder vanzelfsprekend. ${ }^{291}$ Mijns inziens valt er wat voor te zeggen dat onder omstandigheden een inzagerecht bestaat, indien er niet gehoord wordt. Het zal echter afhangen van de omstandigheden van het geval of inzage in de stukken noodzakelijk is voor de uitoefening van de verweermogelijkheden van de desbetreffende belanghebbende(n). Zoals blijkt uit de aangehaalde uitspraak zal met name een rol spelen in hoeverre de desbetreffende stukken nieuwe feiten en/of omstandigheden bevatten, waarop de belanghebbende moet kunnen reageren

\footnotetext{
${ }^{287 .}$ H.J. Simon, Handboek bestuurs(process)recht volgens de Awb, Den Haag: Sdu 1997, p. 263, die verwijst daartoe naar Rb. Amsterdam 8 augustus 1995, Awb-katern 1996, 19.

288. Zie bijvoorbeeld: HR 7 juni 2002, JB 2002/219.

289. CRvB 25 januari 2002, RSV 2002/126; USZ 2002/107. Zie ook: CRvB 19 april 2005, JB 2005/197 m.nt. A. van Eijs.

${ }^{290}$ Koenraad \& Sanders 2006, p. 74

${ }^{291 .}$ De Waard 1987, p. 292.
} 


\section{De inrichting van de voorprocedures}

en waaromtrent deze zijn standpunt moet kunnen verdedigen. De Centrale Raad lijkt ook in algemene zin een zelfstandig inzagerecht niet uit te sluiten, maar het vooral in het voorliggende geval, nu daaruit geen nadere standpuntbepaling van de belanghebbende kon volgen, vanuit een oogpunt van zorgvuldigheid (of van een goede procesorde) niet noodzakelijk te achten. ${ }^{292}$ Opvallend is de aarzeling die de Centrale Raad vertoont in de aangehaalde uitspraak inzake het toepasselijk achten van beginselen van de goede procesorde op de bezwaarschriftprocedure. In andere uitspraken, inzake artikel 7:4, eerste en tweede lid, van de Awb, heeft de Centrale Raad zich daarin minder terughoudend getoond. ${ }^{293}$ Nog opmerkelijker is overigens dat, gelet op de resolute overwegingen in andere zin in sommige uitspraken, de Afdeling in het kader van artikel 7:4 (eerste lid) Awb minder terughoudend lijkt te zijn (dan de Centrale Raad) in het van toepassing verklaren van de goede procesorde op de bezwaarschriftprocedure. ${ }^{294}$

Een concrete uitwerking van het beginsel van hoor en wederhoor

Een andere belangrijke vraag is welke ongeschreven norm aan het inzagerecht, zoals neergelegd in artikel 7:4 Awb of als zelfstandig recht, ten grondslag ligt: het beginsel van hoor en wederhoor dan wel de goede procesorde of het zorgvuldigheidsbeginsel. Het bovenstaande biedt voldoende aanknopingspunten voor het standpunt dat het in deze bepaling neergelegde inzagerecht kan worden gezien als een uitwerking van het beginsel van hoor en wederhoor. ${ }^{295}$ Gelet op de overeenkomsten met de rechterlijke procedure in dit opzicht en de veelvuldige verwijzingen naar dat beginsel of de ratio van dat beginsel, ligt het beginsel van hoor en wederhoor als grondslag ook voor de hand. Het is duidelijk dat de achtergrond van deze eis is dat belanghebbenden over alle relevante informatie beschikken om goed beslagen ten ijs te komen tijdens de hoorzitting. In deze zin gaat het inzagerecht of het recht om informatie te ontvangen vooraf aan de verdediging of het verweer van de belanghebbende(n) tijdens de hoorzitting en vormt het een noodzakelijke voorwaarde ter vervulling daarvan. De Waard stelde zich al op het standpunt dat 'een recht op inzage van in beginsel alle stukken onlosmakelijk is verbonden aan enige procedure waarbij iemand in de gelegenheid wordt gesteld te worden gehoord'. In zijn optiek volgt hieruit dat inzage in elk geval in bezwaar en beroep moet plaatsvinden, maar soms ook al vanuit zorgvuldigheidsoogpunt in de primaire fase van de besluitvorming. ${ }^{296}$ Voor de bezwaarschriftprocedure en het administratief beroep, zoals vormgegeven onder de Awb, is dat ook om die reden een geldende eis voor een behoorlijke procedure. Duidelijk is echter ook dat ten aanzien van deze waarborg - evenals het geval is bij andere eisen die als uitwerking van het beginsel van hoor en wederhoor zouden kunnen worden gezien alsmede bij mogelijke uitwerkingen van andere beginselen van behoorlijke rechtspleging - vooral in de rechtspraak enige ambivalentie te bespeuren is om de grondslag in voor de rechterlijke procedure geldende normen, zoals het beginsel van hoor en wederhoor of de (beginselen van een) goede procesorde, te zoeken. Het algemene zorgvuldigheidsbeginsel, als norm voor behoorlijk bestuurlijk handelen, lijkt voor de bestuursrechter toch primair het handvat te zijn voor het stellen van (aanvullende) eisen die verband houden met de goede procesorde. Op de grondslag voor het inzagerecht en andere aspecten van het recht om informatie te ontvangen in de bestuurlijke voorprocedures, kom ik in meer algemene zin nog nader terug in paragraaf 5.3.6.

\footnotetext{
292. Zie in dezelfde zin en met vergelijkbare overwegingen: CRvB 19 april 2005, USZ 2005/247; JB 2005/197 m.nt. A. van Eijs.

${ }^{293}$ CRvB 4 april 2003, JB 2003/182; CRvB 4 april 2003, JB 2003/155; CRvB 28 mei 2002, AB 2002/364 m.nt. $\mathrm{HBr}$.

294. Zie bijvoorbeeld: AbRvS 3 september 2003, AB 2003/389 m.nt. Sew.

${ }^{295 .}$ Zie: Notten 1998, p. 208/209 e.v.; Teunissen, p. E 6.3.9-2.

${ }^{296 .}$ De Waard 1987, p. 292. Dat is niet het geval bij de hoorplicht op grond van art. 4:7 en 4:8 Awb in de primaire besluitvormingsfase, maar daarvan wordt ook aangenomen dat deze meer in teken staat van de informatiegaring door het bestuur.
} 
Deel II Bestuurlijke voorprocedures

5.3.4.2 Het recht om informatie te ontvangen over procedure en incidenten in de procedure

Het recht om informatie te ontvangen, als onderdeel van het beginsel van hoor en wederhoor, beperkt zich voor rechtspraak niet tot het recht op inzage in stukken. Daarvan maakt tevens het recht op informatie omtrent het verloop van de procedure en de procedurele incidenten onderdeel uit voor zover deze van invloed zijn op de verweermogelijkheden van de procesdeelnemers. ${ }^{297}$ Het is voor de procesdeelnemers van belang dat zij op de hoogte zijn wanneer procedureel relevante handelingen plaatsvinden en welke rechten of mogelijkheden zij te dien aanzien hebben. In de onderhavige paragraaf wordt bezien in hoeverre belanghebbenden in de bestuurlijke voorprocedures recht hebben op informatie over die onderwerpen.

Kennisgeving van de mogelijkheid om gehoord te worden

In de bezwaarschriftprocedure en het administratief beroep vormt de hoorzitting de belangrijkste procedurele 'gebeurtenis'. Het tweede lid van artikel 7:2 Awb bepaalt dan ook dat het bestuursorgaan in ieder geval de indiener van het bezwaarschrift en belanghebbenden die bij de voorbereiding van het primaire besluit hun zienswijze naar voren hebben gebracht, op de hoogte stelt van de hoorzitting (en in administratief beroep het bestuursorgaan dat het bestreden besluit genomen heeft). In de toelichting wordt aangegeven dat het onder omstandigheden wenselijk kan zijn de kring van personen die op de hoogte moeten worden gesteld niet te beperken tot de in die bepaling genoemde personen maar uit te breiden met andere belanghebbenden. ${ }^{298}$ In artikel 7:16 van de Awb is in het tweede lid een vergelijkbare regeling voor het administratief beroep neergelegd. Daarin heeft één aanvulling plaatsgevonden. Het beroepsorgaan dient, naast de indiener van het beroepschrift en belanghebbenden die bij de voorbereiding van het besluit of bij de behandeling van het bezwaarschrift hun zienswijze naar voren hebben gebracht, ook het bestuursorgaan van de hoorzitting op de hoogte te stellen. De toevoeging is inherent aan het feit dat de procedure in administratief beroep bij een ander bestuursorgaan gevolgd moet worden dan het orgaan dat het besluit genomen heeft en dit laatste orgaan derhalve in dit opzicht dezelfde status als een belanghebbende in de procedure krijgt. Datzelfde geldt min of meer indien er een adviescommissie is ingesteld in de zin van artikel 7:13 Awb. In dat geval moet ook een vertegenwoordiger van het bestuur voor het horen worden uitgenodigd ingevolge het vijfde lid van die bepaling. Daaruit volgt dat deze ook op de hoogte moet worden gesteld van de hoorzitting en de gelegenheid om het standpunt toe te lichten. Voorts zal ook de commissie in elk geval de belanghebbenden als bedoeld in artikel 7:2 tweede lid op de hoogte moeten stellen van de hoorzitting.

Het eerste lid van artikel 7:2 Awb bepaalt in algemene zin dat belanghebbenden de gelegenheid moet worden geboden om gehoord te worden, terwijl het tweede lid beoogt te garanderen dat in elk geval de belanghebbenden die al eerder in de procedure betrokken waren ook daarvan op de hoogte worden gesteld. ${ }^{299}$ In deze zin kan de kennisgevingplicht mijns inziens ook als een uitwerking van het beginsel van hoor en wederhoor, althans een noodzakelijke voorwaarde om daaraan recht te kunnen doen, gezien worden. Indien belanghebbenden niet tijdig op de hoogte worden gesteld van de mogelijkheid om gehoord te worden, kunnen zij immers geen gebruik maken van het recht dat zij daarop hebben. De Waard geeft aan dat het recht om informatie te ontvangen ziet op de omstandigheid dat een procedure van start gaat, het onderwerp van het geschil, de stellingen van de wederpartij, het ondersteunend materiaal dat de wederpartij in de procedure inbrengt

\footnotetext{
297. Vgl. De Waard 1987, p. 255 e.v.

298. PG Awb I, p. 330. Bij een grote groep belanghebbenden kan mededeling in een publicatieblad angewezen zijn. De wetgever geeft ook aan dat de kennisgevingplicht beperkt is tot de in het tweede lid genoemde personen omdat lang niet altijd bekend zal zijn wie de belanghebbenden zijn.

${ }^{299 .}$ PG Awb I, p. 331.
} 


\section{De inrichting van de voorprocedures}

alsook wie de wederpartij is. ${ }^{300}$ De kennisgeving van de hoorzitting moet volgens De Waard ondergebracht worden bij de deeleis dat een partij het recht heeft op informatie dat de procedure van start gaat. Omdat daarover in de voorprocedure geen onduidelijkheid kan bestaan voor de belanghebbenden aangezien de procedure - in zijn optiek - dan reeds van start is gegaan (de primaire besluitvorming is reeds gestart en geëindigd) krijgt deze deeleis een iets andere betekenis in die fasen. Het vereiste van behoorlijke kennisgeving ziet volgens De Waard in administratief beroep of in beroep bij de rechter dan ook vooral op elementaire onderdelen van een lopende procedure ${ }^{301}$, zoals kennisgeving van de mondelinge behandeling of andere procedurele stappen. Voor de bezwaarschriftprocedure en het administratief beroep is een dergelijke kennisgevingsplicht van de hoorzitting expliciet neergelegd in de Awb.

\section{Intermezzo: de termijn voor oproeping}

Het beginsel van hoor en wederhoor omvat vier deelaspecten. Het enige aspect dat geen afzonderlijke aandacht krijgt, in de zin dat daaraan een afzonderlijke paragraaf is gewijd in dit onderzoek, vormt de eis dat er voldoende gelegenheid moet worden geboden voor de voorbereiding van het eigen standpunt. Voor zover van belang komt dit aspect terug in de paragrafen die betrekking hebben op uitwerkingen van het recht om informatie te ontvangen en verschaffen. Zoals eerder aangegeven, vormt het bieden van voldoende tijd aan belanghebbenden een belangrijke voorwaarde voor het kunnen uitoefenen van deze rechten. Dit aspect komt ook terug in de eisen die gesteld worden aan de inrichting van de bestuurlijke voorprocedures in de Awb. Te denken valt aan de eerder besproken mogelijkheid om stukken in te dienen tot tien dagen voor de hoorzitting. Een andere uitwerking van dat aspect is de eis dat belanghebbenden een oproeping voor de hoorzitting ontvangen. Van belang is daarbij dat hen een redelijke termijn tot de zitting gegund wordt. Zij dienen op grond van het beginsel van hoor en wederhoor immers voldoende gelegenheid te hebben om zich voor te bereiden daarop en hetgeen zij daar naar voren zouden willen brengen. ${ }^{302}$ In de oproeping behoren dan ook datum, plaats en tijdstip van de hoorzitting te worden aangegeven. Er is echter niet in de Awb bepaald welke termijn in acht moet worden genomen en wat als een redelijke termijn beschouwd kan worden. Het ligt evenwel voor de hand dat een datum en tijdstip om te verschijnen op de hoorzitting niet te kort na de oproeping mag liggen, omdat belanghebbenden daarmee beknot worden in hun voorbereidingsmogelijkheden en dientengevolge in hun verweermogelijkheden. ${ }^{303}$ In artikel 7:4 Awb is in het derde lid geregeld dat belanghebbenden in de oproeping voor de hoorzitting gewezen worden op de mogelijkheid dat zij tot tien dagen voor de hoorzitting nadere stukken kunnen indienen alsmede op de plaats waar en het tijdstip waarop de op de zaak betrekking hebbende stukken ter inzage liggen. Daaruit kan worden afgeleid dat er in elk geval - volgens de wetgever - op zijn minst een termijn van tien dagen ligt tussen de oproeping en het horen. ${ }^{304}$ In de literatuur wordt aangenomen dat er een redelijke termijn in acht moet worden genomen, maar het zal van de omstandigheden van het geval afhangen wat als een redelijk kan worden beschouwd. ${ }^{305}$ Aangenomen moet echter worden dat in veel gevallen een langere termijn dan tien dagen nodig is ter voorbereiding van de hoorzitting. In de jurisprudentie is de duur van de termijn die ligt tussen de uitnodiging en de hoorzitting geen punt van geschil dat regelmatig aan de orde komt. Voor de bestuursrechter geldt op grond van artikel 8:56 Awb dat partijen ten minste drie weken voor de zitting een uitnodiging voor de zitting dienen te ontvangen.

\footnotetext{
${ }^{300 .}$ De Waard 1987 , p. 248.

${ }^{301 .}$ De Waard 1987, p. 253

302. De Waard 1987, p. 247 en 326. Zie ook: Teunissen, p. E. 6.3.7-11, die er ook op wijst dat belanghebbenden voldoende gelegenheid moeten hebben om deskundige bijstand in te roepen en dat ze en/of gemachtigden persoonlijk bij het horen aanwezig kunnen zijn.

${ }^{303 .}$ Vgl. Teunissen, p. E. 6.3.7-11.

304. Teunissen, p. E. 6.3.7-11.

305. Teunissen, p. E. 6.3.7-11.
} 


\section{Deel II Bestuurlijke voorprocedures}

Achtergrond daarvoor is de goede procesorde. ${ }^{306}$ Aan artikel 8:56 Awb lijkt (in combinatie met artikel 8:57 Awb) door de bestuursrechter wel eens ambtshalve te zijn getoetst. ${ }^{307}$ Het is echter de vraag of die bepaling(en) naar de heersende lijn in de jurisprudentie een voorschrift van openbare orde betreft waaraan ambtshalve kan (en moet) worden getoetst. ${ }^{308}$ Het aanhouden van eenzelfde termijn van drie weken voor de bestuurlijke voorprocedures lijkt mij als uitgangspunt redelijk.

Hoewel de redelijkheid van de termijn tussen oproeping en de hoorzitting als zodanig niet aan bod is gekomen in de jurisprudentie van de bestuursrechter, heeft deze wel regelmatig moeten oordelen over weigeringen van het bestuursorgaan op verzoeken om uitstel van de hoorzitting. Het gevolg van die weigeringen is veelal dat een belanghebbende niet of zonder gemachtigde op de hoorzitting is verschenen. De bestuursrechter zal in dat geval moeten beoordelen of een schending van artikel 7:2 Awb heeft plaatsgevonden, nu deze bepaling vereist dat belanghebbenden in de gelegenheid worden gesteld om gehoord te worden. De bestuursrechter is in het algemeen niet snel genegen om aan te nemen dat een bestuursorgaan terecht geen uitstel heeft verleend. Verschillende factoren kunnen een rol spelen in het kader van de vraag of een verzoek om uitstel geweigerd kan worden. Een belangrijke factor lijkt te zijn binnen welke termijn na de uitnodiging om uitstel wordt verzocht. Gebeurt dit direct daarna, bestaat er minder aanleiding om het verzoek te weigeren. ${ }^{309}$ Vakantie van de gemachtigde of ziekte van de gemachtigde vormen in principe omstandigheden die voor rekening van de belanghebbende moeten blijven en nopen niet tot het verlenen van uitstel. Verder kan nog relevant zijn in welke periode de hoorzitting gepland stond (vakantieperiode of niet) en of het bestuur dan wel commissie een bepaalde gedragslijn volgde waarbij verzoeken om uitstel steeds werden gehonoreerd. ${ }^{310}$ Gelet op het belang dat aan het horen gehecht moet worden in de bezwaarfase en aan de voortvarendheid van de besluitvorming is een strenge benadering van de rechter ten aanzien van weigeringen om uitstel te verlenen ook op zijn plaats. Ook voor de zitting in eerste aanleg bij de bestuursrechter geldt immers dat uitstel van de behandeling van de zaak alleen verleend wordt als daartoe aanleiding bestaat gelet op de goede procesorde. ${ }^{311}$ In de handreiking bezwaarschriftprocedure wordt geadviseerd om slechts uitstel te verlenen, indien daar gemotiveerd om is verzocht alsmede om dat slechts eenmaal te doen. Daar wordt ook aangegeven dat indien gemotiveerd om uitstel wordt verzocht dat verzoek in beginsel gehonoreerd moet worden. ${ }^{312}$ Dat lijkt mij, aangenomen dat er goede redenen voor het uitstel worden aangevoerd zoals ziekte of onvoorziene omstandigheden, een goed uitgangspunt. In dit soort gevallen zal een redelijk evenwicht gevonden moeten worden tussen de goede procesorde alsmede de verweermogelijkheden van partijen en een voortvarend verloop van de procedure.

Informatie over hetgeen ter hoorzitting aan de orde is gekomen

Een andere uitwerking van het recht om informatie te ontvangen die samenhangt met het horen in de bestuurlijke voorprocedures is het recht om informatie te ontvangen over hetgeen tijdens het horen aan de orde is gekomen. In artikel 7:7 en 7:21 van de Awb is een verplichting om van het horen een verslag te maken neergelegd. Indien gehoord wordt door een commissie bevat artikel 7:13, zesde lid, van de Awb de verplichting dat het schriftelijke advies van de commissie tevens een verslag van het horen bevat. De wetgever heeft het ten behoeve van de beslissing op het bezwaarschrift als ook ten behoeve van de vorming van het dossier, dat eventueel in een latere fase moet worden

\footnotetext{
306. CRvB 29 maart 1996, $A B$ 1996/368.

307. CRvB 11 april 1996, $A B$ 1996/257 m.nt. P.J. Stolk; CRvB 22 augustus 1997, AB 1997/417 m.nt. F.J.L. Pennings.

${ }^{308 .}$ Zie over ambtshalve toetsing aan bepalingen van openbare orde, o.m. Brumgan 2005, p. 265-277

${ }^{309}$. Zie bijvoorbeeld: AbRvS 2 juli 2003, JB 2003/230.

310. CRvB 26 april 2005, $A B$ 2005/303 m.nt. HBr.

311. CRvB 21 juni 2006, JB 2006/261; CRvB 24 juni 1999, AB 1999/406 m.nt. HH.

312. Handreiking bezwaarschriftprocedure Algemene wet bestuursrecht, Den Haag: BJu 2004, p. 40.
} 


\section{De inrichting van de voorprocedures}

overgelegd aan de beroepsinstantie, noodzakelijk geacht dat het verhandelde tijdens de hoorzitting schriftelijk wordt vastgelegd. ${ }^{313}$ Het vereiste dát een schriftelijke verslaglegging dient plaats te vinden van het horen, is echter ook meteen het enige vereiste dat de Awb stelt aan het verslag van de hoorzitting. Op welke wijze het verslag wordt vormgegeven en wat exact in het verslag behoort te worden opgenomen, laat artikel 7:7 Awb (en ook het zesde lid van artikel 7:13) in het midden. De wetgever stelt dat het afhankelijk is van de omstandigheden van het geval en van het bestuursorgaan op welke wijze en hoe uitvoerig de verslaglegging geschiedt. ${ }^{314}$ Van belang is in dat kader of tijdens de hoorzitting nieuwe feiten of omstandigheden naar voren komen die nog niet in de schriftelijke stukken aan de orde zijn geweest. Dan zal eerder een uitgebreid verslag in de rede liggen waarin deze feiten of omstandigheden worden weergegeven. Essentieel is dat in elk geval de kern van hetgeen aan de orde is gekomen schriftelijk wordt vastgelegd aldus de wetgever. Hoe uitvoeriger de hoorzitting des te meer een uitvoerig verslag in de rede ligt. ${ }^{315}$ Datzelfde moet worden aangenomen voor het aantal belanghebbenden: hoe meer belanghebbenden des te meer ligt een uitvoeriger verslag in de rede. ${ }^{316}$ Ook indien getuigen of deskundigen gehoord worden in het bijzijn van de belanghebbenden moet mijns inziens het verslag uitvoeriger zijn en in elk geval op hoofdlijnen de verklaringen van die personen bevatten. ${ }^{317}$ De bestuursrechter heeft zich aan de bedoeling van de wetgever geconformeerd. In een uitspraak van de Centrale Raad wordt naar aanleiding van een klacht van appellant inzake het verslag van de hoorzitting overwogen dat:

“(...) de Algemene wet bestuursrecht slechts bepaalt dat van het horen een verslag wordt gemaakt. Een nadere precisering van hetgeen een verslag moet inhouden ontbreekt. Het ligt in de rede aan te nemen dat in het verslag kan worden volstaan met een beknopte, zakelijke vermelding van hetgeen tijdens de hoorzitting met betrekking tot de zaak is betoogd. Niet kan worden geëist dat het verslag een woordelijke weergave inhoudt van al hetgeen tijdens de hoorzitting is gezegd." 318

Een woordelijke weergave van hetgeen aan de orde is gekomen is derhalve niet vereist en de bestuursrechter zal aan de hand van de omstandigheden van het geval beoordelen of het verslag voldoet. Er geldt echter wel een ondergrens: de rechtbank Den Bosch achtte bijvoorbeeld een verslag waaruit in het geheel niet blijkt op welke wijze of door wie een belanghebbende is gehoord alsmede wat tijdens het horen naar voren is gebracht ongeoorloofd. ${ }^{319}$ De beweerdelijke (inhoudelijke) onjuistheid van het verslag als zodanig kan, volgens de Afdeling, echter geen grond van vernietiging van het besluit zijn. In die zaak was een verslag gemaakt van de hoorzitting en volgens de Afdeling was dat reeds voldoende vanuit het oogpunt van artikel 7:7 Awb. ${ }^{320}$ De onjuistheid kunnen belanghebbenden bij de Afdeling aan de orde stellen, die de kritiek in haar overwegingen kan betrekken. ${ }^{32}$

Aan de plicht tot schriftelijke verslaglegging kan volgens de wetgever voorts op verscheidene manieren worden voldaan. Er kan een afzonderlijk verslag van het horen worden opgesteld, maar ook kan in de beslissing op bezwaar hetgeen ter sprake is gekomen tijdens de hoorzitting worden opgenomen. ${ }^{322}$ In de Awb is niet bepaald dat en op welk moment, indien er een afzonderlijk verslag is opgesteld, dit verslag ook aan belangheb-

\footnotetext{
313. PG Awb I, p. 342

314. PG Awb I, p. 342

315. PG Awb I, p. 343

316. Teunissen, p. E. 6.3.12-2.

317. Indien belanghebbenden niet gezamenlijk worden gehoord en ook niet de door hen meegebrachte getuigen en deskundigen, zal teruggegrepen moeten worden op art. 7:6 Awb voor de eis dat verslag gemaakt wordt van het horen.

318. CRvB 14 september 2004, JB 2004/360. Zie ook: CRvB 17 maart 2010, JB 2010/131.

${ }^{319 .} \mathrm{Rb}$. 's Hertogenbosch 13 maart 1998, JB 1998/121.

320. AbRvS 1 februari 2001, JB 2001/72 m.nt. AWH.

321. AbRvS 1 februari 2001, JB 2001/72 m.nt. AWH.

322. PG Awb I, p. 343. Dat een weergave van het tijdens de hoorzitting verhandelde in de beslissing op bezwaar mag worden opgenomen en derhalve geen afzonderlijk verslag nodig is, werd door de bestuursrechter ook al aangenomen voor de inwerkingtreding van de Awb, zie: CBb 31 mei 1990, AB 1991/405.
} 
Deel II Bestuurlijke voorprocedures

benden dient te worden toegezonden. De Afdeling heeft echter in een uitspraak van 12 juni 1997 reeds aangegeven dat het verslag uiterlijk met de beslissing op bezwaar aan belanghebbenden moet worden toegezonden. ${ }^{323}$ Toezending na het besluit op bezwaar leidt tot strijd met het zorgvuldigheidsbeginsel. In dezelfde uitspraak geeft de Afdeling ook aan dat het vanuit zorgvuldigheidsoogpunt wenselijk zou zijn om het verslag voor de beslissing op bezwaar toe te zenden, zodat belanghebbenden daar eventueel nog op kunnen reageren. ${ }^{324}$ Het bestuursorgaan kan op die wijze bij de besluitvorming rekening houden met de opmerkingen of aanvullingen van de belanghebbenden. Indien het horen plaatsvindt door een adviescommissie en het bestuursorgaan afwijkt van dat advies, behoort het advies, dat een verslag van het horen moet bevatten, samen met de beslissing aan belanghebbenden te worden toegezonden. ${ }^{325}$

De wetgever zoekt de ratio voor de plicht tot schriftelijke verslaglegging van hetgeen aan de orde is gekomen tijdens de hoorzitting, naast de kwaliteit van de beslissing op bezwaar, met name in de vorming van het dossier met het oog op een mogelijke beroepsprocedure daarna. ${ }^{326}$ Enerzijds speelt derhalve de zorgvuldigheid van de besluitvorming een rol en anderzijds de connexiteit met de procedure bij de bestuursrechter. Teunissen geeft aan dat door de bestuursrechter onder de Wet Arob reeds een ongeschreven plicht tot het schriftelijk vastleggen van het verhandelde tijdens de hoorzitting werd aangenomen, indien het horen niet geschiedde door het bestuur zelf, maar door een of meer leden daarvan dan wel ambtenaren of een commissie (voor zover een dergelijke plicht niet reeds schriftelijk was vastgelegd in een verordening). ${ }^{327}$ In die gevallen heeft de verslaglegging vooral een functie vanuit het oogpunt van zorgvuldige besluitvorming. Het bestuursorgaan (in voltallige samenstelling) is immers niet bij het horen betrokken geweest en moet, teneinde voldoende rekening te kunnen houden met hetgeen naar voren is gebracht bij de besluitvorming, deugdelijk op de hoogte worden gebracht van het verhandelde tijdens de hoorzitting. ${ }^{328}$ Uit enkele uitspraken onder de Wet Arob blijkt echter ook dat schriftelijke verslaglegging van het horen geëist werd, indien het bestuur zelf in volledige samenstelling gehoord had. ${ }^{329}$ In die gevallen schuift het oogpunt van zorgvuldige besluitvorming in mijn ogen meer naar de achtergrond, omdat het bestuur reeds op de hoogte is van hetgeen naar voren is gebracht tijdens de hoorzitting. De plicht tot schriftelijke verslaglegging staat in dergelijke gevallen vooral ten dienste van de dossiervormingsfunctie en de controlerende functie van de bestuursrechter in de beroepsprocedure. De bestuursrechter behoort immers na te gaan of voldoende rekening is gehouden met het verhandelde tijdens de hoorzitting met het oog op de zorgvuldigheid van de besluitvorming en de motivering van het besluit. ${ }^{330}$ Daarmee hangt mijns inziens ook samen dat de verslaglegging ten dienste staat aan de processuele belangen van de belanghebbenden die gehoord zijn. Op die manier worden alle aangevoerde argumenten en informatie van belanghebbenden vastgelegd en is kenbaar voor belanghebbenden en in theorie - verzekerd dat ze, voor zover relevant, bij de besluitvorming worden betrokken. In een enkele uitspraak onder de Wet Arob worden ook de processuele belangen van de bezwaarmakers genoemd als een belang dat gediend wordt met de schriftelijke ver-

\footnotetext{
323. AbRvS 12 juni 1997, JB 1997/188.

${ }^{324}$ Daarmee lijkt zij echter niet te doelen op een plicht daartoe die uit het zorgvuldigheidsbeginsel kan worden afgeleid. De CRvB overweegt eveneens in een uitspraak van 17 maart 2010 dat uit art. 7:7 Awb geen verplichting volgt tot het verzenden van het verslag voor het nemen van het besluit op bezwaar én dat er ook overigens geen rechtsgrondslag voor een zodanige verplichting bestaat, CRvB 17 maart 2010, JB 2010/131.

325. Art. 7:13 lid 6 en 7 Awb.

326. PG Awb I, p. 342. In de memorie van antwoord wordt nog eens aangegeven, op de vraag om welke reden het noodzakelijk is in alle gevallen een dergelijke plicht voor te schrijven, dat het belang daarvan gelegen is in de eventuele latere procedure tegen de beslissing op bezwaar, PG Awb I, p. 344.

327. Teunissen, p. E 6.3.12-1 en de daar genoemde jurisprudentie.

328. Teunissen, p. E. 6.3.12-1.

329. Zie bijvoorbeeld: ArRvS 12 juli 1982, $A B$ 1982/556; ArRvS 12 januari 1993, $A B$ 1993/237 m.nt. Verheij; ArRvS 8 november 1993, $A B$ 1994/208 m.nt. Verheij.

${ }^{330 .}$ Vgl.: Rb. 's Hertogenbosch 13 maart 1998, JB 1998/121; ARRvS 12 juli 1982, AB 1982/556.
} 


\section{De inrichting van de voorprocedures}

slaglegging. ${ }^{331}$ Een vergelijking met de functie van het proces-verbaal van de terechtzitting in de procedure bij de bestuursrechter lijkt op zijn plaats. Opmerkelijk is wel dat een proces-verbaal slechts opgesteld behoeft te worden, indien een partij daarom verzoekt of de rechter dit ambtshalve bepaalt, en indien hoger beroep wordt ingesteld. Het procesverbaal lijkt derhalve onder de Awb voor de procedure van de rechter vooral in het teken te staan van de controlerende functie van de hoger beroepsinstantie. In het geval getuigen of deskundigen gehoord zijn ter terechtzitting behoren hun verklaringen, eveneens met het oog op dat doel, daarin (al dan niet integraal) opgenomen te worden. ${ }^{332}$

De Awb schrijft in elk geval thans voor dat in alle gevallen een schriftelijk verslag van het horen in de bestuurlijke voorprocedures moet worden opgesteld. Die verplichting gaat verder dan in de bestuursrechterlijke procedure. Tegelijkertijd zijn de eisen aan de inhoud van het verslag minder verstrekkend. Daaruit blijkt dat de informatiefunctie van het horen en de dossiervormingsfunctie van de bestuurlijke voorprocedures bij deze eis domineren. De Afdeling lijkt de verslaglegging thans ook vooral in het teken van het zorgvuldigheidsbeginsel, als norm voor de besluitvorming, te plaatsen. Daaraan moet mijns inziens echter ook nog de bescherming van de processuele belangen van belanghebbenden worden toegevoegd.

Kennisgeving van of informatie over andere processuele rechten

Naast informatie omtrent de hoorzitting hebben belanghebbenden ook baat bij andere informatie omtrent de procedurele gang van zaken en ook de hen toekomende procedurele rechten. ${ }^{333}$ De kennisgevingsplicht is in artikelen 7:4 en 7:18, derde lid, van de Awb dan ook nog verder uitgebreid. In de oproeping voor het horen moet het bestuursorgaan tevens aangeven dat een belanghebbende tot tien dagen voor de hoorzitting stukken kan indienen alsmede waar en wanneer de op de zaak betrekking hebbende stukken ter inzage liggen. Zowel het recht om stukken in te dienen als het inzagerecht kunnen worden gezien als een uitwerking van het beginsel van hoor en wederhoor en worden op dezelfde wijze ingevuld als de vergelijkbare rechten die gelden in de procedure bij de bestuursrechter. De uitbreiding van de kennisgevingsplicht dient in het verlengde daarvan dan ook in datzelfde perspectief te worden gezien. Van het vereiste van behoorlijke kennisgeving in bezwaar maakt derhalve ook de eis uit dat belanghebbenden op de hoogte worden gesteld van de procedurele rechten die hen toekomen. De kennisgevingsplicht is in de Awb echter beperkt tot de hiervoor genoemde procedurele rechten. In artikel 7:8 Awb is bijvoorbeeld niet neergelegd dat in de oproeping gewezen moet worden op de mogelijkheid om op verzoek getuigen of deskundigen mee te brengen naar de hoorzitting. Hoewel daartoe geen wettelijke verplichting bestaat, lijkt het desondanks wenselijk indien het bestuur of de commissie van die mogelijkheid melding maakt in de oproeping. Teunissen wijst er voorts nog op dat het wenselijk is dat belanghebbenden ook gewezen worden op de mogelijkheid om zich door een gemachtigde te laten vertegenwoordigen. ${ }^{334}$ Opdat belanghebbende optimaal van hun verweermogelijkheden en de hen toekomende procedurele rechten gebruik kunnen maken, is het wenselijk dat in de oproeping voor de hoorzitting zoveel mogelijk op dergelijke rechten gewezen wordt.

\subsubsection{De gevolgen van schendingen van het recht om informatie te ontvangen}

\section{Gevolgen van schending van het inzagerecht}

Nalaten de op de zaak betrekking hebbende stukken ter inzage te leggen, leidt niet altijd tot een vernietiging van het bestreden besluit. Indien de belanghebbende gehoord is en niet gebleken is dat hij of zij door het achterwege laten van de ter inzage legging is bena-

\footnotetext{
331. ArRvS 22 augustus 1979, AB 1980/266.

332. Art. 8:61 lid 4, lid 5 en lid 8 Awb.

333. Vgl. De Waard 1987, p. 321 e.v.

334. Teunissen, p. E 6.3.7-13.
} 


\section{Deel II Bestuurlijke voorprocedures}

deeld, kan dit gebrek gepasseerd worden met toepassing van artikel 6:22 Awb. ${ }^{335}$ Soms wordt er dan een proceskostenveroordeling toegekend. ${ }^{336}$ In andere gevallen wordt wel overgegaan tot een vernietiging bij schending van artikel 7:4 Awb (of artikel 7:18, tweede lid, dan wel artikel 3:2 Awb, al dan niet in samenhang met de artikelen 7:4 of 7:18 Awb). ${ }^{337}$ Dat ligt in de rede als belanghebbenden door de onbekendheid met de stukken benadeeld zijn of in hun procesbelangen geschaad zijn. In sommige gevallen worden na vernietiging de rechtsgevolgen van het vernietigde besluit in stand gelaten. ${ }^{338}$ Omdat het om een belangrijke waarborg gaat in het kader van de verweermogelijkheden van belanghebbenden en een waarborg die sterk samenhangt met het horen in de bestuurlijke voorprocedures, zou een schending van het inzagerecht in mijn optiek in beginsel tot vernietiging van het besluit moeten leiden.

\section{Gevolgen schending vereiste van behoorlijke kennisgeving}

Schendingen van het vereiste van een behoorlijke kennisgeving van de hoorzitting en de termijn die daarvoor geldt, komen in de jurisprudentie niet regelmatig aan bod. Voor de hand ligt dat als een belanghebbende is verschenen bij de hoorzitting en ook niet benadeeld is door een schending van dit vereiste, het gebrek gepasseerd kan worden zonder dat een vernietiging van het besluit plaatsvindt. In andere gevallen moet, gelet op het belang dat gehecht moet worden aan het horen, vernietiging van het besluit volgen. Datzelfde geldt als er ten onrechte geen uitstel van de hoorzitting wordt verleend. ${ }^{339}$

Of een schending van de plicht tot het maken van een verslag van de hoorzitting in het algemeen moet leiden tot vernietiging van de uitspraak is op grond van de jurisprudentie evenmin duidelijk. Deze plicht is niet regelmatig onderwerp van een uitspraak van de bestuursrechter. Indien het bestuur een schriftelijk verslag van het horen achterwege laat, dat wil zeggen dat er op geen enkele wijze een schriftelijke neerslag heeft plaatsgevonden van hetgeen tijdens het horen aan bod is komen, is sprake van een schending van artikel 7:7 Awb (of artikel 7:21 Awb) en zou die schending tot gevolg kunnen hebben dat de beslissing op het bezwaar wordt vernietigd. Uitspraken waarin vernietiging plaatsvindt wegens schending van deze eis, omdat in het geheel geen schriftelijke verslaglegging heeft plaatsgevonden, ben ik echter niet tegengekomen. In een uitspraak was de verslaglegging volgens de rechtbank onder de maat. ${ }^{340} \mathrm{Zij}$ oordeelt vervolgens dat daardoor niet zeker is dat alle aangevoerde argumenten meegenomen zijn in de besluitvorming en daarmee in strijd met artikel 7:11 Awb is gehandeld alsmede het besluit niet met de vereiste zorgvuldigheid is voorbereid en genomen. Onder meer op die gronden wordt het beroep gegrond verklaard en het besluit vernietigd. Voorts vond in een uitspraak vernietiging plaats van het besluit, omdat het bestuur het verslag van het horen niet uiterlijk met de beslissing op bezwaar aan belanghebbende(n) heeft doen toekomen. Het achterwege laten of niet tijdig toezenden, leidt dan tot vernietiging van het besluit wegens strijd met het zorgvuldigheidsbeginsel. ${ }^{341}$ Onder de Wet Arob leidde het niet schriftelijk vastleggen van hetgeen tijdens het horen aan de orde is gekomen tot vernietiging wegens strijd met het zorgvuldigheidsbeginsel alsook in samenhang daarmee met het

\footnotetext{
335. Zie bijvoorbeeld: AbRvS 6 oktober 2004, JB 2004/369; CBb 23 mei 1995, AB 1995/455 m.nt. JHvdV; JB $1995 / 177$.

336. CBb 23 mei 1995, AB 1995/455 m.nt. JHvdV; JB 1995/177. Het CBb acht een proceskostenveroordeling op zijn plaats omdat appellant door de schending van art. 7:4 lid 2 Awb eerst in beroep kennis kunnen nemen van de inhoud van het advies.

337. Zie bijvoorbeeld: Rb. Arnhem, 23 juni 2009, JB 2009/190 m.nt. R.J.N.S; CRvB 29 november 2005, JB 2006/40; CRvB 6 november 2003, JB 2004/28; AbRvS 25 juni 1996, AB 1996/411 m.nt. ICvdV. Zie ook: Koenraad en Sanders 2006, p. 73.

338. CRvB 26 april 2005, JB 2005/218.

339. CRvB 25 april 2003, $A B$ 2005/303 m.nt. HBr.

${ }^{340 .} \mathrm{Rb}$. 's Hertogenbosch 13 maart 1998, JB 1998/121.

341. AbRvS 12 juni 1997, JB 1997/188
} 


\section{De inrichting van de voorprocedures}

motiveringsbeginsel. ${ }^{342}$ Voorstelbaar zou echter ook zijn dat de bestuursrechter artikel 6:22 Awb toepast ten aanzien van schendingen van dit vereiste. Uitspraken waarin de schending van artikel 7:7 of 7:21 Awb dan wel een ongeschreven plicht tot schriftelijke verslaglegging werd gepasseerd op grond van artikel 6:22 Awb of anderszins gedekt werd verklaard, omdat belanghebbende(n) in beroep kennis hebben gekregen van het verslag ben ik niet tegengekomen. Wel heeft de Afdeling eenmaal het niet tijdig toezenden van het verslag en schending van het zorgvuldigheidsbeginsel gepasseerd. ${ }^{343}$

\section{Conclusies}

Aan schendingen van vereisten die hoor en wederhoor in de bestuurlijke voorprocedures beogen te operationaliseren, worden lang niet altijd rechtens consequenties verbonden. De jurisprudentie laat een wisselend beeld zien. In sommige gevallen vindt vernietiging van het besluit op bezwaar plaats, maar in andere gevallen wordt niet overgegaan tot vernietiging en/of de bevoegdheid neergelegd in artikel 6:22 Awb toegepast. Maatgevend is in hoeverre belanghebbenden door de betreffende schending in hun belangen zijn geschaad of zijn benadeeld. Als het gaat om het kernrecht in artikel 7:4 Awb op inzage in de op de zaak betrekking hebbende stukken geldt dat in veel gevallen vernietiging volgt, indien deze bepaling is geschonden. In die gevallen worden in het kader van het inzagerecht waarbij de goede procesorde of het beginsel van hoor en wederhoor een belangrijke rol speelt, dan ook rechtens consequenties verbonden aan schendingen van de procesbelangen van belanghebbenden.

\subsubsection{Equality of arms in de bestuurlijke voorprocedures}

\subsubsection{De gelding van equality of arms}

Gelijkheid der wapenen: per definitie uitgesloten in de bestuurlijke voorprocedure? Een aspect van het beginsel van hoor en wederhoor dat voor de bestuurlijke voorprocedures nog niet aan de orde is gekomen, vormt equality of arms of gelijkheid der wapenen. Dat vereiste houdt kort gezegd voor de procedure bij de rechter in dat partijen (of procesdeelnemers) gelijke proceskansen behoren te krijgen en een partij procesrechtelijk niet achtergesteld mag worden ten opzichte van een andere partij. ${ }^{344}$ Het EHRM omschrijft het beginsel in het kader van het in artikel 6 EVRM neergelegde recht op een eerlijk proces als volgt:

"(...) that under the principle of equality of arms, one of the features of the wider concept of a fair trial, each party must be afforded a reasonable opportunity to present his case under conditions that do not place him at a disadvantage vis-à-vis his or her opponent. In this context, importance is attached to appearances as well as to the increased sensitivity to the fair administration of justice (see, among other authorities, Bulut v. Austria, 22 February 1996, Reports 1996-II, pp. 380-381, § 47)."345

Belangrijk is derhalve dat een partij zich ten opzichte van de andere procesdeelnemers niet in een nadeliger procespositie bevindt of daarin gedurende de procedure gebracht wordt. Zo moeten de mogelijkheden om informatie te ontvangen of te reageren op informatie in de procedure voor de betrokken procesdeelnemers gelijk zijn. ${ }^{346}$ Zoals De Waard ook aangeeft, speelt het het vereiste van equality of arms bij alle aspecten of deeleisen van het beginsel van hoor en wederhoor een rol. ${ }^{347}$ Voor al deze deeleisen,

\footnotetext{
342. ARRvS 12 juli 1982, $A B$ 1982/556; ARRvS 12 januari 1993, $A B$ 1993/237 m.nt. Verheij; ARRvS 8 november 1993, $A B$ 1994/208 m.nt. Verheij.

343. AbRvS 12 juni 1997, JB 1997/188.

${ }^{344 .}$ De Waard 1987, p. 246-247.

${ }^{345 .}$ EHRM 12 maart 2003, Öcalan tegen Turkije, EHRC 2003/38, par. 159.

346. De Waard 1987, p. 247.

347. De Waard 1987, p. 247.
} 


\section{Deel II Bestuurlijke voorprocedures}

zoals het recht om mondeling het standpunt toe te lichten, het recht om stukken in te dienen, het recht om getuigen en deskundigen te horen of het recht om stukken in te zien dient in beginsel steeds gewaarborgd te zijn dat alle betrokken partijen gelijke kansen geboden krijgen. Het vereiste doet derhalve zijn werking gevoelen gedurende de hele procedure, van begin tot eind, en bij alle processuele rechten die gedurende die procedure ten dienste staan aan de procesdeelnemers. Het vergt tevens van de rechter dat deze zich rekenschap geeft van de positie van de deelnemers aan de procedure en hen gelijke mogelijkheden biedt om daaraan volwaardig deel te nemen. Voorts ligt het ook ten grondslag aan het verbod voor de rechter om onderhands contact met een van de partijen te hebben. ${ }^{348}$

Voor de bestuursrechterlijke procedure is de gelding van dit vereiste onomstreden en ook de werking ervan behoorlijk uitgekristalliseerd. ${ }^{349}$ Dat is echter niet het geval voor de bestuurlijke voorprocedures. Zoals eerder werd aangegeven in paragraaf 5.3.1, kennen we in het Nederlandse bestuursrecht niet zoiets als een beginsel van hoor en wederhoor dat als norm (rechtstreeks) geldt voor het handelen van het bestuur. Dat betekent ook dat in het verlengde daarvan equality of arms, als onderdeel van dat beginsel, niet behoort tot de geldende (ongeschreven) normen voor het bestuur in de bestuurlijke voorprocedures. Bovendien is artikel 6 EVRM, behoudens het redelijke termijn-vereiste, niet rechtstreeks van toepassing op de bestuurlijke voorprocedures en kan equality of arms via deze weg in beginsel ook geen geldingskracht krijgen voor die procedures.

Op het eerste gezicht lijkt het dan ook niet vreemd dat het vereiste van equality of arms niet behoort tot de eisen die in acht moet worden genomen in de bestuurlijke besluitvormingsfase, vooral voor zover het de bezwaarschriftprocedure betreft. Inherent aan de bezwaarschriftprocedure is immers aan de ene kant dat het bestuur optreedt als geschilbeslechtende instantie en aan andere kant als nemer van het besluit en daarmee tegenpartij van de belanghebbende. Volledige toepasselijkheid van het deelvereiste equality of arms lijkt niet goed voorstelbaar. De belanghebbende kan in de procedure immers nooit in dezelfde (uitgangs)positie gesteld worden als het bestuur dat als orgaan dat het bestreden besluit genomen heeft bij voorbaat een voorsprong heeft, bijvoorbeeld ten aanzien van alle relevante informatie die van belang is (geweest) voor de besluitvorming.

Met name in de jurisprudentie wordt gelding van het vereiste voor de bestuurlijke besluitvormingsprocedures stellig ontkend. De Afdeling stelt zich uitdrukkelijk op het standpunt dat aan equality of arms geen betekenis toekomt voor de bestuurlijke besluitvorming. In een uitspraak van 12 juli 2006 verklaart de Afdeling onomwonden dat een beroep daarop ten aanzien van de bezwaarschriftprocedure niet kan slagen, omdát het vereiste niet ziet op bestuurlijke besluitvorming. ${ }^{350}$ Ook heeft de Afdeling de Mantovanelli- uitspraak van het EHRM, waarin equality of arms in het geding was, niet van toepassing geacht op de bezwaarschriftprocedure. ${ }^{351}$ Gelet op het voorgaande is het standpunt van de Afdeling tot op zekere hoogte begrijpelijk. De overige (hoogste) bestuursrechters lijken zich op eenzelfde standpunt te stellen, al heeft de Centrale Raad het in het verleden nog wel eens in het midden gelaten of artikel 6 EVRM en het vereiste van 'equality of arms' van betekenis kan zijn in de bezwaarschriftfase. ${ }^{352}$ Thans lijkt de Centrale Raad, in elk geval wat betreft de toepasselijkheid van artikel 6 EVRM en het daarin neergelegde vereiste van equality of arms, ook op het spoor van de Afdeling te zitten. ${ }^{353}$

\footnotetext{
348. Zie hierover par. 4.3.5 van Deel I.

349. Zie wederom par. 4.3.5 van Deel I

${ }^{350 .}$ AbRvS 12 juli 2006, JB 2006/268 m.nt. Wenders; $A B$ 2008/144 m.nt. Jansen.

351. AbRvS 22 november 2006, $A B$ 2008/62 m.nt. N. Verheij; $J B$ 2007/12 m.nt. AB.

352. CRvB 21 juli 2001, $N J B$ 2001/22, p. 1625; ook gepubliceerd in $J B$ 2001/256; $A B$ 2001/252 m.nt. FP onder AB 2001/253; RSV 2001/205; USV 2001/199.

353. CRvB 13 februari 2002, USZ 2002/101 m.nt. Driessen; $A B$ 2002/96 m.nt. FP. Wat betreft de redelijke termijn heeft de CRvB onlangs ook overwogen dat uit artikel 6 EVRM geen aanspraak tot schadevergoeding kan worden afgeleid voor schending van de redelijke termijn in de bezwaarschriftprocedure, indien daaropvolgend geen beroep wordt ingesteld bij de bestuursrechter (zie: CRvB 29 april 2009, LJN BI2748, JB 2009/152 m.nt. redac-
} 


\section{De inrichting van de voorprocedures}

In de doctrine wordt daarentegen soms in de context van enkele voorschriften in de Awb die de bezwaarschriftprocedure (en het administratief beroep) betreffen, verwezen naar het gelijkwaardigheidsbeginsel. ${ }^{354}$ Hoewel dat beginsel door de verschillende auteurs die het hanteren niet gedefinieerd wordt, lijken zij daarmee (ook) gelijkheid der wapenen of gelijke processuele posities van de betrokkenen op het oog te hebben. Enige gelding van die eis lijkt derhalve in de doctrine niet te worden uitgesloten, maar de vraag in hoeverre equality of arms, al dan niet op grond van artikel 6 EVRM, van betekenis is voor de bestuurlijke voorprocedures is nog niet expliciet en uitvoerig onderzocht.

Relativering van de uitsluiting van equality of arms in de bestuurlijke voorprocedures De overweging van de Afdeling in de uitspraak van 12 juli 2006 dat het vereiste van equality of arms niet (rechtstreeks) op de bestuurlijke voorprocedures (en bestuurlijke besluitvorming in het algemeen) van toepassing wordt geacht, verdient enige relativering. ${ }^{355}$ Met name bij de stelligheid van de overweging van de Afdeling vallen enkele kanttekeningen te plaatsen. Allereerst wordt uit de overwegingen van de Afdeling niet duidelijk waar zij op baseert dat equality of arms zonder betekenis is voor de bestuurlijke besluitvorming (in bezwaar). Zij overweegt slechts dat zulks het geval is. Voor zover de Afdeling met equality of arms het vereiste zoals voortvloeit uit artikel 6 EVRM op het oog heeft, is het terecht dat gesteld wordt dat dit vereiste niet ziet op de bestuurlijke fase. De uit artikel 6 lid 1 EVRM voortvloeiende vereisten, en meer specifiek equality of arms, zijn door het EHRM ook niet expliciet op die fase van toepassing verklaard. ${ }^{356}$ Uit de uitspraak blijkt echter niet of appellant op die bepaling een beroep heeft gedaan dan wel op het ongeschreven beginsel van hoor en wederhoor, een beginsel van behoorlijke rechtspleging waar equality of arms onderdeel van uitmaakt. Was dat laatste het geval, dan was op zijn minst een nadere motivering op zijn plaats geweest. De reikwijdte van het nationale hoor en wederhoor-beginsel behoeft niet samen te vallen met de reikwijdte van de uit artikel 6 EVRM voortvloeiende normen. Te verdedigen valt eerder een ruimere reikwijdte, omdat artikel 6 EVRM slechts minimumwaarborgen bevat. ${ }^{357}$ Louter een ontkenning van de toepasselijkheid van dit vereiste is in dat geval in mijn ogen als motivering dan ook niet toereikend.

Er zijn echter nog andere - en fundamenteler - bezwaren tegen de voornoemde uitspraak aan te voeren. Ofschoon de bestuursrechter de werking van het equality of armsvereiste lijkt uit te sluiten voor de bezwaarschriftprocedure of deze eis in elk geval niet expliciet erkent voor die procedure, zijn in die procedure (en het administratief beroep) zoals geregeld in de Awb enkele bepalingen opgenomen die mede als uitwerkingen van dat vereiste kunnen gelden of waarin dat vereiste mede tot uitdrukking komt. Bovendien staan in de bestuurlijke voorprocedures vaak meer belanghebbenden met tegengestelde belangen tegenover elkaar en vindt de procedure vaak ten overstaan van een adviescommissie plaats, waardoor de procedure een meer contradictoir karakter krijgt. Deze factoren, die hieronder worden toegelicht, nopen in mijn ogen tot relativering van (gehele) uitsluiting van de werking van het vereiste van equality of arms in de bestuurlijke voorprocedures.

tie; nagevolgd door de Afdeling in AbRvS 17 juni 2009, nr. 200901365/2/H2, LJN BI8475). Die uitspraak impliceert dat deze eis uit art. 6 EVRM alleen vanwege de connexiteit met de procedure bij de bestuursrechter rechtstreeks van toepassing kan zijn.

${ }^{354}$ Bijvoorbeeld: Teunissen, p. E 6.3.7-1; Van der Ham 1988, p. 85.

355. Zie hierover ook het commentaar bij de uitspraak in de annotaties $J B$ 2006/268 m.nt. Wenders; $A B$ 2008/144 m.nt. Jansen alsmede Jansen 2008, p. 224.

356. Een uitzondering daarop vormt het vereiste van de redelijke termijn, mits na de bezwaarschriftprocedure beroep wordt ingesteld bij de bestuursrechter zo volgt uit een uitspraak van de CRvB. Dit vereiste en de betekenis daarvan voor de bestuurlijke voorprocedures komt nader aan bod in par. 5.7.

357. Zie hierover par. 4.1 van Deel I. 


\section{Deel II Bestuurlijke voorprocedures}

Equality of arms ten aanzien van alle belanghebbenden

De omstandigheid dat in veel bestuurlijke voorprocedures meer belanghebbenden betrokken zijn (al dan niet als bezwaarmakers of indieners van beroep), die een tegengesteld belang kunnen vertegenwoordigen in de procedure, brengt gevolgen voor de inrichting van die procedure met zich. In iedere bezwaarschriftprocedure zijn er in elk geval twee partijen: het bestuursorgaan dat het primaire besluit heeft genomen en de indiener van een bezwaarschrift. Vaak zal de laatste de aanvrager zijn van een besluit dat uiteindelijk geweigerd is of van een besluit met de inhoud waarvan hij of zij zich niet kan verenigen. In veel gevallen zijn er naast deze twee actoren in de procedure echter ook derde-belanghebbenden die hun belangen willen beschermen door het indienen van een bezwaar- of beroepschrift.

In de verhouding tussen die verschillende belanghebbenden onderling kan het vereiste van equality of arms wel degelijk een rol spelen. Dat vereiste beoogt immers te waarborgen dat alle betrokken belanghebbenden dezelfde mogelijkheden krijgen om te reageren op relevante informatie en op gelijke wijze informatie kunnen inbrengen. Indien er verschillende belanghebbenden rechtstreeks door het besluit geraakt worden, behoren al deze belanghebbenden gelijke processuele mogelijkheden te hebben en een gelijke procespositie te hebben. Een uitwerking in deze zin is ook terug te vinden in de Awb. Artikel 7:2 Awb schrijft voor dat alle belanghebbenden in de gelegenheid worden gesteld om te worden gehoord. Indien meer personen gehoord moeten worden, verdient het vanuit het oogpunt van hoor en wederhoor en equality of arms de voorkeur dat deze personen in elkaars aanwezigheid worden gehoord. Alleen zó kunnen alle betrokkenen immers over en weer op elkaars standpunten reageren en zijn alle betrokkenen op gelijke wijze en in gelijke mate op de hoogte van de relevante informatie en standpunten die aan de orde komen. Het uitgangspunt dat belanghebbenden in elkaars aanwezigheid worden gehoord, is in artikel 7:6, eerste lid, en 7:20, eerste lid, van de Awb neergelegd. Beide artikelen bevatten identieke bepalingen. ${ }^{358}$ In bijzondere omstandigheden kan ervan worden afgezien belanghebbenden gezamenlijk te horen, namelijk indien de zorgvuldigheid van de besluitvorming daardoor in het geding komt of omdat tijdens het horen feiten of omstandigheden bekend zullen worden waarvan geheimhouding om gewichtige redenen is geboden. Die mogelijkheid is neergelegd in het tweede lid van beide bepalingen. Het bestuursorgaan kan daartoe ambtshalve of op verzoek van belanghebbende(n) beslissen. Indien wordt afgezien van het horen van belanghebbenden in elkaars aanwezigheid, zullen zij echter ingevolge het derde lid op de hoogte moeten worden gesteld van hetgeen buiten hun aanwezigheid aan de orde is gekomen, zodat zij daarop eventueel nog kunnen reageren. ${ }^{359}$ Ook hiervan kan op initiatief van belanghebbende(n) dan wel ambtshalve door het bestuursorgaan worden afgezien, indien geheimhouding om gewichtige redenen is geboden. ${ }^{360}$ In administratief beroep betekent dit dat ook het bestuursorgaan in aanwezigheid van de overige belanghebbenden betrokken wordt bij de hoorzitting. Deze bepalingen lijken mij bij uitstek bepalingen waarin tevens het vereiste van equality of arms geïncorporeerd is. ${ }^{361}$ Voor zover zich situaties aandienen die niet wettelijk geregeld zijn, zou het vereiste van equality of arms uitkomst kunnen bieden in de processuele verhouding van de belanghebbenden onderling. Aan het bestuurlijke karakter van de

\footnotetext{
${ }^{358 .}$ Met dien verstande dat het vierde lid van dat artikel een iets aangepaste tekst heeft nu daarin gesproken wordt van beroepsorgaan en verwezen wordt naar art. 7:18 Awb en niet 7:4 Awb.

${ }^{359 .}$ PG Awb I, p. 342.

360. Daarbij is artikel 7:4, zesde lid, tweede volzin alsook zevende en achtste lid Awb van overeenkomstige toepassing verklaard. Concreet betekent dit dat het bestuur geen mededelingsplicht heeft, indien geheimhouding wegens gewichtige redenen is geboden volgens het bestuur. Gewichtige redenen zijn in elk geval niet aanwezig voor zover ingevolge de Wet openbaarheid van bestuur de verplichting bestaat een verzoek om informatie, vervat in deze stukken, in te willigen. Inzage van de desbetreffende stukken kan worden voorbehouden aan een gemachtigde die hetzij advocaat hetzij arts is indien een gewichtige reden is gelegen in de vrees voor schade aan de lichamelijke of geestelijke gezondheid van een belanghebbende.

361. Teunissen E 6.3.11-2.
} 


\section{De inrichting van de voorprocedures}

procedure wordt ook geen afbreuk gedaan door in gevallen als deze het vereiste van equality of arms zich tevens te laten uitstrekken over de bestuurlijke voorprocedures.

In de toelichting op artikel 7:6 Awb wordt opgemerkt dat indien er meer belanghebbenden zijn het horen van de belanghebbenden in elkaars aanwezigheid in het algemeen aanbeveling verdient. ${ }^{362}$ Ratio hierachter is de doelmatigheid, maar ook de kwaliteit van de besluitvorming. De ratio wordt derhalve niet expliciet gezocht in de bescherming van de processuele belangen of de gelijke procespositie van de belanghebbenden. Uit de toevoeging in het derde lid dat belanghebbenden, indien wordt overgegaan tot het afzonderlijk horen, op de hoogte moeten worden gesteld van het verhandelde alsmede de omstandigheid dat zij daarop volgens de wetgever eventueel nog moeten kunnen reageren, kan echter worden afgeleid dat de ratio van het gezamenlijk horen ook is het bieden van gelegenheid aan belanghebbenden om op alle relevante standpunten te kunnen reageren. Die reactiemogelijkheid komt de verweermogelijkheden van belanghebbenden als zodanig ten goede, omdat de reactiemogelijkheid het complement van het informeren van belanghebbenden vormt. Bovendien kan op deze wijze een 'echte' uitwisseling en confrontatie van standpunten plaatsvinden, omdat over en weer op elkaars standpunten kan worden gereageerd. Vanuit een oogpunt van de zorgvuldigheid of kwaliteit van de besluitvorming, verdient zulks derhalve ook de voorkeur. In de literatuur is dit hoor en wederhoor- aspect erkend als ratio van artikel 7:6 Awb. Zo merkt Teunissen op dat deze bepaling een beginsel van behoorlijk procesrecht betreft, dat voortvloeit uit het gelijkwaardigheidsbeginsel. ${ }^{363}$ Ook Simon meent dat deze bepaling invulling geeft aan het beginsel van hoor en wederhoor. ${ }^{364}$ De bestuursrechter heeft zich nog niet vaak uitgelaten over deze bepaling en de ratio ervan, maar lijkt de bepaling vooral te plaatsen in het perspectief van de zorgvuldigheid van de besluitvorming en het zorgvuldigheidsbeginsel. $^{365}$

Is gezamenlijk horen op goede gronden niet wenselijk, dan moet op andere wijze aan het beginsel van hoor en wederhoor tegemoet gekomen worden. Het derde lid van deze bepaling geeft aan die eis gestalte. De bepaling geeft niet aan op welke wijze aan die verplichting moet worden voldaan. Dat betekent dat het ter kennis brengen mondeling of schriftelijk kan geschieden. Hetzelfde geldt voor de mogelijkheid om te reageren. ${ }^{366}$ Uit de tekst van artikel 7:6 Awb blijkt zelfs niet dát er een mogelijkheid behoort te zijn om te reageren. De toelichting stelt dat echter wel ${ }^{367}$ en gelet op het hiervoor gestelde ligt het ook in de rede dat alle belanghebbenden die gelegenheid krijgen.

Ten slotte volgt uit de omstandigheid dat belanghebbenden in beginsel in elkaars aanwezigheid worden gehoord ook dat alle belanghebbenden in beginsel aanwezig zijn bij het horen van door anderen meegebrachte getuigen of deskundigen. Artikel 7:6 Awb verplicht strikt genomen niet ertoe dat deskundigen of informanten slechts gehoord worden in aanwezigheid van de belanghebbenden. ${ }^{368}$ Uit een uitspraak van de Centrale Raad volgt echter dat een belanghebbende de gelegenheid moet krijgen te reageren op feiten of omstandigheden die van aanmerkelijk belang kunnen zijn voor de beslissing, indien die uit het horen van deskundigen of getuigen buiten de hoorzitting naar voren komen. ${ }^{369}$ De hoorzitting lijkt daartoe de eerst aangewezen gelegenheid. Vanuit een oogpunt van gelijke proceskansen voor alle procesdeelnemers - indien een commissie belast is met het

\footnotetext{
362. PG Awb I, p. 342. Een belanghebbende kan zijn recht daarop wel 'verspelen', zie: AbRvS 12 december 2007, nr. 200703100/1.

363. Teunissen, p. E 6.3.11-2.Een omschrijving van dat beginsel geeft hij niet maar zoals ik eerder heb aangegeven begrijp ik hem zo dat er het equality of arms-vereiste onder verstaan wordt.

364. Simon 1997, p. 267.

365. Zie bijv.: CRvB 4 december 1997, JB 1998/38; Rb. Rotterdam 4 december 1995, JB 1996/63.

366. Ministerie van Justitie en Ministerie van Binnenlandse Zaken, Handreiking bezwaarschriftprocedure Algemene wet bestuursrecht, Den Haag: BJu 2004, p. 46. Overigens lijkt een schriftelijke verslaglegging en een schriftelijke reactiemogelijkheid praktisch gezien de beste oplossing.

367. PG Awb I, p. 342

368. Teunissen, p. E 6.3.11-2

369. CRvB 4 december 1997, JB 1998/38.
} 


\section{Deel II Bestuurlijke voorprocedures}

horen, behoort daartoe ook het bestuur - zouden er voorts gelijke mogelijkheden moeten zijn om getuigen op te roepen. ${ }^{370}$ Bovendien - en belangrijker nog - volgt mijns inziens uit artikel 7:6 Awb in samenhang met artikel 7:8 Awb dat indien de belanghebbenden gezamenlijk worden gehoord, in beginsel ook in het bijzijn van (alle) belanghebbenden de desbetreffende getuige of deskundige wordt gehoord. Artikel 7:8 Awb (waarop in paragraaf 5.3.2.5 nader is ingegaan) bepaalt immers dat op verzoek van de belanghebbende door hem naar de hoorzitting meegebrachte getuigen of deskundigen kunnen worden gehoord. ${ }^{371}$ Indien alle belanghebbenden gezamenlijk worden gehoord en tegelijk aanwezig zijn, zullen zij ook aanwezig zijn bij het horen van de getuigen of deskundigen die zijn meegebracht.

\section{De instelling van een adviescommissie en equality of arms}

Ten tweede meen ik dat wat betreft de mogelijke betekenis van het equality of armsvereiste in de voorprocedures een onderscheid gemakt moet worden tussen een voorprocedure waarin wel en een voorprocedure waarin niet door de adviescommissie gehoord wordt. Indien sprake is van een procedure die gevoerd wordt ten overstaan van de adviescommissie, staan het bestuur en de belanghebbende(n) veeleer als partijen in een contradictoire procedure tegenover elkaar, zoals dat ook bij de bestuursrechter het geval is. ${ }^{372}$ In dat geval is van belang dat het bestuur en vooral ook de belanghebbende(n) dezelfde mogelijkheden geboden worden, teneinde hun standpunten voor de commissie voor het voetlicht te brengen.

Is een commissie ingesteld in de zin van artikelen 7:13 of 7:19 van de Awb, dan is deze commissie (in beginsel) ook belast met het horen. Dat betekent echter niet dat deze commissie zo maar kan beslissen tot het afzonderlijk horen van belanghebbenden. Artikelen 7:6 en 7:20 Awb gelden onverkort. Uitgangspunt blijft dat belanghebbenden gezamenlijk worden gehoord. ${ }^{373}$ Voor de bezwaarschriftprocedure waarborgt artikel 7:6 Awb derhalve dat alle betrokken belanghebbenden op elkaars standpunten hebben kunnen reageren, hoewel zij strikt genomen niet (altijd) de partijen hoeven te zijn die tegenover elkaar staan. Veelal is dat het bestuursorgaan enerzijds (met eventueel de aanvragerbelanghebbende) en de derde-belanghebbende(n) anderzijds of het bestuur versus de aanvrager of geadresseerde van het besluit. De belangen van het bestuur als partij in de procedure lijken niet beschermd te worden door deze bepaling, hetgeen ook voor de hand ligt nu deze vaak zelf of een lid daarvan betrokken zal zijn bij het horen. ${ }^{374}$ De situatie ligt echter anders, indien een adviescommissie belast is met het horen. In die gevallen geldt juist dat sprake is van een meer contradictoire behandeling van de zaak waarbij ook het bestuur en belanghebbende(n) over en weer op elkaars standpunten kunnen reageren. Voor deze situatie biedt artikel 7:6 Awb geen voorziening. Om hoor en wederhoor te verzekeren, behoren belanghebbende(n) en bestuur over en weer echter op elkaars standpunten te kunnen reageren. Artikel 7:13, vijfde lid, van de Awb stelt dan ook zeker dat een vertegenwoordiger van het bestuursorgaan voor de hoorzitting wordt uitgenodigd en

\footnotetext{
${ }^{370 .}$ Zie bijvoorbeeld voor de procedure bij de rechter: Widdershoven 1989, p. 141-142.

371. Zie ook: Pres. Rb. Zutphen, 11 november 1999, JB 2000/17, waarin het aanwezig zijn van partijen bij het horen van getuigen in bezwaar volgens de President onder het beginsel van de goede procesorde valt.

372. C.L.G.F.H. Albers, 'Commentaar artikel 7:13', in: M. Scheltema, R.M. van Male, B.W.N. de Waard, A.T Marseille, A.J.C. de Moor-van Vugt (red.), Commentaar Algemene wet bestuursrecht, Amsterdam: Reed Elsevier (voorheen Den Haag: VUGA), losbladige uitgave, E 7:13-3; Koenraad \& Sanders 2006, p. 57; Sanders 2004, p. 34; Verslag Evaluatie Awb I, p. 44-45.

373. In artikel 7:13, vierde lid, van de Awb is overigens niet aangegeven dat de adviescommissie in bezwaar kan beslissen over de toepassing van artikel 7:6, tweede of vierde lid, van de Awb. Uit de tekst van artikel 7:6, vierde lid Awb alsmede uit het ontbreken van de expliciete bevoegdheid daartoe in artikel 7:13 Awb moet afgeleid worden dat de beslissing om belanghebbenden niet afzonderlijk te horen strikt genomen door het bestuur behoort te worden genomen. Evenals het geval is bij de beslissing om meegebrachte getuigen of deskundigen te horen, valt te verdedigen dat de commissie deze beslissing kan nemen.

374. Zie ook de uitspraak van het CBb van 17 december 2002, $A B$ 2003/70 m.nt. JHvdV waarin dit college overweegt dat bestuursorgaan niet kan worden aangemerkt als belanghebbende in de zin van art. 7:6 Awb.
} 


\section{De inrichting van de voorprocedures}

in de gelegenheid wordt gesteld een toelichting op het standpunt van het bestuursorgaan te geven. Daarmee geldt als uitgangspunt dat belanghebbenden en de vertegenwoordiger van het bestuursorgaan gezamenlijk worden gehoord door de commissie. Aan deze bepaling ligt volgens de bestuursrechter het beginsel van hoor en wederhoor ten grondslag. Daarmee is niet verenigbaar dat de commissie voor het horen van de vertegenwoordiger van het bestuursorgaan een afzonderlijke hoorzitting houdt. ${ }^{375}$ De Centrale Raad is van oordeel dat er een bijzondere rechtvaardigingsgrond behoort te bestaan voor het houden van een afzonderlijke hoorzitting voor de vertegenwoordiger van het bestuursorgaan. Ontbreekt deze, dan is in strijd gehandeld met deze bepaling en het mede daaraan ten grondslag liggende beginsel van hoor en wederhoor. In artikel 7:13 Awb is overigens niets geregeld omtrent de gevallen waarin kan worden afgezien van het gezamenlijk horen van de vertegenwoordiger van het bestuursorgaan en de belanghebbende(n). De Centrale Raad licht evenmin nader toe wanneer sprake is van een bijzondere rechtvaardigingsgrond. Zoals Bots opmerkt in de noot bij die uitspraak ligt het echter in de rede om in dat kader aan te sluiten bij de uitzonderingen genoemd in artikel 7:6 Awb. ${ }^{376}$ Gelet op een mogelijke gedachtewisseling tussen de vertegenwoordiger van het bestuursorgaan en de belanghebbende(n) alsmede vanuit equality of arms als ratio van artikel 7:6 Awb ligt in dit geval het gezamenlijk horen als uitgangspunt voor de hand. Het bestuursorgaan is veeleer als wederpartij te beschouwen, waardoor andere uitzonderingsgronden dan genoemd in artikel 7:6 Awb voor belanghebbenden onderling ook niet in de rede liggen.

In administratief beroep ligt de situatie iets anders, want daarin moet het bestuursorgaan dat het bestreden besluit heeft genomen immers ook worden gezien als een partij in de procedure ten opzichte van de belanghebbende die beroep heeft ingesteld en deze eis ook diens processuele belangen kan beschermen. Om die reden verplicht artikel 7:16, tweede lid, Awb het beroepsorgaan om het bestuursorgaan op de hoogte te stellen van de gelegenheid om gehoord te worden. In artikel 7:19 Awb is niets bepaald omtrent de bevoegdheden die een adviescommissie heeft in administratief beroep. Dat betekent dat een bijzondere regeling daarin zou kunnen voorzien en indien dat niet is geschied het beroepsorgaan in beginsel de beslissing omtrent het al dan niet gezamenlijk horen zal moeten nemen. Het ligt echter in de rede dat ook de commissie zowel belanghebbenden als een vertegenwoordiger van het bestuursorgaan dat in primo het besluit heeft genomen gezamenlijk hoort. Op deze wijze kan recht gedaan worden aan het beginsel van hoor en wederhoor.

Tot slot lijkt mij dat het contact tussen commissie en het bestuursorgaan, voor zover mogelijk, niet buiten medeweten van de belanghebbenden plaatsvindt en deze ook de mogelijkheid krijgen om op alle relevante informatie die het bestuursorgaan de commissie (buiten de hoorzitting om) doet toekomen te reageren. Die eis is ten dele gecodificeerd in artikel 7:9 en artikel 7:23 Awb, die vereisen dat belanghebbenden op de hoogte worden gebracht van nieuwe feiten van aanmerkelijk belang. Als zich dergelijke nieuwe feiten voordoen, behoort een adviescommissie toepassing te geven aan artikel 7:9 Awb. ${ }^{377}$ Voor andere gevallen volgt dat mijns inziens uit het beginsel van hoor en wederhoor en het equality of arms- vereiste. ${ }^{378}$ Er valt een parallel met het verbod van onderhands contact met partijen dat voor de (bestuurs)rechter geldt te trekken. ${ }^{379}$

De conclusie moet zijn dat de aard van de bezwaarschriftprocedure, in de gevallen waarin een adviescommissie is ingesteld die is belast met de behandeling van de zaak, in elk geval niet in de weg staat aan toepassing van het beginsel van 'equality of arms' in de procedure. In de processuele verhouding tussen belanghebbenden en het bestuursorgaan

\footnotetext{
375. CRvB 15 januari 2004, JB 2004/107 m.nt. A.M.M.M. Bots.

376. CRvB 15 januari 2004, JB 2004/107 m.nt. A.M.M.M. Bots.

377. Zie par. 5.3.2.3 over de vraag wanneer daarvan sprake is.

${ }^{378 .}$ Vgl. AbRvS 8 april 1997, $A B$ 1998/106 m.nt. PvB. Op deze uitspraak wordt even verderop nader ingegaan.

379. Zie hierover: par. 4.3.5 van Deel I.
} 
Deel II Bestuurlijke voorprocedures

enerzijds en de adviescommissie anderzijds is ook een zekere processuele gelijkwaardigheid gewaarborgd.

Andere uitwerkingen van hoor en wederhoor in het licht van equality of arms Daarnaast zijn er verschillende eisen in de Awb neergelegd waarin mede het vereiste van equality of arms tot uitdrukking komt. Zo kan ook het inzagerecht, zoals neergelegd in artikel 7:4 Awb, in de sleutel van equality of arms geplaatst worden. De plicht tot het ter inzage leggen van alle op de zaak betrekking hebbende stukken door het bestuursorgaan en het daarmee corresponderende recht van belanghebbenden op inzage in die stukken, is onderdeel van het recht om informatie te ontvangen in de bestuurlijke voorprocedures. Voor de rechterlijke procedure vormt dit recht een deelvereiste van het beginsel van hoor en wederhoor. ${ }^{380}$ De wetgever heeft aangegeven dat in de bezwaarschriftprocedure dezelfde stukken ter inzage beschikbaar moeten zijn als die welke in de beroepsprocedure beschikbaar zijn voor partijen. ${ }^{381}$ Hierboven werd al geconcludeerd dat dit recht, zoals neergelegd in de Awb, ook voor de bestuurlijke voorprocedures een uitwerking vormt van het beginsel van hoor en wederhoor. Inzage in de relevante stukken en toegang tot relevante informatie is essentieel voor het verdedigen en onderbouwen van het eigen standpunt. Gebreken op dat punt leiden, zoals Koenraad en Sanders ook opmerken, tot een schending van de processuele belangen van belanghebbenden. ${ }^{382}$ De eis dat de betrokken procesdeelnemers een gelijkwaardige procespositie behoren te hebben en gelijke processuele rechten en bevoegdheden behoren te hebben, brengt ook mee dat alle belanghebbenden op gelijke wijze inzage behoren te hebben in de relevante stukken. Zo expliciet is dat echter door de bestuursrechter nog niet erkend. Opmerkelijk is nog dat de Afdeling dezelfde belangen ten aanzien van de positie van het bestuursorgaan in de procedure wel lijkt te erkennen. In het kader van de vraag wat op de zaak betrekking hebbende stukken zijn, heeft zij meermalen overwogen dat interne of externe adviezen die betrekking hebben op het bepalen van de positie van het bestuur in een procedure bij de rechter dat niet zijn. ${ }^{383}$ Reden daarvoor was, aldus de Afdeling de gewenste gelijkwaardigheid tussen het bestuursorgaan en belanghebbenden in verband met het inwinnen van procesadviezen. De Afdeling lijkt die gelijkwaardigheid te baseren op equality of arms. In elk geval beoogt zij hiermee een gelijkwaardige procespositie voor het bestuur (ten nadele van de burger) te waarborgen.

Een andere eis die de bestuursrechter beschouwt als een uitwerking van het beginsel van hoor en wederhoor, brengt eveneens het vereiste van equality of arms tot uitdrukking. Het betreft de hernieuwde hoorplicht zoals neergelegd in artikel 7:9 Awb. Op grond van die bepalingen rust op het bestuursorgaan een plicht om belanghebbenden in de gelegenheid te stellen om gehoord te worden. Die plicht bestaat echter uitsluitend, indien na de eerste hoorzitting aan het bestuursorgaan feiten of omstandigheden van aanmerkelijk belang voor het te nemen besluit bekend zijn geworden. Hiermee wordt in feite beoogd een ongelijkheid in de procespositie tussen belanghebbenden en het bestuur te compenseren of op te heffen. Niet alleen het bestuur kan daarover (in het besluit) zijn licht laten schijnen, ook de belanghebbenden moeten die kans krijgen. In dit soort gevallen werkt equality of arms derhalve ook door in de verhouding tussen het bestuursorgaan en de belanghebbenden. Bovendien geldt ook hier dat aan alle belanghebbenden de gelegenheid moet worden geboden om gehoord te worden. ${ }^{384}$

\footnotetext{
380. Zie par. 4.3.5 van Deel I.

381. PG Awb I, p. 339.

382. Koenraad en Sanders wijzen met betrekking tot art. 7:4 lid 2 Awb ook op het beginsel van hoor en wederhoor en ongelijkheidscompensatie, Koenraad \& Sanders 2006, p. 73-74.

383. AbRvS 24 april 1998, JB 1998/145 m.nt. R.J.N.S; AbRvS 5 november 2003, AB 2004/176, m.nt. BdeW.

384. De Awb bepaalt niets omtrent de gang van zaken of toepasselijke eisen bij het houden van een tweede hoorzitting. Mij lijkt echter in de rede liggen dat de overige bepalingen, bijvoorbeeld art. 7:4 of 7:6 Awb, worden toegepast.
} 


\section{De inrichting van de voorprocedures}

\section{Equality of arms in administratief beroep}

In administratief beroep kan zich nog de specifieke situatie voordoen dat het in primo beslissende bestuursorgaan, buiten belanghebbenden om, contact heeft met het beroepsorgaan. De Afdeling heeft, in een geval waarin het college van b en w zich rechtstreeks tot de gemeenteraad gewend had zelfs nadat het advies van de adviescommissie al gegeven was en belanghebbenden niet in de gelegenheid waren gesteld om daarop te reageren, geoordeeld dat zulks zich niet verdraagt met artikel 7:10 eerste lid en 7:23 Awb. ${ }^{385}$ Hoewel de verwijzing naar artikel 7:10 niet duidelijk is, omdat deze bepaling voor de bezwaarschriftprocedure geldt en niet het administratief beroep, lijkt de Afdeling hier equality of arms in de strekking van de bepalingen te incorporeren en om die reden aan te geven een dergelijke handelwijze niet geoorloofd is. In feite vertoont een dergelijke situatie in administratief beroep veel gelijkenis met het verbod op onderhands contact met een der partijen voor de (bestuurs)rechter, welk verbod ook op het equality of armsvereiste stoelt. Goorden wijst er ook in meer algemene zin op dat equality of arms in het geding is, indien beroep openstaat op de gemeenteraad tegen beslissingen van het college van $b$ en w, en conform de praktijk het besluit van de gemeenteraad wordt voorbereid door dat college. Dat plaatst de burger in een achtergestelde positie ten opzichte van de andere partij in de procedure, het college van b en w. ${ }^{386}$ Dat bezwaar ligt enigszins in het verlengde van de situatie die de Afdeling vond indruisen tegen de wettelijke regeling in de Awb zoals hiervoor aangehaald. Voor het overige valt administratief beroep, wat betreft equality of arms, mijns inziens te vergelijken met het geval waarin in bezwaar een adviescommissie wordt ingesteld. Het in primo beslissende bestuursorgaan en belanghebbende(n) staan als partijen tegenover elkaar en een gelijke procespositie van alle betrokkenen in de procedure bij het beroepsorgaan gewaarborgd moet worden. Datzelfde kan gesteld worden, indien in administratief beroep een adviescommissie is ingesteld. Dan geldt het vereiste echter in de verhouding tussen alle procesdeelnemers onderling, maar in het bijzonder tussen het primair beslissende bestuursorgaan en belanghebbenden lijkt mij.

Verband met de onpartijdigheideisen voor het bestuur

Een ander punt dat nog de aandacht verdient, is het verband tussen equality of arms en het onpartijdigheidbeginsel. In Deel I van dit onderzoek is al aangegeven dat er een verband kan bestaan en dat een schending van equality of arms, in de zin van benadeling van een procesdeelnemer of het op ongelijke wijze behandelen van procesdeelnemers (in procedureel opzicht), een aanknopingspunt kan vormen voor schending van het onpartijdigheidbeginsel. ${ }^{387}$ Een schending van equality of arms kan immers een aanwijzing vormen voor objectief gerechtvaardigde vrees van vooringenomenheid. In dat perspectief kan ook het al eerder genoemde verbod van onderhands contact met een der partijen worden gezien.

Eenzelfde verband met de onpartijdigheidseisen kan gelegd worden voor de bestuurlijke voorprocedures. Het vereiste van equality of arms kan via de band van het verbod van vooringenomenheid, zoals neergelegd in artikel 2:4 Awb, in die procedures een rol spelen. Te denken valt bijvoorbeeld aan een situatie waarin de besluitvorming door het bestuursorgaan of de advisering aan het bestuursorgaan door een adviseur of adviescommissie door een van de procesdeelnemers wordt beïnvloed of beter gezegd zou kunnen worden beïnvloed. Dat risico bestaat, indien een van de procesdeelnemers overleg of anderszins contact met het bestuursorgaan of de adviseur dan wel adviescommissie heeft buiten de andere procesdeelnemers om. Door de bestuursrechter zal een dergelijk geval veelal getoetst worden aan de norm neergelegd in artikel 2:4 Awb, maar evengoed valt hier mijns inziens te verdedigen dat het vereiste van equality of arms in het geding is.

385. AbRvS 8 april 1997, $A B$ 1998/106 m.nt. PvB.

386. Goorden 1990, p. 131.

387. Par. 4.3.5 van Deel I. 


\section{Deel II Bestuurlijke voorprocedures}

Een voorbeeld van een dergelijk geval waarbij een verband tussen equality of arms en onpartijdigheid kan worden gelegd, is aan de orde in een uitspraak van de Afdeling van 8 november $2006 .{ }^{388}$ In die zaak betoogden appellanten in hoger beroep dat het college van $\mathrm{B}$ en $\mathrm{W}$ het welstandsadvies niet ten grondslag hadden mogen leggen aan de verlening van een bouwvergunning, omdat architecten en stedenbouwkundigen van de vergunninghoudster bij het overleg van de welstandscommissie aanwezig waren geweest (in tegenstelling tot appellanten zelf). De welstandscommissie was bijeengekomen in een vergadering met een besloten gedeelte en een openbaar gedeelte. Appellanten meenden dat bij het besloten vooroverleg ten onrechte architecten en stedenbouwkundigen namens de vergunninghoudster aanwezig waren geweest. Zijzelf konden uitsluitend het openbare deel bijwonen. De Afdeling overweegt dat artikel 2:4, eerste lid, van de Awb niet is geschonden, omdat appellanten niet hebben aangetoond dat deze personen bij het besloten deel van de behandeling aanwezig zijn geweest dan wel anderszins deelgenomen hebben aan de advisering. Daaruit zou kunnen worden afgeleid dat wanneer dat wel het geval was geweest, ook een andere uitkomst van de vraag of artikel 2:4, eerste lid, van de Awb geschonden was mogelijk was geweest. Zoals Nijmeijer in zijn noot bij deze uitspraak aangeeft is het nog maar de vraag of de Afdeling dat ook bedoeld heeft. ${ }^{389} \mathrm{Nij}-$ meijer geeft aan dat zulks tot een verandering van werkwijze van menig welstandscommissie zou moeten leiden, omdat het in de praktijk gebruikelijk is dat voorafgaand aan de openbare vergadering overleg plaatsvindt met de aanvrager van de vergunning en eventueel diens adviseurs. Indien echter de adviseurs of architecten van de directbelanghebbenden de besluitvorming (of in dit geval de advisering van de welstandscommissie) zouden kunnen hebben beinvloed, kan vanuit het oogpunt van equality of arms, al dan niet via de band van het verbod van vooringenomenheid, de vraag gesteld worden of de overige belanghebbenden niet ook bij het overleg aanwezig hadden moeten zijn. $^{390}$

Andere voorbeelden (in de jurisprudentie) waarin zo duidelijk de facto het vereiste van equality of arms in het geding is, maar de iure een beroep op het verbod van vooringenomenheid centraal staat, zijn er bij mijn weten niet. Te denken valt wellicht nog aan de positie van de secretaris van de bezwaaradviescommissie, die meestal werkzaam is bij het bestuursorgaan, maar tevens in dat geval een onafhankelijke positie inneemt of hoort in te nemen. ${ }^{391}$ Uitvoerig overleg met het bestuur, buiten de overige belanghebbenden om (en al dan niet buiten de commissie om), kan vanuit een oogpunt van gelijkheid der wapenen problematisch zijn. Dat geldt niet alleen voor de secretaris maar ook voor de overige leden van de commissie. Het betreft situaties die voor de rechterlijke procedure onder het verbod van onderhands contact met partijen zouden vallen. ${ }^{392}$

\section{De betekenis van equality of arms in de bestuurlijke voorprocedures}

Kortom, vanwege verschillende redenen kan betekenis van het vereiste van equality of arms in de bestuurlijke voorprocedures niet geheel uitgesloten worden. Al met al vormen de hierboven toegelichte factoren en jurisprudentie in mijn ogen voldoende aanwijzing voor gedeeltelijke toepasselijkheid van het vereiste van equality of arms in de bestuurlijke voorprocedures. De bestuursrechter, in het bijzonder de Afdeling, sluit dan ook ten onrechte uit dat dit vereiste gevolgen heeft en kan hebben voor de inrichting van de bezwaarschriftprocedure (en het administratief beroep). De bestuursrechter lijkt ook vooral formeel de gelding van dit vereiste, voor zover gestoeld op artikel 6 EVRM, uit te sluiten. Volgens wat inmiddels vaste jurisprudentie lijkt te zijn sluit de bestuursrechter

\footnotetext{
388. AbRvS 8 november 2006, $A B$ 2007/5 m.nt. A.G.A. Nijmeijer.

389. Noot bij $A B$ 2007/5.

${ }^{390 .} \mathrm{Rb}$. R'dam 4 december 1995, $J B$ 1996/63.

391. Zie: AbRvS 6 augustus 2003, $A B$ 2004/140 m.nt. J.A.F. Peters; AbRvS 19 maart 2003, $A B$ 2003/301 m.nt. Hans Peters.

392. Zie par. 4.3.5 van Deel I.
} 


\section{De inrichting van de voorprocedures}

immers de geldingskracht van de uit die bepaling voortvloeiende eisen of uit het verdedigingsbeginsel voortvloeiende eisen, indien gegrond op artikel 6 EVRM, uit voor de bestuurlijke voorprocedures. ${ }^{393}$ Materieel blijken er ook in de jurisprudentie eisen erkend te worden die eenzelfde ratio hebben als equality of arms en ten dienste staan aan de gelijke procespositie van partijen. Bovendien kunnen via het verbod van vooringenomenheid situaties voorkomen die voor de rechterlijke procedure onder de noemer van equality of arms zouden vallen.

\subsubsection{Gevolgen van schendingen van equality of arms in de bestuurlijke voorprocedures}

Voor daadwerkelijke gelding van het vereiste van equality of arms in de bestuurlijke voorprocedures is vereist dat, expliciet dan wel impliciet, aan de schending van dit vereiste gevolgen worden verbonden. In het onderstaande wordt ingegaan op de jurisprudentie van de bestuursrechter over schendingen van de verschillende in de vorige paragraaf genoemde aspecten waarin in mijn optiek equality of arms tot uitdrukking komt. Een expliciete erkenning van een schending van dit vereiste vindt in de jurisprudentie vanzelfsprekend niet plaats, omdat het vereiste van equality of arms zelf als eis voor de bestuurlijke besluitvorming niet is erkend. Een schending van dit vereiste zal derhalve altijd plaatsvinden via de band van andere eisen. Dat kunnen de wettelijke eisen zijn waarin het vereiste van equality of arms tot uitdrukking komen of andere ongeschreven normen, zoals het zorgvuldigheidsbeginsel of het verbod van vooringenomenheid. De vaststelling van de schending van equality of arms moet derhalve altijd afgeleid worden uit de schending van een ander vereiste waarbij dan de facto sprake is van schending van equality of arms.

Gevolgen schending artikel 7:6 Awb en artikel 7:13 vijfde lid Awb

Een schending van artikel 7:6 Awb kan gepasseerd worden door toepassing van artikel 6:22 Awb door de rechter. Het betreft immers een voorschrift dat geen betrekking heeft op de inhoud van een besluit. Een schending van artikel 7:6 Awb vindt plaats in gevallen waarin het bestuur besluit tot afzonderlijk horen zonder dat sprake is van een van de in artikel 7:6 Awb genoemde uitzonderingen of de commissie besluit tot het afzonderlijk horen van belanghebbenden en de vertegenwoordiger van het bestuur zonder bijzondere rechtvaardigingsgrond (analoog aan de in artikel 7:6 Awb genoemde uitzonderingen). Ook kan de schending bestaan uit het nalaten belanghebbenden te informeren over hetgeen buiten hun aanwezigheid aan bod is gekomen tijdens de hoorzitting. Het achterwege laten van vernietiging van het besluit wegens schending van artikel 7:6 Awb is slechts mogelijk indien belanghebbenden daardoor niet benadeeld worden, gelet op artikel 6:22 Awb. Die benadering volgt ook de bestuursrechter en passeert een gebrek regelmatig, in elk geval waar het gaat om het ten onrechte afzonderlijk horen van belanghebbende(n) en de vertegenwoordiger van het bestuursorgaan in strijd met artikel 7:13, vijfde lid, van de Awb. ${ }^{394}$ Soms wordt echter ook aangegeven dat toepassing van artikel 6:22 Awb juist niet op zijn plaats is bij een dergelijk gebrek vanwege het verband met het beginsel van hoor en wederhoor. ${ }^{395}$ Ik kan me zo voorstellen dat ook indien belanghebbenden niet tezamen zijn gehoord zonder goede reden daarvoor, een vernietiging achterwege wordt gelaten indien zij volledig op de hoogte worden gesteld van het verhandelde en de gele-

\footnotetext{
${ }^{393 .}$ In verschillende uitspraken heeft de bestuursrechter toepasselijkheid van het beginsel van hoor en wederhoor of het recht op een eerlijk proces op bestuurlijke voorprocedures afgewezen. Zie: AbRvS 22 november 2006, $A B$ 2008/62 m.nt. N. Verheij; $J B$ 2007/12 m.nt. AB; AbRvS 12 juli 2006, JB 2006/268; AbRvS 8 mei 2002, $A B$ 2002/299; CRvB 27 september 2002, RSV 2002/311; CRvB 13 februari 2002, AB 2002/96.

394. CBb 28 november 2001, $A B$ 2001/45 m.nt. J.H. van der Veen (wel vernietiging maar het CBb geeft aan wegens een bijkomend gebrek art. 6:22 Awb niet toe te passen); CBb 29 februari 2000, AB 2000/206 m.nt. J.H. van der Veen;

${ }^{395 .}$ CRvB 15 januari 2004, JB 2004/107 m.nt. A.M.M.M. Bots; Gst. 2004, 7212/128 m.nt. Adriaanse.
} 
Deel II Bestuurlijke voorprocedures

genheid hebben gekregen om op elkaars standpunten te reageren. Belanghebbenden zullen tot slot zelf in beroep of hoger beroep moeten aandragen dat zij ten onrechte niet gezamenlijk zijn gehoord of zij ten onrechte niet zijn ingelicht over het verhandelde tijdens de hoorzitting buiten hun aanwezigheid.

Schending van andere uitwerkingen van equality of arms of onpartijdigheidseisen Bij schendingen van equality of arms in combinatie met de onpartijdigheideisen vindt vernietiging plaats, indien de bestuursrechter van oordeel is dat artikel 2:4 Awb is geschonden. Artikel 2:4 Awb betreft geen vormvoorschrift, waardoor de schending van die bepaling niet kan worden gepasseerd met toepassing van artikel 6:22 Awb. In dat kader verwijs ik naar paragraaf 5.4.3.6 waarin de gevolgen van schendingen van artikel 2:4 Awb aan de orde komen.

Voor zover de schending van equality of arms gepaard gaat met een andere norm, als geschreven dan wel ongeschreven uitwerking van het zorgvuldigheidsbeginsel, het fair play-beginsel of het beginsel van hoor en wederhoor geldt dat vernietiging volgt in de gevallen waarin de bestuursrechter normaliter ook het besluit zou vernietigen. ${ }^{396}$ Het gaat dan om eisen die onder de verschillende deelaspecten van het beginsel van hoor en wederhoor zouden kunnen vallen en die onderzocht zijn in de voorgaande paragrafen. In dat verband verwijs ik ook naar de betreffende paragrafen in dit hoofdstuk waarin ingegaan is op de gevolgen van schendingen van die uitwerkingen.

\subsubsection{Doorwerking van het beginsel van hoor en wederhoor}

Het bestaan van een beginsel van hoor en wederhoor in het bestuursrecht

Het beginsel van hoor en wederhoor als onderdeel van het recht op een eerlijk proces, zoals neergelegd in artikel 6 EVRM, of als ongeschreven beginsel van behoorlijke rechtspleging geldt niet rechtstreeks voor de bestuurlijke voorprocedures. In de rechtspraak van de bestuursrechter valt, zo is gebleken, de afgelopen jaren ook een ontwikkeling te bespeuren waarin de gelding van dergelijke voor de rechter geldende eisen wordt uitgesloten voor de verschillende besluitvormingsfasen, waaronder de bestuurlijke voorprocedures. $^{397}$

Het verdedigingsbeginsel of het beginsel van hoor en wederhoor wordt voorts in het Nederlandse bestuursrecht niet algemeen aanvaard als afzonderlijk beginsel van behoorlijk bestuur. ${ }^{398}$ Nicolaï wijst erop dat een dergelijk beginsel in beginfase van de ontwikkeling van de algemene beginselen van behoorlijk bestuur in zowel de literatuur als in de jurisprudentie wel enige malen erkend werd. ${ }^{399}$ Zo komt - aldus Nicolaï - het door Wiar$\mathrm{da}$, al in zijn preadvies voor de Vereniging voor administratief recht in 1952, onderscheiden 'fair play'-beginsel onder meer neer op wat wij thans het verdedigingsbeginsel of het beginsel van hoor en wederhoor zouden noemen. ${ }^{400}$ Ook geeft Nicolaï aan dat verschillende bestuursrechters het verdedigingsbeginsel in enigerlei vorm wel leken te erkennen. Daartoe wijst hij bijvoorbeeld op enkele uitspraken waarin het $\mathrm{CBb}$, in navolging van de Franse Conseil d'Etat, het verdedigingsbeginsel lijkt te erkennen, hoewel ook hier onder de noemer van het 'fair play'-beginsel. ${ }^{401}$ De CRvB leek de voorkeur te hebben voor een algemene zorgvuldigheidsnorm, waaruit eisen voortvloeiden die op hoor en wederhoor betrekking hadden en leek afsplitsing van een afzonderlijk verdedigingsbeginsel van het algemene zorgvuldigheidsbeginsel niet voor te staan. ${ }^{402}$ Nicolaï zelf spreekt over het

\footnotetext{
396. Zie bv.: Rb. R'dam 4 december 1995, JB 1996/63.

397. O.m.: AbRvS 12 juli 2006, JB 2006/268 m.nt. Wenders; AbRvS 8 mei 2002, AB 2002/299 m.nt. Sew.

398. Jansen 2008, p. 224

399. Nicolai 1990, p. 111-113.

${ }^{400 .}$ Nicolaï 1990, p. 81, 92 en 112.

${ }^{401 .}$ Nicolaï 1990, p. 111-113 en 119.

402. Nicolaï 1990, p. 122-123.
} 


\section{De inrichting van de voorprocedures}

beginsel van correcte bejegening dat hij als een specificatie van het algemene zorgvuldigheidsbeginsel ziet. ${ }^{403} \mathrm{Hij}$ acht het wenselijk om te differentiëren tussen normen van zorgvuldige voorbereiding die de bejegening van personen betreffen en normen van zorgvuldige voorbereiding die betrekking hebben op het onderzoek van de feiten. ${ }^{404}$ Deze tweedeling van het zorgvuldigheidsbeginsel is echter geen gemeengoed in de rechtspraak. ${ }^{405}$ De bestuursrechter erkent wel expliciet het zorgvuldigheidsbeginsel, dat deels is neergelegd in artikel 3:2 Awb, waaruit eisen met een vergelijkbare strekking als hoor en wederhoor kunnen voortvloeien. Tegelijkertijd wordt dan de nadruk vaak gelegd op het bestuurlijk perspectief dat gericht is op de zorgvuldigheid van het onderzoek en de besluitvorming. Een beginsel van hoor en wederhoor vormt derhalve geen algemeen erkend beginsel van behoorlijk bestuur - althans niet expliciet - voor de bestuurlijke besluitvormingsprocedures.

\section{Verschillende uitwerkingen van het beginsel van hoor en wederhoor}

Des te opvallender is het dat de Awb aan de inrichting van de bezwaarschriftprocedure en het administratief beroep wel degelijk eisen stelt die zien op hoor en wederhoor en dat er voorschriften zijn die zelfs rechtstreeks op dat beginsel zijn terug te voeren. Ook de bestuursrechter plaatst sommige eisen voor de inrichting van de bestuurlijke voorprocedures expliciet in het licht van het beginsel van hoor en wederhoor.

Het recht om stukken in te dienen en het recht op inzage in de stukken die neergelegd zijn in artikel 7:4 Awb worden bijvoorbeeld in verband gebracht met de goede procesorde en hoor en wederhoor. Beide rechten worden expliciet dan wel impliciet ook op dezelfde wijze toegepast en ingevuld als de equivalente rechten in de procedure bij de bestuursrechter. Het recht om opnieuw gehoord te worden op grond van artikel 7:9 Awb, indien er nieuwe feiten of omstandigheden bekend worden na de eerste hoorzitting, wordt bijvoorbeeld door de bestuursrechter expliciet gebaseerd op het beginsel van hoor en wederhoor. De bestuursrechter lijkt deze bepaling als een uitwerking van dat beginsel te beschouwen. Zelfs van vereisten waarvan de bestuursrechter formeel en expliciet geldingskracht voor de bestuurlijke voorprocedures uitsluit, zoals het vereiste van equality of arms, bestaan materieel equivalente uitwerkingen. In de jurisprudentie van de bestuursrechter worden ook regelmatig bepaalde vereisten erkend of gehanteerd die de facto neerkomen op een uitwerking van het beginsel van hoor en wederhoor. Bepaalde vereisten, die materieel gelijk of vergelijkbaar zijn aan de vereisten die gesteld worden aan de inrichting van de procedure bij de bestuursrechter, gelden derhalve ook voor de bestuurlijke voorprocedures. Zij worden alleen op een andere norm gebaseerd. In veel gevallen vormt het formele zorgvuldigheidsbeginsel de rechtsbasis voor dergelijke eisen. De bestuursrechter legt het zorgvuldigheidsbeginsel in die gevallen dan ook zodanig uit alsof het om het beginsel van hoor en wederhoor gaat en leidt uit dat beginsel uitwerkingen af die in het teken staan van de goede procesorde of hoor en wederhoor. Een voorbeeld daarvan vormt de mogelijkheid om te reageren op adviezen ingewonnen door het bestuur. Hoewel de bestuursrechter die eis weigert te baseren op artikel 6 EVRM en/of equality of arms, geldt die eis evenzeer op grond van het zorgvuldigheidsbeginsel. Eenzelfde invulling vindt plaats in het geval ongeschreven hoorplichten worden aangenomen na vernietiging van een besluit door de bestuursrechter.

De overlap met het zorgvuldigheisbeginsel en het verbod van vooringenomenheid In de voorgaande paragrafen is naar voren gekomen dat bepaalde uitwerkingen van de verschillende deelaspecten van het beginsel van hoor en wederhoor, zoals we die kennen voor rechtspraak, voor de bestuurlijke voorprocedures ten dele voortvloeien uit het zorg-

\footnotetext{
${ }^{403 .}$ Nicolaï 1990 , p. 226 en p. $290-292$

404. Nicolaï 1990, p. 290-291.

${ }^{405 .}$ In de doctrine wordt het wel af en toe gevolgd, zie Addink 1999, p. 190 e.v.
} 


\section{Deel II Bestuurlijke voorprocedures}

vuldigheidsbeginsel. Dat beginsel vormt, naast het beginsel van hoor en wederhoor, in de doctrine en vooral ook in de rechtspraak de grondslag voor verschillende eisen die voor rechtspraak onder het beginsel van hoor en wederhoor worden geschaard. Er bestaat derhalve een overlap tussen het beginsel van hoor en wederhoor als beginsel van behoorlijke rechtspleging en het algemene zorgvuldigheidsbeginsel als beginsel van behoorlijk bestuur wat betreft de bestuurlijke voorprocedures. Die bevinding was ook te verwachten. Vastgesteld kan worden dat deze aanname expliciet bevestigd is door het onderzoek.

Opvallend is daarentegen wel dat niet alle deelaspecten van het beginsel van hoor en wederhoor voor de bestuurlijke voorprocedures herleid worden tot het zorgvuldigheidsbeginsel. Enkele inrichtingseisen in de Awb worden expliciet met het beginsel van hoor en wederhoor in verband gebracht. Het lijken allereerst vooral de ongeschreven eisen of uitwerkingen te zijn waarvoor de bestuursrechter in het bijzonder het zorgvuldigheidsbeginsel van stal haalt. Het gaat bijvoorbeeld om een hoorplicht na vernietiging van het besluit door de bestuursrechter. De expliciete erkenningen van het beginsel van hoor en wederhoor hebben uitsluitend plaatsgevonden in het licht van wettelijke eisen in de Awb of ongeschreven eisen waarbij sterk aangesloten kan worden bij de bepalingen in de Awb. Gaat het echter om ongeschreven eisen, in aanvulling op de wettelijke regeling of ter invulling van een leemte in de wettelijke regeling, dan lijkt het zorgvuldigheidsbeginsel voor de bestuursrechter een veiliger of bekender handvat te bieden. De verklaring daarvoor zou kunnen liggen in de omstandigheid dat het beginsel van hoor en wederhoor niet algemeen aanvaard is als behoorlijkheidsnorm voor het bestuurlijk handelen (in de bestuurlijke voorprocedures).

Uit de omstandigheid dat de bestuursrechter soms als grondslag voor bepaalde eisen kiest voor het zorgvuldigheidsbeginsel en soms voor het beginsel van hoor en wederhoor blijkt dat er ook daadwerkelijk materiële overlap bestaat tussen de eisen die uit beide beginselen voortvloeien. De strikte scheiding die de bestuursrechter soms lijkt voor te staan tussen het beginsel van hoor en wederhoor en het zorgvuldigheidsbeginsel, waarbij het lijkt alsof er sprake is van twee geheel verschillende perspectieven lijkt onnodig en getuigt ook van een zekere mate van formalisme. Duidelijk is immers dat materieel sprake is van vergelijkbare of zelfs dezelfde eisen. Het verdient bovendien de voorkeur om voor de hiervoor bedoelde ongeschreven eisen het beginsel van hoor en wederhoor als grondslag aan te wijzen. Daarmee komt scherper tot uitdrukking wat de ratio is achter de hoorplicht in dergelijke gevallen en waarin het gebrek in de besluitvorming is gelegen. ${ }^{406}$

In sommige gevallen betekent een andere grondslag echter ook daadwerkelijk dat er andere eisen gelden. Zo leidt de bestuursrechter uit het zorgvuldigheidsbeginsel wel een mogelijkheid af om achteraf te reageren op een advies af voor belanghebbenden, maar geen mogelijkheid om dat vooraf te kunnen doen. In dat opzicht is er een verschil met het beginsel van hoor en wederhoor en equality of arms in de rechterlijke procedure. Daarbij wordt het zorgvuldigheidsbeginsel en het verschil in eisen door de bestuursrechter uitdrukkelijk in verband gebracht met het onderscheid in positie en werkzaamheid van het bestuur ten opzichte van de bestuursrechter. Ook op grond van het beginsel van hoor en wederhoor zou geoordeeld kunnen worden dat een reactiemogelijkheid achteraf in de bestuurlijke fase volstaat. Het beginsel van hoor en wederhoor kan in de bestuurlijke fase anders uitwerken of minder verstrekkende eisen met zich brengen. Om dat te bewerkstelligen is niet noodzakelijk dat de bestuursrechter vasthoudt aan de uitsluiting van bepaalde eisen die voor de rechter gelden, enkel en alleen omdat het om bestuurlijke besluitvorming gaat.

Naast de overlap met het formele zorgvuldigheidsbeginsel bestaat er ook een gedeeltelijke overlap met een ander beginsel van behoorlijk bestuur, het onpartijdigheidsbegin-

\footnotetext{
406. Van der Ham 1988, p. 82. Ook Van der Ham merkt meer in het algemeen op dat uit het zorgvuldigheidsbeginsel of de constatering dat in strijd daarmee gehandeld is geen duidelijk inzicht in de aard van het gebrek dat aan een beslissing kleeft blijkt. Zijns inziens geldt dit te meer, indien in het processuele zorgvuldigheidsbeginsel het beginsel van hoor en wederhoor geacht wordt besloten te liggen. Daarin kan ik mij geheel vinden.
} 


\section{De inrichting van de voorprocedures}

sel of het verbod van vooringenomenheid. Evenals het geval is bij de beginselen van behoorlijke rechtspraak kan er een verband bestaan tussen equality of arms en het onpartijdigheidsbeginsel voor het bestuur. Omdat equality of arms geen norm is die aanvaard is voor het bestuur, kunnen situaties die onder de noemer equality of arms geschaard kunnen worden ook genormeerd worden door artikel 2:4 Awb. Op de verhouding tussen de beginselen van behoorlijk bestuur en de beginselen van behoorlijke rechtspleging wordt in meer algemene zin ingegaan in Deel III, paragraaf 4.

\section{Onduidelijkheid inzake toepasselijkheid van het beginsel van hoor en wederhoor}

In de literatuur en jurisprudentie zijn bij specifieke vereisten of voorschriften verwijzingen of refertes aan het beginsel van hoor en wederhoor aangetroffen. Soms wordt dit beginsel expliciet door de wetgever, doctrine of bestuursrechter als grondslag aangewezen voor die eisen. De bestuursrechter erkent bijvoorbeeld uitdrukkelijk het beginsel van hoor en wederhoor als grondslag voor de hernieuwde hoorplicht die is neergelegd in artikel 7:9 Awb. In andere gevallen wordt het beginsel van hoor en wederhoor impliciet als rechtsbasis gehanteerd bij de beoordeling. Dat is bijvoorbeeld het geval wanneer er door belanghebbenden een beroep op het beginsel van hoor en wederhoor wordt gedaan en de bestuursrechter vervolgens zijn oordeel geeft over de aanvaardbaarheid van de handelwijze van het bestuur. Zonder dat uitdrukkelijk te overwegen, lijkt door het al dan niet constateren van een schending of een gebrek impliciet een erkenning van het beginsel plaats vinden. Daarnaast zijn er uitspraken van de Afdeling waarin deze een beroep op het beginsel van hoor en wederhoor behandeld en afdoet aan de hand van de strekking van de bepalingen in de Awb zonder uitdrukkelijk in te gaan op de toepasselijkheid danwel schending van het beginsel van hoor en wederhoor. ${ }^{47}$ Daarmee wordt de toepasselijkheid niet bevestigd of ontkend, maar uitsluitend in het midden gelaten. De Centrale Raad geeft in sommige uitspraken aan te twijfelen aan de toepasselijkheid van bepaalde eisen van het beginsel van hoor en wederhoor of de goede procesorde. ${ }^{408}$ In weer andere gevallen worden eisen gesteld op grond van het algemene zorgvuldigheidsbeginsel die vergelijkbaar zijn met de eisen die aan de rechterlijke procedure gesteld worden op grond van het beginsel van hoor en wederhoor. Tot slot zijn er gevallen waarin de bestuursrechter de geldingskracht van vereisten op grond van het beginsel van hoor en wederhoor expliciet uitsluit. De bestuursrechter hanteert al met al geen consistente lijn waar het gaat om toepasselijkheid van het beginsel van hoor en wederhoor. Uitsluitend voor zover het eisen betreft die gegrond worden op artikel 6 EVRM is er thans een duidelijke lijn. Het zijn die eisen, waarvan de betekenis door de bestuursrechter expliciet wordt ontkend. Met het beginsel van hoor en wederhoor als zodanig lijkt de bestuursrechter minder moeite te hebben.

\section{Verklaringen voor de lijn van de bestuursrechter}

Als het gaat om verdedigingsrechten of eisen op grond van hoor en wederhoor die voortvloeien uit artikel 6 EVRM valt voor de afhoudende benadering van de bestuursrechter enig begrip op te brengen. Die houding kan samenhangen met de omstandigheid dat die bepaling nu eenmaal primair voor rechtspraak en procedures bij rechterlijke instanties geschreven is. Het is begrijpelijk dat de bestuursrechter terughoudend is om de reikwijdte van die bepaling en de daaruit voortvloeiende eisen op te rekken of uit te breiden naar de bestuurlijke voorprocedures. Opgemerkt zij dat zulks uiteraard niet in strijd met artikel 6 EVRM of de daarop gebaseerde jurisprudentie hoeft te zijn, aangezien sprake is van minimumbescherming en de verdragsstaten een verdergaande bescherming dan geboden door (die bepaling van) het EVRM kunnen bieden. ${ }^{409}$ Dat de bestuursrechter

407. Zie bijvoorbeeld: AbRvS 12 december 2007, nr. 200703100/1.

408. Zoals al eerder aangehaald o.m.: CRvB 21 juli 2001, $N J B$ 2001/22, p. 1625; ook gepubliceerd in $J B$ 2001/256; $A B$ 2001/252 m.nt. FP onder $A B$ 2001/253; RSV 2001/205; USV 2001/199.

${ }^{409}$ Zie par. 4.1 van Deel I daarover. 


\section{Deel II Bestuurlijke voorprocedures}

zich daartoe niet geroepen voelt, nu er reeds een regeling van de bestuurlijke voorprocedures in de Awb wordt gegeven, verbaast niet. Het is ook de vraag of het wenselijk is om een uitbreiding van de eisen in het licht van hoor en wederhoor voor de bestuurlijke voorprocedures aan artikel 6 EVRM op te hangen.

Puur nationaalrechtelijk beschouwd lijkt de inconsistente benadering van de bestuursrechter echter vooral terug te voeren op de visie op de verhouding tussen bestuur en rechter in ons staatsbestel. De ontkenning van de gelding van deze eisen voor de besluitvorming, enkel en alleen omdat het besluitvorming betreft, is nationaalrechtelijk beschouwd minder overtuigend. De bestuurlijke voorprocedures, en in het bijzonder de bezwaarschriftprocedure, vormen immers ook rechtsbeschermingsvoorzieningen. Op grond daarvan zou toepasselijkheid van het beginsel van hoor en wederhoor of de goede procesorde zeker denkbaar zijn. In de benadering van de bestuursrechter is ook enige ambivalentie te bespeuren waar het gaat om de toepasselijkheid van het beginsel van hoor en wederhoor en de goede procesorde. De bestuursrechter is in sommige gevallen terughoudend in het expliciet van toepassing verklaren daarvan of daaruit voortvloeiende eisen. In andere gevallen gebeurt dat echter wel of wordt daarvoor een opening gelaten. Het tweeledige karakter van de bestuurlijke voorprocedures lijkt de bestuursrechter parten te spelen bij het uitleggen van de toepasselijke vereisten.

\section{Een beginsel van hoor en wederhoor als norm voor bestuurlijke besluitvorming}

Het onderzoek in de voorgaande paragrafen heeft aangetoond dat er concrete eisen gelden in de bestuurlijke voorprocedures die terug te voeren vallen op het beginsel van hoor en wederhoor en dezelfde ratio hebben als de eisen die daaruit voortvloeien voor de bestuursrechter. Het beginsel van hoor en wederhoor omvat vier deelaspecten: het recht om informatie te verschaffen, het recht om informatie te ontvangen, voldoende voorbereidingstijd ter verdediging van het eigen standpunt en equality of arms. Van al deze deelaspecten zijn uitwerkingen terug te vinden in de eisen die gesteld worden aan de inrichting van de bestuurlijke voorprocedures. Soms betreft het exact dezelfde eisen die gelden voor de procedure bij de bestuursrechter en soms betreft het eisen met een vergelijkbare strekking en functie. Deze eisen worden niet altijd, zoals hiervoor al werd aangegeven, expliciet herleid tot het beginsel van hoor en wederhoor en soms wordt door de bestuursrechter zelfs uitgesloten dat zij te herleiden vallen tot dit beginsel. Desalniettemin kan aangenomen worden dat de vier deeleisen van het beginsel van hoor en wederhoor van betekenis zijn voor de bestuurlijke voorprocedures. Overigens dient een belanghebbende zich wel op schending van de uitwerkingen daarvan te beroepen. De bestuursrechter heeft in het kader van verschillende bepalingen in de Awb die zien op of samenhangen met het horen geoordeeld dat deze niet van openbare orde zijn en daaraan niet ambtshalve mag worden getoetst. ${ }^{410}$ De betekenis van het beginsel van hoor en wederhoor komt in sommige gevallen expliciet tot uitdrukking in de rechtspraak en in andere gevallen impliciet door de strekking of ratio die aan bepaalde eisen moet worden toegekend. De grondslagen voor de verschillende eisen zijn wisselend. De ene keer is dat het zorgvuldigheidsbeginsel en de andere keer het beginsel van hoor en wederhoor of de goede procesorde. Vooral door de bestuursrechter worden wisselende grondslagen gehanteerd en er is dan ook geen sprake van een consistente benadering in de rechtspraak. Daaruit blijkt dat de bestuursrechter worstelt met het tweeledige karakter van de bestuurlijke voorprocedures. Wel is het zo dat de bestuursrechter, indien het zorgvuldigheidsbeginsel wordt gekozen als grondslag, dat beginsel soms zo uitlegt of interpreteert dat daarbij ook een rechtsbeschermingsperspectief of hoor en wederhoor een rol kunnen spelen. Zorgvuldigheid als grondslag betekent derhalve niet per definitie dat de zorgvul-

${ }^{410 .}$ Zie bv.: AbRvS 29 juli 1996, JB 1996/190 m.nt. MAH (art. 7:2 Awb). Zie voorts: R.J.G.M. Widdershoven, R.J.N. Schlössels, F.A.M. Stroink, J.B.J.M. ten Berge, A.J. Bok, W.J.M. Voermans, B.W.N. de Waard, P.A. Willemsen, Hoger beroep, Den Haag, BJu 2001, p. 174 die nog wijzen op de volgende uitspraken: AbRvS 14 november 1997, nr. H01.960749 (art. 7:9 Awb); CRvB 25 november 1997, JAwb 1998/20. 


\section{De inrichting van de voorprocedures}

digheid van de besluitvorming domineert als perspectief. De omstandigheid dat de bestuursrechter sommige eisen baseert op het zorgvuldigheidsbeginsel in plaats van het beginsel van hoor en wederhoor doet aan de betekenis van het beginsel van hoor en wederhoor derhalve niet per definitie af. Ook het zorgvuldigheidsbeginsel kan zo uitgelegd worden dat recht wordt gedaan aan hoor en wederhoor.

\subsection{Onafhankelijkheid en onpartijdigheid van het bestuur in de bestuurlijke voorprocedures}

\subsubsection{Rechterlijke onpartijdigheid en onafhankelijkheid}

De eis van onpartijdigheid voor organen van de overheid wordt vooral, gelet op artikel 6 EVRM, in verband gebracht met rechterlijke instanties. ${ }^{411}$ Uit het eerste lid van dat artikel vloeit immers voort dat rechterlijke instanties onpartijdig dienen te zijn in procedures waarin een 'civil right and obligation' centraal staat dan wel sprake is van een 'criminal charge'. Ook uit het nationale recht vloeit voort dat rechterlijke instanties onpartijdig tot hun uitspraak in het voorliggende geschil behoren te komen. ${ }^{412}$ Zoals in Deel I uiteen is gezet, wordt het onpartijdigheidsbeginsel algemeen aanvaard als een ongeschreven beginsel van behoorlijke rechtspleging dat iedere rechterlijke instantie in acht dient te nemen. ${ }^{413}$ In principe houdt dit beginsel, zoals De Waard het min of meer omschrijft, in dat de taakuitoefening door de geschilbeslechtende instantie zo objectief en neutraal mogelijk dient te geschieden en dat de geschilbeslechtende instantie zich niet mag laten leiden door persoonlijke voorkeuren of belangen (van haar leden). ${ }^{414}$ Hoewel De Waard met name het oog heeft op de instanties die traditioneel gerekend worden tot rechterlijke instanties, is de werking van de beginselen van behoorlijke rechtspleging daartoe in zijn optiek niet beperkt. ${ }^{415}$ Het onpartijdigheidsbeginsel kan ook van betekenis zijn voor het bestuur als geschilbeslechtende instantie. In de literatuur is echter vooral aan de door de rechter in acht te nemen onpartijdigheid veel aandacht besteed. ${ }^{416}$ Dat geldt wellicht nog te meer voor de positie van de bestuursrechter in dat kader. Recentelijk nog vormden de vereisten van onafhankelijkheid en, in het bijzonder, onpartijdigheid zoals neergelegd in artikel 6, eerste lid van het EVRM onderwerp van discussie met betrekking tot de Nederlandse bestuursrechtspraak, in het bijzonder de Afdeling bestuursrechtspraak van de Raad van State. Aanleiding daarvoor is de door het EHRM gewezen uitspraak in de zaak Kleyn e.a. t. Nederland waarin de klagers zich op het standpunt stelden dat de Afdeling niet kon worden beschouwd als een onafhankelijk en onpartijdig gerecht in de zin van artikel 6 lid 1 EVRM. ${ }^{417}$ De discussie betreft met name de objectieve onpartijdigheid van

\footnotetext{
411. Aldus ook Verheij, die opmerkt dat het verbod van vooringenomenheid voor de Awb vooral bekend was als een tot rechters gerichte norm die is vastgelegd in artikel 6 EVRM, N. Verheij, 'Stadsmobiel Amsterdam. Partijdige bezwaarschriftcommissie', in: L.J.A. Damen e.a. (red.) Rechtspraak Bestuursrecht 1994-1995: de annotaties, Den Haag: Vuga 1995, p. 142.

412. Zie hierover nader par. 4.3.4 van Deel I.

413. De Waard 1987, p. 126-127 en hfst. 8.

${ }^{414 .}$ De Waard 1987, p. 127-128. Zie hierover verder par. 4.3.4 van Deel I.

415. De Waard 1987, p. 342 en 360-363.

416. Zie o.m.: M. Kuijer, The blindfold of Lady Justice. Judicial Independence and Impartiality in Light of the Requirements of Article 6 ECHR (diss. Leiden), Nijmegen: Wolf Legal Productions 2004, p. 303 e.v.

417. EHRM 6 mei 2003, Kleyn e.a. t. Nederland, AB 2003/211, m.nt. L.V. en BdeW; JB 2003/119 m.nt. AWH. Zie verder o.m.: Rapport VAR Commissie Rechtsbescherming, De toekomst van de rechtsbescherming tegen de overheid. Van toetsing naar geschilbeslechting., Den Haag: Bju 2004, p. 53-56; A.J. Bok, 'Het EHRM-arrest Kleyn e.a.: Raad van State grotendeels gesauveerd, maar nog niet uit de gevarenzone', Gst. (2003) 7186, p. 296300; Th.G. Drupsteen, 'De Raad van State na Kleyn and others versus the Netherlands, NTB 2003/10, p. 317 323. Overigens wordt deze discussie omtrent de objectieve onpartijdigheid van de Afdeling al geruime tijd gevoerd. Vooral sinds het EHRM een uitspraak in dat kader ten aanzien van de Luxemburgse Raad van State gewezen heeft, EHRM 28 september 1995, Procola t. Zwitserland, AB 1995/588 m.nt. ICvdV. Zie hierover: P. van Dijk, Artikel 6 EVRM en de Afdeling bestuursrechtspraak van de Raad van State, Lezing ter gelegenheid van
} 
Deel II Bestuurlijke voorprocedures

de Afdeling gelet op de uitoefening van zowel adviserende als rechterlijke functies door (bepaal)de volle staatsraden bij de Raad van State. ${ }^{418}$

Veelal wordt in een adem met het vereiste van onpartijdigheid, in het licht van artikel 6 EVRM, ook het vereiste van onafhankelijkheid van rechterlijke instanties genoemd. Terwijl onpartijdigheid ziet op de verhouding van de beslissende rechter of rechterlijke instantie tot de bij het geschil betrokken partijen, heeft de onafhankelijkheid met name betrekking op de (mate van te vermijden) verwevenheid met de beide andere staatsmachten. ${ }^{419}$ Onafhankelijkheid van de rechterlijke macht of rechterlijke instanties wordt echter beschouwd als een voorwaarde voor deze colleges om onpartijdig te kunnen oordelen in een voorliggend geschil. ${ }^{420}$ De onafhankelijkheideis wordt nog sterker dan het onpartijdigheidbeginsel verbonden aan rechterlijke instanties of rechtspraak. Het vereiste van onafhankelijkheid vormt tenminste een beginsel van behoorlijke rechtspraak of inrichtingseis te stellen aan een behoorlijke procedure, terwijl de gangbare opvatting - waarbij in dit onderzoek wordt aangesloten - inhoudt dat onafhankelijkheid (ook) een voorwaarde vormt om te kunnen spreken van rechtspraak. ${ }^{421}$ Dat betekent dat onafhankelijkheid niet tegelijkertijd ook een beginsel van behoorlijke rechtspleging kan vormen. Onafhankelijkheid is een voorwaarde om te kunnen spreken van rechtspraak en de toetsing aan dat vereiste vindt in beginsel plaats in het kader van de beoordeling of sprake is van rechtspraak (of als voorwaarde voor onpartijdigheid). ${ }^{422}$

Ofschoon onpartijdigheid en met name onafhankelijkheid eisen vormen die primair in verband worden gebracht met rechtspraak en rechterlijke instanties, bestaat er voldoende aanleiding, zoals hierna zal blijken, om aan te nemen dat deze vereisten ook van betekenis kunnen zijn voor het bestuur als geschilbeslechtende orgaan in de bestuurlijke voorprocedures. Zowel de betekenis van het vereiste van onafhankelijkheid als van het vereiste van onpartijdigheid wordt in de onderstaande paragrafen nader bezien in verhouding tot die bestuurlijke voorprocedures.

\subsubsection{Onafhankelijk bestuur: een contradictio in terminis?}

\section{De betekenis van rechterlijke onafhankelijkheid}

In Deel I is vastgesteld dat vanuit het beginsel van machtenscheiding en de rechtsstaatgedachte alsmede vanwege de invloed van artikel 6 EVRM van rechterlijke instanties wordt geëist dat zij onafhankelijk zijn. ${ }^{423}$ De eis dat instanties die met rechtspraak zijn

de $19^{\text {e }}$ verjaardag van het SIM op 26 oktober 2000, Utrecht: SIM 2001; N.S.J. Koeman, 'De gevolgen van de Procola-uitspraak voor Nederland', NTB 1996, p. 197 e.v.

418. Op 1 september 2010 is een wet in werking getreden die voorziet in de nodige aanpassingen, zoals de instelling van een afzonderlijke Afdeling advisering, Wet van 22 april 2010, Stb. 2010, 175; Besluit van 8 juni 2010 tot vaststelling van het tijdstip van inwerkingtreding van de wet van 22 april 2010 tot wijziging van de Wet op de Raad van State in verband met de herstructurering van de Raad van State (Stb.175), Stb. 2010, 236. Zie hierover o.m.: A.J. Bok, 'De Raad van State gereorganiseerd, NJB 2007, p. 266-272; T. Barkhuysen, 'Het vereiste van rechterlijke onpartijdigheid en de voorgestelde nieuwe Wet op de Raad van State:mag het een onsje meer zijn?, Regelmaat 2007/3, p. 119-127; L.F.M. Verhey, 'De toekomst van de Raad van State: het einde van de Procolakramp?, in: A.W. Heringa, A.M.L. Jansen, E.C.H.J. van der Linden, L.F.M. Verhey, Het bestuursrecht beschermd (liber amicorum F.A.M. Stroink), Den Haag 2006, p. 17-31. Zie ook de noten bij EHRM 9 november 2006, Sacilor-Lormines t. Frankrijk, AB 2007/281 m.nt. De Waard; EHRC 2007/15 m.nt. Verhey.

${ }^{419 .}$ Stroink 1993, p. 9; De Waard 1987, p. 44. Zie par. 4.3.3 en 4.3.4 van Deel I.

${ }^{420 .}$ Stroink 1999, p. 7 en 9; Stroink 1993, p. 14; De Waard 1987, p. 45 en 330-331.

421. Zie par. 4.3.3 van Deel I.

422. Zie hierover par. 4.3.3 van Deel I. Overigens zal de vraag of een rechterlijke instantie onafhankelijk is in de praktijk veelal in een procedure bij de rechter aan de orde komen in het kader van de vraag of sprake is van een schending van artikel 6 EVRM. Zoals blijkt in par. 4.3.3 van Deel I, toetst het EHRM ook aan dit vereiste in het kader van de vraag of sprake is van een 'tribunal established by law' maar vaak zal, indien daarop een beroep worden gedaan, de toetsing aan de onafhankelijkheideisen pas aan de orde komen in het kader van de toetsing aan de vereiste 'impartiality and independence' van een rechterlijke instantie in de zin van art. 6 EVRM.

423. Zie ook: M. Kuijer, The blindfold of Lady Justice. Judicial independence and impartiality in light of the requirements of article 6 ECHR, Nijmegen:Wolf Legal Publishers 2004, p. 203-210; Widdershoven 1989, p. 21 22 . 


\section{De inrichting van de voorprocedures}

belast onafhankelijk behoren te zijn, hangt samen met de positie van de rechter in ons staatsbestel en zijn verhouding tot de twee andere staatsmachten, wetgever en bestuur. Er dient sprake te zijn van onafhankelijkheid in verschillende opzichten. Over het algemeen wordt een onderscheid gemaakt tussen functionele of zakelijke onafhankelijkheid en persoonlijke of rechtspositionele onafhankelijkheid. ${ }^{424}$ Onafhankelijkheid van rechterlijke instanties vormt primair een waarborg tegen te vergaande inmenging van de beide andere staatsmachten, wetgever en bestuur, in de rechterlijke taakuitoefening. De hoofdfunctie van de eis van onafhankelijkheid is dan ook het waarborgen van het vertrouwen in rechtspraak van het publiek. De onafhankelijkheideis heeft derhalve vooral externe werking en heeft niet primair de bescherming van belangen van de procesdeelnemers bij het concrete geschil op het oog. Daarnaast vormt onafhankelijkheid een waarborg die de vereiste onpartijdigheid van de rechter in het concrete geschil kan bevorderen. Als waarborg voor onpartijdigheid staat de onafhankelijkheideis ook, zij het meer indirect, ten dienste van de bescherming van de belangen van de betrokken partijen in de betreffende procedure.

\section{Onafhankelijk bestuur in de voorprocedures}

Op voorhand lijkt een onderzoek naar de onafhankelijkheid van de geschilbeslechtende instantie in de bestuurlijke voorprocedures niet zinvol. Deze procedures worden immers aanhangig gemaakt bij het bestuur en in het kader daarvan vindt besluitvorming plaats door het bestuur. Deze bestuursorganen zijn als geschilbeslechters per definitie niet onafhankelijk. ${ }^{425}$ Omdat onafhankelijkheid als element van het begrip rechtspraak moet worden gezien, vallen de bestuurlijke voorprocedures buiten dat begrip en kunnen deze niet gekwalificeerd worden als rechtspraak. ${ }^{426}$ Omdat onafhankelijkheid, zoals aangegeven, in dit onderzoek niet beschouwd wordt als een beginsel van behoorlijke rechtspleging, ${ }^{427}$ wordt in beginsel niet onderzocht of het vereiste van onafhankelijkheid als beginsel van behoorlijke rechtspleging van betekenis is voor de bestuurlijke voorprocedures.

Desalniettemin bestaat er aanleiding om de onafhankelijkheideis niet bij voorbaat als irrelevant aan de kant te schuiven voor de bestuurlijke voorprocedures. ${ }^{428}$ Zoals hierboven al naar voren kwam, zijn de eisen van onafhankelijkheid en onpartijdigheid nauw met elkaar verbonden. ${ }^{429}$ Het onpartijdigheidbeginsel vormt wel een beginsel van behoorlijke rechtspleging en de betekenis daarvan voor de bestuurlijke voorprocedures komt in dit onderzoek aan de orde. Onafhankelijkheid vormt bovendien een voorwaarde voor onpartijdigheid van het geschilbeslechtende orgaan en daarmee een voorwaarde voor een objectieve beslissing van het desbetreffende orgaan. ${ }^{430}$ De onafhankelijkheideis kan voor de bestuurlijke voorprocedures in die laatste betekenis, in de verhouding tot de partijen en het concrete geschil, dan ook van belang zijn, mits voor ogen wordt gehouden dat het doel het bewerkstelligen van onpartijdigheid van het geschilbeslechtende bestuursorgaan is. Van volledige onafhankelijkheid en onpartijdigheid ten opzichte van de partijen en het concrete geschil in de voorprocedure is echter hoe dan ook geen sprake, omdat het bestuur immers als geschilbeslechtende instantie in bezwaar en nemer van het

\footnotetext{
424. Kuijer 2004, p. 207-209. Zie hierover nader par. 4.3.3 van Deel I.

425. Widdershoven 1989, p. 44.

426. Zie par. 4.3.3 van Deel I.

${ }^{427}$. Hierop wordt eveneens nader ingegaan in par. 4.3.3 van Deel I.

428. Vgl. ook Van der Ham die eveneens meent dat er geen reden is om het beginsel voor de procedures bij het bestuur 'over boord te gooien', Van der Ham 1998, p. 81.

429. Zie: Kuijer 2004, p. 380; Stroink 1999, p. 6-7; Widdershoven 1989, 125; Van der Ham 1988, p. 81.

${ }^{430}$ Kuijer 2004, p. 380; Stroink 1999, p. 6-7; Widdershoven 1989, p. 125; Van der Ham 1988, p. 81. Soms wordt ook wel gesteld dat onafhankelijkheid opgaat in onpartijdigheid, omdat het primaire doel van onafhankelijkheid is het waarborgen van onpartijdigheid, zie Van der Ham 1998, p. 81. Hierover nader par. 4.3.3 in Deel I.
} 


\section{Deel II Bestuurlijke voorprocedures}

bestreden besluit zelf partij is in de procedure en in administratief beroep (politieke) banden met het primair beslissende bestuursorgaan - een van de partijen - kan hebben. ${ }^{431}$

\section{Onafhankelijkheid en onpartijdigheid in de Awb}

De Awb stelt niet veel eisen aan de samenstelling van het bezwaar- of administratief beroepsorgaan, maar er worden wel degelijk enkele eisen gesteld. Het bestuur dient immers, getuige artikel 2:4 Awb, een bepaalde mate van onpartijdigheid en objectiviteit bij de besluitvorming in acht te nemen. Dit verbod van vooringenomenheid, dat gezien wordt als (de codificatie van) een algemeen beginsel van behoorlijk bestuur geldt ook voor de bestuurlijke voorprocedures. ${ }^{432}$ Bovendien kent de Awb bepalingen in hoofdstuk 7 die (een bepaalde mate van) de objectiviteit van de besluitvorming in bezwaar en administratief beroep moeten garanderen door in die procedures een element van onafhankelijkheid ten opzichte van het in primo beslissende bestuursorgaan in te brengen. Daarbij springt in het bijzonder de instelling van een (gedeeltelijk) externe adviescommissie in de zin van de artikelen 7:13 en 7:19 Awb in het oog. In de literatuur wordt vaak als doel van de instelling van een dergelijke commissie gezien de bevordering van de objectiviteit en onpartijdigheid van de besluitvorming. ${ }^{433}$ De instelling van een dergelijke commissie voegt een judicieel element aan de voorprocedure toe. ${ }^{434}$ Hoewel de instelling van een adviescommissie die aan de eisen van voornoemde artikelen voldoet niet verplicht is, wordt van de mogelijkheid om een dergelijke commissie in te stellen in de praktijk veelvuldig door lagere regelgevers gebruik gemaakt. ${ }^{435}$ Op grond van het eerste lid van artikel 7:13 Awb moet in elk geval de voorzitter van een dergelijke commissie in bezwaar onafhankelijk zijn, dat wil zeggen niet werkzaam zijn onder de verantwoordelijkheid van of deel uitmaken van het betreffende bestuursorgaan. Voor het administratief beroep geldt op grond van het tweede lid van artikel 7:19 Awb dat in de adviescommissie een of meer leden zitting moeten hebben die niet werkzaam zijn onder de verantwoordelijkheid van of deel uitmaken van het beroepsorgaan. Dat element van onafhankelijkheid dat door de instelling van een adviescommissie gebracht wordt in de behandeling van de bezwaar- en beroepschriften, vormt, zoals aangegeven, de basis voor meer objectiviteit of onpartijdigheid in de procedure. ${ }^{436}$ Daarin schuilt ook een belangrijk verschil met de primaire besluitvormingsfase. In beide fasen van de besluitvorming geldt het verbod van vooringenomenheid, zoals neergelegd in artikel 2:4 Awb, maar uitsluitend in de bestuurlijke voorprocedures bestaat de mogelijkheid een adviescommissie in te schakelen die aan een door de Awb voorgeschreven element van onafhankelijkheid, ter waarborging van de objectiviteit, voldoet. De wetgever heeft daartoe voor de bestuurlijke voorprocedures aanleiding gezien. Die aanleiding lijkt te schuilen in het rechtsbeschermingskarakter van de bestuurlijke voorprocedures en de omstandigheid dat sprake is van een geschil tussen de belanghebbenden en het bestuursorgaan in het kader waarvan het genomen besluit nogmaals tegen het licht wordt gehouden (door hetzelfde of een ander bestuursorgaan).

\footnotetext{
431. Sanders 1998, p. 106; Van der Ham 1988, p. 81

432. Op de vraag of het verbod van vooringenomenheid een afzonderlijk algemeen beginsel van behoorlijk bestuur vormt of onderdeel vormt van het zorgvuldigheidsbeginsel wordt in par. 5.4.3.2 nader ingegaan.

433. Verheij 1995, p. 140-141.

434. Zie bijv.: C.L.G.F.H. Albers, 'Commentaar artikel 7:13', in: M. Scheltema, R.M. van Male, B.W.N. de Waard, A.T. Marseille, A.J.C. de Moor-van Vugt (red.), Commentaar Algemene wet bestuursrecht, Amsterdam: Reed Elsevier (voorheen Den Haag: VUGA), losbladige uitgave, E 7:13-3; Koenraad \& Sanders 2006, p. 57; Sanders 2004, p. 34; Verslag Evaluatie Awb I, p. 44-45.

${ }^{435}$. Dat is met name in de bezwaarschriftprocedure het geval, Koenraad \& Sanders 2006, p. 53-54. Zij wijzen er tevens op dat met name bij ministeries en zelfstandige bestuursorganen nog vaak interne adviescommissies worden aangetroffen.

436. Verheij 1995, p. 94/95-140.
} 


\section{De inrichting van de voorprocedures}

De betekenis van onafhankelijkheid in de bezwaarschriftprocedure

Het begrip onafhankelijkheid heeft een iets andere - dat wil zeggen een beperkte - betekenis in het kader van bestuurlijke voorprocedures. Onafhankelijkheid moet worden opgevat als onafhankelijk van het bestuursorgaan als partij in de procedure en houdt in dat er geen hiërarchische of organisatorische band met het (in primo) beslissende bestuursorgaan mag bestaan. Sanders meent dat van onafhankelijkheid bij de behandeling van bezwaarschriften sprake is als de personen die de bezwaarschriften behandelen niet werkzaam zijn onder de verantwoordelijkheid van het bestuursorgaan noch deel uitmaken van het bestuursorgaan. Ter bepaling van de mate van onafhankelijkheid wordt derhalve een formeel criterium gehanteerd. ${ }^{47}$ Mij lijkt dat onafhankelijkheid in de bezwaarschriftprocedure inderdaad in die beperkte betekenis moet worden opgevat. Sanders onderscheidt in zijn onderzoek vervolgens drie gradaties van onafhankelijkheid: geen onafhankelijkheid (behandeling door ambtenaren of bestuurders of advisering door interne adviescommissie), grotendeels onafhankelijkheid (meerderheid behandelaars werkt niet voor of makt geen deel uit van het bestuursorgaan) en volledige onafhankelijkheid (bezwaarschriften worden behandeld door personen die niet werken voor of deel uitmaken van het bestuursorgaan). ${ }^{438}$ Aan deze gradaties zou nog een vierde gradatie kunnen worden toegevoegd: een minderheid van de behandelaars werkt niet voor of maakt geen deel uit van het bestuursorgaan. Dat laatste is namelijk het geval, indien alleen de voorzitter of een minderheid van de leden van een commissie onafhankelijk is.

Een ruime onafhankelijkheidseis, zoals die geldt voor de rechter, wordt niet gesteld aan het bestuur of de personen die betrokken zijn bij het besluit op bezwaar. Uitgangspunt is immers dat het bestuur de heroverweging verricht, omdat sprake is van verlengde besluitvorming. Het bestuur is niet verplicht om een bezwaaradviescommissie in te stellen en kan de bezwaarschriften zelf afhandelen of door ambtenaren die onder zijn verantwoordelijkheid vallen laten afhandelen. Ook kan het bestuur zich laten adviseren door een interne adviescommissie die bestaat uit ambtenaren of personen die werkzaam zijn voor dan wel onderdeel uitmaken van het bestuursorgaan. In dat geval is er geen sprake van onafhankelijkheid. Wel is in die gevallen vereist dat, indien het horen niet geschiedt door of mede door het bestuursorgaan (of leden daarvan) zelf, zulks dient plaats te vinden door een persoon of een meerderheid van personen (waaronder de voorzitter) die niet bij de primaire besluitvorming zijn betrokken op grond van artikel 7:5 Awb. Daaruit volgt echter slechts dat bepaalde ambtenaren, die niet betrokken zijn geweest bij de besluitvorming in primo maar wél werkzaam zijn bij het bestuur, het horen moeten verrichten. Die bepaling ziet derhalve niet op onafhankelijkheid in de bestuurlijke voorprocedure, maar vormt een andere eis om onpartijdigheid te waarborgen. Deze komt dan ook in de volgende paragraaf aan bod. Hetzelfde geldt voor de eis dat een ambtenaar die in mandaat het besluit in primo genomen heeft, niet nogmaals in mandaat het besluit op bezwaar kan nemen, ingevolge het derde lid van artikel 10:3 Awb. De conclusie moet zijn dat, indien het bestuursorgaan zelf het besluit in primo genomen heeft en zelf beslist om de bezwaarschriften af te handelen of door zijn ambtenaren te laten afhandelen, iedere vorm van onafhankelijkheid (in de hiervoor bedoelde beperkte betekenis, maar ook in de ruimere betekenis zoals deze voor de rechter geldt) ontbreekt. De grens van de onafhankelijkheid in de voorprocedures ligt in die gevallen bij het bestuurlijke karakter van die procedure en het primaat van het bestuursorgaan om te heroverwegen en een beslissing te nemen. In die gevallen is dan ook in sterkere mate sprake van verlengde besluitvorming en ligt minder nadruk op het bieden van rechtsbescherming.

\footnotetext{
437. Sanders 1998, p. 106.

438. Sanders 1998, p. 106.
} 


\section{Deel II Bestuurlijke voorprocedures}

De mate van onafhankelijkheid van de adviescommissie

Uitsluitend indien een adviescommissie wordt ingesteld, die voldoet aan de eisen in artikel 7:13 Awb, is een bepaalde mate van onafhankelijkheid gewaarborgd. Ook die mate van onafhankelijkheid is echter niet gelijk te stellen aan de onafhankelijkheid die geëist wordt van rechterlijke instanties. De onafhankelijkheid geldt op grond van het eerste lid van artikel 7:13 Awb slechts voor de voorzitter van de commissie. ${ }^{439}$ In sommige gevallen is de gehele commissie onafhankelijk en zijn de overige leden (tenminste twee) evenmin onderdeel van of werkzaam voor het bestuursorgaan, maar verplicht is dat niet. ${ }^{40}$ Is dat wel het geval dan wordt (in theorie althans) een zo hoog mogelijke objectiviteit bewerkstelligd. ${ }^{441}$ Koenraad \& Sanders merken, onder verwijzing naar een uitspraak van de $\mathrm{Rb}$. Leeuwarden, dan ook terecht op dat een onafhankelijke voorzitter nog niet betekent dat de besluitvorming zonder vooringenomenheid heeft plaatsgehad. ${ }^{442}$ De onafhankelijkheid van de (voorzitter van de) commissie wil immers niet zeggen dat er zonder vooringenomenheid is gehandeld. Dat laatste ziet op andere aspecten. Evenals het geval is bij de rechterlijke onafhankelijkheid vormt onafhankelijkheid één waarborg tegen onpartijdigheid, maar niet de enige waarborg en de vereiste onpartijdigheid kan, ondanks onafhankelijkheid, op andere gronden geschonden zijn. ${ }^{443}$ Onafhankelijkheid van de adviescommissie sluit bijvoorbeeld eerdere betrokkenheid van de leden van de commissie bij de besluitvorming (in een andere hoedanigheid) of relationele banden met (een van de) belanghebbenden en daarmee partijdigheid niet uit. Een niet onafhankelijke commissie, die deels werkzaam is voor of bij het bestuursorgaan, impliceert ook niet per definitie partijdigheid (in de zin van partijdigheid zoals opgevat voor bestuurlijke voorprocedures). De Awb sluit immers de mogelijkheid dat een (geheel) interne adviescommissie adviseert of ambtenaren de bezwaarschriften afhandelen niet uit. Die omstandigheid levert ook niet per definitie strijd met het verbod van vooringenomenheid op, zoals vervat in artikel 2:4 Awb. Hierop kom ik in paragraaf 5.4.3 nog nader terug. Artikel 7:13 lid 1 sub c biedt nog de mogelijkheid om bij wettelijk voorschrift nadere eisen aan de commissie te stellen. ${ }^{444}$ Omdat een adviescommissie (die een orgaan adviseert dat een bestuursorgaan is) zelf ook een bestuursorgaan is in de zin van artikel 1:1 lid 1 sub a Awb, behoort deze overigens ook aan alle eisen te voldoen die gesteld worden aan bestuursorganen, waaronder artikel 2:4 Awb. ${ }^{445}$ Het horen door de commissie dient voorts altijd plaats te vinden door de onafhankelijke voorzitter of een onafhankelijk lid van de commissie, ingevolge het tweede lid van artikel 7:13 Awb.

\footnotetext{
439. AbRvS 31 mei 1999, JB 1999/155 waaruit ook blijkt dat de overige leden van de commissie werkzaam mogen zijn voor of bij het bestuursorgaan.

${ }^{440}$. In dat geval is er sprake van een echt externe commissie. In de literatuur is het gangbaar om alle varianten van adviescommissies die voldoen aan de in art. 7:13 Awb gestelde eisen echter extern te noemen en te plaatsen tegenover een interne adviescommissie die is ingesteld door het bestuursorgaan waarvan de voorzitter of leden banden hebben met het bestuursorgaan of werkzaam zijn bij het bestuursorgaan. Ik gebruik de benaming externe commissie eveneens voor alle adviescommissies die voldoen aan de eisen uit art. 7:13 Awb, hoewel niet al deze commissies derhalve geheel uit externe leden (behoeven te) bestaan.

${ }^{441}$ Gebleken is echter dat aan een geheel externe commissie ook nadelen kleven wat betreft het karakter van de bestuurlijke heroverweging aangezien deze commissies de neiging vertonen om zich te concentreren op de rechtmatigheidsaspecten in de beoordeling en de adviezen van bezwaaradviescommissies veelal door bestuursorganen worden gevolgd, zie: Koenraad \& Sanders 2006, p. 54. Zie hierover par. 4.3.1.1.

${ }^{442 .}$ Koenraad \& Sanders 2006, p. 56. Uit de uitspraak blijkt dat de rechtbank, ondanks de onafhankelijkheid van de voorzitter van de adviescommissie, art. 2:4 Awb geschonden acht, Rb. Leeuwarden 8 februari 1996, JB 1996/100 m.nt. Heldeweg). Als voormalig lid van het bestuursorgaan was er een te grote betrokkenheid bij de totstandkoming van het primaire besluit. Zie verder nog: CRvB 15 januari 2004, JB 2004/107 m.nt. A.M.M.M. Bots waaruit ook blijkt dat art. 2:4 Awb naast art. 7:13 Awb van betekenis blijft (hoewel die bepaling in dat geval niet geschonden werd geacht). Zie hierover nader nog par. 5.4.3.

443. Zie hierover voor de rechterlijke onafhankelijkheid en onpartijdigheid Deel I, par. 4.3.3 en 4.3.4.

444. Als voorbeeld wordt wel de eis van een specifieke deskundigheid genoemd, Koenraad \& Sanders 2006, p. 56; Sanders 2004, p. 35.

445. AbRvS 19 maart 2003, $A B$ 2003/301 m.nt. Hans Peters; AbRvS 6 augustus 2003, $A B$ 2004/140 m.nt. J.A.F. Peters.
} 


\section{De inrichting van de voorprocedures}

Beperkte onafhankelijkheid in bezwaar

De onafhankelijkheid in bezwaar is in het geval van instelling van een adviescommissie beperkt (in vergelijking tot de vereiste rechterlijke onafhankelijkheid), omdat uitsluitend geëist wordt dat een deel van de betrokken personen niet werkzaam is onder de verantwoordelijkheid van of deel uitmaken van het bestuur. Bovendien geeft de Awb geen rechtspositionele waarborgen voor de leden van de commissie. Veelal zal wel in een verordening worden vastgelegd dat en wanneer een adviescommissie ingeschakeld moet worden. ${ }^{446}$ Daarin kan tevens de benoeming en het ontslag van de leden van de commissie geregeld worden, maar dat kan ook geschieden bij besluit van het bestuursorgaan wiens besluit in de bezwaarschriftprocedure centraal staat en waarover de commissie advies moet uitbrengen. De benoemingstermijn kan verschillen evenals de redenen voor ontslag of schorsing. Die onderwerpen zijn ter regeling overgelaten aan de bijzondere regelgever. ${ }^{447}$ De rechtspositionele onafhankelijkheid van de leden van de commissie ten opzichte van het beslissende bestuursorgaan waaraan de commissie moet adviseren, kan derhalve, afhankelijk van de betreffende regeling, in sommige gevallen maar ten dele gerealiseerd zijn. Het komt weleens voor dat een (of meer leden van) bezwaaradviescommissie door het bestuursorgaan ontslagen (of geschorst) wordt. ${ }^{448}$ Enige terughoudendheid bij het gebruik van de ontslagbevoegdheid (of schorsingsbevoegdheid) - die vaak een discretionair karakter zal hebben - is, juist vanwege de onafhankelijkheid van de commissie, op zijn plaats. ${ }^{449}$ Ten tweede moet voor ogen worden gehouden dat de adviescommissie slechts een adviserende rol heeft en de beslissingsbevoegdheid uiteindelijk bij het niet onafhankelijke bestuursorgaan berust. Die omstandigheid doet eveneens afbreuk aan de te bewerkstelligen onafhankelijkheid in de bezwaarschriftprocedure. Daar komt bij dat het bestuursorgaan de adviescommissie inschakelt en de omvang van de adviestaak bepaalt. Zoals Bots opmerkt verkeert de adviescommissie in een afhankelijke vertrouwensrelatie ten opzichte van het bestuursorgaan dat opdracht geeft tot het advies en tevens partij is bij het geschil. ${ }^{450}$ Koenraad \& Sanders wijzen er tot slot nog op dat de ondersteuning van de commissie door een secretaris, die veelal als ambtenaar werkzaam is bij het bestuursorgaan, afbreuk kan doen aan de onafhankelijkheid (en daarmee aan de onpartijdigheid) van de commissie, indien de secretaris niet loyaal is aan de commissie of onder druk wordt gezet door het bestuursorgaan. ${ }^{451}$

Objectiviteit en legitimatie bij inschakeling externe commissie

In het licht van de objectiviteit van de heroverweging en de onpartijdigheid van het bestuur, zou het de voorkeur verdienen om een geheel externe adviescommissie in te stellen. Voorts zouden bepalingen die de rechtspositie van de leden van de commissie betreffen, zoals de aanstelling en het ontslag, bij voorkeur geregeld moeten worden in een algemeen verbindend voorschrift dat voor zover mogelijk afkomstig is van een ander (daartoe bevoegd) bestuursorgaan dan het bestuursorgaan dat de primaire beslissing genomen heeft en waaraan de commissie moet adviseren. De waarborgen moet zodanig

\footnotetext{
${ }^{446 .}$ Dat was het geval in AbRvS 22 juli 2009, JB 2009/213 m.nt. A.M.M.M. Bots. Zie hierover ook: Koenraad \& Sanders 2006, p. 55.

${ }^{447 .}$ De Awb bevat geen voorschriften in dat kader.

448. Zie: AbRvS 22 juli 2009, JB 2009/213 m.nt. A.M.M.M. Bots. In deze zaak was sprake van een vertrouwensbreuk en derhalve terecht ontslag, omdat de commissie tegen de uitdrukkelijk te kennen gegeven wens van het college van $\mathrm{b}$ en $\mathrm{w}$ om geen bemiddelingspoging met de bezwaarmaker te ondernemen toch een lid van gedeputeerde staten had benaderd om een bemiddelingspoging te ondernemen.

449. Zie ook de noot van Bots bij AbRvS 22 juli 2009, JB 2009/213 waarin zij ingaat op de overwegingen van de rechtbank terzake.

${ }^{450}$ Zie de noot van Bots bij AbRvS 22 juli 2009, JB 2009/213.

${ }^{451 .}$ Koenraad \& Sanders 2006, p. 55. De secretaris is immers, nu deze veelal zorg draagt voor de correspondentie en het opstellen van een concept-advies e.d., om invloed uit te oefenen op het advies van de commissie. De bestuursrechter heeft ook meermalen overwogen dat de secretaris van de commissie, veelal een ambtenaar werkzaam voor het bestuursorgaan, in die hoedanigheid onafhankelijk is en niet valt onder de verantwoordelijkheid van het bestuursorgaan, zie bijvoorbeeld: AbRvS 19 maart 2003, AB 2003/301 m.nt. J.A.F. Peters.
} 


\section{Deel II Bestuurlijke voorprocedures}

zijn vormgegeven dat niet lichtvaardig tot ontslag of schorsing overgegaan kan worden. In dat geval is de (mogelijk) te bewerkstelligen objectiviteit gemaximaliseerd.

Daar staat echter tegenover dat de instelling van dergelijke commissies, wier adviezen veelal worden gevolgd, afbreuk kan doen aan het karakter van de bestuurlijke heroverweging. Beleidsoverwegingen spelen vaak een ondergeschikte rol in de beoordeling van deze commissies. ${ }^{452}$ De leden van de commissie ontberen immers, zoals in paragraaf 4.3.1.1 aan de orde is gekomen, de democratische legitimatie om het beleid of de toepassing van het beleid door het bestuursorgaan te beoordelen. Het instellen van een geheel externe commissie kan - en in de praktijk blijkt dat ook zo te zijn - derhalve ten koste gaan van de omvang van de heroverweging en het (verlengde) besluitvormingskarakter van de bestuurlijke voorprocedure. ${ }^{453}$

De keuze voor een geheel of ten dele externe commissie vindt dan ook haar grondslag in de functie die men wilt laten domineren in de bezwaarschriftprocedure: bescherming van de belangen van de betrokken burgers in de procedure of de verlengde besluitvorming door middel van bestuurlijke heroverweging. Indien het gebrek aan legitimatie van de adviescommissie als problematisch wordt gezien, zou ervoor gekozen kunnen worden een dergelijke commissie uitsluitend in te stellen bij overwegend gebonden bevoegdheden waardoor de advisering noodzakelijkerwijs zich beperkt tot rechtmatigheidsaspecten. In de praktijk blijkt echter juist in veel gevallen waarin het bestuur over een meer discretionaire bevoegdheid beschikt, een adviescommissie te zijn ingesteld. ${ }^{454}$ Indien het bestuursorgaan zich er terdege van bewust is dat ook ten aanzien van beleidsaspecten een heroverweging behoort plaats te vinden en het in zoverre niet blind vaart op het advies van de adviescommissie, wordt de neiging tot rechtmatigheidstoetsing (en/of het gebrek aan legitimatie) enigszins ondervangen en behoeft er geen bezwaar te bestaan tegen de instelling van een (geheel) onafhankelijke commissie. ${ }^{455}$ Wel ontstaat dan de vraag waarin de toegevoegde waarde van de instelling van een onafhankelijke commissie is gelegen, indien het bestuursorgaan niet of slechts deels op het advies mag afgaan. In het geval van beleidsvrije bevoegdheden zou daarom een niet geheel onafhankelijke commissie, waarin naast de onafhankelijke voorzitter nog twee leden plaatsnemen die politieke banden met het bestuursorgaan hebben of werkzaam zijn voor of onderdeel uitmaken van het bestuursorgaan, wellicht meer in de rede liggen. ${ }^{456}$ Dat heeft echter tot gevolg dat in die gevallen enigszins aan distantie en objectiviteit (in theorie) wordt ingeboet. Omdat het bestuurlijke karakter in het geval van een discretionaire bevoegdheid meer aanwezig is en het verschil met de rechterlijke werkzaamheid ook groter is, is het echter verdedigbaar dat in die gevallen de inrichting van de procedure, wat betreft onpartijdigheid of objectiviteit, ook in mindere mate gelijkenis met rechtspraak vertoont. De bestuurlijke en rechterlijke werkzaamheid vertoont de meeste overeenkomsten, zoals aangegeven in paragraaf 4.3.1.1, indien het bestuur beschikt over een (meer) gebonden bevoegdheid (of een discretionaire bevoegdheid waarvan de uitoefening door beleidsregels is gebonden). In dat geval is de instelling van een geheel onafhankelijke adviescommissie, die zich beperkt tot de beoordeling van rechtmatigheidsaspecten, niet problematisch. ${ }^{457}$

452. Zie par. 4.3.1.1 van dit deel hierover.

${ }^{453 .}$ L.M. Koenraad en G.A.L. van Schijndel, 'Raadsleden en bezwaar. Enige beschouwingen over

de voor- en nadelen van de aanwezigheid van raadsleden in commissies die zijn belast met advisering over de afhandeling van bezwaren', Gst. 2005, 7226, p. 157 e.v.

454. Zie par. 4.3.1.1 van dit deel.

455. Zie ook Koenraad \& Sanders die opmerken dat het bestuursorgaan, indien in het advies een rechtmatigheidstoetsing overheerst, zelf aanvullend de beleidsaspecten zal moeten beoordelen, Koenraad \& Sanders 2006, p. 54 .

${ }^{456 .}$ Hierover ook: Koenraad \& Van Schijndel 2005, p. 157 e.v. Tegelijkertijd, zo geven zij aan, ligt de betrokkenheid van raadsleden juist dan gevoelig vanwege de mogelijke beleidsmatige keuzes. Zij spreken zich uiteindelijk uit voor een externe adviescommissie, p. 6-7.

457. Een andere mogelijkheid zou zijn om de primaire besluitvorming in het geval van discretionaire bevoegdheden, door de toepassing van de uniforme voorbereidingsprocedure, met meer waarborgen te omkleden. Dan 


\title{
De inrichting van de voorprocedures
}

\begin{abstract}
Onafhankelijkheid in administratief beroep
In het administratief beroep is eveneens geen sprake van onafhankelijkheid in de betekenis die daaraan toekomt voor rechterlijke instanties. Het beoordelende orgaan maakt immers ook in deze voorprocedure deel uit van de uitvoerende macht. Toch wordt tussen administratief beroep en beroep bij de rechter doorgaans eerder gelijkenis aangenomen dan in het geval van de bezwaarschriftprocedure, omdat sprake zou zijn van meer objectiviteit en afstand in de beoordeling. ${ }^{458}$ Reden daarvoor is dat, hoewel er geen van het bestuur als uitvoerende macht onafhankelijk orgaan het geschil beslecht, de beoordeling wel plaatsvindt door een ander orgaan dan het oorspronkelijke bestuursorgaan dat het besluit genomen heeft. Er bestaat derhalve onafhankelijkheid, in hierboven bedoelde zin, van het bestuursorgaan dat het primaire besluit genomen heeft en partij is in de procedure. Het beroepsorgaan of beter gezegd diens leden zijn niet werkzaam onder verantwoordelijkheid van en maken geen deel uit van het primair beslissende bestuursorgaan. De onafhankelijkheid is nog sterker aanwezig, indien het beroepsorgaan geen onderdeel uitmaakt van hetzelfde openbare lichaam als het bestuursorgaan dat het besluit genomen heeft. ${ }^{459}$ In de gevallen waarin dat niet zo is, kunnen er immers (politieke) banden tussen het beroepsorgaan en het beslissende bestuursorgaan bestaan. Te denken valt aan de situatie waarin administratief beroep op de gemeenteraad openstaat tegen een besluit van burgemeester en wethouders. ${ }^{460}$
\end{abstract}

De mate van onafhankelijkheid van de adviescommissie in administratief beroep

Naast deze factor, die een sterkere mate van onafhankelijkheid schept dan in de bezwaarschriftprocedure het geval is, bestaat er nog een factor die een aanvullend element van onafhankelijkheid in het administratief beroep kan bewerkstelligen. Bij of krachtens de wet kan in administratief beroep het horen eveneens worden opgedragen aan een deels onafhankelijke adviescommissie, ingevolge het eerste lid van artikel 7:19 Awb. De instelling van een adviescommissie is niet verplicht, maar is dat geschied, dan bestaat die commissie op grond van het tweede lid uit een of meer leden die geen deel uitmaken of niet werkzaam zijn onder de verantwoordelijkheid van het beroepsorgaan. Dat betekent dat een (in de zin van voornoemde bepaling ingestelde) adviescommissie in administratief beroep altijd één extern lid heeft, maar ook in zijn geheel extern kan zijn. Dat externe lid van de commissie behoeft niet de voorzitter te zijn. Artikel 7:19 Awb schrijft uitsluitend voor dat tenminste één lid onafhankelijk moet zijn. Wellicht ten overvloede merk ik hierbij op dat het ook in de rede ligt dat de leden van de adviescommissie geen banden hebben met het bestuursorgaan dat het bestreden besluit genomen heeft. Dat wil zeggen dat zij niet werkzaam mogen zijn bij of deel uit mogen maken van het primair beslissende bestuursorgaan. Mij is niet bekend of uit onderzoek gebleken is dat adviescommissies zich in administratief beroep, evenals in bezwaar, vooral beperken tot de juridische aspecten in de beoordeling van het voorliggende besluit en beroep. Voorstelbaar is dat zulks het geval is te meer omdat administratief beroepsorganen, vanwege de decentralisatiegedachte, zelf al terughoudend zijn te treden in de beleidsoverwegingen van het primair beslissende bestuursorgaan (zeker indien het beroepsorgaan behoort tot een

behoeft ook geen bezwaarschriftprocedure meer te worden doorlopen. Of dat inwisselbaar is met de instelling van een adviescommissie en voldoende compensatie biedt voor de voordelen daarvan is echter de vraag. ${ }^{458 .}$ Schueler e.a. 2007, p. 29.

459. Zie par. 4.3.1.1 van dit deel. Te denken valt aan de situatie dat administratief beroep openstaat op Gedeputeerde Staten tegen een besluit van een college van burgemeester en wethouders of een gemeenteraad. Rongen noemt daarvan enkele voorbeelden, zie: Rongen 2007, p. 115.

460. Thans is het immers zo dat (namens de coalitiefracties) de gemeenteraad wethouders benoemt (art. 35 lid 1 Gemeentewet) en de gemeenteraad aan de minister van Binnenlandse Zaken een aanbeveling doet van in beginsel twee kandidaten voor het burgemeesterschap (zie art. 61 Gemeentewet voor de procedure). Versteden wijst er ook nog op dat bij administratief beroep op de gemeenteraad tegen besluiten van het college van B en W de voorbereiding van de besluitvorming veelal door $\mathrm{b}$ en $\mathrm{w}$ plaatsvindt, hetgeen een schending van equality of arms oplevert, Versteden 1990, p. 131 e.v. 
Deel II Bestuurlijke voorprocedures

ander openbaar lichaam). ${ }^{461}$ De toelichting op artikel 7:19 Awb wijst er ook op dat het belang van het administratief beroep schuilt in de omstandigheid dat een hoger bestuursorgaan de zaak beoordeelt. Dit voordeel zou voor een groot deel verdwijnen, indien een geheel of gedeeltelijk externe commissie hoort en de voorbereiding van die beslissing grotendeels door de adviescommissie plaatsvindt. Om die reden is het vereiste opgenomen dat de wet daarin rechtstreeks of via delegatie behoort te voorzien. ${ }^{462}$ In dit opzicht is derhalve het toezichtkarakter van het administratief beroep ook een factor van belang die lijnrecht tegenover de (gewenste) mate van onafhankelijkheid van de adviescommissie en de procedure staat in de afweging of instelling van een dergelijke commissie gewenst is.

Voor de aanstelling en het ontslag van de leden van de adviescommissie geldt hetzelfde als hiervoor betoogd is over de leden van de adviescommissie in bezwaar. Belangrijk verschil is wel dat de adviescommissie in elk geval niet adviseert aan het bestuursorgaan dat het bestreden besluit genomen heeft, maar aan het beroepsorgaan, waardoor er wellicht minder noodzaak bestaat (vanuit onafhankelijkheidsoogpunt) de aanstelling en ontslag van de commissieleden wettelijk te regelen.

Verdubbelde onafhankelijkheid in administratief beroep

In vergelijking tot de bezwaarschriftprocedure is de onafhankelijkheid van de adviescommissie van het orgaan dat de beslissing in de procedure moet nemen, als waarborg voor objectieve besluitvorming, derhalve minder ver doorgevoerd. De wet vereist niet dat de voorzitter extern is, maar uitsluitend dat een of meer leden van de commissie dat zijn. Dat hangt samen met het karakter van die procedure en de omstandigheid dat een ander (hoger) bestuursorgaan de herbeoordeling van het besluit verricht. De adviescommissie staat echter, gelet daarop, al in een verder verwijderd verband van het in primo beslissende bestuursorgaan. In totaliteit bezien is er derhalve sprake van een ruimere onafhankelijkheid in administratief beroep in vergelijking tot de bezwaarschriftprocedure, omdat bovenop de (al aanwezige) hogere mate van onafhankelijkheid van het beroepsorgaan zelf (ten opzichte van het in primo beslissende bestuursorgaan), ook nog eens een deels of geheel externe adviescommissie kan worden ingesteld die geen (of beperkte) banden heeft met het beroepsorgaan. Ook in administratief beroep is uiteindelijk echter ook sprake van een beperkte mate van onafhankelijkheid die niet gelijk gesteld kan worden met de van de rechter geëiste onafhankelijkheid. De meest vergaande mate van onafhankelijkheid kan worden bereikt door een geheel externe adviescommissie in te stellen (indien en voor zover de wet dat mogelijk maakt). Daar staat echter tegenover dat zulks voor een groot deel afbreuk doet aan het doel van het openstellen van administratief beroep: een (tevens beleidsmatige) beoordeling door een hoger beroepsorgaan. Indien evenwel een gedeeltelijk externe adviescommissie wenselijk wordt geacht vanwege de onafhankelijkheid en objectiviteit van de besluitvorming als ook equality of arms (waarop ik ben ingegaan in paragraaf 5.3.5), kan een evenwicht tussen deze belangen bereikt worden door een lid van het beroepsorgaan (of een ambtenaar werkzaam bij of onder de verantwoordelijkheid van dat orgaan) deel te laten nemen in de adviescommissie. ${ }^{463}$ Naargelang als functie van het administratief beroep (in overwegende mate) de rechtsbeschermingsfunctie of de toezichtfunctie wordt gezien, wordt echter de instelling van een adviescommissie en het externe karakter daarvan wenselijk of juist niet wenselijk geacht.

${ }^{461 .}$ Zie hierover par. 4.3.1.1 van dit deel.

462. PG Awb I, p. 358-359.

463. Vgl. Versteden 1990, p. 136. 


\section{De inrichting van de voorprocedures}

De gevolgen van schendingen van de artikelen 7:13 en 7:19 Awb

In tegenstelling tot de indruk die wellicht op grond van het bovenstaande is ontstaan, is de instelling van een adviescommissie, die aan de vereisten zoals neergelegd in de artikelen 7:13 en 7:19 Awb voldoet, niet verplicht. Dat betekent ook dat, indien het bestuursorgaan een adviescommissie inschakelt, in bezwaar de voorzitter ervan niet onafhankelijk behoeft te zijn. De instelling van een interne adviescommissie levert geen strijd op met voornoemde bepalingen en heeft rechtens geen consequenties. Wordt echter voorzien in een adviescommissie met een onafhankelijke voorzitter en twee andere leden of een of meer onafhankelijke leden, dan gelden de in artikel 7:13 Awb neergelegde eisen. De eisen in de Awb hebben echter geen betrekking op de onafhankelijkheid van de adviescommissie. Een zekere mate van onafhankelijkheid is uitsluitend vereist voor de toepasselijkheid van de overige en andersoortige eisen, die voortvloeien uit die bepalingen. Schending van die eisen leidt tot vernietiging van het besluit op bezwaar of tot toepassing van artikel 6:22 Awb. ${ }^{464}$ Vanwege de formulering van artikel 7:13, eerste lid, Awb leidt gebrek aan onafhankelijkheid van de adviescommissie derhalve niet tot een vernietiging van het besluit op bezwaar, maar uitsluitend tot niet-toepasselijkheid van artikel 7:13 Awb. Voor administratief beroep geldt dat het beroepsorgaan zelf hoort en alleen een deels externe adviescommissie mag inschakelen, voor zover de wet daartoe de mogelijkheid biedt. Het beroepsorgaan kan het horen opdragen aan een interne commissie of een medewerker. Dat is geoorloofd en levert geen schending op van artikel 7:19 Awb (maar wellicht een bijzondere wettelijke regeling).

\section{Conclusies}

Het vereiste van onafhankelijkheid heeft voor bestuurlijke voorprocedures een beperkte en andere betekenis dan voor de rechter. De onafhankelijkheid die van de rechter geëist wordt, kan nimmer voor het bestuur gelden, voor zover deze bestaat uit onafhankelijkheid van de beide andere staatsmachten, wetgever en uitvoerende macht. Dat is per definitie onmogelijk. De externe of democratische functie die onafhankelijkheid heeft voor rechterlijke instanties, is niet aanwezig en minder noodzakelijk voor de bestuurlijke voorprocedures. Een bepaalde mate van onafhankelijkheid van het bestuursorgaan als partij in de bestuurlijke voorprocedure, in de zin dat personen die bij de procedure betrokken zijn niet werkzaam zijn onder de verantwoordelijkheid van of deel uitmaken van het bestuursorgaan, is in beide voorprocedures echter voorzien. Indien ten behoeve van de beslissing op bezwaar een adviescommissie is ingesteld, dan behoort de voorzitter daarvan onafhankelijk te zijn van het bestuursorgaan. Het doel van die onafhankelijkheideisen in bezwaar is het garanderen van een bepaalde mate van objectiviteit in de besluitvorming. Onafhankelijkheid is derhalve uitsluitend als waarborg voor onpartijdigheid van enige betekenis in de bezwaarschriftprocedure. Die interne werking van de onafhankelijkheideisen, via de band van de onpartijdigheid, kan deels ook in de bezwaarschriftprocedure gerealiseerd worden. Datzelfde geldt voor onafhankelijkheid in administratief beroep. Ofschoon er geen sprake is van onafhankelijkheid van de uitvoerende macht in zijn geheel, functioneert het beroepsorgaan onafhankelijk van het betreffende bestuursorgaan dat partij is in de procedure; dat geldt te meer indien het beroepsorgaan tot een ander openbaar lichaam behoort dan het primair beslissende bestuursorgaan. Daarenboven kan, voor zover daarvoor een wettelijke grondslag bestaat, ook nog een gedeeltelijk of geheel externe adviescommissie worden ingesteld die de mate van onafhankelijkheid verruimt. De vereiste onafhankelijkheid in administratief beroep kan derhalve verdergaan dan die in de bezwaarschriftprocedure.

In beide gevallen zijn derhalve waarborgen voor onafhankelijkheid aanwezig, maar gaan deze op in of hangen deze samen met het onpartijdigheidsbeginsel en de vereisten

\footnotetext{
464. Zie voor een vernietiging bijvoorbeeld: CRvB 1 augustus 2005, $A B$ 2005/421 m.nt. HBr bij $A B$ 2005/422.
} Voorbeeld van het passeren van een schending: CBb 29 februari 2000, $A B$ 2000/206 m.nt. JHvdV. 


\section{Deel II Bestuurlijke voorprocedures}

die daaruit voortvloeien voor de inrichting van de procedure. De onafhankelijkheidseisen in de bestuurlijke voorprocedures staan derhalve ten dienste van de onpartijdigheidseisen. Daarmee hebben deze eisen geen externe werking en is de democratische functie, die deze eisen primair voor rechtspraak hebben, voor de bezwaarschriftprocedure en het administratief beroep te verwaarlozen. Omdat de onafhankelijkheidseisen in de bestuurlijke voorprocedures primair een andere functie hebben als de onafhankelijkheidseisen voor rechterlijke instanties, is er in dat opzicht ook geen sprake van doorwerking van die laatste eisen in bestuurlijke voorprocedures. Dat zou uitsluitend mogelijk zijn voor zover deze eisen beogen onpartijdigheid te waarborgen en interne werking hebben. De instelling van een (gedeeltelijk) onafhankelijke adviescommissie wordt in het algemeen ook gezien als een element waarmee gelijkenis met de procedure voor de rechter, en een daarmee gepaard gaande hogere mate van objectiviteit, te bewerkstelligen. In deze zin werken de onafhankelijkheidseisen derhalve door in de bestuurlijke voorprocedures. De instelling van een (gedeeltelijk) onafhankelijke adviescommissie is echter niet verplicht. Is dat niet geschied, dan kan voor die gevallen ook niet gesproken worden van doorwerking van de rechterlijke onafhankelijkheidseisen in de bestuurlijke voorprocedures. Het onderzoek spitst zich in het onderstaande verder toe op de onpartijdigheid waarbij voor zover nog van belang de onafhankelijkheideisen in dat kader aan bod komen.

\subsubsection{Onpartijdigheid in de bestuurlijke voorprocedures}

\subsubsection{Inleiding}

\section{Bestuurlijke onpartijdigheid}

Niet alleen van rechterlijke instanties wordt geëist dat zij onpartijdigheid betrachten bij het doen van uitspraken in bestuursrechtelijke geschillen. Een vergelijkbare eis van onpartijdigheid wordt ook, thans op grond van de Awb, gesteld aan het bestuur in bestuursrechtelijke rechtsverhoudingen. ${ }^{465}$ De wetgever heeft in de Awb voor het eerst in algemene zin vastgelegd dat het optreden van het bestuur in alle fasen van de besluitvorming op objectieve wijze dient te geschieden. ${ }^{466}$ Daartoe is in artikel 2:4, eerste lid, van de Awb neergelegd dat een bestuursorgaan zijn taak zonder vooringenomenheid dient te vervullen. ${ }^{467}$ In het tweede lid van artikel 2:4 van de Awb is neergelegd dat het bestuursorgaan ertegen dient te waken dat tot het bestuursorganen behorende of daarvoor werkzame personen, die een persoonlijk belang bij een besluit hebben, de besluitvorming beïnvloeden. Het tweede lid vormt, aldus de wetgever, een concretisering van het in het eerste lid gegeven algemene verbod van vooringenomenheid 'voor de situatie waarin personen die in een positie verkeren dat zij invloed kunnen uitoefenen op de besluitvorming (als bestuurder of als voor het bestuur werkzame ambtenaar) tevens een persoonlijk belang hebben bij een bepaald besluit'. ${ }^{468}$ Het eerste lid betreft derhalve het handelen van het bestuursorgaan in het algemeen, terwijl in het tweede lid een uitwerking plaatsvindt

\footnotetext{
465. Omdat dit beginsel ook van toepassing is op de wetgevende en rechterlijke functie van de overheid schaart Nicolaï het onpartijdigheidbeginsel onder de algemene rechtsbeginselen, Nicolaï 1990, p. 443.

466. PG Awb I, p. 179

467. Alhoewel discussie mogelijk is over de vraag of onder onpartijdigheid hetzelfde moet worden verstaan als onder handelen zonder vooringenomenheid, wordt daarvan in het navolgende uitgegaan en worden deze begrippen als uitwisselbaar beschouwd. In beide gevallen wordt immers beoogd aan te geven dat de besluitvorming door het bestuur op objectieve wijze dient te geschieden. Daarmee wordt niet bedoeld aan te geven dat van het bestuur dezelfde mate van onpartijdigheid wordt geëist als van de rechter. Gebruik van die term duidt enkel op de omstandigheid dat het bestuur objectief dient te besluiten maar zegt niets over de mate waarin dat dient te geschieden of over welke eisen gesteld worden in dat kader. Dat laatste is immers juist onderwerp van onderzoek in de nog volgende paragrafen.

468. PG Awb I, p. 179-180.
} 


\section{De inrichting van de voorprocedures}

voor een kring van personen. ${ }^{469}$ Uit de toelichting op het eerste lid blijkt dat de wetgever met die bepaling een verbod voor het bestuursorgaan om de hem toevertrouwde belangen niet oneigenlijk te behartigen, door zich bijvoorbeeld te laten leiden door persoonlijke belangen of voorkeuren, voor ogen heeft gehad. Benadrukt wordt echter dat het bestuursorganen vrij staat om vanuit bepaalde beleidskeuzes te werken omdat het voeren van beleid inherent is aan goed bestuur. ${ }^{470}$ Persoonlijke belangen in de zin van het tweede lid zijn alle belangen die niet behoren tot het (aspect van het) algemeen belang dat het bestuursorgaan uit hoofde van de hem opgedragen taak behoort te behartigen. ${ }^{471}$ Aangenomen wordt dat, hoewel in het tweede lid een zorgplicht voor het bestuursorgaan is neergelegd, die zou kunnen duiden op een inspanningsverplichting, er sprake is van een resultaatsverplichting. Het treffen van maatregelen is in deze zin niet voldoende, indien er ondanks die maatregelen sprake is van vooringenomenheid. ${ }^{472}$ Het tweede lid van artikel 2:4 Awb biedt de burger, volgens de bestuursrechter, een waarborg voor de naleving van de in het eerste lid neergelegde norm. ${ }^{473}$

Dat het bestuursorgaan zich bij de besluitvorming objectief dient op te stellen, is, hoewel geen algemeen voorgeschreven eis in dat kader aanwezig was, een uitgangspunt dat ook in de doctrine en jurisprudentie daterend van voor de Awb terug te vinden is. ${ }^{474}$ Voor de inwerkingtreding van de Awb was dit uitgangspunt echter slechts in enkele bepalingen van bijzondere wetten terug te vinden. ${ }^{475}$ De verschillende bestuursrechtelijke colleges hebben in hun jurisprudentie in de periode voorafgaande aan de Awb regelmatig tot uitdrukking gebracht dat het bestuur bij zijn taakuitoefening onpartijdig dient te zijn. ${ }^{476}$ Het uitgangspunt zoals neergelegd in artikel 2:4, eerste lid, van de Awb is, zoals Verheij aangeeft, dan ook niet nieuw. ${ }^{477}$

In artikel 2:4 Awb is een algemene regel gegeven voor de door bestuursorganen in acht te nemen onpartijdigheid. Het toepassingsbereik van artikel 2:4 van de Awb is derhalve niet beperkt tot de primaire besluitvormingsfase, maar geldt tevens voor het optreden van het bestuursorgaan in onder meer de bezwaarfase. ${ }^{478}$ Dat volgt ook uit de plaatsing van dit verbod in het tweede hoofdstuk van de Awb. Het verbod van vooringenomenheid heeft daarmee een ruim toepassingsbereik en strekt zich uit over alle verkeer tussen bestuur en burger. Daaronder vallen ook de bestuurlijke voorprocedures. ${ }^{479}$ Naast artikel 2:4 Awb bevat hoofdstuk 7 van de Awb, zoals hierboven al is aangestipt, nog specifieke bepalingen die de objectiviteit van de besluitvorming in de bezwaarfase beogen te waarborgen.

\footnotetext{
469. A.L.M. Jansen \& J.A.F. Peters, 'Commentaar op art. 2:4 Awb', in: M. Scheltema, R.M. van Male, B.W.N. de Waard, A.T. Marseille, A.J.C. de Moor-van Vugt (red.), Commentaar Algemene wet bestuursrecht, Amsterdam: Reed Elsevier (voorheen Den Haag: VUGA), losbladige uitgave, E 2.1.4-4.

470. PG Awb I, p. 179

471. PG Awb I, p. 178-180. Zie over het begrip persoonlijk belang: Jansen \& Peters, E 2.1.4- p. 23 e.v.; Neerhof 2004, p. 41;Versteden 2002, p. 552; A.R. Neerhof, 'De beperkte actieradius van art. 2:4 lid 1 Awb', JB 1998, p. 119.

473. AbRvS 25 april 2007, $J B$ 2007/123 m.nt. LJMT; AbRvS 7 augustus 2002, $A B$ 2003/3 m.nt. A.R. Neerhof; $J B$ $2002 / 280$.

${ }^{474 . ~ N i c o l a i ~} 1990$, p. $442-444$ en de daar genoemde verwijzingen. Zie voor een voorbeeld in de jurisprudentie: ArRvS 16 juni 1983, $A B$ 1983/486 m.nt. JHvdV.

475. Zie voor een weergave en verwijzingen: Nicolaï 1990, p. 442-444; Notten 1998, p. 121 e.v.

476. Zie de noot hiervoor.

477. Verheij 1995, p. 141.

478. Zie ook: Notten 1998, p. 92-93.

479. Dat is ook bevestigd in jurisprudentie. Zie bijvoorbeeld: CRvB 29 maart 2005, JB 2005/176 Voor meer verwijzingen naar uitspraken verwijs ik naar het commentaar op art. 2:4 Awb van Jansen \& Peters, E.2.1.4-6. Jansen \& Peters wijzen er ook op dat in het eerste lid gesproken wordt over taakvervulling zonder vooringenomenheid en de omstandigheid dat die terminologie waarschijnlijk samenhangt met de plaatsing van het verbod van vooringenomenheid in hoofdstuk 2 van de Awb, Jansen \& Peters, E 2.1.4-5.
} 


\section{Deel II Bestuurlijke voorprocedures}

Samenhang tussen rechterlijke en bestuurlijke onpartijdigheid?

De eis van onpartijdigheid heeft vooral voor rechtspraak veel aandacht in de literatuur gekregen. In het kader van de vereiste onpartijdigheid van rechterlijke instanties wordt, gelet op de jurisprudentie van het EHRM, doorgaans een onderscheid gemaakt tussen de subjectieve en objectieve onpartijdigheidtoets. ${ }^{400}$ Kort gezegd houdt de eis van subjectieve onpartijdigheid in dat geen sprake mag zijn van persoonlijke vooringenomenheid van de rechter. Het betreft de persoonlijke overtuiging en de houding van de rechter. ${ }^{481}$ De objectieve toets heeft betrekking op vraag of er objectief gerechtvaardigde redenen of factoren zijn die twijfels inzake de onpartijdigheid van de rechterlijke instantie en de organisatie daarvan rechtvaardigen. Deze toets ziet onder meer op waarborgen in het kader van de onpartijdigheid van de rechterlijke instantie in structureel opzicht en houdt tevens in dat iedere schijn van partijdigheid bij de rechterlijke instantie dient te worden vermeden. ${ }^{482}$ Kuijer wijst erop dat subjectieve onpartijdigheid wordt verondersteld door het EHRM en het tegendeel moet worden bewezen, terwijl afwezigheid van objectieve onpartijdigheid wordt aangenomen indien 'slechts' wordt aangetoond dat er gerechtvaardigde redenen bestaan om aan de onpartijdigheid te twijfelen. ${ }^{483}$ De bewijslast in het kader van de objectieve toets door het EHRM ligt lager; zoals aangegeven, speelt zelfs de schijn van partijdigheid die kan ontstaan een belangrijke rol daarin.

Hoewel gelet op artikel 6 EVRM en de samenstelling van de Afdeling bestuursrechtspraak van de Raad van State de meeste aandacht uitgaat naar de hiervoor genoemde onpartijdigheideisen voor rechterlijke instanties, heeft recentelijk ook het verbod van vooringenomenheid voor het bestuur meer in de belangstelling gestaan. Aan deze bepaling zijn de afgelopen tijd, vooral naar aanleiding van uitspraken van de Afdeling dienaangaande, in de literatuur diverse malen beschouwingen gewijd. ${ }^{484}$ Een van de kritiekpunten die daaruit naar voren komt, is dat de wetgever en de rechter het bestuur te zeer bejegenen alsof er sprake is van een rechterlijk orgaan. ${ }^{485}$ Op verschillende plaatsen in de literatuur is gewezen op de mogelijke (al dan niet terechte) samenhang die bestaat of geschapen wordt door rechter of wetgever tussen de eisen voor rechterlijke en bestuurlijke onpartijdigheid. ${ }^{486}$ Het betreft onder meer de omstandigheid dat de wetgever in de toelichting op het verbod van vooringenomenheid naar het beginsel nemo iudex in re sua verwijst dat geldt voor rechterlijke activiteiten. ${ }^{487}$ Ter uitwerking van dit principe worden regelingen inzake wraking en verschoning in het kader van rechterlijke activiteiten opgesteld met als doel omstandigheden en factoren die het vormen van een onpartijdig oordeel kunnen bemoeilijken, zoveel mogelijk te elimineren. ${ }^{488}$ Hoewel dit beginsel slechts voor rechterlijke instanties geldt, sluit artikel 2:4 volgens de wetgever daarbij aan in de zin dat ook het bestuursorgaan zich niet mag laten leiden door persoonlijke belangen of voorkeuren. Ook wordt verwezen naar het beginsel van 'no bias' in het Anglo-

${ }^{480 .}$ Kuijer 2004, p. 304. Zie verder hierover par. 4.3.4 van Deel I

${ }^{481 .}$ Kuijer 2004, p. 304. Zie nader hierover par. 4.3.4 van Deel I.

482. Kuijer 2004, p. 304-305.

${ }^{483 .}$ Kuijer 2004, p. 305

484. Zie onder meer: L.J.M. Timmermans, 'Verbod van vooringenomenheid: een (al)gemeen rechtsbeginsel? Een interne rechtsvergelijking', in: R.J.N. Schlössels e.a. (red.), In beginsel. Over aard, inhoud en samenhang van rechtsbeginselen in het bestuursrecht, Deventer: Kluwer 2004, p. 189-219; A.R. Neerhof, 'De reikwijdte van het verbod van vooringenomenheid', JB-plus 2004, p. 38-55; C.J.N. Versteden, 'Van Simpelveld naar Winsum', Gst. (2002) 7173, p. 549-558.

485. Versteden 2002 , p. $552-553$

${ }^{486}$ Jansen \& Peters E 2.1.4-1-3; Neerhof 2004, p. 46 e.v.; Versteden 2002, p. 549 e.v. Zie ook Stroink die de kritiek van Versteden dat de Awb het besturen teveel benadert alsof het rechtspraak is echter onjuist acht. Hij wijst op de overeenkomsten tussen bestuur en rechter, naast de verschillen, en ziet het gebod aan het bestuur om zonder vooringenomenheid te handelen als een van die overeenkomsten omdat de eis ook voor de rechter geldt, F.A.M. Stroink, 'Besluitvorming zonder vooringenomenheid', in: Gedachten over bestuurlijke en ambtelijke integriteit, CAPRA jubileumsymposium, Den Haag 2003, p. 61. Stroink geeft overigens wel aan dat het onpartijdigheidbeginsel voor de rechter meer inhoudt dan handelen zonder vooringenomenheid.

${ }^{487}$. Neerhof 2004, p. 46; Versteden 2002, p. 552, noot 13; Neerhof 1998, p. 120; Notten 1998, p. 114 en 116-118.

${ }^{488 .}$ PG Awb I, p. 179. 


\section{De inrichting van de voorprocedures}

Amerikaanse recht. ${ }^{489}$ In het Engelse recht geldt het beginsel van 'no bias' zowel voor het bestuur als voor de rechter. ${ }^{40}$ De verwijzingen van de wetgever doen, zoals Neerhof ook stelt, de vraag rijzen of de eis van onpartijdigheid dezelfde inhoud en strekking heeft voor zowel het bestuur als de rechterlijke instanties. ${ }^{491}$ Aanwijzingen daarvoor zijn tevens in de jurisprudentie te vinden, aldus Neerhof en Versteden. Zij doelen daarmee onder meer op de uitspraak Winsum van 7 augustus 2002 waarin de Afdeling overweegt dat 'nu in art. 2:4 Awb een waarborg is neergelegd voor de burger ingevolge lid 2 ook de schijn van belangenverstrengeling dient te worden vermeden' ${ }^{492}$ De gebruikte terminologie 'schijn van belangenverstrengeling' doet immers sterk denken aan de door het EHRM geformuleerde eis van objectieve onpartijdigheid van rechterlijke instanties. Voorts meent Neerhof dat de bestuursrechter vooral een op organisatorische aspecten gerichte benadering hanteert bij de toetsing aan artikel 2:4 Awb die overeenkomsten vertoont met de werkwijze van het EHRM in het kader van de beoordeling van de objectieve onpartijdigheid van een rechterlijke instantie. ${ }^{493}$

In het kader van de vraag naar de doorwerking van de beginselen van behoorlijke rechtspleging in de bestuurlijke voorprocedures, kan een onderzoek naar de werking van het verbod van vooringenomenheid in de bezwaarfase en daaromtrent gevormde jurisprudentie dan ook interessante inzichten opleveren juist omdat voor zowel rechterlijke instanties als bestuursorganen (in alle fasen van de besluitvorming) de eis van onpartijdigheid gesteld wordt. Onderzocht dient te worden of de eis van onpartijdigheid dezelfde inhoud en strekking heeft voor zowel het bestuur in de bezwaarschriftprocedure als de rechterlijke instanties. De gebruikte terminologie 'vermijden van schijn van belangenverstrengeling' lijkt een mogelijk aanknopingspunt in bevestigende richting te zijn.

Opbouw

Om de hierboven opgeworpen vraag te kunnen beantwoorden wordt in de volgende paragraaf allereerst stilgestaan bij de grondslagen en ratio van de onpartijdigheideisen voor het bestuur. Daarna besteed ik in paragraaf 5.4.3.3 aandacht aan de grenzen aan de onpartijdigheid van het bestuur in de bezwaarfase en het administratief beroep die onlosmakelijk verbonden zijn met de rol van het bestuur in die procedures als zodanig alsmede met de rol en positie van het bestuur in ons staatsbestel. Vervolgens wordt in paragraaf 5.4.3.4 onderzocht hoe ver de eisen die aan het bestuur gesteld worden om onpartijdigheid te waarborgen gaan. Daarbij worden zowel artikel 2:4 als de relevante bepalingen van hoofdstuk 7 van de Awb alsmede de daarop gebaseerde jurisprudentie betrokken. Het bestuur dient immers in de bestuurlijke voorprocedures zowel aan de vereisten die voortvloeien uit artikel 2:4 van de Awb als aan de vereisten op grond van de bepalingen van hoofdstuk 7 van de Awb te voldoen. In paragraaf 5.4.3.5 wordt het onderscheid tussen subjectieve en objectieve onpartijdigheidstoets dat bij rechtspraak gehanteerd wordt, doorgetrokken naar het bestuur en een vergelijking gemaakt met die toets voor rechtspraak. Tot slot wordt in paragraaf 5.4.3.6 nog ingegaan op de gevolgen die verbonden worden aan een schending van artikel 2:4 Awb. In de afsluitende paragraaf 5.4.4 vindt een korte samenvatting plaats van de uit het onderzoek naar voren ko-

\footnotetext{
489. PG Awb I, p. 179.

490. P. Cane, Administrative Law, Oxford University Press 2004, p. 140 e.v.

${ }^{491 .}$ Neerhof 2004, p. 46. De problematiek rond de onpartijdigheid van de wetgever wordt thans buiten beschouwing gelaten.

492. AbRvS 7 augustus 2002, $A B$ 2003/3, m.nt. ARN, r.o. 2.7.7. Overigens is, zoals ook de wetgever aangeeft (PG Awb I, p. 179), reeds eerder in de jurisprudentie, ook voor inwerkingtreding van de Awb, uitgemaakt dat ook de 'schijn van belangenverstrengeling' dient te worden voorkomen (zie o.m. Vz. AGvB 16 oktober 1992, $A B$ 1993/9).

493. Zie: Neerhof 2004, p. 39, noot 5; Neerhof 1998, p. 120 en noot 5. Overigens hanteert de Nationale Ombudsman in het kader van het verbod van vooringenomenheid expliciet de twee toetsen aan subjectieve en objectieve onpartijdigheid die op eenzelfde wijze lijken te worden ingevuld als door het EHRM, zie hierover de noot van P.J. Stolk bij No 11 februari 2008, $A B$ 2008/154.
} 
Deel II Bestuurlijke voorprocedures

mende bevindingen en worden de conclusies inzake de doorwerking van de onpartijdigheideisen weergegeven.

\subsubsection{Het onpartijdigheidsbeginsel voor het bestuur: een zelfstandig beginsel of onderdeel van algemenere noties}

Een veelvoud aan grondslagen

Alvorens in de volgende paragrafen de grenzen van de aan het bestuur te stellen onpartijdigheideisen en de concrete invulling van die eisen voor het bestuur bezien worden, wordt aandacht besteed aan de grondslag voor en ratio van deze eisen. Zowel in de parlementaire geschiedenis als in de literatuur en jurisprudentie worden verschillende grondslagen genoemd voor de bestuurlijke onpartijdigheideisen. Aan de ene kant wordt het verbod van vooringenomenheid gegrond op specifiek voor het bestuur geldende beginselen of uitgangspunten dan wel op uitsluitend voor de rechter geldende beginselen, terwijl aan de andere kant teruggegrepen wordt op meer algemene noties of beginselen die gelden voor alle organen van de overheid. Er valt derhalve enige ambivalentie te bespeuren inzake de rechtsbasis voor het verbod van vooringenomenheid voor het bestuur.

Algemene beginselen van behoorlijk bestuur: zorgvuldigheidsbeginsel

De norm neergelegd in artikel 2:4 Awb wordt allereerst veelal gezien als een (gecodificeerde) uitwerking van een of meer ongeschreven algemene beginselen van behoorlijk bestuur dan wel als een (gecodificeerd) zelfstandig algemeen beginsel van behoorlijk bestuur. Regelmatig wordt aangenomen dat artikel 2:4 Awb een nadere uitwerking vormt van het zorgvuldigheidsbeginsel als algemeen beginsel van behoorlijk bestuur. Nicolaï beschouwt het verbod van (schijn van) partijdigheid bijvoorbeeld als onderdeel van het beginsel van een zorgvuldige beslissingsprocedure, dat een specificatie vormt van het zorgvuldigheidsbeginsel. ${ }^{494}$ Ook Addink lijkt het onder een specificatie van het zorgvuldigheidsbeginsel te scharen, maar dan het beginsel van een zorgvuldige bejegening. ${ }^{495}$ Timmermans daarentegen bestempelt het verbod van vooringenomenheid tot een zelfstandig algemeen beginsel van behoorlijk bestuur dat fundamenteel van aard is, maar voegt daaraan toe dat dit beginsel in zekere mate ook dient te worden beschouwd als een nadere uitwerking van het algemene zorgvuldigheidsbeginsel. ${ }^{496}$ De bestuursrechter lijkt eveneens soms op twee gedachten te hinken en heeft besluiten wegens strijd met artikel 3:2 Awb vernietigt of overweegt dat geen sprake is geweest van een onzorgvuldige voorbereiding, terwijl artikel 2:4 in het geding is of lijkt te zijn. ${ }^{497}$ De toelichting op die bepaling zelf is op dit punt evenmin duidelijk en de Raad van State merkte in zijn advies zelfs op dat het de vraag is of artikel 2:4 Awb een voldoende eigen betekenis heeft ten opzichte van de in afdeling 3.2 neergelegde (zorgvuldigheids)normen. ${ }^{498}$

Nog afgezien van de vraag of het verbod van vooringenomenheid als een aspect van het zorgvuldigheidsbeginsel moet worden gezien, kunnen vraagtekens gesteld worden bij artikel 3:2 Awb als grondslag. In dat artikel is immers slechts een aspect van het algemene zorgvuldigheidsbeginsel neergelegd, de plicht tot het vergaren van voldoende kennis over relevante feiten en belangen, en niet alle specificaties van dat beginsel. Indien aangenomen wordt dat het verbod van vooringenomenheid een uitwerking vormt van het zorgvuldigheidsbeginsel, dan zou deze eis, vanwege de strekking ervan, eerder bij een

\footnotetext{
494. Nicolaï 1990, p. 38.

495. Addink 1999, p. 192.

496. Timmermans 2004, p. 207

497. Zie bijvoorbeeld: AbRvS 23 april 2008, $A B$ 2008/216 m.nt. T.E.P.A Lam; AbRvS 23 oktober 2002, JB 2002/360; AbRvS 28 oktober 1997, AB 1997/458 m.nt. PvB (Bestemmingsplan Ganzenhoef). Vgl. ook: Timmermans 2004, p. 207.

498. PG Awb I, p. 178.
} 


\section{De inrichting van de voorprocedures}

andere specificatie van dat beginsel moeten worden ondergebracht. Het beginsel van de zorgvuldige bejegening, dat Nicolaï onderscheidt, zou meer geschikt zijn als grondslag.

Niet iedereen onderschrijft de benadering, waarin het verbod van vooringenomenheid als element van het meer algemene formele zorgvuldigheidsbeginsel wordt beschouwd. Verheij keert zich tegen dat standpunt en meent dat aan artikel 2:4 van de Awb een plaats in het bestuursrecht toekomt die duidelijk onderscheiden moet worden van bijvoorbeeld de algemene notie van zorgvuldigheid. Hij beschouwt dit artikel 'als een norm voor die gevallen, waarbij het preciezer en concreter dan algemene noties als gelijkheid of zorgvuldigheid aangeeft wat er aan de besluitvorming door het bestuur schort'. ${ }^{499}$ Zo opgevat vormt het verbod van vooringenomenheid derhalve een zelfstandige norm voor het bestuur.

\section{Het fair play-beginsel}

Het zorgvuldigheidsbeginsel is niet het enige algemeen beginsel van behoorlijk bestuur waarmee het verbod van vooringenomenheid in verband wordt gebracht. Uit artikel 2:4 Awb volgt volgens de wetgever dat het bestuursorgaan de burger fair dient te behandelen en met open vizier tegemoet moet treden. ${ }^{500}$ Dat lijkt, vanwege de formulering, weer een verwijzing naar het 'fair play'- beginsel te zijn. ${ }^{501}$ Daarin staat de wetgever niet alleen, aangezien in de literatuur door verschillende auteurs het verbod van vooringenomenheid als onderdeel van het 'fair play'-beginsel gezien wordt. ${ }^{502}$ Hierbij verdient echter aantekening dat het, zoals hierna nog zal blijken, omstreden is of het 'fair play'-beginsel moet worden beschouwd als een zelfstandig algemeen beginsel van behoorlijk bestuur dan wel als onderdeel van of een specificatie van het formele zorgvuldigheidsbeginsel. De wetgever zelf merkt reeds (aansluitend op de hiervoor genoemde passage) op dat artikel 2:4 Awb daarmee een specificatie van een van de elementen die behoren tot de zorgvuldige voorbereiding van een besluit vormt. ${ }^{503} \mathrm{De}$ eis dat een burger op een 'faire' wijze behandeld moet worden, vormt in de optiek van de wetgever derhalve een element van het zorgvuldigheidsbeginsel én het verbod van vooringenomenheid wordt weer met die eis van een 'faire' behandeling vereenzelvigd. De passage in de toelichting duidt er mijns inziens op dat de wetgever niet alleen het 'fair play'-beginsel als een specificatie van het zorgvuldigheidsbeginsel ziet, maar ook het verbod van vooringenomenheid.

In de literatuur en rechtspraak bestaat geen overeenstemming over de zelfstandige status van het 'fair play'-beginsel. Wiarda bijvoorbeeld onderscheidde het 'fair play'beginsel reeds in zijn preadvies voor de VAR in 1952, maar een wijd verbreide erkenning ervan heeft sindsdien in de rechtspraak niet plaatsgevonden. ${ }^{504}$ Opgemerkt moet hierbij worden dat Wiarda een ruim begrip van 'fair play' voorstaat. Hij geeft aan dat het beginsel impliceert dat 'van de bestuurder een houding wordt verwacht, waarbij aan de bestuurde, over wiens rechten en belangen wordt beschikt, de gelegenheid wordt gegeven zijn standpunt naar voren te brengen en te verdedigen, het daaraan eventueel tegenovergestelde standpunt van de administratie zelf van andere belanghebbenden te bestrijden; een houding, waarbij althans wordt nagelaten al datgene, dat de bestuurde zou kunnen verhinderen zijn standpunt binnen het kader van de hem toekomende rechten tot

\footnotetext{
${ }^{499 .}$ Verheij 1995, p. 143-144.

500. PG Awb I, p. 178.

501. PG Awb I, p. 178

502. Van Wijk/Konijnenbelt \& Van Male 2008, p. 293; Stroink 2003, p. 61; Addink 1999, p. 191-192 en 210. Van Wijk/Konijnenbelt \& Van Male beschouwen het verbod van vooringenomenheid als een van de twee helften van het 'fair play'-beginsel.

504. G.J. Wiarda, ‘Algemene beginselen van behoorlijk bestuur’, preadvies VAR 1952, in: Verspreide geschriften van G.J. Wiarda, Den Haag: VUGA 1986, p. 57.
} 


\section{Deel II Bestuurlijke voorprocedures}

gelding te brengen. ${ }^{505}$ Deze elementen zouden thans onder het formele zorgvuldigheidsbeginsel worden geschaard. Wiarda doet dat niet en onderscheidt daarnaast nog een zorgvuldigheidsbeginsel, dat in zijn optiek ziet op het voorbereidend onderzoek en mede nauwkeurigheid en oplettendheid inhoudt bij het nemen van besluiten. ${ }^{506}$ Een verbod van vooringenomenheid komt in zijn omschrijving van het 'fair play'-beginsel niet terug. Nicolaï ziet 'fair play' als onderdeel van het beginsel van een correcte bejegening, hetgeen weer een specificatie of uitwerking vormt van wat thans bekend staat als het formele zorgvuldigheidbeginsel. ${ }^{507}$ Ook hij schaart onder correcte bejegening het horen van belanghebbenden en gaat hij derhalve uit van een ruime betekenis van dat beginsel. ${ }^{508}$ Het verbod van schijn van partijdigheid brengt hij echter, zoals hierboven werd aangegeven, onder bij een andere specificatie van het zorgvuldigheidsbeginsel, het beginsel van een zorgvuldige beslissingsprocedure. ${ }^{509}$ Addink ziet het beginsel van correcte (of zorgvuldige) bejegening (in beperkte zin) als uitwisselbaar met het 'fair play'-beginsel en schaart er tevens het verbod van (schijn van) partijdigheid onder. ${ }^{510}$ Ook in zijn optiek vormt het beginsel van zorgvuldige bejegening een specificatie van het algemene zorgvuldigheidsbeginsel. In de recente literatuur lijkt uitsluitend Van Wijk/Konijnenbelt \& Van Male uit te gaan van het bestaan van een afzonderlijk 'fair play'-beginsel, waarvan het verbod van vooringenomenheid een 'helft' vormt. ${ }^{511}$

Zoals Addink ook opmerkt, wordt het beginsel van zorgvuldige bejegening (of 'fair play'-beginsel) in elk geval niet altijd (expliciet) door de bestuursrechter erkend. ${ }^{512}$ Een enkele keer wordt in de jurisprudentie een besluit wegens strijd met het 'fair play'beginsel vernietigd, maar van een brede erkenning kan in mijn ogen inderdaad niet gesproken worden. Een voorbeeld van een vernietiging vormt een uitspraak van de Afdeling van 30 maart 1999 waarin deze ook nog eens een definitie geeft van het beginsel: het beginsel van 'fair play', dat inhoudt dat een bestuursorgaan de burger zorgvuldig bejegent in die zin dat, voorzover relevant in het voorliggende geval, het bestuursorgaan het verkrijgen van wat een burger als zijn recht ziet niet door het uitstellen of het niet nemen van een beslissing waarbij de burger belang heeft, mag bemoeilijken of frustreren. ${ }^{513}$ Aldus opgevat heeft het 'fair play'-beginsel een beperktere betekenis dan bijvoorbeeld Wiarda voor ogen stond en omvat het in elk geval niet het verbod van vooringenomenheid. In recente jurisprudentie van de bestuursrechter lijkt het beginsel verder een marginale(re) rol te spelen en wordt veelal schending van het zorgvuldigheidsbeginsel als grond voor vernietiging gekozen in gevallen, die onder het 'fair play'-beginsel zouden vallen. ${ }^{514}$ Een uitzondering daarop lijkt de jurisprudentie van het $\mathrm{CBb}$ te vormen. Dat rechtscollege hanteert het 'fair play'-beginsel ook recent nog vrij regelmatig als vernieti-

505. Wiarda 1986, p. 57. Ook de verderop in de tekst gedane verwijzingen naar o.m. de benaderingen in het Engelse en Amerikaanse recht doen vermoeden dat hij onder dit beginsel rechten als inzage in stukken, het recht om gehoord te worden e.d. begrijpt.

506. Wiarda 1986, p. 60. Wiarda makt overigens geen expliciet onderscheid tussen het formele en materiële zorgvuldigheidsbeginsel maar schaart beide aspecten onder het zorgvuldigheidsbeginsel.

507. Nicolaï 1990, p. 327. Andere elementen van 'fair play' brengt hij weer onder bij het beginsel van een zorgvuldige beslissingsprocedure, p. 338-341.

508. Nicolaï 1990, p. 327-332.

509. Nicolaï 1990, p. 339.

510. Addink 1999, p. 191-192.

511. Van Wijk/Konijnenbelt \& Van Male 2008, p. 293. Overigens behandelt Schlössels in zijn terugkerende kroniek 'Beginselen van behoorlijk bestuur' in het $N T B$ het verbod van vooringenomenheid ook onder het kopje 'Correcte bejegening en fair play', zie bijvoorbeeld: R.J.N. Schlössels, 'Kroniek Beginselen van behoorlijk bestuur', NTB 2008, p. 97.

512. Addink 1999, p. 200.

513. AbRvS 30 maart 1999, $A B$ 1999/310 m.nt. GJ. Zie voor een vernietiging van de Centrale Raad: CRvB 12 maart 1992, $A B$ 1992/677 m.nt. HH. Zie verder nog een uitspraak waarin het beginsel genoemd wordt: AbRvS 15 december 2004, $A B$ 2005/431 m.nt. JSt (geen contra legem -toepassing 'fair play').

514. Het 'fair play'- beginsel kwam (overigens met wisselend succes) wel aan bod in o.m.: AbRvS 18 december 2002, AB 2003/85 m.nt. FM; AbRvS 4 november 1999, AB 1999/479 m.nt. MSV. De annotator bij eerstgenoemde uitspraak wijst erop dat het wellicht aan de samenstelling van de kamer ligt die de zaak behandelde dat hier een schending van het 'fair play'-beginsel wordt aangenomen. 


\section{De inrichting van de voorprocedures}

gingsgrond ${ }^{515}$ Bovendien wordt (en werd) het 'fair play'-beginsel door de bestuursrechter in een andere betekenis gehanteerd en omvat het niet het verbod van vooringenomenheid. De gevallen waarin in de jurisprudentie een schending wordt geconstateerd van het 'fair play'-beginsel zien op andere situaties dan vermeende partijdigheid of vooringenomenheid. Te denken valt aan misleiding van de burger, het hanteren van vertragingstechnieken door het bestuur waardoor de burger benadeeld wordt of anderszins onzorgvuldige bejegening. ${ }^{516}$ Indien het 'fair play'-beginsel (al dan niet als specificatie van het zorgvuldigheidsbeginsel) ruim wordt opgevat, zou dit beginsel het verbod van vooringenomenheid kunnen omvatten. Mijns inziens betreft het echter, zoals ik verderop nog nader zal toelichten, een afzonderlijk te onderscheiden norm voor het bestuurlijk handelen.

Al met al kan gesteld worden dat het 'fair play'-beginsel in de doctrine wel erkend wordt, maar daarvan lang niet altijd het verbod van vooringenomenheid deel uit lijkt te maken. In de rechtspraak is mindere mate sprake van erkenning en voor zover dat wel het geval is, omvat deze norm niet het verbod van vooringenomenheid.

\section{Rechterlijke uitgangspunten}

Naast (verschillen)de algemene beginselen van behoorlijk bestuur, wordt ook wel, ter duiding van het in artikel 2:4 Awb neergelegde verbod van vooringenomenheid, verwezen naar beginselen die zich primair richten tot de rechter. In de memorie van toelichting wordt bijvoorbeeld gerefereerd aan het onpartijdigheidsbeginsel. Daarbij wordt, zoals hierboven al aangestipt werd, een vergelijking getrokken met het beginsel van 'no bias' in de Anglo-Amerikaanse recht dat voor zowel het bestuur als de rechter van betekenis is. ${ }^{517}$ Interessant is verder de ook al eerder gememoreerde verwijzing van de wetgever naar het beginsel nemo iudex in re sua dat geldt voor rechterlijke activiteiten. Zoals aangegeven geldt dit beginsel uitsluitend voor rechterlijke instanties. Hoewel artikel 2:4 van de Awb volgens de wetgever daarbij aansluit, in de zin dat ook het bestuursorgaan zich niet mag laten leiden door persoonlijke belangen of voorkeuren, werd het niet opportuun geacht een wrakingsactie of een lijst met onverenigbare functies op te nemen in de Awb ter verzekering van de onpartijdigheid van het bestuur. In de visie van de wetgever ligt de primaire verantwoordelijkheid voor een ook in het opzicht van onpartijdigheid correct optreden bij het bestuursorgaan en past het beter in de systematiek van de Awb om een verplichting daartoe voor het bestuursorgaan op te nemen. ${ }^{518}$ In het kader van de verwijzing naar dit principe moet tevens voor ogen worden gehouden dat het bestuur in beginsel in de bezwaarfase altijd rechter in eigen zaak is, omdat het partij en beslisser is, en dit principe om die reden slechts een beperkte betekenis kan toekomen in die fase. In de literatuur wordt in het algemeen ook om die reden een verband of vergelijking tussen de rechterlijke en bestuurlijke onpartijdigheid afgewezen. ${ }^{519}$ Inderdaad kan de onpartijdigheid van het bestuur in de bezwaarfase in dat opzicht niet zo ver strekken als die welke van de rechter geëist wordt (zoals ook nog nader uiteen wordt gezet in de volgende paragrafen), maar dat behoeft niet te betekenen een vergelijking niet zinvol zou kunnen zijn. Voor administratief beroep geldt zulks nog te meer, nu het beroepsorgaan zelf geen partij is in de procedure. Jansen en Peters leggen in hun losbladig commentaar bij artikel 2:4 van de Awb wel een connectie tussen rechterlijke onpartijdigheid (met name de eisen die voortvloeien uit artikel 6 EVRM) en bestuurlijke onpartijdigheid. ${ }^{520}$ Hoewel zij ook wijzen op het feit dat een vergelijking op alle punten tussen rechter en bestuur niet mogelijk is, vanwege het principiële verschil tussen rechtspreken en besturen, wor-

\footnotetext{
515. Zie bijvoorbeeld: CBb 5 december 2007, $A B$ 2008/38 m.nt. G.J.M. Cartigny; CBb 18 oktober 2005, $A B$ 2006/80 m.nt. J.H. van der Veen.

516. Zie bijvoorbeeld: AbRvS 18 december 2002, AB 2003/85 m.nt. Michiels. Zie hierover ook: Damen e.a. 2009, Deel I, p. 356-358; Van Wijk/Konijnenbelt \& Van Male 2008, p. 318

517. PG Awb I, p. 179.

518. PG Awb I, p. 179.

519. Sanders 1998 , p. 106.

520. Jansen \& Peters, E 2.1.4-2.
} 
Deel II Bestuurlijke voorprocedures

den tevens enkele overeenkomsten aangestipt. ${ }^{521} \mathrm{Zij}$ wijzen bijvoorbeeld op de benadering in de rechtspraak dat ook de schijn van partijdigheid onwenselijk is en de parallel met de objectieve toets die het EHRM hanteert in het kader van de aan de rechter te stellen onpartijdigheideisen. Ook menen zij dat het subjectieve element terugkomt in het eerste lid van artikel 2:4 Awb. ${ }^{522}$

De verwijzingen naar rechterlijke uitgangspunten impliceren mijns inziens niet dat de invulling van de onpartijdigheideisen voor het bestuur op dezelfde wijze moet plaatsvinden als voor de rechter. De verwijzingen tonen op zijn minst aan dat zowel de rechter als het bestuur in zekere mate onpartijdig en zonder aanziens des persoons zijn taak behoort uit te oefenen. Dat vloeit voort uit meer fundamentele en rechtsstatelijke uitgangspunten die gelden voor alle overheidsorganen. Bovendien kan de wijze van toetsen of sprake is van partijdigheid of de benadering van de rechter, door bijvoorbeeld een subjectieve toets en objectieve toets te hanteren, gelijkenis vertonen, zonder dat de uitkomst exact hetzelfde behoeft te zijn voor het bestuur en de rechter.

Van belang daarbij is, dat de ratio voor de onpartijdigheideisen voor het bestuur en de rechter hetzelfde is. De ratio van het verbod van vooringenomenheid, zoals neergelegd in artikel 2:4 Awb, is primair het voorkomen dat oneigenlijke belangen een rol spelen bij de besluitvorming. Daartoe is in het eerste lid neergelegd dat het bestuursorgaan zijn taak op onpartijdige wijze dient te vervullen en in het tweede lid dat het bestuursorgaan ervoor zorg dient te dragen dat personen die behoren tot of werkzaam zijn voor het bestuursorgaan met een persoonlijk belang en bij de besluitvorming betrokken zijn, de besluitvorming niet beïnvloeden. Dat betekent dat de rechtsverhouding tussen het bestuursorgaan en de betrokken belanghebbende(n) op objectieve wijze bepaald moet worden. De ratio van de onpartijdigheideisen ligt ook in de bestuurlijke fase in het waarborgen dat de belangen van belanghebbenden in de procedure op juiste wijze meegewogen worden en aan die belangen niet, vanwege niet terzake doende redenen, te veel dan wel te weinig gewicht wordt toegekend.

Daarnaast is het verbod van vooringenomenheid ook van belang voor het vertrouwen dat burgers in het openbaar bestuur hebben. ${ }^{523}$ Het moet waarborgen dat vriendjespolitiek of bevoor- dan wel benadeling, vanwege oneigenlijke redenen, uitgesloten is. Gebeurt dit wel, verliezen burgers het vertrouwen in het bestuur en verdwijnt het draagvlak voor beslissingen van het bestuur. Het verbod van vooringenomenheid heeft derhalve ook een functie die de concrete rechtsverhouding of het concrete geschil overstijgt. Evenals het geval is bij het onpartijdigheidbeginsel voor de rechter, meen ik dat deze functie echter meer in het verlengde ligt van de functie die het verbod van vooringenomenheid heeft in het kader van de bescherming van de belangen van belanghebbenden in de procedure. Primair en in eerste instantie voorkomt (inachtneming van) het verbod dat hun belangen op oneigenlijke, onjuiste of willekeurige wijze bij de besluitvorming betrokken worden.

\section{Fundamentele rechtsbeginselen of algemene rechtsbeginselen}

Voor de onpartijdigheideisen voor het bestuur wordt, zoals hiervoor al werd aangegeven, ook geleund op meer algemene noties die gelden voor alle overheidsorganen, waaronder het bestuur maar ook de rechter. Volgens de wetgever bijvoorbeeld is artikel 2:4 Awb in de eerste plaats een uitwerking voor bestuursorganen van het grondbeginsel dat (alle) overheidsoptreden dient te geschieden zonder aanzien des persoons. Daarbij wordt verwezen naar artikel 1 van de Grondwet waarin is neergelegd dat allen in gelijke gevallen gelijk dienen te worden behandeld. ${ }^{524}$ In het nader rapport naar aanleiding van het advies van de Raad van State wordt deze overweging gepreciseerd. Opgemerkt wordt dat het

\footnotetext{
521. Jansen \& Peters, E 2.1.4-2-2 en 3.

522. Jansen \& Peters, E 2.1.4-2-3.

523. Schlössels 2008, p. 99; Jansen \& Peters, E 2.1.4-1.

524. PG Awb I, p. 179.
} 


\section{De inrichting van de voorprocedures}

eerste lid ten dele een uitwerking vormt van artikel 1 Grondwet en het daarin tot uitdrukking komende gelijkheidsbeginsel, maar dat deze bepaling daarmee niet geheel samenvalt. ${ }^{525}$ Ook Stroink geeft aan dat er een relatie is met het gelijkheidsbeginsel en ziet het verbod van vooringenomenheid als een uitwerking van een essentieel rechtsstatelijk beginsel. ${ }^{526}$ Verschillende andere auteurs alsmede de bestuursrechter hebben het verbod van vooringenomenheid, zoals neergelegd in artikel 2:4 Awb, bestempeld als een fundamenteel rechtsbeginsel. ${ }^{527}$ Daarmee lijkt het verbod van vooringenomenheid een andere status toegekend te krijgen dan de overige beginselen van behoorlijk bestuur. Het wordt van fundamenteler aard geacht te zijn, gelet op de omstandigheid dat het een uiting vormt van de rechtsstaatgedachte. ${ }^{528}$ Overigens betekent de fundamentele aard van het verbod van vooringenomenheid nog steeds niet dat de rechter ambtshalve mag nagaan of het bestuursorgaan dit verbod in acht heeft genomen. In de jurisprudentie is in elk geval niet algemeen aanvaard dat artikel 2:4 Awb een bepaling van openbare orde betreft. ${ }^{529}$

\section{Duiding van de veelvoud aan grondslagen}

Al met al verwijzen parlementaire geschiedenis, literatuur en jurisprudentie naar verschillende beginselen of uitgangspunten als grondslag voor het verbod van vooringenomenheid, zoals neergelegd in artikel 2:4 van de Awb. Enerzijds betreffen het beginselen die gelden voor het overheidsoptreden in het algemeen die samenhangen met het gelijkheidsbeginsel en anderzijds gaat het om beginselen of uitgangspunten die specifiek gelden voor ofwel rechterlijke activiteiten ofwel bestuurlijke activiteiten. De beginselen van behoorlijk bestuur zoals het zorgvuldigheidsbeginsel (of specificaties daarvan) en het 'fair play'-beginsel voeren echter als grondslagen de boventoon. In het algemeen blijft een verwijzing of vergelijking met de voor de rechterlijke geldende onpartijdigheid achterwege. Voor zover daaraan gerefereerd wordt ten aanzien van de bestuurlijke voorprocedures, wordt een verband tussen beide uitgangspunten of een sterke gelijkenis meestentijds van de hand gewezen.

De veelvoud aan grondslagen valt goed te verklaren. Aan alle overheidsoptreden wordt de eis gesteld dat dit geschiedt zonder aanziens des persoons en, voor zover nodig, onder gelijke behandeling van een ieder. Deze algemene rechtsstatelijke eis, die voortvloeit uit het gelijkheidsbeginsel als algemeen en fundamenteel rechtsbeginsel heeft voor de verschillende onderdelen van de overheid een nadere uitwerking gekregen in de beginselen van behoorlijke wetgeving, bestuur en rechtspleging. ${ }^{530}$ In feite is de overkoepelende ratio van al deze eisen het vertrouwen dat de burger in de verschillende overheidsorganen moet kunnen hebben en het feit dat overheid, in welke hoedanigheid dan ook, zijn bevoegdheden moet uitoefenen conform het recht, zonder misbruik van bevoegdheden en willekeur. Omdat de overheid traditioneel opgedeeld wordt in drie staatsmachten en bestaat uit verschillende organen, zijn er voorts specifieke normen ter waarborging van de onpartijdigheid ontwikkeld die zich uitsluitend richten tot de verschillende organen afzonderlijk in hun rechtsverhouding tot de burger. De achtergrond of ratio van die verschillende normen voor de verschillende organen is wel dezelfde en valt te herleiden naar algemene rechtsstatelijke uitgangspunten. Om die reden is het op zich niet vreemd

\footnotetext{
${ }^{525 .}$ Vgl. ook Verheij die dat in het bijzonder ook afleidt uit het tweede lid van art. 2:4 Awb, Verheij 1995, p. 142143.

526. Stroink 2003, p. 60 en 63-64. Vgl. ook: Jansen \& Peters, E 2.1.4-1; Timmersmans 2004, p. 207.

527. Zie bijvoorbeeld: Jansen \& Peters, E 2.1.4-3; Timmermans 2004, p. 207. Een voorbeeld van een uitspraak: CBb 21 december 1994, JB 1995/1; AB 1995/454 m.nt. JHvdV; Rawb 1995/34 m.nt. BdeW; N. Verheij, 'Stadsmobiel Amsterdam. Partijdige bezwaarschriftcommissie', in: L.J.A. Damen e.a. (red.) Rechtspraak Bestuursrecht 1994-1995: de annotaties, Den Haag: Vuga 1995, p. 139-154.

528. Jansen \& Peters, E 2.1.4-1.

529. Jansen \& Peters wijzen op een uitspraak die in bevestigende richting gaat, maar ik heb verder geen aanwijzingen in de jurisprudentie gevonden waaruit blijkt dat de bestuursrechter art. 2:4 Awb beschouwt als een bepaling van openbare orde waaraan ambtshalve behoort te worden getoetst, Jansen \& Peters, E 2.1.4-3.

${ }_{530}$ Vgl. Verheij 1995, p. 142-144.
} 
Deel II Bestuurlijke voorprocedures

dat ter verklaring van de codificatie van het verbod van vooringenomenheid ook naar deze verschillende normen en uitgangspunten verwezen wordt.

\section{Zelfstandige norm}

De grondslag voor onpartijdigheid als norm voor behoorlijk bestuurlijk handelen en behoorlijke besluitvorming (in de bestuurlijke voorprocedures), ligt in mijn optiek echter in de algemene beginselen van behoorlijk bestuur. Dat zijn de normen die het bestuur in acht moet nemen bij het nemen van een besluit en die tot het bestuur gericht zijn alsmede de normen waaraan de rechter het bestuurlijk optreden kan toetsen. Weliswaar kunnen (bepaal)de algemene beginselen van behoorlijk bestuur (mede) worden beschouwd als uitwerkingen of specificaties van algemene, fundamentele rechtsbeginselen, zoals bijvoorbeeld het gelijkheidsbeginsel of het rechtszekerheidsbeginsel, die voor alle overheidsorganen van belang zijn, maar voor de bestuurlijke bevoegheidsuitoefening is het in mijn ogen zuiverder om de concrete grondslag voor de plicht van het bestuur om zonder vooringenomenheid zijn taak te vervullen te zoeken in een algemeen beginsel van behoorlijk bestuur. Zoals het gelijkheidsbeginsel als algemeen beginsel van behoorlijk bestuur een specificatie vormt van het in artikel 1 Grondwet neergelegde principe op grond waarvan het bestuur gelijke gevallen gelijk behoort te behandelen, zo vormt het verbod van vooringenomenheid de norm voor het bestuur waaruit volgt dat het onpartijdig een besluit dient te nemen. Evenzo moet het verbod van vooringenomenheid beschouwd worden als een zelfstandig algemeen beginsel van behoorlijk bestuur en niet als een uitwerking of aspect van het zorgvuldigheidsbeginsel dan wel het 'fair play'-beginsel (al dan niet gezien als beginsel van zorgvuldige bejegening). In de doctrine wordt het verbod van vooringenomenheid nogal eens als uitwerking of specificatie van het zorgvuldigheidsbeginsel gezien. Zoals Verheij echter opmerkt, heeft het verbod van vooringenomenheid (of zo men wil het onpartijdigheidbeginsel) voldoende onderscheidend vermogen en geeft het een preciezere en concretere indicatie van het gebrek dat aan de besluitvorming kleeft. ${ }^{531}$ Datzelfde argument doet afbreuk aan de opvatting waarin het verbod van vooringenomenheid als deelaspect van het 'fair play'-beginsel wordt beschouwd. Het 'fair play'-beginsel heeft een ruimere en ook andere strekking dan het voorkomen van vooringenomenheid. Bovendien is het 'fair play'-beginsel als zelfstandig beginsel van behoorlijk bestuur nog niet algemeen aanvaard in de rechtspraak en komt een beroep op die bepaling niet vaak voor. Het onpartijdigheidsbeginsel voor het bestuur ofwel het in artikel 2:4 Awb neergelegde verbod van vooringenomenheid vormt derhalve thans een zelfstandige rechtsnorm waarvan de herkomst te herleiden valt tot het (alles)overkoepelende zorgvuldigheidsbeginsel en de zorgvuldige bejegening van burgers. Ook het fair play-beginsel kan daartoe worden herleid.

\subsubsection{Inherente grenzen van de onpartijdigheid van het bestuur}

\section{Een beperkte reikwijdte}

Hoewel uit hetgeen in paragraaf 5.4.3.1 is weergegeven aanknopingspunten kunnen worden afgeleid voor een vergelijking tussen de rechterlijke en bestuurlijke onpartijdigheid, moet een aantal beperkingen daarbij niet uit het oog verloren worden. De onpartijdigheideisen voor bestuur en rechter vertonen op voorhand ook een aantal verschillen. De onpartijdigheid die van het bestuur geëist kan worden, wordt in algemene zin door een aantal factoren beperkt. Die beperkte reikwijdte - of zoals Neerhof stelt (inzake artikel 2:4 Awb) actieradius ${ }^{532}$ - vloeit grotendeels voort uit de specifieke positie die het bestuur inneemt in onze democratische rechtsstaat. Voor een deel hangt deze beperkte reikwijdte voor het bestuur in de bezwaarschriftprocedure (en het administratief be-

531. Verheij 1995, p. 143-144.

532. Zie Neerhof 1998, p. 119. 


\section{De inrichting van de voorprocedures}

roep $)^{533}$ ook samen met de specifieke positie die het bestuur in die procedure inneemt en het karakter van die procedure. Alvorens wordt ingegaan op de invulling van de onpartijdigheideisen voor het bestuur en de vraag in hoeverre er overeenkomsten of verschillen bestaan in dat kader met de eisen die gelden voor de rechter, worden de grenzen van de onpartijdigheid van het bestuur in de onderhavige paragraaf in kaart gebracht.

\section{De vrijheid om beleidskeuzes te maken}

Een eerste begrenzing, die samenhangt met de specifieke werkzaamheid van het bestuur en zijn rol en positie in onze rechtsstaat, vormt de omstandigheid dat het verbod van vooringenomenheid niet met zich brengt dat het bestuur zich bij de besluitvorming niet zou mogen laten leiden door bepaalde beleidskeuzes. ${ }^{534}$ De wetgever benadrukt dat artikel 2:4 van de Awb en het daarin neergelegde verbod van vooringenomenheid er niet aan in de weg staat dat het bestuur bepaalde beleidskeuzes maakt. ${ }^{535}$ Het voeren van beleid maakt onderdeel uit van de bestuurlijke taakuitoefening en is - zo stelt de wetgever inherent aan goed bestuur. Die benadering moet doorgetrokken worden naar de bestuurlijke besluitvorming in de bestuurlijke voorprocedures. In de bestuurlijke voorprocedures wordt immers het besluit volledig heroverwogen waarbij, voor zover mogelijk, ook beleidsaspecten de revue passeren. Ook in deze zin wordt de in acht te nemen onpartijdigheid en objectiviteit door het bestuur in de bestuurlijke voorprocedures begrensd door de bestuurlijke werkzaamheid en de positie en de rol van het bestuur in onze rechtsstaat. Doordat de bestuurlijke werkzaamheid te allen tijde in het teken dient te staan van het (aspect van het) algemeen belang ter behartiging waarvan de bevoegdheid is toegekend, ook in de bestuurlijke voorprocedures, vindt een beperking van de werking van het verbod van vooringenomenheid plaats. Voor zover daartoe de vrijheid bestaat, maakt het voeren van beleid onderdeel uit van de bestuurlijke werkzaamheid en impliceert dat een voorkeur voor bepaalde beleidskeuzen of resultaten. ${ }^{536}$ Ook van het enkele feit dat het bestuursorgaan baat kan hebben bij de uitkomst van een bestuurlijke voorprocedure, in financiële zin bijvoorbeeld, wordt algemeen aangenomen dat dit op zichzelf geen strijd met het verbod van vooringenomenheid oplevert. ${ }^{537}$ Het verbod van vooringenomenheid is dan ook een relatief verbod, aldus Jansen en Peters. ${ }^{538}$ Er kan derhalve geen sprake zijn van partijdigheid of van strijd met het verbod van vooringenomenheid indien het bestuursorgaan of beroepsorgaan, ten nadele van de bezwaarmakers of indieners van het beroep, vasthoudt aan de in primo gemaakte keuzes en besluitvorming op grond van beleidsmotieven of politieke voorkeuren. ${ }^{539}$ De bestuursrechter heeft ook aangegeven dat het enkele feit dat een lid van de bezwaarschriftcommissie tevens lid is van een politieke partij of een lid dan wel meer leden van het bestuursorgaan al een politiek standpunt heeft ingenomen in de kwestie, geen strijd met het verbod van vooringenomenheid oplevert. ${ }^{540}$ Evenmin levert de enkele omstandigheid dat het bestuursorgaan, in casu de mi-

\footnotetext{
533. De jurisprudentie en literatuur besteden nauwelijks aandacht in dit verband aan het administratief beroep. Voor administratief beroep geldt in beginsel hetgeen voor besluitvorming in het algemeen of in bezwaar wordt gesteld in deze paragraaf, tenzij anders wordt aangegeven.

539. Vgl. Jansen \& Peters, E 2.1.4-9; zie AB 2003/85 en 86 m.nt. FM: er is geen sprake van strijd met artikel 2:4 eerste lid van de Awb indien het bestuursorgaan het in primo genomen dwangsombesluit uitvoert en dwangsommen int alvorens het besluit op bezwaar is genomen.

${ }^{540 .}$ AbRvS 31 juli 2002, Gmst. 7173/3 m.nt. D.E. Bunschoten; CBb 12 juni 1997, AB 1997/339 m.nt. JHvdV. Zie bijvoorbeeld ook nog enkele uitspraken waar Jansen \& Peters, E 2.1.4-12-13, nog op wijzen: AbRvS 19 januari 1999, $A B$ 1999/257 m.nt. JSt; AbRvS 6 augustus 2003, LJN AI0807;
} 


\section{Deel II Bestuurlijke voorprocedures}

nister van Verkeer en Waterstaat, de medeoprichter is van de tot sanering opdracht gevende stichting en teves het vergunningverlenende orgaan is voor het saneringsproject reeds strijd op met artikel 2:4 Awb. ${ }^{541}$ Schlössels merkt over deze uitspraak op dat daaruit de praktische grenzen van het verbod van vooringenomenheid blijken, omdat eruit blijkt dat politiek-bestuurlijke betrokkenheid die bestaat op grond van beleidsontwikkeling of beleidsuitvoering niet per definitie vooringenomenheid oplevert. ${ }^{542}$ Wel dient het bestuursorgaan, gelet op de gemaakte bezwaren of beroepsgronden, met een open blik naar de besluitvorming te kijken en bereid te zijn het besluit ook wat betreft de gemaakte beleidskeuzes te heroverwegen. Dat laatste volgt ook al uit de heroverwegingsplicht als zodanig. Zo lang het bestuursorgaan echter, ook in de bestuurlijke voorprocedures, een besluit neemt met het oog op de behartiging van het algemene belang waarvoor de wetgever de bevoegdheid heeft toegekend en oneigenlijke belangen daarbij geen rol hebben gespeeld, handelt het echter binnen de marge van het verbod van vooringenomenheid. ${ }^{543}$

\section{Rule of necessity}

De kritiek in de literatuur dat de bestuursrechter het bestuur te zeer bejegent alsof sprake is van een rechterlijke instantie wat betreft de te eisen onpartijdigheid, houdt vooral verband met de situatie waarin het bestuursorgaan zelf (ingeval van een eenhoofdig bestuursorgaan) of een lid daarvan (in het geval van een meerhoofdig bestuursorgaan) het risico van vooringenomenheid loopt. Soms kan zich de situatie voordoen dat een lid van het bestuursorgaan of het bestuursorgaan zelf op grond van de wet de bevoegdheid of plicht heeft om deel te nemen aan de besluitvorming, terwijl er sprake kan zijn van schijn van belangenverstrengeling of partijdigheid. De vraag is dan op welke wijze de beweerdelijke schijn van vooringenomenheid weggenomen kan of moet worden. De wettelijke bevoegdheidsverdeling impliceert immers in beginsel dat de betreffende bestuurder deelneemt aan de besluitvorming. Zou dat, vanwege het verbod van vooringenomenheid, niet meer geoorloofd zijn, dan wordt de wettelijke bevoegdheidstoedeling doorkruist.

Als het gaat om collegiale bestuursorganen zou uitsluiting van het betreffende lid van het bestuursorgaan kunnen leiden tot verschuivingen in de stemverhoudingen. Deze problematiek is uitvoerig door Versteden en Neerhof besproken in verschillende bijdragen, onder meer naar aanleiding van een uitspraak van de Afdeling in de zaak Winsum. ${ }^{544}$ In het geval (schijn van) partijdigheid bestaat bij een lid van een collegiaal bestuursorgaan kan een stemonthouding van het betreffende lid van het bestuursorgaan uitkomst bieden. Bijzondere wetten voorzien vaak in een werkwijze voor dat soort gevallen. Artikel 28 Gemeentewet voorziet in een regeling als het gaat om de gemeenteraad en artikel 58 Gemeentewet verklaart die regeling ook van toepassing op vergaderingen van het college van b en w. ${ }^{545}$ Uit artikel 28 eerste lid sub a Gemeentewet volgt dat een lid van de gemeenteraad of het college van $b$ en w niet deelneemt aan de stemming over een aangelegenheid die hem rechtstreeks ofmiddellijk persoonlijk aangaat of waarbij hij als vertegenwoordiger is betrokken. Die bepaling heeft echter een beperktere strekking dan artikel 2:4 Awb. Er bestaat derhalve slechts in beperkte gevallen een belangenverstrengeling die op grond van artikel 28 Gemeentewet noopt tot stemonthouding. In de literatuur staan de bijzondere regelingen, vanwege hun beperkte strekking, dan ook niet zozeer ter discussie.

\footnotetext{
541. AbRvS 14 november 2007, JB 2008/11 m.nt. LJMT

542. R.J.N. Schlössels, 'Kroniek Beginselen van behoorlijk bestuur', NTB 2008, p. 98. Zie ook de noot van Timmermans onder punt 4 en 5 bij de uitspraak, $J B$ 2008/11

543. Jansen \& Peters, E 2.1.4-12.

544. AbRvS 7 augustus 2002, $A B$ 2003/3 m.nt. ARN; $J B$ 2002/280. Zie ook: Neerhof 2004, p. 46-55; Versteden 2002, p. 549 e.v.

${ }^{545}$ Zie voor een vergelijkbare regeling ten aanzien van GS en PS de artt. 28 lid 1 sub a en 58 de Provinciewet.
} 


\section{De inrichting van de voorprocedures}

Blijkens de jurisprudentie van de Afdeling blijft naast artikel 28 Gemeentewet echter ook nog artikel 2:4 Awb van betekenis en kan er vanwege een schending van artikel 2:4 Awb aanleiding bestaan tot stemonthouding. ${ }^{546}$ Daarop ziet de kritiek in de doctrine, die inhoudt dat de wetgever artikel 28 Gemeentewet als lex specialis bedoeld heeft en daarom geen betekenis aan artikel 2:4 Awb moet worden toegekend naast die regeling. Die opvatting hangt samen met het feit dat wordt aangenomen dat terughoudendheid betracht dient te worden met stemonthoudingen. ${ }^{547}$ Probleem hierbij is immers dat uit het systeem van wettelijke bevoegdheidstoedeling volgt dat een bestuursorgaan of leden daarvan zouden moeten kunnen blijven deelnemen aan de besluitvorming ook als sprake is van eerdere betrokkenheid bij de besluitvorming of belanghebbendheid van (een lid van) het bestuursorgaan bij de besluitvorming dan wel anderszins de schijn van partijdigheid wordt gewekt. ${ }^{548}$ De aanvullende betekenis van artikel 2:4 Awb leidt echter tot meer gevallen waarin stemonthouding moet plaatsvinden. ${ }^{549}$ De Afdeling oordeelt voor leden van meerhoofdige bestuursorganen, zoals de gemeenteraad, in elk geval anders over deze kwestie dan in de literatuur wordt voorgestaan. ${ }^{550}$ In de uitspraak Winsum overwoog de Afdeling dat door deelname aan de stemming van de gemeenteraad over de vrijstelling van het bestemmingsplan voor de bouw van een gemaalgebouw en schutsluis van een gemeenteraadslid, dat als juridisch medewerker van het waterschap betrokken was geweest bij het opstellen van het bouwplan en de aanvraag voor een bouwvergunning die het waterschap had ingediend, de schijn van belangenverstrengeling was gewekt. Omdat de gemeenteraad met de kleinst mogelijke meerderheid tot verlening van de vrijstelling had besloten, was die schijn gewekt en daarmee artikel 2:4, tweede lid, Awb geschonden. De Afdeling legt de verantwoordelijkheid voor de stemonthouding in dat verband bij het bestuursorgaan, de gemeenteraad, en niet bij het betreffende gemeenteraadslid. ${ }^{551}$ De gemeenteraad had deze situatie moeten voorkomen. Dat betekent dat de gemeenteraad een lid kan uitsluiten van de stemming. ${ }^{552}$ Eerder was de Afdeling in de uitspraak Simpelveld nog uitgegaan van een beperkte strekking van artikel 28 Gemeentewet. Aan de schijn van belangenverstrengeling die bestond in dat geval werden, gelet op de omstandigheid dat stemonthouding inbreuk maakt op het fundamentele recht van leden van een gemeenteraad als vertegenwoordigend lichaam om aan een stemming deel te nemen, geen gevolgen verbonden omdat het geen situatie betroft die onder die bepaling viel. ${ }^{553}$

Er wordt veelal een vergelijking getrokken met de uit het Engelse recht stammende 'rule of necessity'. ${ }^{554}$ Daaruit volgt dat uitzonderingen op de vereiste onpartijdigheid van een instantie mogelijk zijn, indien (de schijn van) partijdigheid niet valt te vermijden omdat geen andere instantie (als eindverantwoordelijke) de bevoegdheid kan uitoefenen. Een eenhoofdig bestuursorgaan zal hoe dan ook zijn bevoegdheid formeel moeten kunnen uitoefenen. ${ }^{55}$ Juist om het verschil met rechtspraak te benadrukken wordt in de literatuur aangegeven dat een dergelijke benadering ook grotendeels gehanteerd zou moeten worden bij meerhoofdige bestuursorganen. Argument daarvoor is dat de stemverhoudingen kunnen wijzigen door stemonthouding van een lid, aangezien het betreffende lid niet vervangen kan worden. De Winsum-uitspraak van de Afdeling heeft dan

\footnotetext{
546. AbRvS 7 augustus 2002, AB 2003/3 m.nt. A.R. Neerhof; JB 2002/280. Daarin oordeelde de Afdeling eers dat art. 28 Gemeentewet geen belemmeringen opwierp voor deelname aan de stemming in de gemeenteraad, maar dat er wel sprake was van een schending van art. 2:4 Awb.

${ }^{547 .}$ Neerhof 2004, p. 49-51; Versteden 2002, p. 553-554

548. Neerhof 1998, p. 123

${ }^{549}$ Neerhof 2004, p. 42-44 en 50; Versteden 2002, p. 554.

550. AbRvS 7 augustus 2002, $A B$ 2003/3 m.nt. A.R. Neerhof. Zie over deze uitspraak Versteden 2002, p. 549-558.

${ }^{551 .}$ Neerhof 2004, p. 43 en 50; Versteden 2002, p. 555

552. Zie ook: Neerhof 2004, p. 43 en 50; Versteden 2002, p. 555.

553. AbRvS 20 februari 1998, AB 1998/269 m.nt. GJ; JB 1998/76 m.nt. R.J.N.S. Zie hierover ook: Versteden 2002 , p. 549 e.v.

${ }^{554 .}$ Neerhof 2004, p. 50; Neerhof 1998, p. 123; Verheij 1995, p. 145-146

${ }^{555 .}$ Neerhof 2004, p. 50; Neerhof 1998, p. 123; Verheij 1995, p. 146-147.
} 


\section{Deel II Bestuurlijke voorprocedures}

ook om die reden kritiek ontvangen. ${ }^{556}$ Volgens verschillende auteurs doet de benadering van de Afdeling geen recht aan de democratische legitimatie van politiek ambtsdragers die bij de besluitvorming zijn betrokken en het verschil met ambtenaren of adviseurs die een rol hebben in de besluitvorming. ${ }^{557}$ De Afdeling zou in dit soort gevallen niet moeten oordelen dat sprake is van een schending van artikel 2:4 Awb. Een onderscheid tussen de primaire besluitvorming of de besluitvorming in de bezwaarfase wordt niet gemaakt. In dit soort gevallen kan de partijdigheid in primo ook doorwerken in bezwaar, aangezien het orgaan dat de beslissing neemt hetzelfde blijft.

Het voorgaande geldt mijns inziens ook voor het bestuursorgaan dat in administratief beroep zou moeten oordelen over een besluit waarbij om welke reden dan ook (schijn van) partijdigheid kan bestaan. Verschil is wel dat partijdigheid in primo niet doorwerkt in administratief beroep, omdat een ander orgaan over dat beroep oordeelt.

Vanwege de wettelijke bevoegdheidstoedeling zal, behoudens de mogelijkheid van delegatie, het in het geval van eenhoofdige bestuursorganen lastig zijn om de geconstateerde (schijn van) partijdigheid weg te nemen. Een ander bestuursorgaan het besluit laten nemen is immers geen optie. Het bestuursorgaan zou wellicht om de schijn van belangenverstrengeling te vermijden in dergelijke gevallen ook een externe adviseur kunnen inschakelen of een adviescommissie laten adviseren over de besluitvorming in de bestuurlijke voorprocedures. Mits in dat kader geen onpartijdigheidsgebreken bestaan, is daarmee wellicht de schijn van partijdigheid voldoende weggenomen. ${ }^{558}$

Een andere kwestie waarover vragen zijn gerezen naar aanleiding van de uitspraak Winsum is in hoeverre de Afdeling het (lokale) bestuurders toestaat of moet toestaan, gelet op artikel 2:4 Awb, dat zij uitdrukking geven aan een politieke of maatschappelijke betrokkenheid bij bepaalde onderwerpen. De cruciale overweging in de uitspraak Winsum betreft de passage waarin de Afdeling stelt dat het bestuur even afstandelijk dient te staan ten opzichte van alle af te wegen belangen. Zowel Neerhof als Versteden menen dat de Afdeling het bestuur hiermee te zeer op een lijn stelt met de rechter en de eigen aard van het besturen ontkent. ${ }^{559}$ Inherent aan besturen is nu eenmaal dat het bestuur staat voor een algemeen belang en dat het mogelijk moet zijn voor (lokale) bestuurders om engagement ten toon te spreiden zonder zich daarmee voor de besluitvorming te diskwalificeren. ${ }^{560}$ Voor een rechter ligt dat, gelet op zijn onafhankelijke positie en de onpartijdigheideisen die gelden, uiteraard anders.

Het verdient, gelet op het bovenstaande, dan ook de voorkeur om als het gaat om leden van een bestuursorgaan het begrip persoonlijk belang in artikel 2:4 Awb beperkt uit te leggen en niet te snel tot belangenverstrengeling te concluderen. ${ }^{561}$ Daarbij geldt wel de beperking dat het bestuur tegenover particuliere belangen altijd even afstandelijk en zakelijk dient te staan. Wat dat betreft behoeft er geen verschil te bestaan met de rechter. ${ }^{562}$ Het verschil ligt in de mogelijke politieke of maatschappelijke betrokkenheid bij een bepaald publiek belang. Bovendien moet er rekening gehouden worden met de 'rule of necessity' en mogelijke verschuivingen in stemverhoudingen binnen het collegiale bestuursorgaan, waardoor een beperkte uitleg van artikel 2:4 Awb ten aanzien van bestuurders verdedigbaar is.

\footnotetext{
556. Neerhof 2004, p. 49-50; Versteden 2002, p. 553 en 557.

557. Zie ook de noot van Neerhof bij Winsum, $A B$ 2003/3.

558. Dan zal het bestuursorgaan het advies wel onverkort moeten volgen. Zelfs dan is de vraag of dat voldoende moet worden geacht.

${ }^{559 .}$ Neerhof 2004, p. 46-49; Versteden 2002, p. 553

${ }^{560 .}$ Neerhof 2004, p. 46-49.

561. Zie ook: Neerhof 2004, p. 49

562. Neerhof 2004, p. 46
} 


\section{De inrichting van de voorprocedures}

Onpartijdigheid en bestuurlijke fasen in de jurisprudentie van het EHRM

Een belangrijke uitspraak van het EHRM mag in dit kader niet onbesproken blijven. Het betreft de zaak Kingsley t. Verenigd Koninkrijk. ${ }^{563}$ In die zaak hadden maatregelen plaatsgevonden op last van de 'Gaming Board', een bestuursorgaan dat in het Verenigd Koninkrijk toezicht houdt op de gokindustrie, tegen een gokbedrijf met verschillende casino's waarvan de klager, Kingsley, directeur was. De 'Gaming Board' dient in maart 1992 bezwaren in tegen de jaarlijkse vernieuwing van de vergunningen van het gokbedrijf en dient verzoeken tot intrekking van de bestaande vergunningen in bij het bevoegde bestuursorgaan, de 'Licensing Magistrates'. Kingsley trad terug als directeur en de afspraak was dat de Gaming Board dan geen bezwaar zou maken tegen de vernieuwing van de vergunningen. Het bedrijf verkreeg ook nog de toestemmingsverklaringen van de Gaming Board die nodig waren voor de vernieuwing van de vergunningen. De vergunningen werden in oktober 1992 ook verleend door de Licensing Magistrates. Eind 1992 en begin 1993 gaf de Gaming Board aan voornemens te zijn het certificaat van goedkeuring om een directeurspositie te bekleden in de gokindustrie van Kingsley in te trekken, omdat hij niet meer beschouwd werd als een 'fit and proper person' voor een directeurspositie in de gokindustrie. Vervolgens wordt er in het kader van de klacht van Kingsley dat hij het daar niet mee eens is een hoorzitting (section 19 hearing) gehouden voor 'the panel', een commissie bestaande uit leden van de Gaming Board. Het certificaat werd uiteindelijk ingetrokken. Vanwege het feit dat de leden van het panel van de Gaming Board ook betrokken waren bij de besluitvorming door de Licensing Magistrates en daar al hadden aangegeven dat Kingsley geen 'fit and proper person' meer was voor de directeurspositie, meende Kingsley echter dat er geen onpartijdige en eerlijke behandeling van zijn zaak had plaatsgevonden in die section 19 - procedure. Kingsley verzocht om 'judicial review' van die beslissing, omdat er sprake zou zijn geweest van 'bias'. Zijn klacht werd echter afgewezen. Volgens de oordelende rechter van het High Court was er, verkort weergegeven, geen sprake van 'uncounscious bias' en zelfs als die er wel zou zijn, moest 'the docrine of necessity' in beschouwing worden genomen. De beslissing omtrent de kwaliteiten van Kingsley kon niet gedelegeerd worden zelfs al zou er sprake zijn van 'bias' en daaruit volgt dat de beslissing in stand moest blijven. Ook het verzoek van Kingsley om 'leave to appeal' bij het Court of Appeal werd afgewezen.

Het EHRM moest vervolgens beoordelen in hoeverre het panel dat de 'section 19 hearing' had gehouden kon worden gezien als een onafhankelijk en onpartijdig gerecht in de zin van artikel 6, eerste lid, EVRM. Het Hof oordeelt dat het panel zelf, als 'adjudicatory body', geen onpartijdig gerecht is in de zin van artikel 6, eerste lid, EVRM. Dat is echter op zichzelf niet in strijd met artikel 6 EVRM omdat het een bestuursorgaan betreft en dat gebrek hersteld kan worden door een daaropvolgende procedure bij een onafhankelijke en onpartijdige rechterlijke instantie. Het beziet vervolgens of de beslissing van het panel wel onderhevig was aan controle door een onafhankelijk en onpartijdig gerecht met 'full jurisdiction', zoals het High Court of het Court of Appeal. Op het punt van de omvang van de toetsing en de bevoegdheden van de Engelste rechter loopt het vervolgens mis. Omdat het High Court of het Court of Appeal niet de bevoegdheid had om na een gegrondverklaring van een beroep van een klager wegens geconstateerde 'bias' bij het bestuursorgaan de zaak terug te wijzen naar een ander bestuursorgaan, is er volgens het Hof niet voldaan aan de eis van 'full jurisdiction'. ${ }^{564}$

563. EHRM 7 november 2000, Kingsley t. Verenigd Koninkrijk, AB 2003/25 m.nt. LV; EHRC 2000/92 m.nt. Heringa; EHRM 28 mei 2002, Kingsley t. Verenigd Koninkrijk, nr. 35605/97 (Grote Kamer-uitspraak). De Grote Kamer bevestigt de uitspraak van de Kamer, waardoor het oordeel in die uitspraak nog steeds overeind staat.

${ }^{564 .}$ Hoewel het panel zelf niet voldoende schijn van onpartijdigheid had om als gerecht in de zin van art. 6 lid 1 EVRM te kunnen worden aangemerkt, kon dat gecompenseerd worden indien de toetsing door het High Court wel volledig aan de uit art. 6 lid 1 EVRM voortvloeiende vereisten voldeed. En dat was in casu niet het geval De eis van 'full jurisdiction' vereist dat bij een geconstateerd onpartijdigheidsgebrek de rechter de mogelijkheid moeten hebben om ofwel zelf een beslissing te nemen ofwel terug te wijzen naar een ander orgaan. 
Deel II Bestuurlijke voorprocedures

Evenals in het Engelse recht het geval is, geldt in het Nederlandse bestuursrecht ook een onpartijdigheidsnorm voor bestuursorganen. In het Engelse recht is dat 'the rule against bias ${ }^{565}$ en in het Nederlandse bestuursrecht is dat het in artikel 2:4 Awb neergelegde verbod van vooringenomenheid. Zoals Verhey in zijn noot bij deze uitspraak opmerkt, bestond de klacht van Kingsley eruit dat de nationale onpartijdigheidsnorm voor het bestuur geschonden was, terwijl de rechter vervolgens, bij een gegrondverklaring van de klacht, niet de mogelijkheid had om de zaak terug te verwijzen naar een ander, naar nationaal recht beschouwd onpartijdig, bestuursorgaan. Om die reden acht het EHRM ook artikel 6, eerste lid, EVRM en de eis van 'full jurisdiction' geschonden, en niet de onpartijdigheidseisen uit artikel 6, eerste lid, EVRM. Die onpartijdigheidseisen hebben immers uitsluitend betrekking op rechterlijke instanties. Zoals Verhey ook opmerkt kan uit deze uitspraak derhalve niet worden afgeleid dat een bestuursorgaan niet aan de voor hem geldende onpartijdigheideisen voldoet, omdat het bestuursorgaan al een standpunt heeft ingenomen in de besluitvorming. Die onpartijdigheidseisen worden door het nationale recht genormeerd en worden voor het bestuur ook anders ingevuld, gelet op zijn specifieke positie en taken in het nationale staatsbestel. Daaraan doet de uitspraak Kingsley van het EHRM geen afbreuk. ${ }^{566}$ Hoewel er uit artikel 6, eerste lid, EVRM niet zozeer onpartijdigheidseisen voor het bestuur kunnen worden afgeleid, laat dat vanzelfsprekend onverlet dat er wél naar nationaal recht onpartijdigheideisen (kunnen) gelden. Duidelijk is echter dat de eisen die artikel 6 EVRM stelt aan de rechterlijke procedure niet dezelfde eisen impliceren voor de bestuurlijke procedures. Wel is het zo dat er in sommige gevallen voor de bestuursrechter, bij een schending van artikel 2:4 Awb in de bestuurlijke voorprocedures (of in de primaire besluitvorming zonder dat dit gebrek in de bestuurlijke voorprocedures hersteld wordt) aanleiding kan bestaan om gebruik te maken van zijn bevoegdheid om zelf in de zaak te voorzien op grond van artikel 8:72, vierde lid, Awb. ${ }^{567}$ De bestuursrechter kan de zaak immers niet terugwijzen naar een ander, niet bevoegd, bestuursorgaan. Een andere mogelijkheid zou wellicht zijn dat de bestuursrechter het bestuursorgaan opdraagt om een nieuw besluit te nemen op grond van bijvoorbeeld artikel 8:72, vijfde lid, Awb en daarbij een onafhankelijke adviescommissie in te stellen. De belangrijkste conclusie op grond van het bovenstaande is dat partijdigheid aan de kant van het bestuur, op grond van artikel 6 EVRM en de Kingsley-uitspraak van het EHRM, kan doorwerken in de eisen die gesteld worden aan de omvang van de toetsing en bevoegdheden van de bestuursrechter.

\section{De bestuurlijke heroverweging}

De laatste begrenzing van de onpartijdigheid van het bestuur in de bezwaarschriftprocedure vloeit voort uit de omstandigheid dat het een procedure betreft tegen een besluit van hetzelfde bestuursorgaan dat opnieuw in volle omvang te oordelen heeft over datzelfde besluit. Inherent aan de bezwaarschriftprocedure is derhalve dat de vereiste onpartijdigheid zich niet zover uitstrekt dat hetzelfde bestuursorgaan niet voor de tweede maal zou mogen oordelen over het betreffende besluit. ${ }^{568}$ In dat opzicht vallen de onpartijdigheideisen voor de bezwaarschriftprocedure niet te vergelijken met die voor de rechterlijke procedure. Het bestuur is altijd in zekere zin rechter in eigen zaak en moet in de bezwaarschriftprocedure zijn eigen besluit en eerder ingenomen standpunt opnieuw beoordelen. ${ }^{569}$ Een zekere mate van vooringenomenheid of risico daarop, ligt derhalve in de aard van de procedure besloten. ${ }^{570}$ Een dergelijke dubbele betrokkenheid is voor de rech-

\footnotetext{
${ }^{565 .}$ P. Cane, Administrative Law, Oxford University Press 2004, p. 133 e.v. Zie ook de noot van Verhey bij Kingsley, $A B$ 2003/25.

566. Zie ook: Neerhof 2004, p. 52

567. Zie ook de noot van Verhey bij Kingsley, AB 2003/25

${ }^{568 .}$ Vgl. Verheij 1995, p. 150.

569. Sanders 1998, p. 106. Hiermee wordt overigens niet bedoeld dat het bestuur te allen tijde een persoonlijk belang bij de besluitvorming heeft, zoals het zijn van rechter in eigen zaak voor de rechter impliceert.

${ }^{570 .}$ Verheij 1995, p. 140-141 en 150.
} 


\section{De inrichting van de voorprocedures}

ter, als beslisser in beroep en bijvoorbeeld hoger beroep, vanuit een oogpunt van onpartijdigheid niet geoorloofd. ${ }^{571}$ Het bestuurlijke karakter van de bezwaarschriftprocedure, dat voortvloeit uit de heroverweging door hetzelfde bestuursorgaan en de daarmee samenhangende functies, zou echter tenietgaan, indien dermate verstrekkende onpartijdigheid van het bestuur geëist zou worden. De betekenis van onpartijdigheid is derhalve in de bezwaarschriftprocedure per definitie beperkt(er). Het bestuursorgaan is immers het bevoegde orgaan dat een besluit moet nemen als uitkomst van de te verrichten heroverweging. Derhalve kan de onpartijdigheid in dit opzicht niet verder strekken dan het uitsluiten van betrokkenheid bij de eerdere besluitvorming van (een deel van) de behandelaars van het bezwaar. De omstandigheid dat het niet verplicht is om een geheel externe adviescommissie in te schakelen alsmede dat artikel 7:5 Awb niet voorschrijft dat alle behandelaars van de bezwaarschriften niet bij de eerdere besluitvorming betrokken zijn geweest, duidt er ook op dat eerdere betrokkenheid niet als zodanig strijd met het verbod van vooringenomenheid hoeft op te leveren. Ook Sanders meent dat onpartijdigheid in bezwaar een andere invulling dan voor de rechterlijke procedure behoort te krijgen en moet worden opgevat als geen inhoudelijke bemoeienis van de personen die de bezwaarschriften behandelen met de totstandkoming van de primaire beslissing. ${ }^{572}$ Evenals bij onafhankelijkheid kunnen er verschillende gradaties van onpartijdigheid worden onderscheiden: volledige onpartijdigheid (de bezwaarbehandelaars zijn niet bij de totstandkoming van de bestreden beslissing betrokken geweest), grotendeels onpartijdig (de meerderheid van de bezwaarbehandelaars zijn niet bij de totstandkoming van de bestreden beslissing betrokken geweest), in beperkte mate onpartijdig (de minderheid van de bezwaarbehandeaars is niet bij de totstandkoming van de bestreden beslssing betrokken geweest) en geen onpartijdigheid (de bezwaarbehandelaars zijn allemaal of in meerderheid bij de totstandkoming van de bestreden beslissing betrokken geweest). ${ }^{573}$ De indeling van Sanders ziet ten onrechte uitsluitend op de eerdere betrokkenheid bij de besluitvorming, terwijl er nog andere gevallen denkbaar zijn die zien op persoonlijke belangen van de betrokkenen. Het begrip vooringenomenheid is derhalve ruimer en onder de werking van het verbod van vooringenomenheid, zoals neergelegd in artikel 2:4 Awb, vallen niet alleen situaties waarin sprake is van eerdere betrokkenheid bij de besluitvorming. In welke gevallen er precies strijd met het verbod van vooringenomenheid kan bestaan, komt in de volgende paragraaf aan de orde. Vaststaat dat eerdere betrokkenheid bij de besluitvorming niet per definitie in strijd is met artikel 2:4 Awb.

De hiervoor beschreven problematiek is kenmerkend voor de bezwaarschriftprocedure als bestuurlijke voorprocedure. In administratief beroep speelt dit probleem niet of in mindere mate, omdat een ander bestuursorgaan het genomen besluit moet heroverwegen. In die gevallen oordeelt echter ook een orgaan dat onderdeel is van de uitvoerende macht over een besluit van een ander orgaan dat onderdeel is van diezelfde uitvoerende macht. Dat zou wellicht voor sommige burgers al reden of rechtvaardiging vormen voor twijfel aan de onpartijdigheid van het beroepsorgaan, maar objectief gezien is dat enkele feit onvoldoende reden om partijdigheid in de administratief beroepsprocedure aan te nemen. Dan zouden er nog meer en andere factoren moeten bestaan die duiden op vooringenomenheid. De mogelijkheid bestaat wel dat er al over de betreffende kwestie in een eerdere fase van de besluitvorming overleg is geweest met het administratief beroepsorgaan. Te denken valt aan de situatie waarin overleg wordt gevoerd tussen organen op gemeentelijk en provinciaal niveau over de besluitvorming, beleid of projecten. De grens van wat geoorloofd is ligt hier, lijkt mij, bij wat vereist is voor een objectieve en nieuwe beoordeling van het voorliggende besluit.

\footnotetext{
${ }^{571 .}$ Zie ook Deel I, par. 4.3.4.

572. Sanders 1998, p. 106.

${ }^{573 .}$ Sanders 1998, p. 106. Sanders gaat uit van drie gradaties, maar zoals ik al heb aangegeven in het kader van de onafhankelijkheid in bezwaar, kunnen er mijns inziens vier gradaties worden onderscheiden, zie par. 5.4.2.
} 
Deel II Bestuurlijke voorprocedures

De buitengrenzen van de onpartijdigheideisen

Binnen het hiervoor geschetste kader en tegen de hiervoor geschetste achtergrond, dienen de onpartijdigheideisen van het bestuur geplaatst te worden. Invulling van die eisen vindt plaats, zoals in de volgende paragraaf zal blijken, en behoort ook plaats te vinden met inachtneming van de taken van het bestuur en de positie die het bestuur inneemt in onze democratische rechtsstaat. Dat betekent dat de hiervoor genoemde begrenzingen de buitengrenzen vormen voor de vereiste onpartijdigheid van het bestuur. Van het bestuur kan een bepaalde mate van onpartijdigheid verwacht worden, mits deze eisen de buitengrenzen niet overschrijden. In dat opzicht kan hier reeds vastgesteld worden dat de mate van onpartijdigheid die het bestuur moet betrachten in de bestuurlijke voorprocedures beperkter is dan die van de rechter. Binnen het hiervoor geschetste kader moet derhalve onderzocht worden in hoeverre de rechterlijke onpartijdigheideisen van invloed zijn (geweest) op de bestuurlijke onpartijdigheideisen. Dat onderzoek geschiedt in de volgende paragrafen.

\subsubsection{Categorieën van mogelijke partijdigheid van het bestuur}

\section{Inleiding}

In de literatuur hebben in het kader van artikel 2:4 verschillende categoriseringen plaatsgevonden van gevallen die onder de werking van deze bepaling vallen. ${ }^{574}$ Grotendeels stemmen de onderscheiden categorieën overeen. Het verbod van vooringenomenheid ziet in hoofdlijnen op twee situaties: 1) het voorkomen dat persoonlijke - dat wil zeggen alle niet tot het algemeen belang behorende - belangen de besluitvorming vertroebelen en 2) het voorkomen dat eerdere betrokkenheid bij de besluitvorming (in een andere fase van de procedure) de objectiviteit van de besluitvorming in gevaar brengt. Binnen deze hoofdcategorieën kan een onderscheid gemaakt worden naar de hoedanigheid van het orgaan of de persoon die betrokken is bij het besluit in de voorprocedure. Dat kan het bestuursorgaan zelf of een lid daarvan, een ambtenaar of een adviseur zijn. Artikel 2:4 eerste lid ziet op de gevallen waarin het het bestuursorgaan zelf betreft, terwijl het tweede lid ziet op de gevallen waarin sprake is van personen die werkzaam zijn onder de verantwoordelijkheid van het bestuursorgaan of daarvan deel uitmaken. De verschillende categorieën worden hieronder, aan de hand van jurisprudentie, nader toegelicht. Opmerking verdient dat deze indeling op hoofdlijnen de gevallen dekt die zich in de praktijk kunnen voordoen. ${ }^{575} \mathrm{Bij}$ de verschillende categorieën wordt ook aangegeven, indien van belang, in hoeverre voor de rechter eenzelfde invulling aan het onpartijdigheidsbeginsel wordt gegeven.

\footnotetext{
1) Persoonlijk belang bij de besluitvorming

Evenals voor de rechter is het voor het bestuursorgaan (of leden daarvan) of personen die voor het bestuursorgaan werkzaam zijn en bij de besluitvorming betrokken zijn, niet geoorloofd om een persoonlijk belang te hebben bij de besluitvorming. Dat is ook expliciet tot uitdrukking gebracht in artikel 2:4, tweede lid, van de Awb. Onder persoonlijk belang in de zin van deze bepaling worden, zoals eerder werd aangegeven, alle belangen verstaan die niet behoren tot de belangen die het bestuursorgaan uit hoofde van de hem opgedragen taak behoort te behartigen. Verheij geeft aan dat het tweede lid zich richt tegen bestuurders en ambtenaren die hun persoonlijke belangen laten prevaleren boven het algemeen belang en een uitwerking vormt van het uitgangspunt dat de overheid te allen tijde het algemeen belang dient te behartigen. ${ }^{576}$ Indien het tweede lid niet van

574. Zie: Jansen \& Peters, E 2.1.4-1 e.v.; Neerhof 2004, p. 39 e.v.; Neerhof 1998, p. 120 e.v.; Verheij 1995, p. 144-145.

${ }^{575 .}$ Het administratief beroep wordt uitsluitend afzonderlijk aangestipt voor zover jurisprudentie daartoe aanleiding geeft.

576. Verheij 1995, p. 143.
} 


\section{De inrichting van de voorprocedures}

toepassing is, omdat de belanghebbende niet behoort tot de daar genoemde kring van personen, dan geldt nog steeds het algemenere eerste lid. ${ }^{577}$

Een persoonlijk belang bij de besluitvorming kan zich op verschillende manieren manifesteren:

a) een bestuurder of een ambtenaar (of andere persoon) die werkzaam is voor of onderdeel uitmaakt van het bestuursorgaan, heeft een eigen belang bij de uitkomst van de besluitvorming als belanghebbende;

b) een variant daarop noemt Verheij: de overheidsorganisatie of rechtspersoon waartoe de beslisser (bestuurder of ambtenaar) behoort is belanghebbende bij de besluitvorming; c) een (rechts)persoon waarmee een bestuurder dan wel een ambtenaar een relationele band heeft, heeft belang bij de uitkomst van de besluitvorming als belanghebbende;

d) een door het bestuursorgaan ingeschakelde adviseur of een lid dan wel leden van de adviescommissie zijn belanghebbende bij de besluitvorming;

e) een door het bestuursorgaan ingeschakelde adviseur of een lid dan wel leden van de adviescommissie hebben een relationele band met een (rechts)persoon die belang heeft bij de uitkomst van de besluitvorming als belanghebbende.

Deze verschillende categorieën worden in het onderstaande, voor zover mogelijk, aan de hand van jurisprudentie toegelicht. ${ }^{578}$

\section{a) en c) een bestuurder of ambtenaar met eigen belang of familielid/kennis met eigen belang}

Onder deze categorieën vallen situaties waarbij een bestuur of ambtenaar, dan wel iemand in diens familie- of naaste kennissenkring, een eigen belang heeft bij de besluitvorming, omdat hij of zij (dan wel zijn of haar familielid of kennis) belanghebbende is bij een besluit. Duidelijk is dat een functionaris die direct of indirect een privébelang heeft bij het betreffende besluit, zoveel mogelijk van de besluitvorming moet worden uitgesloten. ${ }^{579}$ Daarbij kan het gaan om een ambtenaar die in mandaat moet beslissen of intern moet adviseren met een persoonlijk belang bij de besluitvorming. Het bestuursorgaan moet ervoor waken dat dergelijke personen betrokken zijn bij de besluitvorming en zo nodig andere personen op de zaak zetten. ${ }^{580}$

Voor bestuurders kan de situatie iets anders liggen. Artikel 28, eerste lid, sub a Gemeentewet en artikel 28, eerste lid, sub a Provinciewet voorzien bijvoorbeeld in een bijzondere regeling in onder meer deze gevallen voor de gemeenteraad, het college van $b$ en w, gedeputeerde staten en provinciale staten. ${ }^{581}$ Doet deze situatie zich voor dan dienen de betreffende leden van deze bestuursorganen niet deel te nemen aan de stemming. Zoals aangegeven, is op grond van de jurisprudentie van de Afdeling voor deze organen daarnaast ook nog artikel 2:4 Awb van belang. Die bepaling kan er, in elk geval wanneer de betreffende bestuurder de doorslaggevende stem heeft en de besluitvorming met de kleinst mogelijke meerderheid plaatsvond, toe leiden dat een bestuurder zich moet terugtrekken uit de stemming. ${ }^{52}$ Aangenomen kan worden dat er buiten deze situatie in dit soort gevallen niet snel sprake zal zijn van een schending van artikel 2:4 Awb.

\footnotetext{
577. PG Awb I, p. 180.

578. Zie in algemene zin voor een uitvoerig overzicht van jurisprudentie: Jansen \& Peters E 2.1.4-1/30.

${ }^{579 .}$ Neerhof 2004, p. 40 met verwijzingen. Zie ook: Neerhof 1998, p. 120; Verheij 1995, p. 144-147.

${ }^{580 .}$ Vgl. Damen e.a. 2009, Deel I, p. 265.

${ }^{581 .}$ In combinatie met artikel 58 van beide wetten overigens voor zover het gaat om het college van b en w en gedeputeerde staten.

582. Dat is het gevolg van de hiervoor besproken uitspraak in de zaak Winsum, AbRvS 7 augustus 2002, $A B$ 2003/3 m.nt. A.R. Neerhof; JB 2002/280. Zie ook: Verheij 1995, p. 146-147.
} 


\section{Deel II Bestuurlijke voorprocedures}

b) de overheidsorganisatie als belanghebbende

Het komt regelmatig voor dat een overheidsorganisatie zelf een aanvraag doet voor een bepaald besluit waarbij ambtenaren of bestuursorganen die behoren tot diezelfde overheidsorganisatie moeten oordelen over die aanvraag. Het meest gebruikte voorbeeld is dat van een bouwvergunning die wordt aangevraagd bij het college van $b$ en w van de eigen gemeente voor een bouwproject van diezelfde gemeente. Een dergelijke situatie levert niet per definitie een schending van artikel 2:4 Awb op. In een zaak waarin door de adviescommissie, bestaande uit een wethouder en twee ambtenaren van de afdeling bouwen en wonen van de gemeente werd geadviseerd over de beslissing op bezwaar tegen de verlening van een bouwvergunning, was er volgens de Afdeling geen probleem. ${ }^{583}$ Een andere situatie was aan de orde in de zaak Stadsmobiel waarin in de bezwaaradviescommissie, in de zin van artikel 7:13 Awb, ambtenaren van de gemeente Amsterdam zitting hadden die moesten oordelen over een vergunning die was aangevraagd door het eigen gemeentelijk vervoerbedrijf van de gemeente Amsterdam. In dat geval achtte het College artikel 2:4 Awb geschonden. ${ }^{584}$ Hierdoor was tenminste de 'schijn van partijdigheid' waardoor deze bepaling was geschonden. Niet nodig is echter dat de bezwaardadviescommissie een andere samenstelling moet krijgen, omdat een ambtenaar van de gemeente, namens de gemeente, een aanvraag voor een vergunning indient. De vereiste onpartijdigheid, op grond van artikel 2:4 Awb, is te meer gewaarborgd, indien de ambtenaar die het primaire besluit heeft genomen en de ambtenaar die het besluit in mandaat heeft genomen geen deel uitmaken van de bezwaaradviescommissie. $^{585}$

d) en e) een adviseur, adviescommissie of deskundige dan wel familie of kennissen daarvan met eigen belang

Niet alleen als een ambtenaar met een eigen belang betrokken is bij de besluitvorming kan dat problematisch zijn in het licht van artikel 2:4 Awb. Ook als het bestuursorgaan externe adviseurs, adviescommissies of deskundigen inschakelt, moet het ervoor waken dat deze of familieleden dan wel andere personen met wie een nauwe band bestaat geen persoonlijk belang hebben bij de besluitvorming. Als de advisering een belangrijke rol speelt bij de besluitvorming, kan immers op deze wijze de besluitvorming oneigenlijk worden beïnvloed. ${ }^{56}$ Volgens het College van beroep voor het bedrijfsleven zal de (grootstmogelijke) meerderheid van de commissie die adviseert geen persoonlijk belang bij de besluitvorming mogen hebben. ${ }^{587}$

In dat verband geldt voor de rechter hetzelfde bij inschakeling van een deskundige zo is gebleken uit de uitspraak Sara Lind Eggertsdóttir t. IJsland van het EHRM. Daarin werkten de gebreken in de onpartijdigheid van de door de rechter ingeschakelde deskundige ook door in de onpartijdigheid van de rechter en leidden tot een schending van de vereisten van artikel 6 EVRM. ${ }^{58}$

\section{2) Eerdere betrokkenheid bij de besluitvorming}

De tweede hoofdcategorie werd gevormd door de situatie dat eerdere betrokkenheid bij de besluitvorming van een functionaris problematisch is. Eerdere betrokkenheid bij de besluitvorming in een andere fase kan met zich brengen dat de personen die betrokken zijn bij de besluitvorming niet meer met een open houding de besluitvorming en de aan-

\footnotetext{
583. AbRvS 16 december 1997, JB 1998/30 m.nt. A.R. Neerhof in $J B 1998 / 24$.

584. CBb 21 december 1994, JB 1995/21; AB 1995/454 m.nt. JHvdV; Rawb 1995/34 m.nt. BdeW. Zie hierover ook Verheij 1995, p. 139-154.

${ }^{585 .}$ AbRvS 16 december 1997, JB 1998/30 m.nt. ARN. Ook speelt volgens de Afdeling mee dat de desbetreffende twee ambtenaren geen persoonlijk belang hadden bij de besluitvorming.

${ }^{586 .}$ Neerhof 1998, p. 120. Vgl. No 4 mei 2004, $A B$ 2004/301 m.nt. P.J. Stolk.

587. Vgl.: CBb 25 januari 1994, $A B$ 1998/338 m.nt. JHvdV.

588. Zie hierover par. 4.3.4 van Deel I.
} 


\section{De inrichting van de voorprocedures}

gevoerde standpunten in de bestuurlijke voorprocedures kunnen bezien. In de bestuurlijke voorprocedures doet zich deze situatie nadrukkelijk voor, aangezien het bestreden besluit een tweede bestuurlijke fase dient te doorlopen. Inherent aan die bestuurlijke voorprocedures, in het bijzonder de bezwaarschriftprocedure, is de eerdere betrokkenheid van het beslissende bestuursorgaan. In dat opzicht kan geen (schijn van) vooringenomenheid aangenomen worden. Wel kan eerdere betrokkenheid in een andere fase van de besluitvorming problematisch zijn, indien het andere personen betreft dan het bestuursorgaan zelf. Het betreft in deze gevallen eerdere betrokkenheid in dezelfde hoedanigheid of functie bij de besluitvorming. Eerdere betrokkenheid bij de besluitvorming kan zich echter ook in een andere hoedanigheid of functie voordoen. Ook in die gevallen kan er schijn van partijdigheid bestaan. Binnen de categorie eerdere betrokkenheid kan derhalve een tweedeling worden aangebracht in eerdere betrokkenheid in dezelfde functie of hoedanigheid en eerdere betrokkenheid in een andere hoedanigheid.

De volgende onderverdeling wordt gehanteerd:

a) eerdere betrokkenheid van (leden van) het bestuursorgaan in dezelfde hoedanigheid bij de besluitvorming;

b) eerdere betrokkenheid van ambtenaren in dezelfde hoedanigheid of functie bij de besluitvorming;

c) eerdere betrokkenheid van adviseurs, adviescommissies en deskundigen in dezelfde hoedanigheid bij de besluitvorming;

d) eerdere betrokkenheid van leden van het bestuursorgaan in een andere hoedanigheid of functie;

e) eerdere betrokkenheid van ambtenaren werkzaam bij of onder de verantwoordelijkheid van het bestuursorgaan in een andere hoedanigheid of functie;

f) eerdere betrokkenheid van door het bestuursorgaan ingeschakelde adviseurs of een lid dan wel de leden van een adviescommissie in een andere hoedanigheid of functie.

a), b) en c) eerdere betrokkenheid van (leden van) het bestuursorgaan, ambtenaren en andere personen in dezelfde hoedanigheid of functie

Ten aanzien van het bestuursorgaan of leden van het bestuursorgaan kan opgemerkt worden, zoals hierboven al werd gedaan, dat het inherent is aan de bestuurlijke heroverweging die moet plaatsvinden in de bestuurlijke voorprocedures dat zij in dezelfde hoedanigheid nogmaals over het besluit oordelen. De eerdere betrokkenheid van het bestuursorgaan is vanzelfsprekend niet in strijd met artikel 2:4 Awb. Datzelfde geldt voor de betrokkenheid van (leden van) het bestuursorgaan bij het horen.

Voor ambtenaren geldt dat niet. Om de objectiveit van ambtenaren in de bestuurlijke voorpocedures te waarborgen is in artikel 10:3, derde lid, Awb neergelegd dat een en dezelfde ambtenaar die in mandaat het besluit in primo genomen heeft niet ook in mandaat het besluit op bezwaar mag nemen. De rechtspraak houdt daaraan ook strikt de hand. ${ }^{589}$ De bepaling wordt gezien als een codificatie van hetgeen reeds voor de Awb gold op grond van het ongescreven recht. ${ }^{590}$ Deze situatie kan zich in administratief beroep niet voordoen, omdat het niet is toegestaan een ambtenaar in mandaat het besluit op het beroep te laten nemen, gelet op artikel 10:3, tweede lid, sub c Awb.

Als het gaat om het horen in de bezwaarschriftprocedure voorziet artikel 7:5 Awb in onpartijdigheidswaarborgen in het kader van eerdere betrokkenheid bij de besluitvorming. Uit die bepaling vloeit immers voort dat het horen, indien het om andere personen dan leden van het bestuursorgaan gaat, moet plaatsvinden door een persoon die niet bij de voorbereiding van het primaire besluit is betrokken of door een meerderheid van personen, onder wie de voorzitter, die niet bij de voorbereiding van het primaire besluit

${ }^{589 .}$ HR 16 februari 2007, $A B$ 2007/138 m.nt. R.J.G.M. Widdershoven; CBb 20 februari 2003, $A B$ 2003/150 m.nt. JHvdV; AbRvS 17 augustus 1999, $A B$ 1999/412.

${ }^{590 .}$ Zie al anticiperend op art. 10:3 lid 3 Awb: AbRvS 16 september 1996, AB 1997/147 m.nt. GJ. 


\section{Deel II Bestuurlijke voorprocedures}

betrokken is geweest. Deze bepaling biedt waarborgen indien het horen door een ambtenaar of interne commissie plaatsvindt. Voorkomen moet worden dat de eerdere betrokkenheid bij de besluitvorming leidt tot het niet meer onbevangen horen.

Over de invulling van het begrip eerdere betrokkenheid bestaat inmiddels wat jurisprudentie. De eerdere betrokkenheid kan immers verschillende vormen aannemen. ${ }^{591}$ De eerdere betrokkenheid mag niet beperkt worden uitgelegd tot 'direct bij de voorbereiding van het primaire besluit betrokken zijn'. ${ }^{592}$ Strijd met artikel 7:5 leidt tot vernietiging van het besluit. ${ }^{593}$

De verhouding van deze bepaling tot artikel 2:4 Awb in de rechtspraak is niet geheel duidelijk. Het lijkt erop dat artikel 2:4 Awb de algemene meeromvattende norm bevat en artikel 7:5 Awb als een uitwerking daarvan gezien wordt. ${ }^{594}$ Aan artikel 2:4 Awb lijkt daarnaast nog aanvullende betekenis toe te komen. ${ }^{595}$ In een uitspraak onderzoekt de Centrale Raad bijvoorbeeld, na geconstateerd te hebben dat artikel 7:5, eerste lid, sub a Awb niet geschonden is, of daarnaast artikel 2:4 Awb in acht is genomen. ${ }^{596}$ Een dergelijke verhouding tussen deze bepalingen lijkt mij ook in de rede liggen, omdat er altijd nog sprake kan zijn van een persoon met een eigen of persoonlijk belang en die situatie wordt niet gedekt door artikel 7:5 Awb.

Als het horen deels extern plaatsvindt door een commissie als bedoeld in artikel 7:13 Awb zijn reeds bepaalde onafhankelijkheidswaarborgen ten behoeve van de onpartijdigheid in acht genomen. Ook hier geldt echter dat de verhouding tussen deze bepaling en artikel 2:4 Awb in de rechtspraak niet geheel duidelijk is, maar dat artikel 2:4 Awb daarnaast nog van betekenis kan zijn. ${ }^{597}$

d), e) en f) eerdere betrokkenheid van (leden van) het bestuursorgaan, ambtenaren en andere personen in een andere hoedanigheid of functie

Er zijn voorbeelden in de jurisprudentie te vinden van bezwaaradviescommissies waarvan de voorzitter of leden een (voormalig) lid van het bestuursorgaan dat het primaire besluit genomen heeft was. Dat levert volgens de bestuursrechter soms strijd op met artikel 2:4 Awb. ${ }^{598}$ Een met het horen belaste bezwaaradviescommissie waarin twee ambtenaren plaatshebben die bij de totstandkoming van het primaire besluit betrokken en waarvan de voorzitter een wethouder waren, is echter niet per definitie in strijd met artikel 2:4 Awb. ${ }^{599}$ Betrokkenheid in drie verschillende hoedanigheden van een wethouder bij alle fasen van de besluitvorming inzake een bestemmingsplan is daarentegen wel teveel van het goede en in strijd met het verbod van vooringenomenheid. ${ }^{600}$

Vergelijking met de rechterlijke onpartijdigheidseisen

In de hiervoor genoemde situaties onder 1) persoonlijk belang en onder 2) eerdere betrokkenheid kan zich een schending van het verbod van vooringenomenheid voordoen. Indien deze situaties zich bij een lid van een rechterlijke instantie of een rechter zouden

591. Zie bijvoorbeeld: CRvB 3 mei 2005, JB 2005/220

592. CRvB 30 mei 2008, JB 2008/171.

593. CRvB 30 mei 2008, JB 2008/171; CBb 27 februari 1996, AB 1997/252 m.nt. ICvdV.

594. CRvB 30 mei 2008, JB 2008/171.

595. Zie bijvoorbeeld: AbRvS 16 december 1997, JB 1998/30; Pres.Rb. Maastricht, 19 augustus 1996, JB 1996/211 m.nt. MAH.

596. CRvB 22 november 2005, JB 2006/37 m.nt. Wenders. Overigens maakt de CRvB in deze uitspraak ook gebruik van zijn bevoegdheid tot ambtshalve aanvulling van de rechtsgronden op grond van artikel 8:69 lid 2 Awb. In een andere uitspraak stelt de CRvB echter weer dat 7:5 Awb dient ter voorkoming van vooringenomenheid. Niet duidelijk wordt daaruit of daarnaast nog aan art. 2:4 Awb betekenis toekomt, zie: CRvB 30 mei 2008, $J B$ 2008/171.

${ }^{597 .}$ Zie ook mijn noot bij $J B$ 2006/37. Zie ook: Neerhof 2004, p. 44; Verheij 1995, p. 140-141.

${ }^{598}$ Zie bv.: Rb. Leeuwarden 8 februari 1996, JB 1996/100.

599. Zie Jansen \& Peters, E 2.1.4-8 die wijzen op AbRvs 24 december 2003, LJN AO0806.

${ }^{600}$ De Afdeling vernietigt het besluit overigens wegens strijd met art. 3:2 Awb, AbRvS 28 oktober 1997, JB 1998/6; AB 1997/458 m.nt. P.J.J. van Buuren. 


\section{De inrichting van de voorprocedures}

voordoen, zou er al eerder een schending van het onpartijdigheidsbeginsel (al dan niet zoals neergelegd in artikel 6 EVRM) worden aangenomen. In die gevallen zou er immers objectief gerechtvaardigde twijfel aan de onpartijdigheid kunnen bestaan en de schijn van partijdigheid gewekt kunnen zijn. Als het gaat om persoonlijke belangen die de beslissing van de oordelende instantie kunnen beïnvloeden lopen de bestuurlijke en rechterlijke onpartijdigheidseisen echter niet zeer uiteen, al zijn er situaties die inherent zijn aan de bestuurlijke besluitvorming en bevoegdheidsverdeling die voor het bestuur geoorloofd zijn, terwijl dat voor de rechter anders zou liggen. Hetzelfde geldt voor de inschakeling en de samenstelling van (bezwaar)adviescommissies of adviseurs. Eerdere betrokkenheid van een deel van een door de rechter ingeschakelde adviescommissie of deskundigen zou mijns inziens in een rechterlijke procedure eerder problematisch zijn.

\subsubsection{Een vergelijking met de rechterlijke onpartijdigheideisen}

De subjectieve en objectieve toets inzake rechterlijke partijdigheid

In de literatuur is meermalen het standpunt ingenomen dat de bestuursrechter het bestuur, ten aanzien van de vereiste onpartijdigheid, te zeer benadert alsof sprake zou zijn van rechtspraak. ${ }^{601}$ Dat punt van kritiek ziet vooral op de te eisen onpartijdigheid van bestuurders zelf en de gevolgen die verbonden worden aan de constatering dat sprake is van vooringenomenheid voor de (collegiale) besluitvorming. Het gaat dan om situaties als aan de orde in de zaak Winsum. De bestuursrechter zou niet te snel moeten oordelen dat verbondenheid aan een algemeen belang van een bestuursorgaan of lid daarvan leidt tot belangenverstrengeling die een schending van artikel 2:4 Awb oplevert. Problematisch daarbij is dat, gelet op de democratische legitimatie van collegiale bestuursorganen en de leden ervan, een bestuurder niet eenvoudig vervangen kan worden. Hierop ben ik paragraaf 5.4.3.3 al ingegaan.

Er wordt echter ten aanzien van nog een ander aspect vaak een verband gelegd met de rechterlijke onpartijdigheideisen: het onderscheid tussen de subjectieve en objectieve toets of sprake is van partijdigheid. Zowel in de literatuur als in de rechtspraak wordt in bepaalde gevallen aangegeven dat niet alleen daadwerkelijke partijdigheid moet worden vermeden, maar ook de schijn van partijdigheid moet worden vermeden op grond van artikel 2:4 Awb. Verheij, die het verbod van vooringenomenheid beschouwt als 'een op het bestuur toegeschreven versie van een veel algemenere norm die diep in ons rechtsbewustzijn is geworteld', neemt bijvoorbeeld dat standpunt in. ${ }^{602}$ Hij meent dat het in beginsel voor het bestuursrecht onjuist is om daadwerkelijke beïnvloeding van de besluitvorming te eisen alvorens partijdigheid geconstateerd kan worden. ${ }^{603}$ De vergelijking met de subjectieve en objectieve rechterlijke onpartijdigheid, zoals het EHRM deze invult voor rechterlijke instanties, dringt zich op. Neerhof wijst er daarenboven op dat de bestuursrechter een institutionele benadering hanteert en zich daarmee concentreert op organisatorische aspecten. ${ }^{604}$ In die benadering speelt vooral een rol wie als functionaris bij de besluitvorming betrokken mag zijn, gelet op zijn hoedanigheden en andere functies. Hij meent op grond daarvan dat de benadering van de bestuursrechter in dat opzicht overeenkomsten vertoont met de benadering van het EHRM in het kader van de objectieve toets van de rechterlijke onpartijdigheid. ${ }^{605}$ Zoals al eerder werd aangegeven, lijkt ook de gehanteerde terminologie in de jurisprudentie, te weten dat 'schijn van partijdigheid' vermeden moet worden, te duiden op invloed van de objectieve toets die het

\footnotetext{
601. Zie bijv.: Versteden 2002, p. 552-553.

${ }^{602 .}$ Verheij 1995, p. 141-142.

${ }^{603 .}$ Verheij 1995, p. 145-146.

${ }^{604}$ Neerhof 2004, p. 39; Neerhof 1998, p. 120. Vgl.: Damen e.a. 2009, Deel I, p. 262

${ }^{605 .}$ Zie de noot hiervoor.
} 
Deel II Bestuurlijke voorprocedures

EHRM in het kader van de onpartijdigheid ten aanzien van rechterlijke instanties hanteert. $^{606}$

Het is juist dat het EHRM zich vaak op de objectieve onpartijdigheid van rechterlijke instanties concentreert en in dat kader vooral beziet in hoeverre de desbetreffende rechterlijke instantie door eerdere functionele betrokkenheid bij de zaak (al dan niet in dezelfde hoedanigheid of functie) of hiërarchische banden met procesdeelnemers de schijn van partijdigheid heeft gewekt. De reden daarvoor is gelegen in het feit dat subjectieve partijdigheid, dat wil zeggen de persoonlijke opvattingen of belangen van de rechter die uit zijn houding en gedrag moeten blijken, zeer lastig te bewijzen valt. ${ }^{607} \mathrm{Om}$ die reden beschouwt het EHRM de objectieve toets, in het kader waarvan ook de schijn van partijdigheid van belang is, als een belangrijke aanvullende toets om onpartijdigheid te waarborgen. ${ }^{608}$ Enige relativering van het onderscheid tussen beide toetsen heeft het EHRM wel aangebracht, aangezien het heeft aangegeven dat een strikte waterscheiding tussen de objectieve en subjectieve toets niet altijd mogelijk is. In gevallen waarin het gedrag of de houding van de rechter duidt op partijdigheid, wordt afhankelijk van de feiten van het desbetreffende gedrag de subjectieve dan wel objectieve toets gehanteerd $^{609}$ In sommige gevallen kunnen de bestreden feiten of omstandigheden onder zowel de subjectieve als de objectieve toets bezien worden. ${ }^{610}$ In de benadering van het EHRM kunnen zich twee situaties voordoen, waarin gebrek aan onpartijdigheid in het geding kan zijn: situaties die functioneel van aard zijn en die persoonlijk van aard zijn. Op de eerste situatie, waarin niet het persoonlijk gedrag van de rechter centraal staat, maar de uitoefening van verschillende functies of de aanwezigheid van hiërarchische dan wel andere banden met een procesdeelnemer, wordt de objectieve toets toegepast. De tweede situatie heeft betrekking op het gedrag van de desbetreffende rechter in de voorliggende zaak. Afhankelijk van de specifieke feiten van het bestreden gedrag, wordt hierop de subjectieve of de objectieve toets dan wel worden beide toetsen toegepast. ${ }^{611}$ Het persoonlijke gedrag van de desbetreffende rechter kan aanleiding geven tot partijdigheid onder de objectieve toets, maar kan ook van die aard zijn dat zelfs onder de subjectieve toets persoonlijke vooringenomenheid moet worden aangenomen. Dat laatste zal echter niet snel het geval zijn.

Vergelijkbare bewijsproblemen inzake bestuurlijke partijdigheid

Niet alleen ten aanzien van de persoonlijke opvattingen of houding van de rechter moet echter aangenomen worden dat subjectieve partijdigheid moeilijk te bewijzen valt. Het aantonen van daadwerkelijke persoonlijke vooringenomenheid van het bestuursorgaan (dat wil zeggen de ambtsdrager), leden van het bestuursorgaan of andere bij de besluitvorming betrokken personen, wegens persoonlijke belangen of opvattingen is eveneens geen eenvoudige zaak. Zoals Schlössels opmerkt, hangt het geringe succes van een beroep op het verbod van vooringenomenheid in de jurisprudentie vaak ook samen met de bewijslevering. ${ }^{612}$ De partijdigheid zou bijvoorbeeld af te leiden moeten zijn uit het gedrag of verklaringen van de desbetreffende personen, uit de motivering van het besluit of anderszins uit feitelijke omstandigheden moeten blijken. Om die reden ligt het voor de hand dat ook de bestuursrechter bij het toetsen van de bestuurlijke besluitvorming aan het verbod van vooringenomenheid zijn toevlucht neemt tot een organisatorische benadering en zich concentreert op omstandigheden die, naar objectieve maatstaven gemeten,

606. Jansen \& Peters E 2.1.4-2/3; Versteden 2002, p. 552.

607. Zie bijvoorbeeld: EHRM 15 december 2005, Kyprianou t. Cyprus, EHRC 2006/21 m.nt. A.M.L. Jansen, par. 118-119. Nader hierover par. 4.3.4 van Deel I van dit onderzoek.

${ }^{608 .}$ Kyprianou, par. 119. Zie hierover nader par. 4.3.4 van Deel I.

${ }^{609 .}$ Kyprianou, par. 121.

610. Zie hierover nader par. 4.3.4 van Deel I.

611. Kyprianou, par 121.

612. Schlössels 2008, p. 97 


\section{De inrichting van de voorprocedures}

twijfel kunnen doen rijzen omtrent de onpartijdigheid. ${ }^{613}$ Voor zover de kritiek in de literatuur zich hiertegen richt en om die reden gesteld wordt dat de bestuursrechter het bestuur of de besluitvorming te zeer benadert als rechtspraak, meen ik dan ook dat dat ten onrechte geschiedt. ${ }^{614}$

Een ander (meer principieel) discussiepunt, dat aan het hiervoor genoemde punt voorafgaat, is of in het kader van de bestuurlijke besluitvorming niet uitsluitend getoetst zou moeten worden of sprake is van daadwerkelijke partijdigheid bij de beslissers of bij de besluitvorming betrokken personen. Dat zou betekenen dat het criterium 'schijn van partijdigheid', dat een rol speelt bij de objectieve toets, voor bestuurlijke besluitvorming verlaten zou worden. Daarmee zou daadwerkelijke beïnvloeding van de besluitvorming geëist worden in het bestuursrecht. ${ }^{615}$ De Afdeling leidt uit het tweede lid van artikel 2:4 Awb in elk geval in bepaalde gevallen af dat de 'schijn van partijdigheid of belangenverstrengeling' eveneens vermeden moet worden. ${ }^{616}$ Mij lijkt eveneens dat het verbod van vooringenomenheid de eis omvat dat schijn van partijdigheid vermeden dient te worden. Zonder de mogelijkheid om een schending van het verbod van vooringenomenheid te kunnen aannemen in gevallen waarin er sterke objectieve factoren bestaan die duiden op partijdigheid, verwordt het verbod van vooringenomenheid tot een lege huls. Het zal immers uitermate lastig zijn om feitelijke partijdigheid te bewijzen. Dat laat onverlet dat de bestuursrechter niet te snel tot de conclusie moet komen dat sprake is van 'schijn van partijdigheid'. Daarvoor moeten, zoals aangegeven, goede objectiveerbare redenen bestaan en er zal ook minder snel sprake zijn van 'schijn van partijdigheid' dan bij de rechter het geval zal zijn.

Ook wil ik op deze plaats nogmaals de buitengrenzen van de onpartijdigheideisen in herinnering roepen en erop wijzen dat de eis van het vermijden van schijn van partijdigheid geenszins daaraan afbreuk doet. Aangenomen dat schijn van partijdigheid vermeden moet worden, dan is uiteraard vervolgens van belang op welke wijze invulling aan deze eis wordt gegeven. Zou deze eis ten opzichte van de beslissers ruimhartig gehanteerd worden, dan zou de invulling ervan in feite dicht in de buurt komen van het eisen van daadwerkelijke beïnvloeding van de besluitvorming. Schlössels merkt op dat, naast de moeilijke bewijsbaarheid van vooringenomenheid, het geringe succes van een beroep op artikel 2:4 Awb ook te wijten is aan de omstandigheid dat de bestuursrechter niet snel geneigd is aan te nemen dat sprake is van schijn van partijdigheid. ${ }^{617}$ Schlössels noemt als voorbeeld een uitspraak van de Afdeling van 21 februari 2007 waarin het bestuursorgaan een werkbezoek naar Kopenhagen heeft afgelegd op kosten van de Puttense nertsenbranche, terwijl er een aanvraag lag om revisievergunning op grond van de Wet Milieubeheer af te geven aan een plaatselijke pelsdierhouderij. ${ }^{618}$ De Afdeling komt in deze uitspraak niet tot een schending van het verbod van vooringenomenheid. Alhoewel met de Afdeling aangenomen kan worden dat subjectieve partijdigheid niet bewezen is - de Afdeling overweegt dat deze omstandigheid niet zonder meer tot de conclusie leidt dat het college niet zonder vooringenomenheid kon beslissen - ben ik het met Schlössels eens dat de schijn van partijdigheid hier wel degelijk gewekt is. Het voorbeeld laat echter wel zien dat de bestuursrechter nog steeds ruimte heeft bij de invulling van het begrip 'schijn van partijdigheid' om rekening te houden met de specifieke bestuurlijke context. $^{619}$

613. Vgl. Neerhof 1998, p. 124

614. De kritiek op de benadering van de Afdeling in de uitpraak Winsum ten aanzien van het bestuursorgaan of leden daarvan, kan ik daarentegen wel onderschrijven. Zie par. 5.4.3.3.

${ }^{615 .}$ Zoals eerder aangegeven is Verheij het hier niet mee eens, Verheij 1995, p. 145-146.

616. Bv. in AbRvS 7 augustus 2002, AB 2003/3 m.nt. ARN. Zie hierover ook: Damen e.a. 2009, Deel I, p. 264 265.

617. Schlössels 2008, p. 97

${ }^{618 .}$ Schlössels 2008, p. 97. Het gaat om AbRvS 21 februari 2007, JB 2007/120 m.nt. LJTM.

619. Verheij geeft bijvoorbeel ook aan dat schijn van partijdigheid niet te snel moet worden aangenomen in bepaalde gevallen, Verheij 1995, p. 145-149. 
Deel II Bestuurlijke voorprocedures

Vergelijkbare methode van toetsing

De ratio en functie van de onpartijdigheidseisen voor het bestuur verschillen niet van die van de rechter. Voor beide organen gelden voorts, hoewel niet met geheel gelijke strekking, onpartijdigheidseisen. Een vergelijkbare methode van toetsing of aan die onpartijdigheidseisen is voldaan door de bestuursrechter lijkt mij dan ook niet bezwaarlijk. Het betreft immers een methode van toetsing waarmee beoordeeld wordt of sprake is geweest van partijdigheid dan wel de schijn van partijdigheid. Die methode van toetsing, via een subjectieve en/of objectieve toets, laat ruimte voor het inhoudelijk stellen van andere eisen aan het bestuur. In bepaalde gevallen wordt immers voor het bestuur, gelet op de aard en het karakter van de besluitvorming, minder snel aangenomen dat sprake is van (de schijn van) partijdigheid. De bestuursrechter hanteert echter niet expliciet dezelfde methode van toetsing in het kader van de aan het bestuur te stellen onpartijdigheideisen. In de rechtspraak wordt nimmer in verband met de toetsing aan artikel 2:4 Awb (of andere eisen) expliciet gerefereerd aan de voor rechtspraak gehanteerde subjectieve en objectieve toets die volgt uit de jurisprudentie van het EHRM in het kader van artikel 6 EVRM. Wel moet ingestemd worden met hetgeen Neerhof opmerkt over de overwegend functionele of organisatorische benadering, die vergelijkbaar is met de objectieve toets die het EHRM toepast, die de bestuursrechter hanteert. De Nationale Ombudsman lijkt overigens in zijn oordelen meer expliciet het onderscheid tussen subjectieve en objectieve onpartijdigheid te hanteren, waarbij enige invloed van de jurisprudentie van het EHRM en de wijze van toetsing in het kader van de rechterlijke onpartijdigheid zeker niet uitgesloten is. ${ }^{620}$ Het feit dat zowel voor het bestuur als voor de rechter de nadruk ligt op een functionele of organisatorische toets, hangt ook samen met de aard van de onpartijdigheidseisen en de moeilijke bewijsbaarheid van daadwerkelijke partijdigheid.

De invloed van 'de schijn van partijdigheid'

Omdat het tweede lid van artikel 2:4 Awb een waarborg voor de burger inhoudt, leidt de Afdeling uit die bepaling af dat ook de 'schijn van belangenverstrengeling of partijdigheid' moet worden vermeden. ${ }^{621}$ Daarbij moet echter wel opgemerkt worden dat de bestuursrechter in het kader van artikel 2:4 Awb lang niet altijd een schending constateert wegens aanwezigheid van 'schijn van partijdigheid'. In sommige gevallen lijkt de Afdeling bijvoorbeeld een feitelijke vooringenomenheid of daadwerkelijk beïnvloeding van de besluitvorming te eisen alvorens een schending van artikel 2:4 Awb wordt aangenomen. ${ }^{622}$ In die gevallen volstaat de enkele schijn van partijdigheid niet. Bovendien zijn er gevallen aan te wijzen waarin als het om de rechter zou gaan wel 'schijn van partijdigheid' zou worden aangenomen, terwijl dat voor het bestuur niet het geval is. In een geval waarin een wethouder zich in de media positief had uitgelaten over een bouwplan, oordeelde de Afdeling bijvoorbeeld dat geen sprake was van schending van artikel 2:4 Awb door het college van $b$ en $w$ bij de verlening van de bouwvergunning. ${ }^{623}$ Voor een rechter die zich inhoudelijk uitlaat over een voorliggende zaak in de media kan dat echter anders liggen. Indien met de uitlating een bepaalde uitkomst van de zaak geïmpliceerd wordt, zal dat eerder tot schending van de vereiste onpartijdigheid leiden. ${ }^{624}$ Wat betreft de invulling van het begrip 'schijn van partijdigheid' met objectieve factoren die daarop duiden, is de bestuursrechter derhalve ook strenger voor de rechter dan voor het bestuur.

\footnotetext{
620. Zie hierover de noot bij No. 11 februari 2008, AB 2008/154 m.nt. Stolk. Stolk wijst in zijn noot op het jaarverslag 2007 van de No, p. 163, waarin het onderscheid expliciet naar voren komt. De formulering die de No hanteert sluit aan bij de door het EHRM gehanteerde formulering, ook inzake de bewijslevering.

621. Zie o.m.: AbRvS 7 augustus 2002, $A B$ 2003/3 m.nt. ARN.

622. Zie bijvoorbeeld: AbRvS 21 februari 2007, JB 2007/120 m.nt. LJTM; AbRvS 16 maart 2005, JB 2005/140. Zie hierover ook: Damen e.a. 2009, Deel I, p. 265

623. AbRvS 21 oktober 2009, nr. 200809406/1/H1.

624. Zie hierover Deel I, par. 4.3.4. Daarbij laat ik nog in het midden of er dan niet tot strijd met de subjectieve partijdigheid geconcludeerd kan worden. In elk geval zal de schijn van partijdigheid bestaan omdat er geobjectiveerde vrees bestaat voor partijdigheid.
} 


\section{De inrichting van de voorprocedures}

Voor het bestuur zal minder snel tot de conclusie worden gekomen dat de schijn van partijdigheid is gewekt en daarmee ook artikel 2:4 Awb is geschonden. Het beperken van de werking van het verbod van vooringenomenheid tot gevallen waarin sprake is van daadwerkelijke vooringenomenheid gaat mijns inziens echter te ver. Dat zou vanwege de bewijsproblematiek kunnen betekenen dat er vrijwel nooit een geslaagd beroep gedaan kan worden op artikel 2:4 Awb en dat kan, gelet op de ratio van deze norm, niet de bedoeling zijn. Bovendien kunnen er ook in de bestuurlijke fasen zodanige objectieve factoren of omstandigheden bestaan dat er, hoewel er oog moet bestaan voor de specifieke bestuurlijke context, gerechtvaardigd getwijfeld kan worden aan de onpartijdigheid van het bestuursorgaan of daarvoor werkzame dan wel daarvan onderdeel uitmakende personen. In dergelijke gevallen moet de geconstateerde schijn van partijdigheid kunnen volstaan.

Ofschoon er verschillen bestaan tussen de rechterlijke en bestuurlijke onpartijdigheid, kan geconcludeerd worden dat er tevens een zekere gelijkenis bestaat tussen de voor het bestuur en de bestuursrechter geldende onpartijdigheidseisen. Die gelijkenis is met name gelegen in de ratio van de onpartijdigheidseisen en in de wijze van toetsen. Dat laatste houdt vooral verband met de lastige bewijsbaarheid van de subjectieve partijdigheid, waardoor in beide gevallen gezocht wordt naar objectiveerbare factoren aan de hand waarvan bepaald kan worden of de vereiste onpartijdigheid in acht is genomen. Ten aanzien van het bestuur lijkt de bestuursrechter echter minder snel tot partijdigheid of schijn van partijdigheid te concluderen dan het geval is voor de bestuursrechter onder artikel 6 EVRM. Gelet op de gemeenschappelijke ratio van de onpartijdigheid voor het bestuur en de rechter, en meer in het algemeen voor de overheid, valt goed te verdedigen dat de bestuursrechter ook ten aanzien van het bestuur strikt de hand houdt aan de onpartijdigheidseisen. Dat betekent in mijn optiek dat naast feitelijke partijdigheid 'de schijn van partijdigheid' evenzeer problematisch moet worden geacht. Of daarvan sprake is moet echter bepaald worden aan de hand van objectiveerbare omstandigheden of factoren. Binnen die beoordeling heeft de bestuursrechter dan enige ruimte om de eigen aard van besturen of de positie van het bestuur te laten meewegen. De objectiveerbare omstandigheden of factoren die leiden tot de conclusie dat sprake is van 'schijn van partijdigheid' zijn voor het bestuur en de rechter derhalve verschillend. Er zal minder snel tot 'schijn van partijdigheid' moeten worden geconcludeerd dan het geval zou zijn bij rechterlijke instanties.

\subsubsection{De gevolgen van schendingen van het verbod van vooringenomenheid}

Indien de bestuursrechter constateert dat het bestuursorgaan bij het nemen van een besluit niet zonder vooringenomenheid heeft gehandeld, leidt dat in beginsel tot vernietiging van het bestreden besluit. ${ }^{625}$ De ruimte om de rechtsgevolgen van een wegens strijd met artikel 2:4 Awb genomen besluit in stand te laten op grond van artikel 8:72 derde lid Awb kan beperkt zijn. In een uitspraak van 19 augustus 2009 van de Afdeling stond die kwestie centraal. ${ }^{626}$ De Afdeling overwoog dat de rechtbank ten onrechte de rechtsgevolgen van het vernietigde besluit in stand had gelaten. De rechtbank had het besluit wegens strijd met artikel 2:4, eerste lid, Awb vernietigd. Volgens de Afdeling lag in haar oordeel derhalve besloten dat de burgemeester niet zonder vooringenomenheid het besluit had genomen. Het geconstateerde gebrek kleeft aan de gehele besluitvorming, zowel in primo als in bezwaar. Er bestond dan ook geen ruimte om de rechtsgevolgen van het vernietigde besluit in stand te laten, omdat het primaire besluit herroepen diende te worden na gegrondverklaring van het bezwaar. Als de (schijn van) partijdigheid zich ook, of in eerste instantie, uitstrekt tot het primaire besluit dan kan derhalve niet volstaan worden met een vernietiging van het besluit op bezwaar waarbij de rechtsgevolgen in stand blij-

625. Zie bijvoorbeeld: AbRvS 7 augustus 2002, $A B$ 2003/3 m.nt. ARN; Rb. Amsterdam, 26 augustus 2003, JB 2003/302 m.nt. A.R. Neerhof.

626. AbRvS 19 augustus 2009, JB 2009/216 m.nt. C.L.G.F.H. Albers. 
Deel II Bestuurlijke voorprocedures

ven. ${ }^{627}$ Instandlating van de rechtsgevolgen van het besluit na vernietiging door de bestuursrechter wegens schending van het verbod van vooringenomenheid is, zoals ook in andere gevallen, slechts mogelijk indien er rechtens nog maar één besluit genomen kan worden of wanneer duidelijk is dat na vernietiging een besluit met dezelfde inhoud genomen wordt. ${ }^{628}$ Schending van artikel 2:4 Awb kan voorts niet gepasseerd worden met toepassing van artikel 6:22 Awb door de bestuursrechter, omdat het geen vormvoorschrift betreft. ${ }^{629}$ Evenmin lijkt een schending van artikel 7:5 $\mathrm{Awb}^{630}$ of 10:3, derde lid, Awb te kunnen worden gepasseerd. Bij een schending van artikel 10:3, derde lid, Awb kan het besluit wel vernietigd worden met instandlating van de rechtsgevolgen. ${ }^{631}$

Schending van het verbod van vooringenomenheid betekent dat de besluitvorming in beginsel over gedaan moet worden door datzelfde bestuursorgaan. In de gevallen waarin de vooringenomenheid gelegen was bij een ambtenaar of andere functionaris die werkzaam is bij of onder de verantwoordelijkheid van het bestuursorgaan, behoeft zulks geen problemen op te leveren. Een andere ambtenaar behoort bij de hernieuwde besluitvorming te worden betrokken. Hetzelfde geldt voor een adviseur of adviescommissie. Er dient een andere adviseur aangetrokken te worden of de adviescommissie behoort een andere samenstelling te krijgen. Grotere problemen ontstaan er echter, indien de vooringenomenheid rust bij het bestuursorgaan zelf of een lid daarvan. In het geval van een collegiaal bestuursorgaan bestaat nog de mogelijkheid dat een van de leden zich terugtrekt. ${ }^{632}$ Maar bij een enkelvoudig bestuursorgaan ligt dat anders. In dat geval rest het bestuursorgaan niets anders, vanwege de wettelijke bevoegdheidstoedeling, om maatregelen treffen om de beïnvloeding van de besluitvorming te beperken door bijvoorbeeld een onafhankelijke adviseur bij de besluitvorming te betrekken. Uit de uitspraak van het EHRM in de zaak Kingsley blijkt dat het in sommige gevallen noodzakelijk kan zijn, om na een rechterlijke vernietiging wegens schending van artikel 2:4 Awb, de zaak terug te verwijzen naar een ander bestuursorgaan. Mij lijkt dat, indien een dergelijke terugverwijzing vanwege de wettelijke bevoegdheidstoedeling niet mogelijk is, de instelling van een onafhankelijke adviseur of adviescommissie ook voldoende kan zijn om te voldoen aan die uitspraak en de schending van artikel 2:4 Awb te redresseren.

Het onpartijdigheidsbeginsel of artikel 2:4 Awb vormt derhalve een door het bestuur in acht te nemen rechtsnorm. De schending ervan leidt tot vernietiging van het bestreden besluit en een gebrek aan onpartijdigheid kan niet worden gepasseerd met toepassing van artikel 6:22 Awb. Wel zou het mijns inziens mogelijk kunnen zijn, bij overwegend gebonden besluitvorming, dat de bestuursrechter door middel van toepassing van artikel 8:72, derde lid, Awb de rechtsgevolgen van het vernietigde besluit in stand laat na geconstateerde (schijn van) partijdigheid, mits duidelijk is dat er rechtens maar een besluit mogelijk was en dat besluit (ondanks de geconstateerde partijdigheid) is genomen.

\footnotetext{
627. De vooringenomenheid hoeft niet altijd in beide fasen aanwezig te zijn: AbRvS 13 augustus 2008, nr. 20075940/1. In die uitspraak stond de situatie centraal dat een ambtenaar in primo in mandaat in strijd met het verbod van vooringenomenheid een besluit had genomen, terwijl de bedoelde ambtenaar niet betrokken was bij de beslissing op bezwaar waarbij het primaire besluit werd bevestigd. In bezwaar was dan ook geen sprake van vooringenomenheid.

${ }^{628 .}$ Schueler e.a. 2007 , p. 60.

629. Zie over deze bevoegdheid: Schueler e.a. 2007, p. 65-69; Van Waterschoot 2002, p. 181-194. CRvB 9 april 1996, Rawb 1996/7 m.a.tB lijkt daar wel op te duiden.

${ }^{630 .}$ Neerhof 1999 b, p. 76.

631. Zie hierover de noot van Widdershoven bij HR 16 februari 2007, AB 2007/138 m.nt. R.J.G.M. Widdershoven.

632. Zie hierover en over de wenselijkheid daarvan par. 5.4.3.3.
} 


\section{De inrichting van de voorprocedures}

5.4.4 Doorwerking van de onafhankelijkheids- en onpartijdigheidseisen in de
bestuurlijke voorprocedures

Doorwerking van de onafhankelijkheidseisen

Onafhankelijkheid is een eis die per definitie niet op dezelfde wijze voor het bestuur kan gelden als voor de rechter. Het bestuur maakt immers onderdeel uit van de uitvoerende macht. De externe of democratische functie die onafhankelijkheid heeft voor rechterlijke instanties bestaat niet voor de bestuurlijke voorprocedures. In dit onderzoek wordt ook niet onderzocht in hoeverre de rechterlijke onafhankelijkheid, als beginsel van behoorlijke rechtspleging, van invloed is op de bestuurlijke voorprocedures. Onafhankelijkheid als eis voor rechtelijke instanties vormt echter ook een waarborg voor onpartijdigheid van die rechterlijke instanties. In die betekenis en voor zover het de interne werking binnen een geschil tussen partijen betreft wordt onafhankelijkheid in dit onderzoek meegenomen. In die betekenis vormt onafhankelijkheid ook voor het bestuur een voorwaarde om onpartijdige besluitvorming te realiseren. In de bezwaarschriftprocedure en het administratief beroep zijn, indien een adviescommissie wordt ingeschakeld (hetgeen veelvuldig geschiedt) in de zin van artikel 7:13 Awb en 7:19 Awb, onafhankelijkheidselementen ingebouwd. Onafhankelijkheid heeft in die procedures weliswaar een iets andere, beperktere betekenis, - namelijk niet werkzaam zijn onder de verantwoordelijkheid van het bestuursorgaan noch deel uitmakend van het bestuursorgaan - het doel ervan is hetzelfde. De onafhankelijkheidselementen staan ten dienste aan een zo objectief mogelijke besluitvorming. In dit opzicht werken de onafhankelijkheidseisen voor rechter en bestuur hetzelfde.

\section{Het onpartijdigheidsbeginsel voor het bestuur}

Het onpartijdigheidsbeginsel voor het bestuur is in de Awb in artikel 2:4 Awb neergelegd in de vorm van het verbod van vooringenomenheid. Omdat onpartijdigheid een uitgangspunt is dat geldt voor alle overheidsorganen zijn de grondslagen waarop de onpartijdigheidseisen voor het bestuur gebaseerd worden veelvoudig. Het gaat vooral om de vraag naar de positie van het verbod van vooringenomenheid binnen de algemene beginselen van behoorlijk bestuur, maar ook wordt regelmatig naar voor de rechter geldende uitgangspunten verwezen. In dit onderzoek is geconcludeerd dat het verbod van vooringenomenheid of het onpartijdigheidsbeginsel voor het bestuur een zelfstandige norm vormt voor het bestuur dat een voldoende onderscheidend vermogen heeft ten opzichte van het beginsel van zorgvuldige bejegening en het 'fair play'-beginsel. Schending van het verbod van vooringenomenheid bij de besluitvorming op bezwaar of administratief beroep leidt in beginsel tot vernietiging van het besluit.

\section{Verschillen met de rechterlijke onpartijdigheid}

Het verbod van vooringenomenheid is voor het bestuur niet verder geconcretiseerd of uitgewerkt in de wettelijke regeling. Voor de bestuursrechter is het onpartijdigheidsbeginsel veel verder geconcretiseerd in wrakings- en verschoningsregelingen in hoofdstuk 8 van de Awb. Voor het bestuur bestaat een dergelijke regeling niet. Belanghebbende burgers kunnen bestuursorganen of leden daarvan dan ook niet wraken. Het is in eerste instantie aan het bestuur zelf om ervoor zorg te dragen dat de besluitvorming op objectieve wijze plaatsvindt. Daarin verschilt de bestuurlijke onpartijdigheid van de rechterlijke onpartijdigheid.

Ook bestaan er inherente grenzen aan de van het bestuur te eisen onpartijdigheid, die samenhangen met de positie en taak van het bestuur in ons staatsbestel. Zo behoeft het voor (leden van) het bestuur geen probleem te zijn indien er beleidskeuzes worden gemakt of indien leden van het bestuur lid zijn van een politieke partij. Tevens is in de bestuurlijke voorprocedures eerdere betrokkenheid bij de besluitvorming geen probleem, maar juist inherent aan het verlengde besluitvormingskarakter van die procedures. In de literatuur wordt er tevens vanuit gegaan dat politiek of maatschappelijk engagement voor 
Deel II Bestuurlijke voorprocedures

bestuurders geoorloofd is alsmede dat vanuit de doctrine van 'rule of necessity' niet (snel) tot stemonthouding mag worden overgegaan op grond van een schending van artikel 2:4 Awb. De bestuursrechter, in het bijzonder de Afdeling, lijkt op deze punten echter een andere benadering te hanteren. In dat opzicht wordt weleens gesteld dat de bestuursrechter het bestuur te zeer benadert alsof het rechterlijke organen zijn, waardoor de eigen aard van het besturen miskend wordt.

Overeenkomsten met de rechterlijke partijdigheid

Er zijn nog meer overeenkomsten aan te wijzen met de rechterlijke onpartijdigheidseisen in de rechtspraak. Als het gaat om de toetsing door de rechter en de bewijslevering ligt de nadruk, evenals bij de rechterlijke partijdigheid, op een objectieve toets, waarbij vooral naar functionele of organisatorische aspecten wordt gekeken en niet alleen daadwerkelijke partijdigheid maar ook de schijn van partijdigheid speelt een rol. Daarbij kan ook de 'schijn van belangenverstrengeling of partijdigheid' van belang zijn. De bestuursrechter lijkt echter terughoudender te zijn in het hanteren van dat begrip ten aanzien van het bestuur dan het geval is ten aanzien van de rechter. Soms lijkt de bestuursrechter zelfs feitelijke onpartijdigheid te vereisen alvorens een schending van artikel 2:4 Awb wordt aangenomen.

Doorwerking van de rechterlijke onpartijdigheideisen in de bestuurlijke voorprocedures De invloed van de rechterlijke onpartijdigheidseisen komt derhalve vooral tot uitdrukking in de wijze waarop de bestuursrechter toetst of het bestuur het verbod van vooringenomenheid in acht heeft genomen. De vergelijkbare toetsingsmethode hangt ook samen met de aard van de toetsen norm en de lastige bewijsbaarheid van partijdigheid. Die problematiek speelt zowel in het kader van de rechterlijke als bestuurlijke onpartijdigheid. Er kan in zoverre niet gesproken worden over expliciete beïnvloeding die blijkt uit dezelfde inrichtingseisen of duidelijke verwijzingen in de jurisprudentie van de bestuursrechter. De invloed lijkt, voor zover daarvan sprake is, veeleer impliciet te zijn, hetgeen valt op te maken uit de toelichting op de verschillende bepalingen in de Awb en de door de bestuursrechter gehanteerde formuleringen en benadering in zijn jurisprudentie. Er bestaan derhalve gelijkenissen tussen de rechterlijke en bestuurlijke onpartijdigheid wat betreft toetsing, die duiden op doorwerking van de rechterlijek onpartijdigheidseisen. Daarentegen vallen er ook in dat verband verschillen te constateren. Als het gaat om bestuurlijke besluitvorming wordt minder snel tot aanwezigheid van partijdigheid of schijn van partijdigheid geconcludeerd. Dat heeft te maken met de inherente grenzen die aan de bestuurlijke onpartijdigheid gesteld kunnen worden. Deze grenzen vloeien voort uit de specifieke taak van het bestuur in de bestuurlijke voorprocedures, maar ook uit de positie van het bestuur in het algemeen in ons staatsbestel. De verschillen zijn derhalve terug te voeren op het besluitvormingskarakter van de bestuurlijke voorprocedures en ook de verbondenheid met het algemeen belang die samenhangt met de toebedeelde bevoegdheden aan het bestuur. In de gevallen waarin de bestuursrechter in de rechtspraak minder oog lijkt te hebben voor die aspecten die verbonden zijn aan het bestuurlijke karakter van de besluitvormingsprocedures, kan wellicht invloed van de benadering bij de rechterlijke onpartijdigheid gezien worden. In de literatuur wordt dat in elk geval wel aangenomen.

Al met al kan in het kader van het beginsel van onpartijdigheid niet geconcludeerd worden dat de doorwerking van de rechterlijke onpartijdigheid volledig en eenduidig is. Er lijkt sprake te zijn van enige mate van doorwerking en beïnvloeding van die eisen op de invulling van en toetsing aan het verbod van vooringenomenheid, maar ook dat vindt veelal impliciet plaats. Hoewel het onpartijdigheidsbeginsel voor zowel het bestuur als de rechter inhoudelijk dezelfde rechtsnorm bevat, lijken de uitwerkingen voor beide organen wel te verschillen. De onpartijdigheidseisen die aan het bestuur gesteld worden zijn in bepaalde opzichten minder streng en worden op andere wijze ingevuld. Dat laatste hangt samen met de specifieke positie van het bestuur in de bestuurlijke voorprocedures, 


\section{De inrichting van de voorprocedures}

maar ook meer in het algemeen met de bevoegdheden en positie van het bestuur in ons staatsbestel.

\subsection{Openbaarheid in de bestuurlijke voorprocedures}

\subsubsection{Openbaarheid als eis voor een behoorlijke voorprocedure}

Eis voor behoorlijke rechtspleging

Zoals is gebleken in Deel I van dit onderzoek is het openbaarheidsbeginsel een beginsel van behoorlijke rechtspleging dat van oudsher geldt voor rechtspraak. ${ }^{633}$ Het is een van de vereisten van behoorlijke rechtspleging die in de Grondwet gecodificeerd zijn en het vereiste is voor de bestuursrechter specifiek in artikel 8:62, 8:68 en 8:79 Awb neergelegd. Ook artikel 6 EVRM eist dat, wil er sprake zijn van eerlijk proces, voldaan moet zijn aan bepaalde openbaarheidsvereisten.

In paragraaf 4.3.6 van Deel I van dit onderzoek is voorts uiteengezet dat de eisen van openbaarheid die gesteld worden aan rechtspraak doorgaans ingedeeld worden in twee categorieën. Enerzijds betreft het eisen die betrekking hebben op de openbaarheid van de behandeling van de zaak of de zitting en anderzijds gaat het om eisen die betrekking hebben op het openbaar maken van de uitspraak. De ratio van het vereiste van een openbare zitting en uitspraak in rechterlijke procedures is primair het inzichtelijk en controleerbaar maken van de werkzaamheid van de rechter voor partijen en het publiek. ${ }^{634}$ Openbaarheid van rechtspraak is van fundamenteel belang vanwege de onafhankelijke positie van de rechter en vanwege het feit dat de rechter omwille van zijn onafhankelijkheid geen verantwoording over zijn uitspraken schuldig is aan andere staatsmachten. Dat wordt ook wel de democratische functie van de openbaarheidvereisten genoemd. ${ }^{635}$ Vandaar dat de openbaarheidseisen en de onafhankelijkheid van de rechter ook sterk samenhangen met het vertrouwen van de samenleving en het publiek in rechtspraak. De democratische functie ziet op de externe werking van de openbaarheidseisen en komt tot uitdrukking in openbaarheidseisen die de toegankelijkheid van de procedure en de uitspraak voor het publiek moeten garanderen. Daarnaast dient de openbaarheid de bescherming van partijen in de procedure tegen willekeur van de kant van de rechter en waarborgt het een gelijke behandeling van de partijen door de rechter. ${ }^{636}$ Deze laatste functie is veeleer gericht op de bescherming van de belangen van partijen in het concrete geschil. Om de toegankelijkheid van de behandeling van de zaak en de uitspraak voor de procesdeelnemers in het concrete geschil te waarborgen worden derhalve ook interne openbaarheidseisen gesteld. ${ }^{637}$ Deze functie en de interne werking van de openbaarheidseisen zijn ondergeschikt aan de democratische functie en kunnen ook (of beter nog) door middel van andere beginselen van behoorlijke rechtspleging, in het bijzonder het beginsel van hoor en wederhoor, gerealiseerd worden. ${ }^{638}$ Deelname aan of aanwezigheid bij de zitting valt in mijn optiek bijvoorbeeld eerder te scharen onder het recht op een mondelinge behandeling (als deelaspect van het beginsel van hoor en wederhoor), terwijl bekendmaking van de uitspraak aan partijen in verband met verweermogelijkheden en het instellen van rechtsmiddelen eveneens op het beginsel van hoor en wederhoor gegrond

633. Zie par. 4.3.6 van Deel I

634. PG Awb II, p. 458; De Werd 2001, p. 68; Widdershoven 1989, p. 142; De Waard 1987, p. 110; Van Galen \& Maarseveen 1978, p. 60. Zie hierover nader par. 4.3.6 van Deel I.

635. S.K. Martens in zijn openingsrede van de website www.rechtspraak.nl (te raadplegen via http://www.rechtspraak.nl/Gerechten/HogeRaad/Actualiteiten/Archief/1999/12/).

636. Zie bijvoorbeeld: Widdershoven 1989, p. 142.

637. Zie ook par. 4.3.6 van Deel I. Interne openbaarheid wordt soms ruimer opgevat, ook toegang tot stukken eronder begrepen, bijv. Somer 1969

638. Zie hierover par. 4.3.6 van Deel I. In beide gevallen moet de grondslag voor de eisen immers gezocht worden in de verweermogelijkheden van de belanghebbenden. 


\section{Deel II Bestuurlijke voorprocedures}

kan worden. ${ }^{639}$ Het openbaarheidsbeginsel ondersteunt in dit opzicht hoogstens het beginsel van hoor en wederhoor. Het voorgaande betekent, zoals aangegeven in Deel I, dat interne openbaarheid een secundaire functie vormt van het openbaarheidsbeginsel en de externe openbaarheid, het mogelijk maken van controle door het publiek, de hoofdfunctie is van dat beginsel. De bescherming van de belangen van partijen in het concrete geschil vormt een daaraan ondergeschikte functie. Deze functie van het openbaarheidsbeginsel bestaat doordat dit beginsel andere beginselen van behoorlijke rechtspleging ondersteunt die als primaire functie de bescherming van de belangen van partijen in het concrete rechtsgeschil hebben, zoals het beginsel van hoor en wederhoor (in verband met de openbare behandeling van de zaak), het onpartijdigheidsbeginsel en het motiveringsbeginsel (in verband met het openbaar maken van de uitspraak). ${ }^{640}$

\section{De openbaarheideisen in de bestuurlijke voorprocedures}

De openbaarheidsvereisten die uit het nationale recht en uit artikel 6 EVRM voortvloeien zijn uitsluitend rechtstreeks van toepassing op procedures bij rechterlijke instanties. De grondwetgever gaf ook in de toelichting op artikel 121 Grondwet aan dat de openbaarheid van behandeling geëist wordt ten aanzien van zittingen van de rechterlijke macht en dat in elk geval de zittingen in administratief beroep buiten de werking van deze bepaling vallen. Datzelfde werd ook gesteld ten aanzien van de eis dat de uitspraak in het openbaar behoort te geschieden. ${ }^{641}$ In tegenstelling tot enkele andere vereisten voor behoorlijke rechtspraak, zoals het beginsel van hoor en wederhoor ${ }^{642}$, wordt openbaarheid nauwelijks uitdrukkelijk in verband gebracht met de bestuurlijke voorprocedures. ${ }^{643}$ Bezien in het licht van de democratische functie van de openbaarheideisen lijkt dat in eerste instantie ook niet vreemd. Het is immers de specifieke - onafhankelijke - positie van de rechter in ons staatsbestel die noopt tot het stellen van eisen aan de (externe) openbaarheid van de zitting en uitspraak.

Voor de bestuurlijke voorprocedures die in dit hoofdstuk centraal staan, kan het ontbreken van aandacht voor de openbaarheid van de procedure en de beslissing van het bestuur niettemin opmerkelijk genoemd worden. De Awb geeft namelijk voor de bezwaarschriftprocedure en het administratief beroep een regeling inzake het houden van een openbare hoorzitting in artikel 7:5, tweede lid en 7:19, derde lid. In administratief beroep is het houden van een openbare zitting zelfs het uitgangspunt, tenzij het bestuursorgaan op verzoek van een belanghebbende of ambtshalve meent zulks achterwege te moeten laten vanwege gewichtige redenen. Voor de bezwaarschriftprocedure is openbaarheid aan de discretie van het bestuursorgaan overgelaten, indien een bijzondere wettelijke regeling in dat kader ontbreekt. In bezwaar of administratief beroep bestaat weliswaar geen met artikel 8:78 Awb vergelijkbare bepaling in de Awb dat de beslissing of het dictum van het besluit in het openbaar dient te worden uitgesproken of anderszins toegankelijk gemaakt moet worden voor het publiek. ${ }^{644}$ Voorschriften inzake de bekendmaking van besluiten aan belanghebbenden, die een vergelijkbare functie hebben als de interne openbaarheidseisen bij de rechterlijke uitspraak, zijn wel degelijk neergelegd in de Awb, meer specifiek in artikel 7:12, tweede lid en 7:26, derde lid. Daar komt nog bij dat in de Awb een verplichting tot openbaarheid van de hoorzitting of een regeling in dat opzicht ontbreekt wat betreft de primaire besluitvormingsfase. Ook in de reguliere primaire fase van totstandkoming van beschikkingen geldt dat belanghebbenden in som-

639. Zie par. 4.3.6 van Deel I.

640. Zie par. 4.3.6. van Deel I.

${ }^{641}$ Zie de toelichting van de grondwetgever op art. $121 \mathrm{GW}$, Kamerstukken II 1979/80, 16 162, nr. 3, p. 21-23.

642. Zie hierover par. 5.3 van Deel II.

${ }^{643 .}$ Wel is er in 1969 een bundel verschenen getiteld Hoe openbaar wordt ons bestuur? waarin door J.C. Somer een bijdrage is geleverd inzake onder meer de openbaarheid in het administratief beroep, J.C. Somer, 'Openbaarheid en de rechtsbescherming van de individu', in: B. de Goede en H.Th.J.F. van Maarseveen, Hoe openbaar wordt ons bestuur, Den Haag: VUGA 1969, p. 243-270.

644. Op de Wet openbaarheid van bestuur kom ik later nog terug. 


\section{De inrichting van de voorprocedures}

mige gevallen in de gelegenheid moeten worden gesteld hun zienswijze te geven tegen het voorgenomen besluit, ingevolge artikel 4:7 en 4:8 Awb. Die zienswijzen kunnen zij naar keuze mondeling of schriftelijk naar voren brengen, zo bepaalt artikel 4:9 Awb. Indien zij die zienswijze mondeling naar voren wensen te brengen, kan het bestuursorgaan een hoorzitting organiseren. Verplicht is dat niet en openbaarheid van die zitting is evenmin voorgeschreven. De bekendmaking van besluiten genomen in de primaire besluitvormingsfase is wel, evenals in bezwaar en administratief beroep, geregeld in de Awb. ${ }^{645}$ Tussen de primaire besluitvormingsfase en de bestuurlijke voorprocedure valt derhalve wat betreft de openbaarheid van de te houden hoorzitting een verschil aan te wijzen.

Verband met het beginsel van behoorlijke rechtspleging?

Om welke reden de bepalingen over het houden van een openbare hoorzitting in bezwaar en administratief beroep terecht zijn gekomen in de regeling in de Awb is echter niet geheel duidelijk. In de parlementaire geschiedenis wordt daaraan ook geen aandacht besteed en wordt uitsluitend ingegaan op het onderscheid tussen bezwaar en administratief beroep in dit verband. Voor bezwaar wordt opgemerkt dat een algemene regeling lastig is en het bestuur zelf maar moet bepalen of openbaarheid gewenst is, terwijl voor administratief beroep vanwege het iets formelere karakter van de procedure openbaarheid van de zitting als uitgangspunt geldt. ${ }^{646}$ Het lijkt er op dat - voor zover het de openbaarheid van de behandeling van de zaak betreft - een typisch aan rechtspraak eigen eis in de regeling van de bestuurlijke voorprocedures is geslopen. Er wordt door de wetgever niet expliciet een verband gelegd tussen deze inrichtingseisen en de externe openbaarheideis zoals die voor rechtspraak geldt en ook is uitgewerkt in artikel 8:62, eerste lid, van de Awb. ${ }^{647}$ Wellicht is een openbare behandeling tijdens de bestuurlijke voorprocedures een vanzelfsprekendheid - in elk geval voor het administratief beroep - waaraan door de wetgever destijds niet werd getwijfeld. ${ }^{648}$ Vóór de inwerkingtreding van de Awb vormde (de externe) openbaarheid van de hoorzitting of het besluit in de bezwaarschriftprocedure dan wel het administratief beroep echter geen uitgangspunt dat te allen tijde gold. Onder de Wet Arob was bijvoorbeeld een openbare hoorzitting in bezwaar niet verplicht. De openbaarheid van de behandeling was een onderwerp dat bij verordening geregeld werd. ${ }^{649}$ Als het houden van een hoorzitting op grond van een verordening uitgangspunt was en een belanghebbende verzocht om dat achterwege te laten, behoorde het bestuur (althans de hoor- en adviescommissie) volgens de Afdeling rechtspraak in elk geval wel voldoende duidelijkheid te verkrijgen omtrent de redenen voor het verzoek. Dat betekende ook dat een belanghebbende voldoende (vertrouwelijke) gelegenheid diende te krijgen die redenen toe te lichten alvorens een beslissing inzake openbaarheid werd genomen. Nalaten hiervan werd in strijd geacht met het beginsel van zorgvuldige voorbereiding. ${ }^{650}$ Somer geeft in een bijdrage in 1969 aan dat voor het administratief beroep, ten onrechte naar zijn mening, niet over gehele linie voldaan wordt aan de eis van een openbare behandeling van de zaak. ${ }^{651}$ Hij wijst erop dat alleen bij beroep op de Kroon en op Gedeputeerde Staten een openbare behandeling in beginsel, met mogelijk-

\footnotetext{
645. Art. 3:40, 3:41 en 3:42 Awb.

646. PG Awb I, p. 341 en 359.

647. Zie de toelichting op art. 7:5 en 7:19 Awb, PG Awb I, p. 340-341 en p. 358-359.

648. Zie ook Somer die meent dat omdat administratief beroep zozeer het karakter van rechtspraak nadert, een openbaarheid vereist zou moeten zijn, Somer 1969, p. 244 en 261 e.v.

${ }^{649}$ Zie: R.W.L. Loeb, B.K. Olivier, H. Troostwijk, De wet Arob toegepast, Nijmegen: Ars Aequi Libri 1986, p. 147. Overigens geldt voor de openbaarheid van de hoorzitting in de bezwaarschriftprocedure thans ook nog steeds dat de bijzondere regelgever zulks nader kan regelen blijkens de formulering van art. 7:5 lid 2 Awb.

650. ArRvS 25 mei 1984, AB 1984/451. Andere uitspraken van de bestuursrechter die betrekking hebben op de openbaarheid van de hoorzitting of de beslissing van het bestuur onder de Wet Arob of andere wetgeving die dateert van voor de Awb heb ik niet kunnen achterhalen.

${ }^{651 .}$ Somer 1969 , p. 261 e.v.
} 


\section{Deel II Bestuurlijke voorprocedures}

heden tot uitzonderingen, was voorgeschreven. Ook het uitspreken van de beslissing in het openbaar was niet algemeen voorgeschreven. ${ }^{652}$ Het Kroonberoep, onder meer op grond van de Wet Bab, ${ }^{653}$ fungeerde als rechtsgang in de plaats van beroep op een bestuursrechter. Daarom is het niet vreemd dat in die gevallen in de regel een openbare behandeling plaatsvond van de zaak $^{654}$ en dat door Somer ook wenselijk werd geacht. Mogelijkerwijs is in de voorgeschiedenis van het administratief beroep en de vroegere status ook een verklaring gelegen voor de geruisloze opname van dit aspect van het openbaarheidsbeginsel in de Awb door de wetgever ten aanzien van die bestuurlijke voorprocedure.

Openbaarheid in de bestuurlijke voorprocedures - in het bijzonder de externe openbaarheid - is voorts ook, als te stellen behoorlijkheidsnorm aan het bestuur, geen onderwerp geweest dat op grote belangstelling kan en kon rekenen in de literatuur. ${ }^{655}$ Van der Ham geeft wel aan dat openbaarheid van de hoorzitting kan worden gezien als inrichtingseis voor de bezwaar- en beroepsprocedures die voortvloeit uit het beginsel van gelijkwaardigheid en/of het beginsel van hoor en wederhoor. ${ }^{656}$ Koenraad en Sanders stellen zich daarentegen op het standpunt dat in bezwaar de openbaarheid van het horen juist niet is voorgeschreven als uitgangspunt, omdat geen sprake is van rechtspraak als bedoeld in artikel 6 EVRM. ${ }^{657}$ Bepalend voor de gelding van de openbaarheidseisen lijkt in beide benaderingen wel de mate van gelijkenis met rechtspraak te zijn die wordt aangenomen. In de jurisprudentie van de bestuursrechter zijn artikel 7:5, tweede lid, en 7:19, derde lid, van de Awb nauwelijks onderwerp van geschil en komen de openbaarheideisen anderszins (bijvoorbeeld in het kader van een beroep op artikel 6 EVRM) voor de bestuurlijke voorprocedures niet of nauwelijks aan bod. ${ }^{658}$ Aandacht voor een extern openbare beslissing van het bestuur, althans in de zin van toegankelijk voor het publiek (erga omnes ${ }^{659}$ ), in literatuur of rechtspraak is er in nog mindere mate.

Of de (ongeschreven) grondslag van de openbaarheidseisen in bezwaar en administratief beroep gevonden moet worden in het openbaarheidsbeginsel als beginsel van behoorlijke rechtspleging staat derhalve geenszins vast. Andere grondslagen voor de openbaarheidseisen in de bestuurlijke voorprocedures, buiten de bepalingen in de Awb en het openbaarheidbeginsel als beginsel van behoorlijke rechtspleging, kunnen evenmin worden aangewezen. Er bestaat geen specifiek of afzonderlijk algemeen beginsel van behoorlijk bestuur waaruit openbaarheideisen voor bestuurlijke besluitvormingsprocedures voortvloeien. Ook worden deze eisen bij mijn weten thans niet (althans niet expliciet) onder het formele zorgvuldigheidsbeginsel, dat toch vaak als kapstok fungeert voor vele procedurele eisen, gebracht. Nicolaï erkent bijvoorbeeld wel een beginsel van correcte bejegening waaruit zijns inziens voortvloeit dat (onder bepaalde omstandigheden) belanghebbenden gehoord moeten worden en dat beginsel normeert tevens in zijn ogen de

\footnotetext{
652. Somer 1969, p. 263-264.

${ }^{653 .}$ Wet beroep tegen administratieve beschikkingen. Zie over ontwikkeling van het Kroonberoep en de bestuursrechtelijke rechtsbescherming o.m.: Damen e.a. 2009, Deel II, p. 32-44; N. Verheij, 'De toegang tot de rechter in het bestuursrecht', in: 50 jaar Europees verdrag voor de Rechten van de Mens (Speciaal nummer NJCMBulletin), Leiden 2000, p. 188-201.

${ }^{654 .}$ Hetzelfde kan gesteld worden ten aanzien van het beroep op Gedeputeerde Staten als rechtsgang.

${ }^{655 .}$ Er wordt aan deze eisen meer in algemene zin aandacht besteed bij de bespreking van de (inrichting van de) bestuurlijke voorprocedures in verschillende handboeken maar daarmee houdt het ook op, zie bijvoorbeeld: Damen e.a. 2009, Deel II, p. 65, 186 en 206; Van Wijk/Konijnenbelt \& Van Male 2008, p. 556; Koenraad \& Sanders 2006, p. 83. In sommige bestuursprocesrechtelijke handboeken komt de eis in het geheel niet ter sprake bij de bespreking van het procesrecht, Schreuder-Vlasblom 2008, p. 266-272. Somer gaat in zijn bijdrage in 1969 uitsluitend in op het administratief beroep, Somer 1969, p. 243-270.

${ }^{656}$. In de betreffende passage stelt hij dat de openbaarheid van de zitting een inrichtingseis is maar maakt hij niet duidelijk of die eis voortvloeit uit het beginsel van hoor en wederhoor of het gelijkwaardigheidsbeginsel. Bovendien is niet duidelijk hoe in zijn optiek de verhouding is tussen deze beide beginselen, Van der Ham 1988, p. 85.

${ }^{657 .}$ Koenraad \& Sanders 2006, p.83.

658. Zie hierover par. 5.5.3 hierna.

659. Deze term externe openbaarheid (erga omnes) is afkomstig van Somer, Somer 1969, p. 243.
} 


\section{De inrichting van de voorprocedures}

procedure en de omvang en diepgang van het horen. ${ }^{660}$ De openbaarheid van de hoorzitting noemt hij echter niet als een van de eisen die het betreft. ${ }^{661}$ Ook in het kader van het door Nicolaï onderscheiden beginsel van zorgvuldige kennisgeving ben ik geen eisen tegengekomen die betrekking hebben op de openbaarmaking of bekendmaking van besluiten als zodanig. ${ }^{662}$ Addink onderscheidt een beginsel van zorgvuldige bekendmaking, maar wijst er ook op dat de bekendmaking van het (definitieve primaire) besluit min of meer samenvalt met de eis dat een besluit zorgvuldig genomen moet worden en dat in de rechtspraak geen afzonderlijk beginsel (van behoorlijk bestuur), inhoudend dat besluiten behoorlijk bekendgemaakt moeten worden, wordt gehanteerd. ${ }^{663}$ In het openbaar uitspreken of openbaar maken van het besluit aan het publiek valt daar in elk geval niet onder. Voorts onderscheidt hij nog een beginsel van zorgvuldig horen dat zijns inziens betrekking heeft op de verplichting tot horen alsook op de wijze van het horen, maar daaronder schaart hij evenmin (expliciet) de openbaarheid van de hoorzitting. ${ }^{664}$ De conclusie moet na deze eerste oppervlakkige beschouwing dan ook zijn dat er naar heersend recht geen beginsel - van behoorlijke rechtspleging noch van behoorlijk bestuur - valt aan te wijzen waaruit de openbaarheid van de behandeling van de zaak en het openbaar maken van de beslissing van het bestuur in de bestuurlijke voorprocedures expliciet voortvloeit.

\section{Plan van aanpak}

Het bovenstaande duidt er op dat de invloed van de aan rechtspraak eigen openbaarheidseisen in of op de bestuurlijke voorprocedures niet eenduidig is (geweest) en dat openbaarheid in de praktijk te bij de voorprocedures geen rol van betekenis lijkt te spelen, althans niet regelmatig een voorwerp van geschil vormt. Vooropgesteld moet worden dat van rechtstreekse toepasselijkheid en rechtstreekse doorwerking van het openbaarheidsbeginsel als beginsel van behoorlijke rechtspleging geen sprake lijkt te zijn. Nu de Awb voorschriften bevat inzake de openbaarheid van de hoorzitting, kan ten aanzien van dit aspect een onderzoek naar de doorwerking van deze eis voor de rechterlijke behandeling van een zaak niettemin zinvol zijn. Zeker omdat op het eerste gezicht niet duidelijk is om welke reden deze inrichtingseis voor de bestuurlijke voorprocedures geldt (al dan niet als hoofdregel) en wat de ratio van deze eis is voor die procedures. Een tweedeling in de openbaarheidseisen, zoals voor rechtspraak het geval is, wordt in het algemeen niet gemaakt bij de bestuurlijke voorprocedures aangezien de eis dat het besluit van het bestuur (extern) openbaar moet zijn, in de zin van in het openbaar uitgesproken of anderszins toegankelijk gemaakt voor het publiek, in het geheel niet gesteld wordt. Teneinde te kunnen beoordelen in hoeverre daadwerkelijk doorwerking van de beginselen van behoorlijke rechtspleging bestaat wat betreft de openbaarheidsvereisten, wordt in het navolgende echter deze tweedeling ook voor de bestuurlijke voorprocedures gevolgd. Allereerst wordt in paragraaf 5.5.3 bezien in hoeverre in bezwaar en administratief beroep een openbare hoorzitting vereist is. Vervolgens wordt in paragraaf 5.5.4 onderzocht in hoeverre een openbare beslissing door het bestuur moet worden gegeven. Tot slot wordt in paragraaf 5.5.5 ook aangegeven in hoeverre (een bepaalde mate van) doorwerking wenselijk zou zijn. Alvorens deze aspecten aan bod komen, wordt echter eerst in paragraaf 5.5.2 de ratio en functie van de openbaarheidseisen voor rechtspraak en bestuur in kaart gebracht aangezien daarin een verklaring gelegen kan zijn voor het al dan niet doorwerken van deze eisen in de bestuurlijke voorprocedures.

\footnotetext{
${ }^{660 .}$ Nicolaï 1990, p. 331.

${ }^{661 .}$ Nicolaï 1990, p. 331-332.

662. Nicolaï 1990, p. 369-371. De door Nicolaï onderscheiden eisen betreffen het formuleren en kennis geven van het besluit in verband met de duidelijkheid die moet bestaan omtrent de concrete gevolgen van het besluit en lijken niet zozeer op de bekendmaking als zodanig te zien.

${ }^{663 .}$ Addink 1999, p. 196-197.

664. Addink 1999, p. 194-195. Dat valt overigens ook niet onder het beginsel van zorgvuldige bejegening dat hij onderscheidt, maar een beperktere strekking toekent dan Nicolaï die daaronder ook het horen van belanghebbenden brengt, Addink 1999, p. 191-192
} 
Deel II Bestuurlijke voorprocedures

5.5.2 Het doel van de openbaarheidseisen in de bestuurlijke voorprocedure

Ratio en functie van de openbaarheidseisen voor rechtspraak

De openbaarheidseisen voor de zitting in de procedure bij de rechter en de uitspraak van de rechter, worden - zoals hierboven al werd aangegeven - primair gesteld ten behoeve van de inzichtelijkheid en controleerbaarheid van de werkzaamheid van de rechter voor de betrokken partijen en het publiek. ${ }^{665}$ Tevens vormt openbaarheid van de behandeling door en de beslissing van de rechter een waarborg voor partijen tegen willekeur en hebben deze eisen een functie ten behoeve van het vertrouwen in de onafhankelijke rechtspraak van partijen. ${ }^{666}$ Beide deelaspecten van het openbaarheidsbeginsel hebben deze functies. De twee functies vertegenwoordigen het onderscheid tussen inwendige en uitwendige openbaarheid ofwel externe en interne werking van de openbaarheidseisen. ${ }^{667}$ De interne openbaarheid heeft betrekking op de bescherming van de belangen van de deelnemers aan de procedure en garandeert toegankelijkheid van de zitting voor die deelnemers en de bekendmaking van de uitspraak aan de betrokken partijen. De uitwendige of externe openbaarheid ziet op de toegankelijkheid van de zitting en uitspraak voor het publiek. ${ }^{668}$

Eenzelfde ratio voor openbaarheid in de bestuurlijke voorprocedure?

Ook in de bestuurlijke voorprocedures zal de hoorzitting in de meeste gevallen in het openbaar plaatsvinden. Wat de ratio of functie van de openbaarheid van behandeling in bezwaar en administratief beroep is, is echter niet duidelijk. Voor de bezwaarschriftprocedure merkt de wetgever immers slechts op dat het lastig is een algemene regeling inzake openbaarheid te scheppen en dat het bestuursorgaan daaromtrent derhalve zelf een beslissing dient te nemen. ${ }^{669}$ Als reden voor het uitgangspunt dat de hoorzitting in administratief beroep in het openbaar dient plaats te vinden, wijst de wetgever het iets formelere karakter van deze voorprocedure aan (in vergelijking tot het meer informele karakter van de bezwaarschriftprocedure). ${ }^{670}$ Dat duidt erop dat de gelijkenis met de procedure voor de rechter de wetgever mogelijk ertoe bewogen heeft openbaarheid (van behandeling) als regel voor te schrijven. ${ }^{671}$ Of dat ook tot de conclusie moet leiden dat de ratio voor openbaarheid in (een bepaal)de voorprocedures niet verschilt van die voor openbaarheid in een rechterlijke procedure staat daarmee echter geenszins vast.

Omdat de publieke controle en het inzichtelijk maken voor het publiek van de rechterlijke werkzaamheid als doel van de openbaarheidseisen samenhangt met de omstandigheid dat de rechter als onafhankelijk orgaan geen verantwoording over zijn uitspraken hoeft af te leggen aan andere organen, staat op voorhand niet vast dat voor openbaarheidseisen in bestuurlijke voorprocedures eenzelfde ratio gevonden kan worden. Voor bestuursorganen geldt zulks immers in mindere mate; bepaalde bestuursorganen dienen in elk geval verantwoording af te leggen aan democratisch gekozen bestuursorganen binnen het openbaar lichaam waartoe zij behoren. In vergelijking tot de rechter beschikt

\footnotetext{
${ }^{665 .}$ PG Awb II, p. 458; Widdershoven 1989, p. 142; De Waard 1987, p. 110; Van Galen \& Maarseveen 1978, p. 60.

666. Widdershoven 1989 , p. 142.

667. Zie hierover par. 4.3.6 in Deel I.

668. Vgl. Van Lent 2008, p. 1. Zie ook: de conclusie van A-G Machielse bij HR 2 juli 2002, NJ 2003/2 m.nt. Kn, par. 3.7. Overigens wordt de interne openbaarheid vaak ruimer opgevat en daaronder ook de toegankelijkheid van stukken e.d. voor de procesdeelnemers begrepen, zie bijv.: E.J. Daalder, Toegang tot overheidsinformatie. Het grensvlak tussen openbaarheid en vertrouwelijkheid (diss. Leiden), Den Haag: BJu 2005, p. 5 en 257. Zoals ik in Deel I heb aangegeven zou ik die vorm van interne openbaarheid eerder onder willen brengen bij het beginsel van hoor en wederhoor, Deel I, par. 4.3.6.

669. PG Awb I, p. 341.

670. PG Awb I, p. 359.

${ }^{671 .}$ Vgl. ook Somer die zoals eerder al aangegeven werd vanwege de gelijkenis met rechtspraak lijkt te pleiten voor openbaarheid in het administratief beroep, Somer 1969, p. 244 en 261 e.v.
} 


\section{De inrichting van de voorprocedures}

het bestuur voorts over een sterke(re) democratische legitimatie. ${ }^{672}$ Bovendien wordt de beslissing van het bestuur getoetst door die onafhankelijke rechter in een procedure waarvoor de openbaarheidsvereisten gelden en wordt het bestuurlijk optreden zelf in openbaarheid op rechtmatigheid getoetst. De democratische functie van het openbaarheidsbeginsel die eruit bestaat dat de rechter zijn democratische legitimatie haalt uit het vertrouwen dat het publiek en rechtzoekenden stellen in rechtspraak lijkt derhalve niet zo sterk aanwezig (en nodig) te zijn voor de bestuurlijke voorprocedures.

\section{De ratio van externe openbaarheid in de bestuurlijke voorprocedures}

Desalniettemin zijn er redenen aan te wijzen voor een zekere mate van externe openbaarheid in de bestuurlijke (voor)procedures, waarbij een vergelijkbare ratio kan worden aangewezen. In de praktijk lijkt allereerst, zoals Somer reeds opmerkte voor het administratief beroep, de politieke verantwoordelijkheid voor de beslissingen in de bestuurlijke voorprocedures nauwelijks tot gelding te worden gebracht. ${ }^{673}$ Daarmee wordt afbreuk gedaan aan het argument dat bij het bestuur een sterkere democratische legitimatie bestaat. Bovendien is ook het vertrouwen in de overheid en in het bijzonder het bestuur gebaat bij zo groot mogelijke openheid en transparantie ten aanzien van de besluitvorming en overheidsinformatie. Openbaarheid in de bezwaarschriftprocedure en het administratief beroep kan daaraan bijdragen. In deze zin kan openbaarheid in die procedures een vergelijkbaar (extern) doel waarborgen. Vertrouwen in de overheid hangt in meer algemene zin samen met de toegankelijkheid van informatie over de besluitvorming en het besluit zelf voor het publiek. Zoals Van Lent opmerkt in het kader van strafrechtelijke procedures kan ook voor andere organen dan de rechter, eigenlijk voor alle overheidsorganen, een vorm van verantwoording aan de rechtsgemeenschap gewenst zijn. ${ }^{674}$ Dat geldt niet alleen voor het openbaar ministerie dat zij als voorbeeld noemt, maar ook voor bestuursorganen. Niet voor niets bestaat er sinds 1 mei 1980 een Wet openbaarheid van bestuur die met het oog op een goede en democratische bestuursvoering een zekere mate van openheid en transparantie voorschrijft. ${ }^{675}$ Volgens de Afdeling dient deze wet ook primair de externe en publieke openbaarheid, waarmee een ander doel wordt gediend dan de interne openbaarheid die geldt op grond van de Awb inzake toegang tot stukken in de bestuurlijke voorprocedures en de procedure bij de bestuursrechter. ${ }^{676}$ Openbaarheid en toegang tot informatie zijn vereisten die in onze democratische rechtsstaat betrekking hebben op alle overheidsinformatie en verder strekken dan procedurele openbaarheid alleen. ${ }^{677}$ In dit onderzoek staat echter uitsluitend de procedurele openbaarheid, dat wil zeggen openbaarheid in de procedure bij de rechter, de bezwaarschriftprocedure en het administratief beroep centraal. Openbaarmakingseisen ten aanzien van de beslissing van het bestuur in bezwaar of administratief beroep die als doel hebben de controle door het publiek kennen we in het algemene Nederlandse bestuursrecht als behoorlijkheidseis niet, althans geen eisen die zien op de uitwendige openbaarheid. ${ }^{678}$ Het doel van

672. Zie over de democratische legitimatie van de rechter, Bovend'Eert 2008, p. 163.

673. Somer 1969, p. 261. De mogelijkheden bestaan daartoe wel op grond van art. 160 lid 1 sub f en art. 169 lid 4 en 5 Gemeentewet alsmede art. 158 lid 1 sub f en 167 lid 4 en 5 en 168, 169, 170, 171 Provinciewet.

${ }^{674 .}$ L. van Lent, Externe openbaarheid in het strafproces (diss. Utrecht), Den Haag: BJu 2008, p. 3.

675. De totstandkomingsgeschiedenis wordt beschreven in: Daalder 2005, p. 77 e.v.; Zie verder over de WOB o.m.: J.A. Hofman, 'Openbaarheid van bestuur: een allemansvriend die ook discreet kan zijn', JB-plus 2004, p. 199-212; P.J. Boukema, 'De WOB: recente ontwikkelingen in de rechtspraktijk', in: A.W. Hins en A.J. Nieuwenhuis, Van ontvanger naar zender (De Meij-bundel), Amsterdam: Otto Cramwinckel 2003, p. 33-44, en L.A.J. Spaans, 'Wet openbaarheid van bestuur: recente ontwikkelingen in jurisprudentie en wetgeving', Mediaforum 2004, p. 22-27; T. Brandsen, E. Cornelissen, S. van der Hof, G.J. Leenknegt, C. Prins en M. de Vries m.m.v. L. Griep, A. Jasiak, R. Loermans, Over wetten en praktische bezwaren. Een evaluatie en toekomstvisie op de Wet openbaarheid van bestuur (Evaluatierapport), Universiteit van Tilburg 2004

676. AbRvS 26 juli 1999, JB 1999/226. Zie hierover nader Daalder 2005, p. 258-259

677. Zie over dit begrip en de in dat kader geldende eisen: Daalder 2005, p. 5 en hfst. 8 (p. 257-309).

678. Zie ook Daalder 2005, p. 262. Daalder wijst echter op enkele bijzondere bestuursrechtelijke wetten waarin een dergelijke externe openbaarheid van besluiten van het bestuur geregeld is, Daalder 2005, p. 263-266. 
Deel II Bestuurlijke voorprocedures

die eisen, controle door het publiek van de beslissing en redenen voor de beslissing, wordt derhalve bij besluitvorming door bestuursorganen niet gerealiseerd door eisen in de Awb. De Wet openbaarheid van bestuur voorziet ten dele in de openbaarmaking van een besluit van het bestuur. ${ }^{679}$ Op grond van die wet vindt echter ook geen publicatie en toegankelijkheid voor het publiek in het algemeen plaats.

Ook ten aanzien van uitwendige openbaarmakingseisen voor de beslissing van het bestuur in de bestuurlijke voorprocedure kan echter gesteld worden dat het vertrouwen in de overheid alleen maar gebaat zou zijn bij het stellen van zulke eisen. Voor zover daar praktische problemen aan kleven, kan een invulling of vorm gekozen worden die daaraan tegemoet komt. Openbaarmaking behoeft niet mondeling te geschieden zoals dat onder de Awb van de rechter geëist wordt, maar zou ook via publicatie op internet of in huisaan-huis-bladen kunnen plaatsvinden. Voor besluiten van algemene strekking geldt zulks thans al op grond van artikel 3:42 of bijzondere wetten. ${ }^{600}$ Wel geldt bij de openbaarmaking van besluiten dat rekening moet worden gehouden met de privacy van belanghebbenden en er eerder redenen kunnen bestaan om niet tot openbaarmaking over te gaan dan wel om verschillende versie van een besluit te hanteren, aldus Daalder. ${ }^{681}$ Ook zou aansluiting gezocht moeten worden bij de uitzonderingen die genoemd worden in de Wob. ${ }^{682}$

\section{Interne openbaarheid}

Naast het vertrouwen van de samenleving in de overheid, dat gediend kan zijn met externe openbaarheid, geldt uiteraard ook dat interne openbaarheid in de bestuurlijke voorprocedures de rechtsbescherming van de belanghebbende(n) ten goede komt. Wat betreft de functie van de interne openbaarheid in de bestuurlijke voorprocedures is er geen onderscheid te constateren met de interne werking van de openbaarheidseisen voor rechtspraak. Inwendige openbaarheidseisen worden ook bij besluitvorming door het bestuur in de bestuurlijke voorprocedures gesteld. Voor besluiten genomen door het bestuur gelden immers - zie hierover nader paragraaf 4.5.5.4 - de algemene bekendmakingsregels die zijn neergelegd in de Awb. De inwendige openbaarheidseisen hebben voor de rechterlijke uitspraak de functie om partijen op de hoogte te stellen van de uitspraak en de bescherming van de belangen van die partijen. Zij worden op de hoogte gesteld van de uitspraak en de termijn voor hoger beroep tegen de uitspraak begint te lopen na de bekendmaking. ${ }^{683}$ Dat doel ligt ook - naast de functie in het kader van het van kracht worden van de rechtsgevolgen van het besluit - ten grondslag aan de bekendmakingsregels voor besluiten. ${ }^{684}$ Deze bekendmakingseisen ten opzichte van belanghebbenden gelden ten behoeve van de rechtsbescherming en verweermogelijkheden van belanghebbenden. Ook wat betreft de openbare behandeling van de zaak gelden er interne openbaarheidseisen, in de zin dat de hoorzitting in beginsel toegankelijk is voor de belanghebbenden en zij daarbij tegelijkertijd aanwezig kunnen zijn, ingevolge artikelen 7:2 en 7:6 Awb. Ook daaraan ligt hetzelfde doel als voor rechtspraak ten grondslag: de verweermogelijkheden en rechtsbescherming van belanghebbenden. ${ }^{685}$ Tot slot kan ook hier gesteld worden dat de interne werking van de openbaarheidseisen in de bestuurlijke voorprocedures gerealiseerd kan worden door inachtneming van andere beginselen, zoals het beginsel van hoor en wederhoor. De primaire functie van de openbaarheidseisen ligt ook in de bestuurlijke voorprocedures in mijn optiek derhalve bij het waarborgen van externe toegang tot de

\footnotetext{
679. Zie hierover: Daalder 2005, p. 261-265

680. Zie ook voor besluiten van de centrale overheid ook de Bekendmakingswet die sinds de inwerkingtreding van de Wet Elektronische bekendmaking op 1 juli 2009 (Stb. 2008, 551) voorziet in bekendmaking in een elektronische Staatscourant.

${ }_{681 .}$ Daalder 2005, p. 261-263.

682. Daalder 2005, p. 261-266.

683. Zie hierover par. 4.3.6 van Deel I.

684. PG Awb I, p. 230. Zie bijvoorbeeld ook: Damen e.a. 2009, Deel II, p. 428 e.v.; Daalder 2005, p. 262.

${ }^{685 .} \mathrm{Zie}$ daarover par. 5.3 van dit deel.
} 


\section{De inrichting van de voorprocedures}

zitting en het besluit van het publiek. De interne openbaarheidseisen passen wat betreft hun functie beter bij het beginsel van hoor en wederhoor.

\subsubsection{Een openbare behandeling in de bezwaarschriftprocedure en het administratief beroep}

\section{Hoorzitting met gesloten of open deuren in bezwaar}

In de bezwaarschriftprocedure is het uitgangspunt dat belanghebbenden in de gelegenheid worden gesteld om te worden gehoord en daartoe wordt in de meeste gevallen een hoorzitting georganiseerd. De hoorzitting behoeft echter niet per definitie in het openbaar te geschieden. Of een openbare behandeling van de zaak en de bezwaren van belanghebbenden plaatsvindt, is in artikel 7:5, tweede lid, van de Awb - voor zover in een bijzonder wettelijk voorschrift niets geregeld is - aan de discretie van het bestuur overgelaten. Is het horen overgelaten aan een adviescommissie als bedoeld in artikel 7:13 Awb dan beslist de commissie omtrent de openbaarheid van de hoorzitting. ${ }^{686}$ Dat betekent dat het bestuur of de adviescommissie, voor zover een wettelijke regeling ontbreekt, per geval kan beslissen of openbaar horen opportuun is. In bezwaar bestaat derhalve niet de 'harde' inrichtingseis dat het horen in beginsel openbaar moet zijn voor publiek zoals neergelegd voor de zitting bij de bestuursrechter in 8:62 van de Awb. Belanghebbenden kunnen het bestuursorgaan verzoeken de hoorzitting al dan niet in het openbaar te laten plaatsvinden - aldus de wetgever. ${ }^{687}$ Criteria aan de hand waarvan een dergelijk verzoek in het concrete geval beoordeeld moet worden of waarop een weigering dan wel toestemming om in het openbaar te horen gestoeld kan worden, biedt de wet of de toelichting daarop echter niet. De wetgever laat hierdoor ook de mogelijkheid open dat bepaalde categorieen zaken nimmer in het openbaar behandeld worden en dat algemene uitzonderingen geoorloofd zijn. Een dergelijke algemene uitzondering op of uitsluiting van categorieën zaken van openbaarheid is voor rechtspraak niet geoorloofd. ${ }^{688}$ In de handreiking bezwaar die het ministerie van Justitie heeft opgesteld wordt, naast een korte schets van het wettelijk kader, aangegeven dat de ervaring leert dat het verstandig is om in het openbaar te horen, tenzij bijzondere redenen zich daartegen verzetten. ${ }^{69}$ Een nadere toelichting ontbreekt echter ook hier.

In welke mate bij bijzondere wettelijke regeling openbaarheid van de hoorzitting is voorgeschreven of juist is uitgezonderd, is mij niet bekend. Ook lagere regelgevers kunnen in verordeningen bepalen of en wanneer de hoorzitting in het openbaar moet plaatsvinden. ${ }^{690}$ Dat betekent dat er een groot aantal lagere regelingen van allerlei verschillende bestuursorganen kan bestaan waarin dit onderwerp (op mogelijk uiteenlopende wijze) geregeld wordt. Om die reden valt niet te zeggen of en onder welke voorwaarden openbaarheid in zijn algemeenheid wel of niet uitgangspunt is. ${ }^{691}$ Teunissen wijst er evenwel

\footnotetext{
${ }^{686 .}$ Zie art. 7:13 lid 4 Awb en PG Awb I, p. 341 en 354.

687. PG Awb I, p. 341

688. Zoals de Centrale Raad overwoog zou een categorische uitsluiting van de openbare behandeling van medische aspecten in WAO-zaken, zoals neergelegd in art. $88 \mathrm{~h}$ WAO, strijd opleveren met artikel 6 EVRM, zie CRvB 25 januari 1998, $A B$ 1998/168 m.nt. FP.

${ }^{689 .}$ Handreiking Bezwaarschriftprocedure Algemene wet bestuursrecht, Den Haag: BJu 2004, p. 26.

${ }^{690 .}$ Teunissen, p. E 6.3.10-2.

691. Vanwege het grote aantal regelingen heb ik ook niet alle bijzondere regelingen, waarin de procedure in bezwaar nader is uitgewerkt, kunnen nalopen. Een blik bij enkele (grotere) gemeenten leverde echter de indruk op dat ofwel de VNG-modelverordening gevolgd wordt ofwel openbaarheid uitgangspunt is, maar niet conform de VNG-modelverordening is vormgegeven. De gemeente Mastricht heeft bijvoorbeeld in zijn verordening bezwaar- en beroepschriften in art. 9 lid 2 bepaald dat de hoorzitting in het openbaar geschiedt, tenzij de commissie op verzoek van een belanghebbende of om gewichtige redenen ambtshalve anders beslist (te raadplegen via www.maastricht.nl). De gemeente Nijmegen heeft in art. 12 lid 1 van de verordening op de commissie voor bezwaarschriften (te raadplegen via www.nijmegen.nl) bepaald dat de zittingen van de commissie waarin personen worden gehoord openbaar zijn en in lid 2 dat de deuren worden gesloten, indien de voorzitter of een van de overige aanwezige leden van de commissie daartoe een verzoek doet. De commissie beslist vervolgens of de zitting verder plaatsvindt met gesloten deuren.
} 


\section{Deel II Bestuurlijke voorprocedures}

op dat in de VNG-modelverordeningen de mogelijkheid is opgenomen om af te zien van een openbare hoorzitting indien een van de hoorders dit nodig acht of een belanghebbende daarom verzoekt. Voorts geeft hij aan dat er volgens de modellen een gewichtige reden moet bestaan voor het horen met gesloten deuren. ${ }^{692}$ Een dergelijke regeling in de VNG-modelverordening sluit aan bij de regeling zoals die geldt voor het administratief beroep in de Awb (zoals hierna zal blijken) en daarmee ook bij het beroep bij de rechter. Dat zou betekenen dat openbaarheid van de hoorzitting ook in bezwaar het uitgangspunt is - in elk geval op gemeentelijk niveau (voor zover niet van de modelverordening is afgeweken). In Damen e.a. wordt aangegeven dat in de praktijk het horen in het openbaar plaatsvindt en dat in concrete gevallen besloten kan worden dat niet te doen. ${ }^{693}$ Koenraad en Sanders merken echter op dat de praktijk een genuanceerd beeld laat zien. ${ }^{694}$ Het is niet duidelijk op welke gegevens deze uiteenlopende bevindingen gebaseerd zijn. Over de toepassing van deze bepaling en het vereiste van een openbare hoorzitting in bezwaar is ook nauwelijks jurisprudentie voorhanden. ${ }^{695}$ Het is daarom lastig conclusies te trekken omtrent de mate waarin openbaarheid in de praktijk vereist is. Het al dan niet houden van een openbare hoorzitting in bezwaar lijkt echter gelet op het voorgaande niet tot veel problemen te leiden in de praktijk. Reden daarvoor zou wellicht kunnen zijn dat het houden van een openbare hoorzitting als vanzelfsprekend wordt gezien, tenzij bepaalde belangen in een specifiek geval zich daartegen verzetten.

Voor de bezwaarschriftprocedure lijkt mij ook in de rede te liggen dat de beslissing omtrent openbaarheid van de zitting op dezelfde wijze en aan de hand van de zelfde criteria die voor de rechter gelden genomen wordt. Omdat er connexiteit bestaat tussen de bezwaarschriftprocedure en de procedure bij de rechter, ligt het voor de hand om wat betreft de openbaarheidseisen aan te sluiten bij de regeling die geldt voor beroep bij de rechter. Indien in bezwaar criteria gehanteerd worden waardoor minder snel tot een zitting met gesloten deuren besloten wordt, en tegen de wil van belanghebbende een openbare zitting plaatsvindt, worden de belanghebbende en de rechter in beroep (voor zover dat wordt ingesteld) immers voor een voldongen feit geplaatst. De bijvoorbeeld privacygevoelige gegevens zijn dan al in de openbaarheid gekomen tijdens de voorprocedure. De rechter kan dan uiteraard nog wel afzien van een openbare behandeling, maar het kwaad is dan al deels geschied. Om de afweging inzake de openbaarheid van de behandeling nog zinvol te laten zijn, lijkt het mij dan ook in de rede te liggen dat die eis in bezwaar op vergelijkbare wijze ingevuld en gehanteerd wordt (of desnoods strenger wordt ingevuld waardoor eerder een hoorzitting met gesloten deuren plaatsvindt).

Ook om andere (meer principiële) redenen kan openbaarheid van de hoorzitting bepleit worden. Allereerst omdat de toegankelijkheid van de mondelinge behandeling in bezwaar voor het publiek in het algemeen kan bijdragen aan het vertrouwen van de samenleving in het openbaar bestuur. Daarnaast kan de openbare behandeling van de zaak in bezwaar ook andere behoorlijkheideisen waaraan de procedure moet voldoen ondersteunen. Indien het horen geschiedt mede of door het bestuursorgaan zelf dan wel door een of meer andere personen (die niet bij de voorbereiding van het primaire besluit betrokken is geweest of van wie de meerderheid niet bij de voorbereiding van het primaire besluit betrokken is geweest) kan de openbaarheid van de zitting voor publiek bijdragen aan de objectiviteit van de besluitvorming en de eisen van hoor en wederhoor. Indien het horen geschiedt door een adviescommissie geldt het voorgaande eens te meer. In dat geval is er een sterkere gelijkenis met de procedure voor de rechter, omdat sprake is van een contradictoire behandeling van de zaak door een derde. Tijdens de zitting zijn belanghebbenden en ook een vertegenwoordiger van het bestuursorgaan aanwezig. Open-

692. Teunissen, p. E 6.3.10-18

693. Zie: Damen e.a. 2009 Deel II, p. 186

694. Koenraad \& Sanders 2006, p. 83. Zij geven echter geen voorbeelden waaruit dit zou blijken.

695. Ik heb geen gepubliceerde uitspraken kunnen vinden van de bestuursrechter waarin de openbaarheid van de hoorzitting ten tijde van de Awb centraal stond. 


\section{De inrichting van de voorprocedures}

baarheid van de zitting versterkt de waarborgen van hoor en wederhoor en onpartijdigheid in de behandeling en advisering door de commissie.

Tot slot wil ik nog opmerken dat de openbaarheid van de hoorzitting, zoals geregeld in artikel 7:5 Awb, uitsluitend betrekking heeft op de toegang voor het publiek. In de bezwaarschriftprocedure wordt een duidelijk onderscheid gemaakt tussen het recht van belanghebbenden om (in elkaars aanwezigheid) gehoord te worden en de toegang van het publiek tot die hoorzitting. Zoals reeds meermalen is betoogd, is die scheiding in mijn optiek het meest zuiver en behoort het recht van belanghebbenden om aanwezig te zijn (al dan niet tegelijkertijd) aan de orde te komen bij de eisen die voortvloeien uit het beginsel van hoor en wederhoor. Om die reden wordt daarop in deze paragraaf niet nader ingegaan - dat is gebeurd in paragraaf 5.3. Deze eisen, die ook wel als interne openbaarheidseisen gezien worden (in het kader van rechtspraak), gelden derhalve wel degelijk maar onder de noemer van een ander beginsel.

\section{Hoorzitting met open deuren als uitgangspunt in administratief beroep}

Voor het administratief beroep geldt dat als uitgangspunt de hoorzitting wel openbaar is. Dit is een van de weinige punten waarop de regeling van het administratief beroep afwijkt van die van de bezwaarschriftprocedure. Ook in deze procedure is echter geen sprake van een absoluut uitgangspunt. Op verzoek van de belanghebbende of ambtshalve om gewichtige redenen kan van openbaarheid worden afgezien. Reden voor het uitgangspunt dat de hoorzitting in administratief beroep in het openbaar dient plaats te vinden, vormt het iets formelere karakter van deze voorprocedure aan (in vergelijking tot het meer informele karakter van de bezwaarschriftprocedure). ${ }^{696}$ Daarmee lijkt de wetgever te doelen op de omstandigheid dat de procedure gevoerd wordt bij een derde, een ander bestuursorgaan, waarbij partijen meer tegenover elkaar komen te staan in een contradictoire procedure. Omdat administratief beroep in zeker opzicht (de procedure wordt immers aangespannen bij een ander orgaan) meer verwantschap vertoont met rechtspraak, lijkt de wetgever de mening toegedaan dat als regel, evenals het geval is bij bestuursrechtspraak, sprake moet zijn van een openbare zitting. Is dat het geval dan vormt de gelijkenis met de procedure bij de rechter voor het administratief beroep een aanwijsbare reden voor de openbaarheid van de hoorzitting. Voor het overige zijn de verschillen met de bezwaarschriftprocedure immers verwaarloosbaar en kan in mijn ogen niet gezegd worden dat de procedure in administratief beroep een formeler karakter heeft (vergelijk de bepalingen inzake de inrichting van de procedure in de Awb die grotendeels overeenstemmen). ${ }^{697}$

In de toelichting wordt - niet limitatief - aangegeven dat gewichtige redenen kunnen bestaan uit redenen van algemeen belang of redenen die samenhangen met de bescherming van de privacy van belanghebbenden. Indien wordt uitgegaan van een formelere opzet van het administratief beroep die meer aansluit bij de procedure voor de bestuursrechter, zou voor de invulling van het begrip gewichtige redenen aangesloten kunnen worden bij de vier gronden die in artikel 8:62 Awb worden genoemd op grond waarvan de bestuursrechter kan besluiten tot een besloten behandeling van de zaak. ${ }^{698}$ Ook in die bepaling vormt openbaarheid het uitgangspunt. In het tweede lid zijn limitatieve criteria opgenomen op grond waarvan van openbaarheid van de zitting kan worden afgezien: in het belang van de openbare orde of goede zeden, in het belang van de veiligheid van de Staat, indien de belangen van minderjarigen of de eerbiediging van de persoonlijke levenssfeer van partijen dat eisen of indien openbaarheid het belang van een goede rechtspleging zou schaden. Daarbij kan besloten worden de zitting geheel achter gesloten deuren te laten plaatsvinden, maar ook gedeeltelijk. De criteria op grond waarvan de

696. PG Awb I, p. 359.

697. Zie ook over de verschillen in functies en heroverweging of toetsing in bezwaar en adminstratief beroep, par. 4.2 en 4.3 van Deel II.

698. Zie hierover par. 4.3.6 van Deel I. 


\section{Deel II Bestuurlijke voorprocedures}

bestuursrechter kan afzien van een openbare behandeling van de zaak lijken grotendeels ontleend te zijn aan artikel 6 lid 1 EVRM en de daarin opgenomen belangen op grond waarvan een beperking van de openbaarheid van behandeling kan plaatsvinden. Voor de invulling van de gewichtige redenen in administratief beroep op grond waarvan openbaarheid van de zitting achterwege kan worden gelaten, verwijst de wetgever echter niet expliciet naar artikel 8:62 Awb of artikel 6 EVRM. Maar de gronden in het algemeen belang of de privacy van belanghebbenden sluiten wel aan bij de in artikel 8:62 lid 2, sub a tot en met d, genoemde gronden en daarmee ook bij de in artikel 6 EVRM genoemde belangen of zijn dermate ruim geformuleerd dat aansluiting daarbij tot de mogelijkheden behoort. Om dezelfde redenen als voor de bezwaarschriftprocedure, moet openbaarheid van de zitting in administratief beroep mijns inziens ook het uitgangspunt zijn. Verschil met de bezwaarschriftprocedure is dat de uitwerking in de Awb die in hoofdregel openbaarheid vorschrijft voor administratief beroep voort lijkt te komen uit de openbaarheideisen zoals die gelden voor de bestuursrechter. Zoals aangegeven, ligt de verklaring daarvoor in de historische plaats van het administratief beroep in het stelsel van de bestuursrechtelijke rechtsbescherming.

\section{Gerechtvaardigd onderscheid bezwaar en beroep}

Wat betreft de door de wetgever gegeven rechtvaardiging voor het onderscheid ter zake van de openbare behandeling in bezwaar en administratief beroep - het formelere karakter van het administratief beroep - vraag ik mij af of deze voldoet. De ratio van de openbare behandeling is onder meer de controleerbaarheid van die behandeling door de rechter voor het publiek. Door in administratief beroep die behandeling als uitgangspunt openbaar te maken, geldt ook hier dat deze onderworpen is (althans in theorie) aan de controle van het publiek. Ik zie echter niet in, gelet op deze ratio, om welke reden in dit opzicht een verschil moet bestaan tussen bezwaar en administratief beroep. Hoewel in administratief beroep een ander orgaan dan het oorspronkelijke bestuursorgaan een oordeel moet geven over het door de belanghebbende bestreden besluit en in dit opzicht meer gelijkenis bestaat met de procedure bij de rechter, is daarmee niet gegeven dat de noodzaak van publieke controle meer of minder aanwezig is. Zowel in bezwaar als in administratief beroep is thans immers sprake van een procedure die voorafgaat aan de procedure bij de rechter waar een openbare behandeling van de zaak het uitgangspunt is. Bovendien is in beide gevallen sprake van een procedure waarin door een bestuursorgaan een geschil tussen een bestuursorgaan en een belanghebbende wordt beslist. De noodzaak voor openbaarheid, lijkt mij, gelet daarop in beide procedures niet te verschillen. In administratief beroep is voorts, evenals in bezwaar, een bestuursorgaan dat ofwel democratisch gelegitimeerd is ofwel aan democratisch gelegitimeerde organen verantwoording schuldig is het orgaan dat een beslissing moet nemen. Controle van de werkzaamheid van het orgaan kan derhalve (in tegenstelling tot bij de rechter) plaatsvinden door andere organen. De ratio voor de openbaarheideis kan derhalve niet meer (of minder) dan in bezwaar gevonden worden in publieke controle van die werkzaamheid. Daar komt nog bij dat het verschil in het formele karakter van de procedure, waar de wetgever op wijst, grotendeels vervaagt, indien een adviescommissie de belanghebbenden en de vertegenwoordiger van het bestuursorgaan hoort.

Een verschil met de bezwaarschriftprocedure, dat wellicht relevant is geweest voor het onderscheid, zou kunnen schuilen in de omstandigheid dat een ander beroepsorgaan het besluit beziet en een nieuw standpunt dat afwijkt van het standpunt van het primaire bestuursorgaan kan innemen. Indien het besluit wordt herroepen, wordt immers de bevoegdheidsuitoefening van het primaire orgaan doorkruist door het beroepsorgaan. Daarin zou een extra reden gelegen kunnen zijn voor openbaarheid van de hoorzitting. De openbaarheid voor het publiek biedt dan een extra waarborg en controle op de wijze waarop het beroepsorgaan met zijn taak omspringt en noopt wellicht tot de benodigde terughoudendheid vanwege de mogelijke doorkruising van de uitoefening van een wettelijke toegekende bevoegdheid door het primaire beslissende bestuursorgaan. Een meer 


\section{De inrichting van de voorprocedures}

voor de hand liggende rechtvaardiging zou derhalve mijns inziens gevonden kunnen worden in de omstandigheid dat een ander orgaan, dan het orgaan dat door de wetgever de bevoegdheid heeft gekregen om in het concrete geval een besluit te nemen, die bevoegdheidsuitoefening kan terugdraaien. Die omstandigheid zou kunnen nopen tot aanvullende controle of verantwoording. Is dat het geval, staan de openbaarheideisen in administratief beroep echter ook niet zozeer in het teken van de rechtsbescherming of waarborgen van de belanghebbende burgers, maar eerder in het teken van publieke controle en het primaat in de besluitvorming van het primair beslissende bestuursorgaan, de bescherming van een algemeen belang. Een andere verklaring die met het voorgaande samenhangt zou kunnen zijn dat het standpunt of de inzichten van het beroepsorgaan (in die betreffende kwestie) niet of minder bekend zijn dan dat van het primaire orgaan dat zijn primaire standpunt al heeft neergelegd in een besluit. Kanttekening hierbij is echter dat ook het primaire orgaan in bezwaar naar aanleiding van bijvoorbeeld een advies van de adviescommissie, wiens standpunt over het besluit eveneens geheel nieuw en onbekend is, op grond van zijn heroverwegingsplicht tot een geheel ander besluit kan komen. Deze verklaringen voor het onderscheid zijn echter niet expliciet door de wetgever aangedragen en daarvan staat derhalve niet vast dat zij ten grondslag hebben gelegen aan het onderscheid tussen beide procedures. In mijn optiek zijn de verschillen tussen de bezwaarschriftprocedure en het administratief beroep ook dermate klein, zeker indien in bezwaar een adviescommissie wordt ingeschakeld, dat een verschil in het openbaarheidsregime daardoor niet gerechtvaardigd wordt. Op de vervolgvraag hoe het openbaarheidsregime er wat betreft de behandeling ter hoorzitting dan voor beide procedures zou moeten uitzien, moet het antwoord luiden dat dit regime zoveel mogelijk moet aansluiten bij de regeling die geldt voor de terechtzitting bij de bestuursrechter. Zoals aangegeven, moet er in bezwaar of administratief beroep in dezelfde gevallen overgegaan worden tot openbaarheid of juist beslotenheid, omdat anders de openbaarheid dan wel beslotenheid in beroep te zeer doorkruist kan worden.

\subsubsection{Openbaarmaking van de beslissing in de bezwaarschriftprocedure en het administratief beroep}

Openbare beslissing in bezwaar en administratief beroep

Zoals hierboven al is aangegeven kennen we in het algemene bestuursrecht geen specifiek vereiste van uitwendige openbaarheid van besluiten in bezwaar en beroep, zoals dat geldt voor de uitspraken van de rechter. Beslissingen op bezwaar behoeven niet zoals de uitspraken van de bestuursrechter op grond van artikel 8:78 Awb in het openbaar uitgesproken te worden of anderszins openbaar gemaakt te worden voor het publiek. In enkele bijzondere wetten worden wel externe openbaarheideisen gesteld ten aanzien van besluiten genomen op grond van die wetten. Daaruit volgt dan dat besluiten ter inzage moeten worden gelegd of in huis-aan-huisbladen moeten worden gepubliceerd. Voorts kan er sprake zijn van een besluit op bezwaar of administratief beroep dat op grond van de Wob openbaar moet worden gemaakt. ${ }^{699}$

Wel geldt voor alle fasen van de besluitvorming dat besluiten op behoorlijke wijze bekend moeten worden gemaakt. Het betreft echter interne bekendmakingseisen (of zo men wil openbaarheidseisen) die beogen te waarborgen dat personen tot wie het besluit is gericht of personen die rechtstreeks door het besluit in hun belangen worden geraakt op de hoogte zijn van het besluit en de rechtsgevolgen daarvan. Bovendien zijn die bekendmakingseisen vooral van belang voor de inwerkingtreding van besluiten. Voor de bezwaarschriftprocedure en het administratief beroep is in de Awb neergelegd dat bekendmaking moet geschieden aan degene(n) tot wie het besluit op bezwaar of beroep is gericht. De algemene bekendmakingseisen die zijn neergelegd in hoofdstuk 3 van de

699. Zie: Daalder 2005, p. 262-265. 


\section{Deel II Bestuurlijke voorprocedures}

Awb gelden in beginsel niet voor de besluiten genomen in de voorprocedures. De beslissing op bezwaar dient door middel van toezending of uitreiking aan de geadresseer$\operatorname{de}(\mathrm{n})^{700}$ bekend gemaakt te worden, ingevolge artikel 7:12, tweede lid, van de Awb. ${ }^{701}$ Gaat het echter om een besluit van algemene strekking dan behoort de beslissing op dezelfde wijze als het primaire besluit te worden bekendgemaakt en dat betekent kennisgeving van het besluit of de zakelijke inhoud ervan in een van overheidswege uitgegeven blad of een dag-, nieuws- of huis-aan-huis-blad dan wel op andere geschikte wijze. ${ }^{702}$ Tevens dient mededeling van het besluit op bezwaar te worden gedaan aan belanghebbenden die in bezwaar of bij de voorbereiding van het besluit hun zienswijze naar voren hebben gebracht, aldus het derde lid van dezelfde bepaling. Daarmee wordt beoogd ook die belanghebbenden, voor zover zij daarvoor nog in aanmerking komen, tijdig beroep te kunnen laten instellen. Voorts behoort bij de bekendmaking en de mededeling te worden aangegeven welke beroepsmogelijkheid openstaat tegen de beslissing op bezwaar. ${ }^{703}$

\section{Interne openbaarheid}

Deze eis voor de bestuurlijke besluitvorming kan voor een deel worden beschouwd als equivalent van de inwendige openbaarheidseisen die voor rechtspraak gesteld worden. Zoals in paragraaf 4.3.6 van Deel I is gebleken beogen de eisen inzake de openbaarmaking van de uitspraak inwendige en uitwendige openbaarheid te bewerkstelligen. De inwendige openbaarheid vereist dat partijen de beschikking moeten krijgen over de uitspraak. De interne werking van de openbaarheidseisen beoogt toegankelijkheid van de uitspraak en het oordeel van de rechter voor de procesdeelnemers te bewerkstelligen. Naast het openbaar maken van de uitspraak (door het in het openbaar uitspreken van het dictum van de uitspraak gelet op artikel 8:78 Awb of anderszins) geldt op grond van het openbaarheidsbeginsel dat de uitspraak aan partijen moet worden toegezonden en voorts voor anderen op verzoek ter beschikking gesteld moet worden. Die inwendige openbaarheidseisen zijn voor de bestuursrechter in artikel 8:79 neergelegd. In de praktijk lijkt ook de openbaarmaking van de uitspraak van de rechter via andere middelen dan het in het openbaar uitspreken de overhand te krijgen. ${ }^{704}$ De openbaarmaking van de uitspraken geschiedt deels op dezelfde wijze als de bekendmaking van besluiten, in elk geval wat betreft de interne openbaarheid, maar is voor een deel ook nog steeds ruimer omdat de toegankelijkheid van de uitspraken voor het publiek op andere wijze gewaarborgd is.

De interne openbaarheid en bekendmaking van de beslissing van het bestuur lijkt ook hetzelfde doel te dienen als de interne openbaarheid van de uitspraak van de rechter. Van belang is dat de betrokken partijen op de hoogte zijn van de beslissing van het bestuur en de rechter waarmee partijen beschermd worden tegen willekeur van de kant van deze organen en daarnaast treden de rechtsgevolgen van die beslissing op het moment van bekendmaking in werking. De (hoger)beroepstermijn begint immers in beide gevallen te lopen op het moment dat de beslissing of uitspraak op de voorgeschreven wijze is bekend gemaakt. ${ }^{705}$ Aantekening verdient wel dat bekendmaking van een besluit van het bestuur een vereiste vormt voor inwerkingtreding van het besluit ${ }^{706}$ en het besluit erga omnes werkt jegens een ieder vanaf het moment van bekendmaking ${ }^{707}$, terwijl de uitspraak van de bestuursrechter al in werking treedt op het moment dat het dictum in het

\footnotetext{
700. Degenen tot wie het besluit op bezwaar is gericht kunnen de geadresseerde van het primaire besluit en/of bezwaarmakers tegen het primaire besluit zijn.

${ }^{701}$ Zie voor administratief beroep art. 7:26 lid $3 \mathrm{Awb}$

702. Zie hiervoor in beginsel art. 3:42 lid 1 en lid 2 Awb.

703. Art. 6:23 Awb.

704. Zie hierover par. 4.3.6 Deel I.

705. Zie art. 6:8 (jo. 6:24) Awb.

706. Art. 3:40 Awb.

707. PG Awb I, p. 231. Zie over de werking van art. 6:8 Awb in het geval er meer belanghebbenden zijn aan wie een uitspraak of besluit bekend moet worden gemaakt de noot van De Waard bij AbRvS 11 september 2002, $A B$ 2003/160 m.nt. BdeW.
} 


\section{De inrichting van de voorprocedures}

openbaar wordt uitgesproken en bekendmaking van de uitspraak aan partijen pas daarna geschiedt. ${ }^{708}$ De uitspraak of de beslissing vormt in beide gevallen het aanknopingspunt voor het instellen van rechtsmiddelen en om die reden is bekendmaking aan partijen in samenhang met de in de uitspraak gegeven motivering van belang in het kader van de verdedigings- of verweermogelijkheden van de betrokken partijen. Uit het vorenstaande blijkt dat de interne openbaarheidseisen die gesteld worden aan de beslissing van het bestuur grotendeels hetzelfde zijn als die gesteld worden aan de rechterlijke uitspraak en tevens eenzelfde doel dienen.

\section{Externe openbaarheid}

De uitwendige openbaarheid van de beslissing en de toegankelijkheid van de beslissing voor het publiek is, zoals aangegeven, in bezwaar en administratief beroep niet vereist op grond van de Awb. Alleen voor besluiten die niet tot een of meer belanghebbenden zijn gericht geldt ook in bezwaar dat bekendmaking plaatsvindt door kennisgeving van overheidswege in een voor het grote publiek toegankelijk blad en bestaat toegang tot de beslissing van het publiek. Dat heeft echter vooral te maken met de omstandigheid dat bij dergelijke besluiten vele belanghebbenden betrokken kunnen zijn die niet op voorhand allemaal geïdentificeerd kunnen worden, terwijl deze wel bereikt moeten worden ${ }^{709}$ en niet zozeer met het garanderen van uitwendige openbaarheid, in de zin van toegankelijkheid voor het publiek. In feite valt de publicatie of openbaarmaking voor het publiek hier samen met de interne bekendmaking.

\subsubsection{De gevolgen van schendingen van de openbaarheideisen}

Gevolgen achterwege laten van een openbare hoorzitting

Indien geen openbare hoorzitting in administratief beroep wordt gehouden, terwijl daarvoor geen gewichtige redenen bestaan, is er sprake van schending van artikel 7:19, derde lid, van de Awb. Voor bezwaar ligt de situatie anders. Allereerst schrijft de Awb openbaarheid niet voor, maar uitsluitend dat het bestuurorgaan daaromtrent een beslissing moet nemen. In voorkomende gevallen kan dat de bezwaaradviescommissie zijn. Indien deze kwestie geregeld is in een verordening of een ander algemeen verbindend voorschrift, behoort die regeling gevolgd te worden. Is openbaarheid van de hoorzitting op dezelfde wijze vormgegeven als in administratief beroep, dan geldt in beginsel hetzelfde als hiervoor gesteld is voor het administratief beroep, met dien verstande dat sprake is van een schending van de wet in materiële zin. Heeft geen regeling van de openbaarheid van de behandeling van de zaak plaatsgevonden, zal in het concrete geval bepaald moeten worden of openbaarheid achterwege moet worden gelaten. Geschiedt zulks zonder goede reden en komt een belanghebbende daartegen op bij de bestuursrechter dan kan deze echter niet oordelen dat artikel 7:5, tweede lid, van de Awb is geschonden. Voor een eventuele vernietiging van de beslissing op bezwaar zal de bestuursrechter een andere grondslag moeten aanwijzen. Een beginsel van behoorlijk bestuur waaruit openbaarheidseisen volgen bestaat vooralsnog echter niet. Het formele zorgvuldigheidsbeginsel ligt dan voor de hand als bron waaruit een dergelijke verplichting voortvloeit. De mogelijkheid bestaat echter ook dat de bestuursrechter niet tot vernietiging zal overgaan, omdat aangenomen wordt dat het bestuur in een dergelijk niet onrechtmatig heeft gehandeld. In een dergelijk geval kan ook geconcludeerd worden dat noch artikel 7:5 tweede lid van de Awb noch een rechtsbeginsel valt aan te wijzen als geschonden rechtsnorm.

${ }^{708 .}$ De dagtekening van de uitspraak is derhalve bepalend voor de inwerkingtreding van de uitspraak ingevolge art. 8:77 lid 1 sub e Awb maar de termijn voor hoger beroep begint pas te lopen na bekendmaking aan partijen op grond van art. 6:8 jo. 6:24 Awb in combinatie met art. 8:79 lid 1 Awb. De Afdeling heeft ook uit art. 8:77 lid 1 sub e Awb afgeleid dat het in het openbaar uitspreken van het dictum niet later dan de bekendmaking aan partijen mag plaatsvinden, AbRvS 17 oktober 2007, AB 2008/114 m.nt. BdeW.

Vgl. PG Awb I, p. 232. 
Deel II Bestuurlijke voorprocedures

Tot slot kan als in bezwaar ten onrechte tot een besloten hoorzitting is overgegaan, dat wel nog in beroep bij de bestuursrechter hersteld worden. In beroep kan immers nog, indien de bestuursrechter daartoe aanleiding ziet, op grond van artikel 8:62 Awb een openbare terechtzitting worden gehouden.

$\mathrm{Nu}$ er geen jurisprudentie voorhanden is waarin een schending van de openbaarheideisen in bezwaar of administratief beroep aan de orde komt, moet wat betreft de gevolgen van een dergelijke schending mijns inziens analoog geredeneerd worden aan hetgeen geldt voor (schending van) andere gelijksoortige processuele eisen in de bestuurlijke voorprocedures. Dat betekent dat het houden van een besloten hoorzitting, in strijd met artikel 7:19 Awb in administratief beroep, onder omstandigheden gepasseerd kan worden met toepassing van artikel 6:22 Awb. Het betreft immers een vormvoorschrift waarvan de schending niet van betekenis is voor de inhoud van het besluit. Ook hier zou onder omstandigheden een vernietiging met instandlating van de rechtsgevolgen op grond van artikel 8:72, derde lid, Awb mogelijk zijn.

Van een gebrek in de openbaarheidseisen in bezwaar of administratief beroep lijkt door de belanghebbende die beroep instelt bij de bestuursrechter te moeten worden aangekaart. Wat betreft artikel 7:5, tweede lid, Awb is dat nog niet expliciet zo overwogen, maar de bestuursrechter heeft voor andere onderdelen van de bezwaarschriftprocedure, zoals artikel 7:2 Awb wel al bepaald dat deze niet van openbare orde zijn en derhalve niet ambtshalve kunnen worden getoetst. ${ }^{710}$

\section{Gevolgen van schending van de bekendmakingseisen}

Schending van de bekendmakingseisen die gelden voor besluiten, in de zin dat een besluit niet is bekendgemaakt, betekent dat in beginsel het betreffende besluit en de rechtsgevolgen van het besluit nimmer in werking zijn getreden. ${ }^{711}$ In sommige gevallen kan een gebrekkige bekendmaking geen gevolgen hebben voor belanghebbenden en zijn zij desondanks op de hoogte van het besluit of anderszins niet benadeeld. Dan behoeft dat volgens Van Wijk/Konijnenbelt \& Van Male geen gevolgen te hebben voor de werking van het besluit. ${ }^{712}$ Ook heeft een schending van de bekendmakingseisen in beginsel geen betekenis voor de kwaliteit van het besluit en kan de bestuursrechter besluiten om geen vernietiging van het besluit alleen om die reden uit te spreken. ${ }^{713}$ De bestuursrechter kan overgaan tot een toepassing van artikel 6:22 Awb. In sommige gevallen gebeurt dat ook bij gebrekkige bekendmaking. ${ }^{714}$ In bepaalde gevallen kan een gebrekkige bekendmaking van een besluit belanghebbenden echter wel benadelen waardoor een toepassing van artikel 6:22 niet in de rede ligt. ${ }^{715}$ Als sprake is van een onjuiste of ontbrekende rechtsmiddelclausule bij de bekendmaking van een besluit, kan dat onder omstandigheden leiden tot verschoonbaarheid van termijnoverschrijdingen. Bij een onjuiste rechtsmiddelclausule is verschoonbaarheid van de termijnoverschrijding regel ${ }^{716}$, terwijl bij het ontbreken van een rechtsmiddelclausule lijkt te gelden geen verschoonbaarheid, tenzij sprake is van bijzondere omstandigheden. ${ }^{717}$

\footnotetext{
710. Zie bijv.: AbRvS 29 juli 1996, JB 1996/90 m.nt. MAH.

711. Zie bijvoorbeeld: CRvB 15 september 2005, JB 2005/311.

712. Van Wijk/Konijnenbelt \& Van Male 2008, p. 384.

${ }^{713 .}$ Van Wijk/Konijnenbelt \& Van Male 2008, p. 384-385.

714. Zie ook: Van Waterschoot 2002, p. 192-193.

715. Zie: Van Wijk/Konijnenbelt \& Van Male 2008, p. 384-385; Van Waterschoot 2002, p. 192-193.

716. Zie bijvoorbeeld: AbRvS 14 februari 2007, $A B$ 2007/156 m.nt. B.W.N. de Waard

717 AbRvS 12 september 2001, $A B$ 2002/4 m.nt. S.E. Zijlstra; ABRS 8 mei 2001, $A B$ 2001/292 m.nt. L.J.A. Damen; CRvB 29 februari 2000, $A B$ 2000/443 m.nt. HBr. Het CBb is soepeler en lijkt uit te gaan van verschoonbaarheid als regel, CBb 13 januari 2004, $A B$ 2004/111 m.nt. JHvdV.
} 


\section{De inrichting van de voorprocedures}

\subsubsection{Doorwerking van de openbaarheidseisen}

\section{Grondslag van de openbaarheidseisen}

Het openbaarheidbeginsel zoals dat voor rechtspraak geldt, is niet rechtstreeks van toepassing op de bestuurlijke voorprocedures. Een equivalent algemeen beginsel van behoorlijk bestuur waaruit openbaarheidseisen voortvloeien kennen we in het Nederlandse bestuursrecht evenmin. Bovendien vormt ook geen reeds erkend beginsel van behoorlijk bestuur de grondslag voor de openbaarheidseisen in de bestuurlijke voorprocedures. Het formele zorgvuldigheidsbeginsel wordt bijvoorbeeld niet expliciet als grondslag voor het stellen van openbaarheidseisen aan bestuurlijke voorprocedures aangewezen. De Awb bevat inrichtingseisen over de openbare behandeling van de zaak op de hoorzitting en ten aanzien van de interne openbaarheid van de zitting en de beslissing van het bestuur. Die laatste eisen kunnen ook onder het beginsel van hoor en wederhoor geschaard worden. Uit de bevindingen valt echter niet eenduidig af te leiden dat die openbaarheidseisen in hoofdstuk 7 van de Awb als uitwerkingen of toepassingen van een (ongeschreven) beginsel van behoorlijk bestuur of behoorlijke rechtspleging moeten worden gezien. De externe openbaarheidseisen voor de zitting of de toepassing daarvan in de praktijk lijken echter grotendeels overeen te stemmen met de voor rechtspraak geldende eisen. Bovendien zijn er voor de primaire besluitvormingsfase geen vergelijkbare externe openbaarheideisen voor te houden hoorzittingen gesteld. Hoewel de ratio voor (externe) openbaarheid in de bestuurlijke voorprocedures niet geheel gelijk is aan de ratio voor (externe) openbaarheid in rechterlijke procedures, is deze wel vergelijkbaar. De ratio voor externe openbaarheid van de zitting en uitspraak voor rechtspraak hangt samen met de onafhankelijke positie van de rechter en zijn democratische legitimatie. Die democratische legitimatie van het openbaar bestuur en het vertrouwen van de samenleving in het openbaar bestuur worden echter ook gediend met openbaarheid van de besluitvorming en de hoorzitting in de bestuurlijke voorprocedures. In het geval van het administratief beroep lijkt de gelijkenis met de procedure bij de rechter ook meegespeeld te hebben bij het vereisten van een openbare behandeling van de zaak op de hoorzitting. Uit de bevindingen kan derhalve niet met zekerheid afgeleid worden dat er sprake is van doorwerking van de beginselen van behoorlijke rechtspleging, maar tegelijkertijd kan niet geheel worden uitgesloten dat de rechterlijke openbaarheidseisen als inspiratiebron hebben gediend voor de voor het bestuur geldende eisen.

Doorwerking van de eis van openbare behandeling

Van rechtstreekse doorwerking van het vereiste van een openbare zitting zoals dat voor (bestuurs)rechtspraak geldt kan in elk geval niet gesproken worden. Hoewel het EHRM zich meermalen heeft uitgelaten over het vereiste van een openbare zitting in het kader van rechtspraak, volgt uit de jurisprudentie niet dat dit vereiste ook geldt in het kader van procedures die voorafgaan aan de eigenlijke rechterlijke procedure. ${ }^{718}$ Die eis wordt evenmin aan de bestuurlijke voorprocedures gesteld door de doctrine en de nationale rechter op grond van een ongeschreven beginsel van behoorlijke rechtspleging of beginsel van behoorlijk bestuur. Refertes aan het openbaarheidsbeginsel als beginsel van behoorlijke rechtspleging of de ratio dan wel functie van dat beginsel ontbreken eveneens. Een expliciet verband met het beginsel van behoorlijke rechtspleging en de inrichtingseisen in de bezwaarschriftprocedure en het administratief beroep, kan derhalve niet worden aangenomen.

Impliciet lijkt er echter wel sprake te zijn van enige doorwerking van het beginsel van behoorlijke rechtspleging. In administratief beroep bijvoorbeeld sluiten de redenen op grond waarvan afgeweken kan worden van een openbare hoorzitting in de praktijk inhoudelijk nauw aan of bieden ruimte voor aansluiting bij de belangen die tot een geslo-

\footnotetext{
${ }^{718}$. Zie par. 4.3.6 van Deel I voor de eisen die het EHRM stelt.
} 


\section{Deel II Bestuurlijke voorprocedures}

ten zitting kunnen nopen in de procedure bij de bestuursrechter als genoemd in artikel 8:62 Awb. In samenhang met de verwijzing van de wetgever naar het formelere karakter van het administratief beroep bestaat het vermoeden dat sprake is van impliciete beïnvloeding van het vereiste van een openbare behandeling van de zaak zoals dat voor rechtspraak geldt. De conclusie voor de bezwaarschriftprocedure is echter dat het beginsel van openbare behandeling niet of nauwelijks (expliciet noch impliciet) doorwerkt in de bezwaarschriftprocedure. In bezwaar wordt de keuze gelaten aan het bestuur, alhoewel het in het algemeen wenselijk wordt geacht de hoorzitting voor publiek open te stellen. In de praktijk wordt naar alle waarschijnlijkheid in de verordeningen op lokaal niveau meestal aangesloten bij de regeling voor het administratief beroep, maar de gegevens om dat te verifiëren ontbreken. Hoe meer gelijkenis met rechtspraak wordt aangenomen, hoe eerder in de doctrine ook ruimte wordt gezien voor openbaarheid van de hoorzitting als regel in de bezwaarschriftprocedure. In beide voorprocedures lijkt de eis van een openbare behandeling of de mogelijkheid daartoe echter met een soort van vanzelfsprekendheid in de regeling te zijn opgenomen. Fundamentele overwegingen of overdenkingen zijn er niet aan besteed in de parlementaire behandeling. De omstandigheid dat de openbare behandeling van de hoorzitting in de jurisprudentie vrijwel niet aan de orde wordt gesteld, kan erop duiden dat openbaarheid vanzelfsprekend is. Het zou er echter ook op kunnen duiden dat openbaarheid door de betrokken actoren in de procedure niet van fundamenteel gewicht wordt geacht.

Gelet op het feit dat de primaire functie van het openbaarheidsbeginsel als beginsel van behoorlijke rechtspleging gelegen is in de controle door het publiek en daarmee de waarborging van het vertrouwen van het publiek in de rechtspraak, ligt het ontbreken van expliciete doorwerking in de lijn der verwachtingen. ${ }^{719}$ Desalniettemin is deze bevinding toch wel opmerkelijk te noemen. Dat is met name het geval, omdat in de regeling van de Awb uitdrukkelijk stilgestaan is bij de openbaarheidseisen en in elk geval deels openbaarheid mogelijk is. De ratio voor (externe) openbaarheid in de bestuurlijke voorprocedures behoeft, zoals aangegeven, ook niet te verschillen van die voor openbaarheid van rechtspraak. Wel is het natuurlijk zo dat veel bestuursorganen reeds verantwoording moeten afleggen aan democratisch gelegitimeerde organen over hun beleid en de toepassing daarvan of zelf democratisch gelegitimeerd zijn. In dat opzicht zouden openbaarheidseisen, als middel ter verantwoording van het bestuur, echter als aanvulling kunnen werken. Bovendien staat een openbare hoorzitting ten dienste aan andere beginselen en vereisten voor een behoorlijke procedure die ook in de bestuurlijke voorprocedures van betekenis zijn (zoals onpartijdigheid en hoor en wederhoor). De interne openbaarheid staat reeds ten dienste aan dezelfde doelen, bescherming van de belangen van de deelnemers aan de procedure.

Het openbaarheidsvereiste lijkt mij voorts een van die vereisten waarbij doorwerking niet of nauwelijks problematisch zou zijn voor het bestuurlijke karakter van de bezwaarschriftprocedure. Openbaarheid van de zitting, extern dan wel intern, zal daarmee niet snel conflicteren. Voor zover er bezwaren rijzen, van praktische dan wel principiële aard, ten aanzien van de openbaarmaking van de beslissing, kan voorzien worden in een op het bestuur toegesneden vorm van openbaarmaking. Te denken valt aan publicatie op internet waarbij bepaalde gegevens worden geanonimiseerd. Mijns inziens zou het de voorkeur verdienen om de hoorzitting in beginsel in het openbaar te laten plaatsvinden. Ik zie niet in waarom dat uitgangspunt, dat voor rechtspraak (en administratief beroep) geldt, niet ook voor de bezwaarschriftprocedure op dezelfde wijze zou moeten gelden. Uiteraard kan uit privacy-overwegingen en ter bescherming van de belangen van de bij de bezwaarschriftprocedure betrokken burgers besloten worden om af te zien van een openbare hoorzitting. Ook andere zwaarwegende redenen van algemeen belang kunnen het bestuur nopen tot het houden van een hoorzitting met gesloten deuren. De Awb biedt

\footnotetext{
719. Zie par. 4.2 en 4.3.6 van Deel I.
} 


\section{De inrichting van de voorprocedures}

daarvoor in de bezwaarschriftprocedure ook de mogelijkheid, omdat het bestuur de bevoegdheid heeft om te beslissen dat de hoorzitting al dan niet in het openbaar plaats moet vinden. Hetzelfde geldt voor het administratief beroep waarin om gewichtige redenen kan worden afgezien van de openbaarheid van de hoorzitting. Om het belang van openbaarheid te benadrukken en willekeur uit te sluiten zou in de wet (of de verordeningen op lager niveau indien daarin een openbaarheidregime is neergelegd of uitgewerkt) moeten worden vastgelegd op welke gronden afgezien kan worden van een openbare hoorzitting. Daarbij ligt aansluiting bij de gronden - en de toepassing daarvan - die in dat kader gelden voor de bestuursrechter op grond van artikel 8:62 Awb het meest in de rede. De uitzonderingen die mogelijk zijn op de openbaarheidseisen en openbaarheidsbeginsel vinden dan hun grondslag in botsing met andere beginselen, zoals de persoonlijke levensfeer van betrokkenen.

Doorwerking van de eisen van openbaarmaking van de uitspraak

De openbaarheidseisen aan de openbaarmaking van de uitspraak van de rechter zien enerzijds op de interne openbaarheid ten opzichte van de procesdeelnemers en anderzijds op de uitwendige openbaarheid ten opzichte van het publiek. In de bezwaarschriftprocedure en het administratief beroep zijn er in de Awb uitsluitend inrichtingseisen te zien die betrekking hebben op de interne openbaarheid van de beslissing. Het gaat om de bekendmakingseisen ten aanzien van de personen tot wie het besluit gericht is of kennisgeving van besluiten van algemene strekking in van overheidswege uitgegeven bladen (al dan niet elektronisch uitgegeven bladen). Externe openbaarheid, in de zin van toegankelijk maken voor het publiek, is op grond van de Awb niet vereist. Dat betekent allereerst dat de uitwendige openbaarheid als behoorlijkheidsnorm van het genomen besluit niet doorwerkt of van betekenis is in de bezwaarschriftprocedure. Wat betreft de inrichtingseisen die zien op de interne openbaarheid kan het volgende geconcludeerd worden. Deze bekendmakingsregels zijn evenmin te herleiden tot het openbaarheidsbeginsel als beginsel van behoorlijke rechtspleging of de daaruit voortvloeiende openbaarheidseisen voor de bestuurs(rechter). Aan de bekendmakingseisen komt evenwel - los van het van kracht worden van besluiten - eenzelfde functie toe als aan de interne openbaarheidseisen inzake de uitspraak van de rechter: de rechtsbeschermingsmogelijkheden van belanghebbenden. Omdat een besluit van een bestuursorgaan ingrijpender is voor de personen tot wie het besluit is gericht dan de uitspraak van de rechter voor betrokken partijen - het bestuur kan immers primair en eenzijdig op ingrijpende wijze de rechtspositie van de belanghebbenden bepalen - ligt het ook voor de hand om dergelijke eisen te stellen aan de besluitvorming door het bestuur. Er gelden derhalve vergelijkbare interne openbaarheidseisen of bekendmakingseisen met eenzelfde ratio, terwijl geen expliciet verband met het openbaarheidsbeginsel, als beginsel van behoorlijke rechtspleging, geconstateerd kan worden. Deze eisen houden, gelet op hun ratio, echter verband met hetzelfde beginsel als het geval is bij de rechter in mijn optiek: het beginsel van hoor en wederhoor en bescherming van de processuele belangen van belanghebbenden. Ook hier is echter niet zo zeer sprake van doorwerking, maar wel van een gemeenschappelijke wortel of functie van de eisen. Gelet op het ingrijpende karakter van bestuursbesluiten ligt het ook in de rede dat er een zelfstandige grondslag bestaat voor de bekendmakingseisen in de bestuurlijke besluitvormingsfasen. Bovendien zijn deze eisen voor de inwerkingtreding van de rechtsgevolgen van besluiten van belang.

\subsection{Motivering van besluiten in de bestuurlijke voorprocedures}

\subsubsection{De verschillende verschijningsvormen van het motiveringsbeginsel}

Beginsel van behoorlijke rechtspleging, wetgeving en bestuur

Het motiveringsbeginsel dat in deze paragraaf centraal staat, kent in het Nederlandse (bestuurs)recht verschillende ongeschreven en geschreven verschijningsvormen. Zo 


\section{Deel II Bestuurlijke voorprocedures}

vormt het een algemeen erkend beginsel van behoorlijke rechtspleging, waaruit voortvloeit dat de (bestuurs)rechter zijn uitspraak deugdelijk dient te motiveren. ${ }^{720}$ Voorts vloeit deze motiveringsplicht voor de rechterlijke macht en ook de overige bestuursrechters voort uit artikel 121 Grondwet. ${ }^{721}$ De plicht tot motiveren voor de rechter heeft daarnaast ook nog een Europese grondslag, aangezien het EHRM een zodanige plicht heeft afgeleid uit het in artikel 6 EVRM neergelegde recht op een eerlijk proces. ${ }^{722}$ Het motiveringsbeginsel is voor de bestuursrechter in de Awb onder meer uitgewerkt in artikel 8:77 eerste en tweede lid. ${ }^{723}$ Deze bepalingen bevatten de verplichting voor de rechter om de gronden van zijn beslissing in de (schriftelijke) uitspraak te vermelden alsook de verplichting om bij de gegrondverklaring van een beroep aan te geven welke geschreven of ongeschreven rechtsregel of algemeen rechtsbeginsel geschonden wordt geacht.

Een motiveringsplicht geldt echter niet uitsluitend voor de bestuursrechterlijke instanties. De (bestuurs)rechter is immers niet het enige orgaan of primaire orgaan dat (publiekrechtelijke) beslissingen kan nemen die van invloed zijn op de rechtspositie van een burger; dat kan te meer van het bestuur gezegd worden. Voor in beginsel alle beslissingen van overheidsorganen die rechtsgevolgen hebben voor de burger geldt dat deze met redenen omkleed dienen te zijn. ${ }^{724}$ Dat betekent dat ook de wetgever en het bestuur niet gevrijwaard zijn van een motiveringsplicht. Zoals Waaldijk heeft uiteengezet, wordt thans voor de wetgever op basis van het geschreven maar ook ongeschreven recht verscheidene motiveringsplichten aangenomen en kan gesproken worden van "een in de literatuur erkend beginsel (van behoorlijke wetgeving) dat wetgeving gemotiveerd moet worden door vermelding van het doel van de wet en door bespreking (...) van de overwegingen die geleid hebben tot de voornaamste in de wet gemaakte keuzen". ${ }^{725}$

Voor bestuursorganen wordt de verplichting tot motivering van besluiten reeds geruime tijd erkend. De grondslag daarvoor is het motiveringsbeginsel als beginsel van behoorlijk bestuur dat in alle fasen van de bestuurlijke besluitvorming in acht genomen moet worden. ${ }^{726}$ In de literatuur wordt ten aanzien van de bestuurlijke besluitvorming veelal een onderscheid gemaakt tussen het formele motiveringsbeginsel en het materiële motiveringsbeginsel. ${ }^{727}$ Het formele motiveringsbeginsel houdt in dat sprake moet zijn van een kenbare motivering. Onder het materiële motiveringsbeginsel wordt gewoonlijk verstaan dat een besluit een deugdelijke en draagkrachtige motivering dient te bevatten. Het laatste omvat in elk geval de volgende deeleisen: een juiste feitelijke grondslag, een begrijpelijke redenering, een juiste interpretatie van het wettelijk (en/of beleids-) kader en een juiste kwalificatie van de feiten. ${ }^{728}$ De wetgever onderscheidt twee aspecten die

\footnotetext{
${ }^{720 .}$ De Waard 1987, p. 371. Zie verder: par. 4.5.7 van Deel I.

${ }^{721 .}$ Strikt genomen ziet de motiveringsplicht in art. 121 Grondwet slechts op vonnissen en vallen uitspraken van de bestuursrechter daar niet onder. Desondanks wordt aangenomen dat de motiveringsplicht zich ook uitstrekt tot uitspraken van de bestuursrechter. A.M.L. Jansen, 'Op goede gronden. De motivering van uitspraken door de bestuursrechter', in: A.W. Heringa, A.M.L. Jansen, E.C.H.J. van der Linden, L.F.M. Verhey (red.), Het be stuursrecht beschermd (liber amicorum prof. mr. F.A.M. Stroink), Den Haag: Sdu 2006, p. 173; De Waard 1995, p. 448-449; Stroink 1993, p. 69.

722. Zie hierover eveneens par. 4.5.7 van Deel I.

${ }^{723 .}$ Voor schriftelijke uitspraken is die eis in art. 8:77 Awb neergelegd en voor mondelinge uitspraken in art. 8:67 Awb.

724. Van Wijk/Konijnenbelt \& Van Male 2008, p. 657; K. Waaldijk, Motiveringsplichten van de wetgever (diss. Leiden), Lelystad: Koninklijke Vermande 1994, p. 297.

${ }^{725}$ Waaldijk 1994, p. 340 en 295-297. Dit beginsel voor de wetgever is echter, in tegenstelling tot het beginsel voor het bestuur of voor de rechter, niet rechtens afdwingbaar.

${ }^{726 .}$ Van Wijk/Konijnenbelt \& Van Male 2008, p. 310; Nicolaï 1990, p. 353 e.v. en 371 e.v; De Waard 1987, p 164. e.v. Zie over de ontwikkeling van het motiveringsbeginsel als abbb en de erkenning daarvan los van het zorgvuldigheidsbeginsel in de rechtspraak, Nicolaï 1990, p. 110-111, 120 en 127-130.

727. Zie bijvoorbeeld: Van Wijk/Konijnenbelt \& Van Male 2008, p. 310-314. Die indeling hanteert de wetgever ook, PG Awb I, p. 268-272.

728. Zie bijvoorbeeld: G.H. Addink, bewerkt door K.F. Bolt, 'Commentaar op art. 7:12', in: M. Scheltema, R.M. van Male, B.W.N. de Waard, A.T. Marseille, A.J.C. de Moor-van Vugt (red.), Commentaar Algemene wet bestuursrecht, Amsterdam: Reed Elsevier (voorheen Den Haag: VUGA), losbladige uitgave, E 7:12-2/5; Van Wijk/Konijnenbelt \& Van Male 2008, p. 310-311; Nicolaï 1990, p. 355. In de literatuur worden verschillende
} 


\section{De inrichting van de voorprocedures}

onder het materiële motiveringsbeginsel vallen: een juiste vaststelling van de feiten en het aspect dat die vaststelling van de feiten moet leiden tot de genomen beslissing. ${ }^{729}$

Het motiveringsbeginsel (in beide varianten: formeel en materieel) is als algemeen beginsel van behoorlijk bestuur van toepassing op zowel de primaire besluitvormingsfase als de bestuurlijke voorprocedures. Voor primaire besluiten zijn thans in artikel 3:46 en 3:47 van de Awb de motiveringseisen uitgewerkt. Deze bepalingen vormen de neerslag van het motiveringsbeginsel als - tot enige tijd geleden ongeschreven - algemeen beginsel van behoorlijk bestuur. ${ }^{730}$ Ook voor de bestuurlijke voorprocedures geldt het motiveringsbeginsel als beginsel van behoorlijk bestuur en zijn de daaruit voortvloeiende motiveringsplichten thans neergelegd in de Awb. Zo bepalen artikel 7:12 en 7:26, eerste lid, van de Awb dat de beslissing op bezwaar of op het beroep een deugdelijke motivering dient te bevatten die bij de bekendmaking van het besluit moet worden vermeld. ${ }^{731}$ Voor de bestuurlijke voorfasen na het primaire besluit is een afzonderlijke motiveringsplicht neergelegd in de daarop betrekking hebbende afdelingen van de Awb en zijn artikel 3:46 en 3:47 Awb expliciet niet van toepassing verklaard in artikel 7:14 en 7:27 Awb. Daartoe is besloten omdat deze bepalingen (en de overige bepalingen van hoofdstuk 4 van de Awb waarin de motiveringsplicht ten tijde van de eerste tranche van de Awb was opgenomen) in dezelfde onderwerpen voorzagen als waarvoor in de hoofdstukken 6 en 7 van de Awb reeds regels waren opgenomen en die regels zijn voor een deel gedetailleerder aldus de wetgever. ${ }^{732}$ Om misverstanden te voorkomen over de vraag of artikel 7:12 Awb derogeert aan de bepalingen in hoofdstuk 3, is besloten om onder meer artikel 3:46 en 3:47 Awb niet van toepassing te verklaren. Voor administratief beroep geldt hetzelfde op grond van artikel 7:27, eerste lid, van de Awb. ${ }^{733}$

\section{Algemene gelding in het (bestuurs)recht}

In het bovenstaande is reeds gebleken dat in beginsel voor alle overheidsorganen, ongeacht of het nu gaat om de wetgever, het bestuur of de (bestuurs)rechter, een plicht tot motiveren bestaat van beslissingen die gevolgen kunnen hebben voor de rechtspositie van de burger. Het motiveringsbeginsel is een algemeen rechtsbeginsel waarvan de reikwijdte derhalve niet beperkt is tot handelingen van enkele overheidsorganen. ${ }^{734}$ Het beginsel heeft een algemene gelding. Wel kent het motiveringsbeginsel als algemeen rechtsbeginsel subcategorieën die specifiek zien op de bevoegdheidsuitoefeningen van de verschillende organen, zoals het bestuur en de rechter, in de vorm van een beginsel van behoorlijk bestuur en een beginsel van behoorlijke rechtspleging. ${ }^{735}$ Voor het bestuursrecht volgt hieruit dat het motiveringsbeginsel van betekenis is in het kader van alle stadia waarin een besluit van het bestuur zich bevindt. Voor elk van de drie fasen, te weten de primaire besluitvormingsfase, de voorprocedures bij het bestuur en de fase bij de bestuursrechter, in de gehele procedure inzake de uitoefening van een publiekrechtelijke bevoegdheid door een bestuursorgaan bestaat (op grond van de Awb) derhalve voor de verschillende organen een (afzonderlijke) plicht tot motivering van beslissingen die rechtsgevolgen kunnen hebben voor de burger. Deze plicht tot motiveren wordt - afge-

elementen genoemd of indelingen gehanteerd, maar deze eisen lijken bij alle auteurs terug te keren. Hierover nader nog par. 5.6.3.

729. PG Awb I, p. 269

730. PG Awb I, p. 268-269. In de eerste tranche van de Awb was het motiveringsbeginsel overigens nog gecodificeerd in art. 4:16 en 4:17 Awb. Bij de derde tranche zijn deze bepalingen overgeheveld naar art. 3:46 en 3:47 Awb waardoor deze nu voor alle besluiten gelden, PG Awb III, p. 153.

${ }^{731 .}$ In artikel 7:26 eerste lid van de Awb is in exact dezelfde bewoordingen de motiveringseis voor besluiten genomen in administratief beroep neergelegd. Het navolgende omtrent de motiveringseisen die gesteld worden aan de beslissing op bezwaar geldt dus evenzeer voor de beslissingen in administratief beroep.

732. PG Awb I, p. 355.

733. PG Awb I, p. 364. Zie een uitspraak waarin art. 3:50 ten onrechte van toepassing lijkt te worden verklaard op de bezwaarfase: AbRvS 17 september 2003, JB 2003/298 m.nt. AMLJ.

734. Waaldijk 1994, p. 295-297.

735. Vgl. Waaldijk 1994, p. 297. 


\section{Deel II Bestuurlijke voorprocedures}

zien van de verschillende wettelijke grondslagen - echter niet voor al deze organen herleid tot dezelfde (sub)grondslag. Voor de primaire en secundaire fase in de besluitvorming geldt het motiveringsbeginsel als algemeen beginsel van behoorlijk bestuur als (voornaamste) grondslag, terwijl voor de bestuursrechter het motiveringsbeginsel als beginsel van behoorlijke rechtspleging (alsmede op grond van artikel 6 EVRM) geldt. $\mathrm{Nu}$ de grondslag voor de motiveringseisen verschilt, is ook goed mogelijk dat de motiveringsplichten in de bestuurlijke fasen niet exact dezelfde strekking hebben of op dezelfde wijze concreet uitwerken als in de rechterlijke fase. Het is denkbaar dat de motiveringsplicht in het kader van bestuurlijke besluitvorming een andere invulling krijgt - zowel in de primaire besluitvormingsfase als de bestuurlijke voorfase - dan in het kader van de rechterlijke fase. De motiveringsplicht voor het bestuur ziet immers op iets anders, een besluit, dan de motiveringsplicht voor de rechter, de uitspraak. De rechter heeft als taak het besluit te toetsen en zijn oordeel daaromtrent in de uitspraak neer te leggen. Het bestuur behoort een beslissing te nemen waarmee de rechtspositie van de betrokken belanghebbende(n) bepaald wordt. Anderzijds kan het ook zo zijn dat gelet op het rechtsbeschermingskarakter van zowel de voorprocedures alsook de rechterlijke fase de daarvoor geldende motiveringseisen onderling meer gelijkenis vertonen dan die voor de primaire fase in de besluitvorming en de voorfasen. Daarbij kan gedacht worden aan de omstandigheid dat in het kader van de motiveringsplicht in de voorprocedure en in de fase van beroep bij de bestuursrechter meer dan in de primaire fase van de besluitvorming de nadruk ligt op de beoordeling van dan wel weerlegging van de aangedragen bezwaar- of beroepsgronden (als ook de gronden in verweer). De motiveringsplicht voor het bestuur zou in de voorprocedure meer in het teken kunnen staan van een dergelijke reactieplicht en de rechtsbescherming die geboden moet worden dan wellicht in de primaire besluitvormingsfase het geval is.

De vragen die in de onderstaande paragrafen beantwoord dienen te worden, zijn derhalve welke motiveringseisen aan de bestuurlijke besluitvorming in de voorprocedures gesteld worden. Daarnaast wordt ook meegenomen of er in dat opzicht een onderscheid gemaakt wordt tussen de primaire en secundaire fase van de besluitvorming en of dat onderscheid gerechtvaardigd is. Ook wordt bezien of en in hoeverre deze motiveringeisen gelijkenis vertonen of zouden moeten vertonen met de eisen die in dat kader aan rechtspraak gesteld worden. De omstandigheid dat de motiveringsplicht wellicht niet in elke fase dezelfde inhoud heeft voor de daarbij betrokken organen, doet aan de algemene gelding van dat beginsel (in het bestuursrecht) niets af. Omdat het motiveringsbeginsel gelding heeft in zowel de besluitvormingsfasen als de fase bij de bestuursrechter, is bij dit beginsel de verwachting gerechtvaardigd dat sprake is of zou kunnen zijn van invloed van de motiveringsvereisten in de laatstgenoemde fase op de bestuurlijke voorfase.

\section{Opbouw}

In het navolgende wordt allereerst in paragraaf 5.6.2 ingegaan op de functie(s) van de motiveringsplichten in de bestuurlijke voorfase. Vervolgens wordt 5.6.3 en 5.6.4 de invulling van de motiveringsplichten in de bezwaarfase in wetgeving en rechtspraak geïnventariseerd. Daarbij zal echter ook aandacht besteed worden aan de motiveringsplichten in de primaire fase van de besluitvorming, aangezien beide fasen onderdeel zijn van het totale besluitvormingsproces, en de grondslag voor de motiveringsplichten van het bestuur in beide fasen van de besluitvorming in elk geval herleid kan worden tot het motiveringsbeginsel als algemeen beginsel van behoorlijk bestuur. Tevens komt aan de hand daarvan aan bod of en in hoeverre de motiveringseisen in bezwaar en administratief beroep afwijken van de motiveringseisen die gelden voor de primaire besluitvorming. De mogelijke gevolgen van schendingen van de motiveringsplicht in de bestuurlijke voorprocedures worden ten slotte in paragraaf 5.6.5 op een rij gezet. Tot slot wordt in paragraaf 5.6.6 ingegaan op de doorwerking van het rechterlijke motiveringsbeginsel in de voor het bestuur geldende motiveringseisen. 


\section{De inrichting van de voorprocedures}

\subsubsection{Waartoe dient de motiveringsplicht in de bestuurlijke voorprocedure(s)?}

\section{De functies van het motiveringsbeginsel voor het bestuur}

In de toelichting op de motiveringsplichten voor de bestuurlijke besluitvorming, zoals neergelegd in artikel 3:46 en verder alsook op artikel 7:12 Awb, wordt door de wetgever nauwelijks aandacht besteed aan de functie(s) van het motiveringsbeginsel. ${ }^{736}$ In de literatuur komen de functies van dit beginsel wat nadrukkelijker aan bod. Soms worden verschillende onderscheidingen van het motiveringsbeginsel gehanteerd die in de functies van dat beginsel doorwerken. Het meest gangbare onderscheid ten aanzien van het motiveringsbeginsel is de indeling (zoals hierboven al aangestipt) in een formeel en materieel motiveringsbeginsel. Zoals bekend bestaat het materiële motiveringsbeginsel ${ }^{737}$ - verkort weergegeven - uit de eis dat het besluit (ook in bezwaar of in administratief beroep) deugdelijk en draagkrachtig gemotiveerd moet zijn, terwijl het formele motiveringsbeginsel inhoudt dat de motivering kenbaar moet zijn voor belanghebbenden. Door sommige auteurs wordt voor het bepalen van de functies van het motiveringsbeginsel dit algemene onderscheid ook van belang geacht. Met name Van Male laat dit onderscheid doorwerken in de functies van het motiveringsbeginsel. Als functies van het formele beginsel merkt hij aan: de kwaliteitsbevordering, de legitimatie van bestuursbesluiten (waardoor onnodige beroepen worden voorkomen) en een functie ter effectuering van beroepsrechten van appellanten. ${ }^{738}$ De bevordering van de kwaliteit van de besluitvorming wordt bewerkstelligd door de kenbaarheid van de motivering, omdat het bestuur door de motiveringsplicht gedwongen wordt 'vooraf zijn gedachten te ordenen'. ${ }^{739}$ De tweede functie bestaat uit het bijdragen aan de aanvaarding van een besluit en aan het daardoor beperken van het beroep op de rechter. Als laatste functie wordt ten slotte genoemd het bewerkstelligen dat een appellant niet in zijn beroepsrechten wordt beperkt. ${ }^{74}$ Voor het materiële motiveringsbeginsel onderscheidt hij ook nog een autonome en accessoire functie. ${ }^{741}$ Met de eerst genoemde functie doelt hij op de situatie waarin de deugdelijkheid of draagkrachtigheid op zichzelf voorwerp van onderzoek vormt. Van de accessoire functie is sprake wanneer het motiveringsbeginsel onderdeel uitmaakt van een andere rechtsregel, zoals het vertrouwensbeginsel. Dit laatste onderscheid laat ik verder in dit onderzoek buiten beschouwing. Doorgaans wordt ook wat betreft de functies van het motiveringsbeginsel niet zo scherp een onderscheid gemaakt tussen het formele en materiële aspect van dat beginsel. De hiervoor genoemde drie functies - die Van Male lijkt te reserveren voor het formele motiveringsbeginsel - worden eerder in het algemeen aan het motiveringsbeginsel als beginsel van behoorlijk bestuur toegekend. ${ }^{742}$ Dat lijkt mij ook in de rede liggen. De combinatie van de materiële en formele motiveringseisen realiseert deze functies. Zowel de inhoudelijke motivering van het besluit, die ziet op de feitelijke grondslag, de redenering, de interpretatie van het wettelijk kader en de kwalifi-

\footnotetext{
736. Vgl. Van Male die dit opmerkt ten aanzien van de motiveringsplicht voor het bestuur in de primaire fase, R. M. Van Male, 'Beredeneerd besluiten. Plaats, functie en betekenis van het motiveringsbeginsel in het Nederlandse bestuursrecht', NTB 1988/3, p. 73.

737. Dat betekent niet dat dit beginsel een materieel beginsel is in de zin dat een schending ervan in alle gevallen per definitie tot een besluit met andere inhoud leidt, Van Wijk/Konijnenbelt \& Van Male 2008, p. 312. Het materiele motiveringsbeginsel is vooral materieel ten opzichte van het formele beginsel waaruit alleen plicht tot mededeling van de motivering volgt. Het materiële motiveringsbeginsel ziet echter op de inhoud van de motivering. De indeling wordt in dit onderzoek in die betekenis gehanteerd.

738. Van Male 1988, p. 76

739. Van Male 1988, p. 76

740. Zie ook Van Male in het losbladig commentaar op art. 3:46 Awb, R.M. van Male, 'Commentaar art. 3:46 Awb', in: M. Scheltema, R.M. van Male, B.W.N. de Waard, A.T. Marseille, A.J.C. de Moor-van Vugt (red.) Commentaar op de Algemene wet bestuursrecht, Amsterdam: Reed Elsvier (voorheen Den Haag: VUGA), losbladige uitgave, p. E 3.6.1-3

741. Van Male 1988 p. 76

742. Damen e.a. 2009, Deel I, p. 431-432; Van Wijk/Konijnenbelt \& Van Male 2008, p. 657.
} 
Deel II Bestuurlijke voorprocedures

catie van de feiten als de kenbaarheid van de motivering aan de betrokkenen staan ten dienste aan de hiervoor genoemde functies.

De functies van het motiveringsbeginsel voor de rechter

De algemene functies die aan het bestuurlijke motiveringsbeginsel worden toegedicht (kwaliteitsbevordering, legitimatiefunctie en rechtsbeschermingsfunctie) verschillen vrijwel niet van de functies die aan het motiveringsbeginsel als beginsel van behoorlijke rechtspleging toegedicht worden. Stroink stelt zich ook uitdrukkelijk op het standpunt dat de motiveringsplicht voor bestuursbesluiten in belangrijke mate dezelfde functie heeft als voor rechterlijke uitspraken. ${ }^{743}$ Hij verwijst daarbij naar de argumenten die Van Male heeft aangehaald in het losbladig commentaar - zoals hiervoor weergegeven - voor een motiveringsplicht bij beschikkingen (in primo). Voor uitspraken in administratief beroep meent hij eveneens dat de motiveringseis dezelfde functies vervult als voor uitspraken van de bestuursrechter. Hij noemt in dat kader de volgende functies: kwaliteitsbevordering van rechterlijke uitspraken, legitimatiefunctie, aanknopingspunten voor hoger beroep of cassatie voor de burger, controlefunctie voor de hogere rechter op de lagere rechter en precedentwerking. ${ }^{74}$ Waaldijk merkt eveneens op dat in het algemeen wordt aangenomen dat aan de motiveringsplichten voor het bestuur dezelfde functies ten grondslag liggen als aan de motiveringsplichten voor de rechter. ${ }^{745}$ De genoemde functies stemmen grotendeels overeen met de hoofdfuncties die De Waard noemt voor het motiveringsbeginsel: kwaliteitsbevordering, functie van informatie over en legitimatie van het besluit en functie in het kader van de rechtsvorming (en indien het een besluit van het bestuur betreft ook beleidsvorming). ${ }^{746}$ De door Stroink en De Waard onderscheiden functies van de rechterlijke motiveringsplicht zijn algemeen aanvaard. ${ }^{747}$ In de doctrine wordt nauwelijks verschil gemaakt tussen de functies van de motiveringsplichten voor het bestuur en de rechter. Noemenswaardige verschillen in functie van het motiveringsbeginsel voor bestuur en rechter vallen mijns inziens ook niet aan te wijzen.

\section{Processuele functie van het motiveringsbeginsel en/of zorgvuldigheid van de besluitvorming}

Van Male wijst naast de hiervoor genoemde functies ook nog op de processuele functie van het motiveringsbeginsel (waarbij hij niet duidelijk aangeeft welke van beide varianten, te weten de formele of materiële, van het beginsel hij op het oog heeft). Onder deze functie verstaat hij de beïnvloeding van het motiveringsbeginsel door het beginsel van hoor en wederhoor. Daaruit volgt dat het bestuur behoort te reageren met tegenargumenten op hetgeen de belanghebbende heeft aangevoerd. ${ }^{78}$ Van Male concentreert zich echter op de betekenis van het motiveringsbeginsel in de primaire besluitvormingsfase of juist op besluitvorming in het algemeen, zonder daarbij expliciet aandacht te besteden aan de bestuurlijke voorprocedures. Indien aangenomen wordt dat een verband gelegd kan worden tussen het motiveringsbeginsel en het hoor en wederhoor beginsel in de primaire besluitvormingsfase, moet datzelfde, gelet op de rechtsbeschermingsfunctie en het contentieuze karakter van die procedures, gelden voor de bestuurlijke voorprocedures. De processuele functie van het motiveringsbeginsel is voorts een functie die ook

\footnotetext{
743. Stroink 1993, p. 70

744. Stroink 1993, p. 70

745. K. Waaldijk, De motiveringsplichten van de wetgever, Lelystad: Koninklijke Vermande 1994, p. 2. Zie ook: Van Wijk/Konijnenbelt \& Van Male 2008, p. 657, waarin ook geen onderscheid gemaakt wordt tussen de functies van het motiveringsbeginsel voor bestuur, rechter en wetgever.

${ }^{746 .}$ De Waard 1987, p. 372.

747. Zie bijvoorbeeld: Van Wijk/Konijnenbelt 2008, p. 657; Waaldijk 1994, p. 2. In par. 4.3 .6 van Deel I wordt nader op het motiveringsbeginsel voor de rechter en de functies daarvan ingegaan.

${ }^{748 .}$ Van Male 1988, p. 78
} 


\section{De inrichting van de voorprocedures}

toekomt aan het motiveringsbeginsel voor de rechter. ${ }^{79}$ Van der Heijden legt bijvoorbeeld een uitdrukkelijk verband tussen de eis dat de motivering van de uitspraak van de rechter recht moet doen aan de standpunten van partijen en het beginsel van hoor en wederhoor. ${ }^{750}$

Ook De Waard wijst erop - zonder daarbij overigens een onderscheid tussen de verschillende fasen van besluitvorming te maken - dat uit het motiveringsbeginsel, als beginsel van behoorlijk bestuur, het algemene criterium kan worden afgeleid dat, indien een belanghebbende met nadruk een stelling inbrengt die in het besluit wordt verworpen, het bestuur die stelling in de motivering moet betrekken. ${ }^{751}$ Ook meent hij dat het besluit met het oog op aan te wenden rechtsmiddelen en de verdediging voldoende motivering moet bevatten. Daaropvolgend geeft hij echter aan dat - hoewel de functie van motivering van bestuursbesluiten in het kader van de verdediging ruime erkenning in literatuur en rechtspraak heeft gekregen - er in één situatie, nl. die van administratief beroep waarin het aspect van verlengde besluitvorming overheerst, minder noodzaak toe bestaat. ${ }^{752}$ In die gevallen wordt volgens De Waard de besluitvorming geheel overgedaan en is er minder behoefte aan motivering vanuit verdedigingsoogpunt, maar ook dan is motivering noodzakelijk vanwege de mogelijke zeefwerking daarvan. Ten aanzien van het administratief beroep verdienen enkele kanttekeningen de aandacht. Hoewel de besluitvorming in beginsel geheel moet worden overgedaan vormt de aanleiding daarvoor de bezwaren (of in de terminologie van het administratief beroep de beroepsgronden) die de belanghebbende(n) heeft tegen het genomen besluit. $\mathrm{Nu}$ bestuur en belanghebbende(n) in die procedure tegenover elkaar komen te staan en over en weer op elkaars standpunten reageren, is het mijns inziens ook noodzakelijk dat een reactie op die standpunten, en zeker op die van de belanghebbende(n), van het beroepsorgaan terugkomt in het besluit. Ongeacht of het bestuurlijke dan wel rechtsbeschermingsperspectief overheerst is de aanleiding voor de procedure altijd gelegen in de bezwaren van een of meer belanghebbenden. Voor de bezwaarschriftprocedure wil ik hieraan toevoegen dat de heroverweging in bezwaar op grond van artikel 7:11 Awb altijd dient plaats te vinden op grondslag van de bezwaarschriften zoals ingediend door de belanghebbende(n). Aanleiding voor de heroverweging vormen ook hier de bezwaren van belanghebbende(n). Bovendien staan verschillende voorschriften in de bezwaarschriftprocedure in het teken van hoor en wederhoor, hetgeen gebleken is in paragraaf 5.3 van Deel II.

Hoe het ook zij, uit het bovenstaande blijkt dat aan het motiveringsbeginsel in de bestuurlijke voorprocedures ook een functie toekomt die in het perspectief staat van hoor en wederhoor. Die functie kan aan de vier eerder genoemde functies worden toegevoegd. Meer in het algemeen komen ook in de functies van het motiveringsbeginsel de hoofdfuncties van de bestuurlijke voorprocedures tot uitdrukking. De motiveringsplicht is vanuit het perspectief van het bestuur primair gericht op de kwaliteit of zorgvuldigheid van de besluitvorming voor zover het de feitelijke grondslag, de redenering, de kwalificatie van de feiten en de interpretatie van het wettelijk kader betreft. Voor zover de motiveringsplicht zich inhoudelijk uitstrekt tot de standpunten van belanghebbenden en vooral op welke wijze het bestuur deze heeft betrokken in de besluitvorming, staat deze meer in het teken van de rechtsbescherming van de belanghebbende(n). Bovendien vormt de motivering van het besluit een aanknopingspunt voor het instellen van rechtsmiddelen daartegen. De processuele functie die Van Male onderscheidt zou wellicht ruimer opgevat moeten worden en meer algemeen in het teken van rechtsbescherming gesteld moeten worden in plaats van uitsluitend hoor en wederhoor. Evenals het geval was bij de functies van het horen valt hier een tweedeling in hoofdfuncties te herkennen

\footnotetext{
749. J. In 't Veld \& N.S.J. Koeman, Beginselen van behoorlijk bestuur, Zwolle: W.E.J. Tjeenk Willink 1985, p. 45; P.F. van der Heijden, Een eerlijk proces in het sociaal recht? Deventer: Kluwer 1984, p. 44 en 49.

750. Van der Heijden 1984, p. 49

${ }^{751 .}$ De Waard 1987, p. 166.

${ }^{752}$ De Waard 1987, p. 382.
} 


\section{Deel II Bestuurlijke voorprocedures}

die parallel loopt aan de karakteristieken van de bestuurlijke voorprocedures: een processuele- of rechtsbeschermingsfunctie (die bestaat uit de functie in het kader van de rechtsbescherming en effectuering van beroepsrechten, maar ook samenhangt met de legitimatiefunctie en het verdedigingsbeginsel) en een kwaliteitsbevorderende functie (die vooral ziet op de inhoudelijke kwaliteit en deugdelijkheid van de besluitvorming).

Uiteraard bestaat een duidelijke samenhang tussen deze twee functies en hangt het ook hier vooral af van het perspectief waarmee naar de motiveringsplichten gekeken wordt welke van deze functies aan het motiveringsbeginsel wordt toegekend. Toch kan het zinvol zijn om deze tweedeling voor ogen te hebben, omdat bij specifieke motiveringseisen de ene functie sterker aanwezig kan zijn dan de andere functie. Het aannemen van een reactieplicht op de door de appellerende burger aangevoerde bezwaren (waarover hierna in paragraaf 5.6.4.2 meer) staat mijns inziens bijvoorbeeld meer in het teken van de rechtsbeschermingsfunctie van het motiveringsbeginsel in bezwaar. Als het goed is, heeft het bestuur reeds een deugdelijke en draagkrachtige motivering gegeven voor het besluit in primo. Wordt dit besluit niet gehandhaafd dan zal het bestuur opnieuw een deugdelijke en draagkrachtige motivering moeten geven voor het herroepen van dat besluit en het nieuwe besluit. Daarnaast of daarbij zal het bestuur in het besluit op bezwaar aandacht moeten besteden aan de ingebrachte bezwaren. Wordt het besluit daarentegen wel gehandhaafd en worden de bezwaarschriften ongegrond verklaard, dan zal het ook moeten aangeven om welke reden de bezwaren niet gehonoreerd worden en er geen aanleiding is het besluit te herroepen. De wetgever heeft immers ook expliciet in de toelichting op artikel 7:12 aangegeven dat er een zwaardere motiveringsplicht geldt, indien de bezwaren ongegrond worden verklaard. De belanghebbende behoort kennis te hebben van de reden waarom de bezwaren niet gehonoreerd worden en de motivering is van belang voor de verweermogelijkheden en de effectuering van zijn beroepsrechten. ${ }^{753}$

Dezelfde functies, dezelfde eisen?

Aangenomen dat de motiveringsplicht of het motiveringsbeginsel voor het bestuur dezelfde functies heeft als voor de rechter, is de vervolgvraag of daaruit volgt dat dezelfde motiveringseisen aan de beslissing van het bestuur gesteld moeten worden. Of moeten er juist aan het bestuur in algemene zin lagere of hogere eisen gesteld worden vanwege andere redenen? De Waard geeft aan dat de motiveringseisen voor rechtspraak en bestuur in belangrijke mate overeenkomsten vertonen en stelt die vraag juist omdat hij eerder aanleiding ziet om hogere eisen aan de motivering van het bestuur te stellen. De beantwoording van de vraag of er een verschil dient te worden gemaakt tussen de plicht tot motiveren voor het bestuur en de rechter, laat hij onder meer afhangen van de vraag of er verschillen te constateren zijn in de functies van de motiveringsplicht voor deze organen. ${ }^{754}$ Reden voor verschil in motiveringseisen kan echter niet gevonden worden in het verschil in functies van de motiveringsplichten, omdat die functies - zoals ook bleek uit het bovenstaande - niet wezenlijk uiteenlopen. De verschillende positie die bestuur en rechter in het recht innemen en het karakterverschil in de bevoegdheid van bestuur en rechter, zouden, volgens de Waard, eerder aanleiding kunnen vormen tot het stellen van verschillende motiveringseisen, maar ook deze bieden in zijn ogen onvoldoende verklaring voor verschillen in motiveringseisen. Wat betreft de positie van het bestuur, wijst hij erop dat het bestuur in zekere zin machtiger is dan de rechter omdat deze actief, op eigen initiatief, een wijziging in rechten en plichten van belanghebbenden te weeg kan brengen. Het bestuur vormt immers primair recht en grijpt (diep) in de rechtspositie van de burger in. Uiteindelijk verschillen de posities van de rechter en bestuur in het recht echter niet dermate volgens De Waard dat daarin aanleiding te vinden is voor hogere motiveringseisen voor het bestuur. Het karakterverschil in de bevoegdheid van bestuur en rech-

\footnotetext{
753. PG Awb I, p. 351.

754. De Waard 1987, p. $380-381$
} 


\section{De inrichting van de voorprocedures}

ter geeft volgens De Waard evenmin aanleiding tot het maken van een dergelijk onderscheid tussen bestuur en rechter. Hoewel de omstandigheid dat het bestuur over beleidsvrijheid kan beschikken en een discretionaire bevoegdheid heeft zou kunnen leiden tot het stellen van geen of lage motiveringseisen, geeft De Waard aan dat zulks niet de heersende benadering is. ${ }^{755} \mathrm{Zijn}$ (tussen)conclusie is dan ook dat er geen verklaring voorhanden is die verschil in motiveringseisen tussen bestuur en rechter rechtvaardigt. ${ }^{756}$

Tussen het bestuur in de bestuurlijke voorprocedure en de rechter bestaat in deze opzichten nog minder reden voor een te maken onderscheid. De positie van het bestuur in die procedures zit immers tussen die van de rechter en het bestuur in primo in. Als er al een onderscheid gemaakt kan worden, dan zou er - aansluitend bij hetgeen De Waard daaromtrent opmerkt - gelet op de positie van het bestuur als primaire rechtsvormer die onafhankelijk van het initiatief van de belanghebbende ingrijpt in diens rechtspositie eerder aanleiding bestaan voor hogere motiveringseisen voor het bestuur (ongeacht de fase van besluitvorming). Al met al vallen er in elk geval geen redenen aan te wijzen waarom aan het bestuur lagere motiveringseisen gesteld moeten worden dan aan de rechter. Doorwerking van het beginsel van behoorlijke rechtspleging in de bestuurlijke voorprocedure zou derhalve in dat opzicht zeer goed mogelijk kunnen zijn.

Of de motiveringseisen voor het bestuur hoger of lager zijn dan voor de rechter dan wel hetzelfde worden ingevuld zal het onderzoek moeten uitwijzen. De motiveringseisen die aan een besluit van het bestuur gesteld worden lijken in elk geval verder geconcretiseerd en uitgewerkt te zijn dan voor de rechter. Uit het bovenstande blijkt immers dat het motiveringsbeginsel eist dat een besluit een deugdelijke feitelijke grondslag dient te bevatten, dat het gehanteerde wettelijk kader juist moet zijn en juist moet zijn geïnterpreteerd, dat de redenering van het bestuur consistent moet zijn en niet innerlijk tegenstrijdig alsmede dat duidelijk moet blijken op welke wijze en op grond waarvan de feiten gekwalificeerd zijn. Dit soort specificaties zijn voor de uitspraken van de bestuursrechter in wetgeving noch jurisprudentie expliciet vastgelegd. ${ }^{757}$ De invulling van de motiveringseisen voor het bestuur in de bestuurlijke voorprocedures komt aan de orde in de volgende paragraaf.

\subsubsection{Invulling van de motiveringsplicht voor het bestuur in bezwaar en administratief beroep}

\section{De algemene wettelijke motiveringseisen in bezwaar}

Zoals aangegeven is de motiveringsplicht voor de bestuurlijke voorfase neergelegd in artikel 7:12 en 7:26 van de Awb. In deze bepalingen is slechts aangegeven dat de beslissing dient te berusten op een deugdelijke motivering die bij bekendmaking van de beslissing dient te worden vermeld. In de toelichting bij deze bepalingen en in de bepalingen als zodanig wordt niet duidelijk aangegeven wat onder een deugdelijke motivering van de besluiten genomen in deze voorprocedure moet worden verstaan. De wetgever heeft bewust nagelaten daaraan een invulling te geven. ${ }^{758}$ Ter verdediging of onderbouwing van de beslissing om niet nader aan te geven waaruit de motiveringsplicht in bezwaar bestaat, verwijst de wetgever naar de omstandigheid dat de motiveringsplicht ook voor rechters niet nader wordt ingevuld aangezien het moeilijk is in abstracto aan te geven wat als voldoende motivering kan worden aangemerkt. ${ }^{759}$ Wel wordt opgemerkt, zoals hiervoor al aan de orde kwam, dat bij een ongegrondverklaring van de bezwaren zwaardere

\footnotetext{
755. Bij mijn weten is er sinds De Waard niemand geweest die dit punt expliciet aan de orde heeft gesteld in de literatuur. Een onderscheid naar de aard van de bevoedheid die in het geding is wordt in het kader van de geldende motiveringseisen in de docrine en rechtspraak ook niet expliciet gemaakt.

${ }^{756 .}$ De Waard 1987, p. 383-387.

757. Zie voor de motiveringsplicht die op de rechter rust par. 4.3.7 van Deel I.

758. PG Awb I, p. 351

759. PG Awb I, p. 351.
} 
Deel II Bestuurlijke voorprocedures

eisen gesteld kunnen worden aan de motivering dan bij een gegrondverklaring van de bezwaren. De reden hiervoor is tweeledig en houdt verband met de processuele en rechtsbeschermingsfunctie van de motivering van het besluit. ${ }^{760}$ Wat het administratief beroep betreft, wordt geen toelichting op de motiveringsplicht in de parlementaire geschiedenis gegeven. Aangenomen moet worden dat deze in beginsel op dezelfde wijze moet worden ingevuld als in de bezwaarschriftprocedure.

Uit artikel 7:12 Awb kan in elk geval wel worden afgeleid dat ook in bezwaar de motivering deugdelijk dient te zijn en kenbaar moet zijn, aangezien deze bij de bekendmaking moet worden vermeld. Voor de invulling van deze deugdelijkheidseis en kenbaarheidseis verwijst de wetgever echter niet expliciet naar artikel 3:46 en 3:47 Awb en hetgeen daaromtrent in de toelichting wordt opgemerkt. De twee eisen van deugdelijkheid en kenbaarheid stemmen overeen met de algemene motiveringseisen die gesteld worden aan besluiten van het bestuur op grond van het motiveringsbeginsel als algemeen beginsel van behoorlijk bestuur. In dat licht is het opmerkelijk dat de wetgever stelt dat geen concrete invulling aan de motiveringseis in bezwaar kan worden gegeven. Vooral opmerkelijk is dat ter rechtvaardiging daarvan verwezen wordt naar de vormgeving van de motiveringsplicht voor de bestuursrechter. De motiveringseisen bij primaire fase in artikel 3:46 en 3:47 Awb zijn immers evemin nader geconcretiseerd, maar een verwijzing naar die bepalingen heeft niet plaatsgevonden. Dat is te meer opmerkelijk, omdat de wetgever ook in de toelichting op deze bepalingen aangeeft dat het niet mogelijk is om in algemene zin aan te geven welke eisen voortvloeien uit de beide aspecten van het motiveringsbeginsel. ${ }^{761}$

Het lijkt mij inherent aan het karakter van het motiveringsbeginsel in het algemeen dat de daaruit voortvloeiende eisen afhankelijk zijn van de concrete omstandigheden van het geval. Daarbij doet het er niet toe in welke fase de procedure zich bij het bestuur bevindt dan wel of de procedure zich in een bestuurlijke of rechterlijke fase bevindt. Van Male merkt bijvoorbeeld ook op dat (over de motiveringseisen voor de primaire besluitvormingsfase zoals neergelegd in destijds nog het Voorontwerp) er geen aanknopingspunten zijn voor een nadere invulling van het vereiste van een deugdelijke motivering en dat de jurisprudentie van voor de Awb (gelet op de codificerende functie van die bepalingen) daarbij leidraad zal zijn. ${ }^{762}$ Voor de motiveringsplicht in de primaire fase ligt het in de rede dat het evenzeer moeilijk is om in algemene eisen te vatten wat in concreto onder een voldoende motivering moet worden begrepen. Die beoordeling zal altijd ten dele afhankelijk zijn van de omstandigheden van het geval. Schlössels wijst ook op het open karakter van het motiveringsbeginsel als beginsel van de goede procesorde en geeft aan dat de maatstaven waaraan een rechterlijke motivering moet voldoen altijd afhankelijk is van de aard van de in het geding zijnde beslissing en de omstandigheden van het geval. ${ }^{763}$ Dat geldt evenzeer voor de motivering van besluiten en is een gemeenschappelijk aspect aan de invulling van een motiveringsplicht in het algemeen. De verwijzing naar de aard van de rechterlijke motiveringsplicht in dit opzicht roept de vraag op of het rechtsbeschermingskarakter van de bestuurlijke voorprocedures en de gelijkenissen met rechtspraak in dat opzicht daaraan ten grondslag hebben gelegen. Het is echter niet duidelijk of de wetgever hiermee bewust een onderscheid tussen de primaire fase en de bezwaarfase heeft willen maken dan wel bewust een gelijkenis met de rechterlijke fase heeft willen benadrukken.

\footnotetext{
760. PG Awb I, p. 351

761. PG Awb I, p. 268

762. Van Male 1988, p. 77.

763. Schlössels in zijn noot bij EHRM 27 september 2001, Hirvisaari t. Finland, NJCM-Bulletin 2002 m.nt R.J.N. Schlössels, p. 293.
} 
De inrichting van de voorprocedures

Een specifiek op de bestuurlijke voorprocedures toegesneden invulling van de motiveringeisen?

Hoewel de bestuurlijke voorprocedures een unieke positie innemen tussen het primaire besluitvormingsproces en de procedure bij de bestuursrechter en gekenmerkt worden door zowel verlengde besluitvorming als rechtsbescherming, wordt zowel door de wetgever als in de literatuur niet of nauwelijks afzonderlijk aandacht besteed aan de motiveringsplicht of het motiveringsbeginsel in de bestuurlijke voorfasen. ${ }^{764}$ Bij beschrijvingen en analyses van het motiveringsbeginsel als algemeen beginsel van behoorlijk bestuur en de uitwerking daarvan door de rechtspraak ligt de nadruk veelal op de primaire besluitvormingsfase en de eisen zoals thans neergelegd (ter codificatie en modificatie van dat beginsel) in artikel 3:46 en 3:47 Awb of worden de eisen gezamenlijk besproken. ${ }^{765}$ Van belang daarbij is dat, zoals eerder aangegeven, de wettelijke motiveringseisen die gelden voor besluiten in primo niet opgaan voor de besluiten die genomen worden op bezwaar en in administratief beroep, aangezien artikel 7:14 en 7:27 Awb de werking daarvan uitsluit. Artikel 3:46 en 3:47 vormen echter een codificatie van het motiveringsbeginsel. ${ }^{766}$ Het motiveringsbeginsel als ongeschreven algemeen beginsel van behoorlijk bestuur houdt echter ook voor de bestuurlijke voorprocedures, als onderdeel van het besluitvormingsproces, gelding. ${ }^{767}$ Gelet op het voorgaande zijn deze bepalingen en de daarin tot uitdrukking gebrachte jurisprudentiële eisen, hoewel niet rechtstreeks van toepassing op de voorfasen, toch relevant voor de invulling van de motiveringsplicht in bezwaar en administratief beroep. Soms zijn ook motiveringseisen uit de Awb voor de primaire besluitvormingsfase expliciet van toepassing op de bestuurlijke voorprocedures. Dat geldt bijvoorbeeld voor artikel 3:49 Awb, waarin wordt aangegeven dat ter motivering van een besluit naar een advies kan worden verwezen.

Uit het motiveringsbeginsel vloeit voort dat een besluit een kenbare en draagkrachtige motivering dient te bevatten. Deze twee onderdelen van het motiveringsbeginsel heeft de wetgever ook tot uitdrukking willen brengen in onder meer artikel 3:46 en 3:47 Awb. ${ }^{768}$ Deze eisen zijn eveneens terug te zien in artikel 7:12 eerste lid van Awb. In beginsel gelden derhalve dezelfde motiveringseisen. ${ }^{769}$ Koenraad en Sanders beschouwen artikel 7:12 eerste lid, eerste volzin, bijvoorbeeld als een species van artikel 3:46. ${ }^{770}$ Beide bepalingen zijn in mijn optiek een uitwerking van het algemene beginsel van behoorlijk bestuur dat een besluit van het bestuur een deugdelijke, draagkrachtige (en kenbare) motivering dient te bevatten. In beide fasen van de besluitvorming dient de motivering derhalve te voldoen aan dezelfde eisen. De vraag is vervolgens of deugdelijkheid, draagkrachtigheid en kenbaarheid hetzelfde inhoudt in beide fasen van de besluitvorming. In de literatuur lijkt daar (al dan niet impliciet) van te worden uitgegaan.

De concrete invulling van beide eisen wordt voor de bezwaarfase in de volgende paragrafen in kaart gebracht. Omdat in de literatuur en wetgeving weinig aandacht is besteed aan deze concrete invulling van de motiveringsplicht in bezwaar, moet ook om

\footnotetext{
764. In het kader van bespreking van de eisen die gelden voor de bezwaarschriftprocedure en het administratief beroep wordt er kort afzonderlijk aandacht aan besteed, zie bijvoorbeeld: Damen e.a. 2009, Deel II, p. 201 Van Wijk/Konijnenbelt \& Van Male 2008, p. 564-565.

765. Zie bijvoorbeeld: Damen e.a. 2009, Deel I, p. 369 e.v.; Van Wijk/Konijnenbelt \& Van Male 2008, p. 310314; R.P.B.A. Dingemans, 'Slecht gemotiveerde besluiten gesauveerd. Reparatie van materiële motiveringsgebreken in Nederland, Frankrijk en Duitsland, JB-plus 2008, p. 102 e.v.; Van Male 1998, p. 73 e.v.

${ }^{766 .}$ De wetgever geeft expliciet aan dat zulks het geval is en dat de codificatie tot gevolg heeft dat de rechter bij schending van het motiveringsbeginsel voor beschikkingen niet meer zal verwijzen naar het ongeschreven beginsel maar naar deze bepalingen, PG Awb I, p. 268. De toelichting heeft betrekking op destijds nog art. 4:16 en 4:17 Awb welke bepalingen thans zijn neergelegd in art. 3:46 en 3:47 Awb.

767. Zie ook Van der Ham, p. 89.

768. PG Awb I, p. 268

${ }^{769}$ Damen e.a. 2009, Deel II, p. 201-202.

${ }^{770 .}$ Koenraad \& Sanders 2006, p. 130.
} 
Deel II Bestuurlijke voorprocedures

deze te kunnen vaststellen teruggegrepen worden op artikel 3:46 en 3:47 Awb. ${ }^{771}$ Artikel 7:12 Awb is echter regelmatig aan bod gekomen in uitspraken van de verschillende bestuursrechters. In de volgende paragrafen wordt derhalve in het bijzonder nader ingegaan op de invulling van de motiveringsplicht in de rechtspraak. Daarbij is de aandacht gericht op de specifiek voor het besluit op bezwaar geldende motiveringseisen of de concrete invulling daarvan voor bezwaar (voor zover een verschil met de primaire besluitvorming valt te onderkennen wordt daarop ingegaan).

\section{Deugdelijkheid en draagkrachtigheid van de motivering}

De eerste eis die artikel 7:12 Awb stelt aan de motivering van de beslissing op bezwaar is dat deze deugdelijk dient te zijn. Artikel 7:12, eerste lid, bevat derhalve ook een uitwerking van het materiële motiveringsbeginsel voor de bezwaarfase. Onder de deugdelijkheideis worden in het algemeen verschillende elementen begrepen waarbij niet zozeer een onderscheid gemaakt wordt tussen de bestuurlijke voorprocedure en de primaire besluitvormingsfase. Het betreft de elementen die ook voortvloeien uit de motiveringsplicht in artikel 3:46 Awb. In de literatuur worden verschillende indelingen gehanteerd ten aanzien van de deugdelijkheidseisen waarbij zoals aangegeven vier elementen steeds terug lijken te keren: deugdelijke feitelijke grondslag, juiste interpretatie van de toepasselijke regel(s), juiste kwalificatie van de feiten en een deugdelijke redenering. ${ }^{772}$

Deze voorgaande eisen gelden uiteraard ook voor het bestuur in de bestuurlijke voorprocedure. Het bestuur zal opnieuw de feiten moeten vaststellen, opnieuw het wettelijk kader moeten interpreteren en opnieuw de feiten moeten kwalificeren. ${ }^{773}$ Deze activiteiten en de redenering van het bestuur die tot de uiteindelijke beslissing moet leiden, moeten tot uitdrukking komen in het besluit. Het besluit dient ook in bezwaar te steunen op een deugdelijke feitelijke grondslag. ${ }^{774}$ Indien er nieuwe feiten of omstandigheden bekend zijn geworden, zal het bestuursorgaan voorts, gelet op het ex nunc-karakter van de heroverweging, in het besluit blijk moeten geven van de wijze waarop deze zijn betrokken bij de besluitvorming. ${ }^{775}$ Voornoemde eisen zijn primair gericht op het besluitvormingsproces en de kwaliteit van de besluitvorming. Voor de primaire besluitvormingsfase spreekt dat ook vanzelf. De motivering van een besluit heeft echter in de bezwaarschriftprocedure ook een functie die verband houdt met de rechtsbescherming van de belanghebbende. Dat aspect of een eis die dat beoogt te waarborgen ligt niet specifiek besloten in de hiervoor genoemde elementen. Uiteraard is ook de rechtsbescherming van de belanghebbende gediend met zorgvuldige besluitvorming waarbij die zorgvuldigheid ook tot uitdrukking komt in de motivering van het besluit. Omdat de bestuurlijke voorprocedures echter een geschilachtig karakter hebben en uitsluitend op initiatief van belanghebbenden geëntameerd worden, is ook van belang dat recht wordt gedaan aan hetgeen door die belanghebbenden is aangevoerd. Voor rechtspraak geldt bijvoorbeeld als motiveringseis dat de rechter in zijn uitspraak ook aandacht behoort te besteden aan de (belangrijkste) standpunten van partijen en de weerlegging of aanvaarding daarvan. ${ }^{776}$ Ook in de bestuurlijke voorprocedures moet ingegaan worden op de bezwaren die belanghebbenden hebben aangevoerd. ${ }^{777}$

\footnotetext{
771. Omdat er weinig specifieke aandacht bestaat voor de motiveringseisen in bezwaar en administratief beroep in algemene zin en de motiveringseisen in beide fasen hetzelfde zijn, bestaat er meer aanleiding om aandacht te besteden aan de eisen die gelden voor de primaire besluitvormingsfase dan in het kader van de andere hoofdstukken het geval is.

772. Zie o.m.: Damen e.a. 2009, Deel I, p. 380-381; Van Wijk/Konijnenbelt \& Van Male 2008, p. 310-311; Nicolaï 1990 , p. 354-355

${ }^{773 .}$ Zie voor voorbeelden in de jurisprudentie: AbRvS 29 september 2004, AB 2004/415 m.nt. NV (ondeugdelijke feitelijke grondslag besluit); CBb 3 maart 2004, AB 2004/198 m.nt. JHvdV (conclusie die getrokken is wordt niet gedragen door beschikbare gegevens).

774. CBb 19 april 1998, AB 1998/265 m.nt. J.H. van der Veen.

${ }^{775 .}$ Koenraad \& Sanders 2006, p. 131.

776. Zie hierover par. 4.3.7 van Deel I.

777. Koenraad \& Sanders 2006, p. 131. Op deze reactieplicht wordt in de volgende par. 5.6.4.2 nader ingegaan.
} 


\section{De inrichting van de voorprocedures}

In bezwaar is voorts om andere redenen wel degelijk sprake van een andere situatie waaruit een verschil voortvloeit met de primaire besluitvormingsfase: in de bezwaarfase staat een besluit centraal waarbij, als het goed is, reeds een draagkrachtige motivering gegeven is voor de inhoud van de beslissing. Dat besluit en die motivering moeten geheel opnieuw heroverwogen worden en die heroverweging dient ook te leiden tot wederom een draagkrachtige motivering van het besluit op bezwaar. In het besluit op bezwaar moet echter ook aangegeven worden waarom het primaire besluit gehandhaafd of herroepen wordt (naar aanleiding van het bezwaar) en om welke redenen. ${ }^{778}$ Eventueel kan de motivering, indien en voor zover nodig, van het primaire besluit nog verbeterd of aangevuld worden. Hoewel de motivering van het besluit op bezwaar ook uiteenvalt in de hiervoor genoemde elementen, zal de motivering tevens op bevestiging of ontkrachting van (de eerdere motivering van) de primaire beslissing gericht zijn. Dat is in de primaire besluitvormingsfase, behoudens de gevallen waarin de uniforme voorbereidingsprocedure gevolgd wordt wellicht ${ }^{779}$, minder het geval. Als het besluit op bezwaar het primaire besluit bevestigt, is denkbaar dat in dit opzicht een minder zware motiveringsplicht geldt dan wanneer het bestuursorgaan het primaire besluit - waaraan als het goed is reeds een draagkrachtige motivering ten grondslag ligt - wilt herroepen. Wel is het zo, dat vanuit het perspectief van de belanghebbende, een bevestiging van het besluit mét ongegrondverklaring van de bezwaren juist noopt tot een zwaardere motiveringsplicht. ${ }^{780}$ Die motiveringseisen hebben dan echter betrekking op de weerlegging van de bezwaren, hetgeen niet geheel hoeft samen te vallen met de inhoudelijke motivering voor het nemen van het besluit.

\section{Een kenbare motivering}

Ook in bezwaar dient de motivering kenbaar te zijn, dat wil zeggen dat de motivering bij bekendmaking van het besluit moet worden vermeld en naar buiten toe moet blijken. De kenbaarheidseis betreft het formele motiveringsbeginsel dat ook in artikel 7:12 eerste lid van de Awb voor besluiten op bezwaar is neergelegd. In de toelichting op deze bepaling wordt daaraan geen nadere aandacht besteed. In de toelichting op artikel 3:47 Awb merkt de wetgever op dat het vereiste van kenbare motivering twee elementen bevat: het verschaffen van inzicht door het bestuur in de gevolgde gedachtegang en de vermelding moet op zodanige wijze geschieden dat zij voor de belanghebbende redelijkerwijs begrijpelijk is. ${ }^{781}$ Indien een motivering ontbreekt zal in beginsel in strijd met deze eis gehandeld zijn door het bestuur. De kenbaarheideis van de motivering houdt in beginsel in dat de volledige motivering bij het besluit bekend gemaakt wordt en niet pas naderhand een deel van de motivering, zoals een advies waarop het besluit is gebaseerd, kenbaar wordt voor de belanghebbenden. ${ }^{782}$

\subsubsection{Specifieke motiveringseisen in de bestuurlijke voorprocedures}

\subsubsection{Wettelijk voorgeschreven aanvullende motiveringseisen}

De verschillende door de wetgever noodzakelijk geachte aanvullende motiveringseisen In de Awb is een tweetal verschillende aanvullende motiveringseisen in bezwaar voorgeschreven: voor het afzien van het horen op grond van artikel 7:3 Awb en voor het afwijken van het advies van de adviescommissie in de zin van artikel 7:13 Awb. Het betreft

\footnotetext{
${ }^{778 .}$ Koenraad \& Sanders 2006, p. 131.

779. In dat geval kan aangegeven worden waarom het ontwerpbesluit gehandhaafd wordt of juist niet gehandhaafd wordt.

780. PG Awb I, p. 351.

781. PG Awb I, p. 271

782. Addink E 7:12-6, die verwijst naar een ongepubliceerde uitspraak van de Afdeling, AbRvS 20 oktober 2004 , nr. 2000402982/1.
} 
Deel II Bestuurlijke voorprocedures

motiveringseisen waarvan de wetgever het blijkbaar nodig heeft geacht om deze wettelijk vast te leggen. In beide gevallen gaat het om twee essentiële onderdelen in de inrichting van de bezwaarschriftprocedure en in beide gevallen gaat het om gevallen waarin het bestuur afwijkt van hetgeen ter waarborging van de belangen of de processuele rechten van de appellerende burger als uitgangspunt is voorgeschreven. Het motiveringsbeginsel staat bij deze aanvullende motiveringseisen dan ook meer in het teken van de rechtsbescherming van de belanghebbende en brengt de eerder al aangestipte - en door Van Male (zij het in een iets andere context) genoemde - processuele functie tot uitdrukking. ${ }^{783}$

\section{Motiveringseisen inzake het horen}

Een concrete bijzondere eis die artikel 7:12, eerste lid, van de Awb stelt is dat indien van het horen wordt afgezien op grond van artikel 7:3 Awb in het besluit op bezwaar moet worden aangegeven op welke grond dit is geschied. ${ }^{784}$ Daarmee wordt in elk geval veilig gesteld dat aan de belanghebbende duidelijk wordt gemaakt waarom van een essentieel onderdeel in de bezwaarfase als het horen wordt afgezien. In de toelichting op artikel 7:3 Awb wordt over deze motiveringseis opgemerkt dat daardoor de indiener van een bezwaarschrift redelijk inzicht kan worden verschaft in het geval toepassing van een van de uitzonderingen op de hoorplicht plaatsvindt, dat daardoor een goede bestuurspraktijk kan worden bevorderd op dit punt en dat de rechterlijke controle op de toepassing van artikel 7:3 Awb daardoor wordt vergemakkelijkt. ${ }^{785}$ Zoals Koenraad en Sanders opmerken verplicht deze motiveringseis het bestuur tot verantwoording van de keuze om van de hoofdregel, het horen van belanghebbenden, af te wijken. ${ }^{786}$ Omdat het horen een fundamenteel onderdeel vormt van het beginsel van hoor en wederhoor dat een belangrijke rol speelt in de bezwaarschriftprocedure, ligt een dergelijke plicht tot motivering ook in de rede. Een schending van die motiveringsplicht leidt tot vernietiging van het besluit wegens strijd met artikel 7:12 eerste lid Awb, maar instandlating van de rechtsgevolgen behoort tot de mogelijkheden, indien de bestuursrechter oordeelt dat het niet horen terecht is geweest. ${ }^{78}$

Voor de bestuursrechter bestaat op grond van artikel 8:54 Awb een aantal vergelijkbare gronden waarop kan worden overgegaan tot behandeling van de zaak zonder zitting. Een motiveringsplicht in dat verband volgt niet expliciet uit artikel 8:77 Awb. Opvallend is dat in dat opzicht de motiveringsplicht voor het bestuur in de bestuurlijke voorprocedures specifieker is uitgewerkt dan de motiveringsplicht voor de bestuursrechter. Aangenomen kan immers worden dat ook de uitspraak van de bestuursrechter gedaan met toepassing van artikel 8:54 Awb vanzelfsprekend moet vermelden waarom de mondelinge behandeling niet nodig werd en welke van de vier gronden genoemd in die bepaling zich voordoet. Het oordeel van de bestuursrechter dat zich een van de vier kennelijkheden voordoet genoemd in die bepaling kan immers ook getoetst worden in verzet op grond van artikel 8:55 Awb. Uit de systematiek van de Awb kan echter worden afgeleid dat afdeling 8.2.6 Awb, waaronder artikel 8:77 Awb, ook geldt voor de uitspraken gedaan met toepassing van artikel 8:54 Awb als voor de uitspraken gedaan op verzet tegen deze uitspraken. $^{788}$

\footnotetext{
783. Van Male 1988, p. 75.

784. PG Awb I, p. 351.

785. PG Awb I, p. 333

${ }^{786 .}$ Koenraad \& Sanders 2006, p. 131.

787. CRvB 7 maart 2000, $A B$ 2000/214 m.nt. $\mathrm{HBr}$

788. PG Awb II, p. 450. Zie ook: HR 12 juni 2009, AB 2009/246 m.nt. Redactie; CRvB 29 april 1996, AB 1997/24 m.nt. HB.
} 


\section{De inrichting van de voorprocedures}

Motiveringseis en advisering in bezwaar

Vooropgesteld moet worden dat ook voor adviezen in het algemeen ${ }^{789}$, althans de verwijzing daarnaar door het bestuursorgaan ter motivering van het besluit op bezwaar, artikel 3:49 in combinatie met artikel 7:12 Awb geldt. Dat betekent dat ter motivering een verwijzing naar het advies mogelijk is, indien het advies zelf de motivering bevat en van het advies kennis is of wordt gegeven. Gebeurt dit niet of pas (enige tijd) na verzending van het besluit, kan dat een grond voor vernietiging van het besluit opleveren. ${ }^{790}$ De Afdeling heeft in een uitspraak vernietiging achterwege gelaten met toepassing van artikel 6:22 Awb vanwege de omstandigheid dat de appellant desondanks tijdig beroep had ingesteld en de gronden van zijn beroep had aangevuld naar aanleiding van het (veel te laat) toegezonden advies. Daaruit kan worden afgeleid dat voor de vraag of het besluit in stand kan blijven vooral bepalend is in hoeverre de belanghebbende in zijn processuele belangen en de effectuering van zijn beroepsrechten geschaad wordt. ${ }^{791}$ Artikel 3:50 Awb geldt daarentegen niet in de bestuurlijke voorprocedures, waardoor het bestuursorgaan in elk geval op grond van die bepaling niet verplicht is om een afwijking van een wettelijk verplicht uitgebracht advies te motiveren. Dat betekent volgens de wetgever slechts dat afwijking van interne ambtelijke adviezen mogelijk is zonder expliciete motivering daarvan. ${ }^{792}$ Aangenomen moet worden dat er op grond van het motiveringsbeginsel bij afwijking van een advies een plicht tot motivering bestaat waarom afgeweken wordt van het advies. ${ }^{793}$ In de bezwaarschriftprocedure kan voorts, evenals in de primaire besluitvormingsfase, een motiveringsgebrek ontstaan indien een advies aan de besluitvorming ten grondslag wordt gelegd, terwijl het bestuursorgaan dit vanwege zorgvuldigheidsgebreken van het advies niet had mogen doen. In dat geval ontbeert het besluit een deugdelijke motivering als vereist in artikel 7:12 Awb. ${ }^{794}$ Een vergelijkbare benadering, waarin de eigen verantwoordelijkheid van het bestuursorgaan voorop staat, hanteert de bestuursrechter in het kader van wettelijk verplichte advisering op grond van artikel 3:9 Awb en de daarin neergelegde vergewisplicht. ${ }^{795}$ Verwijzing naar een advies is mogelijk ter motivering ook in bezwaar, maar het bestuursorgaan moet zich ervan vergewissen dat het advies zorgvuldig tot stand is gekomen, een motivering bevat en ter kennis is gebracht van belanghebbenden, gelet op artikel 3:9 en 3:49 Awb in samenhang met 7:12 Awb. ${ }^{796}$ Als de motivering van het advies summier is, kan het bestuursorgaan niet volstaan met verwijzing ernaar ter motivering van het besluit. ${ }^{797}$

Voorts bevat artikel 7:13 Awb een meer concrete eis aangaande de motivering, indien een bezwaaradviescommissie in de zin van dat artikel is ingeschakeld. Als van het uitgebrachte advies wordt afgeweken, moet zulks uitdrukkelijk worden gemotiveerd ingevolge het zevende lid van die bepaling en moet het advies worden meegezonden. Deze bepaling is overigens volgens de bestuursrechter niet van openbare orde, hetgeen betekent dat niet ambtshalve mag worden getoetst of deze bepaling wel in acht is genomen. ${ }^{798}$ Wordt echter niet van dit advies van de bezwaaradviescommissie afgeweken, geldt hetgeen bepaald is voor de primaire besluitvorming in artikel 3:49 Awb overeen-

\footnotetext{
789. Ongeacht of het een intern ambtelijk advies betreft of een wettelijk verplicht advies, PG Awb I, p. 274.

790. AbRvS 2 maart 2005, JB 2005/117; $A B$ 2005/136 m.nt. FM.

${ }^{791 .}$ Zie r.o. 2.1.2 van de uitspraak genoemd in de noot hiervoor.

792. PG Awb I, p. 275.

793. Damen e.a. 2009, Deel I, p. 433.

794. AbRvS 25 februari 2009, $A B$ 2009/222 m.nt. W. den Ouden en J.M.J. van Rijn van Alkemade.

795. AbRvS 5 december 2001, $A B$ 2002/110.

796. AbRvS 26 juni 2002, $A B$ 2003/407 m.nt. G.A.C.M. van Ballegooij. Zie hierover ook uitvoeriger de noot van Van Ballegooij bij die uitspraak.

797. AbRvS 17 juni 2009, $A B$ 2010/65 m.nt. L.J.A. Damen.

798. CRvB 29 april 2003, $A B$ 2003/307 m.nt. HBr; $J B$ 2003/192. Bröring merkt in de noot bij die uitspraak op dat het vermelden van de reden voor afwijking en het meezenden van het advies van belang is o.m. voor het inschatten van de kansen van een beroep, maar dat het een voorschrift van processuele aard betreft en geen fundamenteel verdedigingsrecht. Was dat laatste wel het geval, dan nog bestaat er volgens de jurisprudentie geen plicht tot ambtshalve toetsing, hoewel dat wel wordt bepleit in de literatuur, zie hierover: par. 4.1 van Deel I.
} 


\section{Deel II Bestuurlijke voorprocedures}

komstig en kan ter motivering naar het meegezonden advies worden verwezen mits van dit advies kennis is of wordt gegeven. ${ }^{799}$ Dat betekent derhalve dat het advies van de bezwaaradviescommissie ter kennis van belanghebbenden moet worden gebracht, indien ter motivering van het besluit verwezen wordt naar het advies, maar ook indien van het advies wordt afgeweken. Het bestuursorgaan moet zich er - op grond van artikel 3:9 Awb of het zorgvuldigheidsbeginsel - voorts van vergewissen dat het advies zelf deugdelijk gemotiveerd is en zorgvuldig tot stand is gekomen, alvorens het volstaat met verwijzing daarnaar. Is dat niet het geval en vindt verwijzing naar het advies plaats in het besluit, moet de conclusie luiden dat ook het besluit onvoldoende is gemotiveerd. ${ }^{800}$

\section{Verband met verweermogelijkheden van belanghebbenden}

Beide specifieke motiveringseisen houden verband met de mogelijkheden van belanghebbenden om inzicht te krijgen in de redenen voor het besluit en de verweermogelijkheden en rechtsbescherming van belanghebbenden. Het gaat om eisen die, hoewel zij zelf wellicht geen fundamenteel verdedigingsrecht betreffen ${ }^{801}$, verband houden met essentiële waarborgen voor de belanghebbenden. Tevens maken zij controle mogelijk door de bestuursrechter van de genomen beslissingen ten aanzien van deze belangrijke onderdelen in de procedure.

\subsubsection{Aanvullende ongeschreven motiveringseisen}

Specifieke ongeschreven motiveringseisen voor procesbelissingen

Hierboven hebben we gezien dat er in de Awb ten aanzien van bepaalde processuele beslissingen die het bestuur of de adviescommissie behoort te nemen specifieke motiveringsplichtingen zijn neergelegd. Het bestuur kan echter gedurende de gehele voorprocedure nog andere processuele beslissingen nemen die voor belanghebbende aanzienlijke gevolgen kunnen hebben. Te denken valt aan gebruikmaking van de bevoegdheid om meegebrachte getuigen en deskundigen niet te horen op grond van artikel 7:8 Awb of het afzien van het houden van een openbare hoorzitting op grond van artikel 7:5 Awb. Andere voorbeelden zijn de bevoegdheid om de beslistermijn te verdagen op grond van artikel 7:10 Awb, de beslissing om belanghebbenden afzonderlijk te horen op grond van artikel 7:6, tweede lid, van de Awb en de beslissing om hetgeen aan bod is gekomen tijdens de hoorzitting niet aan belanghebbenden mede te delen, ingevolge artikel 7:6, vierde lid, van de Awb.

De hiervoor genoemde voorbeelden van procesbeslissingen vormen - buiten de beslissingen in verband met het indienen van stukken en het ter inzage leggen van stukken als bedoeld in artikel 7:4 $\mathrm{Awb}^{802}$ - de belangrijkste procesbeslissingen die het bestuur kan nemen. Deze beslissingen kunnen gevolgen hebben voor zowel de te nemen beslissing op bezwaar als voor het daaropvolgende beroep bij de rechter. Het gaat hoofdzakelijk om bepalingen die bevoegdheden aan het bestuur toekennen om de voor belanghebbenden bestaande processuele rechten te beperken. Deze procesbeslissingen moeten dan ook in het perspectief van de verdedigingsrechten van de belanghebbenden geplaatst worden. Opvallend is daarom dat de wetgever geen verplichting tot motivering van der-

\footnotetext{
799. Art. 7:14 Awb zondert art. 3:49 immers uitdrukkelijk niet uit van werking in de bezwaarschriftprocedure. ${ }^{800}$ Zie bijvoorbeeld: CBb 24 augustus 2006, $A B$ 2007/321 m.nt. O.J.D.M.L. Jansen, waarin aan de orde komt dat in het advies onvoldoende gereageerd is op de door de belanghebbende aangevoerde gronden; AbRvS 12 oktober $2005, J B 2005 / 328$ m.nt. AMLJ waarin het bestuursorgaan afging op een rapport dat niet volledig was en de juiste berekeningen bevatte maar wel ten grondslag was gelegd aan het besluit; AbRvS 3 september 2003, $J B$ 2003/293 waarin het bestuursorgaan het advies van de bezwaarschriftcommissie had overgenomen, die op haar beurt weer verwezen had naar een advies van de Monumentencommissie die eerder in andere zin had geadviseerd. $\mathrm{Nu}$ de bezwaarschriftcommissie niet nader was ingegaan op de wisselende advisering van de Monumentencommissie en waarop haar oordeel was gebaseerd, rustte op het bestuursorgaan een zware motiveringsplicht. ${ }^{801 .}$ Vgl. de noot van Bröring bij $A B$ 2003/307.

802. Op deze beslissingen is in par. 5.3 van Deel II nader ingegaan. Het bestuur zal in het besluit moeten ingaan op beslissingen over ingediende stukken en
} 


\section{De inrichting van de voorprocedures}

gelijke beslissingen heeft voorgeschreven in de Awb, terwijl dat bijvoorbeeld wel is geschied voor de beslissing om van het horen af te zien. Uiteraard vormt de hoorplicht de kern van de processuele rechten van belanghebbenden in de bezwaarschriftprocedure en kan dat een verklaring voor het verschil in motiveringseisen bieden. Desalniettemin lijkt het mij niet wenselijk dat het bestuur naar eigen inzicht zonder enige controle of criteria kan beslissen over de toepassing van dergelijke processuele rechten van belanghebbenden. Dit soort beslissingen die van belang kunnen zijn voor de uitkomst van de procedure, dienen gemotiveerd te worden opdat deze door de rechter later ook gecontroleerd kunnen worden. Voor de bestuursrechter zelf geldt wel dat deze beslissingen die de verdedigingsrechten van belanghebbenden inperken, moet motiveren in zijn einduitspraak. Zo heeft de Afdeling onlangs uitdrukkelijk bepaald dat de bestuursrechter zijn beslissing om door een partij meegebrachte of opgeroepen getuigen of deskundigen niet te horen dient te motiveren. ${ }^{803}$ Voorts is het zo dat de hiervoor bedoelde procesbeslissingen stuk voor stuk betrekking hebben op of samenhangen met eisen voor een behoorlijke procedure (die ook grotendeels door de wetgever en de rechter zijn erkend) en is het om die reden alleen al kwestieus dat een motiveringsplicht ontbreekt. Daar komt nog bij dat dit soort procesbeslissingen of tussenbeslissingen van het bestuur als zodanig niet aangevochten kunnen worden, omdat het geen appellabele besluiten betreft in de zin van de Awb. De enige manier waarop deze aan de orde kunnen worden gesteld bij de rechter is door het besluit zelf aan te vechten. ${ }^{804}$ Om het oordeel van het bestuur goed te kunnen te bestrijden en voor de rechter om dat oordeel goed te kunnen toetsen, is vereist mijns inziens dat het besluit inzicht biedt in de aan dit soort beslissingen ten grondslag liggende keuzes en motivering daarvoor. Een laatste argument dat pleit voor een motiveringsplicht bij dit soort procedurebeslissingen, is dat de weigering om gebruik te maken van de desbetreffende bevoegdheid, zoals het horen van getuigen, zou kunnen doorwerken in de mogelijkheden om die getuigen te horen in de procedure bij de rechter. ${ }^{805}$ Een dergelijke motiveringsverplicht behoeft ook niet altijd te leiden tot een verzwaring van de werklast van het bestuursorgaan of de adviescommissie. Indien bijvoorbeeld tijdens de hoorzitting uitleg wordt gegeven over de reden waarom afgezien wordt van een openbare hoorzitting of het horen van meegebrachte getuigen of deskundigen behoeft die uitleg slechts in het verslag van de hoorzitting of het advies te worden opgenomen.

De vraag of dergelijke procesbeslissingen in de bestuurlijke voorprocedure een expliciete motivering behoeven in de beslissing op bezwaar of administratief beroep is echter bij mijn weten nauwelijks in jurisprudentie aan bod gekomen. Voor de beslissing om de beslistermijn te verdagen, op grond van artikel 7:10, derde lid, van de Awb, heeft de Afdeling uitdrukkelijk bepaald dat deze beslissing moet worden medegedeeld maar niet behoeft te worden gemotiveerd. ${ }^{806}$ Gelet op het bovenstaande lijkt mij dit oordeel van de Afdeling niet wenselijk. Voor de bestuursrechter geldt op grond van artikel 8:66, tweede lid, van de Awb eveneens dat deze verlenging van de termijn voor het doen van uitspraak moet mededelen aan partijen. In hoeverre er voor de bestuursrechter een motiveringsplicht bestaat is niet duidelijk. ${ }^{807}$ Een motiveringsplicht is echter meer in overeenstemming met het groeiend belang dat aan tijdige besluitvorming wordt toegekend en de omstandigheid dat de redelijke termijn-eis van artikel 6 EVRM van toepassing is op de

803. Zie: CRvB 6 mei 2008, AB 2008/243 m.nt Hbr; AbRvS 21 mei 2007, AB 2007/194 m.nt. Sew; JB 2007/134 m.nt. DWMW; AbRvS 22 augustus 2007, $A B$ 2008/72, m.nt. O.J.D.M.L. Jansen. Opgemerkt zij wel dat de Afdeling niet lang daarvoor zich nog op het tegengestelde standpunt had gesteld, AbRvS 26 januari 2005, $A B$ 2005/374 m.nt. De Bock.

${ }^{804 .}$ Het betreft immers besluiten zonder zelfstandig rechtsgevolg. Dit soort besluiten zijn besluiten ter voorbereiding van een besluit en uitgezonderd van bezwaar en beroep, art. 6:3 Awb. Zie ook Koenraad \& Sanders die zulks opmerken ten aanzien van de beslissing om te verdagen, Koenraad \& Sanders 2006, p. 142.

${ }^{805 .}$ Koenraad \& Sanders 2006, p. 76.

${ }^{806 .}$ AbRvS 5 juni 2002, JB 2002/220.

807. Aan schending van art. 8:66 lid 1 of lid 2 worden echter geen gevolgen verbonden, zie bijv.:CBb 13 april 2006, $A B$ 2006/395 m.nt. O.J.D.M.L. Jansen; CRvB 22 april 2005, $A B$ 2006/44 m.nt. A.M.L. Jansen; $J B$ 2005/198. 


\section{Deel II Bestuurlijke voorprocedures}

bestuurlijke voorprocedures (zie hierover paragraaf 5.7). Een motivering kan tot slot van pas komen bij het bepalen of de redelijke termijn door het bestuur overschreden. Zij kan immers inzicht bieden in de factoren die leiden tot het verder uitstel en daarvoor een rechtvaardiging vormen. Hoewel ook Koenraad en Sanders zich op het standpunt stellen dat deze verdagingsbeslissing gemotiveerd moet worden, baseren zij deze plicht mijns inziens ten onrechte op artikel 3:46 en 3:47. ${ }^{808}$ Voor die plicht in bezwaar ligt eerder in de rede dat uit artikel 7:12 lid 1 Awb in samenhang met het daaraan ten grondslag liggende motiveringsbeginsel volgt dat deze beslissing gemotiveerd moet worden. Over een motiveringsplicht bij de overige procesbeslissingen heeft de bestuursrechter nog niet expliciet een oordeel hoeven uitspreken. Het lijkt mij echter (gelet op de hiervoor genoemde uitspraak) in de rede liggen dat de Afdeling niet gauw geneigd zal zijn om buiten de wettelijke motiveringseisen aanvullende motiveringseisen aan te nemen. Of dat ook voor de Centrale Raad of het CBb geldt is niet duidelijk. Wat betreft de bevoegdheden van het bestuur om al dan niet getuigen of deskundigen te horen, al dan niet hetgeen in afwezigheid van belanghebbende aan de orde is gekomen mee te delen of het afzien van het houden van een openbare zitting zou het echter eveneens de voorkeur verdienen een op het bestuur rustende motiveringsplicht aan te nemen. Uit het ontbreken van jurisprudentie moet wellicht worden afgeleid dat dergelijke procesbeslissingen in de praktijk blijkbaar geen problemen opleveren. Uitsluitend indien ten nadele van de belanghebbende van zo'n bevoegdheid gebruik wordt gemaakt, zal een belanghebbende de procesbeslissing aanvechten.

\section{Reactieplicht op alle aangevoerde bezwaren}

Inherent aan het rechtsbeschermingskarakter van de bezwaarschriftprocedure en het administratief beroep is dat op initiatief van een belanghebbende en naar aanleiding van de aangevoerde bezwaren of gronden nogmaals het primaire besluit onder de loep wordt genomen. Hoewel ook sprake is van verlengde besluitvorming en de heroverweging dientengevolge niet gebonden is aan de aangevoerde argumenten ${ }^{809}$, kan niet voorbij worden gegaan aan het feit dat voor een belanghebbende van belang is hoe het bestuur met zijn bezwaren is omgegaan. Bovendien vindt de heroverweging op grond van artikel 7:11 Awb plaats op grondslag van het bezwaar. Daaruit volgt dat in de bezwaarschriftprocedure individuele rechtsbescherming geboden moet worden. Tussen de aangevoerde bezwaren en het besluit van het bestuur bestaat een verband dat voortvloeit uit het beginsel van hoor en wederhoor. Daaruit bestaat ook de eerder genoemde processuele functie van het motiveringsbeginsel. Uit die processuele functie volgt dat het bestuur zal moeten aangeven om welke redenen de bezwaren van belanghebbenden niet gehonoreerd worden en geen aanleiding geven tot het herroepen of vernietigen van het besluit. Aangenomen moet worden dat een dergelijke reactieplicht eerder wordt aangenomen naarmate meer van een contentieuze rechtsbeschermingsprocedure gesproken kan worden. Omdat de bestuurlijke voorprocedures meer dan de primaire besluitvormingsfase in het teken staan van hoor en wederhoor en rechtsbescherming, ligt een dergelijke reactieplicht op aangevoerde bezwaren (zowel in het bezwaarschrift als tijdens de hoorzitting) meer voor de hand dan bij ingediende zienswijzen in de primaire fase. De mogelijkheid tot indienen van zienswijzen en/of het horen in de primaire besluitvormingsfase staat immers meer in het teken van de zorgvuldige besluitvorming. ${ }^{810}$ In het kader van zorgvuldige besluitvorming is het van belang dat het bestuur via de zienswijzen zoveel mogelijk op de hoogte raakt van alle relevante informatie en ook tot uitdrukking brengt in het besluit welke informatie of belangen genoopt hebben tot het nemen van het besluit. In dat geval is de motivering al voldoende draagkrachtig. Daarvoor is niet vereist dat bij iedere

\footnotetext{
${ }^{808 .}$ Koenraad \& Sanders 2006, p. 141.

${ }^{809 .}$ Koenraad \& Sanders 2006, p. 91. Zie hierover par. 4.3.1.2.

${ }^{810 .}$ Zie o.m.: Damen e.a. 2009, Deel I, p. 344-345.
} 


\section{De inrichting van de voorprocedures}

zienswijze of argument van de belanghebbende burger wordt aangegeven hoe deze is meegewogen in de besluitvorming.

Hoewel ook in dit verband zorgvuldige besluitvorming en rechtsbescherming niet geheel aan elkaar zijn tegengesteld en het om twee verschillende perspectieven gaat, dat van de burger en dat van het bestuur, kan in de verschillende fasen van de besluitvorming wel meer gewicht toekomen aan een van beide perspectieven. Die verschuiving kan gevolgen hebben voor de waarborgen die in acht moeten worden genomen. In bezwaar zou de processuele functie van de motiveringsplicht en het perspectief van de burger door het aannemen van een reactieplicht meer nadruk moeten krijgen. Uiteraard behoort de motivering ook in het kader van zorgvuldige besluitvorming inzicht te bieden in de aan het besluit ten grondslag liggende feiten, de gedachtegang van het bestuur en de meegewogen belangen en omstandigheden. Dat behoort het bestuur op grond van het motiveringsbeginsel echter ook al ambtshalve of op eigen initiatief te doen, ongeacht of er zienswijzen of bezwaren tegen een besluit bestaan. De aan het besluit op bezwaar of administratief beroep ten grondslag gelegde gedachtegang of redenering zal echter uitsluitend draagkrachtig kunnen zijn indien de door de belanghebbende aangevoerde en gemotiveerde argumenten behandeld en indien nodig weerlegd worden. ${ }^{811}$

In de doctrine is nauwelijks aandacht besteed aan het bestaan van een reactieplicht voor het bestuur in de bestuurlijke voorprocedures. Koenraad en Sanders geven aan dat het bestuur bij de motivering van het besluit op bezwaar ook behoort in te gaan op de gronden van het bezwaar zonder dat verder uit te werken. ${ }^{812}$ In de rechtspraak is een reactieplicht ook herhaaldelijk aangenomen door de bestuursrechter, zowel voor als na inwerkingtreding van de Awb. ${ }^{813}$ Niet ingaan op aangevoerde bezwaren in het besluit op bezwaar of het onvoldoende ingaan op de aangevoerde argumenten in bezwaar, wordt in strijd met de motiveringseisen van artikel 7:12 lid 1 geacht. ${ }^{814}$ De Afdeling heeft daarentegen ook weleens overwogen dat het niet uitvoerig ingaan op hetgeen is aangevoerd in bezwaar niet betekent dat daaraan onvoldoende gemotiveerd is voorbijgegaan door het bestuursorgaan. ${ }^{815}$ Daaruit kan echter niet worden afgeleid dat er in het geheel geen reactieplicht bestaat voor het bestuur.

De vraag is hoe ver een dergelijke reactieplicht voor het bestuur in bezwaar reikt of zou moeten reiken. Voor de rechter geldt, onder meer op grond van artikel 6 EVRM, dat deze in zijn uitspraak niet gemotiveerd behoeft in te gaan op alle gronden of argumenten die worden aangevoerd door een belanghebbende. ${ }^{816}$ De bestuursrechter heeft in het kader van de vraag of de motivering van een rechterlijke uitspraak voldoet aan artikel 8:77 Awb herhaaldelijk aangegeven dat daarvoor niet vereist is dat in de uitspraak afzonderlijk wordt ingegaan op elk aangevoerd argument. ${ }^{817}$ Gelet op de functies van de motiveringsplicht (voor de rechter) is het uiteraard wenselijk dat de rechter de belangrijkste stellingen of gronden van een belanghebbende bespreekt in zijn uitspraak. ${ }^{818}$ Meer dan dat is niet vereist en ook niet nodig. De vraag is of voor het bestuur in de bezwaarschriftprocedure en het administratief beroep daarom evenzeer geldt dat het in het besluit niet op alle aangedragen bezwaren behoeft in te gaan en uitsluitend de essentie daarvan behoeft te bespreken. Gelet op de vergelijkbare functies die de motiveringsplicht heeft

\footnotetext{
${ }^{811 .}$ Damen e.a. 2009, Deel I, p. 380-381.

812. Koenraad \& Sanders 2006, p. 131.

813. Zie: Addink, E 7:12-3 waarin verwezen wordt naar CRvB 16 januari 1997, ABkort 1997/192; CBb 21 februari 1996, ABkort 1996/172. Voor de Awb was daar ook al sprake van: ArRvS 26 juli 1985, $A B$ 1986/50 m.nt. JHvdV; ArRvS 21 juli 1987, $A B$ 1987/433 m.nt. Van Buuren; ArRvS 4 januari 1985, $A B$ 1985/457 m.nt. JHvdV. ${ }^{814 .}$ Zie de noot hiervoor.

${ }^{815 .}$ AbRvS 16 juli 1998, $A B$ 1998/375 m.nt. MSV bij $A B$ 1998/376.

${ }^{816 .}$ Zie de noot bij EHRM 22 februari 2007, AB 2007/324 m.nt. Barkhuysen en Schuurmans; Jansen 2006, p. 175 en 177 met verwijzingen naar jurisprudentie; Jansen 2004, p. 67; Schlössels in zijn noot bij EHRM 27 september 2001, NJCM-Bulletin 2002 m.nt. R.J.N. Schlössels, p. 294. Zie verder Deel I, par. 4.3.7.

817. Zie o.m.: CRvB 11 december 2003, JB 2004/88 m.nt. AMLJ; AbRvS 17 oktober 2001, AB 2002/108 m.nt. Sew.

${ }^{818 .}$ Zie par. 4.3.7 van Deel I.
} 
Deel II Bestuurlijke voorprocedures

voor het bestuur in de bestuurlijke voorprocedures, ligt dit in de rede. Voorts doet een beperkte reactieplicht geen afbreuk aan het feit dat de motivering het bestreden besluit moet kunnen dragen. Daarvoor is immers niet vereist dat alle bezwaren behandeld worden in het besluit zelf. Een deugdelijke en draagkrachtige motivering voor de genomen beslissing staat tot op zekere hoogte op zichzelf en daarmee los van de aangevoerde bezwaren. Dat blijkt ook uit de omstandigheid dat een besluit herroepen kan worden vanwege een grond die niet is aangevoerd. ${ }^{819}$ Indien de bezwaren van een belanghebbende echter specifiek gericht zijn op een gebrekkige motivering van het primaire besluit, is er lijkt mij te meer reden om op die bezwaren in het besluit op bezwaar in te gaan.

\section{Wenselijkheid van aanvullende motiveringseisen}

Zoals hierboven aangestipt, dienen aanvullende motiveringseisen gesteld te worden aan de door het bestuur te nemen procesbeslissingen, omdat die van belang kunnen zijn voor de mogelijkheid van belanghebbenden om hun processuele rechten te gelde te maken. Naarmate bepaalde procesbeslissingen meer invloed hebben op de processuele rechten, zou er eerder een motiveringsplicht voor het bestuur moeten bestaan. Thans lijkt het zo te zijn dat er uitsluitend een motiveringsplicht bestaat voor de uitkomst van de procedure het besluit - en het afzien van een kernrecht van de belanghebbenden in de procedure het horen. Daarmee lijkt de motiveringsplicht in bezwaar vooral in het teken te staan van de kwaliteit en zorgvuldigheid van de besluitvorming en in mindere mate in het teken van de rechtsbescherming van belanghebbenden. De functies van het motiveringsbeginsel voor het bestuur (in de bestuurlijke voorprocedures) verschillen echter niet van die van het motiveringsbeginsel voor de rechter. Een functie in het kader van de rechtsbescherming van belanghebbenden wordt nadrukkelijk ook daaraan toegekend. Omdat in algemene zin nauwelijks afzonderlijk aandacht bestaat voor de motiveringseisen in bezwaar en administratief beroep en de bestuurlijke motiveringseisen vooral bezien worden in het licht van de primaire besluitvormingsfase, is er te weinig oog voor het specifieke karakter van de bestuurlijke voorprocedures en de gevolgen die dat zou moeten hebben voor de daaraan te stellen motiveringseisen. Meer oog voor het onderscheid tussen de bestuurlijke voorprocedures en de primaire besluitvormingsprocedure in het kader van de te stellen motiveringseisen, zou meer recht doen aan de processuele belangen van belanghebbenden.

Het ontbreken van aanvullende motiveringseisen doet ook geen recht aan het mogelijke belang van procesbeslissingen - zoals het afzien van het horen van meegebrachte getuigen en deskundigen - voor het uiteindelijke besluit en de rechtspositie van belanghebbenden. Het belang van dergelijke beslissingen is bovendien niet minder groot in (of voor de uitkomst van) de bezwaarschriftprocedure dan in de procedure bij de rechter. Daarom is het opvallend dat een dergelijke motiveringsplicht voor procesbeslissingen genomen door de rechter wél aangenomen wordt op grond van het motiveringsbeginsel. Wat betreft deze motiveringseisen zijn er ook geen belemmeringen om doorwerking van de rechterlijke motiveringseisen in de bezwaarschriftprocedure aan te nemen. Het bestuurlijk karakter van de bezwaarschriftprocedure of de bestuurlijke kenmerken komen daardoor niet in het gedrang. Aangenomen mag worden dat het bestuur op grond van bepaalde inhoudelijke afwegingen en op goede gronden overgaat tot het nemen van dergelijke procesbeslissingen. Het aannemen van aanvullende motiveringseisen zou er uiteindelijk slechts toe leiden dat zulks ook tot uitdrukking wordt gebracht in het besluit zelf, waardoor ook een betere rechterlijke controle achteraf kan plaatsvinden. Niet valt in te zien waarom dat bezwaarlijk zou zijn.

\footnotetext{
${ }^{819 .}$ Zie daarover: Koenraad en Sanders 2006, p. 91.
} 


\section{De inrichting van de voorprocedures}

\subsubsection{Gevolgen van schending van de motiveringseisen}

In het algemeen wordt aangenomen dat het motiveringsbeginsel als algemeen beginsel van behoorlijk bestuur behoort tot de categorie formele beginselen behoorlijk bestuur. ${ }^{820}$ Die kwalificatie is met name van belang vanwege de gevolgen die dit met zich brengt, indien het motiveringsbeginsel geschonden wordt geacht door de rechter. Schending van vormvoorschriften of formele procedurele vereisten die voortvloeien uit de algemene beginselen van behoorlijk bestuur behoeven immers geen diskwalificatie van de inhoud van het besluit in te houden of inachtneming van die vereisten behoeft niet per definitie tot een ander inhoudelijk besluit (in de zin van dictum) te leiden. ${ }^{821}$ Dat laatste kan ook het geval zijn, indien het motiveringsbeginsel is geschonden.

Daarnaast is het zo dat schendingen van vormvoorschriften gepasseerd kunnen worden op grond van artikel 6:22 Awb, indien belanghebbenden daardoor niet benadeeld worden. Dat lijkt met name het geval te zijn wanneer er ondanks het vormgebrek inhoudelijk maar één besluit mogelijk is, in het geval van een gebonden bevoegdheid van het bestuur derhalve. ${ }^{822}$ De wetgever heeft duidelijk aangegeven dat de regels inzake de motivering van besluiten behoren tot de vormvoorschriften. ${ }^{823}$ Daarbij moet echter de kanttekening geplaatst worden dat het motiveringsbeginsel zelf twee aspecten kent zoals hierboven aangegeven: een materieel aspect en een formeel aspect. Uitsluitend dit laatste aspect van het motiveringsbeginsel moet worden gezien als een vormvoorschrift waarvan schending eventueel gepasseerd kan worden. ${ }^{824}$ Ook de wetgever meent dat juist voor schendingen van het formele motiveringsbeginsel artikel 6:22 van belang kan zijn. ${ }^{825}$ Schort het aan de materiële motiveringseisen kan een schending volgens de bestuursrechter niet gepasseerd worden op grond van die bepaling. ${ }^{826}$ Al gebeurt dat een enkele keer toch. ${ }^{827}$ Mogelijk is ook dat gedurende de procedure bij de bestuursrechter blijkt dat het besluit deugdelijk is gemotiveerd, waardoor vernietiging achterwege blijft, mits de belanghebbende heeft kunnen reageren. ${ }^{828}$ Ook schending van de specifieke motiveringsplichten, zoals de eis neergelegd in artikel 7:13, zevende lid, van de Awb, is weleens gepasseerd met toepassing van artikel 6:22 Awb. ${ }^{829}$

Voorts heeft de bestuursrechter ook in dit verband vanzelfsprekend de mogelijkheid om het besluit te vernietigen en de rechtsgevolgen in stand te laten, op grond van artikel 8:72, derde lid, van de Awb. Die mogelijkheid bestaat in elk geval, indien na de vernietiging wegens het motiveringsgebrek nog maar één besluit mogelijk is of het bestuur gedurende de procedure het motiveringsgebrek hersteld heeft. ${ }^{830}$ Deze bevoegdheid kan in bepaalde gevallen wel gebruikt worden ten aanzien van materiële motiveringsgebre-

\footnotetext{
${ }^{820 .}$ Zie bijvoorbeeld: CRvB 13 maart 2009, AB 2009/226. Hierover bestaat overigens wel discussie in de literatuur; Van Wijk/Konijnenbelt \& Van Male 2008, p. 312.

${ }^{821 .}$ Van Wijk/Konijnenbelt \& Van Male 2008, p. 312.

822. Schueler e.a. 2007, p. 66.

823. PG Awb I, p. 314.

824. Damen e.a. 2009, Deel II, p. 251; Schueler e.a. 2007, p. 68; Addink, E 7:12-5; Van Waterschoot 2002, p. 191; Neerhof 1999b, p. 73. Zie bijv.: AbRvS 28 september 2005, JB 2005/323; AbRvS 12 januari 2005, JB 2005/65.

825. PG Awb I, p. 270 en p. 272. Overigens werd zulks opgemerkt in het kader van de motiveringsplicht in de primaire fase en gaf de wetgever aan dat gebreken in de kenbaarheid van de motivering nog hersteld konden worden in bezwaar. Maar voor de gebreken in dat opzicht in het besluit op bezwaar, geldt eveneens dat deze in beroep hersteld kunnen worden, zie ook: Van Waterschoot 2002, p. 191.

826. Zie bijvoorbeeld: AbRvS 1 mei 2000, JB 2000/177 m.nt. ARN; CRvB 26 juni 1998, Rawb 1998/8 m.nt. BdeW. Zie hierover ook: Damen e.a. 2009, Deel II, p. 251; Dingemans 2008, p. 105; Van Waterschoot 2002, p. 190.

${ }^{827 .}$ CBb 20 februari 2001, $A B$ 2001/169 m.nt. JHvdV; AbRvS 25 februari 2000, AB 2002/42 m.nt. Verheij.

828. CBb 1 oktober 1997, $A B$ 1998/81 m.nt. HBr; CRvB 27 juni 1997, AB 1997/377 m.nt. de L.; JB 1997/177 m.nt. R. Seerden. De laatste uitspraak betrof overigens een primair besluit waaraan het motiveringsgebrek kleefde. Zie ook: Neerhof 1999b, p. 76.

${ }^{829}$ AbRvS 2 maart 2005, JB 2005/117; $A B$ 2005/136 m.nt. FM

${ }^{830 .}$ Schueler e.a. 2007 , p. $60-61$.
} 


\section{Deel II Bestuurlijke voorprocedures}

ken. ${ }^{831}$ De afgelopen tijd zijn de mogelijkheden om gebruik te maken van deze bevoegdheid in de jurisprudentie bovendien verruimd vanwege de noodzaak tot finale geschilbeslechting. ${ }^{832}$ In een uitspraak waarin het ging om een gebrek in de draagkracht van de motivering van het besluit op bezwaar, overweegt de Afdeling dat voor het instandlaten van de rechtsgevolgen niet vereist is dat rechtens nog maar één besluit mogelijk is. ${ }^{833}$ Vervolgens bevestigt zij de vernietiging van het besluit wegens strijd met artikel 7:12 Awb door de rechtbank met instandlating van de rechtsgevolgen. Daarnaast kan vernietiging met instandlating van de rechtsgevolgen in de rede liggen bij schending van de specifieke motiveringsplichten, zoals de motiveringseisen in combinatie met het achterwege laten van het horen. ${ }^{834}$ Gelet op het feit dat het horen essentieel is in de bezwaarschriftprocedure is de schending van deze specifieke motiveringseis uit artikel 7:12, eerste lid, van de Awb des te klemmender, waardoor wellicht eerder (dan toepassing van artikel 6:22 Awb) een vernietiging met instandlating van de rechtsgevolgen in de rede ligt, indien blijkt dat terecht is afgezien van het horen.

Tot slot bevatten ook de voorschriften inzake de motivering van besluiten geen bepalingen van openbare orde, waardoor de bestuursrechter niet ambtshalve kan nagaan of aan de motiveringseisen is voldaan. ${ }^{835}$

\subsubsection{Doorwerking van het motiveringsbeginsel in de bestuurlijke voorprocedures}

\section{Voor het bestuur geldende motiveringseisen}

Uit de voorgaande paragrafen blijkt duidelijk dat aan besluit van het bestuur in algemene zin, ongeacht of het gaat om de primaire besluitvormingsfase of de bestuurlijke voorprocedures, dezelfde motiveringseisen worden gesteld. Dat wordt zo vanzelfsprekend geacht, dat er zelfs aan de motiveringseisen voor het besluit op bezwaar of administratief beroep vaak geen afzonderlijke aandacht wordt besteed. Tegelijkertijd verwijst met name de wetgever ook naar de rechterlijke motiveringseisen als het gaat om de motiveringseisen in bezwaar. Bovendien hebben de motiveringseisen voor besluiten in het algemeen en de motiveringseisen voor de rechter dezelfde functies. In de motiveringseisen komen de overeenkomsten tussen de bestuurlijke voorprocedures en de primaire besluitvormingsfasen tot uitdrukking, maar tegelijkertijd de verschillen. Voor de besluitvorming in bezwaar of administratief beroep gelden immers, naast de algemene eisen die voor alle besluiten gelden, specifieke motiveringseisen die samenhangen met het rechtsbeschermingskarakter van die procedure en te vergelijken vallen met motiveringseisen voor de rechter. Zo moet aangenomen worden dat er een reactieplicht bestaat bij de aangevoerde bezwaren van belanghebbenden. In dat opzicht bestaat er ook een overeenkomst met de voor de rechter geldende motiveringseisen. Van expliciete en rechtstreekse doorwerking van de rechterlijke motiveringseisen is echter geen sprake. Dat verband wordt in de doctrine niet gelegd noch in de rechtspraak. Toch lijkt het rechtsbeschermingskarakter van de bestuurlijke voorprocedures en de gelijkenissen met rechtspraak wel ten grondslag te liggen aan de specifieke motiveringseisen die alleen gelden voor besluiten genomen in de bestuurlijke voorprocedures.

Doorwerking gewenst?

Doorwerking van of het van toepassing achten van de rechterlijke motiveringseisen op grond van het motiveringsbeginsel als beginsel van behoorlijke rechtspleging zou wel-

\footnotetext{
831. Zie bijvoorbeeld: AbRvS 12 oktober 2005, JB 2005/328 m.nt. A.M.L.J; AbRvS 10 maart 1997, JB 1997/87 m.nt. R.J.G.H. S. Zie hierover ook: Neerhof 1999b, p. 78 e.v.

832. Zie over deze ontwikkelingen par. 4.3.9 van Deel I.

833. AbRvS 10 juni 2009, $A B$ 2009/369 m.nt. Nijhuis en Den Ouden.

834. CRvB 7 maart 2000, $A B$ 2000/214 m.nt. HBr.

835. CRvB 29 april 2003, $A B$ 2003/307 m.nt. HBr; CRvB 12 november 1997, $A B$ 1998/44; CRvB 8 juli 1997, $A B$ 1997/329 m.nt. FP; $J B$ 1997/179 m.nt. R. Seerden.
} 


\section{De inrichting van de voorprocedures}

licht meer aandacht voor de processuele functie van het motiveringsbeginsel in de bezwaarfase (en de samenhang derhalve met het beginsel van hoor en wederhoor en het rechtsbeschermingskarakter van de bezwaarschriftprocedure) met zich kunnen brengen. Doordat voor de motiveringseisen thans veelal wordt aangesloten bij het algemeen beginsel van behoorlijk bestuur en de motiveringseisen die daaruit in het algemeen voor besluiten, met de nadruk op de primaire besluitvormingsfase, gelden wordt tekort gedaan aan dit aspect van de bezwaarfase en de werking van het motiveringsbeginsel in dit opzicht. De bezwaarfase staat als contentieuze procedure meer in het teken van rechtsbescherming en hoor en wederhoor dan de primaire besluitvormingsfase. De belanghebbende heeft ook meer processuele rechten in die procedure dan in de primaire besluitvormingsprocedure ten aanzien waarvan het bestuur bevoegdheden zijn toegekend. Voor een deel gelden voor deze procesbeslissingen aanvullende motiveringseisen op grond van de Awb, maar voor een deel ook niet. Aangezien het motiveringsbeginsel als algemeen beginsel van behoorlijk bestuur en de motiveringseisen voor het bestuur vooral gericht zijn op de primaire besluitvormingsfase, ontbreekt aandacht voor dit soort aanvullende motiveringeisen of worden deze niet aangenomen ten aanzien van de contentieuze bestuurlijke voorprocedures. De motiveringseisen voor (primaire) besluitvorming zijn thans voornamelijk gericht op de deugdelijkheid en draagkrachtigheid van het besluit en lijken in dat kader vooral samen te hangen met de zorgvuldigheid/kwaliteit van de besluitvorming. Indien echter de bezwaarschriftprocedure (primair) als rechtsbeschermingsprocedure wordt gezien en deze nadrukkelijk ook in het teken staat van hoor en wederhoor en de processuele belangen van de appellerende burger, moeten de vereisten in het kader van de motivering dienaangaande ook daarmee in lijn zijn. Dat geldt te meer indien de procesbeslissingen in de bezwaarfase gevolgen kunnen hebben voor de beroepsprocedure, zoals bijvoorbeeld bij het horen van getuigen of deskundigen. Doorwerking van het beginsel van behoorlijke rechtspleging kan in dat kader een nuttige rol vervullen. Daarin schuilt dan ook meteen de toegevoegde waarde van de doorwerking van het beginsel van behoorlijke rechtspleging in de motiveringseisen voor de bezwaarfase ten opzichte van het algemeen beginsel van behoorlijk bestuur. Daarmee wordt meer uitdrukking gegeven aan hetgeen deze procedures gemeenschappelijk hebben, te weten het bieden van rechtsbescherming, en aan de bijzondere positie van de voorprocedures in het besluitvormingsproces (afgezet tegen de primaire besluitvormingsfase).

\subsection{Tijdigheid in de bestuurlijke voorprocedures}

\subsubsection{Groeiend belang van voortvarende besluitvorming in bezwaar en administratief} beroep

Toenemende aandacht voor tijdige besluitvorming

Ter afsluiting van het onderzoek naar de inrichting van de bezwaarschriftprocedure en het administratief beroep staat in deze paragraaf de tijdigheid van de besluitvorming in deze voorprocedures centraal. De van het bestuur vereiste voortvarendheid vormt bij uitstek een eis waarbij doorwerking van de eisen die aan rechtspleging worden gesteld zou kunnen worden geconstateerd. Aan zowel het bestuur als aan de rechter worden immers eisen gesteld die beogen de tijdigheid van en voortvarendheid in de procedure te waarborgen. Sterker nog, de grondslag voor die eisen is (deels) dezelfde: de redelijke termijn-eis neergelegd in artikel 6 EVRM. ${ }^{836}$

Tijdige besluitvorming door bestuursorganen in primo en in bezwaar vormt op nationaal niveau al een geruime periode een heet hangijzer. Uit verschillende onderzoeken is gebleken dat het bestuur op grote schaal de wettelijke termijnen die gelden voor het

\footnotetext{
${ }^{836 .}$ Hierop kom ik nog nader terug in par. 5.7.2.
} 
Deel II Bestuurlijke voorprocedures

nemen van een besluit (ook in bezwaar) met de voeten treedt. ${ }^{837}$ In de literatuur zijn inmiddels vele publicaties aan deze problematiek gewijd. ${ }^{838}$ Veel aandacht wordt daarin besteed aan de vraag op welke wijze de termijnoverschrijdingen teruggebracht kunnen worden. Daarnaast staat de vraag op welke wijze de rechtsbescherming van belanghebbenden tegen termijnoverschrijdingen effectiever kan worden vormgegeven zeer in de belangstelling. ${ }^{839}$ De groeiende aandacht in het Nederlandse bestuursrecht voor dit onderwerp is ook gerechtvaardigd, aangezien de tijdigheid van besluitvorming (en procedures) een belangrijk element in de behoorlijke rechtsbescherming van belanghebbenden vormt. Dat geldt te meer voor de tijdigheid van de besluitvorming in de voorprocedures, omdat deze procedures de toegang tot de rechter blokkeren. Bij uitblijven van een voortvarende definitieve vaststelling van de rechtspositie van belanghebbenden in het bestuursrecht, is geen sprake van (behoorlijke) rechtsbescherming. Een belanghebbende burger heeft immers niets aan een met alle benodigde waarborgen omklede procedure waarin een besluit aangevochten kan worden, terwijl de uitkomst van die procedure onnodig lang op zich kan laten wachten. Rechtsbescherming wordt illusoir zonder het stellen (en naleven) van tijdigheidseisen. ${ }^{840}$

Tijdige besluitvorming en de Awb

Erkenning van het belang van tijdige besluitvorming (zowel in primo als) in bezwaar heeft ook reeds vanaf aanvang in de Awb plaatsgevonden. In de eerste plaats uiteraard door de vastlegging van beslistermijnen voor het nemen van besluiten alsmede door opneming van bepalingen voor de besluitvorming in primo waaruit volgt dat indien een wettelijke termijn ontbreekt binnen een redelijke termijn een (primair) besluit genomen moet worden. ${ }^{841}$ Ook was in de Awb voorzien in een specifieke voorziening om het bestuur tot (meer) voortvarende besluitvorming te dwingen. Er stond op grond van artikel 6:2 sub b Awb bestuursrechtelijke rechtsbescherming open voor een belanghebbende om het bestuur tot voortvarendheid aan te sporen. Voor niet tijdige besluitvorming in bezwaar bestond de mogelijkheid tot het instellen van beroep bij de bestuursrechter op grond van artikel 6:2 sub b Awb, indien de besluitvorming teveel tijd in beslag neemt en de termijnen die daarvoor staan niet in acht worden genomen. Dit rechtsmiddel vormde een middel om een verdere vertraging na overschrijding van de voorgeschreven beslistermijn te voorkomen. ${ }^{842}$

837. Rapport Algemene Rekenkamer, Waar blijft de tijd?, Kamerstukken II 2003/04, 29 495, nr. 2; Rapport Nationale Ombudsman, Behandeling burgerbrieven. Een tussenbalans, nr. 2005/550; Rapport Nationale Ombudsman, Behandeling burgerbrieven, nr. 2003/325; Kamerstukken II 2000/01, 27 461, nr. 1, p. 2 (Nota Termijnen voor bestuur en rechter); Verslag Evaluatie Awb I, p. 32 en 49; Verslag Evaluatie Awb II, p. 20-21.

838. Zie bijvoorbeeld: N. Verheij, 'Dat schiet niet op. Over wetgeving tegen traag bestuur', in: G.H. Addink, G.T.J.M. Jurgens, Ph. M. Langbroek, R.J.G.M. Widdershoven, Grensverleggend bestuursrecht. Opstellen voor prof.mr. J.B.J.M. ten Berge, Deventer: Kluwer 2008, p. 227 e.v.; Niet tijdig beslissen, Preadviezen voor de Jonge VAR 2006, Den Haag: BJu 2006; R.J. van Dam \& R.J.N. Schlössels, 'Het wetsvoorstel Wet dwangsom bij niet tijdig beslissen', Gst. (2005) 7232, p. 359-363; A.T. Marseille, 'Het niet op tijd beslissende bestuur', $O B$ 2005, p. 9-12; F.G.M. de Laat, 'Die dekselse termijnen!', Gst. (2005) 7238, p. 565-571; R.J. van Dam \& R.J.N. Schlössels, 'Het Voorontwerp en Wet beroep bij niet tijdig beslissen', NJB 2002, p. 2137-2142; A.M.L. Jansen, 'Sloom bestuur onder vuur. Enige beschouwingen over niet tijdige besluitvorming', JB-plus 2003, p.152-169; B.M.J. van der Meulen, 'Vooruit te branden bestuur. Over rechtsbescherming tegen uitblijven van besluiten en een requiem voor de fictieve weigering', JB-plus 1999, p. 15-24; M. Scheltema, 'Het tijdigheidsbeginsel', in R.L. Vucsán (red.), De Awb-mens: boeman of underdog? Opstellen aangeboden aan Leo Damen, Nijmegen: Ars Aequi Libri 1996, p. 241-253.

839. Zie voor de (mogelijke) oorzaken voor termijnoverschrijdingen: M. Vos, Tijdig beslissen: een mission (im)possible?, Preadviezen voor de Jonge VAR 2006, Den Haag: BJu 2006, p. 27-30; Verslag Evaluatie Awb I, p. 49; Verslag Evaluatie Awb II, p. 20.

${ }^{840 .}$ Vgl. De Waard 1987, p. 297.

${ }^{841 .}$ Denk aan art. 4:13 Awb voor de primaire besluitvorming voor zover het beschikkingen betreft.

842. Zie hierover ook: Verheij 2008, p. 229-230. 


\section{De inrichting van de voorprocedures}

Gebleken is echter dat deze voorziening in de praktijk niet effectief werd bevonden en een belanghebbende schoot er niet veel mee op. ${ }^{843}$ De bestuursrechter kon, naast gegrondverklaring van het beroep en het bepalen van een termijn voor het nemen van het besluit, op verzoek daartoe een dwangsom aan de termijn koppelen. ${ }^{844}$ De procedure bij de bestuursrechter op grond van artikel 6:2 sub b Awb nam echter enige tijd in beslag en kon in beginsel slechts leiden tot de constatering dat niet binnen de termijn is beslist alsmede de plicht om binnen een bepaalde termijn alsnog een besluit te nemen (met eventueel oplegging van een dwangsom). ${ }^{845}$ Het materiële besluit waar de belanghebbende op zat te wachten, kreeg deze daardoor (nog steeds) niet. ${ }^{846}$ De bestuursrechter was bovendien huiverig om de aan het bestuur op te leggen beslistermijn te versterken met een dwangsom. Daardoor kwam het regelmatig voor dat belanghebbenden ook na het verstrijken van die termijn weer opnieuw naar de bestuursrechter moesten stappen, hetgeen nog meer tijdverlies tot gevolg had. ${ }^{847}$ Er bestond derhalve nog steeds behoefte aan effectieve(re) maatregelen tegen niet tijdig beslissende bestuursorganen. Op 1 oktober 2009 is dan ook de Wet dwangsom en beroep bij niet tijdig beslissen in werking getreden. ${ }^{848}$ De Wet dwangsom en beroep bij niet tijdig beslissen beoogt een effectiever rechtsmiddel aan de burger te verschaffen tegen niet tijdige besluitvorming door bestuursorganen alsmede een sanctie voor het bestuur te scheppen door het verbeuren van een dwangsom. ${ }^{849}$ Voordat de wet in werking is getreden, zijn de bestaande beslistermijnen nog doorgelicht en aangepast. Deze wet wijziging van Algemene wet bestuursrecht, Wet openbaarheid van bestuur en enkele andere wetten in verband met de inwerkingtreding van de Wet dwangsom en beroep bij niet tijdig beslissen is eveneens in werking getreden op 1 oktober $2009 .{ }^{850}$ Het betrof onder meer een verlenging van de beslistermijn in bezwaar en administratief beroep van tien naar twaalf weken, indien een adviescommissie is ingesteld, als bedoeld in artikel 7:13 en 7:19 Awb. De wijzigingen van de Awb als gevolg van deze wet leiden er voor de bestuurlijke voorprocedures onder meer toe dat, alvorens beroep tegen het niet tijdig beslissen openstaat, eerst een ingebrekestelling aan het bestuur moet worden verzonden. In de paragraaf die betrekking heeft op de ge-

\footnotetext{
843. Zo ook de minister van Binnenlandse zaken en Justitie in hun nota Termijnen voor bestuur en rechter, Kamerstukken II, 2000/01, 27 461, nr. 1, p. 7. Zie ook: Verheij 2008, p. 229-230; Koenraad \& Sanders 2006, p. 146; Saris 2006, p. 63; Kamerstukken II 2005/06, 30 435, nr. 3, p. 2; Marseille 2005, p. 10; Kamerstukken II 2004/05, 29 934, nr. 6 (MvT), p. 1; Van Dam \& Schlössels 2002, p. 2137-2138; Jansen 2003, p. 1756; R.H. de Bock, Commentaar art. 6:2 Awb, in: M. Scheltema, R.M. van Male, B.W.N. de Waard, A.T. Marseille, A.J.C. de Moor-van Vugt (red.), Commentaar op de Algemene wet bestuursrecht, Amsterdam: Reed Elsvier (voorheen Den Haag: VUGA), losbladige uitgave, p. E 6.1.3-7; Verslag Evaluatie Awb II, p. 20-21.

844. Zie over de mogelijke varianten van de verschillende rechtbanken: B.J. van Ettekoven, Alternatieven van de bestuursrechter (observaties vanuit de eerste lijn) (preadvies VAR), Den Haag: BJu 2001, p. 15-16. Overigens is thans in de landelijke procesregeling voor de rechtbanken in art. 23 lid 1 de richtlijn neergelegd dat het beroep wegens niet tijdig beslissen, los van de vraag of daarna wordt beslist om de zaak vereenvoudigd te behandelen ex art. 8:54 Awb, in elk geval versneld behandeld wordt op grond van art. 8:52 Awb. Volgens lid 2 en 3 van die bepaling behandelt de rechtbank de zaak zo mogelijk vereenvoudigd en moet binnen vier weken na ontvangst van de op de zaak betrekking hebbende stukken uitspraak worden gedaan dan wel in andere gevallen moet binnen dertien weken na ontvangst van die stukken uitspraak worden gedaan. Zie art. 23 van de Landelijke procesregeling bestuursrecht, Stcrt. 17 juni 2008, 114 (ook te vinden via www.rechtspraak.nl).

${ }^{845}$ Zie ook: Verheij 2008, p. 229-230; Koenraad \& Sanders 2006, p. 146; Van Ettekoven 2001, p. 15.

846. Zie AbRvS 3 december 1998, JB 1999/13 m.nt. FAMS; AB 1999/107 m.nt. FM. In die uitspraak overweegt de Afdeling dat het beroep op grond van art. 6:2 sub b Awb slechts een procedureel middel is dat beoogt het bestuursorgaan tot besluitvorming te bewegen. Jansen wijst erop dat niet geheel duidelijk is of de CRvB en het $\mathrm{CBb}$ dezelfde lijn volgen, Jansen 2003, p. 155-157. Overigens kan het in sommige gevallen, op grond van de bijzondere wet, zo zijn dat van rechtswege wel degelijk een materieel besluit ontstaat waartegen bezwaar of beroep mogelijk is, zie hierover: A. Weggeman, 'De Awb en de tijdgeest', NTB 2008/4-5, p. 152; Vos 2006, p. 33-64; Saris 2006, p. 75-81.

${ }^{847}$ Saris 2006 , p. 61-62.

${ }^{848 .}$ Wet van 28 augustus 2009, Stb. 2009, 383.

${ }^{849}$ Kamerstukken II 2005/06, nr. 30 435, nr. 3, p. 1 (MvT Wet beroep bij niet tijdig beslissen); Kamerstukken II 2004/05, 29 934, nr. 6, p. 1 (MvT Wet dwangsom bij niet tijdig beslissen).

${ }^{850}$ De Eerste Kamer heeft dit wetsvoorstel aangenomen op 16 juni 2009 en de wet is in werking getreden op 1 oktober 2009, Wet van 18 juni 2009, Stb. 384. Zie ook: Kamerstukken II 2008/09, 31 751, nr. 1-4.
} 
Deel II Bestuurlijke voorprocedures

volgen van termijnoverschrijdingen naar nationaal recht, paragraaf 5.7.5, komen deze wijzigingen nog uitvoeriger aan de orde.

\section{Meer fundamentele betekenis voor tijdige besluitvorming}

Niet alleen was er aandacht voor de gebrekkige effectiviteit van de bestaande voorzieningen, ook de ongelijkwaardigheid of de assymetrie in de verhouding van de burger tot de overheid, waarop onder meer Scheltema heeft gewezen, heeft in de belangstelling gestaan. ${ }^{851}$ Voor de burger gelden immers fatale termijnen waarbij overschrijding onherroepelijk leidt tot niet-ontvankelijkheid en rechtens onaantastbare besluiten, terwijl overschrijdingen door het bestuur in het algemeen niet 'bestraft' worden. ${ }^{852}$ De plicht (en bevoegdheid) tot het nemen van een besluit bestond al en blijft bestaan. ${ }^{853}$ Hierdoor hebben (of beter gezegd hadden) de termijnen veelal het karakter van 'termijnen van orde', zo stelt Scheltema. ${ }^{854}$ Daarmee doelt hij op de omstandigheid dat de bepalingen over termijnen in de literatuur vooral gezien worden als technisch noodzakelijk bepalingen. Er zou een meer principiële betekenis aan deze regels moeten worden toegekend. ${ }^{85}$ De tijd lijkt daar inmiddels rijp voor. De wetgever zelf is daar in het kader van de Awb ook vanuit gegaan. In de toelichting op artikel 4:13 Awb, waaruit volgt dat de besluitvorming in primo binnen de wettelijke termijn of binnen een redelijke termijn dient plaats te vinden, overweegt de wetgever dat termijnstellingen voor besluitvorming niet meer kunnen worden gezien als 'termijnen van orde' waaruit voor het bestuur geen verplichting voortvloeit. ${ }^{856}$ Die overwegingen gelden evenzeer voor de termijnstellingen in de bestuurlijke voorprocedures. De rechtsgevolgen van overschrijding van de termijn treden in na afloop van de termijn en bestaan in het geval van een bestuurlijke voorprocedure (in elk geval) uit de mogelijkheid om, na het verzenden van een ingebrekestelling, beroep in te stellen op grond van artikel 6:2 sub b Awb. ${ }^{857}$ Hoewel de gevolgen van overschrijding van de termijn voor het bestuur minder ernstig zijn dan voor een burger aangezien de bevoegdheid c.q. plicht tot het nemen van het besluit blijft bestaan, kan niet tijdige besluitvorming thans leiden tot het verbeuren van een dwangsom en ook schadeplichtigheid ${ }^{858}$ Meer en meer wordt aangenomen dat het bestuur een rechtsplicht schendt, indien het niet tijdig een besluit neemt en daarmee onrechtmatig handelt. ${ }^{859}$ Datzelfde geldt ook voor de besluitvorming in de bestuurlijke voorprocedures.

\footnotetext{
851. Scheltema 1996, p. 243. Zie recent nog: R.M. van Male, 'Termijnen: het wordt tijd voor differentiatie', NTB 2008/4-5, p. 129; Vos 2006, p. 19.

852. Damen e.a. 2009, Deel I, p. 271; Van Male 2008, p. 129; Vos 2006, p. 19; N.J.A.P.B. Niessen, 'Nationale ombudsman en de Awb', in: E.C.H.J. van der Linden \& F.A.M. Stroink (red.), Jurisprudentie Bestuursrecht Select (JB-Select), Den Haag: Sdu 2004, p. 675.

${ }^{853 .}$ PG Awb I, p. 345 en 311; G.H. Addink, Commentaar art. 7:10, in: M. Scheltema, R.M. van Male, B.W.N. de Waard, A.T. Marseille, A.J.C. de Moor-van Vugt (red.), Commentaar op de Algemene wet bestuursrecht, Amsterdam: Reed Elsvier (voorheen Den Haag: VUGA), losbladige uitgave, p. E 6.3.15-3.

${ }^{854 .}$ Scheltema 1996, p. 243. Zie ook: Van Male 2008, p. 129.

${ }^{855 .}$ Scheltema 1996, p. 242 en 246

856. Overigens lijkt de regering in de nota 'Termijn voor bestuur en rechter' wel nog ervan uit te gaan dat de termijn voor het bestuur termijnen van orde zijn, zie Kamerstukken II 2000/01, 27 461, nr. 1, p. 7. De bestuursrechter overweegt nog weleens dat de termijnen in bezwaar van orde zijn, zie bijv.: CRvB 13 november 2007, $R S V$ 2008/15. Zie ook: R. Stijnen, 'Wet dwangsom en beroep bij niet tijdig beslissen (II), NJB 2010, p. 468.

857. PG Awb I, 263; Vos 2006, p. 20.

${ }^{858 .}$ Vgl. Vos 2006, p. 20.

859. Damen e.a. 2009, Deel I, p. 362; Vos 2006, p. 20; PG Awb I, p. 263. Zie bijvoorbeeld in de jurisprudentie: AbRvS 21 juli 2004, $A B$ 2005/14 m.nt. HBr; CRvB 28 juni 2002, $A B$ 2003/9 m.nt. BJS. Dat de beslistermijn is geschonden en er onrechtmatig is gehandeld, wil overigens niet zeggen dat er ook aansprakelijkheid voor gestelde schade bestaat. Daartoe moet nog aan andere voorwaarden worden voldaan, zie hierover: B.J. van Ettekoven, R.C.S. Bakker en R.P. Hoogenboom, Tien jaar jurisprudentie schadevergoeding in het bestuursrecht, Kluwer: Deventer 2004, p. 133 e.v.
} 


\section{De inrichting van de voorprocedures}

Doorwerking van de redelijke termijn- eis als eis voor behoorlijke rechtspleging

De omstandigheid dat de duur van de bestuurlijke voorprocedures meetelt voor de redelijke termijn is mede de oorzaak voor de toename van het belang van en de aandacht voor voortvarende besluitvorming de afgelopen jaren. Mede onder invloed van deze eis uit artikel 6 EVRM is de eis van tijdige besluitvorming of besluitvorming binnen een redelijke termijn steeds nadrukkelijker aanwezig in rechtspraak en literatuur. ${ }^{860}$

Het redelijke termijn-vereiste vormt het enige vereiste van behoorlijke rechtspleging uit artikel 6 EVRM dat, gelet op de jurisprudentie van het EHRM, rechtstreeks van toepassing is op de bestuurlijke voorprocedures en ook door de nationale bestuursrechters als zodanig daarop wordt toegepast. Over de tijdigheid in de bezwaarschriftprocedure kan derhalve reeds op voorhand, in tegenstelling tot de overige eisen van behoorlijke rechtspleging, gesteld worden dat sprake is van doorwerking van de betreffende eis van behoorlijke rechtspleging in de bestuurlijke voorprocedures. De verklaring daarvoor moet gezocht worden in de connexiteit die bestaat tussen de bestuurlijke voorprocedures en de procedure bij de rechter aangezien de bestuurlijke voorprocedures (indien een verplichting tot het doorlopen daarvan bestaat ${ }^{861}$ ) de toegang tot die procedure bij de rechter beperken. Zouden de bestuurlijke voorprocedures niet binnen een redelijke termijn afgerond moeten worden, dan zou de belanghebbende te lang van een beoordeling van het geschil door de rechter worden afgehouden. De ratio voor de plicht tot geschilbeslechting door de rechter binnen een redelijke termijn verschilt dan ook niet van de ratio voor de plicht van het bestuur tot een tijdige en voortvarende besluitvorming. Zowel voor de plicht voor de rechter als het bestuur is deze primair gelegen in het belang van de burger en de rechtszekerheid omtrent zijn rechtspositie. ${ }^{862}$ De procedure bij de rechter ligt in het verlengde van de bestuurlijke voorprocedure en vertraging in die voorprocedure betekent ook dat de uiteindelijke uitspraak van de rechter langer op zich laat wachten. Omdat de redelijke termijn als neergelegd in artikel 6 EVRM ook de bestuurlijke voorprocedures bestrijkt, kan reeds hier vastgesteld worden dat sprake is van een directe vorm van doorwerking. ${ }^{863}$

Desondanks is nader onderzoek naar de doorwerking van dit vereiste in bestuurlijke voorprocedures gerechtvaardigd en noodzakelijk. Het is van belang vast te stellen in hoeverre het bestuur een rechtsplicht schendt, indien het niet tijdig of voortvarend beslist. Daarnaast is het van belang vast te stellen in hoeverre de tijdigheid van besluitvorming in de bestuurlijke voorprocedures een in het nationale recht verankerde grondslag heeft. Die grondslag dient nader in kaart te worden gebracht. Dat geldt te meer omdat de bestuursrechter aanneemt dat aan artikel 6 EVRM geen aanspraak op schadevergoeding ontleend kan worden wegens te lange duur van de bezwaarfase, indien na die procedure geen beroep wordt ingesteld bij de bestuursrechter. ${ }^{864}$ De vraag of ook los van de redelijke termijn- eis uit artikel 6 EVRM een rechtsbasis bestaat voor voortvarende besluitvor-

\footnotetext{
${ }^{860 .}$ A.P. Klap \& R.J.G.M. Widdershoven, 'Snelheid van rechtspraak als mensenrecht', in: P.M. Langbroek, K. Lahuis, J.B.J.M. ten Berge, Kwaliteit van rechtspraak op de weegschaal, Deventer: W.E.J. Tjeenk Willink ism G.J. Wiarda Instituut 1998, p. 191

861. Hoewel er op grond van art. 7:1a de mogelijkheid tot prorogatie, vormt de bezwaarschriftprocedure nog steeds een algemeen verplichte voorprocedure. Uit de evaluatie van het rechtstreeks beroep is bovendien gebleken dat hoewel die mogelijkheid bestaat de rechter een terughoudende benadering heeft bij de beoordeling of een zaak geschikt is voor prorogatie en om die reden onder meer de bezwaarschriftprocedure niet vaak wordt overgeslagen. Bovendien lijken belanghebbenden daarvan minder dan verwacht gebruik te maken. Dat betekent dat de bezwaarschriftprocedure vooralsnog de facto in de meeste gevallen doorlopen moet worden alvorens de bestuursrechter geadieerd kan worden. Zie par. 1.4.2 hierover.

${ }^{862 .} \mathrm{Vgl}$. Jansen 2000, p. 13. Uiteraard zijn nog meer belangen gediend met voortvarende geschilbeslechting en besluitvorming maar het (ook voor dit onderzoek) primaire belang is toch gelegen in het waarborgen van de rechtszekerheid van de belanghebbende burger. Zie Jansen over de overige belangen of accessoire belangen die gediend worden met de redelijke termijn-eis, Jansen 2000, p. 13. Verder hierover ook par. 4.3.8 in Deel I.

863. Op de verschillende vormen van doorwerking die geconstateerd kunnen worden, wordt in Deel III, par. 2 nader ingegaan.

864. CRvB 29 april 2009, LJN BI2748, JB 2009/152 m.nt. redactie; AbRvS 17 juni 2009, nr. 200901365/2/H2, LJN BI8475.
} 
Deel II Bestuurlijke voorprocedures

ming in de bestuurlijke voorprocedures, is derhalve vanwege deze recente uitspraken van de bestuursrechter zeer relevant. Voorts moet bezien worden of en op welke wijze de redelijke termijn-eis in concreto doorwerkt in de bestuurlijke voorprocedures, doordat met het oog daarop bijvoorbeeld bepaalde inrichtingseisen aan die procedures gesteld worden. Tot slot is nog van belang te onderzoeken welke betekenis artikel 13 EVRM en de eis van effectieve rechtsbescherming tegen overschrijdingen van de redelijke termijn (door het bestuur) in dit kader kan hebben voor de bestuurlijke voorprocedures.

\section{Plan van aanpak}

In paragraaf 5.7.2 wordt de nationale grondslag voor voortvarende besluitvorming nader in kaart gebracht. In die paragraaf wordt ook ingegaan op de vraag of er een afzonderlijk beginsel in het Nederlandse bestuursrecht erkend moet worden waaruit die plicht voortvloeit. In de paragraaf die daarop volgt, paragraaf 5.7.3, worden de inrichtingseisen die thans gesteld worden aan de bestuurlijke voorprocedures in de Awb en jurisprudentie in kaart gebracht. Paragraaf 5.7.4 ziet op de gevolgen die verbonden worden aan schendingen van beslistermijnen en de redelijke termijn door het bestuur. In die paragraaf komt tevens de eis van een effectief rechtsmiddel op grond van artikel 13 EVRM aan de orde en de vraag of er in het Nederlandse bestuursrecht een dergelijk effectief rechtsmiddel bestaat voor overschrijdingen van de redelijke termijn door het bestuur. Ten slotte bevat paragraaf 5.7.5 de conclusies inzake de doorwerking van het beginsel van de redelijke termijn in de bezwaarschriftprocedure en het administratief beroep.

\subsubsection{De grondslagen voor de verplichting tot tijdige besluitvorming}

Verschillende grondslagen voor tijdige besluitvorming in de bestuurlijke voorprocedure Niettegenstaande de problemen die bestaan om tijdige besluitvorming door het bestuur te waarborgen, is onomstreden dat de besluitvorming in bezwaar door bestuursorganen tijdig moet plaatsvinden. Voorop staat thans, zoals hierboven werd aangegeven, dat het bestuur een rechtsplicht schendt, indien niet binnen de wettelijke of een redelijke termijn een besluit wordt genomen. ${ }^{865}$ Voor die rechtsplicht worden echter veelal wisselende grondslagen aangewezen. Allereerst kan er een onderscheid gemaakt worden tussen de nationale grondslagen en de Europese grondslag, in de vorm van artikel 6 EVRM. In de onderhavige paragraaf komt eerst de redelijke termijn-eis uit artikel 6 EVRM aan bod, waarna de nationale grondslag aan de orde komt. Voorts bestaat er een verschil tussen tijdige besluitvorming of voortvarende besluitvorming dan wel besluitvorming binnen een redelijke termijn. Tijdige besluitvorming houdt in besluitvorming binnen de daarvoor gegeven wettelijke beslistermijnen of wettelijke redelijke termijnen, zoals neergelegd in de vangnetbepaling in artikel 4:13 Awb. Daarnaast kan voortvarende besluitvorming of besluitvorming binnen een redelijke termijn (al dan niet in de zin van artikel 6 EVRM) worden onderscheiden. Die redelijke termijn vloeit niet voort uit een wettelijk gegeven beslistermijn. Het onderscheid is niet geheel zonder betekenis. Schending van de plicht tot tijdige besluitvorming van de beslistermijnen betekent bijvoorbeeld nog niet dat ook een redelijke termijn als bedoeld in artikel 6 EVRM overschreden is. Het hangt af van de duur van de vertraging en de omstandigheden van het geval of de niet-tijdige besluitvorming ook moet worden beschouwd als besluitvorming waarmee de redelijke termijn niet in acht is genomen. ${ }^{866}$ In het onderstaande worden de begrippen tijdige en voortvarende besluitvorming door elkaar gebruikt (waarbij het begrip voortvarende besluitvorming beide elementen omvat) en wordt aangegeven wanneer slechts een van beide begrippen bedoeld wordt.

\footnotetext{
865. Zie hierover ook nog met verwijzingen naar jurisprudentie: Van Ettekoven e.a. 2004, p. 133 e.v.

866. Schreuder-Vlasblom 2009, p. 461; Jansen 2000, p. 156. De bestuursrechter heeft dat ook meermalen aangegeven in de juriprudentie, zie bijv.: AbRvS 30 januari 2008, JB 2008/58; CRvB 13 november 2007, RSV $2008 / 15$.
} 


\section{De inrichting van de voorprocedures}

De redelijke termijn en de bestuurlijke voorprocedures

Voor de voortvarendheid van het bestuur in de bestuurlijke voorprocedure zijn niet alleen de door de wetgever gestelde termijnen of andere nationaalrechtelijke normen van belang. Het is thans vooral artikel 6 EVRM dat van normatieve betekenis is, ook voor de tijdigheid van de besluitvorming in de voorprocedures. Het EHRM heeft herhaaldelijk uitgemaakt dat de duur van de bestuurlijke voorprocedures meegeteld dient te worden bij de berekening van de voor de redelijke termijn-eis van artikel 6 EVRM relevante periode. ${ }^{867}$ In het kader van procedures die binnen de reikwijdte van artikel 6 EVRM vallen uit hoofde van de vaststelling van een 'civil right or obligation' is voor het EHRM de start van een geschil bepalend. De aanvang van het geschil wordt in bestuursrechtelijke zaken meestal gelegd bij het moment van indiening van een bezwaar- of beroepschrift. ${ }^{868}$ Voor bestuursrechtelijke procedures die binnen het bereik van artikel 6 EVRM vallen, omdat sprake is van de vaststelling van een 'criminal charge', ligt de start van de relevante periode inzake de redelijke termijn-eis vaak nog op een eerder moment. Dan is het moment waarop jegens de betrokkene een vervolgingshandeling plaatsvindt bepalend. ${ }^{869}$ De bestuurlijke voorprocedures worden dan in elk geval ook bestreken door de redelijke termijn- eis. Uit een Kroatische zaak kan wellicht worden afgeleid dat onder omstandigheden het instellen van een rechtsmiddel (bezwaar of administratief beroep dan wel beroep bij de rechter) tegen het uitblijven van een besluit kan worden aangemerkt als de start van het geschil. In Рос̆uča t. Kroatië wordt het moment waarop beroep bij een ander bestuursorgaan ('administrative authority') wordt ingesteld wegens het uitblijven van een besluit binnen de termijn ('failure to respond') aangemerkt als de start van het geschil. ${ }^{870}$ Of dat betekent dat de redelijke termijn in Nederland ook begint te lopen op het moment dat bezwaar (of in de toekomst beroep) wordt gemaakt tegen het uitblijven van het besluit in primo valt daaruit echter niet eenduidig af te leiden, aangezien het onder Kroatisch recht (blijkens die uitspraak) zo lijkt te zijn dat het beroep wordt behandeld als ware het verzoek afgewezen (een fictieve weigering derhalve). Dat is zoals bekend naar geldend Nederlands recht niet het geval, nu artikel 6:2 sub b Awb volgens de bestuursrechter uitsluitend kan worden gezien als een procedureel middel. ${ }^{871}$ Als een paal boven water staat echter dat de redelijke termijn in elk geval begint te lopen op het moment dat de belanghebbende bezwaar maakt of administratief beroep instelt en het initiatief neemt

\footnotetext{
${ }^{867 .}$ Dat geschiedde al in König t. Duitsland, EHRM 28 juni 1978, NJ 1980/54 en Schouten en Meldrum t. Nederland, EHRM 9 december 1994, JB 1995/49 m.nt. AWH; $A B$ 1995/599 m.nt. ICvdV. Zie ook: Jansen 2000, p. 25 29 met verwijzingen naar jurisprudentie; E.A. Alkema, 'Telt de 'voorfase'mee voor de redelijke termijn?', $N J B$ 1994, p. 602. Recent nog in: EHRM 29 juni 2006, Počuča t. Kroatië, EHRC 2006/106; EHRM 29 juni 2006, Bozič t. Kroatië, nr. 22456/02.

868. EHRM 28 juni 1978, König t. Duitsland, NJ 1980/54 en EHRM 9 december 1994, Schouten en Meldrum t. Nederland, $J B$ 1995/49 m.nt. AWH; $A B$ 1995/599 m.nt. ICvdV. Zie verder: A.M.L. Jansen \& D.W.M. Wenders, 'Unificerende werking van het EVRM via de redelijke termijn. Een kroniek van de redelijke termijn', $N J C M$ Bulletin 2006, p. 1093; Jansen 2000, p. 27-28. De nationale bestuursrechter legt de start van het geschil ook op dat moment: CRvB 3 januari 2008, $A B$ 2008/211 m.nt. AMLJ; AbRvS 12 december 2007, $A B$ 2008/34 m.nt. Alfred van Hall; AbRvS 29 juni 2005, $A B$ 2006/43 m.nt. AMLJ. Soms zelfs nog eerder: CBb 4 december 2007, $A B$ 2007/403 m.nt. Sew. In sommige gevallen zou de start van het geschil ook al eerder kunnen liggen, bijvoorbeeld bij het indienen van zienswijzen in de uniforme openbare voorbereidingsprocedure, zie ook: Barkhuysen \& Van Ettekoven 2009, p. 132; T.J. Poppema, 'De redelijke termijn in het nationale (bestuurs)recht: op naar een wettelijke voorziening!', NTB 2009, p. p. 186.

869. Dat is het moment waarop jegens de betreffende persoon of ondernemening een handeling wordt verricht waaraan deze in redelijkheid de verwachting heeft ontleend, en in redelijkheid ook de verwachting heeft kunnen ontlenen, dat wegens overtreding van de Mededingingswet een boete zal kunnen worden opgelegd. Zie bijv.: CBb 7 juli 2008, AB 2009/177 m.nt. Cartigny. Hierover ook: Barkhuysen \& Van Ettekoven 2009, p. 132; Jansen \& Wenders 2006, p. 1093-1096.

870. EHRM 29 juni 2006, Počuča t. Kroatië, EHRC 2006/106. Zie hierover ook: Jansen \& Wenders 2006, p. 1094.

871. Zo volgt althans uit AbRvS 3 december 1998, JB 1999/13 m.nt. FAMS; AB 1999/107 m.nt. FM (De Gier/Haarlemmermeer). De procesregeling voor de sectoren bestuursrecht van de rechtbanken lijkt dat te bevestigen, zie art. 23 van de Landelijke procesregeling bestuursrecht, Stcrt. 17 juni 2008, 114 (ook te vinden via www.rechtspraak.nl).
} 


\section{Deel II Bestuurlijke voorprocedures}

om het primaire besluit ter discussie te stellen. Een te lange duur van de bezwaarschriftfase bergt derhalve het risico van schending van artikel 6 EVRM in zich. ${ }^{872}$ De reden waarom de redelijke termijn-eis ook geldt voor de bestuurlijke voorprocedures is gelegen in de ratio van deze eis, de rechtszekerheid van de belanghebbende(n) ${ }^{873}$ Door de bestuurlijke voorprocedures wordt een belanghebbende immers van de toegang tot de rechter afgehouden en diens beoordeling over zijn rechtspositie.

Daarnaast tekent zich de afgelopen jaren in de jurisprudentie van het EHRM een ontwikkeling af waarin aan effectieve rechtsbescherming op nationaal niveau tegen schendingen van het EVRM, in het bijzonder de redelijke termijn-eis uit artikel 6 EVRM, steeds meer gewicht wordt toegekend. ${ }^{874}$ Die ontwikkeling is in gang gezet met de uitspraak Kudla t. Polen waarin het EHRM voor het eerst aangaf dat er ingevolge artikel 13 EVRM op nationaal niveau een effectieve voorziening dient te bestaan tegen schendingen van de redelijke termijn. ${ }^{875}$ Hoewel de reden voor die ontwikkeling met name gelegen lijkt te zijn in de almaar groeiende werklast van het EHRM (met name ook in het kader van gestelde schendingen van de redelijke termijn) en het benadrukken van de subsidiaire rol van het EHRM in het kader van de mensenrechtenbescherming ${ }^{876}$, heeft deze tot gevolg dat op nationaal niveau ook steeds meer aandacht komt voor de effectiviteit van de bestaande voorzieningen. Dat geldt ook voor de voorzieningen tegen bestuurlijke overschrijdingen van de redelijke termijn. Ook deze voorzieningen behoren effectief te zijn. Het EHRM overweegt zelf dat in het kader van de redresmogelijkheden op nationaal niveau alle fasen van de procedure - dus ook overschrijdingen van de redelijke termijn door het bestuur - aan de orde moeten komen, wil de voorziening als voldoende effectief in de zin van artikel 13 EVRM kunnen worden aangemerkt. ${ }^{877}$

De redelijke termijn uit artikel 6 EVRM en de eis van een effectief rechtsmiddel tegen overschrijdingen daarvan op grond van artikel 13 EVRM vormen derhalve eisen die, hoewel primair gericht op procedures bij rechterlijke instanties, ook belangrijke gevolgen hebben voor de voortvarendheid van besluitvorming in de bestuurlijke voorprocedures.

\section{Het rechtszekerheidsbeginsel}

De grondslag voor de verplichting voor het bestuur zorg te dragen voor tijdige besluitvorming (in de bezwaarfase en administratief beroep) ligt nationaalrechtelijk beschouwd vanzelfsprekend ook in de rechtszekerheid voor de burger. Aan de gestelde wettelijke beslistermijnen ligt de rechtszekerheid ten grondslag en die termijnen staan ook ten dienste aan de rechtszekerheid voor de direct-belanghebbende en derdebelanghebbenden. ${ }^{878}$ Worden de wettelijke beslistermijnen overschreden, dan schendt het

\footnotetext{
872. Op zichzelf hoeft een te lange duur van de bezwaarschriftprocedure nog geen problemen op te leveren, mits de duur van de daaropvolgende procedures de vertraging compenseren of herstellen door middel van een zeer voortvarende behandeling. Dat hangt samen met de omstandigheid dat het EHRM vooral de totale duur van de procedure beoordeelt. Zie: Jansen \& Wenders 2006, p. 1103-1104.

${ }^{873 .}$ Zie hierover Deel I, par. 4.3.8.

874. Zie hierover nader o.m.: T. Barkhuysen \& M. van Emmerik, 'Schadevergoeding bij schending van de redelijke termijn: op weg naar een effectief rechtsmiddel?’, NJB 2008, p. 1579-1582; Jansen \& Wenders 2006, p. 1108 e.v.; T. Barkhuysen \& A.M.L. Jansen, 'Actuele ontwikkelingen in de redelijke termijn- jurisprudentie: over de Nederlandse termijnoverschrijdingen en ontbrekende nationale rechtsmiddelen', NJCM-Bulletin 2003, p. 586600. In par. 4.3.9 van Deel I ga ik in algemene zin nader in op het beginsel van effectieve rechtsbescherming, waarbij ook de jurisprudentie van het EHRM aan bod komt.

875. EHRM 26 oktober 2000, Kudla t. Polen, EHRC 2000/89 m.nt. Van der Velde; NJCM-Bulletin 2001 m.nt. T. Barkhuysen, p. 71-88, m.nt. T. Barkhuysen; $A B$ 2001/275 m.nt. LV.

${ }^{876}$ Zie hierover: Jansen \& Wenders 2006, p. 1107-1108. Zie ook de noot van Barkhuysen bij Kudla, p. 82 e.v.

877. Bijvoorbeeld: EHRM 29 juni 2006, Počuča t. Kroatië, EHRC 2006/106; EHRM 29 juni 2006, Božić t. Kroatië; EHRM 15 maart 2005, Bako t. Slowakije, BNB 2005/336 m.nt. Feteris bij HR 17 juni 2005, BNB 2005/338.

${ }^{878 .}$ Vos 2006, p. 23; Schlössels 2004, p. 29; M.V.C. Aalders e.a., De burger en de Awb. Ervaringen van de repeatplayers met Awb-procedures (Evaluatieonderzoek Awb I), Den Haag: Bju 2001, p. 71, zij wijzen er overigens op dat redelijke termijn onderdeel uitmaakt van een zich ontwikkelend grondrecht op behoorlijk bestuur, art. 41 Handvest grondrechten EU; Kamerstukken II 2000/01, 27 461, nr. 1, p. 2; Scheltema 1996, p. 244 en 246; PG Awb I, p. 263
} 


\section{De inrichting van de voorprocedures}

bestuur in de eerste plaats de wet en daarmee ook het daaraan ten grondslag liggende rechtszekerheidsbeginsel. Diezelfde rechtszekerheid ligt ten grondslag aan besluitvorming (in bestuurlijke voorprocedures) binnen een redelijke termijn door bestuursorganen. Die rechtszekerheid en het maatschappelijk belang zijn, wellicht nog meer dan bij trage rechtspraak, in het geding bij te trage besluitvorming door bestuursorganen. ${ }^{879}$ De Afdeling heeft recent nog eens geëxpliciteerd dat de redelijke termijn-eis voortkomt uit de notie van rechtszekerheid door in verschillende uitspraken te overwegen, dat in bestuursrechtelijke geschillen die niet door artikel 6 EVRM bestreken worden, de beslechting van een geschil binnen een redelijke termijn voortvloeit uit het algemene rechtszekerheidsbeginsel. Dat beginsel geldt in de nationale rechtsorde en ligt tevens ten grondslag aan artikel 6 EVRM. ${ }^{880}$ De bestuurlijke voorprocedures worden, mits deze opgevolgd worden door een procedure bij de (bestuurs)rechter ${ }^{881}$, ook genormeerd door deze redelijke termijn-eis die terug te voeren valt op het rechtszekerheidsbeginsel. $\mathrm{Zij}$ worden daarvan in elk geval niet expliciet door de bestuursrechter uitgesloten. Op de vraag in hoeverre de redelijke termijn-eis, via het rechtszekerheidsbeginsel, ook geldt of moet gelden voor de bestuurlijke voorprocedures, indien er daarna geen procedure bij de bestuursrechter wordt gestart, kom ik later terug.

Ontwikkeling naar erkenning van een afzonderlijk beginsel

De nationale bestuursrechter erkent derhalve sinds kort dat het algemene rechtszekerheidsbeginsel een zelfstandige - los van artikel 6 EVRM derhalve - grondslag vormt voor beslechting van een geschil binnen een redelijke termijn. De bestuursrechter voert de eis echter terug op het algemene rechtsbeginsel en betrekt het beginsel niet specifiek op de bestuurlijke voorprocedures of het bestuur. In de doctrine daarentegen is de afgelopen jaren een ontwikkeling in de richting van erkenning van een 'eigen' voortvarendheidsbeginsel - al dan niet als onderdeel van het rechtszekerheidsbeginsel - voor de bestuurlijke besluitvormingsfasen te bespeuren. In de nota 'Termijnen voor bestuur en rechter' merkt de regering hierover bijvoorbeeld op dat de besluitvorming binnen redelijke termijn onderdeel uitmaakt van het rechtszekerheidsbeginsel. ${ }^{882}$ Daarnaast wordt steeds vaker ook in de literatuur - in lijn met het groeiend belang dat toegekend wordt aan tijdige besluitvorming - aangenomen dat er een afzonderlijk tijdigheids- of voortvarendheidsbeginsel bestaat waaruit de plicht tot voortvarende besluitvorming voor het bestuur zou volgen. ${ }^{883}$

Een dergelijk afzonderlijk beginsel is echter in het Nederlandse bestuursrecht, in het bijzonder de rechtspraak, vooralsnog niet algemeen aanvaard. Nicolaï wijst in zijn dissertatie op een uitspraak van de president van de rechtbank Den Haag (civiel) van 1 juli 1980 waarin deze een 'in het algemeen bewustzijn levend beginsel van behoorlijk bestuur, dat een tot het nemen van een beslissing bevoegde instantie binnen een redelijke termijn beslist op ingediende verzoeken waarbij een burger belang heeft' onderscheidt. ${ }^{884}$ Maar een dergelijk beginsel van behoorlijk bestuur heeft sindsdien in de jurisprudentie geen vaste voet aan de grond gekregen. Nicolaï meent ook dat aan een afzonderlijk beginsel van behoorlijk bestuur dat besluitvorming binnen een redelijke termijn behoort plaats te vinden geen behoefte bestaat, omdat overtreding van deze norm betekent dat sprake is van een onbehoorlijke beslissingsprocedure. Dat is een beginsel van behoorlijk

\footnotetext{
${ }^{879 .}$ Vgl. N. Verheij, 'The need for speed', NTB 2009, p. 109-110.

880. Zie o.m.: AbRvS 3 december 2008, AB 2009/70 m.nt Barkhuysen en Van Emmerik, JB 2009/13; AbRvS 4 maart 2009 JB 2009/82 m.nt. Red; AbRvS 20 mei 2009, JB 2009/167 m.nt. red.

${ }^{881 .}$ CRvB 29 april 2009, JB 2009/152 m.nt. redactie; AbRvS 17 juni 2009, 200901365/2/H2, LJN BI8475.

882. Kamerstukken II 2000/01, nr. 27 461, nr. 1, p. 2.

883. Zie bv.: H.S.M. Kruijer, 'Belastingheffing moet tijdig, binnen een redelijke termijn, plaatsvinden', $W F R$ 2006/888, p. 889 e.v.; Scheltema 1996, p. 246.

${ }^{884 .}$ Nicolaï 1990, p. 338 en p. 134. Het gaat om de uitspraak: Pres. Rb. Den Haag 1 juli 1981, NJ 1982/118. Kanttekening hierbij is overigens dat het een primair besluit bestrof.
} 


\section{Deel II Bestuurlijke voorprocedures}

bestuur dat hij wel onderscheidt. ${ }^{885}$ Hij geeft voorts aan dat algemeen aanvaard is dat het bestuur, indien geen wettelijke beslistermijn is gegeven, binnen een redelijke termijn behoort te beslissen. ${ }^{886}$ Een expliciete en brede erkenning van een zodanig afzonderlijk beginsel heeft in de doctrine nimmer plaatsgevonden. Scheltema is de eerste die een dergelijk beginsel propageert. Hij ziet het beginsel van tijdige besluitvorming - het tijdigheidsbeginsel - echter nog als onderdeel van het rechtszekerheidsbeginsel. ${ }^{887}$ Hij pleit voor meer erkenning van dat uitgangspunt in het bestuursrecht zodat er ook meer fundamentele betekenis toegekend wordt aan regels over het tijdstip waarop beslissingen worden genomen. Deze regels dienen een belangrijke rol te spelen bij het waarborgen van de positie van de burger ten opzichte van het bestuur. ${ }^{888}$ Het door Scheltema beoogde tijdigheidsbeginsel lijkt voornamelijk te zien op de norm dat besluiten binnen de wettelijke termijnen genomen dienen te worden en niet zozeer dat besluitvorming voortvarend behoort te zijn of binnen een redelijke termijn (als bedoeld in artikel 6 EVRM) behoort plaats te vinden. De benadering van Scheltema heeft in de literatuur bij verschillende andere auteurs navolging gevonden. Widdershoven stelt bijvoorbeeld dat het beginsel van de redelijke termijn onderdeel uitmaakt van het rechtszekerheidsbeginsel (en het ongeschreven Nederlandse recht) en als zodanig zou moeten gelden buiten de reikwijdte van artikel 6 EVRM. $^{889}$ In zijn optiek lijken het beginsel van de redelijke termijn en het tijdigheidsbeginsel samen te vallen. ${ }^{890}$ Ook Schlössels meent dat het algemene rechtszekerheidsbeginsel (als een van de rechtsbeginselen die de democratische rechtsstaat constitueren) verschillende uitwerkingen kent, onder meer in het tijdigheidsbeginsel. ${ }^{891}$ Schlössels heeft echter met name het door Scheltema bedoelde tijdigheidsbeginsel op het oog. Een enkele maal wordt het tijdigheids- of voortvarendheidsbeginsel ook beschouwd als een (op zichzelf staand) fundamenteel rechtsbeginsel. Zo heeft Kruijer er in het belastingrecht op gewezen dat de plicht tot tijdige besluitvorming (in bezwaar) voortvloeit uit het voortvarendheidsbeginsel, een van de fundamentele rechtsbeginselen die in een democratische rechtsstaat als rechtsnorm gelden, en welk beginsel ten dele in artikel 6 EVRM en de Awb is gecodificeerd. ${ }^{82}$ Geheel eenduidig is hij echter niet, want even later bestempelt hij dit beginsel weer als beginsel van behoorlijk bestuur dat ook in verband wordt gebracht met de rechtszekerheid. ${ }^{893}$ Voorlopig lijkt een beginsel dat de vaststelling van de rechtspositie van de burger tijdig (dat wil zeggen binnen de wettelijke beslistermijn) dan wel binnen een redelijke termijn moet plaatsvinden nationaalrechtelijk derhalve nog gezien te worden als onderdeel van het rechtszekerheidsbeginsel en niet als afzonderlijk beginsel van behoorlijk bestuur. ${ }^{894}$

\section{Het zorgvuldigheidsbeginsel}

Er wordt soms echter, naast het rechtszekerheidsbeginsel, nog een andere grondslag aangewezen. Sommige auteurs beschouwen de algemene beginselen van behoorlijk bestuur als bron waaruit een verplichting tot voortvarende besluitvorming zou voort-

\footnotetext{
${ }^{885 .}$ Nicolaï 1990, p. 338. Nicolaï geeft overigens later ook aan dat de eis dat binnen een redelijke termijn op een verzoek wordt beslist ook onder te brengen valt bij het rechtszekerheidsbeginsel, Nicolaï 1990, p. 453.

${ }^{886 .}$ Nicolaï 1990 , p. 339

887. Scheltema 1996, p. 246.

${ }^{888 .}$ Scheltema 1996, p. 246.

889. R.J.G.M. Widdershoven, 'Tijdigheid in het bestuursprocesrecht', in: G.R. Rutgers \& H.E. Bröring (red.), Rechtspraak op tijd, Den Haag: Bju 1999, p. 76-77. Daarbij heeft hij overigens wel het oog op rechtspraak en niet zozeer besluitvorming door het bestuur.

${ }^{890}$. Zo ook bij Bosch-Boesjes, die zich op het standpunt lijkt te stellen dat het tijdigheidbeginsel zowel uit het rechtszekerheidsbeginsel als de redelijke termijn van art. 6 EVRM valt af te leiden, J.E. Bosch-Boesjes 'Tijdigheid in het geding: enige beschouwingen over de bestuursrechter en de redelijke termijn, in: M. Herweijer, K.F. Schuiling en H.B. Winter (red.), In wederkerigheid (Scheltema-bundel), Deventer: Kluwer 1997, p. 258-259.

${ }^{891 .}$ Schlössels 2004, p. 29.

892. Kruijer 2006, p. 889 en 891.

${ }^{893 .}$ Kruijer 2006, p. 898

894. Zo ook Van der Meulen die wijst op die ontwikkeling, Van der Meulen 1999, p. 16.
} 


\section{De inrichting van de voorprocedures}

vloeien. Het vereiste van besluitvorming binnen een redelijke termijn wordt dan meer in het bijzonder gebaseerd op het zorgvuldigheidsbeginsel ${ }^{895}$ Vos stelt bijvoorbeeld dat in het Nederlandse bestuursrecht niet zoiets bestaat als het tijdigheidsbeginsel. Een dergelijk beginsel zou in haar ogen in het in artikel 3:2 Awb neergelegde zorgvuldigheidsbeginsel kunnen worden gelezen. ${ }^{896}$ Overschrijding van termijnen heeft schending van dit algemeen beginsel van behoorlijk bestuur tot gevolg. Ook Jansen merkt op dat de plicht tot tijdige besluitvorming voor bestuursorganen voortvloeit uit het zorgvuldigheidsbeginsel (alsmede de wettelijke termijnen) ${ }^{897}$ Hij baseert zich daarvoor op een uitspraak van 4 juni 2002 van de Centrale Raad waarin deze aangeeft dat het vereiste van een redelijke beslistermijn (voor gevallen waarin een wettelijke beslistermijn ontbreekt en artikel 4:13 Awb niet geldt) besloten ligt in het zorgvuldigheidsbeginsel, zoals neergelegd in artikel 3:2 Awb (alsook de redelijke termijn-eis uit artikel 6 EVRM) ${ }^{898}$ Deze uitspraak is, met uitzondering van de recente uitspraken (die hierna nog aan de orde komen) waarin het algemene rechtszekerheidsbeginsel als rechtsbasis wordt aangewezen, een van de weinige uitspraken waarin de bestuursrechter zich expliciet uitlaat over een nationale (ongeschreven) grondslag voor besluitvorming binnen een redelijke termijn. Kanttekening hierbij is dat deze uitspraak op een redelijke beslistermijn voor een besluit in primo ziet. Een expliciete verwijzing naar een van oorsprong nationaal tijdigheids- of voortvarendheidsbeginsel voor het bestuur heeft in recente rechtspraak in elk geval niet plaatsgevonden. Uitsluitend het algemene rechtszekerheidsbeginsel is, zoals hierboven aangegeven, als rechtsbasis in recente rechtspraak gehanteerd.

In mijn optiek zou - voor zover niet een andere grondslag meer aangewezen zou zijn - eerder het algemene ongeschreven zorgvuldigheidsbeginsel als grondslag voor een redelijke beslistermijn aangewezen zijn en niet het door Vos geopperde artikel 3:2 Awb. Die bepaling codificeert immers slechts één aspect van dat beginsel, de kennisvergaringsplicht. ${ }^{899}$ De redelijke beslistermijn valt niet goed te herleiden tot die kennisvergaringsplicht. De Centrale Raad vat de norm, die in artikel 3:2 Awb is neergelegd, in deze uitspraak ten onrechte te ruim op. ${ }^{900}$

Meervoudige grondslagen in de rechtspraak

Hoewel een voortvarendheidsbeginsel, als beginsel van behoorlijk bestuur, door de bestuursrechter niet is erkend, vallen er in de jurisprudentie ontwikkelingen aan te wijzen die duiden op de mogelijkheid van meer of verschillende grondslagen voor de redelijke termijn-eis. Daarbij wordt geen onderscheid wordt gemaakt tussen rechtspraak en (bestuurlijke) voorfasen. Uit een uitspraak van 22 april 2005 waarin de belastingkamer van de Hoge Raad vuistregels formuleert inzake de redelijke termijn kan voorzichtig worden afgeleid dat de belastingrechter niet afwijzend staat tegenover een dergelijke meervoudige grondslag. ${ }^{901}$ Jansen wijst er in dat kader op dat de Hoge Raad in overweging 4.1. overweegt:

\footnotetext{
${ }^{895 .}$ Niessen 2004, p. 675; A.M.L. Jansen, 'Formele rechtskracht na stilzitten: de CRvB als leading judge', $N J B$ 2003/33, p. 1755; De Bock, p. E 6.1.3-8; allen onder verwijzing naar CRvB 4 juni 2002, JB 2002/281. Verder nog: Vos 2006, p. 25; Saris 2006, p. 56-57; P. Nicolaï, 'Kroniek Algemene beginselen van behoorlijk bestuur', NTB 1994/6, p. $183-184$.

896. Vos 2006, p. 25.

897. Jansen 2003, p. 1755.

898. CRvB 4 juni 2002, JB 2002/281. Datzelfde doen Niessen en De Bock op grond van deze uitspraak, Niessen 2004, p. 675; De Bock, p. E 6.1.3-8

${ }^{899 .}$ R.J.N. Schlössels, 'Kroniek Beginselen van behoorlijk bestuur', NTB 2007, p. 225; Addink1999, p. 188 e.v.

${ }^{900 .}$ Zo ook: Schlössels 2007, p. 225.

901. HR 22 april 2005, $A B$ 2006/11 m.nt. AMLJ; JB 2005/166 m.nt. Wenders; BNB 2005/337 met noot Feteris onder $B N B$ 2005/338. De HR lijkt met deze uitspraak de strafkamer te volgen die al eerder uit leek te gaan van een meervoudige grondslag in het kader van de beoordeling van de redelijke termijn, waarbij niet alleen artikel 6 EVRM de leidraad vormt, zie: HR 3 oktober 2000, NJ 2000/721 m.nt. JdH. Vgl. A.M.L. Jansen, 'Tijdige rechtspraak en de rol van de Hoge Raad', WFR 2005/183, p. 1583-1588; A. Den Hartog, 'De Hoge Raad en de redelijke termijn: meerduidige grondslag leidt tot rigide regelgeving', RMThemis 2001/4, p. 101. Onlangs heeft de
} 
Deel II Bestuurlijke voorprocedures

"Het middel bevat een klacht aangaande hetgeen het Hof heeft beslist op het punt van de overschrijding van de redelijke termijn als bedoeld in onder meer artikel 6, lid 1, EVRM., ${ }^{902}$

In de overwegingen die volgen refereert de Hoge Raad echter uitsluitend aan artikel 6, lid 1 EVRM waardoor het nog in het midden blijft of ook voor belastingzaken een meervoudige grondslag geldt. Het standpunt van de Hoge Raad als hoogste belastingrechter en bijzondere bestuursrechter is ook voor het overig bestuursrecht van belang. Omdat belastingzaken vanwege hun typisch publiekrechtelijk karakter buiten de werking van artikel 6 EVRM en de redelijke termijn-eis ${ }^{903}$ vallen (voor zover het niet gaat om een criminal charge), moet deze redelijke termijn-eis op een andere grondslag gebaseerd worden om geldingskracht te hebben voor deze geschillen. Voor die geschillen kan mijns inziens moeilijk worden volgehouden dat de eisen voor behoorlijke rechtspraak en in het bijzonder de redelijke termijn-eis niet behoren te gelden. Ook in reguliere belastingzaken dient het bestuur voortvarend te besluiten. ${ }^{904}$ Vooralsnog heeft de Hoge Raad echter niet expliciet overwogen dat de redelijke termijn-eis eveneens in reguliere belastinggeschillen die buiten de werking van artikel 6 EVRM vallen geldt op basis van een andere grondslag.

De overige bestuursrechters zijn altijd terughoudend geweest in het aannemen van een meervoudige grondslag of andere (dan op artikel 6 EVRM gebaseerde) grondslag voor de plicht tot voortvarende rechtspraak. De Centrale Raad heeft in ambtenaarrechtelijke geschillen overwogen dat artikel 6 EVRM niet van toepassing is en om die reden ook het redelijke termijn-vereiste niet alsmede andere uit die bepaling voortvloeiende eisen. ${ }^{905}$ Hoewel die benadering van de Centrale Raad in ambtenaarrechtelijke geschillen, gelet op de uitspraak van het EHRM in de zaak Vilho Eskelinen e.a., al niet meer houdbaar was ${ }^{906}$, lijkt deze nog verder achterhaald door de recente jurisprudentie van de Afdeling waarin het rechtszekerheidsbeginsel als rechtsbasis is aangewezen. ${ }^{907}$ In deze uitspraken geldt de redelijke termijn-eis, gebaseerd op het rechtszekerheidsbeginsel, ook voor de bestuurlijke voorprocedures. De eerste uitspraak betrof een vreemdelingrechtelijk geschil, waardoor de redelijke termijn-eis, zoals onder meer neergelegd in artikel 6 EVRM, ook op die geschillen van toepassing is in de toekomst. De Afdeling overwoog voorheen altijd in die geschillen dat artikel 6 EVRM niet van toepassing was en daarmee het beroep op de daaruit voortvloeiende eisen, zoals de redelijke termijn-eis, niet kon slagen. ${ }^{908}$ De recente uitspraken zijn een vervolg op een eerdere uitspraak waarin de

HR zijn jurisprudentie weer iets aangepast, HR 17 juni 2008, $N J$ 2008/358 m.nt. P.A.M. Mevis; $A B$ 2009/231 m.nt. AMLJ. Die laatste uitspraak heeft de belastingkamer van HR weer gevolgd in HR 19 december 2008, $A B$ 2009/230 m.nt. Jansen.

902. Jansen 2005, p. 1588.

${ }^{903 .}$ EHRM 21 juli 2001, Ferrazzini t. Italië, EHRC 2001/57 m.nt. Heringa; AB 2004/400 m.nt. TB.

904. Vgl. Kruijer 2006, p. 898.

905. Zie bijvoorbeeld: CRvB 7 oktober 2004, JB 2004/380 m.nt. Overkleeft-Verburg; CRvB 11 december 2003 , $J B$ 2004/88 m.nt AMLJ. Overigens gold art. 6 EVRM in Nederland al voor ambtenaarrechtelijke geschillen sinds de Grote Kamer-uitspraak van het EHRM in de zaak Vilho Eskelinen e.a. t. Finland, (EHRM 19 april 2007, EHRC 2006/82 m.nt. Geurink; $A B$ 2007/317 m.nt. Barkhuysen en Van Emmerik; NJ 2007/375 m.nt. Alkema; NJCM-Bulletin 2007, p. 697 e.v m.nt. Van Dijk; JB 2007/98), omdat er nationaalrechtelijk een recht op toegang tot de bestuursrechter bestaat en dat betekent dat artikel 6 EVRM in beginsel van toepassing is. Zie voor een toepassing van deze eerste voorwaarde uit Vilho Eskelinen e.a. de uitspraak van het EHRM van 31 juli 2007 in de zaak Rizhamadze t. Georgië, EHRC 2007/110; voor een toepassing van de tweede voorwaarde: EHRM 11 september 2007, nr. 59773/00, Sükut t. Turkije, EHRC 2008/16 (ontv. besl.).

906. Zie de noot hiervoor en par. 4.1 van Deel I. De toepasselijkheid van art. 6 EVRM in ambtenaarrechtelijke geschillen op grond van Vilho Eskelinen e.a. is ook al in de jurisprudentie van de CRvB aan de orde gekomen, zie bijv.: CRvB 7 november 2007, TAR 2008/14.

907. AbRvS 3 december 2008, AB 2009/70 m.nt. Barkhuysen en Van Emmerik; JB 2009/13; AbRvS 4 maart 2009, $J B$ 2009/82 m.nt. red.; $A B$ 2009/236 m.nt. Barkhuysen \& Den Ouden; AbRvS 17 april 2009, nr. $200806348 / 1$.

908. Rb. Den Haag, zittingplaats Haarlem, 10 januari 2008, JV 2008/217; AbRvS 25 maart 2003, JV 2003/191 m.nt. PB. De Afdeling verwees daartoe naar de uitspraak van het EHRM in de zaak Maaouia waaruit volgde dat 


\section{De inrichting van de voorprocedures}

Afdeling in een vreemdelingrechtelijke zaak de redelijke termijn- eis van toepassing leek te verklaren. ${ }^{909}$ Zoals Daalder en Van Heukelom naar aanleiding daarvan opmerken, viel daarvoor ook veel te zeggen, maar ontbrak in de uitspraak daarvoor een (expliciete) deugdelijke rechtsbasis. ${ }^{910}$ Die rechtsbasis zou in elk geval ontleend moeten worden aan het nationale recht. ${ }^{911}$ Dat is in de recente uitspraken dan ook gebeurd, in de vorm van het algemene rechtszekerheidsbeginsel dat mede ten grondslag ligt aan artikel 6 EVRM. Opvallend is dat de rechtsbasis volgens de Afdeling niet bestaat uit het nationale beginsel van behoorlijke rechtspleging waarvan de redelijke termijn-eis onderdeel uitmaakt, het decisiebeginsel. ${ }^{912}$

De toekomst moet uitwijzen of de Centrale Raad, het $\mathrm{CBb}$ en de Hoge Raad de uitspraken van de Afdeling zullen volgen, maar dat ligt wel in de rede. ${ }^{913}$ Dat zou betekenen dat voor het gehele bestuursrecht, en ook voor reguliere belastingzaken, het algemene rechtszekerheidsbeginsel als rechtsbasis voor de toepasselijkheid van het vereiste van de redelijke termijn zal dienen. Gelet op de eerdere jurisprudentie van de Hoge Raad staat deze waarschijnlijk niet afwijzend tegenover een dergelijke meervoudige grondslag. Bovendien proberen de overige bestuursrechtelijke rechtscolleges, vanuit rechtseenheidoogpunt, hun jurisprudentie zo veel mogelijk op elkaar af te stemmen. Aangenomen kan derhalve worden dat het algeme rechtszekerheidsbeginsel de nationale grondslag, naast artikel 6 EVRM, zal gaan vormen voor de toepasselijkheid van de redelijke termijn-eis in alle bestuursrechtelijke geschillen.

\subsubsection{Besluitvorming binnen een redelijke termijn als een afzonderlijk beginsel}

\section{Erkenning van een afzonderlijk beginsel}

Uit de vorige paragraaf is gebleken dat de bestuursrechter thans voor bestuursrechtelijke geschillen het algemene rechtszekerheidsbeginsel hanteert teneinde een redelijke termijn-eis te formuleren die ook geldt voor geschillen die buiten de reikwijdte van artikel 6 EVRM vallen. Die eis strekt zich in beginsel ook uit tot de bestuurlijke voorprocedures. Bovendien worden in de doctrine ook eisen voor tijdige of voortvarende besluitvorming afgeleid uit het zorgvuldigheidsbeginsel, als norm voor het bestuur. Daarnaast zijn er echter in de doctrine, hoewel nog geen eenduidige erkenning van een afzonderlijk beginsel voor het bestuur heeft plaatsgevonden, aanknopingspunten te vinden die duiden op een ontwikkeling in die richting. De ontwikkelingen ten aanzien van de redelijke termijneis en voortvarende besluitvorming door het bestuur lijken derhalve plaats te vinden langs twee sporen. Enerzijds is er een spoor in de rechtspraak waarbij de ontwikkeling via de band van het algemene rechtszekerheidsbeginsel vorm krijgt. En anderzijds is er in de doctrine, voordat deze rechtspraak gewezen werd, een ontwikkeling te bespeuren

art. 6 EVRM niet van toepassing is op geschillen inzake de uitzetting en toelating van vreemdelingen, EHRM 5 oktober 2000, Maaouia t. Frankrijk, AB 2001/ 80 m.nt. Battjes; NJCM-Bulletin 2001, p. 762 e.v. m.nt. Kuijer; NJ 2002/424; EHRC 2000/ 84 m.nt. Heringa; JV 200/264 m.nt. Boeles.

909. AbRvS 20 juni 2007, JV 2007/348 m.nt. bij JV 2007/322 van HBA; AB 2008/336 m.nt. AMLJ. De rechtbank Den Haag heeft de hiervoor genoemde uitspraak van de Afdeling gevolgd en aangegeven dat de plicht tot het beslissen binnen een redelijke termijn in vreemdelingrechtelijke zaken weliswaar niet volgt uit artikel 6 EVRM, maar wel uit artikel 4:13 Awb, Rb. Den Haag, nevenzittingsplaats A'dam, 10 september 2008, $A B$ 2008/337 m.nt. AMLJ. Volgens de rechtbank zijn ook de in het kader van artikel 6 EVRM ontwikkelde jurisprudentie en de daarin tot uitdrukking komende criteria van belang. Zoals Jansen ook opmerkt in zijn noot bij die uitspraak lijkt artikel 4:13 Awb niet de juiste grondslag te zijn voor de plicht tot besluitvorming binnen een redelijke termijn in de bezwaarfase; de redelijke termijn als bedoeld in artikel 4:13 Awb ziet op de primaire besluitvormingsfase. Volgens hem zou de rechtsbasis eerder in de ongeschreven beginselen van behoorlijke rechtspleging kunnen liggen

${ }^{910 .}$ E. Daalder \& S. van Heukelom-Verhage, Kroniek van het algemeen bestuursrecht, NJB 2007/35, p. 2196.

911. Zo ook Daalder en Van Heukelom-Verhage die aangeven dat de verwijzing naar rechtspraak van het EHRM door de Afdeling in elk geval niet voldoet.

912. Zo ook Jansen in zijn commentaar bij de uitspraak van de Rb. Den Haag, nevenzittingsplaats A'dam, 10 september 2008, $A B$ 2008/337 m.nt. AMLJ.

913. Vgl. Barkhuysen \& Van Ettekoven 2009, p. 133. 


\section{Deel II Bestuurlijke voorprocedures}

naar erkenning van een afzonderlijk beginsel van behoorlijk bestuur (al dan niet als specificatie van het algemenere rechtszekerheidsbeginsel). De vraag rijst of aan een afzonderlijke grondslag voor het bestuur, in de vorm van een voortvarendheids- of tijdigheidsbeginsel, nog wel behoefte bestaat nu het algemene rechtszekerheidsbeginsel en het zorgvuldigheidsbeginsel daarvoor al dienst doen. Voor een bevestigend antwoord op die vraag zijn goede gronden aan te voeren.

\section{De aard van de redelijke termijn-eis}

Allereerst voldoet het bestaande en erkende (formele) zorgvuldigheidsbeginsel als grondslag niet. Ofschoon er op het eerste gezicht zoals Vos aangeeft geen overwegende bezwaren lijken te bestaan tegen het besloten liggen van de eis van tijdige besluitvorming in het zorgvuldigheidsbeginsel ${ }^{914}$, heeft het inlezen van het tijdigheidsbeginsel in het algemene zorgvuldigheidsbeginsel bij nadere beschouwing enkele belangrijke nadelen. Vooropgesteld zij dat artikel 3:2 Awb, als codificatie van het kennisvergaringsaspect van het zorgvuldigheidsbeginsel, zich allereerst niet leent als grondslag voor de eis van besluitvorming binnen een redelijke termijn. Het onderbrengen van de eisen van voortvarende besluitvorming bij het ongeschreven zorgvuldigheidbeginsel komt voorts het onderscheidend vermogen van dat beginsel niet ten goede. In de praktijk wordt reeds voor veel procedurele eisen die niet specifiek aan een ander beginsel van behoorlijk bestuur gekoppeld kunnen worden het zorgvuldigheidsbeginsel aangewezen als grondslag. Het zorgvuldigheidsbeginsel kan als algemene notie eenvoudig aangegrepen worden als kapstok om (vrijwel alle) eisen van een behoorlijke procedure aan op te hangen. Uiteraard handelt het bestuur ook onzorgvuldig, indien niet binnen de wettelijke termijn of een redelijke termijn een besluit genomen wordt. Tijdigheidseisen betreffen echter specifieke eisen die duidelijk onderscheiden kunnen worden van de overige zorgvuldigheidseisen die gesteld (kunnen) worden aan de totstandkoming van een besluit. Te denken valt aan het vergaren van voldoende informatie over de relevante feiten of af te wegen belangen door bijvoorbeeld het doen van onderzoek, het horen van belanghebbenden of het vragen van advies aan deskundigen. ${ }^{915}$ Door de plicht tot tijdige besluitvorming te baseren op een afzonderlijk voortvarendheidsbeginsel (zoals dat ook voor rechterlijk handelen wordt aangenomen) waarbij miskenning van die plicht leidt tot schending van dat beginsel, wordt duidelijker tot uitdrukking gebracht waar de fout van het bestuur exact in gelegen is en waarin het belang van naleving schuilt. Daarvoor pleit te meer dat de overige zorgvuldigheideisen eerder een de procedure verlengende werking zullen hebben, terwijl de tijdigheidseisen nu juist beogen de procedure voortvarend(er) te laten verlopen. Er bestaat een spanningsveld tussen tijdigheid en zorgvuldigheid. Daarenboven wordt het fundamentele karakter van de termijnen en het belang van naleving van die termijnen of een redelijke beslistermijn meer benadrukt door erkenning van een afzonderlijk beginsel.

Het zorgvuldigheidsbeginsel is om genoemde redenen derhalve geen voor de hand liggende keuze. Eerder nog zou - gelet op de hiervoor genoemde ratio achter de wettelijke termijnen en de plicht tot voortvarende besluitvorming alsmede de jurisprudentie van de bestuursrechter - het aannemen van een schending van het algemene rechtszekerheidsbeginsel in de rede liggen. Daarmee wordt in elk geval meer dan bij het zorgvuldigheidsbeginsel het geval is recht gedaan aan de ratio achter de termijnen en de plicht tot voortvarend beslissen. Bovendien sluit deze grondslag aan bij de eerder aangehaalde jurisprudentie van de bestuursrechter. Hoewel het daar vooral gaat om de redelijke termijn-eis, zoals die ook voortvloeit uit artikel 6 EVRM en deze dus primair gericht is op

914. Zo ook Nicolaï die aangeeft dat, vanwege het bestaan van een beginsel van een zorgvuldige beslissingsprocedure, er geen behoefte bestaat aan erkenning van een afzonderlijk beginsel dat een tot het nemen van een beslissing bevoegde instantie binnen een redelijke termijn beslist op ingediende verzoeken waarbij een burger belang heeft, Nicolaï 1990, p. 338.

${ }^{915 .}$ Damen e.a. 2009, Deel I, p. 336 e.v.; Van Wijk/Konijnenbelt \& Van Male 2008, p. 297 e.v. 


\section{De inrichting van de voorprocedures}

procedures bij de rechter, verschilt de ratio voor een redelijke termijn-eis voor het bestuur in de bestuurlijke voorprocedures niet van die voor de rechter. Om die reden moet het algemene rechtszekerheidsbeginsel dan ook de rechtsbasis vormen voor de toepasselijkheid van de redelijke termijn-eis op de bestuurlijke voorprocedures. Aansluiting daarbij zou voor de bestuurlijke voorprocedures wenselijk zijn. De doorwerking van de redelijke termijn-eis als eis van behoorlijke rechtspleging, te herleiden tot artikel 6 EVRM of het ook daarin tot uitdrukking komende algemene rechtszekerheidsbeginsel, zou in dat opzicht dan volledig zijn. Desalniettemin bestaat er aanleiding om te pleiten voor een afzonderlijke rechtsbasis voor voortvarendheid van het bestuur gelet op de huidige stand van de rechtspraak.

\section{Besluitvorming binnen een redelijke termijn gekoppeld aan toegang tot de rechter}

Voor de geschillen die buiten de reikwijdte van artikel 6 EVRM vallen en ook voor de bestuurlijke voorprocedures in die gevallen bestaat thans in beginsel een zelfstandige verplichting tot voortvarendheid waarvoor de rechtsbasis in het ongeschreven nationale recht wordt gevonden. Dat betekent dat alle geschillen bij de bestuursrechter binnen het bereik van de redelijke termijn-eis komen (ongeacht of artikel 6 EVRM van toepassing is). Op grond hiervan zou de aanname verdedigbaar zijn dat het algemene rechtszekerheidsbeginsel als zodanig ook de nationale grondslag vormt voor voortvarende besluitvorming door het bestuur in de bestuurlijke voorprocedures. Op grond van artikel 6 EVRM is dat immers voor de binnen de reikwijdte van die bepaling vallende geschillen immers ook het geval. Voor de bestuursrechter lijkt dat echter nog niet vast te staan. Zowel de Centrale Raad als de Afdeling heeft namelijk overwogen dat op de redelijke termijn-eis uit artikel 6 EVRM geen aanspraak tot schadevergoeding gebaseerd kan worden, voor zover het de duur van de bezwaarfase betreft én geen beroep is ingesteld bij de bestuursrechter na die bezwaarfase. ${ }^{916}$ Het is nog duidelijk of datzelfde ook geldt voor geschillen waarop de redelijke termijn-eis uit hoofde van het rechtszekerheidsbeginsel van toepassing is, maar dat lijkt mij wel aannemelijk. De Centrale Raad overwoog immers in zijn uitspraak dat hij ook geen andere geschreven (internationale of nationale) rechtsregel en evenmin enige ongeschreven rechtsregel of enig algemeen rechtsbeginsel aangetroffen had die de rechtsgrond voor een dergelijke aanspraak voor immateriële schadevergoeding zou zijn. ${ }^{917}$ Bovendien dateren de bedoelde uitspraken van de Centrale Raad en de Afdeling van na de eerste uitspraak waarin het rechtszekerheidsbeginsel als grondslag werd aangewezen. ${ }^{918}$

In mijn optiek bestaat er echter wel degelijk een andere ongeschreven nationale rechtsgrond die noopt tot toepasselijkheid van de redelijke termijn-eis op de bestuurlijke voorprocedures als zodanig. Vanuit het oogpunt van rechtszekerheid, die ook in het geding is in geval van trage besluitvorming, bestaat er geen rechtvaardiging een knip aan te brengen tussen de bestuurlijke voorprocedures en beroep bij de bestuursrechter. Als het rechtszekerheidsbeginsel noopt tot geschilbeslechting binnen een redelijke termijn en er ook een aanspraak op schadevergoeding kan bestaan bij overschrijding daarvan, dan moet hetzelfde gelden voor de bestuurlijke voorprocedures. ${ }^{919}$ Het algemene rechtszekerheidsbeginsel en de plicht tot voortvarende besluitvorming op grond daarvan is immers niet verbonden met de toegang tot de rechter. Bovendien kan ook een te lange duur van de bestuurlijke voorprocedures, zoals Barkhuysen en Van Ettekoven opmerken,

\footnotetext{
916. CRvB 29 april 2009, LJN BI2748, JB 2009/152 m.nt. redactie. Nagevolgd door de Afdeling in AbRvS 17 juni 2009, 200901365/2/H2, LJN BI8475. Zie hierover ook Barkhuysen en Van Ettekoven die eveneens menen dat het oordeel van de Centrale Raad niet juist is, Barkhuysen \& Van Ettekoven 2009, p. 133.

917. De Afdeling verwijst slechts naar de uitspraak van de Centrale Raad en geeft geen overwegingen in dit verband.

918. De eerste uitspraak waarin dat expliciet geschiedde was immers van 3 december 2008, AbRvS 3 december 2008, AB 2009/70 m.nt. Barkhuysen en Van Emmerik; JB 2009/13.

919. Vgl. Barkhuysen \& Van Ettekoven 2009, p. 133.
} 


\section{Deel II Bestuurlijke voorprocedures}

aanleiding geven tot immateriële schade. ${ }^{920}$ Denkbaar is dat de bestuursrechter de koppeling tussen de bestuurlijke voorprocedures en de procedure bij de rechter legt in verband met de strekking van artikel 6 EVRM. In het perspectief van die bepaling is uiteraard vooral van belang dat de lange duur van de voorprocedures de toegang tot de rechter blokkeren. Is dat laatste niet het geval, omdat geen procedure bij de rechter geëntameerd wordt, kan geredeneerd worden dat er ook geen aanspraak op schadevergoeding ontleend kan worden aan overschrijding van de redelijke termijn in de bestuurlijke voorprocedures in de zin van die bepaling. Ook in dat geval rijst echter de vraag of het gerechtvaardigd is om die knip aan te brengen, aangezien het ook juist de duur van die voorprocedure kan zijn die een belanghebbende ertoe noopt af te zien van het instellen van beroep. Daarmee wordt de traagheid van het bestuur als het ware beloond en wordt een belanghebbende deswege bestraft. Een dergelijke knip is ook niet vereist op grond van de jurisprudentie van het EHRM. Een knip tussen de bestuurlijke besluitvormingsfasen en de procedure bij de bestuursrechter valt derhalve gelet op het rechtszekerheidsbeginsel dat ook de bestuurlijke fasen normeert niet te rechtvaardigen. Het zou aanbeveling verdienen de lijn in deze uitspraken te verlaten en op de bestuurlijke voorprocedures (en besluitvorming in het algemeen) de eis van besluitvorming binnen een redelijke termijn zelfstandig en volledig te laten doorwerken.

Daarbij kan ofwel aansluiting gezocht worden bij het algemene rechtszekerheidsbeginsel ofwel bij de ontwikkeling in de doctrine naar een afzonderlijk voortvarendheidsbeginsel voor het bestuur (al dan niet als onderdeel van het rechtszekerheidsbeginsel). Het laatste zou buiten twijfel stellen dat ook voor het bestuur vanwege de rechtszekerheid van belanghebbenden een zelfstandige eis van besluitvorming binnen een redelijke termijn geldt. Het is immers nog niet duidelijk of de bestuursrechter in het kader van het algemene rechtszekerheidsbeginsel en artikel 6 EVRM bereid is de koppeling met de toegang tot de rechter los te laten. Door erkenning van een afzonderlijk beginsel voor het bestuur kan de knip tussen de bestuurlijke voorprocedures en de procedure bij de bestuursrechter ongedaan worden gemaakt. De koppeling aan de toegang tot de rechter voor de aanspraak op schadevergoeding wegens schending van de redelijke termijn is thans immers een gegeven. Dat gegeven vormt dan ook de reden waarom een afzonderlijke grondslag voor voortvarendheid in de bestuurlijke fasen thans gewenst is.

\section{Beginsel van behoorlijke rechtspleging of bestuur}

De toegevoegde waarde van erkenning van een afzonderlijk voortvarendheidsbeginsel ligt in het voorgaande besloten: het fundamentele karakter van en het belang dat gemoeid is met tijdige besluitvorming wordt daarmee gediend, er wordt duidelijker bloot gelegd wordt waaraan het schort in het besluitvormingsproces en los van het instellen van beroep bij de bestuursrechter zou deze eis kunnen gelden voor bestuurlijke besluitvormingsprocedures. Gelet op het onderscheidend karakter van dit beginsel zou uitbreiding van de beginselencatalogus, zoals die thans geldt voor het bestuur, met dit beginsel ook niet bezwaarlijk zijn. De ontwikkeling in de doctrine duidt bovendien ook op erkenning van een afzonderlijk beginsel van de redelijke termijn, een species van het rechtszekerheidsbeginsel, als norm voor het bestuur. Erkenning van een dergelijk afzonderlijk beginsel laat geen twijfel bestaan over de fundamentele betekenis die gehecht moet worden aan tijdige vaststelling (in elk geval binnen een redelijke termijn) van de rechtspositie van belanghebbenden in het bestuursrecht. Voorts heeft dat de voorkeur boven het onderbrengen van de eis bij het zorgvuldigheidsbeginsel, omdat op die wijze voorkomen wordt dat deze beginsels te ruim opgevat worden en daardoor aan gezag verliezen. Aangesloten zou ook kunnen worden bij het algemene rechtszekerheidsbeginsel waarop de redelijke termijn-eis voor rechtspraak gebaseerd wordt, mits de koppeling met de toe-

\footnotetext{
${ }^{920 .}$ Barkhuysen \& Van Ettekoven 2009, p. 133.
} 


\section{De inrichting van de voorprocedures}

gang tot de bestuursrechter wordt losgelaten. Alleen dan werkt deze eis volledig door in de bestuurlijke voorprocedures.

Voor rechtspraak bestaat het redelijke termijn-beginsel al geruime tijd als onderdeel van het nationale ongeschreven decisiebeginsel of als norm die voortvloeit uit artikel 6 EVRM. ${ }^{921}$ Duidelijk is dat de norm voor rechtspraak belangrijke invloed heeft gehad op het ontwikkelen van en denken over voortvarendheidseisen voor het bestuur. Opvallend is dat voor zover het de redelijke termijn betreft, de eis die geldt voor rechtspraak sterker ontwikkeld is dan een vergelijkbare eis voor het bestuur. Onder invloed van de voor rechtspraak geldende eis, ontwikkelt zich langzamerhand ook een eis voor het bestuur. Er bestaat daardoor en onder invloed van artikel 6 EVRM veel meer aandacht voor de traagheid aan de kant van het bestuur. Uit de voorgaande paragrafen blijkt voorts dat de voortvarendheidseisen voor bestuur en rechter in elk geval een gemeenschappelijke ratio hebben, die te herleiden valt naar de rechtszekerheid van de betrokkenen bij de procedure. De verschillen tussen de bestuurlijke voorprocedures en de procedure bij de bestuursrechter zijn op dit vlak te overzien. Dat pleit ervoor om voor het bestuur de redelijke termijn-eis volledig te laten doorwerken (al dan niet op basis van een andere grondslag). Op de vraag in hoeverre deze ontwikkeling in het kader van de redelijke termijn (en mogelijk ook in het kader van andere beginselen van rechtspleging) meer in het algemeen pleiten voor een catalogus aan behoorlijkheidsbeginselen die gelden voor zowel het bestuur als de rechter in plaats van twee afzonderlijke groepen beginselen kom ik nader terug in Deel III, paragraaf 4. Duidelijk is echter de toepasselijke vereisten voor beide organen in dit opzicht niet zeer uiteenlopen.

De invulling van het vereiste van een redelijke termijn kan echter in concreto verschillen afhankelijk van de fase waarin de procedure zich bevindt. Omdat in elke fase die een besluit kan doorlopen - primaire besluitvormingsfase, voorprocedure en procedure bij de rechter - de procedurele waarborgen toenemen, kan wel verdedigd worden dat het bestuur in verhouding de minste of minder tijd ter beschikking heeft om binnen die redelijke termijn te blijven. Er bestaat in het algemeen ook een zeker spanningsveld tussen de vereiste voortvarendheid en de vereiste procedurele waarborgen voor de inrichting van de procedure. Hoe meer waarborgen ingebouwd zijn in een procedure, hoe meer tijd de procedure immers doorgaans in beslag zal nemen. Dat geldt evenzeer voor bestuurlijke procedures als voor de procedures bij de rechter. Het bieden van rechtszekerheid door middel van een voortvarende besluitvormingsprocedure kan derhalve ten koste gaan van de zorgvuldigheid of behoorlijkheid van de bestuurlijke voorprocedure. ${ }^{922}$ Tussen het belang dat gediend is met voortvarende besluitvorming en het belang dat gediend is met een met voldoende waarborgen omklede procedure zal derhalve een goed evenwicht gevonden moeten worden. Verdedigbaar is dat dit evenwicht in de bestuurlijke voorfasen anders ingevuld moet worden dan in de rechterlijke fase(n). Het bestuur grijpt immers primair op ingrijpende wijze in in de rechtspositie van belanghebbenden en het aanhangig maken van een bestuurlijke voorprocedure heeft geen schorsende werking ten aanzien van het besluit van het bestuur. In die fasen zou de rechtszekerheid van belanghebbenden zwaarder moeten wegen en moet ten behoeve daarvan minder tijd voor het bestuursorgaan ter beschikking staan. In vergelijking daarmee heeft de bestuursrechter meer tijd ter beschikking en weegt hier de behoorlijkheid van de procedure zwaarder. Die gedachtegang is ook terug te zien in de gefixeerde termijnen die door de bestuursrechter gehanteerd worden ter vaststelling van een beweerdelijke overschrijding van de redelijke termijn, aangezien de termijnen voor het bestuur het kortst zijn. ${ }^{923}$ Er moet in de

921. Zie hierover Deel I, par. 4.3.9.

922. Vgl. Verheij 2008, p. 239.

${ }^{923 .}$ Dat geldt voor de niet punitieve zaken waarin geen opgelegde bestuurlijke boete centraal staat, zie: AbRvS 24 december 2008, $A B$ 2008/213 m.nt. Jansen; JB 2009/42 m.nt. Albers; USZ 2009/75 m.nt. Barkhuysen en Van Emmerik; CRvB 26 januari 2009, JB 2009/66 m.nt. Barkhuysen en Van Emmerik. Voor de punitieve zaken, waarin een opgelegde boete centraal staat, heeft de HR aangegeven dat de fase bij het bestuur en de rechtbank 


\section{Deel II Bestuurlijke voorprocedures}

bestuurlijke voorprocedures echter wel meer tijd aan het bestuur gegeven worden om een besluit te nemen ten opzichte van de primaire besluitvormingsfase, tenzij de primaire besluitvormingsfase met meer waarborgen wordt omkleed. Te denken valt aan de uniforme voorbereidingsprocedure. Daarvoor geldt dan ook dat, na die doorlopen te hebben, geen bezwaarschriftprocedure of administratief beroep meer openstaat.

Inrichtingseisen voor een voortvarende procedure in bezwaar en administratief beroep Indien de wetgever zeker gesteld wil zien dat een procedure, meer in het bijzonder de bezwaarschriftprocedure of het administratief beroep, voldoet aan het beginsel van besluitvorming binnen een redelijke termijn, dient hij in de regeling in de Awb daartoe ook voorschriften op te nemen. Deze inrichtingseisen behoren te waarborgen dat de procedure tijdig verloopt of dat het bestuur kan ingrijpen indien dat niet het geval is. Widdershoven wijst er voor rechtspraak op dat ter bevordering van een uitspraak binnen een redelijke termijn in de procesregeling termijnstellingen behoren te worden opgenomen. ${ }^{924}$ In het onderstaande worden de termijnstellingen in de Awb voor de bezwaarschriftprocedure en het administratief beroep alsmede mogelijke (andere) eisen die op grond van jurisprudentie gesteld worden in kaart gebracht. Daarnaast zijn, om inachtneming van het beginsel van de redelijke termijn te verzekeren, middelen om (verdere) vertraging te voorkomen of redresseren van belang. Eisen in dat verband volgen ook uit de combinatie van het beginsel van effectieve rechtsbescherming en het beginsel van de redelijke termijn. Deze eisen komen afzonderlijk aan de orde in paragraaf 5.7.5.

\section{De wettelijke beslistermijnen}

De meest voor de hand liggende inrichtingseis die gesteld kan worden om besluitvorming binnen een redelijke termijn te garanderen is een wettelijke beslistermijn. De relevante beslistermijnen die gelden in de bezwaarschriftprocedure en het administratief beroep zijn neergelegd in respectievelijk artikelen 7:10, 7:13, 7:19 en 7:24 Awb. ${ }^{925}$ De beslistermijn voor de behandeling van het bezwaar door het bestuursorgaan is zes weken, tenzij er een adviescommissie wordt ingeschakeld. In dat laatste geval is de termijn twaalf weken. Daarnaast heeft het bestuursorgaan de mogelijkheid op grond van het derde lid van dat artikel om de termijn voor zes weken te verdagen. De beslissing om te verdagen moet worden medegedeeld, maar behoeft verder niet te worden gemotiveerd met bijzondere omstandigheden die genoopt hebben tot de verdaging. ${ }^{926}$ Bovendien vangt de termijn aan de dag na die waarop de termijn voor het indienen van een bezwaarschrift is verstreken. Vrijwel dezelfde regeling geldt voor het administratief beroep in artikel 7:24 Awb. Die bepaling maakt echter een onderscheid tussen administratief beroep op een orgaan binnen hetzelfde openbare lichaam of op een orgaan van een ander openbaar lichaam. Voor de eerste situatie geldt in beginsel een termijn van zes weken en indien een commissie in de zin van artikel 7:19 Awb is ingesteld een termijn van twaalf weken - beide gerekend vanaf de dag waarop de beroepstermijn is verstreken. Ook dan heeft het bestuursorgaan de mogelijkheid om de beslissing zes weken te verdagen ex artikel 7:24, vijfde lid, van de Awb. Voor de tweede situatie, administratief beroep op

niet meer dan twee jaar mag duren, HR 19 december 2008, $A B$ 2009/230 m.nt. Jansen; HR 22 april 2005, JB 2005/166 m.nt. Wenders; $A B$ 2006/11 m.nt. Jansen. De overige bestuursrechters lijken aan te sluiten bij de HR, in elk geval wat betreft de eerste fase vanaf de start van de termijn tot aan de uitspraak van de rechtbank: AbRvS 24 december 2008, $A B$ 2010/16 m.nt. A.M.L. Jansen; CRvB 28 augustus 2008, AB 2010/17 m.nt. A.M.L. Jansen; CBb 3 juli 2008, $A B$ 2009/305 m.nt. Sew. Het CBb heeft echter in een zaak waarin het ging om hertaxatie van de vaststelling van schadevergoeding voor het ruimen van dieren aangegeven dat de bezwaarfase een jaar mag duren en de fase in eerste aanleg bij de rechter twee jaar, CBb 3 maart 2009, JB 2009/139.

924. Widdershoven 1989 , p. 117 en 119

925. Van de daarin neergelegde termijnen kan worden afgeweken bij bijzondere wet. Zo week bijvoorbeeld de duur van de bezwaarschriftprocedure in belastingzaken op grond van de AWR af van de termijn in de Awb. De belastinginspecteur mocht ingevolge art. 25 AWR een jaar over de behandeling van het bezwaar doen. De uitzondering in de AWR is met ingang van 1 januari 2008 komen te vervallen.

${ }_{926 .}$ AbRvS 5 juni 2002, JB 2002/220. 


\section{De inrichting van de voorprocedures}

een orgaan van een ander openbaar lichaam, geldt op grond van het eerste en vierde lid een termijn van zestien weken (gerekend vanaf de dag waarop de beroepstermijn is verstreken) die met ten hoogste tien weken kan worden verlengd. Zowel in administratief beroep als in bezwaar kan met instemming van de indiener verder uitstel worden verleend, mits alle belanghebbenden daarmee instemmen of niet in hun belangen worden geschaad door dat verdere uitstel. ${ }^{927}$ Van de verdagingsmogelijkheden voor het bestuur moet echter beperkt gebruik worden gemaakt, volgens de wetgever. Verdaging zou slechts in bijzondere gevallen plaats behoren te vinden. ${ }^{928}$

Met de hiervoor genoemde bepalingen geeft de Awb een vrij algemene regeling waarbij geen onderscheid gemaakt wordt tussen het soort zaak of de complexiteit van de betreffende besluitvorming. Voor de afhandeling van bezwaarschriften tegen besluiten van alle soorten en maten gelden dezelfde wettelijke termijnen (met een onderscheid tussen de gevallen waarin wel of niet een adviescommissie is ingesteld), behoudens de afwijkingen daarvan in bijzondere wetgeving. Het is juist deze uniformiteit in de beslistermijnen zonder de mogelijkheid rekening te houden met de specifieke omstandigheden en moeilijkheden van het voorliggende geval die als een van de redenen voor de te trage afhandeling van ingediende bezwaarschriften en overschrijding van de beslistermijnen naar voren wordt geschoven. ${ }^{929}$ Hoewel inmiddels naar aanleiding van de Wet dwangsom en beroep bij niet tijdig beslissen deze termijnen en ook enkele andere termijnen, zowel in de Wob als in bijzondere wetgeving verlengd zijn, doen deze verlengingen niets af aan de uniformiteit van de termijnen.

De wettelijke beslistermijn mag voorts niet zo lang zijn dat besluitvorming binnen een redelijke termijn, als bedoeld in artikel 6 EVRM, in gevaar komt. Daarvan is echter in het geheel geen sprake. Enkele overschrijding van de wettelijke beslistermijn betekent, zoals eerder aangegeven, ook nog niet automatisch dat de redelijke termijn-eis uit artikel 6 EVRM is geschonden. Wel vormt de overschrijding van de wettelijke beslistermijn thans een schending van een rechtsplicht, waardoor er gevolgen verbonden zijn aan die overschrijding. Dat is ook nodig omdat termijnstellingen als zodanig, zo blijkt uit de praktijk, nog niet bewerkstelligen dat er voortvarend beslist wordt.

\section{Overige termijnstellingen en mogelijkheden voor het bestuur om de procedure te versnellen}

Voor het overige bevat de regeling in de Awb termijn voor andere beslissingen of handelingen van zowel bestuur als belanghebbende nauwelijks termijnen of mogelijkheden voor het bestuur om de besluitvorming te versnellen. In het licht van artikel 6 EVRM en de eisen die het EHRM in dat kader stelt, ligt het in de rede de bestuursrechter de beschikking te geven over bevoegdheden om de procedure bij de rechter te bespoedigen. ${ }^{930}$ Een van de inrichtingseisen die gesteld wordt (of moet worden) aan rechtspraakachtige of rechterlijke procedures is dat de bestuursrechter over middelen beschikt om de procedure te versnellen teneinde schending van die bepalingen te voorkomen. De Awb bevat bijvoorbeeld enkele termijnstellingen als het gaat om deskundigenadvisering in de procedure bij de bestuursrechter. De rechtbank heeft bijvoorbeeld de bevoegdheid om de deskundige op grond van het vierde lid van artikel 8:47 Awb een termijn te stellen waarbinnen deze advies moet uitbrengen. ${ }^{931}$ Indien de bestuursrechter een deskundige inschakelt (op grond van artikel 8:47 Awb) die talmt en daarmee een schending van de redelijke termijn veroorzaakt (of dreigt te veroorzaken), zal hij stappen moeten ondernemen om

931. Bovendien heeft zij de bevoegdheid partijen een termijn te stellen waarbinnen zij hun wensen over het onderzoek kenbaar kunnen maken, op grond van lid 3, en hebben partijen een termijn van vier weken om te reageren, op grond van lid 5. De rechtbank kan zelf die termijn verlengen op grond van lid 6.
} 


\section{Deel II Bestuurlijke voorprocedures}

de advisering te versnellen. ${ }^{932}$ De bestuursrechter is verantwoordelijk voor het optreden van ingeschakelde deskundigen (en onnodige vertragingen in dat kader) ${ }^{933}$ Hetzelfde kan gesteld worden voor vertragingen die samenhangen met het oproepen en horen van getuigen (op grond van artikel 8:46 Awb). ${ }^{934}$

Aangenomen kan worden dat ook voor het bestuur in die procedures dergelijke (inrichtings)eisen gelden. Ook het bestuur kan immers gebruik maken van deskundigen en advies vragen in het kader van het onderzoek naar de feiten en de af te wegen belangen. Daarnaast wordt in veel gevallen in de bezwaarschriftprocedure een adviescommissie ingesteld die belast is met het horen van belanghebbenden en wiens advies bij de besluitvorming moet worden betrokken. In beide gevallen kan er een vertraging in de procedure optreden, indien het advies van de ingeschakelde deskundige of adviescommissie op zich laat wachten en niet binnen de daarvoor gegeven termijn wordt afgegeven. Aangezien de bevoegdheid tot het nemen van een besluit én de plicht tot het nemen daarvan binnen de wettelijke termijn bij het bestuursorgaan berust, is het bestuursorgaan verantwoordelijk voor de voortvarendheid van de besluitvorming. Voor de primaire besluitvorming is dit, wat betreft wettelijke advisering, zelfs neergelegd in artikel 3:6 Awb. Uit het eerste lid volgt dat het bestuur de adviseur een termijn kan stellen. De grens daarbij is de zorgvuldigheid van de advisering. Dat betekent dat de termijn niet zo kort mag zijn dat deze in het geding komt, aldus het eerste lid. ${ }^{935}$ Uit het tweede lid volgt dat het bestuur een besluit kan nemen zonder het wettelijke advies, als dat laatste te lang op zich laat wachten. Soms zal echter een advies vanuit een oogpunt van zorgvuldigheid of in verband met de motivering van een besluit nodig zijn en derhalve moeten worden afgewacht. ${ }^{936}$ In dat geval bestaat er een spanning tussen de behoorlijkheidseisen, zorgvuldigheid en motivering, aan de ene kant en de voortvarendheid van de besluitvorming aan de andere kant. In een geval waarin het niet tijdig beslissen zou leiden tot een vergunning van rechtswege, oordeelde de Afdeling in elk geval dat het bestuursorgaan het advies niet behoefde af te wachten. ${ }^{937}$ Overigens geldt het voorgaande niet voor een advies van de bezwaaradviescommissie dat te lang op zich laat wachten, getuige artikel 7:14 Awb waarin artikel 3:6, tweede lid, niet van toepassing is verklaard. In de gevallen waarop artikel 3:6 Awb niet ziet, is het echter verdedigbaar dat dezelfde eisen gelden via het zorgvuldigheidsbeginsel, zoals neergelegd in artikel 3:2 Awb of het beginsel van besluitvorming binnen een redelijke termijn voor het bestuur. Er zal in elk zich voordoend geval, afhankelijk van de concrete omstandigheden, een evenwicht tussen het belang van zorgvuldige besluitvorming en voortvarende besluitvorming gezocht moeten worden (tenzij de wetgever heeft aangegeven welk van beide belangen zwaarder moet wegen). ${ }^{938}$ Soms zal de balans doorslaan ten faveure van de zorgvuldigheid van de advisering en besluitvorming en soms zal de tijdigheid zwaarder moeten wegen.

\footnotetext{
932. Zie over deskundigenadvisering in het bestuursprocesrecht en voortvarendheid: L.M. Koenraad, 'Deskundig rechtspreken: beschouwingen over de plaats van deskundigen in het bestuursprocesrecht', JB-plus 2007, p. 209210 .

935. L.M. Koenraad, 'Deskundig besturen. Beschouwingen over de plaats van de deskundigenadvisering in het bestuursrecht', JB-plus 2006, p. 22.

${ }^{936 .}$ Koenraad 2006, p. 21; Bots 2004, p. 149

937. ABRvS 10 oktober 2000, JB 2000/306 m.nt. RJNS. Zie ook: Koenraad 2006, p. 21

938. Bots merkt in dit verband op dat tijdigheid essentieel is voor een zorgvuldige besluitvorming, A.M.M.M Bots, 'Het zorgvuldigheidsbeginsel en advisering', in: R.J.N. Schlössels, A.J. Bok, H.J.A.M. van Geest, S. Hillegers, In beginsel. Over aard, inhoud en samenhang van rechtsbeginselen in het bestuursrecht, Kluwer: Deventer 2004, p. 148-149. Zoals eerder aangegeven heeft het mijn voorkeur om tijdigheidsaspecten en zorgvuldigheidsaspecten, vanwege het verschil in de aard van de eisen, uit elkaar te trekken. De tijdigheidseisen dienen in zoverre niet tot het algemene zorgvuldigheidsbeginsel herleid te worden. Iets anders is dat beide soorten eisen betrekking hebben op een behoorlijk verloop van de procedure en de behoorlijkheidseisen (in de zin van rechtsnormen) vormen waaraan het bestuur moet voldoen.
} 


\section{De inrichting van de voorprocedures}

Concrete toepassing van een voortvarendheidsbeginsel

Indien een voortvarendheidsbeginsel erkend wordt in het Nederlandse bestuursrecht voor zowel bestuur als rechter dat naast artikel 6 EVRM ook een afzonderlijke basis kent in het Nederlandse ongeschreven (bestuurs)recht, rijst de vraag op welke wijze toepassing van dat beginsel behoort plaats te vinden. Een aantal aspecten kan daarbij van belang zijn. Te denken valt aan de reikwijdte van een dergelijk beginsel, de aanvang en het einde van de periode die van belang is, de factoren om te bepalen wanneer wel en wanneer niet voortvarend gehandeld is.

Zoals reeds eerder is bepleit ${ }^{939}$, zou de reikwijdte van een dergelijk beginsel niet beperkt moeten zijn. Het uitgangspunt dient te zijn dat alle geschillen van bestuursrechtelijke aard en alle procedures onder de werking van dat beginsel vallen. In dat opzicht zou de nationale invulling van dat beginsel afwijken van de redelijke termijn-eis als neergelegd in artikel 6 EVRM. Problematisch is dat echter niet omdat de bescherming op nationaal niveau dan verder strekt en daarmee ook in dit opzicht artikel 6 EVRM in acht wordt genomen.

Vervolgens is van belang wanneer dan sprake is van schending van het nationale beginsel en aan de hand van welke factoren de beoordeling in het kader van dat beginsel zou moeten plaatsvinden. Ook hier zijn uiteenlopende benaderingen tussen de interpretatie en invulling van de redelijke termijn-eis van en door het EHRM en de nationale rechterlijke instanties mogelijk. Als voorbeeld kan de al eerder aangehaalde rechtspraak van de Hoge Raad (zowel belasting- als strafkamer) ${ }^{940}$ en de overige bestuursrechters genoemd worden waarbij gefixeerde termijnen voor de beoordeling of de redelijke termijn overschreden is gehanteerd worden, terwijl het EHRM eerder naar de totale duur van de procedure kijkt aan de hand van de bekende criteria (complexiteit van de zaak, gedrag van de klager, houding van de autoriteiten en het belang dat op het spel staat voor de klager). ${ }^{941}$ De gehanteerde vaste standaardtermijnen gelden ook voor het bestuurlijke aandeel in de procedure. De termijnen in boetezaken zijn voor de procedure in eerste aanleg en in bezwaar gezamenlijk twee jaar, terwijl de termijnen in andere zaken variëren. Bij de Centrale Raad heeft het bestuur in de bezwaarfase een half jaar om tot besluitvorming te komen, terwijl het bestuur bij de Afdeling en het $\mathrm{CBb}$ een jaar lijkt te hebben. ${ }^{942}$ De factoren die het EHRM hanteert spelen wel een nog een rol als correctiefactor. $^{943}$

Voor zowel de gefixeerde termijnen als voor de benadering van het EHRM valt wat te zeggen. ${ }^{944}$ De verschillen of gevolgen lijken in de praktijk gering te zijn en de benadering van de Hoge Raad en de bestuursrechters biedt meer duidelijkheid en rechtszekerheid voor de nationale rechtspraktijk. ${ }^{945}$ Op nationaal niveau ligt daarom een benadering zoals die van de bestuursrechters wellicht meer in de rede. Het risico dat in een concreet geval toch sprake is van strijdigheid met artikel 6 EVRM valt echter niet geheel uit te sluiten. De bestuursrechter dient daarom oog te houden voor de omstandigheden van het geval en de totale duur van de procedure. Van belang is omwille van de duidelijkheid dat ten aanzien van het bestuur ook met gefixeerde termijnen gewerkt wordt, indien dat ook

\footnotetext{
939. Zie Deel I, par. 4.1.

${ }^{940 .}$ HR 19 december 2008, $A B$ 2009/230 m.nt. Jansen; HR 17 juni 2008, $N J$ 2008/358 m.nt. P.A.M. Mevis; $A B$ 2009/231 m.nt. AMLJ; HR 22 april 2005, $A B$ 2006/11 m.nt. AMLJ; JB 2005/166 m.nt. Wenders; $B N B$ 2005/337 met noot Feteris onder $B N B$ 2005/338; HR 3 oktober 2000, NJ 2000/721 m.nt. JdH.

941. Zie hierover: A.M.L. Jansen, 'Overheidsaansprakelijkheid voor overschrijding van de redelijke termijn' $O$ \& A 2009, p. 62; Barkhuysen \& Van Ettekoven 2009, p. 132-134; Jansen 2005, p. 1584-1585. Zie verder Deel I, par. 4.3.9.

942. AbRvS 24 december 2008, AB 2008/213 m.nt. Jansen; JB 2009/42 m.nt. Albers; USZ 2009/75 m.nt. Barkhuysen en Van Emmerik; CRvB 26 januari 2009, JB 2009/66 m.nt. Barkhuysen en Van Emmerik; CBb 3 maart 2009, JB 2009/139.

943. Zie ook: Barkhuysen \& Van Ettekoven 2009, p. 132-133.

944. Zie anders Schreuder-Vlasblom, die kritiek uitoefent op de benadering van het EHRM waarbij de nadruk lig op de totale duur van de procedure en interne compensatie mogelijk is, Schreuder-Vlasblom 2009, p. 462-463.

945. Jansen 2005, p. 1584.
} 
Deel II Bestuurlijke voorprocedures

voor de bestuursrechter het geval is. Daarenboven moet in de gefixeerde termijnen tot uitdrukking komen hoe lang het bestuur de tijd heeft. Ik zou er voor willen pleiten dat de bestuursrechters aangeven welke gefixeerde termijn zelfstandig en los van de duur van de procedure in eerste aanleg voor de bestuurlijke voorprocedures geldt. Dat is te meer van belang, indien de koppeling met de toegang tot de rechter wordt losgelaten. Bovendien moeten de gefixeerde termijnen niet te ruim zijn, wil er voldoende aansporing voor het bestuur bestaan om voortvarend te beslissen. ${ }^{946}$

\subsubsection{Consequenties van stilzittend en traag bestuur}

\subsubsection{Gevolgen verbonden aan schendingen van beslistermijnen en de redelijke termijn}

In deze paragraaf staan de gevolgen die verbonden worden aan schendingen van beslistermijnen en de redelijke termijn door het bestuur centraal. Vooropgesteld kan worden dat schendingen van beslistermijnen of de redelijke termijn door het bestuur in beginsel niet zouden moeten leiden tot een vernietiging, indien het besluit geen andere (materiële) gebreken vertoont. ${ }^{947}$ Voor de rechtmatigheid van het materiële besluit heeft de overschrijding immers geen gevolgen, waardoor een gegrondverklaring van het beroep en vernietiging van het besluit niet in de rede ligt. ${ }^{948}$ Als er sprake is van vernietiging van het besluit bij gebreke van een andere wettelijke voorziening, worden de rechtsgevolgen vervolgens door de betuursrechter in stand gelaten. ${ }^{949}$ In bepaalde gevallen kan overschrijding van de redelijke termijn wel het materiële besluit raken, in die zin dat een boete gereduceerd wordt of op nihil bepaald wordt. ${ }^{950}$ Daarnaast kan er schadeplichtigheid bestaan vanwege het schenden van de wettelijke beslistermijn of de redelijke termijn. De mogelijke gevolgen worden in de volgende paragraaf vanuit het perspectief van effectief rechtsbescherming nader toegelicht.

\subsubsection{Effectieve rechtsbescherming tegen traag bestuur}

Effectieve rechtsbescherming tegen overschrijdingen van de redelijke termijn

Onder invloed van artikel 6 en 13 EVRM en de jurisprudentie van het EHRM van de afgelopen jaren zijn het redres en de gevolgen die schendingen van de redelijke termijn, ook door het bestuur, hebben zoals reeds aangegeven steeds belangrijker geworden. In de jurisprudentie van het EHRM is de afgelopen jaren, ingezet met de uitspraak Kudla t. Polen $^{951}$, een ontwikkeling te bespeuren waarin meer nadruk gelegd wordt op het al dan niet bestaan van een effectief nationaal rechtsmiddel in de zin van artikel 13 EVRM voor schendingen van het redelijke termijn-vereiste. ${ }^{952}$ Deze problematiek is inmiddels verscheidene malen onderwerp geweest van een Grote Kamer-uitspraak, waaruit het belang

\footnotetext{
946. Zie hierover ook: Schreuder-Vlasblom 2009, p. 463-464.

947. Zie bijv.: AbRvS 13 mei 2009, nr. 200808359/1/H3; AbRvS 12 januari 2005, nr. 200404561/1.

948. AbRvS 19 november 2003, AB 2004/27 m.nt. A.M.L. Jansen. Overigens heeft HvJ EU onlangs in een uitspraak eenzelfde benadering gehanteerd: HvJ EU 16 juli 2009, C-385-07 P, EHRC 2010/20 m.nt. Widdershoven. 949. AbRvS 13 juni 2007, $A B$ 2007/261, m.nt. Jansen; CRvB 8 december 2004, AB 2005/73, m.nt. Bröring. Zie ook: Barkhuysen \& Van Ettekoven 2009, p. 136.

950. Zie bijv.: AbRvS 19 november 2003, AB 2004/27 m.nt. Jansen. Zie verder: Barkhuysen \& Van Ettekoven 2009 , p. 136

${ }^{951 .}$ EHRM 26 oktober 2000, Kudla t. Polen, EHRC 2000/89 m.nt. Van der Velde; NJCM-Bulletin 2001, p. 71-88 m.nt. Barkhuysen; $A B$ 2001/275 m.nt. Verhey.

952. Zie hierover met verwijzingen naar de belangrijkste uitspraken: Van Dijk 2009, p. 115-133; SchreuderVlasblom 2009, p. 465-473; Jansen 2009, p. 60 e.v.; Jansen \& Wenders 2006, p. 1108 e.v.; T. Barkhuysen \& A.M.L. Jansen, 'Actuele ontwikkelingen in de redelijke termijn-jurisprudentie: over de Nederlandse termijnoverschrijdingen en ontbrekende rechtsmiddelen, NJCM-Bulletin 2003, p. 586-600; T. Barkhuysen \& A.M.L. Jansen, 'Rechtsmiddelen tegen bestuurlijke en rechterlijke traagheid: het EVRM noopt tot aanpassing van het Nederlandse recht', $N J B$ 2002, p. 1841-1848.
} 


\section{De inrichting van de voorprocedures}

van deze kwestie ook duidelijk blijkt. ${ }^{953}$ Het EHRM eist op grond van artikel 13 EVRM dat er op nationaal niveau een effectieve voorziening bestaat om schendingen van de redelijke termijn aan de orde te stellen. Enkele verdragsstaten hebben naar aanleiding van deze jurisprudentie een rechtsmiddel geschapen waarin geklaagd kan worden over de schending van de redelijke termijn en ook redres geboden wordt. ${ }^{954}$ In Nederland is echter vooralsnog geen afzonderlijke voorziening door de wetgever gecreëerd, maar kunnen overschrijdingen van de redelijke termijn en vergoedingen daarvoor aan bod komen in de reguliere procedures of de reeds bestaande middelen tegen traag bestuur. Een wettelijke voorziening is echter in de maak. ${ }^{955}$

Een effectief rechtsmiddel kan bestaan uit een voorziening die leidt tot compensatie voor de schending en/of een preventieve voorziening die een voortvarender behandeling van de zaak mogelijk maakt. ${ }^{956}$ Beide varianten kunnen (afzonderlijk) voldoende effectief zijn en zijn geoorloofd volgens het EHRM, al lijkt het EHRM een voorkeur te hebben voor preventieve voorzieningen dan wel een combinatie van beide voorzieningen. ${ }^{957}$ Ook een samenstel van (bestaande) voorzieningen kan - hoewel de afzonderlijke voorzieningen op zichzelf niet effectief zijn - voldoende effectief redres bieden. ${ }^{958}$ In het kader van de beoordeling of van een dergelijke effectieve voorziening sprake is, is voor het EHRM onder meer van belang of vertragingen in alle fasen van de procedure, derhalve ook in de bestuurlijke voorprocedure, meegenomen worden. In een uitspraak van 29 juni 2006 in de zaak Božić tegen Kroatië overweegt het EHRM expliciet dat indien naar nationaal recht een klager verplicht is om eerst een bestuurlijke voorprocedure te doorlopen alvorens een rechter kan worden geadieerd, deze procedures bij het bestuur moeten worden meegeteld bij de algehele duur van de procedure in het licht van artikel 6 EVRM. Het EHRM benadrukt dat slechts sprake is van een effectief rechtsmiddel indien daarbij alle fasen van de procedure kunnen worden meegenomen, net zoals het zelf ook de 'overall length' meeneemt bij de beoordeling van de redelijke termijn. ${ }^{959}$ Het Constitutionele Hof in Kroatië weegt bij de beoordeling van een klacht omtrent de lengte van een procedure slechts de periode dat de zaak aanhangig is bij de rechter mee. Het sluit de duur van de bestuurlijke voorprocedures daarvan uit omdat voor het versnellen van die procedures specifieke voorzieningen voorhanden zijn. Om die reden wordt de constitutionele klacht-procedure als zodanig door het EHRM niet beschouwd als een 'effective remedy'.

\footnotetext{
953. Zie onder meer: EHRM 8 juni 2006, Sürmeli t. Duitsland, EHRC 2006/100 m.nt. Jansen; EHRM 29 maart 2006, Scordino (nr. 1) t. Italië, EHRC 2006/61 m.nt. Van der Velde; AB 2006/294 m.nt. Barkhuysen \& Van Emmerik. Zie de wat betreft de belangrijkste overwegingen eensluidende uitspraak van dezelfde datum en afkomstig van de Grote Kamer in de zaak Pizatti, JB 2006/134 m.nt. AMLJ. In 2005 oordeelde de Grote Kamer ook al over deze kwestie in een zaak tegen Slovenië, EHRM 6 oktober 2005, Lukenda t. Slovenië, EHRC 2005/114 m.nt. Van der Velde.

954. Zie par. 186 van Scordino waarin het EHRM zelf enkele landen noemt die combinaties van preventieve en compensatoire voorzieningen hebben geintorduceerd. Italië zelf heeft met de Wet Pinto een zuiver compensatoire voorziening gecreëerd.

955. Inmiddels is er een wetsvoorstel Wet schadevergoeding bij termijnoverschrijdingen gemaakt. Persbericht Ministerie van Justitie, 23 april 2010. Het persbericht en het wetsvoorstel zijn te raadplegen via de website http://www.justitie.nl/actueel/persberichten/archief-2010/100413minister-schadevergoeding-als- rechtszakenveel-te-lang-duren.aspx?cp=34\&cs $=579$. Zie over een mogelijke wettelijke voorziening: Barkhuysen \& Van Ettekoven 2009, p. 129; T.J. Poppema, 'De redelijke termijn in het nationale (bestuurs)recht: op naar een wettelijke voorziening!’, NTB 2009, p. 188-189; Jansen 2009, p. 66

956. Zie par. 183 en 186 van Scordino.

957. Zie par. 186 van Scordino en par. 100 van Sürmeli. Vgl.: Barkhuysen \& Van Ettekoven 2009, p. 129; Van Dijk 2009, p. 121; Schreuder-Vlasblom 2009, p. 465; Jansen \& Wenders 2006, p. 1109.

958. EHRM 29 juni 2006, Božić t. Kroatë, nr. 22457/02, par. 35; EHRM 8 juni 2006, Sürmeli t. Duitsland, EHRC 2006/100 m.nt. Jansen, par. 98 en 115; EHRM 6 oktober 2005, Lukenda t. Slovenië, EHRC 2005/114 m.nt. Van der Velde, par. 44 en 66-67.

${ }^{959 .}$ EHRM 29 juni 2006, Božić t. Kroatië, nr. 22457/02. Idem in: EHRM 29 juni 2006, Počuča t. Kroatië, EHRC 2006/106. Zie al eerder: EHRM 29 november 2005, Wyszczelski t. Polen, nr. 72161/01; EHRM 15 maart 2005, Bako t. Slowakije, BNB 2005/336 met noot Feteris bij HR 17 juni 2005, BNB 2005/338.
} 


\section{Deel II Bestuurlijke voorprocedures}

Het voorgaande betekent dat ook op nationaal niveau geklaagd moet kunnen worden en een voorziening moet worden geboden voor onredelijke vertragingen in de bestuurlijke voorfasen. Schendingen van de redelijke termijn kunnen immers ook (primair of alleen) te wijten zijn aan het bestuur. Voor het EHRM staat echter de beoordeling van de gehele duur van een geschil centraal. Dat betekent ook dat een vertraging in de voorfase goedgemaakt kan worden door een zeer voortvarende behandeling van de zaak in de beroeps- of hoger beroepsfase. ${ }^{960}$ Waar het om gaat is dat de totale duur van de procedures (inclusief de bestuurlijke voorprocedures en alle rechtsgangen bij de rechter) niet excessief is. Gaat het in een van deze fasen in de gehele procedure mis, zoals de bestuurlijke voorfase, en wordt zulks onvoldoende hersteld, kan sprake zijn van een schending van de redelijke termijn- eis. In dat geval behoort een effectief rechtsmiddel te bestaan op nationaal niveau om die schending aan de orde te stellen.

De voorwaarden

Alvorens het EHRM een voorziening beschouwt als een voldoende effectief middel tegen schendingen van de redelijke termijn moet deze voorziening aan een aantal voorwaarden voldoen. De belangrijkste uitspraak in dat kader is Scordino t. Italie van 29 maart 2006, het standaardarrest van de Grote Kamer waarnaar het EHRM thans ook altijd verwijst. ${ }^{961}$ Hoewel het vanwege de casuistische benadering van het EHRM lastig is om algemene voorwaarden te destilleren uit de jurisprudentie, worden hieronder enkele algemene eisen die te onderscheiden vallen op een rij gezet. Die voorwaarden verschillen uiteraard voor preventieve en compensatoire voorzieningen, maar beide soorten voorzieningen behoren in elk geval effectief, adequaat en toegankelijk te zijn.

Een preventief rechtsmiddel moet volgens het Hof ook daadwerkelijk de procedure kunnen bespoedigen. ${ }^{962}$ Uit de Grote Kamer-uitspraak Sürmeli t. Duitsland blijkt ook dat de rechter in dat kader de mogelijkheid moet hebben om termijnen te stellen of anderszins maatregelen moet kunnen treffen om de procedure te bespoedigen. De enkele mogelijkheid om een verzoek te richten tot de trage instantie die met de behandeling van de zaak belast is, voldoet niet. ${ }^{963}$ Ook de omstandigheid dat het Bundesverfassungsgericht gedetailleerde aanwijzingen kon geven, en in de praktijk dat ook al eens had gedaan, over de wijze waarop de procedure versneld kon worden, kan de Duitse regering niet baten, vanwege het uitzonderingskarakter van dat soort aanwijzingen in de rechtspraak van het Bundesverfassungsgericht. ${ }^{964}$ Kortom, een voorziening is pas effectief indien de oordelende instantie de bevoegdheid heeft om specifieke maatregelen te bevelen die de procedure waarin de redelijke termijn is of dreigt te worden overschreden kan bespoedigen.

Ook aan de compensatoire voorzieningen worden eisen gesteld. Uit de Scordinouitspraak blijkt dat excessieve vertragingen in de compensatoire voorziening afbreuk doen aan de effectiviteit van de voorziening. Bovendien moet binnen zes maanden na de uitspraak waarbij compensatie wordt toegekend die compensatie uitbetaald worden wil de voorziening als effectief kunnen worden aangemerkt. De procedurele regels die gelden voor de voorzieningen mogen afwijken van het 'gewone' procesrecht, mits deze nog

${ }^{960 .}$ Zie hierover ook: Schreuder-Vlasblom 2009, p. 462-465

961. EHRM 29 maart 2006, EHRC 2006/61 m.nt. Van der Velde; AB 2006/294 m.nt. Barkhuysen en Van Emmerik. Op dezelfde dag heeft de Grote Kamer nog acht andere uitspraken gedaan met dezelfde uitkomst en grotendeels vergelijkbare overwegingen: Riccardi Pizzati t. Italië, nr. 62361/00, JB 2006/134 m.nt. AMLJ; Cocchiarella t. Italië, nr. 64886/01; Musci t. Italië, nr. 64699/01; Giuseppe Mostacciuolo t. Italië (nr. 1), nr. 64705/01; Mostacciuolo t. Italië (nr. 2), nr. 65102/01; Giuseppina en Orestina procaccini t. Italië, nr. 65075/01; Ernestina Zullo t. Italië, nr. 64897/01. De uitspraak Scordino vormt echter het standaardarrest waarnaar het EHRM zelf altijd verwijst.

962. Scordino t. Italië, par. 184.

${ }^{963 .}$ EHRM 8 juni 2006, Sürmeli t. Duitsland, EHRC 2006/100 m.nt. Jansen, par. 105. Kanttekening hierbij is wel dat ook meespeelde dat het Constitutionele Hof geen schadevergoeding kon toekennen.

964. Sürmeli t. Duitsland, par. 105 e.v. 


\section{De inrichting van de voorprocedures}

steeds voldoen aan 'the principles of fairness' als neergelegd in artikel 6 EVRM. Hetzelfde geldt voor de regels inzake de proceskosten. Ook die mogen afwijken van de normale regels, maar mogen in elk geval niet excessief zijn en daarmee beperking opleveren van de mogelijkheid gebruik te maken van de voorziening. ${ }^{965}$ Ten slotte is uiteraard de hoogte van het toegekende bedrag een belangrijke factor in de beoordeling van de effectiviteit van de voorziening. Wat betreft de materiële schadevergoeding, overweegt het EHRM dat de nationale instanties beter in staat zijn om daarover te oordelen. ${ }^{966}$ Inzake de immateriële schadevergoeding, stelt het uitdrukkelijk dat het uitgaat van een sterke maar weerlegbare presumptie dat overschrijdingen van de redelijke termijn immateriële schade in de vorm van spanning en frustratie tot gevolg hebben. In sommige gevallen mag geen of nauwelijks vergoeding voor dit soort schade worden toegekend. De nationale instanties zullen deze beslissing dan moeten voorzien van een deugdelijke motivering. Voorts kan de omvang van de schadevergoeding afhangen van de kenmerken en de effectiviteit van de voorziening; in het geval van een combinatie van een compensatoir en preventief rechtsmiddel mag de vergoeding lager uitvallen dan de vergoeding die het EHRM zelf normaliter zou toekennen voor de schending van de redelijke termijn. Dan geldt echter wel dat, zoals het Hof stelt:

"(...) the relevant decisions, which must be consonant with the legal tradition and the standard of living in the country concerned, are speedy, reasoned and executed very quickly." 967

Voldoet een nationale voorziening niet aan die voorwaarden dan kan de drempel die gepasseerd moet worden wat betreft de omvang van de vergoeding om niet meer als slachtoffer te kunnen worden aangemerkt hoger komen te liggen. Is de hoogte van het bedrag gelet op die factoren onredelijk laag in vergelijking tot het bedrag dat het EHRM zelf voor de schending van de redelijke termijn zou hebben toegekend, dan is de voorziening niet effectief en kan dus nog geklaagd worden bij het EHRM. Het EHRM heeft ook in andere uitspraken overwogen dat het met name immateriële schade is die een burger lijdt door de vertraging. ${ }^{968}$ De mogelijkheid om daarvoor een vergoeding toe te kennen is dus van bijzonder belang voor de effectiviteit van de voorziening. ${ }^{969}$

Effectief redres mogelijk naar nationaal recht?

Een algemeen beginsel van effectieve rechtsbescherming kennen we in het nationale recht, zoals in paragraaf 4.3.9 van Deel I uiteen is gezet, vooralsnog niet. Hoewel een specifieke grondslag voor de effectiviteit van het redres in ons nationale recht niet bestaat, hangt dit uitgangspunt samen met het tijdigheidsbeginsel/voortvarendheidsbeginsel alsmede met finale geschilbeslechting. Een eis die het bestuurlijk handelen normeert in dit opzicht en gericht is tot het bestuur is er echter evenmin. De eis van effectieve rechtsbescherming, in de betekenis dat er een rechtsmiddel bij het bestuur moet bestaan of het bestuur moet voorzien in een effectieve voorziening om schendingen te voorkomen of te redresseren, bestaat niet. In de eerste plaats ligt thans de verantwoordelijkheid voor het scheppen van effectieve voorzieningen bij de wetgever. Daarnaast is het aan de bestuursrechter om waar nodig soelaas te bieden tegen overschrijdingen van een redelijke beslistermijn door het bestuur. Als zodanig heeft dit beginsel dan ook geen betekenis als behoorlijkheidsnorm voor het optreden van het bestuur in de bestuurlijke voorprocedures. Het ontbreken van effectieve voorzieningen bij de rechter tegen bestuurlijke traagheid in de bestuurlijke voorfasen kan echter in strijd zijn met artikel 13 EVRM in combinatie met artikel 6 EVRM. Er gaat derhalve wel belangrijke invloed uit van die bepalingen op

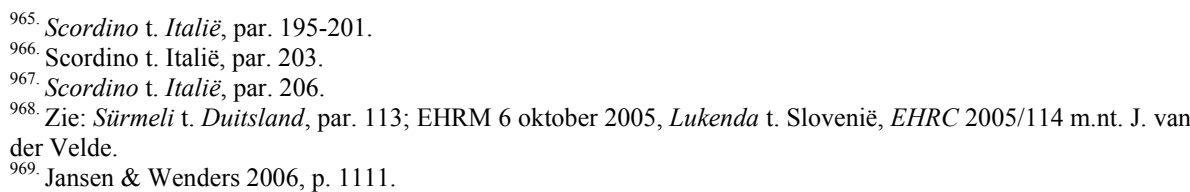




\section{Deel II Bestuurlijke voorprocedures}

de door het bestuur in acht te nemen voortvarendheid in de bestuurlijke voorprocedures en het belang dat daaraan gehecht wordt.

In het Nederlandse bestuursrecht bestaan verschillende algemene voorzieningen gericht tegen trage besluitvorming door bestuursorganen. In het onderstaande vindt uitsluitend een bespreking plaats van die algemene voorzieningen die in beginsel bestaan tegen besluiten (op bezwaar) op grond van de Awb. ${ }^{970}$ Allereerst betreft het een preventief middel, in de vorm van het instellen van beroep bij de bestuursrechter, waarmee het bestuur tot spoed gemaand kan worden. ${ }^{971}$ Deze algemene voorziening staat in beginsel ter beschikking in alle gevallen waarin niet tijdig een besluit in de zin van de Awb is genomen en, zoals blijkt uit artikel 6:12, tweede lid sub a en b Awb, twee weken zijn verstreken na het verzenden van een ingebrekestelling in dat kader aan het bestuur. In combinatie hiermee bestaat ook nog de mogelijkheid om een voorlopige voorziening op grond van artikel 8:81 Awb te vragen in spoedeisende gevallen. Tevens verbeurt het bestuursorgaan, twee weken na de dag van verzending van een ingebrekestelling, van rechtswege een dwangsom, zo volgt uit artikel 4:17 Awb. Het verbeuren van die dwangsom stelt het bestuur zelf vast of deze wordt door de bestuursrechter in het kader van het beroep tegen het niet tijdig beslissen vastgesteld. Voorts kan de bestuursrechter een (materieel) besluit vernietigen wegens strijd met het redelijke termijn-vereiste (van artikel 6 EVRM) en op grond van artikel 8:73 Awb daarbij schadevergoeding voor de vertraging toekennen. ${ }^{972}$ Daarnaast kan een burger los van de procedure tegen het inhoudelijke besluit bij het bestuursorgaan een verzoek tot schadevergoeding indienen. Het al dan niet toekennen van die vergoeding door het bestuur wordt gezien als een besluit in de zin van de Awb waartegen rechtsmiddelen openstaan. ${ }^{973}$ In deze gevallen zal het veelal gaan om geschillen waarin sprake is van de vaststelling van een "civil right or obligation'. Indien de redelijke termijn geschonden is in een geschil waarin een bestuurlijke boete en derhalve een 'criminal charge' centraal staat, kan de bestuursrechter die boete matigen. ${ }^{974}$ Tot slot heeft de bestuursrechter in sommige gevallen volstaan met de enkele constatering dat de redelijke termijn geschonden is; de enkele erkenning van de schending vormt dan het redres dat de burger voor die schending ontvangt. ${ }^{975}$

De vraag is of deze middelen op zichzelf dan wel in samenhang beschouwd kunnen worden als effectief redres voor schendingen van de redelijke termijn in de bezwaar- of administratief beroepsfase. Hieronder worden de verschillende mogelijkheden, onderscheiden naar hun preventieve dan wel compensatoire aard, nader bezien en wordt ingegaan op de vraag of deze als zodanig te beschouwen zijn als effectief redres. Vervolgens wordt bezien of de verschillende voorzieningen in samenhang te beschouwen zijn als effectieve rechtsbescherming.

\section{Preventieve middelen}

Zoals aangegeven, achtte de regering en vooral ook de Tweede Kamer het noodzakelijk om een effectiever middel tegen trage besluitvorming door het bestuur te scheppen voor de burger. Om die reden is door de Wet dwangsom en beroep bij niet tijdig beslissen in de Awb een tweetal preventieve middelen om het bestuur te dwingen tot voortvarender besluiten gecreëerd. De noodzaak tot een effectiever middel lag overigens niet noodzakelijkerwijs in de eis van effectieve rechtsbescherming van artikel 13 EVRM. Meer alge-

\footnotetext{
970. Specifieke consequenties die voorzien zijn in bijzondere wetgeving, zoals het aannemen van een fictief (positief) besluit indien binnen de termijn geen besluit wordt genomen, komen derhalve niet aan bod.

${ }^{1 .}$ Uitgegaan wordt van de mogelijkheid om rechtstreeks beroep in te stellen tegen het niet tijdig nemen van een primair besluit die sinds 1 oktober 2009 door de inwerkingtreding van de Wet dwangsom en beroep bij niet tijdig beslissen bestaat alsmede de mogelijkheid om beroep in te stellen tegen het uitblijven van een besluit op bezwaar.

972. Barkhuysen \& Van Ettekoven 2009, p. 136. Zie ook hiervoor par. 5.7.5.1

${ }^{973 .}$ Barkhuysen \& Van Ettekoven 2009, p. 136-138.

974. Barkhuysen \& Van Ettekoven 2009, p. 135; Jansen \& Wenders 2006, p. 1117-1119.

975. Barkhuysen \& Van Ettekoven 2009, p. 135.
} 


\section{De inrichting van de voorprocedures}

mene effectiviteitsoverwegingen hebben de regering en Tweede Kamer ertoe aangezet een nieuwe regeling te scheppen. ${ }^{976}$

Het beroep tegen het niet tijdig beslissen maakt mogelijk dat de bezwaarschriftprocedure op grond van artikel 6:2 sub b Awb overgeslagen kan worden, indien het bestuur niet binnen de voorgeschreven termijn beslist. Voor niet tijdig beslissen op bezwaar of administratief beroep verandert er echter in dat opzicht niets. Daartegen kon al op grond van artikel 6:2 sub b Awb beroep bij de bestuursrechter worden ingesteld. Wel ontstaat de mogelijkheid om beroep in te stellen pas twee weken na de dag waarop het bestuur schriftelijk ingebreke is gesteld, ingevolge artikel 6:12, tweede lid, van de Awb. Die eis gold voorheen niet. Aan de ingebrekestelling lijken vooralsnog door de bestuursrechter geen specifieke vormeisen te worden gesteld ${ }^{977}$ De bestuursrechter stelt in beroep ook desgevraagd vast welke dwangsom het bestuur verbeurd heeft, zo blijkt uit artikel 8:55c Awb. Op grond van artikel 4:17 Awb verbeurt het bestuursorgaan immers, na het verstrijken van twee weken na de ingebrekestelling, een dwangsom van 20 euro per dag, oplopend met 40 euro per dag en met een maximum van 1260 euro. ${ }^{978}$ Indien de bestuursrechter constateert dat de beslistermijn is overschreden en nog geen besluit bekend is gemaakt, kan hij, op grond van artikel 8:55d Awb, het bestuur een termijn van twee weken stellen waarbinnen alsnog het besluit op bezwaar bekend gemaakt moet worden. In bijzondere gevallen kan een andere termijn worden gegeven. Aan die termijn wordt vervolgens weer een dwangsom verbonden. Die dwangsom zal echter hoger zijn dan de dwangsom die het bestuur op grond van artikel 4:17 Awb verbeurt. ${ }^{979}$ De behandeling van het beroep tegen niet tijdig beslissen vindt in beginsel plaats door middel van een vereenvoudigde behandeling als bedoeld in artikel 8:54 en wordt binnen acht weken afgerond, ingevolge artikel 8:55b Awb. Dat betekent dat een zitting in beginsel achterwege blijft. Als de bestuursrechter een zitting wenselijk acht, vindt de afdoening van de zaak plaats door middel van een versnelde behandeling als bedoeld in artikel 8:52 Awb. Tegen de uitspraak van de rechtbank gedaan met toepassing van de bevoegdheid tot vereenvoudigde behandeling staat geen hoger beroep open, maar alleen verzet op grond van artikel 8:55 Awb. Dat verzet wordt, op grond van artikel 8:55e Awb binnen vier weken behandeld. De beroepsmogelijkheid op grond van artikel 6:2 onder b van de Awb blijft, ook na de Wet dwangsom en beroep bij niet tijdig beslissen, echter louter een procedureel middel om een besluit af te dwingen en de onrechtmatigheid van het stilzitten vast te stellen. ${ }^{980}$ Tot slot bestaat nog aanvullend de mogelijkheid om tegelijkertijd met het beroep tegen het niet tijdig nemen van een besluit op bezwaar of administratief beroep een voorlopige voorziening aan te vragen op grond van artikel 8:81 Awb. In gevallen waarin een spoedeisend belang bestaat, kan een dergelijke voorziening zinvol zijn.

Ook als geen beroep wordt ingesteld bij de bestuursrechter tegen het niet tijdig beslissen verbeurt het bestuursorgaan, na het verstrijken van de beslistermijn en nadat twee weken verstreken zijn na de dag van verzending van de ingebrekestelling, een dwangsom. Dat zal dan echter door het bestuur zelf bij besluit moeten worden vastgesteld. De dwangsom die betaald moet worden, komt de belanghebbende ten goede. Gesteld kan worden dat deze maatregel dus ook in zekere zin compensatoir van aard is, aangezien een soort van vergoeding - althans een geldbedrag - wordt uitgekeerd. Het

\footnotetext{
976. Kamerstukken II 2004/05, 29 934, nr. 6, p. 1.

${ }^{977}$ Een (ten onrechte) ingediend bezwaarschrift kan als zodanig worden aangemerkt, Rb. A'dam 17 december 2009, LJN BL0518.

978. Art. 4:17 Awb. Zie voor de precieze modaliteiten van de wijzigingen uitvoeriger o.m.: R. Stijnen, 'Wet dwangsom en beroep bij niet tijdig beslissen (I), NJB 2010, p. 65-70 en R. Stijnen, 'Wet dwangsom en beroep bij niet tijdig beslissen (II)', NJB 2010, p. 468-474; C.M. Saris, 'Tijdig beslissen. Het doel dichterbij met de Wet dwangsom en beroep bij niet tijdig beslissen en de verruiming van de lex silencio positivo?, Gmst. 2008, 7292, p. 141-148.

${ }^{979}$ R. Stijnen, 'Wet dwangsom en beroep bij niet tijdig beslissen (II)', NJB 2010, p. 470.

${ }^{980 .}$ Schlössels \& Van Dam 2002, p. 2137; Marseille 2005, p. 10; Niessen 2004, p. 676.
} 
Deel II Bestuurlijke voorprocedures

gaat echter vooral om een financiële prikkel voor het betreffende bestuursorgaan om verdere overschrijding van de beslistermijn te voorkomen en voortvarend(er) te handelen. In dat opzicht heeft de dwangsom een ander karakter dan de schadevergoeding die per definitie redres vormt voor een al geconstateerde schending van de redelijke termijn en daardoor geleden (immateriële) schade. Daarom blijft daarnaast de schadevergoedingsmogelijkheid wegens overschrijding van de redelijke termijn gewoon nog bestaan, met dien verstande dat vanwege reeds uitbetaalde dwangsommen wellicht matigiging van de schadevergoeding mogelijk is. ${ }^{981}$

Omdat de bestuursrechter in de regel slechts een korte termijn kan stellen en aan de overschrijding van die termijn ook een dwangsom verbindt, vormt het beroep tegen niet tijdig beslissen een voldoende effectief middel om de besluitvorming te versnellen. Conform de jurisprudentie van het EHRM heeft de besturusrechter immers de mogelijkheid om specifieke maatregelen te treffen, zoals het stellen van een termijn of het verbinden van een dwangsom aan overschrijdiging van die termijn, teneinde bespoediging van de procedure te bewerkstelligen. ${ }^{982}$ Bovendien is met de overschrijding van de wettelijke beslistermijn nog niet overschrijding van de redelijke termijn in de zin van artikel 6 EVRM gegeven. De wettelijke beslistermijnen zijn korter, waardoor het beroep op grond van artikel 6:2 sub b Awb (en vervolgens genomen besluit) in het algemeen binnen de redelijke termijn zal vallen. ${ }^{983}$ Voor bestuurlijke vertragingen beschikt de het Nederlandse bestuursrecht in het licht van artikel 13 EVRM in theorie derhalve over voldoende redresmogelijkheden. Er moet echter voor gewaakt worden dat de procedure bij de bestuursrechter op grond van artikel 6:2 sub b Awb, in de bijzondere gevallen wel een zitting wenselijk wordt geacht, niet teveel tijd in beslag neemt. Ook moet ervoor gewaakt worden dat de termijn die aan het bestuur gegeven wordt in bijzondere gevallen niet te lang is. Indien echter conform de termijn van zes weken via de vereenvoudigde behandeling uitspraak wordt gedaan, lijkt - zeker in combinatie met de dwangsom voor het bestuur bij niet naleving van de door de bestuursrechter gestelde termijn - de effectiviteit van dit rechtsmiddel voldoende gewaarborgd. Daar komt nog bij dat een voorlopige voorziening gevraagd kan worden bij de voorzieningenrechter, welke procedure minder tijd in beslag neemt. De voorzieningenrechter kan in zo'n geval ook gebruik maken van zijn bevoegdheid tot kortsluiting op grond van artikel 8:86 Awb.

\section{Compensatoire middelen}

Compensatoire mogelijkheden om vertragingen te redresseren bestaan hoofdzakelijk uit een vergoeding voor de geleden schade. Die schade kan materieel of immaterieel zijn. Uit de jurisprudentie van het EHRM volgt dat de nationale rechter beide soorten schadevergoeding moet kunnen toekennen om de voorziening (tegen schending van de redelijke termijn) effectief te laten zijn. ${ }^{984}$ Daarbij ligt de focus op de immateriële schadevergoeding, omdat het EHRM veronderstelt dat schending van de redelijke termijn spanning en frustratie met zich brengt. Indien een instantie niet de bevoegdheid heeft om immateriële schadevergoeding toe te kennen, is de voorziening in de ogen van het EHRM niet effectief. ${ }^{985}$ Ook voor bestuurlijke traagheid dient de rechter immateriële schadevergoeding toe te kennen, wil de voorziening effectief zijn.

\footnotetext{
981. Zie ook de toelichting van de wetgever bij het voorstel Wet schadevergoeding bij termijnoverschrijdingen te raadplegeven via http://www.justitie.nl/actueel/persberichten/archief-2010/100413minister-schadevergoedingals-rechtszaken-veel-te-lang-duren.aspx? $\mathrm{cp}=34 \& \mathrm{cs}=579$, p. 3. Barkhuysen \& Van Ettekoven menen dat het in mindering brengen van de uitbetaalde dwangsommen niet mogelijk zou moeten zijn vanwege het verschillende karakter van de dwangsom en schadevergoeding, Barkhuysen \& Van Ettekoven 2009, p. 130, noot 12.

982. Sürmeli t. Duitsland, par. 105.

983. Schreuder-Vlasblom 2009, p. 466.

984. Van Dijk 2009, p. 123.

985. EHRM 8 juni 2006, Sürmeli t. Duitsland, EHRC 2006/100 m.nt. Jansen. Zie ook: EHRM 6 oktober 2005, Lukenda t. Slovenië, EHRC 2005/114 m.nt Van der Velde. Ook in die uitspraak acht het EHRM de onrechtmati-
} 


\section{De inrichting van de voorprocedures}

Op grond van het nationale recht kan de rechter in het kader van een procedure tegen het materiële besluit dat niet tijdig is genomen (maar uiteindelijk wel is genomen) wegens schending van de redelijke termijn door het bestuur schadevergoeding toekennen. In dat geval wordt het besluit vernietigd wegens strijd met artikel 6 EVRM en wordt op grond van artikel 8:73 Awb schadevergoeding toegekend. ${ }^{986}$ Ook kan de belanghebbende nadat de procedure tegen het materiële besluit geëindigd is of nadat hij het besluit ontvangen heeft dat hij wenste, een verzoek tot schadevergoeding wegens de vertraging bij het bestuursorgaan indienen. Het besluit van het bestuursorgaan daarop vormt een zelfstandig schadebesluit dat aangevochten kan worden bij de bestuursrechter. ${ }^{987}$ Een derde mogelijkheid vormt een onrechtmatige daadsactie bij de burgerlijke rechter waarbij op grond van artikel 6:162 BW schadevergoeding wordt gevorderd. ${ }^{988}$

De nationale rechter kan materiële schadevergoeding toekennen die is ontstaan vanwege de vertraging. Dat doet hij ook regelmatig en daarover bestond vanaf aanvang ook geen misverstand. In zoverre heeft de bestuursrechter altijd conform de jurisprudentie van het EHRM terzake geoordeeld. ${ }^{989}$ Inmiddels hanteren de bestuursrechters in het kader van de immateriële schadevergoeding, in navolging van de jurisprudentie van het EHRM, ook de veronderstelling dat overschrijdingen van de redelijke beslistermijn voor een belanghebbende spanning en frustratie met zich brengt. ${ }^{990}$ Daarvoor dient (tenzij expliciet van het tegendeel gebleken is) een immateriële schadevergoeding te worden toegekend. Voor de hoogte van de schadevergoeding kan de bestuursrechter aansluiten bij de criteria en bedragen die het EHRM hanteert, maar dat hoeft hij niet. ${ }^{991}$ Een lagere vergoeding is geoorloofd, mits deze niet onredelijk is. De hoogste bestuursrechters hanteren dan ook een andere berekeningsmethode voor de omvang van de schadevergoeding. ${ }^{992}$

Aangenomen wordt dat het niet tijdig beslissen, in de zin van overschrijding van de wettelijke beslistermijn, eveneens onrechtmatig handelen vormt door het bestuursorgaan waarvoor onder omstandigheden ook aansprakelijkheid kan bestaan. Schadevergoeding verkrijgen in dat verband is echter aanzienlijk lastiger, omdat duidelijk moet zijn wat het reële besluit zou zijn (geworden) en het causale verband tussen de schade en het reële besluit lastig aan te tonen is. Ook in dat verband zijn verschillende wegen voor schadevergoeding mogelijk: een zelfstandig schadebesluit, een verzoek tot schadevergoeding

ge daadsactie wegens overschrijding van de redelijke termijn geen effectief rechtsmiddel omdat niet is gebleken dat ook immateriële schadevergoeding kan worden toegekend.

986. Overigens lag dat lange tijd anders indien de vertraging te wijten is aan de bestuursrechter zelf. In dat geval kon de bestuursrechter wel een oordeel geven over de rechterlijke vertraging (zie: CRvB 8 december 2004, $A B$ 2005/73 m.nt. HBr; USZ 2005/56 m.nt. TB; JB 2005/30 m.nt JHK; CRvB 4 juli 2003, AB 2003/450 m.nt. HBr; $J B$ 2003/249 m.nt. AMLJ) maar aan dat oordeel geen rechtsgevolgen verbinden omdat hij zich onbevoegd acht om schadevergoeding toe te kennen gelet op art. 8:73 Awb. Sinds kort bestaat die mogelijkheid wel via een analoge artikel 13 EVRM-conforme interpretatie van art. 8:73 Awb door de bestuursrechter, zie: AbRvS 4 jun 2008, $A B$ 2008/229 m.nt. R.J.G.M. Widdershoven; JB 2008/146 m.nt. A.M.L. Jansen; USZ 2008/211 m.nt. T. Barkhuysen en M. van Emmerik; CRvB 11 juli 2008, $A B$ 2008/241 m.nt. Widdershoven; JB 2008/172 m.nt. AMLJ. Zie hierover ook: Barkhuysen \& Van Ettekoven 2009, p. 136-138; Barkhuysen \& Van Emmerik 2008, p. 1579 e.v.

${ }^{987}$ Barkhuysen \& Van Ettekoven 2009, p. 136-138.

${ }^{988 .}$ Barkhuysen \& Van Ettekoven 2009, p. 138-139.

989. B.J. van Ettekoven, R.C.S. Bakker, R.P. Hoogenboom, Tien jaar jurisprudentie schadevergoeding in het bestuursrecht, Deventer 2004, p. 133-162. Zie ook de toelichting bij het voorstel Wet schadevergoeding bij termijnoverschrijdingen, p. 3 .

${ }^{990 .}$ Zie o.m.: ABRvS 6 juni 2007, AB 2007/220, m.nt. Jansen; CRvB 22 september 2006, USZ 2006/343 m.nt. D. Wenders; CRvB 7 juli 2006, AB 2007/221, m.nt. Jansen; CRvB 8 december 2004, AB 2005/73 m.nt. HBr.

991. Die criteria heeft het EHRM uiteengezet in EHRM 10 november 2004, Riccardi Pizzatti t. Italië, AB 2005/257 m.nt. Barkhuysen; JB 2005/1 m.nt. A.M.L. Jansen; EHRC 2005/22 m.nt. Van der Velde (Kameruitspraak). Die criteria zijn overigens in de Grote Kamer-uitspraken over dezelfde kwestie later niet meer herhaald, EHRM 29 maart 2006, Scordino t. Italië, AB 2006/294 m.nt. Barkhuysen \& Van Emmerik; EHRC 2006/61 m.nt. Van der Velde. Zie ook: EHRM 29 maart 2006, Ricardi Pizzati t. Italië, (Grote Kamer), JB 2006/134 m.nt. A.M.L. Jansen.

992. Zie hierover: Barkhuysen \& Van Emmerik 2009, p. 135-136. 
Deel II Bestuurlijke voorprocedures

op grond van artikel 8:73 in een procedure gericht tegen het niet tijdig beslissen bij de bestuursrechter op grond van artikel 6:2 sub b jo. 8:55b Awb en mogelijkheid van een vordering bij de burgerlijke rechter op grond van artikel 6:162 BW. ${ }^{993}$ Zodra tevens sprake is van schending van de redelijke termijn, als hiervoor bedoeld, geldt ook het hiervoor gestelde.

Overige mogelijkheden van redres

Strafvermindering kan in gevallen waarin de redelijke termijn-eis uit hoofde van een 'criminal charge' van toepassing adequaat en voldoende redres vormen. ${ }^{994}$ Voor het bestuursrecht gaat het dan om gevallen waarin een bestuurlijke boete is opgelegd (en in bezwaar wordt gehandhaafd). In het geval een bestuurlijke boete is opgelegd, kan de bestuursrechter in beroep wegens schending van de redelijke termijn de boete matigen (tot nihil). De Hoge Raad heeft dat al geruime tijd aangegeven, maar ook de overige bestuursrechters gaan hiertoe over. ${ }^{995}$ Gelet op de jurisprudentie van het EHRM is een reductie van de sanctie geoorloofd als compensatie voor een overschrijding van de redelijke termijn. ${ }^{996}$ Barkhuysen en Van Ettekoven constateren wel nog enige discrepantie tussen de omvang van de reductie en de omvang van schadevergoedingen bij nietpunitieve zaken. ${ }^{997}$

Mogelijk is ook dat wordt volstaan met de vergoeding van het griffierecht of proceskosten ter compensatie van overschrijdingen van de redelijke termijn. Een dergelijke compensatie is in beginsel in overeenstemming met de jurisprudentie van het EHRM. De bestuursrechter dient in zo'n geval wel expliciet te motiveren waarom volstaan wordt met een dergelijke geringe vergoeding. ${ }^{998}$

Tot slot kan de rechter in uitzonderlijke gevallen volstaan met de constatering dat artikel 6 EVRM geschonden is. ${ }^{999}$ De enkele erkenning van de schending vormt dan het redres voor de desbetreffende belanghebbende. De bestuursrechter heeft reeds enkele malen volstaan met een dergelijke erkenning dat de redelijke termijn niet in acht was genomen. ${ }^{1000}$ Het betrof dan bijvoorbeeld gevallen waarin de belanghebbenden voordeel had genoten van de vertraging doordat sprake was van overschuldigd betaalde bedragen die te laat werden teruggevorderd of er sprake was van een geringe overschrijding van de redelijke termijn. ${ }^{1001}$ In zo'n geval wordt het materiële besluit soms niet vernietigd (of de uitspraak van de bestuursrechter waarin het besluit in stand is gelaten wordt niet vernietigd). ${ }^{1002}$ Soms komt het besluit zelf vanwege de schending of een andere schending wel voor vernietiging in aanmerking, maar wordt geen schadevergoeding toegekend. ${ }^{1003}$

\footnotetext{
993. Zie hierover uitvoeriger: B.J. Schueler, Schadevergoeding en de Awb. Aansprakelijkheid voor appellabele besluiten, Deventer: Kluwer 2005, p. 60 e.v.; B.J. van Ettekoven, R.C.S. Bakker en R.P. Hoogenboom, Tien jaar jurisprudentie schadevergoeding in het bestuursrecht, Deventer: Kluwer 2004, p. 133-134.

994. EHRM 15 juli 1982, Eckle t. Duitsland, nr. 8130/78, par. 76.

995. HR 19 december 2008, $A B$ 2009/230 m.nt. Jansen; HR 22 april 2005, JB 2005/166 m.nt. Wenders; $A B$ 2006/11 m.nt. Jansen; HR 26 oktober 1980, $A B$ 1989/20 m.nt. Burg. Zie voor de overige bestuursrechters: ABRvS 19 november 2003, $A B$ 2004/27 m.nt. Jansen, JB 2004/15; CRvB 19 februari 1996, RAwb 1996/70 (m.nt. Widdershoven), RSV 1996/144; CBb 28 maart 1995, AB 1995/513 m.nt. Viering. Indien de boete wordt vernietigd kan de bestuursrechter zelf voorzien in de zaak en een boete opleggen. Sinds de inwerkingtreding van de vierde tranche kan dat op grond van art. 8:72a Awb. Zie hierover ook: Barkhuysen \& Van Ettekoven 2009, p. 135 .

996. EHRM 15 juli 1982, Eckle t. Duitsland, nr. 8130/78, par. 76.

${ }^{997 .}$ Barkhuysen \& Van Ettekoven 2009, p. 135.

998. Zie: Scordino, par. 204.

999. Barkhuysen \& Van Ettekoven 2009, p. 135; Van Ettekoven e.a. 2004, p. 136

1000. Zie bijvoorbeeld: AbRvS 26 maart 2008, LJN BC7604; CRvB 23 november 2006, LJN AZ0644; AbRvS 19 november 2003, $A B$ 2004, 27 m.nt. A.M.L. Jansen.

1001. Zie hierover: Barkhuysen \& Van Ettekoven 2009, p. 135.

1002. AbRvS 26 maart 2008, LJN BC7604; AbRvS 19 november 2003, AB 2004, 27 m.nt. A.M.L. Jansen.

1003. CRvB 23 november 2006, LJN AZ0644. De bestuursrechter zou in een geval waarin slechts een schending van art. 6 EVRM bestaat en geen schending van andere rechtsnormen ook de rechtsgevolgen van het besluit in stand kunnen laten in dit soort gevallen in mijn optiek.
} 


\section{De inrichting van de voorprocedures}

\section{Effectief redres tegen bestuurlijke traagheid}

Op grond van het bovenstaande kan worden aangenomen dat het redres en de rechtsmiddelen tegen overschrijdingen van de redelijke termijn van artikel 6 EVRM door het bestuur in beginsel voldoende effectief zijn en in overeenstemming zijn met de eisen die het EHRM stelt in zijn jurisprudentie. ${ }^{1004}$ Zeker in onderlinge samenhang bezien zullen de redresmogelijkheden, van zowel compensatoire aard als preventieve aard, voor schendingen van de redelijke termijn door het bestuur door de beugel kunnen. Op een punt kan wellicht nog een probleem ontstaan. En dat is de jurisprudentie van de bestuursrechter waarin deze heeft geoordeeld dat, indien na de bezwaarschriftprocedure geen beroep wordt ingesteld, geen aanspraak op schadevergoeding kan worden ontleend aan artikel 6 EVRM bij schending van de redelijke termijn door het bestuur. Tevens is er geen andere rechtsbasis waarop een dergelijke aanspraak kan worden gebaseerd. ${ }^{1005}$ Hoewel het EHRM zich over een dergelijke kwestie bij mijn weten nog niet heeft gebogen, dient deze jurisprudentie om de al in paragraaf 5.7.3 genoemde redenen verlaten te worden. Er zou ook een mogelijkheid tot schadevergoeding moeten bestaan bij overschrijding van de redelijke termijn in de bestuurlijke voorprocedures, indien die procedures niet gevolgd worden door een procedure bij de bestuursrechter. In de meeste gevallen zullen echter de bestaande mogelijkheden tot redres voldoende effectief zijn in het licht van artikel 6 en 13 EVRM.

\subsubsection{Doorwerking van de redelijke termijn-eis}

De vraag naar de doorwerking van de redelijke termijn-eis leek vrij eenvoudig beantwoord te kunnen worden. Voor zover het gaat om de redelijke termijn-eis, zoals neergelegd in artikel 6 EVRM, is die doorwerking rechtstreeks aangezien sprake is van directe toepasselijkheid van die eis op de bestuurlijke voorprocedures en schending van die eis ook consequenties met zich brengt. Bovendien is de ratio van de eis hetzelfde voor het bestuur in de bestuurlijke voorprocedures en de rechter. Vanuit het oogpunt van rechtszekerheid dient er sprake te zijn van voortvarende besluitvorming en rechtspraak. De doorwerking van de redelijke termijn-eis is echter in zeker opzicht beperkt. De redelijke termijn-eis uit artikel 6 EVRM is namelijk niet van toepassing op alle bestuursrechtelijke geschillen. Dat wordt weliswaar ondervangen door een nationale ongeschreven rechtsbasis aan te nemen, in de vorm van het algemene rechtszekerheidsbeginsel (dan wel een andere grondslag). Er kan echter thans uitsluitend een aanspraak voor schadevergoeding op de redelijke termijn-eis uit artikel 6 EVRM worden gebaseerd, indien daarna een procedure bij de bestuursrechter is gestart. Onduidelijk is nog of deze redelijke termijneis, op grond van een ongeschreven nationale rechtsbasis, ook geldt voor de bestuurlijke voorprocedures die niet gevolgd worden door een procedure bij de bestuursrechter. De doorwerking van de redelijke termijn-eis en de invloed ervan lijkt derhalve in dit opzicht toch nog indirect te zijn en plaats te vinden via de koppeling met de toegang tot de bestuuursrechter. Het nationale decisiebeginsel, als beginsel van behoorlijke rechtspleging waarvan de redelijke termijn onderdeel uitmaakt, speelt in deze ontwikkelingen geen rol van betekenis.

Onder invloed van de redelijke termijn-eis uit artikel 6 EVRM is de afgelopen jaren echter steeds meer aandacht in de doctrine voor het belang van naleving van termijnen door het bestuur ontstaan. De ontwikkelingen duiden op erkenning van een afzonderlijke rechtsnorm voor het bestuur. De invloed van artikel 6 EVRM in dit opzicht reikt derhalve verder dan uitsluitend de toepasselijkheid van die vereisten en de noodzaak om daaraan te voldoen op nationaal niveau. Een equivalent beginsel van de redelijke termijn als

\footnotetext{
1004. Vgl. Barkhuysen \& Van Ettekoven 2009, p. 130 en 140.

${ }^{1005}$ CRvB 29 april 2009, LJN BI2748, JB 2009/152 m.nt. redactie; AbRvS 17 juni 2009, 200901365/2/H2, LJN
} BI8475. 


\section{Deel II Bestuurlijke voorprocedures}

rechtsnorm voor het bestuur, al dan niet als onderdeel van het zorgvuldigheidsbeginsel of het rechtszekerheidsbeginsel, is echter nog niet algemeen erkend. Om de hiervoor genoemde redenen is de erkenning van een afzonderlijk beginsel wel wenselijk. De onderliggende grondslag en ratio van een redelijke termijn-eis voor het bestuur valt dan vanzelfsprekend nog steeds te herleiden tot het algemene rechtszekerheidsbeginsel. Uiteindelijk vormt de eis van besluitvorming of rechtspraak binnen een redelijke termijn altijd een uitwerking of specificatie van dat algemene rechtszekerheidsbeginsel. Erkenning van een afzonderlijke norm voor het bestuur sluit echter aan bij de ontwikkelingen in de doctrine en is ook nodig gelet op de ontwikkelingen in de rechtspraak.

Op nationaal niveau bestaat tevens effectief redres tegen schendingen van de redelijke termijn door bestuursorganen in de zin van artikel 13 EVRM. Bovendien zijn er op nationaal niveau wijzigingen doorgevoerd die beogen de rechtsbescherming tegen traag bestuur effectiever te maken. Aanleiding daarvoor was echter niet zozeer artikel 6 en 13 EVRM, maar meer algemeen de discussie over de effectiviteit van bestaande rechtsmiddelen. Die discussie en de aandacht voor deze kwesties is natuurlijk ook beïnvloed door de ontwikkelingen in het kader van die verdragsbepalingen. Aan de schendingen van de redelijke termijn door het bestuur worden in het algemeen consequenties verbonden en die schendingen worden ook voldoende geredresseerd in het licht van artikel 13 EVRM. Er kan schadeplichtigheid bestaan en schending van de redelijke termijn als bedoeld in artikel 6 EVRM leidt in de meeste gevallen tot de vernietiging van het besluit op bezwaar.

\subsection{Conclusies}

Het karakter van de bestuurlijke voorprocedures en de behoorlijkheidseisen

In de bevindingen van het onderzoek naar de werkzaamheid van het bestuur in de bestuurlijke voorprocedures wordt bevestigd dat de bezwaarschriftprocedure en het administratief beroep een vorm van rechtsbescherming en verlengde besluitvorming vormen. De traditionele verschillen met rechtspraak en de toetsing door de bestuursrechter bleken echter kleiner dan altijd verondersteld wordt op grond van de staatsrechtelijke verhoudingen tussen bestuur en rechter. De tegenstellingen zijn niet zo absoluut als vaak wordt aangenomen. De verschillen die in de praktijk bestaan vormen ook geen aanleiding om enige mate van invloed van de beginselen van behoorlijke rechtspleging uit te sluiten. Voor de inrichting van de procedure en de procedurele waarborgen zijn de traditionele verschillen in werkzaamheid tussen bestuur en rechter niet zodanig van belang dat op voorhand geconcludeerd moet worden tot uitsluiting van betekenis van de beginselen van behoorlijke rechtspleging voor de bestuurlijke voorprocedures. Per beginsel zal moeten worden bezien in hoeverre de werkzaamheid van het bestuur en het karakter van de bestuurlijke voorprocedures noopt tot het stellen van andere eisen. Wel is het zo dat de bestuurlijke voorprocedures, in het bijzonder de bezwaarschriftprocedure, niet gekenmerkt kunnen worden als een rechtsbeschermingsvoorziening óf verlengde besluitvormingsvoorziening. De procedures dragen beide kenmerken in zich in algemene zin en afhankelijk van de inrichting van de procedure en de aard van de bevoegdheid in het concrete geval zal een van beide elementen kunnen overheersen. Rechtsbescherming en verlengde besluitvorming zien veeleer op de twee verschillende perspectieven die bij deze procedures betrokken zijn: het perspectief van de belanghebbende of van het bestuursorgaan.

\section{Rechtsbescherming en zorgvuldige besluitvorming}

Uit de bevindingen komt ook naar voren dat de twee karakteristieken van de voorprocedures, rechtsbescherming en verlengde besluitvorming geen tegenstellingen vormen, maar veeleer een uitdrukking vormen van de twee verschillende perspectieven op die procedures. Vanuit het perspectief van de burger overheerst de rechtsbeschermingsfunctie, terwijl vanuit het bestuur geredeneerd de nadruk ligt op het verlengde besluitvor- 


\section{De inrichting van de voorprocedures}

mingskarakter. In mijn optiek betreft het twee keerzijdes van een en dezelfde medaille. Het verlengde besluitvormingskarakter en de toename van de zorgvuldigheid die daarmee samenhangt komt de rechtsbescherming van de burger ten goede. Andersom komen de rechtsbeschermingsmogelijkheden, zoals het horen van belanghebbenden, ook de zorgvuldigheid van de besluitvorming ten goede. Voor de procedure bij de bestuursrechter kan in feite hetzelfde geconstateerd worden. Enerzijds is er sprake van materiële waarheidsvinding en anderzijds moet individuele rechtsbescherming worden geboden. Ook hier gaat het om twee taken die dienstbaar kunnen zijn aan elkaar en geen tegenstelling vormen. Uiteraard kan zich in het concrete geval, in zowel de bestuurlijke voorprocedures als de procedure bij de rechter wel een situatie voordoen waarbij beide taken of perspectieven conflicteren. Ook in de twee karakteristieken van de bestuurlijke voorprocedures, in vergelijking tot de karakteristieken van de procedure bij de bestuursrechter, is derhalve geen aanleiding te vinden om op voorhand betekenis van de beginselen van behoorlijke rechtspleging uit te sluiten voor de bestuurlijke voorprocedures.

\section{Doorwerking van de beginselen van behoorlijke rechtspleging: differentiatie noodzakelijk}

Uit de bevindingen in dit hoofdstuk blijkt allereerst dat bepaalde beginselen van behoorlijke rechtspleging wel degelijk van invloed zijn op de voor de inrichting van de bestuurlijke voorprocedures geldende eisen. Tevens blijkt echter dat een antwoord in algemene zin op de vraag of en in hoeverre de beginselen van behoorlijke rechtspleging doorwerken in de bestuurlijke voorprocedures niet te geven valt. Differentiatie tussen de verschillende beginselen is onontkoombaar, aangezien geen enkel beginsel van behoorlijke rechtspleging dezelfde invloed uitoefent op de bestuurlijke voorprocedures als een van de overige beginselen. Het is ook niet altijd eenvoudig gebleken om de betekenis van de beginselen van behoorlijke rechtspleging voor de bestuurlijke voorprocedures exact vast te stellen. In veel gevallen blijkt er slechts impliciet invloed uit te gaan of zijn gegaan van de beginselen van behoorlijke rechtspleging. Bovendien is de opstelling van met name de bestuursrechter in veel gevallen aarzelend en zoekt deze eerder aansluiting bij bestaande tot het bestuur gerichte normen of algemene beginselen van behoorlijk bestuur met een vergelijkbaar karakter of ontkent deze de werking van bepaalde tot de rechter gerichte eisen voor de bestuurlijke voorprocedures. In Deel III van dit onderzoek worden de bevindingen over de doorwerking van de verschillende beginselen op een rij gezet en onderling vergeleken. Voorts wordt daarin nader ingegaan op de benadering en toetsing van de bestuursrechter ten aanzien van de beginselen van behoorlijke rechtspleging in het algemeen en in het bijzonder voor zover het bestuurlijke voorprocedures betreft. 



\section{DEEL III Slotbeschouwing}

\section{$1 \quad$ Inleiding}

Het onderwerp van dit proefschrift raakt aan verschillende onderwerpen die verband houden met de inrichting van het Nederlandse bestuursrechtelijke systeem van rechtsbescherming en het bestuursprocesrecht. Waarborgen voor een behoorlijke rechtspleging zijn essentieel voor het bieden van behoorlijke en effectieve rechtsbescherming, maar zijn daartoe niet voldoende. Kwaliteit en effectiviteit van rechtsbescherming is afhankelijk van allerlei factoren, die voor een deel buiten het bereik van de eisen van behoorlijke rechtspleging liggen. De gehele inrichting en organisatie van het stelsel van bestuursrechtelijke procedures zijn in dat kader van belang. ${ }^{1}$ Bepaalde elementen in dat stelsel zijn voor het realiseren van behoorlijke rechtsbescherming in een concreet geval evenzeer van betekenis als de inachtneming van eisen van behoorlijke rechtspleging. De wijze van toetsing door de bestuursrechter van besluiten van bestuursorganen en de bevoegdheden van de bestuursrechter spelen bij het daadwerkelijk realiseren van een behoorlijke rechtsbescherming in een concreet geval bijvoorbeeld ook een belangrijke rol. De aan de bestuursrechter toekomende bevoegdheden staan echter niet op zichzelf. Die rechterlijke bevoegdheden ten aanzien van besluiten van het bestuur hangen weer samen met de verhouding tussen de bestuursrechter en het bestuur in ons staatsbestel. Binnen het staatsrechtelijk kader waarin de bestuursrechter zich kan begeven en zijn werkzaamheid kan verrichten, is voorts de opstelling van de bestuursrechter over de beginselen van behoorlijke rechtspleging van belang voor de betekenis die deze beginselen kunnen hebben voor de uitkomst van de procedure in een concreet geval. Hetzelfde kan gesteld worden ten aanzien van de opstelling van de bestuursrechter ten opzichte van de algemene beginselen van behoorlijk bestuur en de betekenis daarvan of daaruit voortvloeiende eisen voor de totstandkoming van een besluit in een concreet geval. Specifiek voor de bestuurlijke voorprocedures is daarbij van belang dat zij, als procedures die ten overstaan van het bestuur gevoerd moeten worden, een unieke positie innemen in het Nederlandse stelsel van rechtsbescherming. De mate waarin die procedures omkleed zijn met processuele waarborgen en de mate waarin daarin sprake is van behoorlijke rechtsbescherming kan van die unieke positie niet los worden gezien. Het tweeledige karakter van de bestuurlijke voorprocedures, te weten verlengde besluitvormig en rechtsbescherming, beinvloedt ook de wijze waarop de bestuursrechter deze procedures benadert en welke eisen de bestuursrechter daaraan stelt.

De resultaten van het onderzoek in de twee voorgaande delen geven dan ook aanleiding tot enkele beschouwingen van meer algemene aard over de positie van de bestuurlijke voorprocedures binnen het bestuursrechtelijke systeem van rechtsbescherming. Tevens vormen de positie en de opstelling van de bestuursrechter ten aanzien van de beginselen van behoorlijke rechtspleging kwesties die herhaaldelijk in de uitkomsten van het onderzoek terugkomen. Ook daarop wordt in dit laatste deel van het onderzoek nader ingegaan. Deze meer algemene beschouwingen vinden plaats naar aanleiding van de conclusies over de invloed van de beginselen van behoorlijke rechtspleging op de bestuurlijke voorprocedures. In paragraaf 2 komen dan ook allereerst de conclusies ten

${ }^{1 .}$ Zie over uiteenlopende aspecten van kwaliteit van rechtspraak o.m. de bijdragen aan het congres 'Kwaliteit van Rechtspraak' in: P.M. Langbroek, K. Lahuis, J.B.J.M. ten Berge (red.), Kwaliteit van rechtspraak op de weegschaal, W.E.J. Tjeenk Willink 1998. 


\section{Deel III Slotbeschouwing}

aanzien van deze doorwerking van de beginselen van behoorlijke rechtspleging aan de orde. In deze paragraaf vindt slechts ten dele een herhaling plaats van de tussenconclusies in hoofdstuk 5 van Deel II, waarin de invloed van de beginselen van behoorlijke rechtspleging op de bezwaarschriftprocedure en het administratief beroep voor ieder beginsel afzonderlijk is vastgesteld. Deze resultaten worden in dit hoofdstuk vooral in een algemeen kader geplaatst en tegen elkaar afgezet. Vervolgens bevat paragraaf 3 enkele algemene beschouwingen over de benadering van de bestuursrechter van de beginselen van behoorlijke rechtspleging en de positie van de bestuurlijke voorprocedures in het Nederlandse bestuursrecht. In paragraaf 4 staat de verhouding tussen de beginselen van behoorlijke rechtspleging en de algemene beginselen van behoorlijk bestuur centraal. Tot besluit wordt in paragraaf 5 geëindigd met enkele slotopmerkingen.

\section{De doorwerking van de beginselen van behoorlijke rechtspleging}

Differentiatie in de mate van doorwerking per beginsel

In deze paragraaf staan de uitkomsten van het onderzoek inzake de mate van toepasselijkheid van de beginselen van behoorlijke rechtspleging centraal. Van de vijf afzonderlijke beginselen van behoorlijke rechtspleging die zijn onderzocht (het beginsel van hoor en wederhoor, het onpartijdigheidsbeginsel, het openbaarheidsbeginsel, het motiveringsbeginsel en het beginsel van de redelijke termijn), is na onderzoek van de wet, de parlementaire geschiedenis, de literatuur en de jurisprudentie de mate van invloed op de bezwaarschriftprocedure en het administratief beroep vastgesteld. Die mate van doorwerking verschilt, zoals ook verwacht werd bij aanvang van het onderzoek, per beginsel. Opmerkelijk is dat, zoals blijkt uit de tussenconclusies in hoofdstuk 5 van Deel II ten aanzien van de verschillende beginselen, de mate van doorwerking voor géén van de onderscheiden beginselen in zijn geheel exact hetzelfde lijkt te zijn. Daar komt nog bij dat er verschillen in betekenis van verschillende aspecten van één en hetzelfde beginsel van behoorlijke rechtspleging zijn geconstateerd.

De verschillende vormen van doorwerking die gevonden zijn, worden hieronder uitgewerkt in verschillende hoofdcategorieën. Daarbij gaat het om categorieën waarin de mate van doorwerking op hoofdlijnen aan de hand van enkele ijkpunten kan worden uitgedrukt. Zoals in het onderstaande nog nader uiteen zal worden gezet, zijn er tussen de beginselen of deelaspecten die binnen een categorie van doorwerking vallen, ook verschillen te constateren.

De verschillende gradaties van invloed van de beginselen van behoorlijke rechtspleging op de inrichting van de bestuurlijke voorprocedures variëren van rechtstreekse toepasselijkheid tot geen invloed op de voor de bestuurlijke voorprocedures geldende eisen. De omvang van die verschillende vormen van doorwerking van de afzonderlijke beginselen kan worden gezien als een glijdende schaal. Die schaal begint met de meest vergaande vorm van doorwerking van een beginsel of aspect van een beginsel en loopt af naar de minst vergaande vorm van doorwerking van een beginsel of aspect daarvan. Op die schaal van doorwerking wordt ingegaan in paragraaf 2.1. In paragraaf $2.2 \mathrm{komt}$ vervolgens een aantal factoren aan bod waarvan werd verondersteld en/of waarvan is gebleken dat zij van belang zijn voor de mate waarin de afzonderlijke beginselen doorwerken in de bestuurlijke voorprocedures. Tot slot komt in paragraaf 2.3 nog één aspect van de doorwerking, de gevolgen die verbonden worden aan schendingen van de beginselen van behoorlijke rechtspleging, afzonderlijk aan de orde.

\subsection{De verschillende vormen van doorwerking}

De verschillende categorieën

Zoals hierboven al werd aangegeven, werd de veronderstelling dat de betekenis van de beginselen van behoorlijke rechtspleging voor de bestuurlijke voorprocedures verschilt per beginsel in dit onderzoek bevestigd. In het onderstaande wordt eerst in algemene zin 


\section{Deel III Slotbeschouwing}

ingegaan op de verschillende gradaties van doorwerking die bestaan en wat zij inhouden. Vervolgens wordt aan iedere gradatie de beginselen van behoorlijke rechtspleging of deelaspecten van de beginselen die deze vorm van doorwerking vertonen gekoppeld.

\section{Rechtstreekse toepasselijkheid}

Allereerst kan een onderscheid worden gemaakt tussen beginselen of deelaspecten die rechtstreeks van toepassing zijn op de bestuurlijke voorprocedures en beginselen of deelaspecten die dat niet zijn. Rechtstreekse toepasselijkheid wil zeggen dat een beginsel van behoorlijke rechtspleging of een deelaspect van een beginsel rechtstreeks wordt toegepast op de bestuurlijke voorprocedures en de bestuursrechter de bestuurlijke voorprocedures aan dat beginsel van behoorlijke rechtspleging toetst. Er wordt, in het geval van een schending, een schending van het beginsel van behoorlijke rechtspleging, als rechtsnorm voor de bestuurlijke voorprocedures, geconstateerd. Inherent aan de rechtstreekse toepasselijkheid is dat deze vorm van doorwerking expliciet is in de zin dat het beginsel van behoorlijke rechtspleging of een deelaspect ervan expliciet van toepassing is verklaard op de bestuurlijke voorprocedures. Het beginsel of de uitwerking ervan heeft in het geval van rechtstreekse toepasselijkheid ook dezelfde ratio voor de bestuurlijke voorprocedures als voor de rechterlijke procedure. Indien het beginsel van behoorlijke rechtspleging in de bestuurlijke voorprocedure niet in acht is genomen, worden aan dat gebrek rechtsgevolgen verbonden door de bestuursrechter.

Binnen de rechtstreekse toepasselijkheid als categorie kan voor de bestuurlijke voorprocedures nog een onderscheid gemaakt worden tussen de subcategorieën zelfstandige en onzelfstandige rechtstreekse toepasselijkheid. De toepasselijkheid van het beginsel van behoorlijke rechtspleging of het deelaspect ervan is zelfstandig, indien de gelding ervan los staat van de toepasselijkheid van het beginsel op de rechterlijke procedure en de samenhang tussen de bestuurlijke voorprocedures en de rechterlijke procedure. Dat betekent dat het beginsel van behoorlijke rechtspleging geldt voor de bestuurlijke voorprocedures, ongeacht of daarna een rechterlijke procedure doorlopen wordt. Er is geen sprake van toepasselijkheid louter en alleen, omdat de bestuurlijke voorprocedures de toegang tot de rechter beperken. Is de rechtstreekse toepasselijkheid daarentegen verbonden aan (de toegang tot) de procedure bij de rechter, dan is zij onzelfstandig van karakter. Dat is bijvoorbeeld het geval bij het beginsel van de redelijke termijn in de jurisprudentie van de bestuursrechter. Dat beginsel kan bij een schending ervan in de bestuurlijke voorprocedure vooralsnog uitsluitend tot een aanspraak op schadevergoeding leiden, voor zover daarna nog een procedure bij de bestuursrechter wordt doorlopen. ${ }^{2}$ Van onzelfstandige rechtstreekse toepasselijkheid kan derhalve gesproken worden, indien een beginsel uitsluitend geldt voor de bestuurlijke voorprocedures indien daaropvolgend nog een rechterlijke procedure doorlopen wordt. Het beginsel geldt dan uitsluitend, indien er connexiteit tussen de bestuurlijke voorprocedure en de procedure bij de bestuursrechter bestaat.

\section{Expliciete indirecte toepasselijkheid}

Onder de rechtstreekse toepasselijkheid als categorie kan de indirecte toepasselijkheid als categorie worden geplaatst. Het betreft dan een vorm van betekenis waarbij het betreffende beginsel of deelaspect ervan - in tegenstelling tot het geval is bij rechtstreekse toepasselijkheid - niet expliciet rechtstreeks van toepassing is verklaard op de bestuurlijke voorprocedures, maar desalniettemin van betekenis is voor die procedures. De betekenis van het beginsel of deelaspect blijkt uit het bestaan van gelijksoortige uitwerkingen van dat beginsel voor de inrichting van de bestuurlijke voorprocedures. Die concrete

\footnotetext{
${ }^{2}$ Wel kan, ongeacht of daarna een procedure bij de rechter wordt doorlopen, een schending van de beslistermijn door een bestuursorgaan leiden tot het verbeuren van dwangsommen, zoals in par. 5.7 van Deel II is toegelicht. De dwangsom heeft echter, zoals is aangegeven in diezelfde paragraaf, een ander karakter dan schadevergoeding.
} 


\section{Deel III Slotbeschouwing}

eisen hebben bovendien dezelfde ratio voor de bestuurlijke voorprocdures als de concrete toepassingen van de beginselen van behoorlijke rechtspleging voor de procedure bij de rechter. Het verschil met de rechtstreekse toepasselijkheid is dat door de bestuursrechter niet expliciet erkend wordt dat het desbetreffende beginsel of deelaspect rechtstreeks van toepassing is op de bestuurlijke voorprocedures. Er is desondanks, evenals het geval is bij rechtstreekse toepasselijkheid, wél sprake van expliciete toepasselijkheid. Dat laatste is het geval, omdat een eis voor de bestuurlijke voorprocedures expliciet herleid wordt tot het beginsel van behoorlijke rechtspleging of het deelaspect daarvan. In het geval van deze vorm van doorwerking wordt door de bestuursrechter, evenals het geval is bij rechtstreekse toepasselijkheid, expliciet getoetst aan het beginsel en worden aan schending van de uitwerking ervan ook rechtsgevolgen verbonden. Het beginsel van behoorlijke rechtspleging is door de bestuursrechter echter nog niet rechtstreeks van toepassing verklaard op de bestuurlijke voorprocedures noch is het als beginsel van behoorlijk bestuur voor de bestuurlijke (voor)procedures erkend. Deze vorm van doorwerking ligt het dichtst aan tegen de rechtstreekse toepasselijkheid.

\section{Impliciete toepasselijkheid}

Impliciete toepasselijkheid van een beginsel of deelaspect ervan betekent dat een concrete eis voor de bestuurlijke voorprocedures niet expliciet herleid wordt tot een beginsel van behoorlijke rechtspleging, maar wat betreft inhoud en functie voor de bestuurlijke voorprocedures niet verschilt van de concrete eis die geldt voor de rechterlijke procedure. De concrete eis voor de bestuurlijke voorprocedure heeft een vergelijkbare of dezelfde strekking als de eis die herleid wordt uit een beginsel van behoorlijke rechtspleging. Daarmee lijkt materieel sprake te zijn van een uitwerking van een beginsel van behoorlijke rechtspleging. De betreffende eis wordt, ondanks de gemeenschappelijke functie en strekking, echter herleid tot een andere norm. Dat kan een voor het bestuur geldende norm in de vorm van een algemeen beginsel van behoorlijk bestuur zijn. Mogelijk is echter ook dat er geen erkend beginsel, van behoorlijke rechtspleging noch van behoorlijk bestuur, als grondslag wordt aangewezen. De bestuursrechter toetst in deze gevallen niet rechtstreeks aan een beginsel van behoorlijke rechtspleging, maar de wettelijke of ongeschreven eisen worden op dezelfde wijze toegepast of ingevuld. In geval van een schending van de concrete eisen wordt echter geen schending van een beginsel van behoorlijke rechtspleging geconstateerd. Het omgekeerde kan ook het geval zijn. De inhoud van de onderliggende rechtsnorm, een algemeen beginsel van behoorlijk bestuur, is hetzelfde en heeft eenzelfde functie als het beginsel van behoorlijke rechtspleging. Dat beginsel van bestuur is echter uitgewerkt voor het bestuur en brengt specifiek op het bestuur toegesneden concrete eisen met zich. Die uitwerkingen verschillen, gelet op de positie van het bestuur, van de uitwerkingen voor de rechter op grond van het equivalente beginsel van behoorlijke rechtspleging. De inhoud en functie van het beginsel, de onderliggende rechtsnorm, is echter dezelfde. De betekenis van het beginsel van behoorlijke rechtspleging voor de bestuurlijke voorprocedures is dan echter beperkt, omdat de beginselen van behoorlijk bestuur vrijwel volledig voorzien in de benodigde eisen. Ook in dit geval wordt door de bestuursrechter geen schending van een beginsel van behoorlijke rechtspleging geconstateerd, maar wordt een schending van een beginsel van behoorlijk bestuur aangenomen.

Bij de beginselen van behoorlijke rechtspleging die in deze categorie vallen worden derhalve aan schendingen van de voor het bestuur geldende eisen worden wel rechtsgevolgen verbonden, maar is de geschonden rechtsnorm geen beginsel van behoorlijke rechtspleging. In de meeste gevallen wordt de geschonden rechtsnorm gevonden in een beginsel van behoorlijk bestuur.

Afwezigheid van doorwerking

Tot slot is er ook een categorie van beginselen van behoorlijke rechtspleging waarvan in het geheel geen doorwerking is geconstateerd. Dat wil zeggen dat er geen aantoonbare 


\section{Deel III Slotbeschouwing}

betekenis van een beginsel valt vast te stellen op de eisen die gelden voor de inrichting van de bestuurlijke voorprocedures. De afwezigheid van doorwerking manifesteert zich in het ontbreken van concrete uitwerkingen van een beginsel. Dat betekent dat er geen concrete uitwerkingen of eisen bestaan die te herleiden zijn tot een beginsel van behoorlijke rechtspleging of een beginsel van behoorlijk bestuur. Dat houdt tevens in dat er geen vergelijkbare eisen voor de bestuurlijke voorprocedures gelden die eenzelfde functie hebben als voor de rechterlijke procedure. Dat betekent ook dat er geen vergelijkbare eisen bestaan die te herleiden vallen tot een beginsel van behoorlijk bestuur. Deze categorie van beginselen - strikt genomen is geen sprake van een categorie van doorwerking of een vorm van doorwerking - wordt als laatste behandeld.

De hiervoor beschreven vormen van doorwerking alsmede het ontbreken van invloed worden in de volgende paragraaf aan de hand van de desbetreffende beginselen waarbij zich een van die vormen van doorwerking voordoet toegelicht. In paragraaf 2.1.1 wordt aangevangen met de sterkste mate van doorwerking die is geconstateerd, de rechtstreekse toepasselijkheid, en in paragraaf 2.1.3 wordt geëindigd met de beginselen waarbij afwezigheid van enige betekenis of invloed is geconstateerd.

\subsubsection{Rechtstreekse toepasselijkheid}

Rechtstreekse toepasselijkheid is, zoals aangegeven, de meest vergaande vorm van doorwerking van een beginsel van behoorlijke rechtspleging die kan bestaan. Het uitgangspunt naar geldend recht is echter dat de beginselen van behoorlijke rechtspleging niet rechtstreeks gelden voor de bestuurlijke voorprocedures. Het ontbreken van rechtstreekse toepasselijkheid vormde juist een van de redenen om te onderzoeken of de beginselen van behoorlijke rechtspleging desondanks van betekenis zijn voor de bestuurlijke voorprocedures. Op dat algemene uitgangspunt dat de beginselen van behoorlijke rechtspleging niet van toepassing zijn op de bestuurlijke voorprocedures bestaat echter, zoals bekend en onder meer uiteen is gezet in paragraaf 5.7 van Deel II, een belangrijke uitzondering.

\section{Het beginsel van de redelijke termijn}

Van één beginsel stond op voorhand - dat wil zeggen voor aanvang van dit onderzoek vast dat het ook rechtstreeks van toepassing wordt geacht op de bestuurlijke voorprocedures: het beginsel van de redelijke termijn. Het beginsel van de redelijke termijn, zoals gepositiveerd in artikel 6 EVRM, maakt onderdeel uit van het nationale decisiebeginsel en valt te herleiden tot het algemene rechtszekerheidsbeginsel. De nationale grondslag voor de geldingskracht wordt in de rechtspraak van de bestuursrechter thans gezocht in dat algemene rechtszekerheidsbeginsel. Een verschil naar bestuurlijke of rechterlijke fase wordt in dat opzicht niet gemaakt. Wat betreft de functie of ratio van het beginsel van de redelijke termijn bestaat er geen noemenswaardig onderscheid tussen procedures bij het bestuur of bij de rechter. Het beginsel van behoorlijke rechtspleging is op dezelfde wijze van toepassing op rechtspraak als op de bestuurlijke voorprocedures. Hoewel de concrete uitwerkingen, wat betreft de duur van de procedure, niet geheel met die voor rechtspraak overeenstemmen, worden in beginsel dezelfde criteria en factoren gehanteerd om te bepalen of het beginsel van de redelijke termijn in acht is genomen in de bestuurlijke voorprocedures. De wijze waarop het beginsel van de redelijke termijn in de rechtspraak wordt toegepast op de bestuurlijke voorprocedures verschilt niet van de wijze waarop dat beginsel wordt toegepast op de rechterlijke procedures. De bestuursrechter toetst er rechtstreeks aan en verbindt dezelfde rechtsgevolgen aan schendingen van dat beginsel in de bestuurlijke voorprocedures en de rechterlijke procedure.

Onzelfstandige toepasselijkheid

De categorie rechtstreekse toepasselijkheid kan, zoals eerder aangegeven, weer onderverdeeld worden in twee subcategorieën: onzelfstandige en zelfstandige (rechtstreekse) 


\section{Deel III Slotbeschouwing}

toepasselijkheid. Hoewel sprake is van rechtstreekse toepasselijkheid van het beginsel van de redelijke termijn wordt in de rechtspraak vooralsnog uitgegaan van een onzelfstandige of accessoire rechtstreekse toepasselijkheid. Dat wil zeggen dat de rechtstreekse toepasselijkheid op de bestuurlijke voorprocedures samenhangt met de toegang tot de rechterlijke procedure. Wordt na de bestuurlijke voorprocedure geen rechterlijke procedure doorlopen, dan is de gelding van het beginsel van de redelijke termijn voor de bestuurlijke voorprocedures beperkt. Vooralsnog dient het rechtszekerheidsbeginsel of het beginsel van de redelijke termijn als specificatie daarvan derhalve niet als zelfstandige grondslag voor toepasselijkheid van de redelijke termijn-eis op de bestuurlijke voorprocedures als zodanig. De doorwerking van het beginsel van de redelijke termijn als beginsel van behoorlijke rechtspleging draagt er wel toe bij dat in de doctrine langzaamaan erkenning plaatsvindt van een zelfstandig voortvarendheids- of tijdigheidsbeginsel voor de bestuurlijke voorprocedures. Voor een dergelijke invloed van het beginsel van behoorlijke rechtspleging op die procedures bestond ruimte, omdat er tot nog toe geen equivalent algemeen beginsel van behoorlijk bestuur is aanvaard op grond waarvan vergelijkbare eisen gesteld worden.

\section{Zelfstandige toepasselijkheid}

Rechtstreekse toepasselijkheid op de bestuurlijke voorprocedures met een zelfstandig karakter is vooralsnog bij geen enkel beginsel of deelaspect ervan vastgesteld. Een dergelijke zelfstandige rechtstreekse toepasselijkheid of een zelfstandig beginsel voor de bestuurlijke voorprocedures wordt wel voor het beginsel van de redelijke termijn in dit onderzoek bepleit. Gelet op het feit dat in veel gevallen een bestuurlijke voorprocedure het eindstation van de rechtsbescherming vormt, omdat er daaropvolgend geen rechterlijke procedure geïnitieerd wordt, valt voor een zelfstandige toepassing of grondslag veel te zeggen. Bovendien valt niet in te zien op welke grond toepasselijkheid van het (nationale) beginsel van de redelijke termijn uitgesloten moet worden voor bestuurlijke voorprocedures die niet gevolgd worden door een procedure bij de rechter. Het beginsel van de redelijke termijn heeft immers eenzelfde functie voor de bestuurlijke voorprocedures als voor de rechter.

\subsubsection{De tussenvormen van doorwerking}

Tussen de rechtstreekse toepasselijkheid van het beginsel van de redelijke termijn en het ontbreken van invloed op de bestuurlijke voorprocedures, bevinden zich verschillende vormen van doorwerking die slechts gradueel van elkaar onderscheiden kunnen worden. Het gaat, zoals aangegeven, om expliciete indirecte doorwerking en impliciete doorwerking. De omvang van de invloed van de desbetreffende beginselen verschilt slechts op enkele punten. Toch meen ik dat er voldoende verschillen vallen aan te wijzen die afzonderlijke categorieën of indelingen rechtvaardigen. Hieronder worden de desbetreffende aspecten van de beginselen waarbij zich een vorm van indirecte expliciete of impliciete toepasselijkheid voordoet op een rij gezet.

\section{Expliciete indirecte doorwerking}

De eerste tussenvorm van doorwerking die kan worden onderscheiden is de expliciete indirecte doorwerking van een beginsel van behoorlijke rechtspleging. Hoewel het beginsel niet rechtstreeks van toepassing is op de bestuurlijke voorprocedures, blijkt uit de geraadpleegde bronnen dat nadrukkelijk verwezen wordt naar het desbetreffende beginsel als grondslag of ter interpretatie van de concrete eisen voor de inrichting van de bestuurlijke voorprocedures. Het kan gaan om eisen die voortvloeien uit de wettelijke regeling in de Awb of de jurisprudentie. In het eerste geval kan de wetgever en/of de bestuursrechter naar het beginsel of deelaspect ervan hebben verwezen, terwijl dat in het laatste geval uitsluitend de bestuursrechter zal zijn geweest. Deze vorm van doorwerking lijkt, zoals aangegeven, sterk op rechtstreekse toepasselijkheid. 


\section{Deel III Slotbeschouwing}

Naast het beginsel van de redelijke termijn wordt uitsluitend één concrete eis die is neergelegd in de Awb ook expliciet gebaseerd op een beginsel van behoorlijke rechtspleging. Het betreft de hoorplicht die is neergelegd in artikel 7:9 Awb. Die hoorplicht wordt in de literatuur en rechtspraak expliciet in verband gebracht met het beginsel van hoor en wederhoor. Deze eis kan naar inhoud en functie ook worden ondergebracht bij een van de vier deelaspecten van dat beginsel, namelijk het recht om informatie te verschaffen. In het kader van de plicht van het bestuur om opnieuw te horen, indien er nieuwe feiten of omstandigheden bekend worden, wordt in de rechtspraak door de bestuursrechter met minder terughoudendheid dan bij andere eisen verwezen naar het beginsel van hoor en wederhoor. Hoewel er geen algemene overwegingen gewijd worden aan toepasselijkheid van dat beginsel op bestuurlijke voorprocedures, wordt artikel 7:9 Awb daar wel expliciet mee in verband gebracht. Omdat in het bestuursrecht het beginsel van hoor en wederhoor als algemeen beginsel van behoorlijk bestuur niet erkend wordt, ligt het in de rede dat het gaat om toepasselijkheid van het beginsel van behoorlijke rechtspleging. In mijn optiek wordt het beginsel van hoor en wederhoor daarmee echter niet expliciet en rechtstreeks van toepassing verklaard op de bestuurlijke voorprocedures. Dat kan ook niet, omdat het beginsel als toepasselijke norm voor het bestuur nimmer in de rechtspraak als zodanig is erkend. De bestuursrechter toetst echter via artikel 7:9 Awb wel aan het beginsel en verbindt aan schending van die bepaling in beginsel rechtsgevolgen. In sommige gevallen worden ook ongeschreven hoorplichten expliciet naar het beginsel van hoor en wederhoor en artikel 7:9 Awb herleid. Dan geldt het voorgaande evenzeer voor die hoorplichten.

In deze categorie van indirecte, expliciete doorwerking valt ook het recht om stukken in te dienen op grond van artikel 7:4 Awb. Ook dat recht kan worden gezien als onderdeel van het beginsel van hoor en wederhoor en het deelaspect recht om informatie te verschaffen. Dit recht om stukken in te dienen wordt door de bestuursrechter op dezelfde wijze ingevuld als in de procedure bij de bestuursrechter en wordt beheerst door de goede procesorde. Dat is ook overeenkomstig de bedoeling van de wetgever en de invulling ervan in de literatuur. Met de goede procesorde lijkt in dit geval het beginsel van hoor en wederhoor bedoeld te worden. Die goede procesorde, die primair in verband wordt gebracht met de rechterlijke procedure, is de bepalende maatstaf voor de toepassing van het recht om stukken in te dienen en de bescherming van de processuele belangen van de wederpartij. De bestuursrechter toetst eraan en verbindt aan een schending van die maatstaf rechtsgevolgen.

Hetzelfde geldt voor het recht op inzage in de stukken op grond van artikel 7:4 Awb. Ook dat recht kan worden gezien als onderdeel van het beginsel van hoor en wederhoor en het recht om informatie te ontvangen. Dat recht op inzage in de stukken wordt ook door de bestuursrechter op dezelfde wijze ingevuld als voor de rechterlijke procedure en de wetgever heeft zelfs expliciet een verband gelegd met het beginsel van hoor en wederhoor.

\section{Impliciete doorwerking}

De impliciete doorwerking bestaat bij beginselen waarvan uitsluitend een vermoeden bestaat dat de concrete eisen die gelden voor de bestuurlijke voorprocedures in enigerlei mate te herleiden zijn tot de desbetreffende beginselen van behoorlijke rechtspleging, dat bij de toetsing door de bestuursrechter vergelijkbare criteria worden gehanteerd of dat sprake is van dezelfde functie van de geldende eisen. Expliciete refertes aan die beginselen zijn echter in de geraadpleegde bronnen niet gevonden. Het gaat derhalve om beginselen die rechtstreeks noch indirect gelden voor de bestuurlijke voorprocedures. De geldingskracht komt uitsluitend impliciet tot uitdrukking in de eisen en hun functie voor de bestuurlijke voorprocedures. Dat betekent ook dat de geldingskracht van deze beginselen beperkt is.

Deze vorm van doorwerking is geconstateerd bij het deelaspect openbaarheid van behandeling van het openbaarheidsbeginsel. In de geraadpleegde bronnen wordt niet 


\section{Deel III Slotbeschouwing}

verwezen naar het beginsel van behoorlijke rechtspleging als grondslag voor de uitwerking ervan in de wettelijke regeling van de bestuurlijke voorprocedures. Er bestaat een vermoeden dat de gelijkenis met rechtspraak de reden is voor de toepasselijkheid van deze openbaarheidseisen, die in hun uitwerking niet verschillen van die voor de rechterlijke procedure. Een achterliggende grondslag bestaat in dit geval ook niet in de vorm van een beginsel van behoorlijk bestuur.

Ook enkele aspecten van het beginsel van hoor en wederhoor kunnen in deze categorie van doorwerking worden ondergebracht. Te beginnen met de reguliere hoorplicht en de ongeschreven hoorplichten als onderdeel van het recht om mondeling informatie te verschaffen. Wat betreft inhoud en functie kunnen zij worden aangemerkt als uitwerkingen van het beginsel van hoor en wederhoor. Met name in de rechtspraak worden zij echter vooral onder het zorgvuldigheidsbeginsel geschaard. Geheel eenduidig is de rechtspraak daar overigens niet in. Ongeacht de gekozen grondslag blijft de inhoud van de eisen echter hetzelfde. De wisselende grondslag duidt er juist ook op dat de eisen die het zorgvuldigheids beginsel stelt op deze punten materieel niet verschillen van de eisen die het beginsel van hoor en wederhoor stelt. Ten slotte valt ook bij het vereiste van equality of arms indirecte, impliciete doorwerking te constateren. Weliswaar heeft de bestuursrechter expliciet geldingskracht aan dit vereiste voor de bestuurlijke voorprocedures ontzegd. Uit het onderzoek blijkt echter dat er eisen gelden voor de bestuurlijke voorprocedures die materieel op hetzelfde neerkomen: het garanderen van gelijke procesposities van belanghebbenden. Dat betekent dat er uitwerkingen van dat aspect van het beginsel van hoor en wederhoor bestaan die eenzelfde functie hebben als de eisen die uit equality of arms voortvloeien voor de rechterlijke procedure. In sommige gevallen worden ook deze eisen gebaseerd op het zorgvuldigheidsbeginsel, maar materieel bestaan er geen of nauwelijks verschillen. Daarmee kan gesteld worden dat ook het vereiste van equality of arms binnen de categorie impliciete doorwerking valt.

Tot slot kunnen ook het motiveringsbeginsel en het onpartijdigheidsbeginsel bij de laatste tussenvorm van doorwerking worden geplaatst. De doorwerking is enigszins verschillend van de doorwerking bij het openbaarheidsbeginsel of het beginsel van hoor en wederhoor. De equivalente beginselen van behoorlijk bestuur hebben dezelfde inhoud en functie voor het bestuur (in de bestuurlijke voorprocedures) als voor de rechter. De wijze waarop zij zijn uitgewerkt en de concrete invulling ervan op grond van artikel 7:12 Awb (en 3:46 en 3:47 Awb) respectievelijk artikel 2:4 Awb verschillen echter in bepaalde opzichten van de wijze waarop dezelfde beginselen zijn uitgewerkt voor de bestuursrechter. Materieel gezien geldt echter dezelfde rechtsnorm. De uitwerking ervan is verschillend, voor zover de taak en positie van het bestuur dat vereist. De toepassing van die beginselen is toegesneden op de werkzaamheid van het bestuur en de positie van het bestuur in de bestuurlijke voorprocedures. Uitsluitend in de functies van het beginsel (of de uitwerkingen ervan) en de wijze van toetsing kan enige betekenis van de beginselen van behoorlijke rechtspleging vermoed worden.

\subsubsection{Afwezigheid van doorwerking}

Als laatste moeten de beginselen of deelaspecten daarvan aan de orde komen, waarbij sprake is van het ontbreken van enige toepasselijkheid of invloed op de bestuurlijke voorprocedures. De vraag is wanneer die situatie zich voordoet. Het volledig ontbreken van invloed kan worden aangenomen als geen vergelijkbare inrichtingseisen bestaan met eenzelfde ratio die te herleiden vallen naar een beginsel van behoorlijke rechtspleging of naar een beginsel van behoorlijk bestuur voor de bestuurlijke voorprocedure. Een dergelijke afwezigheid van betekenis is voor geen enkel beginsel in al zijn facetten geconstateerd. Uitsluitend het externe deelaspect van het openbaarheidsbeginsel dat inhoudt dat de uitspraak - in bezwaar en administratief beroep de beslissing van het bestuur - toegankelijk moet worden gemaakt voor het publiek, vormt geen geldende eis voor de bezwaarschriftprocedure en het administratief beroep op grond van de Awb. De interne 


\section{Deel III Slotbeschouwing}

openbaarheidseisen op grond van dit aspect van het openbaarheidsbeginsel gelden echter ook voor het bestuur in de bestuurlijke voorprocedures. Ook in dat kader bestaan immers voorschriften die de bekendmaking aan partijen of belanghebbenden van de beslissing regelen. Deze interne openbaarheidseisen kunnen echter evenzeer onder het beginsel van hoor en wederhoor worden gebracht. Daarom worden onder de deelaspecten van het openbaarheidbeginsel vooral de externe eisen begrepen. Deze externe bekendmaking van de beslissing van het bestuur aan het publiek vormt geen algemeen geldende eis. Voorzover deze eis geldt in het kader van besluiten van algemene strekking komt daaraan niet dezelfde functie toe als aan de externe openbaarmakingseisen voor de uitspraak van de rechter. Om die reden wordt de eis van externe openbaarmaking van de uitspraak als onderdeel van het openbaarheidsbeginsel ondergebracht bij deze categorie. Er is geen sprake van toepasselijkheid op de bestuurlijke voorprocedures.

De afwezigheid van doorwerking doet zich verder alleen nog voor bij het vereiste van onafhankelijkheid van de rechterlijke instantie, dat in dit onderzoek niet wordt gezien als een beginsel van behoorlijke rechtspleging. Ook hier betreft het een eis die primair externe werking heeft en ziet op het waarborgen van het vertrouwen van het publiek in de rechtspraak. Er zijn onafhankelijkheidswaarborgen te herkennen in de regeling van de bestuurlijke voorprocedures in de Awb, maar deze hebben een beperktere strekking en moeten vooral geplaatst worden in het licht van de vereiste onpartijdigheid van het bestuur. In dat opzicht is onafhankelijkheid ook voor de bestuurlijke voorprocedures van belang. Die waarborgen moeten dan echter worden gezien als uitwerkingen van het onpartijdigheidsbeginsel en hebben dan ook vooral interne werking. De onafhankelijkheidswaarborgen delen derhalve ook in de aard van de doorwerking die toekomt aan het onpartijdigheidsbeginsel.

\subsubsection{De gevolgen van de indeling in verschillende categorieën}

\section{De gevolgen}

De hiervoor omschreven categorieën van doorwerking zijn niet uitputtend, in die zin dat met de kwalificatie van de vorm van doorwerking niet alle gevolgen voor de geldingskracht van de beginselen van behoorlijke rechtspleging voor de bestuurlijke voorprocedures gegeven zijn. Als sprake is van een van de tussenvormen van doorwerking, houdt dat een beperkte gelding van die betreffende beginselen van behoorlijke rechtspleging in. Dat is het geval bij het onpartijdigheidsbeginsel, het openbaarheidsbeginsel, het motiveringsbeginsel en bepaalde onderdelen van het beginsel van hoor en wederhoor. Voor enkele onderdelen van bepaalde beginselen is vastgesteld dat geen of nauwelijks sprake is van doorwerking, zoals het deelaspect 'openbare behandeling van de zaak' en equality of arms. Daarmee is echter niet per definitie gezegd dat eisen van een dergelijke strekking niet van betekenis zijn voor de bestuurlijke voorprocedures. In de gevallen waarin geen of nauwelijks doorwerking is geconstateerd, is het namelijk vooral lastig gebleken om een verband tussen de beginselen van behoorlijke rechtspleging en de voor de bestuurlijke voorprocedures geldende eisen vast te stellen. De geldende rechtsnormen en de daaruit voortvloeiende concrete eisen of uitwerkingen blijken echter in grote mate overeen te stemmen met de eisen die gelden voor de procedure bij de bestuursrechter. Zo kan gesteld worden dat het onpartijdigheidsbeginsel en het motiveringsbeginsel als beginsel van behoorlijk bestuur in feite dezelfde rechtsnormen vormen voor het bestuur als de desbetreffende beginselen van behoorlijke rechtspleging zijn voor de rechter. In hun uitwerkingen verschillen zij slechts omdat de uitwerkingen meer toegespitst zijn op de specifieke positie en taak van enerzijds het bestuur en anderzijds de rechter. Voor beide organen gelden echter in deze gevallen vergelijkbare eisen. In sommige gevallen valt er weliswaar geen doorwerking te constateren van de beginselen van behoorlijke rechtspleging, dat betekent echter niet dat er geen vergelijkbare procedurele waarborgen gelden voor het bestuur in de bestuurlijke voorprocedures. 


\section{Deel III Slotbeschouwing}

Wisselende categorieën

Een aantal vereisten dat geldt voor de bestuurlijke voorprocedures, in geschreven dan wel ongeschreven vorm, valt niet steeds onder te brengen in dezelfde categorie. Dat hangt samen met de omstandigheid dat met name de bestuursrechter deze vereisten niet consistent en eenduidig interpreteert. Deze vereisten vallen daardoor moeilijk te kwalificeren of te herleiden tot een specifiek beginsel. Dat verschijnsel doet zich bijvoorbeeld voor bij verschillende hoorplichten. Dat was bijvoorbeeld zichtbaar bij de ongeschreven hoorplicht die aangenomen wordt na vernietiging van een besluit door de bestuursrechter en de ongeschreven hoorplicht bij nieuwe feiten of omstandigheden waarop artikel 7:9 Awb niet rechtstreeks van toepassing is. Deze hoorplichten worden soms gebaseerd op het zorgvuldigheidsbeginsel en soms op het beginsel van hoor en wederhoor. Wat betreft de functie van deze vereisten lijkt het niet veel verschil te maken welk beginsel als perspectief wordt gekozen. Daarmee kan, zoals hierboven ook al werd aangegeven, de expliciete doorwerking van het beginsel van hoor en wederhoor weliswaar niet vastgesteld worden. Het is in elk geval een gegeven dat zulks niet hoeft te betekenen dat de eisen die gelden niet hetzelfde zijn of dezelfde functie hebben in de bestuurlijke voorprocedures als in de rechterlijke procedure.

\subsection{Factoren die de mate van doorwerking kunnen beïnvloeden}

In Deel I van dit onderzoek werd de veronderstelling geuit dat de beginselen van behoorlijke rechtspleging, die als primaire functie de bescherming van de procesbelangen van de deelnemers aan de procedure hebben, van meer betekenis kunnen zijn of zouden zijn voor de bestuurlijke voorprocedures dan beginselen met primair externe werking. De doorwerking van de intern werkende beginselen wordt immers niet gehinderd door de aard van de werkzaamheid of de aard van de instantie waarbij de procedure plaatsvindt, terwijl de externe werkende beginselen sterk samenhangen met de positie van de rechter als onafhankelijke rechtsprekende macht. In het onderstaande wordt bezien in hoeverre de resultaten uit Deel II van het onderzoek over de bestuurlijke voorprocedures deze veronderstelling bevestigen. Ook wordt nog ingegaan op een andere factor die, de conclusies uit Deel II ten aanzien van de afzonderlijke beginselen van behoorlijke rechtspleging overziend, de mate van doorwerking van de beginselen mogelijkerwijs of daadwerkelijk heeft beïnvloed: het bestaan van een equivalent beginsel van behoorlijk bestuur en/of equivalente daaruit voortvloeiende eisen. Deze factoren bieden als zelfstandige factor geen verklaring voor de verschillende vormen van doorwerking van de beginselen die zijn vastgesteld. Het zijn omstandigheden die een rol kunnen spelen bij de mate waarin een eis doorwerkt in de bestuurlijke voorprocedures. In sommige gevallen bieden de genoemde factoren onvoldoende verklaring voor de geconstateerde mate van doorwerking en is de (aan- of afwezigheid van) betekenis van de beginselen van behoorlijke rechtspleging niet eenduidig of expliciet terug te voeren op een bepaalde omstandigheid of factor.

\subsubsection{De interne of externe werking van de beginselen van behoorlijke rechtspleging}

In paragraaf 4.2 van Deel I van het onderzoek is de verwachting geuit dat de mate van externe of interne werking van een beginsel van behoorlijke rechtspleging van invloed kan zijn op de mate van doorwerking van dat beginsel in bestuurlijke voorprocedures (en ook andere procedures die niet tot echte rechtspraak gerekend kunnen worden). Voor de gelding van beginselen met hoofdzakelijk interne werking voor procedures doet immers de positie en organisatie van het oordelende orgaan niet terzake. Evenmin is de (met die positie samenhangende) aard van de werkzaamheid van de oordelende instantie van belang voor de geldingskracht van beginselen met interne werking. Zoals hieronder zal worden toegelicht, is deze veronderstelling slechts ten dele bevestigd. 


\section{Deel III Slotbeschouwing}

Interne en externe werking

In dit onderzoek werd aangenomen dat sommige beginselen van behoorlijke rechtspleging vooral van betekenis zijn in de onderlinge verhouding tussen de procesdeelnemers en de geschilbeslechtende instantie. Dat wil zeggen dat deze beginselen primair beogen het vertrouwen van die procesdeelnemers in de rechter en de totstandkoming van het oordeel van de rechter in het hun betreffende geschil te waarborgen. Met het oog op die functie vloeien uit die beginselen bepaalde vereisten voort, die waarborgen dat alle procesdeelnemers op een deugdelijke wijze kunnen deelnemen aan de procedure en dat zij op gelijke wijze door de oordelende instantie behandeld worden. De beginselen die primair interne werking hebben, zijn het beginsel van hoor en wederhoor, het onpartijdigheidsbeginsel, het motiveringsbeginsel en het beginsel van de redelijke termijn.

Daarnaast zijn er beginselen of eisen die voornamelijk externe werking hebben. Zij beogen primair het vertrouwen van het publiek en de samenleving, en niet zozeer de procesdeelnemers, in rechtspraak te waarborgen. Die beginselen hebben een externe werking die de desbetreffende procedure en de daaraan deelnemende actoren overstijgt. De externe werking van de beginselen van behoorlijke rechtspleging hangt samen met de positie van de rechter in ons staatsbestel, als onafhankelijke rechtsprekende macht en zijn verhouding tot de andere staatsmachten. Zoals werd aangegeven in Deel I, in paragrafen 4.2, 4.3.3 en 4.3.6, ontbeert de rechter een rechtstreekse democratische legitimatie en vervullen de onafhankelijkheidseis en openbaarheidseisen daarom een belangrijke democratische functie. De externe beginselen vormen de grondslag voor eisen voor de inrichting van de procedure of samenstelling van het orgaan met als doel het vertrouwen van het publiek daarin te handhaven, gelet op die positie van de rechter. Daarom worden uitsluitend de onafhankelijkheidseis en de openbaarheidseisen gerekend tot de eisen die primair extern werken. Uit deze beginselen vloeien immers eisen voort die de toegang tot de procedure of uitspraak voor het publiek garanderen dan wel de verhouding van de rechter tot de andere staatsmachten buiten het voorliggende geschil en de betrokken partijen om regelen.

Het onderscheid naar de interne en externe werking van beginselen van behoorlijke rechtspleging is echter niet absoluut. Tussen alle beginselen, ongeacht welke van beide functies de primaire functie van het beginsel vormt, bestaat een samenhang die zodanig is dat (vrijwel) alle beginselen een complementerende functie hebben ten opzichte van de overige beginselen. Een voorbeeld kan die samenhang tussen de beginselen verduidelijken. Hoewel het openbaarheidbeginsel vooral externe werking heeft en de toegang van het publiek tot de behandeling van de zaak en de uitspraak moet garanderen, kan daadwerkelijke openbaarheid pas zinvol zijn in combinatie met inachtneming van het motiveringsbeginsel, een beginsel dat primair interne werking heeft. Andersom worden de functies van het motiveringsbeginsel slechts geëffectueerd in combinatie met het openbaarheidsbeginsel. Dat betekent dat de beginselen met primair een externe of interne werking via de beginselen die een andere hoofdfunctie hebben, eveneens interne of externe werking verkrijgen of in elk geval aan de andere hoofdfunctie ten dienste staan.

\section{Relevantie van het onderscheid}

In welk opzicht kan het onderscheid tussen beginselen met interne en beginselen met externe werking relevant zijn? Van de beginselen die primair interne werking hebben, ligt doorwerking in of betekenis voor de bestuurlijke voorprocedures meer voor de hand. Die beginselen beogen immers de belangen van de procesdeelnemers in de procedure te waarborgen. Noodzaak daartoe bestaat in alle procedures waarin een geschil tussen verschillende partijen beslecht moet worden. Doorwerking van die beginselen van behoorlijke rechtspleging in bestuurlijke besluitvormingsprocedures behoeft dan ook in beginsel niet geremd of beperkt te worden door de aard van de oordelende instantie of de aard van de werkzaamheid van het beslissende orgaan. Met andere woorden de betekenis van de beginselen van behoorlijke rechtspleging met interne werking is niet uitsluitend gekoppeld te worden aan rechtspraak in eigenlijke zin. Dat is ook gebleken uit het onderzoek 


\section{Deel III Slotbeschouwing}

dat verricht is in Deel II. De uitwerkingen van of eisen gesteld op grond van het beginsel van hoor en wederhoor, het onpartijdigheidbeginsel, het motiveringsbeginsel en het beginsel van de redelijke termijn zijn voor bestuursrechtspraak en de bestuurlijke voorprocedures vergelijkbaar en hebben eenzelfde functie voor beide procedures. De verschillen in de uitwerkingen die geconstateerd kunnen worden, houden weliswaar verband met de positie en werkzaamheid van het bestuur, maar zijn niet dusdanig dat de conclusie gerechtvaardigd is dat er voor bestuur en rechter geheel verschillende normen of eisen gelden. De intern werkende beginselen of deelaspecten daarvan blijken de meest vergaande vormen van doorwerking vertonen. Zelfs de intern werkende beginselen waarvan nauwelijks doorwerking is geconstateerd, zoals het onpartijdigheidsbeginsel of het motiveringsbeginsel, hebben als zelfstandige norm voor het bestuur eenzelfde inhoud en functie als het beginsel van behoorlijke rechtspleging voor de rechterlijke procedure.

\section{Vergelijking met de extern werkende beginselen}

Het openbaarheidbeginsel, waaraan in dit onderzoek voornamelijk externe werking wordt toegekend, biedt een mooie illustratie van de wijze waarop die interne of externe werking van belang kan zijn voor de betekenis van een beginsel. De interne openbaarheideisen die zien op de bekendmaking van de beslissingen aan de procesdeelnemers of belanghebbenden en de aanwezigheid van de procesdeelnemers of belanghebbenden bij de mondelinge behandeling gelden in de bestuurlijke voorprocedures evenzeer voor het bestuur als voor de rechter in de rechterlijke procedure. Ongeacht of deze eisen op het openbaarheidbeginsel of het beginsel van hoor en wederhoor gestoeld worden, volgt uit deze eisen dat in de bestuurlijke voorprocedures de toegang tot de zitting en de beslissing van het beslissende orgaan voor belanghebbenden moet worden gewaarborgd. De geldingskracht van deze interne openbaarheidseisen, als behoorlijkheidseisen op grond van de Awb, is onomstreden in de bestuurlijke voorprocedures.

De externe openbaarheideisen, die zien op de toegang van het publiek tot de zitting en de uitspraak zijn daarentegen als behoorlijkheidsnormen niet of nauwelijks van betekenis voor de bestuurlijke voorprocedures. In de Awb zijn immers geen inrichtingseisen met eenzelfde functie als voor de rechterlijke procedure uitgewerkt waaruit een algemene publicatieplicht van de besluiten van bestuursorganen volgt. Hoogstens kan een verzoek gedaan op grond van de Wob leiden tot publicatie van besluiten. Dit extern werkend deelaspect van het openbaarheidsbeginsel heeft derhalve geen invloed op de bestuurlijke voorprocedures. Het andere extern werkende deelaspect van het openbaarheidsbeginsel, dat ziet op de toegankelijkheid van de zitting voor het publiek valt in een van de minst verstrekkende tussencategorieën van doorwerking. Dat deelaspect lijkt slechts indirect en impliciet van betekenis te zijn.

Invloed van de interne of externe werking van de beginselen op de doorwerking Op grond van de resultaten in hoofdstuk 5 van Deel II van dit onderzoek en hetgeen in paragraaf 2.1 van dit deel aan de orde is gekomen inzake de verschillende categorieën van doorwerking, kan de voorzichtige conclusie worden getrokken dat het onderscheid tussen de interne of externe werking van belang kan zijn voor de mate van betekenis van een beginsel voor de bestuurlijke voorprocedures. Het lijkt vooral zo te zijn dat de omstandigheid dat een extern werkend beginsel vooral ziet op het waarborgen van het vertrouwen van het publiek in de rechtspleging, gelet op de specifieke positie van de rechter in ons staatsbestel, in de weg kan staan aan doorwerking in bestuurlijke voorprocedures. De omstandigheid dat een beginsel primair intern werkt en beoogt de belangen van procesdeelnemers in de procedure te waarborgen, betekent daarentegen niet per definitie dat sprake is van doorwerking of een vergaande vorm van doorwerking. Van enkele primair intern werkende beginselen of deelaspecten van die beginselen is immers geen of nauwelijks doorwerking in de bestuurlijke voorprocedures geconstateerd. Mijns inziens bestaan er echter minder beletselen om die beginselen te laten doorwerken, omdat zij eenzelfde functie hebben voor de bestuurlijke voorprocedures en daaruit vergelijkbare vereisten 


\section{Deel III Slotbeschouwing}

voortvloeien. Bovendien waren alle beginselen waarvan de meest vergaande vormen van doorwerking werden geconstateerd primair intern werkende beginselen.

\subsubsection{Equivalente beginselen van behoorlijk bestuur}

Het bestaan van een equivalent beginsel van behoorlijk bestuur en de mate van doorwerking

Een andere omstandigheid die in hoofdstuk 5 van Deel II voor de afzonderlijke beginselen van behoorlijke rechtspleging steeds aan de orde kwam, is het al dan niet bestaan van een equivalent beginsel van behoorlijk bestuur. De aan- of afwezigheid van een equivalent beginsel van bestuur kan op verschillende manieren van invloed zijn op de mate van doorwerking van een beginsel van behoorlijke rechtspleging.

De afwezigheid van een equivalent beginsel van behoorlijk bestuur zou bijvoorbeeld de weg kunnen openen naar invloed van een beginsel van behoorlijke rechtspleging. Zo is de redelijke termijn-eis, waarvan geen equivalent beginsel van behoorlijk bestuur bestaat, voor het bestuur onder invloed van de voor de rechter geldende eis tot ontwikkeling gekomen. Deze norm heeft een steeds belangrijkere plaats gekregen in het Nederlands bestuursrecht ten opzichte van het bestuur en de ontwikkelingen op dat vlak rechtvaardigen thans een erkenning van dat beginsel voor de bestuurlijke voorprocedures. Denkbaar is voorts dat bij het bestaan van een equivalent beginsel van behoorlijk bestuur, in elk geval in de rechtspraak, eerder teruggegrepen zal worden op een dergelijk beginsel. $^{3}$ De aanwezigheid van een equivalent beginsel van behoorlijk bestuur kan derhalve in de weg staan aan betekenis van een beginsel van behoorlijke rechtspleging. De aanwezigheid van een equivalent beginsel van behoorlijk bestuur kan ertoe leiden dat de noodzaak, met name in de rechtspraak, om de beginselen van behoorlijke rechtspleging expliciet van betekenis te laten zijn of van toepassing te verklaren op de bestuurlijke voorprocedures in mindere mate bestaat. In eerste instantie en naar algemeen wordt aangenomen, worden de bestuurlijke voorprocedures, als besluitvormingsprocedures bij het bestuur, immers genormeerd door de beginselen van behoorlijk bestuur. Aan die beginselen, waaronder de aan de beginselen van behoorlijke rechtspleging equivalente beginselen, worden concrete eisen ontleend voor de inrichting van de besluitvormingsprocedure en de uitkomst daarvan. Anderzijds zou de aanwezigheid van een equivalent beginsel van behoorlijk bestuur met dezelfde of een vergelijkbare ratio de doorwerking van een beginsel van behoorlijke rechtspleging of uitwerkingen ervan ook kunnen vergemakkelijken. Voor de bestuursrechter zouden er bijvoorbeeld meer aanknopingspunten kunnen bestaan voor de toepassing of interpretatie van bepaalde eisen.

Uit de resultaten van het onderzoek in Deel II kan afgeleid worden dat ook de invloed van het al dan niet bestaan van een equivalent beginsel van behoorlijk bestuur op de mate van doorwerking van een beginsel van behoorlijke rechtspleging niet eenduidig is. Aan de uitkomsten van het onderzoek kunnen derhalve geen algemene conclusies ten aanzien van de aan- of afwezigheid van een equivalent beginsel van behoorlijk bestuur verbonden worden. Hieronder zal per beginsel van behoorlijke rechtspleging worden aangegeven van welke mate van doorwerking sprake is en of er een equivalent beginsel van behoorlijk bestuur wordt erkend.

\footnotetext{
${ }^{3 .}$ Enkele algemene beginselen van behoorlijk bestuur zijn gecodificeerd in de Awb, waardoor deze normen strikt genomen niet meer als ongeschreven beginselen van behoorlijk bestuur kunnen worden aangemerkt. Desondanks wordt in het navolgende steeds gesproken over beginselen van behoorlijk bestuur, aangezien deze ook onder de Awb nog steeds van betekenis zijn in hun ongeschreven vorm. Zoals ook door de wetgever is aangegeven bij de totstandkoming van de Awb staat opname van de beginselen in de Awb niet in de weg aan verdere ontwikkeling of verfijning van die beginselen, PG Awb I, p. 30 en 202.
} 
Deel III Slotbeschouwing

De mate van doorwerking afgezet tegen het bestaan van een equivalent beginsel van behoorlijk bestuur

De aanwezigheid of afwezigheid van een equivalent beginsel van behoorlijk bestuur correspondeert, zoals aangegeven, niet consistent met een bepaalde mate van doorwerking. Het beginsel dat het sterkst doorwerkt in de bestuurlijke voorprocedures, omdat sprake is van rechtstreekse toepasselijkheid, is het beginsel van de redelijke termijn. Van dat beginsel bestaat vooralsnog geen equivalent beginsel van behoorlijk bestuur. Daarentegen bestaat van het openbaarheidsbeginsel evenmin een equivalent beginsel van behoorlijk bestuur en is de doorwerking van het ene deelaspect van dat beginsel, de openbaarmaking van de uitspraak afwezig en de doorwerking van het andere deelaspect, de openbare zitting, gering. ${ }^{4}$ De aan- of afwezigheid van een equivalent beginsel van behoorlijk bestuur leidt dus niet tot automatisch tot af- of aanwezigheid van doorwerking van een beginsel van behoorlijke rechtspleging.

Ook bij de (andere) gevallen waarin er wel equivalente beginselen van behoorlijk bestuur bestaan doen zich inconsistenties voor. Voor het motiveringsbeginsel en het onpartijdigheidsbeginsel bestaan bijvoorbeeld equivalente beginselen van behoorlijk bestuur. Bij die beginselen is er, hoewel zij in functie en inhoud nauwelijks verschillen van de voor de rechter geldende normen, slechts beperkte doorwerking van de beginselen van behoorlijke rechtspleging geconstateerd.

Het beginsel van hoor en wederhoor neemt in dit verband bovendien weer een iets afwijkende positie in, omdat er strikt genomen geen equivalent beginsel van behoorlijk bestuur onder dezelfde benaming bestaat, maar een vergelijkbare norm voor het bestuur wel gevonden kan worden in het formele zorgvuldigheidsbeginsel dat een ruimere strekking heeft. Uit het zorgvuldigheidsbeginsel worden voor het bestuur vergelijkbare eisen met een vergelijkbare ratio afgeleid als uit het beginsel van hoor en wederhoor voor de rechter. Van het beginsel van hoor en wederhoor zijn bovendien sommige deelaspecten weer meer van invloed op de eisen die gesteld worden aan de bestuurlijke voorprocedures dan andere deelaspecten.

De conclusie moet dan ook zijn dat alleen op grond van het al dan niet bestaan van een equivalent beginsel van behoorlijk bestuur de mate van doorwerking niet kan worden verklaard.

De combinatie met interne of externe werking

Het al dan niet bestaan van een equivalent beginsel gecombineerd met de interne of externe werking van de beginselen van behoorlijke rechtspleging lijkt echter al iets meer duidelijkheid of inzicht te bieden in de mate van doorwerking van een beginsel. Het enige onderzochte beginsel dat primair externe werking heeft en waarvoor geen equivalent beginsel van behoorlijk bestuur bestaat is het openbaarheidsbeginsel. Dat beginsel werkt niet of nauwelijks door in de bestuurlijke voorprocedures. Het enige beginsel dat intern werkt en waarvan eveneens geen equivalent beginsel van behoorlijk bestuur bestaat is het beginsel van de redelijke termijn. Dat beginsel vertoont de meest vergaande vorm van doorwerking. Van twee van de overige intern werkende beginselen, zoals het onpartijdigheidsbeginsel en het motiveringsbeginselen bestaan equivalente beginselen van behoorlijk bestuur. Bij die beginselen is geen doorwerking geconstateerd. De aanwezigheid van een equivalent beginsel van behoorlijk bestuur dat stevig verankerd is in de nationale doctrine en rechtspraak lijkt er in deze gevallen toe te leiden dat geen aandacht besteed wordt aan of geen noodzaak tot betekenis bestaat van de beginselen van behoorlijke rechtspleging. Voor het beginsel van hoor en wederhoor, als intern werkend beginsel, geldt tot op zekere hoogte hetzelfde. Bepaalde eisen worden herleid tot het zorgvuldigheidsbeginsel en de bestuursrechter lijkt in het geval van ongeschreven eisen ook

\footnotetext{
4. Afgezien van de invloed die uitgaat van de Wob en de daaruit voortlvoeiende openbaarheidseisen op de be-
} stuurlijke voorprocedures inzake een besluit. 


\section{Deel III Slotbeschouwing}

eerder geneigd om daarop terug te grijpen. Tegelijkertijd worden bepaalde eisen ook expliciet op het beginsel van hoor en wederhoor gebaseerd. Het bestaan van een equivalent beginsel van behoorlijk bestuur lijkt daardoor vooral binnen de categorie intern werkende beginselen in de weg te staan aan de doorwerking van de beginselen van behoorlijke rechtspleging. Uitsluitend in het geval van de redelijke termijn lijkt er ruimte te bestaan voor vergaande doorwerking, aangezien daar geen equivalent beginsel van behoorlijk bestuur bestaat.

\subsection{De gevolgen van schendingen van de beginselen van behoorlijke rechtspleging}

\section{Rechtsnormen gericht tot de bestuursrechter}

De beginselen van behoorlijke rechstpleging richten zich in eerste instantie als rechtsnormen tot de bestuursrechter die de inachtneming van die beginselen in de rechterlijke procedure dient te waarborgen. Omdat de beginselen van behoorlijke rechtspleging rechtsnormen zijn, behoort schending van een beginsel of een essentiële uitwerking daarvan in beginsel rechtens gevolgen te hebben. In de regel zal een schending tot vernietiging van de uitspraak van de bestuursrechter dienen te leiden. Als er geen vernietiging volgt, zullen er rechtens andere consequenties verbonden dienen te worden aan de schending. Dat kan bijvoorbeeld betekenen dat er overgegaan wordt tot vergoeding van de gemaakte proceskosten of de betaalde griffierechten.

Zoals in paragraaf 3.2.2 van Deel $\mathrm{I}$ is aangegeven, kan de schending of dreigende schending van een beginsel van behoorlijke rechtspleging gedurende een procedure door de bestuursrechter zelf worden geconstateerd of in hoger beroep door de appelrechter. In veel gevallen zal de schending in een procedure in hoger beroep door de bestuursrechter worden geconstateerd en worden geredresseerd. Daarvan zal in elk geval sprake zijn bij schendingen van het motiveringsbeginsel, aangezien daarvan pas blijkt op het moment dat de uitspraak tot stand is gekomen en aan partijen en het publiek beschikbaar is gesteld. Ook schendingen van de deelaspecten van het openbaarheidsbeginsel, te weten een openbare behandeling van de zaak en een openbare uitspraak, zullen veelal in hoger beroep aan de orde komen en geredresseerd dienen te worden. Indien ten onrechte een zitting met gesloten deuren is gehouden of de uitspraak ten onrechte niet op de voorgeschreven wijze openbaar is gemaakt, zal dat vaak pas in hoger beroep komen vast te staan. Uiteraard kan zich ook in andere gevallen de situatie voordoen dat de schending pas in hoger beroep door een andere rechterlijke instantie wordt onderkend en vastgesteld. De mogelijkheid bestaat echter ook, zoals in paragraaf 3.2.2 van Deel I aan de orde is gekomen, dat de bestuursrechter gedurende de procedure die bij hem gevoerd wordt geconfronteerd wordt met een - door hemzelf of door de procedurevoorschriften veroorzaakte - schending van (een uitwerking van) een beginsel van behoorlijke rechtspleging. In dat geval zal de bestuursrechter voor zover mogelijk het gebrek zelf dienen te herstellen. In sommige gevallen, bijvoorbeeld wanneer (de schijn van) partijdigheid bestaat, zal die herstelwerkzaamheid inhouden dat een andere rechter of een kamer met een andere samenstelling over de zaak zal moeten oordelen. In andere gevallen, indien bijvoorbeeld een aspect van het beginsel van hoor en wederhoor niet in acht is genomen, kan dat gebrek alsnog door dezelfde rechter of kamer in de lopende procedure hersteld worden. Overigens zullen de bestuursrechtelijke appèlcolleges, nog meer dan de bestuursrechters in eerste aanleg, primair zelf inachtneming van de beginselen van behoorlijke rechtspleging dienen te waarborgen. Controle door een andere hogere nationale rechterlijke instantie op de naleving van die eisen ontbreekt immers. Vinden de schendingen van de beginselen van behoorlijke rechtspleging hun grondslag in structurele gebreken in de betreffende wettelijke voorschriften van procesrecht, zoals in de Awb of in een bijzondere wet, ligt er ook een taak voor de wetgever om deze gebreken op te heffen. Omdat de beginselen van behoorlijke rechtspleging zich echter in eerste instantie richten tot de (bestuurs)rechter, zal deze daarnaast of bij het ontbreken van een wettelijke regeling er ook zorg voor dienen te dragen dat deze rechtsnormen in een concreet geval in acht 


\section{Deel III Slotbeschouwing}

worden genomen. Dat kan betekenen, zoals in paragraaf 3.2.2 van Deel I werd aangegeven, dat een wettelijke bepaling van procesrecht in een concreet geval buiten toepassing moeten worden gelaten of een bepaling conform de beginselen van behoorlijke rechtspleging moet worden uitgelegd. Het is dan vervolgens aan de wetgever om de wettelijke regeling zodanig aan te passen dat van een schending van de beginselen van behoorlijke rechtspleging geen sprake meer is.

\section{Rechtsnormen voor de bestuurlijke voorprocedures}

Worden er door de bestuursrechter in het geheel geen consequenties aan een schending van een procedurele eis verbonden, kan dat betekenen dat - aangenomen dat de schending van de eis niet over het hoofd is gezien - de eis niet te herleiden valt tot een beginsel van behoorlijke rechtspleging of dat sprake is van schending van een minder essentiële toepassing van een van deze beginselen. Ook kan het ontbreken van consequenties aan een schending van een beginsel of uitwerking ervan betekenen dat deze in de desbetreffende procedure niet in acht behoeft te worden genomen. Voor dit onderzoek betekent het voorgaande dat de betekenis van de beginselen van behoorlijke rechtspleging voor de bestuurlijke voorprocedures niet alleen tot uitdrukking kan komen in de voor de inrichting van die procedures geldende eisen, maar ook in de gevolgen die schendingen van die eisen met zich brengen. De betekenis van de eisen van behoorlijke rechtspleging voor die procedures wordt immers in belangrijke mate bepaald door de gevolgen die aan schending van deze eisen verbonden worden. Ook voor de bestuurlijke voorprocedures zouden, wil er sprake zijn van geldingskracht van die eisen, aan schendingen van uitwerkingen van de beginselen van behoorlijke rechtspleging in het kader van die procedures in elk geval ook gevolgen moeten worden verbonden.

In Deel II is voor ieder afzonderlijk deelaspect van een beginsel van behoorlijke rechtspleging (of behoorlijk bestuur) onderzocht in hoeverre aan een schending van de voor de bestuurlijke voorprocedures geldende eisen gevolgen verbonden worden door de bestuursrechter. Die vraag werd steeds gesteld om te kunnen bepalen in hoeverre er sprake is van een, naar positief recht, geldende eis. In beginsel leidt schending van procedurele ongeschreven of geschreven vereisten die gelden voor een besluit op bezwaar (of administratief beroep) tot vernietiging van dat besluit. De bestuursrechter heeft echter verschillende mogelijkheden om de gevolgen van schendingen van procedurele eisen te mitigeren. Zo blijkt uit Deel II dat het ten aanzien van vrijwel alle (wettelijke) uitwerkingen van alle beginselen voorkomt dat de bestuursrechter gebruik maakt van zijn bevoegdheid om gebreken in de besluitvorming te passeren op grond van artikel 6:22 Awb. In dat geval leidt de vastgestelde schending niet tot vernietiging van het besluit door de bestuursrechter. Even zo vaak wordt de bevoegdheid gebruikt om de rechtsgevolgen van het vernietigde besluit in stand te laten bij schending van uitwerkingen van de beginselen van behoorlijke rechtspleging (of bestuur) op grond van artikel 8:72, derde lid, van de Awb. De bestuursrechtelijke appelcolleges gaan in het geval van schendingen van een (uitwerking van een) beginsel van behoorlijke rechtspleging ook niet altijd over tot vernietiging van de uitspraak, maar wordt, zoals ook is gebleken in paragraaf 3.2.2. van Deel I van dit onderzoek, de schending wel eens gepasseerd. Een schending van een beginsel van behoorlijke rechtspleging of een essentiële uitwerking ervan door de bestuursrechter leidt derhalve evenmin per definitie tot vernietiging van de uitspraak.

De omstandigheid dat deze bevoegdheden tot mitigatie van de gevolgen van schendingen van bepaalde eisen gehanteerd worden bij schendingen van uitwerkingen van beginselen van behoorlijke rechtspleging - ongeacht of het de rechterlijke of bestuurlijke procedure betreft - doet geen afbreuk aan het rechtsnormkarakter van die eisen of beginselen. Waar het om gaat is dát er rechtens gevolgen aan een schending worden verbonden. Zoals ook is gebleken in paragraaf 3.2.2 van Deel I van dit onderzoek ten aanzien van de procedure bij de bestuursrechter en in de verschillende paragrafen in hoofdstuk 5 van Deel II, die zien op de gevolgen van schendingen van de betreffende eisen in de bestuurlijke voorprocedures, kan de rechtens te verbinden consequentie aan een schen- 


\section{Deel III Slotbeschouwing}

ding van een beginsel van behoorlijke rechtspleging ook bestaan uit een proceskostenveroordeling of vergoeding van betaalde griffierechten. Voor het toekennen van een proceskostenveroordeling of vergoeding van betaalde griffierechten is geen vernietiging van het bestreden besluit of de uitspraak vereist.

De mogelijke gevolgen van een schending

De mogelijke gevolgen die verbonden kunnen worden aan schending van een uitwerking van een beginsel van behoorlijke rechtspleging (of behoorlijk bestuur) kunnen derhalve verschillend van aard zijn. Dat geldt voor zowel de rechterlijke fase als de bestuurlijke voorfase. Als een beginsel of uitwerking ervan in de bestuurlijke voorprocedure wordt geschonden bestaan er in beginsel twee hoofdconsequenties: vernietiging van het besluit of instandlating van het besluit (strikt genomen vormt de laatste geen (rechts)gevolg voor het besluit, omdat het passeren van het geconstateerde gebrek aan het besluit als zodanig niets wijzigt). Vervolgens kunnen aan beide hoofdconsequenties aanvullende gevolgen verbonden worden. Er kan enerzijds sprake zijn van een vernietiging van het bestreden besluit met aanvullend toekenning van schadevergoeding, voor zover daartoe aanleiding bestaat. Daarbij kunnen bij schending in de bestuurlijke fase de rechtsgevolgen van het besluit al dan niet in stand worden gelaten op grond van artikel 8:72, derde lid, van de Awb. Anderzijds hoeft de vastgestelde schending van een procedurele eis niet te leiden tot vernietiging van het bestreden besluit, omdat op grond van artikel 6:22 Awb de schending gepasseerd kan worden en het beroep ongegrond kan worden verklaard. De mogelijkheid van een aanvullende schadevergoeding bestaat in dat geval niet. Een schending van een beginsel van behoorlijke rechtspleging of een uitwerking ervan in de procedure bij de rechter kan eveneens gepasseerd worden. Zowel bij de vernietiging als bij het passeren van gebreken kan voorts nog een proceskostenvergoeding en vergoeding van de betaalde griffierechten in de rede liggen. Bij een vernietiging van het bestreden besluit is een proceskostenveroordeling en vergoeding van het griffierecht regel, terwijl dat bij een ongegrondverklaring van het beroep minder snel het geval zal zijn. Het passeren van een gebrek op grond van artikel 6:22 Awb kan echter voor de bestuursrechter aanleiding vormen om toch over te gaan tot een proceskostenveroordeling of vergoeding van griffierecht. Bij de toepassing van artikel 6:22 Awb vindt in elk geval een constatering van een gebrek of schending in de besluitvorming door de bestuursrechter plaats.

Het signaal dat wordt afgegeven door de gevolgen van een schending

Het onderscheid tussen de verschillende mogelijkheden die de bestuursrechter ter beschikking staan bij de vaststelling van een schending van een procedurele eis die als een uitwerking van een beginsel van behoorlijke rechtspleging kan worden gezien, is om verschillende redenen van belang. De vernietiging van een besluit is verstrekkend en leidt tot onzekerheid inzake de rechtspositie van belanghebbenden. In de regel zal het bestuur immers opnieuw een besluit dienen te nemen. Gelet daarop dienen vernietigingen op louter procedurele gronden zoveel mogelijk voorkomen te worden. Een schending van een procedurele eis, ook als het een uitwerking van een beginsel van behoorlijke rechtspleging betreft, kan immers hersteld worden en behoeft niet per definitie te leiden tot een ander inhoudelijk besluit. Een belanghebbende is derhalve niet altijd gebaat bij een vernietiging van een besluit vanwege schending van een procedurele waarborg. Anderzijds geeft gegrondverklaring van het beroep en vernietiging van het bestreden besluit gecombineerd met andere mogelijke gevolgen een ander (sterker) signaal af aan het bestuur dan een ongegrondverklaring van het beroep en instandlating van het bestreden besluit gecombineerd met andere mogelijke gevolgen. Een vernietiging van het bestreden besluit, al dan niet met instandlating van de rechtsgevolgen, geeft duidelijker het signaal aan het bestuursorgaan dat het een rechtsplicht heeft geschonden en dat het in de toekomst dergelijke schendingen vanwege de mogelijke gevolgen zou moeten proberen te vermijden. De vernietiging van het besluit als zodanig heeft verstrekkendere gevolgen voor het bestuur en opent bovendien, in het huidige systeem van de Awb, een- 
Deel III Slotbeschouwing

voudiger de deur naar schadevergoeding, proceskostenveroordeling en vergoeding van griffierechten.

Gelet op het hiervoor beschreven spanningsveld is het verdedigbaar om een vernietiging van een besluit te beperken tot de gevallen waarin sprake is van schendingen van fundamentele procedurele waarborgen. Ook al leidt de vernietiging van het besluit in die gevallen uiteindelijk niet tot een ander besluit van het bestuursorgaan, het karakter en het belang van naleving van die eisen rechtvaardigt een dergelijke verstrekkende consequentie in die gevallen. Vernietiging van een besluit zou derhalve meer op zijn plaats zijn bij schendingen van essentiële uitwerkingen van de beginselen van behoorlijke rechtspleging of bestuur dan bij schendingen van minder essentiële uitwerkingen van die beginselen. Daarbij zou in gevallen waarin vaststaat dat een belanghebbende materieel niets opschiet met een vernietiging gekozen moeten worden voor instandlating van de rechtsgevolgen. Voor schendingen van minder essentiële uitwerkingen van een beginsel is in mijn optiek toepassing van de bevoegdheid op grond van artikel 6:22 Awb meer geëigend. Als de bestuursrechter het nodig acht ook in die gevallen nog een sterker signaal af te geven aan het bestuur om wat voor reden dan ook, kan aanvullend een proceskostenveroordeling of een veroordeling tot vergoeding van griffierecht worden uitgesproken.

Effectieve geschilbeslechting en procedurele waarborgen

Als het gaat om de mogelijke gevolgen die aan procedurele gebreken in de besluitvorming moeten worden verbonden is niet alleen het signaal dat aan het bestuur afgegeven wordt of de geldingskracht van de procedurele waarborgen van belang. Die mogelijke gevolgen en uitspraakmogelijkheden van de bestuursrechter dienen ook in het licht van het uitgangspunt van effectieve geschilbeslechting in het Nederlandse bestuursrecht geplaatst te worden. Een belanghebbende is niet alleen gebaat bij een behoorlijke procedure, maar ook bij effectieve materiële beslechting van zijn geschil. Deze twee uitgangspunten kunnen echter conflicteren. ${ }^{5}$ Tegenover het gezag van de procedurele waarborgen dat staat of valt met de consequenties die aan schendingen van dergelijke eisen worden verbonden, staat de effectiviteit van de geschilbeslechting die eist dat er zo spoedig mogelijk een definitief materieel besluit voorhanden is. Vanuit een oogpunt van effectieve geschilbeslechting kan het in de rede liggen om een schending van een procedurele eis te passeren, terwijl het vanuit een oogpunt van behoorlijkheid van de gevoerde procedure het geëigend kan zijn een dergelijke schending niet zonder gevolgen te laten. Het is van belang in dat spanningsveld een evenwicht te vinden dat voldoende recht doet aan beide uitgangspunten.

De actuele discussies in het Nederlandse bestuursrecht over de effectiviteit van de geschilbeslechting onder de Awb hebben inmiddels tot concrete voorstellen tot aanpassingen van het bestuursprocesprocesrecht geleid die zich in dat spanningsveld bevinden. Onlangs heeft de regering bijvoorbeeld een wetsvoorstel tot aanpassing van het bestuursprocesrecht opgesteld. De achtergrond van het voorstel is onder meer het streven naar een slagvaardiger bestuursprocesrecht en effectievere geschilbeslechting. ${ }^{6}$ Het voorstel behelst een verruiming van de mogelijkheden om gebreken in de besluitvorming te passeren, indien niemand daardoor wordt benadeeld. De bevoegdheid om gebreken te passeren, zoals neergelegd in artikel 6:22 Awb, bestaat thans voor zover het schendingen van vormvoorschriften betreft. Het wetsvoorstel voorziet in een uitbreiding met gevallen waarin materiële voorschriften worden geschonden. Het beslissende criterium wordt of belanghebbenden benadeeld zijn door de schending van het betreffende voorschrift. Van benadeling is geen sprake, indien vaststaat dat bij naleving van het voorschrift geen ander besluit zou zijn genomen. Tevens wordt in artikel 8:72 Awb een uitspraakmodaliteit voor de bestuursrechter in dat verband toegevoegd. Ook is eenzelfde bepaling opge-

5. Zie bijvoorbeeld: AbRvS 2 december 2009, AB 2010/34 m.nt B. de Waard.

6. Zie par. 1.5 van Deel II van dit onderzoek. 


\section{Deel III Slotbeschouwing}

nomen in de Crisis en herstelwet in artikel 1.5. ${ }^{7}$ In het eerste lid van dat artikel is opgenomen dat een schending van een geschreven of ongeschreven rechtsregel of algemeen rechtsbeginsel kan worden gepasseerd, indien aannemelijk is dat belanghebbenden door de schending niet zijn benadeeld. De tekst van deze bepaling wijkt iets af van de voorgestelde wijziging van artikel 6:22 Awb, die inhoudt dat een schending van een voorschrift kan worden gepasseerd.

\section{Intermezzo: de rechterlijke fase}

De voorgestelde wijzigingen hebben, gelet op de toelichting daarbij, betrekking op de verruiming van mogelijkheden om gebreken in besluiten van het bestuur te passeren en niet zozeer op verruiming van de mogelijkheden om schendingen van procedurele eisen door de bestuursrechter te passeren. Ook in die fase kunnen echter procedurele gebreken in de uitspraak in de weg staan aan effectieve en finale geschilbeslechting, omdat de uitspraak in dat geval door het appèlcollege kan worden vernietigd waardoor er geen zekerheid bestaat omtrent het oordeel van de bestuursrechter over het bestreden besluit. Hoewel er, gelet op het uitgangspunt van effectieve en finale geschilbeslechting, in het bestuursrecht een tendens bestaat naar ruimere mogelijkheden om gebreken te passeren, zou ik ervoor willen pleiten daarin in elk geval terughoudend te zijn waar het gaat om essentiële uitwerkingen van de beginselen van behoorlijke rechtspleging in de rechterlijke fase. Omdat in die fase het zwaartepunt van de rechtsbescherming van de burger gelegen is, klemt het te meer indien aan schending van belangrijke procedurele waarborgen geen gevolgen worden verbonden. Rechtsbescherming heeft naast het materiële en inhoudelijke einde van het geschil ook een procedurele component. Die laatste component is vanuit het perspectief van de burger evenzeer waardevol. Een behoorlijke of zorgvuldige procedure leidt tot acceptatie en legitimatie van de uitkomst van de procedure. Een belanghebbende die het gevoel heeft dat er daadwerkelijk naar zijn standpunt is geluisterd en dat tot uitdrukking ziet komen in de procedure en de totstandkoming van de uitspraak, zal zich eerder neerleggen bij de uitkomst van die procedure. Bovendien leidt een zorgvuldige en behoorlijke procedure ook tot een inhoudelijk deugdelijke uitspraak. In dat opzicht bestaat er een verband tussen procedurele behoorlijkheid en de deugdelijkheid van de materiële beslissing. Van belang is dan ook dat er een goede balans getroffen wordt tussen enerzijds materiële en finale geschilbeslechting en anderzijds behoorlijke procedurele rechtsbescherming. Het is de vraag of met de voorziene wijziging van artikel 6:22 Awb daarvan sprake is. Voor de procedure bij de bestuursrechter (in eerste aanleg) zou in mijn optiek als hoofdregel dienen te gelden dat een schending van de beginselen van behoorlijke rechtspleging of essentiële uitwerkingen daarvan nog steeds leidt tot vernietiging van de uitspraak.

\section{De gevolgen voor de bestuurlijke voorprocedures}

Voor de bestuurlijke voorprocedures kan in beginsel hetzelfde gesteld worden. De voorstellen tot wijziging van het bestuursprocesrecht dienen niet te zeer door te slaan ten gunste van de materiële geschilbeslechting door bijvoorbeeld de mogelijkheden om gebreken in de besluitvorming van het bestuur te passeren te zeer te verruimen zonder aan die gebreken (anderszins) gevolgen te verbinden. Het wetsvoorstel wijst op de noodzaak tot verruiming van de mogelijkheden van finale geschilbeslechting vanuit een oogpunt van artikel 13 EVRM en de eis van een effectief rechtsmiddel. Hoewel er inderdaad, onder meer gelet daarop, aanleiding bestaat tot het scheppen van meer mogelijkheden tot tijdige en finale geschilbeslechting, is het de vraag of een uitbreiding van de mogelijkheden om schendingen van uitwerkingen van fundamentele procedurele waarborgen in een besluit te passeren daarvoor het geëigende middel is. De zorgvuldigheid en

7. Art. 6:22 Awb is in het tweede lid niet van toepassing verklaard. Zie ook par. 1.5 van Deel II van dit onderzoek. 


\section{Deel III Slotbeschouwing}

de behoorlijkheid van de procedure behoren in evenwicht te zijn met de voortvarendheid en effectiviteit van de procedure. De nadruk heeft in het verleden wellicht te zeer gelegen op inhoudelijke en procedurele rechtmatigheid van besluiten, maar dat wil, om bovengenoemde redenen, niet zeggen dat deze aspecten thans geheel ondergeschikt dienen te worden gemaakt aan het uitgangspunt van finale en tijdige geschilbeslechting. Bovendien zou omwille van het signaal dat wordt afgegeven aan het bestuur en de financiële gevolgen die in de praktijk gekoppeld zijn aan vernietiging van een besluit, in de huidige stand van de wetgeving, eveneens terughoudendheid met uitbreiding van mogelijkheden om gebreken te passeren in de bestuurlijke voorprocedures op zijn plaats zijn. De bevoegdheid om na vernietiging de rechtsgevolgen van het besluit in stand te laten, kan in het geval van schending van een essentiële procedurele waarborg tegemoet komen aan de behoefte aan finale geschilbeslechting. Tegelijkertijd krijgt het bestuur het signaal dat het moet krijgen van de bestuursrechter. Indien dat signaal leidt tot het structureel inachtnemen van dergelijke waarborgen, komt dat ook ten goede aan alle voorprocedures bij het bestuur waarop geen procedure bij de bestuursrechter volgt.

De bestuursrechter zou, in het huidige systeem van uitspraakbevoegdheden, bij schending van procedurele waarborgen meer gebruik kunnen maken van zijn bevoegdheid om te vernietigen en de rechtsgevolgen van het vernietigde besluit in stand te laten. Indien er standaard zou worden overgegaan tot compensatie van schendingen van eisen die als essentiële uitwerkingen van beginselen van behoorlijke rechtspleging hebben te gelden, bijvoorbeeld in de vorm van vergoeding van griffierecht of een proceskostenveroordeling, zou het anders kunnen liggen. Ook van een dergelijke veroordeling kan, zonder vernietiging van het besluit, een signaalfunctie uitgaan. Gelet op de geringe bedragen waar het doorgaans om gaat, zou het echter bij schendingen van essentiële uitwerkingen van beginselen van behoorlijke rechtspleging of vergelijkbare waarborgen op grond van de beginselen van behoorlijk bestuur, hoewel van procedurele aard, ook dan nog steeds een vernietiging met instandlating van de rechtsgevolgen de voorkeur verdienen. Wel zou er in de fase van besluitvorming bij het bestuur meer ruimte kunnen bestaan voor het passeren van schendingen van procedurele waarborgen dan in de fase bij de bestuursrechter. De procedurele waarborgen nemen immers in iedere fase van procedure inzake een besluit toe en het zwaartepunt van de rechtsbescherming is gelegen in de rechterlijke fase.

\section{Het bestuursrechtelijke systeem van rechtsbescherming, de bestuurlijke voorprocedures en de beginselen van behoorlijke rechtspleging}

\subsection{Inleiding}

Zoals aangegeven, kunnen de conclusies op grond van Deel I en Deel II van dit onderzoek over de invloed van de beginselen van behoorlijke rechtspleging op de bestuurlijke vooprocedures niet los worden gezien van de positie van die procedures en de opstelling van de bestuursrechter in het Nederlandse bestuursrechtelijke systeem van rechtsbescherming. De specifieke positie en het tweeledige karakter van de bezwaarschriftprocedure en het administratief beroep komen ook tot uitdrukking in de wijze waarop tegen deze procedures, in de doctrine en rechtspraak, wordt aangekeken. Met name in de rechtspraak speelt dat tweeledige karakter en de staatsrechtelijke verhouding tussen bestuur en rechter een rol bij het van toepassing verklaren van bepaalde eisen op de bestuurlijke voorprocedures. Voorts is de wijze van toetsing aan de beginselen van behoorlijke rechttspleging door de bestuursrechter ook van belang voor de betekenis die deze normen kunnen hebben in het Nederlandse bestuursrecht. Op de benadering van de bestuurlijke voorprocedures in dat verband wordt in paragraaf 3.2 nader ingegaan. In paragraaf 3.3 komt vervolgens in meer algemene zin de opstelling van de bestuursrechter ten aanzien van de beginselen van behoorlijke rechtspleging aan bod. 
Deel III Slotbeschouwing

De typering van de bestuurlijke voorprocedures in het Nederlandse bestuursrechtelijke systeem van rechtsbescherming

Het semi-judiciële karakter van de bestuurlijke voorprocedures en artikel 6 EVRM

De bezwaarschriftprocedure en het administratief beroep vormen voorzieningen die onderdeel zijn van het Nederlandse systeem van bestuursrechtelijke rechtsbescherming. Algemeen aanvaard is dat die procedures een semi-judicieel karakter dragen en een rechtsbeschermingsfunctie hebben. Het semi-judiciële karakter van de bestuurlijke voorprocedures schuilt in de omstandigheid dat zij voor een burger met waarborgen omklede procedures vormen waarin een besluit kan worden aangevochten. Die procedurele waarborgen vinden voor de rechterlijke procedure hun oorsprong in de beginselen van behoorlijke rechtspleging. Dit onderzoek toont aan dat de beginselen van behoorlijke rechtspleging - tot op zekere hoogte en voor ieder beginsel in verschillende mate - ook van betekenis (kunnen) zijn voor de bestuurlijke voorprocedures. Uit het onderzoek komt echter ook naar voren dat expliciete aandacht voor de beginselen van behoorlijke rechtspleging als het gaat om de voor de inrichting van de voorprocedures geldende waarborgen slechts incidenteel bestaat. Met name in de rechtspraak wordt in dat kader veeleer een verband gelegd met de algemene beginselen van behoorlijk bestuur, die ook voor de bestuurlijke voorprocedures als besluitvormingsprocedures gelden.

Voor het ontbreken van een expliciet verband tussen de rechterlijke procedurele waarborgen en de inrichting van de bestuurlijke voorprocedures kunnen verschillende verklaringen gegeven worden. Ten dele kan het gebrek aan aandacht voor de gelding van aan rechtspraak eigen waarborgen voor de bestuurlijke voorprocedures teruggevoerd worden op de omstandigheid dat die waarborgen nadrukkelijk met artikel 6 EVRM in verband worden gebracht. Op twee manieren lijkt de associatie met artikel 6 EVRM te zorgen voor (te) weinig oog voor de betekenis van rechterlijke procedurele waarborgen voor de inrichting van de bestuurlijke voorprocedures. Allereerst zien de uit artikel 6 , eerste lid van het EVRM voortvloeiende eisen en waarborgen primair en hoofdzakelijk op geschillen bij rechterlijke instanties. In de jurisprudentie van het EHRM worden op grond van die bepaling ook geen hoge eisen gesteld aan procedures bij het bestuur die aan een geschil bij de rechter voorafgaan - de redelijke termijn-eis daargelaten. Dat heeft tot gevolg dat op nationaal niveau de aandacht vanzelfsprekend vooral uitgaat naar de procedures bij die rechterlijke instanties en de vraag of deze voldoen aan de eisen die artikel 6 EVRM stelt. Omdat de beginselen van behoorlijke rechtspleging thans in de doctrine en rechtspraak grotendeels worden vereenzelvigd met artikel 6 EVRM (gericht op rechtspraak) geldt daarvoor hetzelfde. Met name rechterlijke procedures worden aan de beginselen van behoorlijke rechtspleging en de daaruit voortvloeiende eisen getoetst. Van het equality of arms-vereiste, dat (primair) tot artikel 6 EVRM te herleiden is, wordt gelding voor de bestuurlijke voorprocedures door de bestuursrechter zelfs expliciet ontkend. Die ontkenning valt, zo moet worden aangenomen, in elk geval ten dele te herleiden naar het verband dat gelegd wordt tussen equality of arms en artikel 6 EVRM.

De beginselen van behoorlijke rechtspleging spelen bovendien als zodanig geen grote rol in de nationale jurisprudentie en doctrine. Zij hebben als zelfstandige toetsingsnorm, los van artikel 6 EVRM, niet zo'n sterke ontwikkeling doorgemaakt als bijvoorbeeld de algemene beginselen van behoorlijk bestuur. Daar komt bij dat het gebruik van allerlei verschillende termen voor deze waarborgen in literatuur en jurisprudentie, zoals de goede procesorde, eerlijk proces en beginselen van behoorlijke rechtspraak of rechtspleging niet bijdraagt aan de inzichtelijkheid van de ontwikkeling van die beginselen noch aan de geldingskracht van die beginselen. De afgelopen tijd valt echter een kentering waar te nemen in de rechtspraak van de nationale bestuursrechter als het gaat om nationale normen als rechtsbasis voor eisen van een behoorlijke procedure. De redelijke termijn-eis wordt, zoals uiteen is gezet in hoofdstuk 6 van Deel I en paragraaf 5.7 van Deel II van dit onderzoek, thans ook van toepassing geacht op geschillen die buiten de reikwijdte van artikel 6 EVRM vallen. Voor die toepasselijkheid wordt in de jurispruden- 


\section{Deel III Slotbeschouwing}

tie voorzien in een nationale rechtsbasis: het rechtszekerheidsbeginsel. Kanttekening daarbij is echter dat de katalysator voor deze ontwikkeling nog steeds het door het EHRM op grond van artikel 13 EVRM geëiste effectieve rechtsmiddel tegen schendingen van het redelijke termijn- vereiste op grond van artikel 6 EVRM is. Het loslaten van artikel 6 EVRM is derhalve beperkt. Er wordt nog steeds aansluiting gezocht bij die bepaling, omdat de gekozen rechtsbasis door de nationale bestuursrechter ook geacht wordt ten grondslag te liggen aan de redelijke termijn- eis uit artikel 6 EVRM. De bestuursrechter zoekt zijn toevlucht tot een gemeenschappelijke rechtsbasis die bovendien niet is gelegen in het nationale decisiebeginsel, als beginsel van behoorlijke rechtspleging. Deze vernieuwende jurisprudentie van de bestuursrechter toont echter wel aan dat er behoefte bestaat op nationaal niveau aan de beginselen van behoorlijke rechtspleging of een sterke nationale ontwikkeling daarvan.

\section{Het bestuurlijke karakter van de voorprocedures en de eisen voor een behoorlijke procedure}

Hierboven werd uiteengezet dat de relatie die gelegd wordt tussen eisen voor een behoorlijke inrichting van een procedure en artikel 6 EVRM met zich brengt dat er (te) geringe aandacht voor dergelijke waarborgen in de bestuurlijke voorprocedures bestaat. Die conclusie vloeit voort uit het semi-judiciële karakter van de bestuurlijke voorprocedures. Omdat geen sprake is van 'echte' rechtspraak is de geldingskracht van die eisen op grond van artikel 6 EVRM beperkt. De bestuurlijke voorprocedures vallen nog in een ander opzicht tussen de wal en het schip. Het gaat dan echter om een consequentie van de omstandigheid dat de bestuurlijke voorprocedures als reguliere bestuurlijke besluitvormingsprocedures worden gezien. Ondanks het feit dat de voorprocedures zich tussen bestuurlijke besluitvorming en rechtspraak in bevinden, worden zij voor de toepasselijkheid van de algemene beginselen van behoorlijk bestuur beschouwd als reguliere besluitvormingsprocedures. Er wordt in het kader van de toepassing of invulling van deze algemene beginselen van behoorlijk bestuur geen expliciet onderscheid gemaakt tussen de primaire besluitvormingsfase of de bestuurlijke voorfase als besluitvormingsfase. Die benadering heeft, zoals hierna wordt toegelicht, vervolgens gevolgen voor de wijze waarop de eisen die voortvloeien uit de beginselen van behoorlijk bestuur op die voorprocedures worden toegepast.

Omdat de voorprocedures als reguliere bestuurlijke besluitvormingsprocedures worden gezien voor de toepasselijkheid van de algemene beginselen van behoorlijk bestuur, wordt bij de invulling en toepassing van (bepaalde van) deze beginselen geen of slechts in geringe mate rekening gehouden met het tevens bestaande rechtsbeschermingskarakter. Bij de ontwikkeling en invulling van de beginselen van behoorlijk bestuur in de doctrine en jurisprudentie heeft de nadruk in het algemeen ook gelegen op de primaire besluitvormingsfasen. Aandacht voor de normen die gelden voor de inrichting van de bestuurlijke voorprocedures bestaat voornamelijk voor zover het de specifieke eisen neergelegd in hoofdstuk 7 van de Awb betreft. Deze zijn uiteraard ook deels als uitwerkingen van bepaalde beginselen van behoorlijk bestuur te beschouwen, maar de beginselen van behoorlijk bestuur als zodanig krijgen vooral als algemene normen voor het bestuur aandacht. Bij de invulling of ontwikkeling van de algemene beginselen van behoorlijk bestuur in de doctrine en jurisprudentie bestaat weinig oog voor het specifieke karakter van de voorprocedures en de verschillen met de primaire besluitvormingsfasen.

Deze ontwikkeling doet zich overigens niet bij elk beginsel even sterk gevoelen. Beginselen waarbij dit het duidelijkst te zien is, vormen het motiveringsbeginsel en het verbod van vooringenomenheid. Zoals blijkt uit de paragrafen 5.4 en 5.6 van Deel II, zien de toepassing en invulling van die beginselen in de doctrine en jurisprudentie en de daarin ontwikkelde eisen voornamelijk op de primaire besluitvorming. De omstandigheid dat zich in de voorprocedures andere situaties kunnen voordoen dan in de primaire besluitvormingsfase, in verband met het feit dat het bestuur de besluitvorming overdoet en voor een tweede maal over de voorliggende zaak moet oordelen, komt in de analyse en 


\section{Deel III Slotbeschouwing}

ontwikkeling van deze beginselen in de doctrine en jurisprudentie nauwelijks terug. Afzonderlijke aandacht voor de omstandigheid dat de bestuurlijke voorprocedures ook een rechtsbeschermingscomponent hebben in dat verband is er, buiten de voor de bezwaarschriftprocedure neergelegde uitwerkingen in de Awb, evenmin. Een reactieplicht op de aangevoerde bezwaren wordt daardoor bijvoorbeeld niet nadrukkelijk onderscheiden als uitwerking van het motiveringsbeginsel, neergelegd in artikel 7:12 Awb. Ook voor de werking van het verbod van vooringenomenheid als waarborg voor objectieve besluitvorming in bezwaar (of administratief beroep) bestaat, afgezien van de eisen die voortvloeien uit artikel 7:5 en artikel 7:13 Awb (of artikel 7:19 Awb voor administratief beroep), nauwelijks aandacht. Aandacht voor mogelijke gebreken in het kader van de vereiste onpartijdigheid die zich in de bestuurlijke voorprocedures kunnen voordoen of voor het specifieke karakter van de voorprocedures in relatie tot het verbod van vooringenomenheid, lijkt er uitsluitend te zijn indien zich een dergelijk geval aandient in de jurisprudentie. Het is echter denkbaar dat er in de primaire besluitvorming geen onpartijdigheidsgebrek bestaat, terwijl dat in de bestuurlijke voorprocedure om allerlei redenen wel het geval kan zijn. Bovendien bestaat er door deze benadering ook geen duidelijkheid over de verhouding tussen het verbod van vooringenomenheid, zoals neergelegd in artikel 2:4 Awb, en de specifiek voor de bezwaarschriftprocedure (en het administratief beroep) neergelegde bepalingen in hoofdstuk 7 van de Awb.

\section{Besturen is iets anders dan rechtspreken}

Naast de hiervoor beschreven toepassing van de algemene beginselen van behoorlijk bestuur en de benadering van de bestuurlijke voorprocedures als reguliere besluitvormingsprocedures, houdt de bestuursrechter, in het bijzonder de Afdeling bestuursrechtspraak van de Raad van State, bovendien sterk vast aan de traditionele scheiding die bestaat tussen rechtspraak en bestuur. De Afdeling gaat ervan uit dat het bestuur en de rechter in ons staatsbestel zich niet op elkaars terrein begeven en dat de werkzaamheid van beide organen scherp van elkaar te scheiden zijn. Vanuit die gedachte worden vervolgens andere procedurele waarborgen op het handelen van het bestuur van toepassing geacht dan op het handelen van de bestuursrechter. Daarmee wordt de rechtsbeschermingsfunctie van de bestuurlijke voorprocedures in elk geval in de toepasselijke procedurele waarborgen niet volledig onderkend. Voor de bestuurlijke voorprocedures voldoet een dergelijke benadering, zonder nadere uitleg, om verschillende redenen niet.

Allereerst is het de vraag in hoeverre het gelegde verband tussen de verschillen in de aard van de werkzaamheid van het beslissende orgaan en de voor de inrichting van de procedure waarin de beslissing tot stand komt geldende procedurele waarborgen gerechtvaardigd is. Er zijn geen overtuigende redenen waarom, enkel en alleen vanwege de aard van de werkzaamheid die daarin wordt verricht, een bestuurlijke procedure niet aan vergelijkbare procedurele waarborgen zou moeten voldoen. Bovendien zijn, zoals aangetoond is in hoofdstuk 4 van Deel II van dit onderzoek, zelfs indien uitgegaan wordt van een verband tussen de aard van de werkzaamheid van het beslissende orgaan en de toepasselijkheid van eisen van behoorlijke rechtspleging, de traditionele verschillen tussen de werkzaamheid van het bestuur (in de voorprocedures) en de werkzaamheid van de bestuursrechter minder omvangrijk dan vaak wordt gesuggereerd. Voorts zou evenzeer uitgegaan kunnen worden van de overeenkomsten die bestaan tussen de werkzaamheid van het bestuur in de voorprocedures en de werkzaamheid van de bestuursrechter. Die redenering volgend zou eerder toepasselijkheid van dezelfde vereisten in de rede liggen. Het onderzoek in paragrafen 5.3 tot en met 5.7 van Deel II heeft ook aangetoond dat op de inrichting van de bestuurlijke voorprocedures dezelfde of vergelijkbare eisen van toepassing zijn die soms herleidbaar zijn tot een algemeen beginsel van behoorlijk bestuur en soms tot een beginsel van behoorlijke rechtspleging. Daarmee is vanzelfsprekend niet gezegd dat er geen verschillen bestaan tussen bestuur (ook in de bestuurlijke voorprocedures) en rechtspraak. Daar komt nog bij dat de bestuurlijke voorprocedures ook van belang kunnen voor (de uitkomst van) de rechterlijke procedures. Wat daar ook 


\section{Deel III Slotbeschouwing}

van zij, er zijn in elk geval onvoldoende redenen om op voorhand te stellen dat procedurele normen die voor rechtspraak gelden niet van betekenis kunnen zijn voor bestuurlijke voorprocedures, enkel en alleen omdat het bestuurlijke besluitvorming betreft en geen rechtspraak.

\section{Een formalistische houding en materieel vergelijkbare eisen}

Hoewel de strikte scheiding tussen bestuur en rechtspraak voor de toepasselijke procedurele eisen in met name de rechtspraak te verklaren valt uit het hybride karakter van de bestuurlijke voorprocedures, valt daarin ook een zekere mate van formalisme te bespeuren. Zoals hierboven al werd aangestipt, wordt vooral op grond van het enkele feit dat sprake is van bestuurlijke (voor)procedures de betekenis van de beginselen van behoorlijke rechtspraak of voor de rechter geldende eisen, onder meer zoals voortvloeiend uit artikel 6 EVRM, ontkend. De betekenis van bepaalde eisen wordt uitgesloten, omdat deze eisen zich niet richten tot het bestuur. Een goed voorbeeld daarvan vormt het equality of arms- vereiste, dat onderdeel vormt van het beginsel van hoor en wederhoor. De gelding van dat vereiste wordt uitgesloten, omdat het niet ziet op de bestuurlijke besluitvormingsfase. Hoewel dat formeel juist kan zijn, vanwege het verband met artikel 6 EVRM, getuigt deze benadering van weinig oog voor de materiële werkelijkheid. Materieel gezien gelden bepaalde eisen van behoorlijke rechtspleging immers eveneens voor de bestuurlijke voorprocedures. Vaak gelden zij onder een andere noemer, bijvoorbeeld een equivalent beginsel van behoorlijk bestuur, of valt materieel dezelfde of een vergelijkbare concrete eis onder een ander beginsel dan het geval is voor rechtspraak. Zij gelden echter wel. Zo bezien, is er voornamelijk sprake van een ander etiket. Uit het onderzoek blijkt ook dat hoewel soms sprake is van een ander etiket, de inhoud van de eisen die aan de inrichting van de procedure gesteld wordt niet of nauwelijks verschilt. Ook om die reden volstaat een blote ontkenning van de betekenis van de desbetreffende rechterlijke eisen of eisen van behoorlijke rechtspleging niet.

De wetgever en het tweeledige karakter van de bestuurlijke voorprocedures

Hoewel de rechtstreekse invloed van de beginselen van behoorlijke rechtspleging op de invulling van de beginselen van behoorlijk bestuur voor de bestuurlijke voorprocedures of de in de Awb neergelegde eisen weliswaar niet in alle gevallen aantoonbaar bestaat, kan geconcludeerd worden dat de veronderstelling overeind blijft dat vanwege de overeenkomsten tussen de bestuurlijke voorprocedures en bestuursrechtspraak de procedures bij beide organen door vergelijkbare eisen genormeerd worden.

Evenals het geval is bij de procedure bij de rechter, waarbij sprake is van een mengvorm van recours objectif en recours subjectif, staan de bestuurlijke voorprocedures in het teken van twee functies: de individuele rechtsbescherming en de bestuurlijke heroverweging. Soms levert dat spanningen op in de te stellen procedurele waarborgen, maar dat is meestal niet het geval. In beginsel betreft het kanten van een en dezelfde medaille. Hetzelfde kan gezegd worden van de procedure bij de bestuursrechter en het bestuursprocesrecht.

De wetgever heeft de inrichting van de bezwaarschriftprocedure en het administratief beroep in de Awb dan ook met waarborgen omkleed die mede geënt lijken te zijn op de waarborgen die gelden in het kader van de procedure bij de bestuursrechter. In de toelichting op de betreffende bepalingen wordt echter nauwelijks gerefereerd aan die waarborgen of de beginselen van behoorlijke rechtspleging. Voor zover dat al geschiedt, is dat uitsluitend impliciet en kan daaraan slechts het vermoeden ontleend worden dat de gelijkenis met de procedure bij de bestuursrechter de reden gevormd heeft voor het stellen van de desbetreffende procedurele eis. Dat getuigt niet van een principiële doordenking van de positie van de bestuurlijke voorprocedures in het systeem van rechtsbescherming en de gevolgen die het tweeledige karakter van deze procedures heeft voor de toepasselijke waarborgen. Door die pragmatische benadering van de wetgever bestaat er geen duidelijkheid over de onderliggende normen die op de inrichting van deze procedu- 


\section{Deel III Slotbeschouwing}

res van toepassing zijn en wat de betekenis vervolgens is van de beginselen van behoorlijke rechtspleging voor deze procedures. Daardoor blijft ook de verhouding van deze beginselen tot de beginselen van behoorlijk bestuur in de lucht hangen. Niet alleen de bestuursrechter, maar ook de wetgever heeft een belangrijke taak in het waarborgen van de beginselen van behoorlijke rechtspleging en de goede procesorde bij de inrichting van procedures. Daarom verdient het aanbeveling bij het opstellen van regelingen van procesrecht deze aspecten in de overwegingen mee te nemen. De rechtspraktijk is ook gebaat bij duidelijkheid over de toepasselijke eisen en de grondslagen voor deze eisen alsmede bij duidelijkheid over de verhouding tussen de verschillende normen voor bestuur en rechter.

\section{De nationale context als obstakel voor doorwerking}

Opvallend is ten slotte dat zowel het EHRM als het Hof van Justitie zich minder lijken aan te trekken van de Trias Politica en de scheiding tussen bestuur en rechtspraak als het gaat om de toepasselijkheid eisen van een eerlijk proces of het verdedigingsbeginsel. Het EHRM is in zijn beoordeling onder artikel 6 EVRM vanzelfsprekend in dat opzicht wel gebonden, omdat artikel 6 EVRM uitdrukkelijk gekoppeld is aan rechterlijke instanties. Maar zodra de voorprocedures bij het bestuur op enigerlei wijze de effectieve toegang tot de rechter beknotten of beperken, aarzelt het EHRM niet om de eisen die gelden voor de procedure bij de rechter door te trekken naar de fases daaraan voorafgaand. Dat is duidelijk te zien bij het vereiste van een redelijke termijn. Het Hof van Justitie lijkt in het kader van de eisen die voortvloeien uit de beginselen van behoorlijke rechtspleging evenmin sterk te hechten aan de nationale scheidingen tussen organen. Daarvan getuigt bijvoorbeeld de jurisprudentie inzake het verdedigingsbeginsel, dat geïnspireerd is op artikel 6 EVRM, en volgens het Hof van Justitie ook geldt in de besluitvormingsfase. Een onderscheid wat betreft de werking van dat beginsel wordt niet gemaakt voor de rechterlijke of bestuurlijke fase. Het motiveringsbeginsel en het beginsel van de redelijke termijn lijkt het Hof van Justitie op eenzelfde wijze toe te passen op de besluitvormingsfasen. Een verklaring daarvoor zou kunnen zijn dat het Hof van Justitie primair de effectieve doorwerking van het EG-recht in de nationale rechtsordes voor ogen heeft en daarom veel minder oog heeft (en hoeft te hebben) voor de staatsrechtelijke verhoudingen tussen verschillende organen binnen een nationaal staatsbestel. Uit de jurisprudentie van de Europese rechtscolleges kan ook niet opgemaakt worden dat het verschil in werkzaamheid tussen bestuurlijke en rechterlijke organen een reden vormt voor het toepasselijk achten van verschillende procedurele beginselen of waarborgen. Gelet daarop en de eerder genoemde redenen bestaat er aanleiding om ook op nationaal niveau minder nadruk te leggen op de mogelijke verschillen in werkzaamheid voor zover het de geldingskracht van procedurele waarborgen betreft in de bestuurlijke voorprocedures.

\subsection{De bestuursrechter en de beginselen van behoorlijke rechtspleging}

In paragraaf 1 van dit hoofdstuk werd al aangegeven dat ook de wijze waarop de bestuursrechter de hem toekomende bevoegdheden hanteert in relatie tot de beginselen van behoorlijke rechtspleging van betekenis is voor het behoorlijkheidsgehalte van procedures en van rechtbescherming in het algemeen. Met de vaststelling dat bepaalde procedures die onderdeel vormen van het stelsel van rechtsbescherming aan de beginselen van behoorlijke rechtspleging dienen te voldoen, wordt immers nog niet bewerkstelligd dat zulks ook daadwerkelijk het geval is. De wijze van toetsen van de bestuursrechter aan die beginselen en de gevolgen die aan schendingen van de beginselen van behoorlijke rechtspleging verbonden worden door de bestuursrechter zijn voor de geldingskracht en inachtneming van deze beginselen evenzeer van betekenis. In de voorgaande paragrafen is al enkele malen de houding of benadering van de bestuursrechter ten aanzien van de beginselen van behoorlijke rechtspleging aan de orde gekomen. Aandacht was er in dat kader vooral voor de houding van de bestuursrechter als het gaat om de betekenis van die 


\section{Deel III Slotbeschouwing}

beginselen voor de bestuurlijke voorprocedures. Er kan echter ook meer in algemene zin iets gezegd worden over de wijze waarop de beginselen van behoorlijke rechtspleging door de bestuursrechter in een concreet geval worden gehanteerd. Van belang is vooral de vraag in hoeverre de bestuursrechter ambtshalve aan die beginselen toetst en in hoeverre gronden die betrekking hebben op de behoorlijkheid van een procedure ambtshalve door de bestuursrechter worden aangevuld, gelet op artikel 8:69 Awb.

Ambtshalve toetsing en ambtshalve aanvulling van de rechtsgronden

Van de bevoegdheid tot ambtshalve toetsing wordt door de bestuursrechter in het algemeen terughoudend gebruik gemaakt. Die bevoegdheid is beperkt tot voorschriften van openbare orde. Dat betekent dat, wil de bestuursrechter in een concreet geval ambtshalve nagaan of de beginselen van behoorlijke rechtspleging in acht zijn genomen, deze beginselen als van openbare orde moeten worden beschouwd. Over de vraag of eisen van behoorlijke rechtspraak tot de categorie bepalingen van openbare orde behoren, is de jurisprudentie van de bestuursrechter niet eenduidig. Een enkele keer lijkt de bestuursrechter ambtshalve te toetsen aan een beginsel van behoorlijke rechtspleging, maar nog nimmer is in algemene zin expliciet overwogen dat deze beginselen van openbare orde zijn. Recent heeft de bestuursrechter, zoals uiteen is gezet in paragraaf 4.1 en 4.3.8 van Deel $\mathrm{I}$, in het kader van de redelijke termijn-eis overwogen dat de bevoegdheid tot ambtshalve aanvulling van de rechtsgronden van artikel 8:69 tweede lid Awb ruimhartig moet worden gehanteerd. In een andere recente uitspraak heeft de bestuursrechter zelfs overwogen dat in beginsel niet ambtshalve kan worden getoetst of de redelijke termijn is geschonden, maar dat daarop uitzonderingen kunnen bestaan. ${ }^{8}$ Uit deze uitspraken volgt dat het uitgangspunt is dat niet ambtshalve aan de redelijke termijn-eis kan worden getoetst. Gelet op de stand van de rechtspraak op dit moment kan aangenomen worden dat ook de andere beginselen van behoorlijke rechtspleging geen rechtsnormen vormen waaraan de bestuursrechter amtshalve toetst. ${ }^{9}$ In de literatuur is wel voor ambtshalve toetsing aan die beginselen gepleit, maar vooralsnog lijkt de bestuursrechter terughoudend in het toekennen van een openbare orde-karakter aan deze normen.

Met zijn bevoegdheid tot ambtshalve aanvulling van de gronden van het beroep op grond van artikel 8:69, tweede lid, van de Awb, voor zover deze zien op de behoorlijkheid van de procedure, lijkt de bestuursrechter daarentegen ruimhartiger om te gaan. Het duidelijkst valt dat ook weer te zien in de jurisprudentie inzake overschrijdingen van de redelijke termijn-eis. In het kader van die eis heeft de Afdeling immers uitdrukkelijk aangegeven dat indien er op enigerlei wijze geklaagd wordt over de duur van de procedure, deze klacht via ambtshalve aanvulling van de rechtsgronden moet worden opgevat als een klacht over overschrijding van de redelijke termijn. ${ }^{10}$ In eerdere jurisprudentie gebeurde dat ook $\mathrm{al}^{11}$ en op grond van artikel 8:69, tweede lid, Awb ligt het ook in de rede dat de bestuursrechter zijn plicht tot ambtshalve aanvulling van de rechtsgronden op deze wijze hanteert. Uit deze recente uitspraak van de Afdeling blijkt nog eens expliciet en duidelijk dat de bestuursrechter in dit soort gevallen niet te terughoudend met zijn bevoegdheid tot ambtshalve aanvulling van de rechtsgronden dient om te springen. Aangenomen moet hierbij ook weer worden dat de andere bestuursrechtelijke rechtscolleges, zoals de Centrale Raad of het College van beroep voor het bedrijfsleven, eenzelfde lijn hanteren - zeker gelet op de afstemming die heeft plaatsgevonden in het kader van de vele redelijke termijn- uitspraken die de afgelopen periode het licht hebben gezien. De Hoge Raad lijkt, als hoogste belastingrechter, in het kader van de redelijke termijn meer

8. AbRvS 10 februari 2010, LJN BL3354. Het betrof in dit geval een punitieve sanctie, namelijk een boete opgelegd op grond van de Wet arbeid vreemdelingen.

9. Uit het tweede evaluatie-onderzoek van de Awb inzake hoger beroep bleek overigens dat de CRvB daartoe in het verleden af en toe wel overging, zie: Widdershoven e.a. 2001, p. 179.

${ }^{10 .}$ AbRvS 1 juli 2009 (zaaknr. 200805262/1/M2).

${ }^{11 .} \mathrm{Zie}$ over de ruimhartige toepassing daarvan in het verleden, Widdershoven e.a. 2001, p. 181 e.v. 
Deel III Slotbeschouwing

mogelijkheden te zien voor de feitenrechter om ambtshalve te toetsen of die termijn is overschreden. In hoeverre de verschillende bestuursrechters ten aanzien van de overige vereisten van behoorlijke rechtspleging dezelfde lijn hanteren is nog niet duidelijk, aangezien deze kwestie nog niet expliciet in de jurisprudentie aan de orde is gekomen. Voor de hand ligt echter dat de bevoegdheid tot ambtshalve aanvulling van de rechtsgronden bij alle beginselen van behoorlijke rechtspleging op eenzelfde wijze zal worden gehanteerd. Een ruimhartige toepassing van die bevoegdheid zou eveneens op zijn plaats zijn vanwege het fundamentele karakter van de normen waar het om gaat. Zoals aangegeven, duidt eerdere jurisprudentie er ook op dat de bestuursrechter ten aanzien van de overige normen van behoorlijke rechtspleging ruimhartig met zijn bevoegdheid tot aanvulling van de rechtsnormen omgaat.

Ambtshalve toetsing in uitzonderlijke gevallen

Hoewel uit de jurisprudentie van de bestuursrechter lijkt te volgen dat er geen plicht tot ambtshalve toetsing aan de beginselen van behoorlijke rechtspleging bestaat voor de bestuursrechter, zijn er uitzonderingen denkbaar op dat uitgangspunt. De Afdeling heeft in een zaak waarin een opgelegde boete op grond van de Wav centraal stond overwogen dat er uitzonderingen bestaan op het uitgangspunt dat niet ambtshalve getoetst kan worden door de bestuursrechter of de redelijke termijn als bedoeld in artikel 6 EVRM is overschreden. ${ }^{12}$ De Afdeling geeft als algemeen uitgangspunt te kennen dat de bestuursrechter niet ambtshalve behoeft na te gaan of de redelijke termijn is geschonden, indien daarover in beroep niet is geklaagd. Dat kan echter anders zijn, indien na sluiting van het onderzoek de uitspraak vertraging oploopt en die vertraging ervoor zorgt dat de gefixeerde termijn die voor de duur van het beroep staat in het kader van de redelijke termijn wordt overschreden. In het geval waar het om ging werd het onderzoek gesloten en werd niet, zoals artikel 8:66 Awb vereist, zes weken daarna maar bijna twee en een halve maand later uitspraak gedaan. Over die vertraging kon, nu het onderzoek reeds gesloten was en de vertraging voor het sluiten van het onderzoek niet te voorzien was, vanzelfsprekend niet geklaagd worden in de lopende procedure. In die gevallen behoort de bestuursrechter volgens de Afdeling dan ook ambtshalve te toetsen of de redelijke termijn is geschonden door de vertraging die is opgetreden sinds de sluiting van het onderzoek.

Deze uitzonderingsmogelijkheid moet in mijn optiek ook voor de bestuursrechter bestaan bij de overige beginselen van behoorlijke rechtspleging, indien zich een behoorlijkheidsgebrek aandient of dreigt aan te dienen in een lopende beroepsprocedure waarover niet meer geklaagd kan worden. Deze situatie zal zich bij andere beginselen dan het beginsel van de redelijke termijn niet zo snel voordoen. De bestuursrechter kan bovendien, indien geklaagd wordt over dergelijke beweerdelijke schendingen na sluiting van het onderzoek, altijd nog overgaan tot heropening van het onderzoek. Desondanks zou de mogelijkheid moeten bestaan voor de bestuursrechter daartoe, indien nodig ter inachtneming van de beginselen van behoorlijke rechtspleging, ambtshalve over te gaan. Voorstelbaar is dat ná sluiting van het onderzoek, maar vóór het doen van de uitspraak- zonder dat daarover geklaagd wordt - blijkt dat ten onrechte geen openbare terechtzitting is gehouden of zich een situatie aandient waardoor de onpartijdigheid van de rechter in het geding is. In die gevallen kan de mogelijkheid van ambtshalve toetsing aan het desbetreffende beginsel en ambtshalve heropening van het onderzoek uitkomst bieden. De uitzonderingsmogelijkheid sluit ook goed aan bij de taak en verantwoordelijkheid die op een rechter rust voor de inachtneming van de beginselen van behoorlijke rechtspleging in een bij hem aanhangige procedure. Zoals is uiteengezet in paragraaf 3.2.2 van Deel I van dit onderzoek en hiervoor ook aan de orde kwam in paragraaf 2.3, is het aan de rechter om, voor zover mogelijk, een behoorlijkheidsgebrek in een lopende procedure te voorkomen of te herstellen. Dat dient zo nodig ambtshalve plaats te vinden, indien daarover niet

\footnotetext{
12. AbRvS 10 februari 2010, LJN BL3354.
} 


\section{Deel III Slotbeschouwing}

meer geklaagd kan worden, en kan zelfs tot afwijking van de wettelijke regeling nopen in een concreet geval. Vermeden moet worden dat een dreigend of reeds bestaand behoorlijkheidsgebrek dat in een lopende procedure voorkomen, hersteld of geredresseerd kan worden, onnodig tot een procedure in hoger beroep leidt waarin pas redres kan worden geboden door onder meer vernietiging van de uitspraak.

Hoewel het in de aangehaalde uitspraak van de Afdeling een zaak een punitieve sanctie betrof waarop artikel 6 EVRM van toepassing was, kan deze uitspraak ook relevant zijn voor bestuursrechtelijke geschillen van andere aard. De omstandigheid dat het een punitieve sanctie betreft is immers niet doorslaggevend voor de vraag of ambtshalve toetsing aan de uit artikel 6 EVRM voortvloeiende vereisten mogelijk is. Uit artikel 6 EVRM of de jurisprudentie van het EHRM vloeit een plicht tot ambtshalve toetsing in die gevallen niet voort. Voor geschillen die vallen onder de vaststelling van een civil right or obligation geldt dat evenmin. Uit de overwegingen van de Afdeling kan ook niet opgemaakt worden dat zij de uitzonderingsmogelijkheid heeft willen beperken tot bestuursrechtelijke geschillen waarin een punitieve sanctie centraal staat.

\section{Rol van de bestuursrechter bij de ontwikkeling van de beginselen van behoorlijke} rechtspleging

Zoals in Deel I van dit onderzoek is uiteengezet, is de ontwikkeling van de algemene beginselen van behoorlijk bestuur in de rechtspraak en de doctrine verder gevorderd dan de ontwikkeling van de beginselen van behoorlijke rechtspleging. In elk geval zijn de algemene beginselen van behoorlijk bestuur meer aan de orde in de rechtspraak en ook verder uitgewerkt in concrete eisen dan het geval is voor de beginselen van behoorlijke rechtspleging. De nationale ontwikkeling daarvan is later op gang gekomen en in vergelijking tot de algemene beginselen van behoorlijk bestuur is er betrekkelijk weinig aandacht aan besteed. Dat heeft ook te maken met het feit dat in de procedure bij de rechter een besluit bestreden wordt en de rechter gedurende de procedure zal waken voor een schending van de beginselen van behoorlijke rechtspleging. Gelet op het belang van de normen en dit onderwerp voor het nationale bestuursprocesrecht zou het echter aanbeveling verdienen, indien de bestuursrechter een heldere en consistente benadering van die beginselen tentoonspreidt in zijn uitspraken. Daarbij zou de aandacht minder moeten uitgaan naar de eisen die voortvloeien uit artikel 6 EVRM, maar zouden veeleer de nationale ongeschreven beginselen van behoorlijke rechtspleging verder ontwikkeld moeten worden. De mogelijke opname van een recht op toegang tot de rechter of een recht op een eerlijk proces in de Grondwet zou aan die ontwikkeling kunnen bijdragen. De opname van een dergelijk recht in de Grondwet kan er ook toe leiden dat op de nationale normen meer, dan thans het geval is, door partijen een beroep zal worden gedaan.

\section{De verhouding van de beginselen van behoorlijke rechtspleging tot de algemene beginselen van behoorlijk bestuur}

Een belangrijke vraag die zich naar aanleiding van de resultaten uit Deel II van dit onderzoek en de voorgaande paragrafen aandient, is hoe de beginselen van behoorlijke rechtspleging en de beginselen van behoorlijk bestuur zich tot elkaar verhouden. Juist als het gaat om de bestuurlijke voorprocedures, die zowel rechterlijke als bestuurlijke kenmerken hebben, is deze vraag naar de verhouding tussen de verschillende toepasselijke normen prangend. Uit paragraaf 2 van dit deel blijkt voorts dat de aan- of afwezigheid van een equivalent beginsel van behoorlijk bestuur een rol lijkt te spelen bij de mate van invloed van de beginselen van behoorlijke rechtspleging op de bestuurlijke voorprocedures. Bovendien blijkt uit het onderzoek in Deel II en uit de voorgaande paragrafen dat de geldende procedurele waarborgen, ongeacht of zij te herleiden zijn tot de beginselen van behoorlijke rechtspleging of de beginselen van behoorlijk bestuur, voor de bestuurlijke voorprocedures en de procedure bij de bestuursrechter gelijkenissen vertonen. 


\section{Deel III Slotbeschouwing}

Daarom wordt in de onderhavige paragraaf de verhouding tussen beide categorieën beginselen onder de loep genomen. Daarbij wordt op een drietal aspecten in de verhouding tussen beide categorieën beginselen nader ingegaan. Allereerst komt de overlap die bestaat tussen beginselen van beide categorieën aan de orde. Vervolgens wordt aandacht besteed aan de betekenis van de beginselen van behoorlijke rechtspleging voor de ontwikkeling of invulling van de beginselen van behoorlijk bestuur. Op deze twee aspecten wordt in paragraaf 4.1 ingegaan. Tot slot wordt in paragraaf 4.2 de vraag beantwoord of er aanleiding bestaat om overkoepelende beginselen van een behoorlijke procedure te onderscheiden die voor alle geschilbeslechtende procedures gelden, ongeacht bij welk orgaan die procedure plaatsvindt.

\subsection{De overlap tussen de beginselen van behoorlijk bestuur en behoorlijke rechtspleging}

De beginselen van behoorlijk bestuur en de beginselen van behoorlijke rechtspleging In dit onderzoek is al verschillende malen aan de orde gekomen dat er tussen de beginselen van behoorlijke rechtspleging en de beginselen van behoorlijk bestuur (en de daaruit voortvloeiende vereisten) voor de bestuurlijke voorprocedures een zekere mate van overlap bestaat. Er bestaan voor verschillende beginselen van behoorlijke rechtspleging, zoals het beginsel van hoor en wederhoor, het onpartijdigheidsbeginsel en het motiveringsbeginsel, equivalente beginselen van behoorlijk bestuur - al dan niet onder dezelfde benaming. Voor het beginsel van hoor en wederhoor bestaat het equivalent beginsel van behoorlijk bestuur uit het formele zorgvuldigheidsbeginsel, terwijl van het motiveringsbeginsel en onpartijdigheidsbeginsel equivalenten te vinden zijn in het bestuurlijk motiveringsbeginsel en het verbod van vooringenomenheid. Deze beginselen van behoorlijk bestuur hebben tevens geheel of gedeeltelijk dezelfde functie voor het bestuur als de equivalente beginselen van behoorlijke rechtspleging voor de bestuursrechter. Uit de equivalente beginselen van behoorlijk bestuur vloeien materieel bovendien grotendeels vergelijkbare eisen voort als voor de rechterlijke procedure op grond van de beginselen van behoorlijke rechtspleging het geval is. Kortom, voor zover het betreft het formele zorgvuldigheidsbeginsel, het verbod van vooringenomenheid en het motiveringsbeginsel als beginselen van behoorlijk bestuur, valt er een overlap tussen de eisen die voortvloeien uit die beginselen en de beginselen van behoorlijke rechtspleging te constateren. De vraag is dan vanzelfsprekend in hoeverre de beginselen van behoorlijke rechtspleging naast die beginselen van behoorlijk bestuur van betekenis (kunnen) zijn en in hoeverre toepasselijkheid van die beginselen nodig is.

Aanvullende betekenis van de beginselen van behoorlijke rechtspleging

Omdat er reeds beginselen van behoorlijk bestuur bestaan waaruit vergelijkbare eisen voortvloeien, zal ten aanzien van de drie hiervoor genoemde beginselen en de uitwerkingen daarvan de betekenis van de beginselen van behoorlijke rechtspleging slechts aanvullend kunnen zijn. Rechtstreekse en volledige toepasselijkheid van de beginselen van behoorlijke rechtspleging voor de gevallen waarin een equivalent beginsel van behoorlijk bestuur bestaat is niet geconstateerd. De beginselen van behoorlijke rechtspleging blijken vooral van belang te zijn daar waar de beginselen van behoorlijk bestuur niet voorzien in uitwerkingen of anderszins in een leemte kan worden voorzien. Omgekeerd betekent dit dat de aanwezigheid van equivalente beginselen van behoorlijk bestuur de mogelijke invloed van de beginselen van behoorlijke rechtspleging op de bestuurlijke voorprocedures beperkt, aangezien rechtstreekse en volledige toepassing in die gevallen niet nodig is en dan ook niet bestaat. Voor een aanvullende werking van de beginselen van behoorlijke rechtspleging is echter ook slechts plaats, indien daarin een toegevoegde waarde schuilt. Uit paragrafen 5.3, 5.4 en 5.6 van Deel II van dit onderzoek blijkt dat die toegevoegde waarde er is.

Zoals aangegeven, gelden de beginselen van behoorlijk bestuur voor alle besluitvorming door het bestuur, ongeacht in welke fase die besluitvorming zich bevindt. De 


\section{Deel III Slotbeschouwing}

toepassing en invulling van deze beginselen in de doctrine en rechtspraak zijn, zoals eerder werd aangegeven, echter doorgaans meer gericht op de primaire besluitvormingsfase of besluitvorming in het algemeen, en minder specifiek op de bestuurlijke voorprocedures. In sommige gevallen heeft dat tot gevolg dat het perspectief voor de toepassing van het desbetreffende beginsel wordt meer gericht is op de zorgvuldigheid van de besluitvorming waarbij nauwelijks rekening gehouden wordt met het specifieke karakter van de bestuurlijke voorprocedures. De rechtsbeschermingscomponent, die zo kenmerkend is voor de bestuurlijke voorprocedures en waarin deze verschillen van de primaire besluitvormingsprocedures, komt in de analyses of toepassing van de beginselen van behoorlijk bestuur in mindere mate tot uitdrukking. Dat wil echter, zoals blijkt uit Deel II van dit onderzoek, niet zeggen dat er geen eisen gelden die ten dienste staan aan de rechtsbescherming van belanghebbenden of de processuele belangen van de deelnemers aan de procedure. Het betekent uitsluitend dat het rechtsbeschermingsperspectief in het kader van die eisen niet altijd voldoende onderkend wordt. Zoals hiervoor al is uiteengezet, liggen daaraan verschillende redenen ten grondslag.

Het gebrek aan aandacht voor de rechtsbeschermingscomponent doet zich bijvoorbeeld voor bij het formele zorgvuldigheidsbeginsel, waaruit eisen voortvloeien die overeenkomen met de eisen die voor de rechter voortvloeien uit het beginsel van hoor en wederhoor. In de rechtspraak wordt echter niet altijd onderkend dat het gaat om vergelijkbare eisen, omdat daarmee kennelijk geïmpliceerd zou kunnen worden dat er geen onderscheid bestaat tussen besturen en rechtspreken of het bestuur en de rechter. Bij eisen waarin het perspectief van hoor en wederhoor bepalend lijkt, ziet de bestuursrechter echter ook ruimte om terug te grijpen op het beginsel van hoor en wederhoor of de goede procesorde en aansluiting te zoeken bij de voor de rechter geldende eisen. In het kader van het motiveringsbeginsel bestaat er weinig aandacht voor de processuele functie van dat beginsel voor de bestuurlijke voorprocedures en uitwerkingen van het beginsel die daarop zien. Aandacht voor de specifieke betekenis van het verbod van vooringenomenheid voor het bestuur in de bestuurlijke voorprocedures is er evenmin op grote schaal. Door de beginselen van behoorlijke rechtspleging meer expliciet aanvullend van betekenis te kunnen laten, kan dat grotendeels ondervangen worden. Die beginselen hebben immers grotendeels dezelfde functie en ratio voor de bestuurlijke voorprocedures als de equivalente beginselen van behoorlijke rechtspleging voor de rechterlijke procedure. De betekenis van deze beginselen van behoorlijke rechtspleging voor de bestuurlijke voorprocedure blijft echter beperkt. Voor invloed of doorwerking blijft naast het equivalente beginsel van behoorlijk bestuur weinig ruimte over, omdat de beginselen van behoorlijk bestuur behoorlijk uitgekristalliseerd zijn.

Van niet alle beginselen van behoorlijke rechtspleging bestaan echter, zoals aangegeven, equivalente beginselen van behoorlijk bestuur. Dat betekent dat de betekenis van deze beginselen van behoorlijke rechtspleging in die gevallen ruimer zou kunnen zijn, omdat er meer ruimte bestaat voor invloed van die beginselen op de bestuurlijke voorprocedures. Bij het beginsel van de redelijke termijn kan dan ook duidelijk doorwerking in de bestuurlijke voorprocedures geconstateerd worden. Hoewel er vooralsnog geen equivalent beginsel van behoorlijk bestuur bestaat waaruit vergelijkbare eisen voortvloeien, worden eisen die zien op de voortvarendheid van de besluitvorming een enkele keer gebaseerd op het zorgvuldigheidsbeginsel of het rechtszekerheidsbeginsel. In het algemeen wordt in de doctrine en rechtspraak wordt geen beginsel van behoorlijk bestuur aangewezen dat deze eisen omvat en wordt teruggegrepen op het beginsel van behoorlijke rechtspleging. Onder invloed daarvan vindt langzamerhand echter wel erkenning van een afzonderlijk beginsel van behoorlijk bestuur plaats. Voor het openbaarheidbeginsel geldt eveneens dat geen beginsel van behoorlijk bestuur zich leent als equivalent waarop de (externe) openbaarheideisen die gelden voor de bestuurlijke voorprocedures gebaseerd kunnen worden. Desondanks bestaan er uitwerkingen van het externe openbaarheidsbeginsel die aansluiten bij de uitwerkingen die gelden voor de rechterlijke procedure, voor zover het de behandeling van de zaak betreft. Er wordt echter niet expliciet 


\section{Deel III Slotbeschouwing}

teruggegrepen op het beginsel van behoorlijke rechtspleging, terwijl daarvoor wel ruimte is. Van de eisen inzake de openbaarheid van de hoorzitting wordt derhalve vermoed dat zij te herleiden vallen tot het rechtspraakachtige karakter van de bestuurlijke voorprocedures, maar met zekerheid kon dat niet worden vastgesteld. Directe invloed van het beginsel van behoorlijke rechtspleging valt derhalve niet aan te wijzen. Omdat er geen beginsel van behoorlijk bestuur valt aan te wijzen waar deze openbaarheideisen uit voortvloeien ligt aansluiting bij de rechterlijke openbaarheidseisen voor de hand.

Uit de omstandigheid dat er vergelijkbare eisen afgeleid worden uit beide categorieen beginselen blijkt dat er verwantschap bestaat tussen de hiervoor genoemde beginselen van behoorlijk bestuur en de beginselen van behoorlijke rechtspleging. Voor de bestuurlijke voorprocedures leidt die verwantschap tot een overlap in eisen, die enerzijds herleid kunnen worden tot de equivalente beginselen van behoorlijk bestuur, en anderzijds tot de beginselen van behoorlijke rechtspleging.

\subsection{Overkoepelende beginselen van een behoorlijke procedure of behoorlijk procesrecht}

Verwantschap tussen de beginselen van behoorlijke rechtspleging en behoorlijk bestuur Het bestaan van een zekere overlap tussen de (uitwerkingen van) beginselen van behoorlijke rechtspleging en enkele algemene beginselen van behoorlijk bestuur in de bestuurlijke voorprocedures, hangt samen met het tweeledige karakter van die procedures en het gemeenschappelijke karakter van de beginselen van behoorlijke rechtspleging en de desbetreffende beginselen van behoorlijk bestuur. Het gegeven dat er twee sets van normen bestaan die zich ofwel tot het bestuur ofwel tot de rechter richten, valt met name te herleiden tot het formele onderscheid tussen beide organen.

Op het eerste gezicht zijn er echter veel overeenkomsten tussen beide soorten normen. In beide gevallen betreft het rechtsnormen die door de adressaat van de beginselen, respectievelijk bestuur en rechter, in acht moeten worden genomen. Tussen de formele beginselen van behoorlijk bestuur en de beginselen van behoorlijke rechtspleging bestaat voorts de overeenkomst dat beide soorten beginselen zien op de behoorlijkheid van de procedure, het beslissende orgaan en de totstandkoming van de beslissing. In beide gevallen is sprake van toetsingsnormen waaraan de rechtmatigheid van een genomen beslissing kan worden getoetst door de bestuursrechter. Beide soorten beginselen hebben een gemeenschappelijke oorsprong. ${ }^{13}$ Beide catalogi van normen vloeien onder meer voort uit meer algemene noties, zoals de rechtszekerheid en zorgvuldigheid die overheidsorganen dienen te betrachten bij het nemen van beslissingen jegens burgers waardoor deze burgers in hun rechtspositie geraakt worden. Meer fundamenteel zijn deze normen voor deze organen terug te voeren op de rechtsstaatgedachte en de binding aan rechtsnormen bij de uitoefening van bevoegdheden door de overheid. De overheid is bij zijn optreden in alle hoedanigheden gebonden aan het recht. Enkele van de beginselen gelden immers niet alleen voor het bestuur en de rechter, maar ook voor de wetgever, als beginselen van behoorlijke wetgeving. ${ }^{14}$ Voor het bestuur betekent dit in beginsel dat de beslissing zelf en de procedure waarin deze tot stand is gekomen conform de wet en ongeschreven beginselen van behoorlijk bestuur behoort te hebben plaatsgevonden. ${ }^{15}$

\footnotetext{
13. Volgens sommigen vinden de abbb's hun oorsprong in de algemene beginselen van behoorlijke rechtspleging en zijn de beginselen stamgenoten, De Waard 1987, p. 129.

14. Zie: I.C. van der Vlies, Het wetsbegrip en beginselen van behoorlijke regelgeving: de verandering van het legaliteitsbeginsel in de twintigste eeuw (diss. Amsterdam UvA), Den Haag: VUGA 1984; K. Waaldijk, Motiveringsplichten van de wetgever (diss. Leiden), Lelystad: Vermande 1994, p. 1-2.

15. Zie ook: J. in 't Veld \& N.S.J. Koeman, Beginselen van behoorlijk bestuur, Zwolle: W.E.J. Tjeenk Willink 1985 , p. 5 .
} 


\section{Deel III Slotbeschouwing}

Verschillende normen voor verschillende fasen in de procedure?

Op grond van de rechtsbeschermingsfunctie van de bestuurlijke voorprocedures en de waarborgen die gelden voor de inrichting van deze procedures, is een onderscheid in toepasselijke procedurele behoorlijkheidsbeginselen voor het bestuur en de rechter ook niet voor de hand liggend. De algemene beginselen van behoorlijk bestuur zijn als toetsingsnormen voor de rechter in de rechtspraak tot ontwikkeling gekomen. Pas later zijn, mede onder invloed van artikel 6 EVRM, de beginselen van behoorlijke rechtspleging tot ontwikkeling gekomen. Als toetsingsnormen worden beide soorten normen door de bestuursrechter gehanteerd, maar richten zij zich tot een andere adressaat. De beginselen van behoorlijk bestuur zijn normen die zich specifiek richten tot het bestuur en een op het bestuur en de werkzaamheid van het bestuur toegesneden inhoud hebben. Datzelfde geldt voor de beginselen van behoorlijke rechtspleging ten aanzien van rechterlijke instanties.

Voor zover het de bestuurlijke voorprocedures betreft wordt het echter lastig om de verhouding tussen beide soorten beginselen te bepalen. Omdat deze procedures zich tussen rechtspraak en bestuur in bevinden, zijn - zo is gebleken uit het onderzoek - beide soorten beginselen (of uitwerkingen daarvan) van toepassing op de bestuurlijke voorprocedures. De beginselen en vooral de uitwerkingen ervan in concrete eisen groeien naar elkaar toe voor zover het deze procedures betreft.

Drie fasen in een bestuursrechtelijk geschil

De omstandigheid dat de invulling van beide soorten beginselen en de uitwerkingen ervan naar elkaar toe groeien in de bestuurlijke voorprocedures is verklaarbaar wanneer men de procedures die een besluit doormaakt beschouwt als een geheel bestaande uit verschillende fasen. In het gehele bestuursrechtelijke proces inzake een door het bestuur genomen besluit kunnen in de regel drie fasen worden onderscheiden. De eerste fase betreft de fase van totstandkoming van het besluit, de tweede fase betreft het ontstaan van een geschil over dat besluit tussen bestuur en een belanghebbende in de vorm van de bestuurlijke voorprocedures en de derde fase betreft de procedure bij de onafhankelijke rechter in beroep (en hoger beroep). Gedurende die drie fasen verschuift het perspectief op de verschillende procedures en waarborgen die in deze procedures gelden langzamerhand van overwegend zorgvuldigheid van de besluitvorming en een bestuurlijk perspectief naar uiteindelijk overwegend een rechtsbeschermingsfunctie en het perspectief van de belanghebbende. In de tweede fase komt het duidelijkst een mengvorm van beide perspectieven in de procedure tot uitdrukking. Deze perspectieven zijn niet geheel tegengesteld aan elkaar, maar kunnen wel leiden tot verschillende accenten in de procedurele waarborgen die in acht moeten worden genomen. Omdat de tweede fase een mengvorm betreft van beide perspectieven waarop beide soorten beginselen van toepassing zijn groeien ook de waarborgen die uit deze beginselen voortvloeien naar elkaar toe. De procedurele waarborgen ter bescherming van de belangen van belanghebbenden nemen in iedere fase van de procedure toe. Zij zijn het geringst in de eerste fase, omdat daarin de zorgvuldigheid van de besluitvorming voorop staat en niet zozeer de bescherming van de procedurele belangen van belanghebbenden. Dat laatste is in de tweede fase wel een belangrijk perspectief, waardoor de procedurele waarborgen in die fase toenemen, maar nog niet gelijk zijn aan die in de rechterlijke procedure. In die laatste en derde fasen wordt het meeste gewicht toegekend aan de bescherming van de procedurele belangen van de deelnemers aan de procedure en zijn de waarborgen in dat verband het omvangrijkst.

Een categorie normen gerechtvaardigd

De vraag die zich dan aandient is of er niet een set normen dient te worden onderscheiden voor de procedurele behoorlijkheid van alle procedures die onderdeel vormen van het bestuursrechtelijke systeem van rechtsbescherming. Het zou gaan om beginselen van de goede procesorde of van een behoorlijke procedure die gelden voor de inrichting van 


\section{Deel III Slotbeschouwing}

iedere procedure waarin een geschil tussen burger en de overheid beslecht wordt. Overkoepelende normen betekenen niet automatisch dat deze beginselen voor iedere procedure dezelfde concrete toepassingen of uitwerkingen met zich hoeven brengen. In die concrete toepassingen kunnen de specifieke kenmerken van de betreffende procedure of het oordelende orgaan tot uitdrukking komen. In de inrichting van de procedures en de daarvoor geldende beginselen liggen echter de overeenkomsten. Een vergelijkbare benadering is, zoals aangegeven in paragraaf 1.4 van Deel I, te zien in de jurisprudentie van het EHRM als het gaat om de waarborgen die gelden voor bestuurlijke boetes en andere 'criminal charges'. ${ }^{16}$ Afhankelijk van de soort criminal charge die het betreft, zijn de waarborgen die gelden verstrekkender of juist minder verstrekkend. Artikel 6 EVRM blijft echter van toepassing op alle handelingen van de overheid die, volgens de daarvoor bestaande criteria, kunnen worden aangemerkt als criminal charge. Het beschermingsniveau kan echter verschillen. Voor de beginselen van een goede procesorde of behoorlijke procedure zou kunnen gelden dat zij van toepassing zijn op alle procedures waarin de rechtspositie van de burger door de overheid bepaald wordt. Naargelang de fase waarin de procedure zich bevindt, het rechtsbeschermingskarakter en het oordelende orgaan dat de beslissing neemt, zijn de waarborgen die gelden voor de inrichting van de procedure verstrekkender of juist niet. In dat verband kan ook nog per beginsel een onderscheid worden gemaakt. Op deze wijze kan het bestuurlijke karakter van de besluitvormingsprocedures gewaarborgd blijven en tevens tegemoet worden gekomen aan andere belangrijke uitgangspunten in het bestuurs(proces)recht, zoals rechtszekerheid, effectiviteit en snelheid van de procedures.

De procedurele beginselen kunnen zich in die benadering eveneens uitstrekken tot de primaire besluitvormingsfasen, met dien verstande dat - zoals het ook de Awbwetgever voor ogen stond - de waarborgen (en concrete eisen) toenemen naar gelang de fase waarin de procedure zich bevindt en in de primaire besluitvormingsfase het rechtsbeschermingsperspectief het minst aanwezig is. In die fase staat de rechtszekerheid van de burger en de benodigde feitenvergaring vanuit zorgvuldigheidsoogpunt voor de besluitvorming voorop. Dat zou, zoals aangegeven, betekenen dat de waarborgen in de primaire besluitvormingsfase het geringst moeten zijn en in de procedure bij de bestuursrechter het omvangrijkst. Kanttekening daarbij is wel dat het bestuur primair en eenzijdig ingrijpt in de rechtspositie van de burger. De zorgvuldigheid van de besluitvorming en waarborgen in dat kader zijn ook in die fase belangrijk ter compensatie van de mogelijk vergaande inbreuken op die rechtspositie.

Er zijn echter niet uitsluitend negatieve argumenten voor de mogelijkheid om een gemeenschappelijke categorie beginselen van een behoorlijke procedure, die geldt voor alle procedures gevoerd ten overstaan van de overheid waarin de individuele rechtspositie van de burger eenzijdig bepaald wordt, te onderscheiden. Positieve argumenten die pleiten voor het bestaan van een dergelijke categorie beginselen zijn er ook. Voor de bestuurlijke voorprocedures zou daarmee meer recht gedaan worden aan de gemeenschappelijke kenmerken en de overeenkomsten met bestuursrechtspraak. Niet alleen daaraan zou meer recht worden gedaan, maar ook aan de erkenning van het feit dat bepaalde procedurele vereisten voor de bestuurlijke voorprocedures en de procedure bij de bestuursrechter hetzelfde zijn en op dezelfde wijze worden ingevuld. De lijn in de jurisprudentie waarin dat voor bepaalde vereisten ontkend wordt zou daarmee verlaten kunnen worden, zonder dat afbreuk wordt gedaan aan het bestuurlijke karakter van de procedures. Daarvoor is eerder ruimte als de koppeling met artikel 6 EVRM en de status van het oordelende orgaan losgelaten wordt.

Bovendien zouden daardoor onwenselijke scheidingen tussen de bestuurlijke fasen en de rechterlijke fase(n), zoals thans het geval is in het kader van de toepasselijkheid

\footnotetext{
16. EHRM 23 november 2006, Jussila t. Finland, AB 2007/51 m.nt. Barkhuysen en Van Emmerik; EHRC
} 2007/31 m.nt. Albers. 


\section{Deel III Slotbeschouwing}

van het beginsel van de redelijke termijn in de jurisprudentie zodra geen beroep op de rechter is ingesteld, tot het verleden gaan behoren. Omdat de betekenis of toepasselijkheid van die beginselen niet meer afhankelijk is van het formele onderscheid tussen de oordelende organen, kan de betekenis ervan zich uitstrekken tot andere procedures dan die gevoerd ten overstaan van een rechterlijke instantie. Er bestaat voldoende ruimte om het onderscheid in status of hoedanigheid van het oordelende orgaan tot uitdrukking te laten komen in de mate van toepasselijkheid van de eisen. Hierboven is immers gesteld dat een gezamenlijke categorie beginselen nog niet hoeft te betekenen dat exact dezelfde eisen of uitwerkingen van die beginselen in dezelfde mate hoeven te gelden voor elke procedure. De verschillen in de procedures kunnen ook tot uitdrukking worden gebracht in de mogelijke gevolgen die aan een schending worden verbonden. Dat blijkt in de praktijk ook al plaats te vinden. De beginselen van behoorlijke rechtspleging hebben als rechtsnormen die de rechter in acht moet nemen in de regel tot gevolg dat de uitspraak vernietigd wordt, indien er in dat opzicht een gebrek aan de uitspraak kleeft. Dat is te meer het geval waar een schending van artikel 6 EVRM wordt geconstateerd. Voor de bestuurlijke voorprocedures gelden de uitwerkingen van de beginselen ook als geschreven of ongeschreven eisen, maar gaat de bestuursrechter eerder over tot het passeren van schendingen of het instandlaten van de rechtsgevolgen.

\section{$5 \quad$ Slotopmerkingen}

Als het gaat om de realisatie van procedurele waarborgen en het waarborgen van de beginselen van behoorlijke rechtspleging in het algemeen en in de bestuurlijke voorprocedures, rust een belangrijke taak op de rechter, de wetgever en de procespraktijk. Het onderzoek laat zien dat er nog aandachtspunten bestaan voor de daadwerkelijke realisatie van deze waarborgen in het Nederlandse bestuursprocesrecht.

\section{De hantering van behoorlijkheidsbeginselen door de bestuursrechter}

Uit het onderzoek blijkt dat de bestuursrechter een vrij pragmatische en weinig principiële benadering heeft als het gaat om de toepasselijkheid van beginselen van behoorlijke rechtspleging of daaruit voortvloeiende eisen. Hoewel rechtstreekse toepasselijkheid, zeker als het gaat om eisen neergelegd in artikel 6 EVRM, expliciet wordt uitgesloten, wordt het beginsel van hoor en wederhoor wel regelmatig impliciet of expliciet op de bestuurlijke voorprocedures toegepast. Soms wordt echter ook het zorgvuldigheidsbeginsel gehanteerd om eisen die ook onder de noemer van hoor en wederhoor zouden kunnen vallen op te baseren. Daarom blijft soms onnodig in het midden in hoeverre bepaalde beginselen of eisen van behoorlijke rechtspleging gelden voor de bestuurlijke voorprocedures en in hoeverre bepaalde eisen voor de bestuurlijke voorprocedures gezien moeten worden als uitwerkingen van een beginsel van behoorlijke rechtspleging. Het verdient aanbeveling dat de verschillende bestuursrechters, in het bijzonder de hoogste bestuursrechters, zich meer rekenschap geven van deze problematiek en daarvan ook blijk geven in hun uitspraken. Er zou meer en explicieter aandacht besteed moeten worden aan de vraag welke toepasselijke rechtsnorm geschonden wordt of welke rechtsnorm ten grondslag ligt aan een geschonden (wettelijke of ongeschreven) concrete eis.

\section{Aandacht voor samenhang van waarborgen}

De resultaten van dit onderzoek tonen voorts aan dat er meer samenhang bestaat tussen de bestuurlijke fasen en de rechterlijke fasen als onderdelen van het stelsel van rechtsbescherming tegen een besluit dan, met name in de rechtspraak, wordt aangenomen. Er zou dan ook meer oog moeten bestaan voor de omstandigheid dat er drie fasen in het proces ten aanzien van een besluit voor belanghebbenden bestaan, waarbij in elke fase van de procedure inzake een besluit de procedurele waarborgen toenemen. Die procedurele waarborgen vertonen samenhang, ook al bestaan er soms verschillende grondslagen in de algemene beginselen van behoorlijk bestuur of de beginselen van behoorlijke rechtsple- 


\section{Deel III Slotbeschouwing}

ging. De bestuurlijke voorprocedures bevinden zich in dat geheel van procedures in een unieke positie, omdat zij kenmerken vertonen van zowel besluitvorming als rechtspraak. De procedurele waarborgen die gelden voor de rechterlijke procedure in de vorm van de beginselen van behoorlijke rechtspleging zijn echter, zij het niet altijd voor elk beginsel in gelijke mate, ook van betekenis voor die bestuurlijke voorprocedures.

\section{Ontwikkeling van nationale waarborgen}

Niet alleen zou er meer oog moeten bestaan voor de samenhang tussen de verschillende fasen in de procedure, ook zou er meer aandacht moeten bestaan voor de invulling en ontwikkeling van de nationale procedurele waarborgen en beginselen van behoorlijke rechtspleging. Uit het onderzoek is gebleken dat daaraan behoefte bestaat. De focus op artikel 6 EVRM en de koppeling met de toegang tot de rechter dreigen bijvoorbeeld het zicht te vertroebelen op procedurele waarborgen, zoals het beginsel van de redelijke termijn, die zelfstandig zouden moeten gelden voor de bestuurlijke voorprocedures. Belangrijk is dat ook in alle gevallen - en dat aantal is aanzienlijk - waarin geen bestuursrechter geadieerd wordt voldoende waarborgen gelden en het bestuur ertoe wordt aangezet deze waarborgen in acht te nemen. Bovendien is de reikwijdte van artikel 6 EVRM beperkt, waardoor niet alle bestuursrechtelijke geschillen door de daarin neergelegde waarborgen bestreken worden. Er bestaat dan ook voldoende reden om de nationale (ongeschreven) waarborgen meer tot ontwikkeling te laten komen.

\section{Geen toename waarborgen of juridisering van de voorprocedures}

Toepasselijkheid van de beginselen van behoorlijke rechtspleging op de bestuurlijke voorprocedures of erkenning daarvan betekent voorts niet per definitie dat er daarmee strengere eisen gaan gelden voor die procedures. Sommige beginselen van behoorlijke rechtspleging zijn immers al van toepassing op die procedures en de uitwerkingen van die beginselen voor de bestuurlijke voorprocedures verschillen van die voor de rechterlijke procedure. Bovendien vloeien uit sommige beginselen van behoorlijk bestuur, zoals het motiveringsbeginsel, zelfs verder uitgewerkte concrete eisen voort dan het geval is voor de rechterlijke procedure op grond van het equivalente beginsel van behoorlijk bestuur. Daar komt bij dat een behoorlijke en met waarborgen omklede procedure ook ten dienste staat aan kwalitatief deugdelijke en zorgvuldige besluitvorming. Ook kan in de gevolgen die aan schending van de waarborgen in de bestuurlijke voorprocedures plaatsvinden rekening gehouden worden met de omstandigheid dat de procedure plaatsvindt in de bestuurlijke fase. Gelet daarop zou de bestuursrechter in zijn uitspraken een eenduidigere en consistentere lijn kunnen aanbrengen als het gaat om het passeren van schendingen van procedurele waarborgen, zoals uitwerkingen van de beginselen van behoorlijke rechtspleging of bestuur, of het vanwege dergelijke schendingen vernietigen en instandlaten van de rechtsgevolgen. Op dit moment is nog lang niet altijd duidelijk welke schendingen met toepassing van artikel 6:22 Awb gepasseerd kunnen worden en onder welke voorwaarden.

\section{Evenwicht tussen effectiviteit en behoorlijkheid}

Er dient in alle fasen die een besluit doormaakt een evenwicht te worden gevonden tussen snelheid en finaliteit enerzijds en procedurele behoorlijkheid en zorgvuldigheid anderzijds. Daarbij kan dat evenwicht in iedere fase anders uitpakken. Afhankelijk van de fase waarin het besluit zich bevindt kan meer gewicht worden toegekend aan de ene of andere uitgangspunten. Over het geheel genomen zal er echter een goede balans tussen deze uitgangspunten moeten worden gevonden. Bij de hervormingen van het bestuursprocesrecht en de bestuursrechtelijke rechtsbescherming die in de nabije toekomst op stapel te staan is het goed deze aandachtspunten voor ogen te houden. Voorkomen moet worden dat de procedurele behoorlijkheid als belangrijke eis voor de inrichting van de bestuurlijke rechtsbescherming ondergeschikt wordt gemaakt aan de snelheid en finaliteit van die rechtsbescherming. Er zijn mogelijkheden om aan beide uitgangspunten 


\section{Deel III Slotbeschouwing}

recht te doen. Een voorbeeld zou zijn om aan schendingen van behoorlijkheidseisen geen vernietiging van de beslissing te verbinden, maar zoveel mogelijk alternatieve rechtsgevolgen daaraan te verbinden. Naar de mogelijkheden om los van een vernietiging alternatieve rechtsgevolgen te verbinden aan schendingen van uitwerkingen van de beginselen van behoorlijke rechtspleging en de vormgeving daarvan binnen het bestuursrechtelijk stelsel van rechtsbescherming zou in het kader van de hervorming van dat stelsel nader onderzoek kunnen plaatsvinden. Een uitbreiding van de mogelijkheden om schendingen te passeren, waardoor zij zonder rechtsgevolgen blijven, verdient in dat licht niet de voorkeur. 


\title{
Summary
}

\author{
The applicability of principles of procedural due process on preliminary adminis- \\ trative proceedings
}

This book addresses the question of whether, and if so, to what extent, the principles of procedural due process are applicable in the course of preliminary administrative proceedings. In the Dutch system of administrative judicial protection an interested party generally has to follow a preliminary administrative procedure before lodging an appeal with an administrative court. In most cases this preliminary procedure takes the form of an objection procedure with the administrative authority which took the contested decision ("bezwaarschriftprocedure"). Another possible preliminary procedure is lodging an administrative appeal to a different administrative authority than the one which took the contested decision ("administratief beroep").

Different procedures are governed by different principles. Principles of procedural due process are addressed to courts and thus apply to the administration of justice, whereas the principles of proper administration apply to the preliminary administrative proceedings. However, being a part of the system of judicial protection, the preliminary administrative procedures resemble administrative court procedures. In addition, one principle of procedural due process already applies directly to the preliminary administrative procedures.

The book is divided into three parts. Part I deals with the first part of the central research question: which principles of procedural due process can be distinguished? Part II focuses on the preliminary administrative procedures. In Part II the question of which requirements must be complied with and to what extent those requirements are influenced by principles of procedural due process is answered. Finally, Part III offers the main findings.

\section{Part I}

Part I starts with the scope of principles of procedural due process. Here it is argued that the scope is not limited to the administration of justice by an independent court (Chapters 1 and 2). Principles of procedural due process can influence other procedures in various ways. This influence needs to be established separately for each principle and for each procedure.

Chapter 3 of Part I deals with the question of what the actual legal meaning of principles of procedural due process is. The principles of procedural due process are considered to be legal norms which serve as grounds for review of the actions and judgments of the courts. Violation of these principles is unlawful and will, in principle, lead to the annulment of the judgment. However, principles generally are abstract legal norms which must be made concrete by the courts (or by the legislator). In doing so, the courts (or the legislator) enjoy a certain degree of discretion. As a consequence of this discretion, there are various ways in which these principles can be made concrete. In particular, two types of concrete requirements, which can be deduced from abstract legal norms, can be distinguished: essential requirements and requirements of lesser importance. Violation of essential requirements automatically entails the violation of the underlying principle and therefore leads to legal consequences, whereas a breach of less essential requirements does not necessarily have legal consequences. 
Chapter 4 of Part I studies the legal foundations of the principles of procedural due process. It is established that Article 6 of the European Convention on Human Rights and Fundamental Freedoms (ECHR) has a strong influence on the principles of procedural due process which exist at a national level. In general, therefore, less attention is devoted to the development of national unwritten principles of procedural due process. Furthermore, it is concluded that administrative courts make (too) little use of their power to review ex officio whether or not principles of procedural due process are complied with. The power to complement ex officio the grounds for appeal is used more generously by administrative courts. Next, Chapter 4 discusses the principles of procedural due process. These are: the impartiality principle, the principle of a fair hearing, the publicity principle, the principle that reasons for the decision be given, and the reasonable time principle. In conclusion another principle, which has gained increasing importance in recent years under the influence of the ECHR and European Union law is analyzed: the principle of effective judicial protection. With regard to purely national disputes, this principle is still under development.

The principles of procedural due process can be divided into two categories; principles with internal and external effect. Principles with internal effect primarily aim at safeguarding the interests of the parties to the procedure, whereas principles with external effect have as their primary goal to safeguard interests which fall outside the scope of a procedure and to maintain public confidence in the administration of justice. The assumption is put forward that principles with internal effect can have a greater influence on preliminary administrative procedures than principles with external effect. The validity of this assumption is tested in Part II and III.

Finally, Chapter 5 of Part I deals with the principles of procedural due process in EU law. The European Court of Justice considers these principles general principles of EU law which must be respected. The scope of these EU principles is not limited to court procedures. Some of them apply in the course of procedures before the administrative authorities as well. The general principles of EU law influence the preliminary administrative procedures through the national principles of proper administration. The interpretation of these general principles of EU law hardly differs from the interpretation of the national principles or the interpretation of Article 6 ECHR.

\section{Part II}

The second part of the book studies the preliminary administrative procedures and the requirements with which they must comply. In the first three chapters of Part II the study is limited to two preliminary administrative procedures, the objection procedure (" $b e z$ waarschriftprocedure") and the administrative appeal ("administratief beroep"). The functions of these procedures and the scope of review are studied in the fourth chapter of Part II. The analysis in Chapter 4 shows that judicial review on the one hand, and reconsideration by the administrative authorities on the other hand, differ to a lesser extent than generally assumed. The objection procedure, for example, has a function both with regard to judicial protection and with regard to extended decision-making. These two functions do not conflict. Preliminary administrative procedures bear more resemblance to judicial review than generally assumed. Therefore, there seems to be no reason to conclude that the existing differences between judicial review and preliminary administrative procedures should lead to the applicability of different requirements of procedural due process.

Chapter 5 of Part II further looks into five principles of procedural due process and their influence on the preliminary administrative procedures. Each principle is analysed separately. The following observations may be mentioned here on these principles.

The fair hearing principle has not (yet) been recognized by the administrative courts as a principle of proper administration. The equivalent principle of procedural due process is not directly applicable on the preliminary procedures. Nonetheless, the administrative courts deduce various concrete requirements from the principle of procedural due 
process. This is true, for example, for the right to be informed and to have access to relevant files, the right to be heard when new facts or circumstances which may have considerable relevance to the decision arise, and the right to submit documents. Moreover, there are several concrete requirements with a similar function and meaning as the requirements applying to court procedures. Sometimes the foundation for these requirements is however found in a principle of proper administration, the so-called principle of due care. Even though the administrative courts have explicitly stated that the requirement of equality of arms is of no relevance to preliminary administrative procedures, some requirements which apply to these procedures in substance link up with the equality of arms-requirement. The influence of the fair hearing principle on the preliminary administrative procedures is thus somewhat ambiguous.

The impartiality principle which applies to court procedures has a counterpart in administrative procedures: the prohibition of partiality or prejudice, which is a separately recognized principle of proper administration. Although this principle has the same function for the administration as for the administrative courts, the concrete requirements which are derived from it are slightly different. The various tests under the principle of procedural due process are similar to the tests applied by the courts under the principle of proper administration. Some (implicit) influence of the principle of procedural due process can be observed here.

The publicity principle is neither directly applicable to the preliminary administrative procedures, nor has any equivalent principle of proper administration been recognized. There are no other principles from which publicity requirements can be derived. Nevertheless, requirements concerning a public hearing in preliminary administrative procedures do exist. Requirements concerning access of the public to the decisions of the administrative authorities however do not exist. Therefore, no explicit influence of the principle of procedural due process can be established.

The principle to state reasons for the decision of an administrative authority is a principle of proper administration. This principle has the same functions as its counterpart principle of procedural due process. Both principles consist of a formal and a substantive part. However, the concrete requirements which can be deduced from the principles differ slightly. The principle of proper administration is tailored to the specific nature of the administrative decision-making process. The influence of the principle of procedural due process therefore seems to be limited and implicit.

The reasonable time principle applies directly to the preliminary administrative procedures. The influence of this principle is however limited and accessory, in the sense that the administrative courts refuse to apply this principle when the preliminary administrative procedure is not followed by an appeal to the court. This principle has the same function in the context of preliminary administrative procedure as in court procedures. It has been established that a separate, non-accessory, principle applicable to the preliminary administrative procedures has been slowly developing. From the point of view of legal certainty for interested parties in administrative procedures this may be called a welcome development.

\section{Part III}

Finally, concluding remarks are offered in Part III. After an introduction in Chapter 1, Chapter 2 offers an answer to the main research question ("to what extent are principles of procedural due process applicable to the objection procedure and administrative appeal?"). In light of this, Chapter 2 lists and categorizes the principles of procedural due process and their influence on the requirements for preliminary administrative procedures. These principles will be shortly discussed here, listed gradually from strong influence towards no (visible) influence.

The research shows that the strongest influence can be observed with regard to the principles which are directly applicable. This means that the administrative courts apply the principle to the preliminary administrative procedures and they review whether or not 
the procedure is in compliance with this principle. If the courts establish a violation of the principle, this will have legal consequences. This is the case only for the reasonable time principle.

The principles which are applied indirectly, but which are nonetheless referred to explicitly by the courts, fall within another category. The courts do not apply these principles directly to preliminary administrative procedures. The courts rather explicitly deduce several concrete requirements from principles of procedural due process. These concrete requirements have the same function as principles of procedural due process. Violation of concrete requirements leads to legal consequences. Principles of this second category are: the right to be informed and to access the file, the right to submit documents, and the right to be heard when new facts or circumstances arise which may have considerable relevance to the decision.

A third category is constituted by principles which have an implicit influence. Even though administrative courts do not explicitly refer to these principles, the concrete requirements applicable to preliminary administrative procedures can be deduced from them. Furthermore, administrative courts may employ the same criteria as those which apply to court proceedings. Another possibility is that the applicable requirements have the same functions as the requirements for court proceedings. The requirement of a public hearing, which is part of the publicity principle, falls into this category. The same is true for the right to be heard and the requirement of equality of arms. However, the foundation of these requirements is in some cases the principle of due care, which is a principle of proper administration. The impartiality principle and the principle to state reasons can also be classified under this category. These principles have counterpart principles of proper administration with the same content and function.

A fourth, and last, category is formed by principles with regard to which no influence can be established. Principles which fall into this category are, for example, the publicity principle, as far as it concerns public access to the decisions of administrative authorities, and the requirement of independence.

Furthermore, Chapter 2 of Part III adresses the question of whether or not the internal or external effect and the absence or existence of equivalent principles of proper administration are relevant. The analysis shows that the existence of an equivalent principle of proper administration and the internal or external effect of a principle can be of significance to its influence on preliminary administrative procedures. Principles with internal effect and without a counterpart principle of proper administration seem to have the strongest influence on the preliminary administrative procedures.

Chapter 3 of Part III deals with the attitude of the administrative courts towards the principles of procedural due process. Due to formal reasons the applicability of those principles to preliminary administrative procedures is sometimes denied by the courts. This approach may be considered somewhat formalistic, since, from a more substantive point of view, similar requirements with similar functions apply to these procedures. In general, the courts make little use of their power to examine ex officio the conformity of procedures with the principles of procedural due process. The power to complement ex officio the legal grounds of appeal is used more generously.

Chapter 4 of Part III discusses the relationship between principles of procedural due process and principles of proper administration. Both categories of principles have common roots. The analysis shows that principles of both categories overlap as regards the preliminary administrative procedures. Some principles of procedural due process have counterpart principles of proper administration. Where this is the case, the influence of the principle of procedural due process on the preliminary administrative procedures seems limited. The interpretation and employment of both categories of principles seem to grow towards one another in the preliminary administrative procedures. Therefore, the acknowledgement of a single category of principles, for instance principles of proper procedure, which apply to all procedures which are part of the administrative system of judicial protection, seems legitimate. 


\section{Summary}

Chapter 5 of Part III offers some final remarks. It is argued that more attention should be paid to the coherence between preliminary administrative procedures on the one hand, and administrative court procedures and the applicable procedural requirements on the other. Also the development of national safeguards and principles of procedural due process deserves more attention. Furthermore, it is argued that the administrative courts should be more clear and consistent about the consequences of violations of procedural safeguards. In conclusion, the need for an adequate balance between speediness and effectiveness on the one hand, and due care and process on the other, is emphasized. 



\section{Literatuurlijst}

F.M.D. Aardema, 'De hoorplicht van de artikelen 4:7 en 4:8 Awb: een wettelijke inkleuring van de zorgvuldigheidsnorm in fletse tinten?', JB-plus 2003, p. 50-59

G.H. Addink, 'Commentaar art. 7:10', in: M. Scheltema, R.M. van Male, B.W.N. de Waard, A.T. Marseille, A.J.C. de Moor-van Vugt (red.), Commentaar op de Algemene wet bestuursrecht, Amsterdam: Reed Elsvier (voorheen Den Haag: VUGA), losbladige uitgave, E 6.3.15

G.H. Addink, bewerkt door K.F. Bolt, 'Commentaar op art. 7:12', in: M. Scheltema, R.M. van Male, B.W.N. de Waard, A.T. Marseille, A.J.C. de Moor-van Vugt (red.), Commentaar Algemene wet bestuursrecht, Amsterdam: Reed Elsevier (voorheen Den Haag: VUGA), losbladige uitgave, E 7:12

G.H. Addink, Algemene beginselen van behoorlijk bestuur. Monografiën Algemene wet bestuursrecht, Deventer: Kluwer 1999

C.L.G.F.H. Albers, 'Commentaar artikel 7:13', in: in: M. Scheltema, R.M. van Male, B.W.N. de Waard, A.T. Marseille, A.J.C. de Moor-van Vugt (red.), Commentaar Algemene wet bestuursrecht, Amsterdam: Reed Elsevier (voorheen Den Haag: VUGA), losbladige uitgave, E 7:13

C.L.G.F.H. Albers en R.J.N. Schlössels, 'De omvang van het bestuursrechtelijke geding: het Europese recht als het paard van Troje? Over de (on)toelaatbaarheid van procestechnische trechters en ambtshalve rechtstoepassing', Gst. (2005) 7224, p. 81-94

C.L.G.F.H. Albers, Rechtsbescherming bij bestuurlijke boeten. Balanceren op een magische lijn? (diss. Maastricht), Den Haag: Sdu 2002

M.V.C. Aalders, M.N. Boeve, W.G.A. Hazewindus, K.A.W.M. de Jong, A.P. Klap, B.K. Olivier, B.J. Schueler, R. Uylenburg, C.J. van der Wilt, De burger en de Awb. Ervaringen van de repeatplayers met Awb-procedures (Evaluatieonderzoek Awb I), Den Haag: Bju 2001

E. Alders, 'Deregulering ook voor de Awb?, NJB 1996, p. 1113

E.A. Alkema, 'De rechterlijke macht - enige opmerkingen vooraf', in: J.P. Loof (red.), Onafhankelijkheid en onpartijdigheid. De randvoorwaarden voor het bestuur en beheer van de rechterlijke macht', Leiden: Stichting NJCM-Boekerij 36 1999, p. 3-7

E.A. Alkema, 'Bestuursrecht en EVRM- Awb en artikel 6', NTB 1996, p. 18-24

E.A. Alkema, 'Telt de 'voorfase' mee voor de redelijke termijn?, NJB 1994, p. 601-604

J.A.M. van Angeren, 'Zelf voorzien in stroomversnelling', JB-plus 2009, p. 257-266

J.A.M. van Angeren, 'De rechter als bestuurder-plaatsvervanger. Een pleidooi voor meer zelf voorzien door de bestuursrechter', JB-plus 2007, p. 16-23

C.H. Bangma, 'Wet rechtstreeks beroep. Een regeling voor het overslaan van bezwaar', Gst. (2004) 7215, p. $549-553$

R. Barents en L.J. Brinkhorst, Grondlijnen van Europees recht, Deventer: Kluwer 2006

T. Barkhuysen en B.J. van Ettekoven, 'De compensatie voor schending van de redelijke termijn van artikel 6 EVRM door de bestuursrechter', NTB 2009, p. 129-141

T. Barkhuysen en M.L. van Emmerik, 'Het recht op toegang tot de rechter en een eerlijk proces in de Nederlandse Grondwet?', in: T. Barkhuysen, M.L. van Emmerik en J.P. Loof, Geschakeld recht. Verdere studies over Europese grondrechten ter gelegenheid van de $70^{\text {ste }}$ verjaardag van prof.mr. E.A. Alkema, Deventer: Kluwer 2009, p. 13-39

T. Barkhuysen, M.L. van Emmerik, J.H. Gerards, De toegang tot de rechter en een eerlijk proces in de Grondwet? Behoeft de Nederlandse Grondwet aanvulling met een recht op toegang tot de rechter en een eerlijk proces?, Deventer: Kluwer 2009

T. Barkhuysen en M. Van Emmerik, 'Schadevergoeding bij schending van de redelijke termijn: op weg naar een effectief rechtsmiddel', $N J B$ 2008, 26, p. 1579-1582

T. Barkhuysen, L.J.A. Damen, K.J. de Graaf, A.T. Marseille, W. den Ouden, Y.E. Schuurmans, A. Tollenaar, Feitenvaststelling in beroep (Derde evaluatie van de Awb), Den Haag: Bju 2007

T. Barkhuysen, 'Het vereiste van rechterlijke onpartijdigheid en de voorgestelde nieuwe Wet op de Raad van State: mag het een onsje meer zijn?, Regelmaat 2007/3, p. 119-127

T. Barkhuysen, Eenheid en coherentie van rechtsbescherming in de veellagige Europese rechtsorde (oratie Leiden), Deventer: Kluwer 2006

T. Barkhuysen, 'Het EVRM als integraal onderdeel van het Nederlandse materiële bestuursrecht' in: T. Barkhuysen e.a., De betekenis van het EVRM voor het materiële bestuursrecht, (VAR-reeks 132), Den Haag: BJu 2004, p. 7-113

T. Barkhuysen en M.L. van Emmerik, 'Het EVRM en het Nederlandse milieurecht', JB-plus 2004, p. 234-244 


\section{Literatuurlijst}

T. Barkhuysen en B.J. van Ettekoven, 'De compensatie voor schending van de redelijke termijn van art. 6 EVRM door de bestuursrechter', NTB 2009, p. 129-141

T. Barkhuysen en A.M.L. Jansen, 'Actuele ontwikkelingen in de redelijke termijnjurisprudentie: over Nederlandse termijnoverschrijdingen en ontbrekende nationale rechtsmiddelen', NJCM-bulletin, 2003/5, p. 586-600

T. Barkhuysen en A.M.L. Jansen, 'Rechtsmiddelen tegen rechterlijke en bestuurlijke traagheid, het EVRM noopt tot aanpassing van het Nederlandse recht', $N J B$ 2002, p. 841-848

T. Barkhuysen, A. Hoeneveld en J.J. Nuijten, 'Het Kroonberoep leek dood, leve het kroonberoep? Beslechting van bestuursgeschillen binnen het Koninkrijk?, NTB 2000/4, p. 85-93

T. Barkhuysen, Artikel 13 EVRM: effectieve nationale rechtsbescherming bij schending van mensenrechten (diss. Leiden), Lelystad: Vermande 1998

M.S. Beerten, J.A. Bosch, H.E. Bröring, M. Herweijer, A.J.G.M. van Montfort, F.M. Noordam, F.W Verbaas, Aspecten van financiële beschikkingverlening (verslag in het kader van Evaluatie Awb I), Deventer: W.E.J. Tjeenk Willink 1996

J.B.J.M. Ten Berge en A.Q.C. Tak, Hoofdlijnen van het Nederlands administratief procesrecht, Zwolle: W.E.J. Tjeenk Willink 1990

H.J.M. Besselink, 'Art. 6:13 Awb; een tussenstand', JBplus 2008, p. 197-207

M.B.W. Biesheuvel, 'Weg met de bezwaarschriftprocedure', NJB 1996, p. 390

M.B.W. Biesheuvel, 'Naschrift', NJB 1996, p. 1113-1114

M.H. Blokvoort, 'Rechtstreeks in beroep bij de administratieve rechter', Gst. (2001) 7139, p. 193-198

W. van Blommestein, 'Toetsing ex nunc: in het vreemdelingenrecht én in het bestuursrecht?, NTB 2000/5, p. 128-137

R.H. de Bock, Commentaar art. 6:2 Awb, in: M. Scheltema, R.M. van Male, B.W.N. de Waard, A.T. Marseille, A.J.C. de Moor-van Vugt (red.), Commentaar op de Algemene wet bestuursrecht, Amsterdam: Reed Elsvier (voorheen Den Haag: VUGA), losbladige uitgave, E 6.1.3

A.J. Bok, 'De Raad van State gereorganiseerd, NJB 2007, p. 266-272

A.J. Bok, 'Het EHRM-arrest Kleyn e.a.: Raad van State grotendeels gesauveerd, maar nog niet uit de gevarenzone', Gst. (2003) afl. 7186, p. 296-300

H. Bolt, 'De bezwaarschriftprocedure als voorprocedure: heroverweging en voorbehandeling', NTB 1988/1, p. 6-11

K.F. Bolt, 'Commentaar art. 7:11 Awb', in: M. Scheltema, R.M. van Male, B.W.N. de Waard, A.T. Marseille, A.J.C. de Moor-van Vugt (red.), Commentaar Algemene wet bestuursrecht, Amsterdam: Reed Elsevier (voorheen Den Haag: VUGA), losbladige uitgave, E 7:11

K.F. Bolt, 'Voor de verandering een rechterlijke ex nunc-toets?, JB-plus 2007, p. 3-13

K.F. Bolt, Het rechterlijke toetsingsmoment in het bestuursprocesrecht (diss. Groningen), Den Haag: Bju 2005

K.F. Bolt, 'Dat verandert de zaak! De eerste ervaringen met de rechterlijke ex-nunc-toetsing', JB-plus 2002, p. 158-169

J. Bootsma en E.J. Daalder, 'Kroniek van het algemeen bestuursrecht. All the news that is fit to print', NJB 2005/31, p. 1620-1626

J.J.A. Bosch, 'De bezwaarschriftprocedure moet blijven', NJB 1996, p. 1214-1215

J.E. Bosch-Boesjes, 'Tijdigheid in geding: enige beschouwingen over de bestuursrechter en de redelijke termijn', in: M. Herweijer, K.F. Schuiling en H.B. Winter, In wederkerigheid. Opstellen voor prof.mr M. Scheltema, Deventer: Kluwer 1997, p. 257-267

A.M.M.M. Bots, 'Het zorgvuldigheidsbeginsel en advisering', in: R.J.N. Schlössels e.a. (red.), In beginsel: over aard, inhoud en samenhang van rechtsbeginselen in het bestuursrecht, Deventer: Kluwer 2004, p. 141-165

P.J. Boukema, 'De WOB: recente ontwikkelingen in de rechtspraktijk', in: A.W. Hins en A.J. Nieuwenhuis, Van ontvanger naar zender (De Meij-bundel), Amsterdam: Otto Cramwinckel 2003, p. 33-44

P.P.T. Bovend'Eert, m.m.v. C.A.J.M. Kortmann, Rechterlijke organisatie, rechters en rechtspraak, Alphen aan den Rijn: Kluwer 2008

P.P.T Bovend'eert, 'Het rechtsbeginsel van de machtenscheiding. Ontwikkelingen rond een taai constitutioneel beginsel, in: R.J.N. Schlössels e.a. (red.), In beginsel: over aard, inhoud en samenhang van rechtsbeginselen in het bestuursrecht, Deventer: Kluwer 2004, p. 243-265

P.P.T Bovend'eert, De modernisering van de rechterlijke organisatie: integraal management als staatsrechtelijke probleem, in : A.K. Koekkoek e.a. (red.), Publikaties van Staatsrechtkring, Organisatie van de rechtspraak, Deventer: W.E.J. Tjeenk Willink 1999, p. 3-23

T. Brandsen, E. Cornelissen, S. van der Hof, G.J. Leenknegt, C. Prins en M. de Vries m.m.v. L. Griep, A Jasiak, R. Loermans, Over wetten en praktische bezwaren. Een evaluatie en toekomstvisie op de Wet openbaarheid van bestuur (Evaluatierapport), Universiteit van Tilburg 2004

P. van den Brekel, 'Horen', in: E.H.J.C. van der Linden en F.A.M. Stroink (red.), JB-select, Den Haag: Sdu 2004, p. 139-161 


\section{Literatuurlijst}

H. Bröring en H.B. Winter, 'Massale beschikkingverlening en het bestuursrechtelijk trechtermodel', in: J.L. Boxum e.a. (red.), Aantrekkelijke gedachten. Beschouwingen over de Algemene wet bestuursrecht, Deventer: Kluwer 1993, p. 11-29

A.F.M. Brenninkmeijer en W.J. van Hoogstraten, 'De architectuur van behoorlijk bestuur. De bijdrage van de Nationale ombudsman aan behoorlijk bestuur in 25 jaar', NTB 2008/2, p. 33-39

A.F.M. Brenninkmeijer, 'Algemene beginselen van behoorlijke geschillenbeslechting', in: M.V. Polak (red.), Geschillenbeslechting naar behoren. Algemene beginselen van behoorlijke geschillenbeslechting in traditionele en alternatieve procesvormen, Kluwer: Deventer 1998

A.F.M. Brenninkmeijer, 'Een leerstellig cliché', in: T. Hoogenboom en L.J.A. Damen, In de sfeer van administratief recht, Utrecht: Lemma 1994, p. 13-31

A.F.M. Brenninkmeijer, De toegang tot de rechter. Een onderzoek naar de betekenis vn onafhankelijke rechtspraak in een democratische rechtsstaat (diss. Tilburg), Zwolle: W.E.J. Tjeenk Willink 1987

H.M. Breunese en A. Weggeman, 'Voorontwerp rechtstreeks beroep', NTB 2000/4, p. 113-114

F.F.W. Brouwer en L.M. Koenraad, 'Slagvaardig bestuursprocesrecht. Over bestuurlijke lus, finale geschilbeslechting en conflictoplossing', $N J B$ 2006, p. 1678-1684

D. Brugman, 'Ambtshalve toetsing afgebakend. De plaats van ambtshalve toetsing in het bestuursprocesrecht in nationaal- en Europeesrechtelijk perspectief', NTB 2005, p. 265-277

P.J.J. van Buuren, H. Bolt en M. Scheltema, Kroonberoep en Arob-beroep, Deventer: Kluwer 1981

P. Cane, Administrative Law, Oxford University Press 2004

G.J.M. Cartigny, 'Prorogatie in het bestuursprocesrecht: rechtstreeks beroep op de bestuursrechter', NTB 2001, p. 89-96

P.D.A. Claessen, Beleidsvrijheid in het medebewind, Den Haag: Vuga 1989

P.B. Cliteur, 'De onafhankelijkheid van de rechterlijke macht: acht vormen', in: J.P. Loof (red.), Onafhankelijkheid en onpartijdigheid. De randvoorwaarden voor het bestuur en beheer van de rechterlijke macht', Leiden: Stichting NJCM-Boekerij 36 1999, p. 9-30

Commissie-Ilsink, Toepassing en effecten van de Algemene wet bestuursrecht 2000-2006 (verslag van de Commissie Evaluatie Awb III), Den Haag: BJu 2007

Commissie-Boukema, Toepassing en effecten van de Algemene wet bestuursrecht 1997-2001 (verslag van de Commissie Evaluatie Awb II), Den Haag: Sdu 2001

Commissie-Van Kemenade, Bestuur in geding (rapport werkgroep terugdringing juridisering van het openbaar bestuur), Haarlem: Provinciehuis Noord-Holland 1997

Commissie-Polak, Toepassing en effecten van de Algemene wet bestuursrecht 1994-1996 (verslag van de Commissie Evaluatie Awb I), Den Haag: Sdu 1996

E.J. Daalder, 'Kroniek van het algemeen bestuursrecht. Over de omvang van rechtsbescherming, rechtseenheid en verschillen in benadering', $N J B$ 2008, p. 2128-2136

E. Daalder en S. van Heukelom-Verhage, Kroniek van het algemeen bestuursrecht, NJB 2007/35, p. 2190-2199

E.J. Daalder, Toegang tot overheidsinformatie. Het grensvlak tussen openbaarheid en vertrouwelijkheid (diss. Leiden), Den Haag: BJu 2005

R.J. van Dam en R.J.N. Schlössels, 'Het wetsvoorstel Wet dwangsom bij niet tijdig beslissen. Enkele kritische kanttekeningen', Gst. (2005) 7232, p. 359-363

R.J. van Dam en R.J.N. Schlössels, 'Het Voorontwerp en Wet beroep bij niet tijdig beslissen', NJB 2002 p. $2137-2142$

L.J.A. Damen, H.E. Bröring, K.J. de Graaf, A.T. Marseille, A.J.G.M. van Montfort, P. Nicolaï, B.J. Schueler, H.B. Winter, Bestuursrecht. Rechtsbescherming tegen de overheid. Bestuursprocesrecht (Deel II), Den Haag: BJu 2009

L.J.A. Damen, 'Behoorlijk, en ook rechtmatig, of juist eerlijk?', NTB 2008/2, p. 40-51

P. van Dijk, 'Een effective remedy in de zin van artikel 13 EVRM bij overschrijding van de redelijke termijn in de zin van artikel 6 EVRM - bestuursrechtelijke procedures', in: T. Barkhuysen, M.L. van Emmerik en J.P. Loof (red.), Geschakeld recht. Verdere studies over Europese grondrechten ter gelegenheid van de 70ste verjaardag van prof.mr. E.A. Alkema, Deventer: Kluwer 2009, p. 116-133

P. van Dijk, F. van Hoof, A. van Rijn, L. Zwaak (eds.), Theory and Practice of the European Convention on Human Rights, Antwerpen/Oxford: Intersentia 2006

P. van Dijk, 'De toegang tot de rechter - een Straatsburgse springprocessie', NJCM-bulletin 2003/8, p. 945-961

P. van Dijk, Artikel 6 EVRM en de Afdeling bestuursrechtspraak van de Raad van State, Lezing ter gelegenheid van de $19^{\mathrm{e}}$ verjaardag van het SIM op 26 oktober 2000, Utrecht: SIM 2001

P. van Dijk, 'De objectieve onpartijdigheid van de rechter, $N J B$ 1997, p. 1213-1219

P. van Dijk, De op Nederland rustende internationale verplichtingen ter zake van een behoorlijke rechtspraak (Handelingen NJV deel 1, eerste stuk), Zwolle: W.E.J. Tjeenk Willink 1983 


\section{Literatuurlijst}

G.S.A. Dijkstra, 'Bestuurslasten van de Algemene wet bestuursrecht', in: J.L. Boxum e.a. (red.), Aantrekkelijke gedachten. Beschouwingen over de Algemene wet bestuursrecht, Deventer: Kluwer 1993, p. 161-176

R.P.B.A. Dingemans, 'Slecht gemotiveerde besluiten gesauveerd. Reparatie van materiële motiveringsgebreken in Nederland, Frankrijk en Duitsland, JB-plus 2008, p. 102-123

A.M. Donner, Algemeen bestuursrecht, Alphen aan den Rijn: Samson H.D. Tjeenk Willink 1987

C.E. Drion, 'Het geringe probleemoplossend vermogen van het bestuurs(proces)recht', NJB 2006, p. 1089

Th.G. Drupsteen, 'De Raad van State na Kleyn and others versus the Netherlands', NTB 2003/10, p. 317 323

W. Duk, 'Beoordelingsvrijheid en beleidsvrijheid', RM-Themis 1988, p. 156-169

W. Duk, 'De zachte kern van het bestuursrecht', RM-Themis 1978, p. 564-587

F.J.F.M. Duynstee, 'Rechterlijke onafhankelijkheid', in: G.C.J.J. van den Bergh e.a. (red.), Rechtspleging. Opstellen rond het thema rechterlijke organisatie, Deventer: Kluwer 1974, p. 35-54

B.J. van Ettekoven, R.C.S. Bakker en R.P. Hoogenboom, Tien jaar jurisprudentie schadevergoeding in het bestuursrecht, Kluwer: Deventer 2004

B.J. van Ettekoven, 'Alternatieven van de bestuursrechter (observaties vanuit de eerste lijn)', in: B.J. van Ettekoven, M.A. Pach en I.C. van der Vlies, Alternatieven van en voor de bestuursrechter (VARreeks 126), Den Haag: BJu 2001

A.G. van Galen en H.Th.J.F. van Maarseveen, Beginselen van administratief procesrecht, (VAR-reeks 82) Alphen aan den Rijn: H.D. Tjeenk Willink 1978.

L.J. Gerritsen, "Finale geschilbeslechting; art. 8:72, leden 3 en 4 Awb", JBactueel 2009, p. 66-69

C.P.J. Goorden, 'Toetsing van sanctiebesluiten in bezwaar', NTB 1999/9, p. 231-236

C.P.J. Goorden, 'Bezwaarschriftprocedures in de gemeentelijke praktijk', NTB 1995/9-10, p. 297-308

C.P.J. Goorden, 'Rechtsbescherming tegen en door gemeentelijke bestuursorganen', NTB 1990, p. 129 138

D.J.M. de Grave, 'Ambtshalve toetsing door de Europese rechter: een ander perspectief', SEW 2009, 3, p. $12-20$

B.J. van de Griend, Trechters in het bestuursprocesrecht (diss. Utrecht), Den Haag: BJu 2007

T. Groenewegen, 'De toetsing ex nunc', $N A V 2000 / 4$, p. 245-248

P. de Haan, Th.G. Drupsteen, R. Fernhout, Bestuursrecht in de sociale rechtstaat, Deel I, Deventer: Kluwer 2001

M.A. van der Ham, 'De gemeente als rechter in eigen zaak: (on)behoorlijke rechtspraak of (on)behoorlijk bestuur, in: H.A. Brasz en J.G. Steenbeek (red.), Klachten en bezwaren tegen de gemeente, Den Haag: VUGA 1988, p. 73-98

A. Den Hartog, 'De Hoge Raad en de redelijke termijn: meerduidige grondslag leidt tot rigide regelgeving', RMThemis 2001/4, p. 99-106

P.F. van der Heijden, Een eerlijk proces in het sociaal recht? (diss. Leiden), Deventer: Kluwer 1984

P. van der Heyden,'Weg met de advocatuur', NJB 1996, p. 1111-1112

E. Helder, 'Rechtsbescherming door de gemeente: zijn er klachten of bezwaren?', in: H.A. Brasz en J.G. Steenbeek (red.), Klachten en bezwaren tegen de gemeente, Den Haag: VUGA 1988, p. 11-48

M.A. Heldeweg, 'Confidence in the working of justice. Het (standard)deskundigenbericht in het Awbbestuursproces vanuit het perspectief van hoor en wederhoor volgens art. 6 lid 1 EVRM', NTB 1999/4, p. $81-88$

B.E.M. Hendrickx, 'Weg met de bezwaarschriftprocedure?', NJB 1996, p. 1371

H.Ph.J.A.M. Hennekens, H.J.A.M. van Geest, R. Fernhout, Decentralisatie, Nijmegen: Ars Aequi Libri 1998

A.W. Heringa, in: J.H. Gerards, A.W. Heringa, H.L. Janssen en J. van der Velde, EVRM Rechtspraak en Commentaar, katern. Art. 6 Eerlijk proces, Haag: Sdu 1-1-2004, par. 3.6.1

A.W. Heringa, in: J.H. Gerards, A.W. Heringa, H.L. Janssen en J. van der Velde, EVRM Rechtspraak en Commentaar, katern. Art. 6 Eerlijk proces, Haag: Sdu 1-1-2004, par. 3.6.5

A.W. Heringa, 'Wraking in het bestuursrecht', JB-plus 2001, p. 2-18

M. Herweijer en R.A. van de Peppel, 'Eerst bezwaar maken en daarna wellicht nog in beroep: het perspectief van de belanghebbende', in: F.A.M. Stroink, A.W. Heringa en A.R. Neerhof (red.), Vijf jaar $J B$ en $A w b$, Den Haag: Sdu 1999, p. 39-52

M. Herweijer, 'Tussen het bezwaar en de beslissing op dat bezwaar: verlengde besluitvorming of geschilbeslechting?', in: M. herweijer, K.F. Schuiling en H.B. Winter (red.), In wederkerigheid (Scheltema-bundel), Deventer: Kluwer 1997, p. 199-210

E.M.H. Hirsch Ballin, 'Controversieel bestuursrecht', NTB 1999/3, p. 51-55

E.M.H. Hirsch Ballin, Het grondrecht op behoorlijke rechtspraak in het Nederlands adminstratieve recht, Handelingen NJV deel 1, tweede stuk, Zwolle: W.E.J. Tjeenk Willink 1983 


\section{Literatuurlijst}

J.A. Hofman, 'Openbaarheid van bestuur: een allemansvriend die ook discreet kan zijn', JB-plus 2004, p. $199-212$

R.H. van de Hoogen, Beginselen van behoorlijke elektronische rechtspraak (diss Utrecht), Den Haag: Sdu 2007

S.V. Hoogendijk-Deutsch, 'Advisering in het bestuursrecht (in het bijzonder aan de centrale overheid)', in: S.V. Hoogendijk-Deutsch en R. Samkalden, Advisering in het bestuursrecht (VAR-geschrift LXXX), Deventer: H.D. Tjeenk Willink 1978, p. 11-65

J.H. Jans, R. de Lange, S. Prechal, R.J.G.M. Widdershoven, Europeanisation of Public Law, Groningen: Europa Law Publishing 2007

J.H. Jans, R. de Lange, S. Prechal, R.J.G.M. Widdershoven, Inleiding tot het Europees bestuursrecht, Nijmegen: Ars Aequi Libri 2002

A.M.L. Jansen, 'Overheidsaansprakelijkheid voor overschrijding van de redelijke termijn', $O \& A 2009$, p. $60-68$

A.M.L Jansen, 'De deskundige en een fair trial', Milieu \&Recht 2008, p. 223-226

A.M.L. Jansen en D.W.M. Wenders, 'Unificerende werking via de redelijke termijn of een kroniek van de redelijke termijn', NJCM-Bulletin 2006, p. 1091-1127

A.M.L Jansen, 'Op goede gronden. De motivering van uitspraken door de bestuursrechter', in: A.W. Heringa, A.M.L. Jansen, E.C.H.J. van der Linden, L.F.M. Verhey (red.), Het bestuursrecht beschermd (liber amicorum F.A.M. Stroink), Den Haag: Sdu 2006, p. 171-183

A.M.L. Jansen, 'Tijdige rechtspraak en de rol van de Hoge Raad', WFR 2005/183, p. 1583-1588

A.M.L. Jansen, Constitutionalisering van het bestuursprocesrecht (preadvies NVR), Deventer: Kluwer 2004

A.M.L. Jansen, 'Formele rechtskracht na stilzitten: de CRvB als leading judge', NJB 2003, p. 1752-1756

A.M.L. Jansen, 'Sloom bestuur onder vuur. Enige beschouwingen over niet tijdige besluitvorming', $J B$ plus 2003, p.152-169

A.M.L. Jansen, 'De redelijke termijn, kaders voor de bestuursrechter', JB-plus 2001, p. 50-60

A.M.L. Jansen, 'De redelijke termijn, met name in het bestuursrecht' (diss. Tilburg), Den Haag: BJu 2000

A.M.L. Jansen, 'Bezwaar, van hoofdregel naar uitzondering?', $N J B$ 2000, p. 1748-1749

A.L.M. Jansen en J.A.F. Peters, Commentaar op art. 2:4 Awb, in: M. Scheltema, R.M. van Male, B.W.N. de Waard, A.T. Marseille, A.J.C. de Moor-van Vugt (red.), Commentaar Algemene wet bestuursrecht, Amsterdam: Reed Elsevier (voorheen Den Haag: VUGA), losbladige uitgave, E 2.1.4

A.P. Klap, 'Rechter en bestuur: coomunicerende vaten of concurrerende machten?, NTB 2007, p. 183-194

A.P. Klap en R.J.G.M. Widdershoven, 'Snelheid van rechtspraak als mensenrecht', in: P.M. Langbroek, K. Lahuis, J.B.J.M. ten Berge, Kwaliteit van rechtspraak op de weegschaal, Deventer: W.E.J. Tjeenk Willink ism G.J. Wiarda Instituut 1998, p. 191-200

R.M.M. Kleijkers, 'Over coöptatie en legitimatie: de benoeming van rechters anno 2006, in: A.W. Heringa, A.M.L. Jansen, E.C.H.J. van der Linden, L.F.M. Verhey (red.), Het bestuursrecht beschermd (liber amicorum F.A.M. Stroink), Den Haag: Sdu 2006, p. 33-43

A.W. Koekkoek (red.), De Grondwet. Een systematisch en artikelsgewijs commentaar, Deventer: W.E.J. Tjeenk Willink 2000

N.S.J. Koeman, 'De gevolgen van de Procola-uitspraak voor Nederland', NTB 1996, p. 97-105

L.M. Koenraad, 'Van aanmerkelijk belang. De betekenis van art. 7:9 Awb', Gst. 2008, 7302, (Koenraad 2008b), 100, p. 473-480

L.M. Koenraad, 'Afzien van het horen. De betekenis van art. 7:3 Awb', Gst.2008 (Koenraad 2008a), 7294,45 , p. $201-211$

L.M. Koenraad, 'Deskundig rechtspreken: Beschouwingen over de plaats van deskundigen in het Nederlands bestuursprocesrecht', JB-plus 2007, p. 202-223

L.M. Koenraad, 'Deskundig besturen. Beschouwingen over de plaats van deskundigenadvisering', $J B$ plus 2006, p. 15-33

L.M. Koenraad en K.H. Sanders, Besluiten op bezwaar, Deventer: Kluwer 2006

L.M. Koenraad en G.A.L. van Schijndel, 'Raadsleden en bezwaar. Enige beschouwingen over de vooren nadelen van de aanwezigheid van raadsleden in commissies die zijn belast met advisering over de afhandeling van bezwaren', Gst. (2005) 7226, p. 157-165

L.M. Koenraad en F.F.M. Brouwer, 'De bezwaarschriftprocedure heroverwogen (1). Het karakter van de beslissing op bezwaar', Gst. (2001) 7151, p. 501-507

I. Kolhoop, 'Wet rechtstreeks beroep en Wet elektronisch bestuurlijk verkeer', $A A$ 2004/9, p. 664-670

W. Konijnenbelt, E.J. Daalder, S.E. Zijlstra, R.J.N. Schlössels, A. Weggeman, N.S.J. Koeman, 'Herziening bestuursprocesrecht ter tafel', NTB 2006, p. 259-272

A.H. Korthals, 'Juridisering in het openbaar bestuur', NJB 2000, p. 209-214

C.J.A.M. Kortmann, Constitutioneel recht, Deventer: Kluwer 2008

C.J.A.M. Kortmann, 'Weg met de bezwaarschriftprocedure?', NJB 1996, p. 1113 


\section{Literatuurlijst}

H.S.M. Kruijer, 'Belastingheffing moet tijdig, binnen een redelijke termijn, plaatsvinden', WFR 2006/888, p. 889-900

M. Kuijer, 'De blinddoek van Vrouwe Justitia of de luiken van de rechtspraak open? Over enkele recente ontwikkelingen op het terrein van de rechterlijke onafhankelijkheid en onpartijdigheid', in: T. Barkhuysen, M.L. van Emmerik en J.P. Loof (red.), Geschakeld recht. Verdere studies over Europese grondrechten ter gelegenheid van de $70^{\text {ste }}$ verjaardag van prof. mr. E.A. Alkema, Deventer: Kluwer 2009, p. 279-294

M. Kuijer, The blindfold of Lady Justice.Judicial Independence and Impartiality in Light of the Requirements of Article 6 ECHR (diss. Leiden), Nijmegen: Wolf Legal Productions 2004

F.G.M. de Laat, 'Die dekselse termijnen!', Gst. (2005) 7238, p. 565-571

P.M. Langbroek, K. Lahuis, J.B.J.M. ten Berge (red.), Kwaliteit van rechtspraak op de weegschaal, W.E.J. Tjeenk Willink 1998

R.A. Lawson, 'Boven het maaiveld. Over de 'ruimhartige' toepassing van het EVRM door nationale rechters', in: T. Barkhuysen, M.L. van Emmerik en J.P. Loof, Geschakeld recht. Verdere studies over Europese grondrechten ter gelegenheid van de $70^{\text {ste }}$ verjaardag van prof.mr. E.A. Alkema, Deventer: Kluwer 2009, p. 307-323

R.A. Lawson, 'Procola in de polder. Een kleyne uitspraak over grote vragen', NJB 2003, p. 1114-1118

L. van Lent, Externe openbaarheid in het strafproces (diss. Utrecht), Den Haag: BJu 2008

A.E.M. Lever, 'Het verbod van reformation in peius onder de Awb', JB-plus 2006, p. 69-85

M.E.G. Litjens, B.M.J. van der Meulen, A.A. Freriks, 'De werking van een controversiële rechtsgang. Invoeringsevaluatie rechtstreeks beroep in de Awb, JB-plus 2006, p. 58-68

R.W.L. Loeb, B.K. Olivier, H. Troostwijk, De wet Arob toegepast, Nijmegen: Ars Aequi Libri 1986

S.M.I. van Loon, 'Art. 6:13 Awb en de onderdelenfuik', NTB 2008, p. 333-338

D.A. Lubach, 'Convergerende tendensen in het Europees bestuursrecht', NTB 2004/7, p. 249-259

H.Th.J.F van Maarseveen en H. Stout, ‘Algemene beginselen van behoorlijke rechtspraak', NJB 1979/10, p. 193-200

R.M. van Male, 'Termijnen: het wordt tijd voor differentiatie', NTB 2008/4-5, p. 129-130

R.M. van Male, 'Bezwaar in de Algemene wet bestuursrecht. Van makwwerk tot maatwerk?', in: Awb en ambtenarenrecht; progressie of regressie?, Capra jubileum-symposium, Elsevier 1998 (later bewerkt tot: 'Bezwaar in ambtenarenzaken. Ruimte voor maatwerk?', TAR 1999, p. 320 e.v.), p. 19-73

R.M. van Male, 'Een onsje minder stroperigheid kan!', NTB 1995, p. 307-308

R.M. van Male, 'Beredeneerd besluiten; plaats, functie en betekenis van het motiveringsbeginsel in het Nederlands bestuursrecht, NTB 1988, p. 73-79

A.G. Maris, Grondrechten tegen, jegens en voor de overheid, Deventer: Kluwer 2008

A.T. Marseille en R.R. van der Heide, 'De onderbenutting van de mogelijkheden tot finale beslechting door de bestuursrechter', JB-plus 2008, p. 78-92

A.T. Marseille, 'Voorlopige oordelen, verstrekkende beslissingen', in: De voorlopige voorziening in het bestuursrecht. Preadviezen VAR 2006, Den Haag: BJu 2006

A.T. Marseille, 'Het niet op tijd beslissende bestuur', $O B$ 2005, p. 9-12

S.K. Martens, 'De grenzen van de rechtsvormende taak van de rechter, NJB 2000, p. 747-758

B.M.J. van der Meulen, M.E.G. Litjens, A.A. Freriks, Prorogatie in de Awb. Invoeringesevaluatie rechtstreeks beroep, WODC 2005 (Rapport Prorogatie in de Awb)

B.M.J. van der Meulen, 'Vooruit te branden bestuur. Over rechtsbescherming tegen uitblijven van besluiten en een requiem voor de fictieve weigering', JB-plus 1999, p. 15-24

Ministerie van Justitie en het Ministerie van Binnenlandse Zaken en Koninkrijksrelaties, Handreiking bezwaarschriftprocedure Algemene wet bestuursrecht, Den Haag: BJu 2004

A.J.G.M. van Montfort en H.B. Winter, 'Kleine gebreken geen bezwaar', in: M. Herweijer, K.F. Schuiling en H.B. Winter (red.), In wederkerigheid (Scheltema-bundel), Deventer: Kluwer 1997, p. 187 197

A.J.C. de Moor-van Vugt m.m.v. E.M. Vermeulen, Europees bestuursrecht, Deventer: W.E.J. Tjeenk Willink 1998

A.J.C. de Moor-van Vugt, Algemene beginselen van behoorlijk bestuur en buitenlandse equivalenten, Zwolle: W.E.J. Tjeenk Willink 1987

K. Mortelmans, 'het Handvest van grondrechten van de EU in de Europese en Nederlandse rechtspraak', in: T. Barkhuysen, M.L. van Emmerik en J.P. Loof (red.), Geschakeld recht. Verdere studies over Europese grondrechten ter gelegenheid van de $70^{\text {ste }}$ verjaardag van prof.mr. E.A. Alkema, Deventer: Kluwer 2009, p. 379-397

A.R. Neerhof, 'De reikwijdte van het verbod van vooringenomenheid', JB-plus 2004, p. 46-51

A.R. Neerhof, 'De bezwaarschriftprocedure functioneel voor de rechtsbescherming en de kwaliteit van de besluitvorming', in: F.A.M. Stroink, A.W. Heringa en A.R. Neerhof (red.), Vijf jaar JB en Awb, Den Haag: Sdu 1999, p. 63-72 (Neerhof 1999a) 


\section{Literatuurlijst}

A.R. Neerhof, 'Van effectieve bestuursrechters en geschillen die voorbijgaan...? De bevoegdheden van de bestuursrechter om geschillen definitief op te lossen.', JB-plus 1999, p. 71-87 (Neerhof 1999b)

A.R. Neerhof, 'De beperkte actieradius van art. 2:4 lid 1 Awb', JB 1998, p. 119-126

P. Nicolaï, B.K. Olivier, I.C. van der Vlies, L.J.A. Damen, B.J. Schueler, Bestuursrecht (zesde druk), Amsterdam: Factotum 1997

P. Nicolaï, 'Kroniek Algemene beginselen van behoorlijk bestuur', NTB 1994/6, p. 179-188

P. Nicolaï, 'Algemene beginselen van behoorlijk bestuur', (diss. AmsterdamUvA), Deventer: Kluwer 1990

N.J.A.P.B. Niessen, 'Nationale ombudsman en de Awb', in: E.C.H.J. van der Linden en F.A.M. Stroink (red.), Jurisprudentie Bestuursrecht Select (JB-Select), Den Haag: Sdu 2004, p. 651-684

R.M.P.G. Niessen-Cobben, Behoorlijk fiscaal procesrecht, Arnhem: Gouda Quint BV 1995

J.H.W. Notten, De Algemene wet bestuursrecht en het maken van bezwaar. Zwaartepunten van een bestuurlijke voorprocedure (diss. Maastricht), Den Haag: Sdu 1998

R. Ortlep, 'De fuikendynastie: van afbraak tot verbouwing', NTB 2005/1, p. 1-5

R. Ortlep, 'Rechtstreeks beroep in het bestuursrecht', $A A$ 2004/4, p. 259-263

R.A. van de Peppel en K.H. Sanders, 'Van 'heel' eenzijdig tot 'in één woord correct', in M. Herweijer, K.F. Schuiling en H.B. Winter (red.), In wederkerigheid (Scheltema-bundel), Deventer: Kluwer 1997, p. 219-229

U. van de Pol, Openbaar terecht (diss. Amsterdam VU), Arnhem: Gouda Quint 1986

J.M. Polak, “Termijnen voor rechterlijke uitspraken”, NJB 1996, p. 248-249

J.M. Polak, 'Algemene beginselen van behoorlijke rechtspraak', NJB 1968/17, p. 417-422

J.M. Polak, Vormen en beginselen van rechtspraak in het algemeen, preadvies Vereniging voor Bouwrecht, Deventer: Kluwer 1976

J.E.M. Polak, 'Nationale bestuursrecht in een internationale context. Over verwaarloosde aspecten bij de discussie over de juridisering van het openbaar bestuur.', $N J B$ 2003/6 p. 266-272

J.E.M. Polak, Effectieve bestuursrechtspraak. Enkele beschouwingen over het vermogen van de bestuursrechtspraak geschillen materieel te beslechten (oratie Leiden), Deventer: Kluwer 2000

T.J. Poppema, 'De redelijke termijn in het nationale (bestuurs)recht: op naar een wettelijke voorziening!', NTB 2009, p. 185-190

Van der Pot-Donner, Handboek van het Nederlandse Staatsrecht, $15^{\mathrm{e}}$ druk bewerkt door D.J. Elzinga en R. de Lange, Deventer: Kluwer 2006

S. Pront-Van Bommel, Bestuursrechtspraak; voorstellen voor modernisering van de bestuursrechtspraak (diss. Amsterdam UvA), Den Haag: BJu 2002

Rapport Commissie verbetervoorstellen bestuursrecht, oktober 2006, p. 1-36

M.P.T. Rongen, 'Heeft administratief beroep anno nu nog nut? Haal deze discussie in elk geval uit de vergeetput!, JB-plus 2007, p. 114-128

K.H. Sanders, 'Ruimte voor de heroverweging', JB-plus 2005, p. 2-17

K.H. Sanders, De Bezwaarschriftprocedure, Nijmegen: Ars Aequi Libri 2004

K.H. Sanders, 'De flexibiliteit van een rituele dans', NTB 1999/7, p.171-178

K.H. Sanders, De heroverweging getoetst. Een onderzoek naar de functies van bezwaarschriftprocedures (diss. Groningen), Deventer: Kluwer 1998

C.M. Saris, 'Tijdig beslissen. Het doel dichterbij met de Wet dwangsom en beroep bij niet tijdig beslissen en de verruiming van de lex silencio positivo?, Gmst. 2008, 7292, p. 141-148

C.M. Saris, Tijdig beslissen, Het doel dichterbij? Preadviezen Jonge VAR 2006, Den Haag: BJu 2006

M. Scheltema, 'Het tijdigheidsbeginsel', in R.L. Vucsán, De Awb-mens: boeman of underdog? Opstellen aangeboden aan Leo Damen, Ars Aequi Libri: Nijmegen 1996, p. 241-253

M. Scheltema, 'De rechter en de bezwaarschriftprocedure: meer aandacht voor snelheid en minder voor aansprakelijkheid', in: T. Hoogenboom en L.J.A. Damen (red.), In de sfeer van administratief recht (opstellen aangeboden aan W. Konijnenbelt, Utrecht: Lemma 1994, p. 379-392

R.J.N. Schlössels, 'Kroniek Beginselen van behoorlijk bestuur', NTB 2008, p. 92-106

R.J.N. Schlössels, 'Kroniek Beginselen van behoorlijk bestuur', NTB 2007, p. 220-233

R.J.N. Schlössels en F.A.M. Stroink, Kern van het bestuursrecht, Den Haag: BJu 2006

R.J.N. Schlössels, 'Beginselen van behoorlijk bestuur', NTB 2005/7, p. 252-263

R.J.N. Schlössels, 'Dimensies van rechtsbeginselen. Enige observaties vanuit het bestuursrecht', in: R.J.N. Schlössels e.a. (red.), In beginsel: over aard, inhoud en samenhang van rechtsbeginselen in het bestuursrecht, Deventer: Kluwer 2004, p. 13-43

R.J.N. Schlössels, 'Tussen finaliteit en fuik? Over de omvang van het bestuursrechtelijke geding in eerste aanleg en appèl', in: M.A. Heldeweg, E.C.H.J. van der Linden en R.J.N. Schlössels (red.), Uit de school geklapt? Opstellen uit Maastricht, Den Haag: Sdu 1999, p. 177-203

R.J.N. Schlössels, "Hoe hard mag een appèlverbod zijn?", JB 1997, 166, p. 743-750 


\section{Literatuurlijst}

J.G.C. Schokkenbroek, 'Effectief rechtsmiddel', in: J.H. Gerards, A.W. Heringa, H.L. Janssen, J. van der Velde, EVRM Rechtspraak en Commentaar, Den Haag: Sdu 2002, par. 3.13

M. Schreuder-Vlasblom, 'Dertig jaar later; de redelijke termijn als nationale uitdaging', in: T. Barkhuysen, M.L. van Emmerik en J.P. Loof (red.), Geschakeld recht. Verdere studies over Europese grondrechten ter gelegenheid van de 70ste verjaardag van prof.mr. E.A. Alkema, Deventer: Kluwer 2009, p. $453-474$

M. Schreuder-Vlasblom, Rechtsbescherming en bestuurlijke voorprocedure, Deventer: Kluwer 2008

M. Schreuder-Vlasblom, 'Art. 6:13 Awb: van berustingsbepaling tot koekoeksjong', JBplus 2007, p. 134 153

M. Schreuder-Vlasblom, 'Het gewijzigde artikel 6:13 Awb, een trechter tussen bestuur en rechter', $J B$ plus Verklaard 2006, p. 3-15

B.J. Schueler, J.K. Drewes, F.T. Groenewegen, W.G.A. Hazewindus, A.P. Klap, V.M.Y. van 't Lam, B.K. Olivier, E.M. Vogelezang-Stoute, Definitieve geschilbeslechting door de bestuursrechter (Derde evaluatie van de Awb), Den Haag: BJu 2007

B.J. Schueler, Schadevergoeding en de Awb. Aansprakelijkheid voor appellabele besluiten, Deventer: Kluwer 2005

B.J. Schueler, Vernietigen en opnieuw voorzien (diss. Utrecht), Zwolle: Tjeenk Willink 1994

H.J. Simon, 'Het EVRM en de bestuurlijke besluitvorming (deel II)', JB-plus 2004, p. 2-14

H.J. Simon, 'Het EVRM en de bestuurlijke besluitvorming (deel I)', JB-plus 2003 (Simon 2003a), p. 170 181

H.J. Simon, 'Signalen uit Straatsburg', in: R.M. van Male, H. Bolt e.a. (red.), Centrale Raad van Beroep 1903-2003, Den Haag: Sdu 2003 (Simon 2003b), p. 367-397

H.J. Simon, 'Bestuursrecht en mensenrechten. Topdown of bottom up?', NJB 1999 (Simon 1999a), p. $1187-1197$

H.J. Simon, 'Het nut van de Awb voor bezwaarmakers', in: F.A.M. Stroink, A.W. Heringa en A.R. Neerhof (red.), Vijf jaar JB en Awb, Den Haag: Sdu 1999 (Simon 1999b), p. 53-62

H.J. Simon, Handboek bestuurs(process)recht volgens de Awb, Den Haag: Sdu 1997

Th. G.M. Simons, 'De beoordeling van een verzoek om voorlopige voorziening', JB-plus 2005, p. 56-72

J.A. Smit, 'De administratieve voorprocedures', in: J.B.J.M. ten Berge e.a., Nieuw bestuursprocesrecht, Deventer: Kluwer 1992, p. 47-56

H.J. Snijders, C.J.M. Klaassen, G.J. Meijer, Nederlands burgerlijk procesrecht, Zwolle: Kluwer 2007

J.C. Somer, 'Openbaarheid en de rechtsbescherming van de individu', in: B. de Goede en H.Th.J.F. van Maarseveen, Hoe openbaar wordt ons bestuur, Den Haag: VUGA 1969, p. 243-270

L.A.J. Spaans, 'Wet openbaarheid van bestuur: recente ontwikkelingen in jurisprudentie en wetgeving', Mediaforum 2004, p. 22-27

R. Stijnen, 'Wet dwagsom en beroep bij niet tijdig beslissen (II)', NJB 2010, p. 468-474

R. Stijnen, 'Wet dwangsom en beroep bij niet tijdig beslissen (I)', NJB 2010 p. 65-70

P.J. Stolk, Wet openbaarheid van bestuur, Deventer: Kluwer 2009

F.A.M. Stroink, Kern van de bestuursrechtspraak, Den Haag: Elsevier 2004 (Stroink 2004a)

F.A.M. Stroink, 'Iets over rechtsbeginselen en wat daarop lijkt in het bestuursprocesrecht', in: R.J.N. Schlössels, A.J. Bok, H.J.A.M. van Geest, S. Hillegers, In beginsel. Over aard, inhoud en samenhang van rechtsbeginselen in het bestuursrecht, Deventer: Kluwer 2004 (Stroink 2004b), p. 129-140

F.A.M. Stroink, 'Toetsingsintensiteit', in: E.C.H.J. van der Linden en F.A.M. Stroink (red.), JB-Select, Den Haag: Sdu 2004 (Stroink 2004c), p. 257-266

F.A.M. Stroink, 'Besluitvorming zonder vooringenomenheid', in: Gedachten over bestuurlijke en ambtelijke integriteit, CAPRA jubileumsymposium, Den Haag 2003, p. 58-65

F.A.M. Stroink, 'De betekenis van de Straatsburgse jurisprudentie inzake de oanfhankelijkheid en onpartijdigheid voor het Nederlandse recht', NJCM-bulletin 1999, p. 5-32

F.A.M. Stroink, Rechterlijke organisatie en rechtspraak in beweging, Zwolle: W.E.J. Tjeenk Willink 1993

J.M.H.F. Teunissen, 'Commentaar art. 7:2 Awb', in: M. Scheltema, R.M. van Male, B.W.N. de Waard, A.T. Marseille, A.J.C. de Moor-van Vugt (red.), Losbladig commentaar Algemene wet bestuursrecht, Amsterdam: Reed Elsvevier (voorheen Den Haag: VUGA), losbladige uitgave, E 6.3.7

J.M.H.F. Teunissen, Commentaar art. 7:3 Awb, in: M. Scheltema, R.M. van Male, B.W.N. de Waard, A.T. Marseile, A.J.C. de Moor-van Vugt (red.), Commentaar Algemene wet bestuursrecht, Amsterdam: Reed Elsevier (voorheen Den Haag: VUGA), losbladige uitgave, E 6.3.8

J.M.H.F. Teunissen, 'Commentaar art. 7:4 Awb', in: M. Scheltema, R.M. van Male, B.W.N. de Waard, A.T. Marseille, A.J.C. de Moor- van Vugt (red.), Commentaar Algemene wet bestuursrecht, Amsterdam: Reed Elsevier (voorheen Den Haag: VUGA), losbladige uitgave, E 6.3.9

J.M.H.F. Teunissen, 'Commentaar art. 7:9 Awb', in: M. Scheltema, R.M. van Male, B.W.N. de Waard, A.T. Marseile, A.J.C. de Moor-van Vugt (red.), Commentaar Algemene wet bestuursrecht, Amsterdam: Reed Elsevier (voorheen Den Haag: VUGA), losbladige uitgave, E 6.3.14 


\section{Literatuurlijst}

J.M.H.F. Teunissen, 'Toetsing ex tunc of ex nunc? in: J.B.J.M. ten Berge e.a., Nieuw bestuursprocesrecht, Deventer: Kluwer 1992, p. 111-129

L.J.M. Timmermans, 'Verbod van vooringenomenheid: een (al)gemeen rechtsbeginsel? Een interne rechtsvergelijking', in: R.J.N. Schlössels e.a. (red.), In beginsel. Over aard, inhoud en samenhang van rechtsbeginselen in het bestuursrecht, Deventer: Kluwer 2004, p. 189-219

A. Tollenaar, 'Het is maar wat je bijzonder noemt. Rechterlijke toetsing aan beleid en beleidsregels', $J B$ plus 2006

T. Trimidas, The General Principles of EU Law, Oxford University Press 2006

VAR Commissie Rechtsbescherming, De toekomst van de rechtsbescherming tegen de overheid. Van toetsing naar geschilbeslechting (Rapport Commissie Rechtsbescherming), Den Haag: BJu 2004

J. in 't Veld en N.S.J. Koeman, Beginselen van behoorlijk bestuur, Zwolle: W.E.J. Tjeenk Willink 1985

J. van der Velde, Art. 6 Eerlijk proces. Eerlijke en openbare behandeling', in: J.H. Gerards, A.W. Heringa, H.L. Janssen en J. van der Velde, EVRM Rechtspraak en Commentaar, Den Haag: Sdu 2004, katern 3.6, par. 3.6 .4 , p. $1-41$

N. Verheij, 'The need for speed', NTB 2009, p. 109-110

N. Verheij, 'Dat schiet niet op. Over wetgeving tegen traag bestuur', in: G.H. Addink, G.T.J.M. Jurgens, Ph. M. Langbroek, R.J.G.M. Widdershoven, Grensverleggend bestuursrecht. Opstellen voor prof.mr. J.B.J.M. ten Berge, Deventer: Kluwer 2008, p. 227-240

$\mathrm{N}$. Verheij, 'Tussen toen en nu. Het relevante tijdstip voor besluitvorming in bezwaar en toetsing in beroep', JB-plus 2003, p. 26-47

N. Verheij, 'De toegang tot de rechter in het bestuursrecht', in: R.A. Lawson en E. Myjer (red.), 50 jaar EVRM NJCM-Bulletin (speciale aflevering), Leiden 2000, p. 183-201

N. Verheij, 'Stadsmobiel Amsterdam (nr. 10). Partijdige bezwaarschriftcommissie', in: L.J.A. Damen e.a (red.) Rechtspraak Bestuursrecht 1994-1995: de annotaties, Den Haag: Vuga 1995, p. 94/95-139 $\mathrm{t} / \mathrm{m} 154$

L.F.M. Verhey, 'De toekomst van de Raad van State: het einde van de Procola-kramp?, in: A.W. Heringa, A.M.L. Jansen, E. van der Linden en L.F.M. Verhey, Het bestuursrecht beschermd (liber amicorum F.A.M. Stroink), Den Haag: Sdu 2006, p. 17-31

L.F.M. Verhey, De onafhankelijkheid van de rechter naar Nederlands recht (preadvies Vereniging voor de vergelijkende studie van het recht van België en Nederland, Deventer: W.E.J. Tjeenk Willink 2001, p. 19-76

E.M. Vermeulen, Rechtsbescherming in een communautaire context (diss. Tilburg, Den Haag 2001

C.J.N. Versteden, 'Van Simpelveld naar Winsum. Nieuw licht op belangenverstrengeling en deelname aan stemmingen', Gst. (2002) 7173, p. 549-558

C.J.N. Versteden, 'De plaats van bezwaar en administratief beroep in het stelsel van rechtsbescherming', NTB 1995/9-10, p. 286-292

M.L.W.M. Viering, Het toepassingsgebied van artikel 6 EVRM (diss. Nijmegen), Zwolle: W.E.J. Tjeenk Willink 1994

VMC-studiecommissie Openbaarheid van rechtspraak, Rapport Toegang tot rechterlijke uitspraken, Mediaforum 2006/4, p. 1-20

I.C. van der Vlies, Het wetsbegrip en beginselen van behoorlijke regelgeving: de verandering van het legaliteitsbeginsel in de twintigste eeuw (diss. Amsterdam UvA), Den Haag: VUGA 1984

W. Voermans, 'De bestuursrechter en artikel 120 Grondwet', JB-plus 2003, p. 142-151

M. Vos, Tijdig beslissen: een mission (im)possible?, Preadviezen voor de Jonge VAR 2006, Den Haag: BJu 2006, p. 11-47

K. Waaldijk, Motiveringsplichten van de wetgever (diss. Leiden), Lelystad: Koninklijke Vermande 1994

B.W.N. de Waard, 'Commentaar art. 6:22', in: M. Scheltema, R.M. van Male, B.W.N. de Waard, A.T. Marseille, A.J.C. de Moor-van Vugt (red.), Losbladig commentaar Algemene wet bestuursrecht, Amsterdam: Reed Elsvevier (voorheen Den Haag: VUGA), losbladige uitgave, E 6.2.14

B.W.N. de Waard, 'Doorbreking van appelverboden', JB-plus 2005, p. 98-114

B.W.N. de Waard, 'De goede procesorde', JB-plus 2001, p. 148-162

B.W.N. de Waard, 'De grote ogen van de grondwetgever. Het onderwerp 'rechtspraak' in de Grondwet van 1983', in: J.B.J.M. ten Berge, P.J.J. van Buuren, H.R.B.M. Kummeling, B.P. Vermeulen (red.), De Grondwet als voorwerp van aanhoudende zorg, Burkens-bundel, Zwolle: W.E.J. Tjeenk Willink 1995, p. 435-450

B.W.N. de Waard, Beginselen van behoorlijke rechtspleging, met name in het administratief recht (diss. Utrecht), Zwolle: W.E.J. Tjeenk Willink 1987

B.W.N. de Waard, 'Een eerlijk proces (I en II)', TvO 1983, p. 143-147 en 175-179

N.M. van Waterschoot, 'Het door de vingers zien van gebreken die de materiële inhoud niet raken', $J B$ plus 2002, p. 181-194

A. Weggeman, 'De Awb en de tijdgeest', NTB 2008/4-5, p. 152; Vos 2006, p. 33-64 


\section{Literatuurlijst}

A. Weggeman, 'Afzien van horen in bezwaar' in: W. Konijnenbelt e.a., 'Herziening bestuursprocesrecht ter tafel', $N T B 2006,36$, p. 267-269

A. Weggeman, 'Wetsvoorstel rechtstreeks beroep, NTB 2001/3, p. 85-87

M.F.J.M. de Werd, De openbare uitspraak. Reconstructie van een verwaarloosd leerstuk, NJB 2001/2, p $67-74$

M.F.J.M. de Werd, 'De wetgever en artikel 6 EVRM, in: in: J.P. Loof (red.), Onafhankelijkheid en onpartijdigheid. De randvoorwaarden voor het bestuur en beheer van de rechterlijke macht', Leiden: Stichting NJCM-Boekerij 36 1999, p. 31-42

G.J. Wiarda, 'Rechtsregels als houvast voor de rechtspraak', NJB 1977/7 in: Verspreide geschriften van G.J. Wiarda, Den Haag: VUGA 1986, p. 193-231

G.J. Wiarda, 'De Wet Arob als nieuwe fase in de ontwikkeling van de rechtsbescherming tegenover de overheid', in: Verspreide geschriften van G.J. Wiarda, Den Haag: VUGA 1986, p. 203-211

G.J. Wiarda, Het administratief beroep, VAR-geschrift LVIII, Haarlem 1966, in: Verspreide geschriften van G.J. Wiarda, Den Haag: VUGA 1986, p. 123-125

G.J. Wiarda, 'Het administratief beroep in het ontwerp van de Wet BAB, Geschriften van de Vereniging voor Administratief recht XLVIII, Haarlem 1962, in:Verspreide geschriften van G.J. Wiarda, Den Haag: VUGA 1986, p. 93-99

G.J. Wiarda, Algemene beginselen van behoorlijk bestuur, preadvies VAR 1952, VAR-geschrift XXIV, in: Verspreide geschriften van G.J. Wiarda, Den Haag: VUGA 1986, p. 35-72

R.J.G.M. Widdershoven, M.J.M. Verhoeven, S. Prechal, A.P.W. Duijkersloot, J.W. van de Gronden, B Hessel en R. Ortlep, De Europese agenda van de Awb (Derde evaluatie Awb), Den Haag: BJu 2007

R.J.G.M. Widdershoven, 'De invloed van EG-recht en EVRM op de Nederlandse bestuursrechtspraak', JB-plus 2006, p. 26-47

R.J.G.M. Widdershoven, 'De Europese rol van de nationale rechter: rechtsbeschermer of controleur?', in A.W. Heringa, A.M.L. Jansen, E.C.H.J. van der Linden, L.F.M. Verhey (red.), Het bestuursrecht beschermd (liber amicorum F.A.M. Stroink), Den Haag: Sdu 2006

R.J.G.M. Widdershoven,'Rechtsbeginselen in het Europese recht', in: R.J.N. Schlössels, A.J. Bok, H.J.A.M. van Geest, S. Hillegers (red.), In beginsel. Over aard, inhoud en samenhang van rechtsbeginselen in het bestuursrecht, Deventer: Kluwer 2004, p. 293-327

R.J.G.M. Widdershoven, R.J.N. Schlössels, F.A.M. Stroink, J.B.J.M. ten Berge, A.J. Bok, W.J.M. Voermans, B.W.N. de Waard, P.A. Willemsen, Algemeen bestuursrecht 2001. Hoger beroep (Tweede evaluatie Awb), Den Haag: BJu 2001

R.J.G.M. Widdershoven, 'Tijdigheid in het bestuursprocesrecht', in: G.R. Rutgers en H.E. Bröring (red.), Rechtspraak op tijd, Den Haag: BJu 1999, p. 75-85

R.J.G.M. Widdershoven, Gespecialiseerde rechtsgangen in het administratieve recht, (diss. Utrecht) 1989, Zwolle: W.E.J. Tjeenk Willink 1989

K. Wiersma, 'Administratieve en burgerlijke procesgangen, beginselen en organisatie', in: W.H. Heemskerk, Th.B. ten Kate en B.C. Punt (red.), Een goede procesorde. Opstellen aangeboden aan Mr. W.L. Haardt (Haardt-bundel), Deventer: Kluwer 1983, p. 131-147

H.D. Van Wijk, bewerkt door W. Konijnenbelt en R.M. Van Male, Hoofdstukken van bestuursrecht, Den Haag: Elsevier Juridisch 2008

M.R. Wijnholt, 'Selectie en benoeming van onafhankelijke rechters in het Koninkrijk', in: Publikaties van de Staatsrechtkring, Organisatie van de rechtspraak, Deventer: W.E.J. Tjeenk Willink 1999, p. $73-78$

P.A. Willemsen, Een meer definitieve geschilbeslechting in het bestuursrecht in rechtsvergelijkend perspectief (preadvies NVvR), Nijmegen: Wolf Legal Publishers 2008

P.A. Willemsen, Grenzen van de rechtsstrijd in het bestuursrechtelijk beroep en hoger beroep in rechtsvergelijkend perspectief (diss. Utrecht), Deventer: Kluwer 2005 


\section{Jurisprudentielijst}

\section{Europees Hof voor de Rechten van de Mens}

EHRM 3 maart 2009, Voorhuis t. Nederland, nr. 28692/06 (ontv.besl.)

EHRM 15 oktober 2009, Micaleff t. Malta, AB 2010/75 m.nt. Barkhuysen \& Van Emmerik; EHRC 2009/125 m.nt. A.M.L. Jansen (Grote Kamer-uitspraak)

EHRM 5 februari 2009, Olujić t. Kroatië, EHRC 2009/57 m.nt. De Werd

EHRM 13 november 2008, Frijns t. Nederland, $A B$ 2009/7 m.nt. Barkhuysen en Tjepkema

EHRM 20 mei 2008, Gülmez t. Turkije, EHRC 2008/89 m.nt. Jansen

EHRM 24 april 2008, Kemp e.a. t. Luxemburg, EHRC 2008/78 m.nt. Fernhout

EHRM 8 april 2008, Megadat.com SRL t. Moldavië, EHRC 2008/75 m.nt. Backes; AB 2008/224 m.nt. Barkhuysen \& Van Emmerik

EHRM 18 maart 2008, Piroğlu en Karakaya t. Turkije, nrs. 36370/02 en 37581/02

EHRM 26 februari 2008, Fägerskiöld t. Zweden, EHRC 2008/85 m.nt. Backes; AB 2008/225 m.nt. Barkhuysen \& Van Emmerik (ontv.besl.)

EHRM 17 januari 2008, Ryakib Biryukov t. Rusland, EHRC 2008/43 m.nt. Van der Velde

EHRM 15 januari 2008, Micaleff t. Malta, EHRC 2008/42 m.nt. Jansen

EHRM 29 november 2007, Hummatov t. Azerbeidzjan, EHRC 2008/12 m.nt. Van der Velde

EHRM 4 oktober 2007, Sanchez Cardenas t. Spanje, EHRC 2007/141

EHRM 27 september 2007, Estate of Nitschke t. Zweden, nr. 6301/05

EHRM 11 september 2007, nr. 59773/00, Sükut t. Turkije, EHRC 2008/16 (ontv. besl.)

EHRM 5 juli 2007, Sara Lind Eggertsdóttir t. IJsland, EHRC 2007/115 m.nt. De Werd; AB 2009/319 m.nt. Barkhuysen en Van Emmerik

EHRM 7 juni 2007, Zagorodnikov t. Rusland, nr. 66941/01

EHRM 31 juli 2007, Rizhamadze t. Georgië, EHRC 2007/110

EHRM 26 april 2007, Gebremedhin t. Frankrijk, EHRC 2007/75 m.nt. Woltjer; AB 2007/227 m.nt. Battjes

EHRM 19 april 2007, Vilho Eskelinen e.a. t. Finland, EHRC 2007/82 m.nt. Geurink; AB 2007/317 m.nt. Barkhuysen en Van Emmerik; JB 2007/98; NJ 2007/375 m.nt. Alkema; NJCM-Bulletin 2007 p. 697 e.v. m.nt. Van Dijk

EHRM 22 februari 2007, Tatashvili t. Rusland, ERHC 2007/59; AB 2007/324 m.nt. Barkhuysen en Schuurmans

EHRM 11 januari 2007, Salah Sheekh t. Nederland, EHRC 2007/36 m.nt. Woltjer; AB 2007/76 m.nt. B.P. Vermeulen; $J B$ 2007/52 m.nt. DWMW

EHRM 23 november 2006, Jussila t. Finland, AB 2007/51 m.nt. Barkhuysen en Van Emmerik; EHRC 2007/31 m.nt. Albers

EHRM 9 november 2006, Sacilor-Lormines t. Frankrijk, AB 2007/281 m.nt. De Waard; EHRC 2007/15 m.nt. Verhey

EHRM 2 november 2006, Giacomelli t. Italië, EHRC 2007/7 m.nt Peeters; AB 2008/23 m.nt. Barkhuysen \& Van Emmerik; $J B$ 2007/1

EHRM 21 september 2006, Moser t. Oostenrijk, EHRC 2006/129

EHRM 27 juli 2006, Coorplan Jenni GmbH en Hascic t. Oostenrijk, EHRC 2006/122 en JB 2006/287 m.nt. Schlössels

EHRM 29 juni 2006, Bozič t. Kroatië, nr. 22457/02

EHRM 29 juni 2006, Počuča t. Kroatië, EHRC 2006/106

EHRM 8 juni 2006, Sürmeli t. Duitsland, EHRC 2006/100 m.nt. Jansen (Grote Kamer-uitspraak)

EHRM 24 mei 2006, Liakopoulou t. Griekenland, AB 2006/257 m.nt. Barkhuysen en Van Emmerik

EHRM 29 maart 2006, Scordino (nr. 1) t. Italië, EHRC 2006/61 m.nt. Van der Velde (Grote Kameruitspraak)

EHRM 29 maart 2006, Pizatti t. Italië, JB 2006/134 m.nt. AMLJ

EHRM 15 december 2005, Kyprianou t. Cyprus, EHRC 2006/21 m.nt. A.M.L. Jansen (Grote Kameruitspraak)

EHRM 29 november 2005, Wyszczelski t. Polen, nr. 72161/01

EHRM 6 oktober 2005, Lukenda t. Slovenië, EHRC 2005/114 m.nt. Van der Velde

EHRM 15 juli 2005, Mežnarič t. Kroatië, EHRC 2005/100 m.nt. Jansen

EHRM 24 mei 2005, Intiba t. Turkije, EHRC 2005/70 m.nt. Jansen

EHRM 15 maart 2005, Bako t. Slowakije, BNB 2005/336 m.nt. Feteris bij HR 17 juni 2005, BNB $2005 / 338$ 
Jurisprudentielijst

EHRM 10 november 2004, Riccardi Pizzatti t. Italië, AB 2005/257 m.nt. Barkhuysen; JB 2005/1 m.nt. A.M.L. Jansen; EHRC 2005/22 m.nt. Van der Velde (Kamer-uitspraak)

EHRM 9 november 2004, Svetlana Naumenko t. Oekraïne, nr. 41984/98

EHRM 22 juni 2004, Pabla Ky t. Finland, nr. 47221/99

EHRM 22 mei 2003, Kyrtatos t. Griekenland, EHRC 2003/57 m.nt. Janssen; $A B$ 2004/172, m.nt. TB

EHRM 6 mei 2003, Kleyn e.a. t. Nederland, AB 2003/211, m.nt. L.V en BdeW; JB 2003/119 m.nt. AWH; EHRC 2003/54 m.nt. J.H. Gerards

EHRM 12 maart 2003, Öcalan t. Turkije, EHRC 2003/38

EHRM 28 november 2002, Lavents t. Letland, EHRC 2003/15 m.nt. Redactie

EHRM 28 mei 2002, Kingsley t. Verenigd Koninkrijk, nr. 35605/97 (Grote Kamer-uitspraak)

EHRM 27 september 2001, Hirvisaari t. Finland, NJCM-Bulletin 2001 m.nt. R.J.N. Schlössels

EHRM 21 juli 2001, Ferrazzini t. Italië, EHRC 2001/57 m.nt. Heringa; AB 2004/400 m.nt. Barkhuysen; NJ 2004/435 m.nt. Alkema

EHRM 19 juni 2001, Kreuz t. Polen, EHRC 2002/54 m.nt. AWH

EHRM 24 april 2001, B. en P. t. Verenigd Koninkrijk, EHRC 2001/43

EHRM 1 februari 2001, Ayuntamiento de Mula t. Spanje, nr. 55346/00 (ontv.besl.)

EHRM 7 november 2000, Kingsley t. Verenigd Koninkrijk, AB 2002/25 m.nt. LV; EHRC 2000/92 m.nt. Heringa

EHRM 26 oktober 2000, Kudla t. Polen, NJCM-Bulletin 2001, nr. 1 m.nt. T. Barkhuysen; EHRC 2000/89 m.nt Van der Velde; $A B$ 2001/275 m.nt. LV

EHRM 5 oktober 2000, Maaouia t. Frankrijk, EHRC 2000/84 m.nt. Heringa; AB 2001/80 m.nt. Battjes; NJCM-Bulletin 2001, p. 762 e.v. m.nt. Kuijer; NJ 2002/424; JV 200/264 m.nt. Boeles

EHRM 27 juni 2000, Frydlender t. Frankrijk, EHRC 2000/67 m.nt. Heringa

EHRM 21 januari 1999, Garcia Ruiz t. Spanje, nr. 30544/96

EHRM 25 maart 1998, Belziuk t. Polen, nr. 23103/93

EHRM 19 december 1997, Helle t. Finland, nr. 20772/92

EHRM 26 augustus 1997, De Haan t. Nederland, JB 1997/186 m.nt. AWH

EHRM 29 mei 1997, Georgiadis t. Griekenland, nr. 21522/93

EHRM 19 maart 1997, Hornsby t. Griekenland, JB 1997/98 m.nt. AWH; NJ 1998/434

EHRM 18 maart 1997, Mantovanelli t. Italië, JB 1997/112 m.nt. Heringa; NJ 1998/278 m.nt. Snijders

EHRM 27 januari 1997, Nideröst-Huber t. Zwitserland, nr. 18990/91

EHRM 22 oktober 1996, Stubbings e.a. t. Verenigd Koninkrijk, NJ 1997/449 m.nt. JdB

EHRM 22 januari 1996, Vermeulen t. België, nr. 19075/91

EHRM 28 september 1995, Procola t. Zwitserland, AB 1995/588 m.nt. ICvdV; JB 1995/383 m.nt. FAMS.

EHRM 26 september 1995, Diennet t. Frankrijk, nr. 18160/91

EHRM 9 december 1994, Schouten en Meldrum t. Nederland, JB 1995/49 m.nt. AWH; AB 1995/599 m.nt. ICvdV

EHRM 9 december 1994, Hiro Balani t. Spanje, nr. 18064/91

EHRM 19 april 1994, Van de Hurk t. Nederland, NJ 1995/462 m.nt. EAA

EHRM 27 oktober 1993, Dombo Beheer B.V. t. Nederland, nr. 14448/88, NJ 1994/534 m.nt. HJS en EJD

EHRM 24 juni 1993, Schuler-Zgraggen t. Zwitserland, nr. 14518/89

EHRM 28 augustus 1991, Brandstetter t. Oostenrijk, nrs. 11170/84, 12876/87 en 13468/87

EHRM 21 februari 1990, Hakansson en Sturesson t. Zweden, nr. 11855/85

EHRM 24 mei 1989, Hauschildt t. Denemarken, nr. 10486/83

EHRM 29 april 1988, Belilos t. Zwitserland, nr. 10328/83

EHRM 23 oktober 1985, Benthem t. Nederland, AB 1986/1, m.nt. E.M.H. Hirsch Ballin; NJ 1986/102 m.nt. E.A. Alkema

EHRM 28 mei 1985, Ashingdane t. Verenigd Koninkrijk, NJ 1991/623 m.nt. EAA

EHRM 6 mei 1985, Bönisch t. Oostenrijk, nr. 8658/79,

EHRM 22 oktober 1984, Sramek t. Oostenrijk, nr. 8790/79

EHRM 28 juni 1984, Campbell en Fell t. Verenigd Koninkrijk, nrs. 7819/77, 7878/77

EHRM 22 februari 1984, Sutter t. Zwitserland, nr. 8209/78

EHRM 8 december 1983, Pretto t. Italië, nr. 7984/77

EHRM 8 december 1983, Axen t. Duitsland, nr. 8273/78

EHRM 10 februari 1983, Albert en Le Compte t. België, NJ 1987/315

EHRM 1 oktober 1982, Piersack t. België, nr. 8692/79

EHRM 15 juli 1982, Eckle t. Duitsland, nr. 8130/78, Series A, vol. 51

EHRM 23 juni 1981, Le Compte, Van Leuven en De Meyere t. België, NJ 1982/602

EHRM 27 februari 1980, Deweer t. België, nr. 6903/75

EHRM 24 oktober 1979, Winterwerp t. Nederland, nr. 6301/73

EHRM 9 oktober 1979, Airey t. Ierland, NJ 1980/376 m.nt. E.A. Alkema

EHRM 28 juni 1978, König t. Duitsland, NJ 1980/54

EHRM 21 februari 1975, Golder t. Verenigd Koninkrijk, NJ 1975/462 m.nt. Alkema 


\section{Jurisprudentielijst}

EHRM 16 juli 1971, Ringeisen t. Oostenrijk, nr. 2614/65

EHRM 17 januari 1970, Delcourt t. België, nr. 2689/65

\section{Hof van Justitie}

HvJ EU 18 maart 2010, Alassini, nr. C-317-220/08

GEA 3 maart 2010, Freistaat Sachsen (Duitsland) (T-102/07), MB Immobilien Verwaltungs GmbH en MB System GmbH \& Co. KG (T-120/07) t. Europese Commissie, nrs. T-102/07 en T-120/07

HvJ EU 2 december 2009, Commissie t. Ierland e.a., nr. C-89/08 P

HvJ EG 29 oktober 2009, Pontin t. T-Comalux SA, AB 2010/1 m.nt. R.J.G.M. Widdershoven

HvJ EG 1 oktober 2009, Foshan Shunde Yongjian Housewares \& Hardware Co. Ltd t. De Raad van de Europese Unie, nr. C-141/08 P

HvJ EG 3 september 2009, Papierfabrik August Koehler AG (C-322/07 P), Bolloré SA (C-327/07 P) en Distribuidora Vizcaina de Papeles $S L(C-338 / 07$ P) t. Commissie van de Europese Gemeenschappen, nrs. C-322/07 P, C-327/07 P en C-338/07 P

HvJ EG 16 juli 2009, Der Grüne Punkt - Duales System Deutschland GmbH t. Commissie van de Europese Gemeenschappen, nr. C-385/07 P, EHRC 2010/20 m.nt. R.J.G.M. Widdershoven

HvJ EG 2 april 2009, Bouygues en Bouygues Télécom t. Commissie van de Europese gemeenschappen, nr. C-431/07 P

HvJ EG 19 februari 2009, Gorostiaga Atxalandabaso t. Europees parlement, EHRC 2009/46

GEA 4 februari 2009, Omya AG t. Commissie, nr. T-145/06

HvJ EG 18 december 2008, nr. C-349/07, Sopropé- Organizaçoes de Calçado Lda t. Fazenda Pública en Ministério Público, AB 2009/29 m.nt. Widdershoven

HvJ EG 23 september 2008, C-427/06, Bartsch t. Bosch und Siemens Hausgeräte (BSH) Altersfürsorge $\mathrm{GmbH}, A B$ 2008/356, m.nt. Verhoeven en Ortlep

HvJ EG 10 juli 2008, Bertelsmann en Sony Corporation of America t. Impala, nr. C-413/06 P

HvJ EG 1 juli 2008, Chronopost SA en La Poste e.a., EHRC 2008/94

GEA 1 juli 2008, Compagnie maritime belge SA t. Commissie, nr. T-276/04

HvJ EG 14 februari 2008, Varec SA t. Belgische Staat, EHRC 2008/64

HvJ EG 26 juni 2007, Orde van Franstalige en Duitstalige balies, Franse Orde van advocaten bij de balie te Brussel, Orde van Vlaamse balies, Nederlandse orde van Advocaten bij de balie te Brussel t. Ministerraad, EHRC 2007/10 m.nt. Fermon

HvJ EG 13 maart 2007, Unibet (London) Ltd en Unibet (International) Ltd t. Justitiekanslern, nr. C$432 / 05$

HvJ EG 26 oktober 2006, K. Tas-Hagen en R.A. Tas t. Raadskamer WUBO van de Pensioen- en Uitkeringsraad, nr. C-192/05

HvJ EG 21 september 2006, Technische Unie BV t. Commissie van de Europese Gemeenschappen, nr. C$113 / 04 \mathrm{P}$

HvJ EG 21 september 2006, Nederlandse Federatieve Vereniging voor de Groothandel op Elektrotechnisch Gebied t. Commissie, nr. C-105/04 P (hogere voorziening arrest GEA)

HvJ EG 19 september 2006, Wilson, nr. C-506/04

HvJ EG 15 juni 2006 Dokter e.a. t. Minister van LNV, nr. C-28/05, AB 2006/390 m.nt. R.J.G.M. Widdershoven

HvJ EG 2 mei 2006, Insloventieprocedure met betrekking tot Eurofood IFSC Ltd., EHRC 2006/67

GEA 15 juni 2005, Corsica Ferries France t. Commissie, nr. T-349/03

HvJ EG 2 oktober 2003, Thyssen Stahl AG t. Commissie van de Europese Gemeenschappen, nr. C-194/99 $P$

HvJ EG 10 april 2003, Steffensen, AB 2003/310 m.nt. AdMvV

GEA 6 maart 2003, Westdeutsche Landesbank Girozentrale en Land Nordrhein-Westfalen t. Commissie, nrs. T-228/99 en T-233/99

HvJ EG 15 oktober 2002, Limburgse Vinyl Maaschappij NV (LVM) e.a. t. Commissie, nrs. C-239/99 P, C-244/99 P, C-245/99 P, C-247/99 P, C-250/99 P, tot en met C-252/99 P en C-254/99 P

HvJ EG 27 november 2001, Z. t. Europees Parlement (hogere voorziening tegen arrest GEA), nr. C270/99 P

HvJ EG 30 maart 2000, VBA t. Florimex e.a., nr. C-265/97 P

GEA 20 april 1999, Limburgse Vinyl Maatschappij e.a. t. Commissie, nrs. C-239/99 P, C-244/99 P, C245/99 P, C-247/99 P, C-250/99 P, tot en met C-252/99 P en C-254/99 P

HvJ EG 17 december 1998, Baustahlgewebe t. Commissie, nr. C-185/95

HvJ EG 2 april 1998, Commissie van de Europese Gemeenschappen t. Chambre syndicale nationale des entreprises de transport de fonds et valeurs (Sytraval) en Brink's France SARL, nr. C-367/95 P

GEA 22 oktober 1997, Stichting Certificatie Kraanverhuurbedriif (SCK) en Federatie van Nederlandse Kraanverhuuurbedrijven (FNK) t. Commissie, nrs. T-213/95 en T-18/96

HvJ EG 20 februari 1997, Commissie t. Daffix, nr. C-166/95 P

HvJ EG 24 oktober 1996, Commissie van de Europese Gemeenschappen t. Lisrestal e.a., nr. C-32/95 P

HvJ EG 29 juni 1994, Fiskano AB t. Commissie van de Europese Gemeenschappen, nr. C-135/92 


\section{Jurisprudentielijst}

HvJ EG 16 juni 1993, Frankrijk t. Commissie van de Europese Gemeenschappen, nr. C-325/91

HvJ EG 21 november 1991, Technische universität München t. Hauptzollamt München-Mitte, nr. C-269/90

HvJ EG 15 oktober 1987, nr. 222/86, Union nationale des entraîneurs et cadres techniques professionnels du football (Unectef) t. Heylens

HvJ EG 30 september 1987, Meryem Demirel t. Ville de Swäbisch Gmündt, nr. 12/86

HvJ EG 26 maart 1987, Commissie van de Europese Gemeenschappen t. Raad van de Europese Gemeenschappen, nr. 45/86

HvJ EG 15 mei 1986, Johnston, nr. 222/84

HvJ EG 11 juli 1985, Cinéthèque SA t. Fédération nationale des cinémas français, nr. 60/84

HvJ EG 9 november 1983, San Giorgio, nr. 199/82

HvJ EG 29 oktober 1980, Van Landewyck t. Commissie, nrs. 209-215 en 218/78

HvJ EG 13 februari 1979, Hoffmann - La Roche en CO. AG t. Commissie van de Europese Gemeenschappen, nr. C-85/76

HvJ EG 16 december 1976, Rewe, nr. 33/76

HvJ EG 16 december 1976, Comet, nr. 45/76

HvJ EG 23 oktober 1974, Transocean Marine Paint Association t. Commissie van de Europese Gemeenschappen, nr. $17 / 74$

HvJ EG 12 november 1969, Stauder t. City of Ulm, nr. 29/69

Afdeling bestuursrechtspraak van de Raad van State

AbRvS 3 maart 2010, JB 2010/106

AbRvS 10 februari 2010, LJN BL3354

AbRvS 3 februari 2010, nr. 200903524/1/H2, LJN BL1825

AbRvS 2 december 2009, $A B$ 2010/34 m.n.t B. de Waard

AbRvS 2 december 2009, $A B$ 2009/342 m.nt. B. de Waard

AbRvS 18 november 2009, nr. 200903566/1/H2

AbRvS 21 oktober 2009, $A B$ 2010/29 m.nt. R. Ortlep

AbRvS 21 oktober 2009, nr. 200809406/1/H1

AbRvS 19 augustus 2009, JB 2009/217

AbRvS 19 augustus 2009, $J B$ 2009/216 m.nt. C.L.G.F.H. Albers

AbRvS 12 augustus 2009, $A B$ 2009/368 m.nt. B.W.N. de Waard

AbRvS 22 juli 2009, $J B$ 2009/213 m.nt. A.M.M.M. Bots

AbRvS 1 juli 2009, $L J N$ BJ1126, nr. 200805262/1/M2

AbRvS 17 juni 2009, nr. 200901365/2/H2, LJN BI8475

AbRvS 17 juni 2009, $A B$ 2010/65 m.nt. L.J.A. Damen

AbRvS 10 juni 2009, $A B$ 2009/369 m.nt. Nijhuis en Den Ouden

AbRvS 3 juni 2009, $A B$ 2009/249 m.nt. D.W.M. Wenders

AbRvS 20 mei 2009, JB 2009/167 m.nt. red

AbRvS 13 mei 2009, nr. 200808359/1/H3

AbRvS 17 april 2009, nr. 200806348/1

AbRvS 8 april 2009, $A B$ 2009/375 m.nt. C.M. Bitter

AbRvS 4 maart 2009, JB 2009/82 m.nt. red; $A B$ 2009/236 m.nt. Barkhuysen \& Den Ouden

AbRvS 25 februari 2009, $A B$ 2009/222 m.nt. W. den Ouden en J.M.J. van Rijn van Alkemade

AbRvS 11 februari 2009, $A B$ 2009/224 m.nt. Ortlep; $J B$ 2009/80

AbRvS 28 januari 2009, $L J N$ BH1101

AbRvS 24 december 2008, LJN BG8313

AbRvS 24 december 2008, $A B$ 2010/16 m.nt. A.M.L. Jansen

AbRvS 24 december 2008, JB 2009/42 m.nt. C.L.G.F.H. A.; USZ 2009/75 m.nt. Barkhuysen \& Van Emmerik; $A B$ 2009/213 m.nt. Van Ravels \& Jansen

AbRvS 10 december 2008, nr. 200802431/1; JB 2009/39

AbRvS 3 december 2008, JB 2009/13; $A B$ 2009/70 m.nt. Barkhuysen \& Van Emmerik

AbRvS 27 augustus 2008, $A B$ 2008/328 m.nt. A.B. Blomberg

AbRvS 13 augustus 2008, nr. 20075940/1

AbRvS 4 juni 2008, $A B$ 2008/229 m.nt. Widdershoven; JB 2008/146 m.nt. Jansen; USZ 2008/211 m.nt. Barkhuysen en Van Emmerik

AbRvS 7 mei 2008, $A B$ 2009/4 m.nt. B.W.N. de Waard

AbRvS 23 april 2008, $A B$ 2008/216 m.nt. T.E.P.A Lam

AbRvS 16 april 2008, LJN BC9614

AbRvS 26 maart 2008, $L J N$ BC7604

AbRvS 20 februari 2008, JB 2008/76 m.nt. C.L.G.F.H. A

AbRvS 30 januari 2008, $J B$ 2008/59 m.nt. C.L.G.F.H. A

AbRvS 30 januari 2008, $J B$ 2008/58

AbRvS 21 januari 2008, $A B$ 2008/115 m.nt. De Waard 


\section{Jurisprudentielijst}

AbRvS 16 januari 2008, $A B$ 2008/308 m.nt. Sew

AbRvS 9 januari 2008, $J B$ 2008/41

AbRvS 12 december 2007, AB 2008/34 m.nt. Alfred van Hall

AbRvS 12 december 2007, nr. 200703100/1

AbRvS 14 november 2007, JB 2008/11 m.nt. LJMT

AbRvS 17 oktober 2007, JB 2007/225

AbRvS 17 oktober 2007, $A B$ 2008/114 m.nt. BdeW

AbRvS 26 september 2007, JB 2007/219

AbRvS 5 september 2007, AB 2008/4 m.nt. De Waard; JB 2007/194 m.nt. Red

AbRvS 22 augustus 2007, $A B$ 2008/72 m.nt. O.D.M.L. Jansen

AbRvS 15 augustus 2007, JB 2007/183 m.nt. RJNS

AbRvS 27 juni 2007, $J B$ 2007/164 m.nt. Marc Rongen; $A B$ 2007/243 m.nt. Alfred van Hall

AbRvS 26 juni 2007, $A B$ 2008/88 m.nt. O.J.D.M.L. Jansen

AbRvS 20 juni 2007, $J V$ 2007/348 m.nt. bij $J V$ 2007/322 van HBA; $A B$ 2008/336 m.nt. AMLJ

ABRvS 13 juni 2007, $A B$ 2007/261, m.nt. Jansen

ABRvS 6 juni 2007, $A B$ 2007/220 m.nt. Jansen

AbRvS 27 mei 2007, $A B$ 2007/194 m.nt. Sewandono

AbRvS 22 mei 2007, $A B$ 2008/72 m.nt. O.J.D.M.L. Janssen

AbRvS 21 mei 2007, AB 2007/194 m.nt. Sew; JB 2007/134 m.nt. DWMW

AbRvS 25 april 2007, $A B$ 2007/264 m.nt. L.J.A. Damen

AbRvS 25 april 2007, JB 2007/123 m.nt. LJMT

AbRvS 14 maart 2007, JB 2007/86 m.nt. LJMT

AbRvS 14 maart 2007, $A B$ 2007/213 m.nt A.M.L. Jansen

AbRvS 21 februari 2007, $J B$ 2007/74 m.nt. LJMT

AbRvS 21 februari 2007, $J B$ 2007/120 m.nt. LJTM

AbRvS 14 februari 2007, $A B$ 2007/156 m.nt. B.W.N. de Waard

AbRvS 9 februari 2007, $J B$ 2007/68 m.nt. DWMW; $A B$ 2007/90 m.nt. Sew

AbRvS 22 november 2006, JB 2007/12 m.nt. AB; $A B$ 2008/62 m.nt. N. Verheij

AbRvS 8 november 2006, $A B$ 2007/5 m.nt. A.G.A. Nijmeijer

AbRvS 1 november 2006, $A B$ 2007/95 m.nt. G.M. van den Broek en A.T. Marseille

AbRvS 1 november 2006, $A B$ 2008/55 m.nt. N. Verheij

AbRvS 2 augustus 2006, $A B$ 2008/65 m.nt. N. Verheij

AbRvS 12 juli 2006, $A B$ 2008/144 m.nt. A.M.L. Jansen; JB 2006/268 m.nt. Wenders

AbRvS 12 juli 2006, JB 2006/255

AbRvS 2 juni 2006, $J B$ 2004/262

AbRvS 26 april 2006, $J B$ 2006/184 m.nt. DWMW

AbRvS 26 april 2006, nr. 200509238/1

AbRvS 15 maart 2006, JB 2006/123

AbRvS 28 september 2005, $J B$ 2005/323

AbRvS 23 augustus 2005, $A B$ 2005/371 m.nt. Sew

AbRvS 19 oktober 2005, $J B$ 2006/4 m.nt. NV

AbRvS 12 oktober 2005, $J B$ 2005/327

AbRvS 12 oktober 2005, $J B$ 2005/328 m.nt. AMLJ

AbRvS 4 juli 2005, $A B$ 2006/62; JB 2005/254

AbRvS 29 juni 2005, $A B$ 2006/43 m.nt. AMLJ

AbRvS 15 juni 2005, $J B$ 2005/231

AbRvS 8 juni 2005, $A B$ 2005/310 m.nt. NV

AbRvS 11 mei 2005, $J B$ 2005/188

AbRvS 4 mei 2005, $L J N$ AT5101

AbRvS 4 mei 2005, $J B$ 2005/186

AbRvS 16 maart 2005, $J B$ 2005/140

AbRvS 2 maart 2005, $J B$ 2005/117; $A B$ 2005/136 m.nt. FM

AbRvS 16 februari 2005, $J B$ 2005/102 m.nt. Hamer

AbRvS 11 februari 2005, $A B$ 2005/181 m.nt. BdeW

AbRvS 26 januari 2005, $A B$ 2005/374 m.nt. R.H. de Bock

AbRvS 12 januari 2005, JB 2005/65

AbRvS 12 januari 2005, nr. 200404561/1

AbRvS 12 januari 2005, $A B$ 2005/239 m.nt. Verheij

AbRvS 15 december 2004, $A B$ 2005/431 m.nt. JSt

AbRvS 20 oktober 2004, nr. 2000402982/1

AbRvS 6 oktober 2004, $A B$ 2004/390 m.nt. TN; JB 2004/370 m.nt. AMLJ

AbRvS 6 oktober 2004, $J B$ 2004/369

AbRvS 29 september 2004, $A B$ 2004/415 m.nt. NV

AbRvS 22 september 2004, $A B$ 2005/202 m.nt. BdeW; $J B$ 2005/5 m.nt. M.C.M. Hamer 


\section{Jurisprudentielijst}

AbRvS 18 augustus 2004, $A B$ 2004/416 m.nt. NV

ABRvS 21 juli 2004, $A B$ 2005/14 m.nt. $\mathrm{HBr}$

AbRvS 30 juni 2004, $J B$ 2004/292

AbRvS 27 mei 2004, $A B$ 2007/295 m.nt. O.J.D.M.L. Jansen onder $A B$ 2007/294

AbRvS 28 april 2004, $A B$ 2004/276 m.nt. RW

AbRvS 3 maart 2004, $A B$ 2004/252 m.nt. NV; JB 2004/175

AbRvS 24 december 2003, $A B$ 2004/383

AbRvS 24 december 2003, $A B$ 2004/117 m.nt FM

AbRvS 24 december 2003, LJN AO0806

AbRvS 11 december 2003, $J B$ 2004/55 m.nt. EvdL

AbRvS 19 november 2003, $A B$ 2004/27 m.nt. AMLJ; $J B$ 2004/15

AbRvS 5 november 2003, $A B$ 2004/176 m. nt. BdeW

AbRvS 8 oktober 2003, $J B$ 2003/320

AbRvS 17 september 2003, $A B$ 2004/195 m.nt. N. Verheij

AbRvS 17 september 2003, JB 2003/298 m.nt. AMLJ

AbRvS 10 september 2003, $A B$ 2004/1 en $A B$ 2004/2 m.nt. BdeW

AbRvS 3 september 2003, $A B$ 2003/389 m.nt. Sew

AbRvS 3 september 2003, $J B$ 2003/293

AbRvS 6 augustus 2003, $A B$ 2004/140 m.nt. J.A.F. Peters

AbRvS 6 augustus 2003, LJN AI0807

AbRvS 18 juli 2003, $A B$ 2004/3 m.nt. A.M.L. Jansen; JB 2003/242

AbRvS 2 juli 2003, $J B$ 2003/230

AbRvS 25 juni 2003, nr. 200202706/1

AbRvS 25 maart 2003, $J V$ 2003/191 m.nt. PB

AbRvS 19 maart 2003, $A B$ 2003/301 m.nt. J.A.F. Peters

AbRvS 17 maart 2003, $J B$ 2004/184

AbRvS 27 januari 2003, $A B$ 2003/286 m.nt. BPV

AbRvS 24 december 2002, $A B$ 2003/158

AbRvS 18 december 2002, $A B$ 2003/85 m.nt. FM

AbRvS 13 november 2002, $A B$ 2003/135 m.nt. Verheij

AbRvS 6 november 2002, $A B$ 2003/115 m.nt. NV

AbRvS 23 oktober 2002, $J B$ 2002/360

AbRvS 11 september 2002, $A B$ 2003/160 m.nt. BdeW

AbRvS 14 augustus 2002, nr. 200104239/1

AbRvS 7 augustus 2002, $A B$ 2003/3 m.nt. A.R. Neerhof; $J B$ 2002/280

AbRvS 31 juli 2002, Gmst. 7173/3 m.nt. D.E. Bunschoten

AbRvS 26 juni 2002, $A B$ 2003/407 m.nt. G.A.C.M. van Ballegooij

AbRvS 19 juni 2002, $A B$ 2002/282 m.nt. AMLJ

AbRvS 5 juni 2002, $A B$ 2002/349 m.nt BJS

AbRvS 5 juni 2002, $J B$ 2002/222

AbRvS 5 juni 2002, $J B$ 2002/220

AbRvS 24 mei 2002, $A B$ 2003/158

AbRvS 22 mei 2002, $A B$ 2002/247 m.nt. Sew

AbRvS 16 mei 2002, $A B$ 2002/267 m.nt. Sew

AbRvS 15 mei 2002, $A B$ 2003/196 m.nt. LD

AbRvS 8 mei 2002, $A B$ 2002/299 m.nt. Sew

AbRvS 13 februari 2002, $A B$ 2002/123

AbRvS 28 december 2001, $A B$ 2002/146 m.nt. Sew

AbRvS 19 december 2001, JB 2002/46

AbRvS 5 december 2001, $A B$ 2002/110

AbRvS 17 oktober 2001, $A B$ 2002/108 m.nt. Sew

AbRvS 15 augustus 2001, $A B$ 2001/334 m.nt. Verheij

AbRvS 12 september 2001, $A B$ 2002/4 m.nt. S.E. Zijlstra

AbRvS 25 juli 2001, $A B$ 2001/286

AbRvS 25 juli 2001, $A B$ 2001/339 m.nt. Verheij

AbRvS 13 juni 2001, $A B$ 2001/267 m.nt. Sew

AbRvS 8 mei 2001, $A B$ 2001/292 m.nt. L.J.A. Damen

AbRvS 1 februari 2001, JB 2001/72 m.nt. AWH

ABRvS 10 oktober 2000, JB 2000/306 m.nt. RJNS

AbRvS 26 september 2000, $A B$ 2000/484 m.nt. Sewandono

AbRvS 31 juli 2000, $J B$ 2000/269 m.nt. Red

AbRvS 29 juni 2000, $J B$ 2000/223

AbRvS 1 mei 2000, JB 2000/177 m.nt. ARN

AbRvS 25 februari 2000, $A B$ 2002/42 m.nt. Verheij 
Jurisprudentielijst

AbRvS 4 november 1999, $A B$ 1999/479 m.nt. MSV

AbRvS 17 augustus 1999, $A B$ 1999/412

AbRvS 12 augustus 1999, $A B$ 1999/392 m.nt. MSV

AbRvS 26 juli 1999, JB 1999/226

AbRvS 30 maart 1999, $A B$ 1999/310 m.nt. GJ

AbRvS 19 januari 1999, $A B$ 1999/257 m.nt. JSt

AbRvS 3 december 1998, JB 1999/13 m.nt. FAMS; $A B$ 1999/107 m.nt. FM

AbRvS 30 november 1998, $J B$ 1999/12 m.nt. R.J.N.S

AbRvS 16 juli 1998, $A B$ 1998/375 m.nt. MSV bij $A B$ 1998/376

AbRvS 24 april 1998, $J B$ 1998/145 m.nt. R.J.N.S

AbRvS 20 februari 1998, $A B$ 1998/269 m.nt. GJ; JB 1998/76 m.nt. R.J.N.S

AbRvS 8 januari 1998, $A B$ 1998/194 m.nt. PvB

AbRvS 16 december 1997, JB 1998/30 m.nt. noot A.R. Neerhof in $J B$ 1998/24

AbRvS 28 november 1997, JB 1997/9

AbRvS 14 november 1997, nr. H01.960749

AbRvS 28 oktober 1997, $A B$ 1997/458 m.nt. PvB; JB 1998/6

AbRvS 12 juni 1997, JB 1997/188

AbRvS 15 mei 1997, $A B$ 1997/263

AbRvS 8 april 1997, $A B$ 1998/106 m.nt. PvB

AbRvS 20 maart 1997, BR 1997/575 m.nt. J.W. Weerkamp

AbRvS 10 maart 1997, JB 1997/87 m.nt. R.J.G.H. S

AbRvS 16 september 1996, $A B$ 1997/147 m.nt. GJ

AbRvS 29 juli 1996, JB 1996/190 m.nt. MAH

AbRvS 29 juli 1996, JB 1996/90 m.nt. MAH

AbRvS 8 juli 1996, $A B$ 1996/344 m.nt. Van Buuren

AbRvS 25 juni 1996, $A B$ 1996/411 m.nt. ICvdV

Vz. AbRvS 31 maart 1994, $A B$ 1994/479 m.nt. P.J.J. van Buuren

AbRvS 8 november 1993, $A B$ 1994/205 m.nt. NV

Centrale Raad van Beroep

CRvB 17 maart 2010, JB 2010/131

CRvB 30 december 2009, LJN BK8458

CRvB 30 juni 2009, LJN BJ2125

CRvB 23 juni 2009, $A B$ 2009/267; JB 2009/205 m.nt. Red.

CRvB 12 juni 2009, $L J N$ BI9072

CRvB 13 mei 2009, JB 2009/184

CRvB 8 mei 2009, $A B$ 2009/239 m.nt. Tollenaar

CRvB 28 april 2009, $L J N$ BI2748, $J B$ 2009/152 m.nt. Red

CRvB 9 april 2009, $L J N$ BI2179, JB 2009/150 m.nt. Red

CRvB 13 maart 2009, $A B$ 2009/226

CRvB 4 februari 2009, $A B$ 2009/161 m.nt. Tollenaar

CRvB 26 januari 2009, JB 2009/66 m.nt. Barkhuysen \& Van Emmerik; $A B$ 2009/241 m.nt A.M.L. Jansen

CRvB 8 januari 2009, $L J N$ BH1537

CRvB 25 november 2008, JB 2008/24; $A B$ 2009/50

CRvB 22 oktober 2008, $A B$ 2008/358 m.nt. Marseille

CRvB 28 augustus 2008, $A B$ 2010/17 m.nt. A.M.L. Jansen

CRvB 27 augustus 2008, JB 2008/260 m.nt. C.L.G.F.H. A

CRvB 11 juli 2008, JB 2008/172 m.nt. AMLJ; $A B$ 2008/241 m.nt. R.J.G.M. Widdershoven; USZ 2008/38 m.nt. Barkhuysen en Van Emmerik

CRvB 30 mei 2008, JB 2008/171

CRvB 6 mei 2008, $A B$ 2008/243 m.nt. $\mathrm{HBr}$

Vzr. CRvB 25 februari 2008, $A B$ 2008/254 m.nt. A. Tollenaar

CRvB 16 januari 2008, $A B$ 2008/161 m.nt. Tollenaar

CRvB 11 januari 2008, $A B$ 2008/78 m.nt. Tollenaar

CRvB 3 januari 2008, $A B$ 2008/211 m.nt. AMLJ

CRvB 13 november 2007, RSV 2008/15

CRvB 7 november 2007, TAR 2008/14

CRvB 2 oktober 2007, $A B$ 2008/5 m.nt. A. Tollenaar

CRvB 5 juli 2007, TAR 2007/193

CRvB 17 juli 2007, JB 2007/175

CRvB 27 juni 2007, $R S V$ 2007/303

CRvB 31 mei 2007, $A B$ 2007/285 m.nt. Y.E. Schuurmans

CRvB 16 januari 2007, JB 2007/61 m.nt. LJTM

CRvB 23 november 2006, LJN AZ0644 


\section{Jurisprudentielijst}

CRvB 22 november 2006, $A B$ 2007/180 m.nt. K.F. Bolt

CRvB 31 oktober 2006, $A B$ 2007/74 m.nt. H.E. Bröring

CRvB 22 september 2006, USZ 2006/343 m.nt. D. Wenders

CRvB 7 juli 2006, $A B$ 2007/221, m.nt. Jansen

CRvB 21 juni 2006, JB 2006/261

CRvB 4 januari 2006, $J B$ 2006/83

CRvB 29 november 2005, JB 2006/40

CRvB 22 november 2005, JB 2006/37 m.nt. Wenders

CRvB 15 september 2005, JB 2005/311

CRvB 1 augustus 2005, $A B$ 2005/421 m.nt. HBr bij $A B$ 2005/422

CRvB 9 juni 2005, JB 2005/261

CRvB 17 mei 2005, LJN AT8156, Abkort 2005/495

CRvB 3 mei 2005, JB 2005/220

CRvB 26 april 2005, $A B$ 2005/303 m.nt. $\mathrm{HBr}$

CRvB 26 april 2005, JB 2005/217

CRvB 26 april 2005, $J B$ 2005/218

CRvB 22 april 2005, $A B$ 2006/44 m.nt. A.M.L. Jansen; $J B$ 2005/198

CRvB 19 april 2005, $J B$ 2005/197 m.nt. A. van Eijs; USZ 2005/247

CRvB 29 maart 2005, $J B$ 2005/176

CRvB 8 december 2004, $A B$ 2005/73, m.nt. HBr; USZ 2005/56 m.nt. TB; $J B$ 2005/30 m.nt JHK

CRvB 7 oktober 2004, JB 2004/380 m.nt. Overkleeft-Verburg

CRvB 14 september 2004, JB 2004/360

CRvB 15 januari 2004, JB 2004/107 m.nt. A.M.M.M. Bots; Gst. 2004, 7212/128 m.nt. Adriaanse

CRvB 11 december 2003, JB 2004/88 m.nt. AMLJ

CRvB 6 november 2003, JB 2004/28

CRvB 21 oktober 2003, $A B$ 2004/126 m.nt. BdeW

CRvB 20 augustus 2003, $A B$ 2004/13 m.nt. $\mathrm{HBr}$

CRvB 4 juli 2003, JB 2003/268

CRvB 4 juli 2003, $A B$ 2003/450 m.nt. HBr; $J B$ 2003/249 m.nt. AMLJ

CRvB 1 juli 2003, $J B$ 2003/248 m.nt. Van Eijs

CRvB 25 juni 2003, JB 2003/247; $A B$ 2003/395

CRvB 26 mei 2003, JB 2003/195

CRvB 20 mei 2003, JB 2003/193

CRvB 29 april 2003, $A B$ 2003/307 m.nt. HBr; $J B$ 2003/192

CRvB 25 april 2003, $A B$ 2005/303 m.nt. HBr

CRvB 4 april 2003, JB 2003/156

CRvB 4 april 2003, JB 2003/155

CRvB 4 april 2003, $J B$ 2003/182

CRvB 25 februari 2003, JB 2003/115 m.nt. C.L.G.F.H. A.

CRvB 14 januari 2003, LJN AF6338

CRvB 7 januari 2003, USZ 2003/139

CRvB 3 januari 2003, $A B$ 2003/99 m.nt. FP

CRvB 10 december 2002, USZ 2003/70

CRvB 6 november 2002, JB 2003/25 m.nt. JHK; RSV 2003/38 m.nt. R. Stijnen

CRvB 27 september 2002, $A B$ 2003/83 m.nt. FP

CRvB 27 september 2002, RSV 2002/311

CRvB 6 september 2002, JB 2002/309; RSV 2002/285

CRvB 28 juni 2002, $A B$ 2003/9 m.nt. BJS

CRvB 4 juni 2002, JB 2002/281

CRvB 28 mei 2002, $A B$ 2002/364 m.nt. HBr; JB 2002/211 m.nt A. van Eijs

CRvB 3 mei 2002, TAR 2002/139

CRvB 13 februari 2002, USZ 2002/98 m.nt. red.

CRvB 13 februari 2002, USZ 2002/100 m.nt. red

CRvB 13 februari 2002, USZ 2002/101 m.nt. Driessen; $A B$ 2002/96 m.nt. FP.; JB 2002/126 m.nt. A. van Eijs

CRvB 25 januari 2002, RSV 2002/126; USZ 2002/107

CRvB 8 januari 2002, $A B$ 2002/97 m.nt. $\mathrm{HBr}$

CRvB 21 juli 2001, NJB 2001/22, p. 1625; JB 2001/256; $A B$ 2001/252 m.nt. FP onder $A B$ 2001/253; RSV 2001/205; USV 2001/199

CRvB 5 april 2001, TAR 2001/88

CRvB 7 februari 2001, $A B$ 2001/178 m.nt. HBr

CRvB 21 december 2000, JB 2001/50 m.nt. ARN

CRvB 8 november 2000, $A B$ 2001/41 m.nt. $\mathrm{HBr}$

CRvB 17 oktober 2000, JB 2000/354 
Jurisprudentielijst

CRvB 4 oktober 2000, JB 2000/334

CRvB 7 maart 2000, $A B$ 2000/214 m.nt. $\mathrm{HBr}$

CRvB 29 februari 2000, $A B$ 2000/443 m.nt. $\mathrm{HBr}$

CRvB 4 januari 2000, $A B$ 2000/146 m.nt. $\mathrm{HBr}$

CRvB 4 januari 2000, $A B$ 2000/147 m.nt. $\mathrm{HBr}$

CRvB 24 juni 1999, $A B$ 1999/406 m.nt. HH

CRvB 15 april 1999, Rawb 1999/147 m.nt. Klap

CRvB 21 januari 1999, $A B$ 1999/169 m.nt. $\mathrm{HBr}$

CRvB 21 juli 1998, RSV 1998/306

CRvB 26 juni 1998, Rawb 1998/8 m.nt. BdeW

CRvB 27 mei 1998, $A B$ 1998/367

CRvB 8 april 1998, $A B$ 1998/430

CRvB 3 maart 1998, $A B$ 1998/363

CRvB 28 januari 1998, $A B$ 1998/168 m.nt. FP; $J B$ 1998/ 61 m.nt. Heringa; RSV 1998, 106 m.nt. Van der Kris; USZ 1998/69 m.nt. Driessen

CRvB 25 januari 1998, $A B$ 1998/168 m.nt. FP

CRvB 4 december 1997, JB 1998/38

CRvB 25 november 1997, JAwb 1998/20

CRvB 12 november 1997, $A B$ 1998/44

CRvB 22 augustus 1997, $A B$ 1997/417 m.nt. F.J.L. Pennings

CRvB 8 juli 1997, $A B$ 1997/329 m.nt. FP; $J B$ 1997/179 m.nt. R. Seerden

CRvB 27 juni 1997, $A B$ 1997/377 m.nt. de L; JB 1997/177 m.nt. R. Seerden

CRvB 29 mei 1997, $A B$ 1997/308 m.nt. HH

CRvB 13 maart 1997, JB 1997/104

CRvB 16 januari 1997, ABkort 1997/192

CRvB 23 december 1996, $A B$ 1997/239 m.nt. HBr; JB 1997/28 m.nt. Red

CRvB 23 juli 1996, $R S V$ 1996/241

CRvB 29 april 1996, $A B$ 1997/24 m.nt. HB

CRvB 11 april 1996, $A B$ 1996/257 m.nt. P.J. Stolk

CRvB 9 april 1996, Rawb 1996/7 m.a. tB

CRvB 29 maart 1996, $A B$ 1996/368

CRvB 19 februari 1996, RAwb 1996/70 m.nt. Widdershoven; RSV 1996/144

CRvB 13 februari 1996, $A B$ 1996/170 m.nt. F.J.L. Pennings

CRvB 9 november 1995, $A B$ 1996/175

CRvB 13 juli 1995, JB 1995/222 m.nt. Red

CRvB 29 juni 1995, JB 1995/180 m.nt. Red

CRvB 12 december 1994, JB 1995/25 m.nt. ABJH/ELB

CRvB 12 maart 1992, $A B$ 1992/677 m.nt. HH

College van Beroep voor het bedrijfsleven

CBb 11 november 2009, $A B$ 2009/402 m.nt. Sew

CBb 26 mei 2009, $A B$ 2009/303 m.nt. D.W.M. Wenders

CBb 3 maart 2009, $L J N$ BH6281, JB 2009/139; $A B$ 2009/304 m.nt. Sew

CBb 9 september 2008, $A B$ 2009/300 m.nt. Sewandono; JB 2008/245 m.nt. M.O.-V

CBb 7 juli 2008, $A B$ 2009/177 m.nt. Cartigny

CBb 3 juli 2008, $A B$ 2009/305 m.nt. Sew

CBb 16 april 2008, $A B$ 2008/324 m.nt. I. Sewandono; $J B$ 2008/136

CBb 5 december 2007, $A B$ 2008/38 m.nt. G.J.M. Cartigny

CBb 4 december 2007, $A B$ 2007/403 m.nt. Sew

CBb 24 augustus 2006, $A B$ 2007/321 m.nt. O.J.D.M.L. Jansen

CBb 13 april 2006, $A B$ 2006/395 m.nt. O.J.D.M.L. Jansen

CBb 18 oktober 2005, $A B$ 2006/80 m.nt. J.H. van der Veen

CBb 11 november 2005, $J B$ 2006/46

CBb 3 maart 2004, $A B$ 2004/198 m.nt. JHvdV

CBb 13 januari 2004, $A B$ 2004/111 m.nt. JHvdV

CBb 20 februari 2003, $A B$ 2003/150 m.nt. JHvdV

CBb 17 december 2002, $A B$ 2003/70 m.nt. JHvdV

CBb 10 september 2002, $J B$ 2002/373; $A B$ 2003/54 m.nt. JHvdV

CBb 28 november 2001, $A B$ 2001/45 m.nt. J.H. van der Veen

CBb 20 februari 2001, $A B$ 2001/169 m.nt. JHvdV

CBb 29 februari 2000, $A B$ 2000/206 m.nt. J.H. van der Veen

CBb 3 juni 1999, $A B$ 1999/364 m.nt. JHvdV

CBb 24 juni 1998, JB 1998/213

CBb 19 april 1998, $A B$ 1998/265 m.nt. J.H. van der Veen 
Jurisprudentielijst

CBb 13 januari 1998, AB 1998/112 m.nt. JHvdV

CBb 1 oktober 1997, $A B$ 1998/81 m.nt. $\mathrm{HBr}$

CBb 12 juni 1997, $A B$ 1997/339 m.nt. JHvdV

CBb 27 februari 1996, $A B$ 1997/252 m.nt. ICvdV

CBb 21 februari 1996, ABkort 1996/172

CBb 23 mei 1995, $A B$ 1995/455 m.nt. JHvdV; JB 1995/177

CBb 28 maart 1995, $A B$ 1995/513 m.nt. Viering

CBb 21 december 1994, JB 1995/1; AB 1995/454 m.nt. JHvdV; Rawb 1995/34 m.nt. BdeW

CBb 25 januari 1994, $A B$ 1998/338 m.nt. JHvdV

CBb 31 mei 1990, $A B$ 1991/405

CBb 19 april 1985, $A B$ 1985/443 m.nt. JHvK

\section{Hoge Raad}

HR 12 juni 2009, $A B$ 2009/246 m.nt. Redactie

HR 15 mei 2009, $A B$ 2009/342 m.nt. B. de Waard

HR 19 december 2008, $A B$ 2009/230 m.nt. Jansen

HR 17 juni 2008, NJ 2008/358 m.nt. P.A.M. Mevis; $A B$ 2009/231 m.nt. AMLJ

HR 25 april 2008, $J B$ 2008/123

HR 16 februari 2007, $A B$ 2007/138 m.nt. R.J.G.M. Widdershoven

HR 12 mei 2006, $A B$ 2006/303 m.nt. Knijff

HR 8 juli 2005, $A B$ 2006/17 m.nt. A.M.L. Jansen; $B N B$ 2005/340 m.nt. Bijl

HR 17 juni 2005, $B N B$ 2005/338 m.nt. Feteris

HR 22 april 2005, JB 2005/166 m.nt. Wenders; $A B$ 2006/11 m.nt. A.M.L. Jansen; BNB 2005/337 met noot Feteris onder $B N B$ 2005/338

HR 24 januari 2003, $A B$ 2003/139 m.nt. BdeW

HR 2 juli 2002, $N J$ 2003/2 m.nt. Kn

HR 7 juni 2002, JB 2002/219

HR 3 oktober 2000, NJ 2000/721 m.nt. JdH; Rawb 2001/21 m.nt. A.M.L. Jansen

HR 14 april 1989, $A B$ 1989/207 m.nt. FVvdB

HR 6 februari 1986, $A B$ 1987/272 m.nt. FHvdB

HR 29 maart 1985, $N J$ 1986/242 m.nt. WHH en LWH

HR 20 januari 1984, $N J$ 1984/388

HR 26 juni 1981, $N J 1982 / 450$

HR 26 oktober 1980, $A B$ 1989/20 m.nt. Burg

HR 12 april 1978, $A B$ 1979/262 m.nt. FHvdB (Doorbraakarrest)

Afdeling rechtspraak van de Raad van State

ArRvS 8 november 1993, $A B$ 1994/208 m.nt. Verheij

ArRvS 12 januari 1993, $A B$ 1993/237 m.nt. Verheij

ArRvS 7 augustus 1989, $A B$ 1990/191 m.nt. J.C.J. Dute

ArRvS 21 juli 1987, $A B$ 1987/433 m.nt. Van Buuren

ArRvS 26 juli 1985, $A B$ 1986/50 m.nt. JHvdV

ArRvS 14 mei 1985, $A B$ 1986/103 m.nt. JHvdV

ArRvS 4 januari 1985, $A B$ 1985/457 m.nt. JHvdV

ArRvS 25 mei 1984, $A B$ 1984/451

ArRvS 8 juli 1983, $A B$ 1984/29 m.nt. JHvdV

ArRvS 16 juni 1983, $A B$ 1983/486 m.nt. J.H.v.d.V

ArRvS 12 juli 1982, $A B$ 1982/556

ArRvS 8 april 1982, $A B$ 1982/553 m.nt. v.d.V

ArRvS 9 maart 1982, $A B$ 1982/302, m.nt. J.R.St

ArRvS 22 augustus 1979, $A B$ 1980/266

\section{Gerechtshof}

Hof Leeuwarden 20 maart 2002, AB 2002/316 m.nt. AMLJ

\section{Rechtbank}

Rb. Amsterdam 17 december 2009, LJN BL0518

Rb. Arnhem, 23 juni 2009, JB 2009/190 m.nt. R.J.N.S

$\mathrm{Rb}$. Den Haag, nevenzittingsplaats Amsterdam, 10 september 2008, AB 2008/337 m.nt. AMLJ

Rb. Den Haag, zittingsplaats Haarlem, 10 januari 2008, JV 2008/217

Rb. Den Haag, nevenzittingsplaats A'dam, 8 oktober 2007, zaaknr. AWB 06/57653

Rb. Den Haag, nevenzittingsplaats A'dam, 11 december 2006, AWB 06/46447

Rb. Rotterdam, 22 mei 2006, $L J N$ AX8428

Rb. Amsterdam, 26 augustus 2003, $J B$ 2003/302 m.nt. A.R. Neerhof 
Jurisprudentielijst

Rb. Den Haag, 28 april 2000, $A B$ 2001/125 m.nt. H. Battjes

Pres. Rb. Zutphen 11 november 1999, JB 2000/17

Rb. 's Hertogenbosch 13 maart 1998, JB 1998/12

Pres.Rb. Maastricht, 19 augustus 1996, JB 1996/211 m.nt. MAH

Rb. Leeuwarden 8 februari 1996, JB 1996/100 m.nt. Heldeweg

Rb. Rotterdam 4 december 1995, JB 1996/63

Rb. Amsterdam 8 augustus 1995, Awb-katern 1996, 19

Rb. Maastricht 30 maart 1995, JB 1995/149 m.nt. R.J.G.H. S

Pr. Rb. Zutphen 1 februari 1995, JB 1995/71

Pres. Rb. Rotterdam 29 maart 1994, JB 1994/100

Pres. Rb. Den Haag 1 juli 1981, NJ 1982/118

Nationale ombudsman

No 11 februari 2008, $A B$ 2008/154 m.nt. P.J. Stolk

No 4 mei 2004, $A B$ 2004/301 m.nt. P.J. Stolk

Overig

KB 14 april 1995, $A B$ 1995/618 m.nt. RH

Vz. AGvB 16 oktober 1992, $A B$ 1993/9 



\section{Curriculum vitae}

Daniëlle Wenders behaalde haar vwo-diploma aan het Bernardinus College te Heerlen in 1997. In 2003 rondde zij aan de faculteit der Rechtsgeleerdheid van de Universiteit Maastricht de opleiding Nederlands Recht af. Daarna heeft zij korte tijd als jurist gewerkt bij een juridisch adviesbureau en de Afdeling bestuursrechtspraak van de Raad van State. Eind 2004 is zij als junior-onderzoeker in dienst getreden bij de capaciteitsgroep Publiekrecht van de Universiteit Maastricht. Naast het doen van promotie-onderzoek heeft Daniëlle onderwijs gegeven in verschillende blokken van de opleiding Nederlands Recht. Sinds 1 september 2009 is zij aan de capaciteitsgroep Publiekrecht verbonden als universitair docent. 